\title{
INVESTIGACIONES ARQUEOLÓGICAS EN LA CUENCA MEDIA E INFERIOR DEL RÍO URUGUAY (PROVINCIA DE ENTRE RÍOS)
}

\author{
Juan Carlos Castro
}

TESIS DOCTORAL
Directores
Dr. Gustavo G. Politis
Dr. Mariano Bonomo

Facultad de Ciencias Naturales y Museo

Universidad Nacional de La Plata 2017 
A Jazmín

y a mis padres 


\section{AGRADECIMIENTOS}

En primer lugar agradezco el apoyo recibido por mi familia: Angélica Ester Fernández, Ángel Juan Castro, Juan Ismael Castro, María de los Ángeles Castro, Juan García, María Laura Sánchez, Carina Fernández, y mis sobrinos (Camila, Rosario, Karen, Belén, Nicolás, Bruno, Aldana, Ruth, Renata, Agustina y Anelisse).

En segundo lugar agradezco especialmente a Gustavo Politis y Mariano Bonomo por su dirección, compromiso y por el tiempo y el esfuerzo que le han dedicado a esta tesis.

También hay otras personas cuya colaboraron ha sido fundamental e invalorable y que quiero destacar especialmente: María Laura Maravilla, Ignacio Correa, Santiago Deluca, Ana Deluca, Rodrigo Costa Angrizani, Enrique Terranova, Mariano Del Papa, Diego Gobbo, Violeta Di Prado, Edgardo Ferraris y Verónica Amor y sus niños (Valentina y Manuel).

Un agradecimiento especial para la familia Almeida: Raúl, Julia, Tomás, Julieta y Anita; también a Guillermo, Juan Carlos, Eduardo y Jorge. De la misma forma agradezco a Martín Boari y familia, a Marcelo Lugrin y familia, a Cristina Vassallo de Cettour y familia, a Ignacio Marchesini, Miguel Lemes, Paulina Lemes, Facundo Astorga y Roberto Olcese. Incluyo acá también a Francisco Silva Noelli por su revisión crítica de la tesis y a Fabíola Andréa Silva por permitirme consultar su información inédita.

A los que colaboraron de múltiples maneras y que aún no mencioné: Juliana Bauer de Moura, Luciana Juillerat, Francisco Juillerat, Adela Blasco, Marcos Morard, Paula Angeletti, Mario Sánchez, Mauro Pérez, Diego Marcos, Elio Espoturno, Fernando Larriestra, Susana Martins, Carolina Silva, Canela Castro, Laura Bastourre, Eduardo Apolinaire, Carola Castiñeira, Agustina Ramos van Raap, Clara Scabuzzo, Vanesa Bagaloni, Alejandra Matarrese, Oscar Schwerdt, Marco Álvarez, Germán Moreira, Luciano Prates, Catriel León, Eloísa García, Natalia Barreto, Celia Etchegoyen, Luís Capeletti, Belén Betti, Florencia Gordón, Reinaldo Moralejo, Fernanda Parente, Laura Fuchs, Paula Noelí León, Delfina Bonilla, José Maldonado, Lía Alegre, Carolina Giobergia, Nicolás Iturriarte, María Fernanda Zabalegui, Luís Pérez, Rómulo Rubén Abregu, Julia Vinci, Federico Lotto, Evelyn Velázquez, Karen Álvarez Gödeken, Aylén Chacama, Manuela Parra, Paul Cuart, Jorgelina Zabala, Fabricio Coviello, Nahuel Scheifler, Laura Marchioni, Rocío Blanco, Natalia Derudi, Rogelio Kunzi, Elsa Ramos, Guillermo Pérez, Guido Marengo, Mario De Maggio, Lidia Torres Valori, Marcela Martínez, María Emilia Gighlione, Jorge Flores, Sergio Medina, María Laura Calderón, Juan Manuel Vesco, Manuel Cueto, Magdalena Ferreira, Laura Uehara, Luciano Rey, Fabián Letieri, Carolina Piccoli, Gabriel Cocco, Carolina Barboza, Mariano 
Santini, David Ávila, Marianela Fernández Lapalma, Camila Gianotti, Moira Sotelo, Irina Capdepont, María Amanda Caggiano, Carlos Ceruti, Klaus Hilbert, Silvia Cornero, Darío Hermo, Laura Miotti, Eduardo Góes Neves, Inés Ezcurra de Drago, Iván Pérez, María de los Milagros Colobig, Jimena Franco, Rita Soledad Ramos, Diego Bracco, Pedro Viegas Barros, Blas Omar Jaime, Ana Fernández, Sergio Abelardo Delcanto, Pedro Ángel Báez, Eduardo Rebord, Marcelo Ermacora, Juan Carlos Bertolini, Aristóbulo Maranta, Marina Panziera, Juan Salvador Yone, Eusebio Vidal, Roberto Molinari, Mariana Rominiti, Lorena Ferraro, Alfredo Casella y Oscar Baus.

A las siguientes instituciones:

- Museo de Ciencias Naturales y Antropológicas Profesor Antonio Serrano (Paraná).

- Museo de La Plata y al Laboratorio de Radiocarbono (LATYR-CIG) (La Plata).

- Museo Arqueológico Manuel Almeida (Gualeguaychú).

- Museo Arqueológico y Antropológico Indígena Tierra de Minuanes (Villaguay).

- Museo de Antropología y Ciencias Naturales (Concordia).

- Museo Histórico Martiniano Leguizamón (Paraná).

- Museo de la Ciudad Casa de Haedo de San José de Gualeguaychú (Gualeguaychú).

- Archivo General de la Provincia de Entre Ríos Antonio Saraví (Paraná).

- Administración de Parque Nacionales - Parque Nacional El Palmar (Colón).

- Prefectura Naval Gualeguaychú - Destacamento Puerto Boca (Gualeguaychú).

Al Complejo Turístico Cerros Indios y a las estancias Puerto Boca, Ñandubaysal, Río Uruguay, La Victoria, El Potrero, Punta Caballos y La Estopona.

Y por último a los distintos especialistas que colaboraron en el estudio de algunos materiales: las Dras. Soledad Gouiric (CONICET; FCNyM-UNLP), Itatí Olivares (CONICET; FCNyM-UNLP), Claudia Tambussi (CONICET; CICTERRA), María de las Mercedes Azpelicueta (CONICET; FCNyM-UNLP), Mariana Brea (CICYTTP-CONICET), y Claudia Di Lello (CONICET; FCNyM-UNLP); y los Dres. Mariano Merino (CONICET; FCNyM-UNLP), Alberto Cione (CONICET; FCNyM-UNLP), Francisco Prevosti (CONICET; CRILAR), Esteban Soilberson (FCNyM-UNLP), Leandro Pérez (CONICET; FCNyM-UNLP), Sergio Eduardo Miquel (CONICET; MACNBR), Ariel Beltramino (CONICET; FCEQyN-UNM), Federico Degrange (CONICET; CICTERRA) y Diego Verzi (FCNyM-UNLP). 


\section{RESUMEN}

En esta tesis se investiga la ocupación indígena de la cuenca media e inferior del río Uruguay en la provincia de Entre Ríos. Se busca reconstruir los patrones adaptativos y la trayectoria histórica de las poblaciones indígenas desde el Pleistoceno final al siglo XVI, integrando la información producida con anterioridad con nueva evidencia original. La tesis se organiza en nueve capítulos. En el Capítulo 1 se presenta el área de estudio dentro de la cual se seleccionaron tres sectores de muestreo (A, B y C) en distintos departamentos (Villaguay, Colón -Parque Nacional El Palmar-, y Gualeguaychú). Asimismo, se exponen los objetivos y los contenidos desarrollados de los capítulos siguientes. En el Capítulo 2 se sintetizan los antecedentes arqueológicos regionales y se extraen las tendencias generales relacionadas con los objetivos de esta investigación. En el Capítulo 3 se describe el marco ambiental del área de estudio. En el Capítulo 4 se expone el marco teórico y metodológico general. En los Capítulos 5, 6 y 7 se presentan y discuten los resultados procedentes de las prospecciones sistemáticas, de los sondeos estratigráficos y del análisis de los materiales arqueológicos (artefactos líticos, óseos y cerámicos, restos óseos humanos, faunísticos y vegetales) procedentes tanto de los trabajos de campo como de colecciones particulares y de museos locales. El Capítulo 5 corresponde al sector A, el Capítulo 6 al sector B, y el Capítulo 7 al sector C. En el Capítulo 8 se presentan y discuten los resultados de los estudios realizados en la localidad arqueológica Cerros de Boari ubicada dentro del sector $C$, donde se realizó la excavación sistemática del sitio arqueológico Cerro de Boari 3. En el Capítulo 9 se realiza la discusión integral e interpretación de todos los resultados obtenidos, y a partir de ellas se abordan algunos ejes temáticos generales de la arqueología regional. Asimismo, se exponen las conclusiones de esta investigación, donde se plantea que la mayoría de las evidencias arqueológicas corresponden al Holoceno tardío. También que los sectores A y B fueron ocupados por grupos indígenas cazadoresrecolectores y alfareros vinculados a los ambientes fluviales propios de cada sector. El sector $\mathrm{C}$ fue ocupado por dos poblaciones indígenas diferentes, ambas con una marcada adaptación a ambientes fluviales y a la explotación intensiva de sus recursos. La primera representada por grupos canoeros ribereños cazadores-recolectores-pescadores y alfareros (y posiblemente horticultores), constructores de montículos y con una alta estabilidad residencial. La segunda representada por grupos guaraníes, canoeros ribereños cazadores-recolectores-pescadores, alfareros y agricultores. Durante el Holoceno tardío cada uno de estos grupos habría estado integrado en un sistema macroregional de interacción e integración, que incluía la circulación de bienes, recursos, personas e ideas utilizando preponderantemente como vías de conexión los cursos fluviales de la cuenca meridional del Plata. 


\section{ABSTRACT}

This thesis is a research of the indigenous occupation of the middle and lower Uruguay River basin in the Entre Ríos Province. The adaptive patterns and the historical trajectory of the indigenous populations from the late Pleistocene to the sixteenth century are reconstructed by integrating information previously produced with new original evidence. The thesis is organized in nine chapters. Chapter 1 presents the study area and the three sampling sectors (A, B and C) selected at different departments (Villaguay, Colón -El Palmar National Park-, and Gualeguaychú). The objectives and contents developed in the following chapters are also presented. Chapter 2 synthesizes the regional archaeological background and provide general tendencies related to the goals of this thesis. Chapter 3 describes the environmental framework of the study area. Chapter 4 presents the general theoretical and methodological framework of the thesis. Chapters 5, 6 and 7 present and discuss results from systematic surveys, stratigraphic shovels tests, and analysis of the archaeological materials (lithics, pottery and faunal bone artifacts, human, faunal and plants remains) from fieldworks and private and local museum collections. Chapter 5 corresponds to sector A, Chapter 6 to sector B, and Chapter 7 to sector C. Chapter 8 presents and discusses the results of studies in the Cerros de Boari archeological locality, located in sector C, where the systematic excavation of Cerro de Boari 3 archeological site was carried out. Chapter 9 comprise the discussion and interpretation all the obtained results. In addition, the conclusions of this research are presented. It is argued that most of the archaeological evidence corresponds to the late Holocene. Sectors A and B were occupied by hunter-gatherers and potters adapted to the fluvial environments typical of each sector. Two different indigenous populations, both markedly adapted to fluvial environments and the intensive exploitation of their resources, occupied sector $\mathrm{C}$. The first is represented by riverine canoe people hunter-gatherer-fishermen and potters (and possibly horticulturists), mound builders and with a high residential stability. Guarani groups, riverine canoe people hunter-gatherers-fishermen, farmers and potters represent the second. During the late Holocene each of these groups would have been integrated into a macroregional interaction and integration system that included the circulation of goods, resources, people and ideas using the river courses of the southern La Plata River basin preponderantly as channels. 
Capítulo 1. INTRODUCCIÓN --

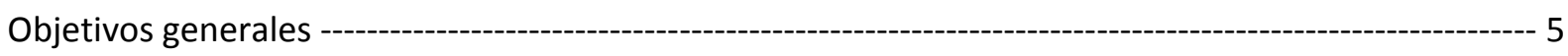

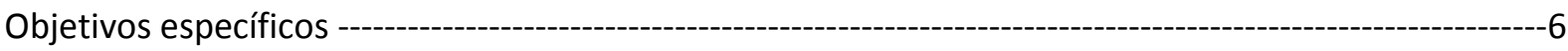

Capítulo 2. ANTECEDENTES --------11

2.1- LOS PRIMEROS DATOS ARQUEOLÓGICOS SOBRE EL NORDESTE --------13

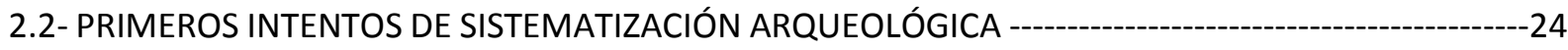

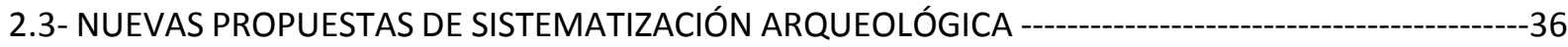

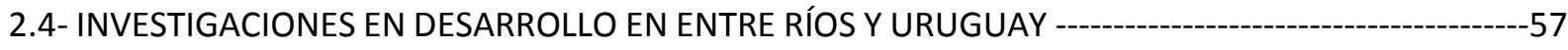

2.5- CONSIDERACIONES FINALES ---

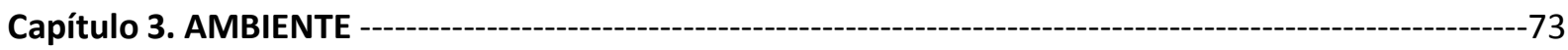

3.1- GEOLOGÍA ---

3.1.1- ESTRATIGRAFÍA REGIONAL ---

3.1.2- GEOMORFOLOGÍA --

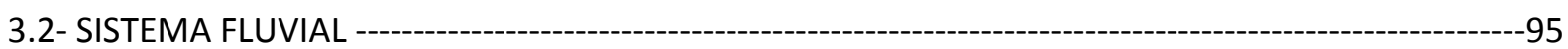

3.3- CONDICIONES CLIMÁTICAS ---1.---10

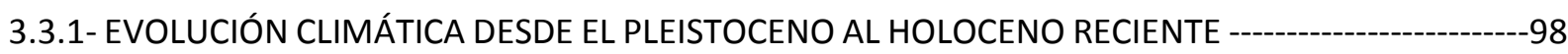

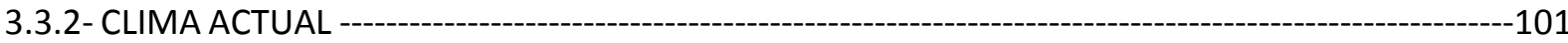

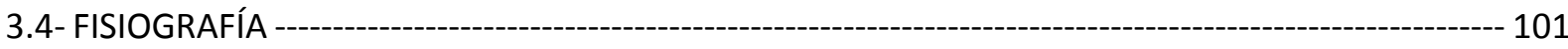

3.4.1- FITOGEOGRAFÍA ----------101

3.4.2- ZOOGEOGRAFÍA -----------104

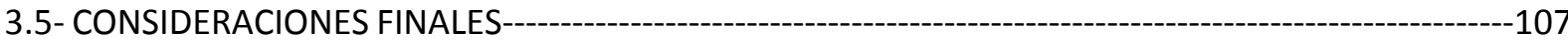

Capítulo 4. MARCO CONCEPTUAL Y METODOLÓGICO

4.1- CONCEPTOS TEÓRICOS GENERALES --111

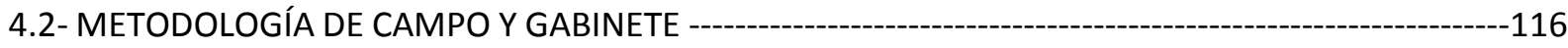

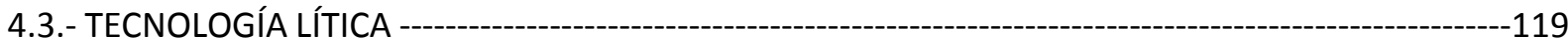

4.4- TECNOLOGÍA CERÁMICA ---

4.5- EXPLOTACIÓN FAUNÍSTICA ---

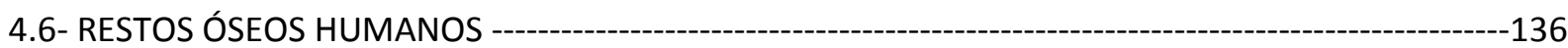

4.7- ANÁLISIS SEDIMENTOLÓGICOS, FITOLÍTICOS Y ANTRACOLÓGICOS EN LA LOCALIDAD ARQUEOLÓGICA CERROS DE BOARI --- 
Capítulo 5. DISTRIBUCIÓN ESPACIO-TEMPORAL Y CARACTERIZACIÓN DEL REGISTRO ARQUEOLÓGICO

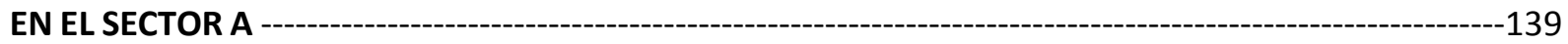

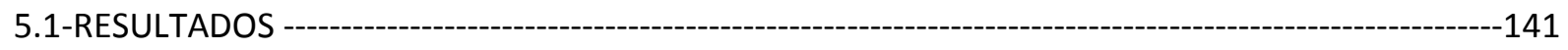

5.1.1- SITIOS ARQUEOLÓGICOS Y HALLAZGOS AISLADOS --

5.1.1.1- Descripción contextual de los sitios arqueológicos y sus conjuntos artefactuales --------------144

5.1.1.2- Descripción contextual de los hallazgos aislados y sus conjuntos artefactuales -----------------148

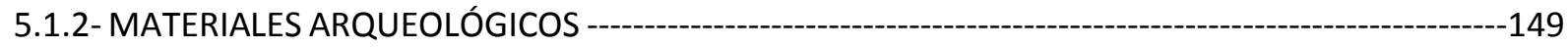

5.1.2.1- Estructura del conjunto lítico ---150

5.1.2.2- Estructura del conjunto cerámico ---159

5.1.3- MATERIALES ARQUEOLÓGICOS DEL MUSEO TIERRA DE MINUANES -----162

5.1.3.1- Artefactos líticos del Museo Tierra de Minuanes --

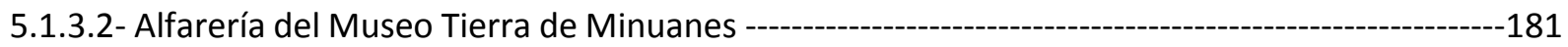

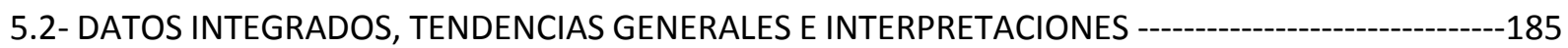

5.2.1- EL REGISTRO ARQUEOLÓGICO ---185

5.2.2- CONJUNTO LÍTICO -

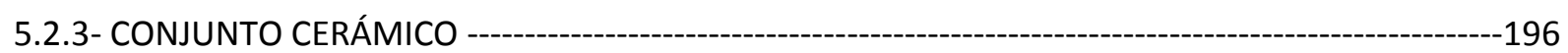

5.3- CONSIDERACIONES FINALES ---

Capítulo 6. DISTRIBUCIÓN ESPACIO-TEMPORAL Y CARACTERIZACIÓN DEL REGISTRO ARQUEOLÓGICO

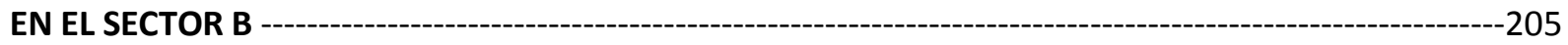

6.1- RESULTADOS -- 207

6.1.1- SITIOS ARQUEOLÓGICOS Y HALLAZGOS AISLADOS ---

6.1.1.1- Descripción contextual de los sitios arqueológicos y sus conjuntos artefactuales --------------209

6.1.1.2- Descripción contextual de los hallazgos aislados y sus conjuntos artefactuales -----------------212

6.1.2- MATERIALES ARQUEOLÓGICOS --214

6.1.2.1- Estructura del conjunto lítico --

6.1.2.2- Estructura del conjunto cerámico --

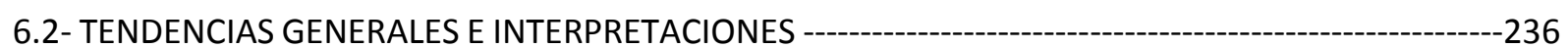

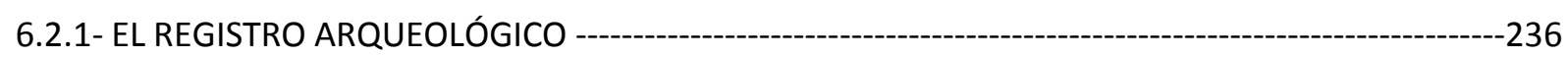

6.2.2. CONJUNTO LÍTICO --

6.2.3- CONJUNTO CERÁMICO -- 243

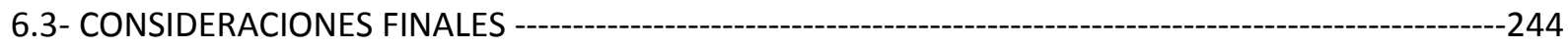

Capítulo 7. DISTRIBUCIÓN ESPACIO-TEMPORAL Y CARACTERIZACIÓN DEL REGISTRO ARQUEOLÓGICO

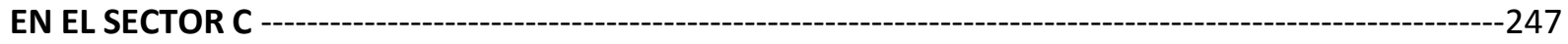

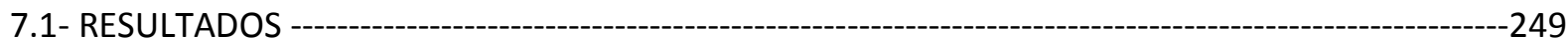


7.1.1.1- Descripción contextual de los sitios arqueológicos y sus conjuntos artefactuales --------------251

7.1.1.2- Descripción contextual de los hallazgos aislados y sus conjuntos artefactuales -----------------258

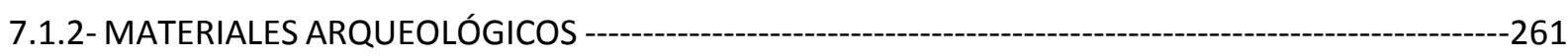

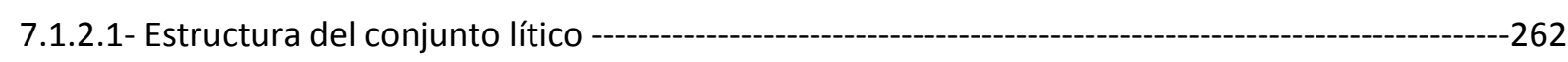

7.1.2.2- Estructura del conjunto cerámico ---

7.1.2.3- Estructura del conjunto faunístico ---

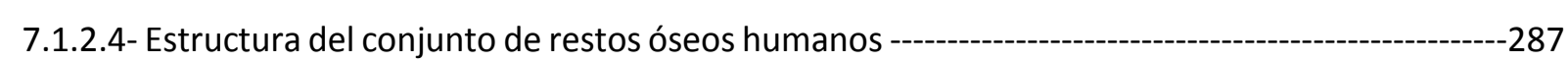

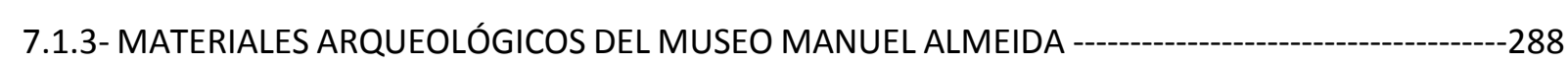

7.1.3.1- Artefactos líticos del Museo Arqueológico Manuel Almeida -----------------------------------290

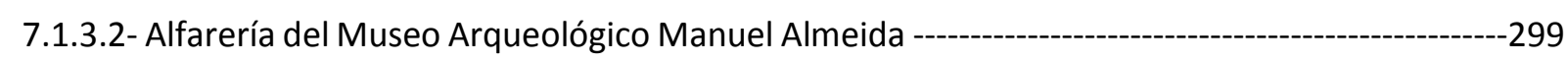

7.1.3.3- Tecnología ósea y arqueofauna del Museo Arqueológico Manuel Almeida -------------------312

7.1.3.4- Restos óseos humanos del Museo Arqueológico Manuel Almeida ----------------------------323

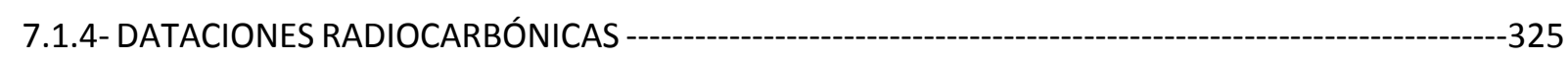

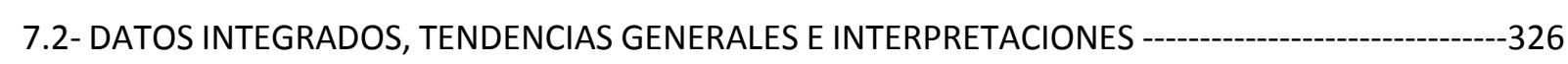

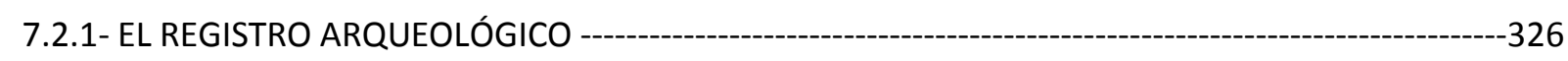

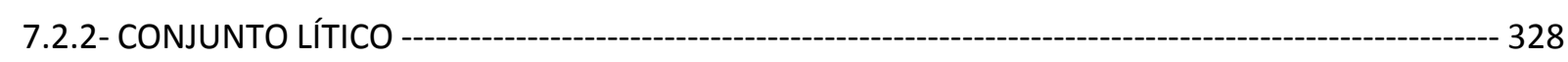

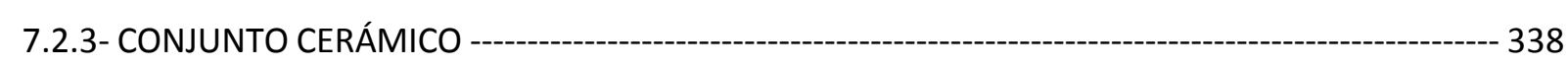

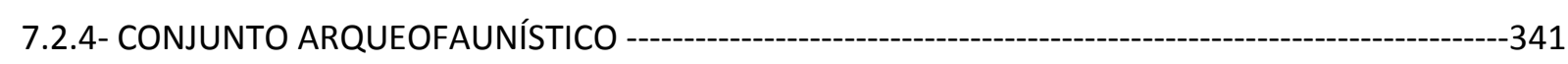

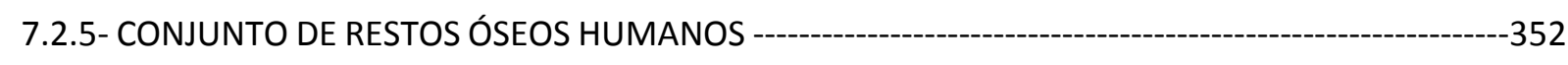

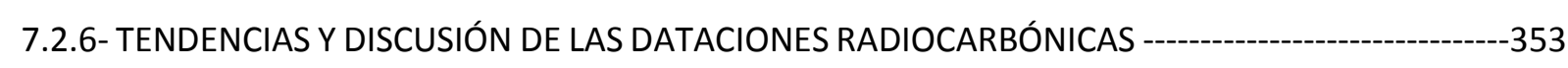

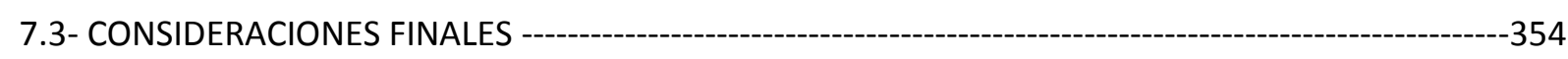

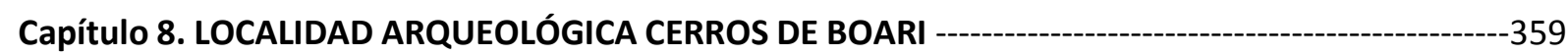

8.1- RESULTADOS -- 361

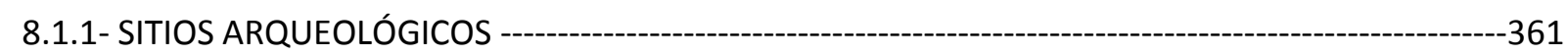

8.1.1.1- Descripción contextual de los sitios arqueológicos y sus conjuntos artefactuales --------------362

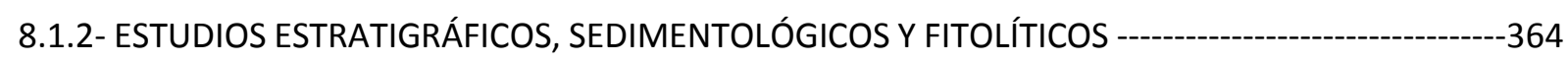

8.1.2.1- Resultados de los estudios sedimentológicos ---

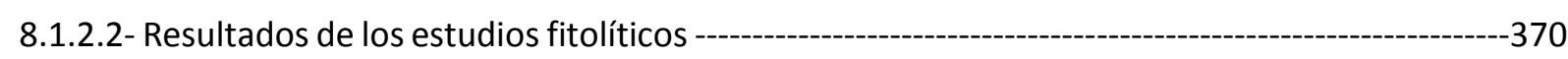

8.1.3- DATACIONES RADIOCARBÓNICAS ---

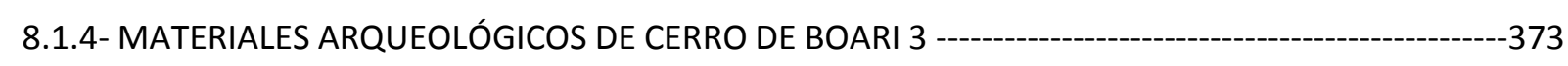

8.1.4.1- Estructura del conjunto lítico de Cerro de Boari 3 -------------------------------------------------374

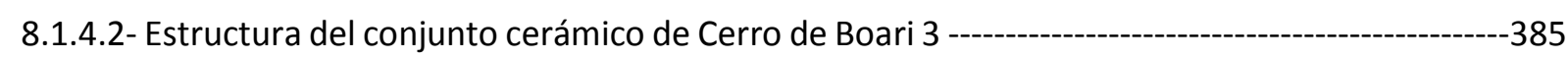

8.1.4.3- Estructura del conjunto faunístico de Cerro de Boari 3 ---------------------------------------390

8.1.4.4- Estructura del conjunto de restos óseos humanos de Cerro de Boari 3 --------------------------397 


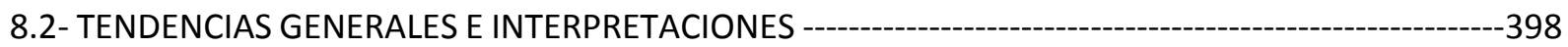

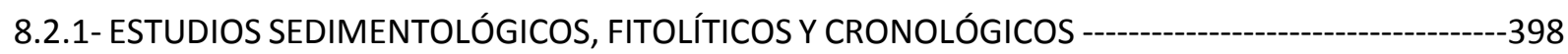

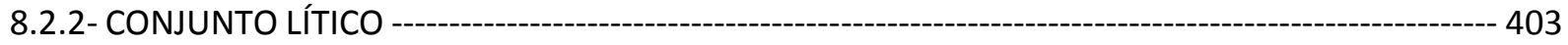

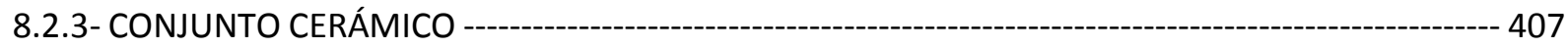

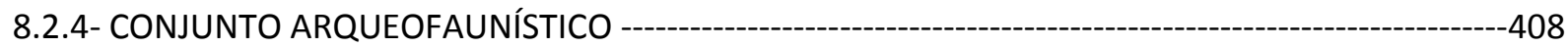

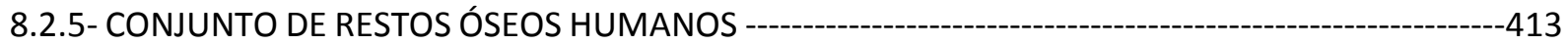

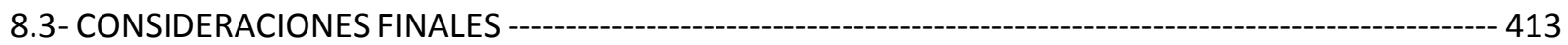

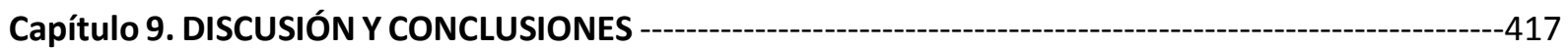

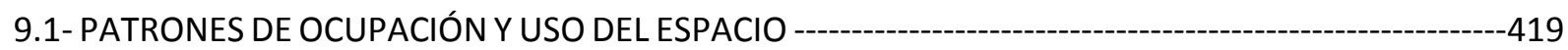

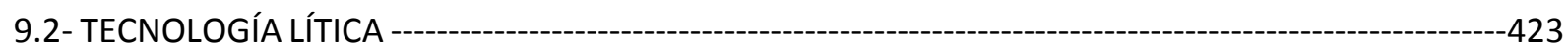

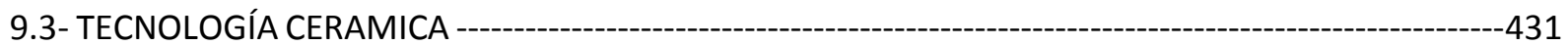

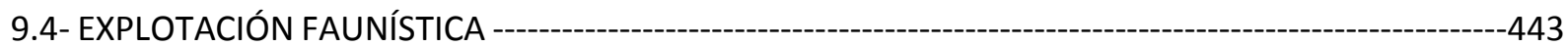

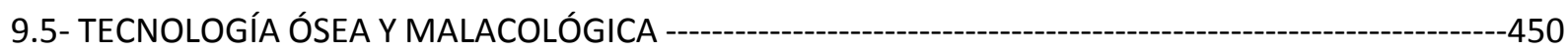

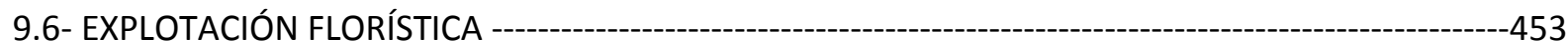

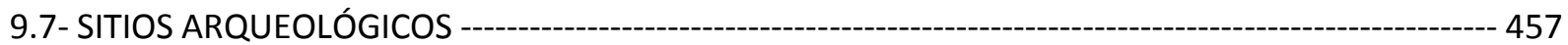

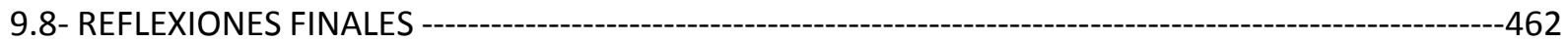

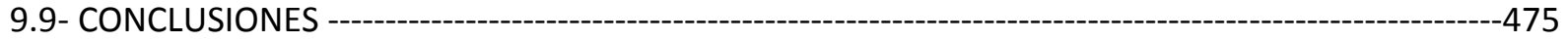

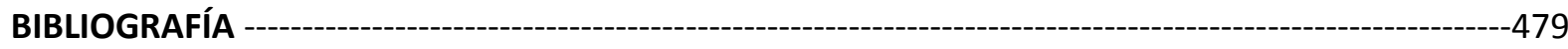

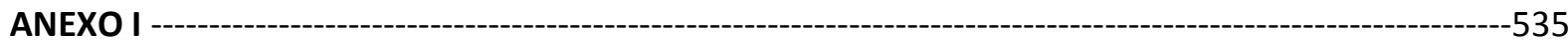




\section{LISTA DE TABLAS}

Tabla 2.1a. Dataciones absolutas para la cuenca media en inferior del río Uruguay (Argentina). ------69

Tabla 2.1b. Dataciones absolutas para la cuenca media en inferior del río Uruguay (Uruguay). --------70

Tabla 3.1. Modelo de evolución paleoclimática y paleoambiental para el Holoceno. $-100$

Tabla 4.1. Expectativas arqueológicas para movilidad baja por clase tipológica. $-123$

Tabla 4.2. Calidad de las materias primas líticas regionales 127

Tabla 5.1. Sitios arqueológicos y hallazgos aislados en el sector $A$. $-142$

Tabla 5.2. Materiales arqueológicos del sector $A$. $-149$

Tabla 5.3. Materias primas por clases tipológicas en el sector A. $-150$

Tabla 5.4. Instrumentos líticos del sector $A$. $-151$

Tabla 5.5. Estado de fragmentación de la muestra de desechos de talla del sector A. $-152$

Tabla 5.6. Tipos de lascas por conjuntos líticos del sector $A$. $-153$

Tabla 5.7. Distribución de la forma e inclinación del talón en relación a la forma del bulbo. $-155$

Tabla 5.8. Presencia de labio según las formas de los bulbos de percusión. 156

Tabla 5.9. Distribución de tipos de lascas según la proporción de corteza y negativos de lascados. --157

Tabla 5.10. Dimensiones relativas de las lascas enteras del sector $A$. $-158$

Tabla 5.11. Núcleos del sector A. $-159$

Tabla 5.12. Materiales arqueológicos de la colección del Museo Tierra de Minuanes (MTM). $-164$

Tabla 5.13. Materias primas por clases tipológicas de los materiales arqueológicos del MTM. $-165$

Tabla 5.14. Instrumentos líticos del MTM. $-166$

Tabla 5.15. Materias primas de bolas y puntas de proyectil del MTM. $-167$

Tabla 5.16. Clasificación de las bolas del MTM según González (1953). $-168$

Tabla 5.17. Distribución geográfica de las bolas identificadas en colecciones y bibliografía. $-171$

Tabla 5.18. Subgrupos tipológicos de puntas de proyectil del MTM. $-174$

Tabla 5.19. Morfología de los bordes y base de los pedúnculos de las puntas de proyectil del MTM. 175 Tabla 5.20. Instrumentos líticos del MTM. $-178$

Tabla 5.21. Materias primas de los desechos de talla del MTM. $-180$

Tabla 6.1. Sitios arqueológicos y hallazgos aislados en el sector B. 208

Tabla 6.2. Materiales arqueológicos del sector $B$.

Tabla 6.3. Materias primas por clases tipológicas en el sector $B$. 
Tabla 6.4. Instrumentos líticos del sector $\mathrm{B}$.

Tabla 6.5. Estado de fragmentación de la muestra de desechos de talla del sector B. -----------------220

Tabla 6.6. Tipos de lascas por conjuntos líticos del sector B. ---------------------------------------------------221

Tabla 6.7. Distribución de la forma e inclinación del talón en relación a la forma del bulbo. -----------224

Tabla 6.8. Presencia de labio según las formas de los bulbos de percusión. -------------------------------225

Tabla 6.9. Distribución de tipos de lascas según la proporción de corteza y negativos de lascados. --227

Tabla 6.10. Módulo longitud-anchura de las lascas enteras del sector B. ---------------------------------228

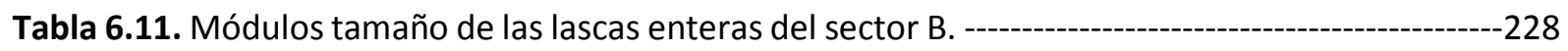

Tabla 6.12. Espesores relativos de las lascas enteras del sector B. -------------------------------------------228

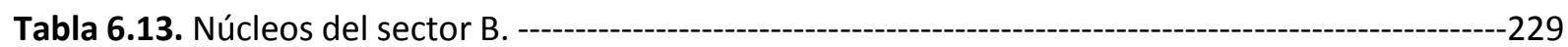

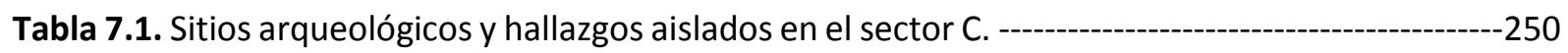

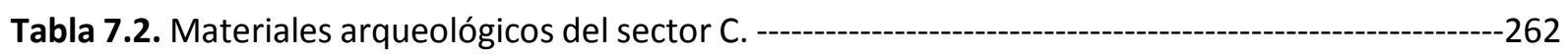

Tabla 7.3. Materias primas por clases tipológicas en el sector C. -------------------------------------------263

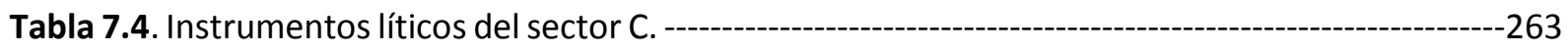

Tabla 7.5. Estado de fragmentación de la muestra de desechos de talla del sector C. -----------------264

Tabla 7.6. Tipos de lascas por conjuntos líticos del sector C. -------------------------------------------------265

Tabla 7.7. Distribución de la forma e inclinación del talón en relación a la forma del bulbo. -----------267

Tabla 7.8. Presencia de labio según las formas de los bulbos de percusión. ------------------------------268

Tabla 7.9. Distribución de tipos de lascas según la proporción de corteza y negativos de lascados. --269

Tabla 7.10. Módulo longitud-anchura de las lascas enteras del sector C. ---------------------------------270

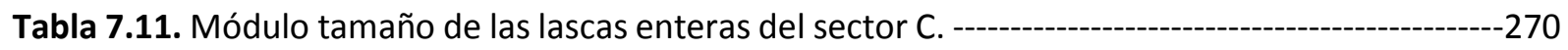

Tabla 7.12. Espesores relativos de las lascas enteras del sector C. -------------------------------------------270

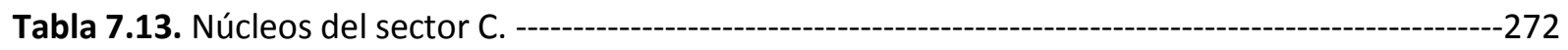

Tabla 7.14. Abundancia taxonómica de los sitios arqueológicos del sector C. -----------------------------278

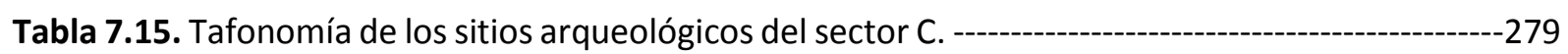

Tabla 7.16. Instrumentos óseos de Cerro Lorenzo 2 y Sambaquí de Puerto Landa. ----------------------285

Tabla 7.17. Materiales arqueológicos de la colección del Museo Manuel Almeida (MAMA). -----------289

Tabla 7.18. Materias primas por clases tipológicas de los materiales arqueológicos del MAMA. ------290

Tabla 7.19. Clasificación de las bolas del MAMA según González (1953) y piedras lenticulares. -------291

Tabla 7.20. Subgrupos tipológicos de puntas de proyectil de colecciones del sector C. ------------------295

Tabla 7.21. Morfología de limbos y pedúnculos de las puntas de proyectil del sector C. ---------------296

Tabla 7.22a. Tratamiento de superficie de la alfarería guaraní del MAMA. --------------------------------307

Tabla 7.22b. Tratamiento de superficie de la alfarería guaraní del MAMA. ------------------------------308

Tabla 7.23a. Artefactos óseos y especímenes faunísticos del MAMA. --------------------------------------314

Tabla 7.23b. Artefactos óseos y especímenes faunísticos del MAMA. --------------------------------------315 
Tabla 7.23c. Artefactos óseos y especímenes faunísticos del MAMA.

Tabla 7.23d. Artefactos óseos y especímenes faunísticos del MAMA.

Tabla 7.24. Estructura del registro de restos óseos humanos del sector $C$.

Tabla 7.25. Dataciones radiocarbónicas obtenidas para el sector $\mathrm{C}$.

Tabla 8.1. Dataciones radiocarbónicas obtenidas en la localidad arqueológica Cerros de Boari. ------372

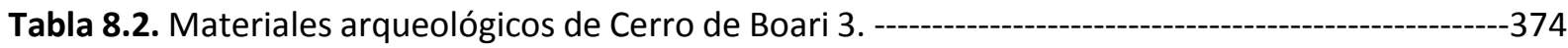

Tabla 8.3. Materias primas por clases tipológicas de Cerro de Boari 3. --------------------------------374

Tabla 8.4. Instrumentos líticos de Cerro de Boari 3. - -

Tabla 8.5. Estado de fragmentación de la muestra de desechos de talla de Cerro de Boari 3. ---------378

Tabla 8.6. Tipos de lascas por conjuntos líticos de Cerro de Boari 3. -

Tabla 8.7. Distribución de la forma e inclinación del talón en relación a la forma del bulbo. -----------379

Tabla 8.8. Presencia de labio según las formas de los bulbos de percusión. ---

Tabla 8.9. Distribución de tipos de lascas según la proporción de corteza y negativos de lascados. --381

Tabla 8.10. Módulo longitud-anchura de las lascas enteras de Cerro de Boari 3. ------------------------382

Tabla 8.11. Módulo tamaño de las lascas enteras de Cerro de Boari 3. ------------------------------382

Tabla 8.12. Espesores relativos de las lascas enteras de Cerro de Boari 3. ---------------------------382

Tabla 8.13. Núcleos de Cerro de Boari 3. -------

Tabla 8.14. Distribución de perfiles, bordes, labios y diámetros entre las vasijas reconstruidas. ------388

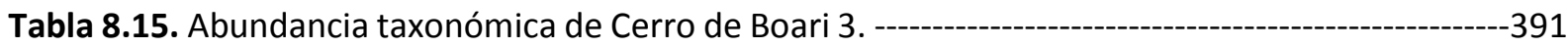

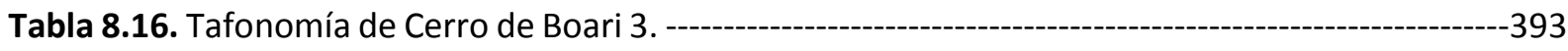

Tabla 8.17. Instrumentos óseos de Cerro de Boari 3. 


\section{LISTA DE FIGURAS}

Figura 1.1. Mapa de Entre Ríos mostrando el área de estudio y los sectores de muestreo ( $A, B$ y $C$ ).---4

Figura 1.2. Sector A. - -

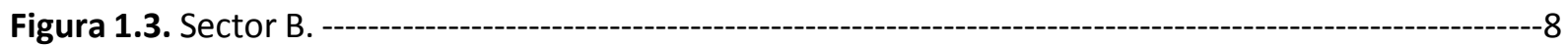

Figura 1.4. Sector C. -

Figura 2.1. Estanislao Zeballos. --

Figura 2.2. Ramón Lista. -

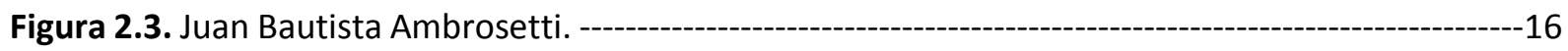

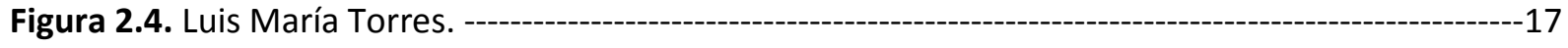

Figura 2.5. Félix Outes. ---

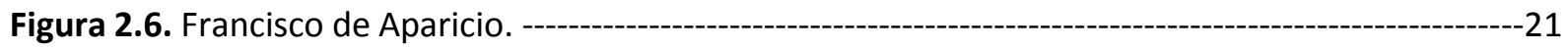

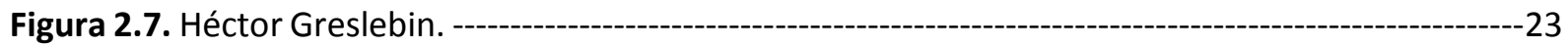

Figura 2.8. Antonio Serrano. ---

Figura 2.9. Excavación en Gualeguaychú en 1933. -

Figura 2.10. Recolección de materiales arqueológicos en los médanos de Paso Paysandú. -------------28

Figura 2.11. Esquema cultural propuesto por Antonio Serrano en 1972. -

Figura 2.12. Víctor Badano. -----o-35

Figura 2.13. Excavación de Lafon en el sitio arqueológico El Aserradero. --

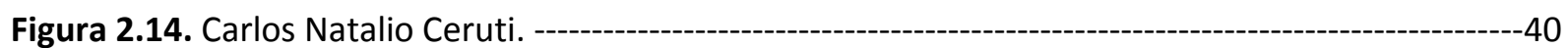

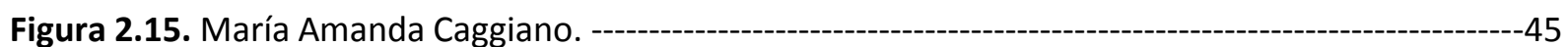

Figura 2.16. Excavación de Cigliano y colaboradores en Salto Grande. ---

Figura 2.17. Amílcar Rodríguez y Jorge Rodríguez. --

Figura 3.1. Mapa de la provincia de Entre Ríos y los sectores de muestreo (A, B y C). --------------------76

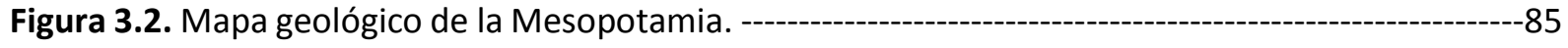

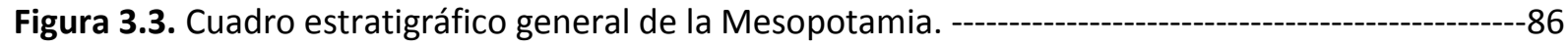

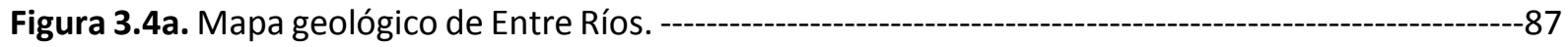

Figura 3.4b. Referencias geológicas ampliadas de la Figura 3.4a. ----------------------------------------88

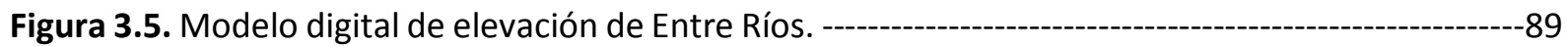

Figura 3.6. Llanura alta entrerriana, departamento Villaguay. ---

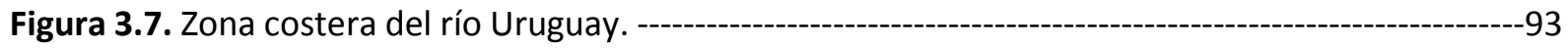

Figura 3.8. Zona de Llanura costera al sur de la desembocadura del río Gualeguaychú. ----------------95

Figura 3.9. Mapas donde se representa la extensión territorial de la Selva de Montiel.---------------103 
Figura 4.1. Área de estudio y sectores de muestreo A, B y C.

Figura 4.2. Modelo de Kuhn (1994), movilidad, aprovisionamiento y transporte de recursos líticos.-122

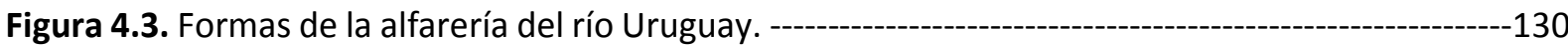

Figura 4.4. Formas predominantes de la alfarería guaraní según las clases funcionales. ---------------132

Figura 5.1. Sector A indicando los sitios arqueológicos y los hallazgos aislados. -------------------------143

Figura 5.2. Sitios arqueológicos del sector A. -

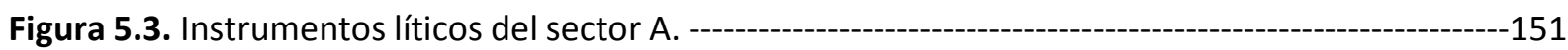

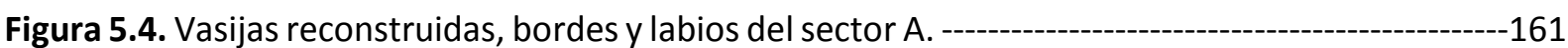

Figura 5.5. Fragmentos de alfarería decorada registrados en el sector A. ---------------------------------162

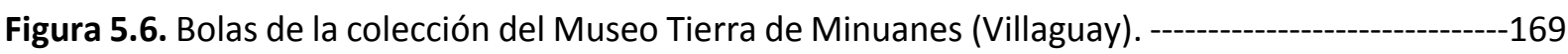

Figura 5.7. Bolas de distintas colecciones de la provincia de Entre Ríos. -------------------------------173

Figura 5.8. Puntas de proyectil de la colección del Museo Tierra de Minuanes (Villaguay). -------------177

Figura 5.9. Fragmentos de alfarería decorada y modelada del Museo Tierra de Minuanes. ------------184

Figura 6.1. Sector B indicando los sitios arqueológicos y los hallazgos aislados. --------------------------209

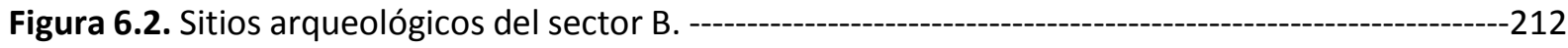

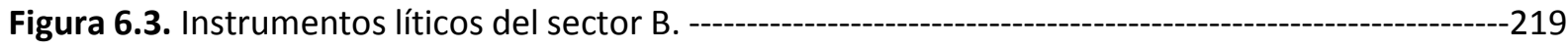

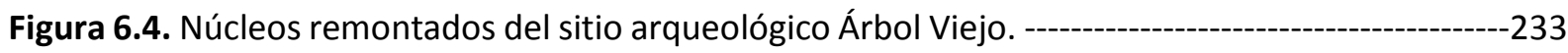

Figura 6.5. Vasijas reconstruidas, bordes y labios del Sector B. ------------------------------------------------235

Figura 7.1. Sector $C$ indicando los sitios arqueológicos y los hallazgos aislados. --------------------------251

Figura 7.2. Sitios arqueológicos del sector C. -

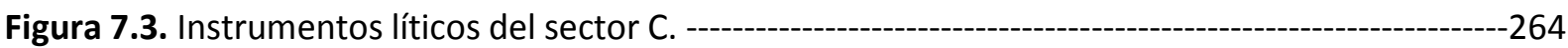

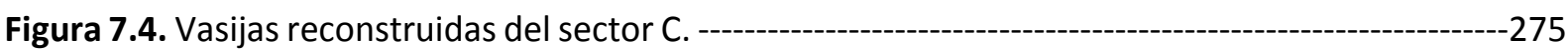

Figura 7.5. Fragmentos de alfarería decorada registrados en sector C. -----------------------------------276

Figura 7.6. Instrumentos óseos, adornos y artefactos decorados recuperados en el sector C. ---------287

Figura 7.7. Instrumentos líticos del Museo Arqueológico Manuel Almeida. -------------------------------294

Figura 7.8. Instrumentos líticos y núcleo del Museo Arqueológico Manuel Almeida. --------------------298

Figura 7.9. Alfarería Goya-Malabrigo del Museo Arqueológico Manuel Almeida. -------------------------302

Figura 7.10. Alfarería Goya-Malabrigo del Museo Arqueológico Manuel Almeida. ------------------------305

Figura 7.11. Alfarería guaraní y con rasgos combinados del Museo Arqueológico Manuel Almeida.--311

Figura 7.12. Instrumentos óseos del Museo Arqueológico Manuel Almeida. -----------------------------319

Figura 7.13. Instrumentos y artefactos óseos y adornos de valvas del MAMA. ----------------------------322

Figura 7.14. Tubos y artefactos óseos decorados del Museo Arqueológico Manuel Almeida. ---------323 
Figura 7.15. Afloramientos de arenisca de la Formación Salto Chico en el río Gualeguaychú.

Figura 8.1. Esquema topográfico de la localidad arqueológica Cerros de Boari. ---------------------------362

Figura 8.2. Sitios de la localidad arqueológica Cerros de Boari. ----------------------------------------------364

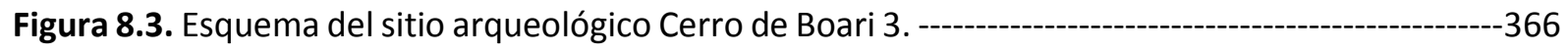

Figura 8.4. Triángulo de clasificación textural de Folk (1954) (fango, arcilla y limo). --------------------367

Figura 8.5. Triángulo de clasificación textural de Folk (1954) (grava, fango y arena). --------------------368

Figura 8.6. Composición sílico y bioclástica de las muestras sedimentarias del Grupo N. -------------369

Figura 8.7. Composición sílico y bioclástica de las muestras sedimentarias del Grupo A. ----------------370

Figura 8.8. Microrestos biosilíceos presentes en el sitio arqueológico Cerro de Boari 3. --------------371

Figura 8.9. Niveles estratigráficos y dataciones radiocarbónicas de Cerro de Boari 3. --------------------373

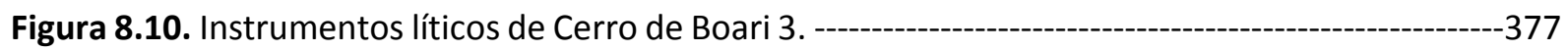

Figura 8.11. Alfarería decorada y modelada de Cerro de Boari 3. ---------------------------------------------386

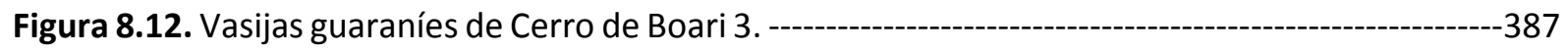

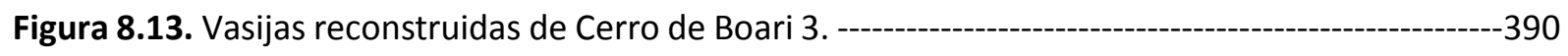

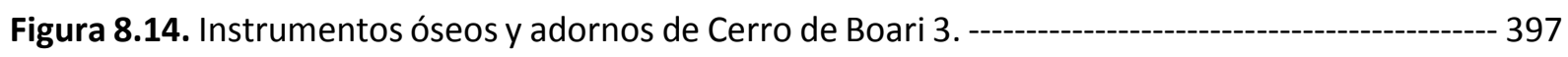

Figura 8.15. Secuencia estratigráfica del sitio arqueológico Cerro de Boari 3. -------------------------------400

Figura 8.16. Curvas de calibración $(1 \sigma)$ de las edades radiocarbónicas de Cerro de Boari 3. -----------402

Figura 8.17. Secuencia cronoestratigráfica de Cerro de Boari 3. ---------------------------------------------402

Figura 9.1. Representación esquemática de la circulación de materias primas líticas. -------------------427

Figura 9.2. Ubicación de los sitios arqueológicos Goya-Malabrigo en el río Uruguay inferior. ----------435

Figura 9.3. Alfarería Goya-Malabrigo de la cuenca del río Uruguay y del Río de la Plata (ROU). -------437

Figura 9.4. Modelados antropomorfos de la cuenca media e inferior río Uruguay. ---------------------438

Figura 9.5. Placas de cobre y bronce del NEA y la ROU procedentes del área andina. -------------------443 


\section{CAPÍTULO 1}

\section{INTRODUCCIÓN}

Esta tesis doctoral es un trabajo de investigación arqueológica que aborda la historia indígena de la cuenca media e inferior del río Uruguay. Se compone de nueve capítulos donde se presentan y discuten los resultados y se exponen las conclusiones generadas en base a los mismos. El presente Capítulo 1 constituye una vía introductoria al área de estudio, a las temáticas abordadas, a los objetivos de la investigación y a los contenidos desarrollados de los capítulos siguientes.

En tiempos prehispánicos la cuenca del río Uruguay ha sido intensamente ocupada por distintas poblaciones (p. ej. chaná-timbú, charrúas, genoa-minuanos y guaraníes). Por esta razón, su estudio reviste una particular importancia arqueológica para comprender los procesos culturales del pasado, no solo del Nordeste argentino (NEA) sino también de países vecinos como la República Oriental del Uruguay (ROU) y Brasil. Particularmente el abordaje de la margen argentina del río Uruguay se torna relevante dado que presenta una relativa escasez de conocimientos arqueológicos (Rodríguez y Ceruti 1999). Esta última situación es la que se pretendió comenzar a revertir con el desarrollo del proyecto "Investigaciones arqueológicas en la cuenca media e inferior del río Uruguay (provincia de Entre Ríos)"11, aportando información relevante que permitiera contrastar los modelos explicativos propuestos para la región (p. ej. Bonomo et al. 2015; Caggiano 1984; Lafon 1972; Politis y Bonomo 2012; Rodríguez 2006; Rodríguez y Ceruti 1999; y Serrano 1972), y/o proponer interpretaciones alternativas.

El área estudio se encuentra dentro de la provincia de Entre Ríos y abarca los departamentos Colón, Concepción del Uruguay, Gualeguaychú y Villaguay (Figura 1.1). Sus límites son: al norte el arroyo Grande o del Pedernal, al sur el arroyo Ñancay, al este el río Uruguay y al oeste el río Gualeguay. Se incluye dentro de lo que Iriondo y Kröhling (2009: 22) denominan cuenca media e inferior del río Uruguay. Ambos tramos del río suman una longitud aproximada de $700 \mathrm{~km}$ que se extienden desde el río Aguapey en Corrientes hasta el Río de la Plata. Dentro de esta área se seleccionaron tres sectores de muestreo (A, B y C) en tres departamentos para realizar los trabajos de campo de manera intensiva. El sector A se encuentra dentro del departamento Villaguay, el sector

\footnotetext{
1 Proyecto de investigación desarrollado desde la División Arqueología del Museo de Ciencias Naturales y Antropológicas "Profesor Antonio Serrano", Castro 2007. El mismo contó con el apoyo del CONICET entre los años 2010 y 2013 mediante una Beca Doctoral Tipo I.
} 
B corresponde al Parque Nacional El Palmar en el departamento Colón y el sector C se encuentra dentro del departamento Gualeguaychú.

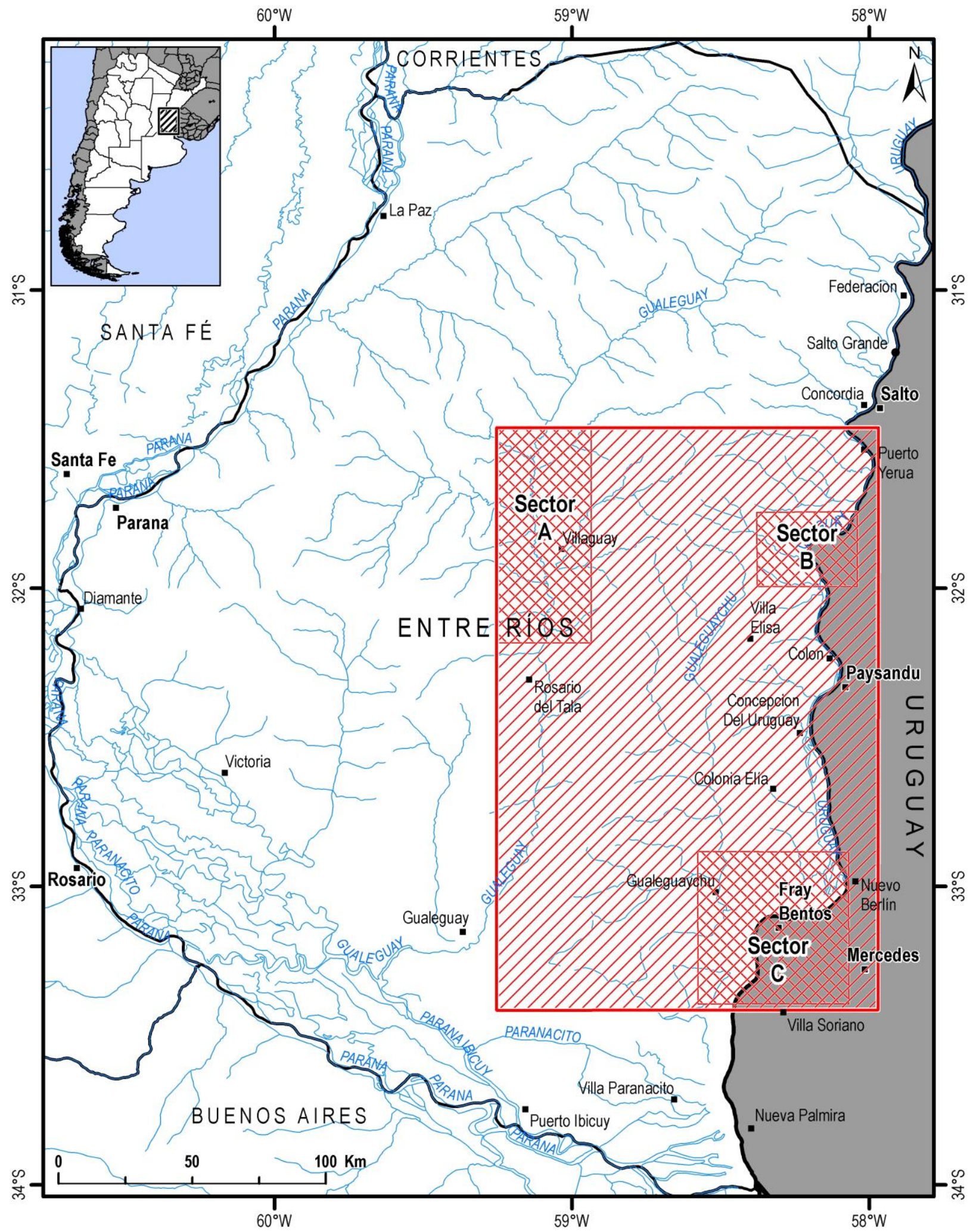

Figura 1.1. Mapa de la provincia de Entre Ríos mostrando el área de estudio y los sectores de muestreo (A, B y C). 
Desde un punto de vista ecológico en el área de estudio se reconocen dos grandes ambientes claramente diferenciados, a los que se prestó particular atención: la zona costera del río Uruguay y la zona de llanuras interiores que son disectadas por el río Gualeguay, el curso de agua más importante del interior la provincia. Además de existir diferencias geomorfológicas entre estos dos ambientes se le agregan otras florísticas, ya que el primero se caracteriza por distintos tipos de bosques xerófilos, selvas de ribera, bosque en galería y palmares; y el segundo por la presencia de monte xerófilo, palmares, pajonales y pastizales (Cabrera 1976). Estas consideraciones son relevantes a la hora analizar la distribución y disponibilidad de recursos bióticos y abióticos, la probable la existencia de diferencias adaptativas entre los dos ambientes considerados, así como también para establecer las posibles relaciones entre el área estudiada y las regiones vecinas de la cuenca del Plata.

Esta investigación integró la información producida con anterioridad a nivel regional (Caggiano 1984; Capdepont 2012; Lafon 1972; Politis y Bonomo 2012; Rodríguez y Rodríguez 1985; Serrano 1972; Torres 1911; entre muchos otros) con nueva evidencia original procedente del área de estudio, ampliando así la base de datos generada con métodos sistemáticos para la región. A partir de ello se busca reconstruir los patrones adaptativos básicos y la trayectoria histórica de las sociedades indígenas que habitaron una porción la cuenca del río Uruguay desde el Pleistoceno final al siglo XVI, cuando arriban a la región los primeros conquistadores europeos.

Los resultados obtenidos proceden del análisis cuali-cuantitativo de varias fuentes de información como son: sitios arqueológicos en superficie y en estratigrafía, análisis bibliográfico y algunos análisis específicos (dataciones radiocarbónicas y estudios sedimentológicos, fitolíticos y antracológicos), así como también del estudio de colecciones arqueológicas particulares y de museos locales. Dentro de estas últimas específicamente se relevaron colecciones del Museo de Antropología y Ciencias Naturales de Concordia, del Museo Municipal de Conscripto Bernardi, del Museo Arqueológico y Antropológico Indígena Tierra de Minuanes de Villaguay, del Museo Arqueológico Manuel Almeida de Gualeguaychú, del Museo de Ciencias Naturales y Antropológicas Profesor Antonio Serrano y del Museo Histórico Martiniano Leguizamón, estos dos últimos de Paraná.

La amplitud temática de esta tesis y el enfoque básicamente regional están justificados en la escasez de información arqueológica obtenida de manera sistemática e interpretada de manera crítica. Al comienzo de estas investigaciones se plantearon objetivos generales y específicos dentro de los cuales se enmarcaron las tareas desarrolladas. Dichos objetivos son los siguientes:

\section{Objetivos generales:}

$\checkmark$ Caracterizar desde una perspectiva regional la ocupación humana prehispánica en el área de estudio.

$\checkmark \quad$ Identificar los componentes económicos básicos de los grupos humanos que habitaron cada uno de los dos ambientes del área de estudio (llanuras interiores y litoral fluvial), prestando 
especial atención a determinar si existieron dos patrones económicos básicos, como se menciona en las crónicas de los siglos XVI a XVII, y en qué medida estos pudieron ser complementados con la horticultura durante el Holoceno tardío.

$\checkmark$ Reconstruir la historia ocupacional del área, prestando particular atención a las diferencias que puedan existir entre los dos ambientes considerados durante el Pleistoceno finalHoloceno tardío.

$\checkmark$ Contribuir mediante el aporte de información relevante al conocimiento arqueológico de un sector de las Tierras Bajas sudamericanas.

\section{Objetivos específicos:}

$\checkmark$ Caracterizar los patrones de ocupación y uso del espacio a nivel regional.

$\checkmark$ Caracterizar desde un punto de vista tecnomorfológico los conjuntos líticos y localizar las posibles fuentes de aprovisionamiento de rocas y minerales.

$\checkmark$ Caracterizar los patrones morfológicos, tecnológicos y estilísticos de la tecnología cerámica.

$\checkmark$ Establecer cuáles fueron las especies faunísticas explotadas en cada uno de los dos ambientes particulares, tanto aquellas usadas con fines alimenticios como las utilizadas con otros fines (p. ej. ajuares funerarios y adornos).

$\checkmark$ Examinar la utilización de materiales faunísticos como materia prima en la manufactura y confección de instrumentos y adornos, y determinar las especies cuya explotación estuvo directamente vinculada con la producción de dichos artefactos.

$\checkmark \quad$ Establecer cuáles fueron las especies vegetales explotadas en cada uno de los dos ambientes particulares, tanto silvestres como domesticadas.

$\checkmark$ Determinar las características y funcionalidad de los sitios arqueológicos, tanto a nivel local como regional.

En el Capítulo 2 se sintetiza la información arqueológica publicada e inédita para el Nordeste argentino y la República Oriental del Uruguay desde fines del siglo XIX hasta la actualidad. Se presentan las temáticas particulares abordadas por los distintos autores y las corrientes teóricometodológicas dentro de las cuales trabajó cada uno de ellos. Por último, del conjunto de antecedentes se obtiene una caracterización del registro arqueológico conocido; y también se extraen las tendencias y las expectativas arqueológicas e ideas a contrastar relacionadas a los objetivos de esta tesis.

En el Capítulo 3 se presenta una caracterización ambiental de la región Nordeste de Argentina y en particular de la provincia de Entre Ríos y del área de estudio. Se describe la columna estratigráfica regional, la geomorfología, el sistema hídrico, las condiciones climáticas y paleoclimáticas, las ingresiones marinas que afectaron la región y la fisiografía. Todos estos aspectos 
son relacionados en los capítulos siguientes con los resultados de la investigación e interpretados desde una perspectiva arqueológica.

En el Capítulo 4 se expone el marco teórico y metodológico general de la tesis y se sintetizan algunos conceptos que permiten integrar los aspectos físicos y biológicos del ambiente con los aspectos culturales. También se definen, discuten y proponen algunos conceptos y categorías que fueron utilizados para el abordaje del registro arqueológico. Asimismo, se detallan las metodologías empleadas tanto en los trabajos de campo como en el análisis de los distintos materiales arqueológicos, sedimentarios, fitolíticos y antracológicos.

En los Capítulos 5, 6 y 7 se presentan y discuten los resultados de las prospecciones sistemáticas, de los sondeos estratigráficos y del análisis de los materiales arqueológicos procedentes tanto de los trabajos de campo como de colecciones particulares y de museos locales. El Capítulo 5 corresponde al sector A (Figura 1.2), donde los trabajos de campo permitieron identificar 14 sitios arqueológicos y nueve hallazgos aislados, todos en posición superficial. Los materiales arqueológicos incluyen artefactos líticos y cerámicos.

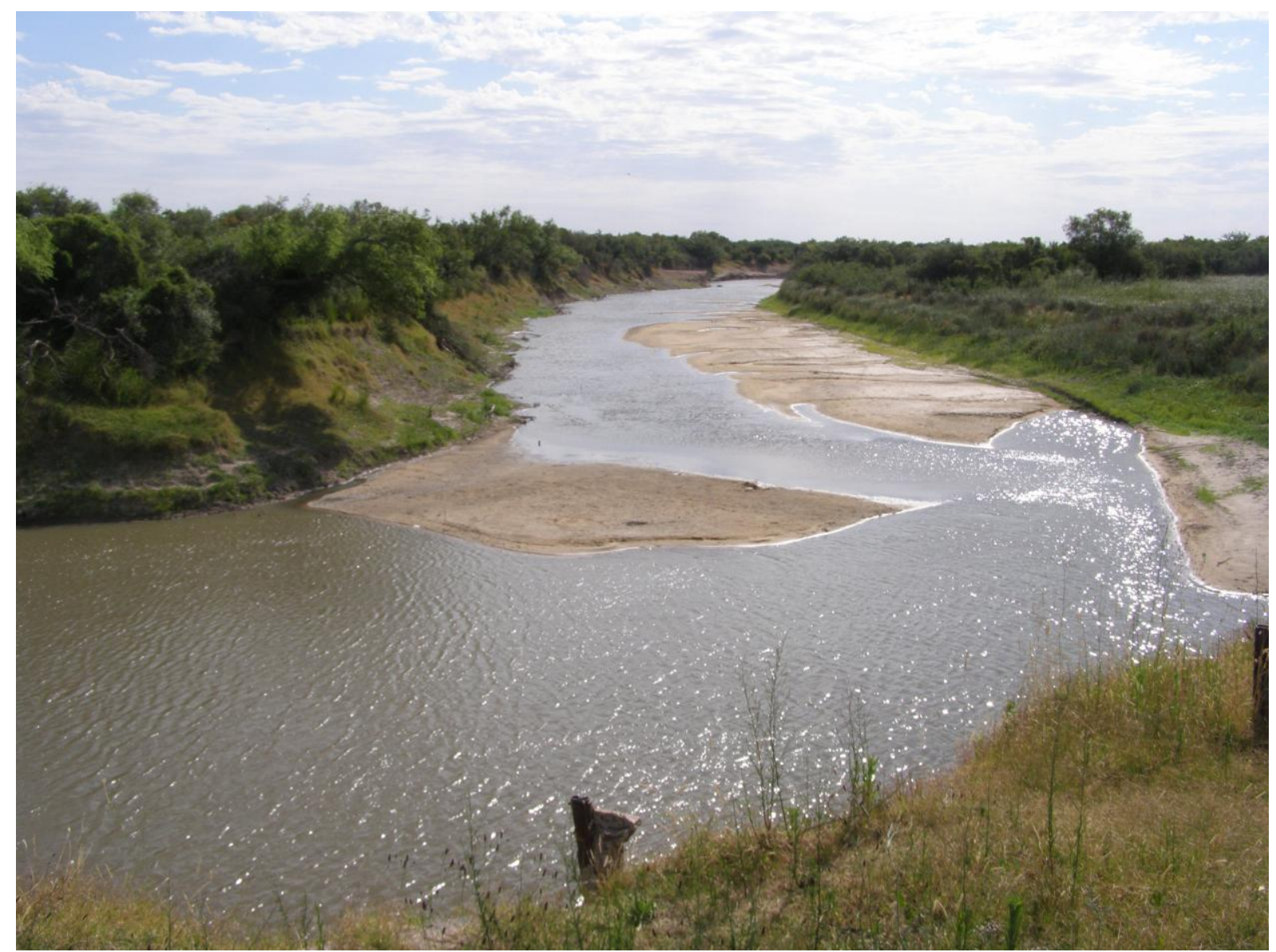

Figura 1.2. Sector A. Se observa el río Gualeguay con un bajo nivel de agua y bordeado por el típico monte xerófilo de las tierras altas entrerrianas. 
El Capítulo 6 corresponde al sector B (Figura 1.3), donde los trabajos de campo permitieron identificar ocho sitios arqueológicos y 14 hallazgos aislados, todos en posición superficial. Los materiales arqueológicos incluyen artefactos líticos y cerámicos.

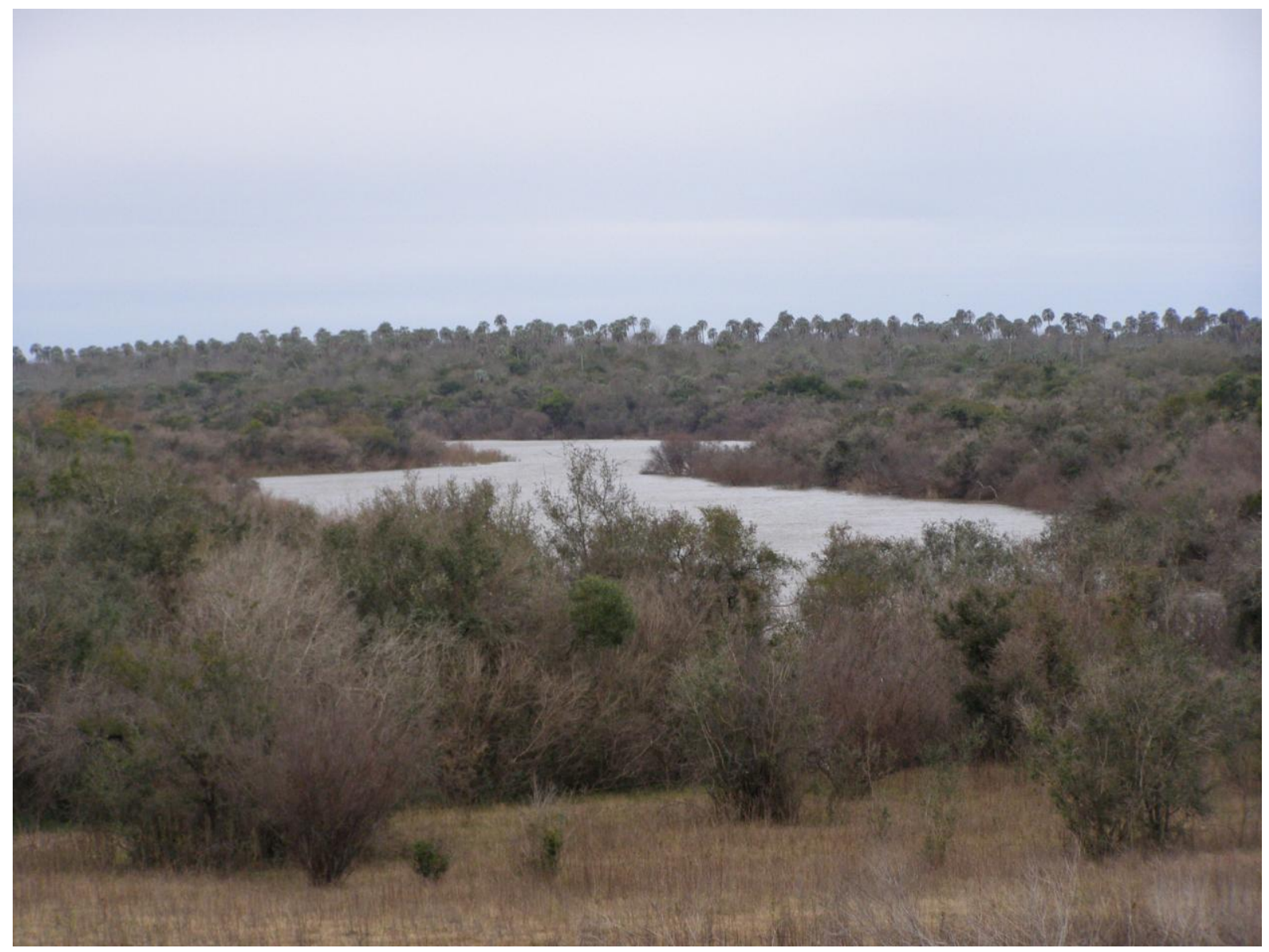

Figura 1.3. Sector B. Se observa el arroyo Ubajay bordeado por la selva en galería y en el fondo una concentración de palmeras (Butia yatay) en el Parque Nacional El Palmar.

El Capítulo 7 corresponde al sector C (Figura 1.4), donde los trabajos de campo permitieron identificar 23 sitios arqueológicos, 13 en estratigrafía y 10 en posición superficial, y 22 hallazgos aislados superficiales. Los materiales arqueológicos incluyen artefactos líticos, óseos y cerámicos, restos óseos humanos, faunísticos y vegetales. Asimismo, en este sector y debido a la presencia de materiales orgánicos se realizaron 15 dataciones radiocarbónicas, 10 de las cuales corresponden a la localidad arqueológica Cerros de Boari. 


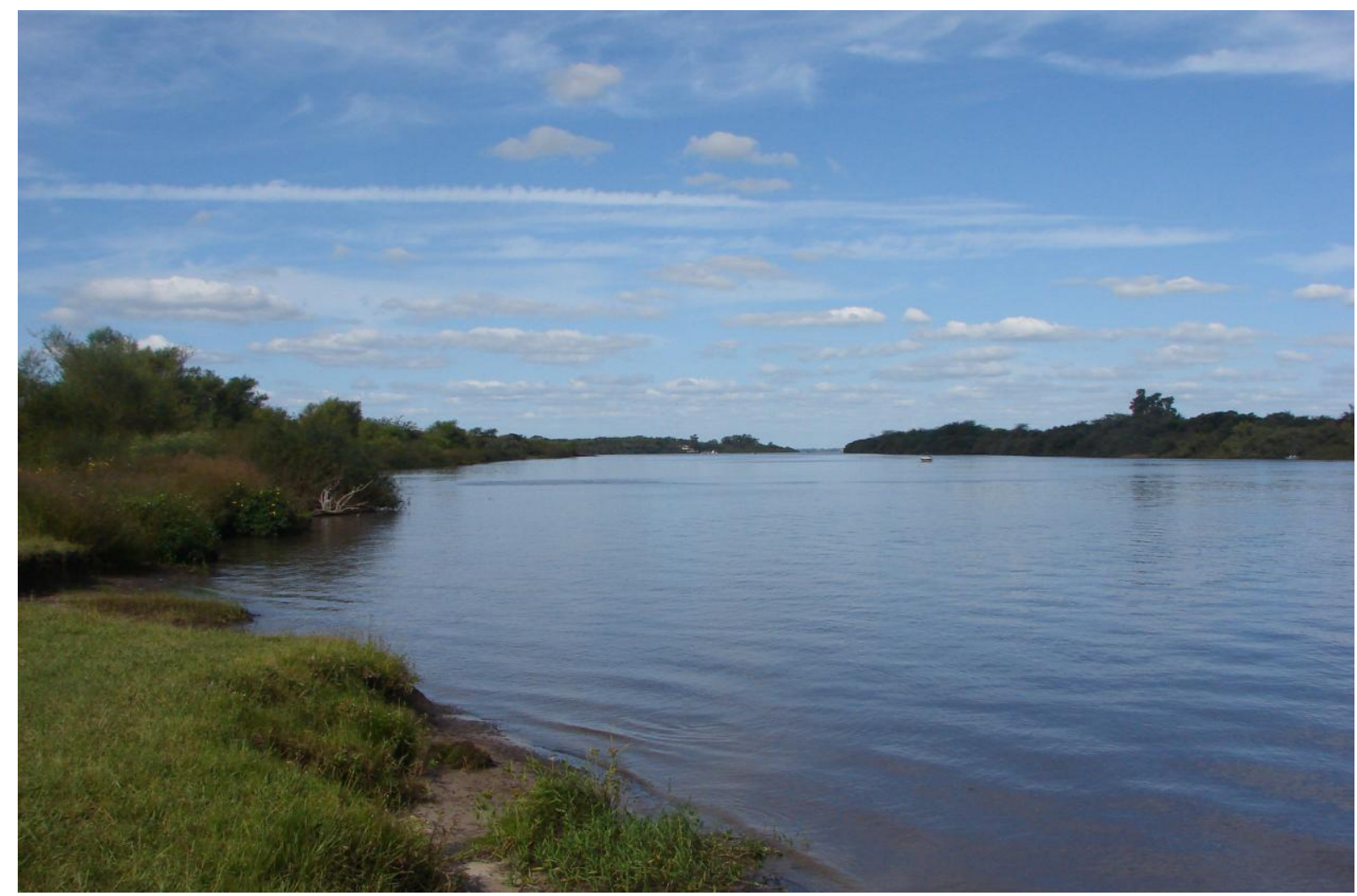

Figura 1.4. Sector C. Se observa el río Gualeguaychú en su desembocadura en el río Uruguay y la selva en galería en sus márgenes.

En el Capítulo 8 se presentan y discuten los resultados de los estudios realizados en la localidad arqueológica Cerros de Boari ubicada dentro del sector C. En esta localidad se efectuaron recolecciones superficiales, sondeos estratigráficos y la excavación sistemática del sitio arqueológico Cerro de Boari 3 (CDB3). Los estudios también incluyen el análisis de los materiales arqueológicos recuperados (artefactos líticos, óseos y cerámicos, restos óseos humanos, faunísticos y vegetales) y análisis estratigráficos, sedimentológicos, bio-composicionales, así como la obtención de 10 dataciones radiocarbónicas que permitieron establecer un marco cronológico preciso para las ocupaciones de la localidad.

En el Capítulo 9 se realiza la discusión integral e interpretación de todos los resultados obtenidos en los capítulos previos en relación a cada uno de los objetivos específicos y se exponen las conclusiones de la tesis. A partir de los resultados se abordan algunos ejes temáticos más generales de la arqueología regional como por ejemplo la modificación antrópica del ambiente, la circulación de recursos utilitarios y simbólicos dentro de extensas redes de interacción, la cronología de las ocupaciones, la dispersión de las poblaciones vinculadas a la entidad arqueológica GoyaMalabrigo (sensu Politis y Bonomo 2012) en el río Uruguay, los guaraníes (Brochado 1984; Noelli 1993, 2004) y las relaciones de interacción con los grupos "locales", el grado de complejidad social alcanzado por las sociedades indígenas del área de estudio, la estabilidad de las ocupaciones, la 
posible influencia de ciertos rasgos ambientales sobre la ocupación de la provincia, y los modelos arqueológicos regionales previos a partir de los aportes realizados de esta tesis.

Finalmente se concluye que los sectores $A$ y $C$ probablemente hayan sido ocupados por cazadores-recolectores durante el Pleistoceno final-Holoceno temprano. Asimismo, los sectores A y B fueron ocupados al menos durante algún momento del Holoceno tardío por cazadores-recolectores y alfareros vinculados a los ambientes fluviales propios de cada sector. En el sector $\mathrm{C}$ los fechados radiocarbónicos y el registro material permitieron determinar que el mismo fue ocupado a partir del ca. 2000 años AP hasta momentos posteriores a la conquista europea. En este sector se pueden diferenciar dos conjuntos arqueológicos que corresponden a dos poblaciones indígenas diferentes, ambas con una marcada adaptación a ambientes acuáticos y con un desarrollo tecnológico orientado a la explotación intensiva y sistemática del ecosistema fluvial determinado por el río Uruguay. La primera representada por grupos canoeros ribereños cazadores-recolectores-pescadores (y probablemente horticultores) y alfareros, constructores de montículos y con una alta estabilidad residencial. Su cultura material puede ser identificada con la entidad arqueológica Goya-Malabrigo. La segunda población representada por grupos guaraníes, canoeros ribereños cazadoresrecolectores-pescadores, agricultores y alfareros, que arribaron a la región en momentos previos a la conquista europea y ocuparon algunas zonas del río Uruguay, desplazando a sus ocupantes previos. Durante el Holoceno tardío cada uno de estos grupos habría estado integrado en un sistema macroregional de interacción e integración, que incluía la circulación de bienes, recursos, personas e ideas a través de fronteras étnicas permeables utilizando preponderantemente como vías de conexión los cursos fluviales de la cuenca del Plata. Asimismo, entre ambos tuvieron interacciones caracterizadas por los aspectos antes mencionados, pero seguramente también por la violencia generada por la guerra de conquista y expansión guaraní.

El desarrollo de esta investigación permitió un primer acercamiento sistemático a la variabilidad arqueológica de un sector del NEA, que no había sido previamente abordado de manera intensiva con metodologías modernas. Las contribuciones realizadas constituyen una base sólida que podrá funcionar en el futuro como un punto de partida, para la profundización de las problemáticas generales y específicas abordadas o bien para el desarrollo de nuevas líneas de investigación. 


\section{CAPÍTULO 2}

\section{ANTECEDENTES}

En el Nordeste de la República Argentina las investigaciones arqueológicas comenzaron a fines del siglo XIX, pero durante aproximadamente 80 años los datos fueron obtenidos por investigadores aficionados, interesados en comprender la ocupación humana del área. Recién en la década de 1960 comienzan las investigaciones sistemáticas. Si bien el NEA fue una de las primeras regiones en despertar el interés de los investigadores, y a pesar de que algunos trabajaron durante más 40 años logrando avances importantes como se verá más adelante, su estudio no ha tenido el mismo impulso, constancia y magnitud que otras regiones del país. Hace pocos años, y particularmente en la provincia de Entre Ríos, han comenzado varios proyectos de investigación a largo plazo, a pequeña y gran escala. Dentro de estos nuevos proyectos se encuentra el que dio origen a esta tesis: "Investigaciones arqueológicas en la cuenca media e inferior del río Uruguay (provincia de Entre Ríos)".

En este capítulo se sintetiza la información arqueológica disponible hasta el momento para el NEA y oeste la ROU. Se presenta el desarrollo de las investigaciones en secciones definidas sobre todo en base a criterios cronológicos. Aun así hay autores cuya obra trasciende los límites operativos que se proponen para cada sección.

\section{1- LOS PRIMEROS DATOS ARQUEOLÓGICOS SOBRE EL NORDESTE}

La primera referencia sobre materiales arqueológicos corresponde a un manuscrito dado a conocer por Milicíades Alejo Vignati (1925). Esta publicación reproduce las observaciones de Francisco Javier Muñiz en 1818 en el arroyo Paycarabí (Delta inferior del río Paraná, provincia de Buenos Aires), donde reconoce sobre un albardón restos de "tinajas" pertenecientes a los "indios". Además, Muñiz identifica un tipo de decoración, y dice que “..., unas están todas labradas como escamas de pez,..." (Muñiz 1825: 18). Posteriormente en 1865 Favier informa sobre entierros en urnas en la isla Paycarabí (Sastre 1891). Ambos hallazgos corresponderían a alfarería y restos óseos humanos guaraníes.

Los primeros trabajos arqueológicos en el NEA fueron realizados en su porción más meridional y algunos de ellos corresponden a recolecciones superficiales y excavaciones realizadas 
por profesionales de otras disciplinas (p. ej. Ingeniería) aficionados a la arqueología. Se destacan Estanislao Zeballos (1878) (Figura 2.1), Estanislao Zeballos y Pedro Pico (1878) y Ramón Lista (1878).

En 1877 Zeballos y Pico excavan un "túmulo" en Campana (Buenos Aires), y extraen restos óseos humanos, faunísticos, cerámicos y líticos (véase Politis y Bonomo 2015, 2016). Plantean que el mismo correspondería a los guaraníes y estaría sobreelevado artificialmente por el aporte antrópico de sedimentos (sensu Eidt 1985). Lo consideran un túmulo similar a otros que hay América y Europa, y sería a la vez un "paradero" y un "enterratorio". Por su parte, en el departamento Islas del Ibicuy (Entre Ríos), Lista (Figura 2.2) descubre “...algunos cementerios y paraderos Minuanes prehistóricos..." (Lista 1878: 35). Este autor distingue "paraderos" y "cementerios", considerando que los primeros no presentarían restos humanos y se ubicarían sobre dunas interiores lejos de la costa. Los segundos tendrían forma de montículos o "cerritos" recubiertos de vegetación, estarían destinados al entierro de los muertos y como defensa contra inundaciones, su origen sería netamente antropogénico. Basándose en el estado de integridad de los restos humanos recogidos postula que los "cementerios" tendrían una antigüedad reciente.

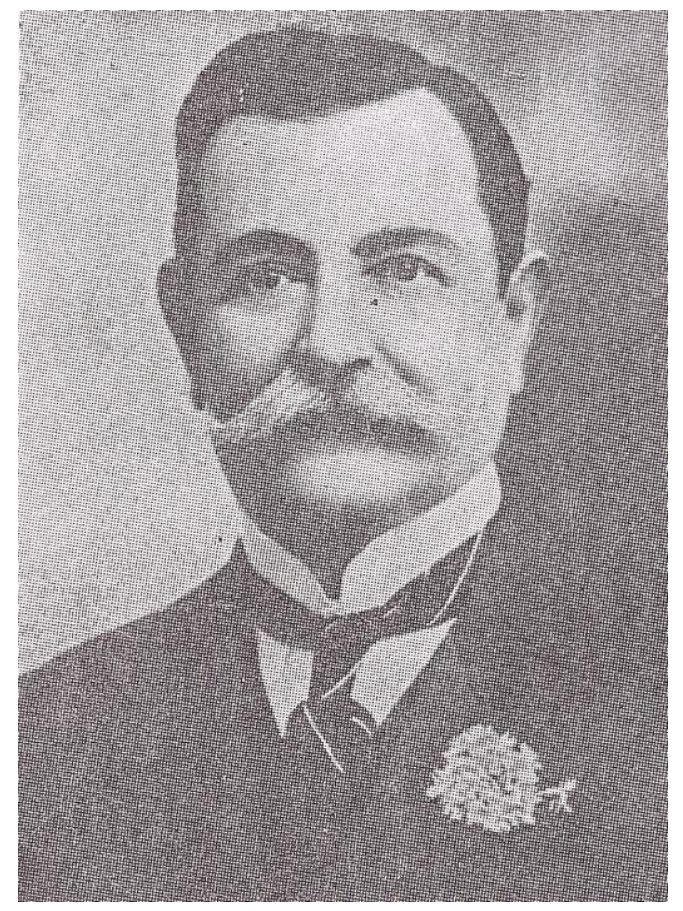

Figura 2.1. Estanislao Zeballos.

Lista excava en dos oportunidades los "cementerios" Medina y Mazaruca (Islas del Ibicuy), una en 1878 y otra acompañado por Benigno Teijeiro Martínez en 1882, allí recuperan restos humanos mezclados con los demás materiales arqueológicos (p. ej. cerámica y restos faunísticos) (Lista 1878; Martínez 1900-1901; Outes 1912). Según Lista los huesos de animales serían el resultado de festines realizados en honor a los muertos. No reconoce similitudes con los montículos de la ROU 
y del sur de Brasil, los cuales según el autor serían monumentos funerarios. En 1885 menciona la presencia de "túmulos" y "campamentos" en Islas del Ibicuy y que habría una estrecha similitud entre la alfarería y los artefactos líticos de esta zona y los de Montevideo (Lista 1885).

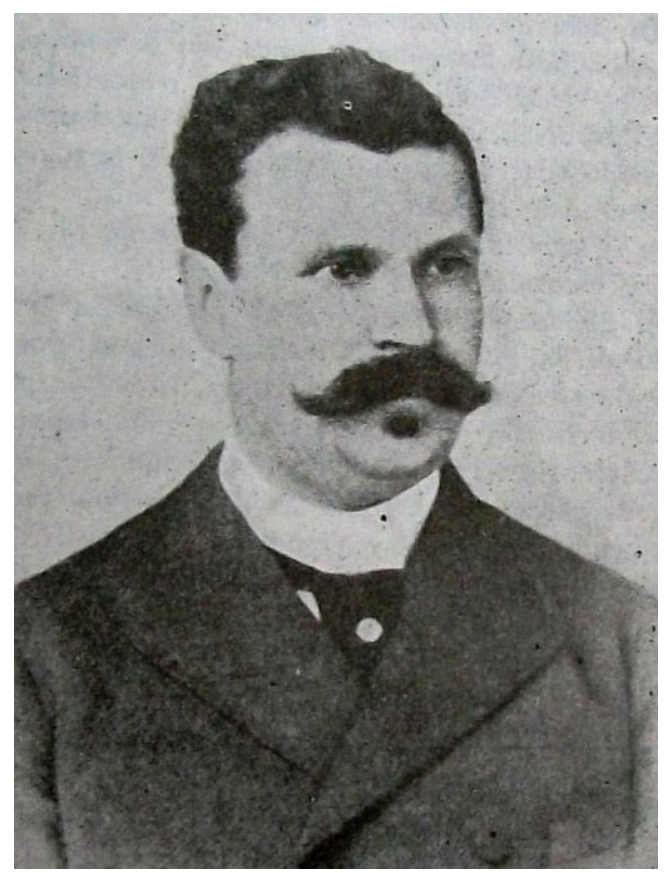

Figura 2.2. Ramón Lista.

Entre 1882 y 1895 Juan Bautista Ambrosetti (Figura 2.3), realiza varios viajes al NEA, por encargo del Instituto Geográfico Argentino (IGA) en algunos casos y por el Museo de La Plata (MLP) en otros. En la mayoría se dirige hacia el Alto Paraná y el Alto Uruguay, pero en ciertas ocasiones lleva a cabo el relevamiento del sudeste de Entre Ríos (Ambrosetti 1893; Torres 1903a; Serrano 1931; Fernández 1982). En el marco de estos viajes dedicó parte de su tiempo al estudio de hallazgos arqueológicos sobre los que publica varios trabajos (Ambrosetti 1893, 1894a, 1894b, 1895a, 1895b). Entre 1882 y 1885 excava en el Cerro de La Matanza (departamento Victoria) sin recuperar materiales arqueológicos (Ambrosetti 1893). También recorre el sector de islas de Victoria donde colecta restos de alfarería y, dado que solo recoge este tipo de material, plantea que los sitios arqueológicos corresponderían a "paraderos" transitorios. Plantea que la zona estuvo habitada por minuanes y que éstos y charrúas podrían corresponder a la misma "nación" y/o tener un origen común. 


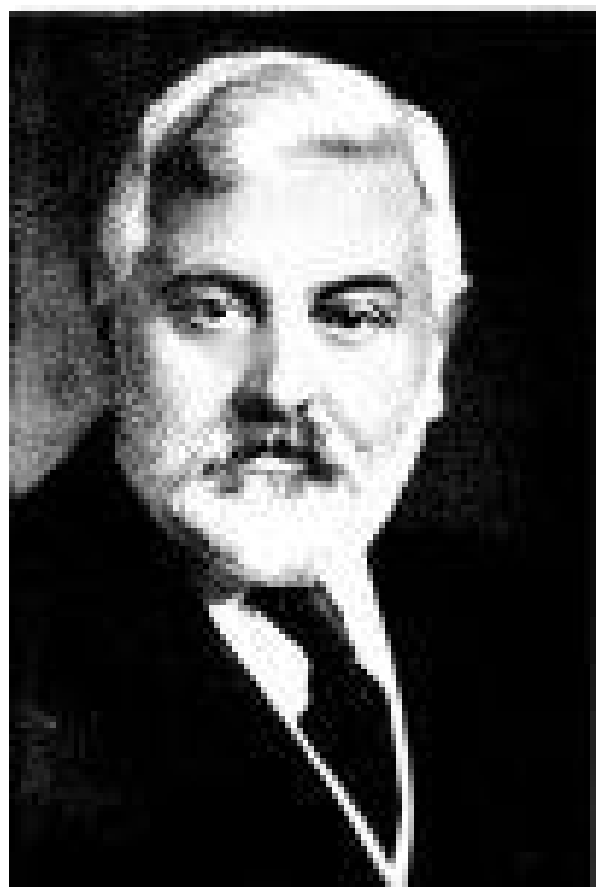

Figura 2.3. Juan Bautista Ambrosetti.

Durante 1893 el Instituto Geográfico Argentino promueve la exploración del sur de Entre Ríos a cargo de Oscar Durand-Savoyat, quién recorre durante cuatro meses "...ambas orillas del Uruguay, desde Colon hasta Rincón del Ibicui, habiendo encontrado en este último punto numerosos paraderos y cementerios Minuanes, donde ha coleccionado interesantes objetos prehistóricos." (Boletín del Instituto Geográfico Argentino 1894: 183). Estos materiales (instrumentos óseos y líticos, alfarería y restos humanos) fueron adjudicados a charrúas, yaros y minuanes.

Uno de los autores más reconocidos en la arqueología de Entre Ríos es Luís María Torres (Figura 2.4), quién realiza numerosas recolecciones superficiales y excavaciones (Torres 1903a, 1903b, 1907, 1911). En 1901 visita en Islas del Ibicuy el "paradero" del Ceibo y los "cerros" Cementerio-Estación de Sagastume Grande y Cementerio de Mazaruca; en 1902, junto a Félix Outes, excava nuevamente el "cementerio" Mazaruca previamente estudiado por Lista (1878), con el objetivo de "...conocer en varios puntos los materiales de que estaba constituido el -cerro-." (Torres 1903a: 68). Además observa, al igual Lista la mezcla de distintos materiales arqueológicos con los restos humanos. Asimismo, Torres hace una comparación entre los "túmulos" de Campana, Uruguay, Brasil y sur de Entre Ríos, tal como lo había sugerido Ameghino (1880); en ésta última zona distingue entre "cementerios" y "paraderos o estaciones". Para los primeros eran utilizados los "cerros" más altos y para los segundos los de menor altura. No considera a los primeros como similares a los “...verdaderos monumentos funerarios que, levantados por la mano del hombre, llevan el nombre de túmulos." (Torres 1903a: 73). 


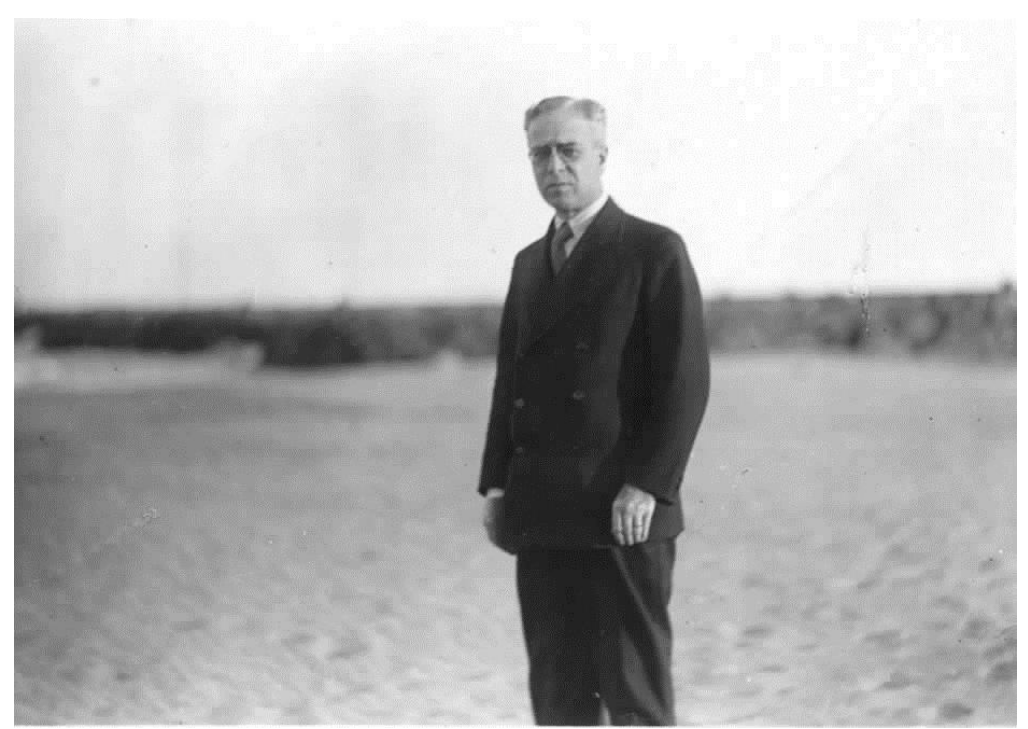

Figura 2.4. Luis María Torres (Tomado de Bonomo y Farro 2014).

En 1907 Torres plantea que en momentos prehispánicos se ocuparon las barrancas altas del río Paraná, y después de la conquista las zonas anegadizas. Considera que el ambiente de la cuenca del río Paraná tuvo una marcada influencia sobre las antiguas poblaciones indígenas. Hasta ese año ha realizado siete viajes a Entre Ríos y en base a la existencia de nuevos datos hace una revisión de las interpretaciones realizadas en 1903, destacando la importancia de elaborar una secuencia cronológica para comparar las "fases de la cultura del litoral" (Torres 1907).

En su obra de síntesis del Delta del río Paraná, una de las más extensas de la arqueología argentina: "Los primitivos habitantes delta del Paraná" (Torres 1911), expone sus interpretaciones y un esquema cultural y cronológico basándose en sus trabajos de campo realizados entre 1896 y 1906. En referencia a los montículos concluyó que si bien el núcleo arenoso de los "túmulos" es natural ha sido aumentado por parte del hombre mediante agregación de tierra y arena de las inmediaciones y residuos antrópicos. A favor de este último punto, menciona que estas elevaciones se encuentran aisladas, en zonas anegadizas o en el centro de verdaderas lagunas, sólo excepcionalmente se disponen sobre albardones. En síntesis, dice que hay montículos totalmente construidos y otros en los que se aprovecharon geoformas preexistentes sin mayor modificación ( $p$. ej. médanos); sobre estos últimos se ubicarían los "paraderos" y "cementerios".

En esta obra Torres presenta una carta arqueológica donde hace una clasificación de tipos de sitios arqueológicos y plantea que estos, primero deben ser estudiados de forma aislada y posteriormente se tienen que realizar las comparaciones. Específicamente en la cuenca inferior del río Uruguay Torres relevó y excavó algunos sitios arqueológicos en el departamento Gualeguaychú (Estación del Arroyo Ñancay 1 y 2, y Estación de Puerto Landa) y en el departamento Islas del Ibicuy (Cementerio-Estación de Sagastume Grande, Túmulo I del Brazo Largo y Túmulo I del Brazo Gutiérrez). 
A partir de sus estudios Torres plantea que:

$\checkmark$ El hallazgo de materia primas líticas no locales en el Delta del río Paraná, permite plantear relaciones con el sur del Buenos Aires, Uruguay y el Alto Paraná.

$\checkmark$ En el delta no existen talleres líticos y que éstos están “...posiblemente en la costa oriental del río Uruguay,..." (Torres 1911: 280). La mayoría de las rocas provendrían de Uruguay y han sido utilizadas sin mayores modificaciones ni retoques.

$\checkmark$ Los modelados zoomorfos y antropomorfos serían una de las principales características de la alfarería del Delta del Paraná.

$\checkmark$ Habría relaciones de intercambio entre el NEA y el Noroeste de Argentina (NOA); para esto se basa en láminas cobre que recupera asociadas a cráneos humanos en el Túmulo I y II del Paraná Guazú y en el Túmulo I del Brazo Gutiérrez.

$\checkmark$ En todos los sitios arqueológicos excavados, excepto en el Cementerio I del Paraná Guazú, habría una sectorización en el uso del espacio; por un lado, están los entierros humanos y por otro, la mayoría de los "residuos de cocina".

$\checkmark$ El registro arqueológico estudiado correspondería a charrúas y afines (querandíes, yaros y minuanes), que estarían asentados en el Delta superior ${ }^{1}$.

$\checkmark$ En el Delta inferior estarían los canoeros y agricultores guaraníes. Los chaná y afines, que se habrían difundido por la costa paranaense y algunas islas del río Paraná de las Palmas llegando a las costas del Uruguay.

Sobre la base de las observaciones tecnológicas y estratigráficas realizadas en cada sitio arqueológico, Torres busca establecer una cronología de desarrollo cultural para la región. Además, intenta determinar el origen y desarrollo de las poblaciones, sus influencias y afinidades étnicas considerando posibles vínculos con territorios limítrofes, incorporando datos lingüísticos y etnográficos para dar una visión más completa de la historia indígena regional. Por último, Torres (1911) reconoce tres grupos o niveles cerámicos, uno déltico muy simple y el más antiguo, otro de influencias arawak con representaciones plásticas y el último que identifica con los tupí-guaraní.

Durante esta etapa también fueron muy relevantes los aportes realizados por Outes (Figura 2.5), quien en 1902 en el viaje que realizara al litoral santafesino y a Entre Ríos junto a Torres, visita Mazaruca y recoge numerosos restos humanos. Del análisis de los mismos concluye que "...los indígenas del sur de Entre Ríos, parecen vinculados estrechamente á ciertos elementos primitivos y agrupaciones étnicas actuales del Brasil meridional." (Outes 1912: 35). Por otro lado, sostiene que los

\footnotetext{
${ }^{1}$ Las subdivisiones del Delta del río Paraná como superior e inferior usadas por Torres no son exactamente equivalentes a las usadas en la actualidad. Delta superior según Torres (y algunos otros investigadores contemporáneos) incluye a grandes rasgos el delta ubicado al norte de los ríos Paraná Pavón-Ibicuy-Guazú, e inferior el delta ubicado al sur.
} 
"cerritos" son médanos naturales consolidados, aunque posteriormente para las islas del Delta del Paraná menciona "construcciones tumulares" donde se realizarían las inhumaciones de los muertos.

En 1917 Outes presenta el primer hallazgo arqueológico en la isla Martín García (restos humanos y faunísticos, artefactos líticos, alfarería pintada, corrugada y unguiculada) (Outes 1917a). Dentro de los restos faunísticos se registró el molusco marino que fue identificado por Martín DoelloJurado (1917, 1940) como Urosalpinx rushi (actualmente Urosalpinx haneti), quién además determinó su modificación antrópica y estableció su procedencia. Como este caracol también fue registrado en Tucumán, entre otros lugares (véase Capítulo 9), Outes plantea una "corriente" de intercambios o "comercio primitivo" de oriente hacia occidente. Estos estudios pueden considerarse los primeros de carácter interdisciplinario de laboratorio sobre las distancias de procedencia de las materias primas.

Este autor utiliza a manera de "fósil guía" la presencia de cerámica pintada de blanco y rojo, refiere su dispersión geográfica y concluye, al igual que Ambrosetti, que es de origen guaraní y que hasta el momento sería la representación más meridional de estos grupos en la cuenca del Plata. Considera que la alfarería policroma no representa solamente un hallazgo aislado o una "infiltración extraña", sino que es evidencia de un "complejo cultural" que se extiende desde Brasil al Delta del Paraná (Outes 1918a). El mismo no solo fue registrado en la isla Martín García sino también en el sitio arqueológico Arroyo Largo (Outes 1918a). Sobre los materiales líticos de este último sitio arqueológico Outes (1918a) realiza un examen microscópico describiendo minuciosamente los artefactos. En cuanto al análisis de los restos de ciervo de los pantanos (Blastocerus dichotomus), identifica marcas de corte de descarne o desarticulación anatómica, y evidencias de alteración térmica en algunos elementos anatómicos. Estos estudios resultan novedosos para ese momento dado que no se habían desarrollado estudios tafonómicos similares en la región.

A lo largo del río Paraná Outes (1918b) reconoce tres grandes manifestaciones culturales, que se distinguirían a partir de los asentamientos y la tecnología. Una sería la guaraní que ocupa gran parte de la cuenca del Paraná; la otra la de modelados zoomorfas y antropomorfos desde Chaco al delta bonaerense; y la última, "la más primitiva de todas", que se encuentra en el complejo insular del delta paranaense. Esta secuencia constituyó un instrumento clave para ordenamiento y la interpretación de la arqueología regional durante varias décadas. 


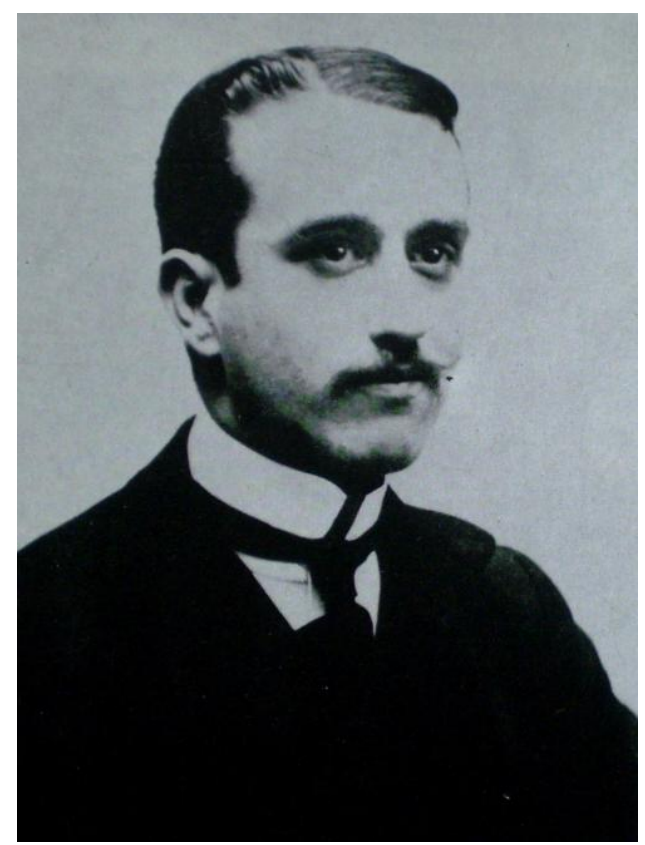

Figura 2.5. Félix Outes.

En 1923 Joaquín Frenguelli junto a Francisco de Aparicio realizan lo que se puede considerar el primer trabajo de campo interdisciplinario en la región. Recorren la costa santafesina entre Reconquista y Puerto Gaboto identificando y excavando sitios arqueológicos con controles estratigráficos. Otorgan al estudio de los montículos un marco geológico y ambiental, a partir de un relevamiento de campo sistemático. Además, observan que el registro arqueológico se encuentra distribuido mayormente en relación a los cursos de agua actuales y que no se registran evidencias lejos de los mismos, salvo en casos vinculados a paleocauces inactivos (Frenguelli y Aparicio 1923).

En cuanto a la génesis de estas estructuras postulan que serían médanos consolidados donde se asentaron los "paraderos" indígenas. La línea de elevaciones estudiadas habrían sido restos de un cordón medanoso de origen eólico paralelo al cauce del río Malabrigo, depositado en una fase de clima árido. Este cordón se habría cortado transversalmente y modelado en forma de lomas por los arroyos y escurrimientos pluviales que descendían al cauce de río. Posteriormente los sectores elevados fueron fijados y humificados parcialmente por la vegetación que se desarrolló encima. En síntesis, estas lomas fueron habitadas cuando ya estaban formadas. Por lo tanto, no serían "túmulos" ni "cementerios", sino "paraderos" o "paraderos-enterratorios" que servían para vivir cerca de los cursos de agua y a la vez protegerse de las inundaciones en épocas lluviosas (Frenguelli y Aparicio 1923).

Por su parte, Aparicio (Figura 2.6), publica numerosos artículos sobre la arqueología del NEA $(1922,1923,1925,1928,1929,1931,1936)$. En algunos casos estudia piezas aisladas de "Representaciones Plásticas" (Aparicio 1922, 1923, 1925) y alfarería guaraní (1931). Aparicio analiza una colección procedente de las estancias Mazaruca y La Argentina (Islas del Ibicuy) y también 
excava expeditivamente en el "cerro" La Argentina, postulando que este sitio arqueológico es un cementerio, donde todas las inhumaciones serían secundarias. Este sitio arqueológico habría sido utilizado como vivienda en casos de emergencia por las inundaciones, ya que el lugar de "vivienda habitual" sería la playa. En su análisis agrupa los materiales de ambos sitios arqueológicos como parte de uno solo. También realiza una clasificación petrográfica de las piedras con hoyuelos de la colección, discute la aplicación del término "bolas" cuando se refiere a las "bolas de boleadora" y plantea que la mayoría de las materias primas presentes en estos sitios arqueológicos provendría del río Uruguay y de la ROU, sin descartar que algunas rocas podrían provenir de la provincia de Buenos Aires (Aparicio 1928).

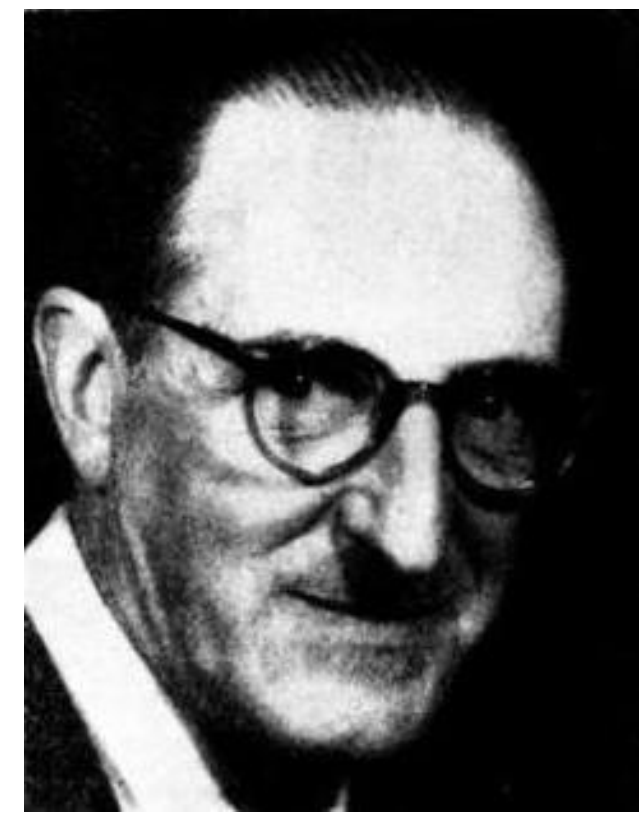

Figura 2.6. Francisco de Aparicio.

Por último, Aparicio (1936) considera que los sitios arqueológicos del río Paraná no son todos homogéneos. Distingue entre los que se ubican próximos al cauce del río y los del delta de acuerdo a sus materiales arqueológicos, pero sobre todo al tipo de entierro que presentan. A su vez, subdivide los sitios arqueológicos del delta en dos tipos: el primero tendría entierros en urnas y correspondería a los guaraníes; el segundo tipo sería el que tiene inhumaciones propiamente dichas, lo que incluiría a todos los sitios arqueológicos restantes. Aparicio concluye que hay tres "conjuntos industriales" diferenciados en la cuenca río del Paraná. Dos en el delta que corresponderían a los guaraníes y los ocupantes de los "cerritos", que el autor no identifica, y el tercero ocuparía ambas márgenes del río y correspondería a los chanás, timbús, beguás, mocoretás, entre otros, que serían parcialidades de un mismo grupo cultural (Aparicio 1936).

En 1926 Héctor Greslebin (Figura 2.7), lleva a cabo relevamientos y excavaciones en los "montículos de origen antrópico ("túmulos")" del departamento Gualeguaychú. Los sitios 
arqueológicos estudiados incluyen: Túmulo 1 y 2 de Pesquería Nicolini ${ }^{2}$, Túmulo de Lucuix, un sitio sin nombre adyacente a éste ubicado a $32 \mathrm{~m}$ al oeste, Quinta Vieja, un sitio superficial ubicado entre el arroyo Malo y el río Uruguay en una zona baja, sin nombre, dos "túmulos" contiguos que denomina Túmulos de Estoponda (= Cerros de los Pampas de Krapovickas 1957; véase más adelante) en la Estancia Rincón de Landa, (éstas dos elevaciones en realidad constituyen uno solo montículo seccionado por un canal de desagüe moderno) y Sambaquí de Puerto Landa, que según Greslebin no es el mismo "sambaquí" que visitó Torres (1911). En sus trabajos recuperó cerámica, restos arqueofaunísticos y restos humanos que corresponderían a entierros primarios y secundarios.

Este autor pone en práctica nuevas técnicas de excavación y de recolección sistemática de materiales para establecer claramente la disposición de las capas estratigráficas y la estructura del perfil de los montículos. Critica los procedimientos empleados previamente por Torres en la región, ya que estos no permitirían observar simultáneamente la disposición del conjunto de las capas, ni de los niveles con materiales arqueológicos (Greslebin 1931a).

A partir de estos trabajos Greslebin esboza un esquema cronológico basándose en el análisis de la cerámica recuperada y en un detallado registro estratigráfico de los montículos de la zona. Debido al hallazgo de elementos posthispánicos (cuentas y punta de proyectil de vidrio) y a que los materiales arqueológicos proceden de la capa de humus, adjudica una corta antigüedad a las ocupaciones. Asimismo, considerando que la riqueza pesquera de la zona es la causa del establecimiento de los indígenas en el lugar, destaca la importancia del estudio de los grandes ríos. También plantea que la finalidad de los "túmulos" en el medio de los bañados es la de procurar pesca fácil en épocas de frecuentes crecidas e inundaciones. Propone además la utilización de canoas por los antiguos habitantes de los mismos. Concluye que los "túmulos" o "cerritos" fueron total (p. ej. Túmulo de Lucuix) o parcialmente construidos (p. ej. Sambaquí de Puerto Landa) y acondicionados para protegerse de las inundaciones del río Uruguay. Así como también que, no serían exclusivamente para el entierro de los muertos, sino también para el desarrollo de actividades cotidianas. De la misma forma habría "paraderos" y "enterratorios" también sobre elementos naturales como albardones, médanos o cordones de arena (Greslebin 1931a, 1931b).

En 1931 Greslebin da a conocer dos "vasos" cerámicos enteros decorados procedentes de la zona de Puerto Basilio (departamento Gualeguaychú). Describe detalladamente las piezas y su decoración incisa y geométrica, y postula una correlación con los motivos decorativos de la placa de piedra grabada de Río Negro encontrada por Moreno (véase Lehmann-Nitsche 1909). A partir de esto menciona una "influencia" étnica entre ambas zonas, pero no establece ni la dirección ni la cronología de la misma (Greslebin 1931b).

\footnotetext{
2 Greslebin no utiliza números para distinguir entre los dos montículos que estudió en la pesquería Nicolini, aquí para diferenciarlos se agregan los números 1 y 2; el 1 corresponde al montículo efectivamente excavado y el 2 al montículo ubicado sobre la ribera del río Uruguay (véase Greslebin 1931a, Figura 13). 


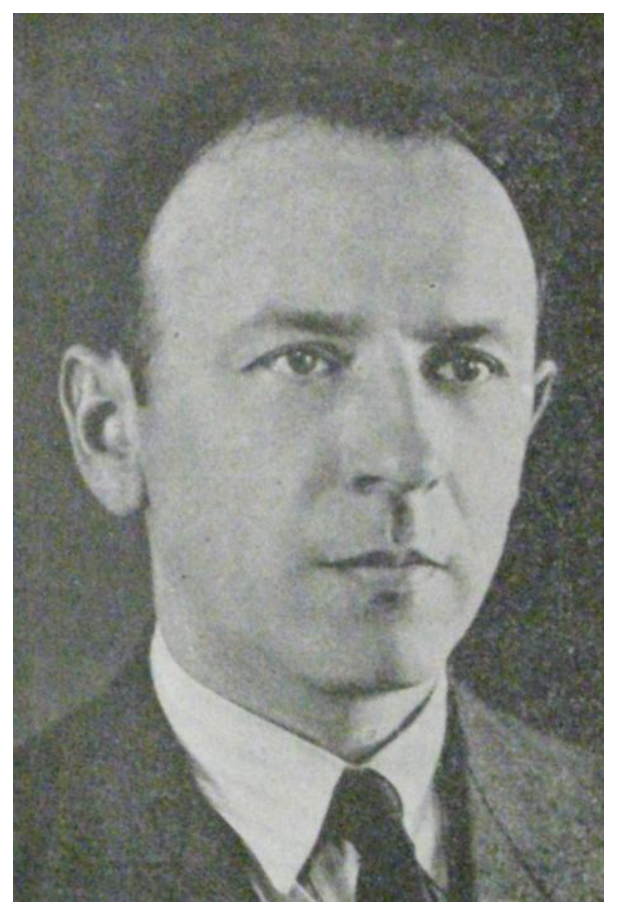

Figura 2.7. Héctor Greslebin (Tomado de Fontana Company 1933).

Otro de los trabajos por destacar realizado dentro del área que abarca esta tesis es el de Pedro Krapovickas (1957). Este autor estudia tres sitios arqueológicos en la Estancia Rincón de Landa, previamente estudiados por Greslebin: Cerro de Godoy (= Sambaquí de Puerto Landa de Greslebin 1931a); Cerros de los Pampas (= Túmulos de Estoponda de Greslebin 1931a); y un montículo que Krapovickas no refiere con ningún nombre particular, pero actualmente se denomina El Aserradero Viejo o El Aserradero (Almeida 1983a, s/fa). A partir de sondeos realizados en Sambaquí de Puerto Landa y en el más oriental de los dos Cerros de los Pampas, identifica diferencias entre ambos en cuanto a su estructura y composición. Para El Aserradero Viejo menciona pozos en cuyos bordes observó cerámica, probablemente se trate de madrigueras o pozos de construcción moderna. En conjunto recupera alfarería, instrumentos óseos, restos arqueofaunísticos y líticos en distintas frecuencias. Presenta un esquema estratigráfico detallado de Sambaquí de Puerto Landa y de Cerros de los Pampas (oriental) y concluye que el primero es un basural sobreelevado por acumulación gradual de desechos y el segundo sería un montículo construido sobre un médano preexistente mezclando, "consciente o inconscientemente" tierra y materiales arqueológicos, con fines desconocidos al parecer del autor.

Sintetizando lo que se podría identificar como un primer momento de las investigaciones arqueológicas del NEA, a partir de los antecedentes mencionados se destaca un marcado interés por la región. Dentro de este contexto histórico se desarrollaron algunos trabajos elaborados y otros que solo se basaban en la presentación y descripción morfológica de una sola pieza con rasgos 
particulares o "novedosos", a partir de la cual se realizaban inferencias sobre su origen y función que luego se generalizaban y extrapolaban directamente a otros sitios arqueológicos o zonas geográficas.

Este período también estuvo marcado por el interés sobre la adscripción étnica de los restos arqueológicos y por determinar la función de las estructuras monticulares, sobre las que no hay un acuerdo en su nomenclatura y mucho menos sobre su génesis. También hubo interés por las posibles relaciones con otras regiones de Argentina, la ROU y Brasil. Dichas relaciones extrarregionales en muchos casos servían para explicar la presencia o ausencia de determinados materiales arqueológicos en cada lugar investigado, dejando entrever la existencia de premisas difusionistas en el pensamiento de los investigadores, que además buscaban explicar las similitudes morfológicas de los objetos. Vale destacar aquí los primeros intentos de trabajos interdisciplinarios en colaboración con especialistas en geología y ciencias naturales. Esto resulta novedoso, ya que no solo se intentaba develar el origen de los montículos "túmulos, cerros o cerritos", sino que además se buscaba determinar la composición mineralógica y procedencia de las rocas con las que se elaboraron los artefactos líticos y también la procedencia y distribución arqueológica de algunas especies de moluscos recuperadas en la región. Básicamente los esquemas de desarrollo cultural propuestos constituyeron un intento clasificatorio y descriptivo del registro arqueológico, identificándolo con alguno de los grupos étnicos conocidos a través de las fuentes etnohistóricas. En muchas de estas propuestas se perciben las ideas difusionistas sobre la persistencia en el tiempo de los rasgos culturales, la ausencia de cambio, la adaptación al medio natural y el origen geográfico único de las innovaciones tecnológicas y su posterior dispersión (véase p. ej. Ibarra Grasso 1967).

\section{2- PRIMEROS INTENTOS DE SISTEMATIZACIÓN ARQUEOLÓGICA}

Antonio Serrano (Figura 2.8) fue quién realizó la primera sistematización profunda de la arqueología del NEA, publicando su obra a lo largo de medio siglo. Su producción cuenta con trabajos en los que realiza análisis novedosos ( $p$. ej. Serrano 1933a) y varias síntesis regionales que sirvieron de base a los investigadores que posteriormente se abocaron a la región (p. ej. Serrano 1931, 1933b, 1950, 1954 y 1972). Algunas de sus primeras publicaciones concuerdan con la práctica descriptiva de piezas aisladas propias de los momentos iniciales de la arqueología regional (Serrano 1922a). Otras se basan en el análisis de fuentes bibliográficas a partir de las cuales ubica geográficamente las etnias que habitaron Entre Ríos entre los siglos XVI y XVIII (Serrano 1923). 

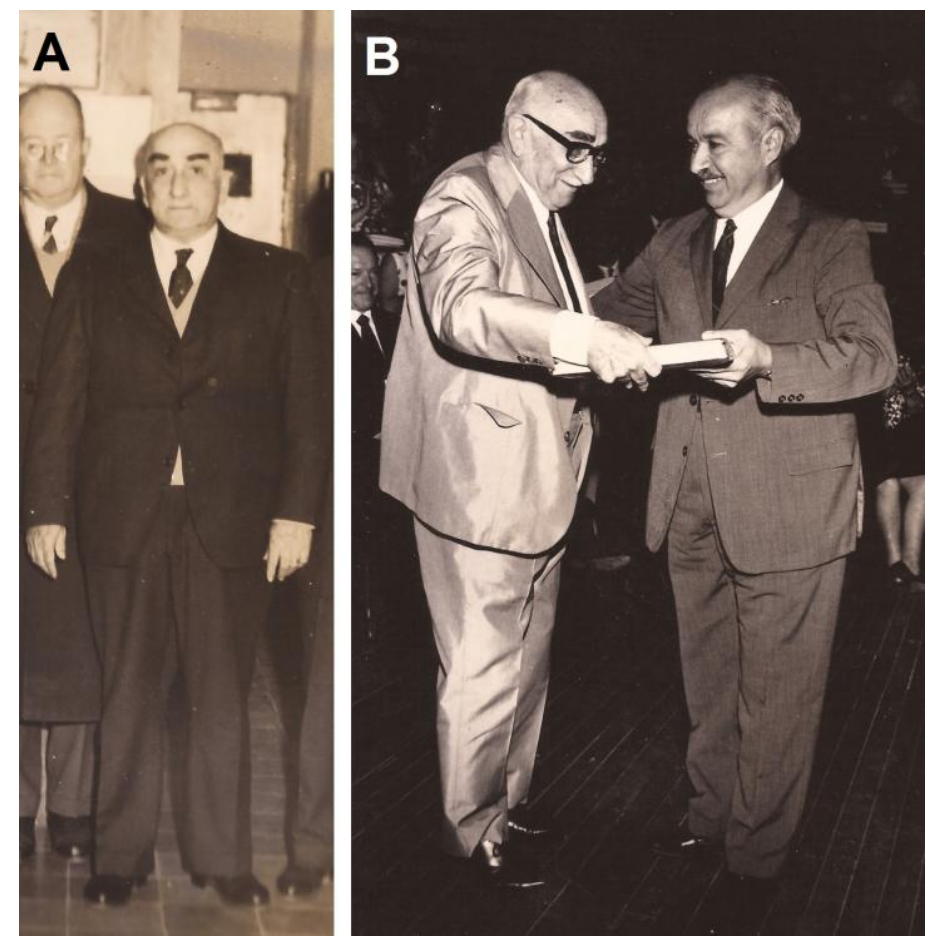

Figura 2.8. A: Antonio Serrano (al frente). B: Serrano (izquierda) recibiendo un reconocimiento por sus Bodas de Oro con la arqueología en 1971.

Este investigador organizó el registro arqueológico según los materiales predominantes en cada uno de los grandes cursos de agua, destacando la predominancia de instrumentos líticos en río Uruguay y de instrumentos óseos en el río Paraná. En este sentido, se refiere a la zona este o de la piedra, donde la alfarería sería escasa, y la zona oeste o del hueso, donde la alfarería alcanza un gran desarrollo tecnomorfológico y estilístico. Para las tierras anegadizas del sur del departamento Gualeguaychú define una tercera zona que considera "mixta", donde hay desarrollo de la tecnología lítica y la alfarería, y esta última al igual que en el oeste es "...rica en formas y ornamentación." (Serrano 1924: 1).

En 1931 intenta por primera vez una clasificación de los sitios arqueológicos y define lo que considera un "paradero" como "... la residencia permanente o temporal de una familia, de un grupo de familias o de una tribu." (Serrano 1931: 5). En las tierras altas no anegadizas éstos se ubican en las hondonadas protegidas de los vientos. En las zonas anegadizas los "paraderos" se ubican en lugares altos como albardones o médanos, conformando montículos llamados "cerros" o "cerritos". Cuando han servido como cementerios no los denomina "paraderos" sino "túmulos" (aunque dice que este nombre debe reservarse para aquellas construcciones artificiales) y a los que han servido para los ambos fines los llama "paradero-cementerio" (Serrano 1933b). Serrano discute la existencia de montículos o "túmulos" artificiales, y siguiendo a Frenguelli y Aparicio (1923), se inclinó por la idea de que en Entre Ríos se tratarían de médanos consolidados, sin modificaciones, sobre los que se asentaron los indígenas (Serrano 1950). También menciona un tipo de sitio arqueológico que, al igual 
que Torres (1903a, 1911), denomina "estaciones", éstas serían un "paradero" temporario ocupado o abandonado según la estación del año (Serrano 1933b). Para la costa del río Uruguay se refiere también a los "paradero-taller", talleres líticos localizados en las costas de los departamentos Colón y Concepción del Uruguay.

En relación a los denominados sambaquíes Serrano discute su presencia en el río Uruguay inferior y sostiene que no cree que sean verdaderos sambaquíes sino “...simples paraderos de tipo corriente con abundancia de restos de moluscos como sucede con el de Salto Grande estudiado por mí." (Serrano 1933b: 13). En referencia a los sambaquíes o conchales referidos por Torres y Greslebin para el departamento Gualeguaychú y por González (1947) para el río Paraná Pavón (véase más adelante), expresa que no toda acumulación de moluscos debe considerarse un sambaquí y que en la zona anegadiza del río Paraná hay bancos naturales de moluscos (Serrano 1950).

En 1930 Serrano releva varios sitios arqueológicos en ambas márgenes del río Uruguay desde Monte Caseros (Santa Lucía, Corrientes) hasta Gualeguaychú (Serrano 1932a). Este constituye quizás el único trabajo de campo intensivo realizado por Serrano en el área de estudio de esta tesis. En Gualeguaychú abordó el sitio arqueológico Cerro Grande, el mismo excavado por Greslebin (1931a) y denominado Túmulo 1 de Pesquería Nicolini, en donde recupera artefactos líticos y cerámicos, y un artefacto óseo (Catálogo de Arqueología del Museo Antonio Serrano, Paraná). En 1968 Serrano junto a Eduardo Berberián y Amílcar Rodríguez visitan nuevamente Monte Caseros y realizan nuevas recolecciones superficiales de material lítico, entre los que se destaca al menos una punta de proyectil "cola de pescado" (PCP) (Rodríguez 1975). No está claro si esta PCP corresponde a la que publica Serrano en 1932 (Castro y Terranova 2015; Nami 2007).

Para el río Uruguay Serrano (1932a) destaca la ausencia de "restos de cocina" y la escasa alfarería, interpretando que estos sitios arqueológicos corresponderían a talleres líticos. Propone relaciones de los pobladores del río Uruguay medio con los patagónicos "protohistóricos" a partir de la tipología de la "industria lítica", y con los indígenas de la región pampeana en cuanto a la alfarería. Sostiene que el Uruguay medio es una zona arqueológica distinta al Uruguay inferior y al Delta del Paraná.

Serrano viajó varias veces a la costa del río Uruguay, en algunos casos a dar conferencias a Concordia por ejemplo, y mantenía una fluida relación con algunos coleccionistas aficionados a la arqueología, entre ellos Andrés García de Concepción de Uruguay. García le proporcionaba materiales arqueológicos y fotografías de los mismos, hallados en recolecciones superficiales y excavaciones en la costa del río Uruguay, que en algunos casos Serrano utilizaba en sus publicaciones (véase p. ej. Serrano 1936 y 1946). Se registraron en el archivo de la División Arqueología del Museo Antonio Serrano algunas fotografías de trabajos arqueológicos en el río Uruguay pero no está claro aún si corresponden a los trabajos de Serrano o de García (Figura 2.9 y 2.10). En base a las fechas de 
las mismas es probable que correspondan a los trabajos de García y que éste se las haya enviado a Serrano en sus frecuentes intercambios epistolares.

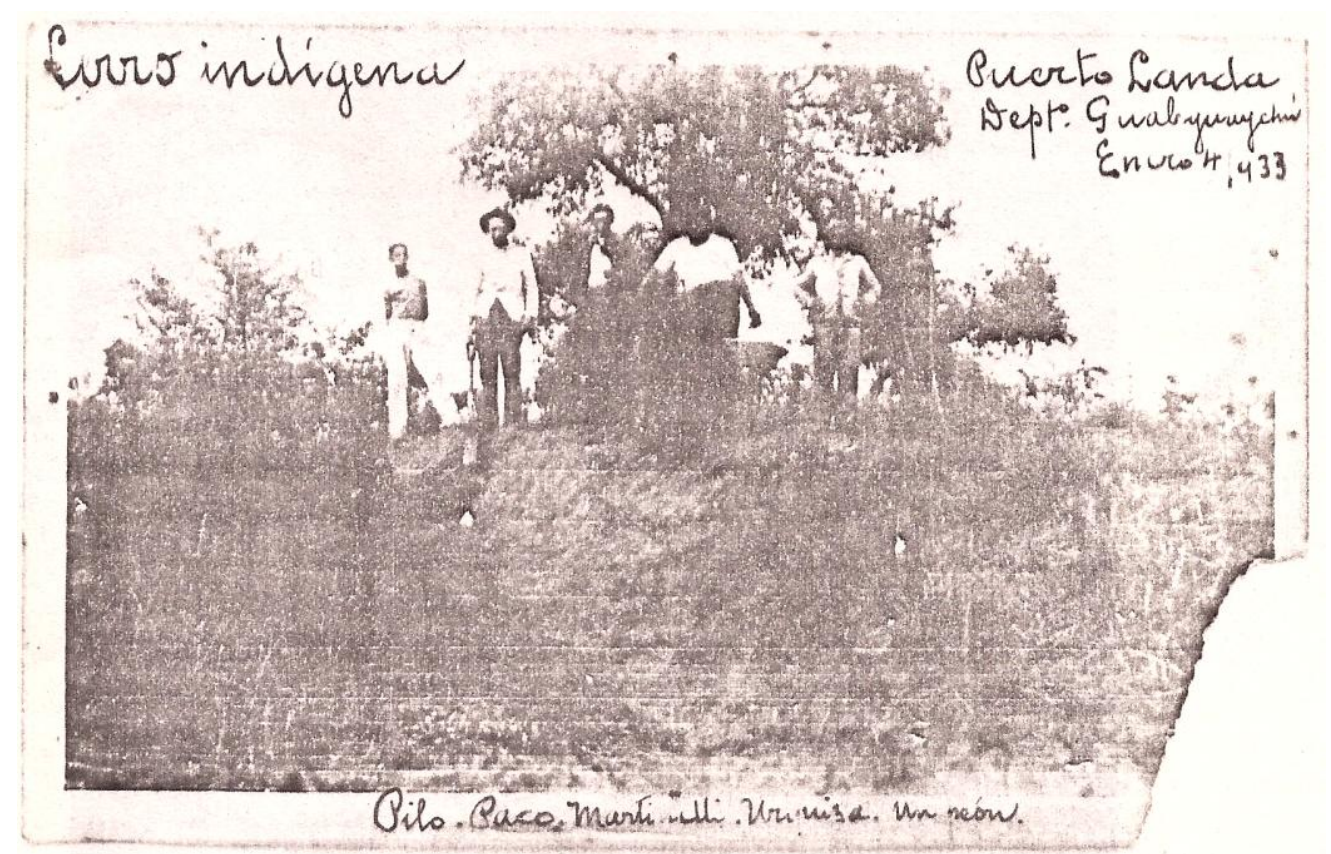

Figura 2.9. Excavación en Gualeguaychú en 1933.

Uno de los aportes novedosos de Serrano para la época es el análisis microscópico de la alfarería de Paso de Paysandú (departamento Colón), ya que identifica espículas de esponjas de agua dulce (Uruguaya corallioides) en la pasta y sostiene que su inclusión es intencional, como sucede en diferentes sectores de la Amazonía. Como alternativa propone que si no fueron agregadas directamente por lo menos ha sido seleccionado el fango que las contenía (Serrano 1950). También registró espículas de esponjas en muestras de alfarería provenientes de los departamentos Colón, Concordia, Federación (Entre Ríos), y Monte Caseros en Argentina; así como de Bella Unión y Villa Constitución en la ROU (Serrano 1933a). En su interés por la cronología llama la atención a los arqueólogos sobre preservar y prestar mucha atención a la estratigrafía (Serrano 1933b). 


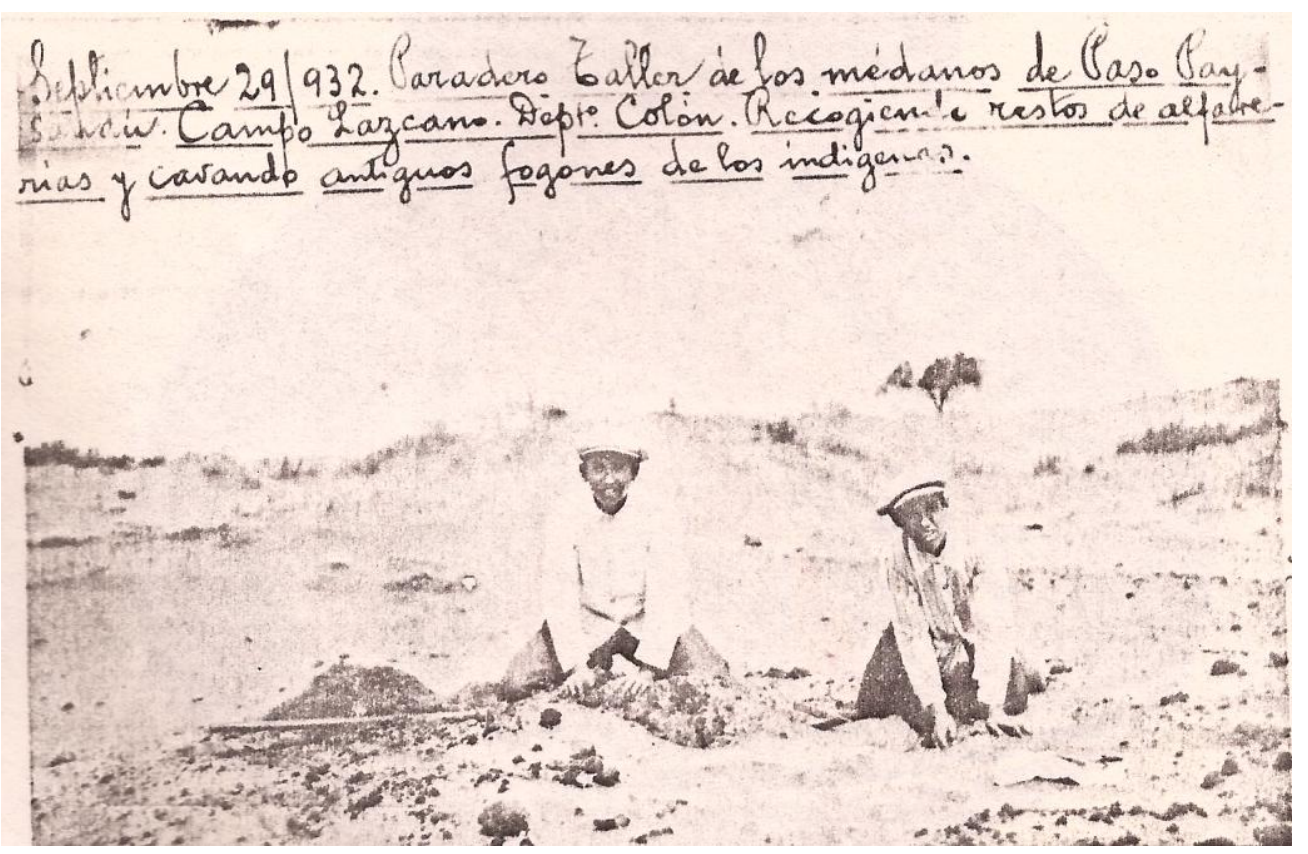

Figura 2.10. Recolección de materiales arqueológicos en los médanos de Paso Paysandú (Colón) en 1932.

Serrano reconoce que los restos arqueológicos más abundantes en la región corresponden a la alfarería y sostiene que "...la técnica alfarera junto con el arte alfarero constituyen un índice seguro para establecer estados culturales." (Serrano 1933b: 14). En este sentido, manifiesta que la presencia o ausencia de los apéndices zoomorfos sirve para definir áreas culturales y clasifica los modelados biomorfos en cinco tipos. Esta primera clasificación de 1933, será levemente modificada en trabajos sucesivos (véase Serrano 1946, 1950, 1954) y definida finalmente en 1972 de la siguiente manera: 1Recortadas o siluetas; 2- Concoides o cóncavas; 3- Escultóricas macizas (incluye las "alfarerías gruesas" o "campanas"); 4- Escultóricas huecas y 5- Tubulares abiertas (Serrano 1972).

En un intento por determinar contactos con otras áreas, Serrano (1931) elabora un cuadro estableciendo posibles vinculaciones entre la alfarería del NEA y la de la región pampeana; además de vías de intercambio de rocas, ocre y cobre con otras zonas como la ROU, y las provincias de Buenos Aires, Córdoba y Chaco. Por otro lado retomó la propuesta de Outes (1918b) sobre la existencia de tres manifestaciones culturales en la cuenca del Paraná. A partir de la alfarería (sobre todo la decoración), los instrumentos óseos y líticos, y los distintos tipos de entierros humanos propone la existencia de cinco "culturas": 1- Guaraní que se manifiesta en toda la cuenca; 2- la de las representaciones plásticas del tipo Malabrigo, Goya y Paradero El Ombú, que predomina en la zona de Goya y Malabrigo y se registra esporádicamente en el delta; 3- la de las alfarerías gruesas se encuentra en la zona anegadiza comprendida entre los 30 y y 35 o de latitud sur; 4- sería igual a la tercera de Outes (1918b), pero con una distribución más amplia que incluye además del complejo insular del Delta del Paraná, el curso inferior del río Uruguay y las tierras altas desde Hernandarias 
hacia el sur (correspondería a la "Cultura Entrerriana"); y 5- la "Ibicueña" localizada en ciertas islas del delta y la costa norbonaerense.

Serrano diferencia en base a la tecnología lítica el registro arqueológico guaraní del río Paraná y el del río Uruguay. Al primero denomina "Guaraní" y al segundo "Tupí-guaraní" (Serrano 1933b). Este último tendría vinculación con los sambaquíes de Santa Catarina y Rio Grande do Sul (Brasil), donde habría un gran desarrollo técnico de artefactos elaborados por picado, abrasión y/o pulido. El autor adjudica la pipa lítica de La Paz (Outes 1917b) y los pilones de Hernandarias (Serrano 1930) a infiltraciones Tupí-guaraní hacia la costa oriental del río Paraná. Para la cuenca del río Uruguay además de la presencia Tupí-guaraní, Serrano reconoce otras dos culturas, diferenciadas por su extensión geográfica y su registro arqueológico, que denomina "Cultura de vinculaciones paranenses" y "Cultura de vinculaciones patagónicas" (Serrano 1933b). A su vez, estas dos últimas comparten algunos elementos generales que permiten determinar un "substratum cultural" en el conjunto, que constituye la llamada "Cultura Básica del Litoral”. Esta última dará origen a las culturas históricas en cada región particular. Finalmente, agrupa todas las culturas del NEA en tres grupos que son:

$\checkmark$ Grupo guaraní (Guaraní del Paraná y Tupí-guaraní del Uruguay).

$\checkmark$ Grupo paranense (Malabrigo; alfarerías gruesas; entrerriana; Ibicueña y vinculaciones paranenses (río Uruguay).

$\checkmark$ Grupo uruguayense (vinculaciones patagónicas).

Este su síntesis final del año 1972, Serrano presenta una periodización y un cuadro cronológico (Figura 2.11), además de un intento de regionalización de las manifestaciones culturales basándose en estimaciones cronológicas relativas y en la distribución geográfica de distintos materiales arqueológicos (cerámica, lítico, prácticas mortuorias, entre otros). Partiendo de sus trabajos previos y con nuevos datos regionales elabora este "...ensayo que constituye el primer ensayo de periodización de la arqueología del litoral." (Serrano 1972: 3). Para esta sistematización de la arqueología del Litoral, desde el punto de vista geográfico Serrano identifica cuatro regiones: Misionera, Paraná Central, Deltica y Uruguay Central. Desde el punto de vista temporal reconoce cuatro períodos: Precerámico, Alfarero temprano, Alfarero tardío e Hispano-indígena. 


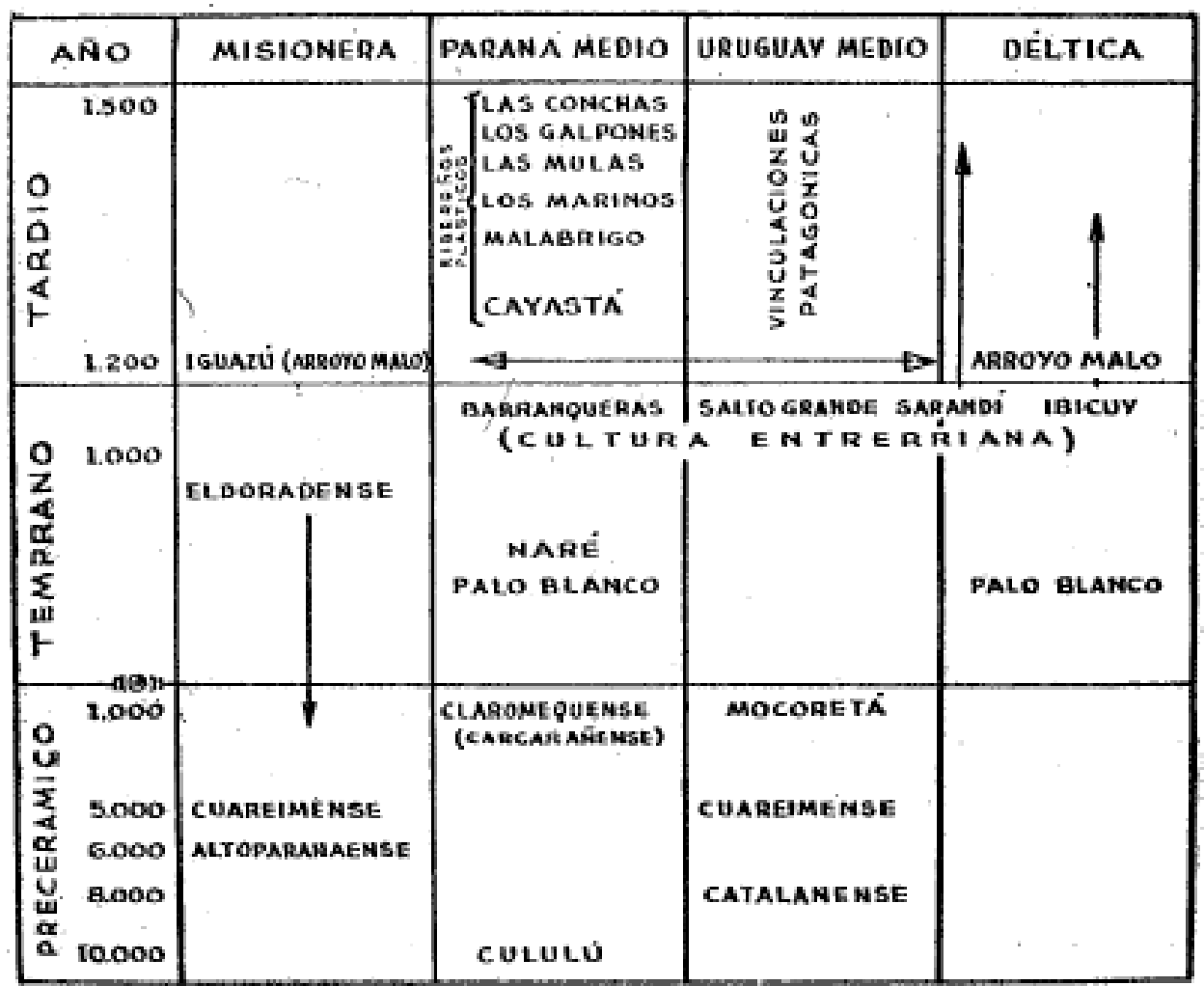

Figura 2.11. Esquema cultural propuesto por Antonio Serrano en 1972.

Precerámico: representado por "cazadores muy primitivos" del alto y medio río Uruguay y del alto Paraná, cuya tecnología lítica se denomina Altoparanaense, Catalanense y Cuareimense (véase Menghin 1955-1956, 1956).

Alfarero Temprano: representado por la cultura entrerriana, equivalente a la cultura básica del litoral pero limitada a la cuenca del Paraná y Uruguay medio e inferior. A la llegada de los europeos su expresión etnográfica eran los chaná y beguás ubicados en curso inferior del Paraná y el Uruguay, por eso el autor en ciertos sectores donde esta manifestación persiste en el tiempo sin grandes variantes la denomina "Cultura Básica Persistente". El registro arqueológico correspondería a cazadores y pescadores, con una alfarería de formas simples, lisas o decoradas, pero sin apéndices zoomorfos y generalmente sin asas. Esta "cultura" presenta facies que se diferencian por la cerámica y el patrimonio en general, entre ellas se encontrarían las facies Ibicuy, Salto Grande y Sarandí, ésta última sería la que mejor caracterizaría la forma básica persistente.

Alfarero Tardío: en el Paraná medio la cultura básica del litoral recibe desde el norte la influencia de un pueblo agrícola, amazónico y con decoración plástica en la cerámica. "Este aporte transforma la cultura básica en la histórica de los ribereños plásticos, con dos sectores: el de las alfarerías "gruesas", cuyos portadores, son sin duda los chaná-timbú y el sector de la facie de Malabrigo, al norte de este." (Serrano 1950: 115). Dichos aportes provendrían de grupos de la familia lingüística arawak u otro afín, siendo su rasgo más diagnóstico los apéndices zoomorfos y 
antropomorfos en la alfarería. Los "Ribereños Plásticos" no presentarían uniformidad en su cerámica dado que Serrano reconoce facies sincrónicas, o sea variaciones de índole espacial, donde "...serían unas más tempranas que las otras y corresponderían a aportes sucesivos de pueblos arawak que habrían llegado en oleadas sucesivas." (Serrano 1972: 39). Las facies reconocidas son: Las Mulas, Malabrigo, Las Conchas, Los Marinos, Cayastá y Los Galpones. Sus “portadores” integran una unidad lingüista y cultural llamada chaná-timbú. La presencia de los ribereños plásticos fuera del límite de esta región, tanto al sur, en el delta y la costa uruguaya se debería a un proceso de expansión que fue interrumpido por la llegada europea. La funcionalidad de las llamadas campanas o alfarerías gruesas es desconocida, pero Serrano les asigna un carácter totémico o religioso (Serrano 1950).

También en este período a lo largo del río Uruguay y parte de Rio Grande do Sul y la ROU, se desarrolla plenamente la cultura de vinculaciones patagónicas propia de los charrúas (Serrano 1950: 26). Esta vendría del sur y sería más reciente, su centro de expansión es el sud-oeste de Rio Grande do Sul y áreas vecinas de la ROU y Argentina. Desde allí se expande hacia el sud-este y en el litoral atlántico uruguayo desalojan a los portadores de la cultura básica persistente. La alfarería es sobre todo lisa y escasa. El material lítico se compone de piedras de boleadoras, lenticulares, núcleos, láminas, puntas de flechas y lanzas y placas grabadas (Serrano 1950, 1972).

Serrano interpreta registro guaraní del NEA como una facie de la expansión guaraní con una antigüedad entre 700 y 500 años AP denominada Arroyo Malo, cuyos núcleos principales estaban en Misiones y en el Delta inferior del río Paraná. La ausencia de hallazgos al norte de Santa Fe lleva al autor a plantear que la "explosión" guaraní sobre el río Paraná se produjo desde el delta hacia el norte y no al revés. La asociación de restos guaraníes con otros de carácter local respondería a contactos post-conquista o inmediatamente anterior a ella, entre éstos y los chaná-timbú.

Para finalizar con Serrano, se puede plantear que si bien en sus primeros trabajos se puede notar la influencia del paradigma evolucionista, en sus trabajos finales publicados sobre todo a partir de 1950, se observa como el autor se encuentra permeado por nociones básicas del difusionismo clásico. En este sentido, cuando Serrano considera que en todos los cambios y transformaciones que sufren las diferentes culturas, siempre existe una influencia externa, aporte o préstamo de alguna otra población de una región diferente; no da lugar a los cambios locales, a la innovación o al desarrollo histórico local. Los cambios se originarían por mezcla de elementos y poblaciones, por desplazamientos geográficos de grupos humanos y/o sustituciones de un conjunto de patrones culturales por otro. Esto también se refleja en los mapas y diagramas culturales que expone el autor. Por otro lado, reconoce poca antigüedad tanto para la presencia guaraní en Entre Ríos, así como para la cerámica.

Otro aspecto a considerar en los trabajos de este investigador es que siempre que caracteriza cada una de las "culturas", determina la dispersión geográfica de su patrimonio material y las identifica con alguna de las etnias conocidas históricamente. Probablemente esto tenga que ver con 
su buen conocimiento de la bibliografía etnohistórica a nivel regional y con sus escasos trabajos de campo en relación a los artículos escritos (para excepciones véanse sus trabajos en los sitios arqueológicos Las Conchas -Serrano 1932b-, Las Tejas -Serrano 1922b- y Arroyo Las Mulas -Serrano 1946-). La obra de Serrano es uno de los pilares de la arqueología de Entre Ríos, que será constantemente revisada, criticada y valorada de variadas maneras por todos los investigadores contemporáneos a él y los que le sucederán en el tiempo hasta la actualidad.

Durante estos momentos de sistematización del trabajo arqueológico se pueden mencionar otras publicaciones que representan un aporte significativo por la singularidad de los hallazgos. Por ejemplo la de Fernando Márquez Miranda (1932), donde se hace una revisión de la bibliografía de la época de la conquista, en relación a la elaboración y uso de canoas monoxílas en Brasil, Paraguay y la Mesopotamia Argentina. Además, describe una canoa monoxíla de timbó del Museo de La Plata hallada en el arroyo La Glorieta (Delta del Paraná). Posteriormente Iribarne (1937) presenta y describe una serie de "vasos" enteros $(n=11)$ recuperados por otros investigadores en las márgenes del Paraná inferior y los adjudica a los responsables de las representaciones plásticas. También Santiago Gatto (1939) excava el sitio arqueológico "paradero-cementerio" de Brazo Largo (Islas del Ibicuy) donde recuperó restos óseos de 21 individuos, identificando entierros primarios y secundarios con ocre rojo. Asimismo, Vignati (1941) describe el hallazgo de dos paquetes funerarios de origen guaraní en el delta bonaerense (arroyos Malo y Fredes).

Otros trabajos destacados, ya sea por su sistematicidad metodológica, por la importancia de los sitios arqueológicos trabajados y los materiales recuperados y/o por las propuestas planteadas, son los de Samuel Lothrop, Alberto Rex González, Fernando Gaspary y Víctor Badano. Lothrop (1932) excava tres sitios arqueológicos en el Delta inferior del río Paraná: Arroyo Malo, El Cerrillo (= Túmulo I del Paraná Guazú de Torres 1911) y Arroyo Sarandí. En todos recupera abundantes restos de alfarería y faunísticos, algunos instrumentos óseos y líticos, y entierros humanos primarios y secundarios. En cuanto a Arroyo Malo sostiene que sería una aldea guaraní, no solo por estar ubicado en el territorio donde las fuentes históricas ubican a este grupo étnico, sino porque los materiales recuperados son similares al patrimonio material de grupos guaraníes antiguos y modernos. Este autor plantea la presencia de una cultura que atribuye a los guaraníes y es característica de Arroyo Malo y otra que atribuye a los querandíes y estaría representada por Arroyo Sarandí. A esta última se sumarían las "tribus" habitantes del Paraná inferior, conformando una misma unidad cultural.

Las representaciones zoomorfas en la zona estudiada por este investigador serían intrusivas y provendrían desde el norte ( $p$. ej. de la cuenca superior y media del río Paraná y del Delta superior del Paraná), zona donde serían más comunes, y plantea que usualmente en otras partes de Sudamérica las cabezas modeladas de arcilla son el producto de grupos arawak o de grupos en contacto con los arawak. De esta forma Lothrop considera a dos de las culturas propuestas para el 
Delta del Paraná por Torres (1911) y Outes (1918b) como una misma unidad arqueológica. El sitio arqueológico El Cerrillo es adjudicado por Lothrop a grupos chaná o chaná-beguá y no concuerda con Torres en cuanto a considerarlo como una construcción artificial. Sostiene que la presencia de fogones indicaría que su superficie fue habitada y su altura se incrementó gradualmente por acreción como resultado de esa ocupación. Por otro lado, en base al descubrimiento de objetos de origen europeo en dos de los sitios arqueológicos (Arroyo Malo y Arroyo Sarandí), propone que la zona fue ocupada en momentos previos a la llegada de los europeos y simultáneamente a estos (Lothrop 1932). En este sentido, el reestudio de los materiales europeos procedentes del Arroyo Malo realizado por Bonomo (2013) permitió acotar la ocupación de este sitio arqueológico al siglo XVI.

González (1947) excava en 1939 el sitio arqueológico Cerro Grande en el río Paraná Pavón, analiza en detalle su estratigrafía y postula, al igual que Lothrop, la idea de un origen mixto de los montículos, pero donde el aporte humano sería menor y no intencional. González (1947) también analiza las diferentes prácticas de inhumación y las clasifica en: 1- restos en desorden; 2- hallazgos de cráneos aislados; 3- esqueletos con algunos de sus huesos en posición lateral, pero incompletos; 4paquetes funerarios y 5 - incineración. Para el NEA reconoce tres etnias diferenciadas a partir de su organización social, subsistencia, hábitat ocupado y alfarería; estas serían: cazadores mediterráneos (cuyos representantes históricos serían, entre otros, los querandíes); agricultores y pescadores litorales responsables de la alfarería Goya-Malabrigo (cuyos representantes históricos serían los chaná-timbú); y agricultores de la floresta tropical que serían los históricos guaraníes (González 1977).

Por su parte, Gaspary $(1945,1947)$ es uno de los autores que demuestra particular interés sobre la posible función las alfarerías zoomorfas y las campanas, ensayando una clasificación morfológica de las mismas. En 1950 Gaspary da a conocer los resultados de la excavación en el Cerro Grande de la Isla Los Marinos (Victoria) y plantea que los "cerritos" son montículos de tierra y arena, que pueden ser tanto naturales como artificiales construidos, y habrían sido aprovechados por todos los habitantes de las zonas anegadizas (aún en la actualidad) para resguardarse de las crecientes del río. Propone que algunos habrían funcionado como "paraderos" y otros como "paraderos y enterratorios" y destaca también que los "cerritos" no fueron patrimonio de ninguna etnia particular y pudieron ser habitados en distintos momentos. El Cerro Grande habría sido construido sobre una elevación natural del terreno y ocupado por los chaná-timbú, además reconoce una zona de préstamo de material constructivo adyacente al montículo (Gaspary 1950). En este sitio arqueológico recupera fragmentos de alfarería "digito-ungueada" guaraní que adjudica a intercambios, y apéndices zoomorfos y campanas que considera como ajuares funerarios por registrarse entremezclados con los restos óseos de 48 esqueletos humanos. Asimismo, Gaspary clasifica los entierros en: primarios, secundarios en paquetes funerarios, huesos en desorden, huesos en posición natural pero incompletos y huesos calcinados. 
Este investigador identifica también vasijas en miniatura, pero no concuerda con la opinión previa de Serrano sobre que las mismas son juguetes de niños, ya que nunca se han hallado junto a esqueletos de niños, sino más bien de adultos de ambos sexos (Gaspary 1950). Gaspary $(1945,1950)$ propone la denominación "campanas" para las Ilamadas alfarerías gruesas de Serrano $(1930,1931)$ y las adjudica, al igual que este último autor, a los chaná-timbú como objetos totémicos o ceremoniales, ya que todos representan a un animal (Gaspary 1947). También diferencia entre la funcionalidad de las campanas grandes y las miniaturas. Para las de mayor tamaño plantea, al igual que Frenguelli (1927a), que fueron para conservar el fuego, pero "que el acto de conservarlo debió ser motivo de un culto especial, confiándole estas piezas el carácter de objetos sagrados. Otra hipótesis que no descartamos es la que hubiesen sido utilizadas como sahumadoras en actos ceremoniales." (Gaspary 1950: 38). Las miniaturas de campanas y otras vasijas, podrían tener carácter simbólico y ser agregadas en los ajuares en reemplazo de las piezas originales (Gaspary 1947, 1950).

Por último, Badano (1940a, 1940b, 1944, 1946, 1955, 1957) (Figura 2.12) focalizó su interés en los denominados ribereños plásticos y en su área de dispersión, abordando además la presencia del registro guaraní en la región. En algunos casos, al igual que la mayoría de los autores anteriormente citados, publica artículos sobre objetos aislados (Badano 1944) o pequeñas colecciones (Badano 1940a, 1940b). De esta forma describe un conjunto de vasijas guaraníes procedentes de la isla del Pillo y del sitio arqueológico Cerro de las Pajas Blancas (Delta superior del Paraná), y de las islas Juanicó y Rica (Concepción del Uruguay), entre otros.

Para Badano (1955) el área de dispersión de los ribereños plásticos, iría desde la confluencia Paraná-Paraguay hasta el Río de la Plata, pero se registraría mayor densidad entre Goya y el Delta del Paraná. Clasifica esta alfarería en ocho tipos que son: 1- Tubulares; 2- Macizas; 3- Macizas con concavidad; 4- Huecas; 5- Siluetas o figuras recortadas; 6- Cóncavas; 7- Macizas marginales y 8Simplificadas (Badano 1955). Al igual que Serrano, Badano $(1944,1946,1955)$ adjudica los "Ribereños paranaenses" a los chaná-timbú y observa que hay sitios arqueológicos con elementos chaná-timbú y guaraní mezclados (p. ej. Cerro de las Pajas Blancas) y otros exclusivamente chanátimbú. 




Figura 2.12. Víctor Badano.

Durante este segundo momento del desarrollo arqueológico del NEA si bien continúan publicándose trabajos dedicados a piezas individuales y pequeñas colecciones sin contexto claro, también se publican trabajos dedicados a un solo sitio arqueológico (p. ej. Las Tejas, Cerro Grande de la Isla Los Marinos y Cerro Grande del Paraná Pavón), y a partir del mismo se vuelcan todos o la mayoría de los datos registrados y su interpretación dentro de un contexto geográfico más amplio. Se advierte también un interés por las clasificaciones del registro arqueológico en categorías morfológicas y/o funcionales.

Esto se observa en relación a los tipos de sitios arqueológicos; a las alfarerías denominadas ribereños plásticos o paranaenses; y a los tipos de inhumaciones. En cuanto a este último aspecto tanto González como Gaspary asumen el hallazgo de huesos humanos calcinados como una práctica funeraria. Otro aspecto importante que despertó el interés, y que ya había sido abordado desde el comienzo de la arqueología regional, fue el registro de piezas adjudicadas de grupos de origen guaraní, así como también las zonas ocupadas por éstos y la dirección y cronología de su expansión. Algunos de los autores mencionados arriba (Serrano, Lothrop) también reconocen la posible influencia de grupos de origen amazónico como los de la familia lingüística arawak.

Desde el punto de vista teórico este periodo se encuentra impregnado por nociones evolucionistas y difusionistas. Siendo estas últimas muy marcadas a la hora de explicar el cambio en el registro arqueológico. El mismo siempre sería producto de aportes o influencias externas. En este sentido, los investigadores de la época se preocuparon también por la delimitación geográfica de las distintas manifestaciones culturales, construyendo diversos esquemas explicativos que muestran las direcciones de estas influencias foráneas. 


\section{3- NUEVAS PROPUESTAS DE SISTEMATIZACIÓN ARQUEOLÓGICA}

Durante la década de 1950 no se registran trabajos de campo sistemáticos en el NEA, solo algunas publicaciones ya mencionadas de Serrano, Badano, y otros. Esta situación de merma de investigaciones probablemente se deba a la situación política del país, que afectó a las instituciones educativas de la época. Asimismo, en este período surge un enfrentamiento teórico y metodológico entre las corrientes difusionistas austro-alemana y norteamericana (González 1991-1992; Politis y Curtoni 2011). Ambas se trasformaron en opciones teóricas opuestas para los jóvenes investigadores de la época, pero las diferencias teóricas no serían tan marcadas según González (1991-1992). Como resultado concreto de esta situación se produjo por un lado, el abandono de los postulados evolucionistas previos, y por otro lado, hubo un importante desarrollo de la metodología arqueológica (Trigger 1992). Recién a fines de 1960 y principios de 1970 se retoman los trabajos de campo sistemáticos y surgen nuevas propuestas para la región. A continuación se mencionan las más relevantes, buscando seguir un orden geográfico se comienza con trabajos referidos a todo el NEA para seguir luego específicamente con la cuenca media del río Paraná, el Delta del Paraná, y por último se abordan ambas márgenes de la cuenca media e inferior del río Uruguay.

Entre 1966 y 1970 Lafon y su grupo de trabajo, comienzan a trabajar en el NEA con un plan teórico-metodológico bien definido y ambicioso, que luego quedaría inconcluso sobre todo por razones políticas. Lafon realiza sólidas críticas a las propuestas de Aparicio, Zeballos y Pico, y Serrano., sobre todo al hecho de adjudicar registro material a las etnias conocidas en los siglos XVI o XVII. Critica también las interpretaciones de Aparicio y de Zeballos y Pico sobre el Túmulo de Campana; y a Serrano sosteniendo que su esquema de desarrollo cultural propuesto en 1972 "...debe ser considerado, más que nada, como una hipótesis digna de ser tenida en cuenta pero que dista mucho de tener valor probatorio." (Lafon 1972: 14).

En cuanto al trabajo de campo Lafon excava varios sitios arqueológicos en Entre Ríos (p. ej. El Estero, Las Ánimas y El Aserradero) (Figura 2.13). Sobre el río Uruguay recorre Salto Grande, Federación, Colón y Concepción del Uruguay, así como las zonas de Puerto Landa y Puerto Basilio en Gualeguaychú, pero no da detalles de los resultados allí obtenidos. En Campana excava un sitio arqueológico adyacente al Túmulo de Campana y sostiene que no es un "túmulo" sino un albardón (véase Politis y Bonomo 2015, 2016). 


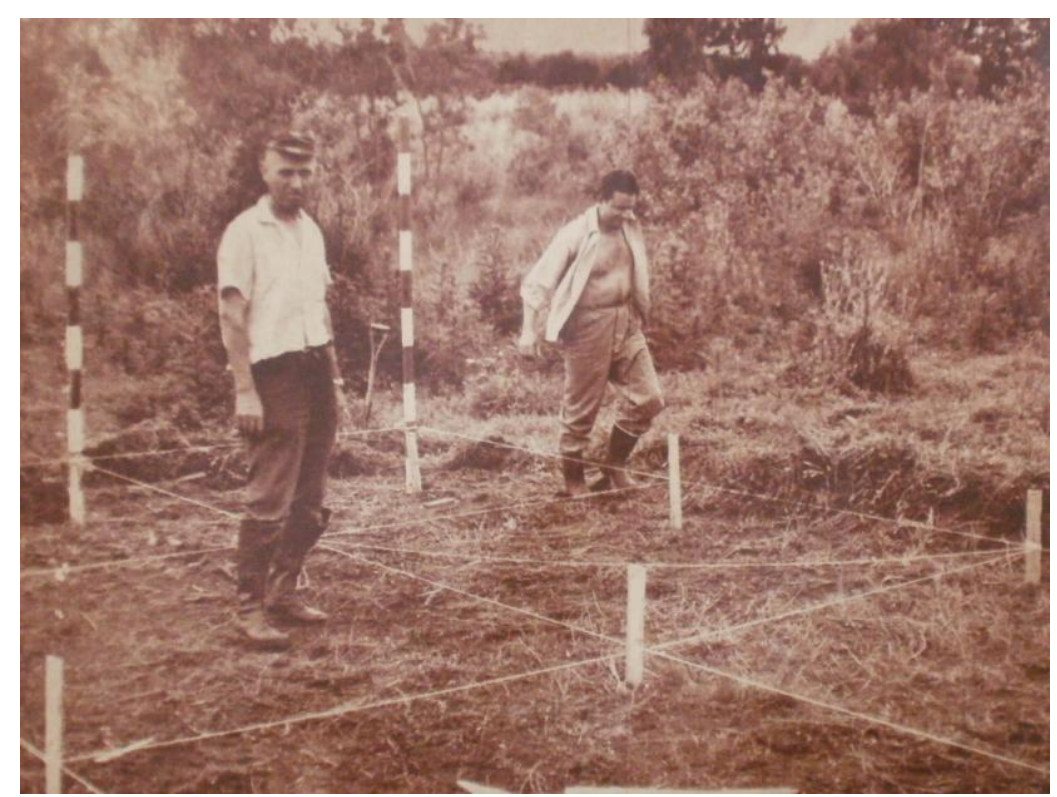

Figura 2.13. Excavación de Lafon en el sitio arqueológico El Aserradero (Tomado de Lafon 1968).

En 1972 Lafon hace un replanteo de la propuesta anterior, mostrándose más crítico con algunas categorías que han sido aceptadas en la bibliografía sin mayor discusión, como por ejemplo: Altoparanaense (Menghin 1955-1956), Eldoradense (Menghin 1956), Carcarañense (González y Lorandi 1959), entre otros. En su intento de sistematización del registro arqueológico aborda la "Fenomenología de los yacimientos" y es así como el autor denomina a la "...suma de características con las que se nos aparecen en la actualidad los restos arqueológicos en su relación con el medio y el paisaje, como resultado de un proceso natural y cultural que debemos reconstruir." (Lafon 1972: 2). A partir de este precepto clasifica los sitios arqueológicos de cada una de las regiones y subregiones determinadas para el NEA (Mesopotamia septentrional, central y meridional) (véase Capítulo 3). En la Mesopotamia central los sitios arqueológicos serían el resultado de la ocupación de albardones, barrancas altas, terrazas fluviales, antiguos médanos edafizados y médanos vivos. En la Mesopotamia meridional habría asentamientos sobre albardones y antiguos médanos edafizados, sobreelevados por la ocupación humana (Lafon 1972).

El modelo que elabora Lafon sobre el poblamiento y desarrollo cultural está concebido sobre todo para la Mesopotamia y áreas adyacentes. Para la Mesopotamia septentrional, basándose en Menghín (1955-1956, 1956 y 1957), propone una secuencia histórica desde el Pleistoceno a la actualidad y reconoce en esta subárea manifestaciones culturales que denomina "Paraneolíticas" y corresponderían a "...cazadores, pescadores y recolectores con cerámica, y que dejaron testimonio de la ocupación estacional más o menos prolongada en albardones contiguos, o en elevaciones naturales, o sobre médanos viejos ya consolidados, a la orilla de ríos, arroyos o lagunas o en medio de esteros, bañados o zonas anegadizas." (Lafon 1972: 8). 
Este patrón cultural sería lo que Serrano (1972) denominó cultura básica del litoral y sus posteriores modificaciones. Particularmente en la Mesopotamia central a partir de estas manifestaciones se habrían gestado los ribereños plásticos. En cuanto a éstos últimos pone en duda que sus responsables hayan sido los indígenas que entraron en contacto con los conquistadores, ya “...que ninguna de las fuentes hace mención a un rasgo tan llamativo, pese a que algunos de los cronistas convivieron largo tiempo con los indígenas de la zona." (Lafon 1972: 13).

En la Mesopotamia central sobre el río Paraná toma como sitios arqueológicos tipo a los del río Malabrigo (Frenguelli y Aparicio 1923) y propone que las campanas podrían tener un origen alóctono y reflejar una vinculación con Santiago del Estero. Por otro lado, observa, al igual que Métraux (1934) y Nordenskiöld [1916] (2009), una similitud en la disposición de muchos apéndices zoomorfos de las vasijas, con la cerámica de Santarém de la cuenca inferior del río Amazonas (Brasil). Asimismo, la forma de ciertos platos le sugiere la preparación de tortillas de mandioca como hacen los grupos hablantes del arawak, esto también fue observado por Serrano (1950) para el norte de Santa Fe. Para la Mesopotamia central sobre el río Uruguay Lafon sostiene que habría que rever todas las interpretaciones sobre los sitios arqueológicos conocidos y critica las interpretaciones de Serrano (1932a) realizadas en Barranca Pelada del Epinillal (ROU). Lafon también considera que la cerámica incisa de Salto Grande es semejante a la del río Paraná y asocia las placas grabadas con los "vasos" de Puerto Basilio (Greslebin 1931b).

Para el Delta del Paraná y los ambientes litorales adyacentes, denominados por Lafon como Bajíos Ribereños, destaca la falta de una cronología definida e intenta un ordenamiento caracterizando los sitios arqueológicos y sus materiales. Buscando objetividad cuando se refiere a los sitios arqueológicos típicos del Delta del Paraná, Lafon expresa que “...son asentamientos en elevaciones no inundables, en medio de tierras bajas y anegadizas, que han sido a la vez lugar de vivienda y de inhumación..." (Lafon 1971: 138). Es así como usa ex profeso "elevaciones" en vez de montículos, túmulos o cerritos, aunque reconoce la sobreelevación antrópica de los mismos por acreción (Lafon 1972). En relación a la cronología identifica dos estadios, uno acerámico y otro cerámico que se subdivide períodos. En su esquema, primero delimita los períodos y dentro de cada uno ubica las distintas manifestaciones culturales, sean acerámicas o cerámicas (véase Lafon 1972).

En la obra de este autor, enmarcada mayormente dentro de la escuela histórico-cultural de Viena, se destacan las amplias excavaciones en algunos de los sitios arqueológicos intervenidos, la metodología de documentación rigurosa de las condiciones de los hallazgos, y el propósito de extraer información sobre el medio ambiente y su vinculación con el aprovechamiento de los recursos. Lamentablemente solo publicó unos pocos trabajos y gran parte de la información generada por este autor aún permanece inédita. Asimismo, cabe mencionar el revisionismo que realiza sobre ciertos supuestos y categorías, aceptadas sin mayor discusión en la literatura arqueológica de la región en ese momento, llamando la atención acerca de la interpretación contextual de registro arqueológico. 
A partir de sus investigaciones elaboró una secuencia de desarrollo cultural constituida por tres "tradiciones": cazadores y recolectores precerámicos, "neolítica" correspondiente a cazadores y recolectores alfareros, y Tupi-Guaraní Generalizada. Luego abandonaría esta clasificación, considerando solo unidades culturales individuales que conformarían un complicado mosaico arqueológico regional.

Luis Abel Orquera (1973), quién integró el equipo de trabajo de Lafon, plantea que en tiempos prehispánicos el Delta del Paraná habría sido un área con una elevada densidad poblacional en medio de las llanuras casi desiertas. Los asentamientos se encontrarían sobre albardones y "cerritos" (considerados como médanos consolidados) que habrían servido como refugio ante el aumento del nivel de las aguas. En el Delta del Paraná este autor reconoce la existencia de cuatro unidades culturales presentes en distintos sitios arqueológicos, unos serían los tupí-guaraní (p. ej. Arroyo Malo) y los tres restantes (representados en Anahí, El Aserradero y Las Vizcacheras) serían cazadores y pescadores que tienen rasgos en común pero que se diferencian entre sí por la pasta y decoración de la cerámica. También plantea que abundancia de restos faunísticos sugiere asentamientos permanentes o al menos que los indígenas residían gran parte del año y durante varios años consecutivos en un mismo lugar. Asimismo, destaca la abundancia de Diplodon sp. en los sitios arqueológicos entrerrianos (Orquera 1973).

En 1972 Pedro Ignacio Schmitz, Carlos Natalio Ceruti, Alberto Rex González y Antonia Rizzo dan a conocer los resultados de los trabajos realizados por González en Corrientes y Santa Fe en 1948 (Schmitz et al. 1972). González había realizado recolecciones superficiales en los sitios arqueológicos Paraná Miní 2, 3 y 4; Arroyo Amores 1; Arroyo Pescado 1; Arroyo Fondita 1; e Isoró 1 y 2 y había excavado el sitio arqueológico Paraná Miní 1 (PM1) mediante 42 cuadrículas de 2×2 m y niveles de 0,20 m. Sobre los materiales recuperados (alfarería, instrumentos óseos, artefactos líticos y restos humanos y faunísticos) se realizaron análisis tecnológicos y morfológicos, mediante los cuales determinan que el registro material de todos los sitios arqueológicos de la zona presenta cierta homogeneidad artefactual.

A partir de la aplicación del método de Ford de seriación cerámica, determinaron cuatro tipos cerámicos con variaciones temporales (Schmitz et al. 1972). La alfarería incluye apéndices zoomorfos y tiestos de origen guaraní (policromo y unguiculado), también torteros y masas de arcilla cocida para las que proponen tres opciones funcionales: como proyectiles, para generar antiplástico, o simplemente desechos de manufactura cerámica (Schmitz et al. 1972). En cuanto a los restos humanos se identificaron inhumaciones de tres tipos: huesos dispersos, entierros primarios, y secundarios.

Como conclusión estos investigadores plantean que los sitios arqueológicos estudiados muestran que se ocuparon albardones y lugares elevados en las márgenes de los afluentes del río Paraná. Las diferencias cualitativas entre el registro artefactual de los distintos sitios arqueológicos 
no son significativas como para diferenciarlos culturalmente. El sitio arqueológico PM1 es representativo de los demás y corresponde a cazadores-pescadores-recolectores. Los desechos de las actividades cotidianas han contribuido a aumentar la altura del asentamiento. Los entierros humanos se realizaban en los basureros. En este sitio arqueológico, a partir de la posición estratigráfica de la alfarería, se reconocieron dos momentos de ocupación que fueron datados en $500 \pm 130$ años ${ }^{14} \mathrm{C} A P$ el más temprano y estratigráficamente inferior (40 a $60 \mathrm{~cm}$ ) y en $385 \pm 145$ años ${ }^{14} \mathrm{C}$ AP el más tardío y estratigráficamente superior (20 a $40 \mathrm{~cm}$ ); a este último momento le correspondería según los autores una tercera datación con una edad de $640 \pm 115$ años ${ }^{14} \mathrm{C}$ AP obtenida entre los 20 y $40 \mathrm{~cm}$. Los materiales corresponderían a los ribereños plásticos y a la facie Malabrigo propuesta por Serrano (1972).

Por su parte, desde finales de la década de 1960 y hasta la actualidad, Ceruti (Figura 2.14) desarrolla sus investigaciones retomando como punto de partida los estudios previos de Serrano. Los estudios de este autor se centraron sobre todo en la cuenca media del río Paraná, abarcando Entre Ríos, Santa Fe y Corrientes (Ceruti 2003a, Ceruti y Hocsman 1999; Ceruti et al. 1999; Schmitz et al. 1972; entre otros). Asimismo, se cuentan algunos trabajos en las provincias de Buenos Aires (Ceruti y Crowder 1973) y Misiones (Ceruti y Natassi 1974). Además de sus investigaciones sobre la ocupación prehispánica de la región, Ceruti se interesó por los periodos de contacto hispano-indígena y colonial (Ceruti 2005, 2009a, 2011, 2014; Ceruti y Cocco 1998; Ceruti y Natassi 1974, 1977); dentro de este último período a su vez abordó la presencia de poblaciones de origen africano en el NEA (Ceruti 2009a, 2010, 2011; Cornero y Ceruti 2012). De igual manera desarrolló estudios sobre arqueología urbana y técnicas constructivas históricas (Ceruti 1999a, 2001a, 2001b, 2003b, 2003c).

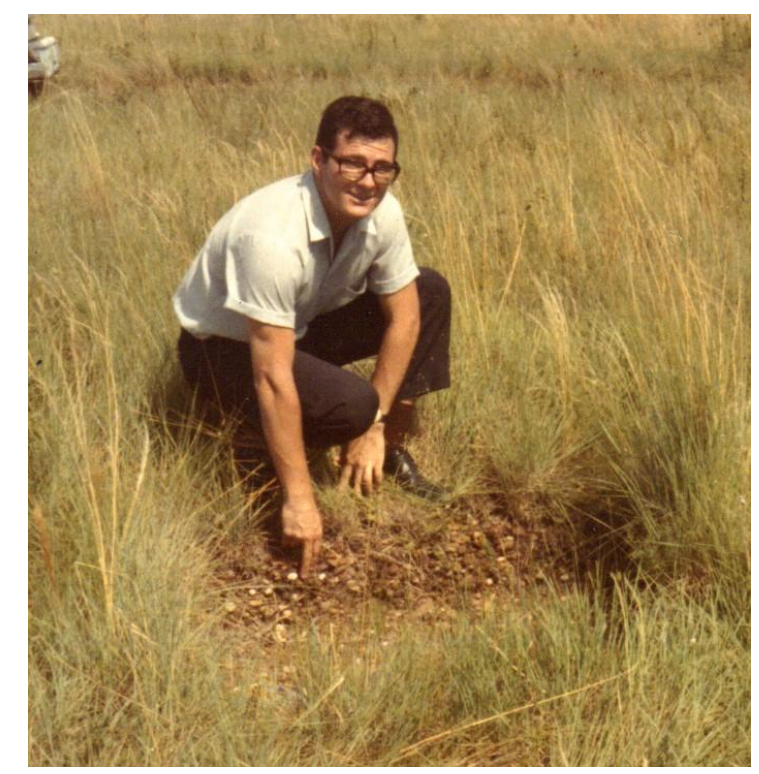

Figura 2.14. Carlos Natalio Ceruti en Salto Grande, señalando una cuadrícula excavada junto a Eduardo Cigliano en la primavera de 1973 en el sitio arqueológico Cerro La Paloma. Fotografía tomada en 1974. (Imagen gentileza de Carlos Ceruti). 
Ceruti no solo realizó estudios desde una perspectiva exclusivamente arqueológica, sino que se interesó por abordajes interdisciplinarios (véase Iriondo y Ceruti 1981; Iriondo et al. 1985; Tonni et al. 1985; Salemme et al. 1985; Salemme et al. 1987). En este sentido, en base a los trabajos de Iriondo busca establecer relaciones entre los asentamientos prehispánicos sobre depósitos fluviales del río Paraná y el ambiente circundante. Busca comprender la evolución ambiental del área desde el Pleistoceno final al presente, para poder contextualizar la estratigrafía de los sitios arqueológicos y por último hacer una caracterización cultural de los mismos (Iriondo y Ceruti 1981).

Un aspecto que también fue considerado por este autor es el efecto de los distintos factores ambientales que pueden llegar a alterar las secuencias culturales de los sitios arqueológicos (véase Salemme et al. 1985; Ceruti 1990, 1991), realizando en algunos casos verdaderos trabajos actualísticos y/o etnoarqueológicos con los habitantes modernos de la región que utilizan y/o viven sobre los sitios arqueológicos (Ceruti 1991). En el caso del sitio arqueológico Arroyo Las Mulas 1 (departamento La Paz), excavado en varias oportunidades, en una de las cuales participó Antonio Austral (19 al 30-9-1980), Ceruti trata de sistematizar los procesos de alteración antrópica y la forma de vinculación de un habitante actual (un nutriero) con el sitio arqueológico y el entorno natural. Así estima que Arroyo Las Mulas 1 pudo soportar en épocas prehispánicas como máximo 10 familias (50 o 60 individuos), aceptando como razonable su ocupación por parte de 5 ó 6 familias (Ceruti 1991). En este sentido, también se destaca un trabajo experimental de reproducción y elaboración de alfarería Goya-Malabrigo (Ceruti y Traver Borny 2007), donde intentan obtener datos sobre la capacidad de las campanas para mantener el fuego, concluyendo que no serían completamente adecuadas para tal fin sin una asistencia humana permanente.

Además de relocalizar y trabajar en sitios arqueológicos que habían sido publicados por Serrano (p. ej. Arroyo Largo 1 y Arroyo Las Mulas), Ceruti identifica y estudia otros que eran desconocidos como Arroyo Arenal 1, 2, 3, 4 y 5; El Dorado I; Arroyo Largo 2, 3, 4 y 5; Arroyo Basilio 1; La Esmeralda 1; Puesto Cuartel 1; Puesto Silvano 1; Arroyo Seco 1; La Palmera V, entre otros. Estos sitios arqueológicos fueron detectados a partir de los estudios de impacto arqueológico realizados en el área del Complejo Hidroeléctrico del Paraná medio (Ceruti 1984). Este autor además reconoce la existencia de un tipo de hallazgo arqueológico particular que denomina "entierros aislados de conjuntos de objetos", estos serían: “...grupos de elementos diversos (recipientes cerámicos, restos de alimentación, instrumentos de hueso, etc.), de tamaño reducido, cuya asociación sea manifiesta, hayan sido depositados intencionalmente bajo la superficie del terreno y se encuentren separados de vestigios culturales de cierta amplitud (talleres, sitios de habitación, sepulturas, etc.)." (Ceruti 1982: 1).

Ejemplos de éstos serían tres hallazgos realizados en cercanía del arroyo Arenal (La Paz) denominados Arroyo Arenal 4 y 5 y El Dorado 1 (Ceruti 1982; Ceruti et al. 1980.) (véase un hallazgo reciente de este tipo en Silva 2013). Además, plantea que bien se podrían incluir en esta categoría los 
hallazgos del Arroyo de Leyes (Serrano 1934, Aparicio 1937) y los denominados Carcarañense y Claromequense que serían escondrijos de materia primas líticas (Ceruti 1993). Este autor además presenta las primeras cuatro dataciones radiocarbónicas para el noroeste de Entre Ríos realizadas en los sitios arqueológicos Arroyo Largo 1: $900 \pm 120$ y $1380 \pm 100$ años ${ }^{14} \mathrm{C}$ AP (Ceruti 2003a); La Palmera V: $640 \pm 70$ años ${ }^{14} \mathrm{C}$ AP (Salemme et al. 1987); y Arroyo Las Mulas 1: $950 \pm 120$ años ${ }^{14} \mathrm{C} \mathrm{AP}$ (Ceruti 2003a).

Ceruti cuestiona la existencia de la "Tradición Cululú" por estar fundamentada solamente en seis instrumentos y adjudicada a una tradición precerámica (Ceruti 1986, 1993, 1995a). En relación a esto discute la postura de Caggiano, Frenguelli, Vignati, Castellanos y Serrano, que le otorgan gran antigüedad a la misma, y finalmente adjudica estos hallazgos, en base a la geología, a la entidad cultural que denomina "Esperanza". Manifiesta que no se conocen en Santa Fe sitios arqueológicos con asociaciones fehacientes entre cazadores-recolectores y fauna extinguida del Pleistoceno final, ni que tampoco habría sitios arqueológicos de cazadores sin cerámica del Holoceno temprano. Todos los sitios arqueológicos corresponderían a cazadores del Holoceno tardío (Ceruti 1993). Los recientes hallazgos y dataciones del sitio arqueológico Laguna del Doce, llevaron recientemente a un reconsiderar esta última afirmación (Ávila y Ceruti 2013).

En 1986 Ceruti evalúa detalladamente el esquema cultural propuesto por Serrano y sostiene que es necesario hacer una revisión crítica de las propuestas sobre la arqueología del Litoral en general y de categorías como "cultura, complejos, tradición, facies". Propone utilizar el término "Tipo cultural" hasta que se profundicen la investigaciones sistemáticas en el área. Plantea además la existencia de tipos culturales, entre el 3000 y el 1000 AP, que serían: "Esperanza" en la faja central de Santa Fe, "Villa Cañás" al sur de la anterior, "Cancha de Luisa" al noroeste de Entre Ríos y "GoyaMalabrigo" en toda la cuenca media e inferior del Paraná. Los dos primeros corresponderían a los cazadores recolectores de la llanura central y los dos últimos estarían representados por cazadores, pescadores y recolectores ribereños (Ceruti 1986).

Cancha de Luisa se manifiesta en los sitios arqueológicos La Palmera II, IV, V; Arroyo Hernandarias II, III, IV, V, VII; y tal vez Arroyo Las Piedras II. A partir de la fauna recuperada en los mismos se plantea la explotación de recursos mixta, con un balance entre recursos ribereños y de las tierras altas. No habría alfarería modelada y la cerámica decorada incisa con surco rítmico se registra en los niveles superiores evidenciando contacto con Goya-Malabrigo. Sería anterior a la misma, ya que hay sitios arqueológicos sin evidencia Goya-Malabrigo y además en el sitio arqueológico La Palmera II ambas manifestaciones se continúan en la estratigrafía. Basándose en los fechados más antiguos de Arroyo Las Mulas 1 y Arroyo Largo I, Ceruti propone que éste contacto debió ocurrir alrededor del 1250 y 1150 AP. Se desconoce su origen pero tiene similitudes con la entidad Salto Grande del río Uruguay, en cuanto a la cerámica, los enterratorios y por la baja estatura de los individuos (Ceruti 2003a). 
Goya-Malabrigo se manifiesta en los sitios arqueológicos Arroyo Canelón I, II; Arroyo Largo I, II, V; Arroyo Basilio I, Arroyo Arenal I, II, IV, VI; Arroyo Las Mulas 1, Puerto Cuartel I, II; La Espesura II, III; La Palmera II y Arroyo Biguá I. El 74\% de estos sitios arqueológicos, se ubican en la llanura aluvial del río Paraná o en unidades geomorfológicas relacionadas (p. ej. terrazas, llanuras aluviales del arroyo Feliciano y Hernandarias). El $16 \%$ se encuentra en las tierras altas (superficie FelicianoFederal), pero de estos, uno está próximo a la llanura aluvial del Feliciano, y los dos restantes son entierros de objetos aislados. La mayoría de estos sitios arqueológicos se ubican sobre médanos y albardones de origen fluvio-eólico. A partir de la cantidad de sitios arqueológicos, la potencia de los depósitos y la gran concentración de materiales, Ceruti postula un aumento poblacional en relación a Cancha de Luisa, probablemente relacionado “...con una explotación mucho más intensa de los recursos fluviales. Así parecen indicarlo en instrumental específico recuperado, la variedad de especies animales capturadas, y la disposición de los asentamientos, todos en relación directa con el río Paraná." (Ceruti 2003a: 117).

La existencia de sitios arqueológicos pequeños o con poca potencia en tierras más bajas y de sitios arqueológicos grandes y con gran potencia en zonas más elevadas (médanos y albardones), lo lleva a plantear periodos de fusión-fisión de la población. En épocas de bajante la población se dispersaría por el complejo isleño para aprovechar mejor el ecosistema y durante las crecientes se concentraría en ciertos puntos privilegiados del espacio, como las terrazas y la llanura de avenamientos impedido. Esto mismo ocurriría en Cancha de Luisa, pero los puntos de concentración estarían en las tierras altas (Ceruti 2003a). Recientemente y debido a las dataciones radiocarbónicas de Arroyo Aguilar y La Palmera V, se plantea se Cancha de Luisa y Goya-Malabrigo coexistirían en la costa entrerriana explotando distintas fajas ecológicas. Además Goya-Malabrigo sería en el río Paraná Medio "...la expresión máxima del aprovechamiento del ecosistema fluvial." (Ceruti y González 2007: 115).

Los apéndices ornitomorfos serían indicadores de la distribución de Goya-Malabrigo, que habría ocupado todas las islas y costas bajas del río Paraná, desde Resistencia (Chaco) hasta el sur de Santa Fe y Entre Ríos (Ceruti 1999b). Ceruti postula la posibilidad de un origen autóctono y descarta la discutida influencia de pueblos vinculados a la lengua arawak al no encontrarse materiales parecidos en Paraguay, ni en el sur de Brasil y tampoco en Misiones. También argumenta, siguiendo en cierta forma la idea previamente planteada por Aparicio (1937), que las similitudes morfológicas de los apéndices con la cerámica etnográfica de los nahukua del alto Xingú (Brasil) y la arqueológica de Santarém; además de la de Santiago del Estero y cualquiera del Noroeste argentino, no tiene más valor que el parecido (Ceruti 2003a); y dice que: "Quizás, como propone Caggiano (1984), el centro de difusión de Goya-Malabrigo esté en el delta entrerriano." (Ceruti 2003a: 128). A partir de los fechados de $1830 \pm 50$ y $2050 \pm 60$ años ${ }^{14} \mathrm{C}$ AP en los sitios arqueológicos Arroyo Aguilar 1 y 2 
respectivamente (Echegoy 1994), plantea que pudo haber otro polo originario en el norte de Santa Fe (Ceruti 2003a).

En cuanto a la cronología, el autor sostiene que Goya-Malabrigo se consolida en las costas entrerrianas del río Paraná medio alrededor del año 1500 AP perdurando hasta el 400 AP. Al igual que la mayoría de los autores tratados, también adjudica este tipo de registro con los antecesores de los chaná-timbú (beguás, chanás, timbús, quiloazas, mocoretás, mepénes, etc.) registrados por las crónicas históricas (Ceruti 1995b).

Con respecto a la ocupación del Delta del Paraná Ceruti reconoce que los "cerritos", tendrían un origen mixto; serían depósitos fluviales sobre antiguos médanos, incrementados por la ocupación humana. Su ubicación elevada en la periferia de las islas y cercana a los cauces activos favorecería las comunicaciones y el control del río. Los albardones interiores de menor altura serían fuente de recursos y áreas se ocupación secundaria (Ceruti 2000). El Delta inferior del Paraná y el río Uruguay inferior hasta la boca del río Negro (ROU) por el norte, habrían sido poblados entre el 1200 y $1000 \mathrm{AP}$ (Ceruti 2000). El arribo de poblaciones guaraníes estaría vinculado con el aumento de la temperatura y humedad ocurrido hace 1500 y 1000 años AP, que provocó la expansión de la selva subtropical hacia el sur. En esta época habría llegado a Misiones la Tradición Tupiguaraní, y poco antes de la conquista ya estaba presente en el Delta inferior, la costa norbonaerense y la isla Martín García (Ceruti 1999b).

Este autor también reconoce la existencia de un período precerámico en el NEA donde menciona la influencia las tradiciones Umbú, Avaí y Humanitá. Sus ideas al respecto serán expuestas más adelante cuando se trate el trabajo que publicara junto a Jorge Rodríguez en 1999. Ceruti va delineando su propuesta a los largo de sus trabajos y propone un modelo de desarrollo cultural para la región que integra de manera crítica las "entidades culturales" dentro de un marco ecológicoadaptativo (Ceruti 1988, 1992, 1995b). En dicho esquema enfatiza los cambios paleoclimáticos, la disponibilidad y explotación de recursos, la organización tecnológica, los patrones de asentamiento y las relaciones con poblaciones de regiones vecinas. En sus primeros trabajos se advierten de manera más clara las influencias de la escuela histórico-cultural norteamericana pero con el correr de los años este autor integra nociones de la Nueva Arqueología. En uno de sus trabajos más recientes plantea la existencia de indicios de complejidad social a partir de un entierro humano con ajuar en el sitio arqueológico La Palmera II (Ceruti 2013a).

Para el Delta del Paraná hay que destacar los trabajos de Caggiano (Figura 2.15) a partir de 1972 (Caggiano 1977a, 1977b, 1979, 1983a, 1984, 1990; Caggiano y Flores 2001; Caggiano et al. 1978; entre muchos otros). Esta autora realiza su tesis Doctoral (1979) en esta zona, además de haber trabajado anteriormente junto a Eduardo Cigliano, Rodolfo Raffino y Pedro Ignacio Schmitz en Salto Grande (véase Caggiano et al. 1971; Cigliano et al. 1971a, 1971b). Caggiano y colaboradores (1978) excavaron el sitio arqueológico Paraná Ibicuy I (Islas del Ibicuy) y en base a los materiales 
líticos recuperados plantean que las materias primas (cuarcita, anfibolita, metamórfica, metamorfita y granito) provendrían del Sistema serrano de Tandilia. Reconocen además a las masas de arcilla cocida como residuos de la elaboración cerámica o cocidas intencionalmente con el fin de ser molidas y usadas como antiplástico (Caggiano et al. 1978).

Esta autora sostiene que todas las inhumaciones del NEA corresponden a una etapa cerámica y propone una secuencia temporal donde los entierros más antiguos serían primarios completos extendidos en posición decúbito dorsal, seguidos posteriormente por primarios flexionados, secundarios, y paquetes funerarios (Caggiano 1983a). Considerando sus excavaciones y los hallazgos de Cerro Grande de la Isla Los Marinos (Gaspary 1950) plantea que los sitios arqueológicos de vivienda o campamentos eran usados también para prácticas mortuorias, y a partir de la llegada de los guaraníes se generalizaría el entierro en urnas.

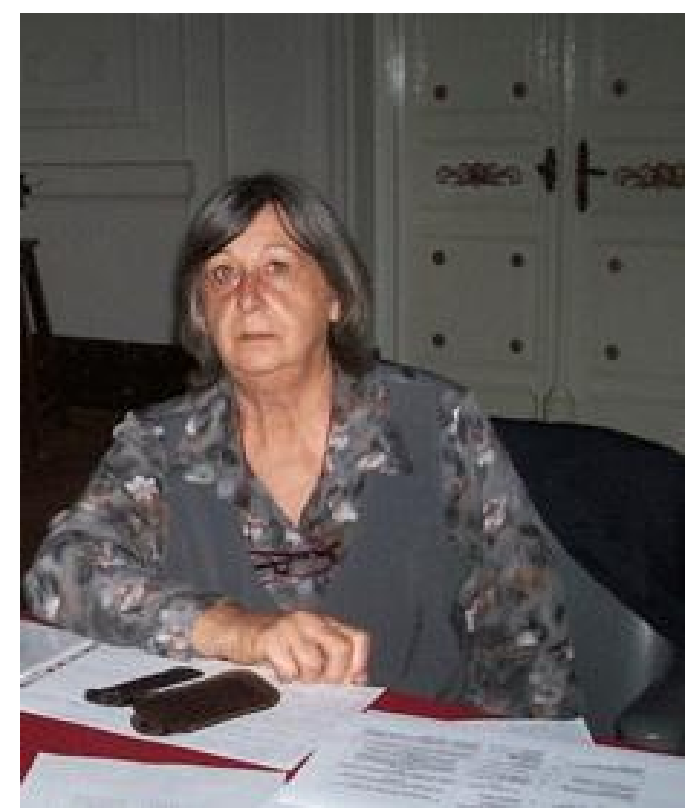

Figura 2.15. María Amanda Caggiano. (Imagen gentileza de María Amanda Caggiano).

En 1984 Caggiano publica una síntesis del desarrollo cultural del NEA, donde da una visión en conjunto y establece posibles vinculaciones con países vecinos. Propone un modelo basándose en sus trabajos de campo y en las propuestas de Serrano y Menghin. Reconociendo las pocas dataciones absolutas que existían entonces, plantea que el poblamiento de la región se desarrolló en dos etapas, una precerámica y otra cerámica. Divide la región en dos subregiones: Misionera y Litoral; dentro de la última diferencia los sectores: Salto Grande, Litoral bonaerense y Déltico. Para este último, que comprendería el área de estudio de esta tesis, presenta el sitio arqueológico Islas Lechiguanas I; donde por debajo de un nivel arqueológicamente estéril (nivel III), constituido mayormente por 
valvas de moluscos y datado entre $2740 \pm 80$ y $2550 \pm 90$ años ${ }^{14} \mathrm{C}$ AP, se encontraría una ocupación acerámica de la llamada Tradición Cululú, con puntas de arpón sobre hueso (nivel IV).

Las entidades cerámicas o facies del sector Déltico, que denomina "Ibicueña" y "Lechiguanas", sumadas a la facie "El Dorado" de Salto Grande (esta última luego denominada Salto Grande para evitar confusiones con "Eldoradense" de Menghin 1956), conformarían desarrollos estilísticos regionales de un mismo horizonte cerámico representado por la cultura básica del litoral o entrerriana. Por un lado, los rasgos compartidos entre las facies serían: las formas de alfarerías sin apéndices (en general); el alto predominio de escudillas y ollas simples restringidas, que varían solo en el antiplástico y las modalidades decorativas; los asentamientos monticulares adyacentes a cursos de agua usados como vías navegables; y las estrategias de subsistencia basadas sobre todo en la caza y la pesca de recursos terrestres y acuáticos (Caggiano 1984). Por otro lado, estas facies o "desarrollos estilísticos regionales" pueden ser separados "...en base al antiplástico, y a rasgos de motivos y técnicas decorativas excluyentes." (Caggiano 1984: 22). En este sentido, la facie Ibicueña se caracteriza por: incisión de línea llena y punteado rítmico, y arena como antiplástico. La facie Lechiguanas se caracteriza por: incisión por surco rítmico, línea llena y quebrado rítmico, pintura roja, y tiestos molidos y hematita como antiplástico. La facie Salto Grande se caracteriza por: incisión línea llena, pintura roja, y espículas de esponjas y valvas trituradas como antiplástico (Caggiano 1984: 34 y 42).. Esta regionalización estilística y de composición de las pastas se habría dado hace ca. 2500 años AP (Caggiano 1982a: 111; Caggiano 1984: 34).

Sobre la cerámica en el NEA, esta autora sostiene que sus orígenes deberían buscarse en las tierras bajas del centro y sur de Brasil (Caggiano 1990). Propone que los ribereños plásticos tendrían un origen local y sería una diversificación de la cultura entrerriana. Al igual que Serrano y Menghin, argumenta que la pintura policroma en todas sus variantes y motivos, asociados a formas compuestas con tiestos molidos como antiplástico, constituye evidencia de Tradición Tupiguaraní, cuya penetración en el sector Déltico se produciría en el siglo XV y XVI (Caggiano 1984).

Caggiano (1984) también demuestra interés por el análisis de la fauna arqueológica, por un lado, las especies faunísticas identificadas le permiten inferir que las condiciones climáticas durante la ocupación de este sector son las mismas que en la actualidad. Por otro lado, explica la ausencia de partes esqueletarias de mamíferos, como consecuencia de que los mismos fueron trozados en los lugares de cacería; y que a los sitios arqueológicos de vivienda, ubicados a orillas de ríos y arroyos propicios para la pesca, llegaban las partes recuperadas en las excavaciones arqueológicas. En sintonía con los investigadores contemporáneos (p. ej. Cigliano y Raffino) y con la escuela históricocultural, Caggiano reconoce en la etapa precerámica la existencia de varios "complejos industriales" líticos (de hacha de mano, de guijarros, de lascas, de puntas de proyectil) y uno sobre hueso (Tradición Cululú). Asimismo, distingue varias entidades cerámicas como cultura entrerriana, "Cultura de los Ribereños Plásticos" y Tupiguaraní. 
Si bien en el trabajo de 1984 aborda las relaciones con Uruguay y Brasil, solo incluye tangencialmente el sudeste de Entre Ríos. Cabe mencionar que Caggiano (1977a) también prospectó el famoso sitio arqueológico Mazaruca y además entre 1982 y 1983 relevó los sitios arqueológicos Cerro El Indio, La Peregrina, Paranacito (Islas del Ibicuy). Dentro del área de estudio de esta tesis relevó un sitio arqueológico denominado Gualeguaychú y excavó El Ceibal 1 y El Potrero (Gualeguaychú), este último junto a la Dra. Rizzo (Caggiano 1982a, 1982b, 1983b, 1984); y excavó y dató Don Santiago (1300 \pm 80 y $1090 \pm 80$ años $\left.{ }^{14} \mathrm{C} \mathrm{AP}\right)$ y Rodeo Viejo La Nena (1420 \pm 80 y $1420 \pm 80$ años ${ }^{14} \mathrm{C}$ AP) en Islas del Ibicuy (Caggiano 1983a, 1984).

En cuanto a la cuenca media e inferior del río Uruguay, se puede sostener que las investigaciones arqueológicas sistemáticas e intensivas relacionadas a la ocupación indígena, comenzaron a fines de la década de 1960, tanto en la ROU como en Argentina (véase Baeza et al. 1977; Boretto et al. 1975; Capdepont 2012; Cigliano 1967, 1968; Cigliano et al. 1971a, 1971b; Díaz 1977; Femenías 1973; Rodríguez 1969; entre muchos otros). En la ROU ${ }^{3}$, al igual que en Argentina, el impulso de estos trabajos sistemáticos respondía a la necesidad de realizar un rescate arqueológico en la zona que iba a ser afectada por el embalse de la represa hidroeléctrica de Salto Grande. Los trabajos más significativos son los realizados por el Centro de Estudios Arqueológicos (CEA) de Montevideo y por una Misión Internacional de UNESCO.

Entre 1972 y 1976 el CEA excava y sondea varios sitios arqueológicos como Isla del Medio Sitio/Corte 1, Aruera, Garzas, Caracoles, Bañadero 1, 1a, 1b y 1c; y realizan las tres primeras dataciones radiocarbónicas para la zona que con los siguientes resultados: Isla del Medio Sitio/Corte 1: $2350 \pm 80$ años ${ }^{14} \mathrm{C}$ AP; Aruera Corte 3: $2370 \pm 80$ años ${ }^{14} \mathrm{C}$ AP; y Aruera Corte 9: $1140 \pm 100$ años ${ }^{14} \mathrm{C} \mathrm{AP}$ (Baeza et al. 1977). A partir de estas dataciones y de los materiales de los sitios arqueológicos Aruera y Garzas (Isla de Arriba) e Isla del Medio Sitio/Corte 1 (Isla del Medio), y de las colecciones del Museo de Salto y de particulares de la zona, Díaz $(1977,1985)$ elabora una secuencia cultural compuesta de tres momentos: Momento 1 (Ceramolítico), Momento 2 (Lítico 1) y Momento 3 (Lítico 2). Las dataciones marcarían el comienzo del Momento 1 y este correspondería a los portadores de facie Salto Grande (cultura entrerriana o básica del litoral) de Serrano (1972); en este momento también se registran restos guaraníes y modelados de los ribereños plásticos, ambos tipos serían intrusivos y corresponderían a momentos cercanos a la conquista europea. Para los ribereños plásticos, se proponen dos vías de llegada: una desde el Delta del río Paraná ascendiendo por el río Uruguay; y la otra desde el Paraná medio vía los ríos Guayquiraró y Mocoretá cuyas cabeceras están próximas.

Díaz y Baeza (1977) también proponen un modelo regional con cuatro periodos, dos precerámicos (I y II) y dos cerámicos (I y II). El Cerámico I y II serían una división del Momento 1 o

\footnotetext{
3 Para profundizar sobre la historia de las investigaciones arqueológicas en la margen izquierda del río Uruguay (ROU) véase por ejemplo Capdepont 2012; Castiñeira 2008; y Farías 2005.
} 
Ceramolítico (Díaz 1977). El Cerámico I comenzaría ca. 3000 años AP y correspondería a la cerámica de la cultura entrerriana o básica del litoral y ribereños plásticos, y El Cerámico II comenzaría ca. 600 años AP y está marcado por la presencia de cerámica Tupiguaraní (véase Capdepont 2012). También Díaz y Fornaro (1977) amplían las divisiones dentro de lo que sería el período caracterizado por la presencia de alfarería. En este sentido, identifican cinco modalidades alfareras que incluyen: Básica del Litoral, ribereños plásticos, tupiguaraní, contactos intergrupales y contactos hispano-indígenas.

También Austral (1977) a partir de la información proveniente de Salto Grande elabora un modelo con dos periodos precerámicos (I y II) y dos cerámicos (I y II) que luego sería retomado y modificado por Guidón (1989) (véase Capdepont 2012; Castiñeira 2008). Por su parte, Cabrera y Curbelo (1990) identifican tres componentes arqueológicos para la ocupación de la zona de Salto Grande (inferior, medio y superior), este último (2000 a 300 años AP) se caracterizaría por una economía de explotación de recursos fluviales y la adopción de la cerámica, y posteriormente de horticultura. Por último, Hilbert (1991) propone un modelo regional donde sintetiza e integra los modelos previos incluyendo también el sur de Brasil y propone un conjunto de "Tradiciones" líticas y alfareras.

La Misión de UNESCO realiza sus investigaciones entre 1976 y 1980 aportando nuevas dataciones radiocarbónicas, pero sin brindar demasiada información sobre el contexto arqueológico (véase Baeza 1985). El conjunto de fechados absolutos de la margen uruguaya del río Uruguay medio e inferior, incluyendo los de UNESCO, muestran ocupaciones para el Pleistoceno final-Holoceno temprano y para el Holoceno medio y tardío (Tabla 2.1b).

En Argentina, anteriormente al abordaje arqueológico sistemático del río Uruguay medio, se registran algunos aportes de Frenguelli (1927b, figura 13), Serrano (1924, 1932a, 1933a, 1950) y Lafon (1971). El primero de los autores menciona la existencia de talleres líticos en la zona de Salto Grande (Federación) (Frenguelli 1927b). El segundo autor recorre algunas zonas en ambas márgenes del río Uruguay, desde Monte Caseros hasta Gualeguaychú. Por último, Lafon (1971) menciona el relevamiento de algunos sectores de la costa del río Uruguay desde Federación hasta Gualeguaychú.

En cuanto a los abordajes arqueológicos sistemáticos en la cuenca media del río Uruguay, los primeros estudios se focalizaron en la zona de Salto Grande (departamentos Federación y Concordia) (Caggiano et al. 1971; Cigliano 1967; Cigliano et al. 1971a, 1971b; Rodríguez 1969; Rodríguez y Rodríguez 1984, 1985; entre otros). En esta zona Cigliano $(1967,1968)$ y Cigliano y colaboradores (1971a, 1971b), cuyos trabajos podrían encuadrarse dentro de la escuela histórico-cultural norteamericana, realizan recolecciones superficiales en el sitio arqueológico Cerro El Tigre (o Cueva del Tigre) y excavaciones sistemáticas los sitios arqueológicos Cerro Chico I y II, Los Sauces I y II, Cerro La Paloma, El Dorado, Arroyo Yarará, Isla de Arriba I y II, Isla del Medio e Isla de Los Lobos; estos cuatro últimos se encuentran en la ROU (Figura 2.16). Dentro de este conjunto de sitios arqueológicos los autores identifican tres tipos de asentamientos ribereños ubicados a diferentes 
cotas en las terrazas del río Uruguay. En las dos terrazas altas (25-30 m y 40-45 m) habría sitios arqueológicos precerámicos, superficiales y en estratigrafía que han sido fuertemente erosionados (Cerro La Paloma, Cerro El Tigre y Los Sauces II). En la terraza media (15-20 m) habría sitios arqueológicos con cerámica en estratigrafía (El Dorado); y en la terraza baja (6-10 m) habría sitios arqueológicos con cerámica en estratigrafía, que serían conchales artificiales (Cerro Chico I y II, Los Sauces I y Arroyo Yarará).

En base a la variabilidad de estos sitios arqueológicos y sus materiales (líticos y cerámicos), además de tres dataciones radiocarbónicas, los autores elaboran una secuencia cronológica compuesta por cuatro fases culturales. La primera sería precerámica y tres restantes cerámicas, y se denominan: La Paloma (ca. 4000-3000 años AP), El Dorado (ca. 1500 años AP), Cerro Chico (ca. 1100700 años AP) y Guaraní tardío (ca. 500 años AP). Las cronologías de las fases La Paloma, El Dorado y Cerro Chico se establecen a partir de criterios geocronológicos a partir de la terraza del río donde se encuentran ubicados los sitios arqueológicos. Para la fase Cerro Chico se cuenta además con tres dataciones radiocarbónicas realizadas en los sitios arqueológicos Cerro Chico I ( $895 \pm 35$ años ${ }^{14} \mathrm{C} \mathrm{AP}$ ), Cerro Chico II (770 \pm 70 años ${ }^{14} \mathrm{C} \mathrm{AP}$ ) y Los Sauces I (1090 \pm 40 años ${ }^{14} \mathrm{C} \mathrm{AP).} \mathrm{La} \mathrm{fase} \mathrm{Guaraní} \mathrm{tardío} \mathrm{en}$ Salto Grande estaría representada por la alfarería de Isla de Arriba I, Isla del Medio e Isla de Los Lobos; comparable al sitio arqueológico El Arbolito (isla Martín García) que presenta una datación radiocarbónica de $405 \pm 35$ años ${ }^{14} \mathrm{C} \mathrm{AP}$ (Cigliano et al. 1971a).

De esta forma queda planteada la secuencia base, que posteriormente será retomada y reelaborada por Jorge Rodríguez. Los postulados sobre una ocupación precerámica planteados por Cigliano y colaboradores serán criticados por Edgar Poenitz (1970a), argumentando que se basan en recolecciones superficiales sin haber considerado las características geológicas del contexto de los hallazgos. Poenitz (1970a), luego de caracterizar los distintos tipos de "yacimientos arqueológicos" y describir detalladamente el contexto geológico de los mismos y las alteraciones ambientales a las que están sometidos los sitios arqueológicos (sobre todo la influencia destructiva del río Uruguay), sostiene que la supuesta ocupación precerámica es el resultado de mezcla de materiales arqueológicos desprendidos de las barrancas del río. 


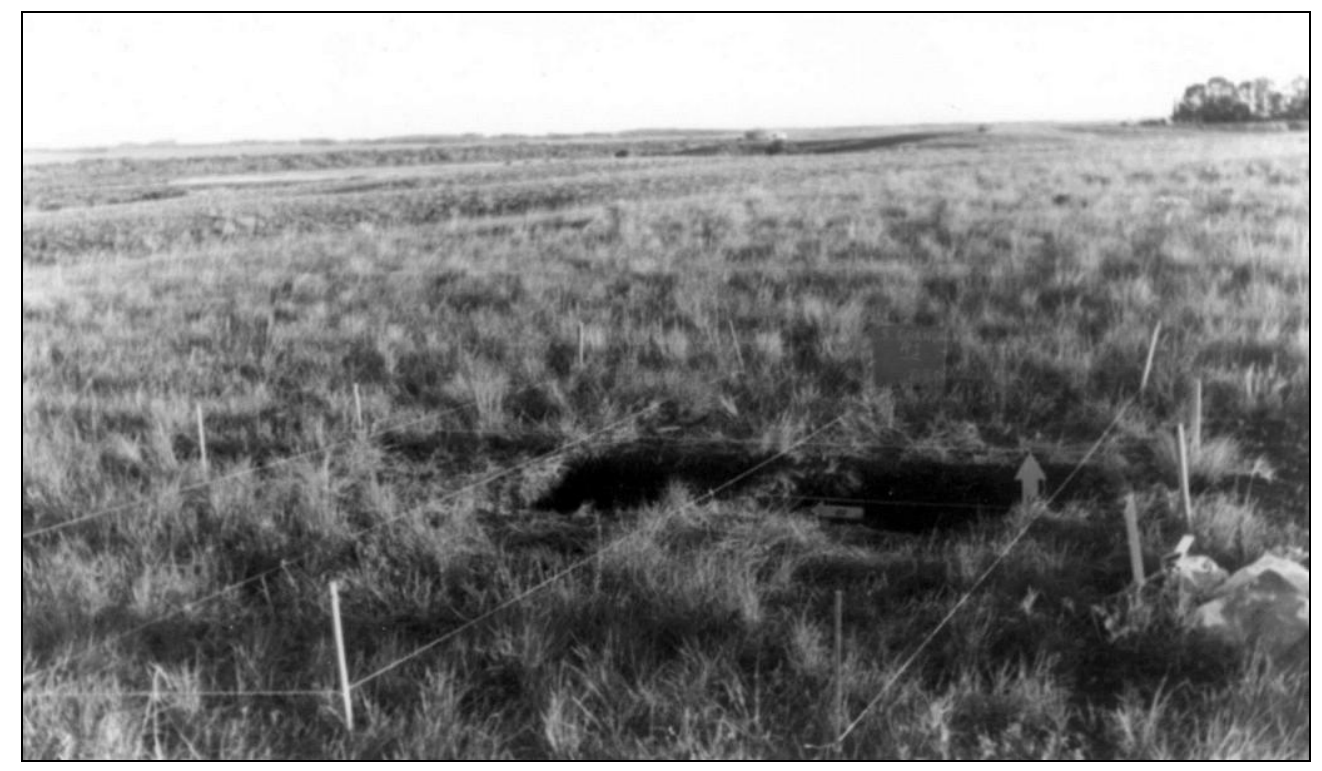

Figura 2.16. Excavación de Eduardo Cigliano y colaboradores en Salto Grande. (Imagen gentileza de María Amanda Caggiano).

Para la cuenca media del río Uruguay, también se destacan las investigaciones de A. Rodríguez y J. Rodríguez (padre e hijo). La mayoría de sus trabajos se focalizaron en el nordeste de Entre Ríos (Federación y Concordia) y sureste de Corrientes (departamentos Mocoretá y Monte Caseros); en algunos casos en Misiones y también en la margen correntina del río Paraná medio; donde llevaron a cabo numerosas prospecciones, recolecciones superficiales y excavaciones. Además, impulsaron la fundación del Centro de Investigaciones Regionales de Concordia, que se transformaría durante esos años un polo de investigación para la zona (Ceruti 2013b). Ambos investigadores (Figura 2.17) participaron en el Proyecto Antropológico-Ecológico Salto Grande iniciado en 1977, que incluía tareas de investigación y rescate arqueológico en la zona de Salto Grande donde se instalaría la Represa Hidroeléctrica. A partir de las mismas se detectaron aproximadamente 80 sitios arqueológicos en Corrientes y Entre Ríos, la mayoría inéditos, de los cuales aproximadamente el $75 \%$ de los mismos quedaría bajo en agua del embalse de la represa (Rodríguez y Rodríguez 1984, 1985).

Por su parte, J. Rodríguez ha realizado algunas síntesis de la arqueología del NEA y otras del sudeste del continente americano, incorporando datos de toda la cuenca del Plata. Este autor ha propuesto varios esquemas de desarrollo cultural para la región (Rodríguez 1992, 2001, 2001-2002, 2006; Rodríguez y Ceruti 1999) que se han ido modificando con el transcurso del tiempo. Más adelante se describe en detalle el esquema propuesto por Rodríguez y Ceruti en 1999, que sintetiza las ideas de ambos investigadores.

Durante los trabajos de rescate arqueológico, particularmente en Entre Ríos, se detectaron 44 sitios arqueológicos, de los cuales 10 fueron estudiados sistemáticamente (Los Sauces II y III, Rancho Colorado, Arroyo Yarará Chico, El Pinar I, El Corral, Rancho Miño, Destacamento Eloísa I, 
Cerro del Tigre II y Cerro Chico). Estos autores aportan siete nuevas dataciones radiocarbónicas para la zona que son: Los Sauces II (1670 \pm 70 y $1370 \pm 70$ años ${ }^{14} \mathrm{C}$ AP), Rancho Miño (1460 \pm 80 años ${ }^{14} \mathrm{C}$ AP), Arroyo Yarará Chico (1470 \pm 80 y $1180 \pm 95$ años ${ }^{14} \mathrm{C}$ AP), y Rancho Colorado I ( $820 \pm 70$ y $750 \pm$ 70 años ${ }^{14} \mathrm{C}$ AP) (Rodríguez y Rodríguez 1985). Utilizando estas dataciones, además de estimaciones cronológicas relativas basadas en la estratigrafía y en algunas comparaciones con sitios arqueológicos datados en la ROU (Baeza at al. 1977), proponen una secuencia temporal con "Tipos culturales" acerámicos y cerámicos. Los tipos culturales acerámicos, solo con tecnología lítica, serían: Los Sauces, La Paloma y Río Uruguay. Los tipos culturales cerámicos, con alfarería, artefactos líticos e instrumentos óseos, serían: Cerro Chico (incluye los sitios Los Sauces II, Rancho Miño y Arroyo Yarará Chico), Salto Grande (incluye el sitio Rancho Colorado) y Tupi Guaraní (véase Rodríguez y Rodríguez 1985).

Los Sauces II es el mismo sitio arqueológico que Cigliano y colaboradores (1971a) denominan Los Sauces, y Caggiano y colaboradores (1971) y Cigliano y colaboradores (1971b) Los Sauces I; por lo tanto este sitio arqueológico contaría con tres dataciones radiocarbónicas. Asimismo, el sitio arqueológico Cerro Chico es alguno de los dos de igual nombre publicados por Cigliano y colaboradores (1971a), pero los autores no especifican cual (véase Rodríguez y Rodríguez 19831985). Los autores sostienen que en la margen argentina de Salto Grande, los hallazgos vinculados a grupos guaraníes han sido de carácter casual y aislado, y corresponden a fragmentos de vasijas. Los asentamientos con materiales más abundantes de este tipo parecerían estar ubicados en las islas de río Uruguay (Rodríguez y Rodríguez 1985).
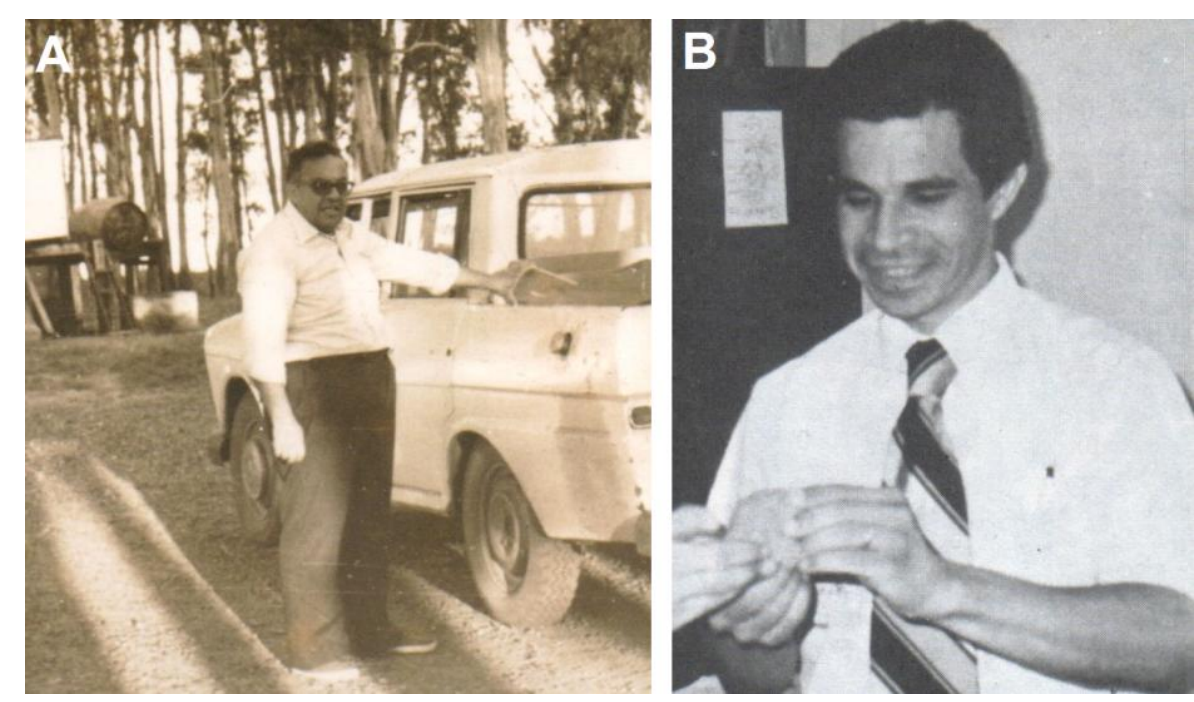

Figura 2.17. A: Amílcar Rodríguez. B: Jorge Rodríguez. (Imágenes gentileza de Carlos Ceruti).

J. Rodríguez, propone una revisión de categorías como: Catalanense, Cuareimense, Altoparanaense, Complejo Mocoretá, cultura de vinculaciones patagónicas y cultura entrerriana. 
Argumenta que están basadas en evidencias no muy precisas y discutibles. Muchas de ellas corresponden a hallazgos de superficie sin un contexto claramente determinado (Rodríguez 1998). Aun así, seguirá usando estas categorías en algunos de sus esquemas posteriores (p. ej. Rodríguez 2001-2002).

Este investigador considera que los cambios climáticos tuvieron un efecto significativo sobre la adaptación de las poblaciones prehispánicas. Establece una correlación directa entre algunos eventos o cambios ambientales y transformaciones culturales. Reconoce una continuidad en los desarrollos culturales regionales, sostiene que en toda la secuencia no hubo cambios bruscos sino graduales, excepto la irrupción de la llegada guaraní y europea. Habría una estabilidad tecnológica, que no fue afectada por los cambios ambientales, dado que su carácter adaptativo era generalizado, lo que permitía reacomodarse sin variaciones sustanciales en la tecnología. Los cambios más marcados se darían a nivel de la subsistencia y el patrón de asentamiento (Rodríguez 1992). En relación a esto, en 2001 plantea que la causa de las rupturas en las secuencias, la adopción de innovaciones y las transformaciones en la tecnología, fueron los cambios climáticos ocurridos. Estas fluctuaciones también deben haber promovido migraciones, sobre todo en el periodo precerámico.

En relación a la alfarería, plantea que la cerámica no tendría un origen local y habría llegado por difusión alrededor del 2500 AP coincidiendo con un periodo climático árido. Su adopción y circulación debe haberse favorecido por la condiciones climáticas que obligaron a reajustes adaptativos. Pudo provenir de Brasil, su ancestro sería la tradición Mina en el Amazonas, o desde el Noroeste argentino vía la entidad acerámica anterior a Esperanza que tendría contacto con Sierras Centrales (Rodríguez 2001). En relación a la postulada influencia de grupos arawak sobre GoyaMalabrigo considera que hasta el momento es una mera especulación (Rodríguez 1998) y propone que sería un desarrollo local del río Paraná, quizá con cierta influencia desde el oeste (región pampeana o Gran Chaco). J. Rodríguez también reconoce que algunos "cerritos de indios" de la "subtradición" Vieira y la "facie" Ibicueña son construidos, remarcando que "...algunas de estas construcciones tuvieron sobre todo una función funeraria..." (Rodríguez 2001: 716). En lo que respecta a la incorporación de la agricultura sostiene que pudo llegar con los guaraníes o, desde el oeste o noroeste. Esta práctica no alteraría demasiado las estrategias cazadoras-recolectoras precedentes ni los modos de vida, sino que funcionó como un complemento o suplemento (Rodríguez 2001).

Conjuntamente con Ceruti, Rodríguez publica una síntesis del NEA donde segmentan el proceso cultural continuo en etapas denominadas: inicial (poblamiento), temprana (segundo momento de las culturas precerámicas), media (ocupación de nuevos espacios, adopción de la cerámica y diversificación regional) y tardía (llegada de los guaraníes, cambios que provoca y la introducción de la agricultura). En la Etapa inicial y temprana habría una alta movilidad residencial, llegando a un cuasi sedentarismo en la Etapa tardía (Rodríguez 2001). Las evidencias arqueológicas 
de las dos primeras etapas precerámicas solo se registran en el sector oriental del NEA, no habiendo evidencias en el Paraná medio y el Delta del Paraná. De esta forma los autores dejan sin consideración el denominado componente acerámico que menciona Caggiano (1984), y que ya fuera discutido previamente por Ceruti (1986, 1993, 1995a). Esta ausencia según los autores podría deberse a: falta de poblamiento de esas zonas, destrucción o enterramientos de los sitios arqueológicos por los cambios en el curso del Paraná y por las ingresiones marinas, o utilización de materias primas perecederas por falta de rocas.

A continuación se describe brevemente cada una de las etapas formuladas, con sus entidades culturales, muchas de ellas definidas en base a propuestas de autores brasileños (p. ej. Miller 1976, 1987; y Schmitz 1987), modificando en algunos casos la propuesta original (véase Ceruti 2013b):

Etapa Inicial: cazadores-recolectores del Pleistoceno final y Holoceno temprano (11.5008500 años AP), de la entidad cultural Uruguay I. Esta se encuentra en el Uruguay medio, con asentamientos ribereños y con un uso generalista de los recursos. Presenta puntas de proyectil pedunculadas triangulares obtenidas por talla bifacial y presión; además de cuchillos, raederas, raspadores bifaciales, choppers, muescas, perforadores, y lascas y nucleiformes con rastros de uso.

Etapa Temprana: cazadores-recolectores del Holoceno temprano y medio de las entidades culturales Uruguay II, Humaitá e Ivaí.

-Uruguay II (7000-2000 años AP) sería la sucesión directa de Uruguay I y presentaría variantes regionales cuyas diferencias se profundizarán en las etapas siguientes. En la Mesopotamia ocupa toda la franja oriental y del Paraná superior. Presenta talleres y campamentos de actividades múltiples, así como una mayor variabilidad morfológica de puntas, y se agregan molinos y morteros.

El arribo de Humaitá e Ivaí, estaría vinculado a las condiciones más cálidas y húmedas del Óptimo climático, que habrían provocado la expansión hacia el sur de bosques y selvas. Ninguna de las dos presenta puntas de proyectil, ni talla por presión o bifacial.

-Humaitá (6000-1000 años AP) Se manifiesta en Misiones y extiende por el río Paraná hasta los saltos de Apipé y por el río Uruguay hasta Salto Grande. Los sitios arqueológicos se ubican en el ámbito de la selva tropical donde hay núcleos de araucaria.

-Ivaí (6000-2000 años AP) marcaría el poblamiento de Salto Grande y los saltos de Apipé. Se ocupan terrazas y albardones con selva en galería, habría campamentos base y talleres líticos ribereños con algunos desplazamientos al interior. Presenta artefactos tallados y pulidos como bolas con y sin surco y placas grabadas.

Etapa Media: cazadores-recolectores del Holoceno tardío de las entidades Salto Grande, Esperanza y Ribereña Paranaense. Se incorpora la cerámica mediante difusión probablemente proveniente desde el bajo Amazonas.

-Salto Grande (2500-600 años AP), su antecedente directo es Avaí, de la que se va diferenciando gradualmente. Ocupa los mismos sectores y a veces los mismos sitios arqueológicos, el 
patrón de asentamiento y uso del espacio también es semejante a Avaí. Se registran grandes conchales con artefactos tallados, de molienda, de hueso y cerámica incisa y con pintura roja.

-Esperanza (2200-1000 años AP) incluye a los cazadores-recolectores de la llanura central argentina, caracterizados por el aprovechamiento de varios ecosistemas (Ceruti 1986).

-Ribereña Paranaense, alrededor de 1000 años AP se registra la ocupación de las costas bajas e islas de la llanura aluvial del Paraná por poblaciones cada vez más numerosas y dependientes del ecosistema fluvial. Esta entidad incluiría Cancha de Luisa, Goya-Malabrigo, Vieira e Ibicueña.

Etapa Tardía: correspondería a la expansión guaraní con dos áreas de mayor concentración de evidencias: Misiones y norte de Corrientes, y el Delta del Paraná. En el Uruguay medio e inferior la ocupación de restringiría a las islas.

Para finalizar, se observa que en la mayoría de sus síntesis, de J. Rodríguez, utiliza los conceptos de Tipo cultural y Tradición pero en algunos casos va modificando su contenido, lo que se presta a confusiones (para ver detalladamente estos aspectos véase Ceruti 2013b). Las propuestas de este investigador claramente podrían enmarcase dentro de la corriente histórico-cultural norteamericana, con un fuerte componente del determinismo ambiental que impregnó las investigaciones en la región llevadas a cabo por el Programa Nacional de Pesquisas Arqueológicas (PRONAPA 1970) de Brasil. En todos sus trabajos la información arqueológica fue contextualizada dentro de un marco ecológico determinante de patrones culturales. Asimismo, este autor incorporó aspectos teóricos y metodológicos de la Nueva Arqueología (Ceruti 2013b).

Para la cuenca inferior del río Uruguay (margen argentina), además de los ya mencionados trabajos de Greslebin y Krapovickas, es preciso destacar el trabajo de Alberto Cione, Antonia Rizzo y Eduardo Tonni (1977), donde presentan los resultados de la excavación de un sector del sitio arqueológico Dos Cerros (= Cerro de los Pampas de Krapovickas 1957). Dentro del área de estudio de esta tesis, éste es el primer trabajo que realiza un análisis sistemático de los restos faunísticos, con el fin de caracterizar las condiciones ambientales y establecer las especies consumidas y/o utilizadas por los ocupantes del sitio arqueológico. Como conclusión los autores postulan que: el área ocupada no era cubierta por las inundaciones; que la fauna indicaría las mismas condiciones climáticas que las actuales; que la ausencia de psitácidos en las representaciones alfareras se relaciona con la poca frecuencia de estas aves en la zona; que los peces indicarían que la pesca se realizaba en verano; que el sitio arqueológico fue ocupado anteriormente a la llegada de los europeos y posiblemente sea preguaraní; que la modalidad de pesca predominante fue el arponeo; que la fuente principal de proteínas animales fueron los peces, seguidos por los coipos y los ciervos; que los huesos fragmentados de mamíferos dan cuenta del consumo de médula ósea y de la confección de instrumentos óseos; que la alfarería con hollín evidencia su uso para cocinar alimentos; y que los "cerritos" del área que forman cadenas de elevaciones serían el resultado albardones disectados por la erosión (Cione et al. 1977). 
Para el área de este estudio también se deben mencionar las investigaciones que desde 1955 hasta 2004 realizara Manuel Salvador Almeida en la margen derecha del río Uruguay (Colón, Concepción del Uruguay y Gualeguaychú), en algunos casos colaborando con distintos investigadores (p. ej. Rizzo y Tonni), dado su amplio conocimientos de la zona y de la localización de numerosos sitios arqueológicos. La mayoría de los escritos de este autor consisten en artículos publicados en diarios de la ciudad de Gualeguaychú (Almeida 1983b, 1996a, 1996b; El Argentino 1992a, 1992b, entre otros). Almeida realizó un relevamiento exhaustivo de la zona y un registro detallado de sus hallazgos. Sus trabajos incluyeron recolecciones superficiales, sondeos y excavaciones estratigráficas, realizadas con variable grado de sistematicidad metodológica. Este autor detectó numerosos sitios arqueológicos (Almeida 1983a, 1996c, Revista El Tren Zonal 1994) de los cuales recuperó los materiales que hoy conforman las colecciones del Museo Arqueológico Manuel Almeida (Gualeguaychú) (véase Bourlot 2008; CCBSJG 1986, Lemes 2013).

Almeida reconoce dos zonas de mayor concentración de evidencias arqueológicas que serían la desembocadura del río Gualeguaychú y la zona ribereña de la antigua estancia Rincón de Landa. Asimismo, destaca que la mayoría de los sitios arqueológicos del área corresponden a "..."cerros" 0 elevaciones de tierra de dimensiones variadas, muchos de ellos artificiales,..." (Almeida 1971: 1), cuya función sería la de resguardarse de las crecientes del río. Los montículos serían sitios arqueológicos reocupados por grupos nómades que en cada nueva ocupación incrementaban la altura rellenando la superficie (Almeida 1997). Asimismo, identifica los materiales recuperados básicamente con grupos chaná y guaraní, adjudicando a los primeros los ribereños plásticos. Considera que la cerámica corrugada y pintada con motivos geométricos es indicadora de la presencia y asentamiento guaraní en la Isla de Goyri, la ensenada del Bellaco y la zona de Ñandubaysal (Gualeguaychú) (Almeida 1983b). Almeida también realiza un inventario de las canteras de areniscas de la Formación Salto Chico ubicadas entre el puerto de Gualeguaychú y la boca del río homónimo (Almeida 1998), muchas de cuales ya no existen debido a la explotación moderna (véase Capitulo 7).

Cabe mencionar que para la región central de Entre Ríos que abarca esta tesis, en la bibliografía solo se registran dos trabajos arqueológicos. El primero corresponde al año 1970 y se enfoca en el análisis de los materiales recuperados en el sitio arqueológico Nogueira (departamento Villaguay) (Poenitz 1970b); el segundo consiste en un análisis sistemático parcial de la Colección Marcelo Lugrin del Museo Tierra de Minuanes (Villaguay), que fue llevado a cabo conjuntamente por Ceruti (2007) y Hocsman (2007), este último estudio no incluyó trabajos de campo.

Como comentarios finales de esta etapa se puede plantear que las investigaciones pasan a estar a cargo de arqueólogos profesionales con una formación académica en universidades argentinas y extranjeras. Si bien en los primeros momentos se percibe una marcada influencia de la corriente histórico-cultural austro-alemana y norteamericana, luego se advierte una marcada influencia de la arqueología procesual, donde los cambios en el ambiente explicaban los cambios 
culturales y los grupos humanos eran entendidos primariamente en relación a sus estrategias adaptativas, con poco énfasis en su agencia. En este sentido, los trabajos reflejan el interés por la adaptación humana en relación al medio ambiente; por influencia del contexto ecológico entendido como un sistema; y por la integridad de los sitios arqueológicos y los procesos posdepositacionales. Así surgen trabajos eclécticos que enriquecen las propuestas realizadas, en comparación con las etapas anteriores. Esto también provoca el abandono de categorías clasificatorias previas y "...un desacople entre la información etnográfica y la arqueológica. El enfoque hacia el estudio de la adaptación al medio ambiente desplazó al de la continuidad histórica." (Politis y Bonomo 2012: 12).

Este periodo se caracteriza además porque se realizan las primeras dataciones radiocarbónicas, tanto en Argentina como en la ROU. De manera similar a la etapa anterior, pero con mayor sistematicidad y rigurosidad, las secuencias y los datos obtenidos en un sitio o localidad arqueológica se extrapolan a otros sitios arqueológicos de la región; y dicho sitio arqueológico en algunos casos es considerado como "sitio o localidad tipo" (p. ej. los Paraná Miní I y Los Sauces II, y las localidades Goya y Malabrigo) y representante de una entidad cultural particular. El problema reside en que, en algunos casos los postulados sobre un sitio arqueológico particular que después se generalizan, se basan en pequeños sondeos estratigráficos o excavaciones de dimensiones reducidas. Además, hay muy pocas publicaciones detalladas sobre los sitios arqueológicos.

Como en todas los períodos anteriores se continúa, aunque en menor medida y con mayores precauciones o argumentos, con las adjudicación del registro arqueológico a etnias históricas (p. ej. Ceruti 1995b). Se desarrollan muchos intentos por establecer el cuadro de desarrollo cultural regional, considerando etapas, períodos, fases, así como también Tradiciones, Horizontes, Complejos, Tipos culturales, Facies, Entidades Culturales, etc. (p. ej. Caggiano 1984; Ceruti 1986, 2003a; Cigliano et al. 1971a, 1971b; y Rodríguez y Ceruti 1999). Más allá de las diferencias en relación a la cronología y al contenido, entre todos los autores hay un reconocimiento unánime de dos periodos o etapas, uno precerámico y otro cerámico (p. ej. Caggiano 1984; Cigliano et al. 1971a, 1971b; Lafon 1972; y Rodríguez y Ceruti 1999). Se produce la incorporación de los análisis arqueofaunísticos de una manera más intensiva y sistemática con dos objetivos principales: por un lado, se intentaba caracterizar la dieta prehispánica, y por otro lado, determinar las condiciones paleoclimáticas.

El estudio de sitios arqueológicos monticulares ocupo poco espacio en las publicaciones, ya que no se realizaron trabajos de campo sistemáticos y específicos enfocados en la clarificación de una cuestión tan relevante como su génesis. También se cierra la discusión sobre el origen de GoyaMalabrigo, proponiendo un origen local. Se registra cierto consenso en relación a su dispersión geográfica y su cronología (ca. 1500-500 años AP), y por otro lado se continua con la adjudicación de esta cerámica como patrimonio de los chaná-timbú históricos o sus antecesores inmediatos. 
Todos los autores concuerdan con que las poblaciones de origen guaraní, ocuparon sobre todo sectores ribereños e islas. No hay datos precisos sobre la época de su llegada, y tampoco hay un acuerdo entre los investigadores sobre las rutas de desplazamiento y las posibles relaciones con los grupos locales. La falencia en cuanto a estos últimos aspectos se debe a la falta de datos sólidos, como sitios arqueológicos con una clara ocupación guaraní y con fechados absolutos. Un tema destacado en estos momentos lo constituye la adopción de la alfarería, su origen y/o lugar de procedencia, las vías de llegada, y sobre todo la antigüedad de la misma en esta región. De igual manera, y con los mismos aspectos en discusión, se trató el tema de la agricultura, que fue discutido de manera hipotética en base a datos históricos. La mayoría de los autores sostienen que fueron los guaraníes los que introdujeron este tipo de práctica a partir de su llegada al NEA (p. ej. Lafon 1972; y Rodríguez y Ceruti 1999).

\section{4- INVESTIGACIONES ARQUEOLÓGICAS EN DESARROLLO EN ENTRE RÍOS Y EN LA REPÚBLICA ORIENTAL DEL URUGUAY}

Antes de continuar exclusivamente con Entre Ríos, se deben mencionar que desde principios de la década de 1990 y hasta la actualidad, en el NEA y en la ROU se desarrollan investigaciones sobre una gran variedad de temas. Se registran trabajos en Santa Fe, Misiones y Corrientes, entre ellos se pueden mencionar a Ávila (2011); Ávila y Ceruti (2013); Ávila y colaboradores (2003); Barboza (2014); Barboza y colaboradores (2007, 2009); Carrara y colaboradores (1998); Cocco (1996, 2004, 2010); Cornero (1999, 2009); Cornero y Cocco (1995); Kozameh (2009); Letieri y Alonso (2004); Mujica (1994, 1996, 2000); Nóbile (1993, 2001); Nóbile y colaboradores (1999); Pascuali y colaboradores (2014); Pérez Jimeno (2005, 2007); Píccoli (2014); Píccoli y colaboradores (2011, 2014); Poujade (1995, 2007); Poujade y Roca (2011); Rizzo (1968, 1969); Roca (2013); Rocchietti y colaboradores (2005); Santiago (2004); Sartori (2013, 2014); Sartori y Pérez Jimeno (2012); Sartori y Galligani (2014); Sempé y Caggiano (1995); Sempé y Rizzo (2000); entre muchos otros. Asimismo, se deben mencionar para Entre Ríos las contribuciones de Hocsman, vinculadas básicamente al estudio de la tecnología lítica de sitios arqueológicos trabajados por Serrano y Ceruti (Hocsman 1999a, 1999b; Ceruti y Hocsman 1999). Más recientemente también se deben mencionar los estudios de Richard (2015) sobre la ocupación indígena del arroyo Las Conchas (Paraná).

Sobre la margen izquierda del río Uruguay se han obtenido numerosas dataciones absolutas y actualmente están trabajando varios investigadores uruguayos (Capdepont 2012, 2014; Capdepont et al. 2010, 2013; Castillo 2000, 2004; Castiñeira 2008; Farías 2005; Farías et al. 2001; Gascue 2009a, 2009b; Gascue et al. 2016; Iriarte 2001; López Mazz et al. 2014; Suárez 2011; entre otros). En una sistematización de antecedentes, Capdepont y colaboradores (2010) determinaron que la mayoría de 
los sitios arqueológicos alfareros se disponen sobre médanos, albardones y planicies arenosas, frecuentemente ubicados en la desembocadura de los tributarios de los grandes cursos de agua y por debajo de los 10 msnm. Para el sector comprendido por los departamentos Paysandú, Río Negro, Soriano y Colonia "El patrón de asentamiento reflejaría la importancia de los ríos como medio de transporte y fuente de recursos,..." (Capdepont et al. 2010: 93).

Asimismo, Capdepont (2012) estudió el río Uruguay reconociendo 84 localidades arqueológicas y presentando información sobre las estrategias de subsistencia variadas, asentamientos en lugares elevados naturales y antrópicos, y sobre la movilidad logística de grupos indígenas entre el Holoceno medio y tardío. Particularmente se destaca el sitio Punta Pereira M8 sobre el Río de la Plata con una antigüedad de $4240 \pm 80$ años ${ }^{14} \mathrm{C}$ AP (URU-0509; carbón vegetal; Capdepont 2012), evidenciando la presencia humana en la zona para el Holoceno medio. Para el Holoceno tardío esta autora propone que los grupos alfareros ocupan la ribera del río Uruguay ca. 2000 años AP, coincidiendo con un cambio ambiental de condiciones frías y secas a cálidas y húmedas. La ocupación humana de la región se intensificaría en dos momentos, 1400-1200 años AP y 400-200 años AP, coincidiendo con condiciones de mayor temperatura y humedad. Para el periodo que va desde el 800 al 450 AP se identificó alfarería atribuible a la entidad arqueológica GoyaMalabrigo (sensu Politis y Bonomo 2012) y poblaciones guaraníes (Brochado 1984, Noelli 2004); así como asentamientos residenciales donde se llevó a cabo la confección y uso de instrumentos líticos y cerámicos, así como el procesamiento de vegetales silvestres y cultivados.

Particularmente para Entre Ríos, de todos los investigadores mencionados en la etapa anterior, sólo Ceruti continúa trabajando en la actualidad. Por su parte J. Rodríguez se ve impedido de investigar desde hace algunos años (véase Ceruti 2013b). Aun así ambos investigadores focalizaron su interés en áreas distintas a la que se pretende abordar en esta tesis. La zona trabajada por Ceruti, el río Paraná medio, está siendo investigada actualmente por Ottalagano y Richard; el Delta inferior del río Paraná está siendo trabajado bajo la dirección de Rolandi, Loponte y Acosta; y el Delta superior del río Paraná, está siendo investigado por un equipo de investigadores dirigidos por Bonomo y Politis. En lo que respecta al río Uruguay medio se encuentra desarrollando sus investigaciones Angrizani y su equipo de trabajo. A continuación se exponen sucintamente las líneas de investigación en desarrollo en cada zona de Entre Ríos mencionada arriba y las contribuciones más relevantes. No se analizarán en profundidad las propuestas particulares de los distintos autores contemporáneos, ya que éstas serán abordadas y discutidas de acuerdo a su relevancia en relación a los resultados de esta tesis (véase Capítulo 5, 6, 7, 8 y 9).

Ottalagano desde el año 2004 está trabajando en el noroeste de la provincia, focalizando su interés sobre el simbolismo de las poblaciones prehispánicas a través de su tecnología cerámica (Ottalagano 2004, 2005, 2007a, 2007b, 2008, 2009, 2010a, 2010b, 2012, 2014, entre otros). En su tesis doctoral aborda la cerámica procedente de nueve sitios arqueológicos relevados previamente 
por Serrano, Badano y Ceruti. Estos sitios arqueológicos, todos ubicados en la margen derecha del río Paraná medio, son: Puesto Cuartel I y II; Arroyo Las Mulas 1; Arroyo Largo I y V; Arroyo Arenal I y IV; La Palmera II y Villa Urquiza III (Ottalagano 2009). Su estudio se basa en el análisis de colecciones y no incluyó prospecciones ni excavaciones. Posteriormente, en el sitio arqueológico Puesto Acosta (Bonomo et al. 2010) del Delta superior, llevó a cabo 12 sondeos estratigráficos (Ottalagano et al. 2010). Más recientemente Ottalagano ha comenzado trabajos de campo en el noroeste de Entre Ríos y ha excavado el sitio arqueológico La Palmera II, donde se obtuvieron dos dataciones rediocarbónicas de $1032 \pm 47$ (coipo) y $1056 \pm 47$ años ${ }^{14} \mathrm{C} \mathrm{AP}$ (restos óseos humanos) (Ottalagano et al. 2015). Estos fechados se suman a los cuatro anteriores (Ceruti 2003a; Salemme et al. 1987) y amplían la información cronológica precisa para el área.

Esta investigadora realiza uno de los aportes sistemáticos más significativos hasta el momento en cuanto a la discusión sobre la funcionalidad y el significado del simbolismo de la alfarería regional, sobre todo la denominada Goya-Malabrigo. Dicho estudio le permitió detectar regularidades en el arte mobiliar, en cuanto a morfología, elaboración y organización del mismo. Estas regularidades son interpretadas por la autora como elementos comunicacionales de diferenciación intra e intergrupal, de identidad y de una creciente complejidad social. Asimismo, observa que esta alfarería fue utilizada de igual manera en contextos domésticos y mortuorios. También Ottalagano ha llevado a cabo trabajos experimentales y comparativos sobre técnicas decorativas e instrumental usado en la manufactura y decoración de piezas cerámicas (véase Ottalagano 2010a). Por su parte, Richard desarrolla el proyecto "Investigaciones Arqueológicas en el Parque Provincial General San Martín" con el objetivo de generar información arqueológica sobre las ocupaciones humanas establecidas en la zona. Los resultados obtenidos hasta el momento indican que en el sitio arqueológico PGSM1 se desarrollaron, durante la primera mitad del siglo XVII, actividades por la "gente de servicio" de una de las estancias santafesinas (Richard 2015).

En cuanto a los trabajos que se vienen realizando desde el 2005 en el Delta inferior entrerriano, dentro del proyecto "Poblamiento y Colonización del Sector Central de la Región Pampeana", se pueden mencionar a Acosta (2005), Acosta y Musali (2002), Acosta y colaboradores (2010, 2011a, 2011b, 2011c, 2015a; 2015b), Arrizurieta y colaboradores (2010), Buc (2010a, 2010b), Buc y Sacur Silvestre (2006), Buc y colaboradores (2014), Loponte (2008), Loponte y Acosta (2007), Loponte y colaboradores (2011a, 2012), Mazza (2010a, 2010b), Mazza y Loponte (2012), Parisi y Liotta (2010), entre otros.

Particularmente en lo que corresponde a Entre Ríos los sitios arqueológicos relevados por estos autores, parte de los cuales fueron previamente dados a conocer por otros investigadores que abordaron la zona, son Cerro Lutz (El Aserradero de Lafon 1971); Las Ánimas (Lafon 1971); Cerro de las Rosas (Lafon 1971); La Argentina (Aparicio 1928); Isla Lechiguanas I (Caggiano 1979, 1984); Casa de Huéspedes (probablemente Mazaruca de Lista -1878-); Escuela 31; Kirpach; Cerro Horst, Cerro 
Mayor y Cerro de los Indios (Acosta et al. 2015a). Entre todos estos, sólo dos han sido excavados sistemáticamente hasta el momento: Cerro Lutz donde se abrieron $19 \mathrm{~m}^{2}$ e Islas Lechiguanas I donde se abrieron $8 \mathrm{~m}^{2}$.

Algunos aportes relevantes proceden de Cerro Lutz, considerado un sitio multicomponente de actividades múltiples, donde además se identificaron inhumaciones primarias y secundarias dispuestas un área formal de entierro, así como también se reconocieron diferentes modalidades de inhumación en relación al sexo y la edad, y la probable utilización de restos óseos humanos para la elaboración de instrumentos óseos (Acosta et al. 2011a; Mazza 2010a, 2010b; Mazza y Loponte 2012). Gran parte de los trabajos sobre este sitio arqueológicos se focalizan en aspectos vinculados a la subsistencia y al análisis arqueofaunístico (Acosta et al. 2011c; Arrizurieta et al. 2010; Parisi y Liotta 2010), así como también al estudio de la tecnología ósea (Buc 2010a). Cerro Lutz correspondería a cazadores-recolectores y pescadores, siendo los peces el principal componente de la dieta, seguidos de roedores y cérvidos. El hallazgo de restos de Canis familiaris con edades de $916 \pm 42$ y $1594 \pm 59$ años ${ }^{14} \mathrm{C} A \mathrm{P}$, contribuye a apoyar la presencia prehispánica de perro en Sudamérica (Acosta et al. 2011b; Acosta et al. 2015a), que ya había sido planteada para el sitio arqueológico Arroyo Las Mulas por Serrano (1946) y para La Palmera V por Salemme y colaboradores (1987).

Asimismo, se han realizado estudios isotópicos sobre restos óseos humanos, lo que ha permitido discutir las dietas de grupos guaraníes y la presencia de maíz (Zea mays) en el área (Loponte y Acosta 2007). También el estudio de la tecnología ósea permitió una aproximación funcional a algunos instrumentos y la identificación de patrones tecnológicos compartidos con el Delta inferior del río Paraná y con la región en general (Buc 2010a). El abordaje del sistema de producción y uso de ornamentos de variadas materias primas, registrados en el sur de Entre Ríos y en el Delta inferior en general, permitió plantear cuestiones vinculadas al simbolismo de algunas especies de carnívoros, a los sistemas de circulación de materias primas, al aumento demográfico y al surgimiento de complejidad social (Acosta et al. 2015a, 2015b).

Por otro lado, se han obtenido un conjunto dataciones radiocarbónicas en distintos sitios arqueológicos (Acosta et al. 2015a, 2015b; Arrizurieta et al. 2010; Loponte y Corriale 2013; Ottalagano y Loponte 2016) (Tabla 2.1a). En Islas Lechiguanas I ( $n=3)$ se fecharon dos componentes arqueológicos, uno cerámico con $408 \pm 30$ años ${ }^{14} \mathrm{C} \mathrm{AP}$ (coipo), y otro inferior acerámico en $2267 \pm 34$ y $2296 \pm 34$ años ${ }^{14} \mathrm{C} \mathrm{AP}$ (ciervo de los pantanos) (Loponte et al. 2012). El reestudio de este último sitio arqueológico permitiría confirmar el nivel acerámico propuesto por Caggiano (1984).

Los sitios arqueológicos de esta zona estarían evidenciando períodos de ocupación más prolongados que en los sitios arqueológicos del norte bonaerense. Los autores proponen que se estarían dando procesos de intensificación en la explotación del ambiente para el Holoceno tardío. Estos procesos incluirían mayor importancia de los peces y los vegetales en la dieta, adopción de la 
alfarería y el cultivo a pequeña escala, mayor estabilidad residencial, aumento de la complejidad social y contactos extraregionales.

En el Delta superior desde el año 2006, se viene desarrollando el proyecto "Ocupaciones humanas prehispánicas en el Delta Superior del río Paraná (provincia de Entre Ríos)" (Bonomo 2005, 2012, 2013; Bonomo y Blasi 2011; Bonomo y Capdepont 2010; Bonomo y Farro 2014; Bonomo et al. 2009, 2010, 2011a, 2011b, 2011c, 2014a; Capdepont y Bonomo 2010-2011; Castiñeira et al. 2013; Di Prado y Castro 2014; Politis y Bonomo 2012; Politis et al. 2011, 2013a; Scabuzzo y Ramos van Raap 2011; Scabuzzo et al. 2015; Silva 2015; entre otros). A partir del mismo hasta el momento se han relevado sistemáticamente 84 sitios arqueológicos en Diamante, Victoria y Gualeguay, y San Jerónimo (Santa Fe), de los cuales 79, eran desconocidos, siendo el resto sitios arqueológicos previamente publicados. Estos últimos fueron nuevamente reubicados y/o georeferenciados y son: Cerro de las Pajas Blancas (Badano 1940a), Cerro Grande de la Isla los Marinos (Gaspary 1950), El Castaño 1 y 2 (Nóbile 2001) y Cerro de La Matanza (Ambrosetti 1893). Se realizaron recolecciones superficiales y 33 sondeos estratigráficos de $1 \mathrm{~m}^{2}$ y de $0,50 \mathrm{~m}^{2}$ que proporcionaron abundantes materiales de estudio (véase Bonomo et al. 2010, 2011c; Silva 2015). Se han excavado sistemáticamente cinco sitios arqueológicos que son Cerro Tapera Vázquez donde se abrieron $16 \mathrm{~m}^{2}$; Los Tres Cerros 1 donde se abrieron $33 \mathrm{~m}^{2}$; Los Tres Cerros 2 donde se abrieron $4 \mathrm{~m}^{2}$; Laguna de los Gansos 1 donde se abrieron $44 \mathrm{~m}^{2}$; y Cerro Farall donde se abrieron $11 \mathrm{~m}^{2}$.

Estos autores han implementado además nuevas tecnologías de estudio ya que realizaron 30 elevamientos planimétricos de alta resolución con Estación Total. Esto ha permitido elaborar modelos digitales de elevación del terreno y a partir del análisis comparado de los mismos se detectaron y evaluaron patrones espaciales recurrentes en los sitios arqueológicos (Bonomo et al. 2010, 2011c). Asimismo, se han desarrollado estudios sistemáticos con metodologías modernas sobre colecciones de museos, procedentes del Delta del Paraná y recuperadas a finales del siglo XIX y principios del XX (Bonomo 2013; Bonomo y Capdepont 2010; Bonomo et al. 2009).

Por otro lado, en esta zona se ha retomado el interés por los trabajos interdisciplinarios (Bonomo y Blasi 2011; Bonomo et al. 2011a, 2011b; Castiñeira et al. 2013, 2014). Esto permitió profundizar aspectos vinculados a la disponibilidad y circulación de recursos líticos mediante el estudio petrográfico de artefactos y afloramientos rocosos (Bonomo y Blasi 2011). Así se pudo determinar la circulación de materias primas a través de medias y largas distancias. Las rocas más usadas fueron areniscas, sobre todo de la Formación Ituzaingó. En los sitios arqueológicos se registraron cantidades mayores de instrumentos por sobre desechos de talla y núcleos. La mayoría de estos fueron elaborados por picado abrasión y/o pulido y llegarían elaborados a la zona donde se los mantenía y reciclaba.

Los estudios bioarqueológicos han determinado el uso de los montículos como lugares de entierros humanos, además de los usos domésticos. Se identificó una gran variabilidad de prácticas 
inhumatorias que incluyen entierros primarios, secundarios, elementos óseos aislados, cremación y probable canibalismo ritual; así como patologías y traumatismos óseos (Scabuzzo y Ramos van Raap 2011; Scabuzzo et al. 2015).

Este grupo de investigación además presentó sólidas evidencias directas sobre el manejo de plantas, silvestres y domésticas, determinando además la frontera suroccidental de las prácticas agrícolas en tiempos prehispánicos (Bonomo et al. 2011a, 2011c). A través del estudio de fitolítos, almidones y macrorestos (Brea et al. 2013; Sánchez et al. 2013) se identificaron leñas usadas como combustible en los fogones: espinillo (Acacia sp.), algarrobo (Prosopis sp.), laurel (Ocotea sp.), curupí (Sapium sp.), timbó colorado (Enterolobium sp.), ceibo (Erythrina sp.) y petiribí (Cordia sp.). También se determinaron restos de palmeras yatay (Butia yatay) y pindó (Syagrus romanzoffiana) (Bonomo y Capeletti 2014), así como maíz (Zea mays), poroto (Phaseolus vulgaris), zapallo (Cucurbitaceae), achira (Canna sp.), arroz silvestre (Orizeae) y posiblemente mandioca (Manihot esculenta). A partir de estos datos los autores proponen que el cultivo sería de carácter local y se habría dado en momentos previos a la conquista, entre el 650 y 490 AP, y no solo sería patrimonio de los guaraníes. El estudio de restos arquebotánicos, sedimentológicos y análisis estratigráficos detallados también han permitido la reconstrucción paleoclimática (Bonomo et al. 2011b).

Estudios petrográficos sobre alfarería permitieron identificar distintos grupos de pasta e inclusiones, aun así se plantea la existencia de patrones tecnológicos compartidos para todo del delta. Tanto la selección de materias primas, la preparación de la pasta, la elaboración y la cocción de las vasijas presentan características comunes (Capdepont y Bonomo 2010-2011). Di Prado (2015) profundizó los estudios sobre la alfarería y plantea su elaboración in situ en los sitios arqueológicos y el aprovisionamiento local de las arcillas. En relación a las inclusiones sostiene que los porcentajes de tiesto molido varían de acuerdo a las elecciones individuales de las ceramistas, mientras que las variaciones en los cristaloclastos se relacionarían con la variabilidad propia de los afloramientos naturales. El agregado de tiesto molido a su vez reflejaría una práctica compartida por las ceramistas del río Paraná y la incisión de surco rítmico fue la decoración principalmente utilizada. Se identificaron platos, escudillas, cuencos, torteros, cuentas de collar, representaciones zoomorfas y campanas; así como el reciclado de los fragmentos cerámicos en tiesto molido, cuentas, torteros, material constructivo y artefactos para decorar y alisar las superficies cerámicas.

En conjunto la muestra estudiada por Di Prado (2015) es homogénea en relación a los modos de hacer y decorar, y es representativa de la entidad arqueológica Goya-Malabrigo (sensu Politis y Bonomo 2015). Esta investigadora considera que la noción de estilo emblemático (sensu Wiessner 1983) solo se aplicaría para algunas técnicas (modelado) y objetos (campanas y apéndices zoomorfos) pero no para todos los recursos técnicos y las representaciones decorativas no figurativas. (Di Prado 2015: 347). Asimismo, muchos de los atributos tecnológicos y elementos decorativos de la alfarería del Delta superior habrían sido compartidos a nivel macroregional y cada 62 
uno de ellos habría circulado de manera independiente dentro de una amplia escala espaciotemporal y entre distintas comunidades alfareras en interacción.

Mediante análisis geoarqueológicos, microestratigráficos, sedimentológicos y de microfósiles de alta resolución, se abordó de manera intensiva el estudio sobre el origen y desarrollo de las estructuras monticulares, que fueran uno de los temas más relevantes desde el comienzo de la arqueología en el NEA, pero cuyo estudio no había sido encarado con metodologías modernas como en la actualidad (Gianotti y Bonomo 2013; Bonomo et al. 2010, 2011a, 2011b, 2011c; Castiñeira et al. 2013, 2014; Politis et al. 2011). En este sentido, se identificaron zonas deprimidas y discretas, adyacentes a los sitios arqueológicos que podrían haber funcionado como áreas de aporte intencional de sedimentos sobre los "cerritos" (Bonomo et al. 2010, 2011c). Estos investigadores plantean que en el área:

“...se estarían dando dos procesos antrópicos que formarían los cerritos: uno es el crecimiento por acreción como producto de los residuos de la ocupación humana (como en el caso del Cerro Tapera Vázquez), y el otro es el aporte ad hoc de sedimentos para elevar artificialmente la superficie habitable a los que se suman también los residuos domésticos resultantes de la ocupación (como en el caso de Los Tres Cerros 1)". (Bonomo et al. 2011c: 316-317).

En relación al segundo proceso, el sitio arqueológico Los Tres Cerros 1 evidencia un crecimiento por capas de origen antropogénico producto de ocupaciones recurrentes. En este sentido, se pudo detectar que los sedimentos que componen el montículo Los Tres Cerros 1 fueron modificados por el fuego y la incorporación de materiales arqueológicos: tiestos, carbón de leña, valvas de moluscos y huesos. Estos agregados probablemente intencionales y a la vez resultado de las múltiples actividades desarrolladas sobre el sitio arqueológico, funcionarían como agentes consolidantes y estabilizadores de la estructura (Politis et al. 2011). La diferencias observadas en la composición y textura mineral de los depósitos del montículo y los de la llanura que lo circunda permitió confirmar el carácter antropogénico del mismo y a la vez un aprovisionamiento distal de sedimentos para su construcción. Este tipo de prácticas se habrían desarrollado en el delta, entre 1800 y 400 años AP (Castiñeira et al. 2013; Politis et al. 2011).

A partir de estos resultados, donde además se identifican posibles diferencias funcionales entre sitios arqueológicos de una misma localidad en momentos previos a la conquista, estos autores proponen la existencia de una jerarquía de asentamientos, que podría ser un reflejo de diferencias sociales, similares a lo que se define como rank societies (Bonomo et al. 2011c; Politis y Bonomo 2012; Politis et al. 2011). Estas sociedades estarían insertas dentro de una extensa y compleja red de interrelaciones a escala regional, que incluiría las Sierras Centrales, el área Andina Meridional y la 
cuenca del río Uruguay, dentro de la cual circulaban materias primas líticas y los objetos de prestigio (p. ej. metales), entre otros (Bonomo et al. 2009, 2010, 2011c).

Hasta el momento se han presentado 45 dataciones radiocarbónicas que evidencian sobre todo una ocupación del delta en momentos tardíos del Holoceno (véase Bonomo 2012, Anexo I; Politis y Bonomo 2012; Bonomo et al. 2016; Scabuzzo et al. 2015; entre otros). Los sitios arqueológicos excavados han sido identificados con lo que se conoce como entidad arqueológica Goya-Malabrigo (Politis y Bonomo 2012), y sus ocupantes como cazadores, recolectores y pescadores con un marcado énfasis en la explotación de recursos fluviales y horticultores a pequeña escala.

Los estudios en el Delta superior han permitido detectar una alta densidad de sitios arqueológicos como no había sido documentada anteriormente, reflejando el alto potencial arqueológico del área. En cuanto a la distribución espacial de los sitios arqueológicos, la mayoría se encuentran en el sector de islas y sobre contextos topográficos variados, frecuentemente en relación a fuentes de agua como lagunas y/o cursos fluviales (o paleocauces). De la misma manera el conjunto de dataciones permite otorgarle a los mismos un contexto temporal que los ubica entre $c a .1800$ años AP y el siglo XVI. También se han detectado sólidas evidencias sobre la manipulación de plantas silvestres y cultivos domésticos, identificando restos de maíz y porotos, tema que siempre había sido mencionado pero para el cual no se contaba con evidencias empíricas. Asimismo, se registraron números entierros humanos evidenciando una gran variabilidad de prácticas inhumatorias dentro de la entidad arqueológica Goya-Malabrigo (Politis y Bonomo 2012).

La identificación de objetos procedentes de largas distancias ha permitido documentar sólidamente procesos de contactos e intercambios extraregionales para el Holoceno tardío. El renovado interés por el origen de las estructuras monticulares en la región ha permitido determinar efectivamente su construcción antropogénica, así como su crecimiento producto de la acreción intencional como de la ocupación humana. También se han planteado hipótesis sobre similitudes adaptativas con grupos de la floresta tropical y el surgimiento de sociedades de rango para momentos previos a la conquista. En este sentido, se ha discutido la influencia de grupos de filiación arawak en la región en base a nuevas evidencias arqueológicas y lingüísticas (Politis y Bonomo 2012), revalorizando y profundizando las ideas y categorías arqueológicas propuestas por autores como Nordenskiöld y Torres, entre otros.

En este contexto, se ha caracterizado de manera más precisa la distribución espaciotemporal de la entidad arqueológica Goya-Malabrigo y se la ha insertado en una discusión sobre dinámica poblacional a un nivel macroregional; integrando al mismo tiempo al Delta del Paraná en una discusión arqueológica más amplía, esto es en el marco de las Tierras Bajas sudamericanas y no ya solo en el marco del NEA. Paralelamente, se han elaborado modelos de expansión de grupos guaraní en el NEA y la cuenca del Plata, en base a la recopilación de más de 200 sitios arqueológicos 
guaraníes con dataciones absolutas y localizados en el sur de Brasil, Uruguay y el NOA y NEA (Bonomo et al. 2015).

En este último período de la arqueología del NEA se observa el predominio de corrientes teóricas procesuales y posprocesuales. Dentro de éstas, se realiza el abordaje de temáticas variadas que incluyen estudios sobre: subsistencia y procesos tafonómicos, el simbolismo de representaciones cerámicas, patrones de asentamientos y complejidad social, entre otros. Asimismo, se observan áreas con distinta intensidad y constancia en las investigaciones. Desde el año 2000 se han intensificado las investigaciones en Entre Ríos, privilegiándose algunos sectores sobre otros y zonas ribereñas por sobre las llanuras interiores. Entre los resultados se destaca el relevamiento masivo de sitios arqueológicos desconocidos, el cuantioso número de dataciones absolutas y los datos novedosos que vienen a clarificar las antiguas discusiones y temas complejos que ocuparon el interés de aficionados, coleccionistas, autodidactas y profesionales en arqueología.

Una de estas discusiones relevantes, sobre la que opinaron la mayoría de los autores relevados, pero que fue dejada de lado gradualmente hasta los recientes trabajos en el Delta superior, trata sobre el origen de montículos. Este nuevo interés por la estructura interna de los "cerritos" ha provocado el desarrollo de trabajos interdisciplinarios y la aplicación de nuevas metodologías, generando nuevos datos y actualizando la discusión sobre la génesis de los mismos. De esta forma, tanto los resultados novedosos como las investigaciones en desarrollo son realmente promisorias para lograr un conocimiento profundo y sólido de la historia prehispánica del NEA en general, pero sobre todo de la provincia de Entre Ríos.

\section{5- CONSIDERACIONES FINALES}

En este capítulo se revisó el desarrollo de las investigaciones arqueológicas en el NEA, focalizando sobre todo en la provincia de Entre Ríos. A su vez se presentaron los autores más importantes con sus ideas y propuestas. Algunas de éstas han trascendido los distintos momentos y actualmente se posicionan como las temáticas en discusión más interesantes sobre la ocupación indígena de Entre Ríos. Dentro de ellas se pueden mencionar: la época de arribo de los primeros pobladores; la época de adopción de la tecnología cerámica; el origen y dispersión de la agricultura en el área; la presencia de poblaciones procedentes desde el norte (arawak y guaraní), su influencia y época de arribo; la relaciones socio-económicas a nivel extraregional; el origen de los llamados "cerritos"; la distribución espacial y cronológica de ciertas manifestaciones alfareras como GoyaMalabrigo; la distribución geográfica de las etnias o parcialidades que encontraron los primeros europeos y la organización sociopolítica de estas poblaciones. 
Cabe destacar que desde el punto de vista teórico, en el NEA no se podrían definir periodos donde se manifieste claramente la predominancia de un paradigma excluyente, como en el caso de la región pampeana (Politis 1988, 1995). Aun así se podrían establecer tres momentos donde la presencia de una corriente teórica determinada es más marcada, sin que esto implique la ausencia de propuestas paralelas. Un primer momento desde 1878 a 1911, donde predomina el evolucionismo cultural asociado a un uso intenso de las fuentes documentales para explicar el registro arqueológico; un segundo momento desde 1956 a 1990, donde predomina el difusionismo tanto austro-alemán como norteamericano, sobre todo este último; y el tercero desde 1990 hasta la actualidad dominado por aspectos del enfoque procesual y adaptativo, acoplados primero a las corrientes histórico-culturales norteamericanas preexistentes (Politis 1995, 2003) y más tarde incorporando perspectivas de la Ecología Histórica y de los estudios sobre etnogénesis e historia indígena.

En síntesis, las investigaciones realizadas en la región estuvieron orientadas básicamente (aunque no exclusivamente) hacia la asignación de los restos arqueológicos en unidades culturales discretas (véase por ejemplo Serrano 1950 y Lafon 1972). En algunos casos, y en relación a la escasa profundidad temporal atribuida, estos conjuntos de materiales eran identificados de manera acrítica como patrimonio de los grupos indígenas descriptos para la región por los informes de conquistadores y las crónicas de la época (p. ej. chaná-timbú, guaraní y charrúas). También a los efectos de organizar el registro arqueológico del NEA se construyeron diversas categorías analíticoclasificatorias y se establecieron secuencias culturales separadas fundamentalmente en dos grandes "etapas" o "períodos" definidos a partir de la presencia o ausencia de cerámica (véase Caggiano 1984; Serrano 1972; Rodríguez 2001); dentro de los cuales se identificaron entidades culturales (Caggiano 1984; Serrano 1972) y tradiciones (Lafon 1971; Rodríguez 2006). Estas categorías fueron subdivididas su vez en variantes sincrónicas como facies (Caggiano 1984; Serrano 1972) o complejos (Rodríguez 2006) (véase Bonomo 2005).

A partir de los antecedentes estudiados, se puede realizar una breve caracterización de la ocupación humana prehispánica en Entre Ríos. En cuanto a la distribución espacial del registro arqueológico se observa sobre todo que el mismo se dispone a lo largo de las cuencas de los ríos Paraná y Uruguay, evidenciando sobre todo ocupaciones ribereñas con predominio de explotación de recursos fluviales. Cabe destacar que las investigaciones sistemáticas en el interior de la provincia aún son escasas, pero los datos existentes apoyan una ocupación más intensiva de los grandes ríos y sus tributarios. Los sitios arqueológicos se ubican tanto en tierra firme como en islas. La gran mayoría se encuentra asociado a una fuente de agua activa o inactiva en la actualidad como lagunas, arroyos, ríos, paleolagunas o paleocauces. Se disponen sobre topografías variadas como barrancas, albardones, afloramientos rocosos, médanos, playas, etc. 
En la cuenca del río Paraná son escasos los artefactos líticos y la mayoría de la materia prima utilizada procede de la Formación Ituzaingó. En tanto que el Uruguay estos materiales son abundantes y allí se explotaron sobre todo los depósitos de rodados silíceos de la Formación Salto Chico y de la Terraza I del río Uruguay. Este fenómeno diferencial está fuertemente determinado por la disponibilidad regional de materias primas líticas en cada una de las cuencas. Globalmente se registran instrumentos elaborados sobre lascas (puntas de proyectil, raederas, raspadores, muescas, entre otros); elaborados mediante abrasión, picado y/o pulido (piedras con hoyuelo, hachas, "bolas de boleadora", placas grabadas, pilones, morteros y manos de moler); y formatizados por uso (percutores, piedras con hoyuelos, sobadores y alisadores).

La alfarería es material más abundante, caracterizado por una gran variedad morfológica, tecnológica y decorativa. En la mayoría de los contextos predominan las formas simples por sobre las complejas y la cerámica lisa por sobre la decorada. Dentro de esta última a su vez predomina la decoración incisa por sobre la pintada, cuyo color más frecuente es el rojo, aunque también se ha registrado blanco, negro y motivos policromos. Un rasgo a destacar dentro del conjunto cerámico son las figuras modeladas Goya-Malabrigo, identificadas por la mayoría de los autores con poblaciones chaná-timbú y afines, y abarcando un rango temporal que va desde ca. 2000 hasta 400 años AP. También a partir de la alfarería se ha podido identificar la presencia de poblaciones guaraníes sobre todo en el Delta del río Paraná y en algunas islas del río Uruguay.

Los recursos faunísticos explotados son propios del ambiente y reflejan un clima similar al actual. Particularmente resulta predominante el consumo de peces y en algunos casos de moluscos de agua dulce; complementado con aves propias de un ambiente acuático y también de llanura, y mamíferos de tamaño mediano y grande entre los que se pueden mencionar coipo, capincho, guazuncho, venado de las pampas y ciervos de los pantanos.

Se registra además una gran variabilidad morfológica de instrumentos óseos que incluyen arpones, puntas de proyectil, biseles, "punzones", agujas, tubos, entre otros. Han sido elaborados sobre astas y huesos de cérvidos, también sobre huesos de coipo y ñandú, y espinas de peces. También se han registrado adornos elaborados sobre caninos de carnívoros y valvas de moluscos.

La existencia de prácticas hortícolas y el manejo de plantas silvestres por parte de poblaciones no-guaraníes siempre fueron temas abordados y/o asumidos a partir de la presencia de instrumentos de molienda, cerámica y de la información histórica, pero faltaba su comprobación empírica. Hace poco tiempo se ha podido confirmar la manipulación de plantas tanto silvestres como domésticas por parte de las poblaciones prehispánicas de Entre Ríos. Dentro de las plantas identificadas se registran algarrobo, palmera pindó y yatay, maíz, poroto, zapallo, entre otras. Lo que no está claro todavía es el origen y/o dispersión de estas prácticas dentro del territorio provincial. Asimismo, no está determinada aún su importancia relativa dentro de la dieta de estas poblaciones. 
En relación a las distintas formas de inhumación de restos humanos se han registrado entierros primarios, secundarios en paquetes y en urnas, huesos dispersos y en algunos casos algunos elementos anatómicos con evidencia de alteración térmica. La disposición de los mismos es muy variada y han sido identificados en distintas topografías dentro de las que se pueden mencionar, albardones, médanos y montículos antrópicos y antropogénicos.

Dentro de la variedad de sitios arqueológicos se han registrado, tanto en superficie como en estratigrafía, talleres líticos, "paraderos", "estaciones", "cementerios", "concheros", sitios multicomponentes y multifuncionales, "túmulos", montículos de origen natural, antrópicos y antropogénicos, y entierros de artefactos aislados. Particularmente en lo que respecta a los montículos, y como ya fue planteado, existen diversas posturas en cuanto a su génesis. Actualmente se ha demostrado que en el Delta superior del Paraná existen construcciones de origen antropogénico para el Holoceno tardío. En cuanto a los sitios arqueológicos en estratigrafía sobre el río Uruguay el espesor de materiales culturales puede variar entre 0,20 m (p. ej. La Paloma y Cerro El Tigre) y $1,15 \mathrm{~m}$ (Rancho Colorado).

Las dataciones absolutas registradas para el río Uruguay (margen argentina) sumarían alrededor de $32^{4}$ y abarcan un rango temporal que se extiende entre ca. 1800-600 años AP. Estas proceden de $15^{4}$ sitios arqueológicos, ninguno de los cuales se ubica dentro del área de estudio de esta tesis (Figura 1.1 y 3.1). Para la margen izquierda del río Uruguay (ROU) se cuentan con 77 dataciones procedentes de 25 sitios arqueológicos que abarcan un rango temporal más amplio (Tablas 2.1a y b).

\footnotetext{
${ }^{4}$ Sobre estos valores véase nota 2 de la Tabla 2.1a. 
Tabla 2.1a. Dataciones absolutas para la cuenca media e inferior del río Uruguay (Argentina).

$\begin{array}{llll}\text { Sitio arqueológico } \quad \text { Edad AP Código de laboratorio } & \text { Material }\end{array}$

\begin{tabular}{|c|c|c|c|c|}
\hline Túmulo I del Brazo Largo & $656 \pm 42$ & AA-93217 & Hueso humano & Bonomo et al. 2011c \\
\hline Rancho Colorado I & $750 \pm 70$ & INGEIS & Valvas de molusco & Rodríguez y Rodríguez 1985 \\
\hline Túmulo I del Brazo Gutiérrez & $752 \pm 41$ & AA-72635 & Diente humano & Bernal 2008 \\
\hline Túmulo II del Brazo Largo & $756 \pm 46$ & AA-103898 & Hueso humano & Politis et al. (en prensa) \\
\hline Cerro Chico II & $770 \pm 70$ & SI-555 & Valvas de moluscos & Cigliano et al. 1971a \\
\hline Rancho Colorado I & $820 \pm 70$ & INGEIS & Valvas de molusco & Rodríguez y Rodríguez 1985 \\
\hline Cerro Chico I & $895 \pm 35$ & GrN-5506 & Valvas de moluscos & Cigliano et al. 1971a \\
\hline Los Sauces I $^{1}$ & $1090 \pm 40$ & SI-556 & Valvas de moluscos & Cigliano et al. 1971a y $1971 b$ \\
\hline Don Santiago & $1090 \pm 80$ & INGEIS-2100-AC-0186 & Valvas de molusco & Albero y Angiolini 1985; Caggiano 1983a \\
\hline Arroyo Yarará Chico & $1180 \pm 95$ & INGEIS & Carbón vegetal & Rodríguez y Rodríguez 1985 \\
\hline Don Santiago & $1300 \pm 80$ & INGEIS-2099-AC-0183 & Valvas de molusco & Albero y Angiolini 1985; Caggiano 1983a \\
\hline Los Sauces $I^{1}$ & $1370 \pm 70$ & INGEIS-AC-110 & Valvas de molusco & Rodríguez y Rodríguez 1985 \\
\hline Rodeo Viejo La Nena & $1420 \pm 80$ & INGEIS-2101-AC-0187 & Valvas de molusco & Albero y Angiolini 1985; Caggiano 1983a \\
\hline Rodeo Viejo La Nena & $1420 \pm 80$ & INGEIS-2102-AC-0188 & Valvas de molusco & Albero y Angiolini 1985; Caggiano 1983a \\
\hline Rancho Miño & $1460 \pm 80$ & INGEIS & Valvas de molusco & Rodríguez y Rodríguez 1985 \\
\hline Arroyo Yarará Chico & $1470 \pm 80$ & INGEIS & Valvas de molusco & Rodríguez y Rodríguez 1985 \\
\hline Los Sauces II ${ }^{1}$ & $1670 \pm 70$ & INGEIS-AC-109 & Valvas de molusco & Rodríguez y Rodríguez 1985 \\
\hline Cerro Lutz $^{2}$ & $730 \pm 70$ & LP-1711 & Humano & Arrizurieta et al. 2010 \\
\hline Cerro Lutz $^{2}$ & $790 \pm 42$ & AIE-26923 & Hueso fauna & Loponte y Corriale 2013 \\
\hline Cerro Lutz ${ }^{2}$ & $795 \pm 42$ & AA-77311 & Humano & Acosta et al. 2015a \\
\hline Cerro Lutz ${ }^{2}$ & $796 \pm 42$ & AA-77311 & Humano & Arrizurieta et al. 2010 \\
\hline Cerro Lutz $^{2}$ & $916 \pm 42$ & AA-77312 & Hueso fauna & Arrizurieta et al. 2010 \\
\hline Cerro Lutz ${ }^{2}$ & $916 \pm 42$ & AA-77310 & Humano & Acosta et al. 2015a \\
\hline Cerro Lutz ${ }^{2}$ & $976 \pm 42$ & AA-77310 & Humano & Arrizurieta et al. 2010 \\
\hline Cerro Lutz $^{2}$ & $1110 \pm 45$ & AA-103643 & Humano & Acosta et al. 2015a \\
\hline Las Ánimas $^{2}$ & $1121 \pm 31$ & AA-97460 & Humano & Acosta et al. 2015a \\
\hline Cerro Mayor $^{2}$ & $1561 \pm 45$ & AA-97469 & Fauna & Acosta et al. 2015a \\
\hline Cerro Mayor $2^{2}$ & $1561 \pm 45$ & AA-97469 & Hueso fauna & Loponte y Corriale 2013 \\
\hline Cerro Mayor $^{2}$ & $1574 \pm 45$ & AA-97457 & Fauna & Acosta et al. 2015a \\
\hline Cerro Mayor $^{2}$ & $1594 \pm 59$ & AA-103658 & Fauna & Acosta et al. $2015 a$ \\
\hline Cerro Mayor $^{2}$ & $1600 \pm 33$ & AA-97466 & Fauna & Acosta et al. 2015a \\
\hline Cerro Mayor $^{2}$ & $1665 \pm 45$ & AA-97468 & Humano & Acosta et al. 2015a \\
\hline
\end{tabular}

(1) Estas dataciones corresponden al mismo sitio arqueológico. (2) Estas dataciones figuran en distintas publicaciones referidas a distintos sitios arqueológicos o para un mismo sitio arqueológico pero con distintas fechas y distintos códigos de laboratorio; también algunas dataciones figuran con referencias a publicaciones previas que no se encuentran citadas en la bibliografía final o en dichas publicaciones las dataciones no se registran. 
Tabla 2.1b. Dataciones absolutas para la cuenca media e inferior del río Uruguay (Uruguay).

$\begin{array}{llll}\text { Sitio arqueológico } \quad \text { Edad AP } & \text { Código de laboratorio } & \text { Material } & \text { Referencias }\end{array}$

\begin{tabular}{|c|c|c|c|c|}
\hline Punta Negra Este & $310 \pm 30$ & - & - & Loponte et al. 2016 \\
\hline Guayacas & $453 \pm 18$ & $05 G y-5$ & Cerámica & Capdepont 2012 \\
\hline Guayacas & $479 \pm 11$ & $05 \mathrm{~Gy}-1$ & Cerámica & Capdepont 2012 \\
\hline La Yeguada & $510 \pm 45$ & URU-0176 & Carbón vegetal & Castillo 2004 \\
\hline Guayacas & $538 \pm 12$ & 02Gy-2 & Cerámica & Capdepont 2012 \\
\hline La Yeguada & $560 \pm 70$ & URU-0178 & Carbón vegetal & Castillo 2004 \\
\hline Arroyo Negro & $590 \pm 50$ & UCTL-1673 & Cerámica & Farías 2005 \\
\hline Arroyo Negro & $610 \pm 40$ & UCTL-1674 & Cerámica & Farías 2005 \\
\hline Isla Vizcaíno (Pirata) & $790 \pm 105$ & URU-0118 & Carbón vegetal & Castillo 2004 \\
\hline Román & $800 \pm 90$ & URU-0180 & Carbón vegetal & Castillo 2004 \\
\hline Isla Vizcaíno (Pirata) & $870 \pm 100$ & URU-0118 & Carbón vegetal & Castillo 2004 \\
\hline Puente & $870 \pm 100$ & URU-0243 & Carbón vegetal & Castillo 2004 \\
\hline Isla Vizcaíno (Pirata) & $1020 \pm 130$ & URU-0117 & Carbón vegetal & Castillo 2004 \\
\hline Isla de Arriba/Aruera - Corte 9 & $1140 \pm 100$ & $\mathrm{~N}-2674$ & Carbón vegetal & Baeza et al. 1977 \\
\hline Túmulo de La Blanqueada & $1150 \pm 70$ & LP-865 & Carbón vegetal & Farías 2005 \\
\hline Túmulo de La Blanqueada & $1275 \pm 150$ & UCTL-1442 & Cerámica & Farías 2005 \\
\hline W-52 & $1300 \pm 70$ & UQ-519/520/521/522 & Valvas de moluscos & Castiñeira 2008; Guidón 1989 \\
\hline Túmulo de La Blanqueada & $1460 \pm 70$ & Beta- 104273 & Carbón vegetal & Farías 2005 \\
\hline Puerto & $1560 \pm 50$ & - & Carbón vegetal & Hilbert 1991 \\
\hline Pingüino & $1590 \pm 80$ & URU-0212 & Carbón vegetal & Castillo 2004 \\
\hline Pingüino & $1690 \pm 140$ & URU-0216 & Carbón vegetal & Castillo 2004 \\
\hline Cerrito de Colonia Concordia & $1710 \pm 110$ & URU-0172 & Hueso fauna & Bracco 2009 \\
\hline Túmulo de La Blanqueada & $1760 \pm 120$ & Beta- 104272 & Carbón vegetal & Farías et al. 2001 \\
\hline Cerrito de Colonia Concordia & $1780 \pm 70$ & URU-0107 & Carbón vegetal & Castillo 2004 \\
\hline K-103- Albardón del Tigre & $1810 \pm 45$ & - & - & Hilbert 1990 \\
\hline Cerrito de Colonia Concordia & $1840 \pm 100$ & URU-0096 & Carbón vegetal & Castillo 2004 \\
\hline El Cerro & $1857 \pm 49$ & AA-104442 & Hueso humano & Gascue et al. 2016 \\
\hline El Cerro & $1910 \pm 50$ & URU-0311 & Hueso humano & Castillo 2004 \\
\hline Isla del Medio - Sitio/Corte 1 & $2350 \pm 80$ & $\mathrm{~N}-2672$ & Carbón vegetal & Baeza et al. 1977 \\
\hline Isla de Arriba/Aruera - Corte 3 & $2370 \pm 80$ & $\mathrm{~N}-2673$ & Carbón vegetal & Baeza et al. 1977 \\
\hline W-52 & $2650 \pm 100$ & UQ-s/n. & Valvas de moluscos & Castiñeira 2008; Guidón 1989 \\
\hline 42-Río Arapey & $3930 \pm 100$ & - & Carbón vegetal & Baeza 1985; Guidón 1989 \\
\hline 42-Río Arapey & $3940 \pm 100$ & GIF-4621 & Carbón vegetal & Baeza 1985; Guidón 1989 \\
\hline 42-Río Arapey & $4070 \pm 100$ & - & Carbón vegetal & Baeza 1985; Guidón 1989 \\
\hline Puerto & $4410 \pm 130$ & - & Carbón vegetal & Hilbert 1991 \\
\hline 42-Río Arapey & $4580 \pm 270$ & GIF-4413 & Carbón vegetal & Baeza 1985; Guidón 1989 \\
\hline Y-62-Bañadero & $4660 \pm 270$ & GIF-4410 & Carbón vegetal & Baeza 1985 \\
\hline Piedra Pelada & $5030 \pm 110$ & - & - & Hilbert 1991 \\
\hline Y-58-Isla de Arriba & $5300 \pm 80$ & GIF-4411 & Carbón vegetal & Guidón 1989 \\
\hline D-03-Calpica & $6040 \pm 65$ & Dik-1223 & Madera & Guidón 1989 \\
\hline K-86-Mandiyú & $6760 \pm 100$ & - & - & Hilbert 1990, 1991 \\
\hline W-52 & $7610 \pm 245$ & $\begin{array}{l}\text { UQ-199; UQ-200; UQ- } \\
201\end{array}$ & Carbón vegetal & Castiñeira 2008; Guidón 1989 \\
\hline D-03-Calpica & $9320 \pm 170$ & Dik-1224 & Madera & Guidón 1989 \\
\hline K-87-Albardón del Tigre & $10.420 \pm 90$ & $\mathrm{KN}-2531$ & Carbón vegetal & Hilbert 1985, 1990, 1991 \\
\hline $\begin{array}{l}\text { Pay Paso } 1 \\
\text { (32 dataciones) }\end{array}$ & $\begin{array}{c}\text { entre } 8570 \pm 150 \\
\text { y } 10.930 \pm 20 \\
\end{array}$ & varios & Carbón vegetal & $\begin{array}{l}\text { Austral 1994, 1995; } \\
\text { Suarez } 2011\end{array}$ \\
\hline Y-58-Isla de Arriba ${ }^{1}$ & $11.200 \pm 500$ & GIF 4412 & Carbón vegetal & Guidón 1989 \\
\hline
\end{tabular}

(1) esta datación ha sido cuestionada por no estar asociada directamente a restos culturales (Meneghin 2005; Politis et al. 2004).

El registro arqueológico de Entre Ríos evidencia la existencia de contactos y relaciones socioeconómicas a nivel extraregional. Autores como Outes y Torres, entre otros, tempranamente postulaban relaciones biológicas y culturales sobre todo con el sur de Brasil. Actualmente se han 70 
identificado zonas de procedencia de algunas materias primas líticas y metales. Así se ha determinado la existencia de una red de intercambio que incluía a las Sierras Centrales, la región pampeana y el Área Andina Meridional.

Para finalizar, esta revisión de antecedentes permite apreciar que el área de estudio que comprende esta tesis, no estaba siendo investigada de forma intensiva y sistemática como otras áreas circundantes y tampoco se registraban dataciones radiocarbónicas para los sitios arqueológicos conocidos. Particularmente para esta área se registran escasas publicaciones, algunas con datos originales (Almeida 1983a, 1983b, 1996c; CCBSJG 1986; Cione et al. 1977; Greslebin 1931a, 1931b; Krapovickas 1957; Poenitz 1970b) y otras de síntesis (Bourlot 2008; Gregori 1968). Esta escasez de conocimientos sistemáticos sumada a las interesantes temáticas planteadas arriba para una provincia que ha sido intensamente ocupada y donde se ha dado una compleja interacción poblacional en tiempos prehispánicos y posthispánicos también, justifica el desarrollo de esta investigación, que intenta, mediante el aporte de nuevos datos originales, reconstruir parte de la historia indígena de la cuenca media e inferior del rio Uruguay. 


\section{CAPÍTULO 3}

\section{AMBIENTE}

En este capítulo se caracterizan los componentes ambientales más relevantes para analizar y comprender la interrelación entre las poblaciones humanas del pasado con su entorno natural. En este sentido, se presenta la información regional sobre los aspectos geológicos, geomorfológicos, hídricos, climáticos, paleoclimáticos y fisiográficos.

La región Nordeste o Litoral donde se encuentra el área de estudio ha recibido distintas denominaciones dependiendo de los criterios utilizados desde la geología y la arqueología. Sobre la base de criterios geológico-ambientales, Iriondo (1991) define al Litoral Argentino como el territorio comprendido por las tres provincias de la Mesopotamia (Misiones, Corrientes y Entre Ríos), el sur y centro de Santa Fe y una faja de un ancho que varía entre 10 y $30 \mathrm{~km}$ sobre la margen derecha del río Paraná entre Resistencia y Santa Fe; además de la faja del río Paraguay en Formosa. Desde la arqueología, se ha considerado a esta región de manera contrapuesta al Noroeste argentino. Algunos autores (Serrano 1972; Torres 1907) la denominan Litoral y otros Nordeste (Caggiano 1983a; Lafon 1971). Estas definiciones además de considerar criterios geológico-ambientales, incorporan explícita o implícitamente información vinculada al desarrollo cultural prehispánico para la delimitación de la región, sus subregiones y/o sectores.

Lafon (1971) presenta una delimitación amplia del Nordeste argentino, que comprende al área entre el meridiano $63^{\circ}$ de longitud oeste, el paralelo $34^{\circ}$ de latitud sur. De acuerdo con este autor, ecológica y ambientalmente puede subdividirse en tres subregiones claramente definidas: Mesopotamia, Chaco (central y austral) y las Ilanuras del extremo nordeste de Pampasia. La Mesopotamia se divide en una faja norte, al norte del paralelo $28^{\circ}$, una faja central desde dicho paralelo hasta la ciudad de Diamante $\left(\mathrm{S}^{\circ} 2^{\circ}, 069792 ; \mathrm{O}^{\circ}, 637892\right)$ y una faja meridional que incluye el Delta del río Paraná en sentido amplio, o Complejo Deltaico del río Paraná (sensu Aceñolaza et al. 2008), que se extiende desde Diamante hasta su desembocadura en el Río de la Plata, sobrepasando hacia el sur el paralelo $34^{\circ}$. Para la delimitación de estas divisiones geográficas además el autor parte de unidades culturales ya definidas (Lafon 1971). Por su parte Politis y Barros (2006), basándose en Soriano y colaboradores (1992) y a partir de bases ecológicas consideran como parte de la región pampeana el sur de la provincia de Entre Ríos, donde predominan los pastizales que son interrumpidos por la cuña de selva en galería de los ríos Paraná y Uruguay. En esta tesis se utiliza la denominación Nordeste en el sentido geográfico amplio, concordante con Lafon (1971). 
El Nordeste presenta una combinación de unidades geomorfológicas producto de diversos procesos geológicos y ambientales. En este caso se focaliza en aquellas correspondientes a la provincia de Entre Ríos, donde se ubica el área de estudio de esta investigación (Figura 3.1). La misma está comprendida entre los $31^{\circ} 28^{\prime}$ y $33^{\circ} 25^{\prime}$ de latitud sur y $59^{\circ} 15^{\prime}$ de longitud oeste y el límite internacional Argentina-Uruguay, incluye los departamentos de Colón, Concepción del Uruguay, Gualeguaychú y parte de Villaguay. Siguiendo el esquema de Iriondo y Kröhling (2009: 22) abarca la porción terminal de la cuenca media y la cuenca inferior del río Uruguay.



Figura 3.1. Mapa de la provincia de Entre Ríos mostrando el área de estudio y los sectores de muestreo (A, B y C). 


\section{1- GEOLOGÍA}

\subsection{1- ESTRATIGRAFÍA REGIONAL}

En primer lugar es necesario hacer una breve descripción de la columna geológica de la región que comprende al área de estudio. Para ello se presenta la secuencia estratigráfica y cronológica tanto de la Mesopotamia argentina como de la República Oriental del Uruguay (ROU) cuyas historias geológicas están estrechamente vinculadas (Aceñolaza 2007: 43). La secuencia se describe en orden de depositación desde el pasado hasta la actualidad; comienza con la mención del Complejo Martín García por la importancia litológica del mismo y continua luego a partir del Jurásico superior. La misma ha sido confeccionada en base a autores como Frenguelli (1927b, 1939), INTA (2002), Iriondo y Kröhling $(1995,2009)$ y Aceñolaza (2007), entre otros.

Hay que destacar que muchas de las formaciones estratigráficas de la región presentan muy pocos afloramientos en superficie y si bien algunas de éstas tienen edades pre-cuaternarias son relevantes desde el punto de vista arqueológico como potenciales fuentes de materias primas para los artefactos líticos y de arcillas para la alfarería ${ }^{1}$.

\section{Precámbrico}

Complejo Martín García (Dalla Salda 1981): sus componentes, rocas ígneo-metamórficas (anfibolitas, gneises, piroxenitas, esquistos y granitos), deben relacionarse con lo que en el oeste de Uruguay se denomina "Terreno Piedra Alta" o "Dominio Occidental" que constituye el basamento Proterozoico. Sus afloramientos colindantes al río Uruguay y al Río de la Plata forman parte de la "Faja Florida" y se encuentran en el sudoeste uruguayo hasta la zona de Carmelo (S33 ${ }^{\circ}, 99985$; $\left.\mathrm{O} 58^{\circ}, 28309\right)$ e incluyen la isla Martín García (S34²,18322; $\left.\mathrm{O58}^{\circ}, 25314\right)$.

\section{Jurásico superior/Cretácico}

Formación Botucatú (Gonzaga de Campos 1889) (Jurásico superior-Cretácico inferior): es equivalente a lo que en Uruguay se denomina Formación Tacuarembó y en algunos casos en Argentina como Formación Solari. Se caracteriza por areniscas rojas, rosadas y amarillentas, que

\footnotetext{
${ }^{1}$ No se describen las formaciones aún en discusión, dado que: su conocimiento es escaso, no afloran en la región y su presencia no ha sido totalmente establecida; $y$ además, algunas de ellas no son significativas desde el punto de vista arqueológico (p. ej. Mariano Boedo, Los Cardos, Toropí, Yupoí, Bonpland y Pujol). La omisión de estas unidades no altera la caracterización general de la columna geológica regional en cuanto a su implicancia arqueológica.
} 
subyacen, se intercalan y, en algunos casos, se sobreponen a diferentes niveles del basalto de la Formación Serra Geral. En Argentina se manifiesta en forma de areniscas cuarzosas a cuarzo feldespáticas de granulometría media a fina bastante homogénea. En el caso donde se produjo el contacto con los basaltos se dieron procesos de cocción, originando una cuarcita de color más oscuro y fractura concoidal, se las denomina areniscas de Intertrap o cuarcitas de Intertrap o Botucatú. En esta tesis dado el alto grado de silicificación y compactación que presentan estas rocas son consideradas como materias primas silíceas. Los afloramientos de esta formación más cercanos al área de estudio se encuentran en San Ignacio $\left(\mathrm{S} 27^{\circ}, 23780 ; \mathrm{O55}^{\circ}, 51822\right)$ (Misiones), en la región centro-oriental de Corrientes y en la cuenca del río Uruguay en algunos casos hasta las proximidades de Concordia $\left(\mathrm{S} 31^{\circ}, 39177 ; 58^{\circ}, 01747\right)$ (Entre Ríos). En Entre Ríos los afloramientos del noreste son poco relevantes y están afectados por las coladas basálticas, van desde Salto Grande $\left(\mathrm{S}^{\circ} 1^{\circ}, 25113\right.$; $\left.\mathrm{O}^{\circ} 7^{\circ}, 9297\right)$ hasta Paso Hervidero $\left(\mathrm{S} 31^{\circ}, 52949 ; \mathrm{O57}^{\circ}, 99796\right)$; desde este punto hacia el sur y oeste solo se encuentra en perforaciones del subsuelo.

Formación Serra Geral (White 1908) (Cretácico inferior): en Uruguay se la conoce como Formación Arapey. Representa un acontecimiento magmático-eruptivo cretácico de extensión regional (Brasil, Paraguay, Argentina y Uruguay) y está constituido por una serie de derrames de rocas basálticas, andesitas basálticas y andesitas piroxénicas con algunas intercalaciones arenosas. El color varía entre pardo-rojizo a grisáceo y negro. Dentro de las coladas se pueden encontrar vesículas y amígdalas rellenas de calcedonia y ópalo que en algunos casos presentan gran tamaño. Estas vesículas cuando se fragmentan por variados motivos (erosión, acción física y mecánica) originan clastos que luego darán origen a los denominados "rodados del río Uruguay".

Afloramientos de esta formación están presentes en abundancia en las provincias de Misiones y Corrientes, en Entre Ríos se encuentra a lo largo del cauce del río Uruguay constituyendo los saltos, correderas y restingas. Su punto más meridional sobre la costa entrerriana es Paso Hervidero (Frenguelli 1927b, 1939), pero en la zona de Puerto Yeruá $\left(\mathrm{S} 31^{\circ}, 45074\right.$; O57 $\left.{ }^{\circ}, 91322\right)$ se pone de manifiesto cuando baja el nivel de las aguas. En Uruguay cubre toda la región noroeste, llegando a la costa del río Uruguay hasta las inmediaciones de Salto $\left(\mathrm{S}^{\circ} 1^{\circ}, 38333 ; 057^{\circ}, 96666\right)$. Cabe destacar que desde Paso Hervidero hacia el sur se pueden encontrar rodados que se han originado a partir de esta formación y hoy integran las formaciones San Salvador y El Palmar.

Formación Guichón (=Formación Puerto Yeruá) (Cretácico superior): se manifiesta en ambas márgenes del río Uruguay, se la denominó Areniscas de Guichón (Lambert 1939) o Formación Guichón (Aceñolaza 2007; Bossi 1966; DINASEGE 1995), también denominada Formación Puerto Yeruá (De Alba y Serra 1959; Tófalo 1986). La denominación Puerto Yeruá se aplica generalmente para la margen argentina de esta formación. En este trabajo se utiliza Formación Guichón por el simple hecho de que las formaciones y depósitos geológicos no respetan límites políticos. Además, al considerar la procedencia de estas rocas registradas en los sitios arqueológicos no se puede 
determinar con precisión de qué margen del río Uruguay provienen, por lo tanto el uso de "Formación Puerto Yeruá" está implícitamente restringiendo la procedencia de las rocas a la margen argentina.

Está conformada por areniscas conglomerádicas hasta pelitas de color variable (naranja rojizo, pardo rojizo a rojo, rojo negruzco). Estas rocas presentan un proceso de calcretización que ha originado distintos tipos de calcretas como son: nodulares, macizas, laminares y brechosas (Tófalo 1986; Tófalo y Pazos 2002). Las macizas y laminares, presentan rellenos silíceos y de calcita. En algunos casos se da un proceso de silicificación que transforma las calcretas en silcretas, a través de una sucesión de fases silíceas, originando "calcretas o areniscas silcretizadas", con colores que van desde el blanco al rojo oscuro y en algunos casos conforman estructuras silíceas traslucidas (calcedonias). Este tipo de calcedonias son similares en composición a las de otras formaciones del área, de las que sólo se diferencian por su origen.

Estas rocas son el resultado de procesos epigénicos de generación de la sílice amorfa que forma láminas, venillas o nódulos que rellenan las cavidades macro y microscópicas de esta formación (INTA 2002; Tófalo y Pazos 2002). En la literatura arqueológica (Berón y Curtoni 2002; Bonomo y Blasi 2011; Flegenheimer et al. 2003; González 2005; Loponte et al. 2011a) han sido denominadas "Calizas silicificadas de la Formación Puerto Yeruá", "Calizas bioclásticas silicificadas" o "Fangolita silicificada" y descriptas como similares a las rocas de la Formación Mercedes y de la Formación Queguay (Calizas del Queguay) de la ROU. Se ha discutido sobre su origen y procedencia, ya que presentan buena calidad para la talla y han sido utilizadas en la manufactura de artefactos líticos recuperados en contextos arqueológicos de las regiones Nordeste y pampeana. En este trabajo, siguiendo a Tófalo (1986: 73) quién sostiene que las “...-calizas del Queguay-, tienen exactamente las mismas características estructurales, texturales y mineralógicas que las que presentan las sedimentitas argentinas de naturaleza calcárea que abundan en la Formación Puerto Yeruá.", este tipo de rocas serán denominadas calizas silicificadas.

En la margen derecha del río los afloramientos son dispersos y de dimensiones reducidas, se encuentran desde el arroyo Ayuí Grande (Concordia) hasta el arroyo Atalaz (Colón) aproximadamente. La continuación de los mismos en la margen uruguaya se da entre los ríos Dayman y Queguay. Desde este último curso de agua la formación va hasta el sur de Soriano $\left(\mathrm{S} 33^{\circ}, 63650 ; 058^{\circ}, 47839\right)$, pero no ya sobre la costa del río Uruguay, sino en el interior del territorio uruguayo y aflora en la cuenca media (y probablemente en la inferior) del río Negro.

En la ROU sobre la Formación Guichón se dispone en discordancia la Formación Mercedes constituida en la base por conglomerados y areniscas de color rosado con intercalaciones de carbonatos (calcretas), en parte silicificados (Aceñolaza 2007: 68). Hacia arriba sigue una secuencia monótona de arenas finas a medias de colores rosados a amarillentos con intercalaciones de calizas de hasta $15 \mathrm{~m}$ de espesor. Cabe destacar que en el Parque Nacional El Palmar (PNEP) hay niveles 
calcretizados por sobre la Formación Guichón, que aún no están claramente identificados como equivalentes a la Formación Mercedes. La transición Cretácico-Terciario en Uruguay está dada por la Formación Queguay (Goso y Perea 2004), también conocida como "Calizas del Queguay" (Daners 2008: 126) conformada por calizas y que para algunos autores equivaldría a la Formación Mariano Boedo de Argentina. Es un paleosuelo del Terciario temprano de tipo calcáreo (Verde y Perea 2008: 147).

\section{$\underline{\text { Terciario }}$}

Formación Fray Bentos (Lambert 1939) (Oligoceno inferior-medio): en ambas márgenes del río Uruguay esta unidad posee la misma denominación y se dispone por sobre los depósitos mesozoicos mencionados previamente. Se compone de una secuencia de limolitas arenosas y limoarcillitas de color castaño claro a rosado, cementadas por carbonato de calcio que en algunos puntos pueden llegar a tener características de calizas (calcretas) y en menor proporción silicificadas, presenta niveles brechosos y conglomerádicos con una matriz limosa. Sus afloramientos son reducidos y con una ubicación saltuaria (INTA 2002), están presentes en la superficie del terreno en distintas localidades de la cuenca del río Uruguay, desde Paso de los Libres $\left(\mathrm{S} 29^{\circ}, 71667 ; \mathrm{O}^{\circ} 7^{\circ}, 08333\right)$

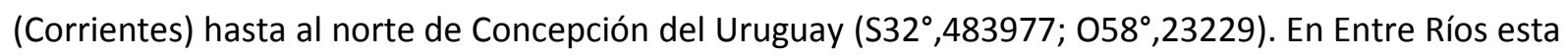
formación se dispone discordantemente sobre la Formación Guichón. En Uruguay forma de franja

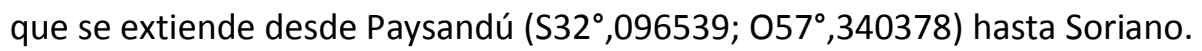

Formación Paraná (Bravard 1858) (Mioceno medio-superior): tiene un origen netamente marino y es producto de la transgresión marina del Mioceno que constituyó el denominado Mar Paranense y que afectó gran parte de Sudamérica, incluyendo el centro y norte de Argentina y sur de Uruguay. Su litología corresponde a areniscas, limos, arcillitas gris-verdosas y calizas con fósiles marinos. No se presentan afloramientos dentro del área que abarca este trabajo, los mismos son comunes en la costa del río Paraná formando parte de sus barrancas. Desde la ciudad de Paraná

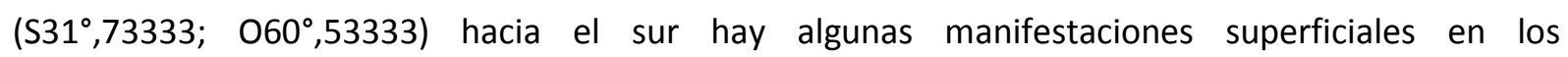
departamentos de Diamante (p. ej. Cantera Cristamine) y Victoria $\left(S 32^{\circ}, 621448 ; 60^{\circ}, 15733\right)$ (p. ej. Arroyo Doll). Es equivalente a la Formación Camacho de Uruguay que se extiende sobre el borde del Río de la Plata.

Formación Ituzaingó/ San Salvador/ Salto Chico (De Alba 1953; Herbst 1971; Herbst et al. 1976/ Iriondo y Kröhling 2007/ Rimoldi 1962; INTA 2002) (Plioceno medio y superior-Pleistoceno inferior): Tienen un origen continental fluvial y es equivalente a lo que en el noroeste de Uruguay se denomina Formación Raigón. Consiste en una secuencia arenosa de colores blanquecinos, amarillos y rojizos que generalmente se encuentra suelta y en algunos casos puede presentarse parcialmente silicificadas o con cemento ferruginoso. En su base presenta niveles conglomerádicos o gravosos con 80 
clastos (rodados) de cuarzo, ópalo, calcedonia y en menor medida basalto. Como señala Aceñolaza (2007: 87) estos rodados "...son los rellenos de las oquedades del basalto de Serra Geral que han sido liberados por la erosión y transportados por un importante sistema fluvial.". También esta unidad puede presentar troncos silicificados (Zucol et al. 2004), entre ellos fósiles de palmeras (Lutz 1984).

Estas formaciones se manifiestan claramente en Entre Ríos, tanto en la margen izquierda del río Paraná (Formación Ituzaingó) como en margen derecha del río Uruguay (Formación San Salvador/ Salto Chico). Se sobreponen mediante una discordancia erosiva sobre las formaciones Paraná, Fray Bentos y Guichón (INTA 2002). En la cuenca del río Uruguay la Formación San Salvador se extiende desde el norte de Paso de los Libres hasta la zona de Concepción del Uruguay y Salto. En varios puntos de la cuenca del río Uruguay no se pueden establecer claramente los límites entre esta formación y los componentes de la Formación El Palmar, ya que ambas unidades tienen un origen fluvial y granulometría similar.

\section{Cuaternario}

La sucesión estratigráfica varía notablemente a partir del Cuaternario, dependiendo del área y las condiciones de depositación. Por este motivo, para simplificar el esquema regional y focalizando sobre todo en Entre Ríos, se describen los depósitos geológicos de acuerdo a tres zonas claramente diferenciables: Llanuras altas y río Paraná, río Uruguay y Complejo Deltáico. Asimismo, se indicará su equivalente en territorio uruguayo cuando sea pertinente.

\section{Llanuras altas y río Paraná}

Formación General Alvear (Iriondo 1980a) (Pleistoceno inferior-medio): se apoya en discordancia sobre la Formación Ituzaingó, se compone de limos y arcillas pardas, pardo-rojizas y pardo-amarillentas con alto contenido de carbonatos. Aflora en las barrancas del río Paraná, mientras que en el subsuelo está presente hasta la cuenca del río Gualeguay.

Formación Hernandarias (Reig 1956) (Pleistoceno medio): tiene un origen continental lacustre-palustre propio de un ambiente árido, semiárido estacional, constituye básicamente un antiguo pantano depositado por el río Uruguay con aportes eólicos menores. Se dispone discordantemente tanto sobre las formaciones Ituzaingó/ San Salvador como sobre la Formación General Alvear. Se presenta en forma de un complejo sedimentario clástico pelítico en parte samítico, formado por arcillas limosas, limos arcillosos y arenas muy finas asociadas, con manifestaciones aisladas de concreciones carbonáticas de tamaño variable y depósitos de yeso (INTA 2002). Su color varía entre pardo rojizo y verdoso. La Formación Hernandarias ocupa todo el centro y norte de Entre Ríos (Iriondo 1991) y se manifiesta tanto en la cuenca del río Paraná y sus tributarios, 
como en la cuenca de los ríos Gualeguay y Gualeguaychú. Su equivalente en territorio uruguayo es la Formación Bellaco.

Formación Tezanos Pinto (Iriondo 1980a) (Pleistoceno superior-Holoceno inferior): se compone de limos y loess de color castaño claro. Se desarrolla en discordancia sobre la Formación Hernandarias y se extiende por el sudoeste de la provincia de Entre Ríos. Esta formación loessica es la unidad sedimentaria representativa de la Faja Periférica de Loess (FPL) del Sistema Eólico Pampeano (SEP sensu Iriondo y Kröhling 1995), y constituye la unidad geomorfológica Lomadas Loessicas de Crespo (Iriondo y Altamirano 1988).

En los valles fluviales de las llanuras altas de Entre Ríos, formados durante este período, afloran dos tipos de terrazas (geoformas), que algunos autores describen como formaciones: la más antigua (Formación Arroyo Feliciano sensu Iriondo et al. 1985) constituye el relleno aluvial acumulado durante el Pleistoceno superior, presenta sedimentos loessicos de color castaño claro con niveles de concreciones carbonáticas e intercalaciones de gravillas. Está formada por grandes paleocauces rellenos y sedimentos asociados a la llanura aluvial. En la mayor parte del área ocupada por la Formación Hernandarias se encuentra en superficie, en cambio en las Lomadas Loessicas de Crespo y la faja asociada al Paraná subyace a los depósitos de la Formación Tezanos Pinto (Erra et al. 2006). La terraza más reciente (Formación La Picada sensu Iriondo et al. 1985), es un depósito aluvial del Holoceno inferior presente en todos los ríos y arroyos, generalmente en forma de terraza baja excavada en otra más antigua (Formación Arroyo Feliciano). En general, la sedimentología se caracteriza por limos y arenas cuarzosas finas. En el río Gualeguay, estos depósitos forman una reducida faja bordeando el cauce actual, dentro de una amplia terraza alta (Formación Arroyo Feliciano).

\section{Río Uruguay}

A partir de los estudios geológicos realizados sobre el período Cuaternario en el río Uruguay han surgido variadas y numerosas posturas sobre el origen e identificación de sus formaciones y geoformas (véase discusión en Aceñolaza 2007; INTA 2002). Los distintos autores han interpretado las mismas unidades de diferentes maneras (p. ej. Frenguelli 1927b, 1939; Gentili y Rimoldi 1979; INTA 2002; e Iriondo 1980a), lo que ha llevado a una confusa nomenclatura que dificulta la correcta interpretación de los procesos geológicos y geomorfológicos ocurridos a lo largo del cauce del río.

Formación El Palmar/ Terraza I (Iriondo 1980a/ INTA 2002) (Pleistoceno superior): se corresponde con la denominada Unidad E y en parte F por Frenguelli (1939), terrazas del Río Uruguay de Cordini (1949), Formación Salto de Bossi (1966), Formación Ubajay de Gentili y Rimoldi (1979). Este depósito fluvial forma una faja de 4 a $15 \mathrm{~km}$ de ancho que se extiende desde Corrientes hasta Concepción del Uruguay (Iriondo y Kröhling 2009), conformando una terraza alta de unos 25 m de altura, por fuera del valle actual en ambas márgenes del río. Está compuesto por arenas fluviales de 
color rojo oscuro que incluyen grandes bancos de rodados y gravas de composición silícea (en su mayor parte de calcedonia, ópalo y cuarzo), así como también troncos fósiles silicificados (Iriondo y Kröhling 2007, 2009). Esta formación puede estar recubierta por otros depósitos más modernos o expuesta en superficie. Los rodados presentan diámetros comprendidos entre 2 y $10 \mathrm{~cm}$, excepcionalmente mayores, su tamaño disminuye paulatinamente de norte a sur, aumentando correlativamente la redondez (Iriondo y Kröhling 2007). Afloran en proximidades de las costas del río Uruguay y en los valles de los principales afluentes. El límite sur de estas psefítas se encuentra en las inmediaciones de Gualeguaychú $\left(\mathrm{S} 33^{\circ}, 007745 ; 058^{\circ}, 510349\right)$ (Gentili y Rimoldi 1979). El origen de esta terraza se vincula estrechamente al incremento relativo del nivel del mar ocurrido durante el final del Pleistoceno superior entre 38.500 y 26.600 años AP (Martínez y Del Río 2005).

Formación Concordia/ Terraza II (Iriondo y Kröhling 2009/ INTA 2002) (Holoceno medio): Equivale a la Unidad G de Frenguelli (1939). Está conformada por depósitos fluvioeólicos, integrados por un loess antiguo retransportado y limos arenosos pardos y grises recientes con tosquilla, y hasta levemente calcretizados cuando están cerca de las formaciones Guichón o Fray Bentos. Estos depósitos forman la terraza más baja y se desarrollan en ambas márgenes del río donde las crecientes ordinarias los cortan en forma de barrancas verticales, de 5 a $7 \mathrm{~m}$ de altura (Frenguelli 1927b). En épocas más recientes a este depósito se adosan albardones de dimensiones variables, lo que a veces impide su clara diferenciación geomorfológica, si bien su origen es diferente (Iriondo y Kröhling 2009). Se manifiesta desde el límite con Brasil hasta Concepción del Uruguay. Una observación pertinente para este estudio es que el material de esta terraza es apto para la elaboración de cerámicas (Bertolini 2001).

Terraza III (Holoceno superior y actual): es un depósito eólico limo-arenoso pardo oscuro deflacionado del río Uruguay por vientos del sudeste que constituye la denominada Unidad H de Frenguelli (1927b, 1939). La misma se extiende en la margen derecha del río desde Concordia hasta Gualeguaychú cubriendo el paisaje y presentando un ancho variable entre 29 y $45 \mathrm{~km}$, aunque al sur

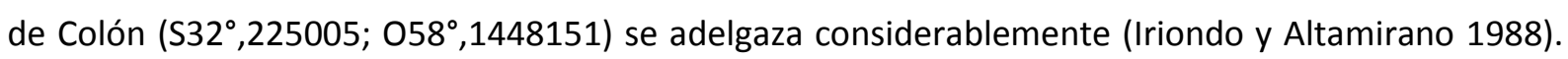
Se trata de una carpeta discontinua, de arena cuarzosa fina de color gris, que alcanza hasta $1 \mathrm{~m}$ de espesor, con algunos campos de dunas. Desde Concepción del Uruguay hacia el sur, los campos de dunas suelen formar fajas de hasta cientos de metros de largo y de ancho junto al río. Las dunas van de 1 a $3 \mathrm{~m}$ de altura y en algunos casos se encuentran cubiertas por vegetación herbácea y arbustiva.

\section{Complejo Deltaico}

El río Uruguay corre encajonado hasta la cercanía de Concepción del Uruguay-Gualeguaychú donde se abre en un amplio valle fluvial. Esta zona junto al sur de la provincia de Entre Ríos fue un ámbito invadido por el "Mar Querandí" que al retirarse depositó la Formación Isla Talavera, equiparable al Querandinense de Buenos Aires, y que afectó el sudeste de Entre Ríos así como parte 
de Uruguay, donde se la conoce como Formación Villa Soriano, también se correspondería con el ambiente holocénico de Cavallotto y colaboradores (2005). Los sedimentos del “Mar Querandí" están constituidos por arenas con intercalaciones limo-arcillosas y material volcánico, siendo observable sobre la costa del río Uruguay hasta la zona de Fray Bentos $\left(\mathrm{S} 33^{\circ}, 127717 ; 058^{\circ}, 300822\right)$ (ROU) (Aceñolaza 2007).

El retiro de las aguas marinas sirvió para que en la planicie resultante el Paraná se abriera paso hacia el Río de la Plata originando todos los depósitos que constituyen el Complejo Deltaico del río Paraná (Aceñolaza et al. 2008). Todos sus componentes corresponden a depósitos holocénicos, y algunos de ellos conforman la geomorfología actual de la zona meridional del área de estudio. Estos depósitos integran un conjunto de geoformas que son: Ilanuras de mareas, cordones litorales asociados a cordones de médanos y llanuras de playas (Cavallotto et al. 2005) y están constituidos básicamente por arcillas, arenas y bancos de valvas de moluscos (Erodona mactriodes y Littoridina pascium). 


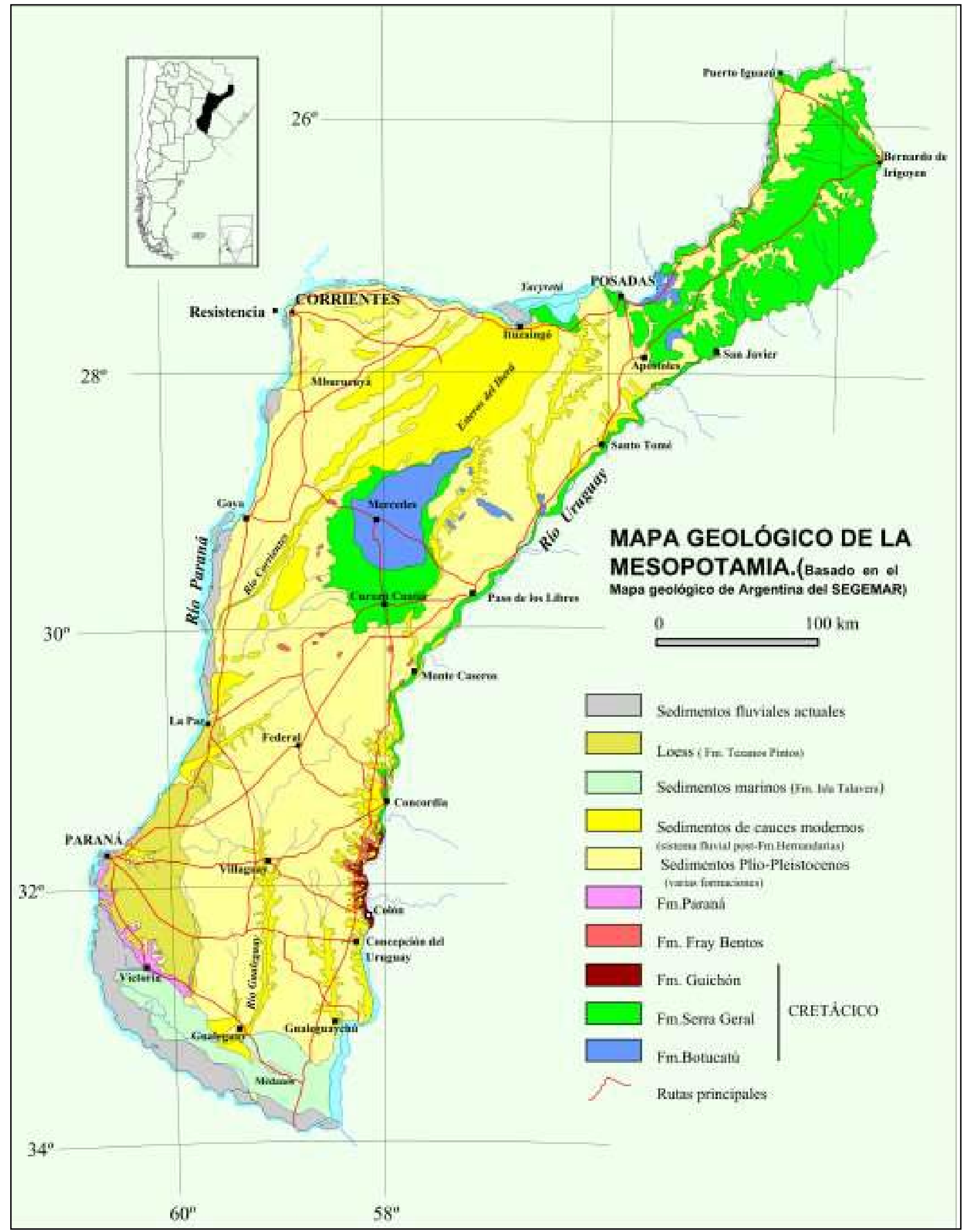

Figura 3.2. Mapa geológico de la Mesopotamia (Tomado de Aceñolaza 2007; calidad del original). 


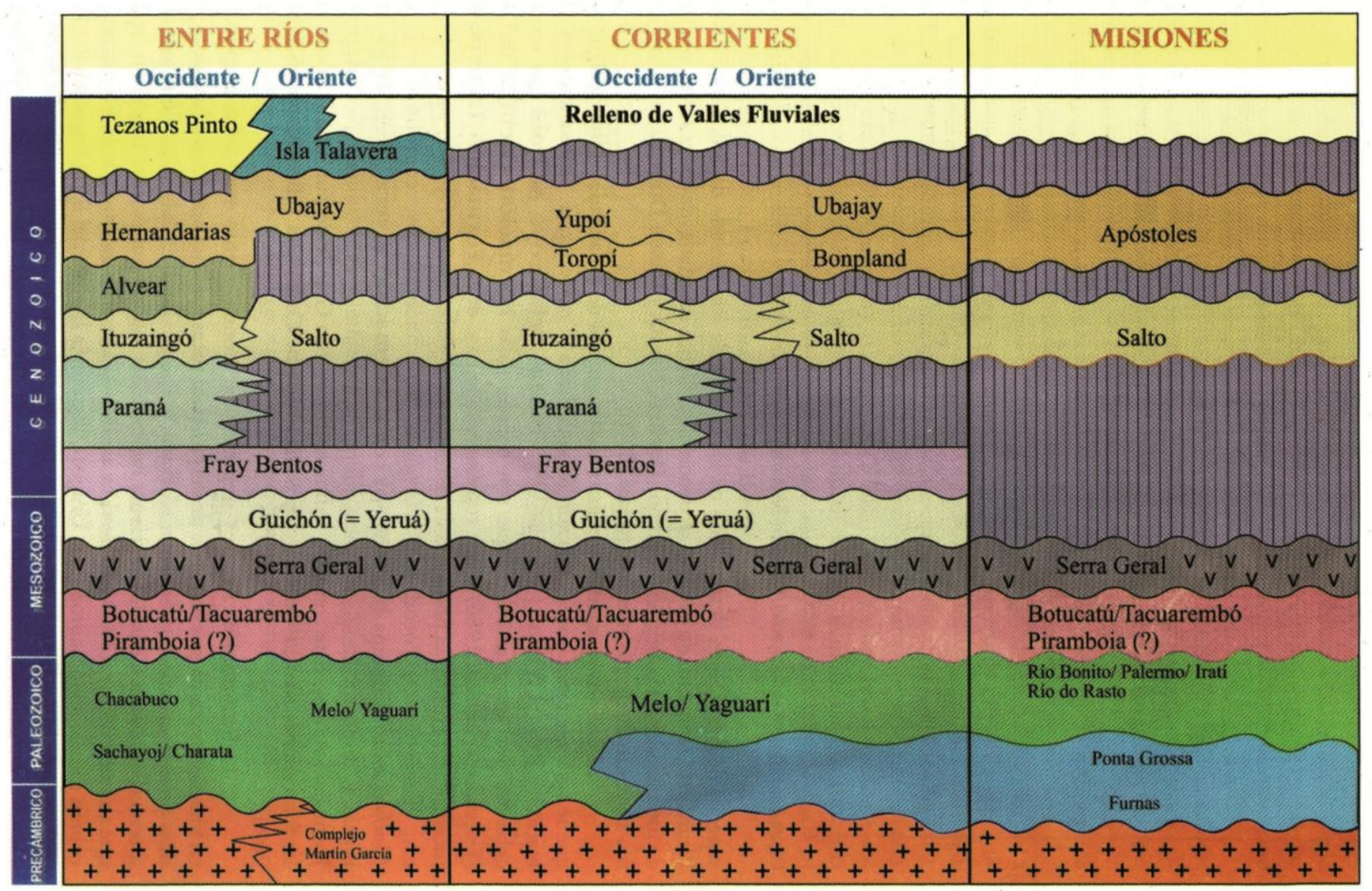

Figura 3.3. Cuadro estratigráfico general de la Mesopotamia (Tomado de Aceñolaza 2007; calidad del original). 


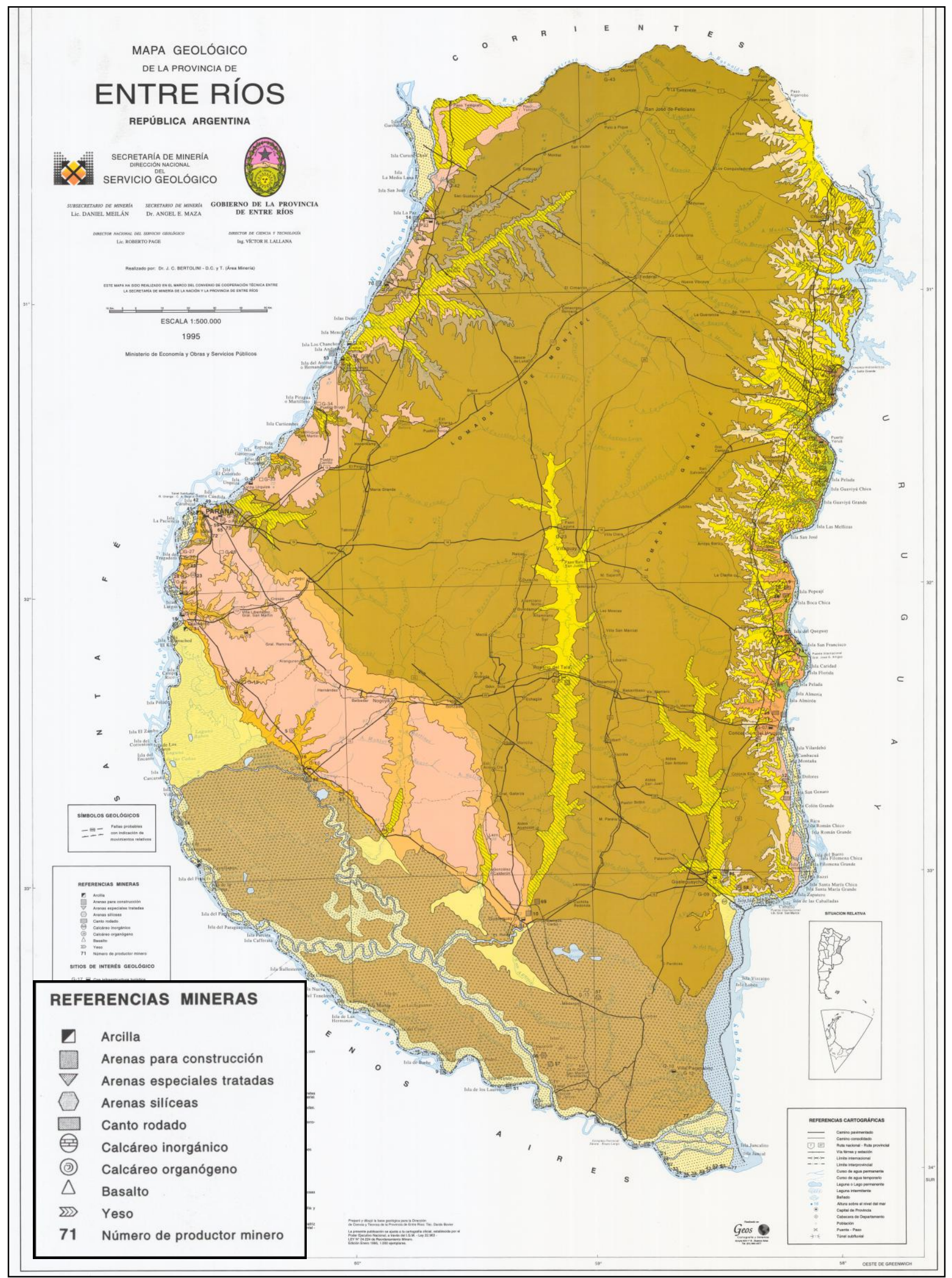

Figura 3.4a. Mapa geológico de Entre Ríos (Tomado y modificado de DINASEGE 1995). 


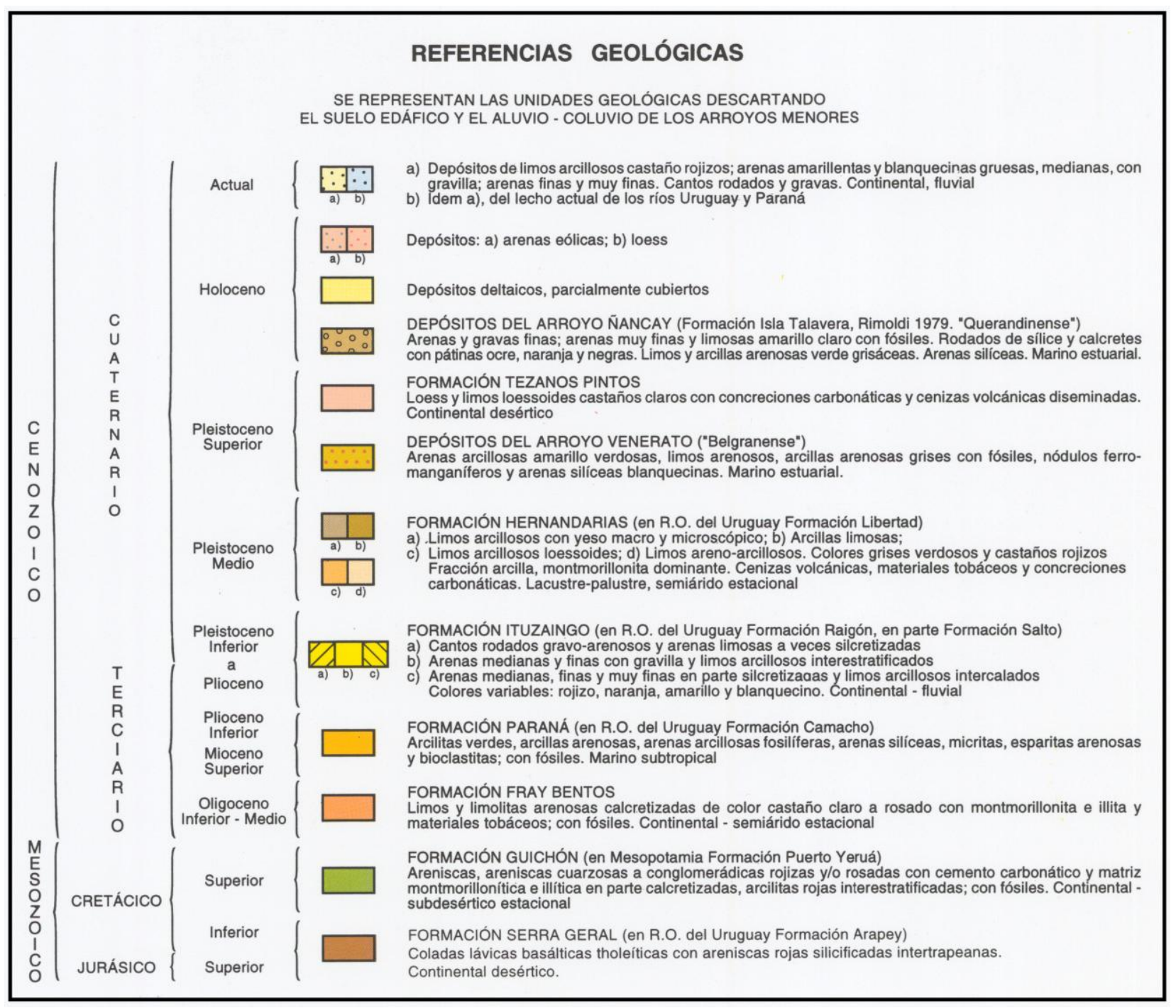

Figura 3.4b. Referencias geológicas ampliadas de la Figura 3.4a.

\subsection{2- GEOMORFOLOGÍA}

Los estudios geológicos y geomorfológicos para el Cuaternario en la provincia de Entre Ríos son escasos, y además no existe un claro consenso entre los distintos investigadores que han trabajado y trabajan en la región, en cuanto a las distintas unidades litoestratigráficas que la componen, a sus edades y a los procesos que las originaron. A esto se suma la gran variabilidad de acontecimientos climáticos y geológicos ocurridos durante este período, lo que complejiza aún más el panorama a la hora de intentar comprender el desarrollo ambiental del área. Aun así es posible esbozar una caracterización de los principales procesos geológicos y ambientales ocurridos dentro del área de estudio para Pleistoceno final-Holoceno superior. De esta manera se sintetizan a continuación los principales aportes de los distintos autores que han trabajado en la región.

La evolución del paisaje en la provincia de Entre Ríos, tanto espacial como temporalmente, estuvo condicionada por la interacción de una multiplicidad de factores como: la acción fluvial de los 
principales ríos, la estructura tectónica, la topografía del sustrato, las ingresiones marinas, eventos eólicos y actualmente la acción antrópica. Globalmente se puede sostener que esta tesis se encuentra dentro del denominado "Ambiente fluvial de los grandes ríos y las playas marinas del Cuaternario" Aceñolaza (2007: 15).

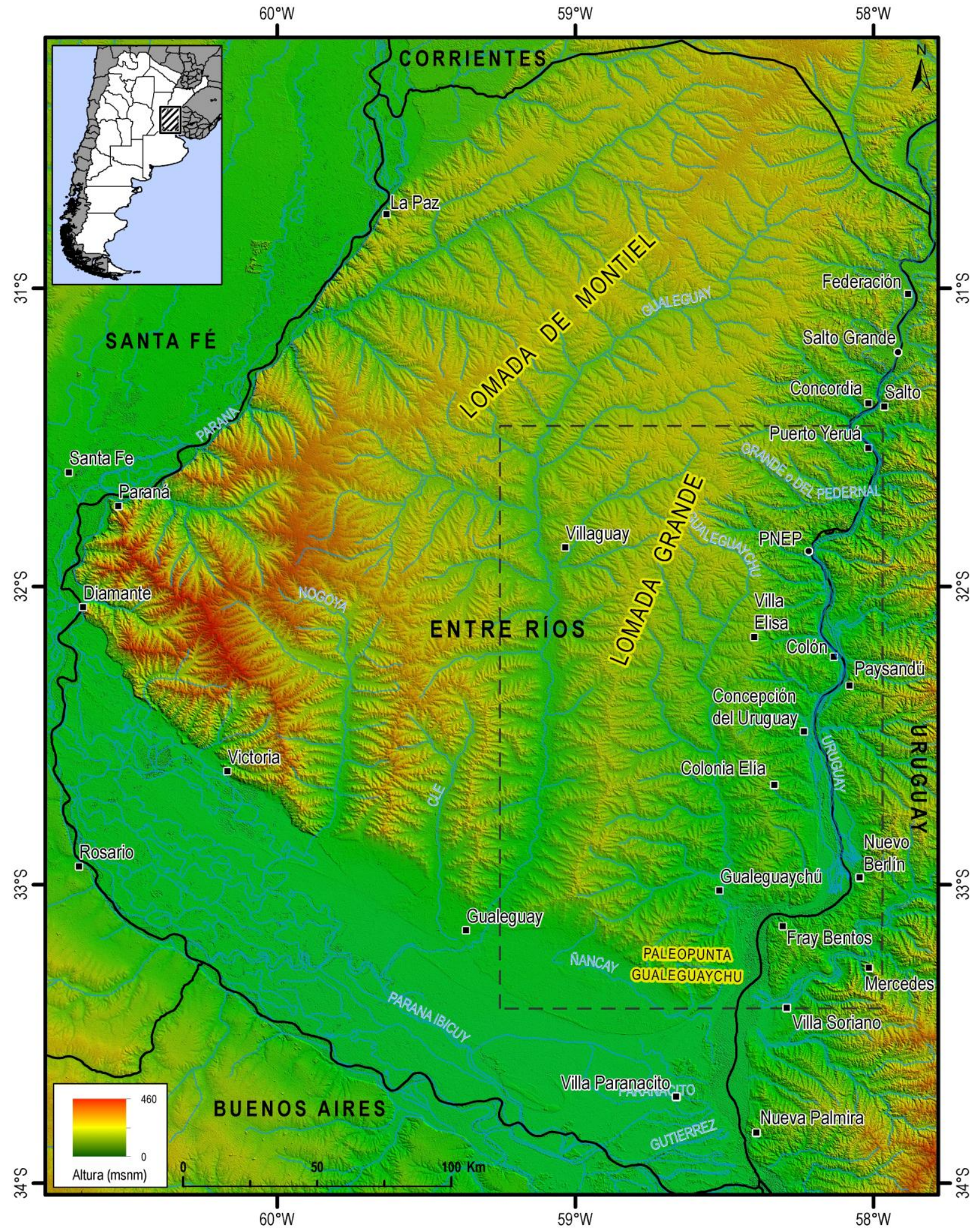

Figura 3.5. Modelo digital de elevación de Entre Ríos. Dentro del recuadro se encuentran las tres grandes zonas geomorfológicas presentes en el área de estudio. 
La mayor parte del área de estudio se corresponde con las denominadas Tierras altas de Entre Ríos (Iriondo 1991); equivalente a Llanura alta definida por Frenguelli (1950) para la provincia de Buenos Aires y extendida para el sur de Entre Ríos por Cavallotto y colaboradores (2005). Por otra parte, el área de estudio abarca unidades que no pertenecen a la Llanura alta como son: la mitad sur de la Faja arenosa del Uruguay (Iriondo 1991) y una porción de la unidad que Cavallotto y colaboradores (2005) denominan Llanura costera entrerriana, y que junto a la unidad Delta del Paraná integran el ambiente morfológico correspondiente al Holoceno. A continuación se describen brevemente cada una de las unidades mencionadas:

\section{Llanura alta}

Cavallotto y colaboradores (2005) la caracterizan como un ambiente Pre-holocénico que no fue afectado por la trasgresión marina del Holoceno medio. Se trata de un territorio que durante el Holoceno recibió escasa sedimentación, debido a que su posición topográfica relativamente alta la aisló de los grandes sistemas sedimentarios de la región. La sedimentación está restringida a fajas aluviales locales y a una delgada carpeta de limo eólico. El relieve es ondulado con colinas bajas y amplias (lomadas), se encuentra recortado por valles originados por ciclos morfogénicos con una mayor actividad fluvial que la actual. Estos valles se orientan de norte a sur y actualmente están ocupados por los arroyos Nogoyá y Clé y los ríos Gualeguay y Gualeguaychú (Cavallotto et al. 2005).

Los márgenes de la Llanura alta se presentan en forma de barrancas o pendientes. El margen que se extiende sobre el Complejo Deltaico se caracteriza por suaves entrantes y salientes. Uno de estos salientes lo constituye la Paleopunta Gualeguaychú, que durante la evolución del área estuvo enfrentada a la dirección dominante de las olas del Río de la Plata y se comportó como un punto de concentración de energía a partir de donde se comenzaron a desarrollar sistemas progradantes de cordones de playa que forman parte de la denominada Llanura costera entrerriana (Cavallotto et al. 2005).

La Llanura alta incluye varias unidades geomorfológicas menores, de las cuales las que están presentes dentro del área de estudio de esta tesis son: Colinas de Gualeguaychú y la porción sudeste de la Superficie Feliciano-Federal (Iriondo 1991; Iriondo y Altamirano 1988).

Colinas de Gualeguaychú: esta unidad presenta colinas bajas y amplias, valles anchos y suelos vertisólicos. Por lo menos en parte, dichas geoformas se desarrollan en la Formación Fray Bentos de edad oligocénica.

Superficie Feliciano-Federal: Es un área plana, muy suavemente ondulada. Deficientemente disectada debido a la existencia de interfluvios muy amplios, destacándose en primer lugar la llamada Lomada de Montiel (o Cuchilla de Montiel), donde existe baja energía morfogenética. Los cursos de agua principales no tienen barrancas y los afluentes menores están muy poco definidos. En los valles se observa una superficie antigua, a veces formando la terraza superior. 
El mayor sistema fluvial de las tierras altas entrerrianas lo constituye el río Gualeguay, que drena una larga depresión ubicada entre las lomadas "Cuchilla de Montiel” y "Cuchilla Grande”, y se extiende desde el departamento Feliciano por el norte, hasta el Delta del Paraná por el sur. Presenta una longitud de $300 \mathrm{~km}$ y una cuenca de cerca de $20.000 \mathrm{~km}^{2}$, se lo considera como afluente del río Paraná, aunque sus desbordes se vuelcan en la cuenca del Uruguay (Iriondo 1991). Las mencionadas "Cuchillas" constituyen las principales divisorias de aguas a ambos lados de este curso fluvial, y además la "Cuchilla Grande" constituye a su vez una divisoria entre los ríos Gualeguay y Gualeguaychú y establece, a una escala más amplia, una divisoria entre las aguas que confluyen al río Uruguay y las que se dirigen al río Paraná (Gentili y Rimoldi 1979).
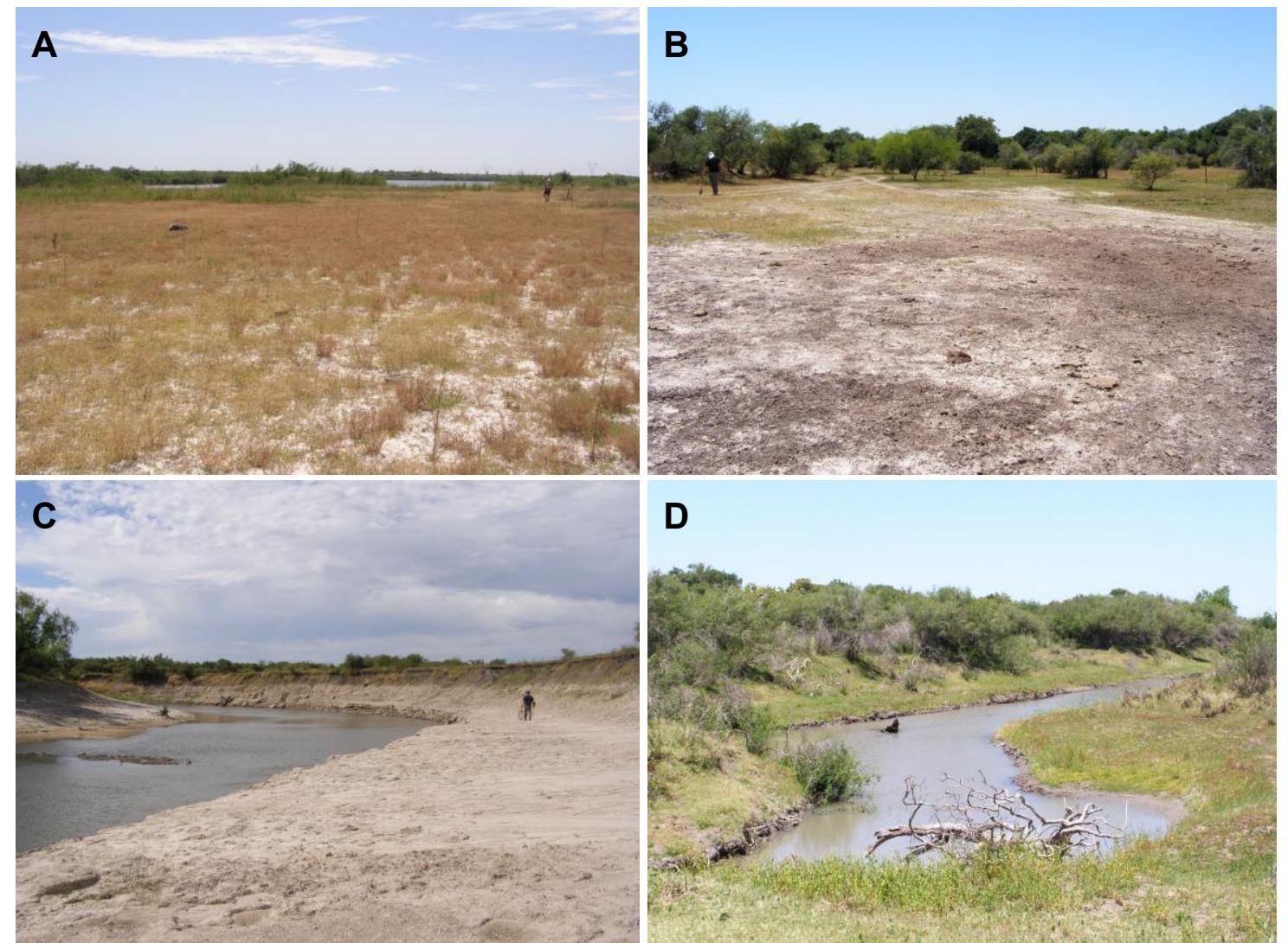

D

Figura 3.6. Llanura alta entrerriana, departamento Villaguay. A: Laguna Blanca. B: Ilanura con vegetación xerófila. C: río Gualeguay con bajo nivel de agua. D: arroyo El Tigre bordeado por vegetación xerófila.

\section{Faja arenosa del río Uruguay}

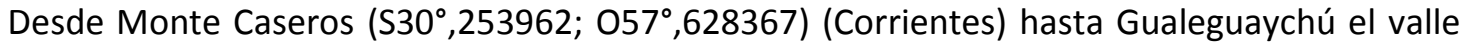
aluvial actual del río Uruguay está parcialmente excavado en dos Formaciones (San Salvador y El Palmar) depositadas por el mismo río (Iriondo 1991). A lo largo del cauce del río Uruguay que corre por la provincia de Entre Ríos se manifiestan las tres terrazas mencionadas anteriormente (véase Sección 3.1.1 Estratigrafía regional) pero cada una de ellas está presente o aflora en distintos tramos del río. En el norte se manifiestan claramente las terrazas pero hacia el sur, debido a la inclinación de 
las placas tectónicas, las mismas van dando lugar a una amplia llanura aluvial que se manifiesta a ambas márgenes del cauce y cuyas aguas terminan por unirse al río Paraná en la zona del delta, desembocando posteriormente en el Río de la Plata. Como ya se describió, estas terrazas presentan distinta antigüedad abarcando desde el Pleistoceno superior hasta la actualidad.

En su cuenca inferior el río Uruguay presenta una serie de depósitos cuyos orígenes están estrechamente vinculados a la ingresión holocénica. Estos comparten características con los depósitos de la Llanura costera entrerriana (Cavallotto et al. 2005) del Complejo Deltáico, que tienen un origen similar. En el río Uruguay la unidad más desarrollada es la llanura de mareas que conformó el Delta del río Uruguay. Este delta está compuesto por dos unidades geomorfológicas principales: a) en el sector superior hay una llanura de bancos actuales, que crece por adosamiento de nuevas acumulaciones de arena aguas arriba de las islas preexistentes; b) una extensa llanura de mareas que comienza $5 \mathrm{~km}$ al norte de Concepción del Uruguay y que se hace visible en las islas, y en ambas márgenes del sistema forma amplias terrazas de $5 \mathrm{~km}$ de extensión. En el frente de estas terrazas y los bordes de las islas se desarrolla un albardón actual (Iriondo y Kröhling 2009). Desde la desembocadura del río Gualeguaychú hasta el arroyo El Bellaco se encuentran playas de regresión bien desarrolladas.

Los sedimentos constitutivos de la Terraza III (arenas eólicas) han conformado dentro del área de estudio y asociados a la faja fluvial del río Uruguay un manto arenoso discontinuo. Este depósito tiene un espesor que generalmente no supera unos pocos decímetros, aunque en algunas zonas asociadas a valles fluviales pueden conformar campos de dunas de hasta $3 \mathrm{~m}$ de potencia. En estos lugares el manto adopta una morfología suavemente ondulada, en el resto de su extensión se adapta a las formas preexistentes del terreno. Varios campos de dunas parabólicas de dirección sureste-noroeste se presentan en la margen derecha del río Uruguay, por ejemplo al sur del Parque Nacional El Palmar, al norte de Colón entre los arroyos Caraballo, Pos Pos y Espino, en la desembocadura del arroyo San Lorenzo (Concepción del Uruguay), al norte de Puerto Unzué (Gualeguaychú) donde las dunas están separadas del río por una faja anegable, y en la zona de Ñandubaysal en la desembocadura del río Gualeguaychú (Gualeguaychú) (Iriondo y Kröhling 2009).

El aluvión actual del río Uruguay se caracteriza por transportar sedimentos gruesos (rodados y gravas) de composición silícea, junto con arena cuarzosa de grano mediano a grueso. Su dinámica de crecientes bastante rápidas provoca en la actualidad la formación de un amplio albardón arenoso a lo largo del cauce, y la aparición de pantanos detrás del mismo donde se desarrolla sobre todo una vegetación de pajonales, juncales y plantas propias de ambientes inundables. Este fenómeno se manifiesta sobre todo en las zonas de costas más bajas donde las terrazas no están bien desarrolladas, por ejemplo al sur del área de estudio y en las islas del río Uruguay (p. ej. islas Rica y Juanicó). Estas islas presentan un patrón geomorfológico similar, con un albardón de más de $50 \mathrm{~m}$ de ancho y más de $2 \mathrm{~m}$ de alto sobre el nivel medio de la aguas, encerrando terrenos bajos y bañados 
con vegetación enmarañada hacia el interior de las islas (Iriondo y Kröhling 2009). Dicho albardón cubre un depósito de 2 a $3 \mathrm{~m}$ de espesor, compuesto por arcilla arenosa con alto porcentaje de coloides, de color marrón grisáceo y gris claro. Esto se correlaciona también con la inclinación que presenta el terreno a lo largo del curso del río en su perfil longitudinal de norte a sur. En Bernardo de Irigoyen $\left(\mathrm{S}^{\circ} 6^{\circ}, 25500 ; \mathrm{O53}^{\circ}, 64349\right)$ (Misiones), límite con Brasil, se encuentra la mayor altura de la región con unos 800 msnm, en el límite entre Corrientes y Entre Ríos la altura es de 30 msnm. Mientras que el punto más bajo, 4 msnm, se ubica en la confluencia de los ríos Paraná y Uruguay (Aceñolaza 2007). Los depósitos que en el norte de Entre Ríos y sudeste de Corrientes se encuentran en superficie (areniscas mesozoicas y basaltos) en el sur de Entre Ríos se ubican por debajo de los sedimentos terciarios y cuaternarios (Frenguelli 1939: 354).
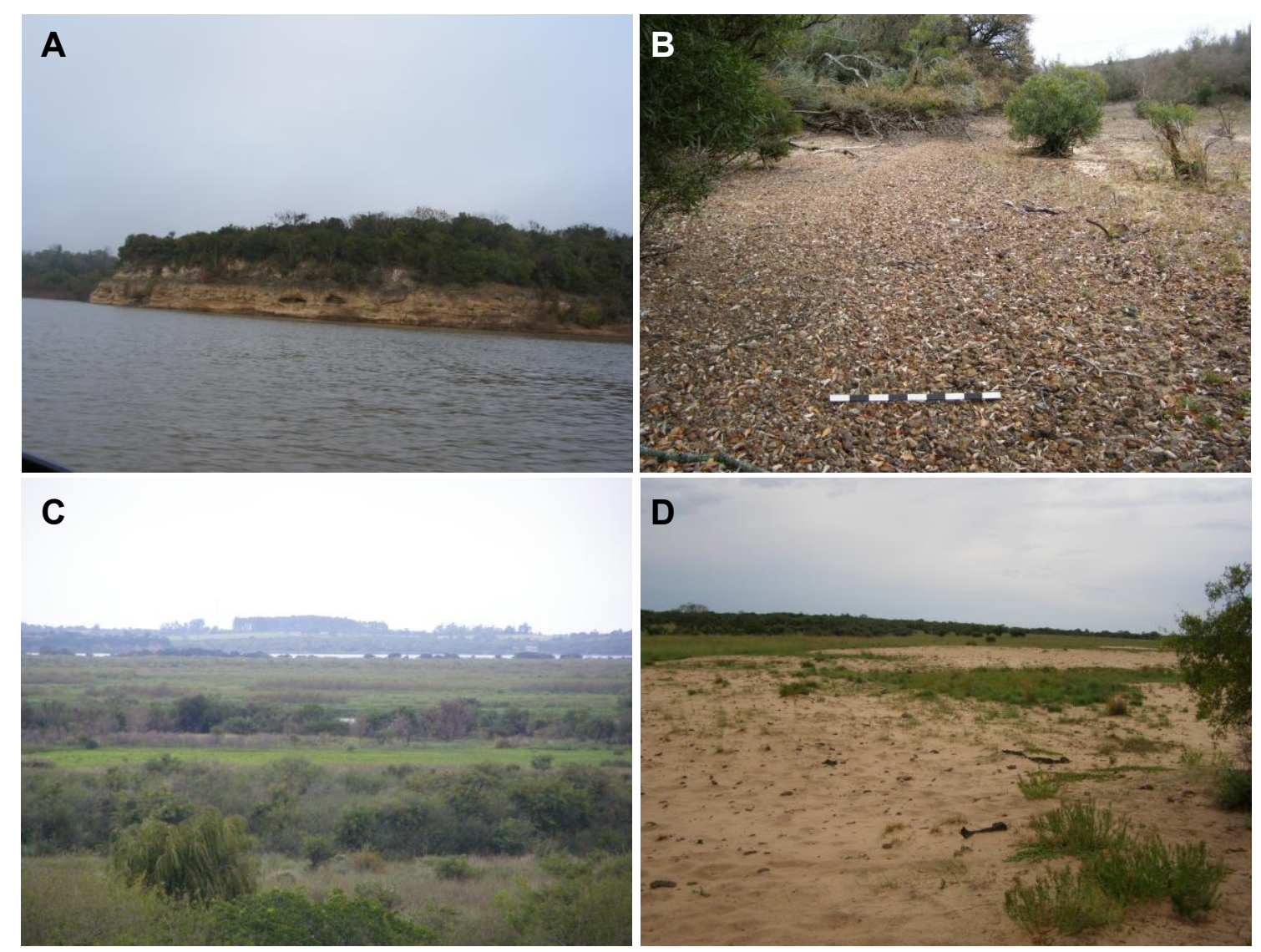

Figura 3.7. Zona costera del río Uruguay. A: terraza alta del Parque Nacional El Palmar (PNEP).

B: depósito de rodados silíceos (PNEP) (la escala tiene $90 \mathrm{~cm}$ ). C: río Uruguay, vista hacia el sur desde la barranca Marina (Gualeguaychú). D: campo de dunas de la zona de Ñandubaysal en la desembocadura del río Gualeguaychú.

\section{Llanura costera entrerriana}

Como se mencionó anteriormente, otra de las unidades geomorfológicas que está presente dentro del área de estudio, pero que no forma parte de la Llanura alta, ni de la Faja arenosa del río 
Uruguay, es la Llanura costera entrerriana (Cavallotto et al. 2005). La misma está estrechamente vinculada a la evolución del Complejo Deltáico.

Para la región sur de Entre Ríos, Cavallotto y colaboradores (2005) modifican parcialmente el esquema propuesto por Iriondo (1980b, 2004) y reconocen dos grandes ambientes morfológicos: Pre-holoceno y Holoceno. El Holoceno comprende dos sistemas depositacionales originados durante el momento de mar alto: Llanura costera entrerriana y Delta del Paraná. La primera está integrada por una sucesión de geoformas desarrolladas en un ambiente estuárico de aguas salobres durante la regresión marina. También se reconocen a estos depósitos con el nombre de Formación Isla Talavera (Gentili y Rimoldi 1979). La segunda unidad se desarrolló en un neto ambiente fluvial y debido a los aportes sedimentarios del río Paraná.

El sistema sedimentario de Llanura costera entrerriana se divide en facies, de las cuales las que se desarrollan dentro del área de estudio de este trabajo son las siguientes:

Facies de llanuras de mareas: se corresponde con las unidades laguna litoral o albufera y parte de la planicie de avenamiento impedido definidas por Iriondo (1980b). Se desarrolla entre la llanura de cordones y la costa. Abarca el área deprimida del interior de la Llanura costera y se caracteriza por la presencia de pantanos, bañados, cauces cortos y meandros, además de un gran número de lagunas permanentes y semipermanentes de tamaño variable. Los cauces son activos solo durante el comienzo y el final de las inundaciones. El avenamiento de las aguas es impedido por la escasa pendiente y las geoformas relativamente altas (p. ej. albardones) (Iriondo y Altamirano 1988). Su origen se vincula con un ambiente de mareas producto del abrigo de los cordones litorales durante el descenso marino que siguió al máximo transgresivo.

Facies de llanuras con cordones de playas litorales y facies cordones de médanos: se corresponde con la unidad cordón litoral de Iriondo y Altamirano (1988). La primera unidad se extiende por toda la parte central de la Llanura costera, desde la Paleopunta Gualeguaychú hasta la localidad de Victoria, entre la llanura de mareas y la llanura de playas. Presenta forma de arco que se bifurca al sur de la localidad de Gualeguay. Está representada por depósitos arenosos de bermas cuyas dataciones radiocarbónicas abarcan entre 6550 y 5180 años AP. Las cadenas de médanos se ubican por encima de la facie anterior con edades OSL de 1610-2980 años AP. La dinámica eólica continúa en la actualidad, y debido a la acción de los vientos del sur, los médanos avanzan hacia el centro de la albufera.

Facies de llanuras de playas: son las denominadas playas de regresión y cheniers por Iriondo y Altamirano (1988). Esta geoforma se desarrolla entre las facies de cordones y el río Paraná, y se compone de una sucesión de playas paralelas separadas, aunque en algunos casos adosadas unas a otras. A partir de su orientación se diferencian dos sistemas separados por llanuras de fangos en las que se desarrollan bañados. El primero se ubica entre los cordones de las facies anteriores por el norte y los ríos Paraná Ibicuy y Paranacito por el sur. El otro sistema se ubica al este del anterior y al 
sur del río Paranacito, donde los cordones están más separados y tienen menos extensión que en el sistema anterior. Su génesis se asocia con momentos de mayor disponibilidad de sedimentos fluviales y presenta edades radiocarbónicas de 2565-1730 años AP.

En la actualidad todo este complejo litoral que se desarrolla en el área interna del Río de la Plata presenta una activa dinámica, ya que periódicamente es anegado por el Paraná. Aun así, uno de los factores de inundación más importantes es el viento del sudeste (sudestada) que afecta sobre todo al delta, la llanura de playas y parte de la llanura de mareas o albufera de Iriondo (2004). Otro efecto importante de los vientos del S y SO es la deflación del cordón litoral, formando dunas que migran hacia el norte sobre la llanura de mareas. Varios campos de dunas son producto de este proceso eólico, que muy probablemente esté intensificado por causas antrópicas modernas.
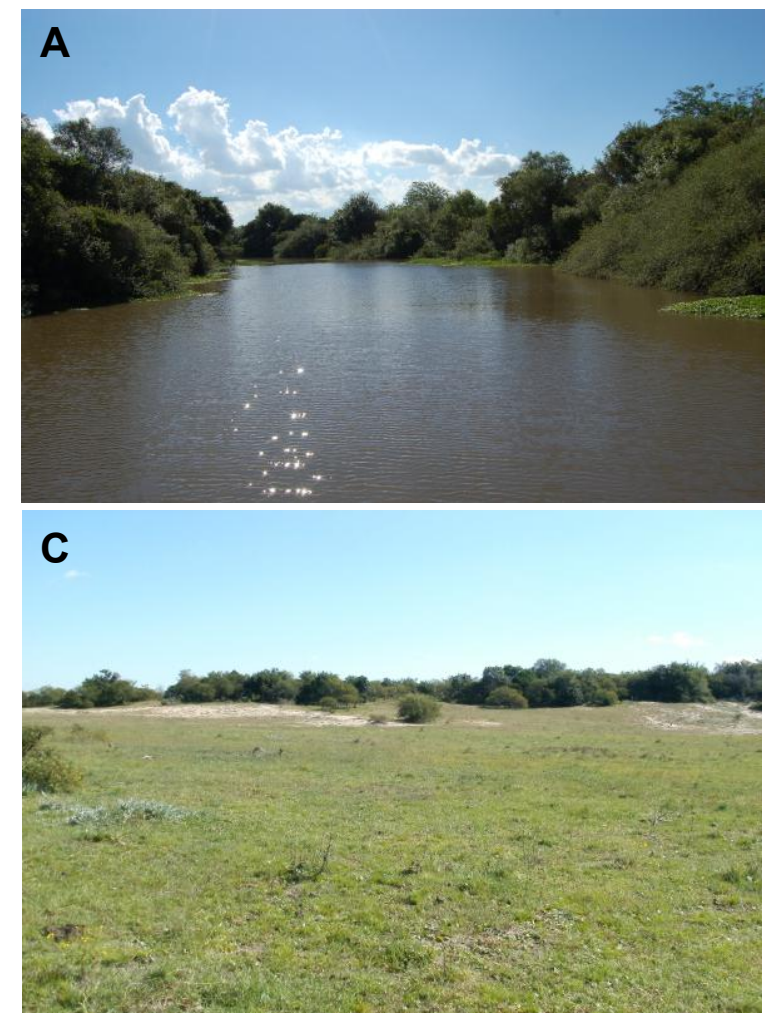

Figura 3.8. Zona de Llanura costera entrerriana al sur de la desembocadura del río Gualeguaychú. A: Arroyo El Bellaco bordeado por selva en galería. B: Llanura de playas, vista desde la barranca marina hacia el río Uruguay. $\mathbf{C}$ y $\mathbf{D}$ : Llanuras de playas.

\section{2- SISTEMA FLUVIAL}

La configuración actual de la Mesopotamia ha sido determinada por los ríos Paraná y Uruguay, estos se caracterizan por ser los principales colectores fluviales de la cuenca del Plata (Aceñolaza 2007). En cuanto al sistema fluvial de la provincia de Entre Ríos, y particularmente el del área de interés de esta tesis, el mismo se caracteriza por estar básicamente controlado por el 
régimen del río Uruguay. Aun así cabe destacar al río Gualeguay como el principal regulador del sistema fluvial de las llanuras centrales.

El río Uruguay tiene sus nacientes en la confluencia de los ríos Canoas y Pelotas en el límite entre Santa Catarina y Río Grande do Sul (Brasil), y tiene una longitud total de $1.600 \mathrm{~km}$ y una cuenca de aproximadamente $365.000 \mathrm{~km}^{2}$. Debido a que su cuenca tiene bajo poder de retención de agua, las oscilaciones de caudales son más pronunciadas que lo que cabría esperar de una cuenca de clima húmedo como esta. El río presenta un régimen fluvial puro desde las nacientes hasta el arroyo Ayuí Grande, un régimen fluvio-marítimo hasta el río Gualeguaychú y uno marítimo desde allí hasta su desembocadura en el Río de la Plata (Iriondo y Kröhling 2009). Recientemente, en base a características geológicas y geomorfológicas, Iriondo y Kröhling (2009: 22) subdividieron la cuenca en tres partes. Una cuenca superior que va desde de las nacientes hasta el río Aguapey (Corrientes), la porción media va desde allí hasta el arroyo del Molino (Concepción del Uruguay) y la porción inferior de la cuenca estaría formada por el tramo restante hasta su desembocadura.

El río Uruguay presenta una salinidad baja que aumenta gradualmente hacia su desembocadura. En la cuenca media está en el orden de los $50 \mathrm{mg} / \mathrm{l}$ (Quirós y Cuch 1981). El Ph se ubica entre 6,5 y 8 , y los niveles de oxígeno disueltos tienden a ser altos, en la cuenca media se han medido valores entre $86 \%$ y $108 \%$. Las aguas turbulentas de la cuenca superior pueden alcanzar niveles de supersaturación (Di Persia y Neiff 1986). A lo largo de todo su curso recibe el aporte de tributarios menores (ríos y arroyos). En el área de estudio se pueden mencionar algunos, como por ejemplo los arroyos Grande o del Pedernal, Caraballo, Urquiza (Colón); Ubajay, El Palmar, Espino (PNEP); del Molino, Osuna, San Lorenzo (Concepción del Uruguay); Bellaco, Malo, Ñancay (Gualeguaychú), entre otros, además del río Gualeguaychú.

\section{Cuenca media}

En este tramo el cauce del río Uruguay presenta un diseño de meandros flanqueados por las terrazas. Desde el embalse de Salto Grande y hasta el arroyo El Palmar el valle del río corre encajonado en rocas cretácicas. Este tramo se divide en dos grandes meandros unidos por un tramo recto de $29 \mathrm{~km}$ de extensión. El primero de estos va hasta el arroyo Yeruá (Concordia) y tiene un ancho regular de 600 a 800 m, sin islas. En el tramo recto el río aumenta su ancho a valores de 1,5 a $1,8 \mathrm{~km}$ y presenta bancos de arena e islas alargadas y estrechas, estas últimas recostadas sobre la margen izquierda. El lecho se encuentra parcialmente cubierto por bloques finos y cantos rodados distribuidos en forma homogénea. El segundo gran meandro comienza $10 \mathrm{~km}$ al norte del arroyo Ubajay y se extiende hasta el arroyo Espino, tiene $10 \mathrm{~km}$ de amplitud y ancho variable entre 1 y 1,7 $\mathrm{km}$. En este tramo hay varios bancos de arena estables que le otorgan al río características transicionales hacia la cuenca inferior. Algunos arroyos de esta zona como el Yeruá y Grande o del 
Pedernal presentan su desembocadura parcialmente bloqueadas por barras laterales del río Uruguay (Iriondo y Kröhling 2009).

\section{Cuenca inferior}

Abarca $170 \mathrm{~km}$ de longitud y finaliza en un estrechamiento producido por el avance actual del Delta del Paraná a la altura del Brazo Gutiérrez o Paraná Bravo, en este punto comienza el Río de la Plata. Este tramo del río presenta dos características particulares: una es que estuvo sometida a la influencia directa del mar durante las ingresiones marinas, y la otra es que la abundancia de arena y sedimentos finos ha dado origen a numerosos bancos arenosos e islas. Los dos afluentes más importantes que recibe son el río Gualeguaychú (margen argentina) y el río Negro (margen uruguaya).

A la altura de Concepción del Uruguay el valle se abre en forma suave pasando de $1 \mathrm{~km}$ de ancho al norte de la ciudad, a $6 \mathrm{~km}$ a la altura de Colonia Elía (S32 $\left.{ }^{\circ}, 66667 ; 058^{\circ}, 31667\right)$ (Entre Ríos) y a $14 \mathrm{Km}$ al norte de Nuevo Berlín $\left(\mathrm{S} 32^{\circ}, 979313 ; 058^{\circ}, 052712\right)$ (ROU). El cauce se divide en dos brazos principales y otros secundarios que envuelven un conjunto de islas remanentes del antiguo delta del río, cuyo origen se remonta al retiro de la ingresión holocénica (véase más adelante). Este paleodelta de $65 \mathrm{~km}$ de longitud llega hasta una gran curva del río que se encuentra ubicada frente a Gualeguaychú-Fray Bentos, allí el río corre de este a oeste por un tramo de 20 km hasta retomar su dirección norte-sur.

El tramo final del río Uruguay desde Gualeguaychú hasta Nueva Palmira (S33º,879661; $\left.058^{\circ}, 39847\right)(\mathrm{ROU})$, tiene $85 \mathrm{~km}$ de longitud por 5 a $12 \mathrm{~km}$ de ancho y no presenta islas. Es una amplia depresión inundada y por su parte interior corre un cañón sumergido. El resto del cauce es un área anegada de escasa profundidad, que en su margen derecha presenta barreales con cheniers y en la izquierda las barrancas altas de Fray Bentos. La margen argentina está sometida a la erosión fluvial provocada por los vientos del noreste y también por la dinámica de las sudestadas y de las mareas del Río de la Plata. En su desembocadura el río Uruguay recibe actualmente los aportes de un sector del Complejo Deltáico, este sector que vuelca sus aguas en el río Uruguay es considerado como parte integrante de su cuenca (Iriondo y Kröhling 2009: 20 -figura 6 -; 294).

\section{Río Gualeguaychú}

Tiene una trayectoria norte-sur y es receptor de las aguas de la "Cuchilla Grande" mediante los arroyos Gualeyán y Géna (Aceñolaza 2007). Este río nace en la localidad de Arroyo Barú $\left(\mathrm{S} 31^{\circ}, 997825 ; 058^{\circ}, 296241\right)$. Corre hacia el sur en un arco hasta los $32^{\circ}$ de latitud sur y su cauce está labrado sobre la Formación Hernandarias. Unos $10 \mathrm{~km}$ al sur de Villa Elisa (S32,163635; $\left.058^{\circ}, 400569\right)$ el río entra en un paleocauce bien definido de $2 \mathrm{~km}$ de ancho, con curvas suaves de 5 
$\mathrm{km}$ de radio de curvatura. Forma una terraza fluvial pantanosa, con laderas definidas de unos $200 \mathrm{~m}$ de ancho. Tiene una carga de sedimento en suspensión mediana a baja y transporta arena fina bien seleccionada. En su tramo medio el río recibe afluentes pequeños de 2 a $6 \mathrm{~km}$ de longitud que terminan en ensanchamientos tipo cárcavas en los últimos cientos de metros. A la latitud de Concepción del Uruguay el valle de ensancha a 3 ó $4 \mathrm{~km}$ hasta la zona de la desembocadura, donde atraviesa las playas de regresión del complejo litoral. En los últimos $25 \mathrm{~km}$ en ancho del cauce aumenta hasta $200 \mathrm{~m}$ y se desarrolla un albardón actual (Iriondo y Kröhling 2009).

\section{3- CONDICIONES CLIMÁTICAS}

\subsection{1- EVOLUCIÓN CLIMÁTICA DESDE EL PLEISTOCENO AL HOLOCENO RECIENTE}

\section{Pleistoceno final y Holoceno inferior}

Según Iriondo (1991) e Iriondo y Kröhling (1995) entre ca. 14.000 y 8500 años AP se estableció un clima seco y frío en la región pampeana, caracterizado por una erosión hídrica generalizada. Las líneas climáticas de la Patagonia se movieron unos $8^{\circ}$ de latitud hacia el norte, o sea $900 \mathrm{~km}$. Siguiendo la analogía del clima actual del norte de la Patagonia, los vientos típicos estarían en el orden de los 30 a 35 nudos. El movimiento de arena en el sector estudiado (noreste del Mar de Arena Pampeano -MAP-) fue modesto; el trabajo más importante del viento fue la excavación de depresiones elípticas de alrededor de $1 \mathrm{~km}$ de largo. El clima no fue completamente árido, más bien semiárido. Se supone que hubo poca vegetación y anegamiento esporádico de las depresiones, debido a la formación de lunetas. En las partes periféricas hacia el norte el viento realizó un considerable transporte de finos en suspensión, con acumulación de hasta $3 \mathrm{~m}$ de espesor de loess. En el área de estudio se dio una gran actividad fluvial, con formación generalizada de albardones y otras formas de cauce.

\section{Holoceno inferior}

En un segundo momento del Holoceno inferior entre $c a .8500$ y 5200 años AP se produce el Hypsitermal u Óptimo Climático (Del Puerto et al. 2011). Así se denomina a un calentamiento general del clima ocurrido a nivel mundial pero con variaciones regionales. En la cuenca inferior del río Uruguay se produce la ingresión del mar, que habría alcanzado regionalmente su máximo entre ca. 7000 y 5000 años AP. Durante este lapso aumenta la humedad y temperatura, y se establecen 
condiciones templadas a cálidas alcanzando sus niveles máximos en torno al año 5500 AP, coincidiendo con el máximo transgresivo del Holoceno (Del Puerto et al. 2011).

\section{Holoceno medio}

Abarca entre ca. 5200 a 3000 años AP, desde el comienzo tuvo lugar la regresión marina acompañada de la disminución de la temperatura y la humedad, lo que lleva a la instauración de condiciones templadas a frías y subhúmedas-secas, o con una marcada estacionalidad en las precipitaciones (Del Puerto et al. 2011).

\section{Holoceno superior}

En torno a los 2500 años AP, comienza a registrarse un cambio hacia las condiciones actuales. Aun así durante este proceso se registran dos pulsos climáticos particulares. Entre $c a .1400$ y 800 años AP hay evidencia de condiciones más cálidas y húmedas que las actuales. Este episodio se denomina Edad o Período Cálido Medieval. Finalizando este primer pulso, se sucede una momento más seco y frío, donde los índices de temperatura y humedad evidencian condiciones climáticas templadas y más secas o estacionales. Este período corresponde a la llamada Pequeña Edad de Hielo (ca. 800-200 años AP) (Iriondo 1991; Iriondo y Kröhling 1995; Del Puerto et al. 2011). 
Tabla 3.1. Modelo de evolución paleoclimática y paleoambiental para el Holoceno en la cuenca inferior del río Uruguay (Tomado de Capdepont 2012, basado en Del Puerto 2009).

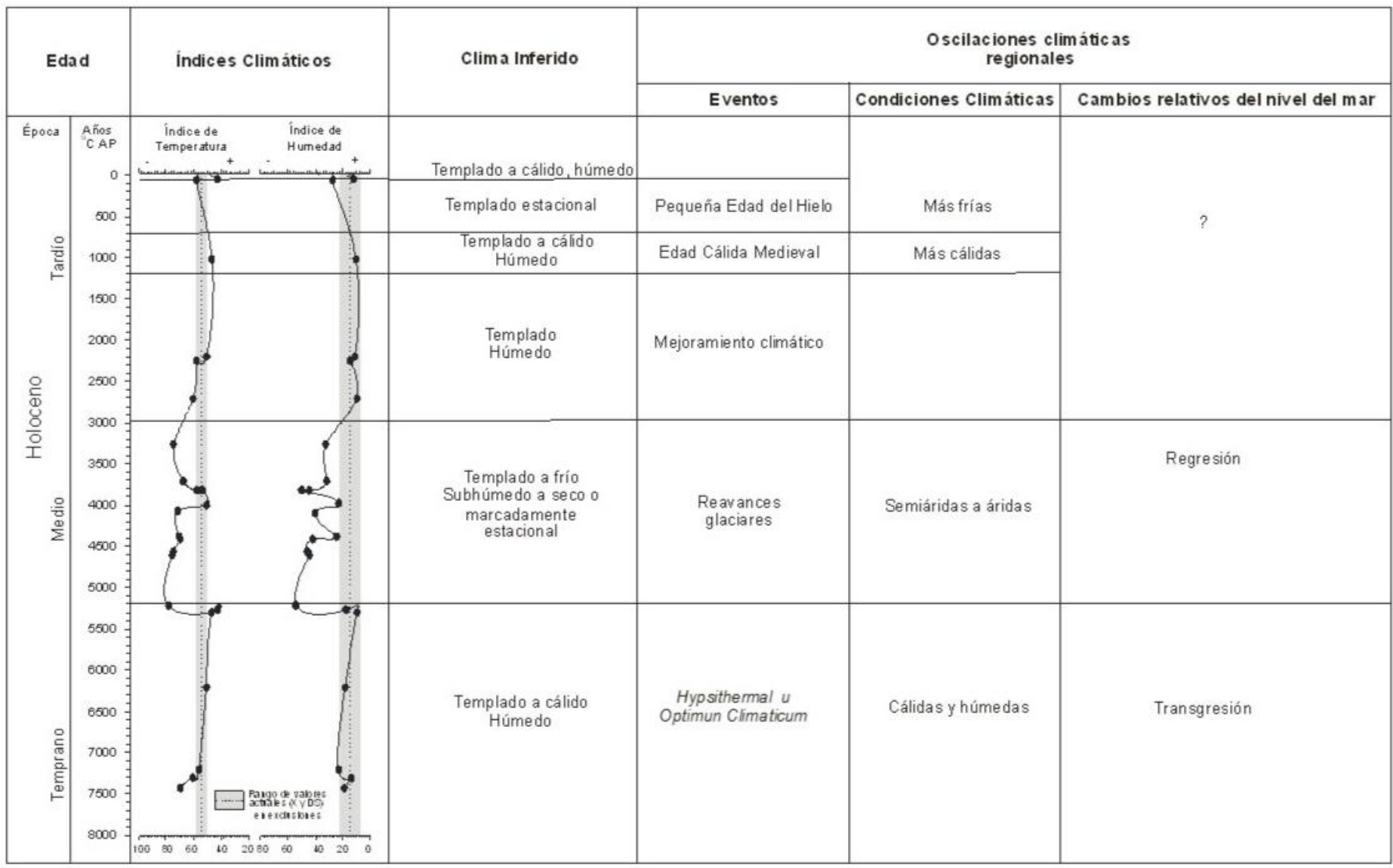

\section{Implicancias de las ingresiones marinas}

El litoral argentino y su inmediato uruguayo fueron afectados por tres eventos de aumento del nivel del mar, los cuales originaron distintos depósitos que contribuyeron con su geomorfología actual. Estos eventos corresponden al Mioceno tardío, Pleistoceno superior y Holoceno medio. Los dos momentos del Cuaternario, durante los cuales en el sudeste de la provincia de Entre Ríos se desarrollaron dos grandes estuarios, fueron el reflejo del incremento relativo del nivel del mar y por consiguiente del estuario del Río de la Plata (Guida y González 1984). El más antiguo de estos paleoestuarios se desarrolló durante el final del Pleistoceno superior entre 38.500 y 26.600 años AP (Martínez y Del Río 2005) y está correlacionado con el último interestadial ocurrido durante la glaciación Wisconsin (=Wurm). El otro se desarrolló entre 7000 y 5000 años AP (Del Puerto et al. 2011), aunque Martínez y Del Río (2005) extienden su influencia hasta el año 3300 AP.

El retiro del mar holocénico provocó la depositación playas marinas (Llanura costera entrerriana) y esto determinó el primer estadío de la formación del paleodelta del río Uruguay. También son el reflejo de este proceso las barrancas marinas y los abundantes depósitos de 
conchillas observables en la margen derecha del río Uruguay, al sur de la desembocadura del río Gualeguaychú.

\subsection{2- CLIMA ACTUAL}

La provincia de Entre Ríos no presenta grandes variaciones climáticas, se caracteriza por una relativa estabilidad tanto durante el ciclo diario como anual. Asimismo, no se observan cambios bruscos durante las distintas estaciones del año. El clima es templado cálido, con lluvias todo el año, más intensas en primavera y otoño, escasas en invierno e insuficientes en verano. Las precipitaciones disminuyen de norte a sur y de este a oeste variando entre 1200 a $600 \mathrm{~mm}$ anuales.

La cuenca media rio Uruguay presenta un clima subtropical húmedo, las temperaturas anuales varían entre 20 y 21 을 La cuenca inferior se caracteriza por un clima subtropical pero presenta algunas características transicionales hacia un clima templado. Las temperaturas anuales rondan los 18 C (Iriondo y Kröhling 2009).

\section{4- FISIOGRAFÍA}

\subsection{1- FITOGEOGRAFÍA}

Fitogeográficamente el área de estudio se ubica en la Región Neotropical. Pertenece al Dominio Chaqueño, y dentro de éste su mayor parte corresponde a la Provincia Pampeana, aunque su porción más septentrional se ubica en una zona de transición hacia la Provincia del Espinal (Cabrera y Willink 1980). Considerando una unidad menor, el área se ubica dentro del Distrito Uruguayense que se desarrolla en la parte norte de la Provincia Pampeana y su comunidad clímax es la pradera de flechillas o "flechillar" donde predominan especies como Stipa neesiana, Stipa tenuísima, Stipa charruana, Poa lanigera, Eragrostis cilianensis, entre otras. Se destaca además la presencia de gramíneas subtropicales como Panaceas y Andropoogoneas de los géneros Paspalum, Axonopus, Digitaria, Schyzachyrium, Bothriochloa, Aristida, Melica, Briza, Paspalum, entre otros, asociadas a varias especies herbáceas y arbustivas de los géneros Heimia, Baccharis y Eupatorium.

Este distrito además presenta comunidades edáficas donde se registran especies procedentes de la Provincia Paranaense (Dominio Amazónico) como las selvas ribereñas (mixtas y marginales) que se extienden hacia el sur formando angostas galerías a lo largo del río Uruguay y penetrando además en todos los arroyos de Entre Ríos. En estas comunidades predominan laureles (Ocotea acutifolia, Nectandra falcifolia), mata-ojo (Pouteria salicifolia), chal-chal (Allophyllus edulis), blanquillo (Sebastiania brasiliensis), lecherón (Sapium haematospermun) y anacahuita (Blepharocalix 
tweediei). Abundan además comunidades sammófilas sobre dunas o suelos arenosos, con gramíneas como Elionurus muticus, Poa lanuginosa, Panicum racemosum y Senecio crassiflorus, y también comunidades hidrófilas como juncales de Scirpus californicus y pajonales de Spartina densiflora.

La Provincia del Espinal presenta bosques xerófilos caducifolios, palmares, sabanas graminosas, estepas graminosas y estepas arbustivas. En Entre Ríos esta Provincia está representada por el Distrito del Ñandubay donde son dominantes las especies arbóreas del género Prosopis. La comunidad climax es el bosque de ñandubay (Prosopis algarrobilla) y algarrobo negro (Prosopis nigra). Otros elementos característicos son el tala (Celtis spinosa), el algarrobo blanco (Prosopis alba), el coronillo (Scutia buxifolia), la sombra de toro (Jodina rhombofolia), el espinillo (Acacia caven), entre otros. También es característica la presencia de palmeras caranday (Trihrinax campstris). Se encuentran además los característicos palmares de Butia yatay, que constituyen en la actualidad representación más austral de este tipo de comunidad en Sudamérica (Zucol et al. 2005) y que antiguamente presentaban una distribución más amplia (Patterer 2012).

En Entre Ríos al Distrito del Ñandubay se lo denomina comúnmente "Selva de Montiel” y está caracterizado por bosques densos, cerrados, intrincados, uniformes e inaccesibles en algunas de sus partes, como se comprobó en nuestras prospecciones (Capítulo 5) y como fue destacado por numerosos autores de distintas especialidades (véase Báez 1942a, 1942b; Chebez y Haene 1993; Ibáñez 1962, 1963; Lorentz 1878; Pérez Colman 1936; Poenitz 1970b). Actualmente, en los relictos de este bosque, los únicos lugares transitables con escasa dificultad se encuentran en los márgenes de los arroyos mayores y del río Gualeguay, zonas conocidas localmente como "barreros" que están libres de vegetación densa debido a los desbordes del río Gualeguay (Sr. Marcelo Lugrin, MTM; comunicación personal 2016). Esta formación vegetal, actualmente diezmada y en vertiginoso retroceso por las modernas prácticas agrícolas, ganaderas y forestales, en el pasado abarcaba probablemente las dos terceras partes de Entre Ríos extendiéndose en su porción central y occidental desde el Delta del río Paraná hasta el norte de la provincia, y llegando también hasta el centro-sur de Corrientes (Báez 1937, 1942a; Cabrera y Willink 1980; Ibáñez 1962). La gran extensión de la Selva de Montiel fue destacada ya en los primeros mapas de la provincia de Entre Ríos (Figura 3.9). 


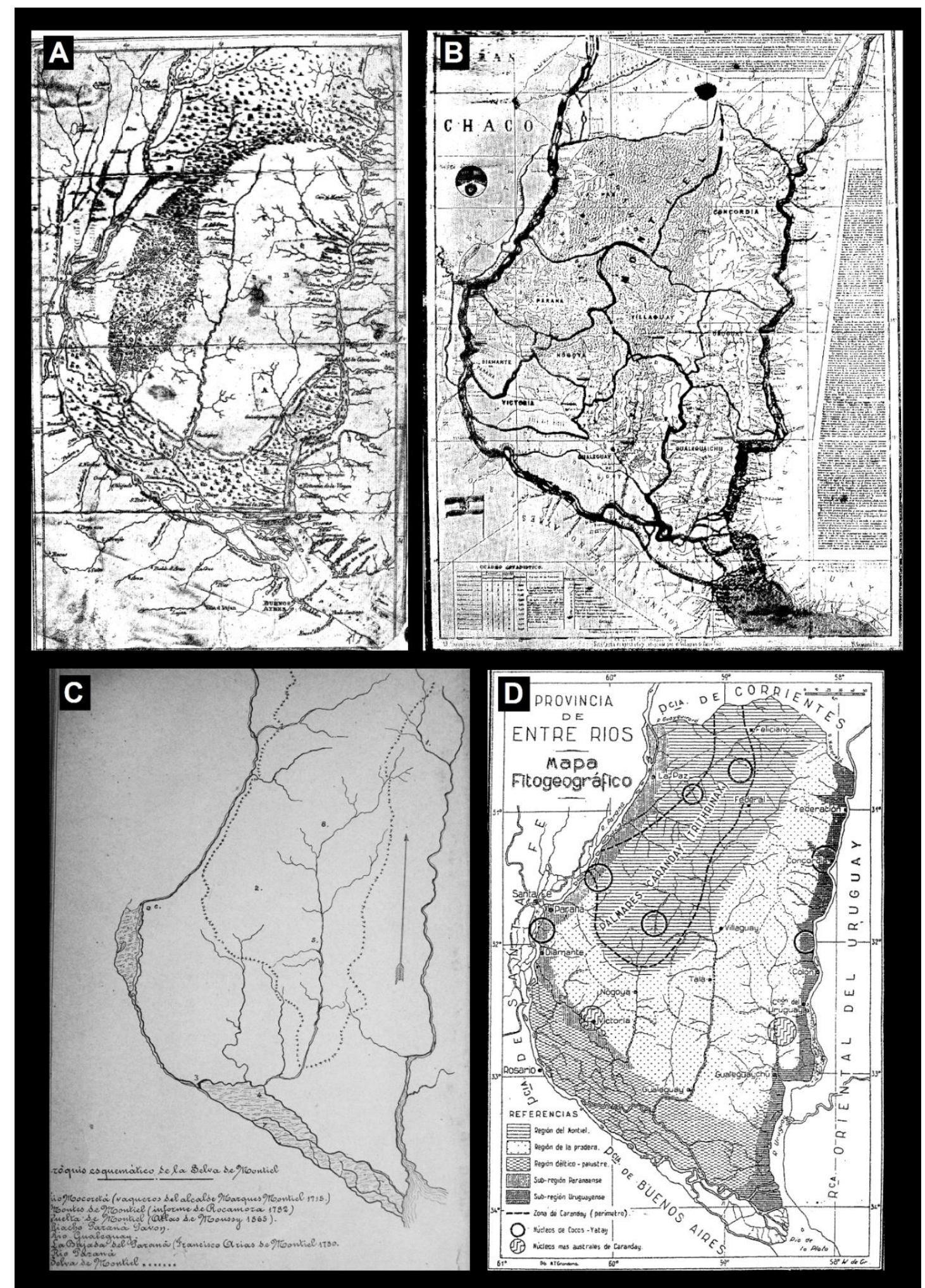

Figura 3.9. Mapas donde se representa la extensión territorial de la Selva de Montiel.

A: Mapa de 1825 donde está graficada como una densa concentración de vegetación. B: Mapa de 1865 donde está graficada con una densa agrupación de rayas y puntos irregulares. C: Mapa de 1903 donde está demarcada por una línea de cruces. D: Mapa de 1937 donde está graficada por una concentración de líneas horizontales.

En la Figura 3.9 se observan cuatro mapas, de 1825, 1862, 1903 y 1937. En todos se presenta con distinto grado de precisión la extensión de la Selva de Montiel. El primero (A) denominado 
"Mapa de Entre Ríos" fue confeccionado en Londres (Inglaterra), representa con bastante exactitud los accidentes naturales y la parte más densa de Selva de Montiel (Ibáñez 1963; Pérez Colman 1936). El segundo (B) denominado “Carta de Entre Ríos” confeccionado por el ingeniero Nicolás Grondona, es más preciso que el anterior y la Selva de Montiel figura con proporciones mayores y seguramente más exactas (Ibáñez 1963; Pérez Colman 1936). El tercero (C) denominado “Croquis esquemático de la Selva de Montiel" confeccionado por Martiniano Leguizamón (1903) donde la formación vegetal presenta proporciones semejantes a las del segundo mapa. Considerando el conocimiento que Leguizamón tenía de Entre Ríos la extensión real de la Selva de Montiel debe haber sido semejante la representación. El cuarto mapa (D) es el más reciente (Báez 1937) y muestra la extensión de la Selva de Montiel delimitada con precisión pero fuertemente diezmada por las actividades antrópicas modernas, que se han intensificado en las últimas décadas (Muñoz et al. 2005). Cabe destacar además que en el mapa de Entre Ríos elaborado por Tomás de Rocamora en 1782 dice "Montiel monte espeso" en el área central de la provincia y a ambos lados del río Gualeguay (Pérez Colman 1936). En relación a la antigua extensión de esta formación vegetal también cabe citar a Paul Lorentz, botánico que comenzó el estudio científico de la vegetación de la provincia de Entre Ríos, cuando menciona que "El interior de la provincia, hasta pocas leguas á ambas costas del Uruguay y del Paraná, está cubierto por el "Montiel"." (Lorentz 1878: 44) (el resaltado es nuestro).

\subsection{2- ZOOGEOGRAFÍA}

Zoogeográficamente el área de estudio se encuentra dentro de la región Neotrópica, subregión Guyano-Brasileña y dominio Subtropical (Ringuelet 1961). Dentro de este último a su vez pertenece al Distrito Mesopotámico. Este distrito comprende tres sectores: Septentrional, Entrerriano y Meridional. La composición faunística de los dos últimos es la que caracteriza el área de estudio de esta tesis.

El sector Meridional bordea los ríos Paraná y Uruguay, comprende el Delta y la franja rioplatense llegando hasta el partido de La Plata. El sector Entrerriano comprende la estepa herbácea de la provincia de Entre Ríos. Este último presenta una fauna terrestre con estrecha vinculación con la Pampásica, siendo la fauna acuática similar al resto del Distrito Mesopotámico.

Para la Mesopotamia y zonas aledañas se encuentran presentes mamíferos de los órdenes Artiodactyla, Rodentia, Carnívora, Cingulata, Pilosa, Primates y Perissodactyla (Mollerach y Ferro 2008). En cuanto a las especies de mamíferos presentes actualmente en la provincia de Entre Ríos, se registra: ciervo de los pantanos (Blastocerus dichotomus), venado de las pampas (Ozotocerus bezoarticus), corzuela parda (Mazama guazoupira), carpincho (Hydrochoerus hydrochaeris), coipo (Myocastor coypus), cuis común (Cavia aperea), zorro de monte (Cerdocyon thous), zorro gris pampeano (Dusicyon gymnocercus), gato montés (Oncifelis geoffroyi), aguará guazú (Chrysocyon 
brachyurus), comadreja colorada (Lutreolina crassicaudata), comadreja overa (Didelphis albiventris), lobito de río (Lontra longicaudis), hurón menor (Galictis cuja), aguara popé (Procyon cancrivorus), zorrino común (Conepatus chinga), coatí (Nasua nasua), mulita (Dasypus hybridus), mulita grande (Dasypus novemcinctus) y Euphractus sexcinctus (tatú peludo). Dentro de las especies que en la actualidad no están presentes ya que han desaparecido aproximadamente a mediados del siglo XX, producto de la caza y persecución, se puede mencionar el yaguareté (Panthera onca) y el puma (Puma concolor); este último es considerado extinto ya que no se han registrado ejemplares en los últimos años (Canevari y Vaccaro 2007; Chebez 1994).

Actualmente en Entre Ríos hay 73 especies y subespecies de reptiles, lo cual representa el 23,3\% del total registrado para Argentina, abarcando una especie de caimán, cuatro de tortugas, cuatro anfisbénidos, 14 de saurios y 50 de serpientes (Sánchez et al. 2008). Algunas de las especies de mayor tamaño son el lagarto overo (Tupinambis merinae) y la tortuga de laguna (Phrynops hilarii). Cabe mencionar además la presencia de numerosas especies de anuros (véase Sánchez et al. 2008) que probablemente fueron un recurso disponible en momentos prehispánicos.

Dentro de las aves, la de mayor proporción corporal es el ñandú (Rhea americana). Otras aves de tamaños considerables son el carrao (Aramus guarauna), la martineta colorada (Rhynchotus rufescens) y la perdiz común (Nothura maculosa). También se registran aves acuáticas como el macá común (Podiceps rolland), macá grande (Podiceps major), macá de pico grueso (Podilymbus podiceps), y varias especies de garzas, hocóes y mirasoles. Otras aves presentes en la región y no de menor importancia son por ejemplo las cigüeñas, flamencos, cisnes, chajás, caranchos, chimangos, halcones, gallinetas, gallaretas, gaviotas, gaviotines, águilas, aguiluchos, gavilanes, lechuzas, búhos, y una gran variedad de patos y de aves de menores dimensiones corporales. Se debe mencionar también la abundancia de aves de la Familia Psittacidae como los loros y cotorras dada su recurrente representación en la alfarería regional.

Es necesario destacar que el litoral fluvial argentino constituye un importante corredor migratorio de aves (Capllonch et al. 2008), entre las que se destacan el águila pescadora (Pandion haliaetus), el halcón peregrino (Falco peregrinus), y varios rayadores y gaviotines (Raffo et al. 2008). En su mayoría las aves del río Uruguay son de hábitos acuáticos y se alimentan de peces.

Según el esquema ictiogeográfico de la República Argentina (Arratia 1997; Ringuelet 1975; Ringuelet et al. 1967) que subdivide los peces continentales en dos subregiones: Brasílica y Austral, la Mesopotamia se localiza dentro de la primera. A su vez pertenece al Dominio Paranaense y forma parte de la Provincia Párano-Platense; la cual incluye la mayor variedad de ambientes lóticos y lénticos, así como la mayor diversidad específica del país (López 2001). La región mesopotámica constituye un sistema de alta complejidad y dinamismo en la que los ambientes lóticos y lénticos cumplen un rol preponderante en el ciclo reproductivo de los peces. Los ríos Paraguay, Paraná y Uruguay, junto con los ríos de origen andino como el Pilcomayo y el Bermejo, y los cursos menores, 
actúan como corredores faunísticos, facilitando la entrada de elementos tropicales y subtropicales. Sus ambientes con características geomorfológicas, hidrológicas y limnológicas propias, albergan una ictiofauna de enorme variedad y riqueza, tanto por el número de especies como por la diversidad de tipos ecológicos que la componen (López et al. 2005).

De los 198 géneros y 457 especies citadas para la Argentina, 161 géneros y 340 especies se encuentran en la Mesopotamia, con 35 especies endémicas de un total de 81 para el territorio argentino. La ictiofauna entrerriana tiene 40 familias, 10 órdenes, 118 géneros y 196 especies (58,2\% de las totales para la Mesopotamia) con 11 endémicas $(29,7 \%$ del total registrado para la Mesopotamia). Se observa una disminución de especies en sentido norte-sur si se compara el número de cada provincia, Misiones y Corrientes poseen 243 y 250 especies respectivamente, mientras que en Entre Ríos hay 196. A su vez el río Paraná tiene 247 especies y el río Uruguay 127, ambos con variaciones de acuerdo a sus distintos sectores (López et al. 2005).

En Entre Ríos la mayoría de los estudios han sido llevados a cabo en los ríos Paraná y Uruguay. Por su parte, los cursos de agua del interior han sido poco estudiados. En el río Uruguay, los peces predominantes pertenecen a los órdenes Characiformes y Siluriformes. Los primeros presentan tamaños que desde pocos centímetros como las mojarras plateadas (Eucinostomus argenteus) hasta peces de más de un metro de longitud y pesos que superan los $30 \mathrm{~kg}$ como los grandes dorados (Salminus brasiliensis). Este grupo incluye además la tararira (Hoplias malabaricus), boga (Leporinus obtusidens), sábalo (Prochilodus lineatus), dientudos (Acestrorhynchus pantaneiro, Raphiodon vulpinus y Roeboides sp.) y pirañas (Pygocentrus nattereri y Serrasalmus spilopleurai). Los segundos también presentan un amplio rango de tamaños, los más abundantes son las viejas del agua (Loricariidae), los bagres (Pimelodidae) y los armados (Doradidae). Otros peces son el surubí (Pseudoplatystoma coruscans), el patí (Luciopimelodus pati) y el manguruyú (Zungaro zungaro) que presentan gran tamaño y son ictiófagos. Las especies de comportamientos migratorios en general son las de tamaño grande como el dorado, boga, sábalo, surubí o patí (Sverlij et al. 1998).

Según un inventario de la ictiofauna realizado por Demonte y Arias (2005) para los cursos de agua del interior de Entre Ríos, los órdenes Characiformes y Siluriformes constituyen los componentes mejores representados en provincia. Los Characiformes corresponden en su mayor parte a especies de pequeño y mediano porte (mojarras y dientudos); en tanto que entre los Silúridos los peces frecuentadores de fondo como las viejas del agua y los bagres son los más abundantes. Puede destacarse también la ausencia de las grandes especies depredadoras de río abierto como surubíes y manguruyúes, a excepción de los dorados, los que estarían siendo reemplazados por especies de charácidos ictiófagas como la tararira, palometas y dientudos.

Además, de la fauna de origen Brasilica (Siluros), Afro-brasilero o Anfiatlántico (Characidos), se registra un tercer grupo de abolengo marino reciente, la "Ictiofauna talasoide y de "penetración" 
(Ringuelet 1975), lo conforman el pejerrey (Odontesthes bonariensis), lenguado (Catathyridium jenynsis) y corvina (Pachyurus bonariensis), entre otros.

\section{5- CONSIDERACIONES FINALES}

Dentro del área de estudio se pueden reconocer tres zonas geomorfológicas: la llanura alta, la planicie de inundación del río Uruguay y la zona sur lindante al Complejo Deltaico. Esta última también podría considerarse como parte de la zona costera en contraposición a las llanuras interiores, ya que también está sometida a la dinámica de la porción terminal del río Uruguay.

Un aspecto importante a considerar es la ingresión marina del Holoceno medio, que provocó la retracción y posterior avance de las líneas de costa sobre el río Uruguay y el Paraná. Es claro que el aumento del nivel de las aguas afectó considerablemente la porción sur del área de estudio, lo que tiene una importante implicancia en cuanto a la cronología de los hallazgos arqueológicos en esta zona. De acuerdo con la información disponible la zona se habría estabilizado y adquirido características similares a las actuales entre aproximadamente 5000 y 3300 años AP, lo que lleva a sostener que la antigüedad del registro arqueológico en la zona afectada por la ingresión marina abarcaría un rango comprendido entre el Holoceno medio y el siglo XVII (Tabla 2.1a-b). En el caso de que hubiera sitios arqueológicos más tempranos en la zona costera probablemente fueron destruidos por el avance de las aguas. También se desconoce el impacto del avance del mar sobre la distribución de la flora, la fauna y los recursos geológicos del río Uruguay.

Finalmente, para este estudio hay tres cuestiones por las que resulta relevante la caracterización ambiental realizada. La primera de ellas se vincula al desarrollo metodológico de la tesis y se refiere a la selección de los sectores de muestreo y al desarrollo de las tareas de campo. El reconocimiento de las variadas condiciones ambientales del área contribuyó a la selección de tres sectores con rasgos diferentes, con la idea de comparar el registro arqueológico de los mismos y observar si existía variabilidad de acuerdo a su entorno ecológico. La segunda de las cuestiones se refiere a la distribución y disponibilidad de los recursos en general, durante un período de tiempo determinado (Pleistoceno final-siglo XVI), y cómo poblaciones en estudio pudieron responder a cambios en las condiciones ambientales, además de la influencia de estos cambios sobre el registro arqueológico y su visibilidad actual. La última de las cuestiones, estrechamente vinculada a la anterior, tiene que ver con la posibilidad de determinar claramente los tipos de estrategias adaptativas, originadas a partir de las interrelaciones entre las poblaciones prehispánicas y su entorno. Dichas estrategias son potencialmente inferibles a partir del registro arqueológico, pero para lo cual es absolutamente necesario conocer, con el mayor grado de detalle posible, los paleoambientes donde las poblaciones en estudio se desenvolvieron. 


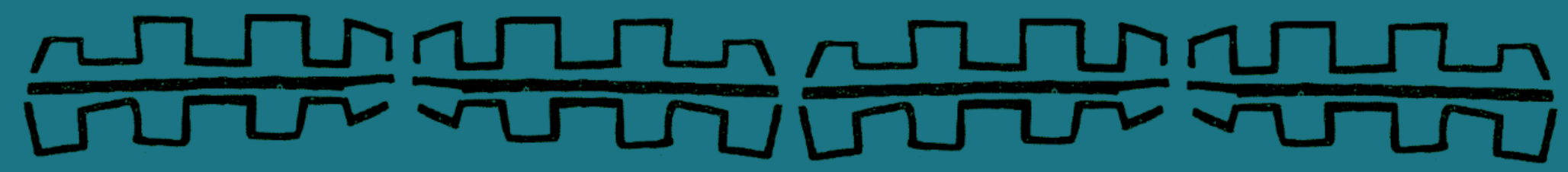

Capítulo 4

MARCO CONCEPTUAL Y METODOLOGICO

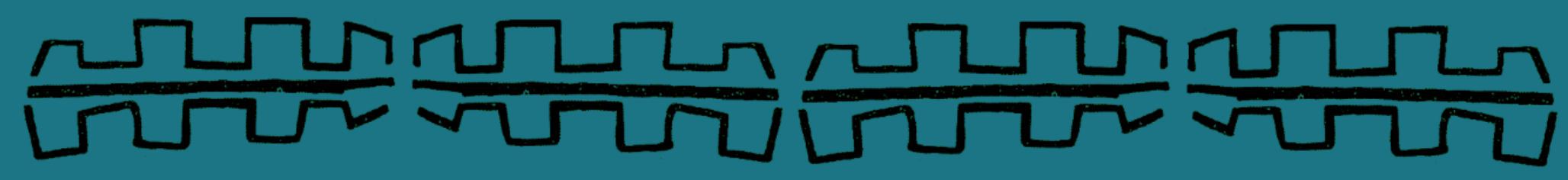




\section{CAPÍTULO 4}

\section{MARCO CONCEPTUAL Y METODOLÓGICO}

\section{1- CONCEPTOS TEÓRICOS GENERALES}

Esta investigación se desarrolla dentro de un marco teórico-metodológico que puede ser caracterizado como ecléctico (sensu Feyerabend 1975; véase también Curtoni 2007). En este sentido, el abordaje del registro arqueológico llevado adelante en esta tesis incluye elementos de varias corrientes o programas teóricos como la arqueología Procesual y post-Procesual, la arqueología del Paisaje y sobre todo de la Ecología Histórica. Por lo tanto, no se siguen los lineamientos de un solo programa teórico, sino que se reconocen los aportes de diversos paradigmas y/o líneas de investigación desarrollados dentro de la disciplina. Se considera que un abordaje dogmático del pasado prehispánico puede llevar a interpretaciones sesgadas, dado que ninguna de las corrientes teóricas permite abordar por sí sola toda la complejidad de la cultura material y los fenómenos culturales del pasado.

Este estudio busca comprender todos los aspectos de la vida de las poblaciones indígenas que habitaron una porción del Nordeste argentino. Estos aspectos incluyen la organización social, la tecnología, la economía, el tratamiento dado a los muertos, el mundo simbólico, los circuitos de circulación de materiales, los patrones de asentamiento y movilidad, la interacción con la naturaleza y las interrelaciones con otras poblaciones cercanas o distantes. Todos estos aspectos integran un sistema cultural-ambiental donde se desarrollan las poblaciones humanas a través del tiempo; por eso, caracterizar con mayor precisión cada uno de los mismos mediante el abordaje integral e interdisciplinario, permitirá elaborar un modelo de desarrollo cultual prehispánico del área y reconstruir las trayectorias históricas de las sociedades indígenas.

Ahora bien, pasando a considerar el entorno donde se desarrolló la vida de las poblaciones pasadas, en esta tesis no se identifica al medio ambiente como un espacio externo estrictamente determinante de rasgos culturales, pero no se desconoce su influencia sobre las necesidades biológicas y sobre ciertos aspectos culturales de las poblaciones humanas; o mejor dicho, no se desconoce que de una o múltiples maneras combinadas el ambiente como sistema, regula y/o estructura el comportamiento de sus componentes, uno de ellos son los seres humanos. Como señala Dincauze: "The ecological contexts of cultures, present or prehistoric, have contributed to the defining characteristics of those cultures. Paleoenvironmental study is essential to an adequate 
understanding of human cultures and to the knowledge we seek about the operation of cultures." Dincauze (2000: 74).

Estas interrelaciones entre los seres humanos y los ecosistemas están mediadas por una visión subjetiva de personas sobre su entorno, conformada a partir de la percepción de los fenómenos, la experiencia colectiva y el tipo de organización social. De esta manera los contextos ecológicos donde se despliega la vida social, son significados y socializados (Anschuetz et al. 2001; Criado Boado 1991), a la vez que son transformados mediante la tecnología, durante proceso adaptativo -supervivencia y reproducción-. En este sentido, no habría ambientes exclusivamente naturales o culturales por separado, ambos son mutuamente dependientes e inseparables. Los seres humanos han transformado la naturaleza con su forma de vida social y han vivido siempre en un mundo que es parte su propia creación (Balée 1994; Dincauze 1993). La idea de un ser humano externo e independiente de la naturaleza y de los demás seres vivos es una concepción occidental moderna (Dincauze 2000; Elíade 1994).

En relación a lo anterior y para el caso de las Tierras Bajas de Sudamérica que incluyen nuestra área de estudio, pero sobre todo para Amazonía y desde la perspectiva de la Ecología Histórica (Balée 1998, 2006, 2008; Balée y Erickson 2006; Erickson 2010; Heckenberger y Neves 2009; Heckenberger et al. 2007; entre otros) se reconoce que "...las poblaciones indígenas y caboclas ejercen acciones que modifican las condiciones naturales de los lugares donde viven; y que, por otro lado, estos grupos ocupan y desarrollan estrategias adaptativas en lugares previamente transformados por la actividad humana." (Neves 2011: 8). Estos contextos modificados incluyen las acciones de grupos que van desde cazadores-recolectores con gran movilidad (Politis 1996) hasta poblaciones agrícolas sedentarias (Balée 1989, 1995); y también habitantes actuales por ejemplo reocupando las llamadas terras pretas debido a su alto grado de fertilidad agrícola (Neves 2006, 2007, 2011; Neves et al. 2003, 2004).

En Amazonía los cambios del ambiente comenzaron desde el mismo momento que fue ocupada, pero las evidencias arqueológicas muestran que las modificaciones antrópicas más significativas y permanentes del paisaje, que incluyen grandes asentamientos sedentarios con estructuras monumentales, se intensificaron hace 2000 años AP (Neves 2008, 2011; Neves y Petersen, 2006). Este punto de vista permite considerar cierta continuidad histórica, no solo en las alteraciones del paisaje por parte de las poblaciones que ocupan un área determinada por un periodo considerable, sino en algo más relevante, que es la percepción social heredada de ese paisaje alterado, por parte de cada nueva generación que habita el territorio de sus ancestros. Esta percepción puede variar en distinto grado con el correr del tiempo de acuerdo a múltiples factores (internos y/o externos), pero generalmente se apoya en una base que es producto de un proceso adaptativo y está constituida por la experiencia colectiva del grupo humano donde cada individuo nace y se desarrolla. 
En el Capítulo 3 se describieron y caracterizaron las propiedades físicas intrínsecas del ambiente. Está claro que la valoración del mismo y de sus recursos es una construcción social, que varía de acuerdo al proceso adaptativo de cada grupo humano y de su trayectoria histórica, y depende de la percepción que éste tenga de su entorno en un momento determinado (Ingold 1993). Si se considera esto como tal, se puede plantear que esa valoración particular del ambiente es el resultado de la interrelación dinámica constante de dos factores que serían parte de una misma continuidad histórica: uno es la percepción social que cada generación hereda y que es el resultado de los propios procesos históricos y adaptativos del grupo humano al que pertenece; el otro se relaciona con los nuevos conocimientos adquiridos colectivamente por cada generación en relación al ambiente en el que desarrolla su existencia. La combinación permanente de estos dos factores es lo que permite conservar el significado social heredado y/o resinificarlo a partir de los cambios percibidos como significativos, tanto en el ambiente circundante y/o dentro de la organización social propia del grupo. En este sentido, la valoración que en esta tesis se le da a los recursos, es parte de este proceso histórico y dinámico de percepción del ambiente propio de nuestra sociedad, y particularmente de las distintas interpretaciones del ambiente por parte de la arqueología.

A través del estudio de datos integrados (arqueológicos, geológicos, ecológicos, climáticos, etc.) del ambiente modificado en el pasado, se pueden inferir ciertos patrones o prácticas sociales que provocaron la modificación del mismo de una determinada forma particular y no de otra. Por ambiente modificado se entiende desde las variaciones fisicoquímicas del suelo (p. ej. en sitios arqueológicos) hasta cambios en la distribución de plantas, animales y recursos geológicos provocados por actividades humanas. Dado que el tipo de interrelación con el entorno incide sobre ciertas características o prácticas sociales, se puede lograr un acercamiento al rango de variabilidad potencial de estrategias adaptativas que desembocaron en lo que se observa en el registro arqueológico.

Está claro que hay una relación directa entre, acciones y comportamientos sociales del pasado y el ambiente modificado que se observa y describe actualmente. El problema es determinar con precisión cuales fueron estas acciones o comportamientos a partir de las características del ambiente o paleoambiente modificado, ya que pueden existir situaciones de equifinalidad y no se puede asumir una relación causal directa. Además, el espectro de respuestas de las sociedades humanas a determinados cambios puede ser muy variado y complejo. "People are the proximate causes of changes in their societies; their environments reflect, amplify, or dampen change, and return changed conditions to the instigators of change, requiring new adaptations." Dincauze (2000: 18).

Es necesario aclarar aquí que adaptación cultural no es lo mismo que adaptación biológica, ambas involucran distintas escalas temporales (Dincauze 2000; Morán 1982). La adaptación cultural implica "ajustes" ante los cambios, no implicando una modificación genética en el corto plazo. Desde 
este punto de vista, los cambios culturales son considerados como respuestas que involucran distintas estrategias disponibles dentro de un contexto cultural particular (Binford 1962). Una estrategia se compone de comportamientos y tecnologías, y sus combinaciones, con las que las poblaciones hacen frente al ambiente físico, en palabras de Dincauze (2000) "The strategies chosen for responses will vary with the nature of the perceived change (good or bad), the amplitude of the change, the flexibility of established lifestyles, the population structure and density, the amount of diversity in the environment, and the technology available to the group." Dincauze (2000: 75). Así, mediante al abordaje de la tecnología y los comportamientos que la generaron se puede tratar de comprender las estrategias sociales involucradas en la supervivencia y reproducción de los grupos humanos estudiados.

De acuerdo a los antecedentes arqueológicos los grupos indígenas del NEA han sido caracterizados, en base a su subsistencia, como cazadores-recolectores-pescadores y más recientemente también como horticultores (véase Capítulo 2). En este sentido, considerando la información regional más reciente sobre la gestión antrópica de vegetales junto a la información presentada en los capítulos siguientes, se considera que la definición clásica de cazadoresrecolectores, focalizada en la movilidad, en la ausencia de marcadas diferencias sociales, en la subsistencia basada en el consumo de plantas y animales no domesticados, excepto el perro (Canis familiaris), y con un modo de vida extractivo que no interfiere en la distribución, reproducción o comportamiento de las especies explotadas (véase p. ej. Ellen 1994), no puede ser aplicado a nuestro caso de estudio. Asimismo, dado que el término cazador-recolector aplicado a grupos etnográficos (y también arqueológicos) contempla una amplia variabilidad en cuanto a modos subsistencia, movilidad y organización social, presencia o ausencia de alfarería, entre otros aspectos (Arnold 1996; Dillehay 2013; Kelly 1995; entre otros); aquí se usará el término cazador-recolector o cazadorrecolector-pescador en el sentido amplio sin privilegiar la importancia de una actividad sobre las otras, a menos que sea especialmente destacada, y considerando también la posibilidad de la presencia de prácticas hortícolas.

Dentro de este contexto la tecnología (lítica, cerámica, ósea y malacológica) no solo es considerada aquí como los artefactos, sus materias primas y las técnicas aplicadas en su obtención, elaboración, uso, reciclaje y descarte, sino también todos los conocimientos asociados a estos aspectos y a la transmisión intergeneracional de ese conocimiento y las relaciones sociales expresadas a través de ella (Bamforth y Bleed 1997; Gosselain 2000; Hodder 1982; Ingold 1990; Lemmonier 1992; Taçon 1991; entre otros). La tecnología no responde únicamente al modo de explotación de la naturaleza con fines adaptativos, aunque claramente la tecnología permite la interacción con la naturaleza de una manera determinada y no de otra. Esta manera en que la tecnología permite, orienta o determina en algunos casos esta interacción, es el resultado del devenir histórico de una sociedad y de la estructura social donde se desenvuelven los individuos 
(Lemmonier 1992). En este sentido, la estructura social es previa los agentes individuales y normativiza las interrelaciones entre los individuos, y entre estos y la naturaleza (Bourdieu 1987; Dobres y Hoffman 1994). Esta estructura general, habitus en el sentido de Bordieu (1987, 1991), asegura la continuidad de las estructuras, pero a la vez contempla la variabilidad de los comportamientos que pueden desarrollarse por fuera de esa estructuración histórica donde se desenvuelven los individuos (Guidens 1979, 1984, 1995), y en algunos casos podría dar lugar a innovaciones y/o soluciones o "ajustes" a nuevos problemas.

Lemmonier (1992) plantea que la tecnología como fenómeno social tiene cinco componentes interrelacionados entre sí y con otros fenómenos sociales de un modo sistémico: materia (materias primas), energía (la fuerza que transforma la materia y mueve los objetos), objetos (artefactos, herramientas), gestos (comportamientos únicos o secuenciales que actúan sobre la materia y los objetos) y los conocimientos específicos asociados (habilidades y conocimientos conscientes o inconscientes que portan los individuos y los grupos, el "saber hacer"). El estudio de estos componentes y de los distintos tipos de interacción entre estos elementos durante la elaboración de artefactos determina el resultado del proceso, que a una escala mayor estarían respondiendo a pautas culturales que pueden ser independientes o no de las necesidades materiales, mecánicas o funcionales de un diseño particular (Frère 2014). En este sentido, el conjunto de elecciones tecnológicas constituyen representaciones sociales compartidas, las cuales se materializan en modos de hacer particulares y, por lo tanto, pueden ser abordadas a través del análisis de la cultura material (Lemmonier 1992).

La manufactura de un artefacto implica una serie de pasos técnicos y decisiones (individuales y/o pautadas socialmente) que van desde la selección de las materias primas hasta el acabado final de la pieza. Todos estos pasos destinados a lograr una funcionalidad (material y simbólica) mínimamente óptima del artefacto en cuestión, constituyen un sistema técnico que desde la arqueología puede ser abordado y seccionado (dado que en la realidad es un proceso continuo, dinámico y no permanentemente unidireccional) mediante el uso del concepto de "cadena operativa" (Lemmonier 1976, 1992; Leroi Gourhan 1964). Este concepto permite identificar etapas del desarrollo de un proceso de elaboración de un artefacto particular dentro de un grupo social específico y reconocer estrategias sociales y económicas.

En este marco las distintas tecnologías implementadas por los cazadores-recolectorespescadores y alfareros bajo estudio, y el abordaje de los diseños artefactuales como reflejo de las estrategias tecnológicas permitirán un acercamiento a aspectos tales como: la organización social, las prácticas alimenticias (Goody 1995; Montón Subías 2005), las redes de interacción social (Gamble 2001), la movilidad residencial y logística (Binford 1980), entre otros. Las propiedades de cada conjunto tecnológico particular reflejan distintos "modos de hacer" particulares del grupo humano que los elaboró y usó (Chilton 1999; Frère 2014; Gosselain 1998; Stark 1998, 1999). La identificación 
de recurrencias y la homogeneidad tecnológica en los diseños de los artefactos permitirían reconocer modos de hacer (estilos tecnológicos) mantenidos en el tiempo, lo que constituye tradiciones tecnológicas, que pueden ser compartidas por otras comunidades vecinas y reflejarían interacción y patrones sociales compartidos (Frère 2014).

\section{2- METODOLOGÍA DE CAMPO Y GABINETE}

Dada la ausencia de información sobre la distribución espacial del registro arqueológico recabada con métodos sistemáticos (Capítulo 2), y a partir de una evaluación crítica del contexto ambiental y paleoambiental (Capítulo 3), se seleccionaron tres sectores de muestreo (A, B y C) para realizar los trabajos de campo de manera intensiva (Figura 4.1). Estos se focalizaron en localizar, muestrear y caracterizar evidencias arqueológicas en superficie y en estratigrafía; identificar sitios arqueológicos potenciales para excavar sistemáticamente; caracterizar la distribución espacial, estructura y composición del registro arqueológico y su contexto ambiental considerando su vinculación con la distribución espacial de los recursos (florísticos, faunísticos, hídricos y litológicos); e identificar posibles fuentes de aprovisionamiento de minerales, rocas y arcillas.

El problema de visibilidad de restos arqueológicos en el área de estudio ha afectado directamente la detección de sitios arqueológicos, así como el número de artefactos que integran cada uno de los conjuntos recolectados $y$, por lo tanto, su definición y/o inclusión dentro de la categoría "sitio arqueológico", "concentración" o "hallazgo aislado" tal como propone Borrero y colaboradores (1992). Asimismo, tienen incidencia sobre éstas frecuencias las actividades previas de aficionados, coleccionistas, y las actividades agro-ganaderas y forestales modernas, así como también la dinámica propia del río Uruguay y sus afluentes. En consecuencia, se estableció el límite arbitrario de 20 unidades como mínimo, dentro de un círculo de $20 \mathrm{~m}$ de diámetro, para distinguir un "sitio arqueológico". Una cantidad menor se considera como "hallazgos aislados", sin establecer diferencias entre "concentración" o "hallazgo aislado" en el sentido de Borrero y colaboradores (1992).

Debido a que cada sector de muestreo presenta particularidades topográficas y ambientales, los procesos posdepositacionales y los antrópicos mencionados arriba no actúan de igual manera en todos ellos. En este sentido, la incidencia de los mismos sobre la visibilidad e integridad de los conjuntos arqueológicos, se evalúa por separado en cada uno de los capítulos correspondientes a cada sector. 


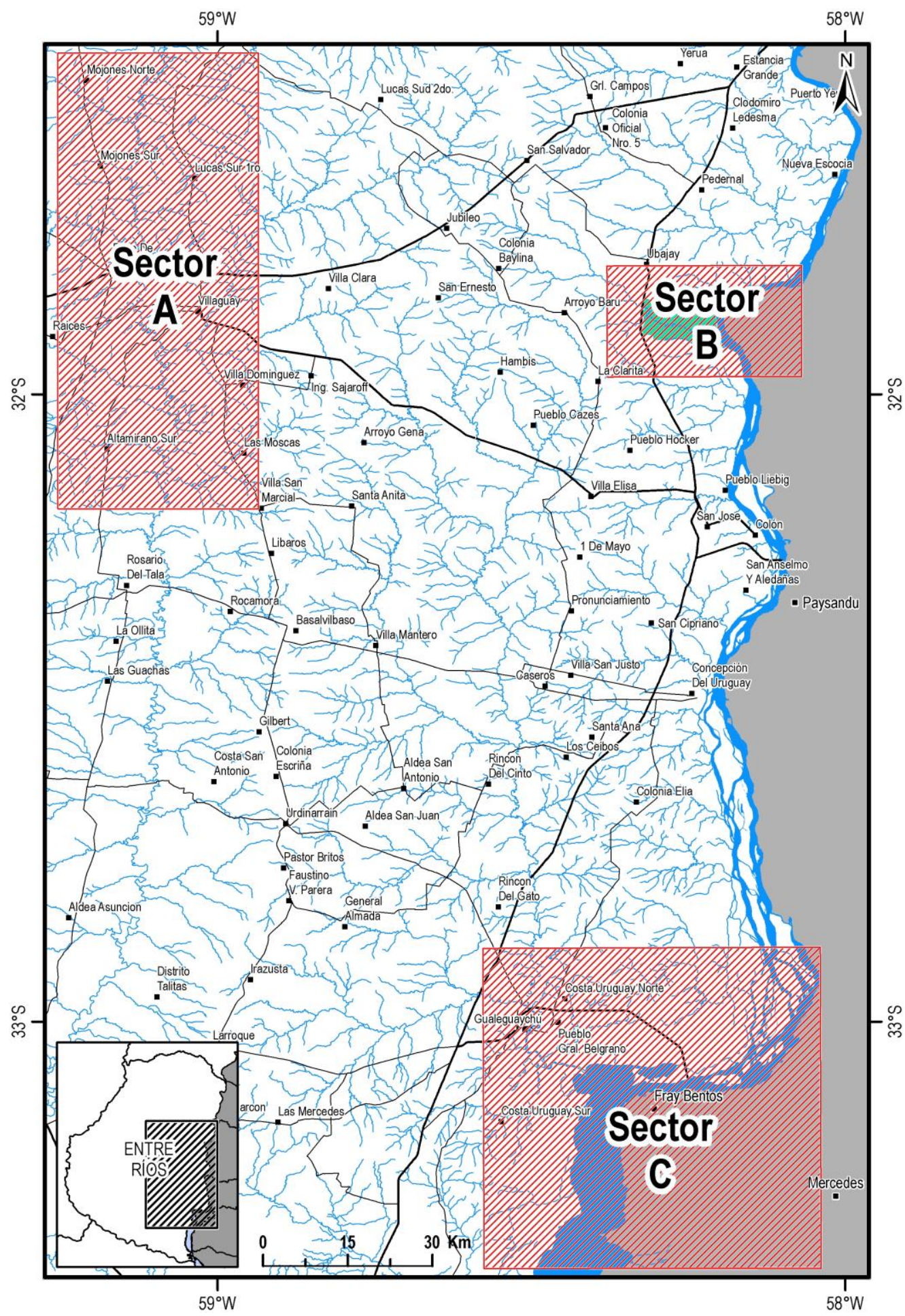

Figura 4.1. Área de estudio y los sectores de muestreo A, B y C.

Los métodos y las técnicas de trabajo utilizados estuvieron condicionados por las particularidades ecológicas de cada sector estudiado. Dentro de cada uno de éstos se realizaron muestreos al azar simple y dirigido, de manera combinada (Cherry y Shennan 1978; Foley 1978; Judge et al. 1979; Orton 2000; Plog et al. 1978; Read 1979; entre otros). 
Como se observó en el Capítulo 3, la geografía de Entre Ríos se caracteriza por una extensa y amplia red fluvial. Considerando esto, conjuntamente con los datos obtenidos del estudio de los antecedentes realizado en el Capítulo 2, sobre la distribución de evidencias arqueológicas; se decidió focalizar los trabajos en el terreno sobre los márgenes de las fuentes de agua principales de cada sector, sean ríos, arroyos o lagunas.

Se realizaron en total 10 campañas de prospección en promedio de siete días de duración cada una, entre el año 2007 y 2013. Las prospecciones se efectuaron de manera pedestre y fluvial; en algunos cursos de agua se emplearon ambas estrategias combinadas. La primera estrategia consistió en seguir la línea de costa, abarcando un máximo de 200 m de ancho hacia la llanura contigua, en los casos donde la topografía y la vegetación lo permitían. En algunos casos puntuales se prospectaron zonas medanosas ubicadas a más de $200 \mathrm{~m}$ de la costa y en el sector B se realizaron dos transectas que atravesaban casi completamente el Parque Nacional El Palmar (PNEP) en sentido norte-sur, una de $3700 \mathrm{~m}$ y otra de $2600 \mathrm{~m}$ de largo, ambas de $5 \mathrm{~m}$ de ancho. Asimismo, en el PNEP relevaron 16 afloramientos rocosos y varios depósitos naturales de rodados fluviales en busca de canteras potenciales. La segunda estrategia estuvo dirigida hacia geoformas elevadas, playas, médanos y afloramientos rocosos. Con ambas estrategias se relevaron barrancas naturales y en algunos casos se practicaron cortes artificiales de las mismas.

También se realizaron prospecciones dirigidas puntualmente al relevamiento sitios arqueológicos conocidos por los pobladores locales y por el personal de los museos locales. Cabe destacar que algunos de los sitios arqueológicos presentados aquí fueron relevados y sondeados en dos oportunidades (p. ej. Arroyo Ubajay, Palmera Sola, Puerto Algarrobos, La Correntina, Cerro Yaguar-í y Cerro Lorenzo 1), e incluso hasta cuatro veces o más (p. ej. Cerro de Boari 1, 2 y 3, y Cerro Lorenzo 2) con el objetivo de profundizar su estudio.

Se llevaron a cabo recolecciones superficiales dirigidas, transectas, sondeos estratigráficos y una excavación sistemática. Los sondeos estratigráficos presentan medidas de 0,5 m y de $1 \mathrm{~m}$ de lado y la profundidad varió de acuerdo a cada caso particular y a las características del sitio arqueológico. La excavación se realizó en el sitio arqueológico Cerro de Boari 3 donde se abrieron $8 \mathrm{~m}^{2}$ alcanzando una profundidad máxima de 1,80 m (véase Capítulo 8). Los sondeos y la excavación se profundizaron por niveles artificiales de $5 \mathrm{~cm}$ de potencia. En algunos casos donde se detectaron hallazgos aislados o sitios arqueológicos, que serán mencionados oportunamente, también se realizaron pruebas de pala y de barreno; cuyo objetivo fue determinar la presencia o ausencia de materiales arqueológicos en estratigrafía y/o la extensión areal de los mismos. Todo el sedimento extraído fue tamizando en seco en mallas de 3x3 mm (excepto en Cerro de Boari 3 donde su utilizó zaranda de agua de mallas de $3 \times 3 \mathrm{~mm})$.

Sobre cada tipo de material se realizó un abordaje macroscópico integral desde el punto de vista tecnológico, morfológico y funcional. Asimismo, para el relevamiento de algunos atributos 
como huellas de filos y negativos de impactos en materiales óseos, inclusiones de la pasta cerámica, microretoques y rastros complementarios de uso sobre filos naturales de artefactos líticos, entre otros, se utilizó un microscopio binocular estereoscópico hasta 40X marca "Estereozoom" Bausch \& Lomb. Todas las medidas fueron tomadas con un calibre digital de carbono marca Caliper y para la determinación de colores se utilizó la "Tabla Munsell" (Revised Standard Soil Color Charts, 2002).

\section{3.- TECNOLOGÍA LÍTICA}

El estudio de la tecnología lítica (y en cierto modo la presencia de materiales exóticos) permite abordar con mayor profundidad las estrategias de aprovisionamiento y en consecuencia la movilidad de los grupos humanos (logística y residencial, sensu Binford 1980). Dado que las canteras se encuentran en puntos fijos del espacio, situación que no ocurre con los recursos faunísticos que tienen mayor movilidad y una distribución relativamente más homogénea. Las fuentes de arcilla serían un buen indicador de movilidad pero no se abordó su estudio sistemático, aun así estas tienen una distribución más homogénea que las canteras potenciales líticas. Por su parte, la distribución de las formaciones vegetales y sus componentes endémicos podrían servir para abordar este tema y en el Capítulo 9 se presentan algunos avances al respecto.

El aprovisionamiento de rocas y minerales destinados a la manufactura de instrumentos implica un conjunto de decisiones que están fuertemente influenciadas por las necesidades del grupo humano y la disponibilidad de los recursos necesitados. Estas decisiones no siempre responden al aumento de la eficacia funcional de los instrumentos a confeccionar ni al de ganancia neta de energía como se desprende de la Teoría del Forrajeamiento Óptimo (Bettinger 1991; Wintherhalder y Smith 1992). Colombo (2013) enumera un conjunto de factores no económicos que influyen en las decisiones de grupos etnográficos vinculadas al aprovisionamiento de materias primas líticas y que contradicen la visión unidireccional del costo-beneficio occidental, donde se procura una mayor tasa de ganancia energética por un menor costo de tiempo y energía de obtención.

Un ejemplo etnoarqueológico de este tipo de comportamiento en las Tierras Bajas sudamericanas está dado por la relación que los awá tienen con sus arcos y flechas de madera; donde por ejemplo: los cazadores dedican mucho tiempo y energía todos los días a la confección, mantenimiento y reparación de flechas; cada cazador tiene un diseño de flecha propio identificado por los demás; en sus salidas de caza llevan más flechas de las que efectivamente disparan (llevan en promedio entre 12,2 y 21,7 y usan dos o tres, máximo seis); siempre intentan recuperar las que fueron disparadas estén enteras o quebradas; todas las flechas (excepto las extraviadas) se descartan en la aldea; y además éstas juegan un papel importante en la conformación de la identidad masculina y otros fenómenos culturales relevantes de la cultura awá (González Ruibal et al. 2013). 
Para poder definir a los instrumentos líticos se utilizan los conceptos de formal e informal (Andrefsky 1994). Se entiende por instrumentos formales aquellos cuyo diseño implica mayor esfuerzo y energía y presentan cierto patrón dentro del conjunto lítico, son manufacturados con anticipación a su uso, pueden ser transportados y usados en múltiples ocasiones, en general son descartados cuando no pueden seguir siendo mantenidos o reciclados cuando ya no pueden cumplir con su función primaria. Por su parte, los instrumentos informales son aquellos de manufactura simple y con un diseño no estandarizado dentro del conjunto lítico, y que son elaborados con bajo grado de modificación, usados y descartados en un lapso de tiempo relativamente corto (Binford 1979). Está claro que no todos estos aspectos dentro de cada categoría siempre deben darse en conjunto (Bamforth 1986). Estas definiciones anteriores traen implícito los conceptos de diseños conservados y expeditivos. Siguiendo a Escola (2004) se considera, que la inclusión de los instrumentos (sobre todo de retoque marginal o parcialmente extendido) en una u otra categoría no deber responder únicamente a la inversión de trabajo, debe medirse en las técnicas de reducción de las formas-base, en la estandarización morfológica de los diseños y en las técnicas de retoque y formatización final.

Si bien en general los instrumentos formales se han asociado a estrategias de conservación y los informales a estrategias expeditivas u oportunísticas, esta relación unívoca debe ser determinada sobre todo a partir del estudio del conjunto de artefactos, del contexto arqueológico del mismo y de la disponibilidad de recursos líticos (reserva o provisión). Dado que instrumentos definidos como informales (confeccionados expeditivamente) pueden ser conservados y transportados para realizar tareas futuras y no necesariamente deben ser descartados con posterioridad a su confección y uso inmediato (Shott 1996). Esto en última instancia podría responder además a la disponibilidad de materias primas (Andrefsky 1994; Bamforth 1986) y a factores sociales invisibles en el registro arqueológico (Colombo 2013; Escola 2004; Hermo 2008). Un ejemplo etnoarqueológico inverso, el descarte de instrumentos formales con potencialidad de uso y/o reparación, o sea de conservación, está dado por el descarte de puntas de flechas de madera realizado por los awá (véase Politis et al. 2013b). Entonces, se distingue entre diseños formales e informales por un lado y estrategias conservadas y expeditivas por otro lado, no reconociendo de antemano una relación directa entre diseños y estrategias (véase Escola 2004).

En esta tesis se evaluaron integralmente en cada uno de los sectores estudiados (Figura 4.1) la disponibilidad de materias primas, las características del conjunto instrumental (grupos y subgrupos morfológicos sensu Aschero 1975, 1983), así como también el conjunto de desechos de talla y núcleos. Esto permitió utilizar las categorías formal e informal y posteriormente interpretar las posibles estratégicas tecnológicas asociadas a cada conjunto de artefactos. Por otro lado, la relación entre instrumentos formales y estrategias conservadas e instrumentos informales y estrategias expeditivas debe ser determinada también a partir del contexto. 
También en el marco de estas estrategias sociales se consideraron posibles eventos de maximización de materias primas (Bamforth 1986; Andrefsky 1994) en relación a la distancia, al tiempo y energía probable requerida para la obtención y al aprovisionamiento de los sitios arqueológicos y de los individuos (destinado al equipamiento personal, toolkit sensu Kelly 1995), y a la calidad de las rocas y minerales utilizados. En relación a esto se también se consideraron estrategias de renovación o reemplazo del instrumental (Kuhn 1994). La renovación del instrumental implica, por un lado, la minimización de los costos de traslado y menor volumen de materias primas, y por otro lado, implica cambios en la morfología y en las propiedades y efectividad original de los instrumentos. Por su parte, el reemplazo del instrumental implica, por un lado, el mantenimiento de las propiedades óptimas de los instrumentos, y por otro lado, implica un mayor requerimiento de materias primas. Estos eventos son observables a través del mantenimiento y el reciclado de las piezas en relación a la distancia a las canteras potenciales y a la calidad de las materias primas. También cabe destacar que no todo evento de mantenimiento y reciclaje responde a la disponibilidad y calidad de materias primas, como se verá en los capítulos siguientes.

El volumen de materias primas con la que se aprovisionan los individuos y sus asentamientos depende del grado de movilidad y también de la distancia a las canteras. En este sentido, Kuhn (1994) propone un modelo (Figura 4.2) que permite relacionar las estrategias de aprovisionamiento, la movilidad y la duración de los eventos ocupacionales. A medida que disminuye la movilidad residencial y aumenta la duración de los eventos ocupacionales, aumenta la dependencia del aprovisionamiento de lugares y disminuye el aprovisionamiento individual; y también aumenta la distancia promedio del traslado de las materias primas para el aprovisionamiento de lugares. En cuanto a la movilidad logística, cuando se da en un rango amplio y la distancia promedio de traslado es alta, el aprovisionamiento de lugares e individuos es alto; pero a medida que el rango y la distancia disminuyen, el aprovisionamiento de individuos de vuelve más relevante. 


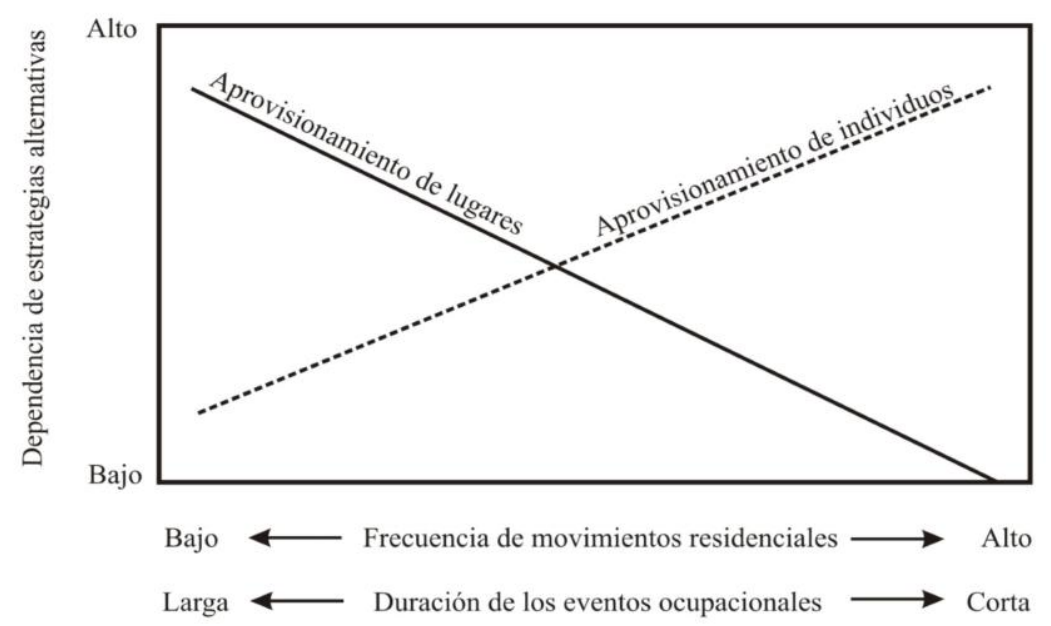

Relación esperada entre movilidad y estrategias de aprovisionamiento

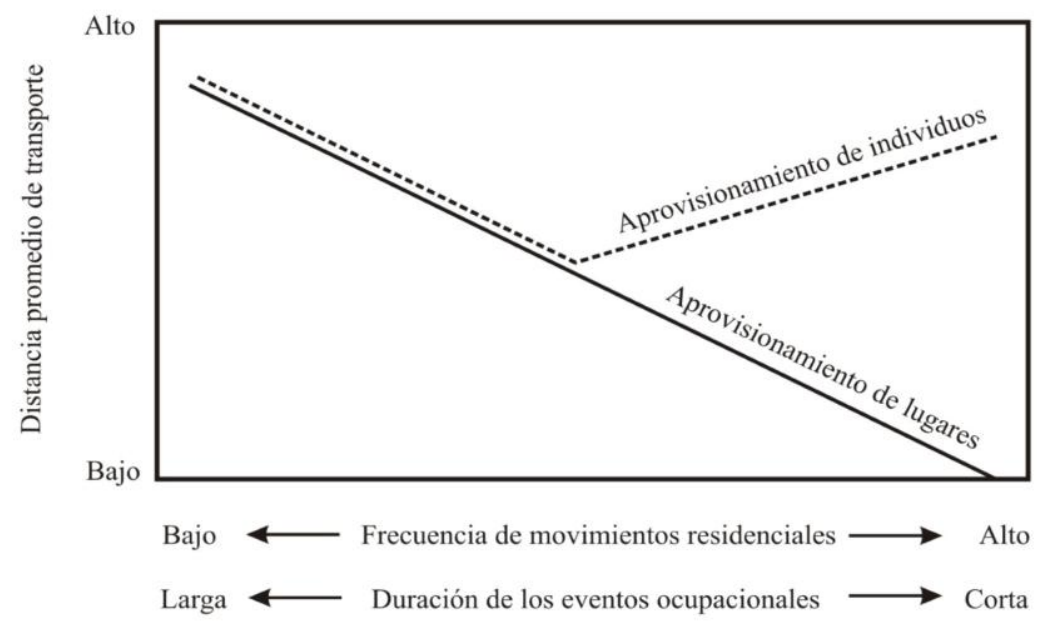

Relación esperada entre movilidad residencial y transporte de artefactos

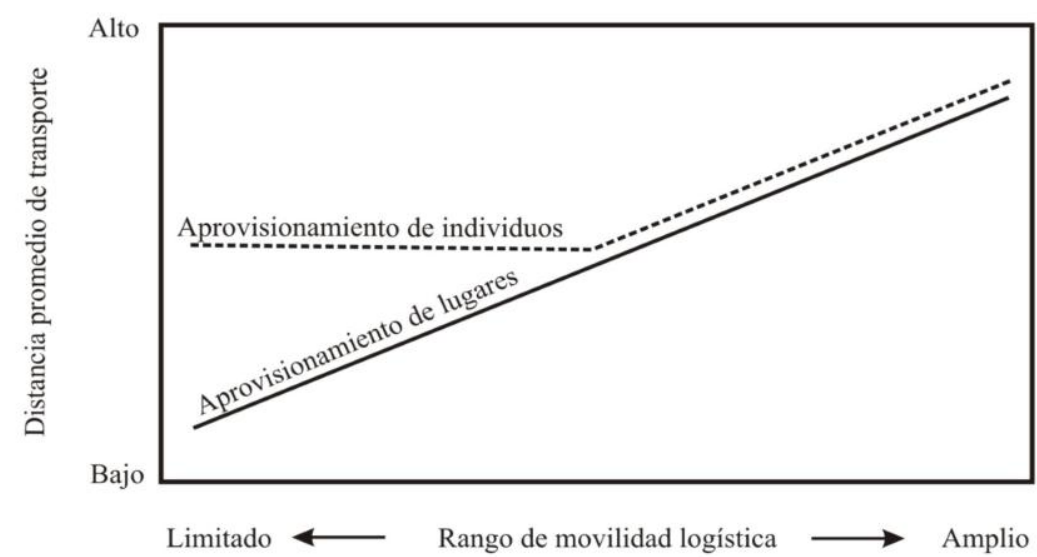

Relación esperada entre movilidad logística y transporte de artefactos

Figura 4.2. Modelo de Kuhn (1994) de relaciones entre movilidad, aprovisionamiento y transporte de recursos líticos (Tomado de Hermo 2008).

Hocsman (2006) propone una serie de expectativas arqueológicas por cada una de las clases tipológicas en relación a aspectos tales como las estrategias de movilidad residencial y el riesgo de subsistencia (Tabla 4.1). Estos aspectos afectarían la estructura y características de los conjuntos 
líticos. Así, en una situación donde el riesgo a corto plazo es elevado y hay una alta movilidad residencial se incrementa la complejidad instrumental, hay más instrumentos estandarizados, portátiles, mantenibles y multifuncionales; sin embargo, si el riesgo a corto plazo es mínimo y se reduce la movilidad residencial ocurre lo contrario. En nuestro caso de estudio se podría dejar de lado el concepto de "riego de subsistencia" si se lo considera como exclusivamente vinculado a la disponibilidad de alimentos. Por el momento su aplicación no sería válida debido a la relativa abundancia de recursos del área de estudio (Capítulo 3). Por el contrario, algunas de las expectativas vinculadas a la movilidad podrían ser útiles para caracterizar el registro arqueológico estudiado.

Tabla 4.1. Expectativas arqueológicas para movilidad baja por clase tipológica según Hocsman (2006).

\begin{tabular}{|c|c|}
\hline Clase tipológica & Expectativas arqueológicas. Riesgo mínimo en corto plazo - Baja movilidad \\
\hline Instrumentos & $\begin{array}{l}\text { - bajo grado de inversión de trabajo en la manufactura } \\
\text { - bajo grado de estandarización del instrumental } \\
\text { - bajo grado de "complejidad" en el instrumental } \\
\text { - bajo grado de diversidad instrumental } \\
\text { - escaso mantenimiento y reciclaje } \\
\text { - diseño de instrumentos de corta vida útil } \\
\text { - ausencia de instrumentos multifuncionales } \\
\text { - elección de materias primas de calidad diversa }\end{array}$ \\
\hline Desechos de talla & $\begin{array}{l}\text { - presencia de técnicas que implican inversión de tiempo y esfuerzo de manufactura mínimos } \\
\text { - baja estandarización } \\
\text { - elección de materias primas de calidad diversa }\end{array}$ \\
\hline Núcleos & $\begin{array}{l}\text { - predominio de núcleos multidireccionales } \\
\text { - baja estandarización } \\
\text { - bajo grado de aprovechamiento de la masa útil } \\
\text { - elección de materias primas de calidad diversa }\end{array}$ \\
\hline
\end{tabular}

(Tomado y modificado de Hocsman 2006).

Para la determinación de las escalas espaciales de aprovisionamiento de rocas y minerales se utiliza la propuesta de Bayón y Flegenheimer (2004). De esta forma los recursos líticos inmediatamente disponibles se encuentran en un radio de $10 \mathrm{~km}$ del sitio arqueológico, entre 10 y 60 km se consideran locales, entre 60 y $100 \mathrm{~km}$ son de distancia media, y más de $100 \mathrm{~km}$ se consideran que provienen de largas distancias. Estas escalas espaciales están pensadas para cazadoresrecolectores pedestres, pero en nuestro caso, y como lo manifiesta además la bibliografía etnohistórica, la ocupación indígena está fuertemente vinculada a ambientes fluviales y el uso de canoas es un hecho comprobado. Por lo tanto, las distancias y el tiempo para recorrerlas varían 
notablemente si la circulación se da por vías fluviales, aumentando notablemente también la capacidad de carga de materiales. Por esto se considera que a medida que avance el conocimiento arqueológico de la región deberían elaborarse escalas espacio-temporales que tengan en cuenta estos aspectos. Por el momento se utilizará la escala mencionada solo para referir a distancias del espacio físico, pero teniendo en cuenta complementariamente que el tiempo para trasladarse de un punto a otro en este ambiente puede verse reducido en comparación al desplazamiento terrestre.

Para el análisis de los materiales líticos se siguieron los lineamientos generales propuestos por Andrefsky (1998), Aschero (1975, 1983), Aschero y Hocsman (2004), Babot (2004), Bellelli y colaboradores (1985-1987), Bonomo (2004), Colombo (2013), Hermo (2008) y Matarrese (2015a). Las materias primas fueron determinadas en base a la colección de referencia del Museo de Ciencias Naturales y Antropológicas "Profesor Antonio Serrano" (Paraná), a nuestra colección obtenida en afloramientos naturales y sitios arqueológicos, además de la consulta a especialistas en geología de la región o en tecnología lítica, geólogos y arqueólogos respectivamente.

Para comprender el sistema de producción lítica (Ericson 1984), esto es, la trayectoria de los artefactos líticos desde su obtención en las canteras hasta su descarte en forma de instrumentos, desechos de talla y/o núcleos en los asentamientos, se utilizarán los conceptos de Obtención (extracción y recolección), Traslado, Aprovisionamiento, Suministro, Provisión, Afloramiento (filóncapa, bloque, clastos y rodados), Cantera potencial, Cantera, Taller y Cantera-Taller según las definiciones de Colombo (2013). En cuanto a las diferencias entre bloque y clasto aquí se considera bloque a toda masa natural de materia prima que no puede ser trasladada por una persona y clasto a toda masa natural que es potencialmente trasladable. Asimismo, se distingue entre afloramientos (fuentes) primarios y secundarios en el sentido de Nami (1992).

Dentro del conjunto lítico se diferenciaron clases tipológicas. Estas son: instrumentos, desechos de talla y núcleos. También se utilizó la categoría nódulo para referir a una masa natural de piedra utilizada como materia prima y geofacto para aquellas rocas o minerales sin modificación antrópica.

Dentro de los instrumentos elaborados mediante lascados los atributos considerados fueron: grupo y subgrupo tipológico; serie técnica; materia prima (tipo de roca o mineral y calidad); formabase primaria; medidas (largo, ancho, espesor); dimensiones relativas (módulos longitud-anchura y tamaño, y espesor relativo); ancho, continuidad y profundidad de los lascados sobre el borde; situación y extensión de los lascados con respecto a las caras de la pieza; forma primaria del filo; forma del filo sobre la arista; extensión del filo en relación a los bordes; forma primaria del bisel; cantidad de filos; forma geométrica del contorno de la pieza; e integridad (entero o fracturado). Para el caso de las puntas de proyectil se consideraron además: la forma perimetral del limbo, la forma primaria del borde, diferenciación del pedúnculo con respecto al limbo, forma de los bordes y base 
del pedúnculo, diferenciación de las aletas con respecto al limbo y al pedúnculo, diferenciación por el ángulo que forma la aleta con el pedúnculo, e integridad (entera o fracturada).

Dentro de los instrumentos elaborados mediante picado, abrasión y/o pulido y los instrumentos modificados por uso, los atributos considerados fueron: grupo tipológico, materia prima (tipo de roca o mineral y calidad), forma-base primaria, medidas (largo, ancho, espesor), dimensiones relativas (módulos longitud-anchura y tamaño, y espesor relativo), e integridad (entero o fracturado). En los modificados por uso además se relevó la posición y morfología general de los rastros de uso (Babot 2004; Matarrese 2015a). Para la clasificación de las bolas se siguió la propuesta de González (1953), dado que además de considerar la forma geométrica general de la pieza incorpora atributos complementarios como el surco, hoyuelos o protuberancias (o mamelones). Si bien está propuesta fue pensada para reconocer la presencia/ausencia de los distintos tipos en determinadas áreas geográficas y donde las características comunes servían para proponer un origen común y/o afinidades étnicas, en nuestro caso es una herramienta clasificatoria que sirve para reconocer la variabilidad morfológica y determinar de manera general los tipos más frecuentes dentro del territorio entrerriano, donde las bolas son uno de los instrumentos más numerosos en el registro arqueológico.

En los desechos de talla se relevaron los siguientes atributos: materia prima (tipo de roca o mineral y calidad), estado de fragmentación (entero, fracturado con y sin talón, no clasificable e indiferenciado), tipo de lasca (primaria, secundaria, con dorso natural, de arista, angular, plana, bipolar e indiferenciada), forma/estado del talón (natural, liso natural, liso, diédrico, facetado, puntiforme, filiforme, fracturado), inclinación del talón (recto, oblicuo e indiferenciado), forma del bulbo (pronunciado, difuso e indiferenciado), presencia o ausencia de labio, origen de la extracción de lascas (externa, interna e indiferenciada), forma-base primaria del núcleo, cantidad de negativos de lascado en la cara dorsal, reserva de corteza (ausencia total $=0 \%$, presencia parcial $<50 \%$, presencia parcial $>50 \%$ y presencia total $=100 \%$ ), medidas (largo, ancho, espesor), dimensiones relativas (módulos longitud-anchura y tamaño, y espesor relativo), rastros complementarios en el filo y el talón, regularización del frente de extracción, y evidencias de alteración térmica.

En el caso de los rastros complementarios sobre filos naturales, y como el origen de los mismos puede ser múltiple (Aschero 1983), para reducir las posibilidades de una clasificación inadecuada, por el momento los artefactos sin formatización que presentan este tipo de evidencia se incluyen dentro de la categoría desechos de talla. Probablemente los filos naturales de estas lascas puedan haber funcionado como instrumentos, pero como señalan Álvarez y Mansur (2004) los rastros complementarios macroscópicos no son evidencia directa de la utilización de un artefacto.

Los desechos no clasificables presentan dos caras, pero no se puede establecer los atributos que evidencian la dirección de la fuerza utilizada para desprenderlos (Martínez et al. 1997-98). En este punto es donde los no clasificables se diferencian de las lascas fracturadas sin talón, ya que éstas 
últimas sí presentan los rasgos característicos de las lascas (caras dorsal y ventral, bulbo, estrías, etc.). Los desechos indiferenciados incluyen aquellos subproductos de talla donde no se pueden diferenciar caras ventral o dorsal, ni ser orientados de acuerdo a su eje tecnológico. Para el abordaje de los artefactos productos de la técnica bipolar se utilizaron los criterios propuestos por Bonomo (2004).

En los núcleos se relevaron los siguientes atributos: materia prima (tipo de roca o mineral y calidad), forma-base primaria, cantidad y forma de los planos de percusión empleados, reserva de corteza (ausencia total= 0; presencia parcial $<50 \%$; presencia parcial $>50 \%$; y presencia total $=100 \%$ ), cantidad mínima de lascados, largo y ancho máximo del lascado, medidas (largo, ancho, espesor), forma según los negativos de lascado, y designación morfológica.

Para la clasificación de rodados fluviales se utiliza la propuesta de Teruggi (1982) que distingue entre guijas $(0,4-1,6 \mathrm{~cm})$, guijarros $(1,6-6,4 \mathrm{~cm})$ y guijones $(6,4-25,6 \mathrm{~cm})$. En cuanto a la calidad de las materias primas líticas se consideraron los criterios de Nami y Rabassa (1988). Estos autores clasifican la calidad en una escala nominal que abarca las categorías: mala, regular, buena y excelente. Para el análisis de los materiales líticos de esta tesis se confeccionó la Tabla 4.2 donde se muestra que la calidad es relativa e inversamente proporcional según la técnica empleada en la elaboración de instrumentos líticos, ya sea por talla o picado, abrasión y/o pulido. Así por ejemplo, un nódulo arenisca es más adecuado para la fabricación de una bola o un mortero que un nódulo de calcedonia, que es más adecuado para confección de filos cortantes. Cabe aclarar que el hecho de que una misma materia prima pueda definirse como mala, regular, buena o excelente, toma en consideración las variaciones faciales de un mismo depósito geológico. Así por ejemplo, una caliza silicificada de la Formación Guichón puede ser buena o excelente dependiendo de la densidad de inclusiones y/o impurezas que tenga; pudiendo incluso una misma roca presentar cualidades heterogéneas. 
Tabla 4.2. Calidad de las materias primas líticas regionales clasificadas nominalmente de acuerdo a la técnica de elaboración de instrumentos utilizada.

\begin{tabular}{|c|c|c|c|}
\hline \multirow{2}{*}{ Origen geológico } & \multirow{2}{*}{ Materia prima } & Percusión y presión & Picado, abrasión y/o pulido \\
\hline & & Calidad & Calidad \\
\hline \multirow{4}{*}{ Rocas magmáticas } & Calcedonia & buena/ excelente & mala \\
\hline & Ágata & excelente & mala \\
\hline & Cuarzo & mala/ regular & mala \\
\hline & Basalto & mala/ regular/ buena & buena/ excelente \\
\hline \multirow{5}{*}{ Rocas sedimentarias } & Sílice & excelente & mala \\
\hline & Caliza silicificada & buena/ excelente & mala \\
\hline & Xilópalo & regular/ buena/ excelente & mala \\
\hline & Silcreta & mala/ regular/ buena & mala/ regular/ buena \\
\hline & Arenisca & mala/ regular/ buena & excelente \\
\hline Rocas metamórficas & Cuarcita intertrap & mala/ regular/ buena & buena/ excelente \\
\hline
\end{tabular}

\section{4- TECNOLOGÍA CERÁMICA}

En relación al abordaje de la tecnología cerámica se buscó determinar las características morfológicas, tecnológicas y funcionales de las vasijas y de los demás artefactos, y reconocer tradiciones tecnológicas que reflejaran interacción y homogeneidad cultural. Asimismo, se buscó una aproximación a su contexto social de producción y uso y a su rol y significado dentro de la sociedad (Calvo Trías y García Roselló 2014; Gosselain 1999, 2000). También se considera que algunos de los atributos de la cerámica, como por ejemplo la variabilidad de tamaño y forma de las vasijas, la densidad de producción y descarte, las técnicas de decoración y modelado, entre otros, permitirían una aproximación a la estabilidad de las ocupaciones (Di Prado 2015; Frère 2014).

Para el estudio de la cerámica se siguieron las propuestas de Balfet y colaboradores (1992), Brochado y Monticelli (1994), Brochado y colaboradores (1990), Cremonte y Bugliani (2006-2009), La Salvia y Brochado (1989), Orton y colaboradores (1997), Primera Convención Nacional de Antropología (1966), Rice (1987), Rye (1994), Shepard (1956), entre otros. En cada tiesto del conjunto cerámico se relevaron e identificaron los siguientes atributos: parte de la vasija, tamaño, espesor, técnica de manufactura, tratamiento de superficie, color, cocción estimada, estructura de la pasta, forma de borde y labio, perfil de las vasijas, diámetro de boca, decoración, rastros de hollín y alteraciones posdepositacionales.

En cuanto a las partes de una vasija los tiestos fueron clasificados como bordes, bases y cuerpos; dentro de estos últimos en algunos casos fue posible identificar hombros. El tamaño máximo de un tiesto de determinó midiendo la distancia absoluta en línea recta entre los dos puntos 
más extremos de su superficie, independientemente si el mismo fuera un fragmento de borde, base o cuerpo. De esta forma la variable continua "longitud" fue seccionada en unidades de $1 \mathrm{~cm}$, donde se incluyeron los tiestos conformando conjuntos de distintos tamaños correlativos $(0-1 \mathrm{~cm} ; 1,1-2 \mathrm{~cm}$; 2,1-3 cm; etc.). Tamaños menores a $5 \mathrm{~cm}$ se consideran pequeños, entre 5,1 y $10 \mathrm{~cm}$ son medianos y mayores a $10 \mathrm{~cm}$ grandes. El espesor se midió en el máximo grosor del tiesto; en el caso de los bordes se tomaron dos medidas, una en el máximo grosor y otra a 0,5 cm de la línea del labio.

En relación a la técnica de manufactura se distinguió entre enrollado y modelado. En cuanto al tratamiento de superficie se distinguió entre plástico y pintado; el primero incluye el alisado, pulido, corrugado (simple, espatulado o estriado), unguiculado (simple, espatulado o estriado), cepillado, y sus combinaciones; y el segundo incluye la aplicación de pigmentos colorantes, en superficie externa y/o interna. El color de la pasta de cada tiesto fue relevado en tres sectores: núcleo, superficie externa e interna. A partir del color fue estimada en algunos casos el tipo de cocción, diferenciándose entre oxidante, oxidante incompleta y no oxidante (Feely 2013; Rye 1994; Vitelli 1997).

En la determinación de atributos de la pasta e inclusiones, además de lupa binocular se utilizó ácido clorhídrico (HIC) e imán magnético. Entre las pastas se diferenció entre pasta con inclusiones o sin ellas; en el caso de presentar se intentó determinar el tipo, distribución y abundancia de las mismas.

Los bordes se diferencian entre rectos, evertidos e invertidos, pudiendo tener refuerzos externos o internos. Los labios se diferencian entre recto, convexo y angular (biselado o doble biselado). Mediante la utilización de una escala de círculos concéntricos equidistantes a intervalos de $0,5 \mathrm{~cm}$, fue posible determinar el perfil y el diámetro de la boca de algunos recipientes. En la clasificación morfológica de las vasijas se siguió básicamente la propuesta de Balfet y colaboradores (1992) y de Cremonte y Bugliani (2006-2009), diferenciándose en vasijas no restringidas, restringidas simples y dependientes, y restringidas independientes. Los contornos de las mismas pueden ser simples, inflexionados, compuestos y complejos. En base a estas clasificaciones se identifican categorías como platos, escudillas, cuencos, ollas y botellas.

Cabe mencionar como antecedente que Serrano (1950) propuso un conjunto de formas para las vasijas de lo que denominó Región Uruguaya-Deltica y que comprende el área de estudio (Figura 4.3A). Posteriormente, Boretto y colaboradores (1975) presentan formas para la alfarería del río Negro (Fase Vizcaíno); Díaz (1980) propone formas para el río Uruguay medio en base a la cerámica de la zona de Salto Grande; Cione y colaboradores (1977) presentan formas para el sitio arqueológico Cerros de los Pampas (Gualeguaychú); Caggiano (1979, 1983b) presenta las formas para los sitios arqueológicos Túmulo I del Brazo Largo, Túmulo I del Brazo Gutiérrez y El Ceibal 1; y por último, Hilbert $(1990,1991)$, tomando como base la propuesta de Díaz (1980) e incorporando datos propios 
de la ROU presenta un conjunto de formas para el río Uruguay que identifica con la cultura entrerriana y los ribereños plásticos.

Las formas básicas de las vasijas de las cinco últimas propuestas no difieren mayormente de las presentadas por Serrano (1950) independientemente de la decoración. En el río Uruguay también se registran formas identificadas con la entidad arqueológica Goya-Malabrigo (Ceruti 2003a; González 1977; Politis y Bonomo 2012) que incluyen las clásicas campanas y los apéndices biomorfos (Díaz 1980; Gaspary 1950; Hilbert 1991). Asimismo, Hilbert (1991) registra otras formas como las denominadas: tacitas (pequeñas vasijas de paredes gruesas elaboradas por modelado y serian ofrendas mortuorias) (Figura 4.3C); vasijas naviculares o en forma de calabazas con morfologías asimétricas y bocas irregulares (subcirculares, elipsoidales, triangulares, etc.) (Figura 4.3D); y botellones. Estos botellones fueron presentados por Freitas (1953a) con dos variantes de base cóncava, una con cuello y boca abierta y otra sin cuello con boca cerrada y agujero lateral (Figura 4.3E y F). Hilbert (1991) plantea que ninguna de estas variantes tiene la base cerrada, sino que serían de base abierta y entonces propone dos tipos que denomina: 1- botellones de forma tubular con abertura doble (bocas y base; aunque ninguno de sus dibujos presenta la base) y cuello que no está siempre simétricamente centrado; y 2- botellones cerrados en la parte "superior" con uno o dos orificios laterales, generalmente tienen cuello y a veces en la zona "superior" o de diámetro menor pueden presentar una protuberancia (Figura 4.3G).

Para la clasificación de los apéndices modelados y campanas identificadas con la GoyaMalabrigo se toma el trabajo de Serrano (1946) por considerar que es el que mejor define las variantes de este tipo de alfarería (Figura 4.3B). Serrano (1946) clasifica los apéndices en: 1Escultóricas macizas con concavidad; 2- Escultóricas macizas (incluye alfarerías gruesas o "campanas"); 3-Cóncavas; 4- Recortadas; 5- Maciza marginal; y 6-vasijas ornitomorfas (o zoomorfas) completas. 


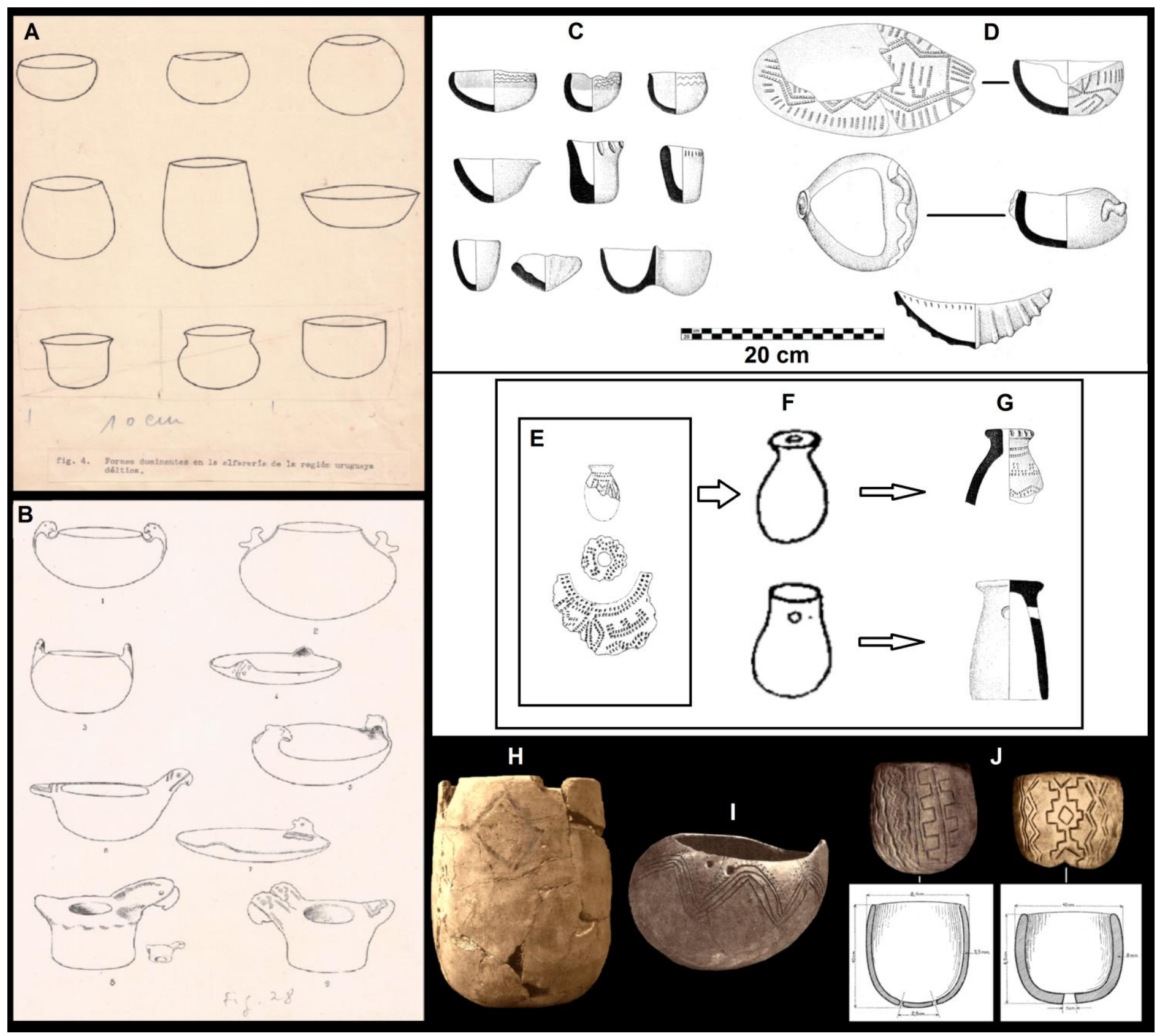

Figura 4.3. Formas de la alfarería del río Uruguay. A: formas predominantes de las vasijas (Serrano 1950$)^{1}$. B: las principales formas de los apéndices zoomorfos y vasijas propuestos para el río Paraná pero también registradas en el río Uruguay (Serrano 1946) ${ }^{2}$. C: tacitas; la última es doble (Hilbert 1991). D: vasijas en forma de calabazas (Hilbert 1991). E: botellón reconstruido por Freitas (1953a) procedente del sitio arqueológico Túmulo de La Blanqueada (ROU). F: las dos variantes de botellones según Freitas (1953a). G: las dos formas de botellones reconstruidas según Hilbert (1991); la superior es la misma pieza que usó Freitas (1953a) (letra E). H: vasija pintada procedente de Paso Paysandú (Colón); altura 24 cm, diámetro de boca 18 (Serrano 1933a). I: vasija incisa procedente de Paso Paysandú (sin medidas) (Serrano 1936). J: "vasos" perforados en la "base" de la zona de Puerto Basilio (Gualeguaychú); altura 10 y $8,5 \mathrm{~cm}$ respectivamente, diámetro de boca 8,4 y $10 \mathrm{~cm}$ respectivamente (Greslebin 1931b).

\footnotetext{
${ }^{1}$ La imagen es la original que fuera preparada por Serrano y sería publicada en 1950 . Se observa letra del autor: "10 cm".

2 La imagen es la original que fuera preparada por Serrano y sería publicada en 1946, 1950 y 1972 . Se observa la letra del autor: "Fig. 28”. 
Para la identificación, clasificación y asignación de tiestos y vasijas cerámicas a los guaraníes se siguieron las propuestas de Brochado (1984), Brochado y Monticelli (1994), Brochado y colaboradores (1990) y La Salvia y Brochado (1989). Estos autores proponen una serie de reglas prácticas para la inferir la forma original de la alfarería guaraní y correlacionarla con usos específicos. Tal abordaje aplica un esquema de analogía etnohistórica y propone un sistema taxonómico que vincula la forma, la decoración y la funcionalidad de los recipientes. Sintéticamente, los autores establecen seis clases funcionales (Figura 4.4): 1) yapepó: asociado con la preparación de alimentos por hervor, análogo a la olla; 2) ñaetá: asociado con la preparación de alimentos por hervor, análogo a la cazuela o cacerola; 3) ñamôpyû: asociado con tostar/asar harina de mandioca, análogo a un tostador; 4) cambuchí: asociado con la preparación, el acopio, la fermentación y el servicio líquidos, análogo a la tinaja, cántaro o jarro; 5) ñaembé o tembiiru: asociado con el servicio y consumo de alimentos, análogo al plato o cuenco; 6) cambuchí caguâbá: asociado con el servicio y consumo de líquidos, análogo al vaso.

Los yapepó se caracterizan por bordes evertidos, con perfiles compuestos y curvos, y base conoidal o redondeada. Los ñaetá se caracterizan por bordes rectos o levemente evertidos, con perfiles simples y abiertos, y base plana o redondeada. Las vasijas destinadas a la producción, el almacenaje y el consumo de bebidas presentan superficies pintadas en su mayoría, además de lisas. De esta forma los ñamôpyû se caracterizan por bordes levemente invertidos, con perfiles simples y playos, y base plana o levemente redondeada. Los cambuchí se caracterizan por bordes rectos o levemente evertidos, con perfiles compuestos y curvos y base conoidal, redondeada o plana. Los cambuchí caguâbá se caracterizan por bordes levemente invertidos y base conoidal o elipsoidal. Por último, los recipientes asociados con el servicio, los ñaembé o tembiiru, se caracterizan por bordes en su mayoría rectos, con perfiles simples y abiertos, y base plana o levemente redondeada. 


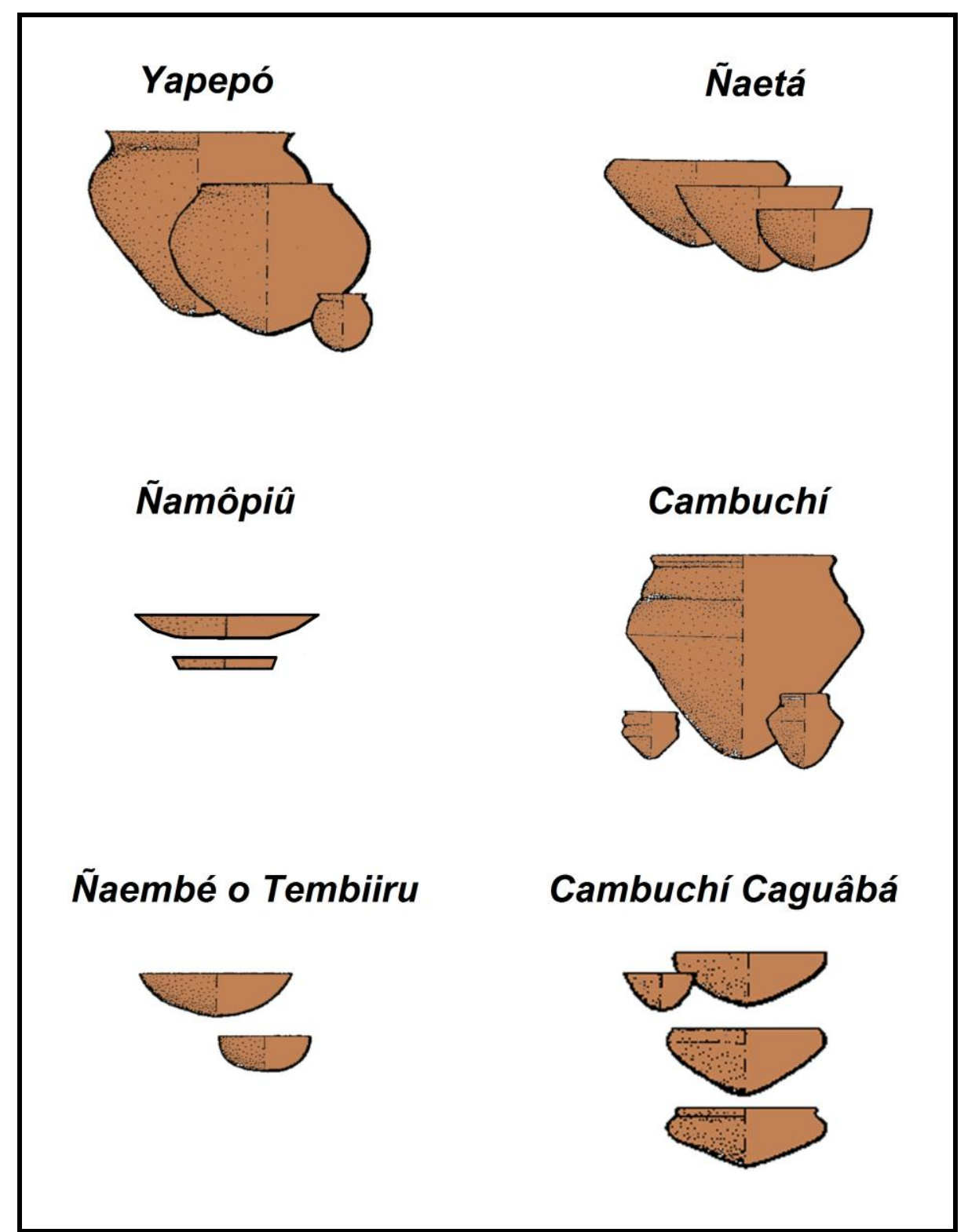

Figura 4.4. Formas predominantes de la alfarería guaraní según las clases funcionales (Tomado y modificado de Brochado y Monticelli 1994).

En relación a la decoración se consideraron cuatro tipos que incluyen; aplicación de pintura, desplazamiento de materia, extracción de materia y pastillaje. Dentro del primer tipo se distinguió entre total o zonal para cada fragmento, y en cuanto a los elementos que componen los diseños decorativos, se distinguió entre franja y línea, con orientación vertical, horizontal o curva, y sus combinaciones. El segundo tipo incluye distintas técnicas como incisión de surco rítmico, línea y punto, corrugado, unguiculado y cepillado, y sus combinaciones. El tercer tipo incluye achaflanamiento y ha conformado bordes y labios dentados. El cuarto tipo consiste en la aplicación sobre el borde y/o cuerpo de porciones de pasta modelada. El corrugado, unguiculado y cepillado fueron considerados simultáneamente como tratamiento de superficie plástico y decoración. 
Se determinó la presencia o ausencia de hollín en la superficie externa o interna y la cantidad relativa (escasa $<33 \%$, moderada $33-66 \%$ y abundante $>66 \%$ ). También se registraron alteraciones postdepositacionales de los tiestos considerando todas aquellas modificaciones estructurales físicas o químicas producto de agentes ambientales, como por ejemplo erosión, resquebrajamiento, agrietado, entre otras. No se realizaron remontajes sistemáticos, pero en los casos donde se remontaron fragmentos o se determinó que varios tiestos pertenecen a la misma vasija, cada grupo de fragmentos se contabilizó como una unidad.

Es necesario hacer una aclaración sobre los conjuntos cerámicos analizados en cada sector. En la muestra procedente de los sectores A y B, dada la baja frecuencia relativa de la alfarería, el análisis integral incluyó todos los tiestos mayores a $2 \mathrm{~cm}$. En la muestra del sector $\mathrm{C}$ se analizaron solo tiestos mayores a $5 \mathrm{~cm}$ (medianos y grandes); y particularmente en el sitio arqueológico Cerro de Boari 3, debido a la abundancia de tiestos producto de una excavación sistemática, el análisis integral incluyó solamente los bordes que permitieran la determinación del diámetro de boca y la estimación el perfil de la vasija.

En los tres sectores (excluyendo Cerro de Boari 3) para la caracterización de formas de bordes, labios y tipos de decoración, se consideraron todos los tiestos independientemente de su tamaño. La inclusión de tiestos pequeños en el análisis se realizó con el objetivo de poder reconstruir la forma de la mayor cantidad posible de recipientes; considerando además que el registro arqueológico regional muestra que hay vasijas muy pequeñas (véase p. ej. Hilbert 1991; y Serrano 1946, 1950), que al romperse probablemente se dispersen en fragmentos de tamaños muy reducidos. En cuanto al análisis de la decoración, los tiestos pequeños se incluyen con el objetivo de establecer la variabilidad general de técnicas utilizadas y de motivos decorativos. La exclusión de este tipo de fragmentos seguramente provocaría, sobre todo en muestras pequeñas como las de los sectores A y B, la subestimación de las frecuencias de formas de bordes y labios, y de tipos de decoración presente en las muestras.

\section{5- EXPLOTACIÓN FAUNÍSTICA}

El abordaje del registro arqueofaunístico desde una perspectiva integral e integrándolo al estudio del resto de las evidencias arqueológicas, resulta crucial para comprender los procesos adaptativos y los sistemas tecnológicos que involucran a las poblaciones indígenas que ocuparon este entorno acuático. Este registro es entendido como el resultado de la combinación de la estructura natural de los recursos y de los procesos culturales y tafonómicos que lo han afectado.

En nuestro caso se considera el concepto de explotación faunística en sentido amplio y no solo referido al consumo de las especies (Quintana et al. 2002). Este concepto involucra además el 
conjunto de procesos y relaciones sociales involucradas en la obtención, uso y descarte de los restos faunísticos. El estudio de los restos de fauna recuperados en sitios arqueológicos permite comprender la estructura y la disponibilidad de recursos en un ambiente y momento dado, hacer inferencias paleoambientales, identificar los métodos de obtención, procesamiento, consumo y descarte de los taxa, identificar su origen y reconocer la incidencia de procesos tafonómicos, y en sentido general determinar las estrategias de subsistencia y la movilidad vinculadas a la distribución, predictibilidad, abundancia y disponibilidad de los animales (Kelly 1992). Esto no significa que la estructura de los recursos determine dichas estrategias, pero sin duda que condiciona la tecnología orientada a su explotación y por lo tanto la organización de ciertas prácticas sociales e ideacionales vinculadas.

Para la determinación anatómica y taxonómica de los materiales arqueofaunísticos recuperados se utilizaron muestras comparativas modernas (de la División Paleontología de Vertebrados del Museo de La Plata y la Colección Zoológica del Museo Antonio Serrano) y atlas osteológicos (Barone 1990; Baumel et al. 1993; Bisbal y Gómez 1986; France 2009; Galván et al. 2001; Loponte 2004). Todos aquellos especímenes óseos de mamíferos cuyo estado de fragmentación no permitió la determinación específica fueron incluidos en la categoría MAMALIA. Siguiendo a González (2002) la categoría se subdividió de acuerdo al tamaño estimado en: pequeños (de 100 grs. 3 kg.), medianos (de 3 a 25 kg.) y grandes mamíferos (mayores a $25 \mathrm{Kg}$.); menores a 100 grs. se consideran micromamíferos y en este estudio todos fueron agrupados dentro de los mamíferos chicos.

Posteriormente a la identificación taxonómica y anatómica se realizó la cuantificación de los datos, calculándose la abundancia taxonómica y anatómica a partir de las siguientes medidas: NISP, NISP\%, MNI, MNE, MAU y MAU\% (Binford 1981, 1984; Grayson 1984; Lyman 2008; Mengoni Goñalons 1986, 1988, 1999; Salemme et al. 1988). Por último, se relevaron las siguientes variables tafonómicas: meteorización, depositación química, marcas de raíces, de roedores, de carnívoros, de pisoteo, huellas de corte, de impacto, evidencias de termoalteración, aserrado perimetral y tipos de fracturas (Behrensmeyer 1978; Binford 1981; De Nigris 1999, 2003; Gutiérrez 2004, 2006; Lyman 1994; Mengoni Goñalons 1988, 1999; Miotti y Salemme 1989; Politis y Madrid 1988; Salemme et al. 1988; Schiffer 1987; Wood y Johnson 1978; entre otros). Para evaluar la meteorización de los roedores pequeños o microroedores se siguió la propuesta de Andrews (1990) para micromamíferos.

En relación al abordaje de la tecnología ósea (en sentido amplio ya que se incluyen huesos, astas y dientes) y malacológica se buscó determinar los taxa y elementos anatómicos utilizados y la composición de los conjuntos instrumentales. También se realizan algunas observaciones sobre el proceso de manufactura y las diferentes tecnologías involucradas. Asimismo, se buscó establecer en qué medida esta tecnología incidió en la representación arqueológica del conjunto faunístico y en la explotación de determinadas especies y/o en la selección de unidades anatómicas a ser utilizadas 
como soportes-base de instrumentos o adornos. A partir del abordaje de los adornos y los artefactos decorados se buscó identificar indicadores de aspectos simbólicos y de diferenciación interpersonal.

Se utiliza el término soporte-base en vez de hueso-soporte, elemento-soporte o forma-base. Hueso-soporte es inadecuado ya que la materia prima de instrumentos y adornos no siempre es un hueso; elemento-soporte es incorrecto dado que en muy pocas ocasiones se utiliza un elemento entero, generalmente se utiliza una porción, un fragmento, una lasca, la raíz de un diente, etc. (un espécimen en el sentido de Salemme et al. 1988); y forma-base si bien sería un sinónimo se reserva para el estudio de la tecnología lítica. Soporte se puede referir a elemento o espécimen anatómico y base se refiere al punto de partida de la formatización.

Para la descripción y clasificación de los artefactos óseos y sus atributos se siguieron los lineamientos generales propuestos por varios autores (Buc 2010a; Camps-Fabrer 1977; CampsFabrer et al. 1974; Laporte 2014; Pérez Jimeno 2007; Pérez Jimeno y Buc 2010; Scheinsohn 1997; Schmitz et al. 1972; entre otros). Para instrumentos y adornos se relevaron las siguientes variables y atributos: integridad, completitud, taxón, elemento anatómico, porción del elemento, dimensiones máximas (largo, ancho, espesor), depositación química, tratamiento y evidencias de manufactura y/o uso. Estos últimos incluyen pulido, desbaste, ahuecado, huellas de filos, aserrado perimetral, decoración (incisión o pintura), perforación y termoalteración. Se considera al pulido como la acción de desgaste abrasivo y formatización de las superficies de un artefacto. Pudiendo ser este un pulido "grueso" o "fino"; en el primer caso generalmente se observan claras marcas abrasivas paralelas que permiten inferir que el instrumento, superficie o sustrato (por ej. arena) de abrasión presentaba grano grueso; en el segundo caso la abrasión genera una superficie muy lisa y pulida y hasta con brillo, no dejando huellas macroscópicas del instrumento, superficie o sustrato utilizado en la formatización. Pudiendo reflejar por ejemplo el uso de rocas de grano más fino, cuero, vegetales, etc. El pulido también podría generarse por el uso del artefacto.

Para la clasificación de los tipos de instrumentos a nivel macroscópico se considera conjuntamente en cada caso: morfología total de la pieza, taxón, elemento anatómico, dimensiones de la porción activa, los tratamientos de manufactura ya mencionados, atributos como la presencia o ausencia de epífisis en huesos largos o cabezas en las espinas de peces, perforaciones, pedúnculos, orificios, canalículos naturales y fracturas. Las denominadas preformas no presentan rastros de uso pero sí de manufactura; y no se consideran tipos sino que se clasifican por su "tendencia morfológica" hacia algunos de los tipos morfológicos determinados o conocidos (Aschero 1975, 1983).

En síntesis, la clasificación se focalizó sobre la morfología total y la funcionalidad hipotética basada en datos etnoarqueológicos, etnohistóricos y arqueológicos (Caggiano 1977b; Camps-Fabrer 1977, 1993, 1995; Camps-Fabrer et al. 1974; Chiri 1973; Hilbert 1991; Lothrop 1928, 1932; Orquera y 
Piana 1986-1987; Paucke 1942, 1943, 1944; Rick et al. 2001; Scheinsohn 1997; Schmitz et al. 1972; entre otros).

\section{6- RESTOS ÓSEOS HUMANOS}

Los restos óseos humanos y su contexto de hallazgo en los sitios arqueológicos constituyen una fuente de información valiosa sobre una multiplicidad de factores biológicos y los comportamientos culturales (p. ej. salud-enfermedad, actividades físicas, dieta, violencia interpersonal y prácticas mortuorias), que caracterizan la trayectoria histórica de las poblaciones que representan. En este sentido, se estudiaron tanto la colección osteológica recuperada en nuestros trabajos de campo, como la colección del Museo Arqueológico Manuel Almeida (MAMA) de Gualeguaychú, una de las más importantes del Nordeste argentino (Castro y Del Papa 2015).

Para la cuantificación de los restos óseos se utilizaron las medidas NISP, MNE y MNI. EI cálculo del MNI se realizó a partir del cráneo. Las estimaciones de edad y sexo se realizaron a partir de cráneos. Para la edad en subadultos, se siguieron técnicas de seriación, a partir de la medición en el desarrollo de la dentición (Ubelaker 1989). Para la edad en adultos se siguió el método de segmentos de suturas craneales (Buikstra y Ubelaker 1994). Para el sexo se utilizó el sistema de puntuación para características craneales sexualmente dimórficas (Buikstra y Ubelaker 1994).

Para evaluar el estado de integridad de los restos óseos humanos de la colección del MAMA se calculó el índice de fragmentación (IF= MNE/NISP) siguiendo la propuesta de Mondini (2003) y diferenciando entre índice bajo $(0,67-1)$, medio $(0,34-0,66)$ y alto $(0,0-0,33)$. Dicho índice se calculó para la muestra total de la colección, así como para elementos craneales y poscraneales por separado. Asimismo, con el fin de evaluar de manera general el grado de completitud de cada uno de los cráneos (Guichón et al. 2000), estos fueron agrupados en categorías de 100\%, 75\% y menor a $50 \%$.

\section{7- ANÁLISIS SEDIMENTOLógICOS, FITOLíticos Y ANTRACOLÓGICOS EN LA LOCALIDAD ARQUEOLÓGICA CERROS DE BOARI}

El estudio sedimentológico fue desarrollado por la Dra. Carola Castiñeira Latorre (CONICETDivisión Mineralogía, Petrología y Sedimentología del Museo de La Plata). Para los análisis sedimentarios y el reconocimiento composicional del contenido en sílice biogénico (fitolitos, diatomeas, espículas, cistos de crisófitas) se seleccionaron muestras representativas de cada capa diferenciada. 
Los análisis sedimentológicos se realizaron según metodologías estándares (Carver 1971). Las muestras fueron sometidas a la eliminación de materia orgánica y carbonatos mediante $\mathrm{H}_{2} \mathrm{O}_{2}$ al $30 \%$ y $\mathrm{HCl}$ al 35\%. Para la dispersión se utilizó $\left(\mathrm{NaPO}_{3}\right) 6$ al $4 \%$ y agitación mecánica. El análisis de tamaño de grano se realizó para las fracciones grava y arena por tamizado a intervalos de un grado de phi, y para las fracciones limo y arcilla por el Método Internacional de la Pipeta (Day 1965; Carver 1971). Las fracciones retenidas en los tamices (de $2 \mathrm{~mm}$ a 0,062 $\mathrm{mm}$ ) fueron observadas en lupa binocular a efectos de discriminar el porcentaje de material silicoclástico del microarqueológico; este último, generalmente representado por fragmentos de carbón, fauna, valvas de moluscos, entre otros. Los porcentajes del contenido de limo, arcilla, arena y grava (integrada por grumos sedimentarios termoalterados y microrestos arqueológicos) se utilizaron para la clasificación granulométrica según Folk (1954). Se semicuantificaron las especies de argilominerales según el método propuesto por Pirce y Siegel (1969), Lluch y Spalleti (1976) y Blasi (1988). Para el análisis comparativo en la composición argilomineral, se colocaron los valores de frecuencia relativa en un triángulo ternario que permite visualizar diferentes áreas de asociación argilomineral (ZAAm).

Los análisis composicionales mineralógicos se desarrollaron mediante microscopía de polarización en las facciones arena muy fina y por difractometría de rayos X (DRX) en muestra total en polvo y para la fracción arcilla en muestras natural, calcinadas y glicoladas. Los análisis biocomposicionales se desarrollaron en la fracción limo mediante microscopía óptica en preparados fijos. Los morfotipos biosilíceos se identificaron en base a datos generados para el área y la región por Castiñeira y colaboradores (2013) y Colobig y colaboradores (2015).

El estudio fitolítico fue desarrollado por la Dra. María de los Milagros Colobig (Centro de Investigaciones Científicas y Transferencia de Tecnología a la Producción-CONICET, Diamante), con el fin de evaluar la presencia de restos vegetales en la secuencia estratigráfica. Se analizaron siete muestras extraídas (Figura 8.3) que fueron procesadas previamente siguiendo el protocolo establecido por Zucol y colaboradores (2010). Para su observación en microscopio Arcano XSZ 107 con cámara acoplada, se montaron en preparados microscópicos líquidos, y se realizaron recuentos e identificaciones taxonómicas en base a los atributos cuali-cuantitativos de ICNWG (2005) y Patterer y colaoradores (2011).

El estudio antracológico fue desarrollado por las Dras. María Jimena Franco (Centro de Investigaciones Científicas y Transferencia de Tecnología a la Producción-CONICET, Diamante) y Rita Soledad Ramos (Facultad de Ciencia y Tecnología, Universidad Autónoma de Entre Ríos, Oro Verde). La metodología usada para el estudio de los carbones fue por fractura, de forma de obtener los tres planos tradicionales de observación (corte transversal, longitudinal radial y longitudinal tangencial). Posteriormente se realizó la observación bajo microscopio estereoscópico para la identificación taxonómica mediante la comparación con material de referencia. Los resultados de estos análisis serán expuestos en la discusión final de la tesis (Capítulo 9) dado su carácter preliminar. 


\section{Capítulo 5}

\section{DISTRIBUCIÓN ESPACIO-TEMPORAL Y CARACTERIZACIÓN DEL REGISTRO ARQUEOLÓGICO EN EL SECTOR A}




\section{CAPÍTULO 5}

\section{DISTRIBUCIÓN ESPACIO-TEMPORAL Y CARACTERIZACIÓN DEL REGISTRO ARQUEOLÓGICO EN EL SECTOR A}

En este capítulo se presentan y discuten los resultados de las prospecciones sistemáticas, de los sondeos estratigráficos y del análisis de los materiales arqueológicos recuperados en el sector A, dentro del departamento Villaguay. En este sector se realizaron prospecciones pedestres intensivas sobre las márgenes del río Gualeguay y de los arroyos El Tigre y Lucas. Además se prospectaron algunos cuerpos de agua que en época de creciente se comunican con el río Gualeguay como son las lagunas Blanca, García, y Blanca y Negra. Las prospecciones fueron dirigidas hacia sitios arqueológicos previamente conocidos por el señor Marcelo Lugrin, Director del Museo Arqueológico y Antropológico Indígena Tierra de Minuanes (MTM) de la ciudad de Villaguay. También se relevaron sectores al azar en zonas adyacentes a los sitios arqueológicos que estaban próximas a fuentes de agua actuales o a paleocuaces.

\section{1- RESULTADOS}

\subsection{1- SITIOS ARQUEOLÓGICOS Y HALLAZGOS AISLADOS}

Se identificaron 14 sitios arqueológicos y nueve hallazgos aislados, todos en posición superficial (Tabla 5.1 y Figura 5.1). No se detectaron sitios en estratigrafía a pesar de que se realizaron cinco sondeos estratigráficos y 10 pruebas de pala. Los materiales arqueológicos incluyen artefactos líticos y cerámicos (Tabla 5.2), además de algunas masas de arcilla cocida y geofactos. No se registraron restos óseos faunísticos o humanos.

Cabe aclarar que en la nomenclatura de los sitios arqueológicos se utilizaron nombres y números correlativos a los previamente usados por el señor Lugrin (véase Ceruti 2007; Hocsman 2007). Además, en siete casos (La Lomita, La Lomita 2, Puente del Tigre, Nogueira 2, Laguna de García, Laguna Blanca y Negra, y Ramblones) se recuperaron menos de 20 objetos, pero aun así se consideran sitios arqueológicos en la Tabla 5.2 dado que el señor Lugrin recolectó en el mismo lugar, y previamente a nuestras prospecciones, numerosos artefactos (véase Tabla 5.12). Todos los 
artefactos recuperados por Lugrin se encuentran depositados en el Museo Tierra de Minuanes.

Algunos de estos materiales son estudiados en la Sección 5.1.3.

Tabla 5.1. Sitios arqueológicos y hallazgos aislados en el sector A.

\begin{tabular}{|c|c|c|c|c|}
\hline $\begin{array}{l}\text { Sigla en la } \\
\text { Figura } 5.1\end{array}$ & Sitios arqueológicos & Topografía & \multicolumn{2}{|c|}{$\begin{array}{l}\text { Coordenadas geográficas, } \\
\text { Datum Wgs84 }\end{array}$} \\
\hline PB2 & Paso Blanco 2 & Ilanura & $\mathrm{S} 31^{\circ}, 52285$ & $059^{\circ}, 10599$ \\
\hline PB3 & Paso Blanco 3 & llanura & $\mathrm{S} 31^{\circ}, 52568$ & O59, 10578 \\
\hline PB4 & Paso Blanco 4 & Ilanura & $\mathrm{S} 31^{\circ}, 52201$ & $059^{\circ}, 10849$ \\
\hline PAa & Pozo Azul a & Ilanura & $\mathrm{S} 31^{\circ}, 58891$ & O59 ${ }^{\circ}, 07711$ \\
\hline $\mathrm{PAb}$ & Pozo Azul b & Ilanura & $\mathrm{S} 31^{\circ}, 58754$ & O59 ${ }^{\circ}, 07762$ \\
\hline LL & La Lomita & llanura & $\mathrm{S} 31^{\circ}, 71879$ & O59 ${ }^{\circ}, 12399$ \\
\hline LL2 & La Lomita 2 & llanura & $\mathrm{S} 31^{\circ}, 71649$ & $059^{\circ}, 11852$ \\
\hline PDT & Puente del Tigre & Ilanura & $\mathrm{S} 31^{\circ}, 73864$ & $059^{\circ}, 18401$ \\
\hline ED & El Dorado & barranca & $\mathrm{S} 31^{\circ}, 75186$ & $059^{\circ}, 13803$ \\
\hline $\mathrm{N} 2$ & Nogueira 2 & Ilanura & $\mathrm{S} 31^{\circ}, 76153$ & $059^{\circ}, 11600$ \\
\hline LDG & Laguna de García & barranca & $\mathrm{S} 31^{\circ}, 79090$ & $059^{\circ}, 13140$ \\
\hline LBN & Laguna Blanca y Negra & Ilanura & $\mathrm{S} 31^{\circ}, 85619$ & $059^{\circ}, 12675$ \\
\hline $\mathrm{R}$ & Ramblones & Ilanura & $\mathrm{S} 31^{\circ}, 86187$ & $059^{\circ}, 14084$ \\
\hline $\mathrm{R} 2$ & Ramblones 2 & Ilanura & $\mathrm{S} 31^{\circ}, 86892$ & O59, 13249 \\
\hline $\begin{array}{l}\mathrm{N}^{\circ} \text { en la } \\
\text { Figura } 5.1\end{array}$ & Hallazgos aislados & Topografía & \multicolumn{2}{|c|}{$\begin{array}{c}\text { Coordenadas geográficas, } \\
\text { Datum Wgs84 }\end{array}$} \\
\hline 1 & PB5 (Paso Blanco 5) & Ilanura & $\mathrm{S} 31^{\circ}, 52402$ & $059^{\circ}, 10542$ \\
\hline 2 & PB6 (Paso Blanco 6) & Ilanura & $\mathrm{S} 31^{\circ}, 52394$ & $059^{\circ}, 10539$ \\
\hline 3 & PB7 (Paso Blanco 7) & llanura & $\mathrm{S} 31^{\circ}, 52445$ & $059^{\circ}, 10524$ \\
\hline 4 & PB8 (Paso Blanco 8) & llanura & $\mathrm{S} 31^{\circ}, 52446$ & $059^{\circ}, 10532$ \\
\hline 5 & RG1 (Río Gualeguay 1) & llanura & $\mathrm{S} 31^{\circ}, 76216$ & $059^{\circ}, 11439$ \\
\hline 6 & RG2 (Río Gualeguay 2) & Ilanura & $\mathrm{S} 31^{\circ}, 76072$ & $059^{\circ}, 11492$ \\
\hline 7 & PG (Puente Gualeguay) & lecho del río & $\mathrm{S} 31^{\circ}, 80373$ & $\mathrm{O} 59^{\circ}, 12642$ \\
\hline 8 & R3 (Ramblones 3) & Ilanura & $\mathrm{S} 31^{\circ}, 86505$ & $\mathrm{O} 59^{\circ}, 14284$ \\
\hline 9 & R4 (Ramblones 4) & llanura & $\mathrm{S} 31^{\circ}, 86406$ & O59, 14162 \\
\hline
\end{tabular}




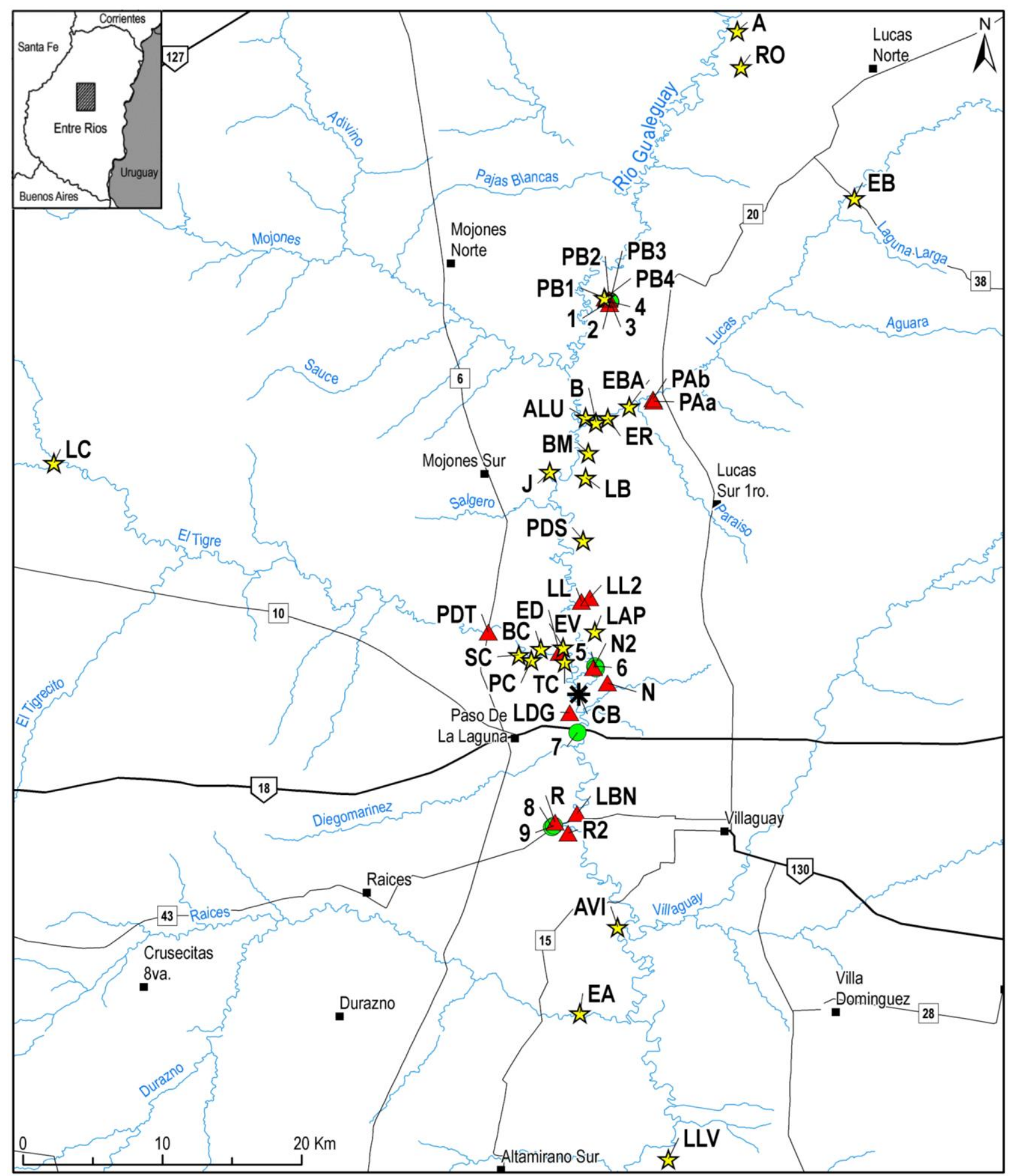

Figura 5.1. Sector A indicando los sitios arqueológicos (triángulos), los hallazgos aislados (círculos) y los materiales arqueológicos de la colección del Museo Tierra de Minuanes (estrellas); la ubicación de estos últimos se realizó utilizando Google Earth. También se indica el sitio arqueológico Nogueira (Poenitz 1970b) (letra N) y el lugar aproximado, denominado El Beso (asterisco), donde se recolectó la punta de proyectil Pay Paso de la Colección Beltrame (Castro y Terranova 2015). 


\subsubsection{1- Descripción contextual de los sitios arqueológicos y sus conjuntos artefactuales}

\section{Paso Blanco 2 (PB2)}

Ubicado en la margen izquierda del río Gualeguay a $1200 \mathrm{~m}$ de la costa y a $315 \mathrm{~m}$ al sudeste de la laguna Blanca (Figura 5.2A). El material arqueológico se dispone sobre un área sin cubierta vegetal. En este sitio se realizaron 18 transectas paralelas norte-sur y adyacentes de $2 \mathrm{~m}$ de ancho y $65 \mathrm{~m}$ de longitud. Cada transecta fue seccionada en unidades de muestreo de $5 \mathrm{~m}$ de largo. Asimismo, se realizó una recolección superficial dirigida sobre una calle adyacente al sitio, y dos

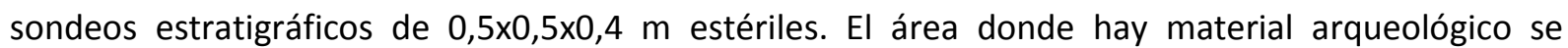
encuentra atravesado en su sector este por una zanja moderna de $1 \mathrm{~m}$ de ancho y 0,5 $\mathrm{m}$ de profundidad. Los materiales recuperados incluyen dos instrumentos líticos y 35 desechos de talla; ocho fragmentos de borde de alfarería y 45 de cuerpo (cuatro decorados -un borde y tres cuerpos- y 49 lisos -siete bordes y 42 cuerpos-) (Tabla 5.2). Se remontaron tres fragmentos cerámicos decorados (un borde y dos cuerpos) que se analizan como uno solo (Figura 5.5A); el fragmento de cuerpo decorado restante (Figura 5.5B) probablemente también corresponda a la misma vasija. Además, se registraron masas de arcilla cocida $(n=922)$ y geofactos $(n=6)$.

\section{Paso Blanco 3 (PB3)}

Ubicado en la margen izquierda del río Gualeguay a 1200 m de la costa y a 310 m al sur PB2. El material arqueológico se dispone sobre una extensa área sin cubierta vegetal. Se realizó una recolección superficial dirigida. Los materiales incluyen 22 desechos de talla y un núcleo (Tabla 5.2). Además, se registraron masas de arcilla cocida $(n=33)$.

\section{Paso Blanco 4 (PB4)}

Ubicado en la margen izquierda del río Gualeguay a $960 \mathrm{~m}$ de la costa, a $85 \mathrm{~m}$ al este de la laguna Blanca y a $255 \mathrm{~m}$ al noroeste de PB2. El material arqueológico se dispone sobre un área sin cubierta vegetal, que a su vez está sobre una lomada que desciende hacia la laguna. Se realizó una recolección superficial dirigida. Los materiales incluyen un instrumento y 13 desechos de talla; dos fragmentos de borde y tres de cuerpo, todos lisos (Tabla 5.2). Además, se registraron geofactos ( $\mathrm{n}=$ 5).

\section{Pozo Azul a (PAa)}

Ubicado en la margen izquierda del río Gualeguay a $4500 \mathrm{~m}$ de la costa y sobre la margen izquierda del arroyo Lucas a $675 \mathrm{~m}$ de su costa (Figura 5.2B). El material arqueológico se dispone sobre un área con una cubierta vegetal de gramíneas que reduce la visibilidad arqueológica, y está rodeado de vegetación xerófila. Se realizó una recolección superficial dirigida. Los materiales 
incluyen un desecho de talla y tres fragmentos de cuerpo lisos (Tabla 5.2). Además, se registraron masas de arcilla cocida $(n=38)$ y geofactos $(n=3)$.

\section{Pozo Azul b (PAb)}

Ubicado en la margen izquierda del río Gualeguay a $4500 \mathrm{~m}$ de la costa y sobre la margen izquierda del arroyo Lucas a $515 \mathrm{~m}$ de su costa, además se sitúa a $160 \mathrm{~m}$ al noroeste de PAa. Presenta características similares a PAa. Se realizó una recolección superficial dirigida. Los materiales incluyen dos desechos de talla y cinco fragmentos de cuerpo lisos (Tabla 5.2). Además, se registraron masas de arcilla cocida $(n=74)$ y geofactos $(n=5)$.

\section{La Lomita (LL)}

Ubicado en la margen izquierda del río Gualeguay a $400 \mathrm{~m}$ de la costa. El material arqueológico se dispone sobre una área de aproximadamente $80 \mathrm{~m}$ de diámetro, con una cubierta vegetal de gramíneas que reduce la visibilidad arqueológica y escasos arboles del bosque xerófilo. Se realizó una recolección superficial dirigida, además de dos sondeos estratigráficos de 0,5×0,5×0,4 m y dos pruebas de pala estériles. Los materiales incluyen tres desechos de talla; un fragmento de borde y 11 de cuerpo, todos lisos (Tabla 5.2).

\section{La Lomita 2 (LL2)}

Ubicado en la margen izquierda del río Gualeguay a $900 \mathrm{~m}$ de la costa y a $580 \mathrm{~m}$ al noreste de LL. El material arqueológico se dispone sobre un área sin cubierta vegetal. Se realizó una recolección superficial dirigida. Los materiales incluyen un fragmento de cuerpo liso (Tabla 5.2). Además, se registraron masas de arcilla cocida $(n=3)$.

\section{Puente del Tigre (PDT)}

Ubicado en la zona de intersección de la Ruta Provincial 6 y el arroyo El Tigre, del lado oriental de la ruta y a $100 \mathrm{~m}$ de la margen derecha del arroyo (Figura 5.2C). Se dispone en una extensa área sin cubierta vegetal rodeado de vegetación xerófila. Se realizó una recolección superficial dirigida. La zona se encuentra muy alterada por las obras de construcción de la ruta y por actividades agrarias como la circulación de ganado y la construcción de sistemas de riego. Los materiales recuperados incluyen seis desechos de talla (Tabla 5.2).

\section{El Dorado (ED)}

Ubicado en la orilla izquierda del arroyo El Tigre, a $8000 \mathrm{~m}$ al este de PDT (Figura 5.2D). El mismo se dispone sobre una barranca alta donde hay vegetación xerófila. Se realizó una recolección superficial dirigida y tres pruebas de pala sobre la terraza y una sobre la ladera donde se recuperó un 
fragmento cerámico probablemente retransportado desde la parte alta. El material es escaso y muy disperso sobre la superficie de la terraza y la ladera que desciende hacia el arroyo. Se destaca la escasa visibilidad arqueológica debido a la cubierta vegetal. Los materiales recuperados incluyen un instrumento y 10 desechos de talla; seis fragmentos de borde y 20 de cuerpo [cuatro decorados (tres bordes y un cuerpo -Figura 5.5C, D y E-) y 22 lisos (tres bordes y 19 cuerpos)] (Tabla 5.2). Se remontaron dos fragmentos bordes decorados que se analizan como uno solo (Figura 5.5C). Además, se registraron masas de arcilla cocida $(n=5)$ y geofactos $(n=7)$.

\section{Nogueira 2 (N2)}

Ubicado en la margen izquierda del río Gualeguay a $15 \mathrm{~m}$ de la costa y a $1500 \mathrm{~m}$ al noroeste del sitio arqueológico Nogueira (Poenitz 1970b), el cual fue relocalizado y georeferenciado (S31.77157; 059.10714) (Figura 5.1). El material se dispone sobre un área sin cubierta vegetal rodeada de pastizales y vegetación xerófila. Se realizó una recolección superficial dirigida. Los materiales incluyen dos instrumentos y cuatro desechos de talla (Tabla 5.2). Además, se registraron masas de arcilla cocida ( $n=3$ ). En Castro (2013) por un error este sitio arqueológico figura en la Tabla 1 como Nogueira cuando debería figurar como Nogueira 2. Lo mismo ocurre con la colección del MTM, todo el material catalogado como "Yacimiento Nogueira" corresponde al que aquí se denomina Nogueira 2 y no al mismo sitio arqueológico publicado por Poenitz (1970b).

\section{Laguna de García (LDG)}

Ubicado sobre la barranca alta de la laguna homónima a $840 \mathrm{~m}$ de la margen derecha del río Gualeguay. Presenta abundante vegetación xerófila y elementos propios de ambientes acuáticos como juncos y camalotes. Sobre la parte alta de la barranca se realizó una recolección superficial

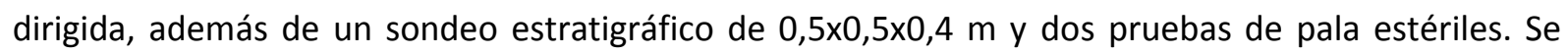
destaca la escasa visibilidad arqueológica debido a la vegetación. Desde este sitio arqueológico se tiene una visión panorámica del entorno de la laguna y es recurrentemente ocupado por pescadores en la actualidad. Los materiales recuperados incluyen tres fragmentos de borde y 11 de cuerpo, todos lisos (Tabla 5.2).

\section{Laguna Blanca y Negra (LBN)}

Ubicado sobre la margen de la laguna homónima a $150 \mathrm{~m}$ de la margen la margen izquierda del río Gualeguay. El material arqueológico se dispone sobre un área sin vegetación. Se realizó una recolección superficial dirigida. Los materiales incluyen dos fragmentos de cuerpo lisos (Tabla 5.2). 


\section{Ramblones (R)}

Ubicado en la margen derecha del río Gualeguay a $140 \mathrm{~m}$ de la costa. El material arqueológico se dispone sobre un área sin cubierta vegetal. Se realizó una recolección superficial dirigida. Los materiales incluyen dos fragmentos de cuerpo lisos (Tabla 5.2). Además, se registraron masas de arcilla cocida $(n=13)$.

\section{Ramblones 2 (R2)}

Ubicado en la margen derecha del río Gualeguay a $850 \mathrm{~m}$ de la costa y a $1100 \mathrm{~m}$ al sureste de R. El material arqueológico se dispone sobre un área con una cubierta vegetal de gramíneas que reduce la visibilidad arqueológica y rodeada de bosque xerófilo. Se realizó una recolección superficial dirigida y dos pruebas de pala con resultados negativos. Los materiales incluyen un desecho de talla; 11 fragmentos de borde y 47 de cuerpo, todos lisos (Tabla 5.2). Se remontaron dos fragmentos bordes que se analizan como uno solo. Además, se registraron masas de arcilla cocida $(n=16)$ y geofactos $(n=4)$.
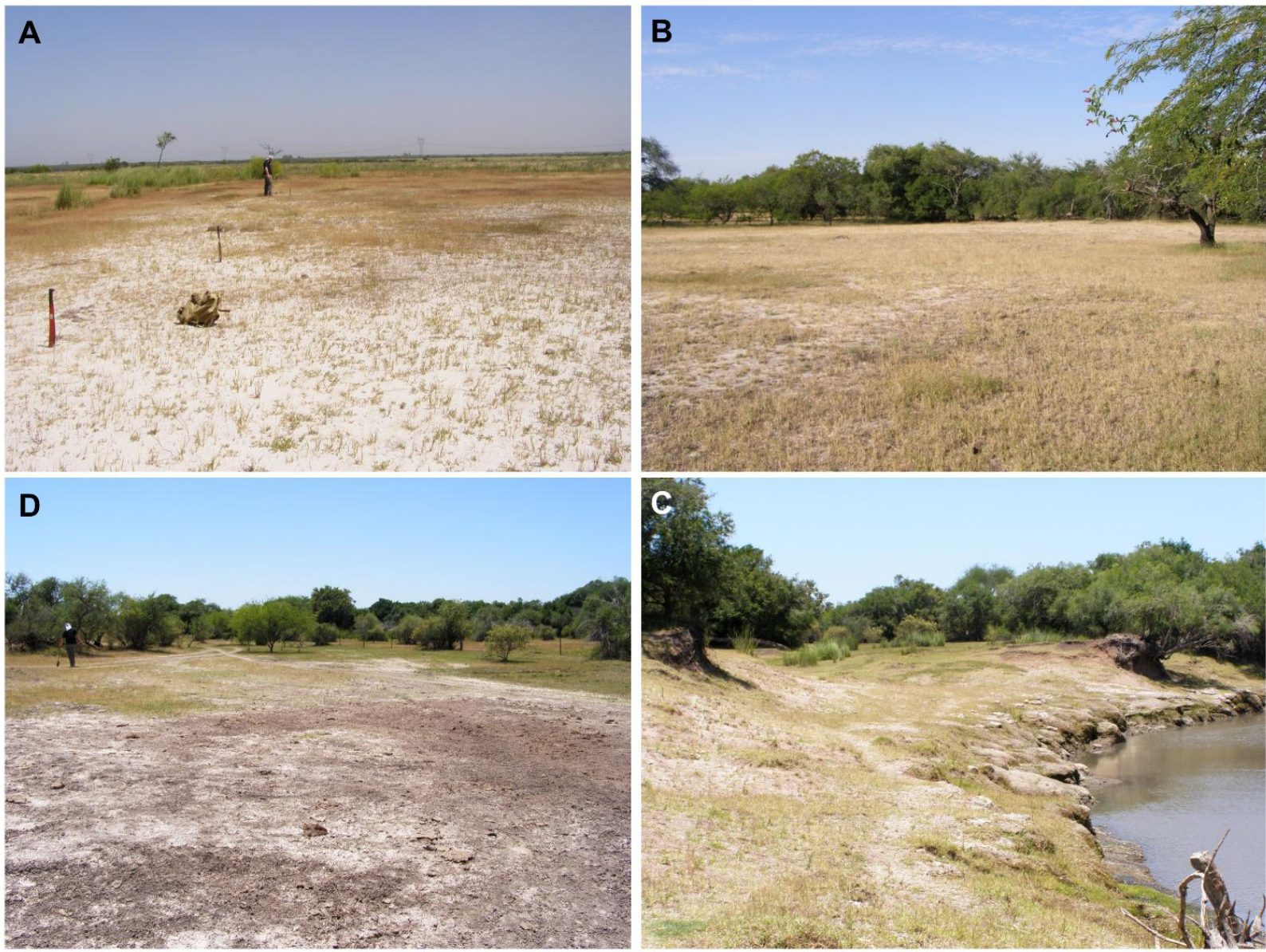

Figura 5.2. Sitios arqueológicos del sector $A$.

A: Paso Blanco 2. B: Pozo Azul a. C: Puente del Tigre. D: El Dorado. 


\subsubsection{2- Descripción contextual de los hallazgos aislados y sus conjuntos artefactuales}

\section{Paso Blanco 5 (PB5)}

Material recolectado en el entorno de la laguna La Blanca, en un área sin cubierta vegetal ubicada a $200 \mathrm{~m}$ al norte de PB3. Se recuperó un desecho de talla (Tabla 5.2).

\section{Paso Blanco 6 (PB6)}

Material recolectado en el entorno de la laguna La Blanca, en un área sin cubierta vegetal ubicada a $20 \mathrm{~m}$ al norte de PB5. Se recuperó un desecho de talla (Tabla 5.2).

\section{Paso Blanco 7 (PB7)}

Material recolectado en el entorno de la laguna La Blanca, en un área sin cubierta vegetal ubicada a $50 \mathrm{~m}$ al sureste de PB5. Se recuperó un instrumento lítico (Tabla 5.2).

\section{Paso Blanco 8 (PB8)}

Material recolectado en una extensa área sin cubierta vegetal ubicada a $20 \mathrm{~m}$ al oeste de PB7. Se recuperó un fragmento de cuerpo liso (Tabla 5.2).

\section{Río Gualeguay 1 (RG1)}

Material recolectado en una extensa área sin cubierta vegetal ubicada a $160 \mathrm{~m}$ al suroeste de N2. Se recuperó un desecho de talla (Tabla 5.2). Además, se registró una masa de arcilla cocida.

\section{Río Gualeguay 2 (RG2)}

Material recolectado en un área sin cubierta vegetal ubicada a $136 \mathrm{~m}$ al noreste de N2. Se recuperó un desecho de talla (Tabla 5.2).

\section{Puente Gualeguay (PG)}

Material recolectado sobre el lecho del río Gualeguay en periodo de bajante, a $200 \mathrm{~m}$ al sur del puente que atraviesa el río sobre la Ruta Nacional 18. Los materiales incluyen tres desechos de talla y un núcleo; y un fragmento de cuerpo liso (Tabla 5.2).

\section{Ramblones 3 (R3)}

Material recolectado en un área sin cubierta vegetal ubicada a $400 \mathrm{~m}$ al suroeste de R. Los materiales incluyen un desecho de talla; un fragmento de cuerpo liso y un tiesto indeterminado liso que está levemente modelado sin representar un modelado acabado (Tabla 5.2). Además, se registraron masas de arcilla cocida $(n=125)$. 


\section{Ramblones 4 (R4)}

Material recolectado en un área sin cubierta vegetal ubicada a $255 \mathrm{~m}$ al suroeste de $\mathrm{R}$ y a 160 $\mathrm{m}$ al noreste de R3. Los materiales incluyen dos fragmentos de cuerpo lisos (Tabla 5.2). Además, se registró una masa de arcilla cocida.

\subsection{2- MATERIALES ARQUEOLÓGICOS}

La Tabla 5.2 muestra las frecuencias de los distintos materiales arqueológicos recuperados. No se incluyen los artefactos recolectados por Lugrin en los mismos sitios arqueológicos (véase Tabla $5.12)$.

Tabla 5.2. Materiales arqueológicos del sector A según sus frecuencias por tipo de material y categorías tecnológicas y morfológicas.

\begin{tabular}{|c|c|c|c|c|c|c|c|c|c|}
\hline \multirow{2}{*}{$\begin{array}{c}\text { Sitios } \\
\text { arqueológicos }\end{array}$} & \multicolumn{4}{|c|}{ Artefactos líticos } & \multicolumn{4}{|c|}{ Cerámica } & \multirow{2}{*}{$\begin{array}{c}\text { Total } \\
\text { genera }\end{array}$} \\
\hline & INS & DES & NUC & Total & BOR & CUE & IND & Total & \\
\hline Paso Blanco 2 & 2 & 35 & - & 37 & 8 & 45 & - & 53 & 90 \\
\hline Paso Blanco 3 & - & 22 & 1 & 23 & - & - & - & - & 23 \\
\hline Paso Blanco 4 & 1 & 13 & - & 14 & 2 & 3 & - & 5 & 19 \\
\hline Pozo Azul a & - & 1 & - & 1 & - & 3 & - & 3 & 4 \\
\hline Pozo Azul b & - & 2 & - & 2 & - & 5 & - & 5 & 7 \\
\hline La Lomita & - & 3 & - & 3 & 1 & 11 & - & 12 & 15 \\
\hline La Lomita 2 & - & - & - & - & - & 1 & - & 1 & 1 \\
\hline Puente del Tigre & - & 6 & - & 6 & - & - & - & - & 6 \\
\hline El Dorado & 1 & 10 & & 11 & 6 & 20 & - & 26 & 37 \\
\hline Nogueira 2 & 2 & 4 & - & 6 & - & - & - & - & 6 \\
\hline Laguna de García & - & - & - & - & 3 & 11 & - & 14 & 14 \\
\hline Laguna Blanca y Negra & - & - & - & - & - & 2 & - & 2 & 2 \\
\hline Ramblones & - & - & - & - & - & 2 & - & 2 & 2 \\
\hline Ramblones 2 & - & 1 & - & 1 & 11 & 47 & - & 58 & 59 \\
\hline Total & 6 & 97 & 1 & 104 & 31 & 150 & - & 181 & 285 \\
\hline \multirow{2}{*}{$\begin{array}{c}\text { Hallazgos } \\
\text { aislados }\end{array}$} & \multicolumn{4}{|c|}{ Artefactos líticos } & \multicolumn{4}{|c|}{ Cerámica } & Total \\
\hline & INS & DES & NUC & Total & BOR & CUE & IND & Total & general \\
\hline PB5 & - & 1 & - & 1 & - & - & - & - & 1 \\
\hline PB6 & - & 1 & - & 1 & - & - & - & - & 1 \\
\hline PB7 & 1 & - & - & 1 & - & - & - & - & 1 \\
\hline PB8 & - & - & - & - & - & 1 & - & 1 & 1 \\
\hline RG1 & - & 1 & - & 1 & - & - & - & - & 1 \\
\hline RG2 & - & 1 & - & 1 & - & - & - & - & 1 \\
\hline PG & - & 3 & 1 & 4 & - & 1 & - & 1 & 5 \\
\hline R3 & - & 1 & - & 1 & - & 1 & 1 & 2 & 3 \\
\hline R4 & - & - & - & - & - & 2 & - & 2 & 2 \\
\hline Total & 1 & 8 & 1 & 10 & - & 5 & 1 & 6 & 16 \\
\hline Total general & 7 & 105 & 2 & 114 & 31 & 155 & 1 & 187 & 301 \\
\hline
\end{tabular}
La tabla no incluye las masas de arcilla cocida y los geofactos. 


\subsubsection{1- Estructura del conjunto lítico}

\section{Materias primas}

La Tabla 5.3 muestra la representatividad de las materias primas en relación a las clases tipológicas.

Tabla 5.3. Materias primas por clases tipológicas en el sector A.

\begin{tabular}{|c|c|c|c|c|c|c|c|c|}
\hline \multirow{3}{*}{ Materia prima } & \multicolumn{6}{|c|}{ Clases tipológicas } & & \\
\hline & \multicolumn{2}{|c|}{ Instrumentos } & \multicolumn{2}{|c|}{ Desechos de talla } & \multicolumn{2}{|c|}{ Núcleos } & \multicolumn{2}{|c|}{ Total } \\
\hline & $\mathrm{n}$ & $\%$ & $\mathrm{n}$ & $\%$ & $\mathrm{n}$ & $\%$ & $\mathrm{n}$ & $\%$ \\
\hline Calcedonia & - & - & 22 & 21 & - & - & 22 & 19,3 \\
\hline Silcreta & - & - & 2 & 1,9 & - & - & 2 & 1,7 \\
\hline Ágata & - & - & 18 & 17,1 & - & - & 18 & 15,8 \\
\hline Sílice & 3 & 42,8 & 9 & 8,6 & 2 & 100 & 14 & 12,3 \\
\hline Xilópalo & - & - & 1 & 0,9 & - & - & 1 & 0,9 \\
\hline Arenisca & 4 & 57,2 & 44 & 42 & - & - & 48 & 42,1 \\
\hline Cuarcita intertrap & - & - & 7 & 6,7 & - & - & 7 & 6,1 \\
\hline Basalto & - & - & 1 & 0,9 & - & - & 1 & 0,9 \\
\hline Cuarzo & - & - & 1 & 0,9 & - & - & 1 & 0,9 \\
\hline Total & 7 & 100 & 105 & 100 & 2 & 100 & 114 & 100 \\
\hline
\end{tabular}

\section{Instrumentos}

En cuanto a los instrumentos (Tabla 5.4) se identificaron: un pedúnculo de una punta de proyectil $^{1}$ "cola de pescado" (PCP), que tiene los bordes de forma paralelos cóncavos y la base cóncava atenuada (Figura 5.3A); una punta de proyectil entera reciclada pedunculada con limbo cordiforme, una aleta es entrante obtusa y la otra en hombro, el pedúnculo es diferenciado y tiene un borde recto y el otro cóncavo-convexo, y la base convexa (Figura 5.3B); un pedúnculo de proyectil, que tiene los bordes divergentes rectos y base recta (Figura 5.3C); y cuatro piezas con retoque sumario (Figura 5.3D, E, F y G).

\footnotetext{
${ }^{1}$ Se utiliza la designación de "punta de proyectil" en el sentido de Aschero (1983), pero también considerando la propuesta de Ratto (2003) que plantea que no toda las puntas o cabezales líticos conformaron un sistema técnico arrojadizo como arco y flecha y lanza arrojada con la mano o con propulsor, pudiendo también funcionar como lanzas de mano no arrojadiza o dagas/puñales.
} 
Tabla 5.4. Instrumentos líticos del sector A.

\begin{tabular}{|c|c|c|c|c|c|c|c|c|c|}
\hline Procedencia & $\begin{array}{l}\text { Grupo } \\
\text { tipológico }\end{array}$ & $\begin{array}{l}\text { Subgrupo } \\
\text { tipológico }\end{array}$ & Serie técnica & $\begin{array}{l}\text { Materia } \\
\text { prima }\end{array}$ & Calidad $^{1}$ & Forma-base & Módulo L-A & Tamaño & $\begin{array}{l}\text { Espesor } \\
\text { relativo }\end{array}$ \\
\hline PB4-RS-14 & $\begin{array}{l}\text { punta de proyectil } \\
\text { (pedúnculo } \mathrm{PCP} \text { ) }\end{array}$ & pedunculadas & $\begin{array}{c}\text { retoque } \\
\text { extendido }\end{array}$ & arenisca & B & $\begin{array}{c}\text { lasca } \\
\text { indiferenciada }\end{array}$ & $\begin{array}{l}\text { corto muy } \\
\text { ancho }\end{array}$ & pequeño & delgado \\
\hline PB7-RS-1 & punta de proyectil & $\begin{array}{c}\text { pedunculadas } \\
\text { con hombro }\end{array}$ & $\begin{array}{c}\text { retoque } \\
\text { extendido }\end{array}$ & sílice & $E$ & $\begin{array}{c}\text { lasca } \\
\text { indiferenciada }\end{array}$ & $\begin{array}{l}\text { mediano } \\
\text { alargado }\end{array}$ & $\begin{array}{l}\text { mediano } \\
\text { pequeño }\end{array}$ & delgado \\
\hline N2-RS-1 & $\begin{array}{l}\text { punta de proyectil } \\
\text { (pedúnculo) }\end{array}$ & pedunculadas & $\begin{array}{c}\text { retoque } \\
\text { extendido }\end{array}$ & arenisca & $\mathrm{B}$ & $\begin{array}{c}\text { lasca } \\
\text { indiferenciada }\end{array}$ & corto ancho & pequeño & delgado \\
\hline ED-RS-10 & $\begin{array}{c}\text { piezas con } \\
\text { retoque sumario }\end{array}$ & $\begin{array}{l}\text { microretoque } \\
\text { alternante }\end{array}$ & $\begin{array}{c}\text { microretoque } \\
\text { marginal }\end{array}$ & sílice & $\mathrm{E}$ & $\begin{array}{c}\text { lasca } \\
\text { angular }\end{array}$ & $\begin{array}{l}\text { laminar } \\
\text { normal }\end{array}$ & pequeño & $\begin{array}{c}\text { muy } \\
\text { delgado }\end{array}$ \\
\hline PB2-RS-28 & $\begin{array}{c}\text { piezas con } \\
\text { retoque sumario }\end{array}$ & $\begin{array}{l}\text { retoque unifacial } \\
\text { directo }\end{array}$ & $\begin{array}{l}\text { retoque } \\
\text { marginal }\end{array}$ & arenisca & $B$ & $\begin{array}{c}\text { lasca } \\
\text { angular }\end{array}$ & $\begin{array}{l}\text { laminar } \\
\text { normal }\end{array}$ & pequeño & delgado \\
\hline PB2-RS-29 & $\begin{array}{c}\text { piezas con } \\
\text { retoque sumario }\end{array}$ & $\begin{array}{c}\text { microretoque } \\
\text { unifacial directo }\end{array}$ & $\begin{array}{l}\text { retoque } \\
\text { marginal }\end{array}$ & arenisca & $B$ & $\begin{array}{c}\text { lasca } \\
\text { angular }\end{array}$ & $\begin{array}{c}\text { mediano } \\
\text { normal }\end{array}$ & pequeño & $\begin{array}{c}\text { muy } \\
\text { delgado }\end{array}$ \\
\hline N2-RS-1 & $\begin{array}{c}\text { piezas con } \\
\text { retoque sumario }\end{array}$ & $\begin{array}{c}\text { microretoque } \\
\text { bifacial }\end{array}$ & $\begin{array}{l}\text { retoque } \\
\text { marginal }\end{array}$ & sílice & $E$ & $\begin{array}{c}\text { lasca } \\
\text { angular }\end{array}$ & $\begin{array}{l}\text { mediano } \\
\text { alargado }\end{array}$ & pequeño & $\begin{array}{c}\text { muy } \\
\text { delgado }\end{array}$ \\
\hline
\end{tabular}

(1) Calidad de las materias primas, E: excelente, B: buena.

Se registraron siete instrumentos confeccionados a partir de lascas mediante retoque y microrretoque marginal, unifacial directo y alternante, y bifacial. La punta reciclada presenta reducción bifacial. Entre los instrumentos enteros se registraron módulos longitud-anchura medianos $(n=3)$ y laminares $(n=2)$, y tamaños pequeños a excepción de la punta de proyectil reciclada que es mediano pequeño. En cuanto al espesor relativo se registraron muy delgados $(n=3)$ y delgados $(n=$ 2). En cuanto a los pedúnculos aislados los módulos y el espesor relativo están determinados por la fractura que presentan.

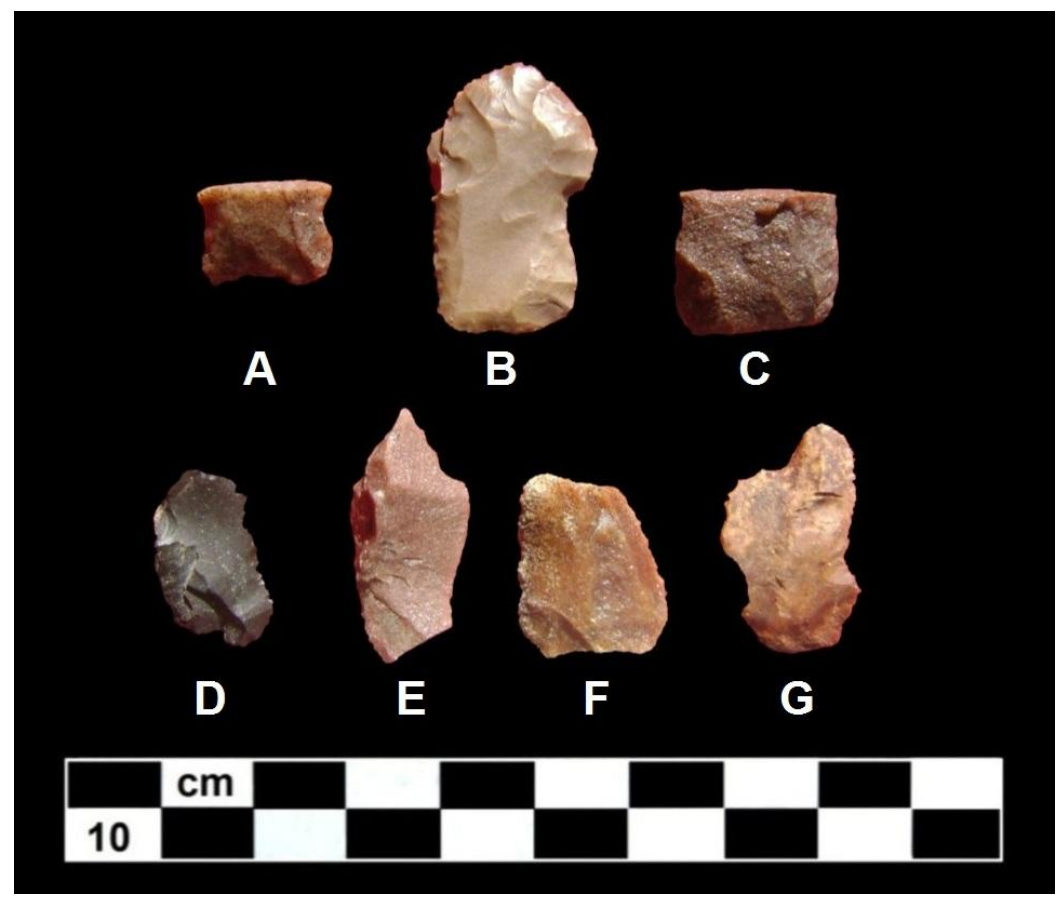

Figura 5.3. Instrumentos líticos del sector $A$.

A: pedúnculo de punta de proyectil "cola de pescado" (PB4-RS-14).

B: punta de proyectil reciclada (PB7-RS-1). C: pedúnculo de punta de proyectil (N2-RS-1).

D, E, F y G: piezas con retoque sumario (ED-RS-10; PB2-RS-28; PB2-RS-29 y N2-RS-1). 


\section{Desechos de talla}

\section{Fragmentación}

La Tabla 5.5 muestra la distribución de los desechos de talla de acuerdo a su estado de fragmentación.

Tabla 5.5. Estado de fragmentación de la muestra de desechos de talla del sector A.

\begin{tabular}{|c|c|c|c|c|c|c|c|c|c|c|c|}
\hline \multirow{3}{*}{$\begin{array}{l}\text { Sitios } \\
\text { arqueológicos }\end{array}$} & \multicolumn{10}{|c|}{ Estado de fragmentación } & \multirow{3}{*}{ Total } \\
\hline & \multicolumn{2}{|c|}{ ENT } & \multicolumn{2}{|c|}{ FCT } & \multicolumn{2}{|c|}{ FST } & \multicolumn{2}{|c|}{ NOC } & \multicolumn{2}{|c|}{ IND } & \\
\hline & $\mathrm{n}$ & $\%$ & $\mathrm{n}$ & $\%$ & $\mathrm{n}$ & $\%$ & $\mathrm{n}$ & $\%$ & $\mathrm{n}$ & $\%$ & \\
\hline Paso Blanco 2 & 3 & 8,6 & 10 & 28,6 & 5 & 14,3 & 6 & 17,1 & 11 & 31,4 & 35 \\
\hline Paso Blanco 3 & 2 & 9,1 & 3 & 13,6 & 5 & 22,7 & 6 & 27,3 & 6 & 27,3 & 22 \\
\hline Paso Blanco 4 & - & - & 3 & 23,1 & 3 & 23,1 & 2 & 15,3 & 5 & 38,5 & 13 \\
\hline Pozo Azul a & - & - & 1 & 100 & - & - & - & - & - & - & 1 \\
\hline Pozo Azul b & - & - & - & - & - & - & 1 & 50 & 1 & 50 & 2 \\
\hline La Lomita & - & - & 1 & 33,3 & - & - & - & - & 2 & 66,7 & 3 \\
\hline Puente del Tigre & - & - & - & - & 2 & 33,3 & 1 & 16,7 & 3 & 50 & 6 \\
\hline El Dorado & 1 & 10 & 4 & 40 & - & - & 1 & 10 & 4 & 40 & 10 \\
\hline Nogueira 2 & - & - & 1 & 25 & - & - & 1 & 25 & 2 & 50 & 4 \\
\hline Ramblones 2 & - & - & - & - & - & - & - & - & 1 & 100 & 1 \\
\hline Hallazgos aislados & - & - & 3 & 37,5 & - & - & 4 & 50 & 1 & 12,5 & 8 \\
\hline Total & 6 & 5,7 & 26 & 24,8 & 15 & 14,2 & 22 & 21 & 36 & 34,3 & 105 \\
\hline
\end{tabular}

ENT: lasca entera; FCT: lasca fracturada con talón; FST: lasca fracturada sin talón;

NOC: desecho no clasificable; IND: desecho indiferenciado.

Se observa un predominio absoluto de desechos fracturados sobre lascas enteras. La mayor frecuencia corresponde a los desechos indiferenciados, seguidos por lascas fracturadas con talón, desechos no clasificables, lascas fracturadas sin talón y por último las lascas enteras. Considerando los sitios arqueológicos PB2, PB3 y PB4, se observa que en PB2 la tendencia se mantiene igual, mientras que en los otros dos sitios, si bien predominan los desechos indiferenciados y las lascas enteras tienen la menor frecuencia, se registran variaciones en el orden jerárquico entre los demás tipos de desechos. Aun así, ésta variación de proporciones se considera poco significativa dado que en segundo orden siguen predominando las lascas fracturadas (con y sin talón).

\section{Formas de las lascas}

Dentro de los desechos de talla, excluyendo aquellos cuyo estado de fragmentación es indiferenciado, se registran varios tipos de lascas $(n=69)$ (Tabla 5.6). 
Tabla 5.6. Tipos de lascas por conjuntos líticos del sector A.

\begin{tabular}{|c|c|c|c|c|c|c|c|c|c|c|c|c|c|}
\hline \multirow{3}{*}{$\begin{array}{c}\text { Sitios } \\
\text { arqueológicos }\end{array}$} & \multicolumn{12}{|c|}{ Tipo de lasca } & \multirow[b]{3}{*}{ Tota } \\
\hline & \multicolumn{2}{|c|}{ PRI } & \multicolumn{2}{|c|}{ SEC } & \multicolumn{2}{|c|}{ DON } & \multicolumn{2}{|c|}{ ANG } & \multicolumn{2}{|c|}{ ARI } & \multicolumn{2}{|c|}{ PLA } & \\
\hline & $\mathrm{n}$ & $\%$ & $\mathrm{n}$ & $\%$ & $\mathrm{n}$ & $\%$ & $n$ & $\%$ & $\mathrm{n}$ & $\%$ & $\mathrm{n}$ & $\%$ & \\
\hline Paso Blanco 2 & - & - & 3 & 12,5 & 1 & 4,2 & 16 & 66,7 & 2 & $\overline{8,3}$ & 2 & $\overline{8,3}$ & 24 \\
\hline Paso Blanco 3 & 4 & 25 & 4 & 25 & 1 & 6,2 & 7 & 43,8 & - & - & - & - & 16 \\
\hline Paso Blanco 4 & 1 & 12,5 & - & - & - & - & $7^{1}$ & 87,5 & - & - & - & - & 8 \\
\hline Pozo Azul a & - & - & - & - & - & - & 1 & 100 & - & - & - & - & 1 \\
\hline Pozo Azul b & - & - & - & - & 1 & 100 & - & - & - & - & - & - & 1 \\
\hline La Lomita & - & - & - & - & - & - & 1 & 100 & - & - & - & - & 1 \\
\hline Puente del Tigre & 1 & 33,3 & 1 & 33,3 & - & - & 1 & 33,4 & - & - & - & - & 3 \\
\hline El Dorado & - & - & - & - & 1 & 16,7 & 5 & 83,3 & - & - & - & - & 6 \\
\hline Nogueira 2 & - & - & - & - & - & - & 2 & 100 & - & - & - & - & 2 \\
\hline Hallazgos aislados & 2 & 28,6 & 1 & 14,3 & - & - & 4 & 57,1 & - & - & - & - & 7 \\
\hline Total & 8 & 11,6 & 9 & 13 & 4 & 5,8 & 44 & 63,8 & 2 & 2,9 & 2 & 2,9 & 69 \\
\hline
\end{tabular}

PRI: lasca primaria; SEC: lasca secundaria; DON: lasca con dorso natural; ANG: lasca angular; ARI: lasca de arista; PLA: lasca plana. (1) Se incluye una lasca de adelgazamiento bifacial.

Dentro de las lascas internas las más representadas son las angulares ( $n=44 ; 63,8 \%$ ), seguidas por las de arista y las planas en igual proporción ( $n=2 ; 2,9 \%)$. Dentro de las angulares se registró una lasca de adelgazamiento bifacial (PB4). En cuanto a las lascas externas, se observa un predominio de las secundarias $(n=9 ; 13 \%)$ sobre las primarias $(n=8 ; 11,6 \%)$ y con dorso natural $(n=$ $4 ; 5,8 \%)$.

Estado de fragmentación, tipos, y materia prima de los desechos por conjunto

PB2: tres lascas enteras: dos son angulares (ágatas) y una plana (arenisca); 10 lascas fracturadas con talón: cuatro angulares (dos calcedonias, una ágata y una arenisca), tres secundarias (dos areniscas y un cuarzo), una con dorso natural (arenisca), una de arista (arenisca), y una plana (ágata); cinco lascas fracturadas sin talón: cuatro angulares (dos ágatas, una calcedonia y una arenisca) y una de arista (arenisca); seis no clasificables: angulares (cuatro areniscas, una calcedonia y una ágata); y 11 indiferenciados: (seis areniscas, dos silcretas, dos ágatas y una calcedonia). PB3: dos lascas enteras: una secundaria (cuarcita intertrap) y una con dorso natural (cuarcita intertrap); tres lascas fracturadas con talón: dos angulares (una ágata y una arenisca) y una secundaria (arenisca); cinco lascas fracturadas sin talón: tres angulares (una ágata, una calcedonia y una cuarcita intertrap), una primaria y una secundaria (areniscas); seis no clasificables: tres primarias (dos calcedonias y una sílice), dos angulares (una arenisca y una cuarcita intertrap), y una secundaria (sílice); y seis indiferenciados: (cuatro calcedonias y dos areniscas). PB4: tres lascas fracturadas con talón: angulares (dos calcedonias y una cuarcita intertrap); tres lascas fracturadas sin talón: angulares (una sílice, una calcedonia y una arenisca); dos no clasificables: una primaria (calcedonia) y una angular (xilópalo); y cinco indiferenciados: (dos sílices, dos ágatas y una calcedonia). 
PAa: una lasca fracturada con talón: angular (calcedonia). PAb: una no clasificable: con dorso natural (arenisca); y un indiferenciado: (arenisca). LL: una lasca fracturada con talón: angular (calcedonia); y dos indiferenciados: (una calcedonia y una sílice). PDT: dos lascas fracturadas sin talón: una angular (arenisca) y una secundaria (sílice); una no clasificable: primaria (arenisca); y tres indiferenciados: (dos calcedonias y una ágata). ED: una lasca entera: angular (arenisca); cuatro lascas fracturadas con talón: tres angulares (dos areniscas y una ágata) y una con dorso natural (sílice); una no clasificable: angular (ágata); y cuatro indiferenciados: (arenisca). N2: una lasca fracturada con talón: angular (arenisca); una no clasificable: angular (arenisca); y dos indiferenciados: (un basalto y una cuarcita intertrap). R2: un indiferenciado: (silcreta). PB5: una lasca fracturada con talón: angular (ágata). PB6: una lasca fracturada con talón: angular (arenisca). RG1: una no clasificable: primaria (cuarcita intertrap). RG2: una lasca fracturada con talón: angular (arenisca). PG: tres no clasificables: una angular, una primaria y una secundaria (areniscas). R3: un indiferenciado: (ágata).

\section{Talones y bulbos}

La Tabla 5.7 muestra la distribución de los distintos tipos de talones y bulbos, identificados en lascas enteras y fracturadas con talón; así como los distintos tipos de bulbos que se pudieron identificar en lascas fracturadas sin talón. 
Tabla 5.7. Distribución de la forma e inclinación del talón en relación a la forma del bulbo de percusión de las lascas del sector A.

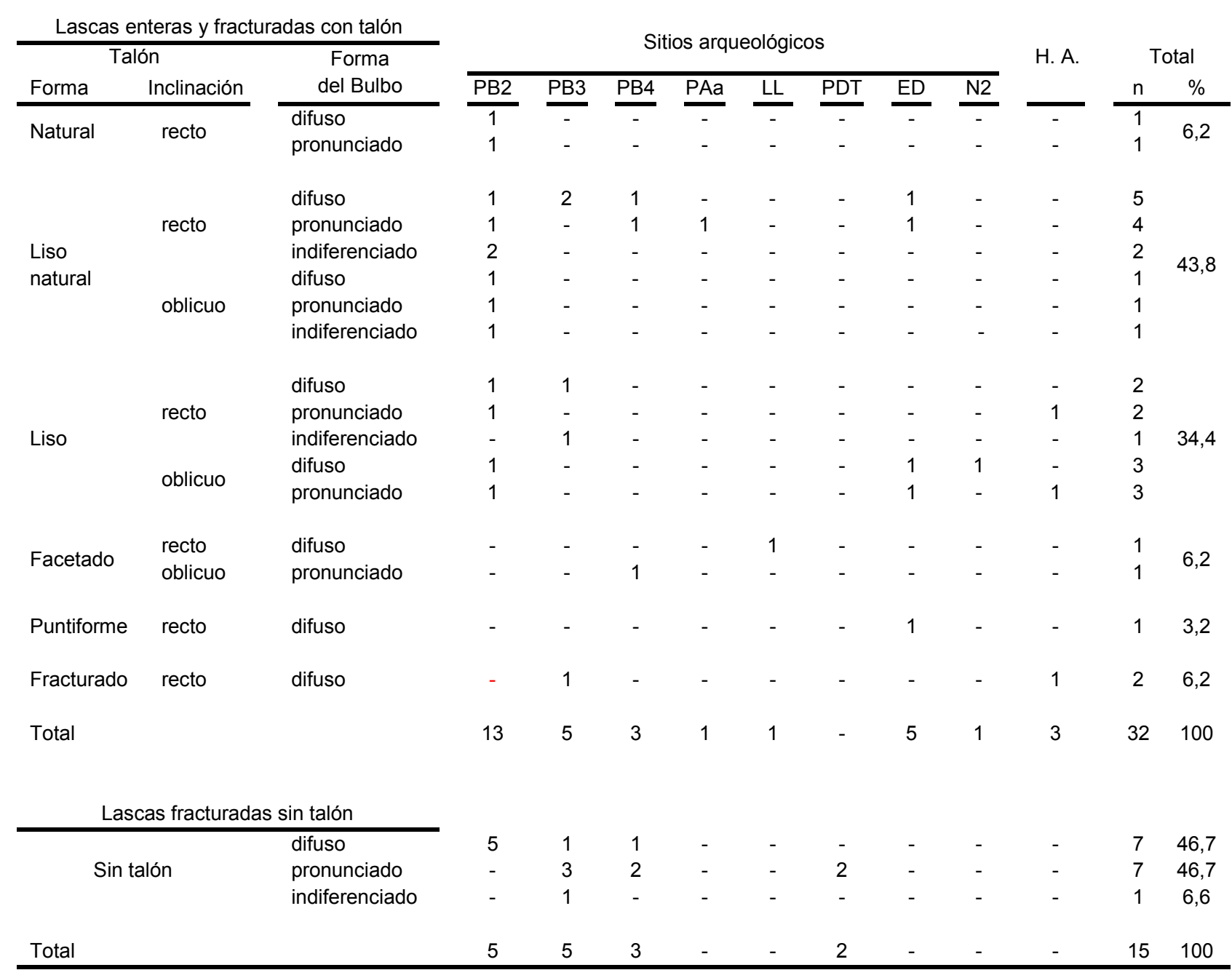

PB2: Paso Blanco 2; PB3: Paso Blanco 3; PB4: Paso Blanco 4; PAa: Pozo Azul a; LL: La Lomita; PDT: Puente del Tigre; ED: El Dorado; N2: Nogueira 2. H. A.: hallazgos aislados.

Se registraron varios tipos de talones entre los que predomina el liso natural ( $n=14 ; 43,8 \%$ ), seguido por el liso $(n=11 ; 34,4 \%)$, natural $(n=2 ; 6,2 \%)$, facetado $(n=2 ; 6,2 \%)$, fracturado $(n=2 ; 6,2 \%)$ y puntiforme $(n=1 ; 3,2 \%)$. Asimismo, el bulbo más frecuente es el difuso ( $n=23 ; 49 \%)$, seguido por los pronunciados $(n=19 ; 40,4 \%)$ e indiferenciados $(n=5 ; 10,6 \%)$. La mayor asociación entre los atributos considerados se da entre talones lisos naturales con inclinación recta y bulbos difusos ( $n=$ 5), seguidos por bulbos pronunciados $(n=4)$. Asimismo, es frecuente la asociación de los talones lisos con inclinación oblicua, y con bulbos difusos y pronunciados en igual proporción $(n=3)$. Dentro de las lascas sin talón se registró una frecuencia idéntica $(n=7)$ entre bulbos difusos y pronunciados.

\section{Bulbos y labios}

La Tabla 5.8 muestra la distribución de los distintos tipos bulbos de acuerdo a la ausencia (A) o presencia $(P)$ de labio en lascas enteras y fracturadas con talón. 
Tabla 5.8. Presencia de labio según las formas de los bulbos de percusión en las lascas enteras y fracturadas con talón del sector $A$.

\begin{tabular}{|c|c|c|c|c|c|c|}
\hline \multirow{2}{*}{$\begin{array}{c}\text { Sitios } \\
\text { arqueológicos }\end{array}$} & \multirow{2}{*}{ Labio $^{1}$} & \multicolumn{3}{|c|}{ Forma del Bulbo } & \multicolumn{2}{|c|}{ Total } \\
\hline & & Difuso & Pronunciado & Indiferenciado & $\mathrm{n}$ & $\%$ \\
\hline Paso Blanco 2 & $\begin{array}{l}\mathrm{A} \\
\mathrm{P}\end{array}$ & $\begin{array}{l}1 \\
4\end{array}$ & $\overline{5}$ & $\begin{array}{l}1 \\
2\end{array}$ & $\begin{array}{c}2 \\
11\end{array}$ & $\begin{array}{r}6,3 \\
34,4\end{array}$ \\
\hline Paso Blanco 3 & $\begin{array}{l}A \\
P\end{array}$ & $\begin{array}{l}4 \\
-\end{array}$ & - & $\begin{array}{l}1 \\
-\end{array}$ & $\begin{array}{l}5 \\
-\end{array}$ & $\begin{array}{c}15,6 \\
-\end{array}$ \\
\hline Paso Blanco 4 & $\begin{array}{l}A \\
P\end{array}$ & $\begin{array}{l}1 \\
-\end{array}$ & $\overline{2}$ & - & $\begin{array}{l}1 \\
2\end{array}$ & $\begin{array}{l}3,1 \\
6,3\end{array}$ \\
\hline Pozo Azul a & $\begin{array}{l}A \\
P\end{array}$ & - & $\overline{1}$ & - & $\overline{1}$ & $\overline{3,1}$ \\
\hline La Lomita & $\begin{array}{l}A \\
P\end{array}$ & - & $\overline{1}$ & - & $\overline{1}$ & $\begin{array}{r}- \\
3,1\end{array}$ \\
\hline El Dorado & $\begin{array}{l}A \\
P\end{array}$ & $\begin{array}{l}1 \\
2\end{array}$ & $\overline{2}$ & - & $\begin{array}{l}1 \\
4\end{array}$ & $\begin{array}{r}3,1 \\
12,5\end{array}$ \\
\hline Nogueira 2 & $\begin{array}{l}A \\
P\end{array}$ & $\overline{1}$ & - & - & $\overline{1}$ & - \\
\hline Hallazgos aislados & $\begin{array}{l}A \\
P\end{array}$ & $\begin{array}{l}1 \\
-\end{array}$ & $\overline{2}$ & - & $\begin{array}{l}1 \\
2\end{array}$ & $\begin{array}{l}3,1 \\
6,3\end{array}$ \\
\hline $\begin{array}{l}\text { Total } \\
\%\end{array}$ & & $\begin{array}{l}16 \\
50\end{array}$ & $\begin{array}{c}12 \\
37,5\end{array}$ & $\begin{array}{c}4 \\
12,5\end{array}$ & 32 & 100 \\
\hline
\end{tabular}

(1) A: ausencia de labio; P: presencia de labio.

Se observa un predominio de las lascas con bulbo difuso por sobre los demás tipos de bulbos, y que el $68,7 \%(n=22)$ de las lascas presentan labio.

\section{Origen de extracción de las lascas y formas-base}

De acuerdo al origen de extracción de las lascas se determinaron 48 internas y 21 externas (Tabla 5.6), a las que se suman 36 desechos cuyo estado de fragmentación es indiferenciado (Tabla 5.5). A partir de 19 lascas externas y 13 desechos indiferenciados con reserva de corteza en su cara dorsal y/o talón, se pudo determinar que las formas-base primarias utilizadas corresponden a: rodados silíceos indeterminados $(n=22 ; 21 \%)$, subesféricos $(n=6 ; 5,7 \%)$, angulares $(n=3 ; 2,8 \%)$ y plano $(n=1 ; 0,9 \%)$. A partir de los desechos de talla restantes $(n=73)$ no se pudieron diferenciar las formas-base de los núcleos.

De acuerdo a los conjuntos líticos las formas-base determinadas se distribuyen de la siguiente manera: PB3 $(n=12) 11$ indeterminados y uno subesférico; PB2 $(n=6)$ indeterminados; PDT $(n=3)$ dos indeterminados y uno subesférico; $E D(n=3)$ dos subesféricos y uno indeterminado; PB4 $(n=3)$ angulares; PG $(n=2)$ uno plano y uno indeterminado; N2 $(n=1)$ indeterminado; PAb $(n=1)$ subesférico; y RG1 ( $n=1)$ subesférico. 


\section{Negativos de lascados y reserva de corteza}

La Tabla 5.9 presenta la distribución de los tipos de lascas de acuerdo a la cantidad de negativos de lascados y a la proporción de corteza en la cara dorsal. La tendencia general esperada es que, a mayor número de lascados menor será la proporción de corteza.

Tabla 5.9. Distribución de tipos de lascas del sector $A$ según la proporción de corteza y el número de negativos de lascados en la cara dorsal.

\begin{tabular}{|c|c|c|c|c|c|c|c|c|c|c|c|c|c|}
\hline \multirow[b]{4}{*}{$\begin{array}{c}\text { Tipo } \\
\text { de lasca }\end{array}$} & \multirow[b]{4}{*}{$\begin{array}{l}\text { Proporción } \\
\text { de corteza }\end{array}$} & \multicolumn{11}{|c|}{ Negativos de lascados } & \multirow[b]{4}{*}{ Total } \\
\hline & & \multicolumn{9}{|c|}{ Sitios arqueológicos } & \multirow{2}{*}{\multicolumn{2}{|c|}{$\begin{array}{l}\text { Hallazgos } \\
\text { aislados }\end{array}$}} & \\
\hline & & PB2 & PB3 & PB4 & PAa & $\mathrm{PAb}$ & LL & PDT & ED & N2 & & & \\
\hline & & $|012345|$ & 012345 & $01234>5$ & 3 & 0 & 3 & 0113 & $134>5$ & 23 & 02 & 34 & \\
\hline \multirow{2}{*}{ Primaria } & $100 \%$ & $\ldots-\cdots$ & $1 \ldots$ & $1 \ldots-$ & - & - & - & $1--$ & $-\ldots-$ & - & $2-$ & $-\quad-$ & 5 \\
\hline & $>50 \%$ & $\ldots \ldots$ & $-3 \ldots$ & $\ldots \ldots$ & - & - & - & $-\ldots$ & $\ldots-$ & - - & - & $-\quad-$ & 3 \\
\hline \multirow{2}{*}{ Secundaria } & $>50 \%$ & $-1 \ldots$ & $-\cdots 1--$ & $\ldots \ldots$ & - & - & - & $-1-$ & $-\ldots-$ & - - & - & $-\quad-$ & 3 \\
\hline & $<50 \%$ & $-11 \ldots$ & $-111-$ & $\ldots \ldots$ & - & - & - & $-\ldots$ & $-\ldots$ & - - & -1 & $-\quad-$ & 6 \\
\hline \multirow{2}{*}{$\begin{array}{l}\text { Con dorso } \\
\text { natural }\end{array}$} & $>50 \%$ & $\ldots \ldots$ & $\ldots \ldots$ & $\ldots \ldots$ & - & 1 & - & $-\ldots$ & $\ldots-$ & - - & - & $-\quad-$ & 1 \\
\hline & $0 \%$ & $-\cdots 1--$ & $\ldots-1$ & $\ldots \ldots$ & - & - & - & $\ldots$ & $1--$ & - - & - - & $-\quad-$ & 3 \\
\hline Angular & $0 \%$ & -24831 & $--223-$ & -11311 & 1 & - & 1 & --1 & -221 & 11 & -1 & 12 & 44 \\
\hline De arista & $0 \%$ & $-2-2$ & $\ldots \ldots$ & $\ldots \ldots$ & - & - & - & $-\ldots$ & $\ldots$ & - - & - - & $-\quad-$ & 2 \\
\hline Plana & $0 \%$ & $2 \ldots \ldots$ & $\ldots \ldots$ & $\ldots \ldots$ & - & - & - & $\ldots$ & $\ldots-$ & - - & - & $-\quad-$ & 2 \\
\hline Total general & & 227931 & 143431 & 111311 & 1 & 1 & 1 & 111 & 1221 & 11 & 22 & $\begin{array}{ll}12 \\
1\end{array}$ & 69 \\
\hline
\end{tabular}

PB2: Paso Blanco 2; PB3: Paso Blanco 3; PB4: Paso Blanco 4; PAa: Pozo Azul a; LL: La Lomita; PDT: Puente del Tigre; ED: El Dorado; N2: Nogueira 2.

A pesar el pequeño tamaño de la muestra, es claro que en los conjuntos arqueológicos donde mejor se puede observar alguna tendencia significativa son aquellos con mayor frecuencia de desechos de talla. En este sentido, se consideran solamente PB2, PB3 y PB4. Las lascas externas presentan corteza y en general menor número de lascados que las internas. Los conjuntos de PB2 y PB3 son los que tienen mayor frecuencia de lascas externas y dentro de aquellas con menos del $50 \%$ de corteza, todas secundarias $(n=5)$, hay dos con un lascado, dos con dos lascados y una con tres lascados. Dentro de las que tienen más del $50 \%$ de corteza, cuatro primarias y dos secundarias $(n=6)$, hay cuatro con un lascado, una con tres lascados y una sin lascados.

Las lascas internas en general no presentan corteza, la diferencia entre ellas reside en el número de lascados que presentan en su cara dorsal. Los conjuntos de PB2, PB3 y PB4 son los que tienen mayor frecuencia de lascas internas. Dentro de las angulares $(n=30)$ predominan las que tienen tres negativos de lascado $(n=13)$, seguidas por las que tienen cuatro $(n=7)$, dos $(n=7), y$ uno, 
cinco y más de cinco en un solo caso. Las lascas de arista $(n=2)$ presentan dos negativos de lascado y las planas ( $n=2)$ ninguno. En PB2 predominan las angulares que tienen tres negativos de lascado ( $n=$ 8/16); en PB3 las que tienen cuatro $(n=3 / 7) ; y$ en PB4 las que tienen tres $(n=3 / 7)$.

\section{Dimensiones relativas}

Los módulos longitud-anchura y tamaño, y el espesor relativo se calcularon para las lascas enteras $(n=6)$ (Tabla 5.10). Dado que la muestra es muy pequeña resulta difícil observar alguna tendencia clara de asociación entre los atributos considerados.

Tabla 5.10. Dimensiones relativas de las lascas enteras del sector $A$.

\begin{tabular}{|c|c|c|c|}
\hline Procedencia & Módulo longitud-anchura & Tamaño & Espesor relativo \\
\hline PB2-RS-13 & corto ancho & mediano pequeño & delgado \\
\hline PB2-RS-19 & mediano normal & pequeño & muy delgado \\
\hline PB2-RS-32 & corto ancho & mediano pequeño & delgado \\
\hline PB3-RS-6 & mediano normal & mediano pequeño & grueso \\
\hline PB3-RS-20 & mediano alargado & grande & grueso \\
\hline ED-RS-1 & corto muy ancho & muy grande & muy grueso \\
\hline
\end{tabular}

\section{Rastros complementarios, regularización del frente de extracción y alteración térmica}

La presencia de rastros complementarios sobre filos naturales en los desechos de talla fue registrada en cinco lascas angulares: dos de PB2 (enteras), dos de ED (una fracturada con talón y una no clasificable), y una de PAa (fracturada con talón). Los rastros corresponden a melladuras, microlascados y ultramicrolascados combinados. Solamente en dos lascas fracturadas con talón (LL y RG2) se registró regularización del frente de extracción mediante abrasión. En ningún caso se registraron rastros complementarios sobre el talón o evidencia de alteración térmica.

\section{Núcleos}

El conjunto lítico del sector A solo presenta dos núcleos, uno proviene de PB3 y el otro de PG (Tabla 5.11). Dado que la muestra es muy pequeña resulta difícil observar una tendencia general. Solo se plantea que las materias primas son de buena calidad y las forma-base son similares. 
Tabla 5.11. Núcleos del sector A.

\begin{tabular}{|c|c|c|c|c|c|c|c|c|c|c|}
\hline \multirow[t]{2}{*}{ Procedencia } & \multirow{2}{*}{$\begin{array}{c}\text { Materia } \\
\text { prima }\end{array}$} & \multirow[t]{2}{*}{ Calidad } & \multirow{2}{*}{$\begin{array}{c}\text { Forma- } \\
\text { base }\end{array}$} & \multicolumn{2}{|c|}{$\begin{array}{l}\text { Planos de } \\
\text { percusión }\end{array}$} & \multirow{2}{*}{$\begin{array}{l}\text { Proporción } \\
\text { de corteza }\end{array}$} & \multirow{2}{*}{$\begin{array}{c}\text { Negativos } \\
\text { de } \\
\text { lascados }\end{array}$} & \multirow{2}{*}{$\begin{array}{l}\text { Largo } \\
(\mathrm{mm})\end{array}$} & \multirow{2}{*}{$\begin{array}{c}\text { Ancho } \\
(\mathrm{mm})\end{array}$} & \multirow{2}{*}{$\begin{array}{c}\text { Espesol } \\
(\mathrm{mm})\end{array}$} \\
\hline & & & & Número & Forma & & & & & \\
\hline PB3-RS-23 & sílice & buena & $\begin{array}{c}\text { guijarro } \\
\text { subesférico }\end{array}$ & 1 & natural & $>50 \%$ & 3 & 35,1 & 31 & 23,9 \\
\hline PG-RS-1 & sílice & excelente & $\begin{array}{c}\text { guijarro } \\
\text { subesférico }\end{array}$ & 3 & natural & $>50 \%$ & 5 & 41,1 & 37,2 & 30,8 \\
\hline
\end{tabular}

\subsubsection{2- Estructura del conjunto cerámico}

La muestra de alfarería proviene de los sitios arqueológicos PB2, PB4, PAa, PAb, LL, LL2, ED, LDG, LBN, R y R2, así como de los hallazgos aislados PB8, PG, R3 y R4. Los fragmentos recuperados suman un total de 187 (Tabla 5.2); 155 corresponden al cuerpo de las vasijas (151 lisos y cuatro decorados), 31 son bordes (27 lisos y cuatro decorados), y se suma un fragmento indeterminado (liso). Del total, 179 fragmentos no presentan decoración y ocho están decorados. Se recuperaron además 1235 fragmentos amorfos de arcilla cocida. Los tamaños de los tiestos se distribuyen como sigue: pequeños $n=185(98,9 \%)$ y medianos $n=2(1,1 \%)$.

Luego de realizar los remontajes $(P B 2=3, E D=2$ y $R 2=2$ ) considerando los tiestos mayores a 2 cm la muestra analizada se compone de 106 tiestos; 83 (78,3\%) corresponden al cuerpo de las vasijas (81 lisos y dos decorados), $22(20,8 \%)$ son bordes (19 lisos y tres decorados), y uno $(0,9 \%)$ es el fragmento indeterminado (liso). Los espesores de los bordes varían entre 5,3 y 12,6 mm, y de los cuerpos entre $4 \mathrm{~mm}$ y $15,5 \mathrm{~mm}$.

Es necesario aclarar que el $96,2 \%$ de la muestra analizada presenta evidencia de alteraciones naturales, como desgaste y erosión en distinto grado; en algunos de ellos se observa redondeamiento de bordes y "efecto pedestal" debido a la remoción de la matriz de la pasta (Sanhueza Riquelme 1998). Esta situación constituyó una limitación para determinar algunos de los atributos relevados.

En relación a la técnica de manufactura se identificaron dos $(1,8 \%)$ tiestos elaborados mediante la técnica de enrollamiento y un $(0,9 \%)$ tiesto modelado, siendo el resto indeterminados ( $n=103 ; 97,3 \%)$. Se determinó tratamiento de superficie plástico en 10 tiestos $(9,4 \%)$ siendo el resto indeterminados ( $n=96 ; 90,6 \%$ ); así hay ocho alisados en ambas superficies y dos en la superficie interna.

La observación del color del núcleo de los tiestos permitió determinar que predomina ampliamente el color negro (7.5YR 2/1-black) ( $n=96 ; 90,6 \%)$, seguido por colores que van desde el naranja amarillento oscuro (10YR 6/6-bright yellowish brown) al castaño oscuro (7.5YR 3/4-dark brown) ( $n=9 ; 8,5 \%)$, hallándose uno de color indeterminado $(n=1 ; 0,9 \%)$. La superficie externa de 54 
$(50,9 \%)$ fragmentos, como la interna de $67(63,2 \%)$, presentan colores que van desde el naranja amarillento (10YR 7/4-dull yellow orange) al negro (7.5YR 2/1-black). El color de las superficies (externa e interna) del resto de los fragmentos es indeterminado.

Los porcentajes de inclusiones se distribuyen de la siguiente manera: arena ( $n=55 ; 51,9 \%$ ), tiesto y arena $(n=27 ; 25,5 \%)$, tiesto y mica $(n=7 ; 6,6 \%)$, tiesto $(n=7 ; 6,6 \%)$, arena y espículas de esponjas de agua dulce $(n=3 ; 2,8 \%)$, arena y carbonato de calcio $(n=1 ; 0,9 \%)$, y con inclusiones indeterminadas o sin ellas $(n=6 ; 5,7 \%)$. En tres tiestos se identificó la presencia de partículas macroscópicas de óxido de Fe. Las espículas de esponja fueron determinadas por la Dra. Inés Ezcurra de Drago (CONICET-INALI-UNL) quién registró la presencia de la esponja Uruguaya corallioides en tres tiestos de distintos sitios arqueológicos (PB2, LL y PAb), además en el mismo tiesto de PB2 registró otra especie (DEMOSPONGIAE) que no fue identificada, debido a que las espículas son del tipo oxeas, estas son las macroscleras más comunes y por lo tanto tienen poco valor diagnóstico (Ezcurra de Drago 1995).

En relación a la morfología de bordes y labios, incluyendo los menores a $2 \mathrm{~cm}$, se determinaron 10 bordes evertidos (Figura 5.4A, B, C y E), siete con labios convexos, dos con angulares, y uno con labio recto; ocho bordes rectos (Figura 5.4D y F), tres con labios convexos, dos angulares, dos rectos y uno indeterminado; cuatro bordes invertidos (Figura 5.4G), tres con labios convexos y uno con labio angular. Se determinaron siete formas no restringidas. Asimismo, a partir de cuatro bordes se reconstruyó el diámetro de boca y el perfil de cuatro vasijas (Figura 5.4):

1- recipiente liso no restringido, con borde evertido y labio convexo, y un diámetro de boca de $30 \mathrm{~cm}$; esta vasija corresponde probablemente a un cuenco grande (PB2-RS-T11/H-1) (Figura $5.4 A)$.

2- recipiente liso no restringido, con borde evertido y labio convexo, y un diámetro de boca de $24 \mathrm{~cm}$; esta vasija corresponde probablemente a un plato hondo (ED-RS-20) (Figura 5.4B).

3- recipiente decorado no restringido, con borde evertido y labio convexo, y un diámetro de boca de $36 \mathrm{~cm}$; esta vasija corresponde probablemente a un cuenco grande (ED-RS-23/24) (Figura $5.4 C)$.

4- recipiente decorado no restringido, con borde recto y labio angular, y un diámetro de boca de $24 \mathrm{~cm}$; esta vasija corresponde probablemente a un plato hondo (ED-RS-25) (Figura 5.4D). 
A

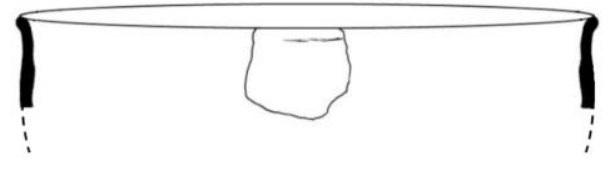

B

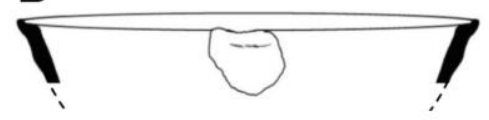

C

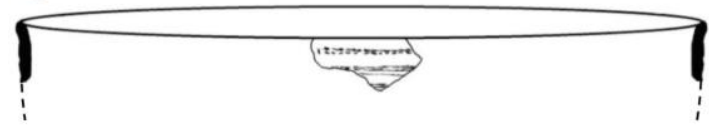

D
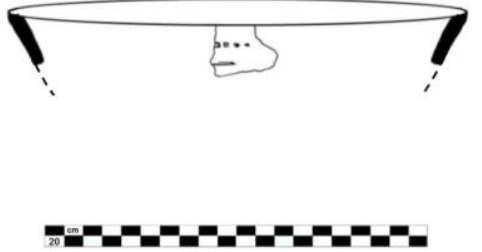

$20 \mathrm{~cm}$
E

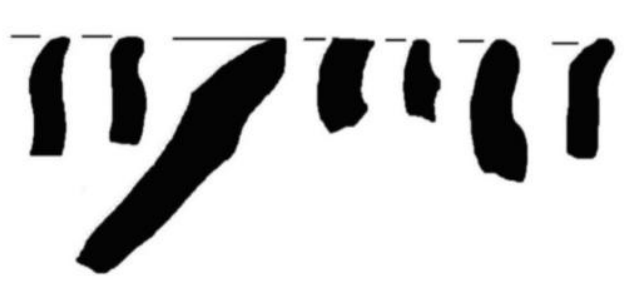

$\mathbf{F}$
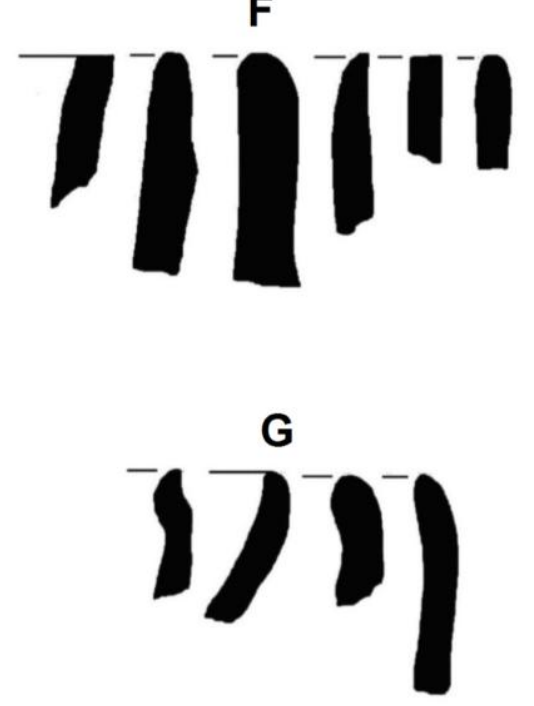

$\mathrm{cm}$

Figura 5.4. Vasijas reconstruidas, bordes y labios del sector $A$.

Formas no restringidas con bordes evertidos: A (PB2-RS-T11/H-1), B (ED-RS-20) y C (ED-RS-23/24). Formas no restringida con bordes rectos: D (ED-RS-25). E: bordes evertidos.

F: bordes rectos. G: bordes invertidos.

Todos los fragmentos decorados ( $n=8$ ) (Figura 5.5) presentan desplazamiento de materia y fueron decorados mediante la técnica incisión de surco rítmico. Además dos de estos tiestos combinan el surco rítmico (Caggiano 1985) con incisión de punto; conformando motivos lineales o geométricos. No se registraron evidencias de ahumado u hollín en ningún tiesto de la muestra. 


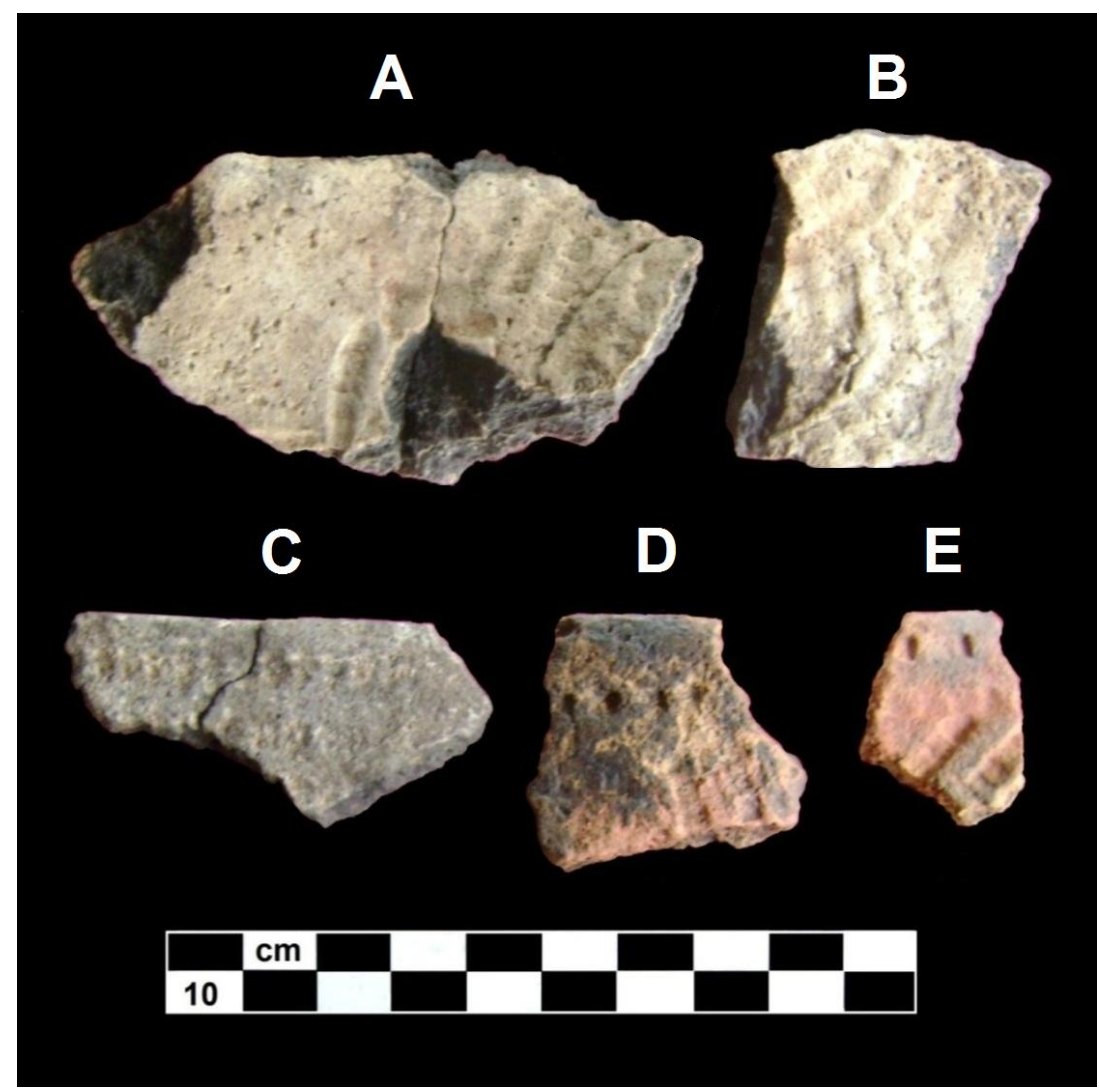

Figura 5.5. Fragmentos de alfarería decorada registrados en el sector $A$.

A y B: Paso Blanco 2. C, D y E: El Dorado. Nótese el alto grado de erosión de los tiestos.

\subsection{3- MATERIALES ARQUEOLÓGICOS DEL MUSEO TIERRA DE MINUANES}

En esta sección se describen algunos de los artefactos más relevantes procedentes de sector A y depositados en el Museo Tierra de Minuanes. Estos artefactos fueron recolectados en superficie por el director del museo, el señor Marcelo Lugrin. Es necesario aclarar que estos materiales de colección no se presentan conjuntamente con los recuperados en nuestros trabajos de campo (Tabla 5.2) porque no fueron analizados con el mismo nivel de detalle. También se destaca que parte de esta colección fue previamente analizada por el Lic. Carlos Ceruti y el Dr. Salomón Hocsman (Ceruti 2007; Hocsman 2007). La procedencia de las piezas depositadas en el museo se identificó a partir de la numeración correlativa que presentan las mismas.

Lugrin denomina "yacimientos" a los lugares donde recolectó todos los materiales arqueológicos que incluyen restos cerámicos y líticos. Estos "yacimientos" en algunos casos corresponderían a localidades arqueológicas y en otros a sitios arqueológicos o hallazgos aislados (sobre este punto véase también Hocsman 2007). Excepto los sitios arqueológicos visitados en nuestras prospecciones (Tabla 5.1) no se pueden determinar por el momento a que categoría corresponden los demás lugares de recolección. Así, ante la imposibilidad de diferenciar entre estos conjuntos artefactuales, se usan los terminos "sitio arqueológico" y "hallazgo aislado" según su 
definición (véase Capítulo 4) pero en este caso solo se consideran las frecuencias artefactuales; asimismo, se tuvo en cuenta la información aportada por Lugrin sobre el contexto arqueológico de las recolecciones superficiales. Dado que los conjuntos recuperados por Lugrin se encuentran espacialmente bastante dispersos (véase Figura 5.1), el problema de no poder identificar su procedencia de forma precisa (hallazgo aislado, sitio arqueológico o localidad arqueológica) no impide arribar a interpretaciones sobre el registro arqueológico del sector de manera general y hasta profundizar las interpretaciones en relación a aquellos sitios arqueológicos relevados en nuestras prospecciones.

La colección del MTM proviene de 43 "yacimientos" en superficie, 36 ubicados en el departamento Villaguay, uno en Federal, uno en Concordia, uno en La Paz, dos en la provincia de Santa Fe y dos en Paysandú (ROU). En esta sección solamente se trataran los conjuntos arqueológicos que fueron analizados (Tabla 5.12) y cuya ubicación aproximada se indica en la Figura 5.1. Todos están ubicados en el departamento Villaguay y provienen de la cuenca del río Gualeguay y los arroyos Lucas, Maidana, Raíces, El Tigre y Moreyra. El conjunto analizado incluye también algunos artefactos de los que no se cuenta con información sobre su procedencia exacta pero al menos se puede plantear que provienen del sector A (Figura 5.1). Los sitios arqueológicos Antivero, El Vertiente y Peñón Colorado presentan mayor cantidad de artefactos (desechos de talla y cerámica) que los presentados en la Tabla 5.12 que por cuestiones de tiempo no fueron analizados. 
Tabla 5.12. Materiales arqueológicos de la colección del Museo Tierra de Minuanes (Villaguay), según sus frecuencias por tipo de material y categorías tecnológicas y morfológicas.

\begin{tabular}{|c|c|c|c|c|c|c|c|c|c|}
\hline \multirow{2}{*}{$\begin{array}{c}\text { Sitios arqueológicos } \\
\text { y hallazgos aislados } \\
\text { (Sigla en la Figura 5.1) }\end{array}$} & \multicolumn{4}{|c|}{ Artefactos líticos } & \multicolumn{4}{|c|}{ Cerámica } & \multirow{2}{*}{$\begin{array}{c}\text { Total } \\
\text { genera }\end{array}$} \\
\hline & INS & DES & NUC & Total & BOR & CUE & $\mathrm{B} / \mathrm{M}$ & Total & \\
\hline Paso Blanco (PB1) & 3 & 99 & - & 102 & - & - & - & - & 102 \\
\hline Pozo Azul a (PAa) & 14 & 98 & 1 & 113 & 9 & 98 & - & 107 & 220 \\
\hline La Lomita (LL) & 2 & 56 & - & 58 & 13 & 286 & - & 299 & 357 \\
\hline La Lomita 2 (LL2) & - & 116 & 1 & 117 & 1 & 8 & - & 9 & 126 \\
\hline Puente del Tigre (PDT) & 9 & 116 & 1 & 126 & 22 & 201 & - & 223 & 349 \\
\hline El Dorado (ED) & 5 & 28 & - & 33 & 12 & 95 & - & 107 & 140 \\
\hline Nogueira 2 (N2) & 7 & 127 & 2 & 136 & 8 & 45 & - & 53 & 189 \\
\hline Laguna de García (LDG) & 12 & 347 & 8 & 367 & 43 & $250^{3}$ & $2^{3}$ & 295 & 662 \\
\hline Laguna Blanca y Negra (LBN) & 2 & 75 & - & 77 & 6 & 41 & - & 47 & 124 \\
\hline Ramblones (R) & - & 42 & - & 42 & 22 & 134 & - & 156 & 198 \\
\hline Base del Maidana (BM) & 38 & 363 & - & 401 & 17 & 355 & $1^{4}$ & 373 & 774 \\
\hline Laguna Las Violetas (LLV) & 1 & 42 & - & 43 & 9 & 50 & - & 59 & 102 \\
\hline Laguna Proto (LAP) & 2 & 81 & 1 & 84 & - & 6 & - & 6 & 90 \\
\hline Jeromito $(\mathrm{J})$ & 7 & 192 & 16 & 215 & 25 & 145 & - & 170 & 385 \\
\hline El Barrero (EB) & 1 & 59 & - & 60 & - & - & - & - & 60 \\
\hline El Remolino (ER) & 2 & 4 & 2 & 8 & 18 & 2 & $1^{5}$ & 21 & 29 \\
\hline Arroyo Villaguay (AVI) & 3 & 1 & 2 & 6 & 3 & 2 & - & 5 & 11 \\
\hline El Algarrobillo (EA) & 5 & 3 & 1 & 9 & 2 & - & - & 2 & 11 \\
\hline Arroyo Lucas (ALU) & - & 1 & - & 1 & 1 & - & - & 1 & 2 \\
\hline Roda (RO) & 2 & 2 & - & 4 & - & - & - & - & 4 \\
\hline El Baletón (EBA) & 3 & 5 & - & 8 & - & - & - & - & 8 \\
\hline Laguna de Beigan (LB) & 1 & 3 & - & 4 & - & - & - & - & 4 \\
\hline Tigre Colorado (TC) & 5 & 3 & - & 8 & 2 & 2 & - & 4 & 12 \\
\hline San Cristóbal (SC) & 5 & 1 & - & 6 & 2 & 3 & - & 5 & 11 \\
\hline La Confluencia (LC) & 1 & - & - & 1 & - & - & - & - & 1 \\
\hline Balatorre (B) & 7 & - & - & 7 & - & - & - & - & 7 \\
\hline Picada de Segovia (PDS) & - & - & - & - & 1 & - & - & 1 & 1 \\
\hline Barranca Chica (BC) & 1 & - & - & 1 & - & - & - & - & 1 \\
\hline Antivero $^{1}(A)$ & 4 & - & - & 4 & 19 & - & - & 19 & 23 \\
\hline El Vertiente ${ }^{1}$ (EV) & 3 & - & - & 3 & - & - & - & - & 3 \\
\hline Peñón Colorado ${ }^{1}$ (PC) & 2 & - & - & 2 & - & - & - & - & 2 \\
\hline Sin procedencia $^{2}(s / p)$ & 197 & - & - & 197 & - & - & - & - & 197 \\
\hline Total & 344 & 1864 & 35 & 2243 & 235 & 1723 & 4 & 1962 & 4205 \\
\hline
\end{tabular}

INS: instrumentos; DES: desechos; NUC: núcleos; BOR: bordes; CUE: cuerpos; B/M: base o modelado. (1) conjuntos arqueológicos que tienen más materiales que los presentados en la tabla y no pudieron ser estudiados en detalle, corresponden a sitios arqueológicos. (2) instrumentos procedentes del sector A sin que se pueda determinar con más precisión su procedencia.

(3) un fragmento de base y un borde con un mamelón modelado. (4) apéndice zoomorfo. (5) base decorada.

\subsubsection{1- Artefactos líticos del Museo Tierra de Minuanes}

\section{Materias primas}

La Tabla 5.13 muestra la representatividad de las materias primas en relación a las clases tipológicas. Se dejaron de lado 408 desechos de talla de Pozo Azul a $(n=56)$, Puente del Tigre $(n=$ 
107) y Laguna de García ( $n=245$ ), ya que no se determinaron las frecuencias de sus materias primas, pero en los tres casos se observaron materiales silíceos y areniscas.

Tabla 5.13. Materias primas por clases tipológicas de los materiales arqueológicos del Museo Tierra de Minuanes (Villaguay).

\begin{tabular}{|c|c|c|c|c|c|c|c|c|}
\hline \multirow{3}{*}{ Materia prima } & \multicolumn{6}{|c|}{ Clases tipológicas } & & \\
\hline & \multicolumn{2}{|c|}{ Instrumentos } & \multicolumn{2}{|c|}{ Desechos de talla } & \multicolumn{2}{|c|}{ Núcleos } & \multicolumn{2}{|c|}{ Total } \\
\hline & $\mathrm{n}$ & $\%$ & $\mathrm{n}$ & $\%$ & $\mathrm{n}$ & $\%$ & $\mathrm{n}$ & $\%$ \\
\hline Calcedonia & 9 & 2,6 & 4 & 0,3 & - & - & 13 & 0,7 \\
\hline Caliza silicificada & 5 & 1,5 & 20 & 1,4 & 12 & 34,2 & 37 & 2 \\
\hline Ágata & - & - & 17 & 1,2 & 1 & 2,9 & 18 & 1 \\
\hline Sílice & 44 & 12,8 & 685 & 47 & - & - & 729 & 39,7 \\
\hline Xilópalo & 8 & 2.3 & - & - & - & - & 8 & 0,4 \\
\hline Arenisca & 156 & 45,3 & 663 & 45,5 & 20 & 57,1 & 839 & 45,7 \\
\hline Cuarcita intertrap & 13 & 3,8 & 33 & 2,3 & 1 & 2,9 & 47 & 2,6 \\
\hline Basalto & 95 & 27,6 & 32 & 2,2 & - & - & 127 & 6.9 \\
\hline Cuarzo & 2 & 0,6 & 2 & 0,1 & 1 & 2,9 & 5 & 0,3 \\
\hline Diabasa & 3 & 0,9 & - & - & - & - & 3 & 0,2 \\
\hline Arcilla & 3 & 0,9 & - & - & - & - & 3 & 0,2 \\
\hline Indeterminada & 6 & 1,7 & - & - & - & - & 6 & 0,3 \\
\hline Total & 344 & 100 & 1456 & 100 & 35 & 100 & 1835 & 100 \\
\hline
\end{tabular}

\section{Instrumentos}

En cuanto a los instrumentos (Tabla 5.14) se identificaron: 233 bolas, 82 puntas de proyectil, siete piezas con retoque sumario, seis raspadores, tres bifaces, tres raederas, dos cuchillos, un unifaz, tres percutores, un instrumento tallado indeterminado, tres instrumentos picados, abradidos $\mathrm{y} / \mathrm{o}$ pulidos indeterminados. 
Tabla 5.14. Instrumentos líticos del Museo Tierra de Minuanes (Villaguay) por conjuntos arqueológicos.

\begin{tabular}{|c|c|c|c|c|c|c|c|c|c|c|c|c|}
\hline \multirow{2}{*}{$\begin{array}{l}\text { Sitios arqueológicos } \\
\text { y hallazgos aislados }\end{array}$} & \multicolumn{11}{|c|}{ Instrumentos } & \multirow{2}{*}{ Total } \\
\hline & $\mathrm{BO}$ & $\mathrm{PU}$ & PRS & RAS & $\overline{\mathrm{BI}}$ & RAE & $\mathrm{CU}$ & UN & $\mathrm{PE}$ & $\mathrm{I}-\mathrm{T}$ & $\mathrm{I}-\mathrm{P}$ & \\
\hline Paso Blanco 1 & 1 & 1 & - & 1 & - & - & - & - & - & - & - & 3 \\
\hline Pozo Azul a & 8 & 4 & - & - & - & 1 & 1 & - & - & - & - & 14 \\
\hline La Lomita & - & 1 & - & - & - & 1 & - & - & - & - & - & 2 \\
\hline Puente del Tigre & 2 & 4 & 2 & 1 & - & - & - & - & - & - & - & 9 \\
\hline El Dorado & 4 & - & - & - & - & - & 1 & - & - & - & - & 5 \\
\hline Nogueira 2 & 2 & 4 & - & 1 & - & - & - & - & - & - & - & 7 \\
\hline Laguna de García & 8 & 2 & - & - & - & - & - & - & 1 & - & 1 & 12 \\
\hline Laguna Blanca y Negra & - & - & 1 & - & - & 1 & - & - & - & - & - & 2 \\
\hline Base del Maidana & 2 & 33 & - & 1 & - & - & - & - & - & 1 & 1 & 38 \\
\hline Laguna Las Violetas & 1 & - & - & - & - & - & - & - & - & - & - & 1 \\
\hline Laguna Proto & 1 & 1 & - & - & - & - & - & - & - & - & - & 2 \\
\hline Jeromito & 4 & - & 3 & - & - & - & - & - & - & - & - & 7 \\
\hline El Barrero & 1 & - & - & - & - & - & - & - & - & - & - & 1 \\
\hline El Remolino & - & 2 & - & - & - & - & - & - & - & - & - & 2 \\
\hline Arroyo Villaguay & 3 & - & - & - & - & - & - & - & - & - & - & 3 \\
\hline El Algarrobillo & - & 5 & - & - & - & - & - & - & - & - & - & 5 \\
\hline Roda & 2 & - & - & - & - & - & - & - & - & - & - & 2 \\
\hline El Baletón & 3 & - & - & - & - & - & - & - & - & - & - & 3 \\
\hline Laguna de Beigan & 1 & - & - & - & - & - & - & - & - & - & - & 1 \\
\hline Tigre Colorado & 4 & - & - & - & - & - & - & 1 & - & - & - & 5 \\
\hline San Cristóbal & 2 & 2 & 1 & - & - & - & - & - & - & - & - & 5 \\
\hline La Confluencia & - & - & - & - & 1 & - & - & - & - & - & - & 1 \\
\hline Balatorre & 2 & 3 & - & - & 1 & - & - & - & 1 & - & - & 7 \\
\hline Barranca Chica & - & 1 & - & - & - & - & - & - & - & - & - & 1 \\
\hline Antivero & 1 & 3 & - & - & - & - & - & - & - & - & - & 4 \\
\hline El Vertiente & - & 2 & - & 1 & - & - & - & - & - & - & - & 3 \\
\hline Peñón Colorado & - & 1 & - & - & 1 & - & - & - & - & - & - & 2 \\
\hline Sin procedencia & 181 & 13 & - & 1 & - & - & - & - & 1 & - & 1 & 197 \\
\hline Total & 233 & 82 & 7 & 6 & 3 & 3 & 2 & 1 & 3 & 1 & 3 & 344 \\
\hline
\end{tabular}

BO: bola; PU: punta de proyectil; PRS: pieza con retoque sumario; RAS: raspador; RAE: raedera; BI: bifaz; CU: cuchillo; UN: unifaz; PE: percutor; I-T: instrumento indeterminado tallado;

I-P: instrumento indeterminado picado, pulido y/o abradido.

La mayor parte de los instrumentos corresponden a piezas elaboradas mediante picado, abrasión y/o pulido ( $n=236$ ), seguidas por las piezas talladas ( $n=105)$, y en muy baja frecuencia la piezas modificadas por uso $(n=3)$. El $42,8 \%(n=147)$ de los instrumentos registra procedencia exacta, mientras que el $57,2 \%(n=197)$ restante no la tiene. La mayoría de los instrumentos sin procedencia son bolas $(n=181)$ y la mayoría fueron encontradas aisladas y/o expuestas por el arado en los campos del sector A. Parte de las mismas fueron recolectadas por pobladores locales y donadas al museo. 
Tabla 5.15. Materias primas de bolas y puntas de proyectil del Museo Tierra de Minuanes (Villaguay) por conjuntos arqueológicos.

\begin{tabular}{|c|c|c|c|c|c|c|c|c|c|c|c|c|c|c|c|c|}
\hline \multirow{3}{*}{$\begin{array}{l}\text { Sitios arqueológicos } \\
\text { y hallazgos aislados }\end{array}$} & \multicolumn{7}{|c|}{ Bolas } & \multicolumn{9}{|c|}{ Puntas de proyectil } \\
\hline & \multicolumn{6}{|c|}{ Materias primas } & \multirow{2}{*}{ Total } & \multicolumn{8}{|c|}{ Materias primas } & \multirow{2}{*}{ Total } \\
\hline & $A$ & $\mathrm{~B}$ & $\mathrm{D}$ & $\mathrm{AR}$ & $\mathrm{C}$ & 1 & & $\mathrm{~S}$ & $A$ & $\mathrm{Cl}$ & $\mathrm{CA}$ & $\mathrm{x}$ & $\bar{B}$ & CAL & $\mathrm{I}$ & \\
\hline Paso Blanco 1 & 1 & - & - & - & - & - & 1 & - & 1 & - & - & - & - & - & - & 1 \\
\hline Pozo Azul a & 6 & 2 & - & - & - & - & 8 & 1 & - & - & 1 & 1 & - & 1 & - & 4 \\
\hline La Lomita & - & - & - & - & - & - & - & - & - & - & 1 & - & - & - & - & 1 \\
\hline Puente del Tigre & 2 & - & - & - & - & - & 2 & 3 & - & 1 & - & - & - & - & - & 4 \\
\hline El Dorado & 2 & 2 & - & - & - & - & 4 & - & - & - & - & - & - & - & - & - \\
\hline Nogueira 2 & 1 & 1 & - & - & - & - & 2 & 2 & 1 & - & - & 1 & - & - & - & 4 \\
\hline Laguna de García & 7 & 1 & - & - & - & - & 8 & 1 & - & - & - & 1 & - & - & - & 2 \\
\hline Base del Maidana & - & 2 & - & - & - & - & 2 & 16 & 5 & 6 & 2 & 2 & 1 & 1 & - & 33 \\
\hline Laguna Las Violetas & 1 & - & - & - & - & - & 1 & - & - & - & - & - & - & - & - & - \\
\hline Laguna Proto & 1 & - & - & - & - & - & 1 & - & - & 1 & - & - & - & - & - & 1 \\
\hline Jeromito & 4 & - & - & - & - & - & 4 & - & - & - & - & - & - & - & - & - \\
\hline El Barrero & 1 & - & - & - & - & - & 1 & - & - & - & - & - & - & - & - & - \\
\hline El Remolino & - & - & - & - & - & - & - & 1 & - & - & - & - & 1 & - & - & 2 \\
\hline Arroyo Villaguay & 2 & 1 & - & - & - & - & 3 & - & - & - & - & - & - & - & - & - \\
\hline El Algarrobillo & - & - & - & - & - & - & - & 2 & - & 1 & 1 & - & - & - & 1 & 5 \\
\hline Roda & 1 & 1 & - & - & - & - & 2 & - & - & - & - & - & - & - & - & - \\
\hline El Baletón & 1 & 2 & - & - & - & - & 3 & - & - & - & - & - & - & - & - & - \\
\hline Laguna de Beigan & 1 & - & - & - & - & - & 1 & - & - & - & - & - & - & - & - & - \\
\hline Tigre Colorado & 3 & 1 & - & - & - & - & 4 & - & - & - & - & - & - & - & - & - \\
\hline San Cristóbal & 1 & 1 & - & - & - & - & 2 & - & 1 & - & - & - & - & - & 1 & 2 \\
\hline Balatorre & 1 & 1 & - & - & - & - & 2 & 1 & 1 & - & 1 & - & - & - & - & 3 \\
\hline Barranca Chica & - & - & - & - & - & - & - & - & - & - & - & - & - & - & 1 & 1 \\
\hline Antivero & 1 & - & - & - & - & - & 1 & - & - & 1 & 1 & - & 1 & - & - & 3 \\
\hline El Vertiente & - & - & - & - & - & - & - & 1 & 1 & - & - & - & - & - & - & 2 \\
\hline Peñón Colorado & - & - & - & - & - & - & - & - & - & - & - & - & - & 1 & - & 1 \\
\hline Sin procedencia & 97 & 74 & 3 & 3 & 1 & 3 & 181 & 9 & 2 & - & - & 1 & 1 & - & - & 13 \\
\hline Total & 134 & 89 & 3 & 3 & 1 & 3 & 233 & 37 & 12 & 10 & 7 & 6 & 4 & 3 & 3 & 82 \\
\hline
\end{tabular}

A: arenisca; B: basalto; D: diabasa; C: cuarzo; AR: arcilla; S: sílice; A: arenisca; CA: calcedonia;

$\mathrm{Cl}$ : cuarcita intertrap; $\mathrm{X}$ : xilópalo; CAL: caliza silicificada; I: Indeterminada.

Bolas $(\mathrm{n}=233)$

En relación a las bolas 52 tienen procedencia y 181 no la tienen. Se registraron 160 enteras, 52 fragmentadas y 21 fragmentos de bola (sensu Vecchi 2010). Siguiendo la clasificación de González (1953), y a pesar de las piezas fregmentadas ( $>50 \%)$ y los fragmentos $(<50 \%)$, se pudo determinar el Tipo, Clase y subclase de 228 bolas (Tabla 5.16). En las cinco piezas restantes no se pudo determinar el tipo debido a que las fracturas impedían relevar los diámetros o la forma general de la pieza (PAa, LDG, BM, AVI y s/p). 
Tabla 5.16. Clasificación de las bolas del Museo Tierra de Minuanes (Villaguay) según González (1953)

\begin{tabular}{|c|c|c|c|c|c|c|c|c|c|c|}
\hline \multirow{2}{*}{ Tipo } & \multirow{2}{*}{ Clase } & \multirow{2}{*}{ subclase } & \multicolumn{6}{|c|}{ Materia prima } & \multicolumn{2}{|c|}{ Total } \\
\hline & & & $\bar{A}$ & $\mathrm{~B}$ & $\bar{D}$ & $\overline{\mathrm{AR}}$ & $\bar{C}$ & $\mathrm{I}$ & $\mathrm{n}$ & $\%$ \\
\hline \multirow{5}{*}{$\begin{array}{c}\text { A } \\
\text { (sin surco) }\end{array}$} & $a$ & - & 14 & 6 & 2 & 1 & - & - & 23 & 45,1 \\
\hline & $\mathrm{b}$ & - & 9 & 3 & 1 & - & 1 & - & 14 & 27,4 \\
\hline & $d$ & 2 & 11 & - & - & - & - & - & 11 & 21,6 \\
\hline & i & - & 1 & 1 & - & - & - & 1 & 3 & 5,9 \\
\hline & Total & - & 35 & 10 & 3 & 1 & 1 & 1 & 51 & 100 \\
\hline \multirow{9}{*}{$\begin{array}{c}\text { B } \\
\text { (con surco) }\end{array}$} & a & - & 10 & 10 & - & - & - & - & 20 & 11,4 \\
\hline & b & 1 & 4 & 3 & - & 1 & - & - & 8 & 4,5 \\
\hline & c & 2 & 9 & 13 & - & - & - & - & 22 & 12,5 \\
\hline & $c$ & 5 & 9 & 6 & - & - & - & - & 15 & 8,5 \\
\hline & $f$ & - & 15 & 11 & - & - & - & 2 & 28 & 15,9 \\
\hline & g & - & 1 & - & - & - & - & - & 1 & 0,6 \\
\hline & $\mathrm{h}$ & - & 28 & 23 & - & 1 & - & - & 52 & 29,6 \\
\hline & $\mathrm{i}$ & - & $19^{1}$ & $11^{1}$ & - & - & - & - & 30 & 17 \\
\hline & Total & - & 95 & 77 & - & 2 & - & 2 & 176 & 100 \\
\hline $\begin{array}{c}\text { C } \\
\text { (con surco doble) }\end{array}$ & - & - & - & 1 & - & - & - & - & 1 & 100 \\
\hline Total general & - & - & 130 & 88 & 3 & 3 & 1 & 3 & 228 & - \\
\hline
\end{tabular}

(1) este valor incluye una de las probables bolas de mazas.

Tomando los datos de la Tabla 5.16, se observa que $177(77,6 \%)$ bolas presentan surco y 51 $(22,4 \%)$ carecen de este atributo. La morfología del surco es variable, en general se presenta bien definido circundando toda la pieza en una línea recta (aunque se observaron casos donde el surco define una línea en zig-zag u ondulante). En muy pocos casos se presenta levemente esbozado y no circunda toda la bola. El mayor surco registrado presenta un ancho máximo de 19,8 mm y una profundidad máxima de 5,6 mm (MTM-PAa-58-21/tipo Ba) (Figura 5.6Ba). Un dato por destacar en cuanto a las bolas cuyo tipo se pudo determinar es que todas las bolas con procedencia $(n=48)$ presentan surco, mientras que del total de bolas sin procedencia exacta $(n=180) 129$ tienen surco y 51 no lo tienen.

A partir de los atributos morfométricos relevados se observó la presencia de 11 tipos (Tabla 5.16 y Figura 5.6) dentro de los cuales el tipo Bh (piriforme) es el más representado, seguido por el tipo Bf (forma de limón). Por su parte, los tipos Aa, Ba (esferas) y Bc2 (esferoide alargado) presentan frecuencias semejantes entre sí, al igual que lo que ocurre entre los tipos Ab (esferoide achatado) y Bc5 (discoide). Los tipos Ad2 y Bb1 tienen baja frecuencia. Se destacan los tipos Bg por ser esferoide y presentar un hoyuelo sobre el surco (Figura $5.6 \mathrm{Bg}$ ) y el tipo $\mathrm{C}$ por ser piriforme y presentar dos surcos perpendiculares entre sí (Figura 5.6C). Cabe mencionar que dentro del conjunto de bolas con surco (tipo B) indeterminadas se incluyen dos que por su morfología general (oval con una cara 168 
plana) podrían corresponder a bolas de mazas, pero la falta de una muestra mayor para poder caracterizar con precisión la presencia de este tipo de arma en el área impide una determinación precisa. Ahora bien, en cuanto a la morfología de las bolas, sin considerar la presencia y posición del surco y/o hoyuelo, se observa un claro predominio de formas con al menos dos diámetros distintos (esferoides) ( $n=152$ ) (tipos Ab, Ad2, Bb, Bb1, Bc2, Bc5, Bf, Bg y Bh) sobre las esferas ( $n=43$ ) (tipos Aa y Ba).

En relación a la variabilidad de tipos registrados en cada uno de los conjuntos arqueológicos con mayor número de bolas (Tabla 5.14) se observa que Pozo Azul a y Laguna de García tienen tres tipos distintos, Tigre Colorado tiene dos tipos, y El Dorado y Jeromito tienen un solo tipo. Los mismos se distribuyen de la siguiente manera: Pozo Azul a [Ba $(n=1), B b 1(n=2), B h(n=1), B$ indeterminada $(n=3)$ e indeterminada por fractura $(n=1)]$; Laguna de García [Bc5 $(n=1), B h(n=3), B g(n=1), B$ indeterminada $(n=2)$ e indeterminada por fractura $(n=1)]$; Tigre Colorado $[B a(n=1), B c 2(n=2)$ y $B$ indeterminada $(n=1)$ ]; El Dorado $[B c 5(n=2)$ y $B$ indeterminada $(n=2)$; y Jeromito $[B h(n=2)$ y $B$ indeterminada $(n=2)]$.

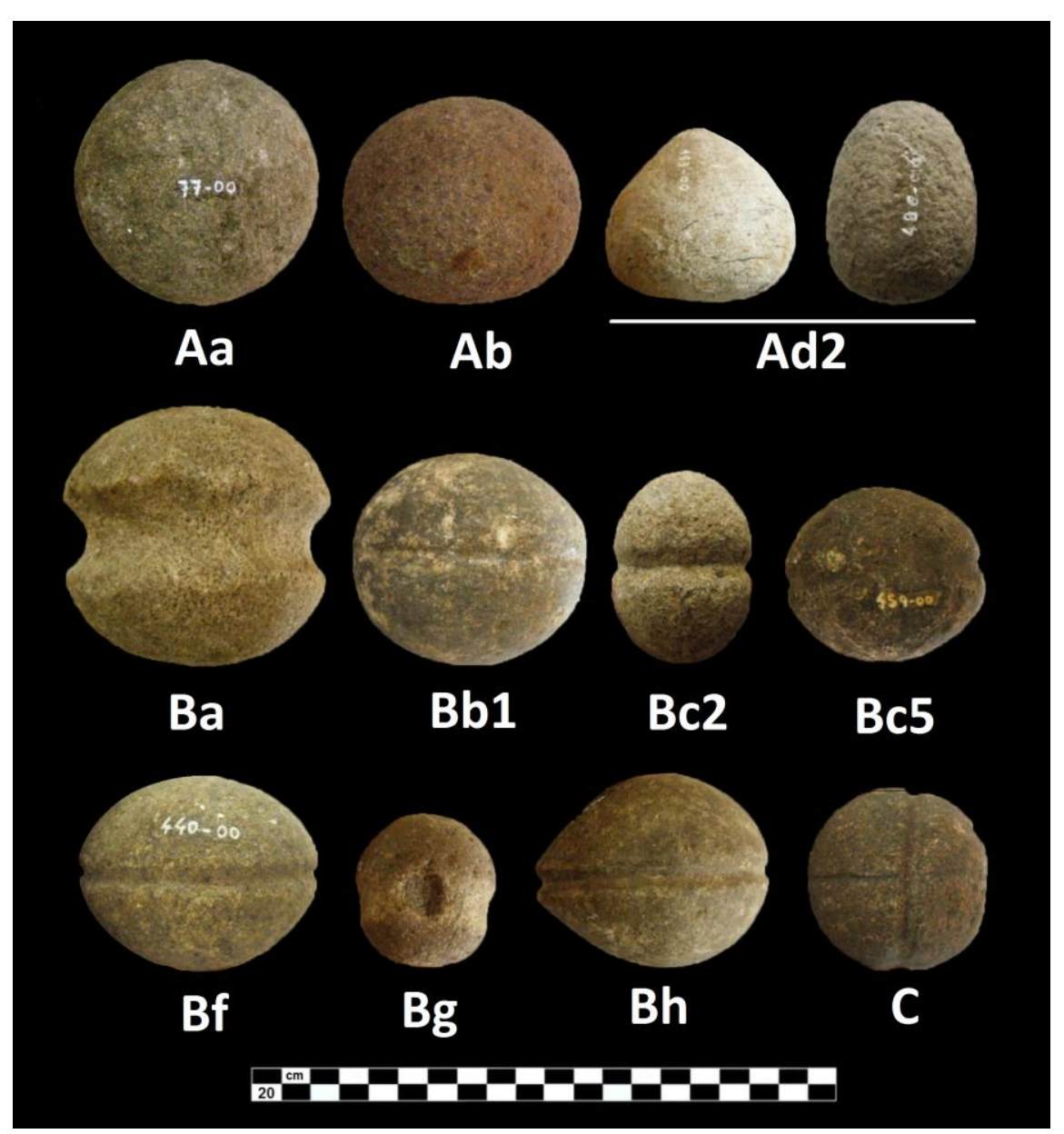

Figura 5.6. Bolas de la colección del Museo Tierra de Minuanes (Villaguay). Tipos: Aa (MTM-s/p-77-00). Ab (MTM-s/p-307-00). Ad2 (MTM-s/p-153-00 y MTM-s/p-486-00). Ba (MTM-PAa-58-21). Bb1 (MTM-PAa-61-21). Bc2 (MTM-s/p-19-00). Bc5 (MTM-s/p-459-00). Bf (MTM-s/p-440-00). Bg (MTM-LDG-08-22).

Bh (MTM-s/p-39-00). C (MTM-s/p-s/n). 
De los 26 tipos de bolas determinados por González (1953) a nivel continental, en Entre Ríos este autor establece la presencia de seis de ellos ( $\mathrm{Aa}, \mathrm{Ad} 2, \mathrm{Ba}, \mathrm{Bc} 2, \mathrm{Bf}$ y $\mathrm{Bb}$ ) basándose sobre todo en bibliografía y solamente en un caso a partir del análisis concreto de una pieza tipo Bf (González 1953: 206). De estos seis tipos mencionados solo los cinco primeros fueron registrados en la muestra del MTM (Tabla 5.16), y a estos se suman otros seis ( $\mathrm{Ab}, \mathrm{Bb} 1, \mathrm{Bc5}, \mathrm{Bg}$, Bh y $\mathrm{C}$ ) (Tabla 5.16-17) que no habían sido documentados siguiendo la clasificación de González (1953)². En síntesis, en la colección del MTM se identificaron 11 de los 26 tipos de bolas definidas por González (Figura 5.6), cinco de ellos ya habían sido identificados por el autor para Entre Ríos y para los seis restantes no había registro sistemático en la provincia. En cuanto a estos seis últimos tipos ( $\mathrm{Ab}, \mathrm{Bb} 1, \mathrm{Bc5}, \mathrm{Bg}, \mathrm{Bh}$ y $\mathrm{C}$ ) no solo fueron registrados en el MTM, sino que también se han identificado y/o analizado en otras colecciones particulares y de museos y/o en publicaciones (Tabla 5.17 y Figura 5.7). Se aclara que las identificaciones basadas en la bibliografía se hicieron a partir imágenes y descripciones morfológicas precisas brindadas por los autores, y en algunos casos se reanalizó dicho material (MACN, MAS y MAMA; véase Tabla 5.17).

Además, mediante este relevamiento de colecciones y bibliografía se identificaron, por un lado, piezas de los demás tipos ( $\mathrm{Aa}, \mathrm{Ad2}, \mathrm{Ba}, \mathrm{Bc2}, \mathrm{Bf}$ ), que no se incluyen aquí por haber sido ya mencionadas para la provincia por González (1953). Por otro lado, además se registraron piezas de los tipos $A c, B c 1, B c 4$ y $D$ (que no están presentes en la colección del MTM); los dos primeros tampoco habían sido mencionados en Entre Ríos. González (1953) también menciona para regiones circundantes a Entre Ríos (Buenos Aires, ROU, Río Grande do Sul) la presencia de algunos tipos que no se han podido identificar dentro de la provincia: Ac1, Ad1, Ad3 y Be. La Tabla 5.17 muestra, por un lado, la distribución geográfica de cada tipo de bola planteada por González (1953), y por otro lado, los nuevos datos obtenidos exclusivamente a partir de bolas cuya procedencia es conocida al menos para la provincia de Entre Ríos, ya que en algunas colecciones se registraron más piezas pero estas contaban con datos de procedencia muy generales.

\footnotetext{
${ }^{1}$ Estos seis tipos no habían sido registrados como tales básicamente por tres causas: 1- porque los tipos se registran en publicaciones previas al trabajo de González; 2- porque simplemente el trabajo de González no fue considerado; y 3- porque los tipos efectivamente no habían sido identificados previamente por ningún autor. 
Tabla 5.17. Distribución geográfica de las bolas tipo Ab, Bb1, Bc5, Bg, Bh, C y D identificadas en colecciones y bibliografía.

\begin{tabular}{|c|c|c|c|c|c|c|c|}
\hline \multirow[b]{2}{*}{$\begin{array}{l}\text { Tipo - } \\
\text { Clase - } \\
\text { subclase }\end{array}$} & \multirow[b]{2}{*}{ González (1953) } & \multicolumn{6}{|c|}{ Bolas registradas en Entre Ríos } \\
\hline & & $\begin{array}{c}\text { Sector A } \\
\text { (MTM) } \\
\mathrm{N}\end{array}$ & $\begin{array}{c}\text { COLECCIONES } \\
\text { Procedencia y (depósito) }\end{array}$ & $\mathrm{n}$ & $\begin{array}{c}\text { BIBLIOGRAFIA } \\
\text { Procedencia (referencia) y } \\
\text { (depósito de las bolas } \\
\text { reanalizadas) }\end{array}$ & $\mathrm{n}$ & Total \\
\hline $\mathrm{Ab}$ & $\begin{array}{c}\text { La Pampa, Neuquén, Río } \\
\text { Negro, Chubut, Santa Cruz, } \\
\text { Tierra del Fuego }\end{array}$ & 14 & - & - & $\begin{array}{l}\text { Federación (Serrano 1932a) } \\
\text { (MAS). }\end{array}$ & 1 & 1 \\
\hline Bb1 & $\begin{array}{c}\text { ROU, Buenos Aires, } \\
\text { Neuquén, Chubut, Santa Cruz }\end{array}$ & 8 & - & - & - & - & \\
\hline Bc5 & $\begin{array}{c}\text { Ecuador, ROU, Buenos } \\
\text { Aires, La Pampa, Neuquén, } \\
\text { Río Negro, Chubut, Santa } \\
\text { Cruz }\end{array}$ & 15 & $\begin{array}{l}\text { Nogoyá (MAS). } \\
\text { Villaguay (MAS). }\end{array}$ & 2 & - & - & 2 \\
\hline $\mathrm{Bg}$ & $\begin{array}{c}\text { Córdoba, Santiago del } \\
\text { Estero, Catamarca, La Rioja }\end{array}$ & 1 & Gualeguaychú (MAMA). & 1 & Islas del Ibicuy (Aparicio 1928). & 1 & 2 \\
\hline $\mathrm{Bh}^{1}$ & $\begin{array}{l}\text { ROU, Río Grande do Sul, } \\
\text { Buenos Aires,La Pampa, } \\
\text { Chubut, Santa Cruz }\end{array}$ & 52 & $\begin{array}{c}\text { Federación }(n=5)(M A C N) . \\
\text { Federación }(M L) . \\
\text { Federación (MAS). } \\
\text { Federal ( } n=2)(M C B) . \\
\text { Paraná (MAS). } \\
\text { Paraná (ML). } \\
\text { Uruguay medio (MCQ). } \\
\text { Entre Ríos (MAS). }\end{array}$ & 13 & $\begin{array}{c}\text { Federación (Rodríguez 1969). } \\
\text { Federación (Poenitz 1971). } \\
\text { Concordia (Rocha 1978). } \\
\text { Paraná (Caggiano 1979). } \\
\text { Concepción del Uruguay } \\
\text { (CCBSJG 1986) (MAMA). } \\
\text { Gualeguaychú (CCBSJG 1986) } \\
\text { (MAMA). } \\
\text { Victoria (Matarrese 2015b). } \\
\text { Gualeguay (Matarrese 2015b). }\end{array}$ & 9 & 22 \\
\hline C & $\begin{array}{l}\text { ROU, Buenos Aires, } \\
\text { Neuquén, Chubut }\end{array}$ & 1 & $\begin{array}{c}\text { Feliciano (CPG). (Figura 5.7A) } \\
\text { Uruguay medio (MCQ). } \\
\text { (Figura 5.7B) }\end{array}$ & 2 & $\begin{array}{l}\text { Diamante (Leguizamón 1935) } \\
\text { (MAS). (Figura 5.7C) } \\
\text { Islas del Ibicuy (Bonomo et al. } \\
\text { 2009). }\end{array}$ & 2 & 4 \\
\hline$D^{2}$ & $\begin{array}{c}\text { Perú, ROU, Jujuy, Buenos } \\
\text { Aires, Río Negro, Chubut, } \\
\text { Santa Cruz }\end{array}$ & - & Feliciano (CPG). & 1 & $\begin{array}{l}\text { Federación (Poenitz 1971). } \\
\text { Federación }(n=2) \text { (Vassallo de } \\
\text { Cettour 1995) (MACN). }\end{array}$ & 3 & 4 \\
\hline
\end{tabular}

Instituciones donde están depositados los materiales registrados: MCQ: Museo Regional Camila Quiroga (Chajarí), Colección Brignardello. MACN: Museo de Antropología y Ciencias Naturales (Concordia). MCB: Museo Municipal de Conscripto Bernardi (Federal). MTM: Museo Arqueológico y Antropológico Indígena Tierra de Minuanes (Villaguay). MAS: Museo de Ciencias Naturales y Antropológicas Profesor Antonio Serrano (Paraná), Colección Serrano. ML: Museo Histórico Martiniano Leguizamón (Paraná). MAMA: Museo Arqueológico Manuel Almeida (Gualeguaychú). CPG: Colección Particular Gómez (Feliciano). En negrita los lugares más cercanos a Entre Ríos donde se registró cada tipo según González (1953). (1) este tipo también fue registrado por Serrano (1932a) en el sitio arqueológico Santa Lucía en Corrientes [MAS-550 (1692)]. (2) se incluye este tipo por provenir de zonas próximas a pesar de que no fue registrado en la colección del MTM. Los números de inventario de cada bola analizada se detallan en el Anexo I.

Es necesario destacar una bola probablemente de basalto registrada en el Museo Histórico Martiniano Leguizamón (Paraná) que figura como "bola arrojadiza charrúa" (ML-992) (Figura 5.7J). Su particularidad reside en su tamaño $(110,2 \times 103,4 \times 100,4 \mathrm{~mm})$ y su peso $(1,780 \mathrm{~kg})$. Esta bola se correspondería con el tipo $\mathrm{Bb} 1$, pero presenta los polos aplanados por lo que pudo sufrir algún tipo de abrasión o pulido posterior a su manufactura y por lo tanto originalmente se habría identificado con otro tipo. Bolas de dimensiones similares son mencionadas por González (1953: 190) para Chubut. Este tipo de bola no había sido documentado en el Nordeste argentino. Asimismo, se registró en la misma colección la presencia de tres bolas erizadas de basalto. Dos piezas (ML-778, ML-998) con 10 salientes o mamelones, simetría bilateral con cinco salientes a cada lado del surco; la 
pieza ML-778 tiene pequeñas fracturas en dos salientes (Figura $5.7 \mathrm{H}$ ) y la pieza ML-998 en cuatro salientes (Figura 5.7I). La bola restante (ML-766) tiene 12 salientes y forma irregular, aun así presenta una depresión central que separa seis salientes de cada lado, cuatro están fracturados (Figura 5.7F). Las tres piezas figuran en el catálogo como "rompecabezas de los indios charrúas". Asimismo, en el museo de Concordia se registraron dos bolas erizadas (MACN-16725 y MACN-16726) procedentes de Salto Grande que presentan seis salientes cada una (Figura 5.7D yE).

En cuanto al estado de completitud de las bolas del MTM, se observa que dentro del conjunto de bolas sin procedencia $(n=181)$ el $78 \%(n=141)$ están enteras, mientras que el $22 \%(n=$ 40) restante están fracturadas, correspondiendo el $21,5 \%(n=39)$ a bolas fragmentadas y el $0,5 \%(n=$ 1) a fragmentos. Asimismo, dentro del conjunto con procedencia exacta ( $n=52)$ el $36,5 \%(n=19)$ están enteras, mientras que el 63,5\% ( $n=33$ ) restante están fracturadas, correspondiendo el 38,5\% $(n=20)$ a fragmentos y el $25 \%(n=13)$ a bolas fragmentadas. Desde otro punto de vista se puede plantear que del total de bolas enteras $(n=160)$ el $88,1 \%(n=141)$ no tiene procedencia exacta y solo el $11,9 \%(n=19)$ proviene de sitios arqueológicos y hallazgos aislados identificados. Por su parte, del total de bolas fracturadas $(n=73)$ el $54,8 \%(n=40)$ no tiene procedencia exacta y el $45,2 \%(n=33)$ proviene de sitios arqueológicos y hallazgos aislados.

A partir de estos datos se puede observar una tendencia general que permite plantear que en los sitios arqueológicos y hallazgos aislados se recuperaron mayor cantidad de bolas fracturadas que de bolas enteras. Ocurre lo contrario con aquellas piezas que no tienen procedencia exacta, ya que la mayoría corresponden a bolas enteras, indudablemente por la recolección selectiva.

Con respecto a los tamaños de las bolas, se registró una amplia variabilidad de acuerdo a cada tipo. Considerando las bolas enteras y las fracturadas cuyas medidas no se veían afectadas, en las esferas ( $\mathrm{Aa}$ y $\mathrm{Ba}$ ) se registró un diámetro máximo de 81,9 mm (MTM-s/p-343-00, tipo Aa) y un diámetro mínimo de 31,1 mm (MTM-PB1-38-26, tipo Ba). Por su parte, para los eferoides (tipos Ab, $\mathrm{Ad} 2, \mathrm{Bb}, \mathrm{Bb} 1, \mathrm{Bc2}, \mathrm{Bc5}, \mathrm{Bf}, \mathrm{Bg}$ y $\mathrm{Bh})$ se distinguen tres diámetros perpendiculares: eje mayor, intermedio y menor, y a su vez dentro de cada uno de estos se presentan las medidas extremas registradas. Para el eje mayor se registró un diámetro máximo de 79,4 mm (MTM-s/p-32-00, tipo Ab) y un diámetro mínimo de $32 \mathrm{~mm}$ (MTM-s/p-22, tipo Bh). Para el eje intermedio se registró un diámetro máximo de 70,4 mm (MTM-s/p-161-00, tipo Ab) y un diámetro mínimo de 33 mm (MTMPDT-36-25, tipo Bc2). Asimismo, para el eje menor se registró un diámetro máximo de 66,8 mm (MTM-s/p-162-00, tipo Ab) y un diámetro mínimo de 32,7 mm (MTM-PDT-36-25, tipo Bc2).

Las materias primas de las bolas de la Tabla 5.15 (a las que deben agregar las cinco piezas cuyo tipo es indeterminado por fractura -cuatro areniscas y una de basalto-) se distribuyen como sigue; arenisca: 134 (57,5\%); basalto: 89 (38,2\%); diabasa: 3 (1,3\%); arcilla: 3 (1,3\%) (Figura 5.7K); cuarzo: $1(0,4 \%)$; e indeterminada: 3 (1,3\%). En este sentido, se observa un claro predominio de las areniscas, seguidas por el basalto. 


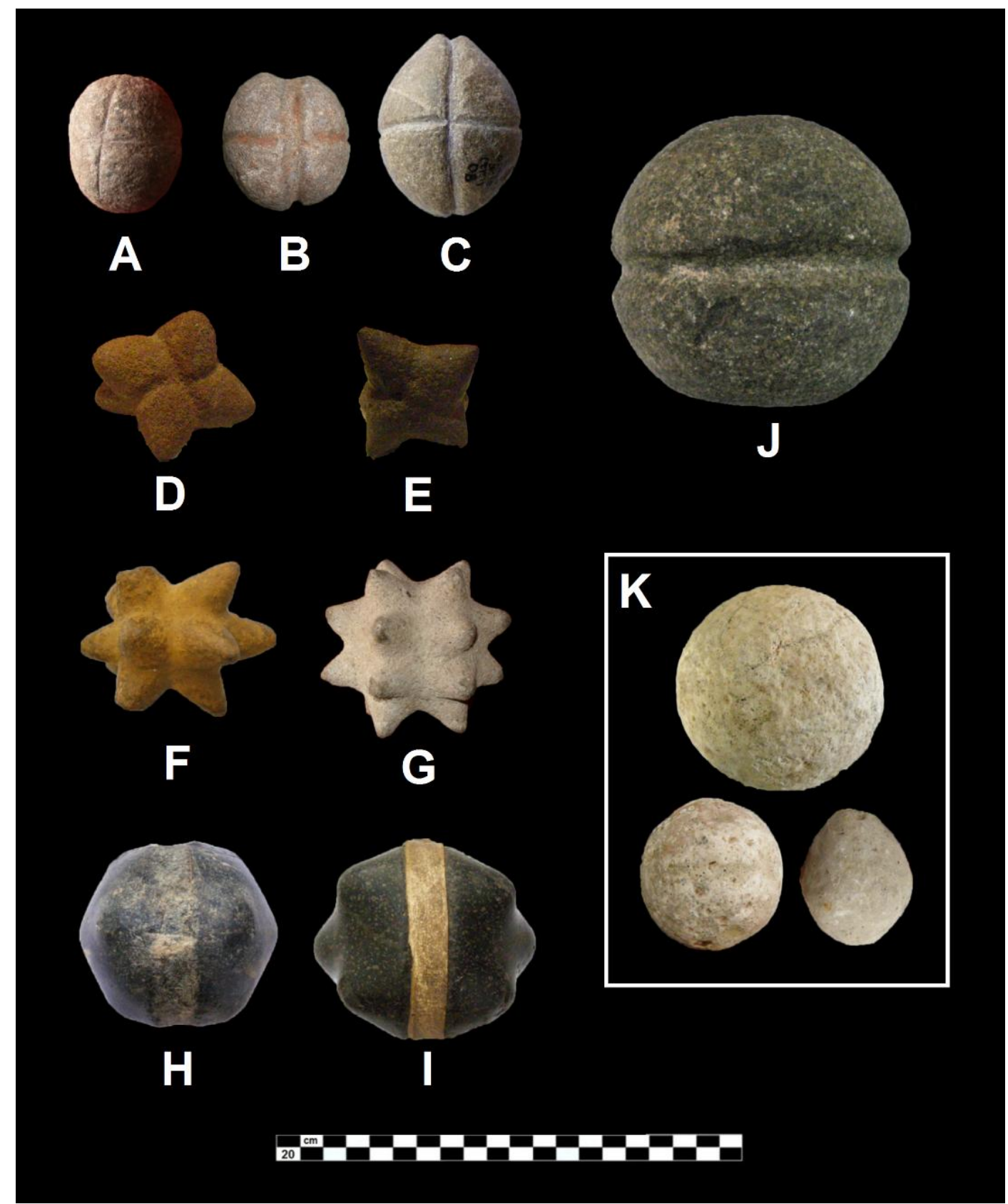

Figura 5.7. Bolas de distintas colecciones de la provincia de Entre Ríos.

A: tipo C (CPG-s/nº. B: tipo C (MCQ-A-B-0154; fotografía de Luís Capeletti). C: tipo C [MAS-80 (1312)]. D: tipo D (MACN-16725). E: tipo D (MACN-16726). F: tipo D (ML-766). G: tipo D (CPG-s/nº). H: tipo D: (ML-778). I: tipo D (ML- 998). J: tipo Bb1 (ML-992). K: bolas de arcilla del MTM (Villaguay).

La escala es valida para todas las piezas.

Puntas de proyectil $(\mathrm{n}=82)$

En el informe de Hocsman (2007) sobre las puntas de proyectil del MTM se menciona el análisis de 70 piezas, de estas se pudieron identificar 66 y las cuatro restantes no pudieron rastrearse, en tres casos debido a que las piezas mencionadas en el informe no tienen número y en el restante simplemente no se encontró la pieza dentro de la colección. A estas 66 puntas de proyectil se agregan otras 16. En las Tablas 5.18 y 5.19 se integran nuestros datos con los de Hocsman (2007), dejando de lado las cuatro puntas que no pudieron identificarse. 
Del total del puntas de proyectil $(n=82) 69$ tienen procedencia exacta y 13 no la tienen (Tabla 5.14). Se registraron 40 piezas enteras y 42 fracturadas; de las enteras 16 presentan reciclaje en filos y/o puntas y dentro de las fracturadas una sola presenta reciclaje. A partir del reciclaje se confeccionaron: 10 cortantes (sensu Hocsman 2007), dos raederas, dos muescas, dos puntas burilantes y un perforador (Figura 5.8E). Según Hocsman (2007) los cortantes, las raederas y el perforador fueron usados enmangados, mientras que puntas burilantes y una de las muescas debieron quitarse del astil para su utilización. Los diseños de limbos (básicos y mantenidos) presentan formas triangulares de lados convexos o lanceoladas (Figura 5.8). Las formas triangulares con bordes rectos o cóncávos corresponden a diseños reciclados (Hocsman 2007).

En cuanto a la tipología de las puntas 79 son pedunculadas con aletas entrantes y en hombro, y tres son indeterminadas por fractura y/o reciclado; predominan aletas obtusas seguidas por las rectas (Tabla 5.18). En este sentido, Hocsman (2007) plantea que las aletas entrantes obtusas y agudas corresponderían a diseños básicos y las restantes serían el resultado de tareas de mantenimiento y reciclaje. Además, en las 70 piezas que analizó este autor identificó la reactivación de limbos y aletas en 47 casos; 17 casos no tienen reactivación y seis casos no se pudieron diferenciar por fractura. Asimismo, identificó técnica de reducción bifacial en 28 casos cuya formasbase son lascas, y adelgazamiento bifacial en 19 casos cuya formas-base secundaria son bifaces; en los 23 casos restantes no se determinó la forma-base. En algunos casos para la formatización final, mantenimiento y reciclaje se implementó talla por presión.

Tabla 5.18. Subgrupos tipológicos de puntas de proyectil del Museo Tierra de Minuanes (Villaguay).

\begin{tabular}{|c|c|c|}
\hline Subgrupo tipológico & Tipo de aleta & Total \\
\hline Pedunculada con aletas y/o hombros & $\begin{array}{l}\text { Aletas obtusas } \\
\text { Aletas rectas } \\
\text { Aletas agudas } \\
\text { Aleta obtusa y recta } \\
\text { Aleta no diferenciada } \\
\text { Hombros } \\
\text { Hombro y aleta obtusa } \\
\text { Hombro y aleta recta } \\
\text { No determinable (aleta u hombro) }\end{array}$ & $\begin{array}{c}23 \\
12 \\
4 \\
3 \\
4 \\
7 \\
12 \\
2 \\
12\end{array}$ \\
\hline Indeterminada & Indeterminada & 3 \\
\hline Total & & 82 \\
\hline
\end{tabular}

Tomada y modificada de Hocsman (2007). 
Los pedúnculos registrados se clasifican en destacados $(n=56)$, diferenciados $(n=10)$, esbozados $(n=1)$, e indeterminados por fractura $(n=15)$. En la Tabla 5.19 se presenta la variabilidad morfológica de los pedúnculos considerando la forma de sus bordes y bases.

Tabla 5.19. Morfología de los bordes y base de los pedúnculos de las puntas de proyectil del Museo Tierra de Minuanes (Villaguay).

\begin{tabular}{|c|c|c|}
\hline Bordes & Base & Total \\
\hline Divergentes rectos & $\begin{array}{l}\text { Recta } \\
\text { Convexa } \\
\text { Cóncava } \\
\text { No diferenciada }\end{array}$ & $\begin{array}{l}5 \\
9 \\
4 \\
2\end{array}$ \\
\hline Divergentes convexos & $\begin{array}{l}\text { Convexa } \\
\text { Cóncava }\end{array}$ & $\begin{array}{l}1 \\
2\end{array}$ \\
\hline Divergentes cóncavos & $\begin{array}{l}\text { Recta } \\
\text { Convexa } \\
\text { Cóncava } \\
\text { Cóncavo-convexa }\end{array}$ & $\begin{array}{l}2 \\
2 \\
2 \\
1\end{array}$ \\
\hline $\begin{array}{l}\text { Divergentes, uno recto y uno } \\
\text { convexo }\end{array}$ & $\begin{array}{l}\text { Convexa } \\
\text { Cóncava }\end{array}$ & $\begin{array}{l}1 \\
1\end{array}$ \\
\hline $\begin{array}{l}\text { Divergentes, uno convexo y uno } \\
\text { cóncavo }\end{array}$ & Recta & 1 \\
\hline Convergentes rectos & $\begin{array}{l}\text { Cóncava, con variantes "profunda" y "no } \\
\text { profunda" }\end{array}$ & 4 \\
\hline Convergentes convexos & $\begin{array}{l}\text { Cóncava } \\
\text { No diferenciada }\end{array}$ & $\begin{array}{l}2 \\
1\end{array}$ \\
\hline Paralelos rectos & $\begin{array}{l}\text { Recta } \\
\text { Convexa } \\
\text { Cóncava } \\
\text { Puntiforme } \\
\text { No diferenciada }\end{array}$ & $\begin{array}{l}4 \\
3 \\
2 \\
1 \\
2\end{array}$ \\
\hline Paralelos convexos & $\begin{array}{l}\text { Convexa } \\
\text { Cóncava }\end{array}$ & $\begin{array}{l}1 \\
1\end{array}$ \\
\hline Paralelos cóncavos & $\begin{array}{l}\text { Recta } \\
\text { Convexa } \\
\text { Cóncava }\end{array}$ & $\begin{array}{l}1 \\
1 \\
1\end{array}$ \\
\hline $\begin{array}{l}\text { Paralelos, uno convexo y uno } \\
\text { cóncavo }\end{array}$ & Puntiforme & 1 \\
\hline \multirow{3}{*}{\multicolumn{2}{|c|}{$\begin{array}{l}\text { Pedúnculo fracturado a nivel de la raíz, sección romboidal biconvexa } \\
\text { No se puede definir características finales del pedúnculo (preformas) } \\
\text { No diferenciados por fractura }\end{array}$}} & 2 \\
\hline & & 2 \\
\hline & & 20 \\
\hline Total & & 82 \\
\hline
\end{tabular}

Tomado y modificado de Hocsman (2007). 
Dentro de la muestra, la variabilidad más relevante se encuentra en la combinación de las formas de los bordes y base de los pedúnculos. Como se observa en la Tabla 5.19 se registraron 27 variantes, que están reflejando una diversidad muy importante (Hocsman 2007). En cuanto a las dimensiones de las puntas enteras, la más pequeña (MTM-BM-86-01) presenta módulos longitudanchura mediano normal y tamaño pequeño (Figura 5.8A), y la más grande (MTM-s/p-B) longitudanchura laminar normal y tamaño grande (Figura 5.8F).

Cabe destacar dentro de la colección del MTM una punta (MTM-s/p-A), que a pesar de tener el pedúnculo fracturado un poco más abajo de la raíz, presenta todos los atributos tecnomorfológicos definidos por Suárez (2011) para puntas de diseño Pay Paso, por lo que se considera que la misma correspondería a este tipo de puntas (Figura 5.8G). Sus características son las siguientes: pedunculada con pedúnculo diferenciado y aletas entrante obtusa y hombro. Limbo triangular alargado con lados levemente convexos. Las formas de los bordes y base del pedúnculo son indeterminadas por fractura. La materia prima es sílice. Las dimensiones son: largo máximo 62,3 mm, ancho máximo (limbo) 21,8 mm, espesor máximo 11,2 mm, largo del limbo 56 mm, ancho del limbo $21,8 \mathrm{~mm}$, largo de pedúnculo (fracturado) $6,3 \mathrm{~mm}$, ancho de la raíz del pedúnculo $13,7 \mathrm{~mm}$, ancho de la aleta obtusa 3,1 $\mathrm{mm}$ y ancho de la aleta en hombro 2,8 $\mathrm{mm}$. El módulo longitud-anchura es laminar angosto y el módulo tamaño es grande.

Otra punta Pay Paso procedente del sector A (Colección Beltrame, Figura 5.1) fue publicada recientemente (Figura 5.8G) (Castro y Terranova 2015). Las características de esta última punta son las siguientes: pedunculada con pedúnculo diferenciado y aletas entrante obtusa y hombro. Limbo triangular alargado con lados levemente convexos. Los bordes del pedúnculo son divergentes, uno convexo y otro cóncavo-convexo. La base del pedúnculo es escotada y adelgazada por una "pseudo" acanaladura sensu Suárez (2011: 190). La materia prima es arenisca muy silicificada. Las dimensiones son: largo máximo 71,2 mm, ancho máximo $21 \mathrm{~mm}$ (limbo), espesor máximo 11,4 mm, largo del limbo 55,4 mm, ancho del limbo $21,8 \mathrm{~mm}$, largo de pedúnculo $15,8 \mathrm{~mm}$, ancho de la raíz del pedúnculo 16,7 mm, ancho de la base del pedúnculo 14,6 mm, ancho máximo del pedúnculo 19,7 $\mathrm{mm}$, ancho de la aleta obtusa $2,7 \mathrm{~mm}$ y ancho de la aleta en hombro 1,6 $\mathrm{mm}$. El módulo longitudanchura es laminar angosto y el de tamaño es grande.

Es necesario mencionar también que en la Colección Brignardello depositada en el Museo Regional Camila Quiroga (Chajarí), se identificó otra punta de este tipo (MCQ-A-B-0260) confeccionada en arenisca silicificada y cuyos datos de procedencia corresponden al río Uruguay medio (Figura 5.8G). Se carece de los datos métricos de esta última pieza debido a que fue identificada en este trabajo a partir de la revisión del registro de la Colección Brignardello realizado por el Lic. Luís Capeletti (FCNyM-UNLP). 
Las materias primas de las puntas de proyectil de la Tabla 5.15 se distribuyen como sigue; sílice: 37 (45,1\%); arenisca: 12 (14,6\%); cuarcita intertrap: 10 (12,2\%); calcedonia: 7 (8,5\%); xilópalo: 6 (7,3\%); basalto: 4 (4,9\%); caliza silicificada: 3 (3,7\%); e indeterminada: $3(3,7 \%)$. En este sentido, se observa un amplio predominio de materiales silíceos por sobre los demás.
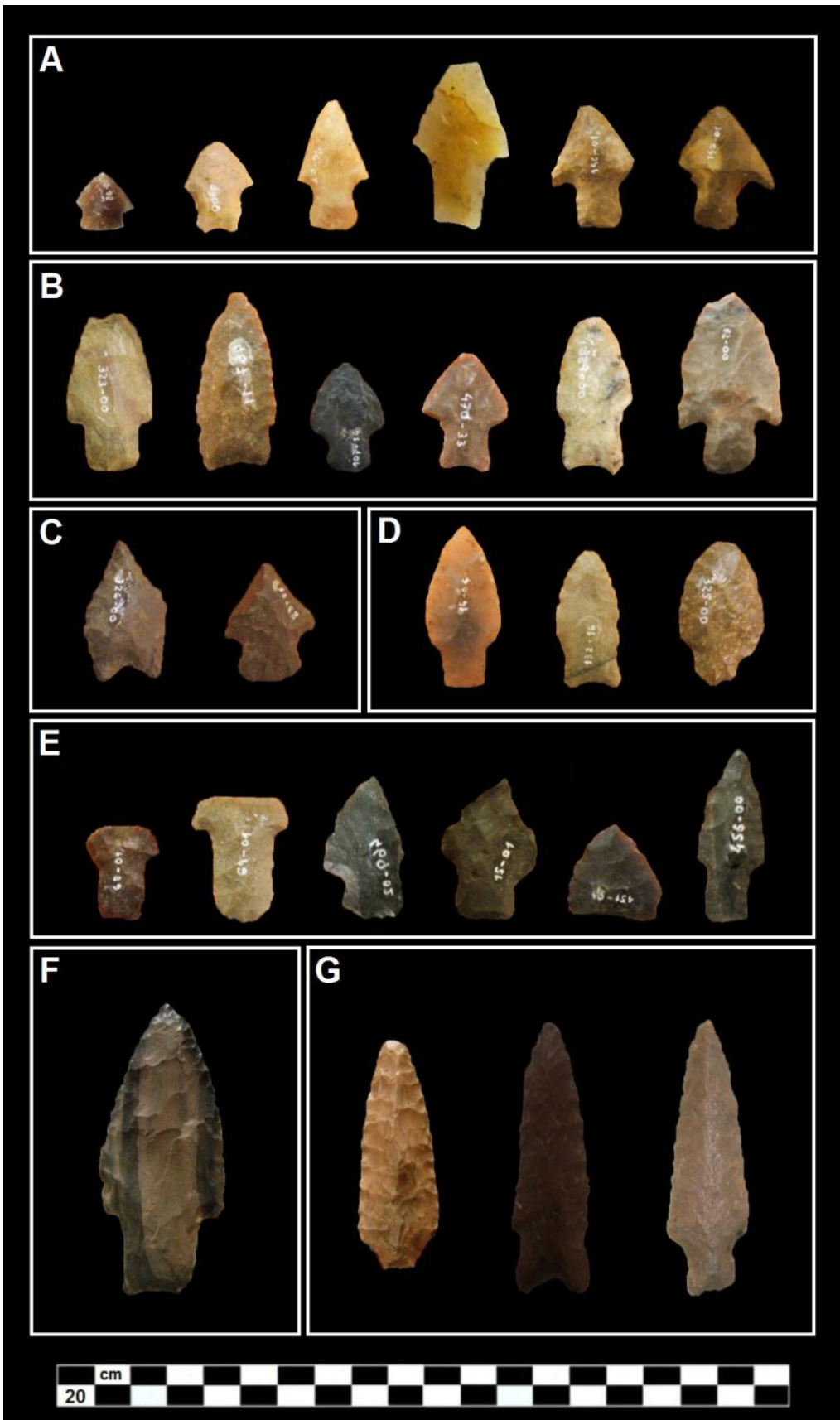

Figura 5.8. Puntas de proyectil de la colección del Museo Tierra de Minuanes (Villaguay).

A: limbo triangular de bordes rectos (de izquierda a derecha: MTM-BM-86-01, MTM-s/p-328-00, MTM-EV-96-07, MTM-s/p-D, MTM-BM-146-01 y MTM-BM-147-01). B: limbo triangular de bordes convexos (de izquierda a derecha: MTM-s/p-323-00, MTM-LAP-467-11, MTM-A-107-16, MTM-B-470-33, MTM-s/p-324-00 y

MTM-s/p-82-00). C: limbo triangular de borde cóncavos (de izquierda a derecha: MTM-s/p-326-00 y

MTM-PDT-83-25). D: limbo lanceolado (de izquierda a derecha: MTM-EA-16-04, MTM-A-132-16 y

MTM-s/p-325-00). E: puntas recicladas (de izquierda a derecha): dos cortantes (MTM-BM-68-01 y MTM- BM-68-01), raedera (MTM-ER-469-029), muesca (MTM-BM-15-01), punta burilante (MTM-BM-151-01) y perforador (MTM-s/p-456-00). F: limbo triangular de bordes convexos (MTM-s/p-B). G: puntas Pay Paso (de izquierda a derecha: MTM-s/p-A, Colección Beltrame -Castro y Terranova 2015- y MCQ-A-B-0260 -Fotografía de Luís Capeletti-). 
Otros instrumentos $(n=29)$

La Tabla 5.20 muestra los atributos de los restantes instrumentos registrados en la colección

del MTM.

Tabla 5.20. Instrumentos líticos del Museo Tierra de Minuanes (Villaguay).

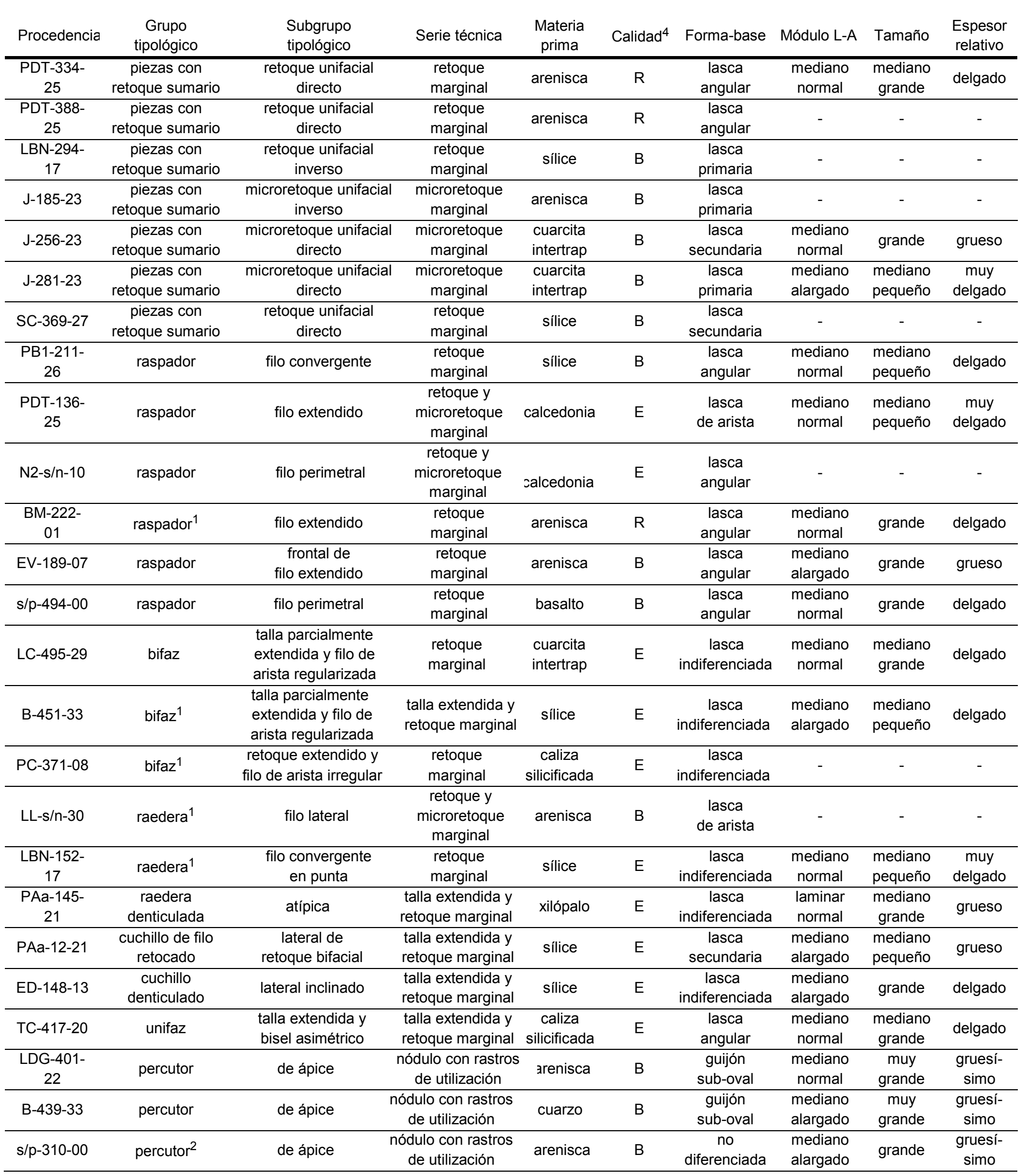




\begin{tabular}{|c|c|c|c|c|c|c|c|c|c|}
\hline BM-05-01 & $\begin{array}{c}\text { instrumento } \\
\text { no determinado } 3\end{array}$ & - & retalla extendida & xilópalo & $E$ & $\begin{array}{c}\text { lasca } \\
\text { indiferenciada }\end{array}$ & $\begin{array}{l}\text { laminar } \\
\text { normal }\end{array}$ & $\begin{array}{c}\text { muy } \\
\text { grande }\end{array}$ & $\begin{array}{l}\text { muy } \\
\text { grueso }\end{array}$ \\
\hline$s / n-345-00$ & $\begin{array}{c}\text { picado, abrasión } \\
\text { y/o pulido } \\
\text { (sobador?) }^{3}\end{array}$ & - & - & arenisca & $\mathrm{R}$ & $\begin{array}{c}\text { no } \\
\text { diferenciada }\end{array}$ & $\begin{array}{c}\text { mediano } \\
\text { normal }\end{array}$ & $\begin{array}{l}\text { muy } \\
\text { grande }\end{array}$ & $\begin{array}{l}\text { gruesí- } \\
\text { simo }\end{array}$ \\
\hline $\begin{array}{c}\text { BM-181- } \\
01\end{array}$ & $\begin{array}{c}\text { picado, abrasión } \\
\text { y/o pulido } \\
\text { (adorno?) }^{3}\end{array}$ & - & - & basalto & $\mathrm{B}$ & $\begin{array}{c}\text { no } \\
\text { diferenciada }\end{array}$ & $\begin{array}{l}\text { mediano } \\
\text { alargado }\end{array}$ & grande & $\begin{array}{c}\text { muy } \\
\text { delgado }\end{array}$ \\
\hline $\begin{array}{l}\text { LDG-s/n- } \\
22\end{array}$ & $\begin{array}{c}\text { picado, abrasión } \\
\text { y/o pulido }{ }^{1,3}\end{array}$ & - & - & arenisca & $\mathrm{R}$ & $\begin{array}{c}\text { no } \\
\text { diferenciada }\end{array}$ & $\begin{array}{c}\text { mediano } \\
\text { normal }\end{array}$ & $\begin{array}{c}\text { muy } \\
\text { grande }\end{array}$ & $\begin{array}{c}\text { gruesí- } \\
\text { simo }\end{array}$ \\
\hline
\end{tabular}

s/n: sin número; s/p: sin procedencia. (1) Instrumentos incompletos por fractura. (2) Este percutor presenta una forma oval muy simétrica por lo que probalemente pueda también identificarse como una bola tipo Ad2, se lo define como percutor dadas las claras evidencias que reflejan esta función. (3) No corresponden a ningún grupo tipológico sensu Aschero 1983.

(4) Calidad de las materias primas, E: excelente, B: buena, R: regular.

Se registraron 23 instrumentos confeccionados por lascados, 20 sobre materias primas de buena y excelente calidad y tres de calidad regular; cuya formas-base son lascas (ocho angulares, tres primarias, tres secundarias, dos de arista y siete indiferenciadas). Fueron elaborados mediante talla extendida, y retoque y microretoque marginal. Entre los instrumentos enteros se registraron módulos longitud-anchura mediano normal $(n=7)$, seguido por mediano alargado $(n=4)$, y laminar normal $(n=2)$. En cuanto al tamaño se registró mediano pequeño $(n=4)$, mediano grande $(n=4)$, grande $(n=4)$, y muy grande $(n=1)$. Considerando el espesor relativo predomina el delgado $(n=6)$, seguido por el grueso $(n=4)$, muy delgados $(n=2)$, y muy grueso $(n=1)$.

Además de los instrumentos tallados se registraron tres instrumentos confeccionados mediante picado, abrasión y/o pulido sobre arenisca $(n=2)$ y basalto $(n=1)$, con formas-base no diferenciadas. Para los instrumentos enteros el módulo longitud-anchura es mediano normal $(n=1)$ y mediano alargado $(n=1)$; el tamaño es muy grande $(n=1)$ y grande $(n=1)$; y el espesor relativo es gruesísimo $(n=1)$ y muy delgado $(n=1)$. Se agregan tres percutores con evidencias de astilladuras confeccionados sobre arenisca $(n=2)$ y cuarzo $(n=1)$, a partir de guijones fluviales (rodados) $(n=2)$ y una forma-base no diferenciada modificados por uso. Cuyos módulos longitud-anchura son mediano alargado $(n=2)$ y mediano normal $(n=1)$; el tamaño es muy grande $(n=2)$ y grande $(n=1)$; y el espesor relativo es gruesísimo ( $n=3)$. En cuanto a los instrumentos fracturados los módulos y el espesor relativo están determinados por la fractura que presentan, probablemente los mismos en su estado entero tuvieron dimensiones mayores.

\section{Desechos de talla}

Se registraron en total 1864 desechos de talla, de los cuales en 1456 casos se determinó su materia prima (Tabla 5.21). Estos desechos no fueron analizados en detalle por lo que solo se mencionan observaciones generales. En este sentido, se observaron distintos estados de fragmentación, la presencia de todas las formas de lascas con un predomio de las internas sobre las 
externas, dimensiones variadas desde muy pequeñas hasta grandes. Asimismo, se registró un importante porcentaje de desechos corticales procedentes de rodados fluviales. También se cuentan dos lascas secundarias con rastros complementarios sobre filos naturales. Las materias primas muestran frecuencias semejantes para materiales silíceos y areniscas, que constituyen los dos tipos de recursos más representados. Cabe aclarar que en tres conjuntos que no figuran en la Tabla 5.21 (Antivero, El Vertiente y Peñón Colorado) también se observaron desechos de talla silíceos, de arenisca y de basalto, tanto internos como externos.

Tabla 5.21. Materias primas de los desechos de talla del Museo Tierra de Minuanes (Villaguay) por conjuntos arqueológicos.

\begin{tabular}{|c|c|c|c|c|c|c|c|c|c|}
\hline \multirow{2}{*}{$\begin{array}{l}\text { Sitios arqueológicos y } \\
\text { hallazgos aislados }\end{array}$} & \multicolumn{8}{|c|}{ Materias primas } & \multirow{2}{*}{$\begin{array}{l}\text { Total } \\
\text { general }\end{array}$} \\
\hline & $\mathrm{S}$ & A & $\mathrm{CA}$ & $\mathrm{Cl}$ & $\mathrm{B}$ & $\mathrm{C}$ & $A G$ & CAL & \\
\hline Paso Blanco 1 & 40 & 52 & - & 1 & 5 & - & - & 1 & 99 \\
\hline Pozo Azul a1 & 12 & 22 & 1 & - & - & 1 & 1 & 5 & 42 \\
\hline La Lomita & 32 & 23 & - & - & - & - & 1 & - & 56 \\
\hline La Lomita 2 & 62 & 39 & & 2 & 1 & & 12 & & 116 \\
\hline Puente del Tigre $^{1}$ & - & 7 & - & - & - & - & 2 & - & 9 \\
\hline El Dorado & 17 & 11 & - & - & - & - & - & - & 28 \\
\hline Nogueira 2 & 67 & 55 & 2 & - & - & - & 1 & 2 & 127 \\
\hline Laguna de García ${ }^{1}$ & 41 & 54 & & & 3 & & & 4 & 102 \\
\hline Laguna Blanca y Negra & 27 & $45^{2}$ & - & - & - & - & - & 3 & 75 \\
\hline Ramblones & 10 & 31 & - & 1 & - & - & - & - & 42 \\
\hline Base del Maidana & 140 & $188^{2}$ & - & 21 & 12 & 1 & - & 1 & 363 \\
\hline Laguna Las Violetas & 25 & 12 & - & 5 & - & - & - & - & 42 \\
\hline Laguna Proto & 54 & 24 & - & 1 & 2 & - & - & - & 81 \\
\hline Jeromito & 114 & 67 & - & 1 & 8 & - & - & 2 & 192 \\
\hline El Barrero & 43 & 16 & - & - & - & - & - & - & 59 \\
\hline El Remolino & 1 & 3 & - & - & - & - & - & - & 4 \\
\hline Arroyo Villaguay & - & 1 & - & - & - & - & - & - & 1 \\
\hline El Algarrobillo & - & 3 & - & - & - & - & - & - & 3 \\
\hline Arroyo Lucas & - & - & - & 1 & - & - & - & - & 1 \\
\hline Roda & - & 2 & - & - & - & - & - & - & 2 \\
\hline El Baletón & - & 3 & 1 & - & 1 & - & - & - & 5 \\
\hline Laguna de Beigan & - & 3 & - & - & - & - & - & - & 3 \\
\hline Tigre Colorado & - & 1 & - & - & - & - & - & 2 & 3 \\
\hline San Cristóbal & - & 1 & - & - & - & - & - & - & 1 \\
\hline Total & 685 & 663 & 4 & 33 & 32 & 2 & 17 & 20 & 1456 \\
\hline
\end{tabular}

S: sílice; A: arenisca; CA: calcedonia; Cl: cuarcita intertrap; B: basalto; C: cuarzo; AG: ágata;

CAL: caliza silicificada. (1) Sitios arqueológicos con más desechos que no fueron clasificados según su materia prima (Pozo Azul a, $n=56$ ), (Puente del Tigre, $n=107$ ) y (Laguna de García, $n=245$ ).

(2) se incluye una lasca secundaria con rastros complementarios sobre filos naturales.

\section{Núcleos}

Se registraron 35 núcleos (Tabla 5.12) de cinco materias primas diferentes (Tabla 5.13). En Jeromito se registró la mayor frecuencia $(n=16$; nueve calizas silicificadas, seis areniscas y una cuarcita intertrap), le siguen Laguna de García ( $n=8$; siete areniscas y una caliza silicificada), Nogueira 
2 ( $n=2$; calizas silicificadas), Pozo Azul a ( $n=1$; ágata), La Lomita $2(n=1$; arenisca), Puente del Tigre $(n=1$; arenisca), y Laguna Proto $(n=1$; arenisca). El resto corresponde a los hallazgos aislados AVI ( $n=$ 2; una arenisca y un cuarzo), ER ( $n=2$; areniscas, uno además podría haber sido previamente un percutor -MTM-ER-289-02-), y EA ( $n=1$; arenisca). La forma-base de cuatro núcleos corresponden a rodados fluviales [LDG, AVI y ER $(n=2)$ ]. Los núcleos no presentan un patrón de reducción estandarizado y tampoco están todos agotados.

Como este sector de estudio carece de afloramientos de materias primas resulta relevante destacar que en los conjuntos analizados se registraron numerosos clastos y rodados fluviales de variados tamaños, algunos con fracturas y lascados probablemente antrópicos (p. ej. MTM-LDG-33522 y MTM-EB-s/n-28) y otros sin una aparente modificación antrópica, que sin duda llegaron al sector por agencia humana. Algunos clastos que presentan superficies alisadas o cóncavas incluso podrían ser instrumentos de molienda, pero aún resta un análisis más profundo sobre ellos. En este sentido, obeservaciones preliminares de la Dra. Alejandra Matarrese (FCNyM-UNLP) sugieren la presencia de manos de moler o abradidores (p. ej. MTM-EA-02-04, MTM-EA-71-04 y MTM-EA-103-04), yunques (MTM-N2-03-10 y MTM-N2-236-10) o un fragmento de mortero chico (MTM-EA-493-04). Resulta interesante destacar que cuatro de estos artefactos provienen de un mismo sitio arqueológico, El Algarrobillo, cuyo nombre se debe a la existencia de Prosopis sp. en sus inmediaciones. Los dos restantes también provienen del mismo sitio arqueológico, Nogueira 2.

\subsubsection{2- Alfarería del Museo Tierra de Minuanes}

La muestra de alfarería analizada suma un total de 1962 (Tabla 5.12); 1723 corresponden al cuerpo de las vasijas (1707 lisos y 16 decorados), 235 son bordes (218 lisos y 17 decorados), dos son bases (una lisa y una decorada), y se suman dos modelados. Del total, excluyendo los modelados, 1926 fragmentos no presentan decoración y 34 están decorados. El tamaño mínimo registrado en un tiesto es de 8,8 mm (BM) y el máximo de 128,2 mm (LL). El espesor mínimo es de 2,9 mm (PDT, N2 y LDG) y el máximo de 18,5 mm (PDT). Se registraron siete bordes y tres cuerpos con agujeros intencionales; en La Lomita un borde liso; en Arroyo Villaguay un borde liso; en Jeromito un cuerpo liso; en Ramblones dos bordes de la misma vasija con un agujero cada uno; y en El Remolino un cuerpo liso con dos agujeros, dos bordes y un cuerpo lisos con dos agujeros cada uno (estos tres tiestos junto a otro borde sin perforar corresponden a la misma vasija), se destaca que uno de los agujeros de uno de los bordes está sin terminar.

En términos generales gran parte de la muestra presenta evidencia de alteraciones naturales, como desgaste y erosión en distinto grado. También en la colección se observaron numerosos fragmentos amorfos de arcilla cocida y/o tierra cocida (p. ej. en BM, J y ER). En algunos conjuntos se 
realizaron remontajes cerámicos (PDT, ED, N2, R, BM y J). También se registraron rastros de hollín en dos bordes de El Remolino, uno con hollín en ambas superficies y el otro en su superficie externa.

Se determinó el diámetro de boca y el perfil de siete recipientes, diferenciando dos formas no restringidas y cinco restringidas:

1- liso no restringido, con borde evertido y labio angular, y un diámetro de boca de $26 \mathrm{~cm}$; esta vasija correspondería a un plato hondo (MTM-BM-s/n-01).

2- liso no restringido, con borde invertido y labio angular, y un diámetro de boca de $19 \mathrm{~cm}$; esta vasija correspondería a un cuenco grande (MTM-EA-383-04).

3- liso restringido, con borde recto y labio angular, y un diámetro de boca de $19 \mathrm{~cm}$; esta vasija correspondería a una olla (MTM-N2-381-10).

4- decorado (inciso) restringido, con borde invertido y labio convexo, y un diámetro de boca de $29 \mathrm{~cm}$; esta vasija correspondería a una olla (MTM-R-382-14) (Figura 5.9A).

5- liso restringido, con borde recto y labio convexo, y un diámetro de boca de $23 \mathrm{~cm}$; esta vasija correspondería a una olla (MTM-BM-s/n-01).

6- liso restringido, con borde recto y labio recto, y un diámetro de boca de $29 \mathrm{~cm}$; esta vasija correspondería a una olla (MTM-BM-s/n-01).

7- liso restringido, con borde recto y labio convexo, y un diámetro de boca de $28 \mathrm{~cm}$; esta vasija correspondería a una olla (MTM-AVI-s/n-06).

De los análisis realizados por Ceruti (2007) sobre la cerámica del MTM se resumen algunos datos de los sitios arqueológicos Jeromito y El Remolino. Para Jeromito se identificó técnica de enrollamiento. La cocción es oxidante incompleta (semicocida y uniforme). Las inclusiones son tiesto $(n=62)$, arena $(n=35)$, tiesto y arena $(n=24)$, materia orgánica $(n=21)$, y arena y espículas de esponjas de agua dulce (Uruguaya corallioides) $(n=2)$. Se determinó el diámetro de boca y la forma de 11 recipientes, diferenciando cinco formas no restringidas y seis restringidas:

1- liso no restringido, con borde evertido y labio convexo, y un diámetro de boca de $11 \mathrm{~cm}$.

2- decorado (inciso) no restringido, con borde recto y labio angular, y un diámetro de boca de $11 \mathrm{~cm}$.

3- liso no restringido, con borde evertido y labio convexo, y un diámetro de boca de $19 \mathrm{~cm}$.

4- liso no restringido, con borde evertido y labio angular, y un diámetro de boca de $22 \mathrm{~cm}$.

5- liso no restringido, con borde recto y labio angular, y un diámetro de boca de $26 \mathrm{~cm}$.

6- liso restringido, con borde recto y labio convexo, y un diámetro de boca de $13 \mathrm{~cm}$.

7- liso restringido, con borde invertido y labio convexo, y un diámetro de boca de $18 \mathrm{~cm}$.

8- liso restringido, con borde recto y labio convexo, y un diámetro de boca de $18 \mathrm{~cm}$.

9- liso restringido, con borde evertido y labio convexo, y un diámetro de boca de $25 \mathrm{~cm}$.

10- liso restringido, con borde recto y labio angular, y un diámetro de boca de $26 \mathrm{~cm}$. 
11- decorado (inciso) restringido, con borde invertido y labio recto, y un diámetro de boca de $28 \mathrm{~cm}$.

Para El Remolino las inclusiones identificadas son arena y tiesto, y se determinó el diámetro de boca y la forma de 11 recipientes, diferenciando nueve formas no restringidas y dos restringidas:

1- liso no restringido, con borde recto y labio convexo, y un diámetro de boca de $16 \mathrm{~cm}$.

2- liso no restringido, con borde invertido y labio convexo, y un diámetro de boca de $16 \mathrm{~cm}$; esta vasija presenta en su superficie externa e interna abundantes rastros de hollín.

3- liso no restringido, con borde invertido y labio convexo, y un diámetro de boca de $19 \mathrm{~cm}$.

4- liso no restringido, con borde evertido y labio convexo, y un diámetro de boca de $19 \mathrm{~cm}$.

5- liso no restringido, con borde recto y labio convexo, y un diámetro de boca de $20 \mathrm{~cm}$.

6- liso no restringido, con borde invertido y labio convexo, y un diámetro de boca de $21 \mathrm{~cm}$; esta vasija (integrada por tres bordes y un cuerpo, que no remontan) presenta seis agujeros y una perforación sin terminar.

7- liso no restringido, con borde invertido y labio recto, y un diámetro de boca de $22 \mathrm{~cm}$; esta vasija presenta en su superficie externa rastros de hollín.

8- liso no restringido, con borde invertido y labio convexo, y un diámetro de boca de $22 \mathrm{~cm}$.

9- liso no restringido, con borde recto y labio convexo, y un diámetro de boca de $23 \mathrm{~cm}$.

10- liso restringido, con borde invertido y labio convexo, y un diámetro de boca de $17 \mathrm{~cm}$.

11- liso restringido, con borde invertido y labio convexo, y un diámetro de boca de $29 \mathrm{~cm}$.

Para este sitio arqueológico también se registró un fragmento de disco cerámico (tortero?) de $25 \mathrm{~mm}$ de diámetro y $8 \mathrm{~mm}$ de espesor.

En cuanto a las dos piezas modeladas (Figura 5.9D), se registró un asa o mamelón en Laguna de García y un posible apéndice zoomorfo sin decoración, semejante a la cabeza de un ofidio o un pato, en Base del Maidana. Ambos tipos piezas son comunes en el registro arqueológico de los ríos Paraná y Uruguay identificado con la entidad arqueológica Goya-Malabrigo definida por Ceruti (2003) y recientemente actualizada por Politis y Bonomo (2012), pero hasta el momento muy escasas en las llanuras interiores.

Dentro del conjunto de tiestos decorados $(n=34)$ se registraron 26 decorados mediante desplazamiento de materia y ocho decorados mediante aplicación de pintura. Los tiestos decorados mediante desplazamiento de materia (17 bordes, ocho cuerpos y una base) presentan técnica de incisión de punto ( $n=12$, un caso con la uña), línea $(n=7)$ y surco rítmico $(n=7)$ (Figura 5.9A, B y C). La decoración se dispone en la superficie externa $(n=23)$, en el labio $(n=2)$ y en la superficie interna $(n=$ 1). El conjunto de tiestos pintados (ocho cuerpos) presenta pintura roja en la superficie externa ( $n=$ 7) e interna ( $n=1)$ (Figura 5.9E). 
En cuanto a la alfarería pintada es interesante destacar que siete cuerpos que provienen de Laguna de García presentan atributos tecnológicos y decorativos distintos al resto de la alfarería del sector A, pero semejantes a los registrados en la alfarería guaraní (Brochado 1984; Brochado y Monticelli 1994; Noelli 1993) (Figura 5.9E). Particularmente esto es evidente a partir del color del núcleo y de ambas superficies, del espesor de los tiestos, del color de la pintura, de la forma de las fracturas, y en un caso debido a la presencia de un ángulo que indicaría un hombro típico de las vasijas guaraníes. Otro fragmento de cuerpo de este mismo sitio arqueológico pereciera presentar cepillado en su superficie externa, pero el grado de erosión que presenta impide la confirmación; fue incluido en el conjunto de los decorados mediante incisión de línea (Figura 5.9B). Ceruti (2007) también describe tiestos decorados procedentes del arroyo El Tigre. Estos son: tres bordes (uno inciso de punto en la superficie externa, uno inciso de línea en la superficie externa, y uno inciso de línea en la superficie externa y pintura roja en ambas superficies) y dos cuerpos (uno inciso con aparentemente surco rítmico en la superficie externa y uno con pintura roja en ambas superficies).

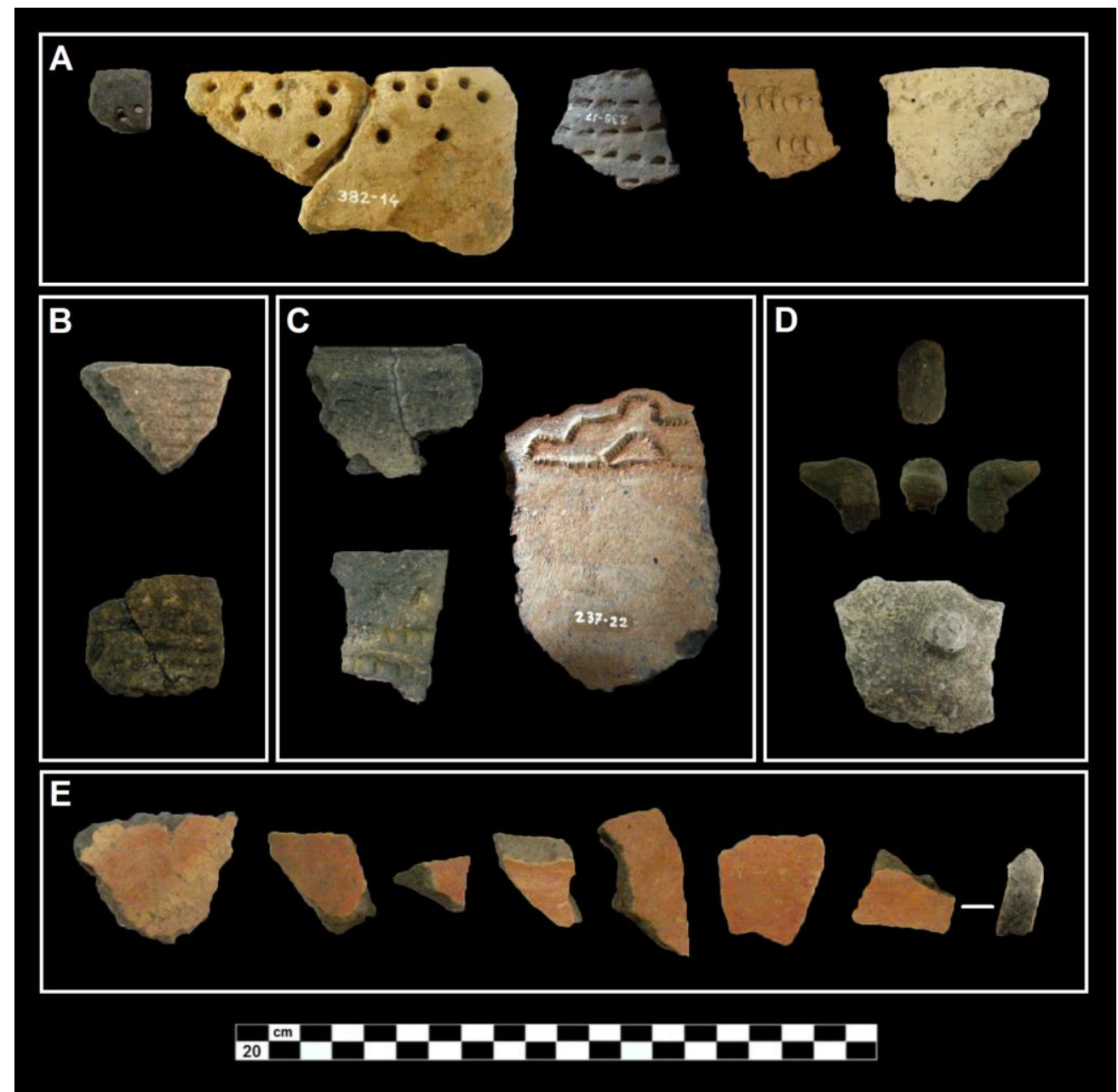

Figura 5.9. Fragmentos de alfarería decorada y modelada del Museo Tierra de Minuanes (Villaguay).

A: técnica de incisión de punto (de izquierda a derecha: MTM-PAa-s/nº, MTM-R-382-14,

MTM-LBN-238-17, MTM-SC-s/n y MTM-TC-s/nº). B: técnica de incisión de línea, pudiendo el primer tiesto estar decorado mediante cepillado (de arriba hacia abajo: MTM-LDG-s/n ${ }^{\circ}$ y MTM-TC-s $/ \mathrm{n}^{\circ}$ ). C: técnica de incisión de surco rítmico (de arriba hacia abajo: MTM-ED-s $/ \mathrm{n}^{\circ}$ y MTM-PDS-s $/ \mathrm{n}^{\circ}$, y a la derecha:

MTM-LDG-237-22). D: fragmento modelado (MTM-BM-s $/ \mathrm{n}^{\circ}$ ) y tiesto con mamelón (MTM-LDG-s $/ \mathrm{n}^{\circ}$ ).

E: cerámica guaraní pintada del sitio arqueológico Laguna de García, el último tiesto corresponde a un hombro. 
Por último, cabe mencionar que en esta colección se registraron artefactos posthispánicos en algunos conjuntos. En Nogueira 2 hay tres fragmentos de gres incluyendo un pico de botella; en Laguna Las Violetas hay 19 fragmentos de gres y uno de hierro; en Jeromito hay tres fragmentos de gres; en El Remolino hay cuatro fragmentos de gres; y en Antivero hay un botón de bronce y un tortero o botón fracturado (MTM-246-16) elaborado a partir de un fragmento de gres que fue abradido y/o pulido (largo 33,8 mm, ancho $17,5 \mathrm{~mm}$, espesor $6,5 \mathrm{~mm}$, diámetro del agujero central $6,3 \mathrm{~mm}$ aproximadamente).

\section{2- DATOS INTEGRADOS, TENDENCIAS GENERALES E INTERPRETACIONES}

En esta sección se integran y describen conjuntamente los resultados procedentes de las dos fuentes de información consideradas: los trabajos de campo propios y la colección del MTM; también se extraen las tendencias generales y se realizan algunas interpretaciones sobre el registro arqueológico del sector A; estas últimas abonan la discusión final de la tesis realizada en el Capítulo 9.

\subsection{1- EL REGISTRO ARQUEOLÓGICO}

En cuanto a la distribución espacial de los conjuntos arqueológicos, la gran mayoría se dispone sobre la llanura de inundación del río Gualeguay y en menor medida sobre barrancas de sus arroyos o lagunas tributarias. Por lo tanto, todo el registro arqueológico estudiado en este sector se vincula espacialmente a la cuenca del río Gualeguay, el mayor cauce fluvial del centro de la provincia de Entre Ríos, y de esta forma posiblemente el río constituyó un vector determinante de la ocupación indígena de las llanuras centrales, al proporcionar un recurso vital como el agua y a su vez propiciar la concentración de recursos florísticos y faunísticos.

Todos los conjuntos arqueológicos fueron recuperados en posición superficial a cielo abierto y en zonas abiertas con escasa vegetación en la mayoría de los casos, aunque también rodeados de vegetación ribereña y xerófila (ED y LDG). Según lo planteado por Poenitz (1970b: 24), en el sitio arqueológico Nogueira (Figura 5.1) los artefactos originalmente estaban en estratigrafía y fueron expuestos por acción del ganado; durante nuestra visita al lugar no se pudo recolectar material ni en superficie ni en la pruebas de pala realizadas. Cabe destacar que la identificación restos arqueológicos en zonas abiertas y vinculadas a fuentes de agua, probablente se deba a un sesgo de muestreo como resultado de las prospecciones dirigidas y de la visibilidad arqueológica.

El registro arqueológico del sector A incluye materiales líticos y cerámicos. La posición superficial de los conjuntos ha impedido la conservación de restos orgánicos. Aun así Poenitz (1970b) 
menciona para el sitio arqueológico Nogueira el hallazgo restos de moluscos y de dos "punzones" óseos sobre huesos largos de especies sin identificar (pero aparentemente mamíferos). Estos "punzones" según las fotografías publicadas se asemejan a lascas óseas con un extremo aguzado.

\subsection{2- CONJUNTO LÍTICO}

En el sector A no se registran afloramientos rocosos de ninguna de las materias primas identificadas (a excepción de la denominada arcilla) (Tabla 5.3 y 5.13). En base a la distancia entre los conjuntos arqueológicos y los afloramientos conocidos de las rocas y minerales, se determinó que las materias primas de los artefactos no están inmediatamente disponibles y necesariamente fueron trasladadas al menos desde distancias medias (entre 60 y $100 \mathrm{~km}$ ). Esta distancia a las canteras potenciales, ubicadas en las márgenes el río Uruguay o de sus afluentes principales ( $p$. ej. los arroyos Grande o del Pedernal y El Palmar) (véase Capítulo 3) cuyas cabeceras se encuentran a $58 \mathrm{~km}$ de distancia del sitio arqueológico El Barrero ubicado en el extremo oeste del sector A, podría explicar la ausencia de materias primas de mala calidad en el sector en general, donde la mayoría de las rocas y minerales ingresarían previamente seleccionados por su calidad. Es probable que parte de las areniscas también procedan de la cuenca del río Gualeguaychú.

En el sector A predominan ampliamente los desechos de talla $(n=1969)$ por sobre instrumentos $(n=351)$ y núcleos $(n=37)$ (Tabla 5.2 y 5.12 ). En relación a las materias primas identificadas ( $n=1949$ ) (Tabla 5.3 y 5.13 ) se observa que la mayor frecuencia corresponde a la arenisca $(n=887)$, seguida por el sílice $(n=743)$, basalto $(n=128)$, cuarcita intertrap $(n=54)$, caliza silicificada ( $n=37)$, ágata $(n=36)$, calcedonia $(n=35)$, xilópalo $(n=9)$, cuarzo $(n=6)$, diabasa $(n=3)$, arcilla $(n=3)$, silcreta $(n=2)$, e indeterminada $(n=6)$. Ahora bien, excluyendo la diabasa, arcilla e indeterminadas, si se consideran las materias primas de modo general en todo el sector se observa un leve predominio de las silíceas ( $n=922 ; 47,3 \%$ ) sobre las areniscas ( $n=887 ; 45,5 \%)$, seguidas por una relativa baja proporción de basalto $(n=128 ; 6,5 \%)$. Esto indicaría que entre las dos materias primas más frecuentes en todo el sector, no se observa una explotación diferencial de las mismas, por lo tanto ambas estarían llegando al sector en volúmenes semejantes.

En este contexto, considerando los 17 sitios arqueológicos con mayor frecuencia de artefactos líticos (Tabla 5.2 y 5.12) se observa que en seis de ellos predominan las areniscas sobre las silíceas y en 11 ocurre lo contrario. Entre los seis primeros, la mayor diferencia intrasitio entre materiales silíceos y areniscas está en $R$ donde el $73,8 \%(n=31)$ son areniscas y el $26,2 \%(n=11)$ silíceos; le siguen, disminuyendo esta diferencia, LDG con el 57,4\% ( $n=45)$ de areniscas y el $39,3 \%$ ( $n=$ 32) silíceos; LBN con el 58,4\% ( $n=45)$ de areniscas y el $41,6 \%(n=32)$ silíceos; PDT con el $56 \%(n=14)$ de areniscas y el $44 \%(n=11)$ silíceos; PB2 con el $54,1 \%(n=20)$ de areniscas y el $45,9 \%(n=17)$ silíceos; y por último BM con el $48,4 \%(n=194)$ de areniscas y el $47,6 \%(n=191)$ silíceos. Por su parte, 186 
en los 11 sitios restantes la mayor diferencia intrasitio está en EB con el 71,7\% ( $n=43)$ de materiales silíceos y el 28,3\% ( $n=17$ ) de areniscas; seguido por LLV con el 69,8\% ( $n=30)$ de silíceos y el 30,2\% $(n=13)$ de areniscas; PB3 con el 69,6\% $(n=16)$ de silíceos y el 30,4\% $(n=7)$ de areniscas; LAP con el $66,7 \%(n=56)$ de silíceos y el 30,9\% ( $n=26)$ de areniscas; LL2 con el $64,9 \%(n=76)$ de silíceos y el $34,2 \%(n=40)$ de areniscas; J con el 60\% $(n=129)$ de silíceos y el $36,3 \%(n=78)$ de areniscas; LL con el $60,7 \%(n=37)$ de silíceos y el 39,3\% ( $n=24)$ de areniscas; N2 con el $57,1 \%(n=81)$ de silíceos y el $41,5 \%(n=59)$ de areniscas; PB1 con el 52,9\% ( $n=54)$ de silíceos y el 42,2\% ( $n=43)$ de areniscas; ED con el $50 \%(n=22)$ de silíceos y el $45,5 \%(n=20)$ de areniscas; y por último, PAa donde los artefactos de arenisca y silíceos tienen la misma proporción, 48,3\% ( $n=28)$.

A partir de estos porcentajes se observa que en ningún caso hay una diferencia mayor al $50 \%$; en R y EB la diferencia se ubica entre el $50 \%$ y $40 \%$; en LLV, PB3, LAP y LL2 la diferencia está entre el $40 \%$ y $30 \%$; en J y LL entre el $30 \%$ y $20 \%$; y los nueve conjuntos restantes tienen una diferencia menor al 20\%, a excepción de PAa donde no hay diferencia porque los porcentajes son idénticos. En este sentido, excepto en $\mathrm{R}$ y EB donde la diferencia sería más marcada, no se observan diferencias relevantes en relación a las proporciones de una u otra materia prima en estos conjuntos arqueológicos.

Si bien no se registra una explotación diferencial entre las dos materias primas más frecuentes, estas habrían sido empleadas con distintos fines. Las materias primas silíceas son consideradas como las de mejor calidad para la talla (Tabla 4.2) y parte de las areniscas registradas tienen granulometría fina y un alto grado de silicificación, lo que también las presenta como una buena opción para la producción de instrumentos tallados. En este sentido, las materias primas utilizadas presentan propiedades adecuadas para elaborar artefactos por percusión o presión (Tabla $5.4,5.15$ y 5.20), y además las areniscas, junto a los basaltos, son adecuadas para elaborar artefactos mediante picado, abrasión y/o pulido (Tabla 5.15). En este caso se considera que los factores que más influyeron en la selección de las rocas y minerales registrados son su calidad y la distancia a las canteras potenciales; pero como destaca Colombo (2013) también hay que considerar que debieron haber existido otros factores humanos involucrados en el circuito de aprovisionamiento de los talladores y los asentamientos.

Algunos de los instrumentos (Tabla 5.4 y $5.14 ; n=351$ ) pueden ser considerados formales en el sentido de Andrefsky (1994), como por ejemplo las bolas, puntas de proyectil, raspadores, bifaces, raederas, raederas denticuladas y las puntas de proyectil recicladas; en contraposición a los informales representados por las piezas con retoque sumario, el cuchillo de filo retocado, el cuchillo denticulado y el unifaz. Los primeros habrían estado asociados a estrategias conservadas y los segundos a expeditivas; resultado de estas últimas también serían las cinco lascas con rastros complementarios que indicarían el uso de filos naturales sin mayor preparación. No se considera que ambas estrategias fuesen mutuamente excluyentes, sino que en los sitios arqueológicos se habrían 
confeccionado tanto diseños conservados como expeditivos. Entre los instrumentos del sector A es necesario mencionar además un hacha pulida con garganta y sobadores registrados por Poenitz (1970b) en el sitio arqueológico Nogueira. El conjunto instrumental en principio refleja una amplia gama de tareas que incluyen la talla de instrumentos líticos y la obtención y procesamiento de diversos materiales (animales y vegetales).

Las bolas $(n=233)$ son el instrumento más numeroso en el sector A. Predominan las bolas con surco $(77,6 \%)$ por sobre las que no tienen surco $(22,4 \%)$, indicando que el método de sujeción más utilizado fue la faja de cuero, tendones, nervios o intestinos de animales (véase Vecchi 2010) (Tabla 5.16). Los surcos presentan gran variabilidad morfológica siendo muy difícil establecer las causas de tal variación, esto podría responder sobre todo al tamaño y peso de la bola como a las preferencias del usuario.

Es notable la gran variabilidad de los tipos de bolas, ya que solamente en la muestra del MTM se contabilizaron 11 tipos distintos (sensu González 1953) (Tabla 5.16). Asimismo, se identificaron, no solo para el sector A, sino también en otras zonas de Entre Ríos, algunos tipos que no habían sido registrados previamente (Tabla 5.17) ampliando así la variabilidad regional de estos instrumentos. La presencia de los tipos $\mathrm{Aa}, \mathrm{Ad} 2, \mathrm{Ba}, \mathrm{Bc2}$ y $\mathrm{Bf}$ ya había sido mencionada para Entre Ríos (González 1953). Particularmente el tipo $\mathrm{Bf}(\mathrm{n}=28$ ) ocupa el segundo lugar en cantidad de bolas. Los tipos $\mathrm{Aa}$, Ba y $\mathrm{Bc2}$ presentan frecuencias semejantes ocupando un tercer lugar, y por detrás de estos el tipo Ba. Por su parte, dentro de los tipos $A b, B b 1, B c 5, B g, B h, C$ y $D$, que según González (1953) no habían sido registrados dentro de la provincia (Tabla 5.17), se destaca el tipo Bh $(n=52)$, que resulta ser el tipo predominante en toda la muestra estudiada, seguido por el tipo Bf ya mencionado.

Considerando los datos obtenidos para toda la provincia se destaca la baja frecuencia de los tipos Bg, C y D. En cuanto a los conjuntos particulares se observa que en PAa y LDG hay mayor variabilidad de formas que en el resto, aunque talvez esto se deba a que también son los conjuntos con mayor cantidad de bolas (Tabla 5.14). También sería válido el razonamiento inverso, que la menor variabilidad en el resto de los conjuntos se deba a la baja frecuencia de bolas.

El dato más relevante es la presencia simultánea de diversas morfologías en algunos conjuntos. Esto podría indicar (si se considera la sincronicidad de los tipos) que en el pasado han coexistido simultáneamente varias formas de bolas, y que por lo tanto cada una de éstas no puede ser considerada como el reflejo de distintos grupos humanos, sino que probablemente reflejen diferencias funcionales o estilísticas (o simplemente preferencias personales de acuerdo a la capacidad del operador). En el caso de que los tipos distintos no sean contemporáneos entonces cabe plantear la posibilidad de la reocupación de los sitios arqueológicos a lo largo del tiempo. Cabe mencionar también la posibilidad de una mezcla de bolas de distintas ocupaciones temporales debido a la reclamación de bolas antiguas (González 1953: 165). 
En cuanto al estado de completitud de las bolas del MTM, y considerando el conjunto de bolas procedente de los hallazgos aislados $(n=17)$ y los sitios arqueológicos $(n=35)$ (Tabla 5.15), es probable que el menor porcentaje de bolas enteras $(36,5 \%)$ responda en parte al uso y extravío fuera de los asentamientos o también a que al ser éstas instrumentos de estrategia conservada hayan sido transportadas por los usuarios al desplazarse a otros asentamientos. Por otra parte, la mayor frecuencia de bolas fracturadas $(63,5 \%)$ podría responder a diferentes causas. Primero podrían considerarse como desechos o errores imprevistos de manufactura. Segundo reflejarían la rotura intencional como ha sido planteada para el área Interserrana bonaerense (Vecchi 2010: 277). Tercero se podría considerar la ocurrencia de accidentes durante el desarrollo de juegos o entrenamientos en las inmediaciones de los asentamientos (Vecchi 2010). Cuarto se puede plantear que las bolas rotas durante su uso (y no extraviadas) retornaban a los asentamientos donde se produciría su reemplazo y la reparación de las boleadoras, al igual que lo que ocurre con las puntas (véase más adelante).

En relación a la primera causa, no se ve apoyada por la evidencia ya que el $66,6 \%$ de las bolas fracturadas (bolas fragmentadas y fragmentos de bola) corresponden a pedazos desprendidos de bolas que ya estaban finalizadas. En cuanto la segunda causa, al no tener evidencias históricas ni arqueológicas sobre esta práctica en la región, no se considera que esto haya ocurrido, ya que no se registraron claros puntos de impacto o negativos de lascados, y en el caso de existir simplemente pueden responder a la fuerza del impacto de las bolas entre sí o contra su objetivo durante su uso, y además sería difícil usar este argumento de rotura intencional para explicar aquellas bolas fracturadas recuperadas en el campo. La tercera causa talvez pueda explicar un pequeño porcentaje de los fragmentos de bolas (38,5\%), pero no se considera que esto alcance a toda la muestra. Por último, la cuarta causa sería la más probable, la presencia de bolas fracturadas en los sitios arqueológicos respondería a un proceso de descarte y recambio de bolas rotas por bolas nuevas.

En este sentido, la práctica del descarte inmediato de las bolas rotas durante el uso en el campo no habría sido preponderante, permitiendo así el retorno de las mismas a los asentamientos donde serían reemplazadas. En consonancia con esto es importante considerar la presencia/ausencia del surco, se ha observado que de las 233 bolas 177 presentan surco, lo que indica la predominancia del tipo de sujeción por faja por sobre la sujeción por retobe, que generalmente es usado en bolas sin surco. El método de sujeción por faja provocaría que aquellas bolas fracturadas durante el uso y aún adheridas a la boleadora deban ser reemplazadas por encontrarse su peso y forma alterados; ya que por el contrario si fueran bolas retobadas la fractura dentro del retobe no afectaría sustancialmente la función de la bola, seguiría manteniendo su peso y forma general. Apoyando este punto cabe recordar que todas las bolas rotas con procedencia exacta presentan surco. Esta idea de reemplazo también sería aplicable a la tercera de las causas. El retorno a los asentamientos de instrumentos fracturados durante su uso y su descarte en el mismo ha sido observado en grupos 
etnográficos como los awá de la Amazonía, quienes aplican esta práctica sobre las flechas de madera (Politis et al. 2013b).

En relación a las dimensiones de las bolas y su funcionalidad se registró una amplia gama de tamaños, pesos y diseños; por lo tanto no se puede sostener que las bolas más pequeñas serían manijas y que la más grande (992-ML) una bola única (también llamada "perdida") o un objeto ritual. Las primeras podrían integrar boleadoras para presas pequeñas (aves y pequeños mamíferos) y la más grande efectivamente pudo ser usada por una persona con la destreza para hacerlo. Tampoco se puede especificar a qué tipo de boleadora perteneció cada tipo de bola, pero sí se puede inferir la existencia dentro del conjunto analizado, más allá del sector $\mathrm{A}$, de al menos dos formas de esta arma: la maza de mango flexible (y/o bola única en el caso de que fuera arrojada) representada por las bolas erizadas (y talvez las bolas de mayor tamaño); y la boleadora de al menos dos bolas, pudiendo existir también la de tres, aunque esta variedad se considera en general una adopción tardía o posthispánica en la región (González 1953; Leguizamón 1919, 1935).

En relación a que las bolas erizadas serían el único tipo arqueológico que podría ser identificado con la bola única o "perdida” (véase González 1953: 144), se debe considerar que las erizadas también han integrado un sistema de dos bolas, una de las cuales era la manija como muestra Darwin (1942: Figura 42). Las bolas erizadas posiblemente fueron mayormente usadas como mazas de mango flexible y en menor medida como bola arrojadiza dada la inversión de trabajo que implicaba su elaboración y su posible perdida en el primer lanzamiento, además de su posible importancia simbólica. Tampoco se debe descartar que algunas hayan estado fijadas al extremo de un mango de madera.

Las bolas erizadas muy bien elaboradas y pulidas, mayormente regitradas en la ROU (González 1953), dada su complejidad y la inversión de trabajo que demanda su elaboración, posiblemente hayan tenido una relevancia o valor simbólico. Como sostiene Vecchi (2010) para el caso de las bolas elaboradas con mayor inversión de trabajo y las decoradas, este tipo de bolas serían un objeto de prestigio para su portador y usuario, y a su vez estarían representando diferencias interpersonales entre los cazadores y guerreros. Además, estas bolas erizadas habrían sido efectivamente usadas como parecen indicarlo las fracturas que presentan. Por lo tanto, el prestigio estaría dado por su portación y por la destreza en su uso, y posiblemente también por la destreza y habilidad en su confección para el caso de las más complejas.

En cuanto a las materias primas de las bolas básicamente fueron confeccionadas en arenisca $(57,5 \%)$ y basalto $(38,2 \%)$. Estas rocas provienen de la cuenca del río Uruguay, y el basalto más específicamente de la zona de Salto Grande. En lo que respecta a la materia prima denominada "arcilla" (Tabla 5.15 y Figura 5.7), no está claro su origen pero podría provenir de depósitos de las formaciones Hernandarias, Arroyo Feliciano o La Picada (véase Capítulo 3); su procedencia es más 
difícil de determinar ya que éstas formaciones tienen gran extensión en el centro y norte de Entre Ríos.

En relación a lo anterior, también es pertinente mencionar la presencia de fragmentos de este mismo material en El Dorado $(n=2)$ y Ramblones $(n=2)$, los primeros son esferoides de $4 \mathrm{~cm}$ aproximadamente y los segundos tabulares de $4 \times 3 \times 2,5 \mathrm{~cm}$ aproximadamente. No está claro si el uso de esta materia prima responde a la baja disponibilidad local de otras rocas durante algún momento paricular o solo por elección personal del operador. Un dato interesante también es que las tres bolas de esta materia prima presentan tipos distintos ( $\mathrm{Aa}, \mathrm{Bb} 1$ y $\mathrm{Bh}$ ), lamentablemente ninguna registra procedencia exacta. Se puede considerar que el tipo Aa estaba retobado pero llama la atención que los tipos Bb1 y Bh presenten surco levemente esbozado, ya que aparentemente no son materiales duros y por lo tanto se asume que serían más propensas a la fractura o desintegración inmediata ante el primer impacto durante el uso. Que el surco esté poco diferenciado se puede deber a procesos erosivos que afectaron las bolas dado que no son materiales duros. Por otra parte, las más pequeñas (Bb1 y Bh) podrían ser bolas de juegos o entrenamientos de niños, dada su materia prima y poco peso (véase Vecchi 2010 y bibliografía allí citada).

En cuanto a la tipología de las puntas de proyectil $(n=85)$ (Tabla 5.4 y 5.14 ), 82 son pedunculadas con aletas entrantes y en hombros, predominando las aletas entrantes obtusas (Tabla 5.18). Se observó la reactivación de limbos y aletas y el reciclaje en filos y/o puntas, lo que ha alterado la morfología original de las piezas. Este fenómeno recurrente de mantenimiento de los instrumentos mediante reactivación y reciclaje extendiendo su vida útil probablemente no se deba totalmente a la escasez natural de materiales líticos en el sector (véase más adelante). Los diseños básicos serían de limbos lanceolados o triangulares de lados convexos y aletas entrantes obtusas y agudas. Los diseños restantes serían el resultado de tareas de mantenimiento y reciclaje (Hocsman 2007).

La mayor variabilidad se encuentra en la combinación de las formas de los bordes y base de los pedúnculos (Tabla 5.4 y 5.19), se registraron 28 variantes que estarían reflejando una diversidad realmente importante (Hocsman 2007). Las dimensiones extremas registradas en las puntas de proyectil solo en primera instancia estarían evidenciado distintos sistemas de armas, probablemente arco y flecha y lanza arrojadiza (proyectil largo y pesado arrojado con la mano; sensu Flegenheimer et al. 2010), y/o a dardo (proyectil corto, liviano y delgado arrojado con propulsor; sensu Flegenheimer et al. 2010). Las materias primas más usadas fueron las silíceas $(75,3 \%)$ seguidas por areniscas $(16,5 \%)$ y basalto $(4,7 \%)$.

La punta de proyectil "cola de pescado" (Tabla 5.4) se asocia a la presencia humana temprana en América de Sur (Bird 1969; Castiñeira et al. 2012; Flegenheimer et al. 2003; Miotti 1995; Nami 2007, 2011; Politis 1991; Prates et al. 2013; Suárez 2011; entre otros). Este tipo de puntas abarcan un rango cronológico comprendido entre ca. 11.000 y 10.000 años ${ }^{14} \mathrm{C}$ AP (Prates et al. 2013; 
Miotti y Terranova 2015). Por este motivo el hallazgo de un pedúnculo de este tipo, presenta algunas particularidades interesantes a discutir. Por un lado, si bien la presencia humana temprana ya fue planteada para el noreste de Entre Ríos y la República Oriental del Uruguay (Castiñeira 2008; Nami 2007; Politis et al. 2004; Rodríguez 2006; Serrano 1972; Suárez 2011, entre otros), la provincia de Entre Ríos carece de dataciones absolutas tempranas y solamente se han dado a conocer dos registros de "cola de pescado" (Capeletti 2011; Castro y Terranova 2015), por lo tanto la evidencia empírica hasta el momento es escasa. Por otro lado, este pedúnculo fue encontrado en un palimpsesto superficial asociado con alfarería, lo que podría indicar que ésta asociación artefactual responde a un proceso de reclamación de instrumentos formales (sensu Andrefsky 1994); o bien a la mezcla de artefactos de distintas ocupaciones debido a procesos posdepositacionales, siendo probablemente el más importante de estos las crecidas del río Gualeguay, cuyas aguas cubren los sitios arqueológicos (Castro 2013, Poenitz 1970b).

En este sentido, además del pedúnculo en cuestión, se han publicado recientemente otros artefactos considerados tempranos como un lito discoidal y una punta de proyectil Pay Paso (Bonomo et al. 2014b; Castro y Terranova 2015). Esto en parte sugiere que la pregunta acerca de si ¿existió efectivamente una ocupación humana temprana en Entre Ríos? (Castro 2013), comienza a tener un mayor apoyo en la evidencia arqueológica. A medida que se profundicen las investigaciones sistemáticas en la región los hallazgos vinculados al poblamiento inicial posiblemente irán surgiendo con mayor frecuencia y mejor resolución. En este contexto cobran relevancia las dos nuevas puntas Pay Paso (Figura 5.8) presentadas en esta tesis que permiten ampliar la muestra y la dispersión geográfica de estos diseños de puntas en la margen argentina del río Uruguay (véase Suárez 2015a, 2015b). En el sitio arqueológico Pay Paso 1, en el río Cuareim (ROU), estas puntas abarcan un rango cronológico comprendido entre ca. 9600 y 8600 años ${ }^{14}$ C AP (Suárez 2011).

A partir de los instrumentos tallados $(n=112$ ) (Tabla 5.4 y 5.20 ) se observa una tendencia hacia la utilización de lascas silíceas de buena y excelente calidad; a partir de las cuales se elaboraron sobre todo mediante talla extendida y retoque y microretoque marginal, instrumentos con filos y puntas bifaciales, y filos unifaciales. De manera general también se plantea que en cuanto a las dimensiones hay un predominio de piezas de módulos medianos y espesores delgados. En cuanto a los percutores $(n=3)$, considerando su tamaño y que en la zona no hay afloramientos líticos, se plantea que no fueron utilizados para la reducción de grandes bloques, sino más bien de núcleos y para la retalla y formatización final de los instrumentos (Colombo 2013; Escola 1993; Torrence 1986).

Considerando, por un lado, las puntas de proyectil que sufrieron mantenimiento y reciclaje, y por otro lado, que se ha transportado un importante volumen relativo de materias primas hacia las llanuras interiores (que además de desechos y núcleos incluye geofactos que no fueron reducidos) reduciendo así la incidencia de su escasez natural; se puede plantear que, el mantenimiento y reciclaje no respondería en todos los casos a la escasa disponibilidad y a la maximización de las 192 
materias primas (Andrefsky 1994; Bamforth 1986). Particularmente en el caso de las puntas de proyectil reactivadas, simplemente es más fácil alargar su vida útil manteniendo los filos y las puntas activas que confeccionar una punta de proyectil nueva. En el caso de las puntas de proyectil recicladas también es más simple, una vez fracturadas o cuando ya no pueden cumplir su función primaria, transformarlas en otros instrumentos (formales y conservados) mediante una serie de retoques y seguir manteniéndolos dentro del contexto sistémico (Schiffer 1971, 1987). En este último caso, Hocsman (2007) plantea que 13 de las puntas de proyectil recicladas (cortantes, las raederas y el perforador) fueron usadas enmangadas, por lo que posiblemente una vez fracturado el limbo o ante la imposibilidad de seguir reactivándolo, se acortaba el astil, se reciclaban las puntas de proyectil y se seguían usando sin necesidad de elaborar un nuevo mango y todo el sistema de sujeción. Para estos instrumentos se daría una estrategia de renovación (Kuhn 1994).

En relación a los desechos de talla $(n=1669)$ (Tabla 5.2 y 5.12$)$ se presentan primero las tendencias observadas en aquellos recuperados en nuestras prospecciones y que fueron analizados en detalle (Tabla 5.2); y cuando sea pertinente se agrega información de los desechos de talla relevados en la colección del MTM (Tabla 5.21). En cuanto al estado de fragmentación (Tabla 5.5), dejando de lado los desechos indiferenciados, se registra un predominio de los desechos fracturados (lascas fracturadas -con y sin talón- y no clasificables) (91,3\%) sobre las lascas enteras (8,7\%). En los tipos de lascas registrados (Tabla 5.6) existe un predominio de lascas internas ( $n=48 ; 69,6 \%$ ) sobre las externas ( $n=21 ; 30,4 \%$ ), siendo las lascas angulares las más representadas en la muestra. El predominio de desechos fracturados sobre lascas enteras y de desechos internos sobre externos sugiere que las actividades más recurrentes, sobre todo en PB2, PB3 y PB4, fueron la formatización, la regularización y el mantenimiento de instrumentos. También se debe considerar que la presencia de lascas externas sugiere que en algunos de los sitios arqueológicos (PB2 y PB3), además de la manufactura de instrumentos, se realizó descortezamiento y reducción primaria. Los desechos de talla del MTM también reflejan estas actividades, se observó un predominio de lascas internas angulares y también una marcada presencia de lascas corticales procedentes de rodados fluviales.

En relación a la distinción entre desechos externos e internos y sus implicancias, los talones de las lascas contribuyen con información al respecto (Tabla 5.7). En este sentido, se registró una frecuencia idéntica $(n=16)$ entre talones corticales (natural y liso natural) y preparados (liso, facetado, puntiforme y fracturado). Si bien las frecuencias son idénticas, lo que apoyaría la idea propuesta anteriormente sobre actividades de manufactura de instrumentos y también de reducción primaria, se destaca que la mayor frecuencia tanto de talones corticales como lisos corresponde al sitio arqueológico PB2.

En cuanto a la combinación entre tipos de talón y bulbo (Tabla 5.7), si bien la muestra es pequeña, la asociación más frecuente entre talones lisos naturales con inclinación recta y bulbos difusos $(n=5)$ y pronunciados $(n=4)$ indicaría tareas de descortezamiento y reducción primaria. En 
consonancia con lo anterior puede mencionarse que la regularización del frente de extracción no fue significativa y los rastros complementarios sobre el talón están ausentes. Por otra parte, en cuanto a la relación entre presencia/ausencia de labio y tipo de bulbo (Tabla 5.8) se observa que la diferencia más significativa entre presencia/ausencia de labio y bulbos se da dentro del conjunto de lascas con el mismo tipo de bulbo. En este sentido, todas las lascas con bulbos pronunciados presentan labio; pero dentro de las lascas con bulbos difusos siete presentan labio y ocho carecen de este rasgo. A partir de esto se observa que existe una asociación absoluta entre bulbos pronunciados y presencia de labio; mientras que para los bulbos difusos la presencia de labio se da en frecuencias casi similares.

Generalmente se han asociado los bulbos difusos a percutores blandos y los bulbos pronunciados a percutores duros (Crabtree 1972). Aunque esta relación no siempre es directa (véase p. ej. Flegenheimer et al. 1995; y Martínez et al. 1997-1998), la evidencia presentada no sugiere el predominio neto de algún tipo de percutor específico, sino más bien la presencia de ambos tipos, blandos y duros. Estos últimos presentes en la muestra analizada. Sin embargo, sí es concluyente la asociación entre bulbo pronunciado y presencia de labio en todos los casos, lo que sugiere probablemente una relación directa entre percutor duro, con mayor fuerza de impacto, y la presencia de labio.

A partir del origen de extracción de lascas externas $(n=19)$ (Tabla 5.6) y desechos indiferenciados $(n=13)$ (Tabla 5.5), se determinó que estos desechos de talla provienen de rodados fluviales silíceos de variadas morfologías $(n=32)$, donde predominan ampliamente los indeterminados ( $n=22$ ). Estos datos, junto a las materias primas identificadas (Tabla 5.3), apoyan la idea de que las rocas y minerales explotados proceden de distancias medias o superiores; ya que los únicos depósitos geológicos de la región que se componen en parte de rodados fluviales silíceos, son la Formación Salto Chico y la Terraza I del río Uruguay (véase Capitulo 3), que afloran en la cuenca del mismo río.

Considerando la presencia de corteza y número de lascados en la cara dorsal de las lascas internas y externas (Tabla 5.9), los resultados se ajustan a lo esperado. Dentro de las lascas externas las mayores proporciones de reserva de corteza se presentan en aquellas con menor cantidad de lascados y viceversa. En los sitios PB2 y PB3 las lascas externas más frecuentes son las que presentan un negativo de lascado ( $n=6$ ). Por su parte, en los sitios arqueológicos PB2, PB3 y PB4 el número de negativos en la cara dorsal de sus lascas internas permite plantear que el proceso de talla habría sido relativamente intensivo, dado que las angulares con tres negativos de lascado son las más frecuentes.

En cuanto a las dimensiones de los desechos (Tabla 5.10), dado que las mismas se calcularon solamente para lascas enteras y su frecuencia relativamente baja $(n=6)$, no se puede inferir ninguna 
tendencia. En la colección del MTM se registraron tanto desechos pequeños como grandes, pero habría una tendencia hacia el predomino de módulos medianos.

Los núcleos registrados $(n=37)$ (Tabla 5.11-12) son de seis materias primas diferentes donde predominan las areniscas $(n=20)$ sobre los materiales silíceos $(n=17)$. Se distribuyen en nueve conjuntos arqueológicos y la mayor frecuencia se registró en Jeromito $(n=16)$ y Laguna de García ( $n=$ 8). La forma-base de seis núcleos corresponden a rodados fluviales lo que indica que los mismos provienen de la cuenca del río Uruguay. La presencia de núcleos evidencia que parte de la materia prima llegaba al sector en forma de clastos, núcleos o geofactos sin modificar. La presencia de reserva de corteza observada tanto en desechos de talla como en núcleos indicaría el descortezamiento y la reducción primaria in situ.

A partir de los atributos del conjunto de desechos de talla, considerando los distintos conjuntos arqueológicos de manera particular e integrando los datos de la colección del MTM, en relación al origen de extracción de los desechos de talla, en los conjuntos arqueológicos PB1, PB2, PB3, PB4, PAa, LL, LL2, PDT, ED, N2, LDG, LBN, R, PG, BM, LLV, LAP, J, EB, EA, RO, EBA, TC, A, EV y PC se registró la presencia de desechos internos y externos. En los conjuntos PB5, PB6, RG2, ALU y LB solo desechos internos. En los conjuntos PAb, RG1, ER, AVI y SC solo desechos externos. En R2 y R3 los desechos son indiferenciados. En este sentido, si se suma la presencia de instrumentos y núcleos en algunos conjuntos, en general se puede plantear que en los asentamientos ocurría tanto la manufactura de instrumentos como la reducción primaria de rodados fluviales y clastos.

Esto último, además implicaría que las materias primas llegarían a la cuenca del río Gualeguay sin reducción previa. En otros sitios arqueológicos que no presentan evidencia de las primeras etapas del proceso de reducción lítica, no se puede descartar que esto no haya sucedido. Además, no se descarta que al sector estuvieran llegando preformas e instrumentos manufacturados en otras áreas. Ambos mecanismos de aprovisionamiento de los asentamientos no son excluyentes, sobre todo si se considera que la distancia entre el sector A y las cabeceras de los afluentes más importantes del río Uruguay no es superior a $65 \mathrm{~km}$; y si además ambos sectores estaban ocupados sincrónicamente por grupos humanos que interactuaban. La gran proporción de desechos de talla registrados en el MTM, junto con el numeroso instrumental, están indicando que el traslado de rocas y minerales desde la cuenca del río Uruguay hacia los asentamientos de las llanuras interiores de Entre Ríos fue muy importante y básico para la supervivencia de sus habitantes.

A partir del análisis tecnomorfológico en general se puede observar que en el sector $A$ están presentes la mayoría de las etapas del proceso de producción lítica (Ericson 1984), excepto la obtención. La presencia de rocas y minerales en este sector implica de por sí el traslado y la provisión; los instrumentos, núcleos y desechos de talla implican la manufactura, uso, mantenimiento, reciclaje y el descarte de instrumentos. Por su parte, la obtención de las materias primas fue realizada fuera del sector y mayormente en las márgenes del río Uruguay y sus tributarios 
principales, incluyendo el río Gualeguaychú. Está presente una tecnología de manufactura unifacial y bifacial. La técnica de talla predominante es la percusión directa con percutores blandos y duros, registrándose también talla por presión; también hay instrumentos elaborados mediante picado, abrasión y/o pulido y probablemente modificados por uso. Se confeccionaron tanto instrumentos conservados y expeditivos, y también se usaron filos naturales.

\subsection{3- CONJUNTO CERÁMICO}

Las alteraciones físicas que presenta la mayor parte de la muestra de alfarería $(96,2 \%)$ (Tabla 5.2), que también fueron registradas en la muestra del MTM (Tabla 5.12), junto al alto grado de fragmentación, donde el 98,9\% de la muestra presenta tamaños menores a $5 \mathrm{~cm}$ (Tabla 5.2), indicaría modificaciones estructurales producto de la acción fluvial y/o eólica, y tal vez antrópica moderna. Esto sugiere que las superficies donde se han registrado los conjuntos arqueológicos, están sometidas a procesos posdepositacionales, que no solo estarían modificando la estructura de los artefactos, sino también la integridad de los sitios arqueológicos (Castro 2013; Poenitz 1970b). Además, esto podría explicar en parte la baja frecuencia de rastros de ahumado u hollín en la muestra.

En referencia a la atmósfera de cocción inferida a partir de la observación del color del núcleo y de ambas superficies de los tiestos, se sugiere que la distribución de frecuencias de colores estaría indicando el predominio de una cocción oxidante incompleta ( $n=54 ; 50,9 \%)$, seguida por la reductora/oxidante incompleta $(n=13 ; 12,3 \%)$, siendo el resto indeterminada $(n=39 ; 36,8 \%)$. Dentro de las inclusiones registradas se plantea que incorporación de arena a la pasta es de carácter natural estando presente en las arcillas seleccionadas para alfarería. El tiesto molido es de carácter claramente intencional, lo que sugiere cierto grado consideración especial en la preparación de la materia prima. Asimismo, se considera que existe una alta probabilidad de que las espículas de esponjas registradas en la pasta de algunas vasijas hayan sido incorporadas intencionalmente.

La presencia de espículas silíceas de esponjas como inclusión intencional en la cerámica de la región fue mencionada para el río Uruguay en primer lugar por Serrano (1933a) y recientemente por Capdepont y colaboradores (2013). Baeza y colaboradores (1977) y Díaz (1980) identifican espículas de esponjas en la cerámica de la zona de Salto Grande pero plantean su incorporación de forma natural, estando presente en la arcilla seleccionada localmente para elaborar la cerámica. Por esta última postura se inclinan también Boretto y colaboradores (1975) al referirse a las espículas de la cerámica de la margen izquierda del río Uruguay inferior.

Serrano (1933a) identificó espículas de Uruguaya corallioides en tiestos procedentes del tramo del río comprendido entre Monte Caseros y los médanos costeros al sur de la ciudad de Colón, y también en la costa de la ROU, en Santa Rosa y Barrancas Peladas del Espinillal. El trabajo de 196 
Capdepont y colaboradores (2013) representa un avance importante en relación al precursor trabajo de Serrano (1933a) ya que se identifican espículas (sin determinar los taxa) en cerámicas adjudicadas a los guaraníes y también en fangos naturales. También reconocen que no todos los fragmentos estudiados presentan espículas (lo mismo que ocurre en nuestro caso de estudio); esto, sumado a que las espículas son más frecuentes y están mayormente enteras en los tiestos estudiados (arqueológicos y experimentales) que en el los fangos donde están sometidas a una mayor destrucción por agentes naturales, apoyaría en este caso el agregado intencional.

En base a lo anterior se observa que en la cuenca media del río Uruguay esta técnica era usada por los guaraníes (Capdepont et al. 2013), y también por otras poblaciones locales (y probablemente en momentos anteriores a la llegada de los guaraníes). Evidentemente el agregado de tiestos y espículas para mejorar las propiedades estructurales de las vasijas refleja un conocimiento tecnológico altamente sofisticado y compartido en una gran área (véase Di Prado 2015). Las espículas en la cerámica ya han sido reconocidas con anterioridad para Brasil (Hilbert 1955; Linné 1932, 1965; Machado 1947) y más recientemente para sectores cercanos a nuestra área de estudio (Bonomo et al. 2009; Capdepont y Bonomo 2010-2011), por lo tanto sería una práctica común en la Tierras Bajas sudamericanas y no debería extrañar su presencia en las cerámicas del sector $A$.

En nuestro caso de estudio la presencia de espículas de esponjas en las llanuras interiores permite plantear que:

1- La presencia de espículas de Uruguaya corallioides en la cerámica de la cuenca del río Gualeguay, más a allá de si su inclusión en la pasta fue intencional o no, es evidencia concreta de vinculaciones con el cauce del río Uruguay. Esta especie solo ha sido registrada en este río y en palabras de Inés Escurra de Drago: “...es una especie que no está en la cuenca del Paraná en nuestro país, ni tampoco la he registrado de tributarios argentinos del rio Uruguay. Es una especie típica de aguas claras, rápidas, con pocos sedimentos suspendidos, bien oxigenadas, con fondos pedregosos." (Ezcurra de Drago; CONICET-INALI-UNL; comunicación personal escrita 2014). Todas estas últimas características fluviales están bien representadas en tramo ritrónico del río Uruguay medio y no así en sus afluentes; por lo que se puede restringir aún más la procedencia de las espículas concretamente al cauce principal de este río; y aún todavía más a lugares con rápidos, restingas y saltos (Frenguelli 1939), dado que la especie presenta una marcada fidelidad ecológica, y aún en estos rasgos geológicos las distintas especies de esponjas tienden a ocupar determinadas posiciones, mostrando además una relativa fidelidad a distintos tipos de sustratos (Ezcurra de Drago y Bonetto 1969).

2- Uruguaya corallioides "...es una especie típica y muy abundante en el río Uruguay, principalmente antes de la construcción del Embalse de Salto Grande..." (Ezcurra de Drago; comunicación personal 2010) y solo se encuentra en el lecho del río Uruguay. Es una especie reófila 
típicamente bentónica y de crecimiento incrustante característica del tramo ritrónico y es una de las especies dominantes en las áreas más profundas del río (Bonetto y Ezcurra de Drago 1968). Raramente sus ejemplares no ramificados puede desarrollarse en sectores de menor profundidad (Ezcurra de Drago; comunicación personal 2011). Por lo tanto, los ejemplares ramificados de esta especie se encuentran sumergidos y solo pueden ser obtenidos, con ciertas dificultades de accesibilidad, en períodos de estiaje o mediante inmersión parcial o total del recolector dependiendo del nivel del agua (Ezcurra de Drago 1995, 2004; Ezcurra de Drago y Bonetto 1969). En este sentido, se destaca que la recolección de los ejemplares estudiados por Bonetto y Ezcurra de Drago (1967, 1968, 1969) y Ezcurra de Drago y Bonetto (1969) fue realizada en 1967 y 1968 durante grandes bajantes del río Uruguay y en varios puntos del cauce entre Monte Caseros (Corrientes) y Paso Hervidero (Entre Ríos) (Bonetto y Ezcurra de Drago 1969; Ezcurra de Drago y Bonetto 1969). De cualquier manera esto apoyaría la idea de que la obtención de estas esponjas sería intencional. No se debe descartar que las espículas hayan estado presentes en los fangos seleccionados tal cual las identificó Capdepont y colaboradores (2013), pero el hecho de que no todos los tiestos estudiados tengan espículas apoyaría mayormente su incorporación intencional a la pasta.

3- Por el momento no se puede postular concretamente la selección prehispánica de alguna especie de esponja en particular, dado que generalmente una de las características de la mayoría de las esponjas Neotropicales es que casi nunca forman colonias aisladas de otras especies (Bonetto y Ezcurra de Drago 1969; Ezcurra de Drago y Bonetto 1969; Ezcurra de Drago; comunicación personal 2011), sino que siempre hay varias especies en distintos sectores, o superpuestas en las mismas rocas o sectores del cauce. La presencia de al menos dos especies distintas en el tiesto de PB2 posiblemente evidencie esta situación. Aun así, que la obtención Uruguaya corallioides implique un nivel bajo del agua o la inmersión total o parcial del recolector podría indicar cierta preferencia sobre este taxón, tal vez condicionada por el gran tamaño que pueden desarrollar algunos de sus ejemplares (Bonetto y Ezcurra de Drago 1967; Ezcurra de Drago y Bonetto 1969). Esto facilitaría su recolección selectiva en relación a la extraordinaria variedad y abundancia de poríferos del río Uruguay medio (Bonetto y Ezcurra de Drago 1969; Ezcurra de Drago 2004; Ezcurra de Drago y Bonetto 1969), y a la vez aumentaría el volumen de espículas recolectadas.

4- Una vez determinada la procedencia de estas espículas queda dilucidar en qué forma llegaron a la cuenca del río Gualeguay. Pudiendo ser trasladadas las vasijas enteras y elaboradas en el río Uruguay; trasladada la mezcla de arcillas preparadas conteniendo las espículas; o quizás directamente trasladadas las esponjas obtenidas en el río. La evidencia disponible es aún insuficiente para profundizar este punto.

En cuanto a las formas de las vasijas su identificación estuvo condicionada por la integridad estructural y el tamaño de los bordes. Se reconstruyeron 33 vasijas que probablemente incluyan 198 
ollas, escudillas y cuencos. Se registraron 20 vasijas no restringidas y 13 restringidas. Dentro de las no restringidas hay 14 con paredes levemente divergentes (tres que corresponderían a cuencos grandes) y seis con paredes fuertemente divergentes (tres que corresponderían a platos hondos). Una de las restringidas (probable olla) presenta decoración incisa de punto. Uno de los cuencos grandes presenta decoración incisa de surco rítmico y uno de los platos hondos combina surco rítmico con incisión de punto. Una de las vasijas descriptas por Ceruti (2007) cuya forma no es diferenciada presenta decoración incisa de punto. En cuanto a la funcionalidad de la alfarería es claro el predominio de cerámica utilitaria lisa, que en muy pocos casos todavía conserva rastros de hollín. Los agujeros registrados en algunos recipientes sugieren el uso de cuerdas o tientos para la suspensión de los mismos (LL, AVI, J, ER) y también la reparación de paredes agrietadas (R y ER).

En relación a la alfarería decorada hay un predominio de la técnica de incisión sobre la pintura, registrándose también decoraciones combinadas. La decoración se sitúa mayormente cerca de los bordes o la parte superior de las vasijas. Las piezas modeladas y los apéndices zoomorfos son comunes en el registro regional y corresponderían a Goya-Malabrigo (Ceruti 2003a; Politis y Bonomo 2012). En este sentido, la presencia de un modelado semejante a una representación zoomorfa en Base del Maidana y un mamelón modelado en Laguna de García (Figura 5.9D), junto a la decoración por surco rítmico y bordes escalonados en El Dorado, Picada de Segovia y Laguna de García (Figura 5.9C), es un dato relevante ya que este tipo de alfarería generalmente ha sido registrada en las riberas del río Paraná sobre todo y el río Uruguay en menor medida. Dada la baja frecuencia relativa de estos rasgos en la alfarería, junto a la ausencia de los demás atributos concurrentes que definen a Goya-Malabrigo (véase Ceruti 2003a; González 1977; Politis y Bonomo 2012), no se puede sostener la presencia de esta entidad arqueológica. Estos hallazgos posiblemente evidencien algún tipo de interacción entre las Tierras altas de Entre Ríos y las sociedades indígenas identificadas con GoyaMalabrigo que ocuparon los grandes ríos.

Otro dato relevante son los tiestos pintados de rojo $(n=7)$ de Laguna de García que corresponderían a un cambuchí o cambuchí caguâbá guaraní, y que siguiendo los trabajos de La Salvia y Brochado (1989), Brochado y colaboradores (1990), y Brochado y Monticelli (1994) son vasijas destinadas a la producción, almacenaje y servicio líquidos, análogos a la tinaja o jarro y al vaso respectivamente. Hasta el momento no había registro de esta alfarería en zonas muy alejadas de los ríos Uruguay y Paraná como en este caso. Por último, los materiales posthispánicos en algunos conjuntos marcarian la presencia indígena en el sector en momentos posteriores a la conquista europea como mencionan algunos documentos a partir del siglo XVI (Bracco 2013; Pérez Colman 1936; Sallaberry 1926; Serrano 1936). 


\section{3- CONSIDERACIONES FINALES}

A partir de las materias primas identificadas se determinó que las rocas y los minerales fueron trasladados hacia las llanuras interiores de la provincia de Entre Ríos desde las márgenes del río Uruguay o sus arroyos tributarios. También es probable que parte de las areniscas fueran trasladadas desde el río Gualeguaychú (véase Capítulo 9). Debido a lo anterior, no se considera que en el sector A haya xilópalos y areniscas procedentes de la cuenca del río Paraná como las estudiadas por Bonomo y Blasi (2011) y Hocsman (1999a, 1999b, 2015). El gran volumen relativo de recursos líticos transportado sugiere que no habría habido impedimentos para el acceso a los mismos y consecuentemente para el aprovisionamiento de los asentamientos y de la zona en general. Este proceso de aprovisionamiento de un área donde los recursos líticos están ausentes también podría considerarse como parte de un proceso de litificación (Webb 1993) del territorio, mediante la conformación de depósitos antropogénicos (provisión) en los mismos asentamientos. Esto además reflejaría la intensidad, estabilidad y planificación de las ocupaciones debido a que ese material acumulado pretende ser utilizado como materia prima en algún momento posterior.

La obtención se realizó en las canteras (depósitos primarios), por extracción en filones y afloramientos de: calizas silicificadas en el Parque Nacional El Palmar (Castro 2012); arenisca en la zona de Salto Grande (Rodríguez 1975); basaltos y "areniscas consolidadas" o "arenisca silicificada" (estas "areniscas" corresponderían a cuarcita intertrap) en Salto Grande (Femenías 1973; Poenitz 1970a; Rodríguez 1975). También se practicó recolección para el caso de los rodados fluviales (depósitos secundarios) y tal vez algunos clastos desprendidos naturalmente. Posteriormente los recursos líticos en forma de geofactos, núcleos, preformas o instrumentos fueron trasladados hacia el interior directamente por las personas que los obtuvieron o mediante aprovisionamiento indirecto por intercambio entre personas que ocupaban ambos sectores sincrónicamente.

Variados ejemplos arqueológicos y etnográficos de comportamientos vinculados al aprovisionamiento de materias primas líticas pueden verse en Colombo (2013) y la bilbiografía allí citada. En nuestro caso de estudio el aprovisionamiento pudo darse mediante la realización de partidas logísticas de talladores (desde el interior hacia las canteras), orientadas exclusivamente a la obtención de materias primas (clastos y rodados enteros, núcleos, preformas o instrumentos), ya sea por extracción y/o recolección en canteras "propias", de libre acceso o de propiedad compartida, o con permiso de otros "propietarios" de la misma etnia u otras etnias (aprovisionamiento directo). También el aprovisionamiento pudo darse en las canteras o cerca de ellas por intercambio con grupos habitantes de la costa o "propietarios" de las canteras (aprovisionamiento indirecto). Cabe la posibilidad de un traslado residencial a zonas cercanas, o a las mismas canteras, durante un corto periodo que permita el aprovisionamiento, ya sea directo o indirecto. En este caso de estudio es 
posible que haya predominado el aprovisionamiento directo, sobre todo si este se daba en el marco de un traslado residencial a las mismas canteras.

También pudo darse el caso inverso (desde las canteras hacia el interior) donde partidas logísticas de talladores obtenían las materias primas en las canteras "propias" o de libre acceso y las trasladaban hacia el interior para intercambiar con los grupos que vivían allí. La posibilidad de que el aprovisionamiento de los sitios arqueológicos del interior se haya dado en el marco de otras actividades ( $p$. ej. partidas logísticas de obtención de recursos animales y vegetales) donde además se obtenían y trasladaban las rocas y minerales desde las canteras hacia el interior ("embedded" sensu Binford 1979), puede ser considerada como la de menor probabilidad; debido a que las canteras están como mínimo a $58 \mathrm{~km}$.

En el sector A, por un lado, se determinó que no hay evidencia de una explotación diferencial materias primas y dada la buena y excelente calidad que presentan, es probable que las mismas hayan sido seleccionadas en las canteras antes de comenzar su traslado hacia las llanuras centrales. Por otro lado, se puede considerar que hay una selección de materias primas para elaborar determinado tipo de instrumentos. Las areniscas estaban destinadas sobre todo a la manufactura de bolas y probablemente instrumentos de molienda; también para las bolas se usó en gran medida el basalto. Los materiales silíceos, sobre todo rodados fluviales, eran destinados a la confección de instrumentos de filos y puntas, y percutores.

El instrumental lítico refleja actividades relacionadas directamente con la subsistencia. Las puntas de proyectil y las bolas se asocian a la caza o pesca (y tal vez a violencia interpersonal). Los raspadores, bifaces, raederas, cuchillos, unifaces, piezas con retoque sumario y lascas con filos naturales se asocian con el procesamiento de subproductos de la caza, pesca y recolección. Por otro lado, los percutores indican la producción de instrumentos mediante talla por percusión directa. Tanto las bolas como las puntas de proyectil reflejan al menos tres sistemas de armas usados en la cuenca del río Gualeguay, sin que esto implique sincronicidad. La boleadora y las puntas que corresponden a dos modalidades, a flechas y lanza (o dardo de propulsor).

Los desechos de talla y los núcleos muestran que las actividades más recurrentes en los asentamientos fueron el descortezamiento y la reducción primaria de rodados fluviales, y sobre todo la formatización, la regularización y el mantenimiento de instrumentos mediante percusión directa (Sullivan y Rozen 1985). Particularmente en PB2 y PB3 además, si se toma como válida la asociación entre percutor y forma del bulbo, se registraron evidencias del uso de percutores blandos y duros en iguales proporciones. Asimismo, las bolas fracturadas, los pedúnculos aislados, las puntas recicladas y reactivadas también indican que en los asentamientos se realizaba el mantenimiento, reemplazo y parte del descarte de los instrumentos líticos. Otra parte del descarte producto seguramente de la pérdida o rotura se daba fuera de los asentamientos, en los contextos principales de uso, sobre todo para bolas y puntas de proyectil. 
La alfarería evidencia sobre todo un uso doméstico y predominan las formas simples, abiertas y sin decoración. Las masas de arcilla cocida permiten plantear que al menos una parte de las vasijas fueron elaboradas localmente. La manufactura de vasijas implicó cierto grado especialización y conocimientos, ya que su elaboración incluyó el agregado intencional en la pasta de tiestos y espículas de esponjas, y en algunos casos la decoración incisa compleja, y hasta la reparación de las mismas como lo muestran los agujeros registrados.

La relativa baja densidad artefactual registrada en los sitios arqueológicos junto a su carácter superficial, reflejarían ocupaciones de menor intensidad que en las cuencas de los grandes ríos, pero planificadas y de mayor duración de lo que hasta el momento se conocía (véase capítulo 2). Estas ocupaciones integrarían redes de interacción amplias que permitían el acceso a los recursos del río Uruguay. En este marco también se debe considerar la incidencia de procesos posdepositacionales como la acción eólica, pluvial, el pisoteo antrópico y de animales, y sobre todo el desborde de las aguas del río Gualeguay, que suele inundar grandes extensiones de terreno, y que posiblemente estén enmascarando ocupaciones artefactualmente más densas. El efecto de estos procesos podría en parte explicar la fragmentación del conjunto lítico, la integridad de la alfarería, y la integridad y resolución espacio-temporal de los sitios arqueológicos.

En síntesis, algunos de los sitios arqueológicos del interior de la provincia de Entre Ríos pueden ser considerados como asentamientos residenciales de actividades múltiples (p. ej. PB2, PAa, LDG, BM y J). En ellos se desarrollaron actividades vinculadas a la subsistencia, como el procesamiento y consumo de alimentos; y a la manufactura, uso, reparación, reciclaje y descarte de instrumentos líticos y vasijas cerámicas.

Para este sector no se cuenta hasta el momento con dataciones absolutas, esto dificulta la ubicación de los distintos sitios arqueológicos dentro de una secuencia cronológica precisa. En cuanto al comienzo de la ocupación de estas llanuras los indicadores paleoindios, como las puntas de proyectil "cola de pescado" y Pay Paso, reflejarían el comienzo de la ocupación en momentos de la transición Pleistoceno tardío-Holoceno temprano (11.000-8600 años ${ }^{14} \mathrm{C}$ AP). Por otra parte, la presencia de alfarería indica que al menos una parte de los contextos arqueológicos corresponden al Holoceno tardío. Asimismo, la presencia de artefactos posthispánicos alertan sobre la posibilidad de que algunos conjuntos sean el resultado de ocupaciones posteriores al siglo XVI. En este sentido, es necesario recordar que las llanuras centrales de Entre Ríos fueron ambientes habitados, transitados y de refugio de los indígenas históricos denominados genéricamente charrúas hasta aproximadamente 1750 (Acosta y Lara 1961; Bracco 2013; Sallaberry 1926).

La carencia de dataciones absolutas genera un serio problema de interpretación de los datos al momento de realizar comparaciones con el registro de áreas próximas, como el río Uruguay medio e inferior, o la cuenca del río Paraná. Aún más, la ausencia de dataciones determina que la comparación con el registro arqueológico del sector más próximo estudiado aquí, el sector B (véase 
Capítulo 6), no permita dilucidar si ambas áreas fueron habitadas sincrónicamente. Además, si en este último caso la respuesta fuera afirmativa, solamente a partir de la tecnología lítica y la cerámica se pueden comparar ambos sectores, y entonces se podría plantear de manera general que el registro arqueológico del río Gualeguay presenta más semejanzas con el registro del río Uruguay en latitudes similares, que con el río Paraná o el río Uruguay inferior. Asimismo, se debe tener en cuenta que la talla lítica no fue una actividad intensiva en la cuenca del río Paraná, debido a la relativa ausencia de rocas y minerales (véase Capitulo 4), por lo que con esta cuenca solo se está comparando el registro cerámico. En este sentido, sería posible que las semejanzas entre los sectores A y B se debieran a que solo se está comparando la explotación de materiales líticos y cerámica muy fragmentada, y dejando de lado aspectos que permitirían una mejor comparación con el río Paraná como los patrones de explotación de la fauna o las prácticas mortuorias por ejemplo. En este estado de situación se plantea que los grupos que habitaron la cuenca del río Gualeguay en el sector estudiado serían parte de una población mayor, que también ocupó la cuenta media del río Uruguay.

Desde que Serrano expresara en 1950 que "Prácticamente nada sabemos de la arqueología del interior de la provincia" y adjudicara algunas boleadoras del área a los charrúas (Serrano 1950: 103), hasta que Poenitz realizó el primer trabajo sistemático en 1970 pasaron 20 años. Luego de Poenitz, los trabajos arqueológicos corresponden únicamente a Marcelo Lugrin y su destacado interés por el pasado indígena de Villaguay. Desde el pionero trabajo de Poenitz (1970b) hasta la revisión de la colección del MTM por Ceruti (2007) y Hocsman (2007) pasaron otros 37 años sin que nada más se escribiera sobre la zona. Desde entonces pasaron otros seis años hasta que en el marco de esta tesis iniciada en 2007 se publicaron los primeros avances en el centro de la provincia (Castro 2013). Por lo tanto, se considera que la información presentada en este capítulo resulta relevante, más que como un resultado final, como un punto de partida para el desarrollo de distintas líneas de investigación que permitan comprender más profundamente la ocupación indígena de las Tierras altas de Entre Ríos. 


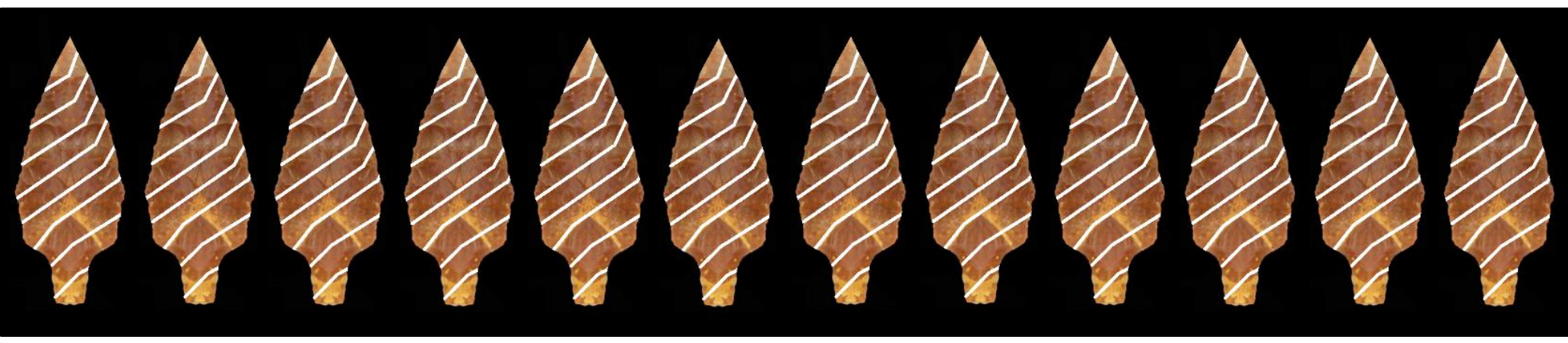

Capítulo 6

\section{DISTRIBUCIÓN ESPACIO-TEMPORAL Y CARACTERIZACIÓN DEL REGISTRO ARQUEOLÓGICO EN EL SECTOR B}

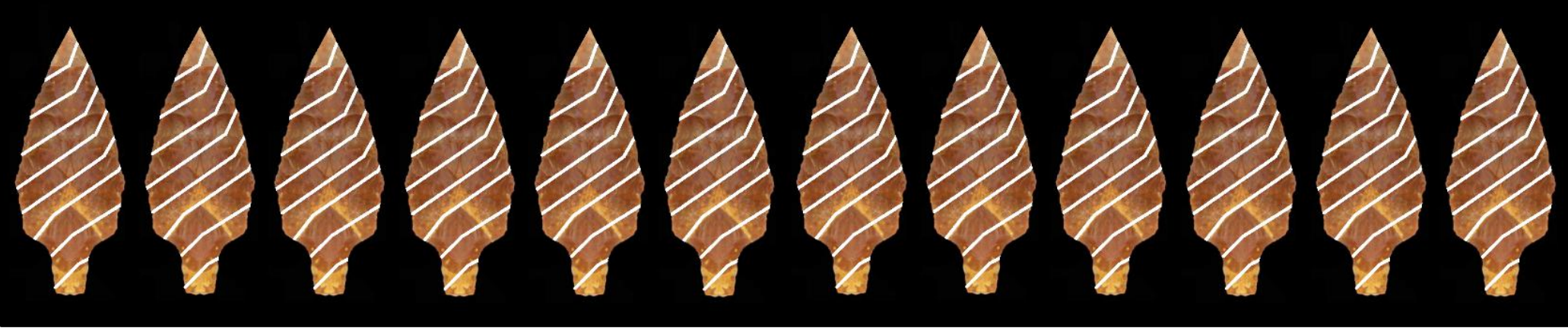




\section{CAPÍTULO 6}

\section{DISTRIBUCIÓN ESPACIO-TEMPORAL Y CARACTERIZACIÓN DEL REGISTRO ARQUEOLÓGICO EN EL SECTOR B}

En este capítulo se presentan y discuten los resultados de las prospecciones sistemáticas, de los sondeos estratigráficos y del análisis de los materiales arqueológicos recuperados en el sector $\mathrm{B}$, dentro del departamento Colón y el Parque Nacional El Palmar (PNEP). En el sector B se realizaron prospecciones intensivas sobre la margen derecha del río Uruguay y ambas márgenes de los arroyos Ubajay, Los Loros y El Palmar, así como en las zona de palmares situada entre el camino de acceso al parque por el norte y el arroyo El Palmar por el sur. La costa del PNEP sobre el río Uruguay presenta básicamente dos topografías diferentes. Una zona baja, formada por playas de arenas y rodados, que se extiende desde el arroyo Ubajay por el norte hasta la Calera Barquín, y una zona alta, de grandes barrancas, desde dicha Calera hasta la desembocadura del arroyo El Palmar al sur. El tramo que va desde este último curso de agua hasta el arroyo Sumaca presenta una costa baja. Los arroyos que desembocan en el río Uruguay presentan una combinación de costas bajas y barrancas.

Considerando estos rasgos geomórficos se implementan dos técnicas de prospección: pedestre y fluvial. En cuanto a la zona de palmares de Butia yatay prospectada, esta presenta lomadas con valles amplios y numerosos afloramientos rocosos de areniscas y rodados. El relevamiento de esta zona de focalizó en el área afectada por un incendio ocurrido en noviembre de 2010; aprovechando la disminución de la vegetación y el mejoramiento de la visibilidad arqueológica. En este sector se prospectó la costa del arroyo El Palmar y en la parte central del área incendiada se trazaron dos transectas norte-sur que la atravesaban completamente, una de $3700 \mathrm{~m}$ (T1) y otra de $2600 \mathrm{~m}$ de largo (T2), ambas de $5 \mathrm{~m}$ de ancho. Además, en esta zona se relevaron 16 afloramientos rocosos (Figura 6.1).

\section{1- RESULTADOS}

\subsection{1- SITIOS ARQUEOLÓGICOS Y HALLAZGOS AISLADOS}

Se identificaron ocho sitios arqueológicos y 14 hallazgos aislados, todos en posición superficial (Tabla 6.1 y Figura 6.1). No se detectaron sitios en estratigrafía a pesar de que se realizaron tres sondeos estratigráficos y seis pruebas de pala. Los materiales arqueológicos incluyen artefactos líticos 
y cerámicos (Tabla 6.2). No se registraron restos óseos faunísticos o humanos. Algunos de los sitios arqueológicos relevados en nuestras prospecciones fueron detectados previamente por el personal del PNEP. En estos lugares dicho personal realizó recolecciones superficiales dirigidas recuperando materiales arqueológicos. Estos artefactos (líticos y cerámicos) se sumaron al conjunto arqueológico recuperado en nuestros trabajos de campo y todo se analizó de manera integral.

Tabla 6.1. Sitios arqueológicos y hallazgos aislados en el sector B.

\begin{tabular}{|c|c|c|c|c|}
\hline $\begin{array}{l}\text { Sigla en la } \\
\text { Figura } 6.1\end{array}$ & Sitios arqueológicos & Topografía & \multicolumn{2}{|c|}{$\begin{array}{c}\text { Coordenadas geográficas, } \\
\text { Datum Wgs84 }\end{array}$} \\
\hline PS & Palmera Sola & médano & $\mathrm{S} 31^{\circ}, 84217$ & $058^{\circ}, 19570$ \\
\hline$A U$ & Arroyo Ubajay & llanura & $\mathrm{S} 31^{\circ}, 84765$ & $\mathrm{O} 58^{\circ}, 20061$ \\
\hline ALL1 & Arroyo Los Loros 1 & barranca & $\mathrm{S} 31^{\circ}, 85933$ & $\mathrm{O} 58^{\circ}, 21086$ \\
\hline ALL2 & Arroyo Los Loros 2 & barranca & $\mathrm{S} 31^{\circ}, 86087$ & $\mathrm{O} 58^{\circ}, 21332$ \\
\hline AEP1 & Arroyo El Palmar 1 & albardón & $\mathrm{S} 31^{\circ}, 90348$ & $\mathrm{O} 58^{\circ}, 21163$ \\
\hline AEP2 & Arroyo EI Palmar 2 & barranca & $\mathrm{S} 31^{\circ}, 90221$ & $\mathrm{O} 58^{\circ}, 22503$ \\
\hline PA & Puerto Algarrobos & Ilanura & $\mathrm{S} 31^{\circ}, 90406$ & $\mathrm{O} 58^{\circ}, 21956$ \\
\hline AV & Árbol Viejo & llanura & $\mathrm{S} 31^{\circ}, 88683$ & $\mathrm{O} 58^{\circ}, 29507$ \\
\hline $\begin{array}{l}\mathrm{N}^{\circ} \text { en la } \\
\text { Figura } 6.1\end{array}$ & Hallazgos aislados & Topografía & \multicolumn{2}{|c|}{$\begin{array}{c}\text { Coordenadas geográficas, } \\
\text { Datum Wgs84 }\end{array}$} \\
\hline 1 & LM2 (Los Monigotes 2) & médano & $\mathrm{S} 31^{\circ}, 84541$ & $\mathrm{O}^{\circ} 8^{\circ}, 19710$ \\
\hline 2 & LM3 (Los Monigotes 3) & médano & $\mathrm{S} 31^{\circ}, 84529$ & O58 ${ }^{\circ}, 19625$ \\
\hline 3 & ALL3 (Arroyo Los Loros 3) & barranca & $\mathrm{S} 31^{\circ}, 86586$ & $\mathrm{O} 58^{\circ}, 20761$ \\
\hline 11 & AEP3 (Arroyo El Palmar 3) & Ilanura & $\mathrm{S} 31^{\circ}, 89735$ & $\mathrm{O} 58^{\circ}, 24238$ \\
\hline 12 & AEP4 (Arroyo El Palmar 4) & llanura & $\mathrm{S} 31^{\circ}, 89727$ & $\mathrm{O} 58^{\circ}, 24191$ \\
\hline 4 & AEP5 (Arroyo El Palmar 5) & albardón & $\mathrm{S} 31^{\circ}, 89424$ & $\mathrm{O} 58^{\circ}, 22379$ \\
\hline 5 & AEP6 (Arroyo El Palmar 6) & Ilanura & $\mathrm{S} 31^{\circ}, 89614$ & $\mathrm{O} 58^{\circ}, 22249$ \\
\hline 6 & AEP7 (Arroyo El Palmar 7) & albardón & $\mathrm{S} 31^{\circ}, 90010$ & $\mathrm{O} 58^{\circ}, 21844$ \\
\hline 7 & AEP8 (Arroyo El Palmar 8) & playa & $\mathrm{S} 31^{\circ}, 90466$ & $058^{\circ}, 22080$ \\
\hline 8 & EM (El Meandro) & playa & $\mathrm{S} 31^{\circ}, 90001$ & $\mathrm{O} 58^{\circ}, 22624$ \\
\hline 9 & PB (Playa Bonita) & playa & $\mathrm{S} 31^{\circ}, 89923$ & $058^{\circ}, 23166$ \\
\hline 10 & MAEP (Mirador Arroyo El Palmar) & llanura & $\mathrm{S} 31^{\circ}, 89407$ & $\mathrm{O} 58^{\circ}, 24014$ \\
\hline 13 & PR (Puente Roto) & llanura & $\mathrm{S} 31^{\circ}, 89835$ & $058^{\circ}, 24454$ \\
\hline 14 & LH (La Huella) & llanura & $\mathrm{S} 31^{\circ}, 89788$ & $\mathrm{O} 58^{\circ}, 24265$ \\
\hline
\end{tabular}




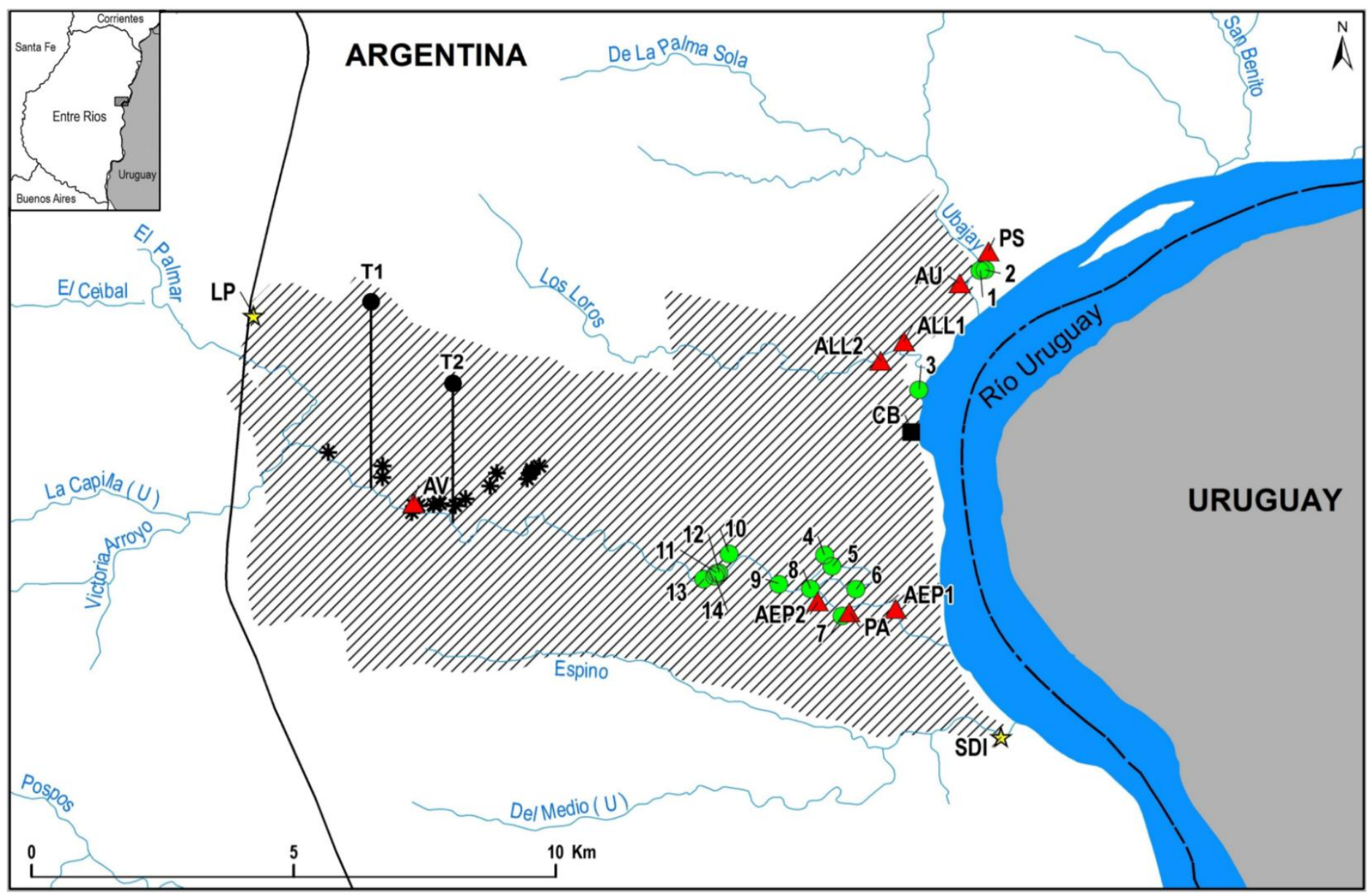

Figura 6.1. Sector B indicando el Parque Nacional El Palmar (área rayada), los sitios arqueológicos (triángulos) y los hallazgos aislados (círculos). También se indican los afloramientos rocosos relevados (asteriscos), las dos transectas norte-sur (T1 y T2) y los puntos de recolección de la bola de La Portada (LP) (estrella) y del núcleo de talla observado en la Sala de Interpretación del parque (SDI) (estrella). CB: Calera Barquín.

\subsubsection{1- Descripción contextual de los sitios arqueológicos y sus conjuntos artefactuales}

\section{Palmera Sola (PS)}

Ubicado en la margen izquierda del arroyo Ubajay, a 1300 m de su desembocadura (Figura 6.2A). Se dispone sobre una extensa zona de médanos móviles con escasa vegetación. El material arqueológico se dispone sobre una superficie aproximada de 250×200 m. Los médanos se extienden sobre la terraza alta del arroyo, a una altura aproximada de $20 \mathrm{~m}$ sobre el nivel de las aguas. Se realizó una recolección superficial dirigida y cuatro pruebas de pala. Este sitio arqueológico se corresponde con el sitio denominado Monigotes 1 (Molinari y Cansanello 1992) o Palmera Sola (APN-PNEP 2002). En 1991 y 1992 personal del PNEP recuperó en este lugar 217 artefactos. Los materiales recuperados incluyen 12 instrumentos, 336 desechos de talla y tres núcleos; cuatro fragmentos de borde de alfarería y 15 de cuerpo, todos lisos (Tabla 6.2). 


\section{Arroyo Ubajay (AU)}

Ubicado en la margen derecha del arroyo Ubajay, a $1000 \mathrm{~m}$ de su desembocadura. El material arqueológico se dispone sobre una extensa superficie llana y sin vegetación, cubriendo una superficie aproximada de $10 \times 7 \mathrm{~m}$, paralela al arroyo y circundada por vegetación xerófila. Se encuentran abundantes rodados en la playa que baja hacia la costa. Se realizó una recolección superficial dirigida. Los materiales incluyen cuatro instrumentos, 30 desechos de talla y 14 núcleos (uno de ellos conformado por dos piezas que remontan) (Tabla 6.13); un fragmento de borde y ocho de cuerpo, todos lisos (Tabla 6.2).

\section{Arroyo Los Loros 1 (ALL1)}

Ubicado en la margen izquierda del arroyo homónimo, a $900 \mathrm{~m}$ de su desembocadura. Se ubica sobre un afloramiento de la Formación Guichón, sobre el cual también se encuentran cantos rodados y arena. Está rodeado de bosque en galería. El material arqueológico se dispone sobre una superficie aproximada de $10 \times 7 \mathrm{~m}$. Se realizó una recolección superficial dirigida. Los materiales incluyen dos instrumentos, 12 desechos de talla y ocho núcleos (Tabla 6.2).

\section{Arroyo Los Loros 2 (ALL2)}

Ubicado en la margen derecha del arroyo homónimo, a 1200 m de su desembocadura (Figura 6.2B). El material arqueológico se dispone sobre un afloramiento de la Formación Guichón y cantos rodados que baja hacia el arroyo, cubriendo una superficie aproximada de 10×10 m. Está rodeado de bosque en galería. Se realizó una recolección superficial dirigida. Los materiales incluyen cuatro instrumentos, 13 desechos de talla y ocho núcleos (Tabla 6.2).

\section{Arroyo El Palmar 1 (AEP1)}

Ubicado en la margen derecha del arroyo El Palmar, en un recodo del mismo y a $1200 \mathrm{~m}$ de su desembocadura (Figura 6.2C). La vegetación circundante se corresponde con el bosque en galería. El material arqueológico se dispone sobre un albardón de arena, cubriendo una superficie aproximada de 15x7 m. Se realizó una recolección superficial dirigida, tres sondeos estratigráficos y dos pruebas de pala. Este sitio había sido identificado por guardaparques anteriormente al desarrollo de estas prospecciones (se lo menciona como zona de Puerto Francia, APN-PNEP 2008). El personal del PNEP recuperó en este lugar 18 tiestos cerámicos lisos, de los cuales sólo cuatro no han podido ser analizados hasta el momento", y una "piedra de boleadora" (APN-PNEP 2008), ésta se incluye en las Tabla 4.17.

\footnotetext{
${ }^{1}$ Estos materiales son mencionados en informes internos de la APN, pero aún no fueron encontrados y se desconoce su ubicación actual. 
Los materiales recuperados incluyen dos instrumentos, siete desechos de talla y un núcleo; siete fragmentos de borde (uno decorado y seis lisos) y 35 de cuerpo lisos (Tabla 6.2).

\section{Arroyo El Palmar 2 (AEP2)}

Ubicado en la margen derecha del arroyo El Palmar, a $1400 \mathrm{~m}$ aguas arriba de AEP1. El material se recuperó sobre la barranca, en una gran acumulación de arena y cantos rodados, y también en la playa que baja hacia el arroyo, cubriendo una superficie aproximada de 10x10 m. El entorno está dominado por especies vegetales del bosque en galería. Se realizó una recolección superficial dirigida. Los materiales incluyen un instrumento, siete desechos de talla y 12 núcleos (Tabla 6.2).

\section{Puerto Algarrobos (PA)}

Ubicado en la margen derecha del arroyo El Palmar, a $800 \mathrm{~m}$ aguas arriba de AEP1. Se dispone sobre un depósito de cantos rodados que se extiende desde la llanura hasta la barranca y la orilla del arroyo. La vegetación que lo rodea corresponde al monte de espinal. El material arqueológico se dispone sobre una superficie aproximada de 100×80 m. Se realizó una recolección superficial dirigida. En este lugar fue hallado previamente un "raspador lítico de sílice" (Molinari y Cansanello 1992: 13) que aún no ha sido estudiado, por lo que no se incluye en el análisis. Los materiales recuperados incluyen tres instrumentos, 12 desechos de talla y nueve núcleos (Tabla 6.2).

\section{Árbol Viejo (AV)}

Ubicado en la margen izquierda del arroyo El Palmar, a $6500 \mathrm{~m}$ aguas arriba de PR (Figura 6.2D). Se ubica entre los albardones del arroyo cubiertos por la selva en galería y la zona donde comienza a elevarse el terreno hacia las planicies con palmares de Butia yatay. El material arqueológico se dispone sobre una zona con afloramientos de areniscas y depósitos de arenas, cubriendo una superficie aproximada de $10 \times 6 \mathrm{~m}$, la misma está deprimida con respecto al terreno circundante. Se realizaron cuatro transectas paralelas norte-sur, adyacentes de $2 \mathrm{~m}$ de ancho y $15 \mathrm{~m}$ de longitud y perpendiculares al curso del arroyo El Palmar. Cada transecta fue seccionada en unidades de muestreo de $2 \mathrm{~m}$ de largo. De esta manera se cubrió toda el área que presentaba materiales arqueológicos. La mayor densidad de materiales se encuentran en un metro cuadrado, entre la transecta 2 y 3 , sectores C y D. Los materiales estaban en superficie y también algunos se encontraban cubiertos o semicubiertos por arena, por lo que algunos restos líticos se recuperaron hasta la profundidad de 15 $\mathrm{cm}$ desde la superficie. La cual no es plana sino que es muy irregular dada la presencia de grandes bloques de arenisca.

Se destaca que fueron remontados 22 artefactos, entre núcleos y desechos, que se agrupan en seis conjuntos líticos que se contabilizan como una unidad (núcleo). De esta forma hay un núcleo compuesto por 10 piezas remontadas (Figura 6.4A), dos núcleos que tienen tres piezas remontadas 
cada uno (Figura 6.4B), y otros tres núcleos tienen dos piezas remontadas cada uno (Figura 6.4C). Los materiales recuperados incluyen 38 desechos de talla y 14 núcleos (Tabla 6.2). El conjunto lítico presenta además 11 geofactos y nueve fragmentos de xilópalo. Asimismo en el sitio se dejaron dos grandes núcleos que no pudieron ser transportados y no se incluyen en este análisis.
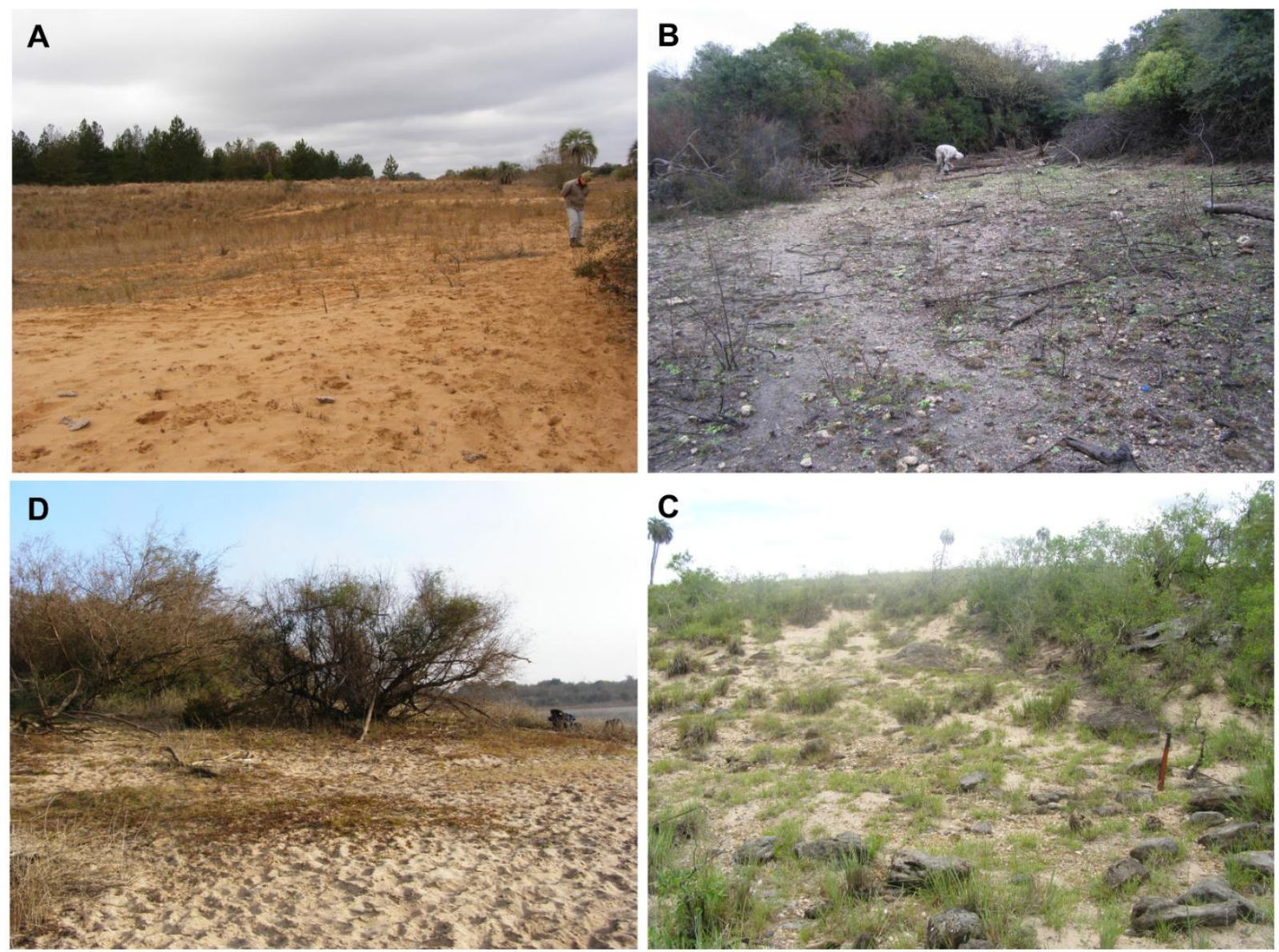

Figura 6.2. Sitios arqueológicos del sector B. A: Palmera Sola. B: Arroyo Los Loros 1.

C: Arroyo El Palmar 1. D: Árbol Viejo.

\subsubsection{2- Descripción contextual de los hallazgos aislados y sus conjuntos artefactuales}

\section{Los Monigotes 2 (LM2)}

Material recolectado en la misma zona de médanos donde se ubica Palmera Sola, aproximadamente a $350 \mathrm{~m}$ al este del mismo. Los materiales incluyen un instrumento, siete desechos de talla y un núcleo (Tabla 6.2).

\section{Los Monigotes 3 (LM3)}

Material recolectado en la misma zona de médanos que LM2 y Palmera Sola, aproximadamente a $500 \mathrm{~m}$ al noreste de este último. Se recuperó un desecho de talla (Tabla 6.2). 


\section{Arroyo Los Loros 3 (ALL3)}

Material recolectado sobre un depósito de la Formación Guichón y cantos rodados en la margen derecha del arroyo Los Loros, a $50 \mathrm{~m}$ de su desembocadura. Los materiales incluyen cinco desechos de talla (Tabla 6.2).

\section{Arroyo El Palmar 3 (AEP3)}

Material recolectado sobre la llanura adyacente a la margen izquierda del arroyo El Palmar, a $233 \mathrm{~m}$ aguas abajo de PR. Se recuperó un desecho de talla (Tabla 6.2).

\section{Arroyo El Palmar 4 (AEP4)}

Material recolectado sobre la llanura adyacente a la margen izquierda del arroyo El Palmar, a $45 \mathrm{~m}$ aguas abajo de AEP3. Los materiales incluyen tres desechos de talla (Tabla 6.2).

\section{Arroyo EI Palmar 5 (AEP5)}

Material recolectado sobre sobre un albardón arenoso en la margen derecha de un pequeño afluente del arroyo El Palmar, $240 \mathrm{~m}$ de la costa de este último. Los materiales incluyen dos desechos de talla y dos núcleos (Tabla 6.2).

\section{Arroyo El Palmar 6 (AEP6)}

Material recolectado sobre la llanura adyacente a la margen izquierda del arroyo El Palmar, a $1200 \mathrm{~m}$ aguas abajo de PB y a $245 \mathrm{~m}$ al sureste de AEP5. Se recuperó un núcleo (Tabla 6.2).

\section{Arroyo El Palmar 7 (AEP7)}

Material recolectado sobre un albardón arenoso en la margen derecha del arroyo El Palmar, frente a la Isleta o Isla del Meandro. Los materiales incluyen un instrumento, seis desechos de talla y un núcleo (Tabla 6.2).

\section{Arroyo El Palmar 8 (AEP8)}

Material recolectado sobre una playa de rodados en la margen derecha del arroyo El Palmar, a $135 \mathrm{~m}$ aguas arriba de PA. Se recuperó un desecho de talla (Tabla 6.2).

\section{El Meandro (EM)}

Material recolectado sobre una playa de rodados en la Isleta o Isla del Meandro, sobre la margen izquierda del arroyo El Palmar, aproximadamente a $750 \mathrm{~m}$ aguas arriba de PA. Los materiales incluyen un instrumento, ocho desechos de talla y dos núcleos (Tabla 6.2). 


\section{Playa Bonita (PB)}

Material recolectado sobre una playa de rodados y arena en la margen izquierda del arroyo EI Palmar, a $620 \mathrm{~m}$ aguas arriba de EM. Los materiales incluyen un instrumento y seis desechos de talla (Tabla 6.2).

\section{Mirador Arroyo El Palmar (MAEP)}

Material recolectado sobre un afloramiento de rodados y areniscas en la margen izquierda del arroyo El Palmar, a 395 m aguas abajo de AEP4. Se recuperó un instrumento lítico (Tabla 6.2).

\section{Puente Roto (PR)}

Material recolectado sobre la llanura adyacente a la margen izquierda del arroyo El Palmar, a $114 \mathrm{~m}$ aguas abajo del llamado Puente Roto. En este lugar fueron hallados previamente tres desechos de talla (APN-PNEP 2002) que aún no han sido estudiados, por lo que no se incluyen en el análisis. Se recuperó un núcleo (Tabla 6.2).

Se cuentan también como hallazgos aislados: una punta de proyectil y cuatro desechos de talla (Tabla 6.2) procedentes de un lugar llamado La Huella (LH) (APN-PNEP 1998, 2002), ubicado sobre la margen izquierda del arroyo El Palmar a $186 \mathrm{~m}$ aguas abajo de PR. También una bola (Tabla 6.2) procedente de la zona de La Portada (LP) del PNEP. Así como un núcleo (Tabla 6.2) procedente de un camino lindero al límite sur del PNEP, recuperado por personal del parque y expuesto al público en la Sala de Interpretación (SDI).

\subsection{2- MATERIALES ARQUEOLÓGICOS}

La Tabla 6.2 muestra las frecuencias de los distintos materiales arqueológicos recuperados. Se incluyen los artefactos recolectados por personal del PNEP en los mismos sitios arqueológicos. 
Tabla 6.2. Materiales arqueológicos del sector B según sus frecuencias por tipo de material y categorías tecnológicas y morfológicas.

\begin{tabular}{|c|c|c|c|c|c|c|c|c|}
\hline \multirow{2}{*}{$\begin{array}{c}\text { Sitios } \\
\text { arqueológicos }\end{array}$} & \multicolumn{4}{|c|}{ Artefactos líticos } & \multicolumn{3}{|c|}{ Cerámica } & \multirow{2}{*}{$\begin{array}{c}\text { Total } \\
\text { general }\end{array}$} \\
\hline & INS & DES & NUC & Total & BOR & CUE & Total & \\
\hline Palmera Sola & 12 & 336 & 3 & 351 & 4 & 15 & 19 & 370 \\
\hline Arroyo Ubajay & 4 & 30 & 14 & 48 & 1 & 8 & 9 & 57 \\
\hline Arroyo Los Loros 1 & 2 & 12 & 8 & 22 & - & - & - & 22 \\
\hline Arroyo Los Loros 2 & 4 & 13 & 8 & 25 & - & - & - & 25 \\
\hline Arroyo El Palmar 1 & 2 & 7 & 1 & 10 & 7 & 35 & 42 & 52 \\
\hline Arroyo El Palmar 2 & 1 & 7 & 12 & 20 & - & - & - & 20 \\
\hline Puerto Algarrobos & 3 & 12 & 9 & 24 & - & - & - & 24 \\
\hline Árbol Viejo & - & 38 & 14 & 52 & - & - & - & 52 \\
\hline Total & 28 & 455 & 69 & 552 & 12 & 58 & 70 & 622 \\
\hline \multirow{2}{*}{$\begin{array}{l}\text { Hallazgos } \\
\text { aislados }\end{array}$} & \multicolumn{4}{|c|}{ Artefactos líticos } & \multicolumn{3}{|c|}{ Cerámica } & \\
\hline & INS & DES & NUC & Total & BOR & CUE & Total & general \\
\hline LM2 & 1 & 7 & 1 & 9 & - & - & - & 9 \\
\hline LM3 & - & 1 & - & 1 & - & - & - & 1 \\
\hline ALL3 & - & 5 & - & 5 & - & - & - & 5 \\
\hline AEP3 & - & 1 & - & 1 & - & - & - & 1 \\
\hline AEP4 & - & 3 & - & 3 & - & 1 & 1 & 4 \\
\hline AEP5 & - & 2 & 2 & 4 & - & - & - & 4 \\
\hline AEP6 & 1 & - & - & 1 & - & - & - & 1 \\
\hline AEP7 & 1 & 6 & 1 & 8 & - & 2 & 2 & 10 \\
\hline AEP8 & - & 1 & - & 1 & - & - & - & 1 \\
\hline EM & 1 & 8 & 2 & 11 & - & - & - & 11 \\
\hline PB & 1 & 6 & - & 7 & - & - & - & 7 \\
\hline MAEP & 1 & - & - & 1 & - & - & - & 1 \\
\hline PR & - & - & 1 & 1 & - & - & - & 1 \\
\hline LH & 1 & 4 & - & 5 & - & - & - & 5 \\
\hline LP & 1 & - & - & 1 & - & - & - & 1 \\
\hline SDI & - & - & 1 & 1 & - & - & - & 1 \\
\hline Total & 8 & 44 & 8 & 60 & & 3 & 3 & 63 \\
\hline Total general & 36 & 499 & 77 & 612 & 12 & 61 & 73 & 685 \\
\hline
\end{tabular}

INS: instrumentos; DES: desechos; NUC: núcleos; BOR: bordes; CUE: cuerpos.

\subsubsection{1- Estructura del conjunto lítico}

\section{Materias primas}

La Tabla 6.3 muestra la representatividad de las materias primas en relación a las clases tipológicas. 
Tabla 6.3. Materias primas por clases tipológicas en el sector B.

\begin{tabular}{|c|c|c|c|c|c|c|c|c|}
\hline \multirow{3}{*}{ Materia prima } & \multicolumn{6}{|c|}{ Clases tipológicas } & & \\
\hline & \multicolumn{2}{|c|}{ Instrumentos } & \multicolumn{2}{|c|}{ Desechos de talla } & \multicolumn{2}{|c|}{ Núcleos } & \multicolumn{2}{|c|}{ Total } \\
\hline & $\mathrm{n}$ & $\%$ & $\mathrm{n}$ & $\%$ & $\mathrm{n}$ & $\%$ & $\mathrm{n}$ & $\%$ \\
\hline Calcedonia & 12 & 33,3 & 227 & 45,5 & 18 & 23,4 & 257 & 42 \\
\hline Caliza silicificada & 4 & 11,1 & 48 & 9,6 & 12 & 15,6 & 64 & 10,45 \\
\hline Silcreta & - & - & - & - & 6 & 7,8 & 6 & 0,9 \\
\hline Ágata & 2 & 5,6 & 5 & 1 & 3 & 3,9 & 10 & 1,7 \\
\hline Sílice & 13 & 36,1 & 133 & 26,7 & 13 & 16,9 & 159 & 26 \\
\hline Xilópalo & - & - & 38 & 7,6 & 15 & 19,5 & 53 & 8,7 \\
\hline Arenisca & 4 & 11,1 & 35 & 7 & 7 & 9,09 & 46 & 7,5 \\
\hline Cuarcita intertrap & - & - & 10 & 2 & - & - & 10 & 1,7 \\
\hline Basalto & - & - & 2 & 0,4 & - & - & 2 & 0,3 \\
\hline Cuarzo & 1 & 2,8 & 1 & 0,2 & 3 & 3,9 & 5 & 0,8 \\
\hline Total & 36 & 100 & 499 & 100 & 77 & 100 & 612 & 100 \\
\hline
\end{tabular}

\section{Instrumentos}

En cuanto a los instrumentos (Tabla 6.4) se identificaron: una punta de proyectil pedunculada con aletas entrantes obtusa y hombro, la forma perimetral del limbo es triangular alargado con bordes convexos y base acuminada asimétrica, el pedúnculo es diferenciado con bordes convergentes rectos y base recta; sus medidas son: $64,6 \mathrm{~mm}$ de largo máximo, $26,7 \mathrm{~mm}$ de ancho máximo y 7,6 mm de espesor sobre el limbo, donde también presenta una charnela que lleva el espesor a 8,7 mm (Figura 6.3A). Siguiendo el modelo de asignación funcional de Ratto (2003) correspondería a una punta de arma de mano (lanza o daga), pero para una asignación más precisa es necesario ampliar la muestra y conocer la variabilidad de morfologías regionales, además no se descarta que debido a la charnela haya sido descartada sin uso.

Se cuentan además tres bifaces (Figura 6.3B, C y D); una preforma de bifaz; una raedera (Figura 6.3E); dos raspadores (Figura 6.3F y G); cuatro muescas (Figura 6.3H); un instrumento compuesto, conformado por una muesca en bisel abrupto y un filo sumario con microrretoque marginal (Figura 6.31); un denticulado con retoque sumario; 15 piezas con retoque sumario (Figura 6.3J); una pieza con retoque alternante; una pieza con retoque; un instrumento indeterminado; dos bolas con surco y dos percutores. Una bola está entera [AEP1 (APN) (2008)-RS-1] y fue caracterizada a partir de un informe del PNEP (APN-PNEP 2008), se desconoce su ubicación actual, corresponde al tipo Bf lo que concuerda con la distribución geográfica propuesta por González (1953) que abarca sobre todo la ROU y las zonas limitrofes de Argentina y Brasil; la otra bola está fragmentada (sensu Vecchi 2010) [LP (APN) (1994)RS-1] y corresponde al tipo $B$ (Figura 6.3K), podría ser Bfo Bh, este último tipo también ha sido registrado en Entre Ríos (véase Capítulo 5, Tabla 5.16). Un percutor está entero [AEP7 (2010)-RS-1] y es de ápice y borde, tiene los dos polos del eje mayor y un borde lateral alterados, y su longitud es de 66,6 mm (Figura 6.3L); en el sector opuesto al borde con rastros de utilización, presenta múltiples 
hoyuelos y machacaduras, posiblemente vinculados con su uso intenso. El otro percutor está fracturado [AEP1 (2009)-RS-9] y es de ápice; la fractura es transversal por lo que sólo se observaron rastros de utilización (picados, astillados y machacaduras) en uno de los polos del eje mayor (Figura 6.3M). Aparentemente, la fractura se posiciona a la mitad, por lo que probablemente la forma-base original sea un rodado tamaño guijón. La longitud del fragmento es de 41,1 mm.

Tabla 6.4. Instrumentos líticos del sector B.

\begin{tabular}{|c|c|c|c|c|c|c|c|c|c|}
\hline Procedencia & $\begin{array}{l}\text { Grupo } \\
\text { tipológico }\end{array}$ & $\begin{array}{l}\text { Subgrupo } \\
\text { tipológico }\end{array}$ & Serie técnica & $\begin{array}{l}\text { Materia } \\
\text { prima }\end{array}$ & Calidad $^{4}$ & Forma-base & $\begin{array}{l}\text { Módulo } \\
\text { L-A }\end{array}$ & Tamaño & $\begin{array}{l}\text { Espesor } \\
\text { relativo }\end{array}$ \\
\hline $\begin{array}{c}\text { PS (APN) } \\
(1991)-R S-1\end{array}$ & $\begin{array}{l}\text { piezas con } \\
\text { retoque } \\
\text { sumario }\end{array}$ & retoque bifacial & $\begin{array}{c}\text { talla o retalla } \\
\text { parcialmente extendida } \\
\text { y retoque marginal }\end{array}$ & calcedonia & $E$ & $\begin{array}{l}\text { lasca } \\
\text { angular }\end{array}$ & $\begin{array}{l}\text { mediano } \\
\text { alargado }\end{array}$ & $\begin{array}{l}\text { mediano } \\
\text { pequeño }\end{array}$ & grueso \\
\hline $\begin{array}{c}\text { PS (APN) } \\
(1991)-R S-2\end{array}$ & bifaz $^{1,2}$ & $\begin{array}{l}\text { talla extendida } \\
\text { con filos de } \\
\text { arista } \\
\text { regularizada }\end{array}$ & $\begin{array}{c}\text { talla o retalla extendida } \\
\text { y retoque marginal }\end{array}$ & sílice & $\mathrm{E}$ & $\begin{array}{c}\text { lasca } \\
\text { indiferenciad } \\
\text { a }\end{array}$ & $\begin{array}{l}\text { mediano } \\
\text { alargado }\end{array}$ & $\begin{array}{l}\text { mediano } \\
\text { grande }\end{array}$ & delgado \\
\hline $\begin{array}{c}\text { PS (APN) } \\
(1991)-R S-3\end{array}$ & bifaz $^{1,2}$ & $\begin{array}{l}\text { talla extendida } \\
\text { con filos de } \\
\text { arista } \\
\text { regularizada }\end{array}$ & $\begin{array}{c}\text { talla o retalla extendida } \\
\text { y retoque marginal }\end{array}$ & sílice & $E$ & $\begin{array}{c}\text { lasca } \\
\text { indiferenciada }\end{array}$ & $\begin{array}{c}\text { mediano } \\
\text { normal }\end{array}$ & grande & grueso \\
\hline $\begin{array}{c}\text { PS (APN) } \\
(1991)-R S-4\end{array}$ & $\begin{array}{c}\text { preforma de } \\
\text { bifaz }\end{array}$ & 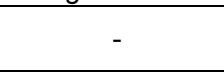 & talla o retalla extendida & sílice & $E$ & $\begin{array}{c}\text { no } \\
\text { diferenciada }\end{array}$ & $\begin{array}{c}\text { mediano } \\
\text { normal }\end{array}$ & grande & grueso \\
\hline $\begin{array}{l}\text { PS (APN) } \\
\text { S/D-1-RS-9 }\end{array}$ & $\begin{array}{l}\text { piezas con } \\
\text { retoque } \\
\text { sumario }\end{array}$ & $\begin{array}{l}\text { retoque unifacial } \\
\text { directo fronto - } \\
\text { lateral }\end{array}$ & retoque marginal & sílice & B & $\begin{array}{l}\text { lasca } \\
\text { angular }\end{array}$ & $\begin{array}{l}\text { corto } \\
\text { ancho }\end{array}$ & $\begin{array}{l}\text { mediano } \\
\text { grande }\end{array}$ & grueso \\
\hline $\begin{array}{l}\text { PS (APN) } \\
\text { S/D-2-RS-9 }\end{array}$ & raedera & $\begin{array}{l}\text { filo lateral e } \\
\text { inclinado }\end{array}$ & $\begin{array}{c}\text { retalla parcialmente } \\
\text { extendida y retoque } \\
\text { marginal }\end{array}$ & ágata & $E$ & $\begin{array}{c}\text { lasca } \\
\text { indiferenciada }\end{array}$ & $\begin{array}{l}\text { laminar } \\
\text { normal }\end{array}$ & $\begin{array}{l}\text { mediano } \\
\text { grande }\end{array}$ & delgado \\
\hline $\begin{array}{c}\text { PS (APN) } \\
\text { S/D-2-RS-10 }\end{array}$ & raspador & $\begin{array}{c}\text { frontal de filo } \\
\text { corto }\end{array}$ & retoque marginal & calcedonia & $E$ & $\begin{array}{c}\text { lasca } \\
\text { angular }\end{array}$ & $\begin{array}{l}\text { mediano } \\
\text { alargado }\end{array}$ & $\begin{array}{l}\text { mediano } \\
\text { pequeño }\end{array}$ & delgado \\
\hline $\begin{array}{c}\text { PS (APN) } \\
\text { S/D-2-RS-11 }\end{array}$ & $\begin{array}{l}\text { piezas con } \\
\text { retoque } \\
\text { sumario }\end{array}$ & $\begin{array}{l}\text { retoque } \\
\text { unifacial }\end{array}$ & $\begin{array}{c}\text { retalla parcialmente } \\
\text { extendida y retoque } \\
\text { marginal }\end{array}$ & sílice & $E$ & $\begin{array}{c}\text { lasca } \\
\text { primaria }\end{array}$ & $\begin{array}{c}\text { mediano } \\
\text { normal }\end{array}$ & $\begin{array}{l}\text { mediano } \\
\text { pequeño }\end{array}$ & grueso \\
\hline $\begin{array}{c}\text { PS (APN) } \\
\text { S/D-3-RS-23 }\end{array}$ & raspador & $\begin{array}{c}\text { frontal de filo } \\
\text { extendido }\end{array}$ & $\begin{array}{c}\text { talla o retalla extendida } \\
\text { y retoque marginal }\end{array}$ & calcedonia & $E$ & $\begin{array}{c}\text { lasca } \\
\text { angular }\end{array}$ & $\begin{array}{c}\text { corto } \\
\text { ancho }\end{array}$ & $\begin{array}{l}\text { mediano } \\
\text { pequeño }\end{array}$ & delgado \\
\hline $\begin{array}{c}\text { PS (2010) } \\
\text {-RS-2 }\end{array}$ & $\begin{array}{l}\text { piezas con } \\
\text { retoque } \\
\text { sumario }\end{array}$ & $\begin{array}{l}\text { retoque unifacial } \\
\text { directo }\end{array}$ & retoque marginal & calcedonia & $\mathrm{E}$ & $\begin{array}{l}\text { lasca } \\
\text { primaria }\end{array}$ & $\begin{array}{l}\text { laminar } \\
\text { normal }\end{array}$ & $\begin{array}{l}\text { mediano } \\
\text { grande }\end{array}$ & delgado \\
\hline $\begin{array}{l}\text { PS (2010) } \\
-R S-45\end{array}$ & muesca & bisel agudo & $\begin{array}{c}\text { talla o retalla } \\
\text { parcialmente extendida } \\
\text { y retoque marginal }\end{array}$ & calcedonia & $\mathrm{E}$ & núcleo & $\begin{array}{c}\text { mediano } \\
\text { normal }\end{array}$ & $\begin{array}{l}\text { mediano } \\
\text { pequeño }\end{array}$ & delgado \\
\hline $\begin{array}{l}\text { PS (2010) } \\
-R S-46\end{array}$ & $\begin{array}{l}\text { piezas con } \\
\text { retoque } \\
\text { sumario }\end{array}$ & $\begin{array}{l}\text { retoque } \\
\text { unifacial }\end{array}$ & retoque marginal & calcedonia & $E$ & $\begin{array}{c}\text { lasca } \\
\text { primaria }\end{array}$ & $\begin{array}{c}\text { mediano } \\
\text { normal }\end{array}$ & pequeño & delgado \\
\hline $\begin{array}{c}\mathrm{AU}(2010) \\
-\mathrm{RS}-7\end{array}$ & $\begin{array}{l}\text { piezas con } \\
\text { retoque }^{3}\end{array}$ & $\begin{array}{c}\text { retoque continuo } \\
\text { unifacial }\end{array}$ & retoque marginal & $\begin{array}{c}\text { caliza } \\
\text { silicificada }\end{array}$ & $E$ & $\begin{array}{c}\text { lasca } \\
\text { angular }\end{array}$ & $\begin{array}{c}\text { mediano } \\
\text { normal }\end{array}$ & grande & grueso \\
\hline $\begin{array}{c}\text { AU (2010) } \\
\text {-RS-9 }\end{array}$ & $\begin{array}{l}\text { piezas con } \\
\text { retoque } \\
\text { sumario }\end{array}$ & $\begin{array}{l}\text { retoque unifacial } \\
\text { directo }\end{array}$ & retoque marginal & calcedonia & $\mathrm{B}$ & $\begin{array}{c}\text { lasca } \\
\text { primaria }\end{array}$ & $\begin{array}{l}\text { mediano } \\
\text { alargado }\end{array}$ & $\begin{array}{l}\text { mediano } \\
\text { grande }\end{array}$ & grueso \\
\hline $\begin{array}{l}\mathrm{AU}(2010) \\
-\mathrm{RS}-13\end{array}$ & $\begin{array}{l}\text { piezas con } \\
\text { retoque } \\
\text { sumario }\end{array}$ & $\begin{array}{l}\text { retoque unifacial } \\
\text { directo }\end{array}$ & retoque marginal & $\begin{array}{c}\text { caliza } \\
\text { silicificada }\end{array}$ & B & $\begin{array}{c}\text { lasca } \\
\text { indiferenciada }\end{array}$ & $\begin{array}{l}\text { mediano } \\
\text { alargado }\end{array}$ & $\begin{array}{l}\text { mediano } \\
\text { grande }\end{array}$ & grueso \\
\hline $\begin{array}{l}\mathrm{AU}(2010) \\
-\mathrm{RS}-17\end{array}$ & $\begin{array}{l}\text { denticulado } \\
\text { con retoque } \\
\text { sumario }\end{array}$ & $\begin{array}{c}\text { retalla y retoque } \\
\text { marginal } \\
\text { alternante }\end{array}$ & talla marginal & $\begin{array}{c}\text { caliza } \\
\text { silicificada }\end{array}$ & $\mathrm{E}$ & $\begin{array}{c}\text { lasca } \\
\text { secundaria }\end{array}$ & $\begin{array}{c}\text { mediano } \\
\text { normal }\end{array}$ & grande & grueso \\
\hline $\begin{array}{l}\text { ALL1 (2010) } \\
\text {-RS-12 }\end{array}$ & muesca & bisel abrupto & retoque marginal & sílice & $E$ & núcleo & $\begin{array}{c}\text { mediano } \\
\text { normal }\end{array}$ & $\begin{array}{l}\text { mediano } \\
\text { pequeño }\end{array}$ & grueso \\
\hline $\begin{array}{l}\text { ALL1 (2010) } \\
- \text { RS-13 }\end{array}$ & $\begin{array}{l}\text { piezas con } \\
\text { retoque } \\
\text { alternante }^{3}\end{array}$ & $\begin{array}{l}\text { microretoque } \\
\text { alternante }\end{array}$ & retoque marginal & sílice & $E$ & $\begin{array}{c}\text { lasca } \\
\text { secundaria }\end{array}$ & $\begin{array}{l}\text { laminar } \\
\text { normal }\end{array}$ & pequeño & grueso \\
\hline $\begin{array}{l}\text { ALL2 (2010) } \\
\text {-RS-1 }\end{array}$ & $\begin{array}{l}\text { muesca/ } \\
\text { piezas con } \\
\text { retoque } \\
\text { sumario }\end{array}$ & $\begin{array}{l}\text { en bisel abrupto/ } \\
\text { retoque unifacial } \\
\text { inverso }\end{array}$ & $\begin{array}{c}\text { retoque marginal/ } \\
\text { microretoque marginal }\end{array}$ & ágata & $E$ & $\begin{array}{l}\text { lasca } \\
\text { primaria }\end{array}$ & $\begin{array}{l}\text { corto } \\
\text { muy } \\
\text { ancho }\end{array}$ & $\begin{array}{l}\text { mediano } \\
\text { pequeño }\end{array}$ & grueso \\
\hline $\begin{array}{l}\text { ALL2 (2010) } \\
\quad-R S-6\end{array}$ & muesca $^{1}$ & bisel agudo & $\begin{array}{c}\text { talla o retalla } \\
\text { parcialmente extendida } \\
\text { y retoque marginal }\end{array}$ & sílice & $E$ & núcleo & $\begin{array}{l}\text { corto } \\
\text { ancho }\end{array}$ & $\begin{array}{l}\text { mediano } \\
\text { grande }\end{array}$ & $\begin{array}{c}\text { muy } \\
\text { grueso }\end{array}$ \\
\hline
\end{tabular}




\begin{tabular}{|c|c|c|c|c|c|c|c|c|c|}
\hline $\begin{array}{l}\text { ALL2 (2010) } \\
\quad-R S-8\end{array}$ & $\begin{array}{l}\text { piezas con } \\
\text { retoque } \\
\text { sumario }\end{array}$ & $\begin{array}{l}\text { microretoque } \\
\text { unifacial } \\
\text { alternante }\end{array}$ & retoque marginal & sílice & B & núcleo & $\begin{array}{c}\text { mediano } \\
\text { normal }\end{array}$ & $\begin{array}{l}\text { mediano } \\
\text { grande }\end{array}$ & $\begin{array}{l}\text { muy } \\
\text { grueso }\end{array}$ \\
\hline $\begin{array}{l}\text { ALL2 (2010) } \\
- \text { RS-34 }\end{array}$ & $\begin{array}{l}\text { piezas con } \\
\text { retoque } \\
\text { sumario }\end{array}$ & $\begin{array}{l}\text { retoque unifacial } \\
\text { directo }\end{array}$ & retoque marginal & sílice & $E$ & $\begin{array}{c}\text { guijarro } \\
\text { facetado }\end{array}$ & $\begin{array}{l}\text { mediano } \\
\text { alargado }\end{array}$ & $\begin{array}{l}\text { mediano } \\
\text { pequeño }\end{array}$ & grueso \\
\hline $\begin{array}{l}\text { AEP1 (APN) } \\
(2008)-R S-1\end{array}$ & $\begin{array}{c}\text { picado, } \\
\text { abrasión y/o } \\
\text { pulido }^{3}\end{array}$ & $\begin{array}{l}\text { bola } \\
\text { tipo Bf }\end{array}$ & con surco & arenisca & B & $\begin{array}{c}\text { no } \\
\text { diferenciada }\end{array}$ & $\begin{array}{c}\text { mediano } \\
\text { normal }\end{array}$ & $\begin{array}{l}\text { muy } \\
\text { grande }\end{array}$ & $\begin{array}{l}\text { gruesí- } \\
\text { simo }\end{array}$ \\
\hline $\begin{array}{l}\text { AEP1 (2009) } \\
\text {-RS-9 }\end{array}$ & percutor $^{1}$ & de ápice & $\begin{array}{c}\text { nódulo con rastros de } \\
\text { utilización }\end{array}$ & cuarzo & $\mathrm{R}$ & $\begin{array}{l}\text { guijón } \\
\text { elíptico }\end{array}$ & $\begin{array}{c}\text { mediano } \\
\text { normal }\end{array}$ & $\begin{array}{l}\text { mediano } \\
\text { grande }\end{array}$ & $\begin{array}{c}\text { muy } \\
\text { grueso }\end{array}$ \\
\hline $\begin{array}{l}\text { AEP2 (2009) } \\
\text {-RS-16 }\end{array}$ & muesca & bisel abrupto & retoque marginal & arenisca & $\mathrm{R}$ & $\begin{array}{c}\text { lasca } \\
\text { primaria }\end{array}$ & $\begin{array}{c}\text { mediano } \\
\text { normal }\end{array}$ & $\begin{array}{l}\text { mediano } \\
\text { grande }\end{array}$ & delgado \\
\hline $\begin{array}{l}\text { PA }(2010) \\
\text {-RS-15 }\end{array}$ & $\begin{array}{l}\text { piezas con } \\
\text { retoque } \\
\text { sumario } \\
\end{array}$ & retoque alterno & retoque marginal & calcedonia & $E$ & $\begin{array}{c}\text { lasca } \\
\text { indiferenciada }\end{array}$ & $\begin{array}{c}\text { corto } \\
\text { muy } \\
\text { ancho }\end{array}$ & $\begin{array}{l}\text { mediano } \\
\text { pequeño }\end{array}$ & delgado \\
\hline $\begin{array}{l}\text { PA (2010) } \\
\text {-RS-16 }\end{array}$ & $\begin{array}{l}\text { instrumento } \\
\text { no } \\
\text { determinado }^{3}\end{array}$ & - & $\begin{array}{c}\text { talla o retalla } \\
\text { parcialmente extendida } \\
\text { y retoque marginal }\end{array}$ & sílice & $E$ & $\begin{array}{c}\text { lasca } \\
\text { indiferenciada }\end{array}$ & $\begin{array}{c}\text { mediano } \\
\text { normal }\end{array}$ & pequeño & delgado \\
\hline $\begin{array}{l}\text { PA (2010) } \\
\text {-RS-21 }\end{array}$ & $\begin{array}{l}\text { piezas con } \\
\text { retoque } \\
\text { sumario } \\
\end{array}$ & $\begin{array}{c}\text { retoque unifacial } \\
\text { directo fronto - } \\
\text { lateral }\end{array}$ & microretoque marginal & calcedonia & $E$ & $\begin{array}{c}\text { lasca } \\
\text { primaria }\end{array}$ & $\begin{array}{c}\text { mediano } \\
\text { normal }\end{array}$ & pequeño & delgado \\
\hline $\begin{array}{l}\text { LM2 (2009) } \\
\quad-\text { RS-1 }\end{array}$ & bifaz & $\begin{array}{l}\text { talla extendida } \\
\text { con filos de } \\
\text { arista irregular }\end{array}$ & talla extendida & calcedonia & $E$ & $\begin{array}{l}\text { lasca } \\
\text { angular }\end{array}$ & $\begin{array}{l}\text { mediano } \\
\text { alargado }\end{array}$ & grande & grueso \\
\hline $\begin{array}{l}\text { AEP6 (2010) } \\
\text {-RS-3 }\end{array}$ & $\begin{array}{l}\text { piezas con } \\
\text { retoque } \\
\text { sumario }^{1}\end{array}$ & $\begin{array}{l}\text { retoque unifacial } \\
\text { directo frontal }\end{array}$ & retoque marginal & sílice & $E$ & $\begin{array}{c}\text { lasca } \\
\text { primaria }\end{array}$ & $\begin{array}{l}\text { mediano } \\
\text { alargado }\end{array}$ & $\begin{array}{l}\text { mediano } \\
\text { pequeño }\end{array}$ & delgado \\
\hline $\begin{array}{l}\text { AEP7 (2010) } \\
\text {-RS-1 }\end{array}$ & percutor & de ápice y borde & $\begin{array}{c}\text { nódulo con rastros de } \\
\text { utilización }\end{array}$ & $\begin{array}{c}\text { arenisca } \\
\text { silicificada }\end{array}$ & $\mathrm{B}$ & $\begin{array}{l}\text { guijón } \\
\text { sub-oval }\end{array}$ & $\begin{array}{c}\text { mediano } \\
\text { normal }\end{array}$ & grande & $\begin{array}{l}\text { gruesí- } \\
\text { simo }\end{array}$ \\
\hline $\begin{array}{l}\text { EM (2010) } \\
\text {-RS-1 }\end{array}$ & $\begin{array}{l}\text { piezas con } \\
\text { retoque } \\
\text { sumario } \\
\end{array}$ & $\begin{array}{l}\text { retoque unifacial } \\
\text { directo }\end{array}$ & retoque marginal & sílice & $\mathrm{B}$ & $\begin{array}{c}\text { lasca } \\
\text { primaria }\end{array}$ & $\begin{array}{c}\text { mediano } \\
\text { normal }\end{array}$ & pequeño & delgado \\
\hline $\begin{array}{l}\text { PB }(2010) \\
\text {-RS-7 }\end{array}$ & $\begin{array}{l}\text { piezas con } \\
\text { retoque } \\
\text { sumario } \\
\end{array}$ & $\begin{array}{l}\text { retoque unifacial } \\
\text { directo }\end{array}$ & retoque marginal & calcedonia & $E$ & $\begin{array}{l}\text { rodado plano } \\
\text { convexo }\end{array}$ & $\begin{array}{c}\text { mediano } \\
\text { normal }\end{array}$ & $\begin{array}{l}\text { mediano } \\
\text { pequeño }\end{array}$ & delgado \\
\hline $\begin{array}{l}\text { MAEP } \\
(2010) \\
-R S-1 \\
\end{array}$ & $\begin{array}{l}\text { piezas con } \\
\text { retoque } \\
\text { sumario }^{1}\end{array}$ & $\begin{array}{l}\text { microretoque } \\
\text { unifacial directo }\end{array}$ & retoque marginal & calcedonia & $\mathrm{B}$ & $\begin{array}{c}\text { lasca de } \\
\text { arista doble }\end{array}$ & $\begin{array}{c}\text { mediano } \\
\text { normal }\end{array}$ & $\begin{array}{l}\text { mediano } \\
\text { pequeño }\end{array}$ & $\begin{array}{c}\text { muy } \\
\text { delgado }\end{array}$ \\
\hline $\begin{array}{c}\text { LH (APN) } \\
(1998)-R S-1\end{array}$ & $\begin{array}{l}\text { punta de } \\
\text { proyectil }^{2}\end{array}$ & $\begin{array}{c}\text { pedunculada con } \\
\text { aletas }\end{array}$ & retoque extendido & $\begin{array}{c}\text { caliza } \\
\text { silicificada }\end{array}$ & $E$ & $\begin{array}{c}\text { lasca } \\
\text { indiferenciada }\end{array}$ & $\begin{array}{l}\text { laminar } \\
\text { normal }\end{array}$ & grande & delgado \\
\hline $\begin{array}{c}\text { LP (APN) } \\
(1994)-R S-1\end{array}$ & $\begin{array}{c}\text { picado, } \\
\text { abrasión y/o } \\
\text { pulido }^{1,3}\end{array}$ & $\begin{array}{l}\text { bola } \\
\text { tipo B }\end{array}$ & - & arenisca & B & $\begin{array}{c}\text { no } \\
\text { diferenciada }\end{array}$ & $\begin{array}{c}\text { mediano } \\
\text { normal }\end{array}$ & grande & $\begin{array}{l}\text { gruesí- } \\
\text { simo }\end{array}$ \\
\hline
\end{tabular}

(1) Instrumentos incompletos por fractura. (2) Presentan retoque por presión.(3) No corresponden a ningún grupo tipológico sensu Aschero 1983. (4) Calidad de las materias primas, E: excelente, B: buena, R: regular.

Se registraron 32 instrumentos confeccionados por lascados, 31 sobre materias primas de buena y excelente calidad, y uno de calidad regular; cuya forma-base corresponde a: 25 lascas (nueve primarias, seis angulares, dos secundarias, una de arista y siete indiferenciadas), cuatro núcleos, dos rodados fluviales y una no diferenciada. Fueron elaborados mediante talla y retalla extendida y parcialmente extendida; y retoques y microretoque marginal, y retoque extendido; se determinó, además, retoque por presión. Nueve instrumentos tienen retoque unifacial directo, uno unifacial inverso, cinco retalla y retoque bifacial, tres retoque alternante y uno retoque alterno. En cuanto a los módulos longitud-anchura predominan el mediano normal $(n=15)$, seguido por mediano alargado $(n=$ 8), laminar normal $(n=4)$, corto ancho $(n=3)$, y corto muy ancho $(n=2)$. En cuanto al tamaño predomina el mediano pequeño $(n=12)$, seguido por mediano grande $(n=9)$, grande $(n=6)$, y pequeño $(n=5)$. Considerando el espesor relativo predomina el delgado $(n=15)$, seguido por el grueso $(n=14)$, muy grueso ( $n=2)$, y muy delgados $(n=1)$. 
Además de los instrumentos tallados se registraron dos bolas, confeccionadas mediante picado, abrasión y/o pulido sobre arenisca con formas-base no diferenciadas; de tamaño grande y muy grande respectivamente y ambas de espesor relativo gruesísimo. Se agregan dos percutores confeccionados a partir de guijones fluviales modificados por uso; de tamaño mediano grande y grande, y espesor relativo muy grueso y gruesísimo, respectivamente. En los cuatro casos el módulo longitud-anchura es mediano normal. En cuanto a los instrumentos fracturados los módulos y el espesor relativo están determinado por la fractura que presentan, probablemente los mismos en su estado entero tuvieron dimensiones mayores.

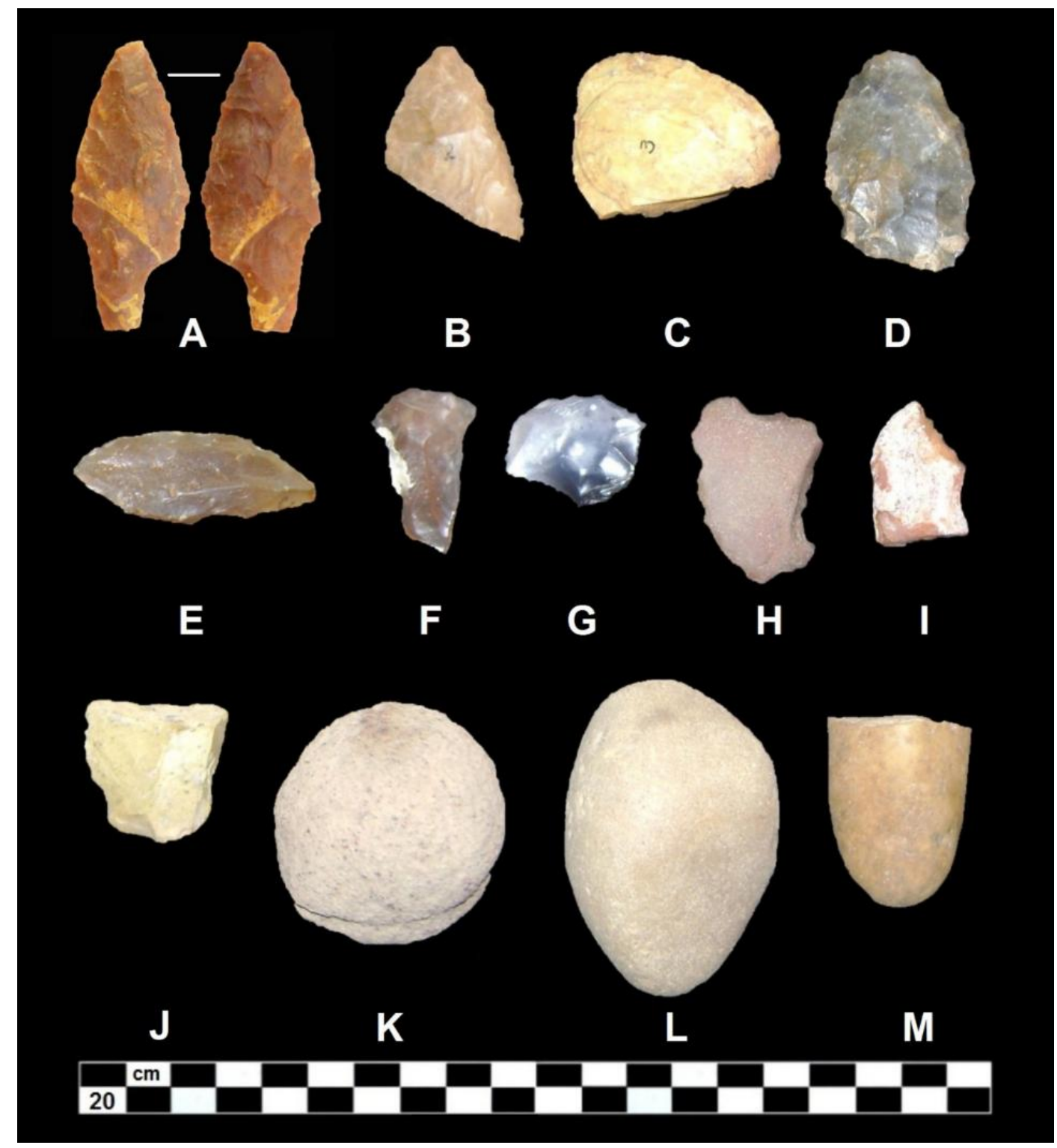

Figura 6.3. Instrumentos líticos del sector $B$.

Punta de proyectil: A [LH (APN) (1998)-RS-1]. Bifaces: B [PS (APN) (1991)-RS-2], C [PS (APN) (1991)-RS-3] y

D [LM2 (2009)-RS-1]. Raedera: E [PS (APN) S/D-2-RS-9]. Raspadores: F [PS (APN) S/D-2-RS-10] y

G [PS (APN) S/D-3-RS-23]. Muesca: H [AEP2 (2009)-RS-16]. Instrumento compuesto: I [ALL2 (2010)-RS-1].

Pieza con retoque sumario: J [PS (APN) S/D-1-RS-9]. Bola: K [LP (APN) (1994)-RS-1].

Percutores: L [AEP7 (2010)-RS-1] y M [AEP1 (2009)-RS-9]. 


\section{Desechos de talla}

\section{Fragmentación}

La Tabla 6.5 muestra la distribución de los desechos de talla de acuerdo a su estado de fragmentación.

Tabla 6.5. Estado de fragmentación de la muestra de desechos de talla del sector B.

\begin{tabular}{|c|c|c|c|c|c|c|c|c|c|c|c|}
\hline \multirow{3}{*}{$\begin{array}{c}\text { Sitios } \\
\text { arqueológicos }\end{array}$} & \multicolumn{10}{|c|}{ Estado de fragmentación } & \multirow{3}{*}{ Tota } \\
\hline & \multicolumn{2}{|c|}{ ENT } & \multicolumn{2}{|c|}{ FCT } & \multicolumn{2}{|c|}{ FST } & \multicolumn{2}{|c|}{ NOC } & \multicolumn{2}{|c|}{ IND } & \\
\hline & $\mathrm{n}$ & $\%$ & $\mathrm{n}$ & $\%$ & $\mathrm{n}$ & $\%$ & $\mathrm{n}$ & $\%$ & $\mathrm{n}$ & $\%$ & \\
\hline Palmera Sola & 72 & 21,4 & 102 & 30,4 & 129 & 38,4 & 17 & 5,1 & 16 & 4,7 & 336 \\
\hline Arroyo Ubajay & 10 & 33,3 & 4 & 13,3 & 8 & 26,7 & 5 & 16,7 & 3 & 10 & 30 \\
\hline Arroyo Los Loros 1 & 5 & 41,6 & 2 & 16,7 & 3 & 25 & 2 & 16,7 & - & - & 12 \\
\hline Arroyo Los Loros 2 & 4 & 30,7 & - & - & 2 & 15,4 & 2 & 15,4 & 5 & 38,5 & 13 \\
\hline Arroyo El Palmar 1 & 2 & 28,6 & 4 & 57,1 & 1 & 14,3 & - & - & - & - & 7 \\
\hline Arroyo El Palmar 2 & 2 & 28,6 & - & - & - & - & 3 & 42,8 & 2 & 28,6 & 7 \\
\hline Puerto Algarrobos & 4 & 33,4 & 4 & 33,4 & 1 & 8,3 & 2 & 16,6 & 1 & 8,3 & 12 \\
\hline Árbol Viejo & 3 & 7,9 & 1 & 2,6 & 5 & 13,2 & 6 & 15,8 & 23 & 60,5 & 38 \\
\hline Hallazgos aislados & 13 & 29,5 & 12 & 27,3 & 11 & 25 & 4 & 9,1 & 4 & 9,1 & 44 \\
\hline Total & 115 & 23,1 & 129 & 25,8 & 160 & 32,1 & 41 & 8,2 & 54 & 10,8 & 499 \\
\hline
\end{tabular}

ENT: lasca entera; FCT: lasca fracturada con talón; FST: lasca fracturada sin talón; NOC: desecho no clasificable; IND: desecho indiferenciado.

Se observa un predominio absoluto de desechos fracturados sobre lascas enteras. La mayor frecuencia corresponde a las lascas fracturadas sin talón, seguidos por lascas fracturadas con talón, lascas enteras, desechos indiferenciados, y por último los desechos no clasificables. Considerando los sitios arqueológicos con mayor frecuencia artefactual (PS, AV y AU), se observa que en PS la tendencia se mantiene igual en las tres primeras categorías, invirtiéndose en las dos últimas, aunque la diferencia es mínima. En AV la única variación se registra entre las lascas enteras y las fracturadas con talón, donde se invierte el orden jerárquico. En AU predominan las lascas enteras, seguidas por lascas fracturadas sin talón, fracturadas con talón, desechos no clasificables e indiferenciados. Esto último, también ocurre en ALL1.

\section{Formas de las lascas}

Dentro de los desechos de talla, excluyendo aquellos cuyo estado de fragmentación es indiferenciado, se registran varios tipos de lascas $(n=445)$ (Tabla 6.6). 
Tabla 6.6.Tipos de lascas por conjuntos líticos del sector B.

\begin{tabular}{|c|c|c|c|c|c|c|c|c|c|c|c|c|c|c|c|c|c|}
\hline \multirow{3}{*}{$\begin{array}{c}\text { Sitios } \\
\text { arqueológicos }\end{array}$} & \multicolumn{16}{|c|}{ Tipo de lasca } & \multirow{3}{*}{ Total } \\
\hline & \multicolumn{2}{|c|}{ PRI } & \multicolumn{2}{|c|}{ SEC } & \multicolumn{2}{|c|}{ DON } & \multicolumn{2}{|c|}{ ANG } & \multicolumn{2}{|c|}{ ARI } & \multicolumn{2}{|c|}{ PLA } & \multicolumn{2}{|c|}{ BIP } & \multicolumn{2}{|c|}{ IND } & \\
\hline & $\mathrm{n}$ & $\%$ & $\mathrm{n}$ & $\%$ & $\mathrm{n}$ & $\%$ & $\mathrm{n}$ & $\%$ & $\mathrm{n}$ & $\%$ & $\mathrm{n}$ & $\%$ & $\mathrm{n}$ & $\%$ & $\mathrm{n}$ & $\%$ & \\
\hline Palmera Sola & 31 & 9,7 & 52 & 16,3 & 10 & 3,1 & $170^{1}$ & 53,1 & 33 & 10,3 & 9 & 2,8 & - & - & 15 & 4,7 & 320 \\
\hline Arroyo Ubajay & 2 & 7,4 & 9 & 33,3 & 1 & 3,7 & 11 & 40,8 & 2 & 7,4 & - & - & 1 & 3,7 & 1 & 3,7 & 27 \\
\hline Arroyo Los Loros 1 & 7 & 58,4 & 2 & 16,7 & - & - & 1 & 8,3 & 1 & 8,3 & - & - & - & - & 1 & 8,3 & 12 \\
\hline Arroyo Los Loros 2 & 2 & 25 & 4 & 50 & - & - & 1 & 12,5 & - & - & 1 & 12,5 & - & - & - & - & 8 \\
\hline Arroyo El Palmar 1 & 1 & 14,3 & 1 & 14,3 & 1 & 14,3 & 3 & 42,8 & 1 & 14,3 & - & - & - & - & - & - & 7 \\
\hline Arroyo El Palmar 2 & 2 & 40 & 1 & 20 & - & - & 1 & 20 & - & - & - & - & - & - & 1 & 20 & 5 \\
\hline Puerto Algarrobos & 2 & 18,2 & 1 & 9,1 & - & - & 6 & 54,5 & 2 & 18,2 & - & - & - & - & - & - & 11 \\
\hline Árbol Viejo & 6 & 40 & 3 & 20 & 2 & 13,3 & 3 & 20 & 1 & 6,7 & - & - & - & - & - & - & 15 \\
\hline Hallazgos aislados & 8 & 20 & 7 & 17,5 & 5 & 12,5 & $12^{2}$ & 30 & 6 & 15 & - & - & 1 & 2,5 & 1 & 2,5 & 40 \\
\hline Total & 61 & 13,7 & 80 & 18 & 19 & 4,3 & 208 & 46,8 & 46 & 10,3 & 10 & 2,2 & 2 & 0,4 & 19 & 4,3 & 445 \\
\hline
\end{tabular}

PRI: lasca primaria; SEC: lasca secundaria; DON: lasca con dorso natural; ANG: lasca angular; ARI: lasca de arista; PLA: lasca plana; BIP: lasca bipolar; IND; lasca indiferenciada. (1) Se incluyen cinco lascas de adelgazamiento bifacial.

(2) Se incluye una lasca de reactivación de filo de AEP4.

Dentro de las lascas internas las más representadas son las angulares ( $n=208 ; 46,8 \%)$, seguidas por las de arista $(n=46 ; 10,3 \%)$, planas $(n=10 ; 2,2 \%)$ y bipolar $(n=1 ; 0,2 \%)$. Dentro de las angulares se registraron cinco lascas de adelgazamiento bifacial (PS) y una de reactivación directa del filo (AEP4). En cuanto a las lascas externas, se observa un predominio de las secundarias ( $n=80 ; 18 \%$ ) sobre las primarias $(n=61 ; 13,7 \%)$, con dorso natural $(n=19 ; 4,3 \%)$ y bipolar $(n=1 ; 0,2 \%)$. En cuanto a las lascas bipolares, una es interna ( $A U$, angular) y otra externa (EM, primaria), grupo 3 y 1 respectivamente en la clasificación de Bonomo (2004: 161).

Estado de fragmentación, tipos, y materia prima de los desechos por conjunto

PS: 72 lascas enteras: 44 angulares (27 calcedonias, 15 sílices y dos calizas silicificadas), 10 de arista (siete calcedonias y tres sílices), siete secundarias (cinco calcedonias y dos sílices), cuatro planas (dos calizas silicificadas y dos areniscas), tres primarias (dos calcedonias y una sílice), tres con dorso natural (dos sílices y una calcedonia) y una indiferenciada (sílice); 102 lascas fracturadas con talón: 52 angulares (28 calcedonias, 18 sílices, cinco calizas silicificadas y una cuarcita intertrap), 21 secundarias (10 sílices, nueve calcedonias, una arenisca y una caliza silicificada), 12 primarias (seis calcedonias, seis sílices y una caliza silicificada), 11 de arista (seis calcedonias, cuatro sílices y una arenisca), cuatro con dorso natural (tres sílices y una caliza silicificada), una plana (calcedonia) y una indiferenciada (sílice); 129 lascas fracturadas sin talón: 73 angulares (42 calcedonias, 23 sílices, cinco areniscas, dos cuarcitas intertrap y una caliza silicificada), 22 secundarias (15 calcedonias, seis sílices y una caliza silicificada), 14 primarias (ocho calcedonias, cuatro sílices, un cuarzo y una cuarcita intertrap), 12 de arista (seis calcedonias, tres sílices, dos calizas silicificadas y una cuarcita intertrap), cuatro planas (calcedonias), tres con dorso natural (dos calcedonias y una sílice) y una indiferenciada (sílice); 17 no clasificables: 12 indiferenciados (cuatro sílices, tres calcedonias, tres areniscas y dos calizas silicificadas), dos 
primarias (una calcedonia y una arenisca), dos secundarias (una sílice y una caliza silicificada), una angular (calcedonia); y $\mathbf{1 6}$ indiferenciados: (siete calcedonias, seis sílices, dos areniscas y una cuarcita intertrap).

AU: 10 lascas enteras: cinco angulares (tres areniscas y dos calizas silicificadas), dos secundarias (areniscas), dos de arista (una arenisca y una caliza silicificada) y una con dorso natural (arenisca); cuatro lascas fracturadas con talón: tres angulares (una calcedonia, una cuarcita intertrap y una caliza silicificada) y una primaria (sílice); ocho lascas fracturadas sin talón: cuatro secundarias (dos calizas silicificadas, una sílice y una arenisca), dos angulares (una calcedonia y una arenisca), una primaria (caliza silicificada) y una bipolar (ágata); cinco no clasificables: tres secundarias (un basalto, una arenisca y una calcedonia), una angular (caliza silicificada) y una indiferenciada (arenisca); y tres indiferenciados: (una calcedonia, una ágata y una caliza silicificada).

ALL1: cinco lascas enteras: primarias (tres calcedonias, una arenisca y una caliza silicificada); dos lascas fracturadas con talón: una primaria (calcedonia) y una secundaria (arenisca); tres lascas fracturadas sin talón: una secundaria (sílice), una angular (calcedonia) y una de arista (cuarcita intertrap); y dos no clasificables: una primaria (sílice) y una indiferenciada (calcedonia). ALL2: cuatro lascas enteras: dos secundarias (una arenisca y una sílice), una angular (calcedonia) y una plana (caliza silicificada); dos lascas fracturadas sin talón: dos secundarias (calizas silicificadas); dos no clasificables: dos primarias (calcedonias); y cinco indiferenciados: (cuatro calizas silicificadas y una sílice).

AEP1: dos lascas enteras: una secundaria (arenisca) y una con dorso natural (ágata); cuatro lascas fracturadas con talón: tres angulares (una calcedonia, una ágata y una caliza silicificada) y una primaria (caliza silicificada); y una lasca fracturada sin talón: de arista (caliza silicificada). AEP2: dos lascas enteras: una primaria (calcedonia) y una angular (calcedonia); tres no clasificables: una primaria (calcedonia), una secundaria (sílice) y una indiferenciada (calcedonia); y dos indiferenciados: (sílices).

PA: cuatro lascas enteras: una primaria (arenisca), una secundaria (calcedonia), una angular (calcedonia) y una de arista (calcedonia); cuatro lascas fracturadas con talón: tres angulares (una calcedonia, una sílice y una cuarcita intertrap) y una de arista (calcedonia); una lasca fracturada sin talón: angular (calcedonia); dos no clasificables: una primaria (calcedonia) y una angular (calcedonia); y un indiferenciado: (ágata). AV: tres lascas enteras: una primaria (xilópalo), una con dorso natural (xilópalo) y una angular (xilópalo); una lasca fracturada con talón: primaria (xilópalo); cinco lascas fracturadas sin talón: tres secundarias (xilópalo), una con dorso natural (xilópalo) y una angular (xilópalo); seis no clasificables: cuatro primarias (xilópalo) [una es lasca nodular, pero no se determinó si tuvo extracciones posteriores], una angular (xilópalo) y una de arista (xilópalo); y 23 indiferenciados: (xilópalo).

LM2: cuatro lascas fracturadas con talón: tres angulares (dos calcedonia y una caliza silicificada) y una secundaria (sílice); y tres lascas fracturadas sin talón: una secundaria (sílice), una 
angular (sílice) y una de arista (cuarcita intertrap). LM3: una lasca entera: angular (calcedonia). ALL3: dos lascas enteras: una primaria (sílice) y una secundaria (sílice); dos lascas fracturadas con talón: una primaria (sílice) y una angular (caliza silicificada); y una no clasificable: indiferenciada (caliza silicificada). AEP3: una lasca entera: secundaria (calcedonia). AEP4: dos lascas enteras: una angular de reactivación- (caliza silicificada) y una de arista (caliza silicificada) y una no clasificable: angular (calcedonia). AEP5: una lasca fracturada con talón: una primaria (calcedonia); y un indiferenciado: (calcedonia). AEP7: una lasca fracturada con talón: una con dorso natural (calcedonia); dos lascas fracturadas sin talón: una angular (caliza silicificada) y una de arista (sílice); una no clasificable: primaria (arenisca); y dos indiferenciados: (una arenisca y una calcedonia). AEP8: una lasca entera: con dorso natural (arenisca).

EM: tres lascas enteras: tres primarias (calcedonias); una lasca fracturada con talón: una secundaria (calcedonia); tres lascas fracturadas sin talón: una secundaria (calcedonia), una de arista (calcedonia) y una bipolar (sílice); una no clasificable: primaria (calcedonia). PB: tres lascas enteras: una con dorso natural (basalto), una angular (arenisca) y una de arista (calcedonia); dos lascas fracturadas con talón: una secundaria (caliza silicificada) y una de arista (caliza silicificada); y una lasca fracturada sin talón: con dorso natural (calcedonia). LH: dos lascas fracturadas sin talón: una con dorso natural (sílice) y una angular (calcedonia); una lasca fracturada con talón: una angular (caliza silicificada); y un indiferenciado: (calcedonia).

Talones y bulbos

La Tabla 6.7 muestra la distribución de los distintos tipos de talones y bulbos, identificados en lascas enteras y fracturadas con talón; así como los distintos tipos de bulbos que se pudieron identificar en lascas fracturadas sin talón. 
Tabla 6.7. Distribución de la forma e inclinación del talón en relación a la forma del bulbo de percusión de las lascas del sector $\mathrm{B}$.

\begin{tabular}{|c|c|c|c|c|c|c|c|c|c|c|c|c|c|}
\hline \multicolumn{3}{|c|}{ Lascas enteras y fracturadas con talón } & \multirow{2}{*}{\multicolumn{8}{|c|}{ Sitios arqueológicos }} & \multirow{3}{*}{ H. A. } & \multirow{2}{*}{\multicolumn{2}{|c|}{ Total }} \\
\hline \multirow{2}{*}{\multicolumn{2}{|c|}{$\begin{array}{ll} & \text { Talón } \\
\text { na } & \text { Inclinación } \\
\end{array}$}} & \multirow{2}{*}{$\begin{array}{c}\text { Forma } \\
\text { del Bulbo }\end{array}$} & & & & & & & & & & & \\
\hline & & & PS & $\mathrm{AU}$ & ALL1 & ALL2 & AEP1 & AEP2 & PA & AV & & $\mathrm{n}$ & $\%$ \\
\hline \multirow{6}{*}{ Natural } & \multirow{3}{*}{ recto } & difuso & 1 & - & - & 1 & - & - & 1 & $\overline{-}$ & - & 3 & \\
\hline & & pronunciado & 1 & - & - & - & - & - & - & - & 1 & 2 & \\
\hline & & indiferenciado & 1 & - & - & - & - & - & - & - & - & 1 & \\
\hline & \multirow{2}{*}{ oblicuo } & difuso & 1 & - & 1 & - & - & - & - & - & 2 & 4 & 4,9 \\
\hline & & pronunciado & - & - & 1 & - & - & - & - & - & - & 1 & \\
\hline & \multirow[t]{2}{*}{ indiferenciado } & indiferenciado & - & - & - & - & 1 & - & - & - & - & 1 & \\
\hline \multirow{7}{*}{$\begin{array}{l}\text { Liso } \\
\text { natural }\end{array}$} & & difuso & 10 & - & - & 1 & - & - & - & 1 & 4 & 16 & \\
\hline & \multirow[t]{2}{*}{ recto } & pronunciado & 11 & 1 & - & - & - & - & 1 & - & 1 & 14 & \\
\hline & & indiferenciado & 1 & - & - & - & - & - & - & - & 1 & 2 & \\
\hline & \multirow{2}{*}{ oblicuo } & difuso & 3 & 2 & - & 1 & 1 & - & - & - & 1 & 8 & 20,1 \\
\hline & & pronunciado & 1 & 2 & - & 1 & - & - & 1 & - & 2 & 7 & \\
\hline & \multirow{2}{*}{ indiferenciado } & pronunciado & 1 & - & - & - & - & - & - & - & - & 1 & \\
\hline & & indiferenciado & 1 & - & - & - & - & - & - & - & - & 1 & \\
\hline \multirow{7}{*}{ Liso } & \multirow{4}{*}{ recto } & difuso & 16 & 1 & 2 & - & 1 & - & 1 & - & 1 & 22 & \\
\hline & & pronunciado & 15 & - & - & - & - & - & 1 & 3 & 2 & 21 & \\
\hline & & indiferenciado & - & - & - & - & 1 & - & - & - & - & 1 & \\
\hline & & difuso & 9 & 1 & 1 & - & - & - & - & - & 1 & 12 & \\
\hline & \multirow[t]{2}{*}{ oblicuo } & pronunciado & 8 & 1 & - & - & - & - & - & - & 2 & 11 & 28,7 \\
\hline & & indiferenciado & 1 & - & 1 & - & - & - & - & - & - & 2 & \\
\hline & indiferenciado & indiferenciado & - & - & - & - & 1 & - & - & - & - & 1 & \\
\hline \multirow{3}{*}{ Diedro } & recto & pronunciado & 3 & - & - & - & - & - & - & - & 1 & 4 & \\
\hline & oblicun & difuso & 1 & - & - & - & - & - & - & - & - & 1 & 2,4 \\
\hline & ODIICUO & pronunciado & 1 & - & - & - & - & - & - & - & - & 1 & \\
\hline & & difuso & 18 & 2 & - & - & - & 1 & 2 & - & 2 & 25 & \\
\hline & recto & pronunciado & 17 & 1 & - & - & - & 1 & - & - & 2 & 21 & \\
\hline racetado & oblicuo & difuso & 11 & - & 1 & - & - & - & - & - & - & 12 & 28,3 \\
\hline & oblicuo & pronunciado & 8 & 1 & - & - & 1 & - & - & - & 1 & 11 & \\
\hline & recto & difuso & 5 & 1 & - & - & - & - & 1 & - & - & 7 & \\
\hline & recto & pronunciado & 8 & - & - & - & - & - & - & - & - & 8 & \\
\hline Filiforme & oblicuo & difuso & 1 & - & - & - & - & - & - & - & - & 1 & 11,1 \\
\hline & indiferenciado & difuso & 4 & 1 & - & - & - & - & - & - & - & 5 & \\
\hline & Indiтerenclado & pronunciado & 6 & - & - & - & - & - & - & - & - & 6 & \\
\hline & recto & difuso & 3 & - & - & - & - & - & - & - & - & 3 & \\
\hline Puntiforme & indiferenciado & difuso & 2 & - & - & - & - & - & - & - & - & 2 & 2,1 \\
\hline & recto & difuso & 2 & - & - & - & - & - & - & - & - & 2 & \\
\hline & recto & pronunciado & - & - & - & - & - & - & - & - & 1 & 1 & \\
\hline Fracturado & oblicuo & pronunciado & 1 & - & - & - & - & - & - & - & - & 1 & 2,4 \\
\hline & & difuso & 1 & - & - & - & - & - & - & - & - & 1 & \\
\hline & Inalierenclado & pronunciado & 1 & - & - & - & - & - & - & - & - & 1 & \\
\hline Total & & & 174 & 14 & 7 & 4 & 6 & 2 & 8 & 4 & $\begin{array}{l}2 \\
5\end{array}$ & $\begin{array}{c}24 \\
4\end{array}$ & 100 \\
\hline & ascas fracturadas & talón & & & & & & & & & & & \\
\hline & & difuso & 70 & 5 & 1 & - & 1 & - & - & 4 & 6 & 87 & 54,4 \\
\hline & in talón & pronunciado & 36 & 1 & 1 & 2 & - & - & - & 1 & 2 & 43 & 26,9 \\
\hline & & indiferenciado & 23 & 2 & 1 & - & - & - & 1 & - & 3 & 30 & 18,7 \\
\hline Total & & & 129 & 8 & 3 & 2 & 1 & - & 1 & 5 & $\begin{array}{l}1 \\
1\end{array}$ & $\begin{array}{c}16 \\
0\end{array}$ & 100 \\
\hline
\end{tabular}

PS: Palmera Sola; AU: Arroyo Ubajay; ALL1: Arroyo Los Loros 1; ALL2: Arroyo Los Loros 2; AEP1: Arroyo El Palmar 1; AEP2: Arroyo El Palmar 2; PA: Puerto Algarrobos; AV: Árbol Viejo. H. A.: hallazgos aislados.

Se registraron varios tipos de talones entre los que predomina levemente el liso $(n=70 ; 28,7 \%)$ sobre el facetado $(n=69 ; 28,3 \%)$, seguidos por el liso natural $(n=49 ; 30,1 \%)$, filiforme $(n=27 ; 11,1 \%)$, natural $(n=12 ; 4,9 \%)$, fracturado $(n=6 ; 2,4 \%)$, diedro $(n=6 ; 2,4 \%)$ y puntiforme $(n=5 ; 2,1 \%)$. Asimismo, 
el bulbo más frecuente es el liso el difuso ( $n=211 ; 52,3 \%$ ), seguido por los pronunciados ( $n=154$; $38,1 \%$ ) e indiferenciados ( $n=39 ; 9,6 \%$ ). En todos los tipos de talones, excepto el liso natural, diedro y filiforme, es más frecuente la asociación entre inclinación recta y bulbos difusos. Asimismo, dentro de las lascas sin talón también predomina ampliamente el bulbo difuso. La mayor asociación entre los atributos considerados se da entre talones facetados con inclinación recta y bulbos difusos $(n=18)$.

\section{Bulbos y labios}

La Tabla 6.8 muestra la distribución de los distintos tipos bulbos de acuerdo a la ausencia (A) o presencia $(P)$ de labio en lascas enteras y fracturadas con talón.

Tabla 6.8. Presencia de labio según las formas de los bulbos de percusión en las lascas enteras y fracturadas con talón del sector B.

\begin{tabular}{|c|c|c|c|c|c|c|}
\hline \multirow{2}{*}{ Sitios arqueológicos } & \multirow{2}{*}{ Labio $^{1}$} & \multicolumn{3}{|c|}{ Forma del Bulbo } & \multicolumn{2}{|c|}{ Total } \\
\hline & & Difuso & Pronunciado & Indiferenciado & $\mathrm{n}$ & $\%$ \\
\hline Palmera Sola & $\begin{array}{l}\mathrm{A} \\
\mathrm{P}\end{array}$ & $\begin{array}{l}26 \\
62\end{array}$ & $\begin{array}{l}14 \\
68\end{array}$ & $\begin{array}{l}3 \\
1\end{array}$ & $\begin{array}{c}43 \\
131\end{array}$ & $\begin{array}{l}17,6 \\
53,7\end{array}$ \\
\hline Arroyo Ubajay & $\begin{array}{l}A \\
P\end{array}$ & $\begin{array}{l}3 \\
5\end{array}$ & $\begin{array}{l}4 \\
2\end{array}$ & - & $\begin{array}{l}7 \\
7\end{array}$ & $\begin{array}{l}2,9 \\
2,9\end{array}$ \\
\hline Arroyo Los Loros 1 & $\begin{array}{l}A \\
P\end{array}$ & $\begin{array}{l}3 \\
2\end{array}$ & $\begin{array}{l}1 \\
-\end{array}$ & $\begin{array}{l}1 \\
-\end{array}$ & $\begin{array}{l}5 \\
2\end{array}$ & $\begin{array}{c}2 \\
0,8\end{array}$ \\
\hline Arroyo Los Loros 2 & $\begin{array}{l}A \\
P\end{array}$ & $\begin{array}{l}2 \\
1\end{array}$ & $\overline{1}$ & - & $\begin{array}{l}2 \\
2\end{array}$ & $\begin{array}{l}0,8 \\
0,8\end{array}$ \\
\hline Arroyo El Palmar 1 & $\begin{array}{l}A \\
P\end{array}$ & $\overline{2}$ & $\begin{array}{l}1 \\
-\end{array}$ & $\begin{array}{l}3 \\
-\end{array}$ & $\begin{array}{l}4 \\
2\end{array}$ & $\begin{array}{l}1,7 \\
0,8\end{array}$ \\
\hline Arroyo El Palmar 2 & $\begin{array}{l}A \\
P\end{array}$ & $\begin{array}{l}1 \\
-\end{array}$ & $\overline{1}$ & $\begin{array}{l}- \\
-\end{array}$ & $\begin{array}{l}1 \\
1\end{array}$ & $\begin{array}{l}0,4 \\
0,4\end{array}$ \\
\hline Puerto Algarrobos & $\begin{array}{l}A \\
P\end{array}$ & $\begin{array}{l}1 \\
4\end{array}$ & $\overline{3}$ & $\begin{array}{l}- \\
-\end{array}$ & $\begin{array}{l}1 \\
7\end{array}$ & $\begin{array}{l}0,4 \\
2,9\end{array}$ \\
\hline Árbol Viejo & $\begin{array}{l}A \\
P\end{array}$ & $\begin{array}{l}1 \\
-\end{array}$ & $\begin{array}{l}1 \\
2\end{array}$ & $\begin{array}{l}- \\
-\end{array}$ & $\begin{array}{l}2 \\
2\end{array}$ & $\begin{array}{l}0,8 \\
0,8\end{array}$ \\
\hline Hallazgos aislados & $\begin{array}{l}A \\
P\end{array}$ & $\begin{array}{l}3 \\
8\end{array}$ & $\begin{array}{l}4 \\
9\end{array}$ & $\begin{array}{l}1 \\
-\end{array}$ & $\begin{array}{c}8 \\
17\end{array}$ & $\begin{array}{c}3,3 \\
7\end{array}$ \\
\hline $\begin{array}{l}\text { Total } \\
\%\end{array}$ & & $\begin{array}{c}124 \\
50,8\end{array}$ & $\begin{array}{r}111 \\
45,5\end{array}$ & $\begin{array}{c}9 \\
3,7\end{array}$ & 244 & 100 \\
\hline
\end{tabular}

(1) A: ausencia de labio; P: presencia de labio.

Se observa un predominio de las lascas con bulbo difuso por sobre los demás tipos de bulbos. Asimismo, se observa que el $70 \%(n=171)$ de las lascas presentan labio.

Origen de extracción de las lascas y formas-base

De acuerdo al origen de extracción de las lascas se determinaron 265 internas, 161 externas y 19 indiferenciadas (Tabla 6.6), a las que se suman 54 desechos cuyo estado de fragmentación es indiferenciado (Tabla 6.5). A partir de 133 lascas externas y 43 internas, siete indiferenciadas y 12 
desechos indiferenciados, con reserva de corteza en su cara dorsal y/o talón, se pudo determinar que las formas-base primarias utilizadas corresponden a: rodados silíceos subesféricos ( $n=109 ; 55,9 \%)$, indeterminados $(n=36 ; 18,5 \%)$, facetados $(n=15 ; 7,7 \%)$, plano-convexos $(n=11 ; 5,6 \%)$, angulares $(n=$ $9 ; 4,6 \%)$, clastos $(n=14 ; 7,2)$, concreción silícea $(n=1 ; 0,5 \%)$. A partir de los desechos de talla restantes $(n=304)$ no se pudieron diferenciar las formas-base de los núcleos.

De acuerdo a los conjuntos líticos las formas-base determinadas se distribuyen de la siguiente manera: PS ( $n=122) 80$ subesféricos, 11 plano-convexos, seis angulares y 25 indeterminados; $A V(n=$ 14) clastos; $A U(n=12)$ cuatro subesféricos, cinco facetados y tres indeterminados; ALL1 $(n=10)$ cinco subesféricos, tres facetados, un angular y una concreción silícea; PA $(n=6)$ dos subesféricos, un facetado, un angular y dos indeterminados; $\operatorname{ALL2}(n=5)$ dos subesféricos, dos facetados y un indeterminado; AEP1 $(n=3)$ dos subesféricos y un facetado; AEP2 $(n=3)$ subesféricos; y HA $(n=20) 11$ subesféricos, tres facetados, un angular y cinco indeterminados.

Negativos de lascados y reserva de corteza

La Tabla 6.9 presenta la distribución de los tipos de lascas de acuerdo a la cantidad de negativos de lascados y proporción de corteza en la cara dorsal. La tendencia general esperada es que, a mayor número de lascados menor será la proporción de corteza. 
Tabla 6.9. Distribución de tipos de lascas del sector $B$

según la proporción de corteza y el número de negativos de lascados en la cara dorsal.

\begin{tabular}{|c|c|c|c|c|c|c|c|c|c|c|c|c|c|c|c|c|c|}
\hline \multirow[b]{4}{*}{$\begin{array}{c}\text { Tipo } \\
\text { de lasca }\end{array}$} & \multirow[b]{4}{*}{$\begin{array}{l}\text { Proporción } \\
\text { de corteza }\end{array}$} & \multicolumn{15}{|c|}{ Negativos de lascados } & \multirow[b]{4}{*}{ Total } \\
\hline & & \multicolumn{14}{|c|}{ Sitios arqueológicos } & \multirow{2}{*}{$\begin{array}{l}\text { Hallazgos } \\
\text { aislados }\end{array}$} & \\
\hline & & \multicolumn{7}{|c|}{ PS } & \multirow{2}{*}{$\begin{array}{c}A U \\
01234>5 \mid\end{array}$} & \multirow{2}{*}{$\begin{array}{l}\text { ALL1 } \\
01123\end{array}$} & \multirow{2}{*}{ 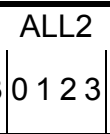 } & \multirow{2}{*}{$\begin{array}{ll}\text { AEP1 } \\
\left|\begin{array}{llll}0 & 2 & 3 & 4\end{array}\right|\end{array}$} & \multirow{2}{*}{$\begin{array}{l}\text { AEP2 } \\
\left|\begin{array}{lll}0 & 1 & 3\end{array}\right|\end{array}$} & \multirow{2}{*}{$\begin{array}{c}\text { PA } \\
0122345\end{array} \mid$} & $\mathrm{AV}$ & & \\
\hline & & 0 & 1 & 2 & 3 & 4 & 5 & $>5$ & & & & & & & 0123 & $0122345>5$ & \\
\hline Primaria & $100 \%$ & 25 & & - & - & - & - & - & $2-\cdots$ & $7-\cdots$ & $1--$ & $1-\cdots$ & $2--$ & $2 \ldots-\cdots$ & $6 \cdots$ & $7-\cdots-$ & 57 \\
\hline 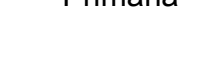 & $>50 \%$ & 1 & 1 & - & - & - & - & - & $-\cdots--$ & $-\cdots$ & $1--$ & $\mid---$ & --- & $-\cdots--$ & --- & $--1--$ & 4 \\
\hline Secundaria & $>50 \%$ & 1 & 16 & 6 & - & - & - & - & $-311--$ & $-2--$ & -211 & $\mid--1$ & $-1-$ & $-1-\cdots$ & $-3-$ & $-22--1-$ & 45 \\
\hline secuntuarla & $<50 \%$ & - & 8 & 13 & 6 & 1 & 1 & - & $-2-2--$ & $-\cdots$ & $-\cdots$ & $-\cdots$ & $-\cdots$ & $-\cdots-$ & $-\cdots$ & $--11--$ & 35 \\
\hline Con dorso & $<50 \%$ & - & 3 & - & - & 1 & - & - & $--1--$ & $-\cdots$ & $-\cdots$ & $-\cdots$ & --- & $-\cdots$ & $-11-$ & $-\ldots$ & 7 \\
\hline natural & $0 \%$ & - & 4 & 1 & - & 1 & - & - & $-\ldots-$ & $-\cdots$ & $-\cdots$ & $--1-$ & $-\cdots$ & $-\ldots$ & $-\cdots$ & $-31-1--$ & 12 \\
\hline & $<50 \%$ & - & 2 & 1 & 6 & 3 & 6 & 6 & $--11-$ & $-\ldots$ & $-\ldots$ & $-2--$ & $-\cdots$ & $-\cdots 1-$ & --1 & $--12-\ldots$ & 33 \\
\hline & $0 \%$ & - & 3 & 31 & 38 & 29 & 16 & 29 & --1332 & ---1 & $-1--$ & $--1-$ & --1 & --1121 & --11 & --13212 & 175 \\
\hline $\mathrm{De}=\mathrm{s}$ & $<50 \%$ & - & - & 2 & 3 & - & 1 & - & $--1--$ & $-\cdots$ & $-\cdots$ & $-1--$ & --- & $-\ldots$ & $-\cdots$ & $-\cdots-\cdots$ & 8 \\
\hline Le alista & $0 \%$ & - & - & 21 & 5 & 1 & - & - & $--1---$ & $--1-$ & $-\ldots$ & $-\ldots$ & $-\cdots$ & $--1-1-$ & $--1-$ & $--411--$ & 38 \\
\hline Plana & $0 \%$ & 5 & 3 & 1 & - & - & - & - & $-\cdots-$ & $\ldots$ & $1 \ldots$ & $-\cdots$ & --- & - . - - - & $\ldots$ & $\ldots \ldots$ & 10 \\
\hline & $0 \%$ & - & - & - & - & - & - & - & $-1---$ & $-\cdots$ & $-\cdots$ & $-\cdots$ & --- & $-\cdots$ & - . - & $\ldots \ldots$ & 1 \\
\hline Bipolar & $100 \%$ & - & - & - & - & - & - & - & $-\ldots$ & $-\ldots$ & $-\cdots$ & - . - - & --- & $-\cdots$ & - - - & $1-\ldots-$ & 1 \\
\hline Indiferenciada & $0 \%$ & 3 & 2 & 2 & 2 & - & - & - & $-1---$ & $\ldots$ & $-\ldots$ & $-\cdots$ & $-\cdots$ & $-\cdots$ & $-\cdots$ & $1-\cdots$ & 11 \\
\hline mumerenctaua & $<50 \%$ & 2 & 2 & 1 & - & - & 1 & - & $-\ldots$ & ---1 & $-\cdots$ & $-\ldots$ & --1 & $-\ldots$ & $-\cdots$ & $-\cdots$ & 8 \\
\hline Total general & & & & 79 & 60 & 36 & 25 & 35 & 273942 & 7212 & 33311 & 1321 & $\begin{array}{lll}2 & 1 & 2\end{array}$ & 212141 & 6441 & 95108422 & 445 \\
\hline
\end{tabular}

PS: Palmera Sola; AU: Arroyo Ubajay; ALL1: Arroyo Los Loros 1; ALL2: Arroyo Los Loros 2; AEP1: Arroyo El Palmar 1; AEP2: Arroyo El Palmar 2; PA: Puerto Algarrobos; AV: Árbol Viejo.

Dado que el tamaño de la muestra de desechos de talla es variable de acuerdo a los distintos conjuntos arqueológicos, se considera que los sitios donde mejor se puede observar alguna tendencia significativa son aquellos con mayor frecuencia de desechos de talla. En este sentido, se consideran solamente PS, AU, ALL1, PA y AV, excluyendo en todos los casos las lascas indiferenciadas.

Las lascas externas presentan corteza y en general menor número de lascados que las internas. Los conjuntos de PS, AU, ALL1 y AV son los que tienen mayor frecuencia de lascas externas y dentro de aquellas con menos del $50 \%$ de corteza $(n=40)$, hay 14 con un lascado, 14 con dos, nueve con tres, dos con cuatro y una con cinco lascados respectivamente. Dentro de las que tienen más del $50 \%$ de corteza $(n=36)$, hay 26 con un lascado, siete con dos, una con tres y dos sin lascados.

Las lascas internas en general no presentan corteza, la diferencia entre ellas reside en el número de lascados que presentan en su cara dorsal. Los conjuntos de PS, AU y PA son los que tienen mayor frecuencia de lascas internas. Dentro de las angulares $(n=187)$ predominan las que tienen tres 
negativos de lascado $(n=49)$, seguidas por las que tienen cuatro $(n=39)$, continúan las que tienen más de cinco lascados $(n=37)$, dos $(n=34)$, cinco $(n=23)$ y un $(n=5)$ lascado respectivamente. Dentro de las lascas de arista $(n=37)$ predominan la que tienen dos negativos de lascado $(n=25)$; y dentro de las planas $(n=9)$ predominan las que no tienen lascados en su cara dorsal $(n=5)$. En PS predominan las angulares que tienen tres negativos de lascado ( $n=44 / 170$ ); en $A U$ las que tienen tres y cuatro $(n=4 / 11)$; $y$ en PA las que tienen cuatro $(n=3 / 6)$.

\section{Dimensiones relativas}

Los módulos longitud-anchura y tamaño, y el espesor relativo se calcularon para las lascas enteras $(n=115)$ (Tablas $6.10,6.11$ y 6.12$)$.

Tabla 6.10. Módulo longitud-anchura de las lascas enteras del sector B.

\begin{tabular}{|c|c|c|c|c|c|c|c|c|c|c|c|}
\hline \multirow{2}{*}{ Módulo L-A } & \multicolumn{8}{|c|}{ Sitios arqueológicos } & \multirow{2}{*}{$\begin{array}{c}\text { Hallazgos } \\
\text { aislados }\end{array}$} & \multicolumn{2}{|c|}{ Total } \\
\hline & PS & $\mathrm{AU}$ & $\overline{\mathrm{ALL} 1}$ & $\overline{\mathrm{ALL} 2}$ & AEP1 & AEP2 & PA & $\mathrm{AV}$ & & $\mathrm{n}$ & $\%$ \\
\hline Corto anchísimo & 1 & - & - & - & - & - & - & - & 1 & 2 & 1,7 \\
\hline Corto muy ancho & 4 & 2 & - & - & - & - & - & 1 & 1 & 8 & 6,9 \\
\hline Corto ancho & 17 & 3 & 1 & 1 & - & - & - & - & 4 & 26 & 22,6 \\
\hline Mediano normal & 26 & 4 & 2 & 2 & - & 1 & 4 & 1 & 4 & 44 & 38,3 \\
\hline Mediano alargado & 14 & 1 & 1 & 1 & 1 & - & - & - & 3 & 21 & 18,3 \\
\hline Laminar normal & 9 & - & 1 & - & - & 1 & - & 1 & - & 12 & 10,4 \\
\hline Laminar angosto & - & - & - & - & 1 & - & - & - & - & 1 & 0,9 \\
\hline Laminar muy angosto & 1 & - & - & - & - & - & - & - & - & 1 & 0,9 \\
\hline Total & 72 & 10 & 5 & 4 & 2 & 2 & 4 & 3 & 13 & 115 & 100 \\
\hline
\end{tabular}

Tabla 6.11. Módulo tamaño de las lascas enteras del sector B.

\begin{tabular}{|c|c|c|c|c|c|c|c|c|c|c|c|}
\hline \multirow{2}{*}{ Tamaño } & \multicolumn{8}{|c|}{ Sitios arqueológicos } & \multirow{2}{*}{$\begin{array}{c}\text { Hallazgos } \\
\text { aislados }\end{array}$} & \multicolumn{2}{|c|}{ Total } \\
\hline & PS & $A U$ & ALL1 & ALL2 & AEP1 & AEP2 & $\mathrm{PA}$ & AV & & $\mathrm{n}$ & $\%$ \\
\hline Muy pequeño & 8 & - & - & - & - & - & - & - & - & 8 & 6,9 \\
\hline Pequeño & 24 & - & - & - & - & 1 & 1 & - & 1 & 27 & 23,5 \\
\hline Mediano pequeño & 28 & 1 & 4 & 1 & - & 1 & 2 & 1 & 4 & 42 & 36,5 \\
\hline Mediano grande & 11 & 6 & - & 2 & 1 & - & - & 1 & 6 & 27 & 23,5 \\
\hline Grande & 1 & 3 & 1 & 1 & 1 & - & 1 & - & 2 & 10 & 8,7 \\
\hline Muy grande & - & - & - & - & - & - & - & 1 & - & 1 & 0,9 \\
\hline Total & 72 & 10 & 5 & 4 & 2 & 2 & 4 & 3 & 13 & 115 & 100 \\
\hline
\end{tabular}

Tabla 6.12. Espesores relativos de las lascas enteras del sector B.

\begin{tabular}{|c|c|c|c|c|c|c|c|c|c|c|c|}
\hline \multirow{2}{*}{ Espesor relativo } & \multicolumn{8}{|c|}{ Sitios arqueológicos } & \multirow{2}{*}{$\begin{array}{c}\text { Hallazgos } \\
\text { aislados }\end{array}$} & \multicolumn{2}{|c|}{ Total } \\
\hline & PS & $\overline{A U}$ & ALL1 & ALL2 & AEP1 & AEP2 & PA & $\mathrm{AV}$ & & $\mathrm{n}$ & $\%$ \\
\hline Muy delgado & 48 & - & $\overline{-}$ & $\overline{-}$ & - & 1 & $\overline{2}$ & $\overline{-}$ & 2 & 53 & 6,9 \\
\hline Delgado & 23 & 1 & 2 & 2 & 1 & 1 & 1 & 1 & 2 & 34 & 23,5 \\
\hline Grueso & 1 & 8 & 2 & 1 & 1 & - & - & 1 & 7 & 21 & 36,5 \\
\hline Muy grueso & - & 1 & 1 & 1 & - & - & 1 & - & 2 & 6 & 23,5 \\
\hline Gruesísimo & - & - & - & - & - & - & - & 1 & - & 1 & 8,7 \\
\hline Total & 72 & 10 & 5 & 4 & 2 & 2 & 4 & 3 & 13 & 115 & 100 \\
\hline
\end{tabular}


En relación a la longitud-anchura predominan las lascas medianas ( $n=65 ; 56,6 \%)$, seguidas por las cortas $(n=36 ; 31,2 \%)$ y las laminares $(n=14 ; 12,2 \%)$. En cuanto al tamaño predominan las lascas medianas ( $n=69 ; 60 \%)$, seguidas por las pequeñas $(n=35 ; 30,4 \%$ ) y las grandes $(n=11 ; 9,6 \%)$. El espesor relativo más frecuente es el muy delgado ( $n=53 ; 46,1 \%)$, seguido por lascas que van disminuyendo su frecuencia a medida que aumenta el espesor.

\section{Rastros complementarios, regularización del frente de extracción y alteración térmica}

La presencia de rastros complementarios sobre filos naturales en los desechos de talla fue registrada en 14 lascas: 11 de PS (nueve angulares, una secundaria y una de arista), una de AEP2 (angular), una de PB (con dorso natural) y una de LH (con dorso natural). Los rastros corresponden a melladuras, microlascados y ultramicrolascados combinados. En PS se registraron 15 lascas con rastros complementarios sobre el talón (12 presentan abrasión, una retoque complementario de preparación y dos tienen abrasión más retoque complementario de preparación), de la cuales seis además presentan regularización del frente de extracción mediante abrasión. Se cuentan además otras nueve lascas con este último atributo. En ningún caso se registró evidencia de alteración térmica.

\section{Núcleos}

El conjunto lítico del sector B presenta 77 núcleos (Tabla 6.13).

Tabla 6.13. Núcleos del sector B.

\begin{tabular}{|c|c|c|c|c|c|c|c|c|c|c|}
\hline \multirow{2}{*}{ Procedencia } & \multirow{2}{*}{$\begin{array}{l}\text { Materia } \\
\text { prima }\end{array}$} & \multirow{2}{*}{ Calidad } & \multirow{2}{*}{ Forma-base } & \multicolumn{2}{|c|}{ Planos de percusión } & \multirow{2}{*}{$\begin{array}{l}\text { Proporción } \\
\text { de corteza }\end{array}$} & \multirow{2}{*}{$\begin{array}{c}\text { Negativos } \\
\text { de } \\
\text { lascados }\end{array}$} & \multirow{2}{*}{$\begin{array}{r}\text { Largo } \\
(\mathrm{mm})\end{array}$} & \multirow{2}{*}{$\begin{array}{c}\text { Ancho } \\
(\mathrm{mm})\end{array}$} & \multirow{2}{*}{$\begin{array}{c}\text { Espesor } \\
(\mathrm{mm})\end{array}$} \\
\hline & & & & Número & Forma & & & & & \\
\hline $\begin{array}{c}\text { PS (APN) (1992)- } \\
\text { L-RS-150 }\end{array}$ & ágata & buena & $\begin{array}{c}\text { nódulo } \\
\text { facetado }\end{array}$ & 2 & natural & $>50 \%$ & 2 & 21 & 20,8 & 9,3 \\
\hline $\begin{array}{c}\text { PS (APN) S/D- } \\
5-R S-1\end{array}$ & $\begin{array}{c}\text { caliza } \\
\text { silicificada }\end{array}$ & excelente & clasto & 2 & liso & $<50 \%$ & 13 & 79,4 & 70,5 & 50,1 \\
\hline $\begin{array}{c}\text { PS (2010)-RS- } \\
47\end{array}$ & $\begin{array}{c}\text { cuarzo } \\
\text { cristalino }\end{array}$ & buena & $\begin{array}{c}\text { guijarro } \\
\text { chato }\end{array}$ & 1 & natural & $>50 \%$ & 1 & 48 & 22,8 & 14,2 \\
\hline $\begin{array}{c}\mathrm{AU}(2010)-\mathrm{RS}- \\
16\end{array}$ & cuarzo $^{2}$ & regular & $\begin{array}{c}\text { guijarro } \\
\text { facetado }\end{array}$ & 2 & natural & $>50 \%$ & 5 & 53,2 & 50,3 & 36,5 \\
\hline $\begin{array}{c}\mathrm{AU}(2010)-\mathrm{RS}- \\
18\end{array}$ & calcedonia & buena & $\begin{array}{c}\text { guijarro } \\
\text { indeterminado }\end{array}$ & 2 & natural & $<50 \%$ & 9 & 47,9 & 29,2 & 26,3 \\
\hline $\begin{array}{c}\mathrm{AU}(2010)-\mathrm{RS}- \\
19\end{array}$ & calcedonia & buena & $\begin{array}{c}\text { guijarro } \\
\text { subesférico }\end{array}$ & 2 & natural & $<50 \%$ & 8 & 27,4 & 26,2 & 22,2 \\
\hline $\begin{array}{c}\text { AU (2010)-RS- } \\
20\end{array}$ & calcedonia & buena & no diferenciada & 2 & liso & $<50 \%$ & 6 & 38,5 & 27,4 & 27,1 \\
\hline $\begin{array}{c}\text { AU (2010)-RS- } \\
21\end{array}$ & calcedonia $^{2}$ & buena & $\begin{array}{c}\text { guijarro } \\
\text { facetado }\end{array}$ & 2 & $\begin{array}{c}\text { natural } \\
\text { y liso }\end{array}$ & $<50 \%$ & 6 & 52,3 & 41,3 & 16,5 \\
\hline $\begin{array}{c}\text { AU (2010)-RS- } \\
39\end{array}$ & arenisca & mala & no diferenciada & 6 & natural & $<50 \%$ & 6 & 52,1 & 37,1 & 29,2 \\
\hline $\begin{array}{c}\text { AU (2010)-RS- } \\
40\end{array}$ & $\begin{array}{c}\text { caliza } \\
\text { silicificada }\end{array}$ & mala & $\begin{array}{c}\text { nódulo laminar o } \\
\text { veta de sílice }\end{array}$ & 2 & liso & $<50 \%$ & 2 & 46 & 32,5 & 21,8 \\
\hline $\begin{array}{c}\mathrm{AU}(2010)-\mathrm{RS}- \\
41\end{array}$ & $\begin{array}{c}\text { caliza } \\
\text { silicificada }\end{array}$ & buena & $\begin{array}{c}\text { nódulo laminar o } \\
\text { veta de sílice }\end{array}$ & 7 & natural & $>50 \%$ & 7 & 70 & 53,8 & 30,4 \\
\hline $\begin{array}{c}\mathrm{AU}(2010)-\mathrm{RS}- \\
42\end{array}$ & $\begin{array}{c}\text { caliza } \\
\text { silicificada }\end{array}$ & buena & $\begin{array}{c}\text { nódulo o veta de } \\
\text { sílice }\end{array}$ & 12 & $\begin{array}{c}\text { natural } \\
\text { y liso }\end{array}$ & $<50 \%$ & 12 & 96,7 & 58,4 & 54,4 \\
\hline $\begin{array}{c}\mathrm{AU}(2010)-\mathrm{RS}- \\
43\end{array}$ & $\begin{array}{c}\text { caliza } \\
\text { silicificada }\end{array}$ & buena & $\begin{array}{c}\text { nódulo o veta de } \\
\text { sílice }\end{array}$ & 5 & liso & $<50 \%$ & 5 & 39,3 & 30,5 & 21,3 \\
\hline
\end{tabular}


AU (2010)-RS-

45
AU $(2010)-R S-$

silcreta regular

clasto

2 natural

$<50 \%$

$4 \quad 80 \quad 40,8 \quad 35,6$

AU (2010)-RS-

46

silcreta regular no diferenciada

2 liso

liso

$<50 \%$

$4 \quad 54,8 \quad 41,4 \quad 32,6$

AU (2010)-RS-

47

silcreta regular

clasto

2

AU (2010)-RS$48^{1}$

silcreta regular

clasto

2 liso

liso $\quad<50 \%$

$\begin{array}{llll}6 & 57,3 & 43,3 & 23,3\end{array}$

ALL1 (2009)RS-10

\begin{tabular}{ccc} 
calcedonia & buena & $\begin{array}{c}\text { guijarro sección } \\
\text { plano convexa }\end{array}$ \\
sílice & regular & $\begin{array}{c}\text { guijón } \\
\text { subesférico }\end{array}$ \\
\hline
\end{tabular}

ALL1 (2009)RS-12

ALL1 (2009)RS-13

ALL1 (2010)-

$\frac{\text { RS-3 }}{\text { ALL1 (2010) }}$

sílice

1

$\begin{array}{cc}\text { natural } & >50 \% \\ \text { natural } & >50 \% \\ \text { natural } & >50 \%\end{array}$

1

$4 \quad 33$
RS-6

ALL1 (2010)RS-7 caliza
silicificada

buena clasto o veta de
caliza sílice

buena nódulo laminar o

3

natural

$>50 \%$

\begin{tabular}{llll}
3 & 64,7 & 43,2 & 37,5 \\
2 & 71 & 55,5 & 46,8 \\
\hline
\end{tabular}

veta de sílice

caliza

ALL1 (2010) RS -9 buen

nódulo laminar o

veta de sílice

3

liso
natura
veta de sílice

$\begin{array}{cc}3 & \begin{array}{c}\text { natural } \\ \text { y liso }\end{array} \\ 3 & \begin{array}{c}\text { natural } \\ \text { y liso }\end{array}\end{array}$

$<50 \%$

$9 \quad 65,5 \quad 48,1 \quad 34,5$

ALL1 (2010)RS-11 silicificada

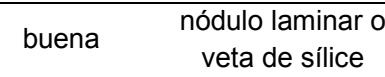

$\begin{array}{cc}3 & \begin{array}{c}\text { natural } \\ \text { y liso }\end{array} \\ 3 & \text { natural }\end{array}$

$>50 \%$

$\begin{array}{llll}5 & 42,4 & 29,5 & 27,4\end{array}$

ALL2 (2010)RS-9

ALL2 (2010)RS-10

ALL2 (2010)RS-11

ALL2 (2010)RS-15

ALL2 (2010)RS-16 caliza

buena

no diferenciada

$\begin{array}{cc}3 & \begin{array}{c}\text { y liso } \\ 1\end{array} \\ \text { natural }\end{array}$

$<50 \%$

$\begin{array}{llll}3 & 38,9 & 32,4 & 18\end{array}$

sílice

buena

guijarro
facetado
guijarro sección

$\begin{array}{cc}\text { buena } & \begin{array}{l}\text { guijarro sección } \\ \text { plano convexa }\end{array}\end{array}$

1 natural

$>50 \%$

\begin{tabular}{cccc}
7 & 30,9 & 25,9 & 24 \\
\hline 5 & 34,3 & 19 & 16,9 \\
\hline
\end{tabular}

calcedonia buena guijarro sección-

tabular

caliza regular nódulo laminar o

2 natural

$>50 \%$

1

\begin{tabular}{lll}
38,8 & 27,7 & 20,5 \\
\hline 42,9 & 23,4 & 13,6 \\
\hline
\end{tabular}

ALL2 (2010)-
RS-28

ALL2 (2010)-

RS-29

ALL2 (2010)RS-35

AEP1 (2009)RS-5

sílice

buena veta de sílice

guijarro sección
plano convexa

1 natural

guijarro
regular

\begin{tabular}{ll} 
& facetado \\
\hline
\end{tabular}

facetado

\begin{tabular}{ccccccc}
1 & natural & $>50 \%$ & 7 & 60,8 & 35,6 & 22,3 \\
\hline 1 & natural & $>50 \%$ & 2 & 48,3 & 39,7 & 23,7 \\
2 & natural & $<50 \%$ & 3 & 28,2 & 17,5 & 15 \\
\hline 2 & natural & $>50 \%$ & 2 & 77,2 & 43,9 & 41,3 \\
\hline
\end{tabular}

nódulo facetado

AEP2 (2009)RS-3

calcedonia buena $\quad \begin{gathered}\text { guijarro } \\ \text { subesférico }\end{gathered}$

1

AEP2 (2009)RS-4

AEP2 (2009)RS-5

\begin{tabular}{|c|c|c|c|c|c|c|c|c|c|c|}
\hline no-3 & & & sudestenco & & & & & & & \\
\hline $\begin{array}{l}\text { AEP2 (2009)- } \\
\text { RS-4 }\end{array}$ & arenisca & regular & $\begin{array}{c}\text { guijarro } \\
\text { subesférico }\end{array}$ & 3 & natural & $>50 \%$ & 5 & 44,2 & 37,4 & 30,2 \\
\hline $\begin{array}{c}\text { AEP2 (2009)- } \\
\text { RS-5 }\end{array}$ & calcedonia & buena & $\begin{array}{c}\text { guijarro } \\
\text { subesférico }\end{array}$ & 1 & natural & $<50 \%$ & 3 & 38,7 & 41,4 & 28,5 \\
\hline $\begin{array}{l}\text { AEP2 (2009)- } \\
\text { RS-6 }\end{array}$ & sílice & buena & $\begin{array}{c}\text { guijón elíptico } \\
\text { sección sub oval }\end{array}$ & 1 & natural & $>50 \%$ & 3 & 84,1 & 33,9 & 26,5 \\
\hline $\begin{array}{l}\text { AEP2 (2009)- } \\
\text { RS-7 }\end{array}$ & sílice & buena & $\begin{array}{c}\text { guijarro } \\
\text { subesférico }\end{array}$ & 1 & natural & $>50 \%$ & 5 & 39,2 & 38,1 & 26,6 \\
\hline $\begin{array}{l}\text { AEP2 (2009)- } \\
\text { RS-8 }\end{array}$ & ágata & buena & $\begin{array}{c}\text { guijarro } \\
\text { subesférico }\end{array}$ & 2 & natural & $>50 \%$ & 4 & 46,6 & 35,6 & 25,6 \\
\hline $\begin{array}{l}\text { AEP2 (2009)- } \\
\text { RS-9 }\end{array}$ & calcedonia & buena & $\begin{array}{c}\text { nódulo facetado } \\
\text { tabular }\end{array}$ & 2 & natural & $<50 \%$ & 7 & 31,7 & 25,2 & 22,4 \\
\hline $\begin{array}{l}\text { AEP2 (2009)- } \\
\text { RS-10 }\end{array}$ & calcedonia & buena & $\begin{array}{c}\text { guijarro } \\
\text { subesférico }\end{array}$ & 2 & natural & $>50 \%$ & 3 & 42,6 & 40,2 & 25 \\
\hline $\begin{array}{l}\text { AEP2 (2009)- } \\
\text { RS-12 }\end{array}$ & sílice & buena & $\begin{array}{c}\text { nódulo } \\
\text { facetado }\end{array}$ & 3 & natural & $>50 \%$ & 6 & 30,7 & 28,2 & 15 \\
\hline $\begin{array}{c}\text { AEP2 (2009)- } \\
\text { RS-13 }\end{array}$ & calcedonia & buena & $\begin{array}{c}\text { guijarro } \\
\text { subesférico }\end{array}$ & 2 & natural & $>50 \%$ & 3 & 30,9 & 27,6 & 22,3 \\
\hline $\begin{array}{l}\text { AEP2 (2009)- } \\
\text { RS-14 }\end{array}$ & calcedonia & buena & $\begin{array}{l}\text { guijarro } \\
\text { chato }\end{array}$ & 1 & natural & $>50 \%$ & 2 & 44,9 & 41,8 & 20,5 \\
\hline $\begin{array}{l}\text { AEP2 (2010)- } \\
\text { RS-4 }\end{array}$ & sílice & buena & $\begin{array}{l}\text { nódulo facetado- } \\
\text { angular }\end{array}$ & 2 & natural & $>50 \%$ & 3 & 34,6 & 22,1 & 15,1 \\
\hline
\end{tabular}
guijarro
subesférico

\begin{tabular}{|c|c|c|c|c|c|c|c|c|c|c|}
\hline $\begin{array}{l}\text { AEP2 (2009)- } \\
\text { RS-4 }\end{array}$ & arenisca & regular & $\begin{array}{l}\text { guijarro } \\
\text { subesférico }\end{array}$ & 3 & natural & $>50 \%$ & 5 & 44,2 & 37,4 & 30,2 \\
\hline $\begin{array}{c}\text { AEP2 (2009)- } \\
\text { RS-5 }\end{array}$ & calcedonia & buena & $\begin{array}{c}\text { guijarro } \\
\text { subesférico }\end{array}$ & 1 & natural & $<50 \%$ & 3 & 38,7 & 41,4 & 28,5 \\
\hline $\begin{array}{l}\text { AEP2 (2009)- } \\
\text { RS-6 }\end{array}$ & sílice & buena & $\begin{array}{l}\text { guijón elíptico } \\
\text { sección sub oval }\end{array}$ & 1 & natural & $>50 \%$ & 3 & 84,1 & 33,9 & 26,5 \\
\hline $\begin{array}{l}\text { AEP2 (2009)- } \\
\text { RS-7 }\end{array}$ & sílice & buena & $\begin{array}{c}\text { guijarro } \\
\text { subesférico }\end{array}$ & 1 & natural & $>50 \%$ & 5 & 39,2 & 38,1 & 26,6 \\
\hline $\begin{array}{l}\text { AEP2 (2009)- } \\
\text { RS-8 }\end{array}$ & ágata & buena & $\begin{array}{c}\text { guijarro } \\
\text { subesférico }\end{array}$ & 2 & natural & $>50 \%$ & 4 & 46,6 & 35,6 & 25,6 \\
\hline $\begin{array}{l}\text { AEP2 (2009)- } \\
\text { RS-9 }\end{array}$ & calcedonia & buena & $\begin{array}{c}\text { nódulo facetado } \\
\text { tabular }\end{array}$ & 2 & natural & $<50 \%$ & 7 & 31,7 & 25,2 & 22,4 \\
\hline $\begin{array}{c}\text { AEP2 (2009)- } \\
\text { RS-10 }\end{array}$ & calcedonia & buena & $\begin{array}{c}\text { guijarro } \\
\text { subesférico }\end{array}$ & 2 & natural & $>50 \%$ & 3 & 42,6 & 40,2 & 25 \\
\hline $\begin{array}{c}\text { AEP2 (2009)- } \\
\text { RS-12 }\end{array}$ & sílice & buena & $\begin{array}{c}\text { nódulo } \\
\text { facetado }\end{array}$ & 3 & natural & $>50 \%$ & 6 & 30,7 & 28,2 & 15 \\
\hline $\begin{array}{c}\text { AEP2 (2009)- } \\
\text { RS-13 }\end{array}$ & calcedonia & buena & $\begin{array}{c}\text { guijarro } \\
\text { subesférico }\end{array}$ & 2 & natural & $>50 \%$ & 3 & 30,9 & 27,6 & 22,3 \\
\hline $\begin{array}{l}\text { AEP2 (2009)- } \\
\text { RS-14 }\end{array}$ & calcedonia & buena & $\begin{array}{c}\text { guijarro } \\
\text { chato }\end{array}$ & 1 & natural & $>50 \%$ & 2 & 44,9 & 41,8 & 20,5 \\
\hline $\begin{array}{c}\text { AEP2 (2010)- } \\
\text { RS-4 }\end{array}$ & sílice & buena & $\begin{array}{l}\text { nódulo facetado- } \\
\text { angular }\end{array}$ & 2 & natural & $>50 \%$ & 3 & 34,6 & 22,1 & 15,1 \\
\hline
\end{tabular}

3

\begin{tabular}{llllll} 
& $>50 \%$ & 3 & 28,3 & 18,3 & 20,8 \\
\hline natural & $>50 \%$ & 5 & 44,2 & 37,4 & 30,2 \\
\hline atural & $<50 \%$ & 3 & 38,7 & 41,4 & 28,5
\end{tabular}




\begin{tabular}{|c|c|c|c|c|c|c|c|c|c|c|}
\hline $\begin{array}{c}\text { PA (2009)-RS- } \\
2\end{array}$ & calcedonia & buena & $\begin{array}{l}\text { nódulo } \\
\text { tabular }\end{array}$ & 2 & $\begin{array}{l}\text { natural } \\
\text { y liso }\end{array}$ & $<50 \%$ & 4 & 50 & 28,1 & 26 \\
\hline $\begin{array}{c}\text { PA (2009)-RS- } \\
2\end{array}$ & arenisca & regular & $\begin{array}{c}\text { guijón } \\
\text { subesférico }\end{array}$ & 2 & natural & $<50 \%$ & 5 & 67,5 & 50,8 & 29,1 \\
\hline $\begin{array}{c}\text { PA (2010)-RS- } \\
11\end{array}$ & sílice & buena & $\begin{array}{c}\text { guijarro } \\
\text { subesférico }\end{array}$ & 2 & natural & $>50 \%$ & 2 & 30,3 & 23,6 & 21,1 \\
\hline $\begin{array}{c}\text { PA (2010)-RS- } \\
13\end{array}$ & arenisca & regular & $\begin{array}{l}\text { guijarro } \\
\text { facetado }\end{array}$ & 1 & natural & $>50 \%$ & 5 & 53,9 & 35 & 18,5 \\
\hline $\begin{array}{c}\text { PA (2010)-RS- } \\
14\end{array}$ & sílice & buena & $\begin{array}{c}\text { guijarro } \\
\text { subesférico }\end{array}$ & 2 & $\begin{array}{c}\text { natural } \\
\text { y liso }\end{array}$ & $>50 \%$ & 3 & 39,8 & 28,1 & 26,4 \\
\hline $\begin{array}{c}\text { PA (2010)-RS- } \\
17\end{array}$ & sílice & buena & $\begin{array}{c}\text { guijarro } \\
\text { facetado }\end{array}$ & 2 & natural & $>50 \%$ & 4 & 54,1 & 48,4 & 40,2 \\
\hline $\begin{array}{c}\text { PA (2010)-RS- } \\
18\end{array}$ & arenisca & regular & $\begin{array}{l}\text { guijarro } \\
\text { facetado }\end{array}$ & 1 & natural & $>50 \%$ & 1 & 50,1 & 35,1 & 19,8 \\
\hline $\begin{array}{c}\text { PA (2010)-RS- } \\
19\end{array}$ & arenisca & regular & $\begin{array}{c}\text { guijarro } \\
\text { subesférico }\end{array}$ & 2 & natural & $<50 \%$ & 9 & 51,5 & 48,5 & 38,2 \\
\hline $\begin{array}{c}\text { PA (2010)-RS- } \\
20\end{array}$ & calcedonia & buena & $\begin{array}{l}\text { guijarro } \\
\text { facetado }\end{array}$ & 2 & $\begin{array}{l}\text { natural } \\
\text { y liso }\end{array}$ & $>50 \%$ & 1 & 44,8 & 39,8 & 29,3 \\
\hline $\begin{array}{c}\text { AV (2010)-RS- } \\
\text { T1-F-1 }\end{array}$ & xilópalo & buena & clasto & 3 & $\begin{array}{c}\text { natural } \\
\text { y liso }\end{array}$ & $>50 \%$ & 6 & $\begin{array}{c}189 \\
1\end{array}$ & $\begin{array}{c}146 \\
5\end{array}$ & 106,3 \\
\hline $\begin{array}{c}\text { AV (2010)-RS- } \\
\text { T1-G1 }\end{array}$ & xilópalo & buena & clasto & 3 & liso & $<50 \%$ & 4 & $\begin{array}{c}128 \\
2\end{array}$ & $\begin{array}{c}109 \\
2\end{array}$ & 103,2 \\
\hline $\begin{array}{c}\text { AV (2010)-RS- } \\
\text { T2-C- } 1^{1}\end{array}$ & xilópalo & buena & clasto & 1 & natural & $<50 \%$ & 1 & $\begin{array}{c}130 \\
3\end{array}$ & $\begin{array}{c}122 \\
6\end{array}$ & 109,1 \\
\hline $\begin{array}{c}\text { AV (2010)-RS- } \\
\text { T2-C-11 }\end{array}$ & xilópalo & buena & clasto & 3 & natural & $>50 \%$ & 3 & $\begin{array}{c}154 \\
2\end{array}$ & 142 & 106,2 \\
\hline $\begin{array}{c}\text { AV (2010)-RS- } \\
\text { T2-C-17 }\end{array}$ & xilópalo & buena & clasto & 4 & $\begin{array}{c}\text { natural } \\
\text { y liso }\end{array}$ & $>50 \%$ & 1 & $\begin{array}{c}197 \\
6\end{array}$ & 84,6 & 111,8 \\
\hline $\begin{array}{c}\text { AV (2010)-RS- } \\
\text { T2-C-19 }\end{array}$ & xilópalo & buena & clasto & 3 & natural & $>50 \%$ & 3 & $\begin{array}{c}156 \\
3\end{array}$ & $\begin{array}{c}125 \\
9\end{array}$ & 73,1 \\
\hline $\begin{array}{c}\text { AV (2010)-RS- } \\
\text { T2-C-20 }\end{array}$ & xilópalo & buena & clasto & 1 & liso & $<50 \%$ & 3 & 84,9 & 69,9 & 54 \\
\hline $\begin{array}{c}\text { AV (2010)-RS- } \\
\text { T2-C-22 }\end{array}$ & xilópalo & buena & clasto & 1 & liso & $>50 \%$ & 3 & $\begin{array}{c}135 \\
3\end{array}$ & $\begin{array}{c}114 \\
7\end{array}$ & 82,9 \\
\hline $\begin{array}{c}\text { AV (2010)-RS- } \\
\text { T2-C-23 }\end{array}$ & xilópalo & buena & clasto & 2 & liso & $<50 \%$ & 3 & $\begin{array}{c}114 \\
8\end{array}$ & 52,7 & 49,1 \\
\hline $\begin{array}{c}\text { AV (2010)-RS- } \\
\text { T2-D- } 2^{1}\end{array}$ & xilópalo & buena & clasto & 2 & $\begin{array}{l}\text { natural } \\
\text { y liso }\end{array}$ & $>50 \%$ & 5 & $\begin{array}{c}167 \\
6\end{array}$ & $\begin{array}{c}129 \\
9\end{array}$ & 74,6 \\
\hline $\begin{array}{c}\text { AV (2010)-RS- } \\
\text { T3-C-2 }\end{array}$ & xilópalo & buena & clasto & 1 & natural & $>50 \%$ & 1 & $\begin{array}{c}146 \\
1\end{array}$ & $\begin{array}{c}114 \\
8\end{array}$ & 71,6 \\
\hline $\begin{array}{c}\text { AV (2010)-RS- } \\
\text { T3-C-3 }\end{array}$ & xilópalo & buena & clasto & 2 & liso & $>50 \%$ & 2 & 95,1 & 85,6 & 54,7 \\
\hline $\begin{array}{c}\text { AV (2010)-RS- } \\
\text { T3-D-1 }\end{array}$ & xilópalo & buena & clasto & 3 & $\begin{array}{c}\text { natural } \\
\text { y liso }\end{array}$ & $>50 \%$ & 13 & $\begin{array}{c}146 \\
5\end{array}$ & 145 & 123,9 \\
\hline $\begin{array}{c}\text { AV (2010)-RS- } \\
\text { T3-D-2 }\end{array}$ & xilópalo & buena & clasto & 2 & liso & $>50 \%$ & 2 & 94,6 & 81,9 & 61,6 \\
\hline $\begin{array}{c}\text { LM2 (2009)- } \\
\text { RS-9 }\end{array}$ & silcreta & buena & clasto & 2 & $\begin{array}{c}\text { natural } \\
\text { y liso }\end{array}$ & $>50 \%$ & 4 & 95,7 & 82,5 & 66,1 \\
\hline $\begin{array}{c}\text { AEP5 (2010)- } \\
\text { RS-3 }\end{array}$ & calcedonia & buena & $\begin{array}{c}\text { guijarro } \\
\text { subesférico }\end{array}$ & 2 & natural & $>50 \%$ & 2 & 54,5 & 50,5 & 27,1 \\
\hline $\begin{array}{c}\text { AEP5 (2010)- } \\
\text { RS-4 }\end{array}$ & sílice & buena & $\begin{array}{c}\text { guijarro } \\
\text { facetado }\end{array}$ & 2 & natural & $>50 \%$ & 2 & 34,7 & 32,3 & 21 \\
\hline $\begin{array}{c}\text { AEP7 (2010)- } \\
\text { RS-8 }\end{array}$ & calcedonia & buena & $\begin{array}{l}\text { guijarro } \\
\text { facetado }\end{array}$ & 2 & natural & $>50 \%$ & 4 & 46,4 & 34,6 & 27,3 \\
\hline $\begin{array}{c}\text { EM (2010)-RS- } \\
6\end{array}$ & sílice $^{2}$ & buena & $\begin{array}{c}\text { guijón elíptico } \\
\text { sección plano } \\
\text { convexa }\end{array}$ & 2 & natural & $>50 \%$ & 1 & 70,2 & 33,4 & 26,6 \\
\hline $\begin{array}{c}\text { EM (2010)-RS- } \\
7\end{array}$ & arenisca & regular & $\begin{array}{c}\text { guijarro } \\
\text { facetado }\end{array}$ & 1 & natural & $>50 \%$ & 1 & 52,8 & 43,3 & 22,1 \\
\hline $\begin{array}{c}\text { PR (2010)-RS- } \\
1\end{array}$ & calcedonia & buena & $\begin{array}{c}\text { guijarro } \\
\text { facetado }\end{array}$ & 2 & natural & $>50 \%$ & 3 & 39 & 38,7 & 26,6 \\
\hline SDI & $\begin{array}{l}\text { xilópalo y } \\
\text { arenisca }\end{array}$ & buena & clasto & 3 & $\begin{array}{c}\text { natural } \\
\text { y liso }\end{array}$ & $>50 \%$ & 21 & 250 & 240 & 137 \\
\hline
\end{tabular}

(1) Núcleos que presentan remontajes; (2) Núcleos bipolares. 
En el 90,9\% ( $n=70)$ de los casos las materias primas son silíceas de buena a excelente calidad. Las formas-base corresponden a clastos $(n=21)$; rodados subesféricos $(n=14)$, facetados $(n=13)$, rodados de morfologías variadas $(n=15)$; nódulos o fragmentos de vetas de sílice $(n=10)$; y no diferenciados $(n=4)$.

Del total de núcleos, 48 presentan planos de percusión naturales y en 15 casos estos se combinan con planos lisos; 13 tienen planos lisos y uno solo presenta liso natural. Predominan los núcleos con dos planos de percusión utilizados $(n=38)$ seguidos por los que tienen uno $(n=21)$ y tres ( $n=13)$; también se registraron núcleos con cuatro, cinco, seis, siete y 12 planos utilizados. Se registraron de uno a 21 lascados por núcleo, siendo tres lascados los más frecuentes ya que se registraron en 16 núcleos; seguidos por dos y cuatro lascados que se registraron en 11 núcleos; y por uno y cinco lascados que se registraron en 10 núcleos; el resto de los núcleos presentan entre seis y 21 lascados. El remanente de corteza es superior al 50\% en 49 de los núcleos, y es menor en los restantes $(n=28)$. Se registraron tres núcleos bipolares con ambos polos y caras modificadas, que corresponden a $\mathrm{AU}(\mathrm{n}=2)$ y al hallazgo aislado $\mathrm{EM}(n=1)$. La medida máxima de los núcleos va entre $2,1 \mathrm{~cm}$ y $25 \mathrm{~cm}$. Los valores más grandes se registran en piezas cuya forma-base son clastos y los valores menores en rodados fluviales. 

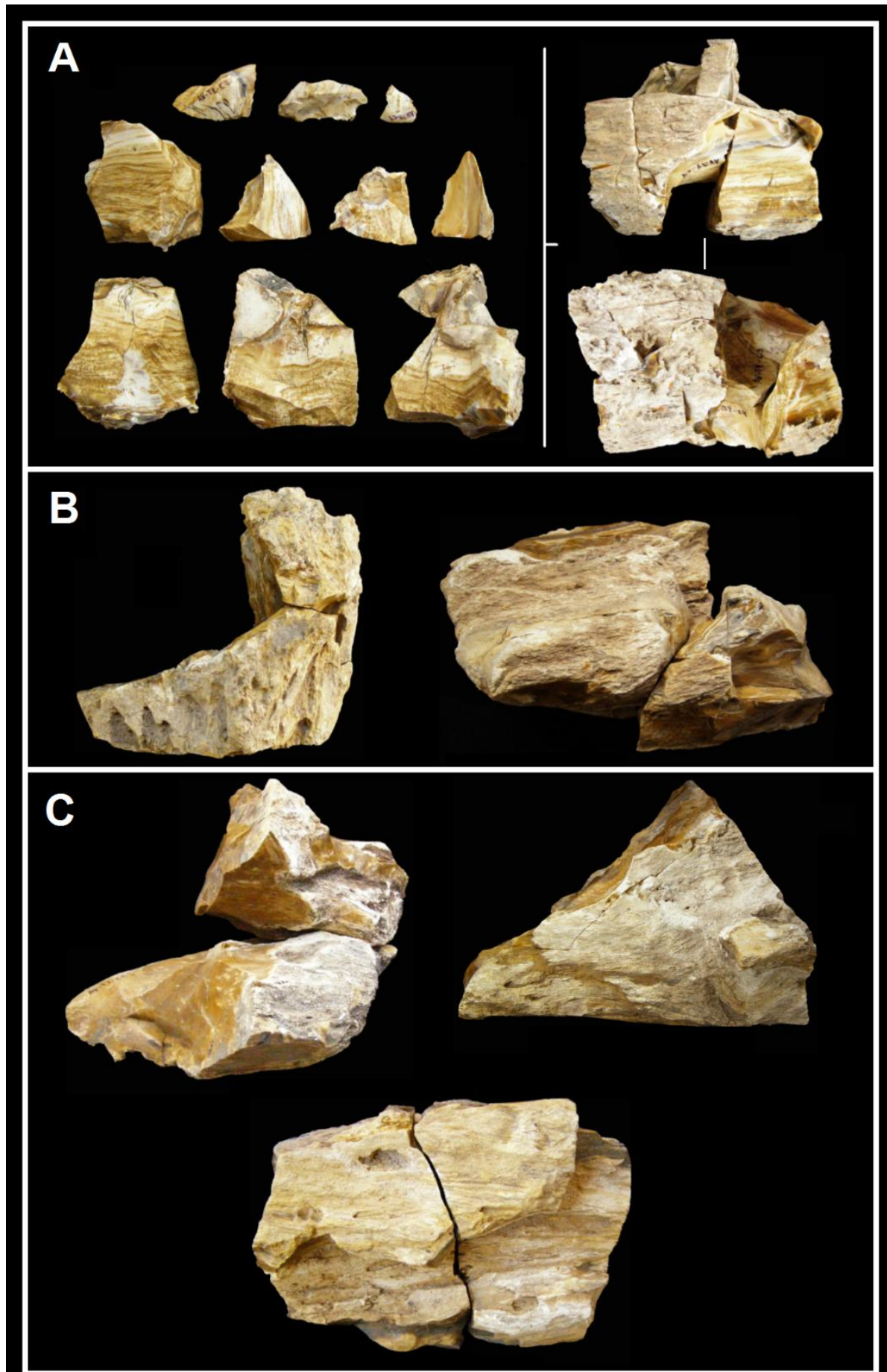

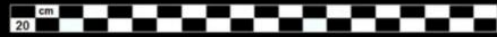

$20 \mathrm{~cm}$

Figura 6.4. Núcleos remontados del sitio arqueológico Árbol Viejo.

A: AV (2010)-RS-T2-C-1. B (de izquierda a derecha): AV (2010)-RS-T2-C-11 y AV (2010)-RS-T2-C-17.

C: (de izquierda a derecha): AV (2010)-RS-T1-F-1, AV (2010)-RS-T2-D-2 y (abajo) AV (2010)-RS-T2-C-19.

\subsubsection{2- Estructura del conjunto cerámico}

La muestra de alfarería proviene de los sitios arqueológicos PS, AU y AEP1, así como de los hallazgos aislados AEP4 y AEP7. Los fragmentos recuperados suman un total de 73 (Tabla 6.2); 61 
corresponden al cuerpo de las vasijas (61 lisos) y 12 son bordes (11 lisos y uno decorado). Los tamaños se distribuyen como sigue: pequeños $n=62(84,9 \%)$ y medianos $n=11(15,1 \%)$

Considerando los tiestos mayores a $2 \mathrm{~cm}$ la muestra analizada se compone de $\mathrm{n}=62$ tiestos; $51(82,3 \%)$ corresponden al cuerpo de las vasijas (51 lisos) y $11(17,7 \%)$ son bordes (10 lisos y uno decorado). Los espesores de los bordes varían entre 4,9 y $8,8 \mathrm{~mm}$, y de los cuerpos entre $5 \mathrm{~mm}$ y 13,4 $\mathrm{mm}$.

Es necesario aclarar que el $98,4 \%$ de la muestra analizada presenta evidencia de alteraciones naturales, como desgaste y erosión en distinto grado, producto de la acción fluvial y/o eólica. En algunos tiesos se observa redondeamiento de bordes y "efecto pedestal" debido a la remoción de las partes blandas de la pasta (Sanhueza Riquelme 1998). Esta situación constituyó una limitación para determinar algunos de los atributos relevados.

En relación a la técnica de manufactura se identificaron tres $(4,8 \%)$ tiestos elaborados mediante la técnica de enrollamiento, siendo el resto indeterminados ( $n=59 ; 95,2 \%$ ). Se pudo determinar el tratamiento de superficie plástico en 21 tiestos (33,8\%) siendo el resto indeterminados ( $n=41 ; 66,2 \%$ ); así, hay nueve alisados en ambas superficies, además de tres en la superficie externa y siete en la interna; se suman dos pulidos en la superficie interna.

La observación del color del núcleo de los tiestos permitió determinar que predomina el color castaño (10YR 4/6-brown) ( $n=29 ; 46,8 \%$ ), seguido en igual frecuencia por el negro (7.5YR 2/1-black) ( $n=15 ; 24,2 \%$ ), luego el castaño oscuro (7.5YR 3/4-dark brown) ( $n=10 ; 16,1 \%)$, y por último se registraron el castaño claro (7.5YR5/8-bright brown) ( $n=5 ; 8,1 \%$ ), y el anaranjado (7.5YR6/8-orange) $(n=3 ; 4,8 \%)$. En la superficie externa predomina el color castaño (10YR 4/6-brown) ( $n=34 ; 54,9 \%)$, seguido por el negro (7.5YR 2/1-black) ( $n=10 ; 16,1 \%)$, luego por el castaño oscuro (7.5YR 3/4-dark brown) ( $n=9 ; 14,5 \%)$, y por último se registraron el castaño claro (7.5YR5/8-bright brown) ( $n=6 ; 9,7 \%)$, y el anaranjado (7.5YR6/8-orange) ( $n=3 ; 4,8 \%$ ). En la superficie interna predomina el color el castaño claro (7.5YR5/8-bright brown) ( $n=30 ; 48,4 \%$ ) seguido por el castaño (10YR 4/6-brown) ( $n=18 ; 29,1 \%)$, luego por el anaranjado (7.5YR6/8-orange) ( $n=10,16,1 \%$ ), el castaño oscuro (7.5YR 3/4-dark brown) ( $n=1 ; 1,6 \%)$, y el negro (7.5YR 2/1-black) $(n=1 ; 1,6 \%)$, y por último se registraron dos indeterminados $(3,2 \%)$.

Los porcentajes de inclusiones se distribuyen de la siguiente manera, arena y espículas de esponjas de agua dulce $(n=37 ; 59,7 \%)$, arena $(n=16 ; 25,8 \%)$, tiesto y arena $(n=8 ; 12,9 \%)$ y espículas de esponjas de agua dulce $(n=1 ; 1,6 \%)$. En 40 tiestos se identificó la presencia de partículas macroscópicas de óxido de Fe. Las espículas de esponja de dos tiestos de AEP1 y AU fueron determinadas por la Dra. Inés Ezcurra de Drago (CONICET-INALI-UNL) y corresponden a Uruguaya corallioides.

En relación a la morfología de bordes y labios, incluyendo menores a $2 \mathrm{~cm}$, se determinaron cinco bordes evertidos, tres con labios angulares y dos convexos; cuatro bordes rectos con labios 
convexos; y tres bordes invertidos con labios convexos. Se determinaron cinco formas no restringidas y una restringida. Asimismo, a partir de cuatro bordes se reconstruyó el diámetro y el perfil de cuatro vasijas (Figura 6.5):

1 - Un recipiente liso no restringido, con borde recto y labio convexo, y un diámetro de boca de $32 \mathrm{~cm}$; esta vasija correspondería a un cuenco grande [AEP1 (APN) (2008)-RS-1] (Figura 6.5A).

2 - Un recipiente liso no restringido, con borde recto y labio convexo, y un diámetro de boca de $26 \mathrm{~cm}$; esta vasija correspondería a un cuenco grande [AEP1 (2009)-RS-2] (Figura 6.5B).

3 - Un recipiente liso no restringido, con borde evertido y labio convexo, y un diámetro de boca de $26 \mathrm{~cm}$; esta vasija correspondería a un cuenco grande [AEP1 (2009)-RS-1] (Figura 6.5C).

4 - Un recipiente liso restringido, con borde recto y labio convexo, y un diámetro de boca de $24 \mathrm{~cm}$; esta vasija correspondería a una olla [AEP1 (APN) (2008)-RS-2] (Figura 6.5D).

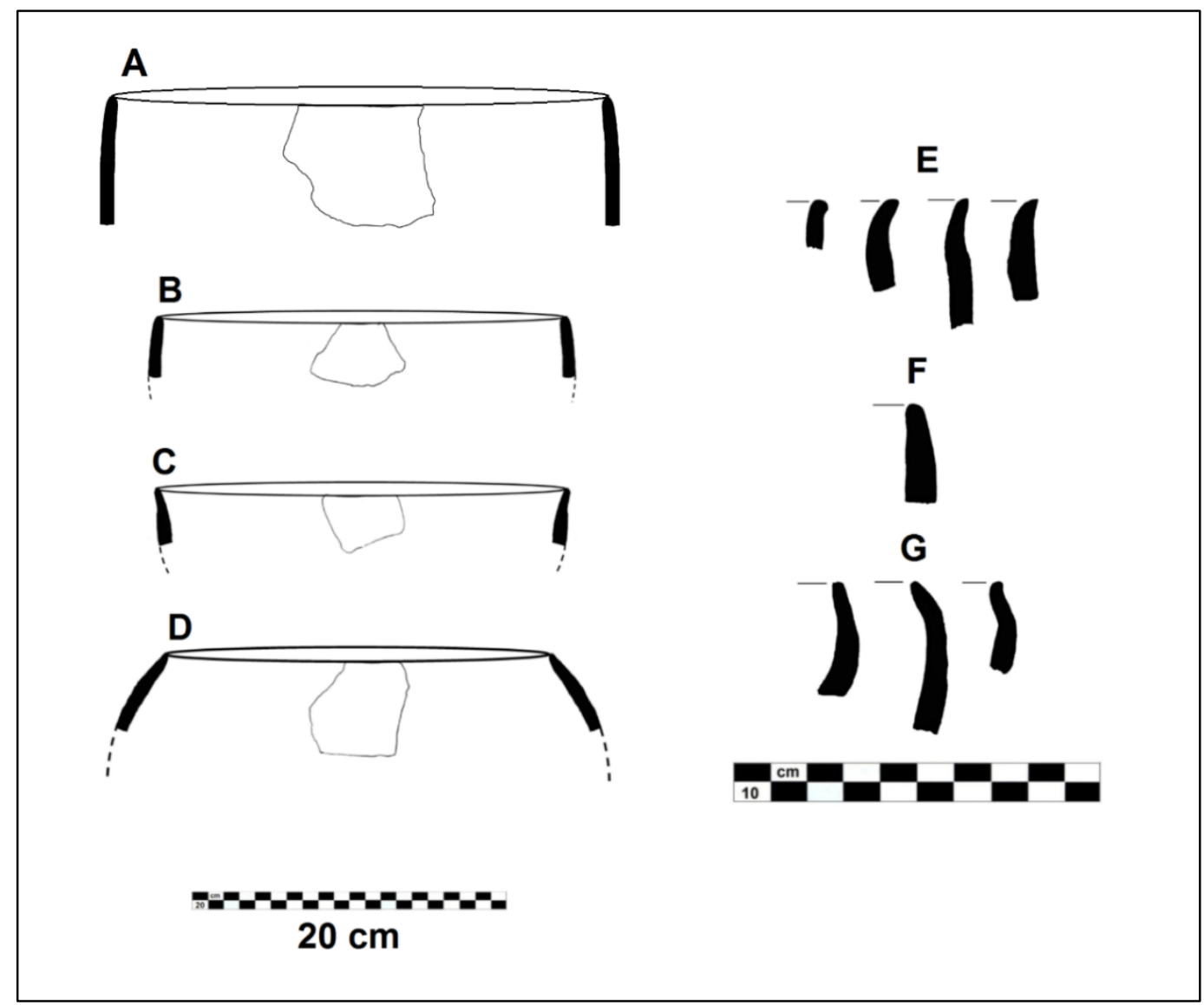

Figura 6.5. Vasijas reconstruidas, bordes y labios del Sector $B$.

Formas no restringidas con bordes rectos: A [AEP1 (APN) (2008)-RS-1] y B [AEP1 (2009)-RS-2]. Formas no restringidas con borde evertido: C [AEP1 (2009)-RS-1]. Forma restringida simple y dependiente con borde recto: D [AEP1 (APN) (2008)-RS-2]. E: bordes evertidos. F: bordes rectos. G: bordes invertidos.

El fragmento decorado presenta desplazamiento de materia sobre el labio mediante la técnica incisión de punto. No se registraron rastros de ahumado u hollín en ningún tiesto de la muestra. 


\section{2- TENDENCIAS GENERALES E INTERPRETACIONES}

En esta sección se extraen las tendencias generales y se realizan algunas interpretaciones sobre el registro arqueológico del sector B; estas últimas abonan la discusión final de la tesis realizada en el Capítulo 9.

\subsection{1- EL REGISTRO ARQUEOLÓGICO}

En cuanto a la distribución espacial de los conjuntos arqueológicos, la evidencia permite sostener que todos ellos se vinculan estrechamente a cursos de agua. Las prospecciones desarrolladas en zona de llanuras, donde predominan los palmares, y en los 16 afloramientos rocosos, no permitieron detectar evidencias arqueológicas. En este sentido, se ocuparon geoformas originadas por un ambiente fluvial (albardones y playas) y eólico (médanos). Se destaca que los sitios arqueológicos (excepto AV) se sitúan en zonas más cercanas al río Uruguay, a una distancia máxima de 2 km en línea recta a la costa (AEP2), mientras que la mayoría de los hallazgos aislados se ubican más hacia la llanura central, pero siempre asociados a algún curso de agua (Figura 6.1). Todos los conjuntos arqueológicos recuperados se encontraron en posición superficial a cielo abierto, en zonas abiertas con escasa vegetación como PS, AU y PA, o rodeados densa vegetación ribereña como ALL1, ALL2, AEP1, AEP2 y AV. La posición superficial de los conjuntos ha impedido la conservación de restos orgánicos. En todos los conjuntos es clara la superioridad numérica de los materiales líticos sobre los cerámicos.

\subsubsection{CONJUNTO LÍTICO}

En el sector B predominan ampliamente los desechos de talla $(n=499)$ por sobre los núcleos $(n=77)$ y los instrumentos $(n=36)$ (Tabla 6.2). Es importante destacar que la alta frecuencia de artefactos líticos del sitio arqueológico PS $(n=351)$ en relación a los demás conjuntos artefactuales, influyó en gran medida en las tendencias generales observadas. En relación a las materias primas identificadas (Tabla 6.3) se observa que la mayor frecuencia corresponde a la calcedonia $(n=257)$, seguida por el sílice $(n=159)$, caliza silicificada $(n=64)$, xilópalo $(n=53)$, arenisca $(n=46)$, ágata $(n=10)$, cuarcita intertrap $(n=10)$, silcreta $(n=6)$, cuarzo $(n=5)$ y basalto $(n=2)$. Ahora bien, si se consideran las materias primas de modo general en todo el sector se observa un predominio de las silíceas ( $n=564$; $92,2 \%)$ sobre las areniscas $(n=46 ; 7,5 \%)$ y el basalto $(n=2 ; 0,3 \%)$. Esto es acorde, en primer lugar con que las silíceas son consideradas como las de mejor calidad para la talla (Tabla 4.2); y en segundo lugar con la disponibilidad de materiales líticos en el área del PNEP, donde, debido a la litología de las formaciones Guichón, Salto Chico y la Terraza I del río Uruguay (véase Capítulo 3), los materiales silíceos son los más abundantes. Estos se encuentran conformando depósitos que habrían funcionado 
como canteras de materias primas inmediatamente disponibles $(<10 \mathrm{~km})$. En la actualidad, las canteras potenciales se encuentran a $500 \mathrm{~m}$ de los sitios arqueológicos (PS) y, en algunos casos, los conjuntos arqueológicos se encuentran sobre los mismos afloramientos y/o bancos de rodados (p. ej. ALL1, ALL2, ALL3 y PA).

Ahora bien, considerando los porcentajes de materias primas a nivel intrasitio, la mayor diferencia se observa en ALL2 donde el $96 \%(n=24)$ son artefactos silíceos y el $4 \%(n=1)$ de areniscas; seguido por PS con el 95,7\% ( $n=336)$ de artefactos silíceos y el 4,3\% ( $n=15)$ de areniscas; ALL1 con el $90,9 \%(n=20)$ de artefactos silíceos y el 9,1\% $(n=2)$ de areniscas; AEP2 con el $90 \%(n=18)$ de artefactos silíceos y el $10 \%(n=2)$ de areniscas; AEP1 con el $80 \%(n=8)$ de artefactos silíceos y el $20 \%(n=2)$ de areniscas; PA con el 79,2\% $(n=19)$ de artefactos silíceos y el $20,8 \%(n=5)$ de areniscas; y por último AU con el $75 \%(n=36)$ de artefactos silíceos, el 22,9\% $(n=11)$ de areniscas y el 2,1\% $(n=1)$ de basalto. En el caso particular de AV, el $100 \%$ de los artefactos son silíceos y corresponden a xilópalo. En general se observa que en todos los sitios arqueológicos considerados existe una tendencia marcada en favor de la explotación de materias primas silíceas.

Algunos de los instrumentos (Tabla 6.4) pueden ser considerados formales en el sentido de Andrefsky (1994), como por ejemplo los bifaces, raederas, raspadores, bolas y la punta de proyectil; en contraposición a los informales que componen parte de los hallazgos aislados y tal vez de algunos sitios arqueológicos, y están representados por las muescas, piezas con retoque sumario, denticulados con retoque sumario, piezas con retoque y los instrumentos compuestos. Los primeros habrían estado asociados a estrategias conservadas y los segundos a expeditivas; resultado de estas últimas también podrían ser, junto con los artefactos informales, las 14 lascas con rastros complementarios que indicarían el uso de filos naturales sin mayor preparación. La primera de estas estrategias no respondería, en este caso y como suele sostenerse (Andrefsky 1994; Bamforth 1986; entre otros), a la disponibilidad y maximización de materias primas, sino tal vez a la eficacia funcional de los instrumentos, a la inversión de tiempo en su manufactura u otras causas no económicas e invisibles en el registro (para una discusión más amplia, véase Colombo 2013; Escola 2004; Hermo 2008). No se considera que ambas estrategias fuesen mutuamente excluyentes, sino que en los asentamientos se habrían confeccionado tanto instrumentos conservados como expeditivos, y que los hallazgos aislados responderían a estrategias expeditivas de carácter puntual. Esto queda planteado a modo de hipótesis, dado que para establecer claramente las conductas que han generado estos conjuntos es necesario que se amplíe la muestra de sitios arqueológicos de la costa del río Uruguay.

A partir de los instrumentos tallados se observa una tendencia hacia la utilización de lascas externas, y en menor medida internas, de buena materia prima; a partir de las cuales se elaboraron sobre todo mediante retalla extendida y retoque y microretoque marginal, instrumentos bifaciales y filos unifaciales. En cuanto a las dimensiones de los instrumentos, en los tallados hay una predominancia marcada de piezas de módulos medianos y en proporciones similares en cuanto a 
espesores delgados y gruesos. En cuanto a los instrumentos elaborados por picado, abrasión y/o pulido o modificados por uso, estos tienden a ser mediano normales, grandes y gruesísimos. Particularmente los percutores, si bien son de tamaño mediano grande y grande (Tabla 6.4), no son percutores pesados por lo que habrían sido utilizados mayoritariamente para retalla y formatización final, más que para extracción en filones o la reducción de grandes de bloques (Colombo 2013; Escola 1993; Torrence 1986).

En relación a los desechos de talla y su estado de fragmentación (Tabla 6.5), más allá de las variaciones registradas en PS, AV y AU y dejando de lado los desechos indiferenciados, en todo el sector se registra un predominio de los desechos fracturados (lascas fracturadas -con y sin talón- y no clasificables) $(66,1 \%)$ sobre las lascas enteras $(23,1 \%)$. En cuanto a los tipos de lascas registrados (Tabla 6.6), excluyendo aquellos cuyo estado de fragmentación es indiferenciado, existe un predominio de lascas internas ( $n=265 ; 59,5 \%$ ) sobre las externas ( $n=161 ; 36,2 \%)$; el resto son indiferenciadas $(n=19$; $4,3 \%$ ). En la muestra total los desechos más representados son las lascas angulares (que incluyen cinco lascas de adelgazamiento bifacial y una lasca de reactivación de filo). El predominio de desechos fracturados sobre lascas enteras y de desechos internos sobre externos sugiere que en los sitios arqueológicos con mayor frecuencia artefactual (PS, AU y AV) las actividades más recurrentes fueron la formatización, la regularización y el mantenimiento de instrumentos. También se debe considerar que la presencia de las lascas externas sugiere que en algunos de los sitios arqueológicos (PS, AU, ALL1, ALL2 y AV) se realizó descortezamiento y reducción primaria. Asimismo, tal vez la menor frecuencia de lascas externas responda, por un lado, a que por ser este tipo de lascas las más utilizas para la confección de instrumentos (Tabla 6.4) los mismos fueron descartados fuera de los asentamientos, o por otro lado, a que una parte de la reducción primaria se habría realizado fuera de los asentamientos.

En relación a la distinción entre desechos externos e internos y sus implicancias, los talones de las lascas contribuyen con información al respecto (Tabla 6.7). En este sentido, se registró una amplio predominio de talones preparados (liso, diedro, facetado, filiforme, puntiforme y fracturado) $(n=183)$ sobre los corticales (natural y liso natural) ( $n=61$ ). Esto apoyaría la idea sobre la preparación de las plataformas de percusión para optimizar el resultado de los golpes, y además la propuesta anterior sobre la preponderancia de actividades de manufactura de instrumentos, sobre todo en PS y AU. En PS los talones se distribuyen en facetados ( $n=54)$, lisos $(n=49)$, corticales $(n=32)$, filiformes $(n=24)$, puntiformes $(n=5)$, diedros $(n=5)$ y fracturados $(n=5)$. No se observa una diferencia porcentual significativa entre los talones facetados y lisos, ambos tipos podrían evidenciar un descortezamiento inicial de los rodados mediante el uso de percusión directa (Nami 1991). Los talones corticales también serían indicadores de este tipo de actividad. Por su parte, los talones filiformes y puntiformes podrían estar asociados a la técnica de talla por presión (técnica registrada en dos de los instrumentos de PS y en la punta de proyectil de $\mathrm{LH})$. 
En cuanto a la combinación entre tipos de talón y bulbo (Tabla 6.7), la asociación más frecuente entre talones facetados con inclinación recta y bulbos difusos $(n=18)$ indicaría la búsqueda de lascas internas para la producción de instrumentos a partir de plataformas y frentes de extracción preparados; como además lo sugieren las lascas de PS con talones y frentes de extracción abradidos y retocados $(n=24)$, siendo estos atributos evidencia clara de la preparación tanto del frente de extracción como de la plataforma de percusión del núcleo, antes de la extracción. Por otra parte, en cuanto a la relación entre presencia/ausencia de labio y tipo de bulbo (Tabla 6.8) se observa que el $70 \%(n=171)$ de las lascas presentan labio, y que este se encuentra en frecuencias similares tanto en lascas con bulbo pronunciado ( $n=86 ; 35,2 \%$ ) como difuso ( $n=84 ; 34,4 \%$ ). La diferencia más significativa entre presencia/ausencia de labio y bulbos se da dentro del conjunto de lascas con el mismo tipo de bulbo. En este sentido, se observa que existe una mayor asociación entre bulbos pronunciados y presencia de labio, que entre bulbos difusos y labio; ya que dentro de las lascas con bulbos pronunciados el $77,5 \%(n=86)$ presenta labio, mientras que el $22,5 \%(n=25)$ carece de este rasgo. A su vez, dentro de las lascas con bulbos difusos la diferencia es un poco menos marcada, ya que el $67,8 \%$ $(n=84)$ presenta labio, mientras que el $32,2 \%(n=40)$ carece de este rasgo. La evidencia presentada sugiere un relativo predominio de percutores blandos y una relación directa entre percutor duro, con mayor fuerza de impacto, y la presencia de labio.

A partir del origen de extracción de lascas externas ( $n=133)$, internas $(n=43)$, indiferenciadas $(n=7)$ (Tabla 6.6) y desechos indiferenciados $(n=12)$ (Tabla 6.5), además de los tipos de talón (Tabla 6.7); se determinó que estos desechos de talla provienen en su mayoría de rodados fluviales silíceos de variadas morfologías $(n=180)$, donde predominan ampliamente los subesféricos $(n=109)$. Estos datos, junto a las materias primas identificadas (Tabla 6.3), apoyan la idea de que gran parte de los recursos líticos explotados proceden de los depósitos secundarios de rodados fluviales inmediatamente disponibles.

Considerando la presencia de corteza y número de lascados en la cara dorsal de las lascas internas y externas (Tabla 6.9), los resultados se ajustan a lo esperado. Dentro de las lascas externas $(n=161)$ las mayores proporciones de reserva de corteza se presentan en aquellas con menor cantidad de lascados y viceversa. En los sitios PS, AU, ALL1 y AV las lascas externas más frecuentes son las que presentan un negativo de lascado $(n=40)$ y en menor medida dos $(n=21)$. Por otra parte, cabe destacar que dentro de las lascas internas $(n=265)$ el $15,5 \%(n=41)$ presenta remanente de corteza, y este ocupa menos del $50 \%$ de su cara dorsal. Considerando los sitios arqueológicos con mayor número de lascas internas donde son mayoría las angulares (PS, AU y PA), se observa que en PS predominan las que tienen tres negativos de lascado ( $n=44 / 170)$; en $A U$ las que tienen tres y cuatro $(n=4 / 11)$; y en PA las que tienen cuatro lascados $(n=3 / 6)$. En este sentido, a partir de que tres y cuatro negativos de lascado son los más frecuentes se podría plantear que el proceso de talla en estos sitios arqueológicos habría sido relativamente intensivo. 
En cuanto a las dimensiones de los desechos de talla (Tablas 6.10, 6.11 y 6.12) predominan desechos de módulos medianos y espesores muy delgados. En este sentido, la preponderancia de módulos medianos refleja una talla orientada a la producción de lascas adecuadas para la posterior formatización de instrumentos, ya que como se observó previamente, los instrumentos fueron mayoritariamente elaborados a partir de lascas de módulos medianos (Tabla 6.4). Ahora bien, considerando particularmente el tamaño de los desechos de talla, se plantea que la ausencia y escasez de lascas de tamaño muy pequeño $(n=8,7,1 \%)$ y pequeño $(n=27,24,1 \%)$ en la mayoría de los conjuntos, respondería en parte al problema de visibilidad ya mencionado y a la acción de procesos posdepositacionales; que pudieron haber sesgado las frecuencias de los artefactos más chicos. En relación con esto, se observa que el 91,4\% de la muestra de lascas pequeñas (ocho muy pequeñas y 24 pequeñas) corresponde a PS y que además éstas constituyen el $44,4 \%$ de las lascas enteras de este sitio arqueológico. En este caso, además de plantear que PS está afectado por la visibilidad, se considera que la mayor representación de lascas pequeñas en este sitio arqueológico, en relación con los demás, se debe a la alta densidad artefactual que el mismo presenta, con un 95,7\% de desechos, y representando a la vez el $80,6 \%$ de la muestra total de desechos del sector B (Tabla 6.2). También cabe recordar que PS está muy elevado topográficamente, y posiblemente no haya sufrido el incremento del nivel de las aguas como algunos de los otros sitios arqueológicos (AU, ALL2, AEP1 y PA), donde el agua pudo haber sido un factor más que incidiera en la representación de artefactos pequeños.

Se recuperaron 77 núcleos (Tabla 6.13) caracterizados por buena y excelente materia prima, la mayoría de los planos de percusión son naturales, mayormente se usaron de uno a dos planos de percusión para extraer lascas, y en general presentan pocos lascados y gran proporción de corteza. Si se considera la distribución de núcleos por sitio arqueológico se observa que la mayor frecuencia la presentan AU, AEP2 y AV. Algunas diferencias observables entre estos tres sitios arqueológicos permiten sostener que $A U(n=14)$ presenta núcleos pequeños $(<10 \mathrm{~cm})$ de materias primas silíceas procedentes de la Formación Guichón y que fueron intensamente explotados ya que la mayoría ( $\mathrm{n}=$ 12) tiene menos del $50 \%$ de corteza. AEP2 $(n=12)$ presenta núcleos pequeños $(<10 \mathrm{~cm})$ de materias primas silíceas procedentes de rodados fluviales y que no fueron intensamente explotados ya que la mayoría ( $n=10$ ) tiene más del $50 \%$ de corteza. En AV ocurre una situación particular ya que se trata de núcleos de xilópalo $(\mathrm{n}=14)$ relativamente grandes $(8-20 \mathrm{~cm})$, tallados in situ, que no fueron intensamente explotados, ya que la mayoría $(n=10)$ tiene más del $50 \%$ de corteza. En este sitio arqueológico el xilópalo fue la única materia prima explotada, como lo evidencian los grandes núcleos con negativos de extracciones y fracturas (no pudieron ser transportados), los remontajes realizados y los desechos de talla recuperados.

Los porcentajes de reserva de corteza tanto en desechos de talla como en núcleos muestran una explotación predominante de depósitos secundarios de rodados de la Formación Salto Chico y de la Terraza I del río Uruguay. También se registró la presencia de 64 artefactos provenientes de la 
Formación Guichón, cuyas formas-base probablemente deriven de la extracción directa de los afloramientos o de recolección de clastos. Cualquiera que fuera la forma de obtención, la Formación Guichón es considerada en este estudio como una fuente primaria.

Considerando únicamente PS se pueden discutir aspectos relacionados con la funcionalidad y la ocupación del espacio. Este sitio arqueológico se vincula espacialmente con dos hallazgos aislados (LM2 y LM3), probablemente como parte de un mismo asentamiento, y el emplazamiento topográfico de estos tres conjuntos presenta una particularidad en relación con los restantes. Se sitúan en una zona muy elevada, sobre las barrancas altas de arroyo Ubajay. Desde allí se puede observar gran parte del área que actualmente ocupa el PNEP, por lo que, sin duda, estos fueron lugares estratégicos, no sólo por estar protegidos del aumento del nivel de las aguas del arroyo y del río Uruguay, sino también en relación con el dominio visual del entorno sobre determinados recursos y otros grupos humanos, como sostienen Molinari y Cansanello (1992: 14).

Las características topográficas de PS, más las propiedades del conjunto arqueológico allí recuperado, sumado a su cercanía a cursos de agua importantes (arroyo Ubajay y río Uruguay) permiten definir a Palmera Sola como un sitio arqueológico de actividades múltiples. No obstante, por tratarse de un sitio arqueológico superficial sobre un médano, podría darse el caso de que fuera un palimpsesto, es decir, que no responda a una sola ocupación, sino a varias, con distintas funciones a lo largo del tiempo. Allí se realizó la reducción primaria de rodados, la producción de lascas, la manufactura de instrumentos y su descarte (y probablemente también el mantenimiento de los mismos); además del uso y descarte de alfarería. Aunque el número de artefactos líticos y cerámicos recuperados es mucho menor que en PS, la caracterización como sitio arqueológico de actividades múltiples puede ser válida también para AU y AEP1, ambos con más del 60\% de desechos de talla.

Los restantes sitios arqueológicos (ALL1, ALL2, AEP2, PA y AV) presentan exclusivamente artefactos líticos. En ALL1, ALL2 y PA, el conjunto lítico se compone de más del 50\% de desechos de talla, más del 30\% de núcleos y una baja proporción de instrumentos (Tabla 6.2). En el caso de AEP2, se invierten las proporciones; predominan los núcleos con un $60 \%$ sobre los desechos con un $35 \%$, y el $5 \%$ restante corresponde a los instrumentos. Las características en conjunto de cada uno de estos sitios arqueológicos permitirían considerarlos como canteras-taller, donde se llevaron a cabo tareas vinculadas a la reducción primaria de rodados silíceos, los cuales no eran reducidos totalmente, ya que la mayoría de los núcleos presentan pocos lascados y conservan una gran proporción de corteza.

Particularmente AV tiene características que lo distingue del resto de los conjuntos arqueológicos del sector. En este sitio arqueológico se registró la explotación exclusiva de una sola materia prima (xilópalo); circunstancia que no había sido registrada en la región. Asimismo, el conjunto lítico se compone solo de desechos de talla $(n=38)$ y núcleos $(n=14)$, sin registrarse instrumentos (Tabla 6.2). Todos los núcleos (Tabla 6.13) tienen clastos como forma-base, y en general presentan tamaños grandes, pocos lascados y conservan gran proporción de corteza. Estos atributos distintivos 
de $\mathrm{AV}$, donde los artefactos en general se presentan fracturados, con gran proporción de corteza, pocos lascados, de tamaño relativamente grandes y donde además se pudieron realizar 22 remontajes, permiten plantear que este lugar corresponde a una cantera-taller de explotación de xilópalos. Donde se obtenían formas-base de lascas que serían reducidas y/o formatizadas en otros lugares. Ahora bien, dado que no es muy común encontrar una acumulación tan grande de esta materia prima, es pertinente preguntarse ¿si esta acumulación de xilópalos es natural o antrópica, o una combinación de ambos procesos?, cabe recordar que además del conjunto analizado aquí en el sitio arqueológico se dejaron dos núcleos que no pudieron ser transportados, además de otros grandes fragmentos de xilópalos que no presentaban claras evidencias de talla. La información obtenida hasta el momento sugiere que AV habría funcionado como un lugar donde en un primer momento se hallaron algunos xilópalos depositados naturalmente y en otro momento posterior las actividades de talla en el lugar propiciaron la acumulación y el transporte intencional de materia prima desde las cercanías hacia ese mismo punto, donde se obtenían las formas-base deseadas.

En cuanto a los hallazgos aislados, a excepción de LM2 y LM3 indudablemente relacionados a PS, los demás están compuestos en total por 36 desechos de talla, donde predominan las lascas externas ( $n=19)$, siete núcleos y siete instrumentos. Sólo dos presentan cerámica (AEP4 y AEP7) y en uno se determinó técnica de talla bipolar (EM). Si bien la muestra es chica, los conjuntos en general se relacionan con actividades de reducción primaria de recursos líticos (excepto LP y LH que presentan instrumentos formales). En este sentido, se plantean dos posibilidades: que los materiales respondan a estrategias expeditivas o que sean el resultado de procesos posdepositacionales que han alterado sitios arqueológicos de mayores dimensiones, con lo cual se modificó la distribución de sus materiales. La primera posibilidad coincide con lo planteado por Iriarte (1995) para la misma zona (margen uruguaya), quién destaca la presencia de conjuntos líticos expeditivos, en parte como consecuencia de la abundancia de materias primas. Esta postura también se ve fortalecida por el hecho de que entre los instrumentos que integran los hallazgos aislados (excepto LM2, LM3, LP y LH), cuatro son piezas con retoque sumario y uno es un percutor; artefactos cuya manufactura no estandarizada requiere un bajo gasto de tiempo y energía. La segunda opción podría considerarse la de menor probabilidad, ya que si bien la remoción fluvial debido a las crecidas del nivel de las aguas es uno de los agentes de transporte y redepositación más importantes de la zona, los materiales se recuperaron en topografías elevadas, adonde no suelen llegar las fluctuaciones regulares de los arroyos. Asimismo, sobre este último punto y sobre la representación de artefactos pequeños, restaría hacer una evaluación más detallada sobre los procesos posdepositacionales en el área.

A partir del análisis tecnomorfológico en general se puede observar que están presentes todas las etapas del proceso de producción lítica (Ericson 1984), desde el aprovisionamiento hasta el descarte. Está presente una tecnología de manufactura unifacial y bifacial. La técnica de talla predominante es la percusión directa con percutores blandos y duros, registrándose también por 
presión y bipolar; también hay instrumentos elaborados mediante picado, abrasión y/o pulido y modificados por uso. Se confeccionaron tanto instrumentos conservados y expeditivos, y también se usaron filos naturales.

La técnica de talla bipolar se registró en escasos artefactos, pero si se considera que en los contextos arqueológicos que presentan conjuntos líticos manufacturados sobre rodados es común la utilización de esta técnica (Bonomo y Prates 2009), se observa que, en este caso, su presencia no es significativa. Aquí, la talla bipolar probablemente responda a la reducción del tiempo de manufactura de algún artefacto (Flegenheimer et al. 1995), y no al aprovechamiento de materias primas escasas y de buena calidad o a una estrategia puramente ocasional (Curtoni 1996), dada la abundancia de buenos recursos líticos en la zona y a que tres de estos artefactos integran un sitio arqueológico considerado de actividades múltiples (AU). De la misma manera, esto fue registrado para la zona de Salto Grande (Argentina) y algunos sitios arqueológicos de la ROU (véase Capdepont 2012, Cigliano et al. 1971a; Rodríguez 1992; Tobella y Figueiro 2002; Vega y Andrade 2002). Asimismo, al igual que para la zona de Salto Grande (Nami 1992), se verifica la explotación de fuentes primarias y secundarias de materiales líticos, siendo ampliamente superior la explotación de las últimas por su calidad.

Considerando la importancia de las fuentes secundarias de rodados silíceos, se puede plantear que varias cuestiones vinculadas a su explotación pueden en parte explicarse por la alta disponibilidad, distribución y abundancia de estos depósitos. Entre los resultados se pueden mencionar, por ejemplo, que sean las formas-base predominantes y la materia prima más utilizada; que la mayoría de los núcleos no se encuentren agotados, sino con pocos lascados; escasos indicadores directos de talla bipolar (Curtoni 1996); los conjuntos probablemente expeditivos y la ausencia de formas estandarizadas (Bamforth 1986), ya que el aprovisionamiento demanda un bajo costo en el área del PNEP. Consideraciones semejantes para sitios arqueológicos de la margen izquierda del río Uruguay (ROU) son planteadas por Capdepont (2012), Iriarte (1995) y Vega y Andrade (2002). Todo esto indica que, a partir de los conjuntos estudiados no se puede proponer una estrategia de maximización de recursos líticos.

\subsection{3- CONJUNTO CERÁMICO}

Las alteraciones físicas que presenta la mayor parte de la muestra de alfarería $(98,4 \%)$ (Tabla 6.2), junto al alto grado de fragmentación, donde el $84,9 \%$ de la muestra total presenta tamaños menores a $5 \mathrm{~cm}$, indicaría modificaciones estructurales producto de la acción fluvial y/o eólica, y tal vez antrópica moderna. Esto sugiere que las superficies donde se han registrado los conjuntos arqueológicos, están sometidas a procesos posdepositacionales, que no solo estarían modificando la estructura de los artefactos, sino también la visibilidad y posiblemente la integridad de los sitios 
arqueológicos (Castro 2013; Poenitz 1970b). Además, esto podría explicar en parte la ausencia de rastros de ahumado u hollín en la muestra.

En referencia a la atmósfera de cocción inferida a partir de la observación del color del núcleo y de ambas superficies de los tiestos, se sugiere que la distribución de frecuencias de colores estaría indicando la predominancia de una cocción oxidante incompleta ( $n=59 ; 95,1 \%$ ), siendo el resto indeterminada ( $n=3 ; 4,9 \%$ ). Dentro de las inclusiones registradas se puede plantear que el tiesto molido de carácter claramente intencional, lo que sugiere cierto grado consideración especial en la preparación de la materia prima. Asimismo, la Dra. Inés Ezcurra de Drago (CONICET-INALI-UNL) ha determinado la presencia de espículas de esponja Uruguaya corallioides en un tiesto de AU y un tiesto de AEP1. Se considera que en estos dos casos, al igual que en todo el sector $B$, el agregado es intencional (para ampliar este punto véase Capítulo 5). Además, esta situación se registró en dos sitios arqueológicos relativamente alejados entre sí evidenciando una práctica común en el sector; concordando además con otros sectores del río Uruguay (Capdepont et al. 2013; Serrano 1933a; y véase Capítulo 7 y 8 ).

En cuanto a las formas de las vasijas su identificación estuvo condicionada por la integridad estructural y el tamaño de los bordes. Las formas estimadas son arriesgadas en este caso pero se hicieron considerando la variabilidad regional de formas. Las cuatro vasijas reconstruidas corresponden a AEP1. Se registraron tres vasijas no restringidas con paredes levemente divergentes, que corresponderían a cuencos grandes; y una vasija restringida de paredes invertidas, que correspondería a una olla. En relación a la funcionalidad es claro el predominio de cerámica utilitaria lisa. El tamaño de la muestra y su estado no permite avanzar más allá en relación al uso de los recipientes.

\section{3- CONSIDERACIONES FINALES}

A partir de las materias primas identificadas se determinó la utilización de recursos líticos inmediatamente disponibles, tanto de fuentes primarias (Formación Guichón) como secundarias (Formación Salto Chico y de la Terraza I del río Uruguay). Una situación similar se registra en la margen uruguaya un poco más al norte del sector B (Capdepont 2014). Asimismo, se determinó que hay una explotación diferencial materias primas en favor de las silíceas de buena y excelente calidad para la talla, mayormente provenientes de rodados fluviales. Estos rodados tienen una alta disponibilidad en la zona, tal vez por esta razón, como lo evidencian los núcleos, cada uno de ellos no era trabajado hasta su agotamiento, presentando una escasa reducción al momento de ser descartado. Estos depósitos se disponen en forma constante sobre la costa del río Uruguay y en ambas márgenes de los arroyos del 
PNEP, por lo que fueron una fuente secundaria de obtención de rocas y minerales por recolección, y de acceso inmediato.

El instrumental lítico también refleja actividades relacionadas directamente con la subsistencia. Las bolas y la punta de proyectil se asocian a la caza (o tal vez a violencia interpersonal), la punta también podría vincularse a la pesca. Los raspadores, bifaces, raederas, muescas, denticulados, piezas con retoque sumario y lascas con filos naturales se asocian con el procesamiento de subproductos de la caza, pesca y recolección. Por otro lado, los percutores indican la producción de instrumentos mediante talla por percusión directa. Las bolas reflejan el uso de la boleadora y la punta de proyectil podría asignarse a un arma de mano aunque no está claro si fue funcional o no. Para el río Uruguay medio Serrano (1933c) presenta lo que considera una punta arpón lítica procedente de Federación y la compara a otras procedentes de la ROU y Brasil. Esta pieza podría ser una punta de proyectil reciclada luego de que se le fracturara una aleta, semejante a la raedera de la Figura 5.8E (MTM-ER-469-029); Serrano presenta solo un dibujo y una descripción somera que impide determinar si se trata de una punta de proyectil reciclada o un instrumento completo.

Los desechos de talla y los núcleos muestran que en PS, AV y AU las actividades más recurrentes fueron la formatización, la regularización y el mantenimiento de instrumentos (Sullivan y Rozen 1985). Además, en PS, AU, ALL1, ALL2 y AV se realizó el descortezamiento y la reducción primaria de rodados fluviales y bloques de xilópalo, y la producción de formas-base mediante percusión directa.

Los palmares Butia yatay, que dan nombre al Parque Nacional, concentran numerosas especies florísticas y faunísticas. Específicamente el fruto de esta palmera es un recurso alimenticio de alto valor nutricional, que en época de madurez seguramente atrajo a los animales y a los seres humanos (como también sucede en la actualidad). La importancia de las palmeras en la subsistencia de los pueblos indígenas de la región ha sido destacada por Fernández (1979), quién plantea que en momentos históricos éstas tuvieron distinta relevancia y sufrieron distintos grados de intensidad en su explotación. Particularmente sobre el uso múltiple de las palmeras en la región en general resulta relevante el trabajo de Bonomo y Capeletti (2014).

La alfarería evidencia sobre todo un uso doméstico y predominan las formas simples, abiertas y sin decoración. Si bien no se recuperaron masas de arcilla cocida que evidencien la manufactura local de vasijas, el agregado intencional de tiesto molido y espículas de esponjas en la pasta implicó cierto grado especialización y conocimientos para la optimización del rendimiento estructural de las vasijas. La baja frecuencia de cerámica en relación a otros sitios arqueológicos de la costa del río Uruguay o del río Paraná (véase Bonomo et al. 2009, 2010; Lafon 1971; Rodríguez y Ceruti 1999; Serrano 1931, 1932a; entre otros; y véase Capítulo 7 y 8) es un aspecto a tener en cuenta con el objetivo de determinar si esto responde a las actividades de coleccionistas o aficionados (véase Lafon 1971), a los procesos posdepositacionales o simplemente a su escasa presencia en la zona. 
Otro punto importante es la ausencia total de alfarería guaraní, cuya presencia es mencionada en otros sitios arqueológicos de la región (p. ej. Isla del Medio, Isla de los Lobos, Isla Juanicó, Islas Mellizas, Isla Rica, Punta Negra Este, Guayacas, Hervidero, Cerro de Boari 3, Ensenada del Bellaco, El Arbolito, Isla del Pillo y Cerro de las Pajas Blancas) por algunos autores (Badano 1940a; Boretto et al. 1975; Capdepont 2012, 2014; Castro y Costa Angrizani 2014; Cigliano et al. 1971a). No hay hasta el momento artefactos de hueso, al contrario de la variedad que se registra en la zona de Salto Grande, en el río Paraná medio, en el río Uruguay inferior y en el Delta del río Paraná (Bonomo et al. 2009; Buc 2010a; Rodríguez 1992; entre otros); esta ausencia puede ser explicada por la posición superficial de los conjuntos arqueológicos.

En síntesis, algunos de los sitios arqueológicos de la zona del PNEP pueden ser considerados asentamientos residenciales de actividades múltiples (p. ej. PS, AU y AEP1). En ellos se desarrollaron actividades vinculadas a la subsistencia, como el procesamiento y consumo de alimentos; al aprovisionamiento, manufactura, uso y descarte de instrumentos líticos; y al uso y descarte de vasijas cerámicas. Asimismo, se identificaron sitios considerados como canteras-taller (p. ej. ALL1, ALL2, AEP2, $\mathrm{PA}$ y $\mathrm{AV}$ ) donde predominaron las actividades de obtención y talla de materias primas. El conjunto de los hallazgos aislados, donde predominan los subproductos de la manufactura (desechos de talla), también sugieren actividades de reducción inicial de rocas y minerales.

Para este sector no se cuenta con dataciones absolutas por carecer materiales datables. Los contextos arqueológicos más cercanos al PNEP que han sido datados y presentan alfarería se encuentran en la zona de Salto Grande; estos se ubican cronológicamente como máximo ca. 2500 años ${ }^{14}$ C AP (Baeza et al. 1977; Cigliano et al. 1971a; Politis et al. 2001; Rodríguez y Rodríguez 1985). Dada la presencia de alfarería en los algunos contextos arqueológicos del PNEP, se propone que estos corresponden al Holoceno tardío. 


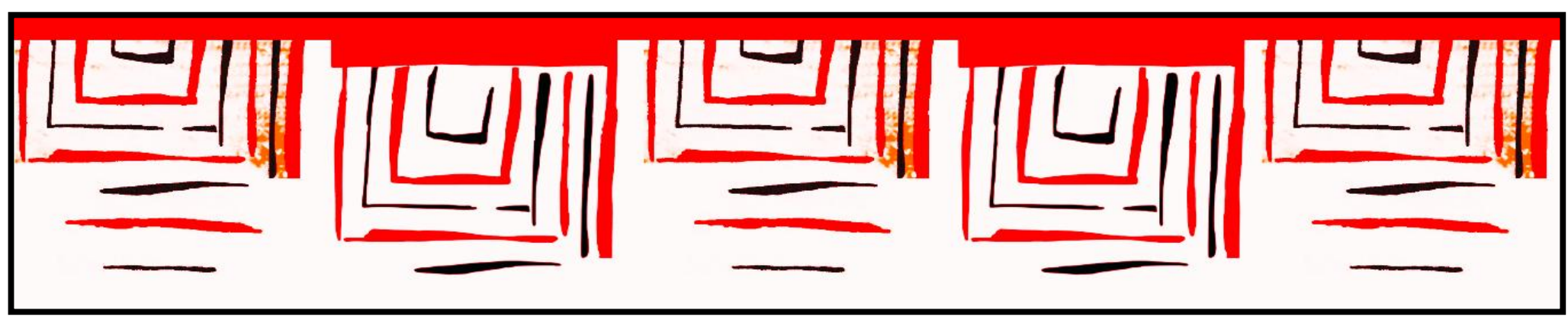

Capítulo 7

\section{DISTRIBUCIÓN ESPACIO-TEMPORAL Y CARACTERIZACIÓN DEL REGISTRO ARQUEOLÓGICO EN EL SECTOR C}

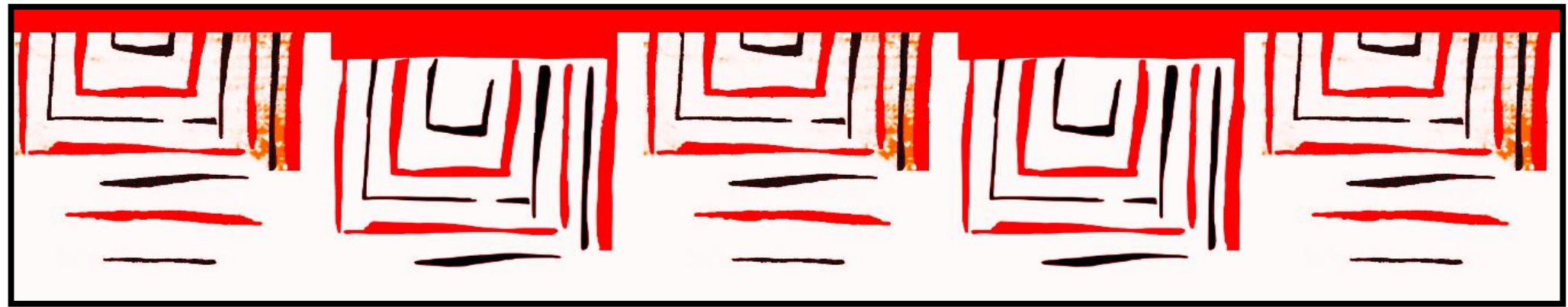




\section{CAPÍTULO 7}

\section{DISTRIBUCIÓN ESPACIO-TEMPORAL Y CARACTERIZACIÓN DEL REGISTRO ARQUEOLÓGICO EN EL SECTOR C}

En este capítulo se presentan y discuten los resultados de las prospecciones sistemáticas, de los sondeos estratigráficos y del análisis de los materiales arqueológicos recuperados en el sector $\mathrm{C}$, dentro del departamento Gualeguaychú. En el sector $C$ se realizaron prospecciones intensivas de manera pedestre y fluvial, sobre la margen derecha del río Uruguay y ambas márgenes del río Gualeguaychú y los arroyos Lorenzo, El Bellaco, de La Cruz, Ubajay, Mendisco, El Naranjo, Jeremías y Malo (Figura 7.1).

\section{1- RESULTADOS}

\subsection{1- SITIOS ARQUEOLÓGICOS Y HALLAZGOS AISLADOS}

Se identificaron 23 sitios arqueológicos, 13 en estratigrafía y el resto en posición superficial, y 22 hallazgos aislados superficiales (Tabla 7.1 y Figura 7.1). Se realizaron 17 sondeos estratigráficos, 18 perforaciones de barreno, 15 pruebas de pala y siete cortes artificiales de barrancas. Los materiales arqueológicos incluyen artefactos líticos, óseos y cerámicos, restos óseos humanos, faunísticos y vegetales (Tabla 7.2). Algunos de los sitios arqueológicos relevados en nuestras prospecciones fueron previamente estudiados por otros autores (p. ej. Almeida 1983a, 1983b; Cione et al. 1977; Greslebin 1931a; y Krapovickas 1957). Almeida fue quién más tiempo trabajó en el área y los materiales arqueológicos por él recuperados se encuentran depositados en el Museo Arqueológico Manuel Almeida (MAMA) de la ciudad de Gualeguaychú. Algunos de estos materiales son estudiados en la Sección 7.1.3. 
Tabla 7.1. Sitios arqueológicos y hallazgos aislados en el sector C.

\begin{tabular}{|c|c|c|c|c|}
\hline $\begin{array}{l}\text { Sigla en la } \\
\text { Figura } 7.1\end{array}$ & Sitios arqueológicos & Topografía & \multicolumn{2}{|c|}{$\begin{array}{c}\text { Coordenadas geográficas, } \\
\text { Datum Wgs84 }\end{array}$} \\
\hline CDB1 & Cerro de Boari 1 & montículo & $\mathrm{S} 33^{\circ}, 06899$ & O58, 43932 \\
\hline CDB2 & Cerro de Boari 2 & montículo & $\mathrm{S} 33^{\circ}, 06884$ & $\mathrm{O} 58^{\circ}, 43725$ \\
\hline CDB3 & Cerro de Boari 3 & montículo & $\mathrm{S} 33^{\circ}, 06871$ & $\mathrm{O} 58^{\circ}, 43660$ \\
\hline EP1 & El Pinar 1 & médano & $\mathrm{S} 33^{\circ}, 06569$ & O58, 39988 \\
\hline EP2 & El Pinar 2 & médano & $\mathrm{S} 33^{\circ}, 06629$ & $\mathrm{O} 58^{\circ}, 39796$ \\
\hline EP3 & El Pinar 3 & médano & $\mathrm{S} 33^{\circ}, 06575$ & $\mathrm{O} 58^{\circ}, 40081$ \\
\hline ME & Mendisco Este & médano & $\mathrm{S} 33^{\circ}, 06602$ & $\mathrm{O} 58^{\circ}, 39673$ \\
\hline MLB & Médano La Boya & médano & $\mathrm{S} 33^{\circ}, 06706$ & $\mathrm{O} 58^{\circ}, 34034$ \\
\hline $\mathrm{J} 1$ & Jeremías 1 & médano & $\mathrm{S} 33^{\circ}, 06564$ & $\mathrm{O} 58^{\circ}, 33536$ \\
\hline $\mathrm{CY}$ & Cerro Yaguar-í & albardón & $\mathrm{S} 33^{\circ}, 07122$ & $\mathrm{O} 58^{\circ}, 44312$ \\
\hline CL1 & Cerro Lorenzo 1 & montículo & $\mathrm{S} 33^{\circ}, 07397$ & $\mathrm{O} 58^{\circ}, 44237$ \\
\hline CL2 & Cerro Lorenzo 2 & montículo & $\mathrm{S} 33^{\circ}, 07639$ & $\mathrm{O} 58^{\circ}, 44530$ \\
\hline IDG1 & Isla de Goyri 1 & playa & $\mathrm{S} 33^{\circ}, 07191$ & $\mathrm{O} 58^{\circ}, 43253$ \\
\hline LC & La Correntina & albardón & $\mathrm{S} 33^{\circ}, 07241$ & $\mathrm{O} 58^{\circ}, 43168$ \\
\hline $\mathrm{ET}$ & El Taller & barranca & $\mathrm{S} 33^{\circ}, 07557$ & $\mathrm{O} 58^{\circ}, 42242$ \\
\hline EDB & Ensenada del Bellaco & albardón & $\mathrm{S} 33^{\circ}, 09147$ & $058^{\circ}, 43493$ \\
\hline T1-CNM & Túmulo 1 - Cerro Norte de Machado & montículo & $\mathrm{S} 33^{\circ}, 12673$ & $\mathrm{O} 58^{\circ}, 46266$ \\
\hline T2-CSM & Túmulo 2 - Cerro Sur de Machado & montículo & $\mathrm{S} 33^{\circ}, 12781$ & $\mathrm{O} 58^{\circ}, 46210$ \\
\hline SPL & Sambaquí de Puerto Landa & montículo & $\mathrm{S} 33^{\circ}, 32362$ & $\mathrm{O} 58^{\circ}, 45372$ \\
\hline EAV & El Aserradero Viejo & montículo & $\mathrm{S} 33^{\circ}, 33545$ & $\mathrm{O} 58^{\circ}, 47082$ \\
\hline $\mathrm{CP}$ & Cerros de los Pampas & montículo & $\mathrm{S} 33^{\circ}, 34246$ & $\mathrm{O} 58^{\circ}, 48743$ \\
\hline$F Q$ & Fajina Quemada & montículo & $\mathrm{S} 33^{\circ}, 34466$ & $\mathrm{O} 58^{\circ}, 47717$ \\
\hline LCs & Las Conchillas & montículo & $\mathrm{S} 33^{\circ}, 36854$ & $\mathrm{O} 58^{\circ}, 50010$ \\
\hline $\begin{array}{c}\mathrm{N}^{\circ} \text { en la } \\
\text { Figura } 7.1\end{array}$ & Hallazgos aislados & Topografía & \multicolumn{2}{|c|}{$\begin{array}{c}\text { Coordenadas geográficas, } \\
\text { Datum Wgs84 }\end{array}$} \\
\hline 1 & EP4 (El Pinar 4) & médano & $\mathrm{S} 33^{\circ}, 06617$ & $058^{\circ}, 39821$ \\
\hline 2 & EP5 (El Pinar 5) & médano & $\mathrm{S} 33^{\circ}, 06582$ & $\mathrm{O} 58^{\circ}, 39770$ \\
\hline 3 & N1 (Ñandubaysal 1) & médano & $\mathrm{S} 33^{\circ}, 06673$ & $\mathrm{O} 58^{\circ}, 39427$ \\
\hline 4 & N2 (Ñandubaysal 2) & médano & $\mathrm{S} 33^{\circ}, 06598$ & $\mathrm{O} 58^{\circ}, 39675$ \\
\hline 5 & N3 (Ñandubaysal 3) & playa & $\mathrm{S} 33^{\circ}, 06791$ & $\mathrm{O} 58^{\circ}, 38173$ \\
\hline 6 & J2 (Jeremías 2) & médano & $\mathrm{S} 33^{\circ}, 06690$ & $\mathrm{O} 58^{\circ}, 33584$ \\
\hline 7 & J3 (Jeremías 3) & médano & $\mathrm{S} 33^{\circ}, 06540$ & $\mathrm{O} 58^{\circ}, 33585$ \\
\hline 8 & J4 (Jeremías 4) & médano & $\mathrm{S} 33^{\circ}, 06186$ & $\mathrm{O} 58^{\circ}, 33904$ \\
\hline 9 & ERU1 (Estancia Río Uruguay 1) & médano & $\mathrm{S} 33^{\circ}, 07033$ & $\mathrm{O} 58^{\circ}, 32491$ \\
\hline 10 & ERU2 (Estancia Río Uruguay 2) & médano & $\mathrm{S} 33^{\circ}, 07007$ & $\mathrm{O} 58^{\circ}, 32573$ \\
\hline 11 & ERU3 (Estancia Río Uruguay 3) & médano & $\mathrm{S} 33^{\circ}, 06999$ & $\mathrm{O} 58^{\circ}, 32619$ \\
\hline 12 & ERU4 (Estancia Río Uruguay 4) & médano & $\mathrm{S} 33^{\circ}, 06951$ & $\mathrm{O} 58^{\circ}, 32777$ \\
\hline 13 & ELV (Estancia La Victoria) & médano & $\mathrm{S} 33^{\circ}, 04922$ & $\mathrm{O} 58^{\circ}, 30180$ \\
\hline 14 & AL (Arroyo Lorenzo) & playa & $\mathrm{S} 33^{\circ}, 07735$ & $058^{\circ}, 44565$ \\
\hline 15 & IDG2 (Isla de Goyri 2) & playa & $\mathrm{S} 33^{\circ}, 07132$ & $\mathrm{O} 58^{\circ}, 43972$ \\
\hline 16 & IDG3 (Isla de Goyri 3) & playa & $\mathrm{S} 33^{\circ}, 07159$ & $\mathrm{O} 58^{\circ}, 44001$ \\
\hline 17 & IDG4 (Isla de Goyri 4) & playa & $\mathrm{S} 33^{\circ}, 07169$ & $\mathrm{O} 58^{\circ}, 44034$ \\
\hline 18 & IDG5 (Isla de Goyri 5) & playa & $\mathrm{S} 33^{\circ}, 07154$ & $\mathrm{O} 58^{\circ}, 43885$ \\
\hline 19 & IDG6 (Isla de Goyri 6) & playa & $\mathrm{S} 33^{\circ}, 07146$ & $058^{\circ}, 43970$ \\
\hline 20 & IDG7 (Isla de Goyri 7) & playa & $\mathrm{S} 33^{\circ}, 07148$ & $\mathrm{O} 58^{\circ}, 43762$ \\
\hline 21 & IDG8 (Isla de Goyri 8) & playa & $\mathrm{S} 33^{\circ}, 07193$ & $\mathrm{O} 58^{\circ}, 43250$ \\
\hline 22 & IDG9 (Isla de Goyri 9) & playa & $\mathrm{S} 33^{\circ}, 07229$ & O58, 43191 \\
\hline
\end{tabular}




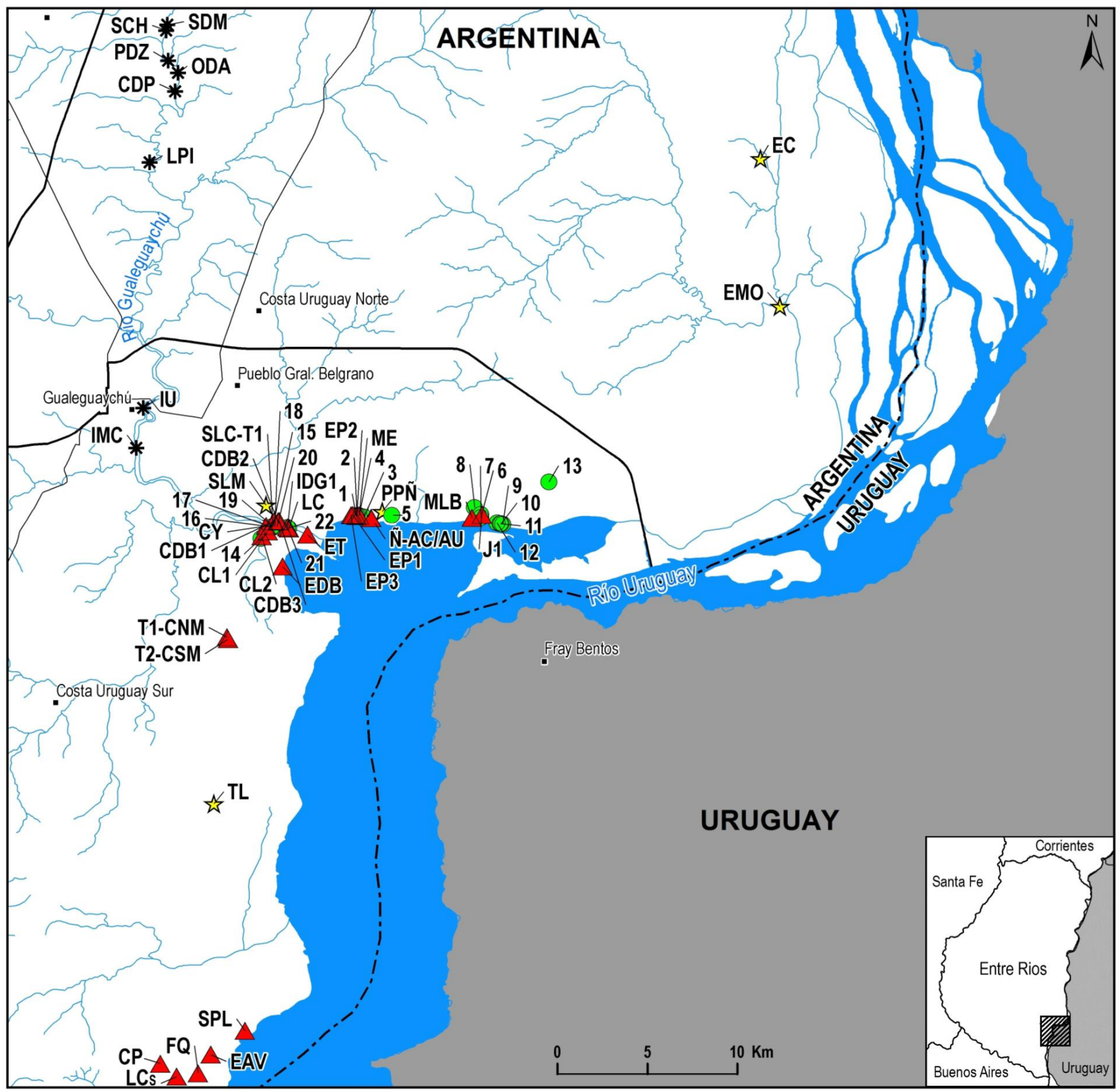

Figura 7.1. Sector $C$ indicando los sitios arqueológicos (triángulos), los hallazgos aislados (círculos), los conjuntos arqueológicos de la colección del Museo Arqueológico Manuel Almeida (estrella) y la punta de proyectil de Ñandubaysal (PPÑ) (estrella); la ubicación de estos últimos se realizó utilizando Google Earth.

También se indican algunos de los afloramientos de arenisca antiguos y actuales del río Gualeguaychú (asteriscos): Salto de Méndez (SDM), Salto Chico (SCH), Picada del Zapatero (PDZ), Ojo de Agua (ODA), Cancha de Piedra (CDP), Las Piedras (LPI), Islote Ubajay (IU) e Islote Martín Chico (IMC).

\subsubsection{1- Descripción contextual de los sitios arqueológicos y sus conjuntos artefactuales}

Cerro de Boari 1, 2 y 3 conforman la localidad arqueológica Cerros de Boari, que es estudiada integralmente en el Capítulo 8. 


\section{El Pinar 1 (EP1)}

Ubicado en la margen derecha del río Uruguay, en una zona de médanos cercana a la desembocadura del río Gualeguaychú (Figura 7.2A). El lugar se encuentra entre una plantación de pinos y la costa del río, la distribución de los materiales no es homogénea ya que se concentra en las zonas bajas de las dunas. Se realizó una recolección superficial dirigida y dos pruebas de pala. Los materiales incluyen tres desechos de talla; nueve fragmentos de borde de alfarería y 118 de cuerpo (siete decorados -cuatro bordes y tres cuerpos- y 120 lisos -cinco bordes y 115 cuerpos) (Tabla 7.2).

\section{El Pinar 2 (EP2)}

Ubicado a $120 \mathrm{~m}$ al este de EP1, en la misma zona de médanos. Se realizó una recolección superficial dirigida. Los materiales incluyen un desecho de talla; seis fragmentos de borde y 80 de cuerpo (cinco decorados -tres bordes y dos cuerpos- y 81 lisos -tres bordes y 78 cuerpos); y un fragmento de concha de bivalvo (NISP) (Tabla 7.2).

\section{El Pinar 3 (EP3)}

Ubicado a $110 \mathrm{~m}$ al oeste de EP1, en la misma zona de médanos. Se realizó una recolección superficial dirigida y una prueba de pala. Los materiales incluyen nueve fragmentos de borde y $97 \mathrm{de}$ cuerpo, todos lisos (Tabla 7.2). Además, se registró una masa de arcilla cocida.

\section{Mendisco Este (ME)}

Ubicado a $160 \mathrm{~m}$ al sudeste de EP2, en la margen izquierda de un curso de agua menor que desemboca en el río Uruguay. Se realizó una recolección superficial dirigida. Los materiales incluyen un instrumento lítico; un fragmento de borde y 21 de cuerpo, todos lisos (Tabla 7.2).

\section{Médano La Boya (MLB)}

Ubicado en la margen derecha del río Uruguay, en una zona de médanos a 200 m de la costa (Figura 7.2B). Se realizó una recolección superficial dirigida. Los materiales incluyen un instrumento, 11 desechos de talla y seis núcleos; 22 fragmentos de borde y 108 de cuerpo (13 decorados -tres bordes y 10 cuerpos- y 117 lisos -19 bordes y 98 cuerpos-) (Tabla 7.2). Además, se registraron concreciones de pigmentos minerales amarillentos $(n=2)$.

\section{Jeremías 1 (J1)}

Ubicado en la margen derecha del arroyo Jeremías, en una zona de médanos a $558 \mathrm{~m}$ de la desembocadura del arroyo en el río Uruguay, y a $491 \mathrm{~m}$ al noreste de MLB. Se realizó una recolección superficial dirigida y tres pruebas de pala. Los materiales incluyen ocho desechos de talla; nueve 
fragmentos de borde y 72 de cuerpo, todos lisos (Tabla 7.2). Además, se registraron masas de arcilla cocida $(n=3)$.

\section{Cerro Yaguar-í (CY)}

Ubicado sobre un albardón a $10 \mathrm{~m}$ de la margen derecha del río Gualeguaychú. Presenta forma elíptica y su eje mayor oeste-este mide $35 \mathrm{~m}$ y el eje norte-sur varía entre 6 y $10 \mathrm{~m}$ aproximadamente, tiene una altura de $2 \mathrm{~m}$ en relación al terreno circundante caracterizado por selva ribereña. Sobre la playa ubicada entre del sitio y el río se realizó una recolección superficial dirigida, en la parte más alta del albardón se realizó un sondeo estratigráfico $(0,5 \times 0,5 \times 0,6 \mathrm{~m})$ y una prueba de pala. El material arqueológico se presenta entre los 0,10 y $0,50 \mathrm{~m}$ de profundidad. Los materiales recuperados incluyen 16 fragmentos de borde y 139 de cuerpo (tres decorados -tres bordes- y 152 lisos -13 bordes y 139 cuerpos-); dos peces y cuatro mamíferos (NISP) (Tabla 7.2). Además, se registraron masas de arcilla cocida $(n=20)$ y carbón $(n=1)$. Este sitio arqueológico fue estudiado previamente por Almeida (1983a).

\section{Cerro Lorenzo 1 (CL1)}

Montículo ubicado a $10 \mathrm{~m}$ de la margen derecha del arroyo Lorenzo, en la Isla de Goyri. Presenta forma circular con un diámetro mayor de $16 \mathrm{~m}$ y una altura de 1,2 m en relación al terreno circundante caracterizado por selva ribereña. Se realizó un sondeo estratigráfico $(0,5 \times 0,5 \times 0,3 \mathrm{~m})$ en la parte más elevada del montículo sin llegar a niveles estériles, y tres pruebas de pala en la periferia. Los materiales recuperados incluyen 13 fragmentos de borde y 72 de cuerpo, todos lisos; 82 peces, 49 mamíferos, un reptil y nueve especímenes indeterminados (NISP) (Tabla 7.2). Además, se registraron masas de arcilla cocida $(n=21)$, carbón $(n=4)$, y hasta los $0,15 \mathrm{~m}$ de profundidad fragmentos de Whiteware $(n=1)$, gres $(n=3)$, vidrio $(n=5)$, teja $(n=1)$ y ladrillos $(n=14)$.

\section{Cerro Lorenzo 2 (CL2)}

Montículo sobre un gran albardón ubicado a $30 \mathrm{~m}$ de la margen izquierda del arroyo Lorenzo (Figura 7.2C). Tiene forma elipsoidal, su eje mayor norte-sur mide $45 \mathrm{~m}$ y el eje oeste-este mide 18 $\mathrm{m}$, tiene una altura de $1,5 \mathrm{~m}$ en relación al terreno circundante caracterizado por selva ribereña y pajonales. Se realizó una recolección superficial dirigida y tres sondeos estratigráficos $(0,5 \times 0,5 \times 0,2 \mathrm{~m}$; 0,5 $\times 0,5 \times 0,5 \mathrm{~m}$; y $1 \times 1 \times 0,45 \mathrm{~m}$ ) en la parte más elevada del montículo sin llegar a niveles estériles. Los materiales recuperados incluyen un instrumento, 31 desechos de talla y un núcleo; 118 fragmentos de borde y 672 de cuerpo (21 decorados -12 bordes y nueve cuerpos- y 769 lisos -106 bordes y 663 cuerpos-); 1309 peces, 383 mamíferos, 344 moluscos, 78 reptiles, dos aves, un anuro y 96 especímenes indeterminados (NISP) (Tabla 7.2). Se agregan cuatro especímenes que han sido transformados en dos instrumentos óseos (Tabla 7.16) y un adorno de valva de molusco, y el 
restante es un fragmento de artefacto óseo decorado (Sección 7.1.2.3). Asimismo, se cuentan 18 especímenes óseos humanos que corresponden a un individuo. Además, se registraron masas de arcilla cocida $(n=118)$, carbón $(n=28)$, restos de un fogón, y hasta los $0,10 m$ de profundidad fragmentos de Whiteware $(n=1)$, hierro $(n=2)$, alambre $(n=2)$ y un botón de metal $(n=1)$. Se obtuvo una datación radiocarbónica de $2050 \pm 60$ años ${ }^{14} \mathrm{C}$ AP (Sección 7.1.4; Tabla 7.25). Este sitio arqueológico también es denominado Túmulo del Arroyo Lorenzo y fue estudiado previamente por Almeida (1983a).

\section{Isla de Goyri 1 (IDG1)}

Ubicado sobre una pequeña playa costera en la margen derecha del río Gualeguaychú, en la Isla de Goyri en un entorno caracterizado por selva ribereña, bañados y pajonales. Se realizó una recolección superficial dirigida. Los materiales incluyen nueve desechos de talla, un núcleo; dos fragmentos de borde y 32 de cuerpo (17 decorados -un borde y 16 cuerpos- y 17 lisos -un borde y 16 cuerpos-) (Tabla 7.2). Además, se registraron masas de arcilla cocida $(n=1)$, gres $(n=1)$ y vidrio $(n=7)$.

\section{La Correntina (LC)}

Ubicado sobre un albardón adyacente a la margen derecha del río Gualeguaychú, en la Isla de Goyri. Tiene forma elipsoidal, su eje mayor este-oeste mide $35 \mathrm{~m}$ y el eje norte-sur $18 \mathrm{~m}$, tiene una altura de 1,5 $\mathrm{m}$ en relación al terreno circundante caracterizado por selva ribereña, bañados y pajonales. Antiguamente existía sobre el mismo un puesto rural. Se realizó una recolección superficial dirigida, dos sondeos estratigráficos $(1 \times 1 \times 0,85 \mathrm{~m}$ y $0,5 \times 0,5 \times 0,5 \mathrm{~m})$ y tres pruebas de barreno de 0,25 $\mathrm{m}$ de diámetro y 0,90 $\mathrm{m}$ de profundidad. Todas las pruebas de barreno y el sondeo 1 se ubicaron en el eje más largo del albardón siguiendo una orientación paralela al río y en la zona más elevada. El sondeo 2 se ubica cerca de la barranca generada por la acción del río que ha erosionado gran parte del albardón original. Los materiales recuperados incluyen un desecho de talla; tres fragmentos de borde y 23 de cuerpo (ocho decorados -dos bordes y seis cuerpos- y 18 lisos -un borde y 17 cuerpos-); y un mamífero (NISP) (Tabla 7.2). Además, se registró carbón ( $n=1)$. Este sitio arqueológico fue estudiado previamente por Almeida (1983a) y durante nuestro relevamiento se observó que el río Gualeguaychú lo ha erosionado casi completamente.

\section{El Taller (ET)}

Ubicado a $976 \mathrm{~m}$ al este de LC sobre la barranca costera en la margen derecha del río Gualeguaychú, en la Isla de Goyri rodeado por selva ribereña. Consiste en una concentración de areniscas y rodados de la Formación Salto Chico que se extiende aproximadamente por $40 \mathrm{~m}$ metros paralela a la barranca. Se registraron bloques y clastos de areniscas y algunos xilópalos. Se realizó 
una recolección superficial dirigida. Los materiales incluyen un instrumento, 37 desechos de talla y dos núcleos (Tabla 7.2).

\section{Ensenada del Bellaco (EDB)}

Ubicado sobre un extenso albardón paralelo a la margen derecha del río Uruguay a $20 \mathrm{~m}$ de la costa, en la Isla de Goyri. Tiene forma elipsoidal, su eje mayor norte-sur mide $150 \mathrm{~m}$ y el eje esteoeste mide $30 \mathrm{~m}$, tiene una altura de $2 \mathrm{~m}$ en relación al terreno circundante caracterizado por selva ribereña, bañados y pajonales. Antiguamente existía sobre el mismo una pesquería comercial y una plantación de papa. En el sector central del albardón se realizó una recolección superficial dirigida, un sondeo estratigráfico $(1 \times 1 \times 1,10 \mathrm{~m})$, quince pruebas de barreno de $0,25 \mathrm{~m}$ de diámetro y $0,90 \mathrm{~m}$ de profundidad (distribuidas en tres líneas paralelas, orientadas norte-sur y distantes $5 \mathrm{~m}$ entre sí) y cinco pruebas de pala de $0,30 \mathrm{~m}$ de lado y profundidades variables entre $0,75 \mathrm{~m}$ y $1 \mathrm{~m}$. Los materiales recuperados incluyen un desecho de talla y un núcleo; siete fragmentos de borde, 25 de cuerpo y dos tiestos indeterminados (22 decorados -seis bordes, 15 cuerpos y un indeterminado- y 12 lisos -un borde, 10 cuerpos y un indeterminado-) (Tabla 7.2). Además, se registraron masas de arcilla cocida $(n=4)$, carbón $(n=13)$, y hasta los 0,25 m de profundidad gres $(n=1)$, vidrio $(n=1)$ y clavos $(n=2)$. Asimismo, se obtuvo una datación radiocarbónica de $526 \pm 45$ años ${ }^{14} \mathrm{C} \mathrm{AP}$ (Sección 7.1.4; Tabla 7.25). Este sitio arqueológico también es denominado Pesquería Vieja y fue estudiado previamente por Almeida (1983a, s/fb).

\section{Túmulo 1 - Cerro Norte de Machado (T1-CNM)}

Montículo ubicado a $2 \mathrm{~m}$ de la margen derecha del arroyo Bellaco y a $3890 \mathrm{~m}$ de la costa del río Uruguay y a $2280 \mathrm{~m}$ de la desembocadura del arroyo. Tiene forma oval, su eje mayor norestesudoeste mide $58,5 \mathrm{~m}$ y el eje noroeste-sudeste mide $40 \mathrm{~m}$, tiene una altura de $4,5 \mathrm{~m}$ en relación al terreno circundante caracterizado por selva ribereña, bañados y pajonales. Sobre este sitio, y también sobre T2-CSM, pasa actualmente un camino rural. No se recolectaron materiales arqueológicos. Este sitio arqueológico fue estudiado previamente por Almeida (1983a)

\section{Túmulo 2 - Cerro Sur de Machado (T2-CSM)}

Montículo ubicado $5 \mathrm{~m}$ al sudoeste de T1-CNM, adyacente a la margen derecha del arroyo Bellaco (Figura 7.2D). Tiene forma elipsoidal, su eje mayor noreste-sudoeste mide $200 \mathrm{~m}$ y el eje noroeste-sudeste mide $20 \mathrm{~m}$, tiene una altura de $4,5 \mathrm{~m}$ en relación al terreno circundante caracterizado por selva ribereña, bañados y pajonales. Antiguamente existía sobre el mismo un puesto rural. Se recolectó superficialmente un núcleo (Tabla 7.2). Se obtuvo una datación radiocarbónica de $840 \pm 50$ años ${ }^{14} \mathrm{C}$ AP (Sección 7.1.4; Tabla 7.25). Este sitio arqueológico fue estudiado previamente por Almeida (1983a). 


\section{Sambaquí de Puerto Landa (SPL)}

Montículo ubicado a 500 m de la margen derecha del río Uruguay (véase también Greslebin 1931a, figura 26). Tiene forma elipsoidal, su eje mayor noreste-sudoeste mide $80 \mathrm{~m}$ y el eje noroestesudeste mide $38 \mathrm{~m}$, tiene una altura de $3 \mathrm{~m}$ en relación al terreno circundante caracterizado por selva ribereña, bañados y pajonales. En el extremo noreste del montículo se realizó un sondeo estratigráfico $(1 \times 1 \times 0,70 \mathrm{~m})$. Los materiales recuperados incluyen 77 desechos de talla y dos núcleos; 187 fragmentos de borde y 2661 de cuerpo (118 decorados -62 bordes y 56 cuerpos- y 2730 lisos 125 bordes y 2605 cuerpos-); 22242 peces, 3513 moluscos, 717 mamíferos, 29 reptiles, seis anfibios, tres aves y 692 especímenes indeterminados (NISP) (Tabla 7.2). Se agregan cuatro especímenes óseos que han sido transformados en tres instrumentos (Tabla 7.16), y el restante es un fragmento de artefacto decorado (Sección 7.1.2.3). Asimismo, se cuentan 39 especímenes óseos humanos que corresponden a un individuo. Además, se registraron masas de arcilla cocida $(n=1288)$, carbón $(n=$ $332)$, concreciones de pigmentos minerales rojos $(n=129)$, numerosos endocarpos de palmera carbonizados y fragmentados, restos de un fogón, y hasta los 0,35 $\mathrm{m}$ de profundidad fragmentos de vidrio $(n=6)$. Se obtuvo una datación radiocarbónica de $630 \pm 50$ años ${ }^{14} \mathrm{C}$ AP (Sección 7.1.4; Tabla 7.25).

Este sitio arqueológico fue excavado previamente por Greslebin (1931a), Krapovickas (1957) quién lo denomina Cerro de Godoy (véase Capítulo 2), y Almeida (1983a). Las dimensiones presentadas aquí varían levemente con las aportadas por estos autores, lo que probablemente se deba a la erosión fluvial del río Uruguay, a la existencia de un antiguo puesto rural encima y a las actividades antrópicas modernas.

\section{El Aserradero Viejo (EAV)}

Montículo ubicado a $1100 \mathrm{~m}$ de la margen derecha del río Uruguay. Tiene forma oval, su eje mayor norte-sur mide $58 \mathrm{~m}$ y el eje este-oeste mide $40 \mathrm{~m}$, tiene una altura de $3 \mathrm{~m}$ en relación al terreno circundante caracterizado por selva ribereña, bañados y pajonales. En su parte más elevada presenta restos de una construcción dedicada a la explotación de madera. No se recolectaron materiales arqueológicos. Este sitio arqueológico fue visitado previamente Krapovickas (1957) quién menciona que se halla muy destruido (véase Capítulo 2), y también fue referenciado por Cione y colaboradores (1977, Figura 1). También fue estudiado previamente por Almeida (1983a, s/fa) y denominado El Aserradero (EAS; en Castro 2016).

\section{Cerros de los Pampas (CP)}

Dos montículos ubicados a $1100 \mathrm{~m}$ de la margen derecha del río Uruguay. Estas dos elevaciones antiguamente constituían un solo montículo, a partir de 1940 fue seccionado en dos para construir un canal de desagüe. La forma original montículo era elipsoidal y su eje mayor noreste- 
sudoeste mide $315 \mathrm{~m}$ y el eje noroeste-sudeste mide $55 \mathrm{~m}$, y una altura aproximada de $7 \mathrm{~m}$ desde el nivel de los bañados que lo circundan. No se recolectaron materiales arqueológicos. Este sitio arqueológico fue estudiado previamente por Greslebin (1931a), Krapovickas (1957), Cione y colaboradores (1977) (véase Capitulo 2), y también por Almeida (1983a). Ha sido mencionado por estos autores como Túmulos de Estoponda (Greslebin 1931a), Cerros de los Pampas (Krapovickas 1957), Cerros de Las Pampas o Dos Cerros (Cione et al. 1977), o también como Cerro Pampa (Almeida 1983a).

En esta zona la franja costera del río Uruguay se caracteriza por terrenos bajos donde predominan los bañados y esteros, las únicas superficies emergidas son los extensos albardones depositados por el río Uruguay, sobre los cuales se ubican en la mayoría de los casos los sitios arqueológicos. Desde el siglo XIX estos albardones, muchos de los cuales están interconectados, han sido utilizados como base para construir caminos que permitan el acceso desde las llanuras altas hasta la costa del río. Como resultado, estas geoformas y/o sitios arqueológicos han sido modificados, en muchos casos siendo seccionados longitudinal o transversalmente por los caminos y/o canales modernos. Este es el caso de $\mathrm{CP}$, donde una de sus laderas está demarcada por un camino adyacente, que luego divide al albardón en su extremo noroeste en dos secciones; asimismo, el albardón está seccionado transversalmente en su sector medio por un canal. Todas estas modificaciones han provocado que Almeida distinga entre distintos sectores sobre el albardón que él denomina "núcleos", contando un total de 5. Las dos elevaciones estudiadas por otros autores se corresponden con el núcleo 1 y 2 de Almeida, todos los estudios (Greslebin, Krapovickas y Cione y colaboradores) se realizaron sobre el núcleo 2. En síntesis, todo indica que se trata de un gran montículo, sobre un extenso albardón que ha sido altamente alterado en tiempos posthispánicos.

\section{Fajina Quemada (FQ)}

Montículo ubicado a $40 \mathrm{~m}$ de la margen izquierda del arroyo Malo, adyacente a una laguna temporaria y a $1600 \mathrm{~m}$ de la costa del río Uruguay. Tiene forma elipsoidal, su eje mayor norte-sur mide $57 \mathrm{~m}$ y el eje este-oeste mide $35 \mathrm{~m}$, tiene una altura de 2,5 m en relación al terreno circundante caracterizado por selva ribereña, bañados y pajonales; No se recolectaron materiales arqueológicos. Este sitio arqueológico fue estudiado previamente por Almeida (1983a).

\section{Las Conchillas (LCs)}

Montículo ubicado a $40 \mathrm{~m}$ de la margen izquierda del arroyo Malo, adyacente a una laguna temporaria y a $1900 \mathrm{~m}$ de la costa del río Uruguay. Tiene forma elipsoidal, su eje mayor norestesudoeste mide $90 \mathrm{~m}$ y el eje noroeste-sudeste mide $45 \mathrm{~m}$, tiene una altura de $2 \mathrm{~m}$ en relación al terreno circundante caracterizado por selva ribereña, bañados y pajonales. No se recolectaron 
materiales arqueológicos. Este sitio es mencionado por Krapovickas (1957) pero el autor no lo visita y fue estudiado previamente por Almeida (1983a).
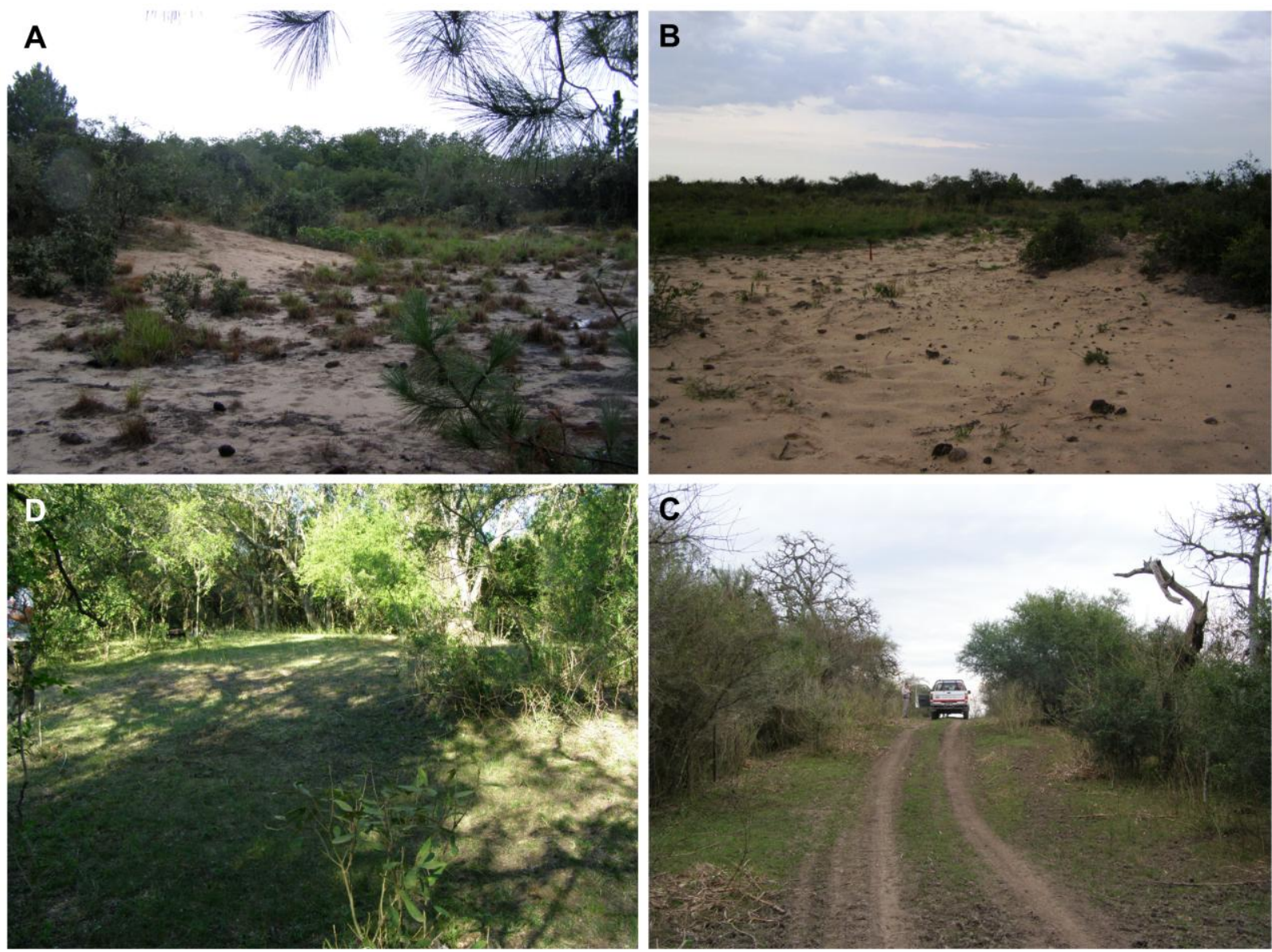

Figura 7.2. Sitios arqueológicos del sector $\mathrm{C}$.

A: El Pinar 1. B: Médano La Boya. C: Cerro Lorenzo 2. D: Túmulo 2 - Cerro Sur de Machado.

\subsubsection{2- Descripción contextual de los hallazgos aislados y sus conjuntos artefactuales}

\section{El Pinar 4 (EP4)}

Material recolectado en la misma zona de médanos donde se ubican EP1, EP2 y EP3, a 135 m al este de EP1. Los materiales incluyen dos fragmentos de borde y 17 de cuerpo, todos lisos (Tabla $7.2)$.

\section{El Pinar 5 (EP5)}

Material recolectado en la misma zona de médanos donde se ubican EP1, EP2 y EP3, a 174 m al este de EP1. Los materiales incluyen dos fragmentos de borde y siete de cuerpo, todos lisos (Tabla 7.2). 


\section{Ñandubaysal 1 (Ñ1)}

Material recolectado en la margen derecha del río Uruguay en una zona de médanos, a 246 $\mathrm{m}$ al este de ME. Los materiales incluyen tres fragmentos de borde decorados y dos de cuerpo lisos (Tabla 7.2).

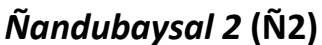

Material recolectado en la misma zona de médanos donde se ubica ME, a $22 \mathrm{~m}$ al oeste del mismo, sobre la margen derecha de un curso de agua menor que desemboca en el río Uruguay. Los materiales incluyen seis fragmentos de cuerpo lisos (Tabla 7.2).

\section{Ñandubaysal 3 (Ñ)}

Material recolectado en la margen derecha del río Uruguay sobre la playa, a $1180 \mathrm{~m}$ al oeste de Ñ1. Los materiales incluyen seis fragmentos de cuerpo lisos (Tabla 7.2).

\section{Jeremías 2 (J2)}

Material recolectado en la misma zona de médanos donde se ubica J1, a $147 \mathrm{~m}$ al sur del mismo y a 426 m del río Uruguay. Los materiales incluyen un núcleo; un fragmento de borde y 15 de cuerpo, todos lisos (Tabla 7.2). Además, se registró una masa de arcilla cocida.

\section{Jeremías 3 (J3)}

Material recolectado en la misma zona de médanos donde se ubica J1, a $53 \mathrm{~m}$ al noroeste del mismo y a $600 \mathrm{~m}$ del río Uruguay. Los materiales incluyen un fragmento de borde y cinco de cuerpo, todos lisos (Tabla 7.2).

\section{Jeremías 4 (J4)}

Material recolectado en la misma zona de médanos donde se ubica J3, a $494 \mathrm{~m}$ al noroeste del mismo y a $835 \mathrm{~m}$ del río Uruguay. Los materiales incluyen cuatro fragmentos de cuerpo lisos (Tabla 7.2).

\section{Estancia Río Uruguay 1 (ERU1)}

Material recolectado en la margen derecha del río Uruguay en una zona de médanos, a 129 $\mathrm{m}$ del río Uruguay. Los materiales incluyen un desecho de talla; y 11 fragmentos de cuerpo lisos (Tabla 7.2). 


\section{Estancia Río Uruguay 2 (ERU2)}

Material recolectado en la misma zona de médanos donde se ubica ERU1, a $81 \mathrm{~m}$ al noroeste del mismo y a 143 m del río Uruguay. Los materiales incluyen un desecho de talla; un fragmento de borde y nueve de cuerpo, todos lisos (Tabla 7.2).

\section{Estancia Río Uruguay 3 (ERU3)}

Material recolectado en la misma zona de médanos donde se ubica ERU2, a $44 \mathrm{~m}$ al noroeste del mismo y a 147 m del río Uruguay. Se recuperó un fragmento de borde liso (Tabla 7.2).

\section{Estancia Río Uruguay 4 (ERU4)}

Material recolectado en la misma zona de médanos donde se ubica ERU3, a $157 \mathrm{~m}$ al noroeste del mismo y a $186 \mathrm{~m}$ del río Uruguay. Los materiales incluyen un fragmento de borde y 12 de cuerpo, todos lisos (Tabla 7.2). Además, se registró una masa de arcilla cocida.

\section{Estancia La Victoria (ELV)}

Material recolectado sobre un camino que va desde el casco de la estancia hacia el río Uruguay, distante del mismo a $2500 \mathrm{~m}$. Los materiales incluyen dos desechos de talla (Tabla 7.2).

\section{Arroyo Lorenzo (AL)}

Material recolectado sobre una pequeña playa sobre la margen izquierda del arroyo Lorenzo, a $123 \mathrm{~m}$ al sur de CL2. Se recuperó un fragmento de cuerpo liso (Tabla 7.2).

\section{Isla de Goyri 2 (IDG2)}

Material recolectado sobre una pequeña playa sobre la margen derecha del río Gualeguaychú. Los materiales incluyen tres fragmentos de cuerpo lisos (Tabla 7.2).

\section{Isla de Goyri 3 (IDG3)}

Material recolectado sobre una pequeña playa a $33 \mathrm{~m}$ al oeste de IDG2. Se recuperó un fragmento de cuerpo liso (Tabla 7.2).

\section{Isla de Goyri 4 (IDG4)}

Material recolectado sobre una pequeña playa a $40 \mathrm{~m}$ al oeste de IDG3. Se recuperó un fragmento de cuerpo liso (Tabla 7.2). 
Isla de Goyri 5 (IDG5)

Material recolectado sobre una pequeña playa a $85 \mathrm{~m}$ al este de IDG2. Los materiales incluyen cuatro fragmentos de cuerpo lisos (Tabla 7.2).

\section{Isla de Goyri 6 (IDG6)}

Material recolectado sobre una pequeña playa a $16 \mathrm{~m}$ al oeste de IDG2. Los materiales incluyen un núcleo; y un fragmento de cuerpo liso (Tabla 7.2).

\section{Isla de Goyri 7 (IDG7)}

Material recolectado sobre una pequeña playa a $115 \mathrm{~m}$ al este de IDG5. Se recuperó un fragmento de borde liso (Tabla 7.2).

\section{Isla de Goyri 8 (IDG8)}

Material recolectado sobre una pequeña playa a $20 \mathrm{~m}$ al oeste de IDG1. Los materiales incluyen cuatro fragmentos de cuerpo decorados (Tabla 7.2).

\section{Isla de Goyri 9 (IDG9)}

Material recolectado sobre una pequeña playa a $51 \mathrm{~m}$ al oeste de IDG8. Los materiales incluyen dos fragmentos de borde y siete de cuerpo (cuatro decorados - cuerpos- y cinco lisos -dos bordes y tres cuerpos-) (Tabla 7.2).

\subsection{2- MATERIALES ARQUEOLÓGICOS}


Tabla 7.2. Materiales arqueológicos del sector $C$ según sus frecuencias por tipo de material y categorías tecnológicas y morfológicas.

\begin{tabular}{|c|c|c|c|c|c|c|c|c|c|c|}
\hline \multirow{2}{*}{$\begin{array}{c}\text { Sitios } \\
\text { arqueológicos }\end{array}$} & \multicolumn{4}{|c|}{ Artefactos líticos } & \multicolumn{3}{|c|}{ Cerámica } & \multirow{2}{*}{$\frac{\text { Fauna }}{\text { NISP }^{1}}$} & \multirow{2}{*}{$\begin{array}{l}\text { Humano } \\
\text { NISP/MNI }\end{array}$} & \multirow{2}{*}{$\begin{array}{l}\text { Total } \\
\text { general }\end{array}$} \\
\hline & INS & DES & NUC & Total & BOR & CUE & Total & & & \\
\hline El Pinar 1 & - & 3 & - & 3 & 9 & 118 & 127 & - & - & 130 \\
\hline El Pinar 2 & - & 1 & - & 1 & 6 & 80 & 86 & 1 & - & 88 \\
\hline El Pinar 3 & - & - & - & - & 9 & 97 & 106 & - & - & 106 \\
\hline Mendisco Este & 1 & - & - & 1 & 1 & 21 & 22 & - & - & 23 \\
\hline Médano La Boya & 1 & 11 & 6 & 18 & 22 & 108 & 130 & - & - & 148 \\
\hline Jeremías 1 & - & 8 & - & 8 & 9 & 72 & 81 & - & - & 89 \\
\hline Cerro Yaguar-í & - & - & - & - & 16 & 139 & 155 & 6 & - & 161 \\
\hline Cerro Lorenzo 1 & - & - & - & - & 13 & 72 & 85 & 141 & - & 226 \\
\hline Cerro Lorenzo 2 & 1 & 31 & 1 & 33 & 118 & 672 & 790 & 2213 & $18 / 1$ & 3054 \\
\hline Isla de Goyri 1 & - & 9 & 1 & 10 & 2 & 32 & 34 & - & - & 44 \\
\hline La Correntina & - & 1 & - & 1 & 3 & 23 & 26 & 1 & - & 28 \\
\hline El Taller & 1 & 37 & 2 & 40 & - & - & - & - & - & 40 \\
\hline Ensenada del Bellaco & - & 1 & 1 & 2 & 7 & $27^{2}$ & 34 & - & - & 36 \\
\hline Túmulo 2-Cerro Sur de Machado & - & - & 1 & 1 & - & - & - & - & - & 1 \\
\hline Sambaquí de Puerto Landa & - & 77 & 2 & 79 & 187 & 2661 & 2848 & 27202 & $39 / 1$ & 30168 \\
\hline Total & 4 & 179 & 14 & 197 & 402 & 4122 & 4524 & 29564 & $57 / 2$ & 34342 \\
\hline \multirow{2}{*}{$\begin{array}{l}\text { Hallazgos } \\
\text { aislados }\end{array}$} & \multicolumn{4}{|c|}{ Artefactos líticos } & \multicolumn{3}{|c|}{ Cerámica } & Fauna & Humano & Total \\
\hline & INS & DES & NUC & Total & BOR & CUE & Total & NISP & NISP/MNI & general \\
\hline EP4 & $\overline{-}$ & - & - & - & 2 & 17 & 19 & - & - & 19 \\
\hline EP5 & - & - & - & - & 2 & 7 & 9 & - & - & 9 \\
\hline$\tilde{\mathrm{N}} 1$ & - & - & - & - & 3 & 2 & 5 & - & - & 5 \\
\hline$\tilde{\mathrm{N}} 2$ & - & - & - & - & - & 6 & 6 & - & - & 6 \\
\hline Ñ3 & - & - & - & - & - & 6 & 6 & - & - & 6 \\
\hline $\mathrm{J} 2$ & - & - & 1 & 1 & 1 & 15 & 16 & - & - & 17 \\
\hline J3 & - & - & - & - & 1 & 5 & 6 & - & - & 6 \\
\hline J4 & - & - & - & - & - & 4 & 4 & - & - & 4 \\
\hline ERU1 & - & 1 & - & 1 & - & 11 & 11 & - & - & 12 \\
\hline ERU2 & - & 1 & - & 1 & 1 & 9 & 10 & - & - & 11 \\
\hline ERU3 & - & - & - & - & 1 & - & 1 & - & - & 1 \\
\hline ERU4 & - & - & - & - & 1 & 12 & 13 & - & - & 13 \\
\hline ELV & - & 2 & - & 2 & - & - & - & - & - & 2 \\
\hline $\mathrm{AL}$ & - & - & - & - & - & 1 & 1 & - & - & 1 \\
\hline IDG2 & - & - & - & - & - & 3 & 3 & - & - & 3 \\
\hline IDG3 & - & - & - & - & - & 1 & 1 & - & - & 1 \\
\hline IDG4 & - & - & - & - & - & 1 & 1 & - & - & 1 \\
\hline IDG5 & - & - & - & - & - & 4 & 4 & - & - & 4 \\
\hline IDG6 & - & - & 1 & 1 & - & 1 & 1 & - & - & 2 \\
\hline IDG7 & - & - & - & - & 1 & - & 1 & - & - & 1 \\
\hline IDG8 & - & - & - & - & - & 4 & 4 & - & - & 4 \\
\hline IDG9 & - & - & - & - & 2 & 7 & 9 & - & - & 9 \\
\hline Total & - & 4 & 2 & 6 & 15 & 116 & 131 & - & - & 137 \\
\hline Total general & 4 & 183 & 16 & 203 & 417 & 4238 & 4655 & 29564 & $57 / 2$ & 34479 \\
\hline
\end{tabular}

INS: instrumentos; DES: desechos; NUC: núcleos; BOR: bordes; CUE: cuerpos; NISP: Número de especímenes identificados; MNI: Número mínimo de individuos. (1) este valor no incluye los instrumentos óseos.

(2) este valor incluye dos tiestos indiferenciados.

\subsubsection{1- Estructura del conjunto lítico}

\section{Materias primas}

La Tabla 7.3 muestra la representatividad de las materias primas en relación a las clases tipológicas. 
Tabla 7.3. Materias primas por clases tipológicas en el sector C.

\begin{tabular}{|c|c|c|c|c|c|c|c|c|}
\hline \multirow{3}{*}{ Materia prima } & \multicolumn{6}{|c|}{ Clases tipológicas } & & \\
\hline & \multicolumn{2}{|c|}{ Instrumentos } & \multicolumn{2}{|c|}{ Desechos de talla } & \multicolumn{2}{|c|}{ Núcleos } & \multicolumn{2}{|c|}{ Total } \\
\hline & $\mathrm{n}$ & $\%$ & $\mathrm{n}$ & $\%$ & $\mathrm{n}$ & $\%$ & $\mathrm{n}$ & $\%$ \\
\hline Calcedonia & 3 & 75 & 30 & 16,4 & 7 & 43,7 & 40 & 19,7 \\
\hline Caliza silicificada & - & - & 64 & 35 & 3 & 18,7 & 67 & 33 \\
\hline Silcreta & - & - & 3 & 1,6 & 1 & 6,3 & 4 & 2 \\
\hline Sílice & 1 & 25 & 22 & 12 & 1 & 6,3 & 24 & 11,8 \\
\hline Xilópalo & - & - & 3 & 1,6 & - & - & 3 & 1,5 \\
\hline Arenisca & - & - & 57 & 31,2 & 3 & 18,7 & 60 & 29,5 \\
\hline Cuarcita intertrap & - & - & - & - & 1 & 6,3 & 1 & 0,5 \\
\hline Cuarzo & - & - & 4 & 2,2 & - & - & 4 & 2 \\
\hline Total & 4 & 100 & 183 & 100 & 16 & 100 & 203 & 100 \\
\hline
\end{tabular}

\section{Instrumentos}

En cuanto a los instrumentos (Tabla 7.4) se identificaron cuatro piezas con retoque sumario

(Figura 7.3).

Tabla 7.4. Instrumentos líticos del sector C.

\begin{tabular}{|c|c|c|c|c|c|c|c|c|c|}
\hline Procedencia & $\begin{array}{l}\text { Grupo } \\
\text { tipológico }\end{array}$ & $\begin{array}{l}\text { Subgrupo } \\
\text { tipológico }\end{array}$ & Serie técnica & $\begin{array}{l}\text { Materia } \\
\text { prima }\end{array}$ & Calidad $^{1}$ & Forma-base & $\begin{array}{l}\text { Modulo } \\
\text { L-A }\end{array}$ & Tamaño & $\begin{array}{l}\text { Espesor } \\
\text { relativo }\end{array}$ \\
\hline ME-RS-1 & $\begin{array}{c}\text { piezas con } \\
\text { retoque sumario }\end{array}$ & $\begin{array}{l}\text { retoque unifacial } \\
\text { directo }\end{array}$ & $\begin{array}{l}\text { retoque } \\
\text { marginal }\end{array}$ & calcedonia & $E$ & $\begin{array}{c}\text { lasca } \\
\text { indiferenciada }\end{array}$ & $\begin{array}{l}\text { mediano } \\
\text { alargado }\end{array}$ & $\begin{array}{l}\text { mediano } \\
\text { pequeño }\end{array}$ & $\begin{array}{c}\text { muy } \\
\text { delgado }\end{array}$ \\
\hline MLB-RS-12 & $\begin{array}{c}\text { piezas con } \\
\text { retoque sumario }\end{array}$ & $\begin{array}{l}\text { retoque unifacial } \\
\text { directo }\end{array}$ & $\begin{array}{l}\text { retoque } \\
\text { marginal }\end{array}$ & calcedonia & $E$ & $\begin{array}{c}\text { lasca } \\
\text { angular }\end{array}$ & $\begin{array}{c}\text { mediano } \\
\text { normal }\end{array}$ & $\begin{array}{l}\text { mediano } \\
\text { pequeño }\end{array}$ & delgado \\
\hline CL2-S3-1-1 & $\begin{array}{c}\text { piezas con } \\
\text { retoque sumario }\end{array}$ & $\begin{array}{c}\text { retoque unifacial } \\
\text { inverso }\end{array}$ & $\begin{array}{l}\text { retoque } \\
\text { marginal }\end{array}$ & calcedonia & $E$ & $\begin{array}{c}\text { lasca } \\
\text { angular }\end{array}$ & $\begin{array}{c}\text { mediano } \\
\text { normal }\end{array}$ & pequeño & $\begin{array}{c}\text { muy } \\
\text { delgado }\end{array}$ \\
\hline ET-RS-38 & $\begin{array}{c}\text { piezas con } \\
\text { retoque sumario }\end{array}$ & $\begin{array}{l}\text { retoque unifacial } \\
\text { directo }\end{array}$ & $\begin{array}{l}\text { retoque } \\
\text { marginal }\end{array}$ & sílice & $B$ & $\begin{array}{c}\text { lasca } \\
\text { primaria }\end{array}$ & $\begin{array}{c}\text { mediano } \\
\text { normal }\end{array}$ & $\begin{array}{l}\text { mediano } \\
\text { pequeño }\end{array}$ & grueso \\
\hline
\end{tabular}

(1) Calidad de las materias primas, E: excelente, B: buena.

Se registraron cuatro instrumentos confeccionados por lascados sobre materias primas de buena y excelente calidad; cuyas formas-base son lascas. El instrumento de ET está elaborado sobre una lasca primaria desprendida de un rodado fluvial. Fueron elaborados por retoque marginal unifacial, directo en tres casos e inverso en el restante. En cuanto a los módulos longitud-anchura hay tres mediano normales y uno mediano alargado. En cuanto al tamaño hay tres mediano pequeños y uno pequeño. Considerando el espesor relativo hay dos muy delgados, uno delgado y uno grueso. 


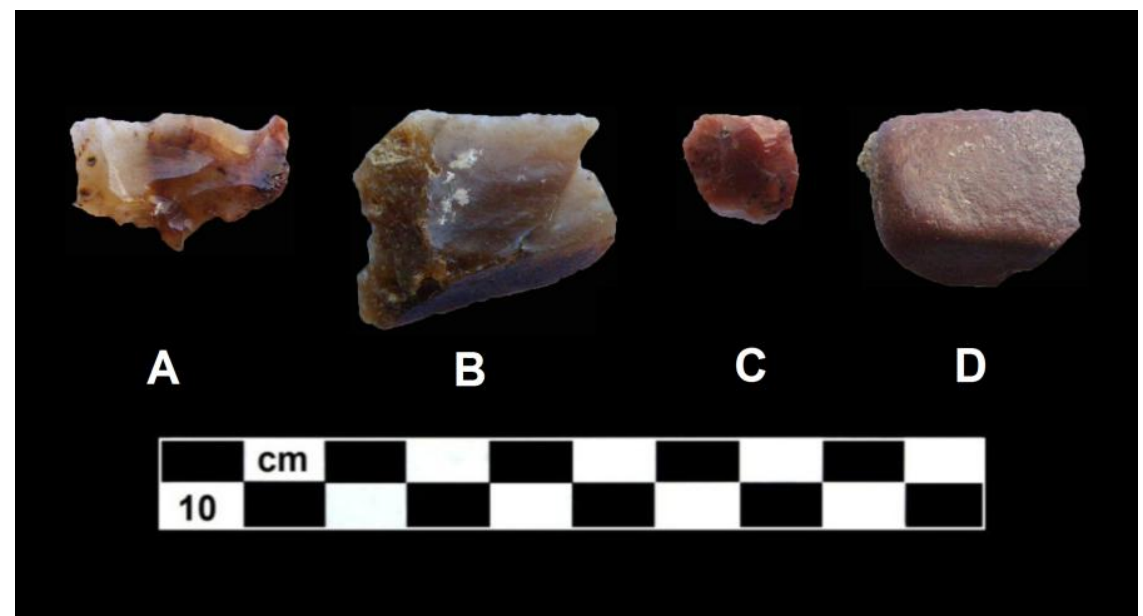

Figura 7.3. Instrumentos líticos del sector $C$.

Piezas con retoque sumario: A (ME-RS-1), B (MLB-RS-12), C (CL2-S3-1-1) y D (ET-RS-38).

\section{Desechos de talla}

\section{Fragmentación}

La Tabla 7.5 muestra la distribución de los desechos de talla de acuerdo a su estado de fragmentación.

Tabla 7.5. Estado de fragmentación de la muestra de desechos de talla del sector C.

\begin{tabular}{|c|c|c|c|c|c|c|c|c|c|c|c|}
\hline \multirow{3}{*}{$\begin{array}{c}\text { Sitios } \\
\text { arqueológicos }\end{array}$} & \multicolumn{10}{|c|}{ Estado de fragmentación } & \multirow{3}{*}{ Total } \\
\hline & \multicolumn{2}{|c|}{ ENT } & \multicolumn{2}{|c|}{ FCT } & \multicolumn{2}{|c|}{ FST } & \multicolumn{2}{|c|}{ NOC } & \multicolumn{2}{|c|}{ IND } & \\
\hline & $\mathrm{n}$ & $\%$ & $\mathrm{n}$ & $\%$ & $\mathrm{n}$ & $\%$ & $\mathrm{n}$ & $\%$ & $\mathrm{n}$ & $\%$ & \\
\hline El Pinar 1 & - & - & 1 & 33,3 & $\overline{-}$ & - & $\overline{1}$ & 33,3 & 1 & 33,4 & 3 \\
\hline El Pinar 2 & - & - & 1 & 100 & - & - & - & - & - & - & 1 \\
\hline Médano La Boya & 2 & 18,2 & - & - & - & - & 3 & 27,3 & 6 & 54,5 & 11 \\
\hline Jeremías 1 & - & - & 2 & 25 & 1 & 12,5 & 2 & 25 & 3 & 37,5 & 8 \\
\hline Cerro Lorenzo 2 & 5 & 16,1 & 5 & 16,1 & 5 & 16,1 & 6 & 19,4 & 10 & 32,3 & 31 \\
\hline Isla de Goyri 1 & - & - & 1 & 11,1 & - & - & 3 & 33,3 & 5 & 55,6 & 9 \\
\hline La Correntina & - & - & 1 & 100 & - & - & - & - & - & - & 1 \\
\hline El Taller & 7 & 18,9 & 9 & 24,3 & 2 & 5,4 & 6 & 16,2 & 13 & 35,2 & 37 \\
\hline Ensenada del Bellaco & - & - & - & - & 1 & 100 & - & - & - & - & 1 \\
\hline Sambaquí de Puerto Landa & 12 & 15,6 & 11 & 14,3 & 15 & 19,4 & 17 & 22,1 & 22 & 28,6 & 77 \\
\hline Hallazgos aislados & - & - & 1 & 25 & - & - & 2 & 50 & 1 & 25 & 4 \\
\hline Total & 26 & 14,2 & 32 & 17,5 & 24 & 13,1 & 40 & 21,9 & 61 & 33,3 & 183 \\
\hline
\end{tabular}

IND: desecho indiferenciado.

Se observa un predominio absoluto de desechos fracturados sobre lascas enteras. La mayor frecuencia corresponde a desechos indiferenciados, seguidos por no clasificables, lascas fracturadas con talón, lascas enteras, y por último las lascas fracturadas sin talón. Considerando los sitios arqueológicos con mayor frecuencia artefactual (CL2, ET y SPL), se observa que en CL2 la tendencia 
se mantiene igual en las dos primeras categorías, siendo idénticas las tres restantes. En ET predominan desechos indiferenciados, seguidos por lascas fracturadas con talón, lascas enteras, desechos no clasificables y fracturadas sin talón. En SPL la tendencia se mantiene igual en las dos primeras categorías, seguidas por lascas fracturadas sin talón, lascas enteras y fracturadas con talón.

Formas de las lascas

Dentro de los desechos de talla, excluyendo aquellos cuyo estado de fragmentación es indiferenciado, se registran varios tipos de lascas $(n=122)$ (Tabla 7.6).

Tabla 7.6.Tipos de lascas por conjuntos líticos del sector C.

\begin{tabular}{|c|c|c|c|c|c|c|c|c|c|c|c|c|c|c|c|}
\hline \multirow{3}{*}{$\begin{array}{c}\text { Sitios } \\
\text { arqueológicos }\end{array}$} & \multicolumn{14}{|c|}{ Tipo de lasca } & \multirow{3}{*}{ Total } \\
\hline & \multicolumn{2}{|c|}{ PRI } & \multicolumn{2}{|c|}{ SEC } & \multicolumn{2}{|c|}{ DON } & \multicolumn{2}{|c|}{ ANG } & \multicolumn{2}{|c|}{ ARI } & \multicolumn{2}{|c|}{ PLA } & \multicolumn{2}{|c|}{ IND } & \\
\hline & $\mathrm{n}$ & $\%$ & $\mathrm{n}$ & $\%$ & $\mathrm{n}$ & $\%$ & $\mathrm{n}$ & $\%$ & $\mathrm{n}$ & $\%$ & $\mathrm{n}$ & $\%$ & $\mathrm{n}$ & $\%$ & \\
\hline El Pinar 1 & - & - & - & - & - & - & 1 & 50 & - & - & - & - & 1 & 50 & 2 \\
\hline El Pinar 2 & - & - & 1 & 100 & - & - & - & - & - & - & - & - & - & - & 1 \\
\hline Médano La Boya & 2 & 40 & 2 & 40 & - & - & 1 & 20 & - & - & - & - & - & - & 5 \\
\hline Jeremías 1 & 1 & 20 & 1 & 20 & - & - & 2 & 40 & - & - & 1 & 20 & - & - & 5 \\
\hline Cerro Lorenzo 2 & 3 & 14,3 & 5 & 23,8 & 2 & 9,5 & 3 & 14,3 & 3 & 14,3 & 3 & 14,3 & 2 & 9,5 & 21 \\
\hline Isla de Goyri 1 & 1 & 25 & 1 & 25 & - & - & 2 & 50 & - & - & - & - & - & - & 4 \\
\hline La Correntina & - & - & - & - & - & - & - & - & 1 & 100 & - & - & - & - & 1 \\
\hline El Taller & 5 & 20,8 & 3 & 12,5 & 2 & 8,3 & 6 & 25 & 4 & 16,7 & 4 & 16,7 & - & - & 24 \\
\hline Ensenada del Bellaco & - & - & 1 & 100 & - & - & - & - & - & - & - & - & - & - & 1 \\
\hline Sambaquí de Puerto Landa & 2 & 3,6 & 2 & 3,6 & - & - & 24 & 43,7 & 13 & 23,7 & 11 & 20 & 3 & 5,4 & 55 \\
\hline Hallazgos aislados & 1 & 33,3 & - & - & - & - & 1 & 33,3 & - & - & 1 & 33,4 & - & - & 3 \\
\hline Total & 15 & 12,3 & 16 & 13,1 & 4 & 3,3 & 40 & 32,8 & 21 & 17,2 & 20 & 16,4 & 6 & 4,9 & 122 \\
\hline
\end{tabular}

PRI: lasca primaria; SEC: lasca secundaria; DON: lasca con dorso natural; ANG: lasca angular; ARI: lasca de arista; PLA: lasca plana; IND; lasca indiferenciada.

Dentro de las lascas internas las más representadas son las angulares ( $n=40 ; 32,8 \%$ ), seguidas por las de arista $(n=21 ; 17,2 \%)$ y planas $(n=20 ; 16,4 \%)$. En cuanto a las lascas externas, se observa un predominio de las secundarias $(n=16 ; 13,1 \%)$, sobre las primarias $(n=15 ; 12,3 \%$ ) y con dorso natural $(n=4 ; 3,3 \%)$.

Estado de fragmentación, tipos, y materia prima de los desechos por conjunto

EP1: una lasca fracturada con talón: indiferenciada (arenisca); una no clasificable: angular (caliza silicificada); y un indiferenciado: (caliza silicificada). EP2: una lasca fracturada con talón: secundaria (arenisca). MLB: dos lascas enteras: una primaria (calcedonia) y una secundaria (calcedonia); tres no clasificables: una primaria (calcedonia), una secundaria (calcedonia) y una angular (calcedonia); y seis indiferenciados: (tres calcedonias y tres sílices). J1: dos lascas fracturadas con talón: una secundaria (calcedonia) y una angular (caliza silicificada); una lasca 
fracturada sin talón: angular (silcreta); dos no clasificables: una primaria (calcedonia) y plana (cuarzo); y tres indiferenciados: (dos calizas silicificadas y una calcedonia).

CL2: cinco lascas enteras: una con dorso natural (arenisca), una angular (caliza silicificada), dos de arista (calizas silicificadas) y una plana (caliza silicificada); cinco lascas fracturadas con talón: una con dorso natural (calcedonia), dos angulares (calizas silicificadas) y dos planas (una calcedonia y una caliza silicificada); cinco lascas fracturadas sin talón: una primaria (sílice), dos secundarias (una calcedonia y una sílice), una de arista (caliza silicificada) y una indiferenciada (sílice); seis no clasificables: dos primarias (calcedonias), tres secundarias (una calcedonia, una sílice y un xilópalo) y una indiferenciada (arenisca); y $\mathbf{1 0}$ indiferenciados: (tres calcedonias, tres calizas silicificadas, dos xilópalos, una sílice y una arenisca). IDG1: una lasca fracturada sin talón: secundaria (arenisca); tres no clasificables: dos angulares (areniscas) y una primaria (arenisca); y cinco indiferenciados: (areniscas). LC: una lasca fracturada con talón: de arista (caliza silicificada).

ET: siete lascas enteras: una primaria (arenisca), una secundaria (arenisca), dos angulares (areniscas), una de arista (arenisca) y dos planas (areniscas); nueve lascas fracturadas con talón: dos primarias (areniscas), una con dorso natural (arenisca), dos angulares (areniscas), tres de arista (areniscas) y una plana (arenisca); dos lascas fracturadas sin talón: una con dorso natural (sílice) y una plana (arenisca); seis no clasificables: dos primarias (cuarzo), dos secundarias (areniscas) y dos angulares (areniscas); y 13 indiferenciados: (11 areniscas, una calcedonia y una de cuarzo).

EDB: una lasca fracturada sin talón: secundaria (caliza silicificada). SPL: 12 lascas enteras: cinco angulares (tres calizas silicificadas, una calcedonia y una silcreta), cuatro de arista (una calcedonia, una caliza silicificada, una sílice y una arenisca) y tres planas (dos calizas silicificadas y una arenisca); 11 lascas fracturadas con talón: ocho angulares (siete calizas silicificadas y una sílice), una de arista (caliza silicificada) y dos planas (calizas silicificadas); 15 lascas fracturadas sin talón: una primaria (calcedonia), seis angulares (cuatro calizas silicificadas y dos sílice), tres de arista (calizas silicificadas) y cinco planas (cuatro calizas silicificadas y una sílice); 17 no clasificables: una primaria (caliza silicificada), dos secundarias (calizas silicificadas), cinco angulares (tres sílices, una calcedonia y una caliza silicificada), cinco de arista (tres calizas silicificadas y dos areniscas), una plana (caliza silicificada) y tres indiferenciadas (dos areniscas y una caliza silicificada); y 22 indiferenciados: (10 calizas silicificadas, cinco areniscas, cinco sílices y dos calcedonias). ERU1: una lasca fracturada con talón: primaria (calcedonia). ERU2: un indiferenciado: (silcreta). ELV: dos no clasificables: una angular (calcedonia) y una plana (calcedonia).

\section{Talones y bulbos}

La Tabla 7.7 muestra la distribución de los distintos tipos de talones y bulbos, identificados en lascas enteras y fracturadas con talón; así como los distintos tipos de bulbos que se pudieron identificar en lascas fracturadas sin talón. 
Tabla 7.7. Distribución de la forma e inclinación del talón en relación a la forma del bulbo de percusión de las lascas del sector $\mathrm{C}$.

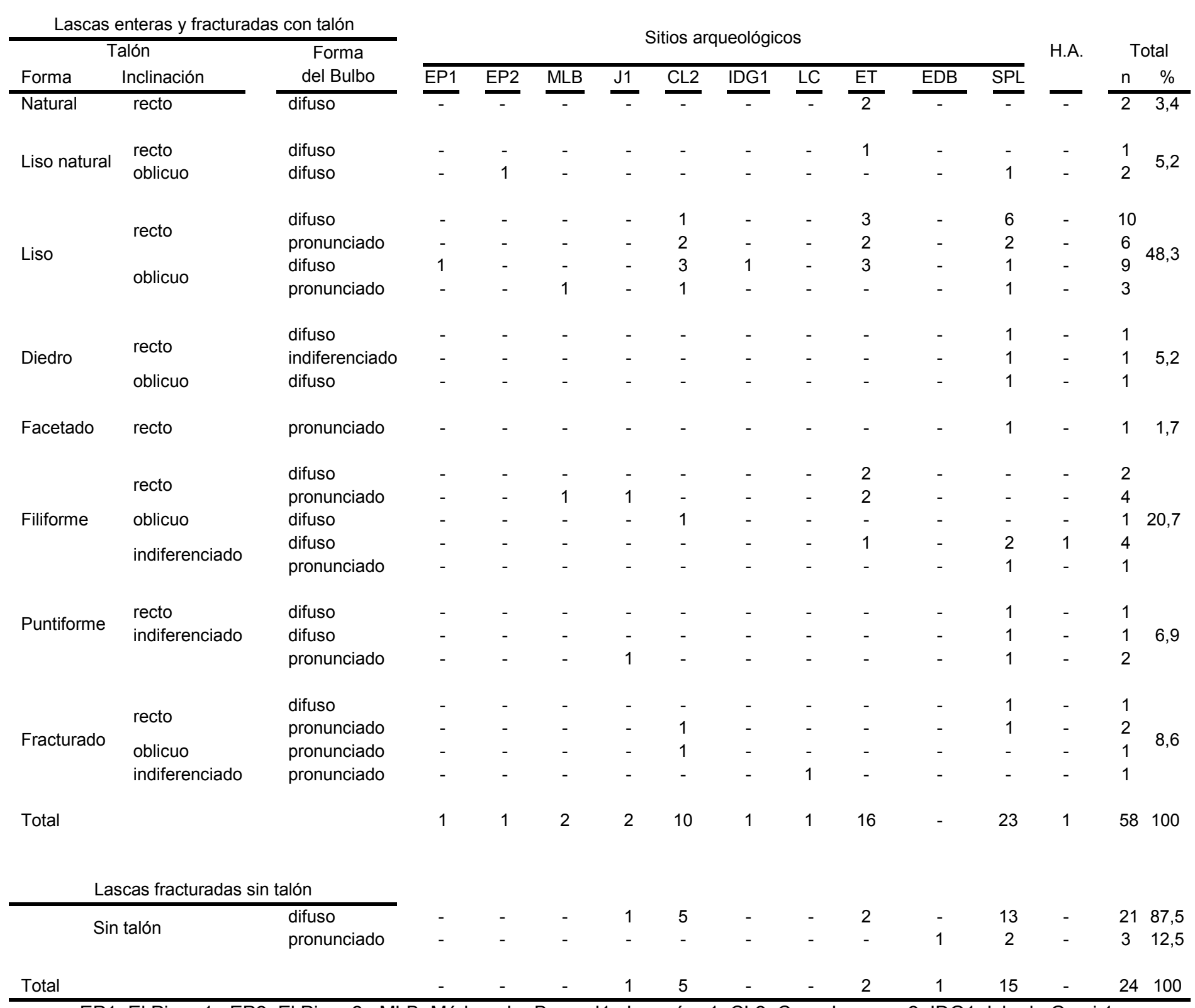

EP1: El Pinar 1; EP2: El Pinar 2; MLB: Médano La Boya; J1: Jeremías 1; CL2: Cerro Lorenzo 2; IDG1: Isla de Goyri 1;

LC: La Correntina; ET: El Taller; EDB: Ensenada del Bellaco; SPL: Sambaquí de Puerto Landa. H. A.: hallazgos aislados.

Se registraron varios tipos de talones entre los que predomina el liso ( $n=28 ; 48,3 \%$ ), seguido por el filiforme $(n=12 ; 20,7 \%)$, fracturado $(n=5 ; 8,6 \%)$, puntiforme $(n=4 ; 6,9 \%)$, liso natural $(n=3$; $5,2 \%)$, diedro $(n=3 ; 5,2 \%)$, natural $(n=2 ; 3,4)$ y facetado $(n=1 ; 1,7)$. Asimismo, el bulbo más frecuente es el difuso ( $n=57 ; 69,5 \%)$, seguido por los pronunciados $(n=24 ; 29,3 \%)$ e indiferenciados $(n=1 ; 1,2 \%)$. La mayor asociación entre los atributos considerados se da entre talones lisos con inclinación recta y los bulbos difusos $(n=10)$, seguidos por aquellos con inclinación oblicua y bulbos difusos $(n=8)$. Asimismo, dentro de las lascas sin talón también predomina ampliamente el bulbo difuso. 


\section{Bulbos y labios}

La Tabla 7.8 muestra la distribución de los distintos tipos bulbos de acuerdo a la ausencia (A) o presencia $(P)$ de labio en lascas enteras y fracturadas con talón.

Tabla 7.8. Presencia de labio según las formas de los bulbos de percusión en las lascas enteras y fracturadas con talón del sector C.

\begin{tabular}{|c|c|c|c|c|c|c|}
\hline \multirow{2}{*}{ Sitios arqueológicos } & \multirow{2}{*}{ Labio $^{1}$} & \multicolumn{3}{|c|}{ Forma del Bulbo } & \multicolumn{2}{|c|}{ Total } \\
\hline & & Difuso & Pronunciado & Indiferenciado & $\mathrm{n}$ & $\%$ \\
\hline El Pinar 1 & $\begin{array}{l}A \\
P\end{array}$ & $\overline{1}$ & $\begin{array}{l}- \\
-\end{array}$ & $\begin{array}{l}- \\
-\end{array}$ & $\overline{-}$ & $\begin{array}{l}- \\
1,7\end{array}$ \\
\hline El Pinar 2 & $\begin{array}{l}\text { A } \\
P\end{array}$ & 1 & - & - & 1 & $\begin{array}{l}1,7 \\
-\end{array}$ \\
\hline Médano La Boya & $\begin{array}{l}A \\
P\end{array}$ & - & 2 & - & 2 & $\begin{array}{c}3,4 \\
-\end{array}$ \\
\hline Jeremías 1 & $\begin{array}{l}A \\
P\end{array}$ & - & $\begin{array}{l}2 \\
-\end{array}$ & - & $\begin{array}{l}2 \\
-\end{array}$ & $\begin{array}{c}3,4 \\
-\end{array}$ \\
\hline Cerro Lorenzo 2 & $\begin{array}{l}A \\
P\end{array}$ & $\begin{array}{l}2 \\
3\end{array}$ & $\overline{5}$ & - & $\begin{array}{l}2 \\
8\end{array}$ & $\begin{array}{c}3,4 \\
13,8\end{array}$ \\
\hline Isla de Goyri 1 & $\begin{array}{l}A \\
P\end{array}$ & $\overline{1}$ & - & - & $\overline{1}$ & $\overline{1,7}$ \\
\hline La Correntina & $\begin{array}{l}A \\
P\end{array}$ & - & $\begin{array}{l}1 \\
-\end{array}$ & - & $\begin{array}{l}1 \\
-\end{array}$ & $\begin{array}{l}1,7 \\
-\end{array}$ \\
\hline El Taller & $\begin{array}{l}A \\
P\end{array}$ & $\begin{array}{l}4 \\
8\end{array}$ & $\begin{array}{l}2 \\
2\end{array}$ & - & $\begin{array}{c}6 \\
10\end{array}$ & $\begin{array}{l}10,4 \\
17,3\end{array}$ \\
\hline Sambaquí de Puerto Landa & $\begin{array}{l}A \\
P\end{array}$ & $\begin{array}{c}5 \\
10\end{array}$ & $\overline{7}$ & $\begin{array}{l}1 \\
-\end{array}$ & $\begin{array}{c}6 \\
17\end{array}$ & $\begin{array}{l}10,4 \\
29,4\end{array}$ \\
\hline Hallazgos aislados & $\begin{array}{l}A \\
P\end{array}$ & $\overline{1}$ & - & - & $\overline{1}$ & $\begin{array}{l}- \\
1,7\end{array}$ \\
\hline $\begin{array}{l}\text { Total } \\
\%\end{array}$ & & $\begin{array}{c}36 \\
62,1\end{array}$ & $\begin{array}{c}21 \\
36,2\end{array}$ & $\begin{array}{c}1 \\
1,7\end{array}$ & 58 & 100 \\
\hline
\end{tabular}

(1) A: ausencia de labio; P: presencia de labio.

Se observa un predominio de las lascas con bulbo difuso por sobre los demás tipos de bulbos. Asimismo, se observa que el $65,5 \%(n=38)$ de las lascas presentan labio.

Origen de extracción de las lascas y formas-base

De acuerdo al origen de extracción de las lascas se determinaron 81 internas, 35 externas y seis indiferenciadas (Tabla 7.6), a las que se suman 61 desechos cuyo estado de fragmentación es indiferenciado (Tabla 7.5). A partir de 18 lascas externas, tres internas y 11 desechos indiferenciados, con reserva de corteza en su cara dorsal y/o talón, se pudo determinar que las formas-base primarias utilizadas corresponden a: rodados silíceos subesféricos $(n=3 ; 9,4 \%)$, plano-tabulares $(n=3 ; 9,4 \%)$, 
indeterminados $(n=17 ; 53,1 \%)$, y clastos $(n=9 ; 28,1)$. A partir de los desechos de talla restantes $(n=$ 151) no se pudieron diferenciar las formas-base de los núcleos.

De acuerdo a los conjuntos líticos las formas-base determinadas se distribuyen de la siguiente manera: MLB $(n=9)$ tres rodados plano-tabulares, dos subesféricos y cuatro indeterminados; J1 ( $n=2)$ uno subesférico y uno indeterminado; CL2 ( $n=9)$ ocho indeterminados y un clasto; y ET ( $n=12)$ ocho clastos y cuatro rodados indeterminados.

\section{Negativos de lascados y reserva de corteza}

La Tabla 7.9 presenta la distribución de los tipos de lascas de acuerdo a la cantidad de negativos de lascados y a la proporción de corteza en la cara dorsal. La tendencia general esperada es que, a mayor número de lascados menor será la proporción de corteza.

Tabla 7.9. Distribución de tipos de lascas del sector $C$ según la proporción de corteza y el número de negativos de lascados en la cara dorsal.

\begin{tabular}{|c|c|c|c|c|c|c|c|c|c|c|c|c|c|c|c|c|c|c|c|c|c|}
\hline \multirow[b]{4}{*}{$\begin{array}{c}\text { Tipo } \\
\text { de lasca }\end{array}$} & & \multicolumn{19}{|c|}{ Negativos de lascados } & \multirow[b]{4}{*}{ Total } \\
\hline & & \multicolumn{17}{|c|}{ Sitios arqueológicos } & \multirow{2}{*}{\multicolumn{2}{|c|}{ H.A. }} & \\
\hline & & \multicolumn{3}{|c|}{ EP1 EP2 } & \multicolumn{3}{|c|}{ MLB } & \multicolumn{3}{|c|}{ CL2 } & \multirow{2}{*}{$\begin{array}{l}\text { IDG1 } \\
02334\end{array}$} & \multirow{2}{*}{$\begin{array}{l}\mathrm{LC} \\
3\end{array}$} & \multirow{2}{*}{$\begin{array}{cccc} & E T \\
0 & 1 & 2 & 3\end{array} \mid$} & \multicolumn{2}{|c|}{ EDB } & \multicolumn{3}{|c|}{ SPL } & & & \\
\hline & $\begin{array}{l}\text { Proporción } \\
\text { de corteza }\end{array}$ & 24 & 1 & 0 & 1 & 3 & 5 & 0123 & 0 & 1234 & & & & 1 & 0 & 1 & 2 & 345 & 0 & 2 & \\
\hline Primaria & $100 \%$ & $-\quad-$ & - & 2 & - & - & - & $1---$ & 3 & $-\quad--1$ & $1--$ & - & $5---$ & - & 2 & - & - & $-\quad-$ & 1 & - & 15 \\
\hline & $>50 \%$ & $-\quad-$ & - & - & 1 & 1 & - & $-1--$ & -4 & $41--$ & $-1--$ & - & $-11-$ & 1 & - & - & - & --- & & - & 12 \\
\hline secundarla & $<50 \%$ & - & 1 & - & - & - & - & $-\cdots$ & - & $-\cdots-$ & $-\cdots$ & - & $-1--$ & - & - & 2 & - & $-\quad-$ & & - & 4 \\
\hline Con dorso & $<50 \%$ & $-\quad-$ & - & - & - & - & - & $-\cdots$ & - & $1 \ldots$ & - - - & - & $-1--$ & - & - & - & - & $-\quad-$ & - & - & 2 \\
\hline natural & $0 \%$ & $-\quad-$ & - & - & - & - & - & $-\cdots$ & - & $1 \ldots$ & - - - & - & $--1-$ & - & - & - & - & $-\quad-$ & & - & 2 \\
\hline & $<50 \%$ & -1 & - & - & - & - & - & $-\cdots$ & - & $-\quad-$. & 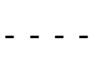 & - & $-\ldots 2$ & - & - & - & - & $-\quad-$ & & - & 3 \\
\hline Angular & $0 \%$ & $-\quad-$ & - & - & - & - & 1 & $-\cdots$ & - & $-\quad-21$ & --11 & - & ---4 & - & - & - & 3 & 1722 & & 1 & 35 \\
\hline De arista & $0 \%$ & $-\quad-$ & - & - & - & - & - & $-\begin{array}{ll}-1 & 1\end{array}$ & - & $-3--$ & - - - & 1 & $--4-$ & - & - & - & 13 & $-\quad-$ & - & - & 23 \\
\hline Plana & $0 \%$ & - & - & - & - & - & - & $1--$ & - & $3 \ldots$ & - - - & - & $-4--$ & - & - & 11 & - & $-\quad-$ & 1 & - & 20 \\
\hline & $0 \%$ & $1-$ & - & - & - & - & - & $-\ldots$ & - & $11-$ & - - - & - & $-\cdots$ & - & - & 1 & - & $1--$ & - & - & 5 \\
\hline Inalierenclada & $100 \%$ & $-\quad-$ & - & - & - & - & - & $-\cdots$ & - & $-\quad--$ & $-\cdots$ & - & - . - & - & 1 & - & - & --- & - & - & 1 \\
\hline Total general & & 11 & 1 & 2 & 1 & 1 & 1 & 2111 & 31 & 10521 & 1111 & 1 & 5766 & 1 & 3 & 14 & 16 & 1822 & 2 & 1 & 122 \\
\hline
\end{tabular}

EP1: El Pinar 1; EP2: El Pinar 2; MLB: Médano La Boya; J1: Jeremías 1; CL2: Cerro Lorenzo 2; IDG1: Isla de Goyri 1; LC: La Correntina; ET: El Taller; EDB: Ensenada del Bellaco; SPL: Sambaquí de Puerto Landa; H.A.: Hallazgos aislados.

Las lascas externas presentan corteza y en general menor número de lascados que las internas. Dentro de aquellas con menos del $50 \%$ de corteza $(n=8)$, hay siete con un lascado y una con 
dos lascados. Dentro de las que tienen más del $50 \%$ de corteza $(n=27)$, hay ocho con un lascado, tres con dos, una con tres y 15 sin lascados.

Las lascas internas en general no presentan corteza, la diferencia entre ellas reside en el número de lascados que presentan en su cara dorsal. Dentro de las angulares $(n=38)$ predominan las que tienen tres negativos de lascado $(n=26)$, seguidas por las que tienen cuatro $(n=5)$, dos $(n=4), y$ cinco $(n=3)$ lascados respectivamente. Dentro de las lascas de arista $(n=23)$ predominan la que tienen dos negativos de lascado $(n=21)$ sobre las que tienen un lascado $(n=2)$. Dentro de las planas $(n=20)$ predominan las que tienen un lascado en su cara dorsal $(n=18)$.

\section{Dimensiones relativas}

Los módulos longitud-anchura y tamaño, y el espesor relativo se calcularon para las lascas enteras $(n=26)$ (Tablas $7.10,7.11$ y 7.12$)$.

Tabla 7.10. Módulo longitud-anchura de las lascas enteras del sector C.

\begin{tabular}{|c|c|c|c|c|c|c|}
\hline \multirow[b]{2}{*}{ Módulo L-A } & \multicolumn{4}{|c|}{ Sitios arqueológicos } & \multicolumn{2}{|c|}{ Total } \\
\hline & $\overline{M L B}$ & $\overline{C L 2}$ & $\overline{E T}$ & SPL & $\mathrm{n}$ & $\%$ \\
\hline Corto muy ancho & $\overline{-}$ & - & 2 & 3 & 5 & $\overline{19,2}$ \\
\hline Corto ancho & - & - & 2 & 3 & 5 & 19,2 \\
\hline Mediano normal & - & 4 & 2 & 4 & 10 & 38,5 \\
\hline Mediano alargado & 1 & 1 & 1 & 2 & 5 & 19,2 \\
\hline Laminar normal & 1 & - & - & - & 1 & 3,9 \\
\hline Total & 2 & 5 & 7 & 12 & 26 & 100 \\
\hline
\end{tabular}

Tabla 7.11. Módulo tamaño de las lascas enteras del sector C.

\begin{tabular}{|c|c|c|c|c|c|c|}
\hline \multirow[b]{2}{*}{ Tamaño } & \multicolumn{4}{|c|}{ Sitios arqueológicos } & \multicolumn{2}{|c|}{ Total } \\
\hline & MLB & CL2 & ET & SPL & $\mathrm{n}$ & $\%$ \\
\hline Muy pequeño & - & - & 1 & - & 1 & $\overline{3,9}$ \\
\hline Pequeño & 1 & 4 & 1 & 9 & 15 & 57,6 \\
\hline Mediano pequeño & - & - & 2 & 3 & 5 & 19,2 \\
\hline Mediano grande & - & 1 & 1 & - & 2 & 7,7 \\
\hline Grande & 1 & - & - & - & 1 & 3,9 \\
\hline Muy grande & - & - & 2 & - & 2 & 7,7 \\
\hline Total & 2 & 5 & 7 & 12 & 26 & 100 \\
\hline
\end{tabular}

Tabla 7.12. Espesores relativos de las lascas enteras del sector C.

\begin{tabular}{|c|c|c|c|c|c|c|}
\hline \multirow[b]{2}{*}{ Espesor relativo } & \multicolumn{4}{|c|}{ Sitios arqueológicos } & \multicolumn{2}{|c|}{ Total } \\
\hline & MLB & CL2 & $\mathrm{ET}$ & SPL & $\mathrm{n}$ & $\%$ \\
\hline Muy delgado & - & 3 & 2 & 6 & 11 & 42,3 \\
\hline Delgado & 1 & 1 & 2 & 5 & 9 & 34,6 \\
\hline Grueso & - & 1 & 2 & 1 & 4 & 15,4 \\
\hline Muy grueso & 1 & - & 1 & - & 2 & 7,7 \\
\hline Total & 2 & 5 & 7 & 12 & 26 & 100 \\
\hline
\end{tabular}


En relación a la longitud-anchura predominan las lascas medianas ( $n=15 ; 57,7 \%$ ), seguidas por las cortas $(n=10 ; 38,4 \%)$ y las laminares $(n=1 ; 3,9 \%)$. En cuanto al tamaño predominan las lascas pequeñas $(n=16 ; 61,5 \%)$, seguidas por las medianas $(n=7 ; 27,9 \%)$ y las grandes $(n=3 ; 11,6 \%)$. El espesor relativo más frecuente es el muy delgado $(n=11 ; 42,3 \%)$, seguido por lascas que van disminuyendo su frecuencia a medida que aumenta el espesor.

\section{Rastros complementarios, regularización del frente de extracción y alteración térmica}

La presencia de rastros complementarios sobre filos naturales en los desechos de talla fue registrada en 11 lascas: seis de ET (cuatro angulares, una de arista y una plana), tres de SPL (dos angulares y una de arista), una de LC (de arista) y una de EDB (secundaria). Los rastros corresponden a melladuras y microlascados combinados. Se registró evidencia de alteración térmica en 18 desechos de talla: 11 de SPL (siete calcinados y cuatro carbonizados), cuatro de CL2 (calcinados), dos de MLB (calcinados) y uno de J1 (calcinado). En total corresponden a ocho indiferenciados, cuatro no clasificables, dos enteras, dos lascas fracturadas con talón y dos lascas fracturadas sin talón. En ningún caso se registraron rastros complementarios sobre el talón o regularización del frente de extracción.

\section{Núcleos}

El conjunto lítico del sector C presenta 16 núcleos (Tabla 7.13). 
Tabla 7.13. Núcleos del sector C.

\begin{tabular}{|c|c|c|c|c|c|c|c|c|c|c|}
\hline \multirow{2}{*}{ Procedencia } & \multirow{2}{*}{$\begin{array}{l}\text { Materia } \\
\text { prima }\end{array}$} & \multirow{2}{*}{ Calidad } & \multirow{2}{*}{ Forma-base } & \multicolumn{2}{|c|}{ Planos de percusión } & \multirow{2}{*}{$\begin{array}{l}\text { Proporción de } \\
\text { corteza }\end{array}$} & \multirow{2}{*}{$\begin{array}{c}\text { Negativos } \\
\text { de } \\
\text { lascados }\end{array}$} & \multirow{2}{*}{$\begin{array}{l}\text { Largo } \\
(\mathrm{mm})\end{array}$} & \multirow{2}{*}{$\begin{array}{l}\text { Ancho } \\
(\mathrm{mm})\end{array}$} & \multirow{2}{*}{$\begin{array}{c}\text { Espesor } \\
(\mathrm{mm})\end{array}$} \\
\hline & & & & Número & Forma & & & & & \\
\hline MLB-RS-13 & calcedonia & buena & guijarro & 2 & liso & $<50 \%$ & 7 & 51,7 & 25,1 & 17,9 \\
\hline MLB-RS-14 & calcedonia & excelente & $\begin{array}{l}\text { guijarro } \\
\text { angular }\end{array}$ & 4 & $\begin{array}{c}\text { natural } \\
\text { y liso }\end{array}$ & $>50 \%$ & 8 & 31,4 & 27,4 & 25,3 \\
\hline MLB-RS-15 & calcedonia & buena & $\begin{array}{l}\text { guijarro } \\
\text { angular }\end{array}$ & 2 & natural & $>50 \%$ & 2 & 29.7 & 26,2 & 19,1 \\
\hline MLB-RS-16 & calcedonia & excelente & $\begin{array}{l}\text { guijarro } \\
\text { angular }\end{array}$ & 2 & $\begin{array}{l}\text { natural } \\
\text { y liso }\end{array}$ & $>50 \%$ & 5 & 25,6 & 24,2 & 22,6 \\
\hline MLB-RS-17 & calcedonia & excelente & $\begin{array}{l}\text { guijarro } \\
\text { angular }\end{array}$ & 4 & $\begin{array}{c}\text { natural } \\
\text { y liso }\end{array}$ & $<50 \%$ & 6 & 28,3 & 24,8 & 18,9 \\
\hline MLB-RS-18 & calcedonia & buena & $\begin{array}{c}\text { guijarro } \\
\text { plano-tabular }\end{array}$ & 2 & natural & $>50 \%$ & 5 & 31,6 & 31,2 & 11,1 \\
\hline CL2-S3-1-2 & $\begin{array}{c}\text { caliza } \\
\text { silicificada }\end{array}$ & buena & no diferenciada & 3 & liso & $0 \%$ & 6 & 32,7 & 27 & 17,9 \\
\hline IDG1-RS-1 & silcreta & regular & no diferenciada & 2 & liso & $<50 \%$ & 4 & 62 & 39 & 32,7 \\
\hline ET-RS-39 & arenisca & regular & clasto & 2 & liso & $>50 \%$ & 3 & $\begin{array}{c}110 \\
6\end{array}$ & 59,1 & 45,7 \\
\hline ET-RS-40 & arenisca & regular & clasto & 2 & liso & $<50 \%$ & 3 & 61,5 & 41,2 & 23,5 \\
\hline EDB-TP-1 & arenisca & regular & no diferenciada & 3 & liso & $<50 \%$ & 7 & 81,2 & 62,3 & 44,8 \\
\hline T2-CSM-RS-1 & $\begin{array}{c}\text { caliza } \\
\text { silicificada }\end{array}$ & excelente & no diferenciada & 3 & liso & $0 \%$ & 5 & 38,5 & 31,1 & 23,4 \\
\hline SPL-S1-1-G3 & $\begin{array}{c}\text { caliza } \\
\text { silicificada }\end{array}$ & buena & no diferenciada & 2 & liso & $0 \%$ & 3 & 53,6 & 34,6 & 31 \\
\hline SPL-S1-12-G5 & sílice & buena & no diferenciada & 2 & liso & $0 \%$ & 5 & 29,7 & 18,8 & 17,5 \\
\hline J2-RS-1 & calcedonia & excelente & $\begin{array}{c}\text { guijarro } \\
\text { subesférico }\end{array}$ & 2 & $\begin{array}{l}\text { natural } \\
\text { y liso }\end{array}$ & $>50 \%$ & 2 & 32,3 & 24,4 & 19,1 \\
\hline IDG6-RS-1 & $\begin{array}{l}\text { cuarcita } \\
\text { intertrap }\end{array}$ & buena & $\begin{array}{c}\text { guijón } \\
\text { subesférico }\end{array}$ & 2 & liso & $<50 \%$ & 12 & 88 & 62,8 & 41 \\
\hline
\end{tabular}

Las materias primas son silíceas de buena a excelente calidad en 12 casos y regular en cuatro. Las formas-base corresponden a guijarros angulares $(n=4)$, subesférico $(n=1)$, plano-tabular $(n=1)$, indeterminado $(n=1)$, guijón subesférico $(n=1)$, clastos $(n=2)$, y no diferenciados $(n=6)$. Del total de núcleos, 10 presentan planos de percusión lisos, cuatro presentan planos lisos naturales y dos naturales. Predominan los núcleos con dos planos de percusión utilizados $(n=11)$ seguidos por los que tienen tres $(n=3)$ y cuatro $(n=2)$. Se registraron de dos a 12 lascados por núcleo, siendo cinco lascados los más frecuentes ya que se registraron en cuatro núcleos; seguidos por tres que se registraron en tres núcleos; dos, seis y siete registrados en dos núcleos respectivamente; y por cuatro, ocho y 12 lascados que se registraron en un núcleo respectivamente. El remanente de corteza es superior al $50 \%$ en seis de los núcleos y menor a este valor en otros seis, los cuatro restantes no presentan corteza. La medida máxima de los núcleos va entre $2,5 \mathrm{~cm}$ y $12 \mathrm{~cm}$.

\subsubsection{2- Estructura del conjunto cerámico}

La muestra de alfarería proviene de los sitios arqueológicos EP1, EP2, EP3, ME, MLB, J1, CY, CL1, CL2, IDG1, LC, EDB y SPL, así como de los hallazgos EP4, EP5, Ñ1, Ñ2, Ñ3, J2, J3, J4, ERU1, ERU2, 
ERU3, ERU4, AL, IDG2, IDG3, IDG4, IDG5, IDG6, IDG7, IDG8 e IDG9. Los fragmentos recuperados suman un total de 4655 (Tabla 7.2); 4236 corresponden al cuerpo de las vasijas (4111 lisos y 125 decorados), 417 son bordes (318 lisos y 99 decorados) y dos indeterminados (uno liso y uno decorado). Los tamaños se distribuyen como sigue: pequeños $n=4512(96,9 \%)$, medianos $n=137$ (3\%) y grandes $n=6(0,1 \%)$

Es necesario aclarar que el $12,8 \%$ de la muestra presenta evidencia de alteraciones naturales, como desgaste y erosión en distinto grado, producto de la acción fluvial y/o eólica. En algunos tiesos se observa redondeamiento de bordes y "efecto pedestal" debido a la remoción de la matriz de la pasta (Sanhueza Riquelme 1998). Esta situación constituyó una limitación para determinar algunos de los atributos relevados. Particularmente se registró este tipo de alteraciones en aquellos sitios arqueológicos y hallazgos aislados recuperados en posición superficial. De esta manera todos los tiestos registrados en EP1, EP2, EP3, ME, MLB, EP4, EP5, Ñ1, N2, Ñ3, J2, J3, J4, ERU1, ERU2, ERU3, ERU4, AL, IDG2, IDG3, IDG4, IDG5, IDG6 e IDG7 están alterados; en igual condición se registraron siete tiestos en IDG1, uno en IDG8 y uno en IDG9. En los restantes conjuntos no se registraron tiestos alterados estructuralmente.

Considerando los tiestos mayores a $5 \mathrm{~cm}$ la muestra analizada se compone de 143 tiestos; 114 (79,7\%) corresponden al cuerpo de las vasijas (89 lisos y 25 decorados) y 29 (20,3\%) son bordes (17 lisos y 12 decorados). Los espesores de los bordes varían entre 3,9 y 10,2 mm, y de los cuerpos entre $4,7 \mathrm{~mm}$ y $16,6 \mathrm{~mm}$.

En relación a la técnica de manufactura se identificaron $75(52,4 \%)$ tiestos elaborados mediante la técnica de enrollamiento, siendo el resto indeterminados ( $n=68 ; 47,6 \%$ ). Se pudo determinar el tratamiento de superficie plástico en 129 tiestos (90,2\%), nueve pintados (6,3\%) y el resto indeterminados $(n=5 ; 3,5 \%)$. En este sentido, hay 101 alisados en ambas superficies, ocho en la superficie interna y con decoración incisa la externa, 10 corrugados simples, cinco unguiculados simples y cinco cepillados. Dentro de los pintados hay dos con pigmento en ambas superficies, cinco en la superficie interna y dos en la superficie externa.

La observación del color del núcleo de los tiestos permitió determinar que predomina ampliamente el color negro (7.5YR 2/1-black) ( $n=132 ; 92,3 \%)$, seguido por el castaño oscuro (7.5YR 3/4-dark brown) ( $n=11 ; 7,7 \%$ ). En la superficie externa predomina el color castaño (10YR 4/6-brown) ( $n=88 ; 61,5 \%)$, seguido por el negro (7.5YR 2/1-black) ( $n=53 ; 37,1 \%)$, y por último se registraron dos indeterminados $(1,4 \%)$. En la superficie interna predomina el color el castaño (10YR 4/6-brown) (n= 115; $80,4 \%)$, seguido por el negro (7.5YR $2 / 1$-black) ( $n=27 ; 18,9 \%$ ), y por último se registró un indeterminado $(0,7 \%)$. Los porcentajes de inclusiones se distribuyen de la siguiente manera, arena $(n=84 ; 58,7 \%)$, arena y espículas de esponjas $(n=38 ; 26,6 \%)$, arena, tiesto y espículas de esponjas $(n=$ $11 ; 7,7 \%)$, tiesto y arena ( $n=8 ; 5,6 \%)$, espículas de esponjas $(n=1 ; 0,7 \%)$, y $\sin$ inclusiones $(n=1 ;$ $0,7 \%)$. 
En relación a la morfología de bordes y labios, incluyendo menores a $5 \mathrm{~cm}$, se determinaron 240 bordes rectos, 142 con labios convexos, 55 con labios rectos, 41 con labios angulares y dos indeterminados; 78 bordes invertidos, 51 con labios convexos, 13 con labios angulares, 12 con labios rectos y dos indeterminados; y 64 bordes evertidos, 38 con labios convexos y 26 con labios angulares. Asimismo, a partir de nueve bordes se reconstruyó el diámetro y el perfil de nueve vasijas (Figura 7.4):

1- recipiente liso restringido, con borde invertido y labio convexo, y un diámetro de boca de $21 \mathrm{~cm}$; esta vasija correspondería a una olla y presenta en su superficie externa escaso hollín [CL2-S29-G1] (Figura 7.4A).

2- recipiente liso no restringido, con borde recto y labio convexo, y un diámetro de boca de $23 \mathrm{~cm}$; esta vasija correspondería a una escudilla y presenta en su superficie externa abundante hollín [CL2-S2-10-G1] (Figura 7.4B).

3- recipiente liso no restringido, con borde evertido y labio convexo, y un diámetro de boca de $21 \mathrm{~cm}$; esta vasija correspondería a un cuenco grande [IDG1-RS-1] (Figura 7.4C).

4- recipiente decorado (corrugado) restringido, con borde evertido y labio convexo, y un diámetro de boca de $33 \mathrm{~cm}$; esta vasija correspondería a un yapepó guaraní [LC-RS-1] (Figura 7.4D y $7.5 R)$.

5- recipiente decorado (inciso) no restringido, con borde evertido y labio convexo, y un diámetro de boca de $18 \mathrm{~cm}$; esta vasija correspondería a un cuenco y presenta en su superficie externa abundante hollín [SPL-S1-11-G1] (Figura 7.4E y 7.5J).

6- recipiente decorado (inciso) no restringido, con borde recto y labio recto, y un diámetro de boca de $27 \mathrm{~cm}$; esta vasija correspondería a un cuenco grande [SPL-S1-13-G1] (Figura 7.4F).

7- recipiente decorado (inciso) restringido, con borde recto y labio recto, y un diámetro de boca de $21 \mathrm{~cm}$; esta vasija correspondería a una olla y presenta en ambas superficies escaso hollín [SPL-S1-13-G2] (Figura 7.4G).

8- recipiente liso restringido, con borde evertido y labio convexo, y un diámetro de boca de $27 \mathrm{~cm}$; esta vasija correspondería a una olla [SPL-S1-14-G1] (Figura 7.4H).

9- recipiente decorado (pintado) restringido, con borde evertido y labio convexo, y un diámetro de boca de $20 \mathrm{~cm}$; esta vasija correspondería a un cambuchí guaraní [Ñ1-RS-1] (Figura 7.4I y $7.5 \mathrm{U})$. 


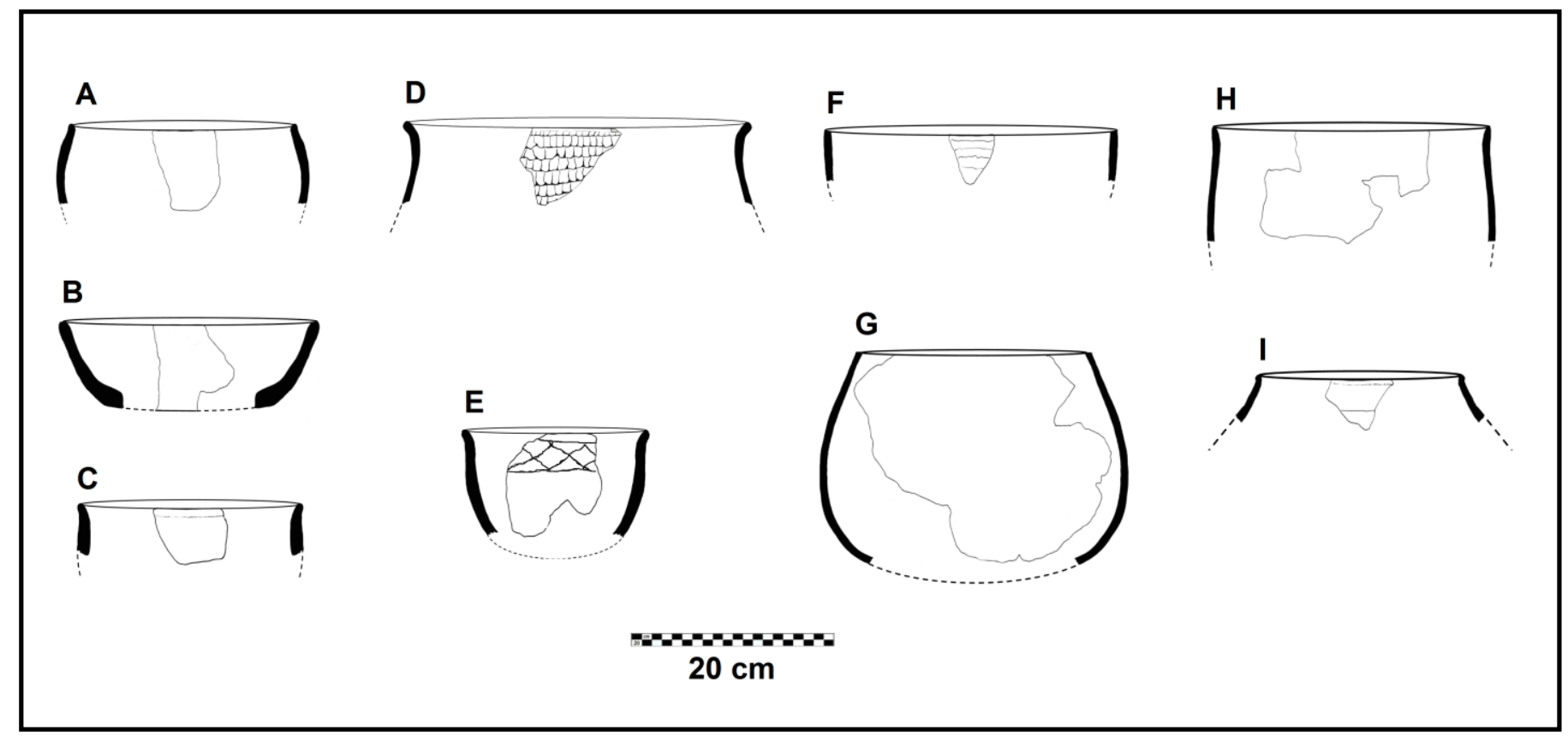

Figura 7.4. Vasijas reconstruidas del Sector $C$.

A (CL2-S2-9-G1), B (CL2-S2-10-G1), C (IDG1-RS-1), D (LC-RS-1), E (SPL-S1-11-G1), F (SPL-S1-13-G1), G (SPL-S1-13-G2), H (SPL-S1-14-G1) e I (Ñ1-RS-1).

Dentro del conjunto de tiestos decorados $(n=225)$ se registraron 182 decorados mediante desplazamiento de materia (Figura 7.5A, B, C, D, E, F, G, H, I, J, K, L, M, N, P, Q, R, S y T); tres mediante extracción de materia; y 35 mediante aplicación de pintura (Figura 7.5Ñ , O y U). Asimismo, se registraron combinaciones entre extracción y desplazamiento de materia $(n=4)$, y pintura y desplazamiento de materia $(n=1)$.

El conjunto de tiestos decorados mediante desplazamiento de materia $(n=182,80$ bordes y 102 cuerpos) presenta incisión de surco rítmico, punto y/o línea en 139 casos (130 en la superficie externa, seis en el labio y cuatro en la superficie externa y labio simultáneamente); y corrugado en 22 casos, cepillado en 10 casos, unguiculado en ocho casos, rodetes en un caso (roletado) y unguiculado-corrugado en un caso; todos en su superficie externa. La decoración mediante extracción de materia se registró sobre el borde y el labio conformando bordes dentados $(n=3)$. El conjunto de tiestos pintados ( $n=35,11$ bordes, 23 cuerpos y un indeterminado) presenta pintura en la superficie interna $(n=23)$, en la externa, $(n=8)$ y en ambas superficies $(n=4)$. Se registró pintura color rojo en 32 casos, seguida por el negro y el blanco en un caso respectivamente. Por su parte, en aquellos tiestos donde se combinan decoraciones $(n=5)$ la misma se presenta de la siguiente manera: cuatro bordes dentados con incisiones en la superficie externa, y un borde con incisiones en la superficie externa y pintura roja en ambas superficies.

Cabe señalar que la alfarería corrugada, unguiculada, cepillada y roletada ( $n=42$ ), es morfológica y decorativamente distintiva del resto del conjunto, y es compatible con la alfarería 
guaraní (Brochado 1984; Brochado y Monticelli 1994; Noelli 1993). Esta cerámica se registró en EDB= 12, $\mathrm{LC}=5, \operatorname{IDG} 1=17, \mathrm{IDG} 8=4$, e IDG9= 4 .

Se registraron rastros de hollín en tres conjuntos arqueológicos, CL2, SPL e IDG9. En CL2 el hollín se presenta en la superficie externa de tres bordes, en un caso es abundante y en los otros dos es escaso. En SPL el hollín se presenta en la superficie externa de tres cuerpos y dos bordes, en cuatro casos es abundante y en uno moderado; también hay un borde con hollín en ambas superficies. En IDG9 el hollín se presenta en la superficie externa de dos bordes en cantidad moderada.

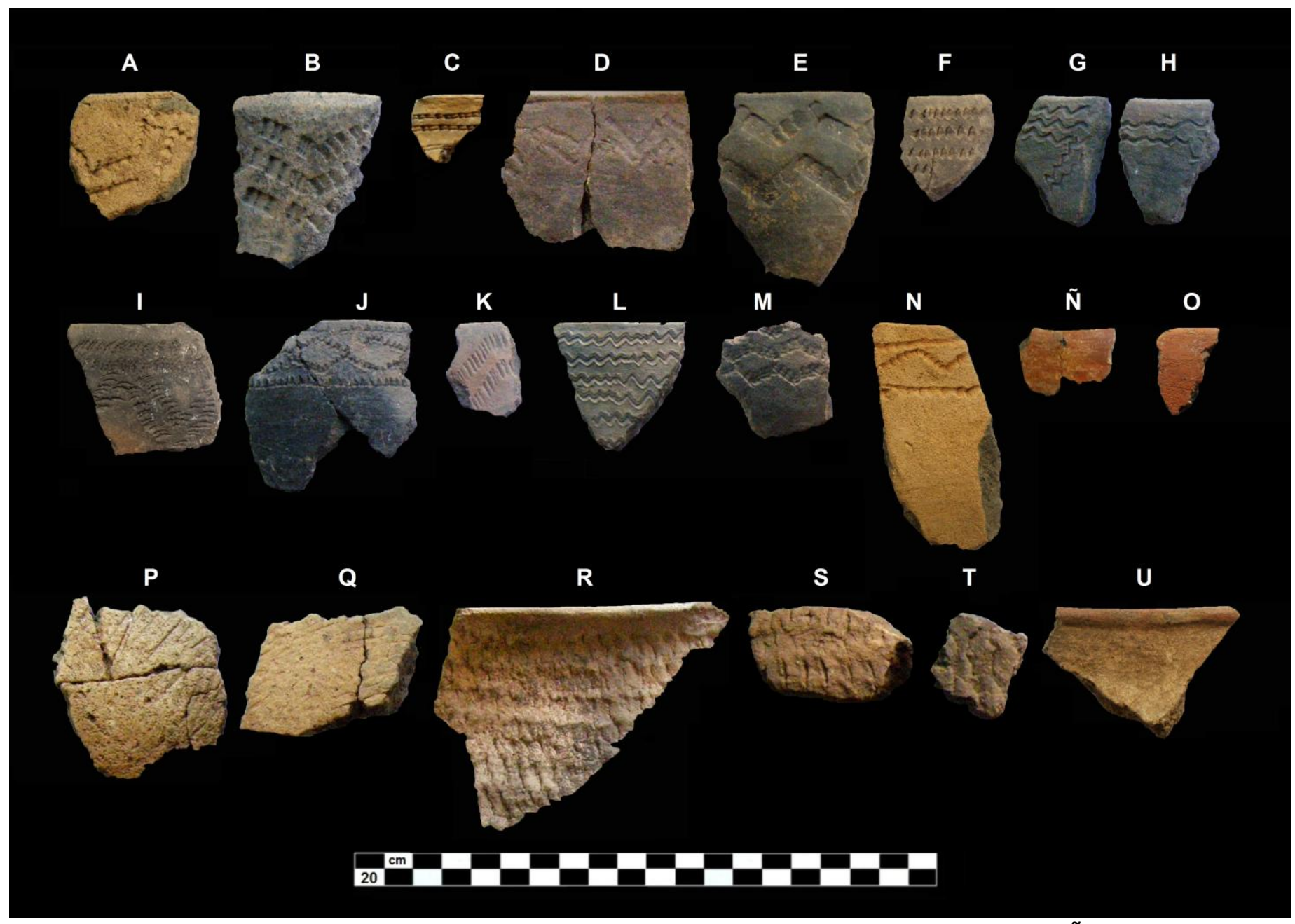

Figura 7.5. Fragmentos de alfarería decorada registrados en sector C. A: El Pinar 1. B: El Pinar 2. C, Ñ y O: Cerro Lorenzo 2. P y Q: Isla de Goyri 1. D y R: La Correntina. S y T: Ensenada del Bellaco.

E, F, G, H, I, J, K, L y M: Sambaquí de Puerto Landa. N y U: Ñandubaysal 1.

\subsubsection{3- Estructura del conjunto faunístico}

El conjunto faunístico del sector C proviene exclusivamente de seis sitios arqueológicos (EP2, CY, CL1, CL2, LC y SPL). En cuatro casos los materiales provienen de sondeos estratigráficos (CL1, CL2, LC y SPL), en un caso de un testeo de pala (CY) y en el restante de recolecciones superficiales (EP2). 
Los restos faunísticos, que incluyen especímenes óseos, dentarios, astas y valvas de moluscos, suman un total de 29564. Este valor no incluye cinco instrumentos óseos, un adorno y dos artefactos decorados.

Del total $(\mathrm{NISP}=29564), 28767$ especímenes se asignaron a alguna categoría taxonómica (Filo, Clase, Orden, Familia, Género y Especie) siendo el resto materiales indeterminados (NISP=797). Dentro de estos últimos el $85,8 \%$, $(n=684)$ son fragmentos de tamaños menores a $2 \mathrm{~cm}$ y el $14,2 \%$ $(n=113)$ restante mayores a esta medida. En la Tabla 7.14 se presenta la abundancia taxonómica de los tres sitios arqueológicos con mayor frecuencia de restos faunísticos (CL1, CL2 y SPL), y se expresan los valores de NISP, NISP\%, MNI y MNE de los distintos taxa. Los tres sitios arqueológicos restantes (EP2, CY y LC) se presentan por separado más abajo. 
Tabla 7.14. Abundancia taxonómica de los sitios arqueológicos del sector C.

\begin{tabular}{|c|c|c|c|c|c|c|c|c|c|c|c|c|}
\hline \multirow{3}{*}{ Taxón } & \multicolumn{12}{|c|}{ Sitios arqueológicos } \\
\hline & \multicolumn{4}{|c|}{ Cerro Lorenzo 1} & \multicolumn{4}{|c|}{ Cerro Lorenzo 2} & \multicolumn{4}{|c|}{ Sambaquí de Puerto Landa } \\
\hline & NISP & NISP\% & $\mathrm{MNI}$ & MNE & NISP & NISP\% & $\mathrm{MNI}$ & MNE & NISP & NISP\% & $\mathrm{MNI}$ & MNE \\
\hline BIVALVIA & - & - & - & - & 339 & 15,38 & - & - & 3452 & 12,6 & - & - \\
\hline GASTRÓPODA & - & - & - & - & 5 & 0,2 & - & - & 49 & 0,18 & - & - \\
\hline Pomacea sp. & - & - & - & - & - & - & - & - & 9 & 0,03 & - & - \\
\hline Asolende sp. & - & - & - & - & - & - & - & - & 1 & 0,003 & 1 & 1 \\
\hline Rectartemon depressus & - & - & - & - & - & - & - & - & 2 & 0,007 & 2 & 2 \\
\hline ACTINOPTERYGII & 82 & 58,2 & - & - & 1297 & 58,6 & - & - & 21974 & 80,7 & - & - \\
\hline Leporinus obtusidens & - & - & - & - & 11 & 0,5 & - & - & 37 & 0,1 & - & - \\
\hline Doradidae & - & - & - & - & - & - & - & - & 231 & 0,8 & - & - \\
\hline Hoplias malabaricus & - & - & - & - & 1 & 0,04 & - & - & - & - & - & - \\
\hline AVES & - & - & - & - & 2 & 0,1 & 1 & 2 & 3 & 0,01 & 2 & 3 \\
\hline MAMMALIA & 33 & 23,4 & - & - & 302 & 13,6 & - & - & 565 & 2 & - & - \\
\hline Blastocerus dichotomus & 1 & 0,7 & 1 & 1 & 15 & 0,7 & 1 & 13 & 17 & 0,062 & 1 & 14 \\
\hline Ozotocerus bezoarticus & 13 & 9,2 & 1 & 1 & 2 & 0,1 & 1 & 2 & 5 & 0,01 & 1 & 5 \\
\hline Cervidae & - & - & - & - & 4 & 0,2 & 1 & 4 & 12 & 0,04 & 1 & 12 \\
\hline Hydrochoerus hydrochaeris & is - & - & - & - & 9 & 0,4 & 1 & 4 & 4 & 0,01 & 1 & 3 \\
\hline Myocastor coypus & 1 & 0,7 & 1 & 1 & 19 & 0,8 & 1 & 15 & 38 & 0,1 & 2 & 29 \\
\hline Cavia aperea & 1 & 0,7 & 1 & 1 & 20 & 0,9 & 5 & 19 & 45 & 0,1 & 13 & 42 \\
\hline Caviidae & - & - & - & - & 2 & 0,1 & 1 & 2 & 4 & 0,01 & 1 & 4 \\
\hline Holochilus brasiliensis & - & - & - & - & - & - & - & - & 1 & 0,003 & 1 & 1 \\
\hline Sigmodontinae & - & - & - & - & 6 & 0,3 & 3 & 6 & 10 & 0,037 & 2 & 8 \\
\hline Dicolpomys sp. & - & - & - & - & - & - & - & - & 1 & 0,003 & 1 & 1 \\
\hline Rodentia & - & - & - & - & - & - & - & - & 1 & 0,003 & 1 & 1 \\
\hline Lycalopex gimnocercus & - & - & - & - & - & - & - & - & 2 & 0,007 & 1 & 2 \\
\hline Testudines & 1 & 0,7 & - & - & 75 & 3,4 & 1 & 1 & 2 & 0,007 & 1 & 1 \\
\hline Squamata & - & - & - & - & 3 & 0,1 & 1 & 3 & 18 & 0,6 & 1 & 16 \\
\hline REPTILIA & - & - & - & - & - & - & - & - & 2 & 0,007 & 1 & 2 \\
\hline Serpentes & - & - & - & - & - & - & - & - & 7 & 0,025 & 1 & 7 \\
\hline Dasypus cf. novemcinctus & - & - & - & - & 1 & 0,04 & 1 & 1 & - & - & - & - \\
\hline Euphractus cf. sexcinctus & - & - & - & - & 2 & 0,1 & 1 & 2 & 6 & 0,022 & 1 & 6 \\
\hline Dasypus sp. & - & - & - & - & 1 & 0,04 & 1 & 1 & 6 & 0,022 & 1 & 6 \\
\hline Anura & - & - & - & - & 1 & 0,04 & 1 & 1 & 6 & 0,022 & 1 & 6 \\
\hline Indeterminado & 9 & 6,4 & - & - & 96 & 4,36 & - & - & 692 & 2,536 & - & - \\
\hline Total & 141 & 100 & 4 & 4 & 2213 & 100 & 21 & 76 & 27202 & 100 & 38 & 172 \\
\hline
\end{tabular}

La Tabla 7.15 muestra las alteraciones tafonómicas identificadas en los especímenes óseos determinados taxonómicamente (NISP= 24909), exceptuando los moluscos. Para el caso particular de la meteorización (sensu Behrensmeyer 1978), la muestra analizada es igual a 1062 especímenes, ya que se excluyeron los peces, las aves, los reptiles, los anfibios y los roedores pequeños (cuis, sigmodontinos, cávidos, Dicolpomys sp. y Rodentia). El diagnóstico de estos últimos se presenta por separado más abajo siguiendo la propuesta de Andrews (1990) para micromamíferos. Si bien los estadíos de meteorización propuestos por Behrensmeyer (1978) en principio deben ser aplicados para animales con un peso mayor a $5 \mathrm{~kg}$, en este estudio y con objetivo es evaluar la meteorización 
de forma global sobre el conjunto óseo se incluyeron los especímenes de coipo y los dasipódidos, cuyos pesos pueden ser generalmente menores a $5 \mathrm{~kg}$.

Una variable cuya sistematización no será profundizada aquí, pero que es necesario mencionar brevemente es la identificación en gran parte de los taxa de varios tipos de fracturas frescas: helicoidal, columnar, oblicua, irregular y transversal, y en algunos casos asociadas con aserrado perimetral. También se destaca la presencia de numerosas lascas óseas pertenecientes a mamíferos de variados portes. Estas lascas pertenecen a huesos largos que son los que tienen mayor cantidad de médula ósea y a pesar de que la mayoría no presenta huellas de impacto, sin duda son el resultado de algún tipo de presión que ha fracturado el hueso original en estado fresco.

Tabla 7.15. Tafonomía de los sitios arqueológicos del sector C.

\begin{tabular}{|c|c|c|c|c|c|c|c|c|}
\hline \multirow{3}{*}{ Variables } & \multicolumn{8}{|c|}{ Sitios arqueológicos } \\
\hline & \multicolumn{2}{|c|}{$\mathrm{CY}$} & \multicolumn{2}{|c|}{ CL1 } & \multicolumn{2}{|c|}{ CL2 } & \multicolumn{2}{|c|}{ SPL } \\
\hline & NISP & $\%$ & NISP & $\%$ & NISP & $\%$ & NISP & $\%$ \\
\hline Meteorización 0 & - & - & 23 & 47,9 & 28 & 7,9 & 75 & 11,5 \\
\hline Meteorización 2 & 2 & 50 & 1 & 2,1 & 297 & 83,7 & 536 & 81,8 \\
\hline Meteorización 3 & 2 & 50 & 23 & 47,9 & 27 & 7,6 & 39 & 5,9 \\
\hline Meteorización 4 & - & - & 1 & 2,1 & 3 & 0,8 & 5 & 0,8 \\
\hline Total & 4 & 100 & 48 & 100 & 355 & 100 & 655 & 100 \\
\hline Óxido de Manganeso $\left(\mathrm{MnO}_{2}\right)$ & 5 & 83,4 & 124 & 93,9 & 1342 & 75,7 & 11100 & 48,4 \\
\hline Carbonato de calcio $\left(\mathrm{CaCO}_{3}\right)$ & - & - & - & - & 11 & 0,6 & - & - \\
\hline $\mathrm{CaCO}_{3}$ y $\mathrm{Mn}$ & - & - & - & - & 142 & 8 & - & - \\
\hline Huellas de corte & - & - & - & - & 13 & 0,7 & 17 & 0,07 \\
\hline Aserrado perimetral & - & - & - & - & - & - & 2 & 0.01 \\
\hline Negativos de impacto & - & - & - & - & 4 & 0,2 & 5 & 0,02 \\
\hline Alteración térmica & 1 & 16,6 & 7 & 5,3 & 63 & 3,6 & 456 & 1,9 \\
\hline Sin alteración & - & - & 1 & 0,8 & 198 & 11,2 & 11417 & 49,6 \\
\hline Total & 6 & 100 & 132 & 100 & 1773 & 100 & 22997 & 100 \\
\hline
\end{tabular}

\section{El Pinar 2 y La Correntina}

En cuanto a la abundancia taxonómica y anatómica, y la tafonomía de estos sitios arqueológicos, en El Pinar 2 se registró un fragmento de concha de bivalvo (NISP=1, MNE=1, MNI=1) y en La Correntina una lasca ósea de diáfisis de hueso largo de mamífero indeterminado, que tiene meteorización estadío 2, está carbonizada y es mayor a $2 \mathrm{~cm}(\mathrm{NISP}=1, \mathrm{MNE}=1, \mathrm{MNI}=1)$.

\section{Cerro Yaguar-í}

\section{Abundancia taxonómica y anatómica}

En Cerro Yaguar-í el conjunto faunístico se compone de un total de seis restos óseos que corresponden a peces ( $\mathrm{NISP}=2, \mathrm{MNE}=2$; vértebras), Blastocerus dichotomus (ciervo de los pantanos, en adelante ciervo) $(\mathrm{NISP}=1, \mathrm{MNI}=1, \mathrm{MNE}=1$; falange), mamíferos medianos ( $\mathrm{NISP}=2, \mathrm{MNE}=2$; 
huesos largos) y mamíferos indeterminados ( $N I S P=1, M N E=1$; espécimen indeterminado). Solo este último tiene un tamaño menor a $2 \mathrm{~cm}$.

Tafonomía

Las alteraciones tafonómicas en CY muestran que cinco especímenes tienen depósito de óxido de Manganeso y el espécimen de ciervo está carbonizado. Asimismo, para la meteorización se registraron dos especímenes con estadío 2 y dos con estadío 3.

\section{Cerro Lorenzo 1}

Abundancia taxonómica y anatómica

Del total especímenes óseos (NISP=141) 132 se asignaron a alguna categoría taxonómica. La mayoría corresponden a peces óseos (NISP=82). Los elementos presentes son vértebras (NISP=50), fragmentos de cráneo (NISP=3), espina pectoral $(\mathrm{NISP}=1)$, y especímenes indeterminados (NISP= 28).

La categoría MAMMALIA (NISP= 33) se subdivide en mamíferos chicos (NISP=1), medianos $(\mathrm{NISP}=16)$ e indeterminados (NISP=16). En cuanto a los grandes mamíferos identificados a nivel de especie se cuentan el ciervo representado por un radio $(\mathrm{MNE}=1)$ y Ozotoceros bezoarticus (venado de las pampas, en adelante venado) representado por un axis (MNE=1).

Dentro de los roedores se registraron Myocastor coypus (coipo) representado por una vértebra $(\mathrm{MNE}=1)$ y Cavia aperea (cuis) representado por una hemimandíbula (MNE=1). Por su parte, la tortuga está representada por un fragmento de espaldar $(\mathrm{MNE}=1)$ y probablemente corresponda a Phrynops hilarii (tortuga de laguna).

\section{Tafonomía}

En cuanto a la meteorización tanto los especímenes con estadío 3 como aquellos sin aparente meteorización presentan el mismo porcentaje (47,9\%). Los estadíos 2 y 1 presentan una frecuencia muy baja. Por otro lado, el cuis presenta meteorización estadío 1 (sensu Andrews 1990).

En cuanto a la depositación química el 93,9\% presenta oxido Manganeso sobre sus superficies. Se registró alteración térmica en especímenes óseos de pez (una vértebra quemada), mamíferos medianos (dos huesos largos calcinados) y mamíferos indeterminados (cuatro calcinados; un hueso largo y tres elementos indeterminados).

\section{Cerro Lorenzo 2}

\section{Abundancia taxonómica y anatómica}

Del total de especímenes óseos (NISP= 2213), 2117 se asignaron a alguna categoría taxonómica. La mayoría corresponden a peces óseos (NISP=1309), dentro de los cuales se determinaron dientes de Leporinus obtusidens (boga) (NISP=1) y maxilar con dientes de Hoplias 
malabaricus (tararira) (NISP = 1). Los elementos son vértebras (NISP=574), elementos axiales como espinas dorsales, dientes y fragmentos de cráneo (NISP=370), espinas pectorales (NISP=53) y fragmentos de cinturas (NISP=13). Asimismo, se contabilizaron espinas y radios indeterminados (NISP=139), y especímenes indeterminados (NISP=160). En orden decreciente, siguen los moluscos (NISP $=344)$ representados mayormente por valvas, de bivalvos $(\mathrm{NISP}=339)$ y de gasterópodos (NISP= 5). Según las determinaciones del Dr. Leandro Pérez (CONICET; FCNyM-UNLP) la mayoría de los bivalvos corresponderían a Diplodon sp.

La categoría MAMMALIA (NISP= 302) se subdivide en mamíferos chicos (NISP=18), medianos $(\mathrm{NISP}=120)$, grandes $(\mathrm{NISP}=63)$ e indeterminados $(\mathrm{NISP}=101)$. En cuanto a los grandes mamíferos identificados a nivel de especie se cuenta el ciervo que está representado por molares (MNE=2), radio $(\mathrm{MNE}=1)$, cúbito $(\mathrm{MNE}=1)$, calcáneo $(\mathrm{MNE}=1)$, metatarso $(\mathrm{MNE}=1)$ y falanges $(\mathrm{MNE}=7)$. El venado está representado por un húmero $(\mathrm{MNE}=1)$ y un metatarso $(\mathrm{MNE}=1)$. Los especímenes agrupados dentro de la categoría Cervidae $(\mathrm{NISP}=4)$, pueden corresponder a venado o Mazama gouazoubira (guazuncho o corzuela parda, en adelante guazuncho). Esta categoría incluye molares $(\mathrm{MNE}=2)$, húmero $(\mathrm{MNE}=1)$ y falange $(\mathrm{MNE}=1)$. También se registró Hydrochoerus hydrochaeris (carpincho) que está representado por un incisivo $(\mathrm{MNE}=1)$, radio $(\mathrm{MNE}=1)$, carpo $(\mathrm{MNE}=1)$ y fémur $(\mathrm{MNE}=1)$

Dentro de los roedores, además de carpincho, se registraron Cavia aperea (cuis) representado por hemimandíbulas $(\mathrm{MNE}=7)$, maxilares $(\mathrm{MNE}=2)$, radios $(\mathrm{MNE}=2)$, hemipélvis $(\mathrm{MNE}=4)$ y fémures $(\mathrm{MNE}=4)$. $\mathrm{A}$ esta especie corresponde el mayor $\mathrm{MNI}(\mathrm{MNI}=5)$ que fue determinado a partir de las hemimandíbulas. El coipo está representado por un incisivo (MNE=1), hemimandíbula $(\mathrm{MNE}=1)$, vértebras $(\mathrm{MNE}=2)$, húmero $(\mathrm{MNE}=1)$, cúbito $(\mathrm{MNE}=1)$, hemipélvis $(\mathrm{MNE}=1)$, fémur $(\mathrm{MNE}=1)$, calcáneo $(\mathrm{MNE}=1)$, metatarsos $(\mathrm{MNE}=5)$ y falange $(\mathrm{MNE}=1)$. Los sigmodontinos están representados por tibias $(\mathrm{MNE}=6)$. La categoría Caviidae incluye un maxilar $(\mathrm{MNE}=1)$ y un húmero $(\mathrm{MNE}=1)$.

Se determinaron elementos de dasipódidos como Euphractus cf. sexcinctus (tatú peludo) (NISP= 2), Dasypus cf. novemcinctus (mulita grande) (NISP=1) y otro elemento clasificado como Dasypus sp. (NISP=1), que podría ser tanto de Dasypus novemcinctus o Dasypus hybridus (mulita). Todos los elementos corresponden a osteodermos, móviles (MNE=2) y fijos (MNE=2).

También se registraron Testudines y Squamata, los primeros probablemente correspondan a Phrynops hilarii (tortuga de laguna) y están representados por elementos del espaldar y/o peto (MNE=1); y los segundos corresponderían a Salvator merianae (lagarto overo) y están representados por vértebras $(\mathrm{MNE}=3)$. El anuro está representado por una vértebra $(\mathrm{MNE}=1)$. Asimismo, se registraron aves indeterminadas representadas por un fémur $(\mathrm{MNE}=1)$ y una diáfisis de hueso largo $(\mathrm{MNE}=1)$. 


\section{Tafonomía}

En cuanto a la meteorización el 83,6\% corresponde al estadío 2; los estadíos 0,3 y 4 presentan muy bajo porcentaje. Por otro lado, los restos de microroedores (NISP $=28$ ) se ubicarían dentro del estadío 1 de Andrews (1990). En cuanto a la depositación química el 75,8\% presenta oxido Manganeso sobre sus superficies. También se registraron $11(0,6 \%)$ especímenes con carbonato de Calcio; y la presencia conjunta de óxido de Manganeso y carbonato de Calcio en 142 (8\%) especímenes.

Las huellas de corte se registraron en $13(0,7 \%)$ especímenes adjudicados a los siguientes taxa: pez (NISP= 1, elemento indeterminado), ciervo (NISP=2, epífisis distal de radio y cóndilo de metapodio), venado (NISP=1, epífisis distal de húmero), carpincho (NISP=1, epífisis proximal de radio), coipo (NISP= 1, epífisis proximal y diáfisis de fémur), mamíferos grandes (NISP= 5, epífisis proximal de cúbito y cuatro diáfisis de huesos largos), mamífero chico (NISP=1, epífisis proximal de fémur) y mamífero indeterminado (NISP= 1 , diáfisis de hueso largo). El radio de ciervo de los pantanos además tiene un negativo de impacto externo y uno de los huesos largos de mamífero grande tiene dos negativos de impacto.

Estas trazas se cuentan desde una a seis por espécimen y se distribuyen como sigue: dos especímenes con una huella única; ocho especímenes con varias huellas concentradas en un mismo sector; y tres especímenes con varias huellas concentradas en varios sectores del mismo elemento. En los casos donde hay más de una huella estas se orientan de forma paralelas y subparalelas. Asimismo, en seis casos son transversales al eje mayor del elemento, en cuatro casos son oblicuas, en un caso oblicuas y transversales, en un caso oblicuas y longitudinales, y en un caso longitudinales. En total las huellas de corte se registran en siete epífisis y seis diáfisis de huesos largos, además del pez que probablemente dicho espécimen corresponda al cráneo. Claramente las marcas están indicando actividades de desarticulación y descarne.

Cuatro $(0,2 \%)$ especímenes presentan negativos de impacto externo. Los dos ya mencionados: el radio de ciervo y el hueso largo mamífero grande, a los que se suman dos diáfisis de huesos largos (lascas) de mamífero grande con un negativo cada una.

Un total de $63(3,6 \%)$ especímenes de distintos taxa evidencian termoalteración en diferentes grados, tanto quemados $(n=2)$, carbonizados $(n=37)$ y calcinados $(n=24)$. Se registró esta evidencia en peces (uno quemado, ocho carbonizados y cuatro calcinados), carpincho (uno calcinado), Cervidae (uno calcinado), sigmodontino (uno carbonizado), tortuga (uno carbonizado), y mamíferos grandes (uno quemado y cuatro carbonizados), medianos (nueve carbonizados y 10 calcinados), chicos (uno carbonizado y dos calcinados) e indeterminados (13 carbonizados y seis calcinados). 


\section{Sambaquí de Puerto Landa}

\section{Abundancia taxonómica y anatómica}

Del total de especímenes óseos (NISP= 27202), 26510 se asignaron a alguna categoría taxonómica. La mayoría corresponden a peces óseos (NISP= 22242), dentro de los cuales se determinaron restos de boga $($ NISP $=37)$ y Doradidae $($ NISP $=231)$. Los elementos son vértebras (NISP $=6153$ ), elementos axiales como espinas dorsales, dientes, fragmentos de cráneo e hipurales (NISP $=159)$, espinas pectorales $(N I S P=283)$ y fragmentos de cinturas (NISP=64). Asimismo, se contabilizaron espinas y radios indeterminados (NISP $=7921$ ), placas óseas laterales $(N I S P=231)$ y especímenes indeterminados (NISP= 7431).

En orden decreciente, siguen los moluscos $(N I S P=3513)$ representados mayormente por valvas de bivalvos (NISP= 3452) que corresponderían a Diplodon sp. (Dr. Leandro Pérez; CONICET; FCNyM-UNLP). También se registraron gasterópodos indeterminados (NISP=49); Pomacea sp. (NISP= 9), Rectartemon depressus (NISP=2) y Asolende sp. (NISP=1). Estos tres últimos taxa fueron determinados por el Dr. Sergio Miquel (CONICET; MACNBR).

La categoría MAMMALIA (NISP= 565) se subdivide en mamíferos chicos (NISP= 133), medianos (NISP= 208), grandes $(N I S P=100)$ e indeterminados (NISP=124). En cuanto a los grandes mamíferos identificados a nivel de especie se cuenta el ciervo que está representado por un molar $(\mathrm{MNE}=1)$, capitatum $(\mathrm{MNE}=1)$ y falanges $(\mathrm{MNE}=12)$. El venado está representado por una hemimandíbula $(\mathrm{MNE}=1)$, húmero $(\mathrm{MNE}=1)$, hemipélvis $(\mathrm{MNE}=1)$, astrágalo $(\mathrm{MNE}=1)$ y metatarso $(M N E=1)$. Los especímenes agrupados dentro de la categoría Cervidae (NISP= 12) pueden corresponder a venado o guazuncho en nueve casos, cuyos elementos son: hemimandíbula (MNE= $1)$, astrágalo $(\mathrm{MNE}=1)$, metacarpo $(\mathrm{MNE}=2)$, metapodio $(\mathrm{MNE}=1)$ y falanges $(\mathrm{MNE}=4)$. En los tres casos restantes corresponden a cérvidos no determinados, cuyos elementos son: molares $(\mathrm{MNE}=2) \mathrm{y}$ asta $(\mathrm{MNE}=1)$. El carpincho está representado por un incisivo $(\mathrm{MNE}=1)$, metatarso $(\mathrm{MNE}=1) \mathrm{y}$ falange (MNE= 1).

Dentro de los roedores, además de carpincho, se registraron cuis, coipo, sigmodontinos, cávidos, Dicolpomys sp. y un microroedor indeterminado. El cuis está representado por hemimandíbulas ( $M N E=19)$, hemimaxilar $(M N E=5)$, molares aislados $(M N E=3)$, incisivos aislados (MNE= 2), húmero (MNE=1), cúbito (MNE=1), hemipélvis (MNE=3), fémures (MNE= 5), tibia (MNE= 1), calcáneo $(\mathrm{MNE}=1)$ y metapodio $(\mathrm{MNE}=1)$. A esta especie corresponde el mayor $\mathrm{MNI}(\mathrm{MNI}=13)$ que fue determinado a partir de las hemimandíbulas. El coipo está representado por incisivos (MNE= $2)$, molares $(\mathrm{MNE}=3)$, hemimandíbulas $(\mathrm{MNE}=2)$, vértebra $(\mathrm{MNE}=1)$, húmero $(\mathrm{MNE}=1)$, radio $(\mathrm{MNE}=1)$, cúbitos $(\mathrm{MNE}=3)$, tibia $(\mathrm{MNE}=1)$, calcáneo $(\mathrm{MNE}=1)$, astrágalo $(\mathrm{MNE}=1)$, metacarpo $(\mathrm{MNE}=1)$, metatarsos $(\mathrm{MNE}=3)$, metapodios $(\mathrm{MNE}=7)$ y falanges $(\mathrm{MNE}=2)$. Holochilus brasiliensis está representado por una hemimandíbula $(\mathrm{MNE}=1)$. Los sigmodontinos están representados por tibias $(\mathrm{MNE}=5)$, vértebras $(\mathrm{MNE}=2)$ y fémur $(\mathrm{MNE}=1)$. Los cávidos incluyen una escápula $(\mathrm{MNE}=1)$, 
húmeros $(\mathrm{MNE}=2)$ y fémur $(\mathrm{MNE}=1)$. Dicolpomys sp. está representado por una hemimandíbula (MNE= 1) y el microroedor por un incisivo aislado (MNE= 1 ).

Se determinaron elementos que corresponderían a tatú peludo $(\mathrm{NISP}=6)$ y otros que podrían ser tanto de mulita o mulita grande $(\mathrm{NISP}=6)$ y se clasifican como Dasypus sp. Todos los elementos corresponden a osteodermos, móviles (MNE= 7) y fijos (MNE= 5). La tortuga (cf. Phrynops hilarii) está representada por un elemento del espaldar y/o peto $(\mathrm{MNE}=1)$. El lagarto (cf. Salvator merianae) está representado por un axis $(\mathrm{MNE}=1)$, tibia $(\mathrm{MNE}=1)$, fémur $(\mathrm{MNE}=1)$, vértebras ( $\mathrm{MNE}=9)$ y costillas $(\mathrm{MNE}=4)$. La serpiente y el reptil indeterminado están representados por vértebras, $\mathrm{MNE}=7$ y $\mathrm{MNE}=$ 2 respectivamente. Los anuros están representados por vértebras $(\mathrm{MNE}=6)$. Las aves indeterminadas $(\mathrm{NISP}=3)$ incluyen fémur $(\mathrm{MNE}=1)$, tarso-metatarso $(\mathrm{MNE}=1)$ y falange $\mathrm{MNE}=1)$. El zorro gris (Lycalopex gimnocercus) está representado por una hemimandíbula y un hemimaxilar (MNE=2).

\section{Tafonomía}

En cuanto a la meteorización el $81,8 \%$ corresponde al estadío 2; los estadíos 0,3 y 4 presentan muy bajo porcentaje. Por otro lado, los restos de microroedores se ubicarían en el estadío $1(\mathrm{NISP}=61)$ y $2(\mathrm{NISP}=1)$ de Andrews (1990). En cuanto a la depositación química el 48,4\% presenta oxido Manganeso sobre sus superficies.

Las huellas de corte se registraron en 17 (0,07\%) especímenes adjudicados a los siguientes taxa: venado (NISP $=1$, acetábulo de hemipélvis), coipo (NISP $=1$, cóndilo y apófisis de hemimandíbula), lagarto (NISP=2, vértebras), mamíferos grandes (NISP=4; diáfisis de costilla $-n=2-$, íleon de hemipélvis, y diáfisis de hueso largo), mamífero mediano (NISP=6; diáfisis de huesos largos n= 4-, epífisis proximal y diáfisis de costilla, y diáfisis de costilla), y mamífero indeterminado (NISP=3; diáfisis de hueso largo y elementos indeterminados $-n=2-$ ). El aserrado perimetral (NISP $=2 ; 0,01 \%$ ) se registró en la epífisis distal de un metatarso de venado de las pampas y en un fragmento de diáfisis de hueso largo de mamífero mediano.

Dentro de este conjunto una diáfisis de hueso largo de mamífero mediano y otra similar de mamífero grande están quemadas. Asimismo, una diáfisis de hueso largo de mamífero mediano presenta un negativo de impacto externo e interno simultáneamente.

Estas trazas se cuentan desde una a 17 por espécimen y se distribuyen como sigue: tres especímenes con una huella única; 11 especímenes con varias huellas concentradas en un mismo sector; y tres especímenes con varias huellas concentradas en varios sectores del mismo elemento. En los casos donde hay más de una huella estas se orientan de forma paralelas y subparalelas. Asimismo, en 12 casos son transversales al eje mayor del elemento, en dos casos son oblicuas, en dos casos oblicuas y transversales, y en un caso longitudinales. En total las huellas de corte se registran en 10 diáfisis y una epífisis de huesos largos, en dos hemipélvis, una hemimandíbula, dos vértebras, y dos elementos indeterminados. También hay aserrado perimetral en una diáfisis y en una epífisis. 
Claramente las huellas están indicando actividades de desarticulación y descarne, y el aserrado probablemente la explotación de la medula ósea y/o la confección de tecnofacturas.

Un total de cinco $(0,02 \%)$ especímenes presentan negativos de impacto externo. Uno que ya fue mencionado, el mamífero mediano que tiene huellas de corte, además presenta un negativo interno en el mismo lugar que el externo, evidentemente son el resultado del mismo golpe. Los cuatro restantes corresponden a lascas óseas procedentes de diáfisis de huesos largos de mamíferos medianos $(n=3)$ y grandes $(n=1)$. Uno de estos especímenes de mamífero mediano además tiene alteración térmica (quemado).

Un total de 456 (1,9\%) especímenes de distintos taxa evidencian termoalteración en diferentes grados, tanto quemados $(n=41)$, carbonizados $(n=288)$ y calcinados $(n=127)$. Se registró esta evidencia en peces (cuatro quemados, 199 carbonizados y 73 calcinados), Cervidae (uno carbonizado y uno calcinado), ciervo (uno quemado y uno carbonizado), Caviidae (uno quemado), cuis (uno quemado), Euphractus cf. sexcinctus (uno carbonizado), Dasypus sp. (cuatro carbonizados), coipo (dos carbonizados), sigmodontino (uno calcinado), lagarto (dos carbonizados), y mamíferos grandes (dos quemados, 12 carbonizados y cinco calcinados), medianos (tres quemados, 16 carbonizados y 12 calcinados), chicos (14 quemados, 22 carbonizados y 11 calcinados) e indeterminados (15 quemados, 28 carbonizados y 24 calcinados).

\section{Instrumentos óseos y adornos}

La Tabla 7.16 muestra los instrumentos óseos recuperados en CL2 y SPL.

Tabla 7.16. Instrumentos óseos de los sitios arqueológicos Cerro Lorenzo 2 y Sambaquí de Puerto Landa.

\begin{tabular}{|c|c|c|c|c|c|c|c|c|c|c|c|}
\hline \multirow{2}{*}{ Pieza } & \multirow{2}{*}{ Instrumento } & \multirow{2}{*}{ Taxón } & \multirow{2}{*}{ Elemento } & \multicolumn{5}{|c|}{ Atributos } & \multicolumn{3}{|c|}{ Dimensiones mm. } \\
\hline & & & & $\mathrm{P}$ & $D$ & $A$ & $\mathrm{~F}$ & AP & $\mathrm{L}$ & A & $E$ \\
\hline CL2-S2-1-G1 & Punta acanalada & MAMMALIA & hueso largo & si & $\overline{\text { no }}$ & no & si & si & 38,8 & 8 & 4,3 \\
\hline CL2-S3-6-G1 & Gancho de propulsor & Cervidae & astrágalo & si & si & no & si & no & $29,8^{1}$ & 21,5 & $32,7^{2}$ \\
\hline SPL-S1-5-G1 & Punta acanalada & Cervidae & metapodio & si & no & no & si & no & 69 & 10,3 & 5,3 \\
\hline SPL-S1-12-G1 & Punta con epífisis & Cervidae & metapodio & si & no & no & si & no & 38,3 & 14,5 & 11,7 \\
\hline SPL-S1-14-G1 & Punta con epífisis & Cervidae & metapodio & si & si & no & no & no & 59,5 & 21,7 & 15,1 \\
\hline
\end{tabular}

Atributos. P: pulido; D: desbaste; A: ahuecado; F: huellas de filos; AP: aserrado perimetral. Dimensiones. L: largo máximo; A: ancho máximo; E: espesor máximo. (1) con el gancho de propulsor en su posición de lanzamiento esta medida corresponde al largo en sentido horizontal y (2) corresponde a la medida vertical.

Los instrumentos consisten en: dos puntas acanaladas, elaboradas sobre metapodio de Cervidae y hueso largo de mamífero indeterminado; dos puntas con epífisis, elaborados sobre metapodios Cervidae; y un gancho de propulsor elaborado sobre astrágalo de Cervidae 
(probablemente ciervo de los pantanos) (Figura 7.6). Cabe destacar que los soportes-base de las puntas con epífisis corresponden a elementos de animales inmaduros.

Todos los instrumentos presentan pulido en alguna sección de su superficie, sobre todo en el extremo distal en el caso de las puntas. A su vez, cuatro presentan huellas de filos, algunas podrían ser de corte y otras generadas durante el proceso de confección del instrumento mediante el uso de herramientas líticas con filos agudos. Por otra parte, dos piezas presentan algún tipo de desbaste. Por último, solo una pieza tiene aserrado perimetral en su porción proximal. Se registró depósito de óxido de Manganeso sobre la superficie de las cinco piezas. También todas presentan algún tipo de fractura que afecta, las tres dimensiones en tres casos (CL2-S2-1-G1, SPL-S1-5-G1 y SPL-S1-12-G1) y en dos casos (CL2-S3-6-G1 y SPL-S1-14-G1) solamente se ve afectada la longitud. No se registraron negativos de impacto, lascados o decoración.

El adorno consiste en una cuenta de collar con morfología piriforme curvada, confeccionada sobre valvas de molusco gasterópodo indeterminado (probablemente Megalobulimus sp.), Está entera y presenta un pequeño orificio natural por donde pasaba el hilo suspensor. Fue elaborada mediante el recorte de la forma y el posterior pulido-abrasión de los bordes. Esta cuenta proviene de CL2 (CL2-S2-1-G2) y presenta además restos de pintura roja en ambas caras. Sus dimensiones son $35,1 \times 16,8 \times 4,6 \mathrm{~mm}$ (Figura 7.6C).

Los otros dos artefactos por destacar son fragmentos de diáfisis de huesos largos de una especie indeterminada que presentan decoración incisa en zigzag (CL2-S3-10-G1; 15,6×12,9×5,5 mm) (Figura 7.6D) y en zigzag y una línea transversal (SPL-S1-13-G1; 19,9x8,8x3,1 mm) (Figura 7.6H). Ambas piezas provienen de sitios arqueológicos distintos (CL2 y SPL) pero son muy semejantes ya que además de la decoración ambas están quemadas y presentan un color negro y un brillo intenso. No está claro a qué tipo de artefacto pertenecieron estos fragmentos pero pudieron integrar algún adorno o instrumento de los ya conocidos (p. ej. un tubo decorado, véase más adelante). 


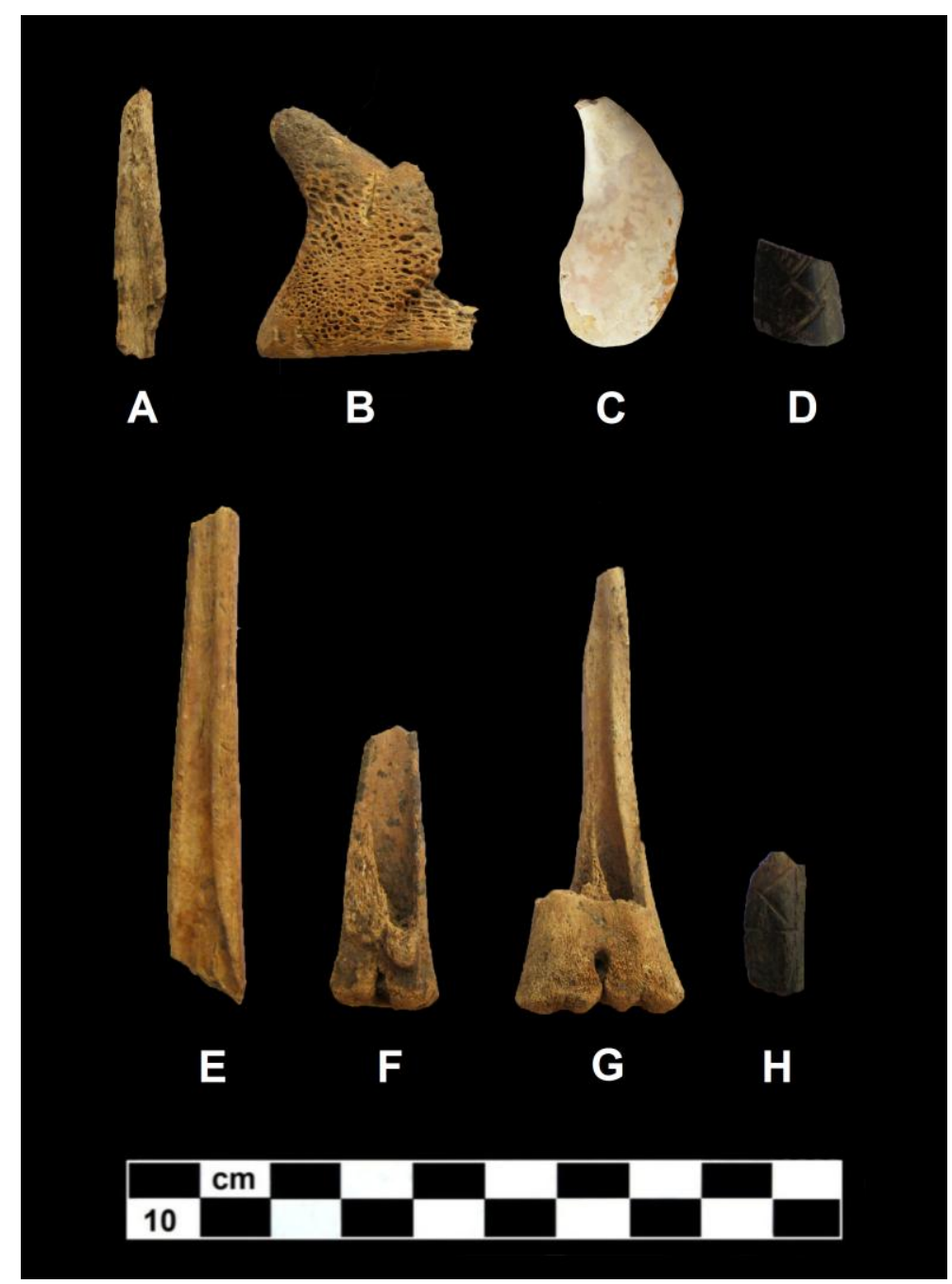

Figura 7.6. Instrumentos óseos, adornos y artefactos decorados recuperados en el sector $\mathrm{C}$. A (CL2-S2-1-G1), B (CL2-S3-6-G1), C (CL2-S2-1-G2) y D (CL2-S3-10-G1) sitio arqueológico Cerro Lorenzo 2. E (SPL-S1-5-G1), F (SPL-S1-12-G1), G (SPL-S1-14-G1) y H (SPL-S1-13-G1) sitio arqueológico Sambaquí de Puerto Landa.

\subsubsection{4- Estructura del conjunto de restos óseos humanos}

Los restos óseos humanos recuperados en nuestros trabajos de campo en Cerro Lorenzo 2 y Sambaquí de Puerto Landa fueron analizados por la Lic. Agustina Ramos van Raap, la Dra. Clara Scabuzzo y el Sr. Oscar Schwerdt (CONICET; FCNyM-UNLP).

En CL2 se recuperaron 18 especímenes procedentes de los sondeos 2 y 3 . Se calculó un MNE= 9 y un $\mathrm{MNI}=1$, correspondiente a un individuo subadulto de 14 a 18 años y sexo indeterminado. Los elementos anatómicos estaban desarticulados y se registraron tanto elementos craneales y poscraneales que incluyen cráneo, vértebra toráxica, falanges ( $1^{\mathrm{a}}$ y $2^{\mathrm{a}}$, mano), metatarso $\left(5^{\circ}\right)$, costillas, cúbito, radio, esternón y molares.

En SPL se recuperaron 39 especímenes procedentes del sondeo 1. Se calculó un $\mathrm{MNE}=3$ y un $\mathrm{MNI}=1$, correspondiente a un individuo de edad y sexo indeterminado. Los elementos anatómicos 
estaban desarticulados y se registraron sobre todo elementos craneales que incluyen cráneo, maxilar, incisivo, canino, premolares, molares, falanges (2aㅡ) y ganchoso. El cráneo fue mayormente recuperado en el nivel 0,65-0,70 cm y estaba posicionado lateralmente con la porción frontal hacía oeste. Se encontraba muy frágil y deteriorado y estaba asociado a valvas enteras de bivalvo y a los grandes tiestos que integran las vasijas $\mathrm{G}$ y $\mathrm{H}$ de la Figura 7.4.

\subsection{3- MATERIALES ARQUEOLÓGICOS DEL MUSEO MANUEL ALMEIDA}

En esta sección se describe una muestra de artefactos y restos óseos humanos y faunísticos procedentes en su mayor parte del sector C, y depositados en el Museo Arqueológico Manuel Almeida. Estos materiales fueron recolectados por el Profesor Manuel Salvador Almeida y sus colaboradores (véase Capítulo 2). La procedencia de la colección ya ha sido presentada en trabajos anteriores por lo que aquí no se redundará en ese punto (véase Bourlot 2008; Castro y Costa Angrizani 2014; Castro y Del Papa 2015). Estos materiales de colección resultan ser complementarios a los obtenidos en nuestros trabajos de campo ya que algunos provienen de los mismos sitios arqueológicos estudiados de manera sistemática en esta tesis. Es necesario aclarar que estos materiales de colección no se presentan conjuntamente con los recuperados en nuestros trabajos de campo (Tabla 7.2) porque no fueron analizados con el mismo nivel de detalle. La procedencia de las piezas depositadas en el museo fue identificada a partir de su numeración correlativa y los catálogos, publicaciones y manuscritos de Almeida ubicados en el archivo de la institución.

La colección del MAMA proviene de diversos sitios arqueológicos en superficie y en estratigrafía ubicados en los departamentos Gualeguaychú, Concepción del Uruguay, Colón e Islas del Ibicuy. En esta sección solamente se trabaja con una muestra seleccionada en base a su procedencia y a sus atributos tecnomorfológicos y taxonómicos (Tabla 7.17), y cuya ubicación se indica en la Figura 7.1. La mayor parte de los materiales analizados tiene procedencia exacta, pero también se presentan algunos artefactos poco comunes en el registro regional más allá de que no se cuenta con información precisa sobre su procedencia, pero al menos se puede sostener que la mayoría proviene del sector C o zonas adyacentes (Figura 7.1). También se describen algunas piezas de otras colecciones pequeñas del sector $\mathrm{C}$ y zonas cercanas que resultan relevantes para las interpretaciones del registro arqueológico y serán mencionadas oportunamente. 
Tabla 7.17. Materiales arqueológicos de la colección del Museo Manuel Almeida (Gualeguaychú), según sus frecuencias por tipo de material y categorías tecnológicas, morfológicas y taxonómicas.

Sitios arqueológicos

(Sigla en la Figura 7.1)
Artefactos líticos

\begin{tabular}{|c|c|c|c|}
\hline INS & DES & NUC & Total \\
\hline 3 & - & 2 & 5 \\
\hline - & - & - & - \\
\hline 7 & 7 & 3 & 17 \\
\hline 1) 2 & 2 & - & 4 \\
\hline- & - & 1 & 1 \\
\hline 4 & - & - & 4 \\
\hline 1 & - & - & 1 \\
\hline 3 & 3 & 2 & 8 \\
\hline- & - & - & - \\
\hline - & - & - & - \\
\hline 2 & 2 & - & 4 \\
\hline 1 & 1 & - & 2 \\
\hline - & - & - & - \\
\hline 3 & - & - & 3 \\
\hline - & - & - & - \\
\hline- & - & - & - \\
\hline- & - & - & - \\
\hline
\end{tabular}

Cerámica

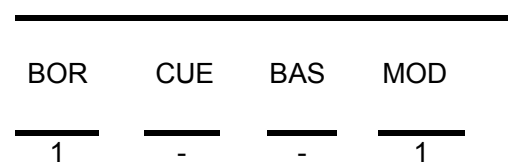

Cerro Lorenzo 2 (CL2)

La Correntina (LC)

Ensenada del Bellaco (EDB)

Túmulo 1-Cerro Norte de Machado (T1-CNM) 2

Túmulo 2-Cerro Sur de Machado (T2-CSM)

Sambaquí de Puerto Landa (SPL)

El Aserradero Viejo (EAV)

Cerros de los Pampas (CP)

Fajina Quemada (FQ)

Las Conchillas (LCs)

Ñandubaysal-A. La Cruz/Ubajay (Ñ-AC/AU)

San Luís Costa - Túmulo 1 (SLC-T1)

San Luís Médanos (SLM)

Túmulo de Lucuix (TL)

Túmulo 1 - La Argentina (T1-LA)

El Monzón ${ }^{2}(E M O)$

El Cuatro ${ }^{2}(\mathrm{EC})$

Sin procedencia ${ }^{3}$

Total

INS: instrumentos; DES: desechos; NUC: núcleos; BOR: bordes; CUE: cuerpos; BAS: bases; MOD: modelados; NISP: Número de especímenes identificados; MNI: Número mínimo de individuos. (1) este valor incluye especímenes faunísticos, instrumentos, artefactos y adornos. (2) la ubicación de estos conjuntos en la Figura 7.1 es aproximada. (3) estos materiales proceden de los sitios arqueológicos de la tabla y de los campos del departamento Gualeguaychú, Concepción del Uruguay, Colón e Islas del Ibicuy pero no se cuenta con su procedencia exacta (p. ej. estancias EI Potrero-EP-, Punta Caballos-PC-, La Selmira-LS-, La Estopona-LE-, Pehuajó Sud-PS-, Arroyo Gualeyán-AG-, Paso Paysandú-PP- y Río Paranacito-RP-). (4) este valor incluye un fragmento indeterminado.

Todos los sitios arqueológicos tienen más materiales que los presentados en la tabla.

En la Tabla 7.17 y en las siguientes de esta sección se incluyen algunos sitios arqueológicos publicados previamente como Túmulo de Lucuix (Greslebin 1931a) y Túmulo 1 - La Argentina (Aparicio 1928). Otros como Ñandubaysal - Arroyo de La Cruz/Arroyo Ubajay, San Luís Costa - Túmulo 1, San Luís Médanos, El Monzón, El Cuatro y Túmulo de Irungaray (TI) que corresponden a sitios arqueológicos trabajados por Almeida (s/fa).

Particularmente SLC-T1 es un montículo sobre albardón de $30 \mathrm{~m}$ de largo por $10 \mathrm{~m}$ de ancho y $3 \mathrm{~m}$ de altura, se encuentra en la localidad arqueológica Cerros de Boari (véase Capitulo 8) y podría corresponder a Cerro de Boari 1 o a otro que ya ha sido destruido completamente por el río Gualeguaychú (Almeida s/fa, s/fc). El sitio arqueológico Ñ-AC/AU corresponde a ocupaciones superficiales sobre playas en la margen derecha del Uruguay; SLM corresponde a una ocupación de médanos en la margen derecha del río Gualeguaychú, debido a que el material arqueológico conocido proviene del MAMA y la zona ha sido intensamente explotada en tiempos modernos para la extracción de arena, no está claro si este sitio arqueológico correspondía a un montículo; Almeida ( $\mathrm{s} / \mathrm{fa}$ ) recogió el material expuesto por vientos y lluvia en una hondonada sobre los médanos; EMO y 
EC corresponden a ocupaciones sobre albardones (Figura 7.1). Por último, Tl se ubica en el distrito Ceibas, pero actualmente la porción norte del distrito Ceibas pertenece al departamento Gualeguaychú y su porción sur al departamento Islas del Ibicuy. A partir de la información disponible no se puede precisar en cuál de estos departamentos se encuentra el sitio arqueológico.

\subsubsection{1- Artefactos líticos del Museo Arqueológico Manuel Almeida}

\section{Materias primas}

La Tabla 7.18 muestra la representatividad de las materias primas en relación a las clases tipológicas.

Tabla 7.18. Materias primas por clases tipológicas de los materiales arqueológicos del Museo Manuel Almeida (Gualeguaychú).

\begin{tabular}{|c|c|c|c|c|c|c|c|c|}
\hline \multirow{3}{*}{ Materia prima } & \multicolumn{6}{|c|}{ Clases tipológicas } & & \\
\hline & \multicolumn{2}{|c|}{ Instrumentos } & \multicolumn{2}{|c|}{ Desechos de talla } & \multicolumn{2}{|c|}{ Núcleos } & \multicolumn{2}{|c|}{ Total } \\
\hline & $\mathrm{n}$ & $\%$ & $\mathrm{n}$ & $\%$ & $\mathrm{n}$ & $\%$ & $\mathrm{n}$ & $\%$ \\
\hline Calcedonia & 2 & 2,8 & - & - & 1 & 12,5 & 3 & 3,1 \\
\hline Caliza silicificada & 4 & 5,5 & 11 & 73,3 & 4 & 50 & 19 & 20 \\
\hline Sílice & 2 & 2,8 & 2 & 13,3 & - & - & 4 & 4,2 \\
\hline Xilópalo & 2 & 2,8 & - & - & 1 & 12,5 & 3 & 3,1 \\
\hline Arenisca & 29 & 40,3 & 1 & 6,7 & 1 & 12,5 & 31 & 32,7 \\
\hline Cuarcita intertrap & - & - & - & - & 1 & 12,5 & 1 & 1,1 \\
\hline Basalto & 29 & 40,3 & 1 & 6,7 & - & - & 30 & 31,6 \\
\hline Cuarzo & 3 & 4,1 & - & - & - & - & 3 & 3,1 \\
\hline Diabasa & 1 & 1,4 & - & - & - & - & 1 & 1,1 \\
\hline Total & 72 & 100 & 15 & 100 & 8 & 100 & 95 & 100 \\
\hline
\end{tabular}

\section{Instrumentos}

La mayoría fueron elaborados mediante picado, abrasión y/o pulido $(n=38)$, e incluyen 37 bolas y una mano de mortero. Continúan las piezas talladas $(n=16)$ que incluyen siete puntas de proyectil, tres piezas con retoque sumario, dos choppers, un bifaz, un perforador, un raspador frontal y una punta entre muescas. También se registraron piezas modificadas por uso $(n=18)$ que incluyen 14 piedras con hoyuelos o "rompecocos", un molino, un mortero y dos pulidores en canaleta.

Bolas $(n=37)$

La mayoría de las bolas fueron encontradas aisladas en los campos, médanos y playas del sector C (Figura 7.7). Tres proceden de TL (MAMA-TL-57, MAMA-TL-59, MAMA-TL-75) y una de EDB (MAMA-EDB-313), las restantes 27 no tienen procedencia exacta. La Tabla 7.19 muestra que 21 $(56,8 \%)$ bolas presentan surco y $10(27 \%)$ carecen de este atributo. La morfología del surco es 
variable, en general se presenta bien definido circundando toda la pieza en una línea recta. Se incluyen en este conjunto seis de las llamadas "piedras lenticulares", tres proceden de la costa del río Uruguay en la estancia Punta Caballos al sur de Gualeguaychú (MAMA-PC-320, MAMA-PC-526, MAMA-PC-446) y las restantes no tienen procedencia exacta. Todas tienen forma circular aplanada (forma de lenteja) con el máximo espesor generalmente en el centro, tienen distinto grado de abrasión y pulido estando algunas muy bien regularizadas (Figura 7.7F). Del total se registraron 32 enteras y cinco fragmentadas con más del 80\% de completitud (sensu Vecchi 2010).

Tabla 7.19. Clasificación de las bolas del Museo Manuel Almeida (Gualeguaychú) según González (1953) y piedras lenticulares.

\begin{tabular}{|c|c|c|c|c|c|c|c|}
\hline \multirow{2}{*}{ Tipo } & \multirow{2}{*}{ Clase } & \multirow{2}{*}{ subclase } & \multicolumn{3}{|c|}{ Materia prima } & \multicolumn{2}{|c|}{ Total } \\
\hline & & & $\mathrm{A}$ & $\mathrm{B}$ & $\mathrm{D}$ & $\mathrm{n}$ & $\%$ \\
\hline \multirow{5}{*}{$\begin{array}{c}\text { A } \\
\text { (sin surco) }\end{array}$} & $a$ & - & 1 & 2 & - & 3 & 30 \\
\hline & b & - & 1 & 1 & 1 & 3 & 30 \\
\hline & c & - & 1 & - & - & 1 & 10 \\
\hline & $d$ & 2 & 2 & 1 & - & 3 & 30 \\
\hline & Total & - & 5 & 4 & 1 & 10 & 100 \\
\hline \multirow{8}{*}{$\begin{array}{c}\text { B } \\
\text { (con surco) }\end{array}$} & a & - & 1 & 3 & - & 3 & 19 \\
\hline & b & 1 & - & 1 & - & 2 & 4,8 \\
\hline & c & 1 & - & 1 & - & 1 & 4,8 \\
\hline & c & 2 & - & 1 & - & 1 & 4,8 \\
\hline & $f$ & - & 4 & 4 & - & 8 & 38 \\
\hline & g & - & 1 & - & - & 1 & 4,8 \\
\hline & $\mathrm{h}$ & - & 3 & 2 & - & 5 & 23,8 \\
\hline & Total & - & 9 & 12 & - & 21 & 100 \\
\hline Lenticulares & - & - & 2 & 4 & - & 6 & 100 \\
\hline Total general & - & - & 16 & 20 & 1 & 37 & - \\
\hline
\end{tabular}

A partir de los atributos morfométricos se observó la presencia de 11 tipos dentro de los cuales el tipo Bf (forma de limón) es el más representado, seguido por el tipo Bh (piriforme). Por su parte, los tipos $\mathrm{Aa}, \mathrm{Ba}$ (esferas) y $\mathrm{Ab}$ y $\mathrm{Ad} 2$ (esferoide alargado) presentan frecuencias iguales. Los tipos restantes tienen baja frecuencia. Se destaca el tipo Bg por ser piriforme y presentar un hoyuelo sobre el surco (Figura 7.7A). Ahora bien, en cuanto a la morfología de las bolas, sin considerar la presencia y posición del surco y/o hoyuelo, se observa que hay un predominio de formas con al menos dos diámetros distintos (esferoides) sobre las esferas. En TL las tres bolas son de tipos distintos ( $A a, A b$ y $B h$ ) y en EDB es tipo Ab con una cara aplanada lo que lleva a considerar que pudo ser usada como sobador. Asimismo, una bola tipo Ad2 presenta dos caras más planas opuestas fuertemente alisadas, mucho más que el resto de la superficie por lo que también pudo ser un sobador. 
De los 26 tipos de bolas determinados por González (1953) a nivel continental, en Entre Ríos este autor establece la presencia de seis de ellos ( $A a, A d 2, B a, B b, B c 2$ y $B f$ ) basándose sobre todo en bibliografía y solamente en un caso a partir del análisis concreto de una pieza tipo Bf (González 1953: 206). De estos seis tipos todos fueron registrados en la muestra del MAMA (Tabla 7.19), y a estos se suman otros cinco ( $\mathrm{Ab}, \mathrm{Ac}, \mathrm{Bc}$, Bg y Bh) que no habían sido documentados siguiendo la clasificación de González (1953). En síntesis, en la colección del MAMA se identificaron 11 de los 26 tipos de bolas definidas por González, seis de ellos ya habían sido identificados por el autor para Entre Ríos y para los cinco restantes no había registro sistemático en la provincia (excepto algunos mencionados en el Capítulo 5).

Asimismo, en el Museo Martiniano Leguizamón de Paraná se registró una bola de arenisca que corresponde al tipo Bc4 (Figura 7.7D). Lleva el código ML-777 y según el catálogo de la institución procede de Calá, Concepción del Uruguay. Leguizamón en 1919 publica un dibujo similar a esta pieza, junto a otras de variadas morfologías, pero las presenta como "Bolas charrúas de la Banda Oriental"; es difícil suponer que ambas sean dos piezas diferentes por lo que muy probablemente el origen de ML-777 esté en la ROU, pero ante la duda y la particularidad morfológica de la pieza se decidió incluirla igual. Otra pieza por destacar depositada en el mismo museo es una bola de arenisca tipo Bf (ML-2367) procedente del departamento Gualeguaychú, que en uno de sus polos presenta una decoración grabada incisa representando motivos geométricos, este mismo polo presenta una pequeña fractura; el surco también tiene la particularidad de no ser en " $U$ " como la mayoría sino que se asemeja a una "W" con el ángulo central convexo en vez de angular agudo, perecen dos surcos finos paralelos que fueron unidos mediante el picado o abrasión de la franja intermedia (Figura 7.7E).

Con respecto a los tamaños de las bolas, se registró una amplia variabilidad de acuerdo a cada tipo. Considerando las bolas enteras y las fracturadas cuyas medidas no se veían afectadas, en las esferas ( $\mathrm{Aa}$ y $\mathrm{Ba}$ ) se registró un diámetro máximo de 66,9 mm (MAMA-EP-291, tipo Aa) y un diámetro mínimo de 54,7 mm (MAMA-TL-75, tipo Aa). Por su parte, para los esferoides (tipos Ab, Ac, $\mathrm{Ad} 2, \mathrm{Bb} 1, \mathrm{Bc1}, \mathrm{Bc2}, \mathrm{Bf}, \mathrm{Bg}$ y $\mathrm{Bh}$ ) se distinguen tres diámetros perpendiculares: eje mayor, intermedio y menor, y a su vez dentro de cada uno de estos se presentan las medidas extremas registradas. Para el eje mayor se registró un diámetro máximo de 81,8 mm (MAMA-s/p-s/n, tipo Ad2) y un diámetro mínimo de 45,3 mm (MAMA-s/p-s/n, tipo Bf). Para el eje intermedio se registró un diámetro máximo de 75,1 mm (MAMA-s/p-s/n, tipo Ad2) y un diámetro mínimo idéntico en tres bolas de $42,8 \mathrm{~mm}$ (MAMA-AG-1038, MAMA-s/p-s/n y MAMA-EP-295, tipo Bc2, Bf y Bh). Asimismo, para el eje menor se registró un diámetro máximo de $42 \mathrm{~mm}$ (MAMA-s/p-s/n, tipo $\mathrm{Bh}$ ) y un diámetro mínimo de $38 \mathrm{~mm}$ (MAMA-s/p-s/n, tipo Bf). En cuanto a las materias primas de las bolas en la Tabla 7.19 se observa un predominio del basalto $(n=20)$ sobre la arenisca $(n=16)$ y la diabasa $(n=1)$. 
Mano de mortero $(n=1)$

Se registró una pieza de arenisca de 78,3×47,9 mm procedente de CL2 (MAMA-CL2-307) y asociada a un mortero (Figura 7.7J).

Piedras con hoyuelos $(n=14)$

Proceden de los sitios arqueológicos CL2 ( $n=1$; MAMA-CL2-396), T1-CNM ( $n=2$; MAMA-T1CNM-247 y MAMA-T1-CNM-378), CP ( $n=3$; MAMA-CP-700, MAMA-CP-706, MAMA-CP-853), SPL ( $n=$ 4; MAMA-SPL-359, MAMA-SPL-500, MAMA-SPL-501, MAMA-SPL-590) y otras sin procedencia $(n=4)$ (Figura 7.7G). En nueve casos tienen un solo hoyuelo, cuatro tienen dos hoyuelos, y una tiene tres hoyuelos. Los hoyuelos son de diámetros homogéneos y de variada profundidad.

Las formas-base utilizadas corresponden a rodados fluviales $(n=2)$, a clastos formatizados por lascados y abrasión, picado y/o pulido ( $n=2$ ), y una bola (tipo $B$, de CL2) indicando actividades de reciclaje; el resto de las formas-base es indeterminado (Figura $7.7 \mathrm{H}$ ). En cuanto a las materias primas se observa un predominio del basalto $(n=7)$ sobre la arenisca $(n=4)$ y el cuarzo $(n=3)$. Es necesario destacar que en estos instrumentos se identificó una formatización previa al origen de los hoyuelos, mediante lascados y picado, abrasión y/o pulido. Algunas de las piezas tienen caras sin hoyuelos que sufrieron este tratamiento lo que ha originado formas cuadrangulares o tabulares. También hay formas discoidales con dos caras opuestas achatadas. Estos instrumentos pueden considerarse elaborados por picado, abrasión y/o pulido, y luego modificados por su uso como yunques. Teniendo en cuenta su tratamiento en la bibliografía y su función final se los considera modificados por uso.

\section{Otros instrumentos modificados por uso $(n=4)$}

Consisten en dos pulidores en canaleta de EDB, un mortero de CL2 y un molino de EAV, todos de arenisca. Los pulidores en canaleta consisten en clastos tabulares con surcos de sección semicircular en forma de "U" producidos por abrasión. Uno de ellos (MAMA-EDB-s/n) presenta cuatro canaletas en una cara y tres en la otra, tiene módulo longitud-anchura mediano normal y tamaño grandísimo. El otro (MAMA-EDB-467) tiene una canaleta que se dispone sobre el eje más largo del soporte, tiene longitud-anchura laminar angosto y tamaño grandísimo (Figura 7.71).

El mortero (MAMA-CL2-307) se encuentra montado para exhibición en el museo y pegado en posición de uso a la mano mencionada arriba (Figura 7.7J). Sus atributos no se estudiaron en detalle. El molino (MAMA-EAV-1035) fue elaborado a partir de un clasto tabular sobre el cual la actividad abrasiva, probablemente de vegetales, originó una depresión piriforme y de distinta profundidad. La parte más ancha de la depresión es a la vez la más profunda evidenciando que el gesto técnico de moler se realizó predominantemente en una dirección y aplicando más fuerza de procesamiento en un extremo que en el otro del molino. Sus dimensiones máximas son: 21,4 cm de largo, $17 \mathrm{~cm}$ de ancho y $34,2 \mathrm{~mm}$ de espesor (Figura $7.7 \mathrm{~K}$ ). 


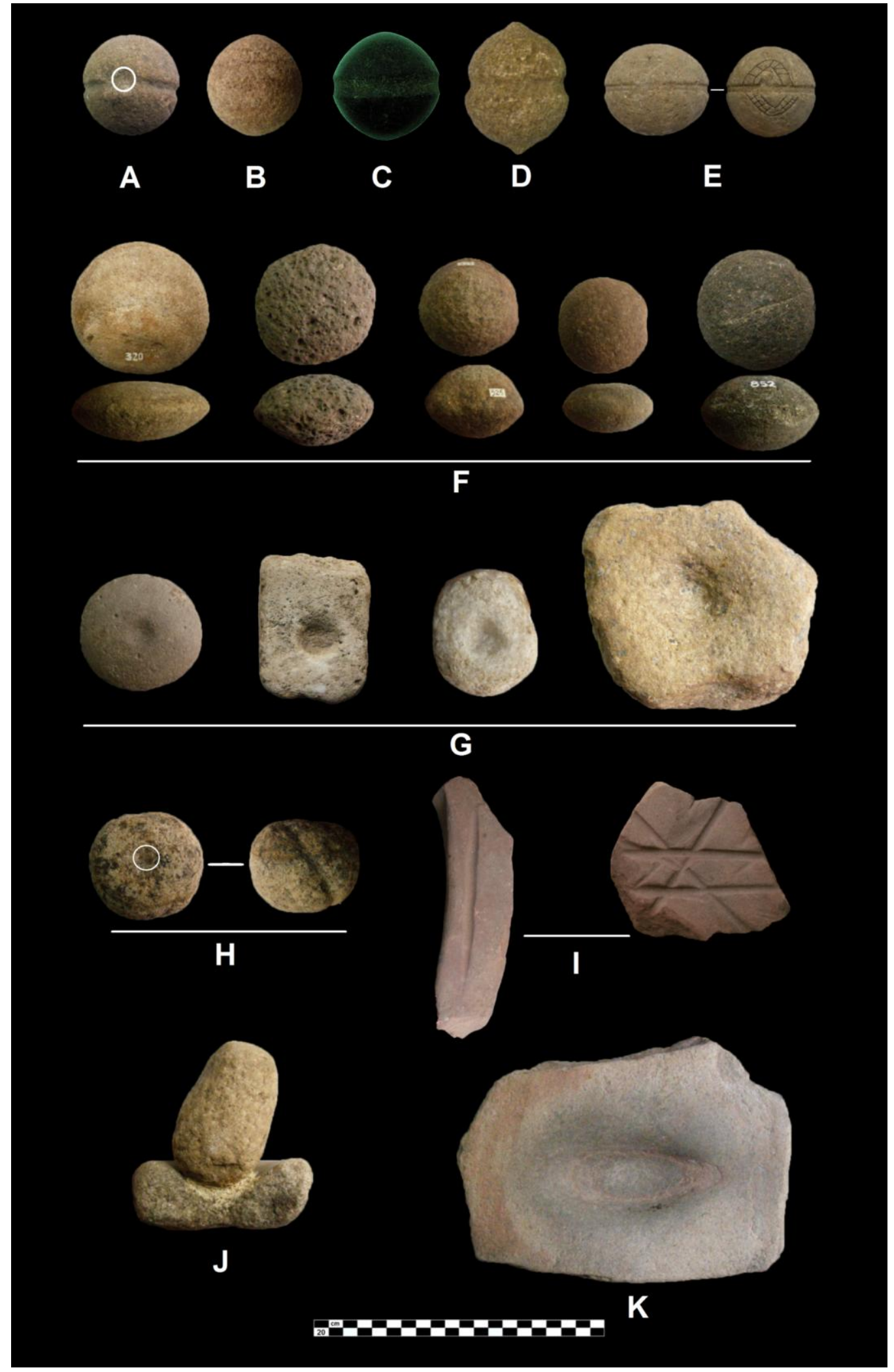

Figura 7.7. Instrumentos líticos del Museo Arqueológico Manuel Almeida (Gualeguaychú). A: bola tipo Bg, el círculo blanco delimita el hoyuelo (MAMA-AG-1039). B: bola tipo Ac (MAMA-EP-287). C: bola tipo Bc1 (MAMA-s/p-s/nº. D: bola tipo Bc4 (ML-Calá (?)-777). E: bola con decorado inciso remarcado en color

negro, tipo Bf (ML-Gualeguaychú-2367). F: piedras lenticulares (de izquierda a derecha: MAMA-PC-320,

MAMA-PC-446, MAMA-PC-526, MAMA-s/p-s/nº MAMA-s/p-852). G: piedras con hoyuelos (de izquierda a derecha: MAMA-s/p-s/n ${ }^{\circ}$ MAMA-SPL-501, MAMA-CP-853 y MAMA-s/p-s/nº. H: piedra con hoyuelo elaborada a partir de una bola con surco, el círculo blanco delimita el hoyuelo (MAMA-CL2-396). I: Pulidores en canaleta

(de izquierda a derecha MAMA-EDB-467 y MAMA-EDB-s $/ \mathrm{n}^{\circ}$ ). J: mano y mortero (MAMA-CL2-307).

K: molino (MAMA-EAV-1035). 
Puntas de proyectil $(\mathrm{n}=11)$

En cuanto a las siete piezas del MAMA, una procede del río Gualeguaychú $25 \mathrm{~km}$ aguas arriba de la ciudad y fue recolectada en el lugar llamado Ojo de Agua (Figura 7.1); Las otras seis proceden de los médanos de Paso Paysandú (PP) en el departamento Colón. Además de estas piezas se incluyen en esta sección otras cuatro cedidas al autor para su estudio, una procede de Ñandubaysal (PPÑ; Figura 7.1 y 7.8F) y fue recolectada superficialmente en la playa por la Sra. Mariel Gavilán (CEIA-FHyA-UNR), y las tres restantes proceden de Basavilbaso y fueron recolectadas por pobladores locales (Figura 7.8).

Se registraron dos piezas enteras y nueve fracturadas; de las enteras una fue reciclada y se confeccionó un cortante similar a los definidos por Hocsman (2007) para el sector A (Figura 7.8G). Se registran siete puntas pedunculadas con aletas entrantes y dos puntas apedunculadas (Tabla 7.20). Todas fueron elaboradas mediante retalla y retoque, y en cuatro casos se identificó retoque a presión. También fue identificada técnica de reducción bifacial en cinco casos. En cuatro casos las formas-base corresponden a lascas, siendo el resto indeterminadas.

Tabla 7.20. Subgrupos tipológicos de puntas de proyectil de colecciones del sector $\mathrm{C}$.

\begin{tabular}{llll}
\hline \multicolumn{1}{c}{ Subgrupo tipológico } & \multicolumn{1}{c}{ Tipo de aleta } & & Total \\
\cline { 1 - 1 } Pedunculada con aletas & Aletas obtusas & 4 \\
& Aletas rectas & 3 \\
Apedunculada & Aletas agudas & 2 \\
Total & - & 2 \\
\hline
\end{tabular}

Los pedúnculos registrados se clasifican en diferenciados $(n=7)$ y destacados $(n=2)$. En la Tabla 7.21 se presenta la variabilidad morfológica de limbos y pedúnculos, y los módulos longitudanchura y tamaño. A pesar de que nueve puntas presentan fracturas en limbos y aletas, lo que afecta el largo y el ancho, se pudo reconstruir la forma original de siete de las mismas siguiendo las líneas de los bordes. 
Tabla 7.21. Morfología de los bordes del limbo y de los bordes y base de los pedúnculos de las puntas de proyectil de colecciones del sector $\mathrm{C}$.

\begin{tabular}{|c|c|c|c|c|c|c|}
\hline \multirow{3}{*}{ Procedencia } & \multirow{3}{*}{$\begin{array}{l}\text { Materia } \\
\text { prima }\end{array}$} & \multirow{3}{*}{ Limbo y bordes } & & & \multicolumn{2}{|c|}{ Módulos } \\
\hline & & & \multicolumn{2}{|c|}{ Pedúnculo } & \multirow{2}{*}{$\begin{array}{l}\text { Longitud } \\
\text { Anchura }\end{array}$} & \multirow{2}{*}{ Tamaño } \\
\hline & & & bordes & base & & \\
\hline Gualeguaychú & xilópalo & triangular corto lados convexos & paralelos rectos & cóncava & $\begin{array}{l}\text { Mediano } \\
\text { alargado }\end{array}$ & Grande \\
\hline Basavilbaso & xilópalo & triangular corto lados convexos & divergentes rectos & $\begin{array}{c}\text { no } \\
\text { diferenciada }\end{array}$ & $\begin{array}{c}\text { Mediano } \\
\text { normal }\end{array}$ & $\begin{array}{l}\text { Mediano } \\
\text { grande }\end{array}$ \\
\hline $\begin{array}{l}\text { Basavilbaso } \\
\text { Paso Paysandú }\end{array}$ & $\begin{array}{c}\text { sílice } \\
\text { arenisca }\end{array}$ & triangular corto lados rectos & divergentes convexos & $\begin{array}{c}\text { cóncava } \\
\text { no } \\
\text { diferenciada }\end{array}$ & $\begin{array}{c}\text { Laminar } \\
\text { normal } \\
\text { Laminar } \\
\text { normal }\end{array}$ & $\begin{array}{c}\text { Mediano } \\
\text { grande } \\
\text { Mediano } \\
\text { grande }\end{array}$ \\
\hline Paso Paysandú & calcedonia & triangular corto lados rectos & divergentes cóncavos & convexa & $\begin{array}{l}\text { Mediano } \\
\text { alargado }\end{array}$ & $\begin{array}{l}\text { Mediano } \\
\text { pequeño }\end{array}$ \\
\hline Ñandubaysal & $\begin{array}{c}\text { caliza } \\
\text { silicificada }\end{array}$ & no diferenciado por fractura & & cóncava & - & - \\
\hline Paso Paysandú & xilópalo & no diferenciado por reciclado ${ }^{1}$ & $\begin{array}{l}\text { divergentes, uno recto y } \\
\text { uno cóncavo }\end{array}$ & convexa & $\begin{array}{l}\text { Mediano } \\
\text { alargado }\end{array}$ & $\begin{array}{l}\text { Mediano } \\
\text { grande }\end{array}$ \\
\hline Paso Paysandú & arenisca & triangular corto lados convexos & $\begin{array}{l}\text { divergentes, uno recto y } \\
\text { uno convexo }\end{array}$ & cóncava & $\begin{array}{l}\text { Mediano } \\
\text { alargado }\end{array}$ & $\begin{array}{l}\text { Mediano } \\
\text { pequeño }\end{array}$ \\
\hline Basavilbaso & sílice & no diferenciado por fractura & divergentes rectos & $\begin{array}{l}\text { cóncava } \\
\text { "escotada" }\end{array}$ & - & - \\
\hline Paso Paysandú & arenisca & triangular corto lados rectos & sin pedúnculo & - & $\begin{array}{l}\text { Laminar } \\
\text { normal }\end{array}$ & $\begin{array}{l}\text { Mediano } \\
\text { grande }\end{array}$ \\
\hline Paso Paysandú & sílice & triangular corto lados rectos & sin pedúnculo & - & $\begin{array}{l}\text { Laminar } \\
\text { normal }\end{array}$ & Grande \\
\hline
\end{tabular}

(1) punta reciclada.

Como se observa en la Tabla 7.21 los diseños de limbos presentan formas triangulares cortos de lados rectos y convexos. Las apedunculadas tienen limbos triangulares cortos de lados irregulares rectos. La mayor variabilidad se encuentra en la combinación de las formas de los bordes y base de los pedúnculos, se registraron siete variantes. Todas las piezas son distintas, si bien la muestra es pequeña y de un área geográfica grande estaría reflejando una diversidad relativamente importante. En cuanto a los módulos longitud-anchura en las pedunculadas predomina el mediano seguido por laminares y en el tamaño también predomina el mediano. Las apedunculadas son laminares y grandes.

\section{Otros instrumentos tallados $(n=9)$}

Consisten en tres piezas con retoque sumario elaboradas sobre lascas de caliza silicificadas de EDB ( $n=2$; MAMA-EDB-411 y MAMA-EDB-R105) y arenisca de Ñ-AC ( $n=1$; MAMA-Ñ-AC-195); dos choppers (MAMA-EDB-642 y MAMA-EDB-R225) elaborados mediante retalla sobre rodados de basalto de EDB (véase Castro y Costa Angrizani 2014, Figura 2e-f); un bifaz de PP (MAMA-PP-s/nº) 
(Figura 7.8L) y un perforador de Ñ-AC (MAMA-Ñ-AC-600) elaborados sobre lascas de calcedonia mediante retalla y retoque marginal (Figura 7.8M); un raspador frontal sin procedencia elaborado sobre una lasca de caliza silicificada mediante retoque marginal (Figura 7.8N); y una punta entre muescas de SLC-T1 (MAMA-SLC-T1-33) elaborada a partir de un rodado chato de arenisca mediante retalla y retoque marginal (Figura 7.80).

\section{Desechos de talla}

Se registraron 15 lascas de cuatro materias primas diferentes y procedentes de cinco sitios arqueológicos.

-EBD $(n=7)$ : dos lascas angulares y tres indiferenciadas (caliza silicificada), una angular (arenisca), y una primaria (basalto).

-CP $(n=3)$ : una lasca angular y una en cresta (sílice), y una angular (caliza silicificada).

-T1-CNM ( $n=2)$ : dos lascas angulares (caliza silicificada).

-Ñ-AC/AU ( $n=2)$ : dos lascas secundarias (caliza silicificada).

-SLC-T1 $(n=1)$ : una lasca angular (caliza silicificada).

De las internas, dos angulares de caliza silicificada (CP y SLC-T1) presentan rastros complementarios sobre filos naturales que corresponden a microlascados.

\section{Núcleos}

Se registraron ocho núcleos de cinco materias primas diferentes y procedentes de cuatro sitios arqueológicos (Tabla 7.18).

-EDB $(n=3)$ : dos de caliza silicificada (MAMA-EDB-641 y MAMA-EDB-873) con nueve extracciones, sin corteza y agotados; y el restante de calcedonia (MAMA-EDB-630) con una extracción y más del 50\% de corteza, cuya forma-base es un rodado fluvial indeterminado.

-CL2 ( $n=2$ ): uno de xilópalo (MAMA-CL2-225) con tres extracciones y menos del 50\% de corteza, cuya forma-base es un clasto; y el restante de cuarcita intertrap (MAMA-CL2-389) con dos extracciones y más del 50\% de corteza, cuya forma-base es un rodado fluvial tamaño guijón (Figura 7.8P).

-CP $(n=2)$ : uno de caliza silicificada (MAMA-CP-R229) con 10 extracciones, sin corteza y agotado; $y$ el restante de arenisca (MAMA-CP-1369) con tres extracciones y sin corteza, cuya formabase es un clasto.

-T2-CSM ( $n=1$ ): es de caliza silicificada (MAMA-T2-CSM-1370) con siete extracciones y sin corteza. 


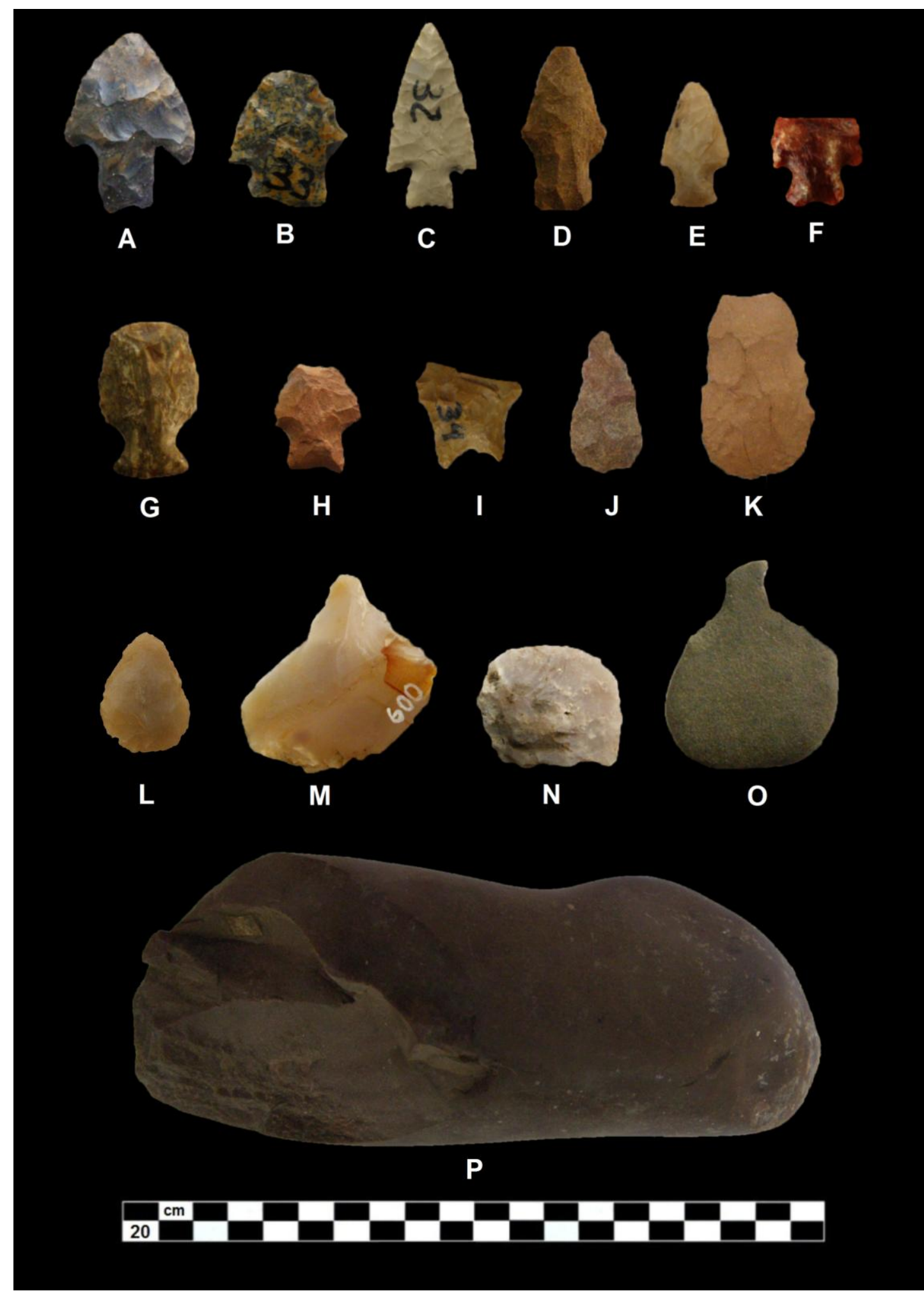

Figura 7.8. Instrumentos líticos y núcleo del Museo Arqueológico Manuel Almeida (Gualeguaychú). Puntas de proyectil pedunculadas: A (MAMA-río Gualeguaychú); B, C, e I (Basavilbaso); D, E, G y H (MAMA-PP); F (PPÑ ; Fotografía de Mariel Gavilán). Puntas de proyectil apedunculadas: J y K (MAMA-PP). L: bifaz (MAMA-PP-s/nº ). M: perforador (MAMA-Ñ-AC-600). N: raspador (MAMA-s/p-s/n'). O: punta entre muescas (MAMA-SLC-T1-33). P: núcleo sobre rodado fluvial de cuarcita intertrap (MAMA-CL2-389). 


\subsubsection{2- Alfarería del Museo Arqueológico Manuel Almeida}

EI MAMA conserva 3825 fragmentos cerámicos catalogados además de un importante conjunto de tiestos sin numerar. Esta cerámica en general es similar a la registrada en nuestros trabajos de campo; por este motivo se seleccionaron algunas piezas de las cuales una parte corresponderían a la entidad arqueológica Goya-Malabrigo (Ceruti 2003a; Politis y Bonomo 2012) (en adelante Goya-Malabrigo) y otra parte es compatible con la alfarería guaraní (Brochado 1984; Brochado y Monticelli 1994; Noelli 1993).

\section{Alfarería Goya-Malabrigo}

Este conjunto de 161 piezas incluye campanas $(n=13)$, fragmentos gruesos de cuerpos, bordes y/o bases que podrían corresponder a campanas $(n=15)$, apéndices zoomorfos $(n=13)$, bordes y cuerpos con apliques $(n=75)$, vertederos cerrados $(n=13)$, rebordes con cuello o gollete $(n=$ $18)$, tubos $(n=8)$, cuentas $(n=3)$, pipa $(n=1)$, pesa de red $(n=1)$ y una vasija de boca subcuadrangular $(n=1)$.

Campanas $(n=13)$

El estado de integridad y completitud de las piezas es variable. Proceden una de T1-CNM, una de EDB, y 11 sin procedencia exacta.

-dos bordes-cuerpos campanuliformes, con agujeros laterales (uno es MAMA-T1-CNM-101) (Figura 7.9A).

-un cuerpo campanuliforme con un aplique lateral que representa el ala de un ave (MAMAEDB-1136) (Figura 7.9A).

-un cuerpo con surco rítmico y orificio lateral.

-tres apéndices escultóricos macizos que corresponden a cabezas de aves $(n=2)$ y carpincho $(n=1)$, una de las aves tiene surco rítmico y una es lisa, y el carpincho es liso (Figura 7.9B).

-seis apéndices escultóricos macizos que corresponden a colas de aves; tres lisas y tres con surco rítmico (Figura 7.9C).

Fragmentos gruesos de cuerpos, bordes y/o bases $(n=15)$

Por la ausencia de atributos más diagnósticos no se puede determinar con claridad su forma original pero algunos posiblemente correspondan a campanas. Proceden tres de T1-LA, uno de T1CNM, uno del río Paranacito y 10 sin procedencia exacta.

-nueve fragmentos de cuerpo; dos lisos, dos con surco rítmico (MAMA-T1-LA-82 y MAMA-RP1529), uno con surco rítmico y pintura blanca (MAMA-T1-LA-80), uno inciso de punto (MAMA-T1-LA84), y tres con mamelones. 
-tres fragmentos de borde de campana; o de una forma similar a un vaso pero en la base tienen un orificio de alrededor de $22 \mathrm{~cm}$ de diámetro. En uno de estos fragmentos no se observa el orificio por fractura, pero claramente corresponde a mismo tipo, más aún podrían ser todas de una misma pieza.

-tres fragmentos gruesos indeterminados pueden ser bordes superiores de campanas o bases de otras formas (uno es MAMA-T1-CNM-102),

\section{Apéndices zoomorfos $(\mathrm{n}=13)$}

Estos apéndices presentan variable grado de integridad y completitud, cinco de ellos corresponden a modelados ubicados en los bordes de las vasijas, siendo el resto indeterminados. Proceden tres de CP, uno de T1-LA, uno de T1-CNM y ocho sin procedencia exacta.

-11 escultóricos macizos que corresponden a cabezas de siete aves (uno es MAMA-CP-2714), un mamífero, una tortuga (MAMA-T1-CNM-39), una posible serpiente (MAMA-T1-LA-79) y un biomorfo (MAMA-s $/ \mathrm{p}-\mathrm{s} / \mathrm{n}^{\circ}$ ) (ave o serpiente). La tortuga y el biomorfo están orientados hacia el exterior de la vasija (Figura 7.9D).

-dos cóncavos que corresponderían a aves que están orientados hacia el interior de la vasija (MAMA-CP-1686 y MAMA-CP-2731).

\section{Apliques por pastillaje $(\mathrm{n}=75)$}

Estos apliques pueden ser considerados como apéndices y hasta algunos de ellos como asas (véase Caggiano 1982a), y se distinguen por su morfología y ubicación en las vasijas.

Apéndices sobre el borde ( $n=47)$; proceden 40 de CP, dos de T2-CSM, uno de T1-CNM, uno de SPL, uno de EMO y dos sin procedencia exacta.

-40 apéndices alargados verticales adosados al borde ${ }^{1}$ y que por lo tanto elevan la línea original del labio conformando un borde angular en $\mathrm{V}$ invertida, que generalmente no se inclina hacia el interior de la vasija sino que es recto. En todos los casos estos apéndices son aplicaciones posteriores al acabado de la vasija. Pueden ser perforados o no y/o decorados mediante incisión de punto, línea y/o surco rítmico, tanto en el apéndice mismo como en la porción del cuerpo de la vasija que lo rodea (Figura 7.9D). En dos casos se registró decoración interna sobre el labio original de la vasija. Algunos podrían representar aves ya que tienen marcas que se asemejan a ojos (MAMA-CP2362; Figura 7.9D).

\footnotetext{
1 Procedencia: $n=34$ de MAMA-CP con los números de pieza: 1349, 1352, 1485, 1486, 1674, 1689, 1721, 1726, 1738, 1978, 2007, 2020, 2024, 2026, 2053, 2075, 2149, 2362, 2393, 2399, 2400, 2402, 2418, 2721, 2736, 2799, 2822, 2846, 2893, 2953, 2961, 3421, 3533, 3548. Los seis restantes: MAMA-T1-CNM-1088, MAMA-T2-CSM-67, MAMA-SPL-915, MAMA-EMO-393; y dos sin procedencia exacta. 
-dos apéndices alargados externos de orientación vertical sobre el borde pero que no elevan el labio, sino que mantienen la línea del borde original (MAMA-CP-3737 y MAMA-T2-CSM-64).

-cinco apéndices adosados al labio y perforados (Figura 7.10F). El agujero que presentan indicaría que por el mismo debió pasar un cordel para suspender la vasija. Tres de los bordes son lisos (MAMA-CP-1422, MAMA-CP-2682, MAMA-CP-2684), uno está decorado en la superficie interna con líneas paralelas anchas en zig-zag (MAMA-CP-3014), y el restante es liso y consiste en un fragmento del apéndice (MAMA-CP-3448).

Apéndices alargados sobre el cuerpo $(n=5)$; proceden de CP (Figura 7.10A).

-un apéndice externo de orientación vertical por debajo de la línea del borde, en el cuerpo de la vasija (MAMA-CP-1544).

-cuatro apéndices externos de orientación horizontal por debajo de la línea del borde, en el cuerpo de la vasija (MAMA-CP-1472, MAMA-CP-1545, MAMA-CP-1764, MAMA-CP-2748).

Apéndices mamelonares sobre el cuerpo $(n=16)$; proceden 13 de CP y tres de T2-CSM.

-11 simples; cuatro conos redondeados macizos (MAMA-T2-CSM-156, MAMA-CP-1846, MAMA-CP-1896, MAMA-CP-2359) y siete conos truncados [cinco con concavidad (MAMA-CP-1488, MAMA-CP-1658, MAMA-CP-1990, MAMA-CP-2413, MAMA-CP-2932) y dos macizos (MAMA-CP-1428 y MAMA-CP-2938)] (Figura 7.10B). Se presentan lisos ( $n=6)$ o decorados, tanto en el mamelón como a su alrededor, con surco rítmico $(n=4)$ y con la uña $(n=1)$.

-uno simple; cono redondeado macizo y liso, rodeado por un aplique circular (MAMA-CP2732) (Figura 7.10B).

-tres dobles; una pieza con los dos conos redondeados macizos y lisos (MAMA-T2-CSM-59); dos piezas con sus dos conos truncados macizos y lisos (MAMA-T2-CSM-53), uno de los cuales tiene incisión de línea y surco rítmico alrededor (MAMA-CP-1347) (Figura 7.10C). En todos los casos ambos mamelones están dispuestos en línea horizontal.

-un borde dentado con mamelones múltiples $(n=10)$, cónicos, macizos y lisos. Los mamelones se disponen horizontalmente cerca del borde rodeando la pieza, que además tiene su superficie interna pintada completamente de rojo (MAMA-CP-2757/2759/3073) (Figura 7.10C).

Apliques en cresta ( $n=7)$; proceden cuatro de CP, uno de T2-CSM, uno de SPL y uno de CL2 (Figura 7.10E).

-siete apliques horizontales posteriores a la terminación de la vasija (MAMA-CP-2215, MAMA-CP-2633, MAMA-CP-2741, MAMA-CP-2954, MAMA-T2-CSM-54, MAMA-SPL-355, MAMA-CL2369). Las tres últimas piezas presentan en zig-zag y son los que por ejemplo Serrano (1950, Figura 36) identifica con la representación de serpientes. Algunos presentan incisión de punto y línea, y surco 
rítmico en el aplique y alrededor. Considerando la Primera Convención Nacional de Antropología (1966) estos apliques pueden denominarse como pastillaje decorativo.
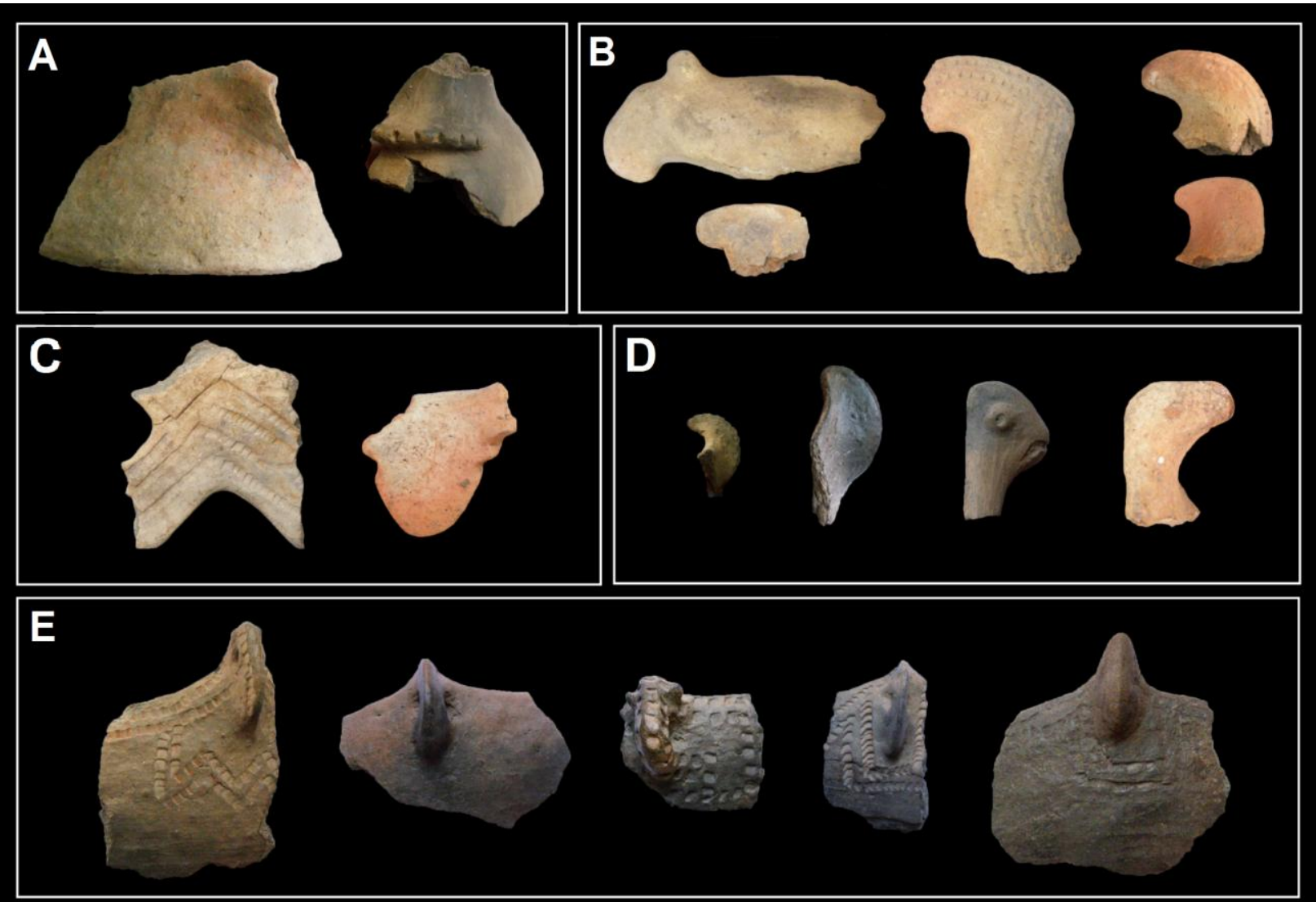

${ }_{20}^{\mathrm{cm}} \mathrm{c}$

Figura 7.9. Alfarería Goya-Malabrigo del Museo Arqueológico Manuel Almeida (Gualeguaychú).

A: campanas (de izquierda a derecha: MAMA-s/p-s/n y MAMA-EDB-1136). B: apéndices macizos escultóricos (sin procedencia), el primer apéndice superior representa un carpincho y el inferior un mamífero, los tres restantes aves. C: colas de aves de campanas (sin procedencia), la primera bifurcada y la segunda simple.

D: apéndices zoomorfos (de izquierda a derecha: posibles aves -MAMA-CP-2731 y MAMA-CP-2362-, tortuga -MAMA-T1-CNM-39- y biomorfo-MAMA-s/p-s/nº-). E: Apliques sobre el borde que están perforados transversalmente excepto el último (de izquierda a derecha: MAMA-CP-2736, MAMA-CP-2400, MAMA-CP-2953, MAMA-CP-1721 y MAMA-CP-2026).

Vertederos cerrados $(n=13)$

Proceden 11 de CP, uno de EC y uno de la estancia Punta Caballos (Figura 7.10D).

-nueve de boca oblicua en relación a la pared de la vasija (MAMA-CP-1444, MAMA-CP-1451, MAMA-CP-1889, MAMA-CP-2021, MAMA-CP-2022, MAMA-CP-2366, MAMA-CP-2416, MAMA-CP2737, MAMA-CP-2860) y cuatro de boca recta (MAMA-CP-2631, MAMA-CP-268?, MAMA-EC-77, MAMA-PC-58) todos lisos. Dos de los oblicuos presentan decoración incisa de punto en la interna del borde. 
Rebordes con cuello o gollete $(n=18)$

Estas formas son semejantes a las de la ROU que Freitas (1953a) denominó botellones con cuello y boca abierta, y Hilbert (1991) denominó botellones de forma tubular con abertura doble (véase Capítulo 4). Podrían corresponder a botellas (sensu Balfet et al. 1992) o formas semejantes pero no se ha registrado ninguna entera o con un grado de completitud que permita su reconstrucción total. Proceden nueve de CP ( $\mathrm{N}^{\circ}$ de pieza 1448, 1542, 1647, 1842, 2206, 2672, 2680, 2804,2853 ) y nueve sin procedencia exacta (Figura 7.10G).

-18 piezas representadas por distintas porciones de reborde, gollete y cuerpo de las vasijas. Son de paredes gruesas, con un diámetro externo de la boca máximo de $11 \mathrm{~cm}$ y un diámetro máximo del orificio de 25,1 mm; la longitud vertical máxima del gollete es de 34,6 mm. Algunos son lisos $(n=8)$ y otros están decorados en la parte interna de la boca, siete con surco rítmico (uno también inciso de línea y punto en el cuerpo), dos con incisión de punto y uno de línea. Del total 15 tienen la boca de forma circular y tres tienen un contorno con ángulos.

Tubos $(\mathrm{n}=8)$

Se definen como tubos algunas piezas que se diferencian claramente de las alfarerías tubulares (Ghiani Echenique et al. 2013). Presentan paredes rectas conformando un tubo cilíndrico o paredes levemente cóncavas, curvadas hacia el interior en la zona media conformando un tubo hiperboloide. Proceden cinco de EMO, dos de CP y uno de EC (Figura 7.10H).

-tres tubos, uno liso (MAMA-EMO-312); uno inciso de punto en el cuerpo e inciso de línea en el labio (MAMA-EMO-s $/ \mathrm{n}^{\circ}$ ); y uno decorado en el superficie externa en la zona media mediante incisión de punto, y también decorado cerca de los bordes, en uno mediante incisión de punto y en el otro mediante surco rítmico lineal y en zigzag (MAMA-EMO-2540). Si bien solo uno de los tubos se presenta casi completo (MAMA-EMO-s/n ${ }^{\circ}$ ), se determinaron algunas de las dimensiones de tres piezas y son, largo máximo: 134,6 mm; 125,7 mm y 142,3 mm; y diámetros máximos de boca respectivos: $76 \mathrm{~mm}$; $96,6 \mathrm{~mm}$ y $95 \mathrm{~mm}$.

También se registraron cinco fragmentos de paredes rectas pero sin uno de los bordes lo que impide una clara determinación; cuatro son lisos (MAMA-CP-2503, MAMA-CP-2774, MAMA-EMO2537, MAMA-EC-2548/2549/2558/2559) y uno está decorado mediante incisión de punto y surco rítmico (MAMA-EMO-2536). Los diámetros determinados para estas piezas son: $110 \mathrm{~mm}, 100(\mathrm{n}=2)$ mm, $120 \mathrm{~mm}$ y $95 \mathrm{~mm}$. Además de sus caracteres generales similares a los tubos, cuatro de las piezas tienen la misma procedencia que los tres primeros tubos presentados.

Cuentas $(n=3)$

-tres de forma discoidal irregular con una pequeña perforación central y diámetros máximos de $34,9 \mathrm{~mm} ; 24,5 \mathrm{~mm}$ y 34,9 mm; y espesores máximos de $11,3 \mathrm{~mm} ; 8,6 \mathrm{~mm}$ y 7,9 mm, 
respectivamente. Proceden dos de CP (MAMA-CP-1739 y MAMA-CP-1780) y una sin procedencia exacta (Figura 7.10I).

$\operatorname{Pipa}(\mathrm{n}=1)$

-tiene 90,2 mm de largo, el diámetro de la boca del hornillo es de $67 \mathrm{~mm}$, el diámetro del extremo opuesto es de $16,8 \mathrm{~mm}$, el espesor máximo del borde del hornillo es de $8,6 \mathrm{~mm}$ y del borde opuesto de 5,8 mm. Procede de EMO (MAMA-EMO-49) (Figura 7.10J).

Pesa de red $(\mathrm{n}=1)$

Se registró una masa de arcilla cocida con un surco poco marcado pero que delimita dos mitades. Además, parece que estando la pasta fresca fue introducida en una funda o retobe y luego se ató en el centro una cuerda que al ser ajustada provocó que la funda se plegara dejando claras marcas de este proceso en la pieza (Figura 7.10K). No está claro si fue confeccionada de esta manera y luego endurecida se le retiró la funda o si fue usada como bola o pesa retobada. Debido a su materia prima y peso (197 grs.) se considera que se trata de una pesa de red. No se registró su procedencia exacta.

$\operatorname{Vasija}(\mathrm{n}=1)$

Tiene cuerpo globular y boca subcuadrangular, su superficie externa se encuentra decorada mediante incisión de punto, además tiene un mamelón cónico truncado con concavidad y un aplique horizontal en zig-zag (Figura 7.10L). Este tipo de aplique es el que Serrano (1950) considera como la representación de una serpiente. Procede de CL2 (MAMA-CL2-s/nº). 

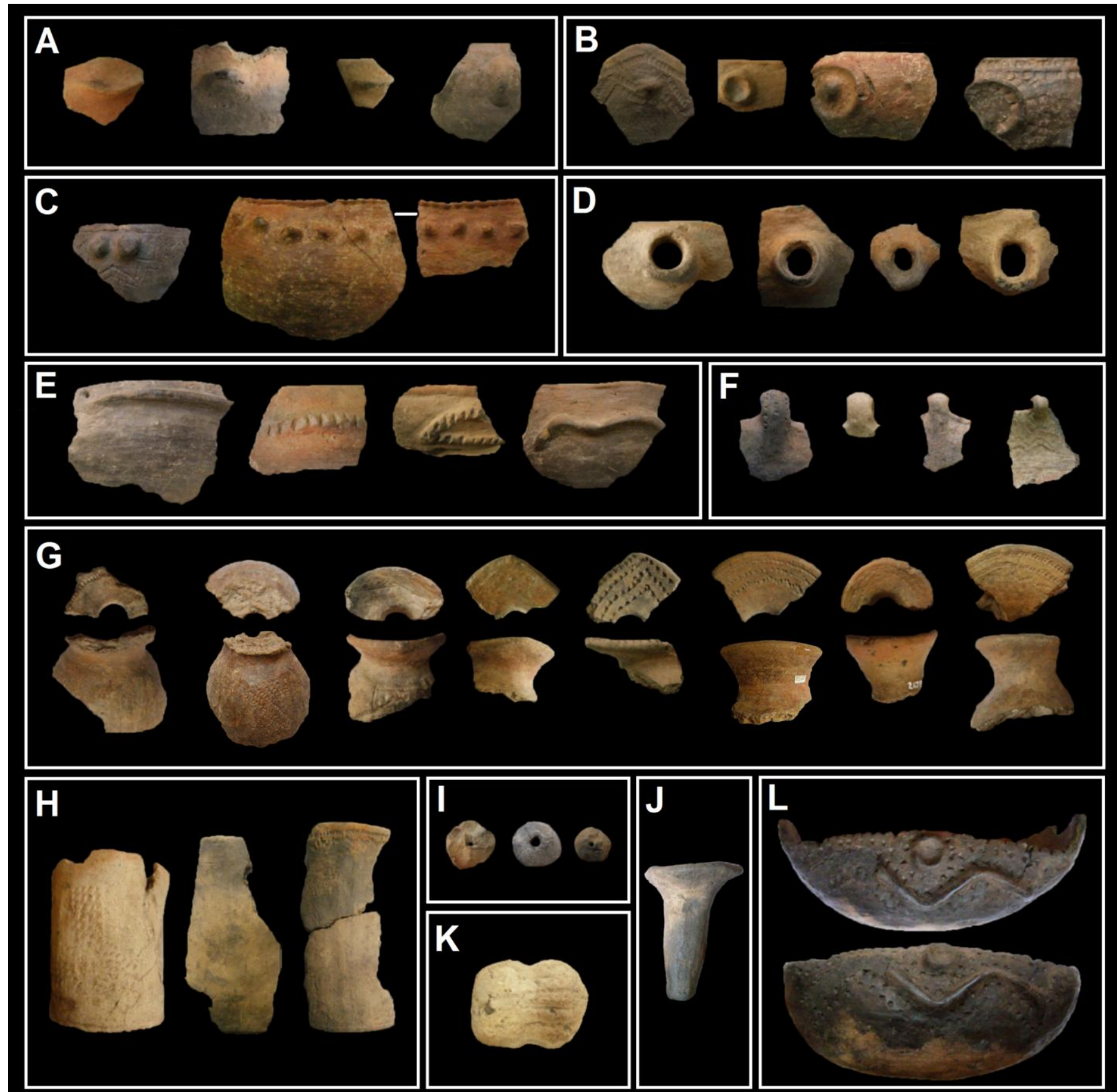

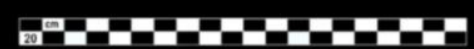

Figura 7.10. Alfarería Goya-Malabrigo del Museo Arqueológico Manuel Almeida (Gualeguaychú). A: apliques sobre el cuerpo (de izquierda a derecha: MAMA-CP-1472, MAMA-CP-1764, MAMA-CP-2748 y MAMA-CP-1544), los tres primeros horizontales y el cuarto vertical. B: apliques mamelonares simples (de izquierda a derecha: MAMA-CP-2359, MAMA-CP-1990, MAMA-CP-2732 y MAMA-CP-2932). C: apliques mamelonares dobles (MAMA-CP-1347) y múltiples (MAMA-CP-2757/2759/3073). D: vertederos cerrados con boca vertical el primero (MAMA-PC-58) y boca oblicua los restantes (MAMA-CP-1889, MAMA-CP-2021 y

MAMA-CP-2366). E: apliques en cresta (de izquierda a derecha: MAMA-CP-2215, MAMA-CP-2741,

MAMA-s/p-s/n $/ n^{\circ}$ y MAMA-T2-CSM-54). F: apliques sobre labios perforados transversalmente (de izquierda a derecha: MAMA-CP-3448, MAMA-CP-2684, MAMA-CP-1422 y MAMA-CP-3040). G: Rebordes con cuello, vista superior (arriba) y lateral (abajo) de la misma pieza (de izquierda a derecha: MAMA-CP-1448, MAMA-CP-1647, MAMA-CP-2853, MAMA-s/p-s/nº, MAMA-s/p-s/n, MAMA-CP-1542, MAMA-CP-2672 y MAMA-CP-2680).

H: tubos (de izquierda a derecha: MAMA-EMO-s/n, MAMA-EMO-312 y MAMA-EMO-2540). I: cuentas (de izquierda a derecha: MAMA-CP-1739, MAMA-CP-1780 y MAMA-s/p-s/nº. J: pipa (MAMA-EMO-49).

K: pesa de red (MAMA-s/p-s/n ${ }^{\circ}$ ). L: vasija de boca subcuadrangular decorada incisa y con apliques, vista superior y lateral (MAMA-CL2-s/nº). 


\section{Alfarería guaraní}

Todo el relevamiento de esta alfarería se realizó con la colaboración del Dr. Rodrigo Costa Angrizani (CONICET-CICYTTP; FCNyM-UNLP) en base a los criterios propuestos por Brochado (1984), Brochado y colaboradores (1990), Brochado y Monticelli (1994) y La Salvia y Brochado (1989) (véase Capítulo 4). Luego de los remontajes, se identificaron 1897 fragmentos cerámicos, 1317 corresponden al cuerpo de las vasijas, 521 son bordes, 58 son bases y uno es indeterminado. La muestra de alfarería guaraní proviene de EDB $(n=287), \operatorname{LC}(n=16), \tilde{\mathrm{N}}-A C(n=167), \tilde{\mathrm{N}}-A U(n=64), S P L$ $(n=3), C P(n=3), C L 2(n=1)$, y de la costa río Uruguay en la estancia Puerto Landa al sur de la ciudad de Gualeguaychú ( $n=6)$. Asimismo, se cuentan 1350 tiestos sin procedencia exacta, cuya gran parte seguramente proviene de EDB y LC (véase Almeida 1971, s/fa, s/fb).

Las Tablas 7.22a y b muestran la distribución de los distintos tratamientos de superficie de acuerdo a las distintas partes de las vasijas para los cuatro conjuntos más numerosos (EDB, LC, Ñ$\mathrm{AC} / \tilde{\mathrm{N}}-\mathrm{AU}$ y sin procedencia). Los materiales de $\tilde{\mathrm{N}}-\mathrm{AC}$ y $\tilde{\mathrm{N}}-\mathrm{AU}$ se presentan conjuntamente, ya que pueden considerarse como la misma localidad arqueológica (Almeida s/fa). 
Tabla 7.22a. Tratamiento de superficie de la alfarería guaraní del Museo Manuel Almeida (Gualeguaychú).

Sitio arqueológico Ensenada del Bellaco.

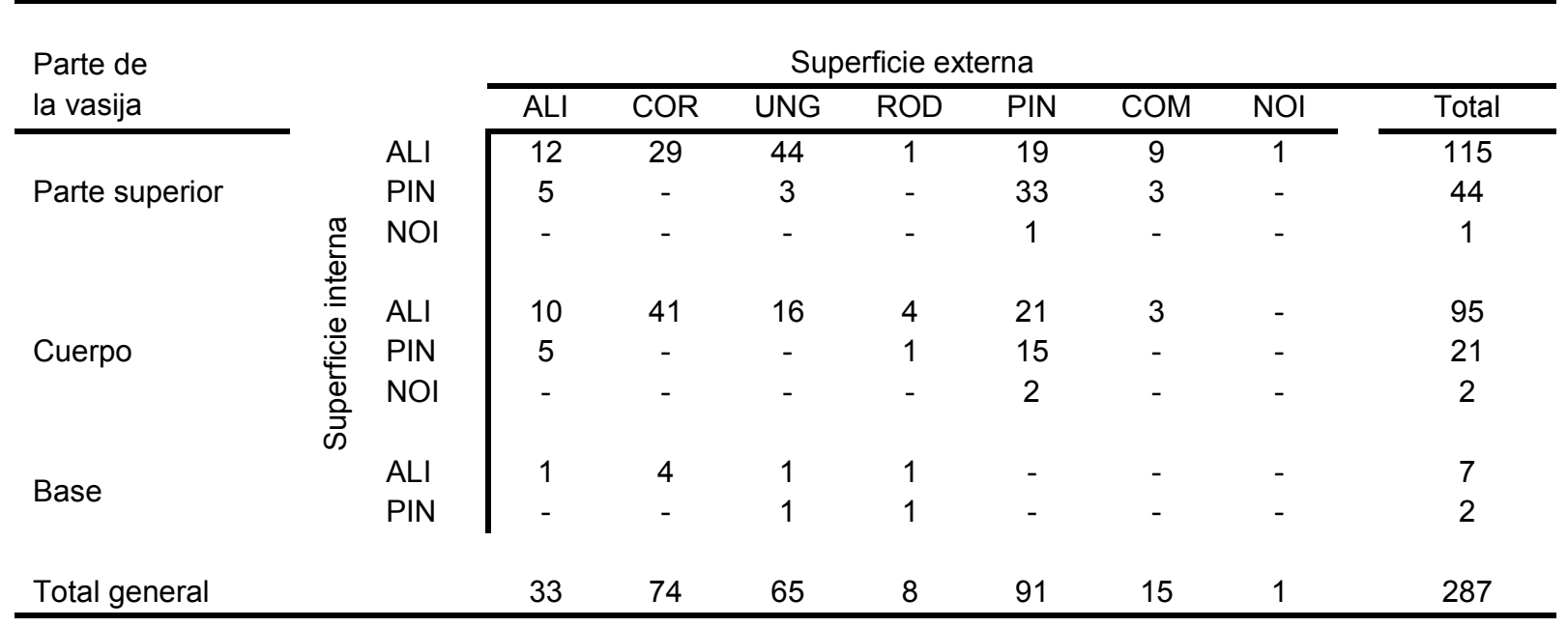

Sitio arqueológico La Correntina.

\begin{tabular}{|c|c|c|c|c|c|c|c|c|c|c|}
\hline \multirow{2}{*}{$\begin{array}{l}\text { Parte de } \\
\text { la vasija }\end{array}$} & \multicolumn{10}{|c|}{ Superficie externa } \\
\hline & & & ALI & COR & UNG & ROD & PIN & COM & $\mathrm{NOI}$ & Total \\
\hline \multirow{4}{*}{ Parte superior } & & ALI & 1 & 1 & 2 & - & - & - & - & 4 \\
\hline & 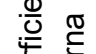 & PIN & - & - & 2 & - & - & - & - & 2 \\
\hline & $\stackrel{2}{\frac{2}{5}}$. & ALI & 2 & 3 & 1 & - & 3 & - & - & 9 \\
\hline & & $\mathrm{NOI}$ & - & - & - & - & 1 & - & - & 1 \\
\hline Total general & & & 3 & 4 & 5 & - & 4 & - & - & 16 \\
\hline
\end{tabular}

ALI: alisado; COR: corrugado; UNG: unguiculado; ROD: rodetes; PIN: pintados; COM: técnicas combinadas (alisado-inciso-pintado-corrugado-unguiculado-cepillado-rodetes); NOI: no identificados. 


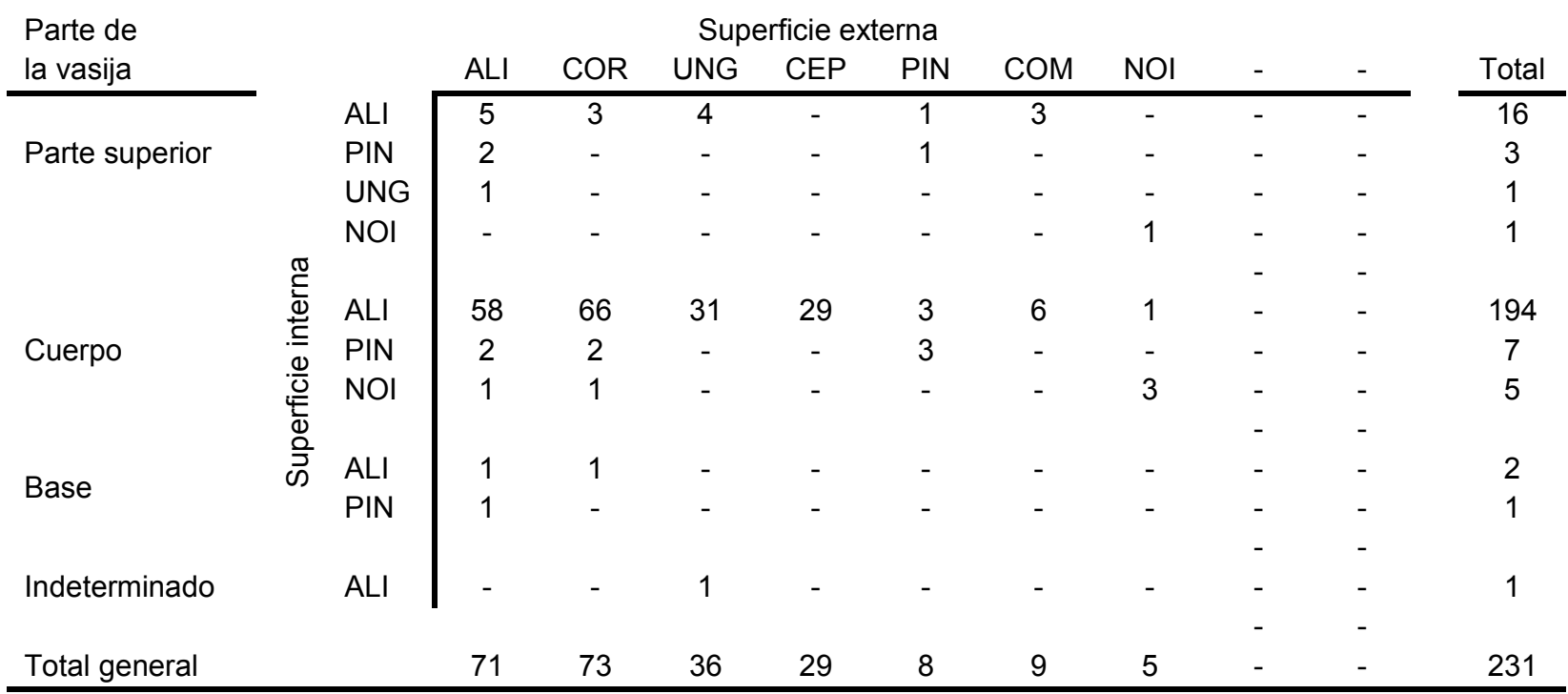

Sin procedencia exacta sector $C$.

Parte de

la vasija

Parte superior
Cuerpo

Base

Total general

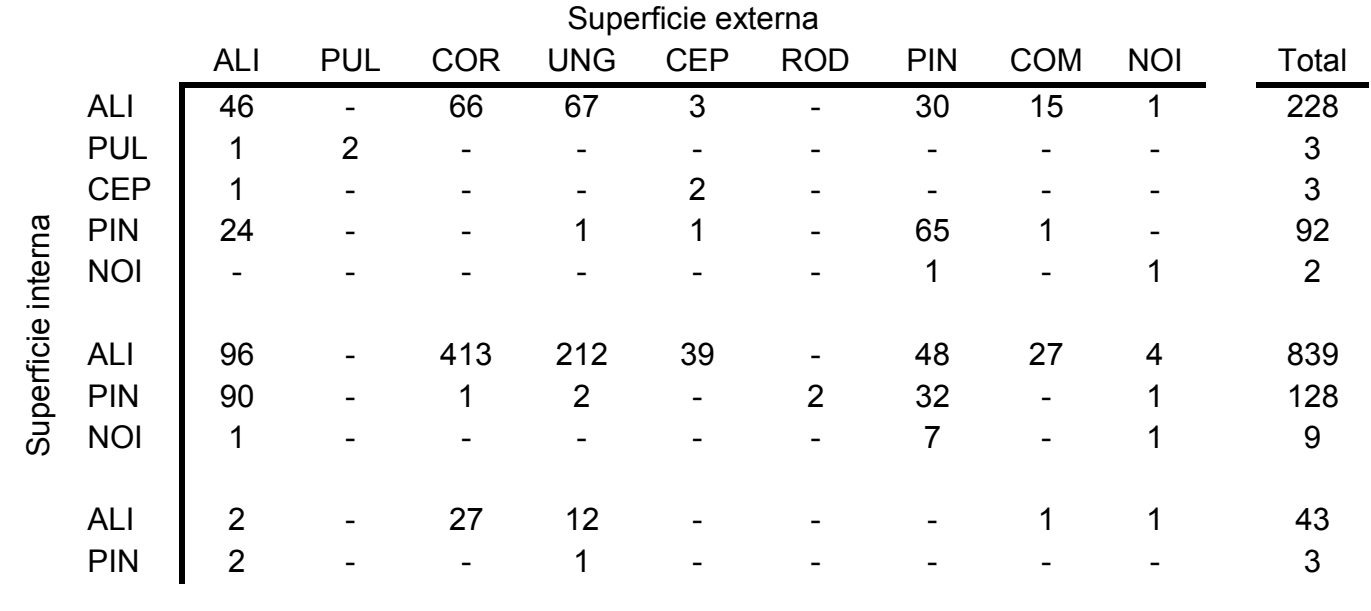

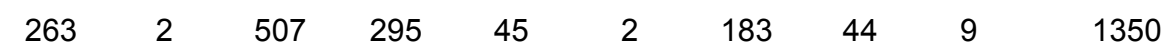
COM: técnicas combinadas (alisado-inciso-pintado-corrugado-unguiculado-cepillado-rodetes); NOI: no identificados.

En los demás conjuntos arqueológicos, procedentes de estratigrafía, se registraron: un borde y dos cuerpos, todos corrugados en las superficies externas y con alisado interno (SPL); tres bordes, dos unguiculados y uno corrugado, en las superficies externas y con alisado interno (CP); y un borde con alisado externo y pintura roja interna (CL2). Procedentes de recolección superficial en la zona de Puerto Landa se cuentan un borde y cuatro cuerpos, todos corrugados en la superficie externa y con alisado interno; y un cuerpo unguiculado-estriado en la superficie externa y con alisado interno. 
En las tablas $7.22 a$ y b se observa que en $\operatorname{EDB}(n=287)$ predomina el tratamiento de superficie externa mediante aplicación de pintura $(n=91 ; 31,7 \%)$, seguido por el corrugado $(n=74$, $25,8 \%$ ) y el unguiculado $(n=64,22,3 \%)$. El tratamiento interno en mayoritariamente alisado $(n=217$; $75,6 \%)$. En LC si bien la muestra es pequeña $(n=16)$ se observa que el tratamiento externo pintado $(n=4)$, corrugado $(n=4)$ y unguiculado $(n=5)$ tienen frecuencias semejantes. El tratamiento interno más frecuente es el alisado $(n=13)$. Para Ñ-AC/AU $(n=231)$ el tratamiento externo predominante es el corrugado ( $n=73 ; 31,6 \%$ ), seguido con una frecuencia semejante por el alisado ( $n=71,30,7 \%)$. El tratamiento interno es mayoritariamente alisado $(n=213 ; 92,2 \%)$. En el conjunto sin procedencia exacta $(n=1350)$ predomina el tratamiento externo corrugado $(n=507 ; 37,5 \%)$, seguido por el unguiculado ( $n=295 ; 21,8 \%)$, alisado $(n=263 ; 19,5 \%)$ y el pintado $(n=183 ; 13,5 \%)$. El tratamiento interno en mayoritariamente alisado $(n=1110 ; 82,2 \%)$, pero también se registra una alta frecuencia de pintado $(n=223 ; 16,5 \%)$.

Se deben destacar cinco fragmentos incluidos en las tablas precedentes que si bien presentan técnica de manufactura, tratamiento de superficie y características de la pasta iguales al resto de la cerámica estudiada, su morfología y combinación de técnicas de tratamiento de superficie no son comunes en la tipología establecida para la alfarería guaraní, por lo que su identificación con este grupo debe ser mejor estudiada. Se trata de un borde de EDB con un asa en arco vertical y que presenta decoración combinada incisa de punto y pintada en la superficie externa, y alisada y pintada en la interna (Figura 7.11A). También de EDB se registró un fragmento de cuerpo con un mamelón decorado mediante unguiculado en la superficie externa y alisada en la interna (Figura 7.11B). De ÑAC se cuenta una vasija con bordes con asas en arco horizontales que presenta decoración combinada unguiculada y cepillada en la superficie externa y alisada en la interna (Figura 7.11C). También de $\tilde{\mathrm{N}}$-AC se cuenta un borde que presenta decoración combinada unguiculada y con improntas de hojas de palmas (según observación directa en 2015 del Dr. Francisco Silva Noelli; UEM, Brasil) en la superficie externa y pintada en la interna (Figura 7.11D). Por último, una vasija sin procedencia exacta con la superficie externa alisada y la interna con una combinación de bandas pintadas e inciso de surco rítmico (Figura 7.11E). También cabe mencionar una pieza no incluida en las tablas y procedente de EDB que consiste en la porción central de una probable vasija trilobulada (Figura 7.11F).

Además de la cerámica presentada anteriormente, en la colección del MAMA se registraron ocho vasijas remontadas que corresponden a: tres yapepó corrugados (uno procede de $\tilde{\mathrm{N}}$-AC y dos de EDB) (Figura 7.11G y L); un ñaetá corrugado (procede de EDB); un cambuchí caguâbá decorado externamente con finas líneas rojas horizontales onduladas sobre fondo blanco (procede de Paso Paysandú en Concepción del Uruguay) (Figura 7.11H); un ñaetá con base plana y paredes rectas y bordes levemente invertidos, decorado externamente mediante la combinación de corrugado/unguiculado y cepillado (procede de Ñ-AC) (Figura 7.11l); una vasija con características 
muy particulares ya que presenta forma globular, un asa en arco e improntas de hojas de palmas (según el Dr. Francisco Silva Noelli 2015) en la superficie externa (procede de Ñ-AC) (Figura 7.11J); y por último, una mitad de una pequeña vasija bilobulada lisa y con una asa (fragmentada) que se ubicaba en el medio de los dos recipientes, uno de los cuales está ausente. En esta pieza por debajo del asa se observa claramente una superficie cóncava hacia el exterior que evidencia que había otro recipiente adherido (procede de $\tilde{N}$-AC) (Figura 7.11K). Uno de los yapepó y el ñaetá de EDB probablemente corresponden a una urna funeraria y su tapa (véase Castro y Costa Angrizani 2014, Figura 2a).

Asimismo, se menciona aquí una urna funeraria (cambuchí) de la colección particular Etchegoyen (Gualeguaychú). Procede de la cuenca del arroyo Ñancay a 2 km del río Uruguay en Islas del Ibicuy $\left(S 33^{\circ}, 528611 ; 058^{\circ}, 561667\right)$ y fue rencontrada aislada y enterrada, por pobladores locales en el año 2000. La urna está pintada con motivos de bandas color negro en el cuello pero no se distingue claramente el motivo. Dentro de la misma se registraron restos óseos humanos y faunísticos (véase más adelante). Según la información de sus descubridores la vasija se recuperó entera y con una tapa de cuero, pero luego sufrió una rotura por lo que fue remontada y su tapa se desintegró (Figura 7.11M).

En un trabajo previo sobre el sitio arqueológico Ensenada del Bellaco (Castro y Costa Angrizani 2014) y en relación a las clases funcionales identificadas siguiendo a La Salvia y Brochado (1989), Brochado y colaboradores (1990) y Brochado y Monticelli (1994), se reconstruyeron el perfil y el diámetro de 71 vasijas guaraníes. Estas corresponden a: 28 cambuchí, 24 yapepó, 14 ñaembé o tembiiru, tres ñaetá y dos cambuchí caguâbá. En cuanto a la alfarería pintada de este sitio se observó el uso de pigmentos blancos, rojos y negros en múltiples combinaciones sobre superficies alisadas, formando bandas horizontales que acompañan la sectorización del perfil de los recipientes. Se registraron bandas simples de color rojo, blanco o negro, así como también bandas blancas superpuestas por finos trazos de color rojo que dibujan líneas curvas, oblicuas y rectas (Castro y Costa Angrizani 2014: 237, y Figura 1). Estas características de la pintura pueden hacerse extensivas de manera general al resto de la alfarería pintada del MAMA. 

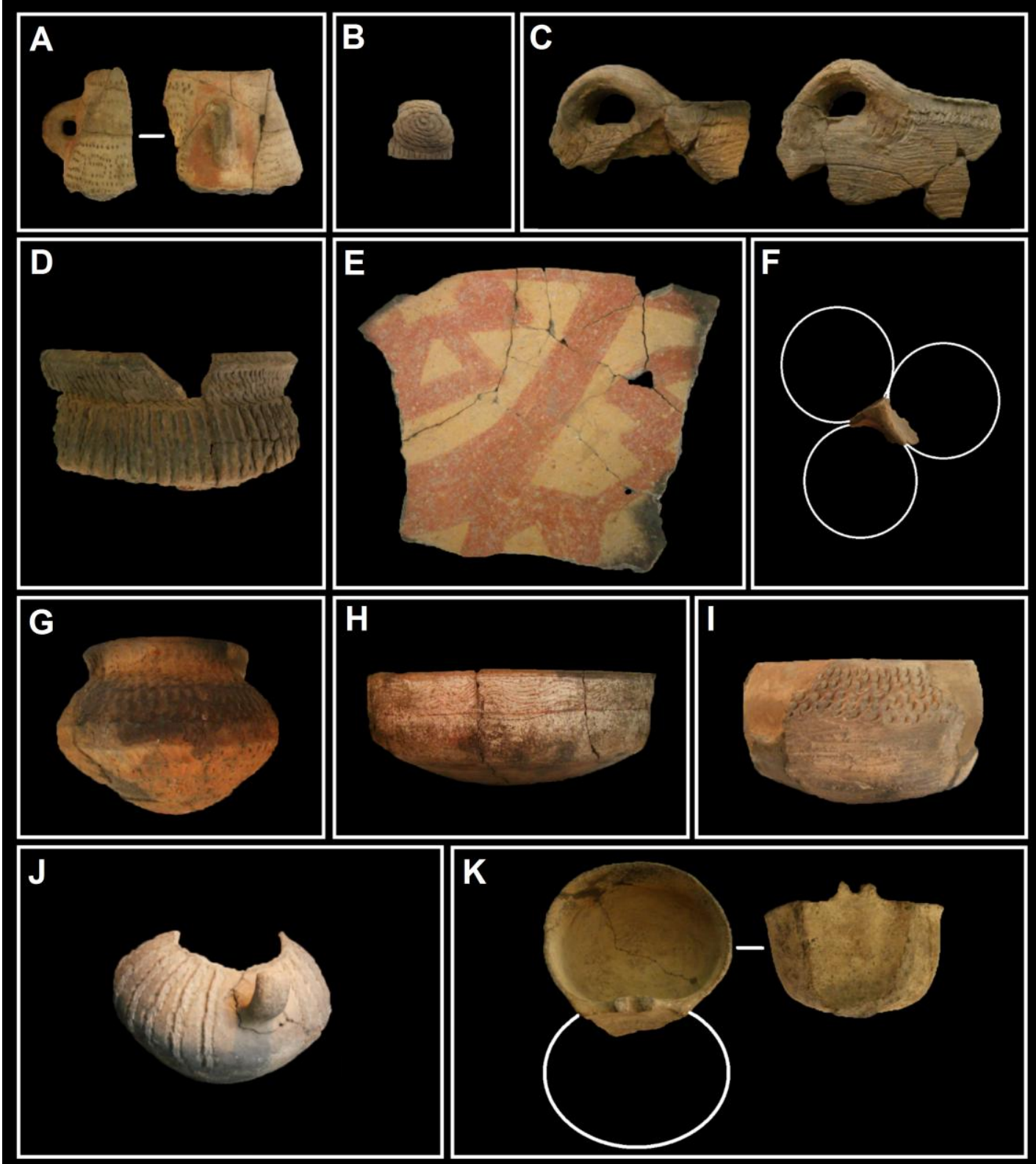

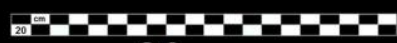

$20 \mathrm{~cm}$

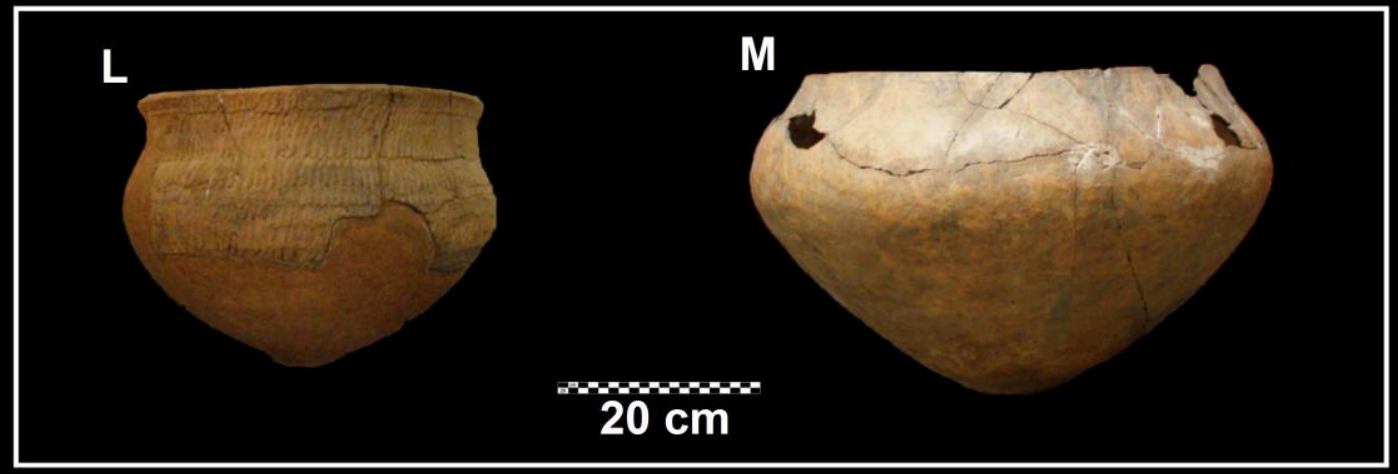

Figura 7.11. Alfarería guaraní y con rasgos combinados del Museo Arqueológico Manuel Almeida

(Gualeguaychú). A: borde con asa (MAMA-EDB-33). B: mamelón unguiculado (MAMA-EDB-564).

C: bordes con asas (MAMA-Ñ-AC-s $/ \mathrm{n}^{\circ}$ ). D: borde con improntas de hojas de palmas (MAMA-Ñ-AC-s $/ \mathrm{n}^{\circ}$ ).

E: vasija pintada y con surco rítmico (MAMA-s/p-s/nº). F: probable vasija trilobulada (MAMA-EDB-s $/ \mathrm{n}^{\circ}$ ).

G y L: yapepó corrugados (MAMA-Ñ-AC-9 y MAMA-EDB-s/ $\mathrm{n}^{\circ}$ ). H: cambuchí caguâbá pintado líneas rojas sobre fondo blanco (MAMA-PP-11). I: ñaetá corrugado/unguiculado y cepillado (MAMA-Ñ-AC-s/n ${ }^{\circ}$ ). J: vasija con asa e improntas de hojas de palmas (MAMA-Ñ-AC-s/nº). K: vasija bilobulada (MAMA-Ñ-AC-8). M: cambuchí pintado. 


\subsubsection{3- Tecnología ósea y arqueofauna del Museo Arqueológico Manuel Almeida}

EI MAMA conserva una muestra representativa de la fauna existente en los sitios arqueológicos de la zona. En esta sección se analiza un conjunto compuesto por 438 especímenes (huesos, astas, dientes y valvas de moluscos) divididos en cinco grupos: 1- instrumentos ( $n=235)$; 2 adornos $(n=32)$; 3- artefactos decorados indeterminados $(n=4)$; 4- especímenes con claras evidencias de modificación antrópica (ECEA) $(n=114)$, estos incluyen especímenes óseos, astas y dientes en los cuales se registraron huellas de filos, negativos de impacto, aserrado perimetral, desbaste del dentado en las espinas de peces, fracturas frescas, alteración térmica y decorado. Algunos serían resultado del consumo humano y otros son desechos de manufactura; asimismo algunos podrían corresponder a instrumentos o adornos, pero ante la duda con respecto a algunos de sus atributos no se los incluye por el momento como tales; y 5- especímenes sin modificación antrópica (ESEA) ( $n=53$ ), algunos serían resultado de consumo y otros (p. ej. lascas óseas) en parte probablemente también desechos de manufactura de instrumentos.

Las Tablas 7.23a, b, c y d muestran la distribución espacial, la determinación taxonómica y anatómica, y los atributos del grupo 1, 4 y 5; los grupos restantes (2 y 3) se describen a continuación de las mismas. Para reducir el tamaño de las tablas se realizaron agrupamientos en las siguientes categorías:

- En la categoría Taxón aquellos especímenes determinados como "cf." ( $n=22)$ se incluyeron en la especie a la cual remitían (p. ej. cf. Ozotocerus bezoarticus se incluyó en Ozotocerus bezoarticus).

-En la categoría Elemento metapodio se incluyeron los metacarpos, metatarsos y los metapodios indeterminados.

- La categoría Bisel incluye instrumentos sobre hueso, asta, o hemidiáfisis y diáfisis entera de huesos largos, que presentan el extremo distal activo producto de una formatización oblicua a su eje longitudinal o morfológico. La formatización pudo ser realizada por corte, desbaste, abrasión o pulido y conforma un filo, arista o tubo biselado (o bisel tubular) en el caso de las diáfisis enteras. Estas últimas piezas son denominadas por Scheinsohn (1997) "Piezas tubulares con extremo biselado (TUBOS)" e incluidas dentro de los biseles, aclarando además que podrían corresponder a mangos de instrumentos. En este sentido, algunas diáfisis enteras que además conservan una de las epífisis pudieron haber sido usadas como mangos de incisivos de roedores, como se ha registrado en varias colecciones de las Tierra Bajas sudamericanas (véase más adelante). Un ejemplo de esto último podría ser la pieza de la Figura 7.12C (MAMA-SPL-1).

- La categoría Punta incluye todos aquellos instrumentos que comparten el rasgo de presentar un ápice activo conformado por la convergencia de bordes o filos (Aschero 1975). A partir 
de este rasgo, junto a los restantes atributos morfológicos y tecnológicos de cada pieza, se distinguen subcategorías, a continuación se aclara que es lo que incluyen algunas de las mismas:

Punta ahuecada $(n=38)$ incluye las puntas semiacanaladas ahuecadas $(n=32)$ y las puntas cónicas ahuecadas $(n=6)$. Presentan un eje longitudinal morfológico relativamente recto entre el ápice y la zona basal, y una relativa simetría bilateral; rasgos que las distinguen de las Puntas curvas.

Punta curva $(n=2)$ incluye generalmente astas curvadas que pueden estar ahuecadas o no. En general tienen mayores dimensiones que las Punta ahuecadas.

Punta plana $(n=8)$ incluye las puntas planas sin epífisis y sin pedúnculo diferenciado $(n=4)$; y puntas cuya sección transversal distal o ápice se presenta como biplana o biconvexa levemente pronunciada; y en cuya sección transversal medial y proximal se combinan caras ventrales y dorsales: planas, convexas o cóncavas levemente pronunciadas $(n=4)$; estas últimas se corresponderían con el Grupo morfológico-funcional Punta Plano-convexa rectangular según Buc (2010a) o con el Grupo morfológico Puntas-mam plano convexa de Pérez Jimeno (2007).

Punta con epífisis ("Punzón") ( $n=53$ ) incluye las puntas semiacanaladas con epífisis ( $n=43)$ y puntas con epífisis $(n=10)$; las epífisis pueden estar completas o incompletas por fractura o reducción intencional. Algunas de las puntas con epífisis $(n=4)$ se corresponderían con el Grupo morfológico-funcional Punta Plana con epífisis según Buc (2010a) o con el Grupo morfológico Biselmam sobre cubitos de Pérez Jimeno (2007).

Espina aguzada $(\mathrm{n}=21)$ incluye todas las puntas elaboradas sobre espinas de peces con modificaciones antrópicas macroscópicas, con cabeza articular o sin ella. Esta modificación puede situarse en toda su extensión, pero en general se manifiesta sobre su porción distal y/o medial. El extremo apical y la zona medial pueden estar modificados por desbastes, pulido o desgastados por uso. Si bien las espinas que presentan la cabeza articular podrían incluirse dentro de las Puntas con epífisis, por el momento se agrupan todas juntas, con o sin cabeza, debido a su soporte-base específico, lo que probablemente esté en relación directa con su funcionalidad. Se corresponderían con el Grupo morfológico-funcional Alisadores según Buc (2010a).

Punta (no clasificable) $(n=16)$ incluye instrumentos con puntas y ápices activos aislados fracturados, que por su estado de integridad y/o completitud no se pueden clasificar como alguno de los demás tipos de instrumentos con puntas.

- La categoría Espátula incluye instrumentos similares en forma a las espátulas (o estecas) que usan los alfareros modernos en diferentes tareas. Hasta el momento el registro arqueológico del NEA no presenta instrumentos similares (véase más adelante).

Los instrumentos óseos analizados $(n=235)$ provienen de 15 sitios arqueológicos, 195 tienen procedencia exacta y 40 no la tienen por no estar catalogados o por haberse deteriorado su número (Tabla 7.23a, b, c y d). De estos últimos una gran parte provendría de CL2, SPL y CP, ya que fueron los sitios arqueológicos más trabajados por Almeida. El conjunto incluye: agujas $(n=3)$, espinas aguzadas 
$(n=21)$, tubos $(n=5)$, biseles $(n=5)$, puntas no clasificables $(n=16)$, bipuntas $(n=4)$, puntas acanaladas $(n=62)$, puntas ahuecadas $(n=38)$, puntas curvas ahuecadas $(n=2)$, puntas planas $(n=8)$, puntas con epífisis $(n=53)$, puntas de arpón $(n=10)$, preformas de puntas de arpón $(n=4)$, horquetas $(n=2)$ y espátulas $(n=2)$.

Tabla 7.23a. Artefactos óseos y especímenes faunísticos del Museo Manuel Almeida (Gualeguaychú).

\begin{tabular}{|c|c|c|c|c|c|c|c|c|c|c|c|c|}
\hline \multirow{3}{*}{$\begin{array}{c}\text { Sitios } \\
\text { arqueológicos }\end{array}$} & \multirow{3}{*}{ Taxón } & \multirow{3}{*}{ Elemento } & \multicolumn{8}{|c|}{ Instrumentos } & \multirow{3}{*}{$\begin{array}{c}\text { ECEA } \\
(n)\end{array}$} & \multirow{3}{*}{$\begin{array}{c}\text { ESEA } \\
(n)\end{array}$} \\
\hline & & & \multirow{2}{*}{ Instrumento } & \multirow{2}{*}{ Total } & \multicolumn{6}{|c|}{ Atributos } & & \\
\hline & & & & & $P$ & D & A & $\mathrm{F}$ & AP & DE & & \\
\hline \multirow{9}{*}{$\begin{array}{c}\text { Cerro } \\
\text { Lorenzo } \\
2\end{array}$} & AVES & hueso largo & Tubo & 1 & - & - & 1 & 1 & - & 1 & - & - \\
\hline & \multirow{2}{*}{ MAMMALIA } & hueso largo & Punta & 1 & 1 & - & - & 1 & - & - & - & - \\
\hline & & hueso largo & Punta acanalada & 2 & 2 & - & - & - & - & - & - & - \\
\hline & \multirow{4}{*}{ Ozotocerus bezoarticus } & \multirow{4}{*}{ metapodio } & Punta ahuecada & 3 & 3 & 2 & 3 & 3 & 1 & 2 & - & - \\
\hline & & & Punta plana & 2 & 2 & - & - & - & - & - & - & - \\
\hline & & & Punta acanalada & 1 & 1 & - & - & 1 & - & 1 & - & - \\
\hline & & & Punta con epífisis & 1 & 1 & 1 & - & 1 & - & - & - & - \\
\hline & Doradidae & espina pectoral & - & - & - & - & - & - & - & - & 1 & - \\
\hline & Cervidae & asta & - & - & - & - & - & - & - & - & 1 & - \\
\hline La Correntina & MAMMALIA & hueso largo & Punta acanalada & 1 & 1 & 1 & - & - & - & - & - & - \\
\hline \multirow{2}{*}{$\begin{array}{l}\text { Ensenada } \\
\text { del Bellaco }\end{array}$} & MAMMALIA & hueso largo & Tubo & 1 & - & - & 1 & 1 & 1 & - & - & - \\
\hline & Cervidae & asta & Punta ahuecada & 1 & 1 & 1 & 1 & 1 & 1 & - & - & - \\
\hline \multirow{4}{*}{$\begin{array}{l}\text { Túmulo } 1 \text { - } \\
\text { Cerro Norte } \\
\text { de Machado }\end{array}$} & MAMMALIA & hueso largo & Punta ahuecada & 1 & 1 & 1 & 1 & 1 & 1 & - & - & - \\
\hline & \multirow{2}{*}{ Ozotocerus bezoarticus } & \multirow{2}{*}{ metapodio } & Punta ahuecada & 2 & 2 & 2 & 2 & 1 & - & - & - & - \\
\hline & & & Punta con epífisis & 1 & 1 & 1 & - & 1 & - & - & - & - \\
\hline & Mazama gouazoubira & metapodio & Punta con epífisis & 2 & 2 & 1 & - & 2 & - & - & - & - \\
\hline \multirow{8}{*}{$\begin{array}{l}\text { Túmulo } 2 \text { - } \\
\text { Cerro Sur de } \\
\text { Machado }\end{array}$} & \multirow{2}{*}{ AVES } & hueso largo & Punta acanalada & 1 & 1 & 1 & - & 1 & - & - & - & - \\
\hline & & tarso-metatarso & Punta con epífisis & 1 & 1 & 1 & - & 1 & - & - & - & - \\
\hline & Rhea americana & tarso-metatarso & Punta con epífisis & 1 & 1 & 1 & - & 1 & - & - & - & - \\
\hline & MAMMALIA & hueso largo & Punta ahuecada & 2 & 2 & 2 & 2 & 2 & 1 & - & - & - \\
\hline & Ozotocerus bezoarticus & metapodio & Punta con epífisis & 3 & 3 & 3 & - & 2 & - & - & - & - \\
\hline & Mazama gouazoubira & metapodio & Punta con epífisis & 2 & 2 & 2 & - & 2 & - & - & - & - \\
\hline & \multirow{2}{*}{ Cervidae } & metapodio & Punta con epífisis & 1 & 1 & 1 & - & 1 & - & - & - & - \\
\hline & & asta & Punta & 1 & 1 & 1 & - & - & - & - & 1 & - \\
\hline \multirow{3}{*}{$\begin{array}{c}\text { El Aserradero } \\
\text { Viejo }\end{array}$} & \multirow{2}{*}{ Ozotocerus bezoarticus } & \multirow{2}{*}{ metapodio } & Punta acanalada & 1 & 1 & 1 & - & - & - & - & - & - \\
\hline & & & Punta con epífisis & 1 & 1 & 1 & - & 1 & - & - & - & - \\
\hline & Cervidae & asta & - & - & - & - & - & - & - & - & - & 1 \\
\hline \multirow{5}{*}{$\begin{array}{c}\text { Fajina } \\
\text { Quemada }\end{array}$} & Pseudoplatystoma sp. & espina pectoral & Espina aguzada & 1 & 1 & 1 & - & - & - & - & - & - \\
\hline & \multirow{2}{*}{ Ozotocerus bezoarticus } & cúbito & Punta con epífisis & 1 & 1 & 1 & - & 1 & - & - & - & - \\
\hline & & metapodio & - & - & - & - & - & - & - & - & 2 & - \\
\hline & Cervidae & metapodio & Punta acanalada & 1 & 1 & - & - & 1 & - & - & - & - \\
\hline & MAMMALIA & hueso largo & - & - & - & - & - & - & - & - & 1 & - \\
\hline
\end{tabular}

Atributos. P: pulido; D: desbaste; A: ahuecado; F: huellas de filos; AP: aserrado perimetral; DE: decorados. ECEA: espécimen con evidencia de procesamiento antrópico (artefacto); ESEA: espécimen sin evidencia de procesamiento antrópico. 
Tabla 7.23b. Artefactos óseos y especímenes faunísticos del Museo Manuel Almeida (Gualeguaychú).

\begin{tabular}{|c|c|c|c|c|c|c|c|c|c|c|c|c|}
\hline \multirow{2}{*}{$\begin{array}{c}\text { Sitios } \\
\text { arqueológicos }\end{array}$} & \multirow{2}{*}{ Taxón } & \multirow{2}{*}{ Elemento } & \multicolumn{8}{|c|}{ Instrumentos } & \multirow{2}{*}{$\begin{array}{c}\text { ECEA } \\
(n)\end{array}$} & \multirow{2}{*}{$\begin{array}{c}\text { ESEA } \\
(\mathrm{n})\end{array}$} \\
\hline & & & Instrumento & Total & $\mathrm{P}$ & D & A & $\mathrm{F}$ & AP & DE & & \\
\hline \multirow{29}{*}{$\begin{array}{c}\text { Sambaquí } \\
\text { de } \\
\text { Puerto Landa }\end{array}$} & Siluriforme & espina pectoral & Espina aguzada & 5 & 4 & 5 & - & - & - & - & - & - \\
\hline & Doradidae & espina pectoral & Espina aguzada & 2 & 2 & 2 & - & - & - & - & - & - \\
\hline & ACTINOPTERYGII & vértebra & - & - & - & - & - & - & - & - & - & 28 \\
\hline & \multirow{3}{*}{ AVES } & hueso largo & Tubo & 2 & 1 & - & 2 & 2 & 2 & 2 & - & - \\
\hline & & hueso largo & Punta ahuecada & 1 & 1 & 1 & 1 & 1 & - & - & - & - \\
\hline & & hueso largo & Punta con epífisis & 2 & 2 & 2 & - & 1 & - & - & - & - \\
\hline & \multirow[t]{3}{*}{ MAMMALIA } & \multirow{2}{*}{ hueso largo } & Punta con epífisis & 1 & 1 & - & - & 1 & - & 1 & - & - \\
\hline & & & Espátula & 2 & 2 & 1 & - & 2 & - & - & - & - \\
\hline & & indeterminado & Punta & 1 & 1 & - & - & - & - & - & 1 & - \\
\hline & \multirow{2}{*}{ Blastocerus dichotomus } & asta & Horqueta & 1 & - & - & 1 & 1 & 1 & - & 12 & 4 \\
\hline & & cúbito & Punta con epífisis & 1 & 1 & - & - & 1 & - & - & - & - \\
\hline & \multirow{4}{*}{ Ozotocerus bezoarticus } & \multirow{3}{*}{ metapodio } & Punta acanalada & 4 & 4 & 1 & - & 4 & - & - & 3 & - \\
\hline & & & Punta ahuecada & 5 & 4 & 2 & 5 & 4 & - & 1 & - & - \\
\hline & & & Punta con epífisis & 7 & 7 & 6 & - & 3 & - & - & - & - \\
\hline & & cúbito & Punta con epífisis & 1 & 1 & 1 & - & - & - & - & - & - \\
\hline & \multirow{4}{*}{ Cervidae } & metapodio & Punta con epífisis & 1 & 1 & 1 & - & 1 & - & - & - & - \\
\hline & & \multirow{3}{*}{ asta } & Punta & 1 & 1 & - & - & 1 & - & 1 & 9 & 6 \\
\hline & & & Arpón & 5 & 5 & 5 & 5 & 5 & 3 & - & - & - \\
\hline & & & Preforma arpón & 3 & 2 & 3 & 3 & 2 & - & - & - & - \\
\hline & Chrysocyon brachyurus & cúbito & Punta con epífisis & 1 & 1 & 1 & - & - & - & - & - & - \\
\hline & Indeterminado & hueso largo & Punta ahuecada & 1 & 1 & 1 & 1 & - & - & - & - & - \\
\hline & Lontra longicaudis & húmero & - & - & - & - & - & - & - & - & 1 & - \\
\hline & \multirow{2}{*}{ Canis familiaris } & mandíbula & - & - & - & - & - & - & - & - & 1 & - \\
\hline & & canino & - & - & - & - & - & - & - & - & - & 1 \\
\hline & \multirow{2}{*}{ Panthera onca } & radio & - & - & - & - & - & - & - & - & 1 & - \\
\hline & & maxilar & - & - & - & - & - & - & - & - & - & 1 \\
\hline & \multirow{3}{*}{ Otaria flavescens } & húmero & - & - & - & - & - & - & - & - & 1 & - \\
\hline & & radio & - & - & - & - & - & - & - & - & 1 & - \\
\hline & & canino & - & - & - & - & - & - & - & - & - & 1 \\
\hline Total & - & - & - & 64 & 59 & 46 & 22 & 40 & 6 & 6 & 32 & 43 \\
\hline
\end{tabular}

Atributos. P: pulido; D: desbaste; A: ahuecado; F: huellas de filos; AP: aserrado perimetral; DE: decorados. ECEA: espécimen con evidencia de procesamiento antrópico (artefacto); ESEA: espécimen sin evidencia de procesamiento antrópico. 
Tabla 7.23c. Artefactos óseos y especímenes faunísticos del Museo Manuel Almeida (Gualeguaychú).

\begin{tabular}{|c|c|c|c|c|c|c|c|c|c|c|c|c|}
\hline \multirow{3}{*}{$\begin{array}{c}\text { Sitios } \\
\text { arqueológicos }\end{array}$} & \multirow{3}{*}{ Taxón } & \multirow{3}{*}{ Elemento } & \multicolumn{8}{|c|}{ Instrumentos } & \multirow{3}{*}{$\begin{array}{c}\text { ECEA } \\
(n)\end{array}$} & \multirow{3}{*}{$\begin{array}{c}\text { ESEA } \\
(n)\end{array}$} \\
\hline & & & \multirow{2}{*}{ Instrumento } & \multirow{2}{*}{ Total } & \multicolumn{6}{|c|}{ Atributos } & & \\
\hline & & & & & $P$ & D & A & $\mathrm{F}$ & AP & DE & & \\
\hline \multirow{3}{*}{$\begin{array}{c}\text { Las } \\
\text { Conchillas }\end{array}$} & MAMMALIA & hueso largo & Punta ahuecada & 1 & 1 & 1 & 1 & 1 & 1 & - & - & - \\
\hline & Ozotocerus bezoarticus & metapodio & Punta acanalada & 1 & 1 & 1 & - & 1 & - & - & 1 & - \\
\hline & Cervidae & asta & - & - & - & - & - & - & - & - & - & 1 \\
\hline \multirow{18}{*}{$\begin{array}{c}\text { Cerros de los } \\
\text { Pampas }\end{array}$} & Pseudoplatystoma sp. & espina pectoral & Espina aguzada & 1 & 1 & 1 & - & - & - & - & - & - \\
\hline & Rhea americana & tarso-metatarso & Punta con epífisis & 1 & 1 & 1 & - & 1 & - & - & - & - \\
\hline & \multirow{3}{*}{ MAMMALIA } & \multirow{2}{*}{ hueso largo } & Punta & 2 & 2 & 2 & - & 1 & - & - & - & - \\
\hline & & & Punta con epífisis & 1 & 1 & 1 & - & - & - & - & - & - \\
\hline & & indeterminado & Punta ahuecada & 1 & 1 & 1 & 1 & - & - & - & - & - \\
\hline & \multirow{3}{*}{ Blastocerus dichotomus } & asta & Horqueta & 1 & - & - & 1 & 1 & 1 & - & 1 & 1 \\
\hline & & metapodio & Punta con epífisis & 1 & 1 & 1 & - & 1 & - & - & - & - \\
\hline & & radio & - & - & - & - & - & - & - & - & 1 & - \\
\hline & \multirow{4}{*}{ Ozotocerus bezoarticus } & \multirow{4}{*}{ metapodio } & Punta acanalada & 5 & 5 & 3 & - & 3 & - & - & 1 & - \\
\hline & & & Punta ahuecada & 3 & 3 & 1 & 3 & 2 & - & 1 & - & - \\
\hline & & & Punta plana & 1 & 1 & - & - & - & - & - & - & - \\
\hline & & & Punta con epífisis & 15 & 15 & 12 & - & 7 & - & - & - & - \\
\hline & \multirow{4}{*}{ Cervidae } & \multirow{2}{*}{ asta } & Arpón & 3 & 3 & 3 & 3 & 1 & - & 1 & - & - \\
\hline & & & Preforma arpón & 1 & - & - & 1 & - & - & - & - & - \\
\hline & & \multirow{2}{*}{ metapodio } & Punta acanalada & 3 & 3 & 2 & - & 2 & 1 & - & 2 & - \\
\hline & & & Punta plana & 1 & 1 & 1 & - & 1 & - & - & - & - \\
\hline & Canis familiaris & mandíbula & - & - & - & - & - & - & - & - & - & 1 \\
\hline & Chrysocyon brachyurus & canino & - & - & - & - & - & - & - & - & 1 & - \\
\hline \multirow{6}{*}{$\begin{array}{l}\text { San Luís } \\
\text { Costa - } \\
\text { Túmulo } 1\end{array}$} & ACTINOPTERYGII & espina dorsal & Aguja & 1 & 1 & 1 & - & - & - & - & - & - \\
\hline & Pseudoplatystoma sp. & espina pectoral & Espina aguzada & 2 & 2 & 2 & - & 1 & - & - & - & - \\
\hline & MAMMALIA & hueso largo & Punta acanalada & 3 & 3 & 2 & - & 2 & - & 1 & 1 & - \\
\hline & Blastocerus dichotomus & metapodio & Punta acanalada & 1 & 1 & 1 & - & - & - & - & - & - \\
\hline & \multirow{2}{*}{ Cervidae } & asta & Punta & 1 & 1 & 1 & - & - & - & - & - & - \\
\hline & & metapodio & - & - & - & - & - & - & - & - & 1 & - \\
\hline \multicolumn{4}{|l|}{ Total } & 86 & 80 & 61 & 17 & 49 & 11 & 4 & 17 & 6 \\
\hline
\end{tabular}

Atributos. P: pulido; D: desbaste; A: ahuecado; F: huellas de filos; AP: aserrado perimetral; DE: decorados. ECEA: espécimen con evidencia de procesamiento antrópico (artefacto); ESEA: espécimen sin evidencia de procesamiento antrópico. 
Tabla 7.23d. Artefactos óseos y especímenes faunísticos del Museo Manuel Almeida (Gualeguaychú).

\begin{tabular}{|c|c|c|c|c|c|c|c|c|c|c|c|c|}
\hline \multirow{2}{*}{$\begin{array}{c}\text { Sitios } \\
\text { arqueológicos }\end{array}$} & \multirow{2}{*}{ Taxón } & \multirow{2}{*}{ Elemento } & \multicolumn{8}{|c|}{ Instrumentos } & \multirow{2}{*}{$\begin{array}{c}\text { ECEA } \\
(n)\end{array}$} & \multirow{2}{*}{$\begin{array}{c}\text { ESEA } \\
(n)\end{array}$} \\
\hline & & & Instrumento & Total & $P$ & D & $A$ & $F$ & $\mathrm{AP}$ & $\mathrm{DE}$ & & \\
\hline \multirow{3}{*}{$\begin{array}{l}\text { Túmulo de } \\
\text { Lucuix }\end{array}$} & \multirow{2}{*}{ MAMMALIA } & \multirow{2}{*}{ hueso largo } & Punta acanalada & 1 & 1 & 1 & - & 1 & - & - & 1 & - \\
\hline & & & Punta ahuecada & 1 & 1 & 1 & 1 & 1 & - & - & - & - \\
\hline & Cervidae & metapodio & Punta acanalada & 1 & 1 & 1 & - & - & - & - & - & - \\
\hline $\begin{array}{c}\text { Túmulo } 1 \text { - La } \\
\text { Argentina }\end{array}$ & MAMMALIA & hueso largo & Punta ahuecada & 2 & 2 & 1 & 2 & 1 & 1 & - & - & - \\
\hline $\begin{array}{l}\text { Ñandubaysal - } \\
\text { Arroyo La Cruz }\end{array}$ & MAMMALIA & hueso largo & Punta & 1 & 1 & 1 & - & - & - & - & - & - \\
\hline \multirow{20}{*}{$\begin{array}{c}\text { Sin } \\
\text { procedencia }\end{array}$} & AVES & hueso largo & Punta ahuecada & 1 & 1 & - & 1 & 1 & 1 & - & - & - \\
\hline & \multirow{6}{*}{ MAMMALIA } & \multirow{6}{*}{ hueso largo } & Punta & 1 & 1 & 1 & - & - & - & - & 3 & - \\
\hline & & & Bipunta & 2 & 2 & 2 & - & 1 & - & - & - & - \\
\hline & & & Punta acanalada & 8 & 8 & 8 & - & 2 & - & 1 & - & - \\
\hline & & & Punta ahuecada & 2 & 1 & 1 & 2 & 1 & - & - & - & - \\
\hline & & & Punta plana & 4 & 4 & 1 & - & - & - & - & - & - \\
\hline & & & Punta con epífisis & 1 & 1 & 1 & - & - & - & - & - & - \\
\hline & \multirow[b]{2}{*}{ Blastocerus dichotomus } & asta & - & - & - & - & - & - & - & - & 22 & - \\
\hline & & húmero & - & - & - & - & - & - & - & - & 2 & - \\
\hline & Mazama gouazoubira & asta & Punta & 1 & 1 & 1 & - & 1 & - & - & 1 & - \\
\hline & \multirow{5}{*}{ Cervidae } & \multirow{4}{*}{ asta } & Punta & 3 & 3 & 1 & - & 1 & - & - & 19 & 1 \\
\hline & & & Bisel & 1 & 1 & 1 & - & 1 & 1 & 1 & - & - \\
\hline & & & Punta curva & 1 & - & - & 1 & - & 1 & - & - & - \\
\hline & & & Arpón & 2 & 2 & 1 & 2 & - & - & - & - & - \\
\hline & & metapodio & Punta con epífisis & 1 & 1 & 1 & - & - & - & - & 1 & - \\
\hline & Myocastor coypus & tibia & Bisel & 1 & - & 1 & - & 1 & - & - & - & - \\
\hline & \multirow{2}{*}{$\begin{array}{l}\text { Hydrochoerus } \\
\text { hydrochaeris }\end{array}$} & húmero & - & - & - & - & - & - & - & - & 1 & - \\
\hline & & fémur & - & - & - & - & - & - & - & - & 1 & - \\
\hline & Canis familiaris & canino & - & - & - & - & - & - & - & - & 1 & - \\
\hline & Lycalopex gimnocercus & mandíbula & - & - & - & - & - & - & - & - & - & 1 \\
\hline Total & - & - & - & 48 & 43 & 32 & 11 & 17 & 6 & 4 & 59 & 3 \\
\hline
\end{tabular}

Atributos. P: pulido; D: desbaste; A: ahuecado; F: huellas de filos; AP: aserrado perimetral; DE: decorados. ECEA: espécimen con evidencia de procesamiento antrópico (artefacto); ESEA: espécimen sin evidencia de procesamiento antrópico. 
Dentro de estos instrumentos se destacan las espátulas por ser un registro novedoso (Figura 7.12M). Una de las piezas está fracturada en cuatro partes, de las cuales tres están remontadas y falta una porción intermedia que completaría el instrumento. Tiene dos extremos activos, uno convexo y otro recto, ambos recto-convexos en sección longitudinal. Su longitud estimada es de 200 $\mathrm{mm}$, el ancho máximo es de $12 \mathrm{~mm}$ y el espesor máximo es de 5,6 $\mathrm{mm}$. La otra pieza también está fracturada, el extremo activo es transversal inclinado debido al mayor desgaste de una de las equinas, y en sección longitudinal está aguzado por desgaste. Su largo es de 59,5 mm, el ancho máximo es de 7,5 mm y el espesor máximo es de $3,7 \mathrm{~mm}$. 


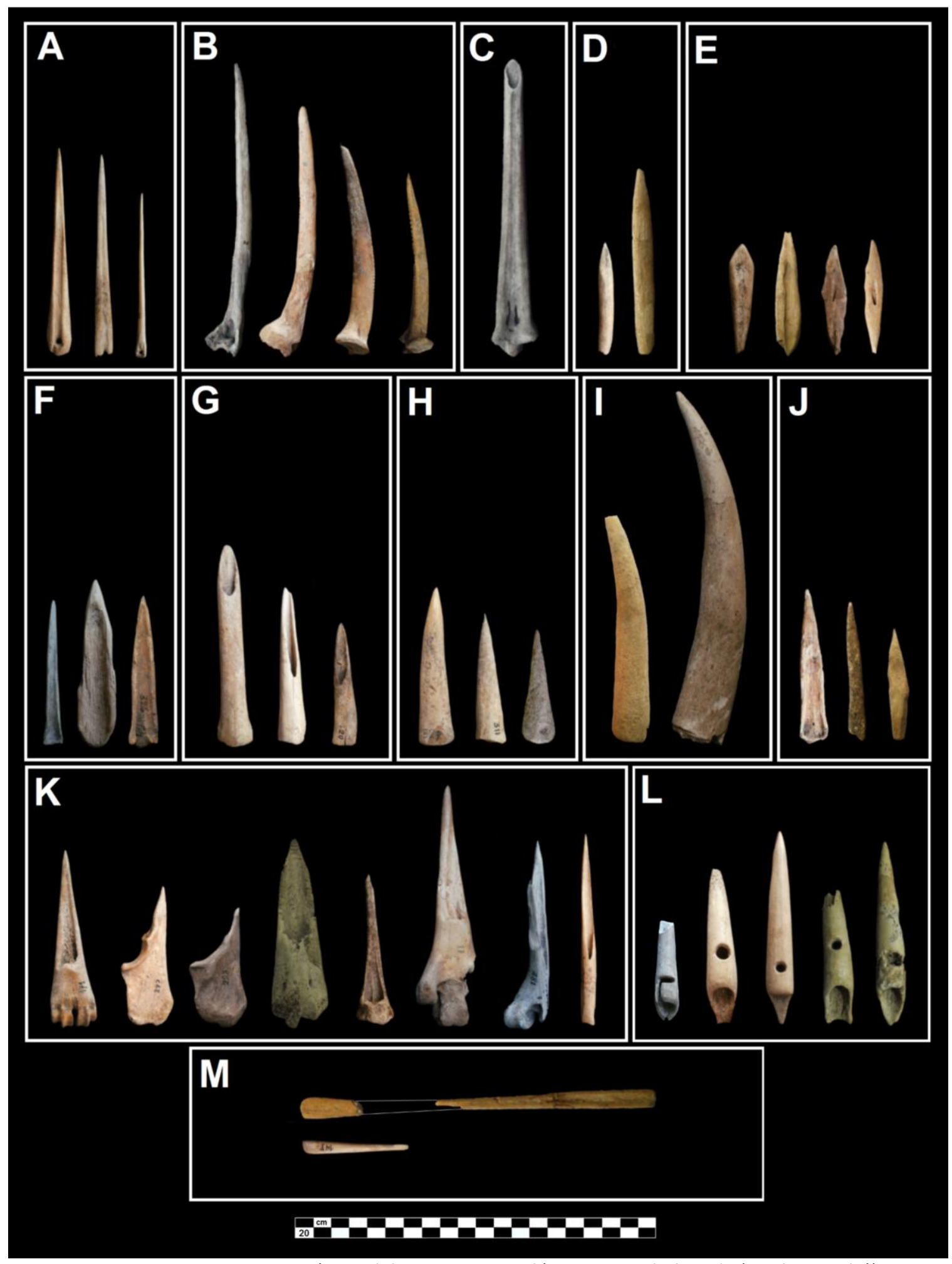

Figura 7.12. Instrumentos óseos del Museo Arqueológico Manuel Almeida (Gualeguaychú).

A: agujas con ojo (de izquierda a derecha: MAMA-SPL-52, MAMA-SPL-149 y MAMA-SLC-T1-30). B: espinas aguzadas (de izquierda a derecha: MAMA-SPL-2, MAMA-SPL-4, MAMA-SPL-36 y MAMA-s/p-s/ $\mathrm{n}^{\circ}$ ). C: bisel (MAMA-SPL-1). D: puntas (de izquierda a derecha: MAMA-s/p-341 y MAMA-s/p-s/n ${ }^{\circ}$ ). E: bipuntas (de izquierda a derecha: MAMA-CP-266, MAMA-s/p-s/n, MAMA-s/p-s/n y MAMA-CP-289). F: puntas acanaladas (de izquierda a derecha: MAMA-T2-CSM-69, MAMA-s/p-223b y MAMA-CP-326). G: puntas ahuecadas semiacanaladas (de izquierda a derecha: MAMA-CL2-7, MAMA-SPL-143 y MAMA-T2-CSM-20). H: puntas ahuecadas cónicas (de izquierda a derecha: MAMA-CP-329, MAMA-CP-311 y MAMA-CP-219). I: puntas curvas ahuecadas (de izquierda a derecha: MAMA-s/p-s/n y MAMA-CP-222). J: puntas planas sin pedúnculo

(de izquierda a derecha: MAMA-CL2-34, MAMA-s/p-s/n y MAMA-s/p-s/n ${ }^{\circ}$ ). K: puntas con epífisis (de izquierda a derecha: MAMA-SPL-171, MAMA-SPL-295, MAMA-FQ-298, MAMA-T2-CSM-70, MAMA-CP-205,

MAMA-T2-CSN-17, MAMA-CP-182 y MAMA-SPL-9). L: puntas de arpón (de izquierda a derecha: MAMA-CP-212, MAMA-SPL-43, MAMA-SPL-156, MAMA-SPL-44 y MAMA-s/p-22b). M: espátulas

(de arriba hacia abajo: MAMA-SPL-148 y MAMA-SPL-3). 


\section{Especímenes con evidencias de procesamiento antrópico (ECEA) $(n=114)$}

Dentro del conjunto se destacan los siguientes taxa y elementos:

- 35 astas de ciervo de los pantanos. La mayoría tiene aserrado perimetral en sus ramas y algunas son similares a las horquetas pero no tienen perforación central. Se registró un asta adherida al cráneo (proceso cornual y frontal) con huellas de corte en el proceso cornual que indican claramente desprendimiento del cuero del cráneo.

- dos astas de guazuncho con huellas de corte y fracturas frescas. Ambas están adheridas al cráneo.

- un fémur y un húmero de carpincho con huellas de corte y fracturas frescas.

- un canino inferior de aguará guazú (Chrysocyon brachyurus) con huellas de corte en la raíz, el cíngulo y la corona.

- un radio de yaguareté (Panthera onca) con huellas de corte distribuidas por todo el hueso; algunas son de desarticulación y descarne, y otras transversales subparalelas cruzadas por longitudinales subparalelas conforman una decoración reticulada en algunos sectores.

- un humero de lobito de río (Lontra longicaudis) con huellas de corte.

- un humero y un radio de lobo marino sudamericano (Otaria flavescens) con huellas de corte y fracturas frescas (Figura 7.13C).

- una hemimandíbula y un canino inferior de perro doméstico (Canis familiaris) con huellas de corte.

\section{Especímenes sin evidencias de procesamiento antrópico (ESEA) $(n=53)$}

Este conjunto incluye especímenes que evidencian la presencia de determinadas especies y de elementos que no fueron registrados a través de los instrumentos o artefactos y permiten ampliar variedad anatómica y taxonómica registrada. Se destaca la presencia de un canino superior de lobo marino sudamericano, un maxilar y premaxilar de yaguareté y una hemimandíbula de zorro gris. Además, se registraron dos especímenes más de perro doméstico (hemimandíbula y canino).

\section{Adornos ( $\mathrm{n}=32$ )}

Estos objetos (Figura 7.13B) se registraron en CL2, SPL y otros sin procedencia exacta. En Cerro Lorenzo 2 consisten en cuentas de collar con morfología piriforme curvada $(n=21)$, confeccionadas sobre el labio interno (columela) de valvas de Megalobulimus sp. (MAMA-CL2-s/ $\mathrm{n}^{\circ}$ ). Fueron recuperadas asociadas a un cráneo humano (CCBSJG 1986: 52). En Sambaquí de Puerto Landa consisten en ornamentos labiales inferiores con forma de " $\mathrm{T}$ " denominados tembetás $(\mathrm{n}=2)$, y confeccionados sobre valvas de Diplodon sp. Uno se encuentra entero (MAMA-SPL-164) y el otro fracturado (MAMA-SPL-163).

Los adornos sin procedencia consisten en: cuentas de collar $(n=2)$ confeccionadas sobre el labio interno de valvas de Megalobulimus sp. similares en forma y dimensiones a las de CL2. Cuentas indeterminadas que corresponden a fragmentos recortados sobre el labio externo de valvas de 
Megalobulimus sp. con contorno semicircular o trapezoidal irregular con un orificio central $(n=3)$. Un disco circular con un orificio central confeccionado sobre valva de Diplodon sp. $(n=1)$. Todos los adornos de valvas fueron confeccionados mediante el corte de la forma aproximada y el posterior pulido-abrasión de los bordes. También se cuentan pendientes confeccionados sobre caninos de yaguareté $(n=2)$ y de aguará guazú $(n=1)$ (Castro 2016; Figura 4).

\section{Artefactos decorados $(n=4)$}

Se registraron dos en SPL y otros dos sin procedencia exacta. Algunos podrían ser adornos o instrumentos (p. ej. tubos o puntas) (Figura 7.14B).

Los de SPL consisten en: una diáfisis de cúbito de ave indeterminada (tamaño chajá, Chauna torquata) decorada con siete líneas incisas transversales subparalelas y cuatro líneas oblicuas; y un fragmento de diáfisis de hueso largo de un taxón indeterminado (probable ave) decorada con 10 líneas incisas subparalelas.

Los que no tienen procedencia consisten en: dos fragmentos de diáfisis y epífisis proximal de metapodio de cérvido (cf. venado de las pampas); uno está decorado con 20 líneas incisas subparalelas y un pequeño esbozo de orificio en la epífisis, y el restante está decorado con líneas incisas en zigzag, en " $Y$ " y en " $X$ ", además está carbonizado en la epífisis. Se destaca la similitud de estas piezas, en cuanto a la decoración, con los dos artefactos que proceden de CL2 y SPL y que fueron presentados en la Sección 7.1.2.3 y en la Figura 7.6D y H. 


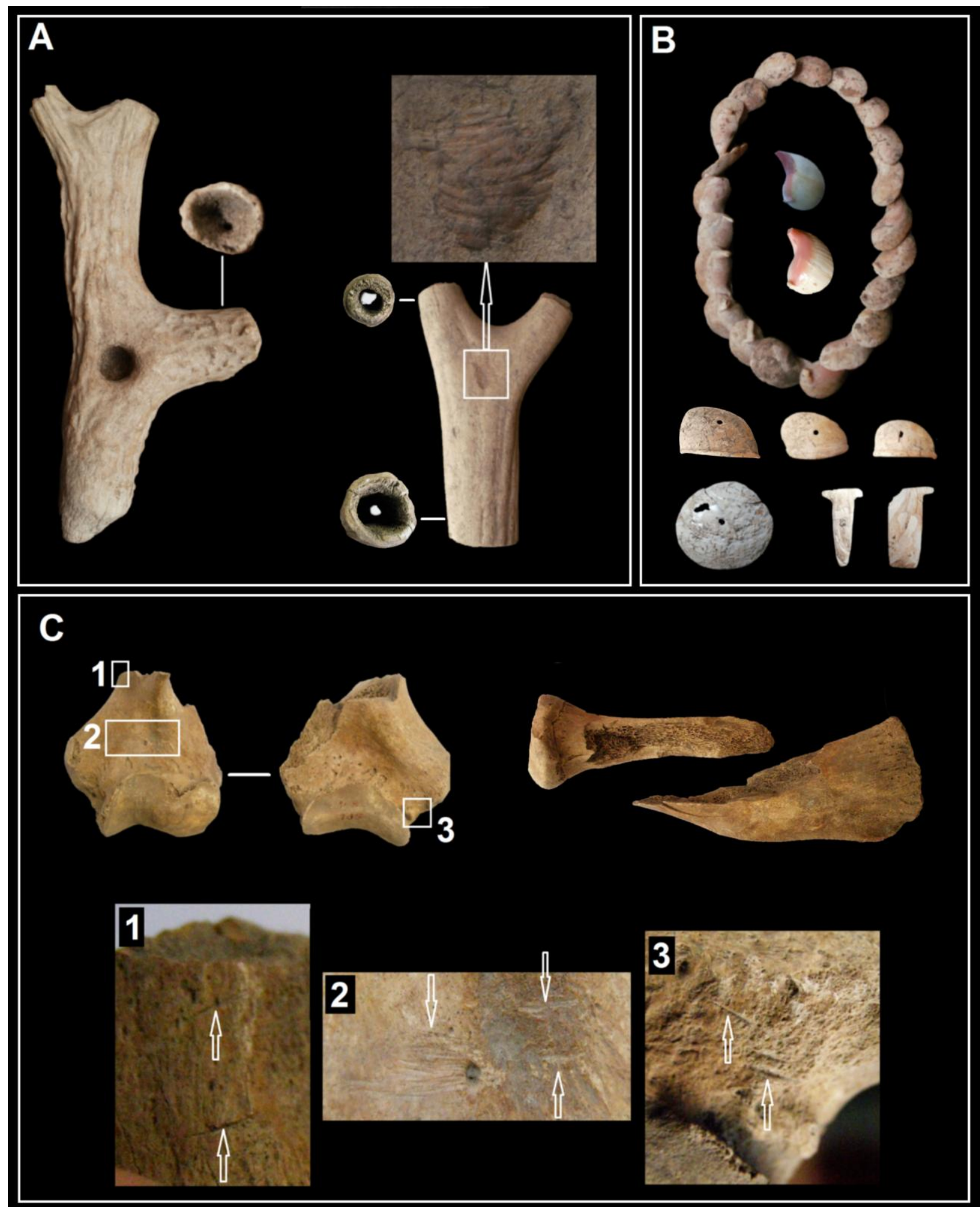

\section{0}

Figura 7.13. Instrumentos y artefactos óseos y adornos de valvas del Museo Manuel Almeida (Gualeguaychú). A: horquetas (de izquierda a derecha: MAMA-SPL-121 y MAMA-CP-301). B: adornos sobre valvas de moluscos: collar (MAMA-CL2-s $/ \mathrm{n}^{\circ}$ ), cuentas aisladas y disco perforado (sin procedencia), y tembetás (MAMA-SPL-164 y MAMA-SPL-163). C: húmero y radio fragmentado en dos partes de lobo marino sudamericano (Otaria flavescens) (MAMA-SPL-s $/ \mathrm{n}^{\circ}$ ). Se muestran en detalle y en distinta escala las huellas de corte y desarticulación sobre el húmero. 


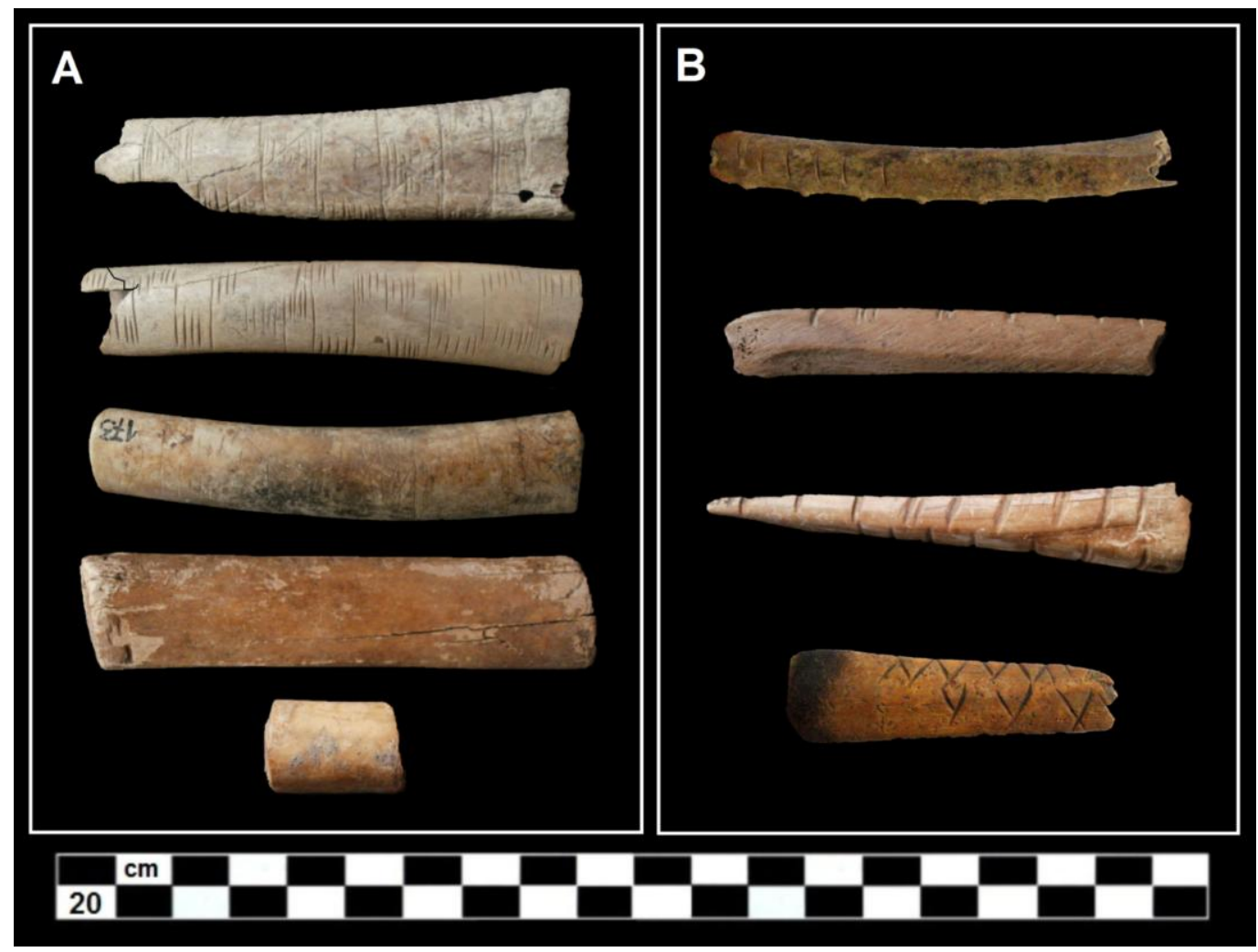

Figura 7.14. Tubos y artefactos óseos decorados del Museo Arqueológico Manuel Almeida (Gualeguaychú). A: tubos (de arriba hacia abajo: MAMA-CL2-176, MAMA-EMO-174, MAMA-SPL-173, MAMA-EDB-s $/ n^{\circ}$ y MAMA-SPL-s $/ n^{\circ}$ ). B: artefactos decorados indeterminados (de arriba hacia abajo: MAMA-SPL-s/nº, MAMA-SPL-296, MAMA-s/p-s/nº yAMA-s/p-s/n ${ }^{\circ}$.

\subsubsection{4- Restos óseos humanos del Museo Arqueológico Manuel Almeida}

La Tabla 7.24 muestra la estructura del registro bioarqueológico del sector $C$, integrando la colección del MAMA y los restos humanos recuperados en nuestros trabajos de campo y presentados anteriormente. Se presenta la distribución espacial, el cálculo de los distintos indicadores de abundancia (NISP, MNE y MNI) y la estimación sexo-etaria. Estas últimas estimaciones fueron realizadas por el Dr. Mariano Del Papa (FCNyM-UNLP) y la Dra. Mariana Fabra (CONICET; FFyH-UNC).

La colección bioarqueológica del MAMA está integrada por restos óseos humanos procedentes de 12 sitios arqueológicos, 10 ubicados en el departamento Gualeguaychú, uno en el departamento Islas del Ibicuy y el restante en el distrito Ceibas. Los 12 sitios arqueológicos figuran en el Catálogo de Restos óseos humanos del museo, donde cada uno registra distintas frecuencias de elementos anatómicos. Durante el relevamiento se pudieron identificar especímenes óseos provenientes de 11 sitios arqueológicos (CL2, LC, EDB, T1-CNM, T2-CSM, SPL, CP, FQ, T1-LA, SLM y $\mathrm{TL}$ ); el sitio arqueológico restante (TI) presenta al menos un cráneo fragmentado y este dato fue conocido únicamente a partir del catálogo mencionado. Probablemente los especímenes de este último sitio arqueológico están incluidos en el conjunto de los restos óseos sin procedencia exacta de la Tabla 7.24 
Tabla 7.24. Estructura del registro de restos óseos humanos del sector $\mathrm{C}$.

\begin{tabular}{|c|c|c|c|c|c|c|c|c|c|}
\hline $\begin{array}{l}\text { Sigla en la } \\
\text { Figura } 7.1\end{array}$ & Sitios arqueológicos & $\begin{array}{c}\text { NISP } \\
\text { poscráneo }\end{array}$ & $\begin{array}{l}\text { NISP } \\
\text { cráneo }\end{array}$ & MNE & $\begin{array}{c}\text { MNI } \\
\text { cráneo }\end{array}$ & Subadulto & Adulto & $\mathrm{F}$ & M \\
\hline CL2 & Cerro Lorenzo 2 & 384 & 32 & 352 & 18 & 1 & 12 & 4 & 8 \\
\hline LC & La Correntina & 55 & 10 & 31 & 4 & - & 3 & 3 & - \\
\hline EDB & Ensenada del Bellaco & 37 & 44 & 33 & 4 & 1 & - & - & - \\
\hline T1-CNM & Túmulo 1 - Cerro Norte de Machado & 51 & 6 & 52 & 5 & 1 & 1 & 1 & - \\
\hline T1-CSM & Túmulo 2 - Cerro Sur de Machado & 71 & 8 & 61 & 4 & - & 2 & 2 & - \\
\hline SPL & Sambaquí de Puerto Landa & 244 & 54 & 231 & 18 & - & 3 & 1 & 2 \\
\hline $\mathrm{CP}$ & Cerros de los Pampas & 52 & 19 & 33 & 3 & - & - & - & - \\
\hline $\mathrm{FQ}$ & Fajina Quemada & 2 & 1 & 3 & 1 & - & - & - & - \\
\hline SLM & San Luís Médanos & - & 2 & 1 & 1 & - & - & - & - \\
\hline $\mathrm{TL}$ & Túmulo de Lucuix & 3 & 11 & 4 & 1 & - & 1 & - & 1 \\
\hline T1-LA & Túmulo 1 - La Argentina & 58 & 6 & 54 & 2 & - & 1 & - & 1 \\
\hline $\mathrm{TI}$ & Túmulo de Irungaray ${ }^{1}$ & - & $1(?)$ & $1(?)$ & $1(?)$ & - & - & - & - \\
\hline Sector $\mathrm{C}^{2}$ & sin procedencia & 259 & 57 & 245 & 28 & - & 1 & 1 & - \\
\hline Total & - & 1216 & 250 & 1100 & 89 & 3 & 24 & 12 & 12 \\
\hline
\end{tabular}

NISP: número de especímenes óseos identificados; MNE: número mínimo de elementos óseos; MNI: número mínimo de individuos; F: Femenino; M: Masculino. (1) no se puede ubicar con precisión en la Figura 7.1 y el NISP, MNE y MNI probables fueron identificados a partir de la revisión del catálogo del museo, sus frecuencias no se suman al total.

(2) sector de procedencia de la mayoría de colección delimitada por la Figura 7.1.

La colección de restos óseos humanos analizada suma un total de 1466 especímenes óseos, 250 corresponden al cráneo y 1216 al poscráneo. Del total de especímenes 1150 (78,4\%) pudieron adjudicarse a algún sitio arqueológico y $316(21,6 \%)$ no presentan procedencia exacta, debido a la pérdida de numeración o a que no fueron catalogados. El número mínimo de elementos es de 1100 y el número mínimo de individuos calculado a partir del relevamiento de cráneos es de 89. A partir de los datos consignados en el catálogo se contabilizaron restos óseos correspondientes a 56 individuos, lo que muestra que no todos los restos humanos ingresados a la colección del MAMA fueron registrados.

Con respecto al índice de fragmentación (IF= MNE/NISP), los resultados arrojan un valor de 0,75 para la muestra total; de 0,83 para el poscráneo y de 0,35 para el cráneo. Estos valores sugieren un grado de fragmentación bajo para la muestra total. Por su parte, el poscráneo presenta un bajo grado de fragmentación, mientras que el cráneo tiene un grado de fragmentación medio. De esta manera, el cráneo es el elemento anatómico cuya estructura ha sido más afectada por procesos tafonómicos. En este sentido, se observó que 87 de los 89 cráneos, presentan fracturas posmortem y perdida ósea posdepositacional en grados variables.

En relación con el grado de completitud de los cráneos, se registraron 27 que tienen entre el 76 y el $100 \%$ de completitud, dentro de los cuales se estimaron 19 adultos y un subadulto, los siete 
cráneos restantes son indeterminados. Se registraron seis cráneos que tienen entre el 75 y $51 \%$ de completitud, dentro de los cuales se estimaron cinco adultos, siendo el restante indeterminado. Dentro de los cráneos que presentan menos del $50 \%$ de su estructura, se registraron 56 de los cuales dos son subadultos y 54 son indeterminados. El conjunto de indeterminados ( $n=62)$ está integrado por cráneos que básicamente presentan fractura con pérdida de material óseo o ausencia de porciones diagnósticas, lo que impide la estimación de su edad y sexo. Por otra parte, los datos muestran que la mayor cantidad de estimaciones sexo-etarias se realizaron dentro del conjunto de los cráneos más completos; confirmando que a mayor porcentaje de completitud de un cráneo mayor es la probabilidad de estimar su sexo y edad.

Se destaca la presencia de dos elementos con huellas de corte. Uno es de SPL (MAMA-SPL$\mathrm{RH}-166)$ y es un radio izquierdo, epífisis proximal-diáfisis. El otro es de CL2 (MAMA-TAL-RH-78.15) y es un húmero derecho, epífisis proximal-diáfisis. Ambos tienen en la diáfisis numerosas huellas de corte subparalelas, transversales y oblicuas. Dada su orientación y disposición mayoritaria, sobre la tuberosidad radial y en torno a ella en el caso del radio, y sobre la tuberosidad deltoidea en el caso del húmero, estas trazas estarían indicando tareas de descarne y desarticulación en el primer elemento y de descarne en el segundo.

Un párrafo aparte merecen los restos óseos humanos no contabilizados arriba y relevados en la urna funeraria guaraní (cambuchí pintado) de la colección Etchegoyen ya mencionada. Dentro de la urna hay elementos craneales y poscraneales muy deteriorados y con abundante ocre rojo pertenecientes a dos individuos ( $\mathrm{MNI}=2$ ), un adulto y un subadulto. En asociación con los restos óseos humanos también se registraron restos faunísticos indeterminados con ocre rojo.

\subsection{4- DATACIONES RADIOCARBÓNICAS}

Para el sector $C$ se realizaron 15 dataciones radiocarbónicas de las cuales 10 corresponden a la localidad arqueológica Cerros de Boari y por lo tanto se presentan en el siguiente capítulo (Tabla 8.1). A continuación en la Tabla 7.25 se presentan las cinco restantes. Cabe destacar que la datación de CL2 es hasta el momento la más antigua registrada a lo largo de la margen argentina del río Uruguay. 
Tabla 7.25. Dataciones radiocarbónicas obtenidas para el sector C.

\begin{tabular}{|c|c|c|c|c|c|c|}
\hline $\begin{array}{l}\text { Sitio arqueológico } \\
\text { y código de muestra }\end{array}$ & $\begin{array}{l}\text { Procedencia y } \\
\text { profundidad desde } \\
\text { la superficie }(\mathrm{cm})\end{array}$ & Edad AP & $\begin{array}{l}\text { Edad calibrada } \\
\qquad \text { AP }(1 \sigma)^{1}\end{array}$ & $\begin{array}{l}\text { Código de } \\
\text { laboratorio }\end{array}$ & Material & Referencia \\
\hline $\begin{array}{l}\text { Ensenada del Bellaco } \\
\text { MAMA-EDB-RH-63 }\end{array}$ & sector F (40) & $526 \pm 45$ & $502-538$ & AA-103895 & $\begin{array}{l}\text { Hueso } \\
\text { humano }\end{array}$ & $\begin{array}{l}\text { Bonomo et } \\
\text { al. } 2015\end{array}$ \\
\hline Ensenada del Bellaco & sondeo $1(55-60)$ & moderno & - & LP-2882 & $\begin{array}{l}\text { Carbón } \\
\text { vegetal }\end{array}$ & este trabajo \\
\hline $\begin{array}{c}\text { Sambaquí de Puerto Landa } \\
\text { MAMA-SPL-RH-95 }\end{array}$ & sector D (40) & $630 \pm 50$ & $540-635$ & LP-2828 & $\begin{array}{l}\text { Hueso } \\
\text { humano }\end{array}$ & $\begin{array}{l}\text { Castro y Del } \\
\text { Papa } 2015\end{array}$ \\
\hline $\begin{array}{c}\text { Túmulo } 2 \text { - Cerro Sur } \\
\text { de Machado } \\
\text { MAMA-T2-CSM-RH-81 }\end{array}$ & sector D (50) & $840 \pm 50$ & $674-741$ & LP-2838 & $\begin{array}{l}\text { Hueso } \\
\text { humano }\end{array}$ & $\begin{array}{l}\text { Castro y Del } \\
\text { Papa } 2015\end{array}$ \\
\hline $\begin{array}{l}\text { Cerro Lorenzo } 2 \\
\text { MAMA-CL2-RH-72 }\end{array}$ & sector C (100) & $2050 \pm 60$ & $1889-2019$ & LP-2830 & $\begin{array}{l}\text { Hueso } \\
\text { humano }\end{array}$ & $\begin{array}{c}\text { Castro y Del } \\
\text { Papa } 2015\end{array}$ \\
\hline
\end{tabular}

(1) La calibración de las dataciones se realizó con el programa Calib 7.0.

\section{2- DATOS INTEGRADOS, TENDENCIAS GENERALES E INTERPRETACIONES}

En esta sección se integran y describen conjuntamente los resultados procedentes de las dos fuentes de información consideradas: los trabajos de campo propios y la colección del MAMA; también se extraen las tendencias generales y se realizan algunas interpretaciones sobre el registro arqueológico del sector C; estas últimas abonan la discusión final de la tesis realizada en el Capítulo 9.

\subsection{1- EL REGISTRO ARQUEOLÓGICO}

En cuanto a la distribución espacial de los conjuntos arqueológicos, la evidencia permite sostener que todos ellos se vinculan estrechamente a cursos de agua. La gran mayoría se dispone sobre la llanura de inundación de los ríos Uruguay y Gualeguaychú, y sus arroyos tributarios. Mostrando tanto la ocupación de costas de tierra firme como de islas. Cabe aclarar que el sitio arqueológico IDG1 y los hallazgos IDG8 e IDG9, seguramente integraron el sitio arqueológico LC, que fue identificado posteriormente, gracias a la colaboración del MAMA, pero notablemente destruido por el avance del río y actualmente se encuentra casi totalmente desaparecido. El registro arqueológico de estos cuatro conjuntos es similar, básicamente conformado por alfarería guaraní. Una situación similar se plantea para algunos conjuntos procedentes de Ñandubaysal como Ñ1, Ñ2 y Ñ3 que seguramente integraban un mismo sitio arqueológico más amplio como Ñ-AC/AU, que fue identificado a partir del estudio de las colecciones del MAMA. 
Los sitios arqueológicos, en superficie y en estratigrafía, evidencian la ocupación de topografías variadas, los primeros se disponen sobre playas y médanos, y los segundos sobre médanos y albardones, constituyendo en este último caso los montículos o "cerritos", algunos de los cuales serían antrópicos (modificados por actividad humana sin intencionalidad especifica) y otros antropogénicos (intencionalmente modificados con fines productivos o constructivos) (sensu Eidt 1985) (véase Capítulo 8). Asimismo, se reconocieron sitios arqueológicos formados por un gran volumen de valvas de moluscos constituyendo básicamente concheros.

Se registran sitios arqueológicos aislados y también agrupados ocupando extensas áreas costeras. En el caso de los montículos hay algunos aislados y otros agrupados hasta en número de tres (Capítulo 8). Sus dimensiones son variables debido en parte a que todos se encuentran sobre albardones previamente formados por el curso de agua adyacente, entonces las medidas varían de acuerdo al tamaño del depósito fluvial preexistente y al cúmulo de desechos antrópicos descartados o depositados sobre los mismos. Asimismo, han sido alterados por erosión y por la acción humana actual, lo que ha afectado su volumen original. En este sentido, los principales procesos postdepositacionales que alteran los sitios arqueológicos relevados y sus materiales son la acción del agua, del ganado y de las poblaciones humanas actuales.

El registro arqueológico incluye materiales líticos, cerámicos, faunísticos, vegetales y óseos humanos en distintas frecuencias según los sitios arqueológicos. La alfarería está presente en la mayoría de los sitios arqueológicos y permitió identificar al menos dos conjuntos artefactuales claramente distinguibles, uno compatible con Goya-Malabrigo (ca. 2000-600 años ${ }^{14} \mathrm{C} \mathrm{AP}$ ) y otro con los guaraníes (ca. 500 años ${ }^{14} \mathrm{C}$ AP-siglo XVI). Por su parte las tendencias e interpretaciones más sólidas en cuanto a la explotación de los recursos líticos, faunísticos y en menor medida vegetales pudieron observarse en aquellos sitios arqueológicos asignables a Goya-Malabrigo (p. ej. CL2 y SPL). Por el contrario, estos mismos aspectos no se pudieron determinar claramente en los sitios arqueológicos guaraníes (EDB, LC y Ñ-AC/AU), debido a la baja frecuencia de artefactos líticos, faunísticos y vegetales. Aun así, el registro lítico de EDB permitió identificar algunos rasgos vinculados al aprovisionamiento y las técnicas de manufactura y uso de instrumentos líticos (véase Castro y Costa Angrizani 2014).

A continuación, en cada una de las secciones siguientes se tratan primero los atributos generales del registro arqueológico del sector $\mathrm{C}$ y luego según corresponda se abordan de manera separada el conjunto Goya-Malabrigo y guaraní. En este sentido, en la sección 7.2.3 (conjunto cerámico) se manifiesta más claramente esta distinción, y en las secciones 7.2.2 y 7.2.4 (conjunto lítico y arqueofaunístico respectivamente) se expone sobre todo la información obtenida a partir del registro considerado Goya-Malabrigo y cuando se trata el registro guaraní se hace una mención específica a EDB, LC/IDG1 o Ñ-AC/AU. 


\subsection{2- CONJUNTO LÍTICO}

En el sector C predominan ampliamente los desechos de talla $(n=198)$ por sobre los instrumentos $(n=76)$ y los núcleos $(n=24)$ (Tabla 7.2 y 7.17$)$. Es importante destacar que la mayor frecuencia de artefactos líticos en los sitios arqueológicos CL2 y SPL, en relación a los demás conjuntos artefactuales, se debe a los sondeos estratigráficos realizados en los mismos. La mayor frecuencia de instrumentos por sobre los núcleos se debe a la inclusión de los materiales del MAMA. Excluyendo dichos materiales del cálculo predominarían los núcleos sobre los instrumentos, pero siempre son mayoría los desechos de talla.

En relación a las materias primas identificadas (Tabla 7.3 y 7.18 ) se observa que la mayor frecuencia corresponde a la arenisca $(n=91)$, seguida por la caliza silicificada $(n=86)$, calcedonia $(n=$ $43)$, basalto $(n=30)$, sílice $(n=28)$, cuarzo $(n=7)$, xilópalo $(n=6)$, silcreta $(n=4)$, cuarcita intertrap $(n=$ 2) y diabasa $(n=1)$. Ahora bien, excluyendo la diabasa, si se consideran las materias primas de modo general en todo el sector se observa un predominio de las silíceas ( $n=176 ; 59,3 \%$ ) sobre las areniscas $(n=91 ; 30,6 \%)$, seguidas por una relativa baja proporción de basalto $(n=30 ; 10,1 \%)$. Cabe destacar que aquí se incluyeron los materiales del MAMA que corresponden a una muestra seleccionada por lo tanto su representatividad en cierto punto podría ser considerada relativa. Pero la frecuencia de las materias primas también fue calculada sin la muestra del MAMA y los resultados son semejantes. Además, las observaciones realizadas sobre otros materiales líticos del MAMA y no incluidos en este estudio reflejan la misma tendencia general.

Considerando de manera particular los sitios arqueológicos con mayor frecuencia de artefactos líticos de la Tabla 7.2 (MLB, CL2, ET y SPL) la mayor diferencia se observa en CL2 donde el $90,9 \%(n=30)$ son artefactos silíceos y el $9,1 \%(n=3)$ de arenisca; seguido por SPL con el $96,1 \%(n=$ 68) de artefactos silíceos y el $13,9 \%(n=11)$ de arenisca; y por último, ET donde las proporciones se invierten con el $85 \%(n=34)$ de artefactos arenisca y el $15 \%(n=6)$ silíceos. En el caso particular de MLB, el $100 \%$ de los artefactos son silíceos. En general se observa que en todos los sitios arqueológicos considerados existe una tendencia marcada en favor de la explotación de rocas y minerales silíceos. En ET el predominio de areniscas respondería a que el sitio arqueológico se encuentra sobre un afloramiento de la Formación Salto Chico donde esta roca es predominante.

El predominio de materias primas silíceas (véase también Capitulo 8) presenta dos cuestiones relevantes, en primer lugar es acorde con que los materiales silíceos son considerados como los de mejor calidad para la talla (Tabla 4.2); y segundo lugar, en este sector no son dominantes los afloramientos de estos materiales silíceos, sino por el contrario los afloramientos de areniscas de la Formación Salto Chico (que también incluye un escaso porcentaje de rodados fluviales). En este sentido, los afloramientos de rodados silíceos más voluminosos están ubicados en lugares bastante delimitados, como por ejemplo la cantera de Puerto Campichuelo $\left(\mathrm{S} 32^{\circ}, 709444 ; 058^{\circ}, 184445\right)$ 
(Colonia Elía, Concepción del Uruguay) sobre el río Uruguay, ubicada a $47 \mathrm{~km}$ en línea recta al noreste de la desembocadura del río Gualeguaychú; también hay otros afloramientos más restringidos en algunos sectores del rio Gualeguaychú al norte de la ciudad homónima en lugares denominados Ojo de Agua y Picada del Zapatero (Figura 7.1), y en el arroyo Venerato cerca de su desembocadura (Cordini 1949).

Por su parte, los afloramientos de areniscas están presentes en el río Gualeguaychú y fueron mayores en el pasado, y se disponían en distintos tramos de su curso, tanto hacia el norte de la ciudad como hacia la desembocadura del río. Se ubicaban en ambas márgenes así como también conformando pequeñas islas en el medio del cauce, como por ejemplo el Islote Ubajay o Isla Chica que estaba ubicado en la zona del Puerto de Gualeguaychú y fue dinamitado entre 1915 y 1920 (Rivas 2014) para permitir un mejor flujo náutico en ese sector del río (Figura 7.15A y B). Desde fines del siglo XIX estos afloramientos sufrieron una explotación por obras de infraestructura modernas ( $p$. ej. para el empedrado de las calles de la ciudad de Gualeguaychú, para las construcción de las escolleras del río Gualeguaychú y por el dragado del cauce del río); desde entonces se han explotado tanto las que estaban al sur de la ciudad como las del norte (Almeida 1998; Rivas 2014). Algunos afloramientos de los que fueron explotados y reducidos aún hoy son visibles en la zona de la desembocadura del arroyo Munilla, del Club Pescadores, del Frigorífico de Gualeguaychú y del llamado Paso de la Guardia frente al arroyo Lorenzo (o sea en la localidad arqueológica Cerros de Boari). Un ejemplo actual es el caso del islote Martín Chico ubicado a 1,9 km al sur del Puerto de Gualeguaychú en el medio del cauce, es el remanente de un afloramiento mayor que obstruía la circulación fluvial (Figura 7.15C y D). También en la actualidad sobre el río Gualeguaychú se pueden encontrar afloramientos de areniscas en lugares conocidos como Salto de Méndez, Salto Chico, Picada del Zapatero, Ojo de Agua, Cancha de Piedra y Las Piedras, entre otros (véase Figura 7.1).

En base a lo anterior se observa que los rodados silíceos y las areniscas están inmediatamente $(<10 \mathrm{~km})$ y localmente disponibles $(<60 \mathrm{~km})$ a los sitios arqueológicos. Por lo tanto, el registro lítico del sector $C$ refleja una selección de materias primas en favor de las silíceas, probablemente por su mejor calidad para a talla. Más aún dentro de las rocas y minerales silíceos predomina la caliza silicificada de la Formación Guichón, cuyos afloramientos se encuentran a distancias medias o largas (>60 km), pudiendo ser su punto de origen el área del PNEP (ambas márgenes del río Uruguay) o la cuenca del río Negro en la ROU. Dada las características macroscópicas generales (color, textura, inclusiones) y que las canteras potenciales están más cercas del sector C, su origen estaría en la ROU. Cualquiera sea la procedencia de esta roca la situación refuerza la hipótesis de una selección de materias primas.

Considerando que el basalto de la Formación Serra Geral provenga de depósitos primarios, estos afloramientos se encuentran en la zona de Salto Grande, a distancias largas ( $>100 \mathrm{~km}$ ). Se menciona también que tanto basaltos como calizas silicificadas ( $y$ también areniscas) se pueden 
presentar en forma de rodados fluviales contenidos en los depósitos de rodados secundarios de la Terraza I del río Uruguay o en los niveles basales de conglomerados de la Formación Salto Chico disponibles inmediatamente y localmente. En este sentido, tal vez una parte del basalto, cuya frecuencia en los sitios arqueológicos no es tan significativa, provenga de rodados y otra parte de depósitos primarios. Por su parte, es poco probable que todo el volumen de calizas silicificadas y areniscas registrado en los sitios arqueológicos del sector $\mathrm{C}$ provenga de estos rodados, ya que los rodados de estas materias primas tienen muy baja frecuencia relativa en este tipo de depósitos.

En síntesis, se plantea que las areniscas eran obtenidas en los afloramientos del río Gualeguaychú (que están inmediatamente disponibles a algunos sitios arqueológicos como CL2, ET, EP1 y EP2, y localmente disponibles a otros como SPL), y trasladadas a los asentamientos en forma de clastos, núcleos y preformas (y en menor medida probablemente como instrumentos previamente elaborados en las canteras-taller cercanas). Las rocas y minerales silíceos en general (excepto la caliza silicificada), y probablemente parte de los basaltos, eran obtenidos en los depósitos secundarios de rodados fluviales y trasladados sin reducción a los asentamientos. La caliza silicificada, debido a su alta frecuencia en el sector C (véase también Capítulo 8) habría sido obtenida en canteras de la ROU. Esta roca, y tal vez parte del basalto obtenido en afloramientos primarios, habrían sido trasladados al sector en forma de clastos, núcleos y preformas, desde las canteras potenciales hasta los asentamientos en canoas.

Si se consideran las dataciones obtenidas en los sitios arqueológicos Goya-Malabrigo (Tabla 7.25) probablemente esta forma de aprovisionamiento de materiales líticos se desarrolló desde ca. 2000 años ${ }^{14} \mathrm{C}$ AP al menos hasta la llegada de los guaraníes al sector. Asimismo, las materias primas de los sitios arqueológicos guaraníes, sobre todo EDB, proceden de las mismas formaciones geológicas (p. ej. Guichón y Salto Chico) (Castro y Costa Angrizani 2014) por lo que posiblemente los guaraníes continuaron utilizando los afloramientos previamente conocidos. 

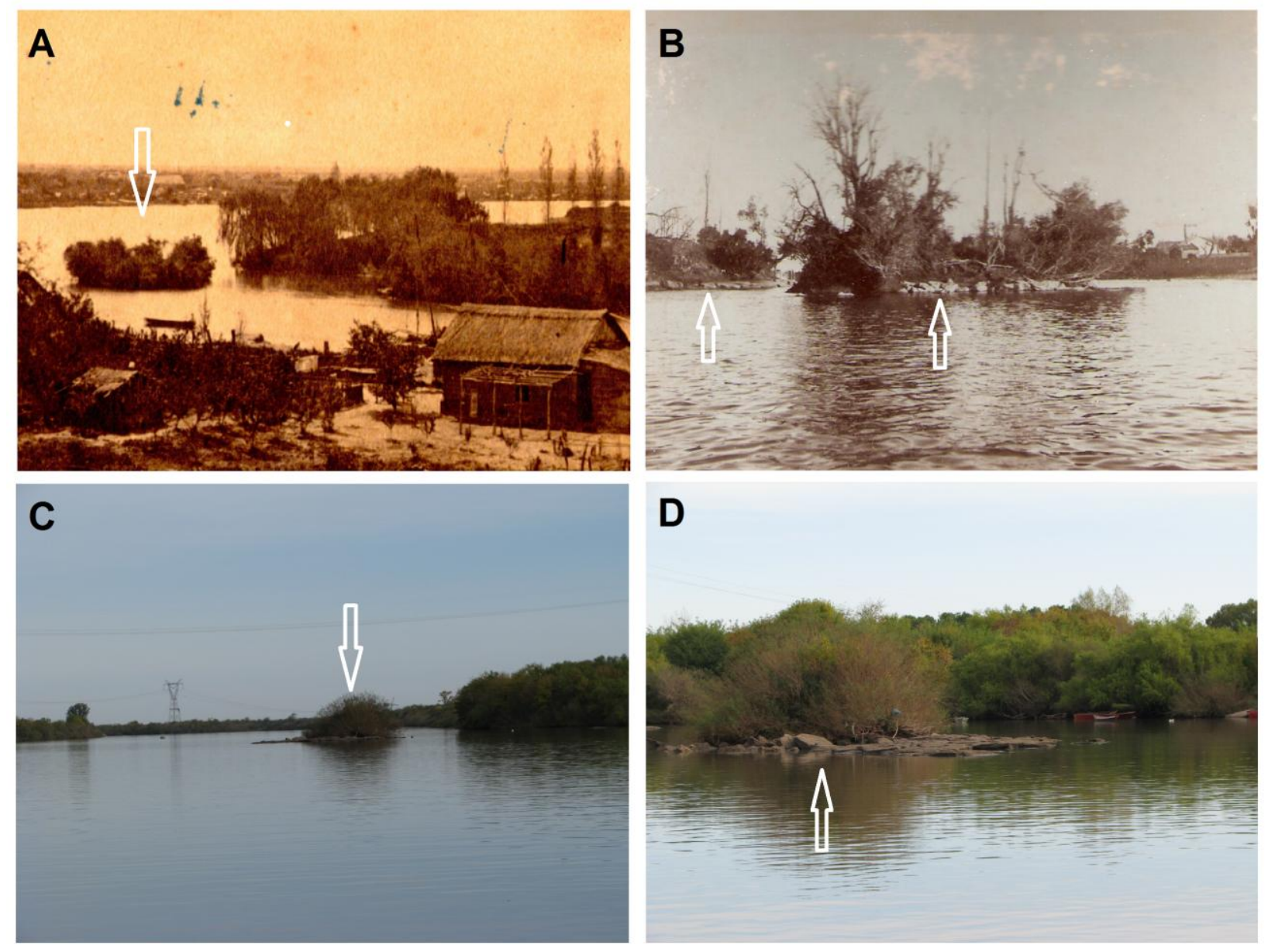

Figura 7.15. Afloramientos de arenisca de la Formación Salto Chico en el río Gualeguaychú.

A: Islote Ubajay indicado con una flecha (Imagen del Archivo Histórico Municipal - Museo de la Ciudad "Azotea de Lapalma" -AHMAL- de Gualeguaychú). B: detalle del Islote Ubajay, las flechas indican los bloques de arenisca tanto en el islote como en tierra firme (Imagen del AHMAL Álbum Podestá-Haedo). C: Islote Martín Chico indicado con una flecha. D: detalle del islote Martín Chico, la flecha indica los bloques de arenisca. La ubicación geográfica de los islotes se indica en la Figura 7.1. (Las imágenes A y B son gentileza de Natalia Derudi).

Algunos de los instrumentos del sector $C(n=76$, integrando los del MAMA. Tabla 7.4 y 7.17$)$ pueden ser considerados formales en el sentido de Andrefsky (1994) como por ejemplo las bolas, piedras lenticulares, piedras con hoyuelos, molino, mano, mortero, puntas de proyectil, raspador, bifaz y la punta de proyectil reciclada; en contraposición a los informales representados por las piezas con retoque sumario y la punta entre muescas. Los primeros habrían estado asociados a estrategias conservadas y los segundos a expeditivas; resultado de estas últimas también serían las 13 lascas con rastros complementarios que indicarían el uso de filos naturales sin mayor preparación. No se considera que ambas estrategias fuesen mutuamente excluyentes, sino que en los sitios arqueológicos se habrían confeccionado tanto instrumentos conservados como expeditivos. Particularmente en el caso de la bola de arenisca reciclada en rompecocos de CL2 (MAMA-CL2-396), no se considera que esta situación responda a la disponibilidad y a la maximización de la materia prima (Andrefsky 1994; Bamforth 1986), dada la cercanía de este sitio arqueológico con las canteras 
potenciales del río Gualeguaychú, sino a otras causas indeterminadas por el momento dado que es un caso único. Un antecedente regional semejante, es el caso de las tres bolas reutilizadas como manos de mortero registradas en el Cerrito de Colonia Concordia, identificado con Goya-Malabrigo (Capítulo 9), y que está ubicado en la margen izquierda del río Uruguay inferior, donde también se registraron morteros, manos, molinos, "estecas", un pulidor en canaleta y bolas (tipo A, B, Bf, Bb1, Bc2 y Bc5) (Díaz et al. 1980).

Las bolas $(n=37)$ (Tabla 7.17) son el instrumento más numeroso en el sector $C$. Predominan las bolas con surco $(56,8 \%)$ por sobre las que no tienen surco (27\%). Dentro del conjunto de bolas la presencia de los tipos $\mathrm{Aa}, \mathrm{Ad} 2, \mathrm{Ba}, \mathrm{Bb}, \mathrm{Bc} 2$ y $\mathrm{Bf}$ ya había sido mencionada para Entre Ríos (González 1953). El tipo $B f(n=8)$ ocupa el primer lugar en cantidad de bolas, seguido por el $B h(n=5)$, los restantes tipos presentan frecuencias menores. Por su parte, dentro de los tipos $A b, A c, B c 1, B g, B h$ y probablemente $B c 4$, que según González (1953) no habían sido registrados dentro de la provincia, se destaca la frecuencia del tipo Bh que ocupa el segundo lugar en toda la muestra. Las cuatro bolas con procedencia fueron recuperadas en estratigrafía, tres en TL y una en EDB. Otras bolas en estratigrafía dentro del sector C fueron recuperadas por Torres (1911) y Greslebin (1931a), este último también recuperó piedras lenticulares.

Las piedras lenticulares registradas en el sector C, así como las cuatro publicadas por Serrano (1932a) procedentes de Monte Caseros, y también otras tres procedentes de Salto Grande observadas en el Museo de Antropología y Ciencias Naturales de Concordia, siempre han sido consideradas en la bibliografía como "piedras de honda" (p. ej. Torres 1911). Esta funcionalidad ha sido cuestionada por Leguizamón (1919) quién plantea que, por un lado, no hay registro etnohistórico confiable del uso de la honda en la cuenca del Plata, y por otro lado, que dado el trabajo que implica la elaboración de estas piedras es poco probable que estén destinadas a ser usadas una sola vez, ya que luego de un lanzamiento la mayor probabilidad es que el objeto lanzado mediante una honda se pierda si no acierta en el blanco. Para esta interpretación también considera relevante la escasez de rocas en la llanura bonaerense y en el Delta del Paraná donde se han recuperado estas piedras. Si bien este último punto puede ser discutido a partir de los conocimientos actuales sobre la circulación de rocas y minerales en momentos prehispánicos, se destaca que esta idea fue planteada a principios del siglo XX.

Leguizamón (1919) las considera como un tipo más de bola, integrantes de boleadoras de una y/o dos bolas que eran retobadas en cuero. Por su parte, Hilbert (1991) considera que podrían ser retocadores líticos ("retoucheur") o manos de moler. Si se consideran como bolas retobadas también podrían funcionar como pesas para la pesca, o también usarse en el alisado y pulido de la cerámica, ya que en lugares como el Delta del río Paraná donde hay una alta frecuencia cerámica y las materias primas líticas son escasas y en general no locales, estas piedras funcionarían adecuadamente para la tarea y su morfología tal vez responda a que son instrumentos conservados y 
mantenidos por las alfareras, y no simples rodados usados en esta tarea (véase Paucke 1944: 182183). También se aclara que han sido registradas en zonas donde hay rodados fluviales potencialmente utilizables. Cabe señalar que Larrañaga en 1813 menciona a la honda como una de las armas usadas por los minuanos, pero no describe la forma o el tipo de proyectil que se arrojaba con ella (véase López Mazz y Bracco 2010: 246).

El caso de la bola decorada con motivos geométricos parecería indicar el valor simbólico de estos artefactos para su usuario. Como sostiene Vecchi (2010) este tipo de bolas serían un objeto de prestigio para su portador y usuario, y a su vez estarían representando diferencias interpersonales entre los cazadores. Además, este tipo de bolas decoradas serían efectivamente usadas como parece indicarlo la fractura que presenta. En este sentido, el prestigio no solo estaría dado por la posesión y/o capacidad de confección sino también por la destreza en el uso de la misma.

En cuanto a las materias primas de las bolas no se registró gran variabilidad, básicamente fueron confeccionadas en basalto $(54,12 \%)$ y arenisca $(43,2 \%)$. Dada la presencia de desechos de talla en los sitios arqueológicos y su cercanía a las canteras potenciales de arenisca, se considera que la manufactura de bolas de esta materia prima se realizó en los asentamientos, donde además se han recuperado bolas enteras (Torres 1911, Greslebin 1931a; colección del MAMA). Para el caso del basalto, pudo ocurrir lo mismo, o también, dado que la frecuencia de desechos es muy baja, que las bolas hayan llegado a los asentamientos ya confeccionadas. En este sentido, cabe mencionar que la confección de bolas involucra la formatización poliédrica y esferoidal (Vecchi 2010: 90), que implican la reducción de un nódulo mediante lascados y picado que generan la pérdida de entre $30 \%$ y $72 \%$ del peso del nódulo original, con un promedio del 39\% (Vecchi 2010: 107). Además, Vecchi (2010: 105) sostiene que no hay diferencias significativas en la morfología de los desechos de talla de la formatización poliédrica y esferoidal con los desechos de instrumentos confeccionados enteramente mediante talla. Entonces es probable parte de los desechos de talla de arenisca y basalto registrados correspondan a la confección de bolas y piedras con hoyuelo.

La piedras con hoyuelos $(n=14)$ tienen una importante representación en algunos sitios arqueológicos del sector C y en ambas márgenes del río Uruguay en general (Aparicio 1928; CCBSJG 1986; Greslebin 1931a; Hilbert 1991; Rodríguez y Rodríguez 1983-1985). En algunos sitios arqueológicos se registran más de un ejemplar y además algunos ejemplares presentan hoyuelos múltiples. Tienen morfologías y pesos variados, algunos son simples bloques con hoyuelos y otras más trabajadas tienen forma discoidal y tamaños reducidos de no más de $10 \mathrm{~cm}$ en su diámetro mayor. El contexto de uso mayoritario de estas piezas serían los asentamientos, lo que a su vez indica que gran parte de los materiales a ser procesados estarían siendo trasportados hacia los mismos, y allí se realizaría su procesamiento, consumo final y descarte. Asimismo, las más pequeñas y elaboradas pueden haber formado parte del instrumental mueble de los individuos en sus salidas diarias de forrajeo o partidas logísticas de recolección de los productos que serían procesados. Se 
asocia su uso con la reducción de frutos de palmeras de distintas especies (Bonomo y Capeletti 2014). Otros instrumentos vinculados al procesamiento de vegetales $u$ otras sustancias orgánicas y/o minerales son la mano y el mortero de CL2 (MAMA-CL2-307) y el molino de EAV (MAMA-EAV-1035). Las materias primas de estos instrumentos son arenisca, basalto y cuarzo. Evidentemente fueron seleccionadas por su resistencia a las presiones a las que estaban sometidas, pero aun así se fracturaban (véase Capítulo 8).

En cuanto a las puntas de proyectil (Tablas 7.20 y 7.21 ) las dimensiones registradas solo en primera instancia estarían evidenciando distintos sistemas de armas, probablemente arco y flecha, lanza y/o propulsor (véase más adelante). Las materias primas más usadas fueron las silíceas $(81,8 \%)$ y areniscas silicificadas $(18,2 \%)$, todas de buena y excelente calidad para la talla; todas vinculadas a la cuenca de los ríos Uruguay y Gualeguaychú.

En relación a los desechos de talla se discutirán exclusivamente aquellos recuperados en nuestros trabajos de campo ya fueron analizados en detalle (Tabla 7.2). Se excluyen los desechos de talla de los sitios guaraníes EDB, LC, N-AC/AU y de IDG1 vinculado a LC $(n=20)$. Además, cuando sea pertinente se agrega información de los desechos de talla de la colección del MAMA (Tabla 7.17).

En cuanto al estado de fragmentación (Tabla 7.5), más allá de las variaciones registradas en CL2, SPL y ET, y dejando de lado los desechos indiferenciados, en todo el sector se registra un predominio de los desechos fracturados (lascas fracturadas -con y sin talón- y no clasificables) $(77,6 \%)$ sobre las lascas enteras (22,4\%). En cuanto a los tipos de lascas registrados (Tabla 7.6), excluyendo aquellos cuyo estado de fragmentación es indiferenciado, existe un predominio de lascas internas $(n=78 ; 67,2 \%)$ sobre las externas $(n=32 ; 27,6 \%)$, el resto son indiferenciadas $(n=6 ; 5,2 \%)$. En la muestra total las lascas angulares son las más representadas. Esto estaría evidenciando que las actividades más recurrentes fueron la formatización, la regularización y el mantenimiento de instrumentos, pero también actividades de descortezamiento y reducción primaria.

En relación a la distinción entre desechos externos e internos y sus implicancias, los talones de las lascas contribuyen con información al respecto (Tabla 7.7). En este sentido, se registró un amplio predominio de talones preparados (liso, diedro, facetado, filiforme, puntiforme y fracturado) $(n=51)$ sobre los corticales (natural y liso natural) $(n=5)$. Esto apoyaría la idea sobre la preparación de las plataformas de percusión para optimizar el resultado de los golpes, y además la propuesta anterior sobre las actividades de manufactura de instrumentos, sobre todo en CL2 y SPL. Los talones lisos $(48,2 \%)$ evidenciarían un descortezamiento inicial de los nódulos. Por su parte, los talones filiformes y puntiformes estarían asociados a la técnica de talla por presión.

En cuanto a la combinación entre tipos de talón y bulbo (Tabla 7.7), las frecuencias de los talones lisos con bulbos difusos, tanto con inclinación recta $(n=10)$ como oblicua $(n=8)$, indicarían la búsqueda de lascas internas para la producción de instrumentos y posiblemente también la preparación, tanto del frente de extracción como de la plataforma de percusión del núcleo antes de 
la extracción. Por otra parte, en cuanto a la relación entre presencia/ausencia de labio y tipo de bulbo (Tabla 7.8) se observa que el $66,1 \%(n=37)$ de las lascas presentan labio. La diferencia más significativa entre presencia/ausencia de labio y bulbos se da dentro del conjunto de lascas con el mismo tipo de bulbo. En este sentido, existe una mayor asociación entre lascas con bulbos pronunciados y presencia de labio, ya que el $70 \%(n=14)$ presenta labio, mientras que el $30 \%(n=6)$ carece de este rasgo. A su vez, dentro de las lascas con bulbos difusos el $65,7 \%(n=23)$ presenta labio, mientras que el $34,3 \%(n=12)$ carece de este rasgo. La evidencia sugiere un relativo predominio de percutores blandos y una relación directa entre percutor duro, con mayor fuerza de impacto, y la presencia de labio.

A partir del origen de extracción de lascas externas $(n=18)$, internas $(n=3)$ (Tabla 7.6) y desechos indiferenciados ( $n=11$ ) (Tabla 7.5), además de los tipos de talón (Tabla 7.7); se determinó que una parte de estos desechos de talla proviene de rodados fluviales silíceos $(n=23)$ y otra parte de clastos silíceos o de arenisca $(n=9)$. Estos rodados proceden de depósitos secundarios o de la Formación Salto Chico y corresponden al $12,5 \%$ de las rocas y minerales explotados. La baja frecuencia total de desechos con reserva de corteza ( $n=43$; Tabla 7.7 y 7.9) concuerda con que la mayoría de las materias primas identificadas en los sitios arqueológicos (Tabla 7.3) corresponden a rocas de la Formación Guichón (calizas silicificadas y probablemente algunas silcretas y sílices); las cuales generalmente no presentan corteza dado que se obtienen de filones, clastos o bloques, y en menor frecuencia en forma de rodados. En síntesis, esto apoya la idea de que los rodados fluviales ingresarían enteros a los asentamientos y las calizas silicificadas y las areniscas con un previo descortezamiento y reducción primaria, total o parcial.

En relación a la presencia de corteza y número de lascados en la cara dorsal de las lascas internas y externas (Tabla 7.9), los resultados se ajustan a lo esperado. Dentro de las lascas externas $(n=32)$ las mayores proporciones de reserva de corteza se presentan en aquellas con menor cantidad de lascados y viceversa. Las lascas externas más frecuentes son, en idéntica frecuencia $(n=14)$, las que no presentan lascados (primarias) y las que presentan un negativo de lascado. Por otra parte, dentro de las lascas internas $(n=78)$ el 3,8\% $(n=3)$ presenta remanente de corteza, y este ocupa menos del $50 \%$ de su cara dorsal. El resto $(n=75)$ presenta negativos de lascados en frecuencias variables. Dado que el tamaño de la muestra de desechos de talla es variable de acuerdo a los distintos conjuntos arqueológicos, donde mejor se puede observar alguna tendencia significativa es en SPL, donde se plantea que el proceso de talla pudo haber sido relativamente intensivo dado que predominan ampliamente las lascas internas $(n=48)$ sobre la externas $(n=4)$, y dentro de las primeras predominan las lascas angulares $(n=24)$ con tres negativos de lascado $(n=17)$, seguidas por las de arista con dos negativos ( $n=13)$.

En cuanto a las dimensiones de los desechos de talla (Tablas 7.10, 7.11 y 7.12) predominan desechos con longitud-anchura mediana, tamaño pequeño y espesores muy delgados. Estas 
dimensiones estarían reflejando en los cuatro sitios arqueológicos considerados (MLB, CL2, ET y SPL) actividades de retalla y formatización de instrumentos. Por otra parte, se registraron alteraciones térmicas en 18 desechos de talla de cuatro conjuntos (MLB, CL2, SPL y J1). Dada la baja frecuencia de este atributo no se considera como tratamiento térmico intencional, sino que probablemente los desechos fueron arrojados el fuego o en su cercanía, o también es posible la realización de un fogón sobre un sustrato donde ya se hallaban depositados previamente los desechos de talla.

Los núcleos registrados ( $n=19$, integrando los del MAMA y excluyendo los sitios guaraníes EDB e IDG1, $n=5$. Tabla 7.13 y 7.17$)$ son silíceos $(n=16)$ y de arenisca $(n=3)$. Se distribuyen en ocho conjuntos arqueológicos y la mayor frecuencia se registró en $\operatorname{MLB}(n=6)$. Las formas-base corresponden a rodados fluviales silíceos $(n=9)$, clastos $(n=4)$ y no diferenciados $(n=6)$. En general presentan muchos lascados y menos del 50\% de corteza. La presencia de núcleos evidencia que parte de la materia prima llegaba a los asentamientos, y también al sector en general para aquellas materias primas lejanas, en forma de clastos, núcleos o rodados sin modificar. La presencia de reserva de corteza de rodados observada tanto en desechos de talla como en núcleos indicaría su descortezamiento y reducción primaria in situ.

Ahora bien, considerando los distintos sitios arqueológicos de manera particular, se pueden identificar algunas diferencias entre los mismos. En cuanto a los sitios superficiales se observa que en MLB las materias primas de todos los artefactos son silíceas (calcedonias y sílices). Las formas-base de seis núcleos y nueve desechos de talla corresponden a rodados fluviales. Esto parece indicar que en MLB predominó la talla de rodados. Lo mismo podría ocurrir con otros conjuntos superficiales cercanos a MLB, como J1 donde predominan los materiales silíceos y se determinaron dos formasbase correspondientes a rodados. En relación a ET, este sitio arqueológico solo presenta artefactos líticos (Tabla 7.2) y el conjunto se compone de 37 desechos de talla, dos núcleos y un instrumento informal; y a la inversa del resto de los conjuntos arqueológicos predomina la explotación de arenisca, sobre rocas y minerales silíceos. Estos atributos sumados a la ubicación de ET sobre un afloramiento de la Formación Salto Chico permiten plantear que este lugar corresponde a una cantera-taller, donde se llevaron a cabo tareas vinculadas a la reducción primaria de bloques y clastos de arenisca. Asimismo, la presencia de un instrumento con retoque sumario sugiere la confección de instrumentos, y éste junto a las seis lascas con rastros complementarios sobre los filos naturales sugiere actividades de procesamiento in situ de materias primas blandas. En cuanto a las materias primas silíceas registradas se determinó que la forma-base del instrumento y cuatro desechos de talla corresponden a rodados fluviales. Por lo tanto, ET también muestra talla de rodados (reducción primaria y formatización de instrumentos), disponibles dentro de los conglomerados de areniscas presentes en el lugar.

En cuanto a los sitios arqueológicos en estratigrafía como CL2 y SPL, se plantea que allí se realizaron actividades de descortezamiento y reducción primaria, así como la formatización, la 336 
regularización y el mantenimiento de instrumentos. En CL2 se registraron tres instrumentos formales y uno informal, y en SPL se registraron cuatro instrumentos formales. En ambos sitios arqueológicos los instrumentos implicaron actividades de talla, retalla, retoque, y picado, abrasión y/o pulido. La presencia de núcleos es escasa pero indican que parte de las materias primas llegaban a los asentamientos en forma de nódulos o núcleos con pocas extracciones y fueron posteriormente reducidos.

En cuanto a los hallazgos aislados, solamente J2, ERU1, ERU2, ELV e IDG6 presentan artefactos líticos; en total cuatro desechos de talla y dos núcleos. Algunos de estos conjuntos se encuentran relacionados espacialmente a los sitios arqueológicos (Figura 7.1), talvez representando restos de actividades puntuales o la acción de procesos posdepositacionales, sobre todo las crecidas de los ríos Uruguay (J2, ERU1 y ERU2) y Gualeguaychú (ELV e IDG6).

A partir del análisis tecnomorfológico en general se puede observar que están presentes todas las etapas del proceso de producción lítica (Ericson 1984), desde el aprovisionamiento hasta el descarte. Está presente una tecnología de manufactura unifacial y bifacial. La técnica de talla predominante es la percusión directa con percutores blandos y duros, registrándose también por presión; también hay instrumentos elaborados mediante picado, abrasión y/o pulido y modificados por uso. Se confeccionaron tanto instrumentos conservados y expeditivos, y también se usaron filos naturales.

El instrumental lítico guaraní de EDB incluye dos pulidores en canaleta, dos choppers, una bola y dos piezas con retoque sumario; y el de Ñ-AC incluye un perforador y una pieza con retoque sumario. No se puede determinar si la punta de proyectil recuperada en Ñandubaysal (PPÑ; Tabla 7.21 y Figura 7.8F) procede también a una ocupación guaraní. El conjunto indica la manufactura de instrumentos informales (piezas con retoque sumario y choppers) mediante talla, retalla y retoque marginal, y formales (pulidores en canaleta, bola y perforador) mediante picado, abrasión y/o pulido. Los pulidores en canaleta son característicos (aunque no exclusivos) de la tecnología lítica guaraní y fueron elaborados en arenisca con textura friable, estos generalmente son asociados con la regularización de objetos cilíndricos, de bordes, aristas o filos; y permiten inferir la elaboración/formatización de otros instrumentos de madera, hueso y/o asta, o adornos de dientes y/o valvas de moluscos como por ejemplo: astiles y puntas de madera, tembetás, pendientes, entre otros (véase Noelli 1993; Noelli y Dias 1995; Prous y Alonso 2010; Ribeiro 2008; Soares 2004).

El conjunto de desechos y núcleos de EDB, LC, N-AC/AU (y de IDG1 vinculado a LC) (n=25) sugiere que en EDB se realizó la reducción primaria de rodados silíceos y clastos (o núcleos con escasa reducción previa) de arenisca y caliza silicificada, la obtención de lascas, y la formatización de instrumentos (a su vez los pulidores en canaleta indican regularización y mantenimiento de los mismos). En LC/IDG1 se realizó la reducción primaria de clastos (o núcleos con escasa reducción previa) de arenisca y silcreta, y la obtención de lascas. Además en EDB y LC las lascas se usaron como 
filos sin mayor preparación. En Ñ-AC/AU las dos lascas secundarias indican al menos la reducción de clastos de caliza silicificada. Si bien los núcleos son escasos indican que parte de las materias primas llegaban a los asentamientos en forma de rodados fluviales y clastos sin reducir o núcleos con pocas extracciones, y que posteriormente eran reducidos por talla o modificados por picado, abrasión y/o pulido. Asimismo, las materias primas utilizadas por los guaraníes implican un aprovisionamiento de recursos inmediatamente disponibles $(<10 \mathrm{~km})$, como las areniscas y rodados de la Formación Salto Chico, y de otros procedentes de distancias medias o largas (>60 km) como las calizas silicificadas de la Formación Guichón (Castro y Costa Angrizani 2014).

\subsection{3- CONJUNTO CERÁMICO}

Una parte de la muestra (12,8\%) (Tabla 7.2) presenta evidencia de haber sufrido algún tipo de desgaste físico producto de la acción fluvial y/o eólica, y tal vez antrópica moderna. Estas modificaciones también fueron observadas en la muestra del MAMA, sobre todo en la cerámica guaraní de Ñ-AC/AU (Tabla 7.22b). Estas alteraciones estructurales fueron registradas especialmente en los conjuntos arqueológicos superficiales, lo que sugiere que los mismos están sometidos a procesos posdepositacionales, que no solo estarían modificando la estructura de los artefactos, sino también la visibilidad y la integridad de los sitios arqueológicos. Además, esto explicaría en parte la ausencia de rastros de ahumado u hollín en la muestra de superficie. Una situación inversa se da con los conjuntos procedentes de sondeos estratigráficos, tanto en relación a las alteraciones estructurales como a la presencia de hollín. El 96,9\% de la muestra (Tabla 7.2) presenta tamaños menores a $5 \mathrm{~cm}$ evidenciando un alto grado de fragmentación.

En referencia a la atmósfera de cocción inferida a partir de la observación del color del núcleo y de ambas superficies de los tiestos, se sugiere que la distribución de frecuencias de colores estaría indicando la predominancia de una cocción oxidante incompleta ( $n=115 ; 80,4 \%$ ), siendo el resto indeterminada $(n=28 ; 19,6 \%)$. Dentro de las inclusiones registradas es predominante la presencia de arena en el $98,6 \%(n=141)$ de los tiestos; se presenta como inclusión única o combinada con los demás tipos. Esto sugiere que su incorporación a la pasta es de carácter natural estando presente en las arcillas seleccionadas para alfarería. El tiesto molido $(13,3 \% ; n=19)$ es claramente intencional, lo que sugiere cierto grado consideración especial en la preparación de la materia prima. Asimismo, se determinó el agregado intencional de espículas de esponja en el 34,9\% ( $n=50)$ de la muestra. La presencia de espículas de esponjas como inclusión intencional fue discutida en profundidad en el Capítulo 5 y se hacen extensivas algunas de esas consideraciones al sector $C$, aclarando que en este caso no se realizaron identificaciones taxonómicas.

Como se mencionó anteriormente en el sector C la alfarería estudiada muestra un conjunto artefactual con decoración incisa, surco rítmico, modelados, campanas y apéndices zoomorfos 338 
compatibles con Goya-Malabrigo; y otro conjunto corrugado, unguiculado, cepillado, roletado y pintado policromo compatible con los guaraníes. Dentro del primer conjunto se registraron tres vasijas no restringidas, dos con paredes levemente divergentes que corresponderían a un cuenco (SPL-S1-11-G1) y a un cuenco grande (SPL-S1-13-G1), y una con paredes fuertemente divergentes que correspondería a una escudilla (CL2-S2-10-G1). También se registraron tres vasijas restringidas que corresponderían a ollas (CL2-S2-9-G1; SPL-S1-13-G2 y SPL-S1-14-G1). En relación a su funcionalidad es claro el predominio de cerámica utilitaria dado que la mayoría de estas vasijas todavía conserva rastros de hollín.

Un dato novedoso para la margen argentina es la presencia de rebordes con cuello y una porción cuerpo de formas no claramente definidas aún, pero que podrían ser botellas (sensu Balfet et al. 1992). Formas similares y hasta más completas denominadas botellones fueron registradas en el sitio arqueológico Túmulo de La Blanqueada y en la desembocadura del río Negro (ROU), también asociadas a modelados zoomorfos (Freitas 1953a; Hilbert 1991; Maruca Sosa 1957). De acuerdo a la morfología de las piezas registradas que se caracterizan por tener un reborde amplio, grueso, evertido y marcadamente extendido hacia afuera, cuello corto y bien definido con un punto de inflexión bien marcado, la porción presente del cuerpo tiende a ser globular y a cerrarse hacia la base. Esto, además de que no se han encontrado bordes mayores, permite plantear que no serían alfarerías tubulares como las definidas por Ghiani Echenique y colaboradores (2013); además estas últimas tienen una forma general cónica con paredes levemente o marcadamente cóncavas, que no se registraron en estos casos.

Otra forma novedosa para la zona son los tubos, similares a los de Cañada Honda (Buenos Aires) (Lanzelotti et al. 2011) que Migale y Bonaparte (2008: 23) denominan "modelado tubular grueso" y cuya función no está determinada. En principio no tendrían la misma función de transferencia de líquidos que se propone para las alfarerías tubulares (Ghiani Echenique et al. 2013), ya que ambos extremos o bocas tienen diámetros semejantes.

Por su parte, las cuentas de cerámica son adornos destinados a la ornamentación corporal de las personas y ya habían sido registrados en el NEA (Caggiano 1979; Di Prado 2015; González 1947; Serrano 1950; entre otros) y en la ROU (Bello y Bracco Boksar 2007; Farías 2005; Hilbert 1991; Maruca Sosa 1957; entre otros). Por otra parte, la pipa y la pesa de red posiblemente también correspondan a Goya-Malabrigo. La primera reflejaría la presencia y uso de plantas como medicina o narcóticos, y no ya solamente como alimentos o para la confección de refugios, instrumentos, armas, entre otros, (o para decorar la alfarería en el caso guaraní). Para la zona de Puerto Landa Torres (1911: 411) menciona el hallazgo de una pipa de cerámica y presenta un dibujo en el cual se observan algunas diferencias morfológicas con la presentada aquí. También se registran algunas pipas en la ROU (Maruca Sosa 1957). La pesa de red es un hallazgo único en el río Uruguay y muy distinta a las publicadas por Serrano $(1946,1950)$ procedentes de Arroyo Las Mulas. Se menciona 
aquí que en la Colección Oberti de Victoria se registraron dos piezas similares (Lic. Carolina Silva, CONICET; FCNyM-UNLP; comunicación personal 2016). Esta pieza sería evidencia concreta del uso de redes o líneas de pesca en la zona.

De manera general, se plantea que la alfarería del sector $C$ es similar a la registrada en el Cerrito de Colonia Concordia (Díaz et al. 1980; Maruca Sosa 1957) sobre la margen izquierda del río Uruguay inferior. La semejanza se da en las formas de las vasijas, en la decoración, en los apéndices y apliques modelados por pastillaje y sus diseños, en la presencia recurrente de agujeros de suspensión y vertederos, en las inclusiones (excepto las espículas de esponjas), y en la presencia de un apéndice zoomorfo. De hecho, Díaz y colaboradores (1980) adjudican tanto la alfarería, el material lítico y los instrumentos óseos y adornos de este sitio arqueológico a los ribereños plásticos de Serrano (1972). También en cuanto a formas, decoraciones y presencia de modelados zoomorfos y campanas, el registro del sector $\mathrm{C}$ es similar al registrado en la zona de Nueva Palmira y la desembocadura del río Negro (ROU) (véase Fontana Company 1928; Freitas 1953a; Hilbert 1991; entre otros).

Considerando la alfarería de los sitios arqueológicos guaraníes, específicamente a partir de aquella recuperada en nuestros trabajos de campo (Tabla 7.2) se reconstruyeron un cuenco grande liso (IDG1-RS-1) (Figura 7.4C), un yapepó corrugado (LC-RS-1) (Figura 7.4D), y un cambuchí con rastros de pintura blanca (Ñ1-RS-1) (Figura 7.41). Asimismo, a partir de la colección del MAMA también se reconstruyeron 71 vasijas procedentes EDB (Castro y Costa Angrizani 2014), a las que se suman las vasijas completas y/o remontadas del MAMA y de la colección Etchegoyen. Este conjunto está integrado por vasijas clasificadas como yapepó, ñaetá, cambuchí, cambuchí caguâbá y ñaembé o tembiiru; y en conjunto dan cuenta de una presencia importante de grupos guaraníes en el sector $\mathrm{C}$ (Castro y Costa Angrizani 2014).

En cuanto a las clases funcionales identificadas en EDB, y también en LC y Ñ-AC/AU (aunque estas no fueron cuantificadas), los yapepó y ñaetá son vasijas utilizadas para procesar alimentos en el fuego, análogos a la olla y cazuela respectivamente. El cambuchí es una vasija destinada a la producción, almacenaje y servicio de líquidos, análoga a la tinaja o jarro; y el cambuchí caguâbá destinado al servicio de líquidos, análogo al vaso. El ñaembé o tembiiru son vasijas utilizadas para el servicio y consumo de alimentos, análogo al plato o cuenco. Asimismo, el yapepó y el cambuchí también pueden funcionar como urna funeraria (como es el caso de la urna de la colección Etchegoyen que corresponde a un cambuchí), y los ñaetá y los cambuchí caguâbá de bocas más anchas pueden ser usados como tapas de vasijas domésticas o de urnas funerarias. Además, los cambuchi y cambuchí caguâbá indican específicamente la producción y consumo de bebidas fermentadas (cauim) e indirectamente que existían los medios y los recursos necesarios para el cultivo y manejo de las plantas usadas para producir estas bebidas, típicas de los beberagens, los rituales antropofágicos y las ceremonias de reciprocidad guaraní (Noelli y Brochado 1998). Asimismo, 
estas clases de vasijas (y en general las vasijas pintadas) tienden a ser elaboradas y usadas casi exclusivamente en asentamientos con alta estabilidad residencial como las aldeas. Por el contrario la frecuencia de estas vasijas destinadas a la producción y consumo de cauim, es nula o muy baja los campamentos de obtención de recursos (animales, vegetales, líticos, etc.) o en las rozas (Noelli y Brochado 1998; Noelli 1993).

\subsection{4- CONJUNTO ARQUEOFAUNÍSTICO}

A continuación se discute el registro faunístico de los sitios arqueológicos con mayor frecuencia de especímenes (CL1, CL2 y SPL) (Sección 7.1.2.3). Asimismo, se integran los datos del MAMA (Sección 7.1.3.3) correspondientes a CL2 y SPL, y también aquellos sin procedencia exacta, ya que como se mencionó anteriormente es altamente probable que gran parte procedan de CL2 y SPL (y también de CP). Luego se discutirán los instrumentos y los adornos, y por último las especies representadas por éstos en los demás sitios arqueológicos de las Tablas 7.23a, b, c y d.

Todos los restos faunísticos del sector $\mathrm{C}$ proceden de intervenciones estratigráficas lo que ha permitido indudablemente su conservación. En cuanto a los agentes tafonómicos (Tabla 7.15) la meteorización afectó a los restos faunísticos en todos los sitios arqueológicos siendo el estadío 2 el más representado. En CL2 (83,7\%) y SPL $(81,8 \%)$ habría sido el agente que más habría afectado al conjunto arqueofaunístico. Asimismo, para mamíferos pequeños la meteorización corresponde al estadío 1 (sensu Andrews 1990). Todo indicaría que en general los restos no estuvieron expuestos a las condiciones ambientales por un período considerable y sufrieron un enterramiento relativamente rápido. Esta misma situación se registró en Cerro de Boari 3 (Capitulo 8) y en Cerro Lutz ubicado aproximadamente a $50 \mathrm{~km}$ al sur de SPL (Arrizurieta et al. 2010). La depositación de óxido de Manganeso se registró en CL1 y CL2 en una proporción mayor al 75\% y en SPL alcanza el 48,3\%. La presencia de carbonato de Calcio y su combinación con óxido de Manganeso se registró únicamente en CL2 en bajas proporciones ( $0,6 \%$ y 8\%). La abundancia de Manganeso es acorde con lo que cabría esperar para este tipo de ambiente relativamente húmedo, lo que favorece su depositación.

Parte de los especímenes faunísticos, de los instrumentos y de los adornos presentan evidencias de procesamiento antrópico en grado variable (ya sean huellas de corte, aserrado perimetral, pulido, ahuecado, desbaste, decorado, negativos de impacto, termoalteración o fracturas frescas). La escasa representación de modificaciones por causa de raíces y roedores, y la nula de carnívoros y pisoteo, evidencia que estos agentes no afectaron la muestra más que en casos muy puntuales; una situación similar se registró en sitios arqueológicos cercanos como Cerro de Boari 3 (Capitulo 8) y Cerro Lutz (Arrizurieta et al. 2010).

Dentro de la amplia variedad de especies propias de este tipo de ambiente fluvial (Capítulo 3) en el conjunto determinado (Tabla 7.14) predominan los peces (NISP= 23633), seguidos por los 
moluscos (NISP= 3857), mamíferos (NISP=1149), reptiles (NISP=108), anfibios (NISP=7) y por último las aves (NISP=5). Particularmente en CL1 los peces son seguidos por los mamíferos indeterminados y en CL2 y SPL por los moluscos bivalvos.

La mayoría de los peces óseos solo pudieron ser identificados a nivel de Clase y no se ha calculado el MNI, debido tanto al estado de integridad como a la dificultad intrínseca que conlleva su estudio a partir elementos con escaso valor diagnóstico, sumado a la gran diversidad de especies que presenta la región. Para los peces se registraron elementos axiales y apendiculares, lo que indicaría, de manera general, junto a las evidencias antrópicas, que los mismos habrían ingresado completos a los asentamientos donde fueron procesados, consumidos y descartados. Ahora bien, considerando conjuntamente los peces de CL1, CL2 y SPL (Tabla 7.14) y los instrumentos (Tabla 23a, b, c y d) se identificaron bogas, tararira, surubíes y armados; las primeras representadas exclusivamente por dientes, la segunda por un maxilar y los restantes por sus espinas. Algunas de las espinas pectorales registradas en el MAMA procedentes de CL2 y SPL, y otras sin procedencia, fueron transformadas en espinas aguzadas (Tabla 23a, b, c y d). Dentro del total de peces de la Tabla 7.14 (NISP= 23633) se registraron 290 especímenes con alteración térmica (CL1, CL2 y SPL) y uno con huellas de corte (CL2). En base al NISP (y en la tecnología orientada a la pesca) se puede considerar que la explotación de peces ocupó un lugar preponderante en la dieta.

Los moluscos solo se registraron en CL2 y SPL y en su determinación específica existe una dificultad similar a lo que ocurre con los peces, dado que se presentan generalmente muy deteriorados. Se destaca su abundancia y se plantea que ingresaban de manera completa a los asentamientos; luego del consumo la mayoría de sus valvas fueron descartadas y otras usadas para la elaboración de adornos. Estos últimos se confeccionaron sobre valvas de Megalobulimus sp. y Diplodon sp., y además de registrarse en CL2 y SPL también están presentes en el conjunto sin procedencia del MAMA (Sección 7.1.3.3). Evidentemente consumo de bivalvos fue muy importante dado que en varios sitios arqueológicos sus valvas son muy abundantes a lo largo de toda la columna estratigráfica (SPL) y en otros conforman grandes concheros (LCS).

Considerando tanto el volumen y frecuencia relativa de peces y moluscos (Tabla 7.14), se plantea que estos taxa resultaron de gran importancia para la subsistencia de los habitantes de CL2 y SPL. Esta tendencia se registró en otros sitios arqueológicos del río Uruguay inferior (Arrizurieta et al. 2010; Chiri 1972; Cione et al. 1977; Parisi y Liotta 2010; Torres 1911; y véase Capítulo 8) y también en la zona de Salto Grande (Díaz 1980).

Dentro de los mamíferos identificados, el mayor MNI corresponde al cuis, presentando un $\mathrm{MNI}=13$ en SPL y un MNI= 5 en $\mathrm{CL2}$; en $\mathrm{CL1}$ el cuis tiene un $\mathrm{MNI}=1$ al igual que los otros taxa. $\mathrm{A}$ partir de su perfil esqueletario que incluye elementos axiales y apendiculares, junto a las evidencias antrópicas, se determinó que en CL2 y SPL los individuos ingresaron completos y allí fueron procesados, consumidos y descartados, lo mismo probablemente ocurrió en CL1. Del total (NISP=66) 
solo se registró un espécimen de SPL con alteración térmica. Si se considera que es altamente probable que los cávidos identificados correspondan a cuis, se podría agregar otro espécimen más a SPL con este tipo de alteración. No se registraron huellas de corte, probablemente debido al pequeño tamaño de la especie cuyo consumo no requiere un alto grado de trozamiento. Además, su desarticulación, una vez cocidos mediante hervido o asado (Paucke 1944: 356), se puede realizar sin grandes dificultades utilizando las manos y los dientes. En el sitio arqueológico Cerro Aguará (río Paraná medio, Santa Fe), donde el consumo de cuis fue muy importante se determinó un bajo porcentaje de marcas de corte (Santiago 2004). Otros sitios arqueológicos donde el cuis tienen una alta representación son, el mencionado Cerro Aguará y Barrancas del Paranacito en Santa Fe (Pérez Jimeno 2007; Santiago 2004) y La Bellaca 2 en Buenos Aires (Acosta 2005), demostrando una explotación intensiva de esta especie a nivel regional.

Otros roedores identificados son Holochilus brasiliensis en SPL ( $M N I=1)$, sigmodontinos (ratas o ratones) en CL2 (MNI=3) y en SPL ( $\mathrm{MNI}=2)$, y Dicolpomys sp. en SPL (MNI=1). El primero está representado por el cráneo sin evidencias antrópicas por lo que podría tener un origen natural (p. ej. egagrópilas). Los segundos están representados por elementos axiales y apendiculares lo que indica, junto a las evidencias antrópicas, que ingresaron completos a los asentamientos y allí fueron procesados, consumidos y descartados. Se registró alteración térmica en dos especímenes. Esto último apoyaría su origen antrópico. Los mismos pudieron haber sido capturados fuera o dentro de los asentamientos. Dicolpomys sp. es un registro novedoso para la región (Dr. Diego Verzi; FCNyMUNLP; comunicación personal 2016) y como solo se identificó una hemimandíbula no se puede profundizar sobre su ingreso a SPL.

Siguiendo con los roedores, el coipo presenta un MNI= 2 en SPL y un MNI= 1 en CL1 y CL2. Esta es una de las especies más representadas en el registro arqueológico regional (Acosta y Sartori 2011; Bonomo et al. 2014a; Tonni et al. 1985; entre otros). Su escasez relativa en estos sitios arqueológicos, en relación a otros como Cerro Lutz (Arrizurieta et al. 2010) o Cerro Tapera Vázquez (Bonomo et al. 2014a), talvez se deba a que aquí solo se estudiaron materiales de sondeos estratigráficos y no de excavaciones amplias. Aun así a partir de su perfil esqueletario que incluye elementos axiales y apendiculares, junto a las evidencias antrópicas, se determinó que en CL2 y SPL los individuos ingresaron completos y allí fueron procesados, consumidos y descartados, lo mismo probablemente ocurrió en CL1. Dentro del total de coipos (NISP=58) se registraron dos especímenes con alteración térmica (SPL), y huellas de corte en un fémur ( $C L 2)$ y una hemimandíbula (SPL), indicando actividades de desarticulación y descarne. También en el MAMA aunque sin procedencia exacta se registró una tibia transformada en un bisel (Tabla 7.23d).

El bajo porcentaje de huellas de corte en el coipo es acorde con los datos regionales (Acosta y Sartori 2011; Bonomo et al. 2014a; Santini 2009, 2011). Esto seguramente se debe al bajo nivel de trozamiento que requieren animales de este tamaño. El registro de incisivos en CL2 y SPL apoyaría la 
idea del ingreso de estos animales completos a los asentamientos, ya que indicarían que los animales fueron cuereados allí, debido a que estos dientes son fracturados previamente al cuereo del animal para que no dañen la piel durante su extracción (Amaya 1984; Ceruti 1991; Escosteguy y Vigna 2010).

Los incisivos además podrían servir en la decoración de la alfarería (Frère et al. 2004; Ottalagano y Castro 2011) y también para el trabajo con madera, huesos, o cueros (Bonomo et al. 2014a). En este sentido, el señor Blas Omar Jaime (último Chaná parlante) brinda información de importancia al explicar que los incisivos de coipo y vizcacha (Lagostomus maximus) eran utilizados por los antiguos chaná para raspar los restos de músculos o grasa adheridos a los cueros durante su curtido (Blas Omar Jaime; comunicación personal 2014). En algunos casos los dientes se encontrarían todavía implantados en maxilares y mandíbulas, por lo que no habrían sido fracturados previamente al cuereo como en general se realiza cuando se emplea el método de "bolsa" (Escosteguy y Vigna 2010). Si se considera esto como una opción también posiblemente se haya implementado otro método de cuereo que no implicaba la fractura previa de los incisivos.

En relación a lo anterior cabe mencionar un instrumento guayakí elaborado con un incisivo de coipo enmangado en un hueso largo que conserva una epífisis y amarrado con cera y tiras del cipó güembé (Philodendron bipinnatifidum), que se registró en la colección Federico Mayntzhusen del Museo Regional Aníbal Cambas, Posadas (Misiones) (Mayntzhusen 2009: 151; y Dr. Francisco Silva Noelli; UEM, Brasil; comunicación personal 2016). Semejantes a este instrumento son dos piezas sirionó dibujadas por Nordenskiöld (1912: 196). También instrumentos amazónicos (bororo, amahuaca, amarakaeri) compuestos por incisivos de roedores (carpincho, agutí -Dasyprocta sp.-, paca -Cuniculus paca- y pacarana -Dinomys branickii-) enmangados en huesos largos y madera se registran en las colecciones etnográficas del American Museum of Natural History de Nueva York (Dr. Mariano Bonomo; CONICET; FCNyM-UNLP; comunicación personal 2016). Asimismo, instrumentos semejantes enmangados en madera y elaborados por los asurini del río Xingú (Brasil) se registran en la colección etnográfica hecha por el cura Anton Lukesch del Welt Museum (Viena) (Dra. Fabióla Andréa Silva; MAeE; USP, Brasil; comunicación personal 2016). Los guaraníes usaban incisivos de carpincho como herramientas para raspar, cortar, perforar, grabar y alisar maderas, huesos, valvas y otros materiales (Noelli 1993). También cabe mencionar que frente al sector C, en la margen izquierda del río Uruguay, se registraron dos incisivos perforados y con decoración incisa en el Cerrito de Colonia Concordia (Díaz et al. 1980; Maruca Sosa 1957).

La presencia de carpincho en CL2 (MNI=1) y SPL (MNI=1) representado por pocos elementos axiales y apendiculares, junto a las evidencias antrópicas, indicaría que los mismos habrían ingresado completos y allí fueron procesados, consumidos y descartados. Se registró alteración térmica en un carpiano (CL2) y huellas de desarticulación en un radio (CL2). También en el MAMA aunque sin procedencia exacta se registraron un fémur y un húmero con evidencias antrópicas (Tabla 7.23d). Considerando que es una de las especies más abundantes de la región, su escasez en el registro 
arqueológico regional es significativa (Acosta 2005; Arrizurieta et al. 2010; Bonomo et al. 2014a; Caggiano 1982a; Cornero et al. 2007; Pérez Jimeno 2007; Santini 2009; Sartori y Colasurdo 2010; entre otros). En el sector C probablemente, además de su carne, también fueron utilizados sus huesos, incisivos y cueros. Probablemente la baja frecuencia de sus elementos se deba a la intensidad del procesamiento que impide la identificación taxonómica. Un caso relevante al sur del sector $\mathrm{C}$ fue registrado en el Túmulo II del Brazo Largo donde este espécimen está representado por elementos de los miembros y una hemipélvis, algunos de los cuales presentan huellas de corte (Politis et al. en prensa).

Considerando los cérvidos (Sección 7.1.2.3 y Tabla 23a-b-c-d) se identificaron ciervo, venado y guazuncho. El ciervo presenta un $\mathrm{MNI}=1$ en $\mathrm{CL2}$ y $\mathrm{SPL}$, aunque si para este último sitio arqueológico se consideran las astas del MAMA (Tabla 7.23b) el MNI aumenta. Se registraron elementos axiales y apendiculares de unidades anatómicas de bajo rinde económico (falanges, cúbitos, radio, metatarso, calcáneo, capitatum, molares y astas). Se registró alteración térmica en tres especímenes, y huellas de corte de desarticulación en un metapodio y un radio, este último también con un negativo de impacto. En el MAMA y procedente de SPL se registraron cuatro astas sin evidencias antrópicas y 14 especímenes (13 astas y un cúbito) con evidencias antrópicas, siendo dos de ellos instrumentos (horqueta perforada y punta con epífisis) (Tabla 7.23b). En la misma colección aunque sin procedencia exacta se registraron además un cúbito sin evidencias antrópicas y 25 especímenes (22 astas, dos húmeros y un cúbito) con evidencias antrópicas (Tabla 7.23d).

Observando los datos de la Sección 7.1.2.3 en primera instancia se podría considerar que la ausencia de partes esqueletarias con buenas oportunidades para preservarse (fémur y húmero) y con medio y alto rinde económico están ausentes, y que esto podría deberse a una decisión antrópica de extraer o descartar estos elementos fuera de los asentamientos. Ahora si se consideran además los datos del MAMA se observa que hay dos húmeros derechos con fractura helicoidal y huellas de corte, y un asta adherida al frontal con huellas de corte. Esto indicaría, por un lado, el ingreso del cráneo completo al asentamiento y consecuentemente el cuereo in situ. Lamentablemente no está claro a que sitio arqueológico corresponden estos tres especímenes (posiblemente a CP o SPL) pero aun así evidencian el ingreso de estas partes esqueletarias a los asentamientos, y que tal vez aún no se han identificado por la reducida superficie excavada. Además, en Cerro de Boari 3 se registró un húmero con evidencias antrópicas (véase Capítulo 8).

El venado presenta un $\mathrm{MNI}=1$ en $\mathrm{CL2}$ y SPL. Se identificaron elementos axiales y apendiculares de unidades anatómicas de bajo, medio y alto rinde económico (húmeros, radios, cúbitos, hemipélvis, tibia, metapodios, astrágalo y hemimandíbula). Se registraron huellas de corte de desarticulación en una hemipélvis y aserrado perimetral en un metatarso. También en el MAMA, procedentes de CL2 se registraron siete instrumentos sobre metapodios (puntas ahuecadas, puntas planas, punta acanalada y punta con epífisis), y procedentes de SPL se registraron dos especímenes 
(radio y tibia) sin evidencias antrópicas y 21 especímenes (19 metapodios, un cúbito y un radio) con evidencias antrópicas, siendo 17 de ellos instrumentos (puntas acanaladas, puntas ahuecadas y puntas con epífisis) (Tabla 7.23b). En la misma colección aunque sin procedencia exacta se registraron además seis metapodios sin evidencias antrópicas y ocho especímenes (siete metapodios y una tibia) transformados en instrumentos (puntas acanaladas, punta ahuecada, puntas con epífisis) (Tabla 7.23d).

A partir de la representación esqueletaria y de las evidencias de procesamiento sobre ciervos y venados de CL2 y SPL se plantea que los individuos de ambas especies ingresaron completos a los asentamientos y allí fueron procesados de manera intensiva; aprovechando además de su carne, sus cueros, huesos, astas, probablemente sus tendones, nervios e intestinos al igual que como se hacía con los guanacos en Pampa-Patagonia (véase en Vecchi 2010 el uso de estos tres elementos para elaborar los ramales de las boleadoras). Particularmente para CL1 donde el ciervo y el venado presentan un $\mathrm{MNI}=1$ están representados por un radio y un axis respectivamente, si bien su ingreso sería antrópico no se puede profundizar sobre su representación anatómica, solo mencionar que la vértebra pudo ingresar adherida al cráneo.

La presencia de guazuncho solo fue determinada en SPL a partir del MAMA. Se registró un asta adherida al frontal con evidencia antrópica y un punta de asta (Tabla 7.23b). En la misma colección aunque sin procedencia también se registró un asta adherida al frontal con evidencia antrópica y una punta de asta (Tabla 7.23d). Las astas indicarían el ingreso del cráneo entero a los asentamientos. Considerando de forma complementaria los elementos de guazuncho identificados como instrumentos, en sitios arqueológicos cercanos a CL1, CL2 y SPL, como son T1-CNM y T2-CSM (metapodios) y CP (cúbito), se podría proponer que en algunos asentamientos del sector $\mathrm{C}$ el guazuncho (cuyo peso no es muy diferente a un carpincho grande o un venado) ingresaría completo y su aprovechamiento sería integral como el de los demás cérvidos.

La categoría Cervidae presenta un MNI= 1 en $\mathrm{CL} 2$ y SPL. Se registraron elementos axiales y apendiculares de unidades anatómicas de bajo y medio rinde económico (húmero, metapodios, astrágalo, falanges, hemimandíbula y molares). Se registró alteración térmica en dos especímenes. Asimismo, tres metapodios de SPL fueron transformados en instrumentos (punta acanalada y puntas con epífisis) y un astrágalo de CL2 transformado en gancho de propulsor (Tabla 7.16). También en el MAMA, procedente de CL2 se registró un asta con evidencias antrópicas, y procedentes de SPL se registraron seis astas sin evidencias antrópicas y 24 especímenes (18 astas y seis metapodios) con evidencias antrópicas, siendo 15 de ellos instrumentos (agujas, puntas ahuecadas, punta con epífisis, punta, arpones y preformas de arpones) (Tabla 7.23a y b). En la misma colección aunque sin procedencia exacta se registraron además un asta sin evidencias antrópicas; 28 especímenes (26 astas y dos metapodios) con evidencias antrópicas, siendo ocho de ellos instrumentos (puntas, bisel, punta ahuecada, arpones y punta con epífisis) (Tabla 7.23d); y dos metapodios decorados (Sección 
7.1.3.3). Es posible que estos elementos correspondan a venado o guazuncho, y en menor medida a ciervo.

El procesamiento de huesos largos de cérvidos en general, tanto para extracción de médula o para confeccionar instrumentos, redujo la frecuencia de especímenes determinables. Cabe señalar que cuatro instrumentos de CL2, 7 de SPL y 18 sin procedencia exacta (Tabla 7.16 y Tabla 7.23a, b y d) fueron elaborados sobre huesos largos que solo pudieron determinarse como mamíferos. Entonces la mayoría de los especímenes asignados a la categoría Mamífero grande (NISP=163) y mediano (NISP= 346) indeterminados (CY, CL1, CL2 y SPL), probablemente correspondan a cérvidos o carpinchos dado que en la región estos son los animales de mediano y gran porte que estaban presentes en mayor abundancia. No se descarta que podrían pertenecer a otros mamíferos (p. ej. yaguareté, aguará guazú, perro o lobo marino) pero estas especies tienen baja frecuencia en el registro arqueológico. A su vez, la mayoría de estos especímenes son fragmentos de diáfisis de huesos largos (lascas y en menor medida cilindros), lo que estaría indicando un procesamiento intensivo de estas especies de mediano y gran porte. Estos desechos de procesamiento a su vez tienen fracturas de tipo helicoidal, columnar, oblicua, irregular, transversal, negativos de impacto ( $n=$ 9), huellas de corte $(n=15)$, aserrado perimetral $(n=1)$ y alteración térmica $(n=76)$. Esto se podría vincular con la extracción de la médula ósea y/o a la elaboración de instrumentos (Tabla 7.16 y Tabla 23a-b-c-d). Los mamíferos chicos e indeterminados (CL1, CL2 y SPL) también registraron evidencias de alteración térmica y huellas de corte en grado variable.

En cuanto a los dasipódidos se registraron al menos dos especies distintas en cada sitio arqueológico (CL2 y SPL) y con un $\mathrm{MNI}=1$ cada una de ellas. Se identificaron elementos de tatú peludo, mulita grande y otros que podrían ser mulita o mulita grande. Todos los elementos corresponden a osteodermos, móviles (MNE=9) y fijos (MNE=7). En cinco de los osteodermos de SPL se registró alteración térmica. El ingreso de estos taxa a los asentamientos respondería al consumo y no actividades fosoriales propias su etología. Habrían sido procesados, consumidos y descartados, y la termoalteración puede ser producto del asado directo al fuego (como lo señala Paucke 1944: 353 para el siglo XVIII) o del descaste de partes en el fuego o en su cercanías. Asimismo, sus placas pudieron haber sido usadas como herramientas en la decoración de la alfarería (Di Prado 2013, 2015). Los dasipódidos también se han registrado en sitios arqueológicos de la región como La Bellaca 2 (Acosta 2005), Playa Mansa (Sartori y Colasurdo 2010) y Cerro de Boari 3 (Capítulo 8).

El zorro gris $(\mathrm{MNI}=1)$ se registró en SPL y está representado por elementos craneales sin evidencias antrópicas. En este sentido, no es posible sostener la hipótesis de su consumo, ya que por un lado, su ingreso pudo ser natural o con el fin de usar sus huesos para la elaboración de artefactos (véase Paucke 1943: 161; Pérez Jimeno 2007). En este sentido, este taxón ha sido registrado con evidencias antrópicas en sitios arqueológicos de la región como el Túmulo II del Brazo Largo (Bonomo et al. 2009; Politis et al. en prensa); y sin evidencias antrópicas en Cerro Tapera Vázquez (Bonomo et 
al. 2014a), Anahí, La Bellaca 2 (Acosta 2005), Cerro de Boari 3 (Capitulo 8) y en la colección del MAMA (hemimandíbula) aunque sin procedencia exacta (Tabla 7.23d). Asimismo, también se han registrado en la región pendientes elaborados con dientes de zorro (Acosta et al. 2015b).

En relación a los reptiles se registraron al menos dos especies distintas, la tortuga se registró en CL1, CL2 y SPL, y el lagarto en CL2 y SPL; en cada sitio arqueológico cada taxón tiene un MNI= 1 . Para la tortuga los elementos corresponden al espaldar y/o peto, y para el lagarto vértebras, costillas, tibia y fémur. Se registró un espécimen de tortuga (CL2) y dos de lagarto (SPL) con alteración térmica; y dos vértebras de lagarto con huellas de corte (SPL). A partir de la representación esqueletaria y las evidencias antrópicas se plantea que tanto tortugas como lagartos ingresaron completos a los asentamientos y allí fueron procesados, consumidos y descartados. El consumo de lagarto fue observado por Paucke (1944: 355) entre los mocovíes. Estos taxa también se han registrado en sitios arqueológicos de la región como Cerro Tapera Vázquez (Bonomo et al. 2014a), Cerro Aguará y Barrancas del Paranacito (Pérez Jimeno 2007), Anahí, Garín y La Bellaca 2 (Acosta 2005), y Cerro de Boari 3 (Capitulo 8). Para el caso de la serpiente y el reptil indeterminado de SPL, dado que no presentan evidencias antrópicas, no se puede profundizar sobre las causas de su presencia en el sitio arqueológico. Por su parte, la presencia de los anuros en dos sitios arqueológicos distintos (CL2 y SPL) posiblemente indicaría su consumo, ya que al ser un recurso abundante y con un bajo costo de obtención no debe haber sido desaprovechado.

Las aves se registraron en $\mathrm{CL2}(\mathrm{MNI}=1)$ y $\mathrm{SPL}(\mathrm{MNI}=2)$, en todos los casos son indeterminadas y están representadas por huesos largos. Si bien no presentan evidencias de procesamiento su presencia en los sitios arqueológicos respondería a causas antrópicas. En este sentido, en el MAMA, procedente de CL2 se registró un hueso largo de ave indeterminada transformado en un tubo decorado, y procedente de SPL se registraron cinco huesos largos de ave indeterminada transformados en instrumentos (tubos, puntas con epífisis y punta ahuecada), un tarso-metatarso de cigüeña transformado en un bisel (Tabla 7.23a y b), y un cúbito y un hueso largo de aves indeterminadas decorados (Sección 7.1.3.3). En la misma colección aunque sin procedencia exacta se registró además un hueso largo de ave indeterminada transformado en una punta ahuecada (Tabla 7.23d). En los ambientes ribereños del sector $C$ son abundantes sobre todo las aves de hábitos acuáticos, por lo que su consumo explotación debió ser recurrente. Estas también han sido registradas en sitios arqueológicos de la región como Cerro Tapera Vázquez (Bonomo et al. 2014a), Anahí, Garín y La Bellaca 2 (Acosta 2005). También en Cerro Aguará y Barrancas del Paranacito las aves fueron utilizadas para la elaboración de instrumentos óseos (Pérez Jimeno 2007).

En relación a los instrumentos, se identificaron 240 piezas de las cuales 200 proceden de 15 sitios arqueológicos y el resto $(n=40)$ no tiene procedencia determinada (Tabla 7.16 y Tabla 7.23a, b, c y d). Se identificaron un total de 13 tipos (además de preformas, Puntas no clasificables y puntas sobre espinas de peces aguzadas) elaborados sobre 10 elementos anatómicos distintos (huesos 348 
largos, cúbitos, tibias, tarso-metatarso, metacarpos, metatarsos, astrágalo, astas y espinas pectorales y dorsal de peces) de 13 taxa diferentes (peces, siluriformes, doradidos, surubíes, aves, ñandú, cigüeña, mamíferos, ciervo, venado, guazuncho, aguará guazú y coipo). En conjunto los instrumentos reflejarían actividades de caza (puntas, bipuntas, gancho de propulsor), pesca (arpones), trabajos sobre pieles, textiles, cestería y/o cerámica (agujas, puntas con epífisis) y seguramente otras tareas domésticas o rituales (espinas aguzadas, biseles, tubos, puntas curvas ahuecadas, horquetas).

Particularmente las espátulas ( $n=2 ; \mathrm{SPL}$ ) sobre mamíferos pueden haberse usado en la manufactura de alfarería, de manera similar a las herramientas modernas de los ceramistas, para la mezcla de pastas, para el alisado de superficies, para la decoración por incisión y/o por la aplicación de pintura. La espátula más completa (MAMA-SPL-148) presenta la zona apical semejante a las de los instrumentos que Rusconi (1933) denomina "espátulas" destinadas a la alfarería procedentes de Santiago del Estero. Otro instrumento semejante proviene del sitio arqueológico Las Tunas (ROU) y también es considerado como una espátula (Seijo 1931). La espátula más pequeña (MAMA-SPL-3) presenta la extremo apical semejante a la del instrumento que Rusconi (1933) denomina "separador de urdimbre (?)" procedente de Santiago del Estero. Otros autores mencionan espátulas pero las imágenes publicadas o sus descripciones se refieren a instrumentos diferentes a los presentados aquí (p. ej. Hilbert 1991; Serrano 1946; Schmitz et al. 1972; y Torres 1907, 1911), aun así para los mismos plantean funciones relacionadas a la producción cerámica.

Los adornos (Sección 7.1.2.3 y 7.1.3.3) corresponden a cinco tipos: pendientes, cuentas de collar, tembetás, y fragmentos de valvas bivalvos y gasterópodos recortados y con una perforación central de funcionalidad desconocida, que en base a su morfología general se denominan discos y cuentas. Se elaboraron sobre cinco taxa diferentes (Diplodon sp., GASTRÓPODA, Megalobulimus sp., Chrysocyon brachyurus y Panthera onca). Estos objetos forman parte de la ornamentación corporal de las personas reflejando una porción de su mundo simbólico. Las cuentas de valvas asociadas a un cráneo podrían ser propiedad del individuo o ajuar funerario. Asimismo, estas piezas evidencian que en su proceso de manufactura se usaron instrumentos líticos para cortar, perforar y abradir-pulir.

A partir de la colección del MAMA además de los instrumentos y adornos se identificaron especímenes con modificaciones antrópicas (ECEA) y sin ellas (ESEA) que permitieron en algunos sitios arqueológicos, reconocer, por un lado, taxa poco representados o inéditos en el registro arqueológico regional; y por otro lado, unidades anatómicas previamente no determinadas de las especies que ya habían sido identificadas y que a su vez permitieron ampliar el perfil anatómico de los taxa involucrados. Este conjunto incluye algunos taxa ya mencionados incluidos arriba como instrumentos y/o adornos que son: el surubí, el guazuncho, la cigüeña, el ñandú, el aguará guazú, el yaguareté, Megalobulimus sp. y Diplodon sp.; y otros mencionados por primera vez en esta sección como el lobito de río, el perro y el lobo marino. 
El surubí ya mencionado como espinas aguzadas para SPL, también fue registrado en esta misma forma en FQ, CP y SLC-T1 (espinas pectorales) (Tabla 7.23a, b y c). El ñandú fue registrado como un punta con epífisis en T2-CSM y CP (tarso-metatarso) (Tabla 7.23a y c). El lobito de río fue registrado en SPL y está representado por una húmero con huellas de desarticulación (Tabla 7.23b). Esta especie debió haber sido consumida o por lo menos usado su cuero y al igual que el coipo de tamaño similar habría ingresado completo al asentamiento.

El perro fue registrado en SPL, CP y sin procedencia exacta, y está representado por elementos craneales, algunos con evidencias antrópicas (Tabla 7.23b, c y d). Si bien están en proceso dataciones rediocarbónicas para confirmar su cronología, se destaca que en Cerro Lutz se registró la misma especie con una antigüedad de $916 \pm 42$ años ${ }^{14} \mathrm{C}$ AP (Arrizurieta et al. 2010). El lobo marino fue registrado en SPL con evidencias antrópicas (Tabla 7.23b y Figura 7.13C) que indicarían su consumo. Posiblemente ingresó completo a SPL como parece indicarlo la presencia del canino superior que representa al cráneo. El registro arqueológico de esta especie marina en un ambiente fluvial como el que caracteriza al sector $\mathrm{C}$ es un dato novedoso. Si bien es una especie exótica se destaca que la presencia esporádica de mamíferos marinos en el río Uruguay y aún en el río Gualeguaychú no es extraña. El avisaje más reciente de un lobo marino de dos pelos (Arctocephalus australis) fue en 2014 en el río Gualeguaychú en inmediaciones de la ciudad homónima. También en la misma zona se avistó recientemente (28/04/2016) un elefante marino (Mirounga leonina). Asimismo, se tiene información de pescadores de Gualeguaychú de la captura en el río Uruguay de tortugas marinas. También en el año 2012 se registró una ballena en cercanías de Villa Paranacito. Una mención más antigua para lobos marinos cerca de la desembocadura del río Uruguay corresponde a Cattaneo (1730; en Freitas 1953b: 155).

En los demás sitios arqueológicos no abordados en profundidad aquí (Tablas 7.23a, b, c y d), el relevamiento de los instrumentos permite sostener de manera general que se encuentran representados los mismos taxa. En este sentido, cabe considerar que si los elementos de esos taxa fueron usados para la elaboración de instrumentos, también deben haber sido consumidos como ocurrió en CL1, CL2 y SPL por mencionar los sitios arqueológicos más estudiados. Además, en estos casos no se considera que la presencia de estos elementos en los sitios arqueológicos responda exclusivamente a la manufactura de instrumentos o adornos. En este sentido, al igual que para todo el sector C habría habido un bajo costo de obtención de las materias primas óseas (y también malacológicas) ya que la mayoría provendría de los animales consumidos.

Los mamíferos grandes habrían ingresado completos a CL2 y SPL donde fueron procesados, consumidos y descartados. Dependiendo del modo de traslado hacía los mismos y del número de cazadores, en algunas ocasiones posiblemente por su tamaño el ciervo y tal vez el venado y los carpinchos grandes, sufrieron un trozamiento primario en el lugar de caza, permitiendo así su traslado hacía los asentamientos ya sea por vía terrestre o fluvial; esta última forma de traslado a lo 
mejor reduciría la posibilidad del trozamiento primario al menos para el venado y carpincho. Una vez en los asentamientos habría ocurrido el trozamiento secundario y final, el consumo y el descarte, y en algunos casos también la transformación de sus elementos en instrumentos.

Los peces, los moluscos, el coipo, el cuis, la tortuga, el lagarto, los dasipódidos y los microroedores, también habrían ingresado completos a los asentamientos (CL1, CL2 y SPL) y allí fueron trozados con distinta intensidad según su tamaño y posteriormente consumidos $y$ descartados. El ingreso de peces, cérvidos, carpincho y coipo de forma completa también fue propuesto para Cerro Lutz (Arrizurieta et al. 2010). Asimismo, Caggiano (1982a) identifica también el ingreso completo de los peces a El Ceibal 1, no así de los mamíferos. Aunque no hay evidencia concluyente sobre el consumo de algunas especies como el zorro gris, el aguará guazú, el yaguareté o el perro; en parte su presencia en los sitios arqueológicos puede vincularse a hechos de connotaciones simbólicas. El caso de lobo marino claramente su explotación responde a un evento de oportunismo.

La variedad de instrumentos muestra una tecnología ósea bien desarrollada y diversificada. Cuya elaboración no responde a la ausencia de otras materias primas, ya que como se observó los recursos líticos usados son abundantes. Respondería a la decisión de contar con un amplio instrumental donde cada tipo de instrumento era destinado a una tarea más o menos específica, lo que evidencia una gran complejidad de las actividades realizadas.

El registro de puntas de proyectil y arpones fracturados en los sitios arqueológicos, algunas puntas con evidencias de haber sido descartadas en el fuego, además de las preformas, y los desechos de manufactura permite proponer que tanto la confección de las armas, la reparación y el recambio de las puntas y los proyectiles se realizada en los asentamientos. Al igual que la confección de la mayoría del instrumental restante y los adornos. Por otro lado, la presencia de estos instrumentos fracturados podría estar relacionada con una conducta semejante a lo observado entre los awá de la Amazonía (Politis et al. 2013b), donde las puntas de flecha de madera fracturadas durante una evento de cacería retornan al campamento y allí son descartadas.

La gran variabilidad de puntas de proyectil óseas y los arpones evidencian la importancia de la caza y la pesca. Como muestran las especies explotadas estas actividades fueron recurrentes e intensivas en el sector $\mathrm{C}$. Considerando esto, la presencia de decoraciones complejas en las armas, así como en los demás objetos decorados, permiten plantear que los usuarios buscaron marcar diferencias a través del tratamiento especial de estos objetos. Al igual que los adornos serían una representación material de parte del mundo simbólico y de diferencias interpersonales entre sus usuarios y portadores (Wiessner 1983, 1989; Wobst 1977).

Por último, a partir de los datos obtenidos en relación a la explotación de la fauna se plantea que dentro de la gran biodiversidad de este ambiente fluvial se aprovecharon la mayoría de las especies presentes. Esto no solo implica una simple actividad extractiva del entorno, sino que la 
explotación de cada taxón identificado requirió un profundo conocimiento sobre la ecología y la zoología del sector (para el caso guaraní véase Noelli 1993, 1994, 1998a, 1998b, entre otros).

\subsection{5- CONJUNTO DE RESTOS ÓSEOS HUMANOS}

El registro bioarqueológico del sector $\mathrm{C}$ procede de sitios arqueológicos que evidencian inhumaciones en distintas geoformas ribereñas como albardones (LC y EDB), médanos (SLM) o montículos (CL2, T1-CNM, T2-CSM, SPL, CP, FQ, TL, T1-LA y TI) (Tabla 7.24). El estado de integridad y completitud de la muestra permitió estimar la edad en 27 cráneos, 24 registrados como adultos y tres como subadultos. Entre los adultos, 12 son femeninos y 12 masculinos.

La información contextual de la colección del MAMA y de excavaciones propias (Capitulo 8) indica que en el sector $C$ hay entierros primarios y secundarios directos. El cambuchí de la colección Etchegoyen muestra en un área cercana la presencia de entierros secundarios guaraníes en urnas con ajuares faunísticos. Los entierros secundarios implicaron un tratamiento especial de los cuerpos que incluyó el desmembramiento y descarne, evidencia de estas tareas se registraron en un radio (SPL) y un húmero (CL2).

Esta evidencia complementa la información regional sobre la manipulación y uso de huesos humanos tanto para el armado de los paquetes funerarios o su introducción en una urna cerámica, así como también como soportes-base de instrumentos óseos. En este último caso un instrumento elaborado sobre una epífisis proximal-diáfisis de radio izquierdo humano fue recuperada por Torres (1911) en el Túmulo I del Brazo Largo y presentada por primera vez por Caggiano (1979), pero sin que ambos autores identifiquen el taxón. Podría corresponder a una punta con epífisis pero la fractura del extremo distal del instrumento dificulta la determinación precisa. Esta misma pieza fue reestudiada por Bonomo y colaboradores (2009) quienes la identifican finalmente como humana. Asimismo, Acosta y colaboradores (2011a) dan a conocer dos especímenes (húmero y tibia) con aserrado perimetral procedentes de Cerro Lutz y estarían asociados a la elaboración de instrumentos óseos según los autores. También en sitios arqueológicos de la ROU se identificaron huellas de corte sobre elementos óseos humanos (Capdepont 2004; Gianotti y López Mazz 2004; Pintos Blanco 2001a).

En EDB y CL2 se registraron adornos asociados a los entierros humanos. Si bien no pueden interpretarse como ajuares, su presencia revela la importancia simbólica de estos objetos. Además, no todos los ajuares necesariamente deben ser adornos o artefactos con un tratamiento especial, simplemente algunos restos faunísticos funcionarían de igual manera. De este modo es interpretada la fauna con aplicación de colorante rojo hallada en la urna funeraria guaraní (colección Etchegoyen). Adornos asociados a entierros humanos en áreas cercanas fueron recuperados por ejemplo en Arroyo Sarandí (Lothrop 1932). Un hallazgo particular asociado a un cráneo humano consiste en un 
fragmento de cobre recuperado por Torres (1911) en el Túmulo I de Brazo Gutiérrez (véase Bonomo et al. 2009).

En el sector $C$ en general se destaca el elevado número de individuos por sitio arqueológico, alcanzando en $\mathrm{CL2}$ y SPL un MNI=18. Esto refleja que los asentamientos también eran lugares de recurrencia ritual, marcando una continuidad de las ocupaciones por un rango temporal que trasciende el de una generación. Asimismo, la persistencia de las mismas de prácticas rituales a lo largo de varias generaciones, podría estar reflejando una misma identidad étnica ocupando este sector de manera constante a lo largo de cientos de años. Paralelamente, el entierro de jóvenes y adultos de ambos sexos en los mismos asentamientos indica que las diferencias por sexo y edad vinculadas a las prácticas mortuorias no serían muy marcadas. Esto reflejaría probablemente sociedades de rango como plantean Bonomo y colaboradores (2011c) y Politis y Bonomo (2012) (sobre este punto véase Capítulo 9). En estas sociedades las diferencias interpersonales estarían vinculadas al acceso diferencial a determinados recursos exóticos o a las habilidades personales relacionadas por ejemplo con: el liderazgo en situaciones de estrés social por diversas causas, la subsistencia (como la caza y la pesca), o la guerra. En este sentido, podrían ser interpretados los arpones, las puntas, la bola y los artefactos decorados, así como también los pendientes de carnívoros y los acompañamientos funerarios de elementos suntuarios como los collares.

Todos los restos óseos humanos se registraron entremezclados con los demás materiales arqueológicos (artefactos líticos, alfarería y restos faunísticos), siendo esto recurrente en el registro arqueológico regional (Bonomo et al. 2010; Caggiano 1983a; Díaz et al. 1980; Greslebin 1931a; Lista 1978; Torres 1911; entre otros). Esto indicaría la multifuncionalidad de los sitios arqueológicos en el río Uruguay inferior. En relación a los montículos estas características permiten plantear, en oposición a Lista (1978) y coincidiendo con Greslebin (1931a), que la utilización y/o construcción de los "cerritos" o montículos no estaba destinada primariamente al entierro de los muertos, sino que responden a una estrategia de ocupación de un ambiente fluvial muy dinámico y rico en recursos. Esto llevó a que no solo se ocuparan geoformas elevadas preexistentes (albardones), sino a que las mismas se sobreelevaran mediante el descarte masivo de desechos durante las ocupaciones, como así también mediante el agregado intencional de sedimentos, desechos antrópicos y entierros humanos. A su vez, en algunos sitios arqueológicos como CL2 y SPL se puede plantear que todo el espesor de restos culturales y la recurrencia ritual estaría evidenciando un largo período de ocupación (continuo o no).

\subsection{6- TENDENCIAS Y DISCUSIÓN DE LAS DATACIONES RADIOCARBÓNICAS}

El conjunto de dataciones son relevantes debido a la ausencia de información cronológica precisa dentro del área de estudio de esta tesis. Los fechados se ubican en el Holoceno tardío, lo que 
confirma la presencia humana en el sector $C$ aproximadamente entre 2000-500 años AP. Asimismo, en los restantes sitios arqueológicos aún no datados la presencia de alfarería, cuyas dataciones más antiguas en contextos arqueológicos de áreas circundantes se ubican ca. 2500 años AP (véase Baeza et al. 1977), sugiere su ubicación temporal en el Holoceno tardío. La datación de Cerro Lorenzo 2 indicaría que en la cuenca inferior del río Uruguay (margen argentina) la ocupación de lugares sobreelevados y su utilización simultanea como asentamiento residencial y lugar de entierros humanos, compatibles con Goya-Malabrigo, se produjo hace al menos 2050 años ${ }^{14} \mathrm{C}$ AP (véase Capítulo 9). La datación de Ensenada del Bellaco también permite corroborar la presencia guaraní en el área en momentos prehispánicos. Cabe mencionar que en la margen uruguaya se registran evidencias de ocupación humana más antiguas (Tabla 2.1b), con fechados tanto para el Pleistoceno final-Holoceno temprano como para el Holoceno medio (Baeza 1985; Hilbert 1991; Suárez 2011).

\section{3- CONSIDERACIONES FINALES}

A partir de las materias primas identificadas se determinó la utilización de recursos líticos disponibles inmediata y localmente, y a distancias medias y largas, tanto de fuentes primarias (Formación Salto Chico y Formación Guichón) como secundarias (Terraza I del río Uruguay). Para el caso de las rocas y minerales disponibles a medias y largas distancias su traslado desde las canteras potenciales hasta los asentamientos se daría mayormente mediante el uso de canoas. Esto se determinó principalmente para el registro identificado con Goya-Malabrigo, pero también en el caso guaraní se observa el uso de los mismos recursos aunque la frecuencia de artefactos líticos es mucho menor, lo que tampoco permite realizar mayores interpretaciones.

Para Goya-Malabrigo se determinó que hay una tendencia hacia una explotación diferencial de materias primas en favor de las silíceas de buena y excelente calidad para la talla; mayormente provenientes de rodados fluviales y clastos de caliza silicificada. Los rodados tienen una alta disponibilidad en la zona, tal vez por esta razón, como lo evidencian los núcleos, cada uno de ellos no era trabajado hasta su agotamiento, presentando una escasa reducción al momento de ser descartado. En cambio se registraron núcleos de caliza silicificada mayormente agotados o con muchas extracciones, mostrando una talla intensiva y también un importante volumen de esta roca aprovisionando los asentamientos. Lo que implícitamente también refleja una importante circulación de personas a través de las vías fluviales y las zonas costeras.

En este sector, al igual que lo que ocurre en el sector $A$, hay una selección de rocas y minerales para elaborar determinado tipo de instrumentos. Las silíceas se usaron para la manufactura de instrumentos de filos y puntas, y como percutores en el caso de los rodados. Las areniscas para instrumentos picados, pulidos y/o abradidos (p. ej. bolas), así como para instrumentos 354 
de abrasión y/o pulido ( $p$. ej. pulidores en canaleta), y de molienda y percusión ( $p$. ej. molino y rompecocos).

El instrumental lítico del sector $\mathrm{C}$ que refleja actividades vinculadas a la subsistencia como la caza o la pesca (y tal vez a violencia interpersonal) se compone de puntas de proyectil y bolas, que debido a su procedencia heterogénea o desconocida (Sección 7.1.3.1) no permiten establecer claramente su asignación cultural o cronológica con precisión. Posiblemente el caso de la bola de CL2 reciclada en yunque (rompecocos; MAMA-CL2-396) pueda ser el único de estos instrumentos identificable con Goya-Malabrigo. Por su parte, el conjunto de instrumentos procedentes de sitios arqueológicos asignables a Goya-Malabrigo (CL2, SPL, CP, T1-CNM, T2-CSM y ET) se asociarían, por un lado, con el procesamiento de subproductos de la caza, pesca y recolección, y/o a la confección de instrumentos y adornos de hueso, asta, dientes o valvas (piezas con retoque sumario y lascas con filos naturales), y por otro lado, con el procesamiento de vegetales o minerales, o también de peces (harina) y/o valvas de moluscos (pigmentos) (morteros y yunques). Por su parte, el instrumental lítico guaraní también reflejaría actividades de subsistencia o violencia interpersonal (bola), el procesamiento de subproductos alimenticios y/o la confección de instrumentos y adornos sobre distintas materias primas (choppers, perforador, piezas con retoque sumario, lascas con filos naturales y pulidores en canaleta).

Además de los instrumentos, el conjunto de desechos de talla y los núcleos sugieren que en CL2, SPL y ET las actividades más recurrentes fueron la formatización, la regularización y el mantenimiento de instrumentos mediante percusión directa (Sullivan y Rozen 1985). Asimismo, en CL2, SPL y ET se realizó el descortezamiento y la reducción primaria de rodados fluviales y clastos de arenisca y caliza silicificada, y también de bloques de arenisca en el caso de ET. En MLB se realizó el descortezamiento y la reducción primaria de rodados fluviales. Por su parte, en los sitios guaraníes como EDB, Ñ-AC/AU y LC/IDG1 el escaso número de desechos de talla y núcleos en conjunto sugiere el descortezamiento y la reducción primaria de rodados fluviales y clastos de arenisca, silcreta y caliza silicificada. También la formatización de instrumentos mediante percusión directa, y la formatización, la regularización y el mantenimiento de instrumentos mediante pulido y abrasión.

La alfarería Goya-Malabrigo de formas simples, lisas o decoradas mediante incisión y/o apliques modelados, evidencia sobre todo un uso doméstico. Por su parte, las campanas y apéndices zoomorfos tendrían un alto contenido simbólico (Politis y Bonomo 2012). A estas formas habría que agregar los tubos, y las piezas troncocónicas sin boca ni borde menor y con agujeros laterales (véase la presencia de una de estas formas en Cerro de Boari 3 en el Capítulo 8). En el caso de las botellas, si es que se confirma tal hipótesis, su uso podría ser tanto doméstico como ritual. La alfarería guaraní con formas mayormente compuestas y cerradas (también hay simples), lisas, corrugadas, unguiculadas o cepilladas indican sobre todo un uso doméstico; y aquellas pintadas policromas evidencian un uso ceremonial vinculado a la producción y consumo de cauim y también un uso ritual 
como urna funeraria. También es importante recordar (véase Sección 7.2.3) que este último tipo de cerámica guaraní es un claro indicador de alta estabilidad residencial.

Los recursos faunísticos explotados son variados y propios del tipo de ambiente actual donde están ubicados los sitios arqueológicos. Las especies de roedores identificadas, son claros indicadores de condiciones climáticas húmedas y cálidas (Quintana 2001). Por lo tanto, desde el punto de vista paleoambiental, el registro faunístico refleja condiciones ambientales semejantes a las actuales para el período de ocupación de los sitios arqueológicos, y a su vez una relativa estabilidad ambiental para los últimos 2000 años AP. Los taxa explotados fueron consumidos y también utilizados en la confección de instrumentos, adornos, vestimenta y probablemente viviendas. El aporte más importante a la dieta en los contextos Goya-Malabrigo lo constituyen los peces y en segundo término se ubicarían los moluscos y mamíferos, incluyendo mamíferos chicos y micromamíferos. Esto refleja la explotación de una amplia variedad de especies disponibles en el ambiente, pero marcando una tendencia hacia la explotación de especies acuáticas. El instrumental elaborado a partir de estos mismos taxa refleja actividades de caza y pesca (y tal vez a violencia interpersonal), y una amplia gama de tareas domésticas y simbólicas. La tecnología ósea y malacológica refleja también un sistema instrumental integrado y mutuamente complementario entre el uso de artefactos de hueso, asta, valvas y lítico. A su vez estas tecnologías reflejan especializaciones en tareas de manufactura y uso de las mismas dentro de las estrategias adaptativas y sociales de los grupos humanos, por lo menos en el lapso temporal comprendido entre ca. 2000 y 500 años ${ }^{14} \mathrm{C}$ AP.

Tanto las bolas como las puntas de proyectil líticas y óseas, y el gancho de propulsor reflejan al menos cuatro sistemas de armas usados en la cuenca inferior del río Uruguay, sin que esto implique sincronicidad. La boleadora, pudiendo ser la bola lenticulada, esférica o esferoide; las puntas pueden corresponder a flechas, lanzas y dardo de propulsor; este último claramente representado por el gancho de CL2. Las lanzas pueden tener o no punta separable, este último caso está ejemplificado por las puntas de arpón con una función específica orientada (aunque no exclusiva) a la pesca.

Las prácticas funerarias en los montículos se asocian estrechamente a la vida cotidiana, dado que las inhumaciones se realizaban en los mismos lugares habitados. Los campamentos residenciales fueron usados como sitios de actividades múltiples y lugares de entierro por varias generaciones de manera constante. Los adornos personales se relacionan al mundo simbólico durante la vida pero también durante la muerte al estar en algunos casos asociados directamente con los entierros humanos.

En síntesis, algunos rasgos de los montículos del sector C estarían indicando mayor sedentarismo y estabilidad residencial de la que se había considerado previamente para el área en general (sobre este punto véase también el Capítulo 9). Estos rasgos serían: la alta densidad artefactual, donde el espesor de materiales culturales en algunos casos alcanza y/o supera el metro 356 
de profundidad; la presencia de montículos antrópicamente elevados (intencionalmente o no) que además permiten habitar de una forma más prolongada estos ambientes inundables; la formación de concheros con gran volumen de valvas; una economía estrechamente asociada a los ambientes fluviales donde se concentran los recursos; las inhumaciones en los cerritos como marcadores de apropiación territorial perdurable en el tiempo; y el elevado número de individuos de diferentes sexos y edades por montículo.

Algunos sitios arqueológicos como CL2, SPL, CP, T1-CNM y T2-CSM son los que más claramente evidencian la presencia de Goya-Malabrigo con la mayoría de sus rasgos en esta porción del río Uruguay. Particularmente ET es una cantera-taller que comparte los atributos generales de la explotación lítica de los sitios identificados con Goya-Malabrigo en este sector. Otros sitios arqueológicos como EMO y EC presentan materiales como alfarería modelada y tubos óseos decorados y esto sugiere que probablemente reflejen ocupaciones Goya-Malabrigo pero aún no han sido relevados. En este sector, los conjuntos arqueológicos asociados a esta entidad además se caracterizan por la presencia de abundantes artefactos líticos tallados, pulidos y modificados por uso. Debido sin duda a la disponibilidad de recursos líticos en el área, al contrario de lo que ocurre en el río Paraná. Esto permitió abordar el sistema de producción lítica dentro de esta entidad arqueológica.

CL2 y SPL pueden ser considerados como asentamientos residenciales de actividades múltiples con una alta estabilidad residencial. En ellos se desarrollaron actividades rituales y otras vinculadas a la subsistencia, como el procesamiento y consumo de alimentos y el descarte de sus desechos; al aprovisionamiento, manufactura, uso, mantenimiento, reciclaje y descarte de instrumentos líticos; a la manufactura, uso, reciclaje y descarte de vasijas cerámicas; y a la manufactura, uso, reparación y descarte de instrumentos óseos y adornos personales. Por su parte, el sitio arqueológico EDB correspondería a una aldea guaraní, al menos formada por un Teii (familia extensa), lo que implica una alta estabilidad residencial. Asociados a EDB estarían LC/IDG1 y Ñ-AC/AU posiblemente como otros Teii o campamentos satélites de actividades específicas (p. ej. pesca). Este conjunto de asentamientos posiblemente hayan conformado en un territorio de dominio (Tekohá), que seguramente incluyera otros campamentos de actividades específicas y las rozas (Noelli 1993, 2004; y Capítulo 9).

El conjunto de dataciones radiocarbónicas contribuyen a la elaboración de un marco cronológico confiable y reafirman la presencia humana durante el Holoceno tardío en el Uruguay inferior. Estos fechados extienden el rango temporal conocido para el área y además evidencian la ocupación de montículos desde aproximadamente 2000 años AP. La datación de EDB contribuye a confirmar la presencia guaraní prehispánica. Además, el conjunto de fechados muestran que el área estuvo ocupada por un lapso aproximado de 1500 años, desde el ca. 2000 años AP hasta el siglo XVI, 
e inclusive en momentos post-conquista europea como lo demuestran las cuentas de collar de vidrio de EDB (Castro y Costa Angrizani 2014).

Por último, a partir de las características generales del registro arqueológico estudiado (montículos, adaptaciones fluviales, alfarería modelada, cronología, etc.) se plantea que algunos de los sitios arqueológicos estudiados en el sector $C$ fueron ocupados por canoeros ribereños cazadoresrecolectores-pescadores ( $\mathrm{y}$ probablemente horticultores) y alfareros; con una alta estabilidad residencial y un desarrollo tecnológico fuertemente orientado a la explotación intensiva del ambiente fluvial determinado por la cuenca del río Uruguay. Estos grupos pueden ser identificados, con algunos agregados como el desarrollo de la tecnología lítica y algunas formas cerámicas modeladas no registradas en otras zonas, con la entidad arqueológica Goya-Malabrigo (sensu Politis y Bonomo 2012). Asimismo, hay un conjunto de sitios arqueológicos que también reflejan una ocupación más reciente de determinados puntos del espacio por grupos guaraníes, que posiblemente desplazaron de estos lugares a los ocupantes previos. 


\section{CAPÍTULO 8}

\section{LOCALIDAD ARQUEOLÓGICA CERROS DE BOARI}

En este capítulo se presentan los resultados de los estudios realizados en la localidad arqueológica Cerros de Boari (LACDB), que está conformada por tres sitios arqueológicos: Cerro de Boari 1, 2 y 3 (Figura 8.1 y 8.2). Los mismos son estructuras monticulares, regionalmente conocidas como "cerritos" que se disponen sobre un gran albardón (400 m de largo por un ancho variable entre 30 y $50 \mathrm{~m}$, y hasta $4 \mathrm{~m}$ de altura) paralelo a la margen izquierda del río Gualeguaychú. En esta localidad el material arqueológico en superficie se distribuye aproximadamente en una franja de 550 $\mathrm{m}$ de largo por $80 \mathrm{~m}$ de ancho adyacente al río, dentro de la cual se destacan los montículos. Se observó que el montículo menos impactado por actividades modernas es Cerro de Boari 3 (CDB3), por este motivo y por sus destacadas dimensiones fue seleccionado para realizar una excavación sistemática. En los restantes montículos se procedió al reconocimiento de su secuencia estratigráfica y composición mediante perforaciones de barreno y sondeos estratigráficos en los epicentros.

\section{1- RESULTADOS}

\subsection{1- SITIOS ARQUEOLÓGICOS}

Se realizaron recolecciones superficiales dirigidas sobre la zona de playas y los montículos, ocho sondeos estratigráficos sobre los montículos y una excavación sistemática en el montículo 3 (Cerro de Boari 3). Los materiales arqueológicos recuperados incluyen artefactos líticos, óseos y cerámicos, restos óseos humanos, faunísticos y vegetales. Se realizaron estudios estratigráficos, sedimentológicos, bio-composicionales y se obtuvieron 10 dataciones radiocarbónicas (Tabla 8.1). Cabe aclarar que los datos sobre los sondeos estratigráficos y los materiales arqueológicos de Cerro de Boari 1 (CDB1) y Cerro de Boari 2 (CDB2) provienen de un estudio de impacto arqueológico realizado por Bonomo y colaboradores (2008). 

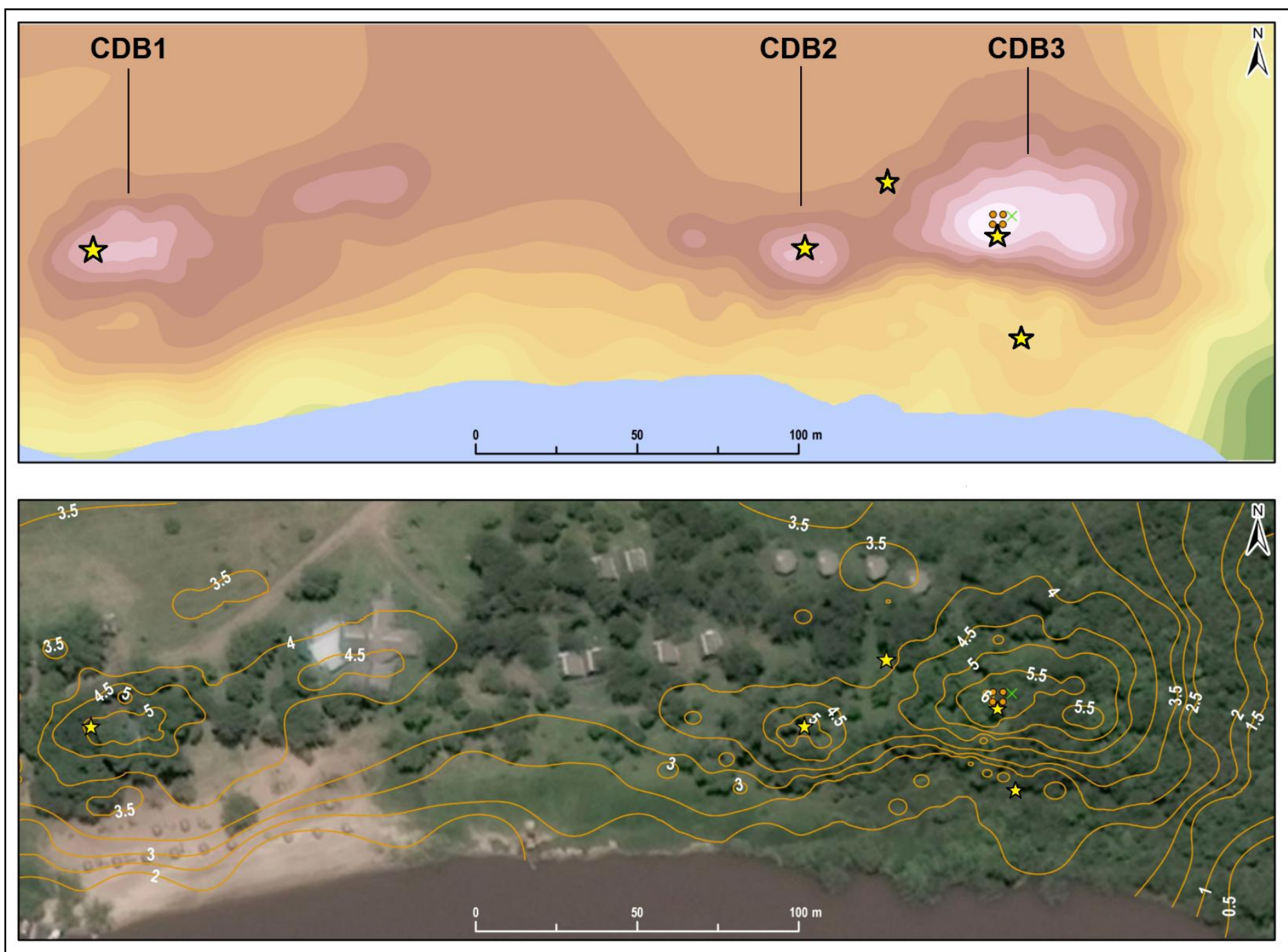

Figura 8.1. Esquema topográfico de la localidad arqueológica Cerros de Boari.

Las estrellas amarillas indican los puntos en los cuales se desarrollaron las perforaciones de barreno.

Los puntos verdes indican los cuatro extremos de la excavación sistemática y

la letra equis $(\mathrm{x})$ la posición del Punto cero.

\subsubsection{1- Descripción contextual de los sitios arqueológicos y sus conjuntos artefactuales}

\section{Cerro de Boari 1 (CDB1)}

El sitio está ubicado a $35 \mathrm{~m}$ de la margen izquierda del río $\left(\mathrm{S} 33^{\circ}, 06899 ; \mathrm{O}^{\circ}, 43932\right)$ y tiene forma oval; su eje mayor oeste-este mide $53 \mathrm{~m}$ y el eje norte-sur mide $37 \mathrm{~m}$, tiene una altura de 1,5 $\mathrm{m}$ en relación al terreno circundante. Encima presenta una construcción del camping (Figura 8.2A). Se realizaron dos sondeos estratigráficos de $0,5 \times 0,5 \times 0,5 \mathrm{~m}$ y se recuperaron cinco desechos de talla; 487 tiestos cerámicos que incluyen 43 fragmentos de borde y 444 de cuerpo (11 decorados y 476 lisos); y 181 restos faunísticos. Además, se registraron masas de arcilla cocida $(n=3)$, carbón $(n=189)$ y un fragmento de mandíbula humana. 


\section{Cerro de Boari 2 (CDB2)}

El sitio está ubicado a $30 \mathrm{~m}$ de la margen izquierda del río y $50 \mathrm{~m}$ al este de CDB1

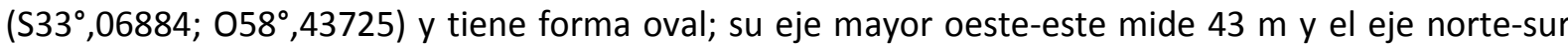
mide $34 \mathrm{~m}$, tiene una altura de 2,5 m (Figura 8.2B). Se realizaron dos sondeos estratigráficos de 0,5 $\times 0,5 \times 0,75 \mathrm{~m}$ y se recuperaron 27 desechos de talla; 1107 tiestos cerámicos que incluyen 99 fragmentos de borde y 1008 de cuerpo (19 decorados y 1088 lisos); y 186 restos faunísticos. Además, se registraron masas de arcilla cocida $(n=50)$ y carbón $(n=15)$.

\section{Cerro de Boari 3 (CDB3)}

El sitio está ubicado a $40 \mathrm{~m}$ de la margen izquierda del río y $25 \mathrm{~m}$ al este de CDB2

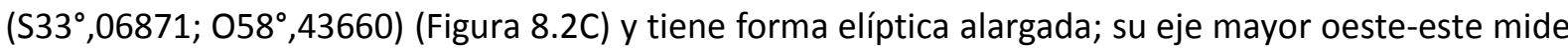
$115 \mathrm{~m}$ aproximadamente y el eje norte-sur mide $47 \mathrm{~m}$, tiene una altura aproximada de $4 \mathrm{~m}$. En su parte más elevada se procedió a la apertura de un área de $8 \mathrm{~m}^{2}$ la cual fue excavada sistemáticamente por niveles artificiales de $5 \mathrm{~cm}$ de potencia. Las cuadriculas 1,2 y 3 fueron seleccionadas para el reconocimiento de la evolución estratigráfica y composicional, alcanzando una profundidad de 1,80 m, llegando a niveles basales arqueológicamente estériles. En las restantes cuadrículas $(4,5,6,7$ y 8$)$ por constricciones de tiempo la excavación sistemática se desarrolló hasta los $0,75 \mathrm{~m}$ de profundidad (Figura 8.2D). El material arqueológico se registra desde la superficie actual del montículo hasta 1,55 m de profundidad, siendo muy escaso a partir de 1,45 m. Además, se realizaron cuatro sondeos estratigráficos, el sondeo 1 y 2 de $0,5 \times 0,5 \times 0,3 \mathrm{~m}$, el sondeo 3 de $1 \times 1 \times 1,6$ $\mathrm{m}$, y el sondeo 4 de $1 \times 1 \times 0,25 \mathrm{~m}$; en este último a partir de los $0,25 \mathrm{~m}$ se continuó la excavación hasta los $0,85 \mathrm{~m}$ pero solo en una superficie de $0,6 \times 0,6 \mathrm{~m}$ ubicada en el cuadrante SO del sondeo. Cabe mencionar que durante la excavación se detectaron algunas estructuras de combustión conteniendo numerosos restos faunísticos, líticos, cerámicos, carbones y cenizas. 

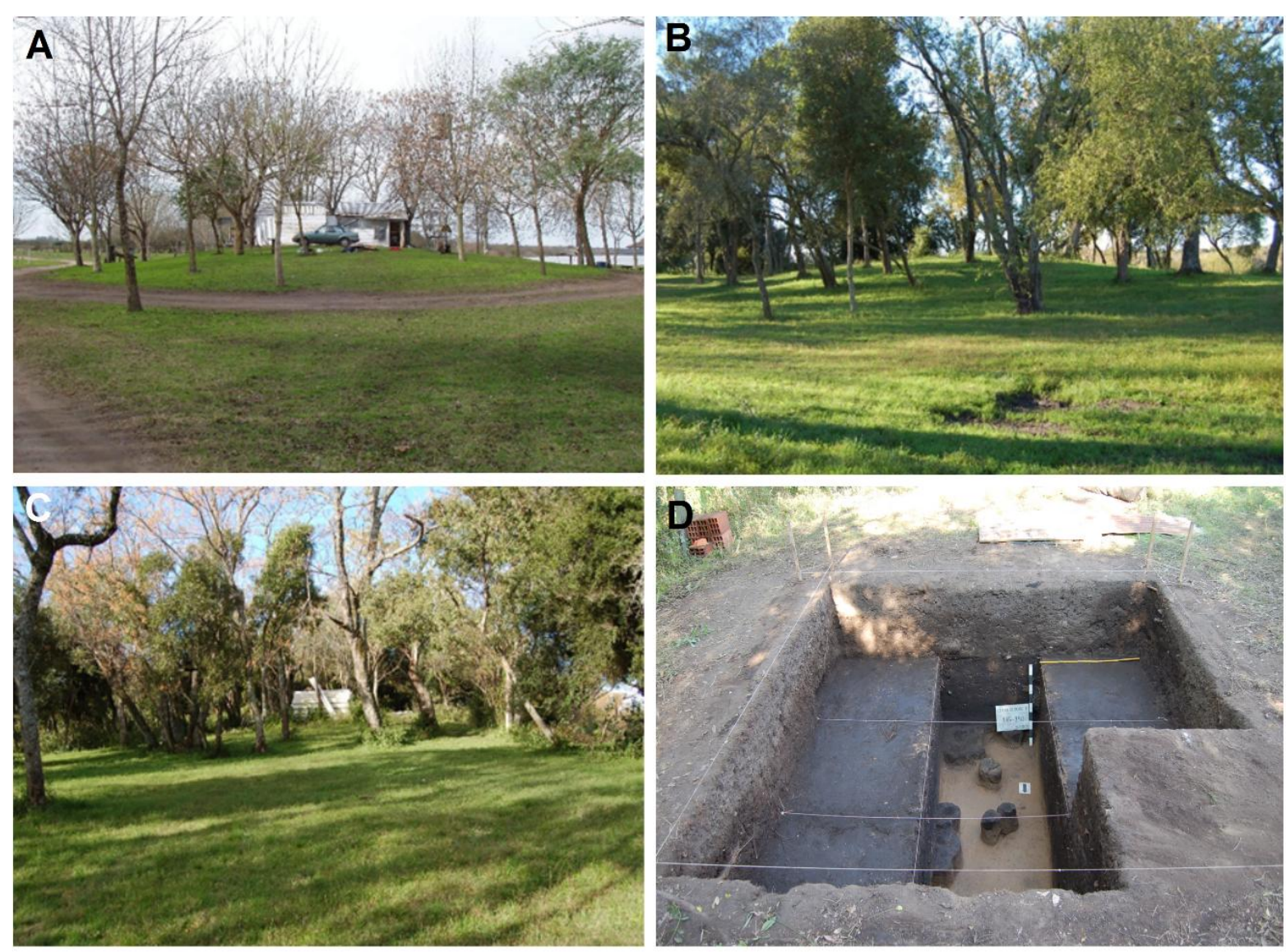

Figura 8.2. Localidad arqueológica Cerros de Boari. A: Cerro de Boari 1. B: Cerro de Boari 2.

C: Cerro de Boari 3. D: Excavación sistemática de Cerro de Boari 3.

\subsection{2- ESTUDIOS ESTRATIGRÁFICOS, SEDIMENTOLÓGICOS Y FITOLÍTICOS}

Desde el punto de vista geológico la LACDB se encuentra sobre los depósitos de la llanura de mareas (o albufera), vinculada a la regresión marina holocénica (ca. 5000-3300 años AP), que comparten características con los depósitos de la Llanura costera entrerriana del Complejo Deltáico (Cavallotto et al. 2005) (Capítulo 4). La llanura de mareas se caracteriza por la presencia de pantanos, bañados y lagunas permanentes y semipermanentes, y donde el avenamiento de las aguas es impedido por la escasa pendiente y los albardones costeros (Iriondo y Altamirano 1988). Sobre estos albardones en general se ubican la mayoría de los sitios arqueológicos registrados en el sector $\mathrm{C}$ (Capítulo 7), y lo mismo ocurre con la LACDB. En este sentido la excavación sistemática de CDB3 expuso un perfil donde se observa (Figura 8.3; perfil oeste) el albardón (A), la interfase (1,40-150 m desde la superficie) (I), un probable piso de ocupación (P) y el agregado antrópico que conforma el cerrito (C).

En esta localidad los estudios estudios sedimentológicos fueron realizados por la Dra. Carola Castiñeira Latorre (CONICET-FCNyM-UNLP) y los estudios fitolíticos por la Dra. María de los Milagros Colobig (CICyTTP-CONICET) (Capítulo 4). La obtención de las muestras se realizó de la siguiente 
manera: en el perfil sur de la cuadrícula 1 se procedió a la apertura de una ampliación de 0,25×0,25 $\mathrm{m}$, cuya profundización también fue mediante niveles de $5 \mathrm{~cm}$, desde la superficie hasta $1,80 \mathrm{~m}$ de profundidad (Figura 8.3). La matriz sedimentaria de este sector conjuntamente con todo su contenido material fue guardada en bolsas a efectos de que en laboratorio se pudieran realizar estudios puntuales de relación entre matriz y componentes. Asimismo, a partir del perfil sur de esta última ampliación se realizó mediante un sacabocado la extracción de siete muestras de sedimentos para análisis texturales, minerales y bio-composicionales (Figura 8.3, punto B del esquema y detalle B). Cada una de estas muestras fue dividida en dos porciones iguales y estas porciones fueron destinadas a estudios sedimentológicos y fitolíticos respectivamente. De esos muestreos se presentan a continuación solamente los resultados del análisis de fitolitos dado que el resto se encuentra en proceso.

Paralelamente, sobre el perfil norte del sondeo 3, y desde 1,40 m de profundidad hacia la superficie del montículo, se tomaron mediante un sacabocado trece muestras [doce cada $10 \mathrm{~cm}$ entre $1,40 \mathrm{~m}$ y $0,20 \mathrm{~m}$ y la restante a los $0,10-0,0 \mathrm{~m}$ ] para análisis texturales, mineralógicos y biocomposicionales (Figura 8.3, punto A del esquema). A partir de 1,40 m (base del sondeo al momento de tomar las muestras, luego se profundizó hasta 1,60 m) se continuó el reconocimiento de la sucesión inferior mediante barreno (taladro holandés) y se tomaron tres muestras más (1,70 m; $1,55 \mathrm{~m}$ y 1,50-140 m) seleccionadas como representativas de los cambios litológicos, colorimétricos y composicionales observados. Paralelamente se realizaron cuatro perforaciones mediante barreno sobre los montículos 1 (CDB1) y 2 (CDB2), en la planicie al noroeste del montículo 3 por fuera de la elevación y en el albardón edafizado entre el montículo 3 el río Gualeguaychú (Figura 8.1). 


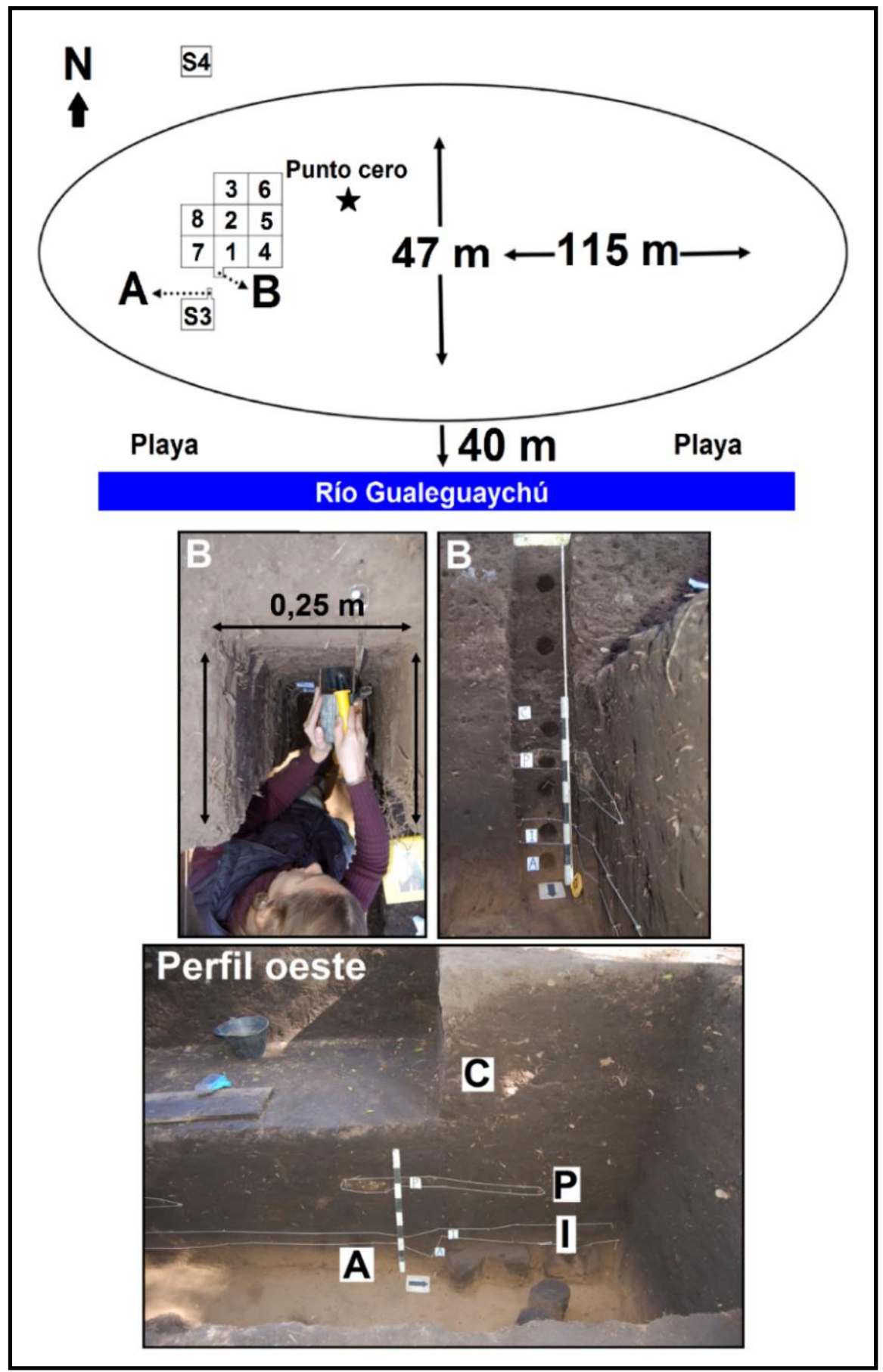

Figura 8.3. Esquema del sitio arqueológico Cerro de Boari 3. S3: sondeo 3. S4: sondeo 4. A y B puntos donde se tomaron muestras sedimentarias: A corresponde al perfil norte del sondeo 3 donde se tomaron las 16 muestras para el analisis textural y composicional; y B corresponde a la ampliación de 0,25x0,25 m del perfil sur de la cuadrícula 1 donde se tomaron las siete muestras para el análisis fitolítico y sedimentológico.

\subsubsection{1- Resultados de los estudios sedimentológicos}

Las muestras del sondeo 3 seleccionadas para análisis textural y composicional fueron: CDB316 (2,80 m), CDB3-15 (2,65 m), CDB3-14 (2,60-2,50 m), CDB3-12 (2,40-2,30 m), CDB3-10 (2,20-2,10 m), CDB3-7 (1,90-1,80 m), CDB3-4 (1,60-1,50 m), CDB3-1 (1,20-1,10 m); la profundidad está en 
metros desde el punto cero de la excavación ubicado 1,10 m por encima de la superficie del montículo en el sondeo 3 (Figura 8.9).

La secuencia de muestras analizadas permitió clasificar texturalmente a los depósitos basales como Areno fangosos, Areno limosos a Limo arenosos los cuales se agrupan en el Grupo N (muestras CDB3-16, CDB3-15 y CDB3-14) (Figura 8.4). En tanto que los suprayacentes hasta el tope del perfil se clasificaron como Areno fangosos ligeramente gravillosos y fueron agrupados en el Grupo A (muestras CDB3-12, CDB3-10, CDB3-7, CDB3-4 y CDB3-1) (Figura 8.5).

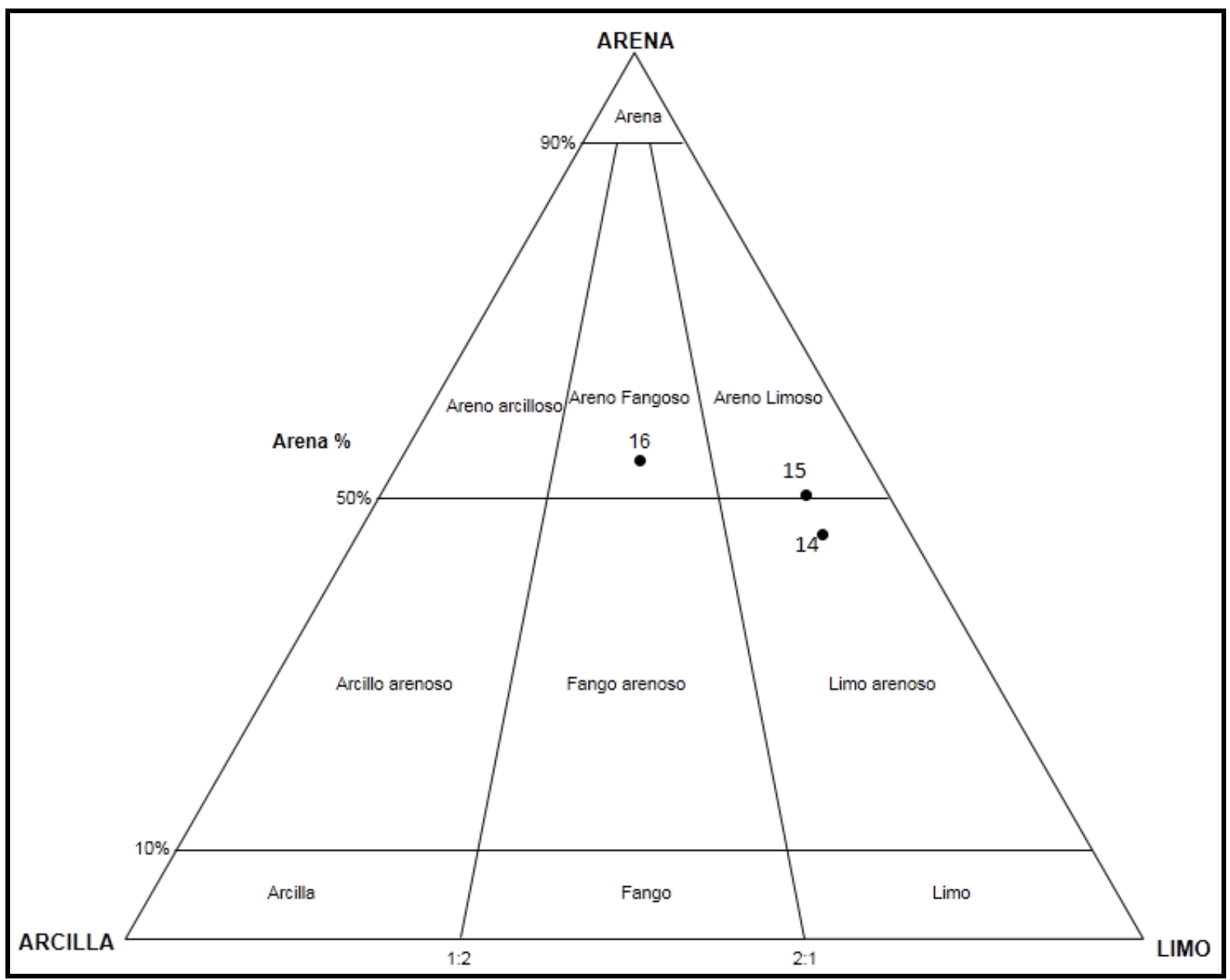

Figura 8.4. Triángulo de clasificación textural de Folk (1954). En el mismo se plotean los resultados alcanzados para las muestras basales del Grupo N del sitio arqueológico Cerro de Boari 3 (CDB3-14, CDB3-15 y CDB3-16), de acuerdo a su contenido de arena, fango, arcilla y limo. 


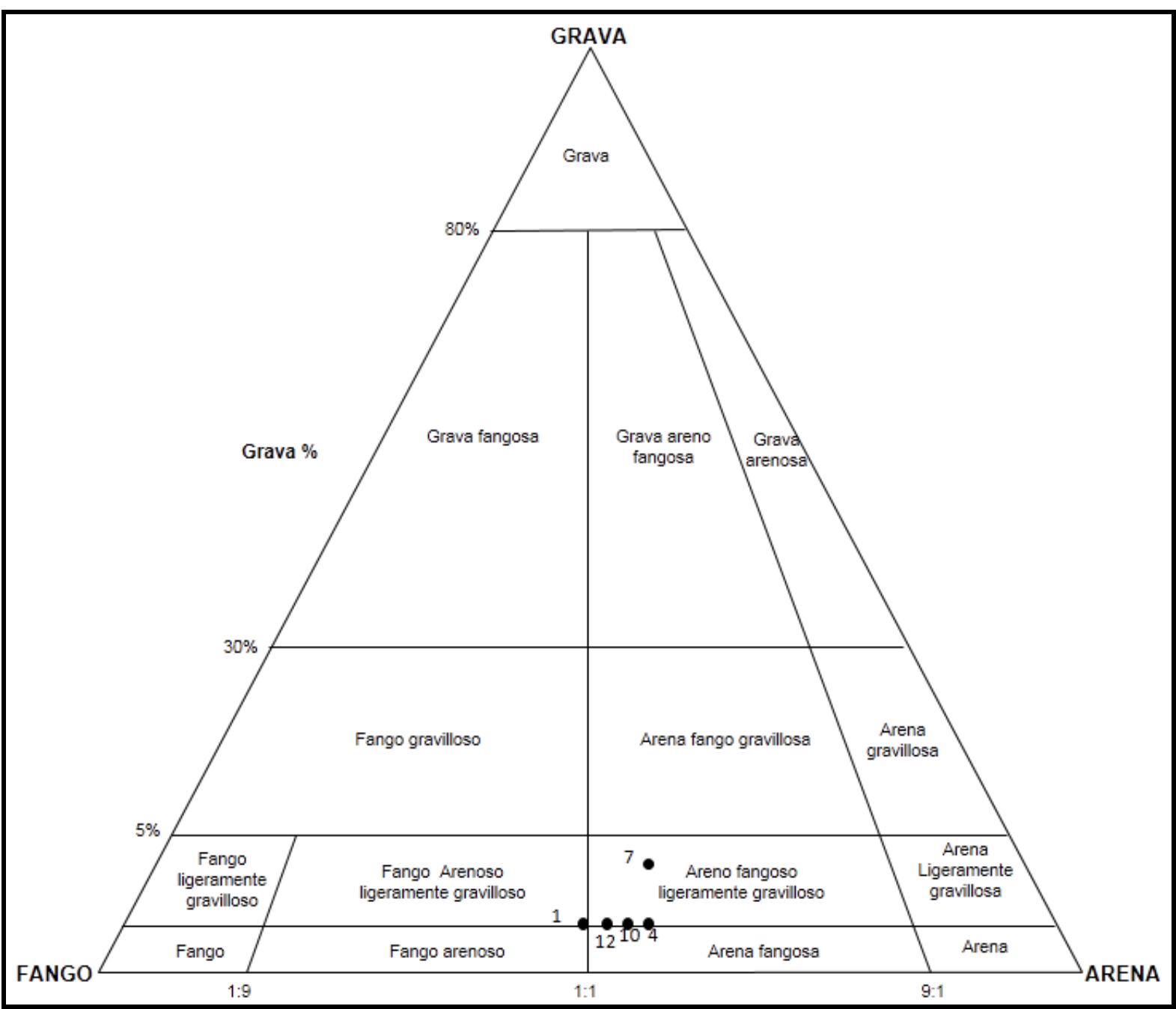

Figura 8.5. Triángulo de clasificación textural de Folk (1954). En el mismo se plotean los resultados alcanzados para las muestras suprayacentes del Grupo A del sitio arqueológico Cerro de Boari 3 (CDB3-1, CDB3-4, CDB3-7, CDB3-10 y CDB3-12), de acuerdo a su contenido de grava, fango y arena.

\section{Características sedimentológicas de los depósitos del Grupo N}

La mineralogía de esta porción inferior de la sucesión se caracteriza por el dominio silicoclástico del cuarzo, seguido por la presencia de plagioclasa, hematita y la escasa presencia de turmalina, piroxenos, (clinopiroxenos), zircón, epidoto, biotita, horblenda, augita, feldespato potásico y granate (Figura 8.6A, B y C). Por DRX se han reconocido con buen grado de desarrollo las reflexiones máximas de: cuarzo, plagioclasa, hematita, y con menor intensidad (trazas): anfíboles (hornblenda) y magnetita. Las fracciones limosas de las muestras procedentes de estos depósitos presentaron: trizas (vidrio volcánico) y sílice biogénico (Figura 8.6D). Este último, representado mayoritariamente por fitolitos, diatomeas y espículas. También por DRX, se reconoció para estos depósitos una asociación argilomineral: illítica-clorítica-caoliníticas, con escasa presencia de esmectita (menor al 10\%). 

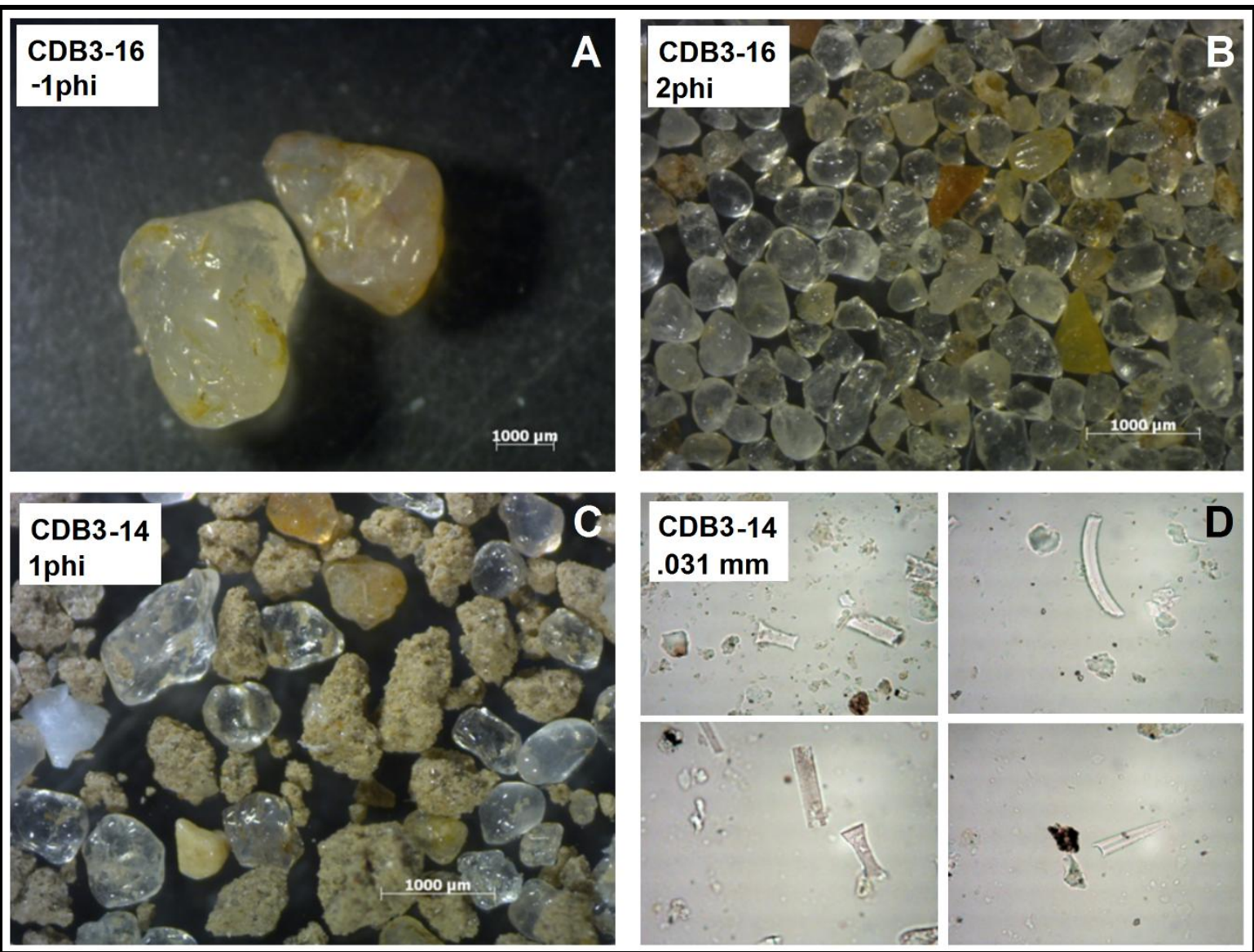

Figura 8.6. Composición sílico y bioclástica de las muestras sedimentarias del Grupo $\mathrm{N}$ del sitio arqueológico Cerro de Boari 3. A: muestra CDB3-16, grava (rodados de Cuarzo teñidos por sectores con Fe). B: muestra CDB3-16, arena media. C: muestra CDB3-14, arena gruesa (silicoclastos y grumos sedimentarios). D: muestra CDB3-14, en fracción limo <53 um el sílice biogénico con signos de corrosión (fragmentos de espículas de esporangios, diatomeas y fitolitos).

\section{Características sedimentológicas de los depósitos del Grupo A}

A partir de la muestra CDB3-12 comienza a desarrollarse una segunda unidad depositacional. Está caracterizada por depósitos húmicos de textura Areno fangosa ligeramente gravillosa, en los cuales se han recuperado numerosos de materiales arqueológicos incluyendo entierros humanos. La fracción grava de estos depósitos se compone básicamente de concreciones de Fe, grumos de hematita, grumos sedimentarios termoalterados (tierras quemadas), carbones, fragmentos cerámicos, óseos y líticos (Figura 8.7B). Estos componentes también son dominantes en la composición de las arenas gruesas (Figura 8.7A y D), mientras que, los clastos minerales listados para el conjunto de muestras del Grupo N, son preponderantes recién en las fracciones arenosas, medianas a finas (de 0.25 a $0.062 \mathrm{~mm}$ ). En las fracciones limosas se observan en microscopio (Figura 8.7C), fitolitos de gramíneas (panicoides y pooides) espículas, escasas diatomeas y crisófitas. Sin embargo, la característica más sobresaliente de este segundo grupo es que alberga numerosos fragmentos cerámicos, líticos, óseos, malacológicos y vegetales. 


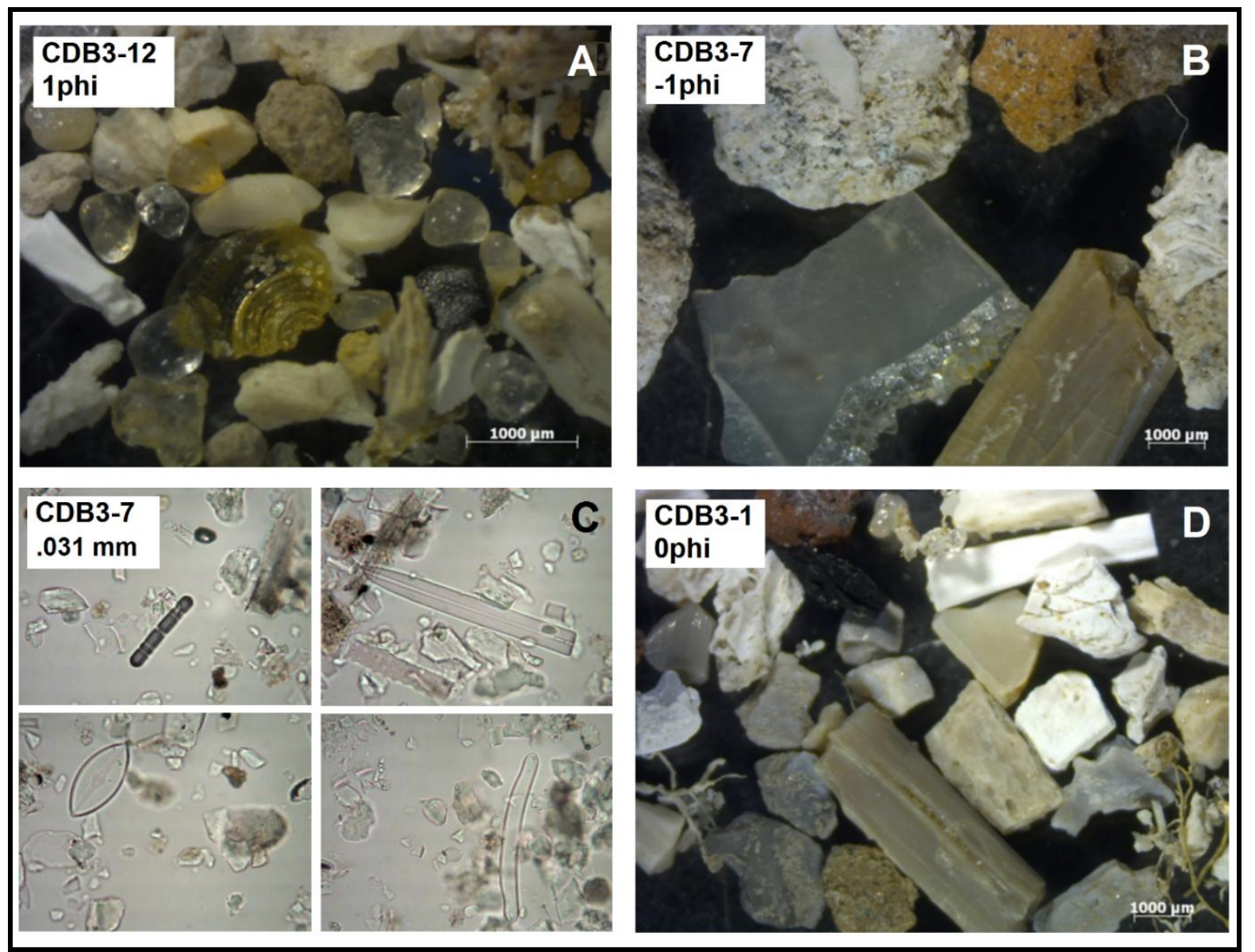

Figura 8.7. Composición sílico y bioclástica de las muestras sedimentarias del Grupo A del sitio arqueológico Cerro de Boari 3. A: muestra CDB3-12, arena gruesa (bioclastos -escamas de pez, carbón y semillas- y silicoclastos -rodados de cuarzo-). B: muestra CDB3-7, grava (grumos sedimentarios y microlascas de arenisca silicificada). C: muestra CDB3-7, en fracción limo <53 un (sílicofitolitos, vidrio volcánico, espículas de esporangios y cistos de crisófitas). D: muestra CDB3-1, arena muy gruesa (carbones, fragmentos óseos termoalterados, hematita, fragmentos líticos y grumos sedimentarios).

\subsubsection{2- Resultados de los estudios fitolíticos}

A partir de las siete muestras del perfil sur de la ampliación de la cuadrícula 1, se determinó que los microrrestos silíceos son abundantes en las muestras de la sección inferior de la columna estratigráfica, donde la asociación fitolítica está definida por la presencia de elementos graminoides, principalmente elongados, flabelos, poliédricos y aciculares acompañados de conos truncados de afinidad danthonioides, bilobados y cruces tipo panicoides y en menor frecuencia oblongos y crenados afines a gramíneas pooides. En las mismas muestras es frecuente la presencia de espículas de esporangios enteras y fragmentadas, y son escasas las diatomeas y los quistes de crisostomatácea. En la sección media se observó de escasa a nula presencia de microrrestos, mientras que en las sección superior la asociación quedó definida por elementos graminoides (elongados y en forma de abanico), bilobados panicoides, conos truncados danthonioides y fitolitos 
cónicos afines a ciperáceas. También se registró escasa presencia de espículas de esponjas y diatomeas (Figura 8.8).
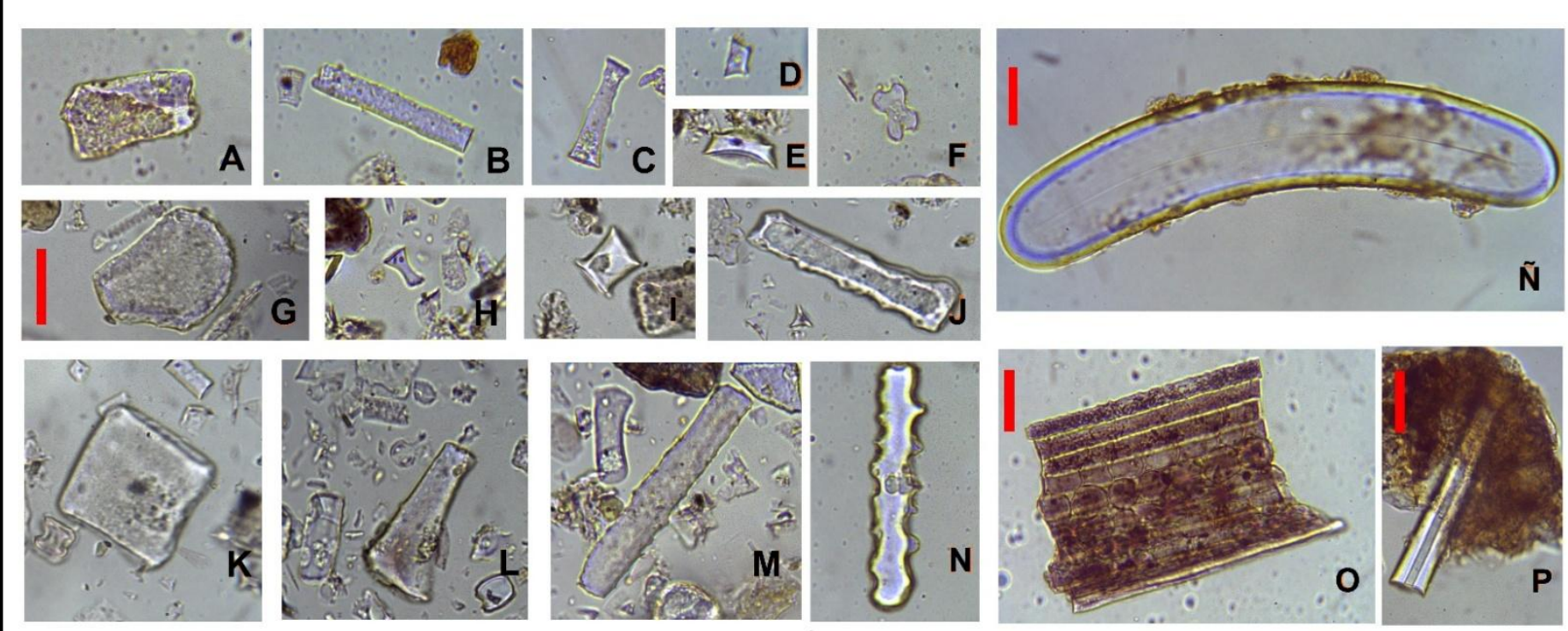

Figura 8.8. Microrestos biosilíceos presentes en las muestras analizadas del sitio arqueológico Cerro de Boari 3. A y B: fitolitos prismáticos lisos. C, D, E, H e I: forma de conos truncados. F: bilobados. $\mathbf{G}$ y L: forma de flabelos. J, $\mathbf{M}$ y $\mathbf{N}$ : prismáticos ondulados. $\mathbf{K}$ : poliédrico. $\mathbf{O}$ : fitolito articulado. $\tilde{\mathbf{N}}$ y $\mathbf{P}$ : espículas de esponjas.

Escala: 20 micrones.

\subsection{3- DATACIONES RADIOCARBÓNICAS}

Para la localidad arqueológica Cerros de Boari se han realizado 10 dataciones radiocarbónicas que se detallan en la Tabla 8.1. 
Tabla 8.1. Dataciones radiocarbónicas obtenidas en la localidad arqueológica Cerros de Boari.

\begin{tabular}{|c|c|c|c|c|c|c|}
\hline $\begin{array}{c}\text { Sitio } \\
\text { arqueológico }\end{array}$ & $\begin{array}{l}\text { Procedencia y profundidad desde } \\
\text { la superficie del montículo }(\mathrm{cm})\end{array}$ & Edad AP & $\begin{array}{l}\text { Edad calibrada } \\
\qquad \operatorname{AP}(1 \sigma)^{1}\end{array}$ & $\begin{array}{l}\text { Código de } \\
\text { laboratorio }\end{array}$ & Material & Referencia \\
\hline Cerro de Boari 2 & barreno $(60)$ & $1160 \pm 80$ & $930-1092$ & LP-3113 & $\begin{array}{l}\text { Materia } \\
\text { orgánica }\end{array}$ & este trabajo \\
\hline Cerro de Boari 2 & barreno $(105-110)$ & $1890 \pm 80$ & $1702-1889$ & LP-3080 & $\begin{array}{l}\text { Materia } \\
\text { orgánica }\end{array}$ & este trabajo \\
\hline Cerro de Boari 3 & sondeo $3(5-10)$ & $660 \pm 50$ & $555-645$ & LP-3078 & $\begin{array}{l}\text { Materia } \\
\text { orgánica }\end{array}$ & $\begin{array}{c}\text { Castro y } \\
\text { Castiñeira } 2017\end{array}$ \\
\hline Cerro de Boari 3 & cuadrícula 5 (50-55) & $1060 \pm 60$ & $806-967$ & LP-2590 & $\begin{array}{l}\text { Carbón } \\
\text { vegetal }\end{array}$ & Castro 2011 \\
\hline Cerro de Boari 3 & cuadrículas 7 y $8(20-45)$ & $1080 \pm 60$ & $820-1050$ & LP-2871 & $\begin{array}{l}\text { Hueso } \\
\text { humano }\end{array}$ & este trabajo \\
\hline Cerro de Boari 3 & cuadrículas $1,2,7$ y $8(20-45)$ & $1120 \pm 60$ & $928-1056$ & LP-2840 & $\begin{array}{l}\text { Hueso } \\
\text { humano }\end{array}$ & este trabajo \\
\hline Cerro de Boari 3 & sondeo $3(120-125)$ & $1130 \pm 40$ & $936-1053$ & LP-2744 & $\begin{array}{l}\text { Materia } \\
\text { orgánica }\end{array}$ & este trabajo \\
\hline Cerro de Boari 3 & cuadrícula 1 (95-100) & $1270 \pm 70$ & $1067-1261$ & LP-3069 & $\begin{array}{l}\text { Carbón } \\
\text { vegetal }\end{array}$ & este trabajo \\
\hline Cerro de Boari 3 & sondeo $3(130-140)$ & $1440 \pm 50$ & $1275-1349$ & LP-2746 & $\begin{array}{l}\text { Materia } \\
\text { orgánica }\end{array}$ & $\begin{array}{c}\text { Castro y } \\
\text { Castiñeira } 2017\end{array}$ \\
\hline Cerro de Boari 3 & cuadrículas 1 y $7(15-20)$ & moderno & - & LP-2573 & $\begin{array}{l}\text { Carbón } \\
\text { vegetal }\end{array}$ & este trabajo \\
\hline
\end{tabular}

(1) La calibración de las dataciones se realizó con el programa Calib 7.0. 


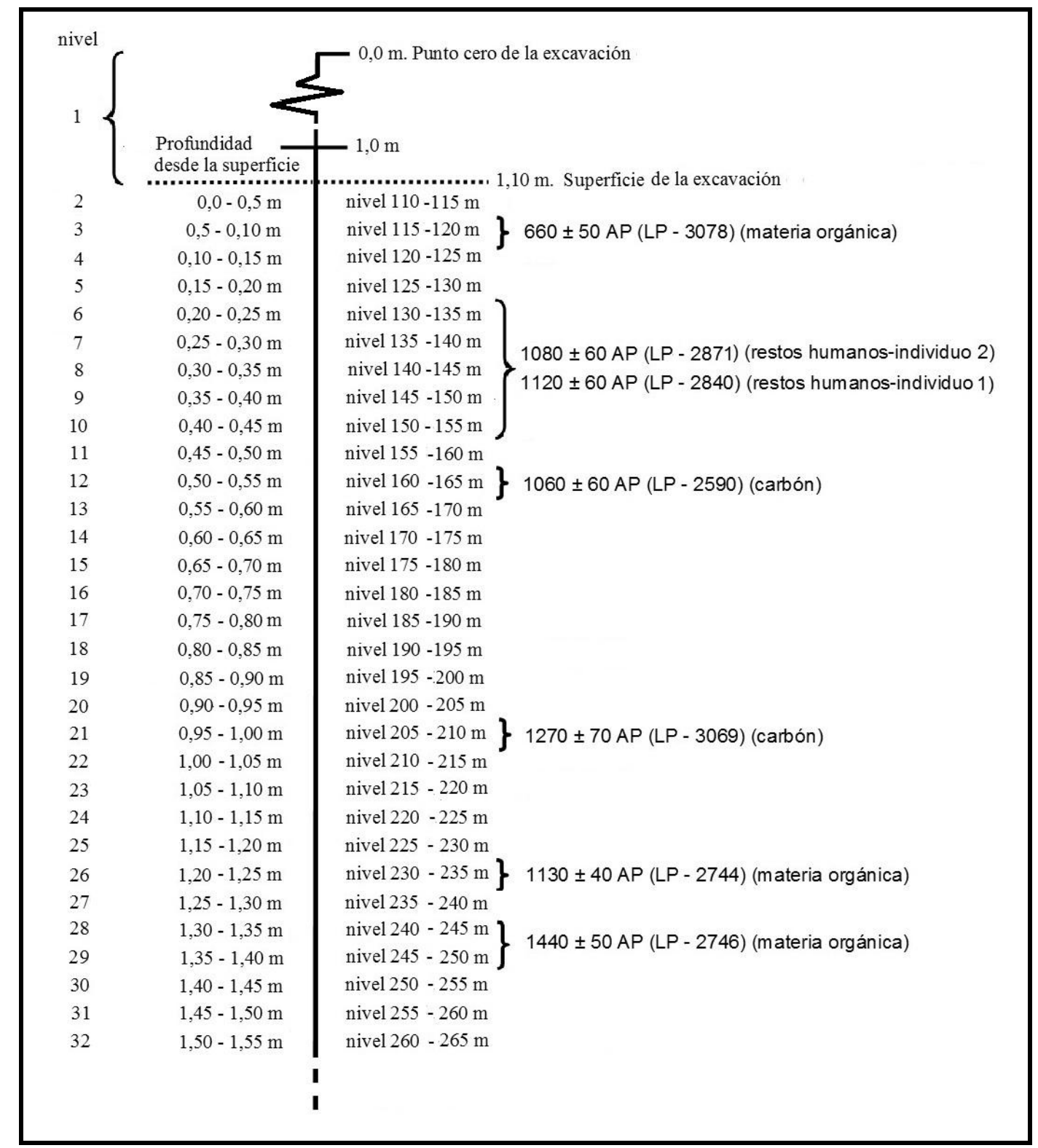

Figura 8.9. Niveles estratigráficos y dataciones radiocarbónicas del sitio arqueológico Cerro de Boari 3. El nivel 1 abarca $1,10 \mathrm{~m}$.

\subsection{4- MATERIALES ARQUEOLÓGICOS DE CERRO DE BOARI 3}

A continuación se presentan los resultados del análisis de los materiales obtenidos en las cuadrículas 1, 2 y 3 de la excavación sistemática de Cerro de Boari 3. Se consideran materiales procedentes de otras cuadriculas, sondeos estratigráficos y/o recolecciones superficiales realizadas en la localidad arqueológica Cerros de Boari cuando, debido a sus atributos particulares, los artefactos sean relevantes para este estudio (p. ej. instrumentos líticos y óseos). La Tabla 8.2 muestra las frecuencias de los distintos materiales recuperados en CDB3. 
Tabla 8.2. Materiales arqueológicos de Cerro de Boari 3.

\begin{tabular}{|c|c|c|c|c|c|c|c|c|c|c|c|}
\hline \multirow{2}{*}{ CUA } & \multicolumn{4}{|c|}{ Artefactos líticos } & \multicolumn{4}{|c|}{ Cerámica } & \multirow{2}{*}{$\frac{\text { Fauna }}{\text { NISP }}$} & \multirow{2}{*}{$\begin{array}{l}\text { Humano } \\
\text { NISPMNI }\end{array}$} & \multirow{2}{*}{$\begin{array}{c}\text { Total } \\
\text { general }\end{array}$} \\
\hline & INS & DES & NUC & Total & BOR & CUE & MOD & Total & & & \\
\hline 1 & 11 & 1073 & 4 & 1088 & 1245 & 9962 & 1 & 11208 & $12602^{1}$ & - & 24898 \\
\hline 2 & 4 & 977 & 7 & 988 & 1158 & 10149 & 2 & 11309 & - & - & 12297 \\
\hline 3 & 3 & 828 & 10 & 841 & 1265 & 9732 & 3 & 11000 & - & - & 11841 \\
\hline Total & 18 & 2878 & 21 & 2917 & 3668 & 29843 & 6 & 33517 & 12602 & $110 / 3$ & 49146 \\
\hline
\end{tabular}

CUA: cuadrículas; INS: instrumentos; DES: desechos; NUC: núcleos; BOR: bordes; CUE: cuerpos; NISP: Número de especímenes identificados; MNI: Número mínimo de individuos. (1) El valor incluye un instrumento óseo y

dos adornos sobre valvas de gasterópodos.

\subsubsection{1- Estructura del conjunto lítico de Cerro de Boari 3}

Dentro del conjunto lítico total $(n=2917)$ (Tabla 8.1), se observa un predominio de desechos de talla $(n=2878)$ por sobre los núcleos $(n=21)$ y los instrumentos $(n=28$; este valor agrupa a los instrumentos recuperados en las cuadrículas 1,2 y $3-n=18$ - y a los de otras procedencias $-n=10-$ ). La Tabla 8.3 muestra la representatividad de las materias primas en relación a las clases tipológicas de los artefactos recuperados en las cuadrículas 1,2 y 3.

Tabla 8.3. Materias primas por clases tipológicas en el sitio arqueológico Cerro de Boari 3.

\begin{tabular}{|c|c|c|c|c|c|c|c|c|}
\hline \multirow{3}{*}{ Materia prima } & \multicolumn{6}{|c|}{ Clases tipológicas } & & \\
\hline & \multicolumn{2}{|c|}{ Instrumentos } & \multicolumn{2}{|c|}{ Desechos de talla } & \multicolumn{2}{|c|}{ Núcleos } & \multicolumn{2}{|c|}{ Total } \\
\hline & $\mathrm{n}$ & $\%$ & $\mathrm{n}$ & $\%$ & $\mathrm{n}$ & $\%$ & $\mathrm{n}$ & $\%$ \\
\hline Calcedonia & 2 & 10,5 & 288 & 10 & 2 & 9,5 & 292 & 10 \\
\hline Caliza silicificada & 10 & 52,6 & 1618 & 56,3 & 13 & 61,9 & 1641 & 56,2 \\
\hline Silcreta & 4 & 21,1 & 404 & 14,04 & 4 & 19 & 412 & 14,1 \\
\hline Ágata & - & - & 3 & 0,1 & - & - & 3 & 0,1 \\
\hline Sílice & - & - & 170 & 5,9 & 1 & 4,8 & 171 & 5,9 \\
\hline Xilópalo & - & - & 1 & 0,03 & - & - & 1 & 0,03 \\
\hline Arenisca & 2 & 15,8 & 360 & 12,5 & 1 & 4,8 & 364 & 12,5 \\
\hline Cuarcita intertrap & - & - & 1 & 0,03 & - & - & 1 & 0,03 \\
\hline Cuarzo & - & - & 26 & 0,2 & - & - & 26 & 0,9 \\
\hline Indeterminada & - & - & 7 & 0,9 & - & - & 7 & 0,24 \\
\hline Total & $18^{1}$ & 100 & 2878 & 100 & 21 & 100 & 2917 & 100 \\
\hline
\end{tabular}

(1) Este valor no incluye los instrumentos recuperados por fuera de las cuadrículas 1,2 y 3 ( $n=10)$.

\section{Instrumentos}

En cuanto a los instrumentos (Tabla 8.4) se identificaron: un raspador (Figura 8.10A); seis piezas con retoque sumario (Figura 8.10B, C, D, E y F); ocho piezas con retoque; una piedra lenticular (Figura 810G); dos instrumentos indeterminados por fractura elaborados mediante picado, abrasión y/o pulido; y un percutor de ápice con rastros de utilización (picados y astillados) en uno de los polos del eje mayor, y su longitud es de 54,1 mm (Figura 8.10H). 
Tabla 8.4. Instrumentos líticos del sitio arqueológico Cerro de Boari 3.

\begin{tabular}{|c|c|c|c|c|c|c|c|c|c|}
\hline Procedencia & Grupo tipológico & $\begin{array}{l}\text { Subgrupo } \\
\text { tipológico }\end{array}$ & Serie técnica & $\begin{array}{c}\text { Materia } \\
\text { prima }\end{array}$ & Calidad $^{3}$ & Forma-base & $\begin{array}{c}\text { Módulo } \\
\text { L-A }\end{array}$ & Tamaño & $\begin{array}{c}\text { Espesor } \\
\text { relativo }\end{array}$ \\
\hline $\begin{array}{c}\text { CDB3-C1-4- } \\
\text { G9 }\end{array}$ & $\begin{array}{l}\text { piezas con } \\
\text { retoque }^{1,2}\end{array}$ & $\begin{array}{l}\text { retoque continuo } \\
\text { unifacial directo }\end{array}$ & $\begin{array}{l}\text { retoque } \\
\text { marginal }\end{array}$ & silcreta & B & $\begin{array}{c}\text { no } \\
\text { diferenciada }\end{array}$ & $\begin{array}{l}\text { mediano } \\
\text { alargado }\end{array}$ & pequeño & delgado \\
\hline $\begin{array}{l}\text { CDB3-C1-4- } \\
\text { G10 }\end{array}$ & $\begin{array}{l}\text { piezas con } \\
\text { retoque }^{1,2}\end{array}$ & $\begin{array}{c}\text { retoque continuo } \\
\text { unifacial directo }\end{array}$ & $\begin{array}{l}\text { retoque } \\
\text { marginal }\end{array}$ & silcreta & B & $\begin{array}{c}\text { no } \\
\text { diferenciada }\end{array}$ & $\begin{array}{c}\text { mediano } \\
\text { normal }\end{array}$ & pequeño & $\begin{array}{c}\text { muy } \\
\text { delgado }\end{array}$ \\
\hline $\begin{array}{l}\text { CDB3-C1-4- } \\
\text { G13 }\end{array}$ & $\begin{array}{l}\text { piezas con } \\
\text { retoque }^{1,2}\end{array}$ & no diferenciado & $\begin{array}{l}\text { retoque } \\
\text { marginal }\end{array}$ & calcedonia & $E$ & $\begin{array}{c}\text { no } \\
\text { diferenciada }\end{array}$ & $\begin{array}{l}\text { mediano } \\
\text { alargado }\end{array}$ & $\begin{array}{c}\text { muy } \\
\text { pequeño }\end{array}$ & $\begin{array}{c}\text { muy } \\
\text { delgado }\end{array}$ \\
\hline $\begin{array}{l}\text { CDB3-C1-5- } \\
\text { G1 }\end{array}$ & $\begin{array}{l}\text { piezas con } \\
\text { retoque }^{1,2}\end{array}$ & $\begin{array}{c}\text { retoque continuo } \\
\text { unifacial directo }\end{array}$ & $\begin{array}{l}\text { retoque } \\
\text { marginal }\end{array}$ & $\begin{array}{c}\text { caliza } \\
\text { silicificada }\end{array}$ & $E$ & $\begin{array}{c}\text { lasca } \\
\text { angular }\end{array}$ & $\begin{array}{c}\text { mediano } \\
\text { normal }\end{array}$ & pequeño & $\begin{array}{c}\text { muy } \\
\text { delgado }\end{array}$ \\
\hline $\begin{array}{c}\text { CDB3-C1-6- } \\
13 \\
\end{array}$ & $\begin{array}{c}\text { piezas con } \\
\text { retoque sumario }\end{array}$ & $\begin{array}{c}\text { retoque unifacial } \\
\text { inverso }\end{array}$ & $\begin{array}{l}\text { retoque } \\
\text { marginal }\end{array}$ & $\begin{array}{c}\text { caliza } \\
\text { silicificada }\end{array}$ & $E$ & $\begin{array}{c}\text { lasca } \\
\text { angular }\end{array}$ & $\begin{array}{c}\text { corto } \\
\text { ancho }\end{array}$ & $\begin{array}{l}\text { mediano } \\
\text { pequeño }\end{array}$ & grueso \\
\hline $\begin{array}{l}\text { CDB3-C1-6- } \\
25\end{array}$ & $\begin{array}{c}\text { picado, abrasión } \\
\text { y/o pulido }{ }^{2}\end{array}$ & $\begin{array}{c}\text { esferoide } \\
\text { "piedra } \\
\text { lenticular" }\end{array}$ & - & arenisca & $\mathrm{B}$ & $\begin{array}{c}\text { no } \\
\text { diferenciada }\end{array}$ & $\begin{array}{c}\text { mediano } \\
\text { normal }\end{array}$ & grande & $\begin{array}{l}\text { muy } \\
\text { grueso }\end{array}$ \\
\hline $\begin{array}{c}\text { CDB3-C1- } \\
\text { 10-G4 }\end{array}$ & $\begin{array}{l}\text { piezas con } \\
\text { retoque } \\
\text { sumario }^{1}\end{array}$ & $\begin{array}{l}\text { retoque unifacial } \\
\text { inverso }\end{array}$ & $\begin{array}{l}\text { retoque } \\
\text { marginal }\end{array}$ & $\begin{array}{c}\text { caliza } \\
\text { silicificada }\end{array}$ & $E$ & $\begin{array}{c}\text { lasca de } \\
\text { arista } \\
\text { inclinada }\end{array}$ & $\begin{array}{c}\text { mediano } \\
\text { normal }\end{array}$ & pequeño & $\begin{array}{c}\text { muy } \\
\text { delgado }\end{array}$ \\
\hline $\begin{array}{c}\text { CDB3-C1- } \\
\text { 12-G11 }\end{array}$ & $\begin{array}{c}\text { piezas con } \\
\text { retoque sumario }\end{array}$ & $\begin{array}{c}\text { retoque unifacial } \\
\text { inverso }\end{array}$ & $\begin{array}{l}\text { retoque } \\
\text { marginal }\end{array}$ & $\begin{array}{c}\text { caliza } \\
\text { silicificada }\end{array}$ & $E$ & $\begin{array}{c}\text { lasca } \\
\text { angular }\end{array}$ & $\begin{array}{c}\text { corto } \\
\text { ancho }\end{array}$ & pequeño & $\begin{array}{c}\text { muy } \\
\text { delgado }\end{array}$ \\
\hline $\begin{array}{c}\text { CDB3-C1- } \\
\text { 12-G22 }\end{array}$ & $\begin{array}{l}\text { piezas con } \\
\text { retoque }^{1,2}\end{array}$ & $\begin{array}{c}\text { bifacial - } \\
\text { unifacial inverso }\end{array}$ & $\begin{array}{l}\text { retoque } \\
\text { marginal }\end{array}$ & silcreta & B & $\begin{array}{c}\text { lasca } \\
\text { angular }\end{array}$ & $\begin{array}{l}\text { mediano } \\
\text { alargado }\end{array}$ & $\begin{array}{c}\text { muy } \\
\text { pequeño }\end{array}$ & $\begin{array}{c}\text { muy } \\
\text { delgado }\end{array}$ \\
\hline $\begin{array}{c}\text { CDB3-C1- } \\
16-10\end{array}$ & $\begin{array}{l}\text { piezas con } \\
\text { retoque sumario }\end{array}$ & $\begin{array}{l}\text { retoque unifacial } \\
\text { directo }\end{array}$ & $\begin{array}{l}\text { retoque } \\
\text { marginal }\end{array}$ & $\begin{array}{c}\text { caliza } \\
\text { silicificada }\end{array}$ & B & $\begin{array}{c}\text { no } \\
\text { diferenciada }\end{array}$ & $\begin{array}{l}\text { corto } \\
\text { muy } \\
\text { ancho }\end{array}$ & $\begin{array}{l}\text { mediano } \\
\text { pequeño }\end{array}$ & delgado \\
\hline $\begin{array}{c}\text { CDB3-C1- } \\
16-13\end{array}$ & percutor & de ápice & $\begin{array}{l}\text { nódulo con } \\
\text { rastros de } \\
\text { utilización }\end{array}$ & silcreta & $\mathrm{B}$ & $\begin{array}{l}\text { guijón } \\
\text { sub-oval }\end{array}$ & $\begin{array}{c}\text { mediano } \\
\text { normal }\end{array}$ & grande & $\begin{array}{l}\text { muy } \\
\text { grueso }\end{array}$ \\
\hline $\begin{array}{c}\text { CDB3-C2- } \\
\text { 10-G6 }\end{array}$ & $\begin{array}{l}\text { piezas con } \\
\text { retoque }^{1,2}\end{array}$ & no diferenciado & $\begin{array}{l}\text { retoque } \\
\text { marginal }\end{array}$ & $\begin{array}{c}\text { caliza } \\
\text { silicificada }\end{array}$ & $E$ & $\begin{array}{c}\text { lasca } \\
\text { angular }\end{array}$ & $\begin{array}{c}\text { mediano } \\
\text { normal }\end{array}$ & pequeño & delgado \\
\hline $\begin{array}{c}\text { CDB3-C2- } \\
\text { 12-G9 }\end{array}$ & $\begin{array}{l}\text { piezas con } \\
\text { retoque }^{1,2}\end{array}$ & no diferenciado & $\begin{array}{l}\text { retoque } \\
\text { marginal }\end{array}$ & $\begin{array}{c}\text { caliza } \\
\text { silicificada }\end{array}$ & $\mathrm{B}$ & $\begin{array}{c}\text { lasca } \\
\text { angular }\end{array}$ & $\begin{array}{l}\text { mediano } \\
\text { alargado }\end{array}$ & pequeño & delgado \\
\hline $\begin{array}{c}\text { CDB3-C2- } \\
15-G 26\end{array}$ & $\begin{array}{c}\text { piezas con } \\
\text { retoque }^{1}\end{array}$ & no diferenciado & $\begin{array}{l}\text { retoque } \\
\text { marginal }\end{array}$ & $\begin{array}{c}\text { caliza } \\
\text { silicificada }\end{array}$ & $\mathrm{B}$ & lasca plana & $\begin{array}{l}\text { mediano } \\
\text { alargado }\end{array}$ & pequeño & $\begin{array}{c}\text { muy } \\
\text { delgado }\end{array}$ \\
\hline $\begin{array}{c}\text { CDB3-C2- } \\
24-8 \\
\end{array}$ & raspador & filo convergente & $\begin{array}{l}\text { retoque } \\
\text { marginal }\end{array}$ & $\begin{array}{c}\text { caliza } \\
\text { silicificada }\end{array}$ & $E$ & $\begin{array}{c}\text { lasca de } \\
\text { arista recta }\end{array}$ & $\begin{array}{c}\text { mediano } \\
\text { normal }\end{array}$ & $\begin{array}{l}\text { mediano } \\
\text { grande }\end{array}$ & delgado \\
\hline $\begin{array}{c}\text { CDB3-C3-4- } \\
33\end{array}$ & $\begin{array}{c}\text { picado, abrasión } \\
\text { y/o pulido } 1,2\end{array}$ & $\begin{array}{c}\text { instrumento } \\
\text { no determinado }\end{array}$ & - & arenisca & $\mathrm{R}$ & $\begin{array}{c}\text { no } \\
\text { diferenciada }\end{array}$ & $\begin{array}{c}\text { mediano } \\
\text { normal }\end{array}$ & grande & $\begin{array}{l}\text { muy } \\
\text { grueso }\end{array}$ \\
\hline $\begin{array}{c}\text { CDB3-C3- } \\
14-26 \\
\end{array}$ & $\begin{array}{c}\text { piezas con } \\
\text { retoque sumario }\end{array}$ & retoque bifacial & $\begin{array}{c}\text { retoque } \\
\text { marginal }\end{array}$ & $\begin{array}{c}\text { caliza } \\
\text { silicificada }\end{array}$ & B & $\begin{array}{c}\text { lasca } \\
\text { angular }\end{array}$ & $\begin{array}{c}\text { corto } \\
\text { ancho }\end{array}$ & $\begin{array}{l}\text { mediano } \\
\text { pequeño }\end{array}$ & delgado \\
\hline $\begin{array}{c}\text { CDB3-C3- } \\
25-2\end{array}$ & $\begin{array}{l}\text { piezas con } \\
\text { retoque sumario }\end{array}$ & $\begin{array}{l}\text { retoque unifacial } \\
\text { directo }\end{array}$ & $\begin{array}{c}\text { retoque y } \\
\text { microretoque } \\
\text { marginal }\end{array}$ & calcedonia & B & $\begin{array}{c}\text { lasca } \\
\text { angular }\end{array}$ & $\begin{array}{c}\text { corto } \\
\text { ancho }\end{array}$ & grande & grueso \\
\hline
\end{tabular}

(1) Instrumentos fragmentados e incompletos. (2) No corresponden a ningún grupo tipológico sensu Aschero 1983.

(3) Calidad de las materias primas, E: excelente, B: buena, R: regular.

Se registraron 15 instrumentos confeccionados por lascados sobre materias primas de buena y excelente calidad, la forma-base de 11 son lascas (ocho angulares, dos de arista y una plana). Fueron elaborados mediante retoque y microrretoque marginal; cinco tienen retoque unifacial directo, cuatro unifacial inverso, uno bifacial, y uno combina bifacial con unifacial inverso. Entre los instrumentos enteros $(n=8)$ se registraron módulos longitud-anchura corto ancho $(n=4)$, mediano normal $(n=3)$ y corto muy ancho $(n=1)$; y tamaños mediano pequeño $(n=3)$, grande $(n=3)$, pequeño $(n=1)$ y mediano grande $(n=1)$. En cuanto al espesor relativo se registraron grueso $(n=2)$, muy grueso $(n=2)$, delgados $(n=2)$ y muy delgados $(n=1)$. En cuanto a los instrumentos fracturados los módulos y el espesor relativo están determinado por la fractura que presentan, probablemente los mismos en su estado entero tuvieron dimensiones mayores. 
Además de los instrumentos tallados se registraron dos confeccionados mediante picado, abrasión y/o pulido sobre arenisca; uno corresponde a un fragmento que no permite la identificación del instrumento entero y el restante es una piedra lenticular con forma-base indiferenciada. Se agrega un percutor con evidencias de uso como astilladuras confeccionado a partir de un guijón fluvial modificado por uso.

A los instrumentos de la Tabla 8.4 se agregan otros 10 confeccionados sobre arenisca y procedentes de las cuadrículas 5, 7, sondeo 3 y recolección superficial sobre la playa. Estos son: una bola con surco fragmentada que corresponde al tipo B (sensu González 1953); un instrumento indeterminado fragmentado con una cara plana; ambos elaborados mediante picado, abrasión y/o pulido; cuatro piedras con hoyuelos o "rompecocos", de las cuales tres están fragmentadas, dos de ellas directamente sobre los hoyuelos (Figura $8.10 \mathrm{~J}$ y $\mathrm{K}$ ) probablemente debido a la fuerza del golpe sobre ese mismo punto, lo que apoyaría la idea de que estos artefactos eran usados como yunques probablemente para romper los endocarpos de las palmeras mediante percusión. Una de las piezas presenta tres hoyuelos en diferentes caras (Figura 8.10J), otra tiene dos hoyuelos en diferentes caras (Figura 8.10L) y la tercera tiene un solo hoyuelo (Figura 8.10K); la pieza restante está entera y tiene un solo hoyuelo (Figura 8.10I). El registro de dos y tres hoyuelos en la misma pieza indica que estos instrumentos eran constantemente reutilizados. Las piedras con hoyuelos son instrumentos modificados por uso, aunque en dos de ellas se identificó una formatización previa mediante picado, abrasión y/o pulido.

Se suman dos artefactos clasificados aquí como pulidores o abradidores activos; uno de ellos presenta un canal en una de sus caras (Figura $8.10 \mathrm{M}$ ) y el otro es una pieza plana fragmentada en dos partes en cuyo perímetro se encuentran cinco concavidades (o "bocas") que delinean un contorno sinuoso del borde del instrumento (Figura 8.10N). Se propone que estas "bocas" o muescas cóncavas funcionaron superficies de abrasión y/o pulido probablemente de materiales blandos como madera o hueso. Los pulidores/abradidores son considerados instrumentos modificados por uso.

Por último, se agregan dos instrumentos analizados por la Dra. Alejandra Matarrese (FCNyMUNLP), que son: un yunque múltiple (rompecocos) y un artefacto indeterminado reciclado en una pieza con retoque sumario. En yunque está entero y pesa 3,99 kg.; su forma-base es un nódulo facetado sin modificaciones previas al uso, y presenta cuatro hoyuelos distribuidos en dos caras. Estas oquedades son de dimensiones y formas regulares y rastros de uso comunes; tienen diámetros entre 22 y $18 \mathrm{~mm}$, contorno circular, secciones transversal y longitudinal de tipo cóncava semicircular y media, y redondeo y desgaste por uso. La otra pieza constituye un caso de reciclaje donde un fragmento (lasca) de un artefacto picado/abradido fue utilizado como forma-base para confeccionar por talla un instrumento de formatización sumaria (Matarrese 2016). 


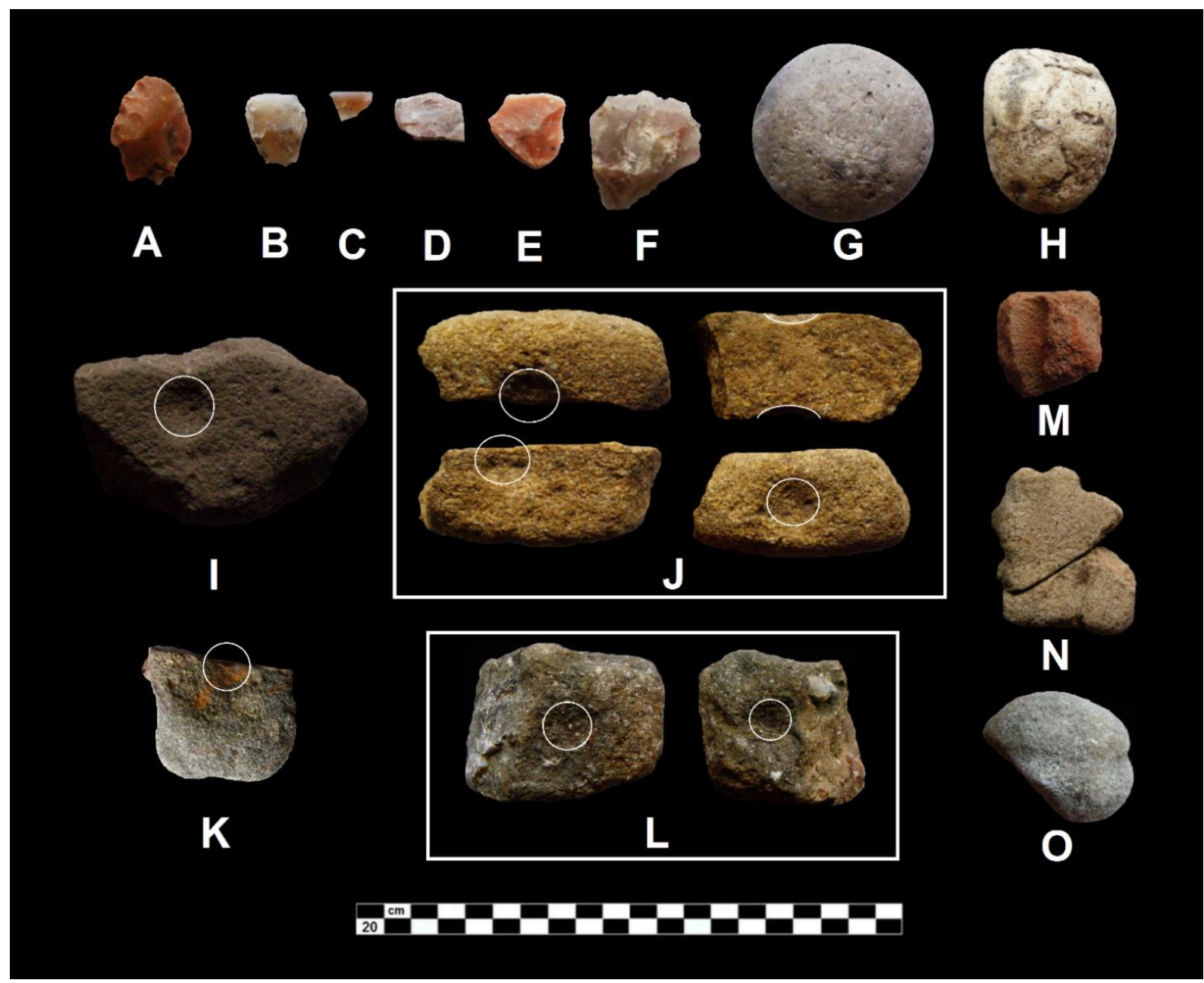

Figura 8.10. Instrumentos líticos del sitio arqueológico Cerro de Boari 3.

Raspador: A (CDB3-C2-24-8). Piezas con retoque sumario: B (CDB3-C1-6-13), C (CDB3-C1-10-G4),

D (CDB3-C1-16-10), E (CDB3-C3-14-26) y F (CDB3-C3-25-2). Piedra lenticular: G (CDB3-C1-6-25).

Percutor: H (CDB3-C1-16-13). Piedras con hoyuelos: I (CDB3-C7-4-3), J [CDB3-S3-3-A),

K [CDB-RS-playa-2014a) y L (CDB-RS-playa-2014b). Pulidores: M (CDB3-C5-12-G38),

N [CDB3-S3-5-C). Bola tipo B: O [CDB-RS-playa-2014c).

\section{Desechos de talla}

En el análisis integral de los desechos de talla desarrollado a continuación se incluyen solamente los artefactos de tamaño mayor a $1 \mathrm{~cm}(n=1586)$. Sobre el conjunto de microdesechos de tamaño menor a $1 \mathrm{~cm}(\mathrm{n}=1292)$ solo se realizó un análisis de 176 artefactos con el objetivo de observar tendencias generales (véase al final de esta sección).

\section{Fragmentación}

La Tabla 8.5 muestra la distribución de los desechos de talla de acuerdo a su estado de fragmentación. 
Tabla 8.5. Estado de fragmentación de la muestra de desechos de talla del sitio arqueológico Cerro de Boari 3.

\begin{tabular}{|c|c|c|c|c|c|c|c|c|c|c|c|}
\hline \multirow{3}{*}{ Cuadrícula } & \multicolumn{10}{|c|}{ Estado de fragmentación } & \multirow{3}{*}{ Tota } \\
\hline & \multicolumn{2}{|c|}{ ENT } & \multicolumn{2}{|c|}{ FCT } & \multicolumn{2}{|c|}{ FST } & \multicolumn{2}{|c|}{$\mathrm{NOC}$} & \multicolumn{2}{|c|}{ IND } & \\
\hline & $n$ & $\%$ & $\mathrm{n}$ & $\%$ & $\mathrm{n}$ & $\%$ & $\mathrm{n}$ & $\%$ & $\mathrm{n}$ & $\%$ & \\
\hline 1 & 97 & 45,1 & 103 & 34,6 & 93 & 35,2 & 104 & 35 & 162 & 31,6 & 559 \\
\hline 2 & 70 & 32,6 & 94 & 31,5 & 109 & 41,3 & 107 & 36 & 203 & 39,7 & 583 \\
\hline 3 & 48 & 22,3 & 101 & 33,9 & 62 & 23,5 & 86 & 29 & 147 & 28,7 & 444 \\
\hline Total & 215 & 100 & 298 & 100 & 264 & 100 & 297 & 100 & 512 & 100 & 1586 \\
\hline
\end{tabular}

ENT: lasca entera; FCT: lasca fracturada con talón; FST: lasca fracturada sin talón; NOC: desecho no clasificable; IND: desecho indiferenciado.

Se observa un predominio de los desechos indiferenciados $(n=512 ; 32,3 \%)$ sobre las lascas fracturadas con talón ( $n=298 ; 18,8 \%)$, los no clasificables $(n=297 ; 18,7 \%)$, las lascas fracturadas sin talón $(n=264 ; 16,6 \%)$ y las lascas enteras $(n=215 ; 13,6 \%)$.

\section{Formas de las lascas}

Dentro de los desechos de talla, excluyendo aquellos cuyo estado de fragmentación es indiferenciado, se registran varios tipos de lascas $(n=1074)$ (Tabla 8.6). Predominan las internas $(n=$ $805 ; 75 \%)$ sobre las externas ( $n=130 ; 12,1 \%)$, el resto son indiferenciadas ( $n=139 ; 12,9 \%)$. A su vez, dentro de las lascas internas predominan las de arista $(n=288 ; 26,9 \%)$, seguidas por las angulares ( $n=$ $285 ; 26,5 \%)$, planas $(n=228 ; 21,2 \%)$, tableta de núcleo $(n=3 ; 0,3 \%)$ y bipolar $(n=1 ; 0,1 \%)$. Dentro de las angulares se registró una lasca de adelgazamiento bifacial. La lasca bipolar es interna (angular) y corresponde al grupo 3 de la clasificación de Bonomo (2004: 161). En cuanto a las lascas externas, se observa un predominio de las primarias $(n=72 ; 6,7 \%)$ sobre las secundarias $(n=43 ; 4 \%)$ y las lascas con dorso natural $(n=15 ; 1,4 \%)$.

Tabla 8.6.Tipos de lascas del sitio arqueológico Cerro de Boari 3.

\begin{tabular}{|c|c|c|c|c|c|c|c|c|c|c|c|c|c|c|c|c|c|c|c|}
\hline \multirow{3}{*}{ CUA } & \multicolumn{18}{|c|}{ Tipo de lasca } & \multirow{3}{*}{ Total } \\
\hline & \multicolumn{2}{|c|}{ PRI } & \multicolumn{2}{|c|}{ SEC } & \multicolumn{2}{|c|}{ DON } & \multicolumn{2}{|c|}{ ANG } & \multicolumn{2}{|c|}{$\mathrm{ARI}$} & \multicolumn{2}{|c|}{ PLA } & \multicolumn{2}{|c|}{ BIP } & \multicolumn{2}{|c|}{$\mathrm{TAB}$} & \multicolumn{2}{|c|}{ IND } & \\
\hline & $\mathrm{n}$ & $\%$ & $\mathrm{n}$ & $\%$ & $\mathrm{n}$ & $\%$ & $\mathrm{n}$ & $\%$ & $\mathrm{n}$ & $\%$ & $\mathrm{n}$ & $\%$ & $\mathrm{n}$ & $\%$ & $\mathrm{n}$ & $\%$ & $\mathrm{n}$ & $\%$ & \\
\hline 1 & 18 & 25 & 16 & 37,2 & 6 & 40 & $137^{1}$ & 48,1 & 111 & 38,6 & 82 & 36 & - & - & 3 & 100 & 24 & 17,3 & 397 \\
\hline 2 & 29 & 40,3 & 15 & 34,9 & 5 & 33,3 & 85 & 29,8 & 98 & 34 & 88 & 38,6 & 1 & 100 & - & - & 59 & 42,4 & 380 \\
\hline 3 & 25 & 34,7 & 12 & 27,9 & 4 & 26,7 & 63 & 22,1 & 79 & 27,4 & 58 & 25,4 & - & - & - & - & 56 & 40,3 & 297 \\
\hline Total & 72 & 100 & 43 & 100 & 15 & 100 & 285 & 100 & 288 & 100 & 228 & 100 & 1 & 100 & 3 & 100 & 139 & 100 & 1074 \\
\hline
\end{tabular}

CUA: cuadrícula; PRI: lasca primaria; SEC: lasca secundaria; DON: lasca con dorso natural; ANG: lasca angular; ARI: lasca de arista; PLA: lasca plana; BIP: lasca bipolar; TAB: lasca tableta de núcleo; IND; lasca indiferenciada.

(1) Se incluye una lasca de adelgazamiento bifacial. 
La Tabla 8.7 muestra la distribución de los distintos tipos de talones y bulbos identificados en lascas enteras y fracturadas con talón; así como los distintos tipos de bulbos que se pudieron identificar en las lascas fracturadas sin talón.

Tabla 8.7. Distribución de la forma e inclinación del talón en relación a la forma del bulbo de percusión de las lascas del sitio arqueológico Cerro de Boari 3.

\begin{tabular}{|c|c|c|c|c|c|c|c|}
\hline \multicolumn{3}{|c|}{ Lasca enteras y fracturadas con talón } & \multirow{2}{*}{\multicolumn{3}{|c|}{ Cuadrícula }} & \multirow{2}{*}{\multicolumn{2}{|c|}{ Total }} \\
\hline \multicolumn{2}{|c|}{ Talón } & \multirow{2}{*}{$\begin{array}{c}\text { Forma } \\
\text { del Bulbo }\end{array}$} & & & & & \\
\hline Forma & Inclinación & & 1 & 2 & 3 & $\mathrm{n}$ & $\%$ \\
\hline \multirow{2}{*}{\multicolumn{2}{|c|}{ recto }} & difuso & 2 & 1 & 1 & 4 & \multirow{5}{*}{2,1} \\
\hline & & pronunciado & - & 1 & 2 & 3 & \\
\hline \multirow[t]{3}{*}{ Natural } & \multirow{2}{*}{ oblicuo } & difuso & 1 & 1 & - & 2 & \\
\hline & & pronunciado & 1 & - & - & 1 & \\
\hline & indiferenciado & indiferenciado & - & 1 & - & 1 & \\
\hline \multirow{4}{*}{ Liso natural } & \multirow{3}{*}{ recto } & difuso & 4 & 6 & 3 & 13 & \multirow{4}{*}{4,7} \\
\hline & & pronunciado & 2 & 1 & 1 & 4 & \\
\hline & & difuso & 3 & 2 & 1 & 6 & \\
\hline & oblicuo & indiferenciado & - & - & 1 & 1 & \\
\hline \multirow{6}{*}{\multicolumn{2}{|c|}{ oblicuo }} & difuso & 48 & 26 & 34 & 108 & \multirow{6}{*}{55,6} \\
\hline & & pronunciado & 28 & 25 & 14 & 67 & \\
\hline & & indiferenciado & 4 & 6 & 3 & 13 & \\
\hline & & difuso & 26 & 14 & 10 & 49 & \\
\hline & & pronunciado & 8 & 17 & 19 & 44 & \\
\hline & & indiferenciado & - & 1 & 2 & 4 & \\
\hline \multirow{5}{*}{\multicolumn{2}{|c|}{ oblicuo }} & difuso & - & - & 2 & 2 & \multirow{5}{*}{2,3} \\
\hline & & pronunciado & 2 & 1 & 1 & 4 & \\
\hline & & indiferenciado & - & - & 1 & 1 & \\
\hline & & difuso & 1 & - & 1 & 2 & \\
\hline & & pronunciado & 1 & 1 & 1 & 3 & \\
\hline \multirow{4}{*}{ Facetado } & & difuso & 4 & 4 & 5 & 13 & \multirow{4}{*}{5,8} \\
\hline & recto & pronunciado & 4 & 5 & 5 & 14 & \\
\hline & & indiferenciado & 1 & - & - & 1 & \\
\hline & oblicuo & difuso & 1 & 1 & - & 2 & \\
\hline & & difuso & 17 & 6 & 16 & 39 & \\
\hline & recto & pronunciado & 11 & 11 & 9 & 31 & \\
\hline & & indiferenciado & - & 1 & 1 & 2 & \\
\hline Filiforme & & difuso & 2 & - & - & 2 & 16,4 \\
\hline & oblicuo & pronunciado & 3 & - & - & 3 & \\
\hline & & difuso & 1 & 1 & - & 2 & \\
\hline & ındıterencıado & pronunciado & 1 & 2 & 2 & 5 & \\
\hline & & difuso & 4 & 2 & 1 & 7 & \\
\hline & recto & pronunciado & 4 & 1 & 1 & 6 & \\
\hline & & difuso & 1 & - & - & 1 & \\
\hline Puntiforme & oblicuo & pronunciado & 1 & 1 & - & 2 & 4,3 \\
\hline & indiferenciadn & difuso & 3 & 1 & - & 4 & \\
\hline & Inditerenciado & pronunciado & - & 1 & 1 & 2 & \\
\hline & & difuso & 5 & 9 & 1 & 15 & \\
\hline & recto & pronunciado & 3 & 3 & 7 & 13 & \\
\hline & & indiferenciado & - & 2 & - & 2 & \\
\hline Fracturado & oblicun & difuso & - & 5 & - & 5 & 8,8 \\
\hline & Oblicuo & pronunciado & 1 & - & 1 & 2 & \\
\hline & indiferenciado & difuso & 2 & 4 & 2 & 8 & \\
\hline Total & & & 200 & 164 & 149 & 513 & 100 \\
\hline & ascas fracturadas & alón & & & & & \\
\hline & & difuso & 61 & 53 & 30 & 144 & 54,5 \\
\hline & talón & pronunciado & 29 & 23 & 14 & 66 & 25 \\
\hline & & indiferenciado & 3 & 33 & 18 & 54 & 20,5 \\
\hline Total & & & 93 & 109 & 62 & 264 & 100 \\
\hline
\end{tabular}


A partir de la Tabla 8.7 se observa que el talón y el bulbo más frecuente son el liso y el difuso respectivamente. En todos los tipos de talones, excepto el facetado, es más frecuente la asociación entre inclinación recta y bulbos difusos. Asimismo, dentro de las lascas sin talón también predomina el bulbo difuso. La mayor asociación entre los atributos considerados se da entre talones lisos con inclinación recta y bulbos difusos ( $n=108)$, seguidos por aquellos con bulbos pronunciados $(n=67)$.

\section{Bulbos y labios}

La Tabla 8.8 muestra la distribución de los distintos tipos bulbos de acuerdo a la ausencia (A) o presencia $(P)$ de labio en lascas enteras y fracturadas con talón.

Tabla 8.8. Presencia de labio según las formas de los bulbos de percusión de las lascas enteras y fracturadas con talón del sitio arqueológico Cerro de Boari 3.

\begin{tabular}{|c|c|c|c|c|c|c|}
\hline \multirow{2}{*}{ Cuadrícula } & \multirow{2}{*}{ Labio $^{1}$} & \multicolumn{3}{|c|}{ Forma del Bulbo } & \multicolumn{2}{|c|}{ Total } \\
\hline & & Difuso & Pronunciado & Indiferenciado & $\mathrm{n}$ & $\%$ \\
\hline 1 & $\begin{array}{l}A \\
P\end{array}$ & $\begin{array}{l}52 \\
73\end{array}$ & $\begin{array}{l}11 \\
59\end{array}$ & $\begin{array}{l}5 \\
-\end{array}$ & $\begin{array}{c}68 \\
132\end{array}$ & $\begin{array}{l}13,3 \\
25,7\end{array}$ \\
\hline 2 & $\begin{array}{l}A \\
P\end{array}$ & $\begin{array}{l}31 \\
52\end{array}$ & $\begin{array}{l}10 \\
59\end{array}$ & $\begin{array}{c}10 \\
2\end{array}$ & $\begin{array}{c}51 \\
113\end{array}$ & $\begin{array}{l}9,9 \\
22\end{array}$ \\
\hline 3 & $\begin{array}{l}A \\
P\end{array}$ & $\begin{array}{l}37 \\
40\end{array}$ & $\begin{array}{c}5 \\
59\end{array}$ & $\begin{array}{l}7 \\
1\end{array}$ & $\begin{array}{c}49 \\
100\end{array}$ & $\begin{array}{c}9,6 \\
19,5\end{array}$ \\
\hline $\begin{array}{c}\text { Total } \\
\%\end{array}$ & & $\begin{array}{r}285 \\
55,5\end{array}$ & $\begin{array}{r}203 \\
39,6\end{array}$ & $\begin{array}{l}25 \\
4,9\end{array}$ & 513 & 100 \\
\hline
\end{tabular}

(1) A: ausencia de labio; P: presencia de labio.

De la tabla 8.8 se desprende que predominan las lascas con bulbo difuso por sobre los demás tipos de bulbos. Asimismo, se observa que el $67,2 \%(n=345)$ de las lascas presentan labio, y que este se encuentra en frecuencias casi semejantes tanto en lascas con bulbo pronunciado ( $n=177 ; 34,5 \%)$ como difuso $(n=165 ; 32,1 \%)$.

\section{Origen de extracción de las lascas y formas-base}

De acuerdo al origen de extracción de las lascas se determinaron 805 internas, 130 externas y 139 indiferenciadas (Tabla 8.6), a las que se suman 512 desechos cuyo estado de fragmentación es indiferenciado (Tabla 8.5). A partir de 80 lascas externas y 18 internas, seis indiferenciadas y 44 desechos indiferenciados, con reserva de corteza en su cara dorsal y/o talón, se pudo determinar que las formas-base primarias utilizadas corresponden a: rodados indeterminados $(n=83 ; 56,1 \%)$, facetados $(n=17 ; 11,5 \%)$, subesféricos $(n=15 ; 10,1 \%)$, angulares $(n=3 ; 2 \%)$, y clastos $(n=30 ; 20,3)$. A partir de los desechos de talla restantes $(n=1438)$ no se pudieron diferenciar las formas-base de los núcleos. 


\section{Negativos de lascados y reserva de corteza}

La Tabla 8.9 presenta la distribución de los tipos de lascas de acuerdo a la cantidad de negativos de lascados y a la proporción de corteza en la cara dorsal. La tendencia general esperada es que, a mayor número de lascados menor será la proporción de corteza.

Tabla 8.9. Distribución de tipos de lascas en el sitio arqueológico Cerro de Boari 3 según la proporción de corteza y el número de negativos de lascados en la cara dorsal.

\begin{tabular}{|c|c|c|c|c|c|c|c|c|c|c|c|c|c|c|c|c|c|c|c|c|c|c|}
\hline \multirow{4}{*}{$\begin{array}{c}\text { Tipo } \\
\text { de lasca }\end{array}$} & \multirow{4}{*}{$\begin{array}{l}\text { Proporción } \\
\text { de corteza }\end{array}$} & \multicolumn{20}{|c|}{ Negativos de lascados } & \multirow[b]{4}{*}{ Total } \\
\hline & & \multicolumn{20}{|c|}{ Cuadrículas } & \\
\hline & & \multicolumn{6}{|c|}{1} & \multicolumn{7}{|c|}{2} & \multicolumn{7}{|c|}{3} & \\
\hline & & 0 & 1 & 2 & 3 & 4 & $5>$ & & ) & 1 & 2 & 3 & 4 & $>5$ & 0 & 1 & 2 & 3 & 4 & 5 & $>5$ & \\
\hline Primaria & $100 \%$ & 18 & - & - & - & - & - - & & 9 & - & - & - & - & - & 25 & - & - & - & - & - & - & 72 \\
\hline \multirow{2}{*}{ Secundaria } & $>50 \%$ & - & 6 & 1 & - & 1 & - & & - & 3 & 1 & 1 & - & - & - & 1 & 1 & - & 1 & - & - & 16 \\
\hline & $<50 \%$ & - & 7 & 1 & - & - & - & & 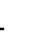 & 5 & 4 & - & 1 & - & - & 8 & 1 & - & - & - & - & 27 \\
\hline Con dorso natural & $0 \%$ & - & 3 & 2 & 1 & - & - & & 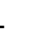 & 5 & - & - & - & - & - & 3 & 1 & - & - & - & - & 15 \\
\hline \multirow{2}{*}{ Angular } & $<50 \%$ & - & 1 & 1 & 3 & - & - & & 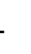 & - & - & 2 & - & - & - & - & - & 2 & 1 & - & - & 10 \\
\hline & $0 \%$ & - & - & 12 & 90 & 26 & 31 & & - & - & - & 66 & 16 & 1 & - & - & 4 & 45 & 7 & 3 & 1 & 275 \\
\hline De arista & $0 \%$ & - & - & 105 & 5 & 1 & - & & - & - & 88 & 10 & - & - & - & 1 & 74 & 2 & 2 & - & - & 288 \\
\hline Plana & $0 \%$ & - & 81 & 1 & - & - & - - & & 9 & 79 & - & - & - & - & - & 58 & - & - & - & - & - & 228 \\
\hline Bipolar & $0 \%$ & - & - & - & - & - & - - & & - & - & - & 1 & - & - & - & - & - & - & - & - & - & 1 \\
\hline $\begin{array}{l}\text { Tableta de } \\
\text { núcleo }\end{array}$ & $0 \%$ & - & 1 & - & 2 & - & - & & - & - & - & - & - & - & - & - & - & - & - & - & - & 3 \\
\hline \multirow{2}{*}{ Indiferenciada } & $0 \%$ & 2 & 13 & 9 & - & - & - & & 1 & 43 & 12 & - & 1 & - & - & 48 & 7 & 1 & - & - & - & 137 \\
\hline & $100 \%$ & - & - & - & - & - & - - & & 2 & - & - & - & - & - & - & - & - & - & - & - & - & 2 \\
\hline Total general & & 20 & 112 & 132 & 101 & 28 & 31 & & 1 & 135 & 105 & 80 & & 1 & & 119 & 88 & 50 & 11 & 3 & 1 & 1074 \\
\hline
\end{tabular}

Las lascas externas presentan corteza y en general menor número de lascados que las internas. Todas las lascas con menos del $50 \%$ de corteza $(n=27)$ son secundarias y predominan las que tienen un lascado $(n=20)$. También son secundarias la que tienen más del $50 \%$ de corteza $(n=16)$ y predominan las que tienen un lascado $(n=10)$. Todas la primarias $(n=72)$ presentan corteza total y ausencia de lascados; así como todas las lascas con dorso natural $(n=15)$ no presentan corteza más que en su dorso, y dentro de ellas predominan las que tienen un lascado $(n=11)$.

Las lascas internas en general no presentan corteza, la diferencia entre ellas reside en el número de lascados que presentan en su cara dorsal. Dentro de las lascas de arista $(n=288)$ predominan ampliamente la que tienen dos negativos de lascado $(n=267)$. Dentro de las angulares $(n=285)$ (10 presentan remanentes de corteza) predominan las que tienen tres negativos de lascado 
$(n=188)$, seguidas por las que tienen cuatro lascados $(n=50)$. Dentro de las planas $(n=228)$ predominan las que no tienen lascados en su cara dorsal $(n=218)$.

\section{Dimensiones relativas}

Los módulos longitud-anchura y tamaño, y el espesor relativo se calcularon para lascas enteras ( $n=215)$ (Tablas 8.10, 8.11 y 8.12$)$.

Tabla 8.10. Módulo longitud-anchura de las lascas enteras del sitio arqueológico Cerro de Boari 3.

\begin{tabular}{|c|c|c|c|c|c|}
\hline \multirow{2}{*}{ Módulo L-A } & \multicolumn{3}{|c|}{ Cuadrículas } & \multicolumn{2}{|c|}{ Total } \\
\hline & 1 & 2 & 3 & $\mathrm{n}$ & $\%$ \\
\hline Corto anchísimo & - & 3 & 1 & 4 & 1,9 \\
\hline Corto muy ancho & 15 & 9 & 5 & 29 & 13,5 \\
\hline Corto ancho & 27 & 21 & 14 & 62 & 28,8 \\
\hline Mediano normal & 33 & 22 & 21 & 76 & 35,3 \\
\hline Mediano alargado & 12 & 9 & 6 & 27 & 12,6 \\
\hline Laminar normal & 10 & 6 & 1 & 17 & 7,9 \\
\hline Total & 97 & 70 & 48 & 215 & 100 \\
\hline
\end{tabular}

Tabla 8.11. Módulo tamaño de las lascas enteras del sitio arqueológico Cerro de Boari 3.

\begin{tabular}{|c|c|c|c|c|c|}
\hline \multirow{2}{*}{ Tamaño } & \multicolumn{3}{|c|}{ Cuadrículas } & \multicolumn{2}{|c|}{ Total } \\
\hline & 1 & 2 & 3 & $\mathrm{n}$ & $\%$ \\
\hline Muy pequeño & 26 & 13 & 6 & 45 & 20,9 \\
\hline Pequeño & 50 & 44 & 31 & 125 & 58,2 \\
\hline Mediano pequeño & 16 & 10 & 9 & 35 & 16,3 \\
\hline Mediano grande & 4 & 2 & 2 & 8 & 3,7 \\
\hline Grande & 1 & 1 & - & 2 & 0,9 \\
\hline Total & 97 & 70 & 48 & 215 & 100 \\
\hline
\end{tabular}

Tabla 8.12. Espesores relativos de las lascas enteras del sitio arqueológico Cerro de Boari 3.

\begin{tabular}{|c|c|c|c|c|c|}
\hline \multirow{2}{*}{ Espesor relativo } & \multicolumn{3}{|c|}{ Cuadrículas } & \multicolumn{2}{|c|}{ Total } \\
\hline & 1 & 2 & 3 & $\mathrm{n}$ & $\%$ \\
\hline Muy delgado & 68 & 39 & 32 & 139 & 64,7 \\
\hline Delgado & 20 & 27 & 12 & 59 & 27,5 \\
\hline Grueso & 8 & 4 & 4 & 16 & 7,4 \\
\hline Muy grueso & 1 & - & - & 1 & 0,4 \\
\hline Total & 97 & 70 & 48 & 215 & 100 \\
\hline
\end{tabular}

En relación a la longitud-anchura predominan levemente las lascas medianas ( $n=103 ; 47,9 \%)$ por sobre las cortas $(n=95 ; 44,2 \%)$, seguidas por las laminares $(n=17 ; 7,9 \%)$. En cuanto al tamaño, 
predominan ampliamente las lascas pequeñas ( $n=170 ; 79,1 \%)$ por sobre las medianas $(n=43 ; 20 \%)$, y en muy baja frecuencia se registran las grandes ( $n=2 ; 0,9 \%)$. El espesor relativo más frecuente es el muy delgado ( $n=139 ; 64,7 \%$ ), seguido por lascas que van disminuyendo su frecuencia a medida que aumenta el espesor. En conjunto, se puede plantear que las lascas enteras más frecuentes son las de tamaño pequeño y espesor relativo muy delgado, tanto de longitud-anchura medianas como cortas.

\section{Rastros complementarios, regularización del frente de extracción y alteración térmica}

La presencia de rastros complementarios sobre filos naturales en los desechos de talla fue registrada en 25 lascas: 13 angulares, cinco de arista, cuatro planas, dos indiferenciadas y una tableta de núcleo. Los rastros corresponden a melladuras, microlascados y ultramicrolascados combinados. Se registraron dos lascas de arista con rastros complementarios sobre el talón, una presenta abrasión y la otra retoque complementario de preparación. Se agrega una lasca de arista con regularización del frente de extracción mediante abrasión.

En 122 casos se registraron evidencias de alteración térmica, los desechos presentan un color blanco y en pocos casos negro (sobre todo en areniscas), además se registró la presencia de craquelado y/o pequeños desprendimientos de materia. Las materias primas más afectas son las silcretas $(n=49)$, seguidas por el sílice $(n=46)$ y en menor frecuencia por la caliza silicificada $(n=14)$, la arenisca $(n=11)$ y la calcedonia $(n=2)$. Si se considera que tanto las silcretas y las calizas silicificadas provienen de la Formación Guichón, y probablemente también algunos de los sílices dado que su coloración actual producto de la alteración térmica dificulta la adjudicación a algún depósito geológico con mayor especificidad, se observa que las rocas de ésta formación son las que más frecuentemente fueron sometidas a la acción del fuego y/o calor.

\section{Núcleos}

El conjunto lítico de Cerro de Boari 3 presenta 21 núcleos (Tabla 8.13). 
Tabla 8.13. Núcleos del sitio arqueológico Cerro de Boari 3.

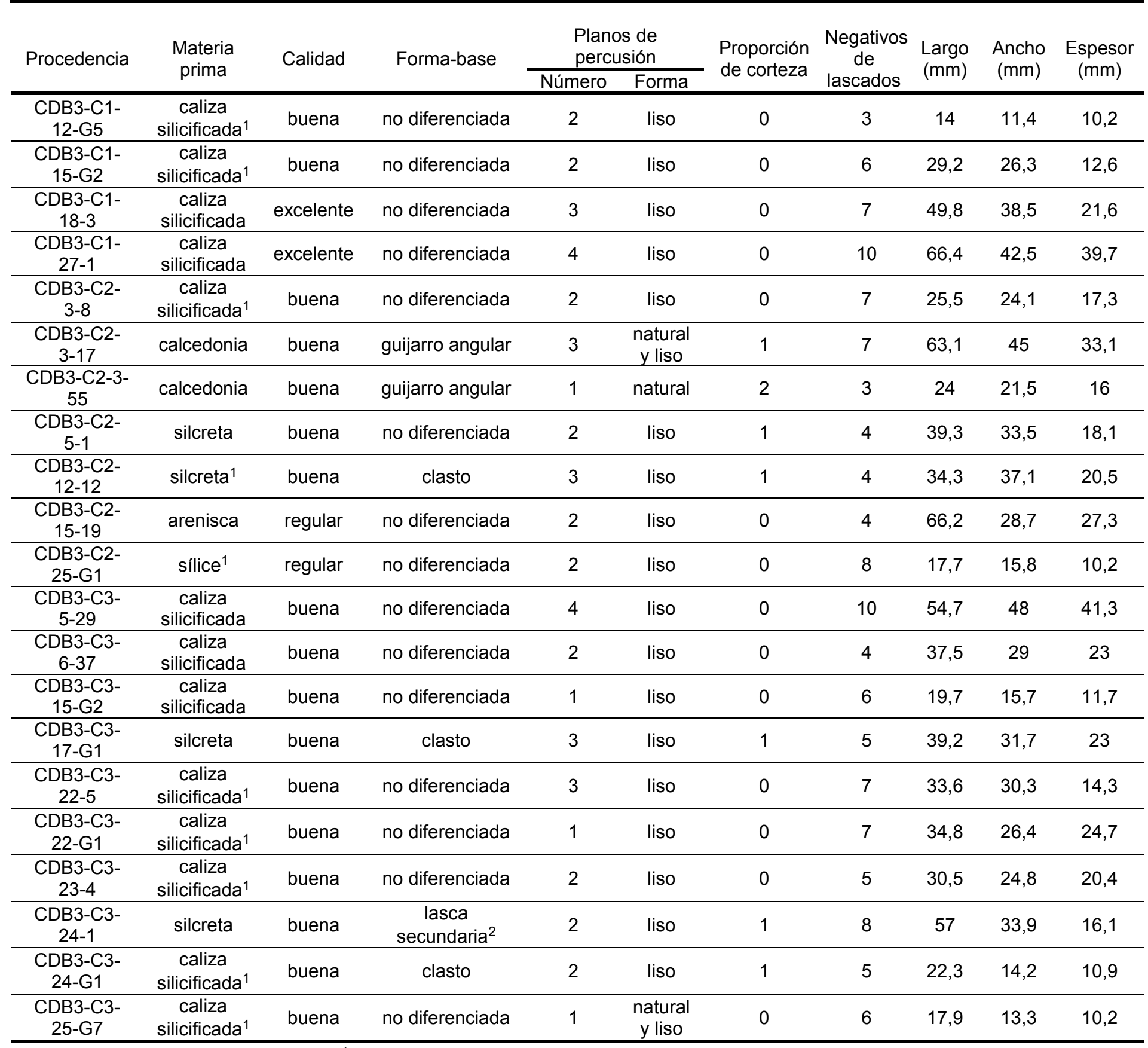

(1) Núcleos agotados; (2) Corresponde a un nucleiforme.

En todos los casos las materias primas son silíceas de buena a excelente calidad. Las formasbase determinadas indican que en dos casos corresponden a guijarros fluviales, en tres casos corresponden a clastos, y en un caso a una lasca secundaria con extracciones (nucleiforme); las cuatro últimas proceden de la Formación Guichón.

Del total de núcleos, 20 presentan planos de percusión lisos y en dos casos estos se combinan con planos naturales; uno solo núcleo tiene plano natural. Predominan los núcleos con dos planos de percusión utilizados $(n=10)$ seguidos por los que tienen tres $(n=5)$, uno $(n=4)$ y cuatro $(n=$ 2) respectivamente. Se registraron de tres a 10 lascados por núcleo, siendo siete lascados los más 
frecuentes ya que se registraron en cinco núcleos. Solo en siete núcleos se observó remanente de corteza y en seis casos esta es menor al 50\%. La medida máxima de los núcleos no sobrepasa los 7 $\mathrm{cm}$, por lo que todos núcleos son relativamente pequeños y en 10 casos se pueden considerar núcleos agotados sin posibilidad de realizar más extracciones.

\section{Microdesechos}

De los 176 desechos de talla menores a $1 \mathrm{~cm}$ (excluyendo los desechos indiferenciados $n=60$ ) se determinaron $95(81,9 \%)$ desechos fracturados y $21(18,1 \%)$ lascas enteras; $83(71,5 \%)$ lascas internas, 19 externas $(16,4 \%)$ y 14 indiferenciadas $(12,1 \%)$; y 114 talones preparados y dos talones corticales (liso naturales).

\subsubsection{2- Estructura del conjunto cerámico de Cerro de Boari 3}

Los fragmentos de alfarería suman un total de 33517 (Tabla 8.2); 29843 corresponden al cuerpo de las vasijas (29743 lisos y 100 decorados) y 3668 son bordes (3451 lisos y 217 decorados), y se suman seis fragmentos modelados. Del total, excluyendo los modelados, 33194 fragmentos no presentan decoración y 317 están decorados. Los tamaños de los tiestos se distribuyen como sigue: pequeños $n=32918(98,2 \%)$, medianos $n=595(1,7 \%)$ y grandes $n=4(0,1 \%)$. Se recuperaron además abundantes fragmentos amorfos de arcilla cocida en todas las cuadrículas y todos los niveles de la excavación, algunos con improntas de dedos humanos y/o algún tipo de instrumento.

Dentro del conjunto de tiestos decorados $(n=317)$ se registraron 106 decorados mediante desplazamiento de materia (Figura 8.11A), 154 mediante extracción de materia (Figura 8.11B), y 39 decorados mediante aplicación de pintura (Figura 8.11C). Asimismo, se registraron combinaciones entre extracción y desplazamiento de materia $(n=5)$, extracción de materia y pintura $(n=4)$, y pintura y desplazamiento de materia $(n=9)$.

El conjunto de tiestos decorados mediante desplazamiento de materia $(n=106,39$ bordes y 67 cuerpos) presenta técnica de incisión de surco rítmico, punto y/o línea en 87 casos (77 en la superficie externa, tres en la interna y siete en el labio), y técnica de unguiculado-estriado en 19 casos y en la superficie externa. La decoración mediante extracción de materia se registró sobre el borde y el labio conformando bordes dentados $(n=154)$. El conjunto de tiestos pintados $(n=39,10$ bordes y 29 cuerpos) presenta pintura en la superficie interna $(n=19)$, en la externa $(n=10)$ y en ambas superficies $(n=10)$. Se registró pintura de color rojo en 33 casos, seguida por el negro en cinco, y rojo sobre blanco en un caso. Por su parte, en aquellos tiestos donde se combinan decoraciones $(n=18)$ la misma se presenta de la siguiente manera: cinco bordes dentados con incisiones en la superficie externa; cuatro bordes dentados con pintura roja en la superficie interna; $y$ 
nueve tiestos (cinco bordes y cuatro cuerpos) con incisiones $(n=8)$ y unguiculado $(n=1)$ combinados con pintura roja en la superficie externa.

En cuanto a las seis piezas modeladas (Figura 8.11D), se registró un vertedero cerrado de boca vertical (CDB3-C3-20-2); un mamelón con una concavidad circular en el centro (CDB3-C1-24-2); un apéndice o aplique decorado con cinco líneas incisas paralelas (CDB3-C2-16-G2); tres fragmentos gruesos, uno de los cuales corresponde al reborde evertido del extremo de diámetro menor de una forma troncocónica sin boca ni borde menor y con orificios laterales (CDB3-C2-17-G1) (botellones cerrados en la parte "superior" con orificios laterales sensu Hilbert 1991) (véase Capítulo 4 y 9), los dos restantes podrían corresponder a piezas similares, o también a campanas o apéndices zoomorfos (CDB3-C3-23-3 y CDB3-C3-22-64). A estos elementos procedentes de la excavación se agrega un apéndice escultórico macizo que representa la cabeza de un ofidio y está decorado en toda su superficie mediante incisión de surco rítmico y de punto (CDB-RS-playa-2008-1); y un asa en arco con un pequeño apéndice modelado (CDB-RS-playa-2008-2). Ambas piezas proceden de recolección superficial sobre la playa frente a CDB2 (Figura 8.11E).
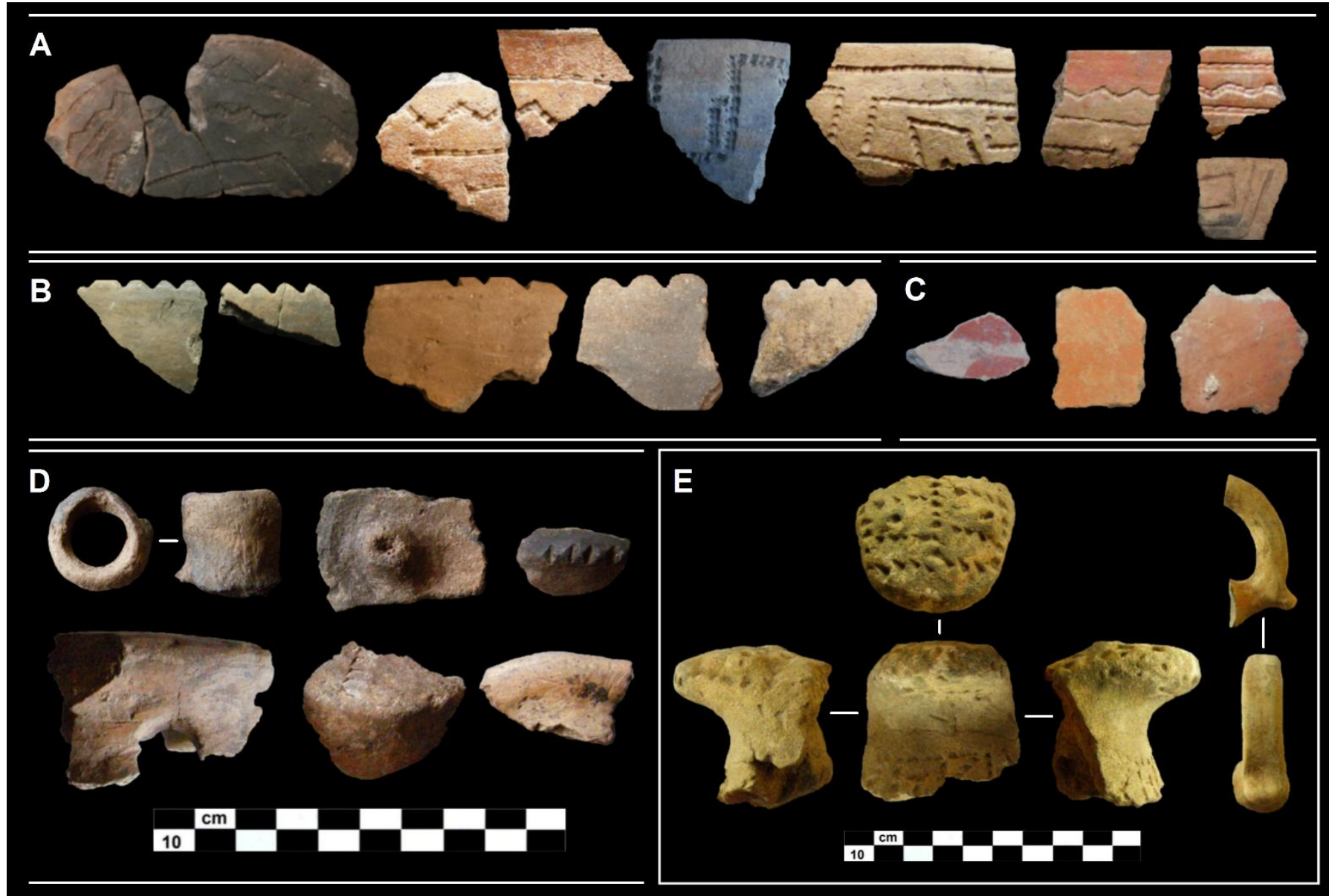

Figura 8.11. Alfarería decorada y modelada del sitio arqueológico Cerro de Boari 3.

A: tiestos decorados mediante incisión. B: bordes dentados mediante extracción de materia. C: tiestos pintados de rojo. D: fragmentos modelados (de izquierda a derecha fila superior: CDB3-C3-20-2, CDB3-C1-24-2 y CDB3-C2-16-G2; de izquierda a derecha fila inferior: CDB3-C2-17-G1, CDB3-C3-23-3 y CDB3-C3-22-64). E: apéndice zoomorfo (ofidio) (CDB-RS-playa-2008-1) y asa (CDB-RS-playa-2008-2). 
A partir de la decoración se pudo determinar que los 19 tiestos unguiculado-estriados, a los que se agregan 70 tiestos con igual decoración y procedentes de las cuadrículas 4, 5, 6, 7, 8, y del sondeo 3, forman parte de la misma vasija (no todos remontan), cuya forma es restringida independiente y el diámetro de boca es igual a $35 \mathrm{~cm}$. Lo mismo ocurre con el borde pintado y unguiculado, y al que se agregan 44 tiestos procedentes de las cuadrículas 4, 5, 7, 8, y del sondeo 3 (no todos remontan), cuya forma es restringida simple y dependiente, y el diámetro de boca es igual a $42 \mathrm{~cm}$ (Tabla 8.14). En ambos casos los tiestos proceden de los niveles 2 a 10 de la excavación, o sea desde la superficie del montículo hasta los 0,45 m de profundidad. La mayor concentración, también en ambos casos, se da en las cuadrículas 7 y 8 donde en total suman 80 tiestos (49 unguiculado-espatulados y 31 pintado-unguiculado). Estas dos vasijas, morfológica y decorativamente distintivas del resto de la alfarería de CDB3, son compatibles con la alfarería guaraní (Brochado 1984; Brochado y Monticelli 1994; Noelli 1993) y son clasificadas como un yapepó (Figura $8.12 \mathrm{~A}$ ) y un cambuchí (Figura 8.12B).

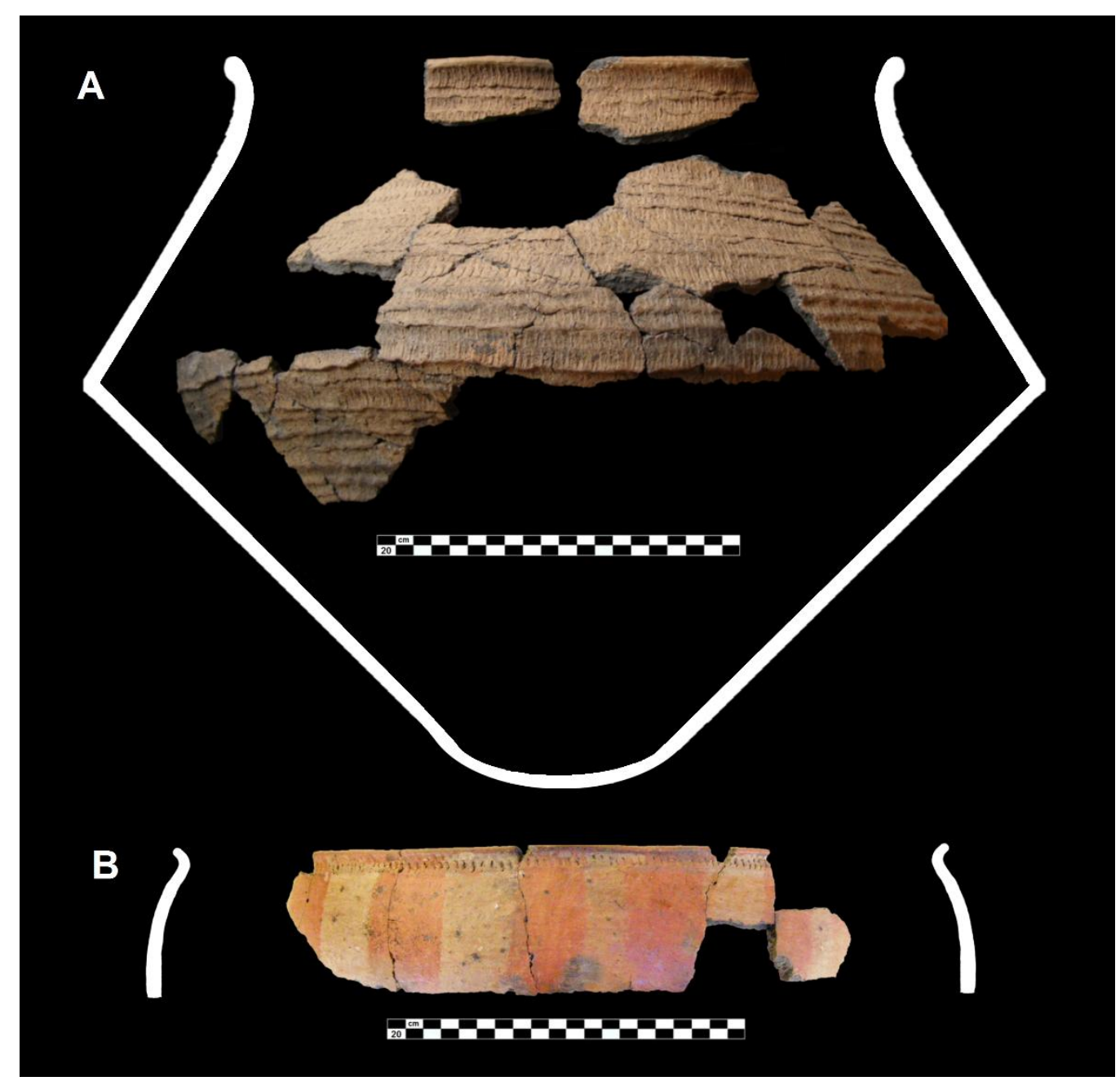

Figura 8.12. Vasijas guaraníes del sitio arqueológico Cerro de Boari 3. A: yapepó. B: cambuchí. 
Considerando la muestra total de alfarería $(n=33517)$ se registraron agujeros de suspensión en 14 bordes y 11 cuerpos. Asimismo, se registró la presencia de hollín en 13 tiestos. Este se presenta de manera abundante en la superficie externa de seis bordes y cinco cuerpos, y en la superficie interna de un cuerpo; y de manera escasa en la superficie externa de un borde. A partir del total de bordes $(n=3668)$ se reconstruyó el diámetro de boca y el perfil de 59 vasijas. Los espesores de los bordes varían entre 2,9 y $9,1 \mathrm{~mm}$.

Tabla 8.14. Distribución de perfiles, bordes, labios y diámetros entre las vasijas lisas y decoradas reconstruidas del sitio arqueológico Cerro de Boari 3.

\begin{tabular}{|c|c|c|c|c|c|}
\hline Perfil & Borde & Labio & $\begin{array}{c}\text { Lisas } \\
\text { Diámetros cm (n) }\end{array}$ & $\begin{array}{c}\text { Decoradas } \\
\text { Diámetros cm }\end{array}$ & Total \\
\hline \multirow{7}{*}{ NR } & \multirow{3}{*}{ Recto } & Recto & $9,17(2), 18,20(2), 24(3), 25,26(2), 27,29,32$ & - & 15 \\
\hline & & Convexo & $13,16(2), 17,19,22(2), 24,26,27$ & $19,20,22,32$ & 14 \\
\hline & & Angular & $12,20,21,23,25$ & - & 5 \\
\hline & \multirow{3}{*}{ Invertido } & Recto & 12,37 & - & 2 \\
\hline & & Convexo & $12,17,23,25$ & - & 4 \\
\hline & & Angular & $15,21(2)$ & - & 3 \\
\hline & Evertido & Recto & - & 13 & 1 \\
\hline \multirow{5}{*}{ RSD } & \multirow{2}{*}{ Recto } & Convexo & $19,20,24,26,30$ & - & 5 \\
\hline & & Angular & 21 & - & 1 \\
\hline & \multirow{2}{*}{ Invertido } & Convexo & $13,17,27,32$ & - & 4 \\
\hline & & Angular & 13,23 & - & 2 \\
\hline & Evertido & Convexo & - & 42 (cambuchí) & 1 \\
\hline \multirow{2}{*}{$\mathrm{RI}$} & \multirow{2}{*}{ Evertido } & Recto & 30 & - & 1 \\
\hline & & Convexo & - & 35 (уареро́) & 1 \\
\hline Total & & & 52 & 7 & 59 \\
\hline
\end{tabular}

NR: Vasija No Restringida; RSD: Vasija Restringida Simple y Dependiente; RI: Vasija Restringida Independiente.

Se registraron 44 vasijas no restringidas, 13 restringidas simples dependientes y dos restringidas independientes; 52 no presentan decoración y siete están decoradas. Dentro de los recipientes no restringidos se determinaron: una vasija lisa con un diámetro de boca de $13 \mathrm{~cm}$ que correspondería a un plato (CDB3-1-28-1) (Figura 8.13D); dos vasijas lisas con un diámetro de boca de $21 \mathrm{~cm}$ que corresponderían a cuencos grandes (CDB3-2-10-18 y CDB3-3-6-82) (Figura 8.13E y F); y una vasija lisa con un diámetro de boca de $25 \mathrm{~cm}$ que correspondería a un plato grande (CDB3-1-111) (Figura 8.13G). El resto de estos recipientes probablemente también incluya otros cuencos (p. ej. piezas A y B de la Figura 8.13), platos hondos (p. ej. pieza C de la Figura 8.13) y escudillas. En cuanto a los recipientes restringidos simples dependientes probablemente correspondan a ollas (p. ej. piezas I, J y $\mathrm{K}$ de la Figura 8.13). Por último, los dos recipientes restringidos independientes son un yapepó (Figura 8.12A) y el otro probablemente una olla (CDB3-2-24-5) (Figura 8.13H). 
Dentro del conjunto de vasijas reconstruidas $(n=59)$ en siete se registró la presencia de hollín. Seis de estas son lisas y corresponden a formas no restringidas con bordes rectos e invertidos y diámetros de boca entre 15 y $29 \mathrm{~cm}$. Todas presentan paredes levemente divergentes y serían similares a las piezas A, B, E y F de la Figura 8.13, por lo que corresponderían a cuencos grandes. La pieza restante es un yapepó decorado con forma restringida independiente, borde evertido y diámetro de boca de $35 \mathrm{~cm}$ (Figura 8.12A).

En relación a la técnica de manufactura 29 (49,2\%) bordes fueron elaborados mediante la técnica de enrollamiento, siendo el resto indeterminados $(n=30 ; 50,8 \%)$. Se determinó tratamiento de superficie plástico en 56 bordes (94,9\%) (50 alisados en ambas superficies, dos pulidos en ambas superficies, tres incisos en la superficie externa y alisados en la interna, y uno corrugado en la superficie externa y alisado en la interna); pintura en ambas superficies en un borde $(1,7 \%)$; tratamiento plástico unguiculado y pintado en la superficie externa y pintado en la interna en un borde $(1,7 \%)$; y tratamiento plástico alisado en la superficie externa y pintado en la interna en un borde $(1,7 \%)$.

La observación del color del núcleo de los bordes permitió determinar que predomina ampliamente el color negro (7.5YR 2/1-black) ( $n=51 ; 86,4 \%$ ), seguido el castaño oscuro (7.5YR 3/4dark brown) ( $n=4 ; 6,8 \%)$, el color gris (7.5YR 5/1-brownish gray) ( $n=1 ; 1,7 \%)$, e indeterminado ( $n=3$; 5,1\%). El color de la superficie externa es castaño (7.5YR 5/6-bright brown) en 40 (67,8\%) bordes, negro en $15(25,4 \%)$, pintado rojo en dos $(3,4 \%)$, e indeterminado en dos $(3,4 \%)$. El color de la superficie interna es castaño (7.5YR 5/6-bright brown) en 46 (78\%) bordes, negro en ocho (13,5\%), pintado rojo en tres $(5,1 \%)$, e indeterminado en dos $(3,4 \%)$. En referencia a la cocción estimada la distribución de frecuencias de colores estaría indicando la predominancia de una cocción oxidante incompleta. Los porcentajes de inclusiones se distribuyen de la siguiente manera: arena $(n=48$; $81,3 \%)$; tiesto y arena $(n=3 ; 5,1 \%)$; tiesto $(n=1 ; 1,7 \%)$; arena y espículas $(n=5 ; 8,5 \%)$; arena, espículas y carbón $(n=1 ; 1,7 \%) ; y$ espículas ( $n=1 ; 1,7 \%)$. 


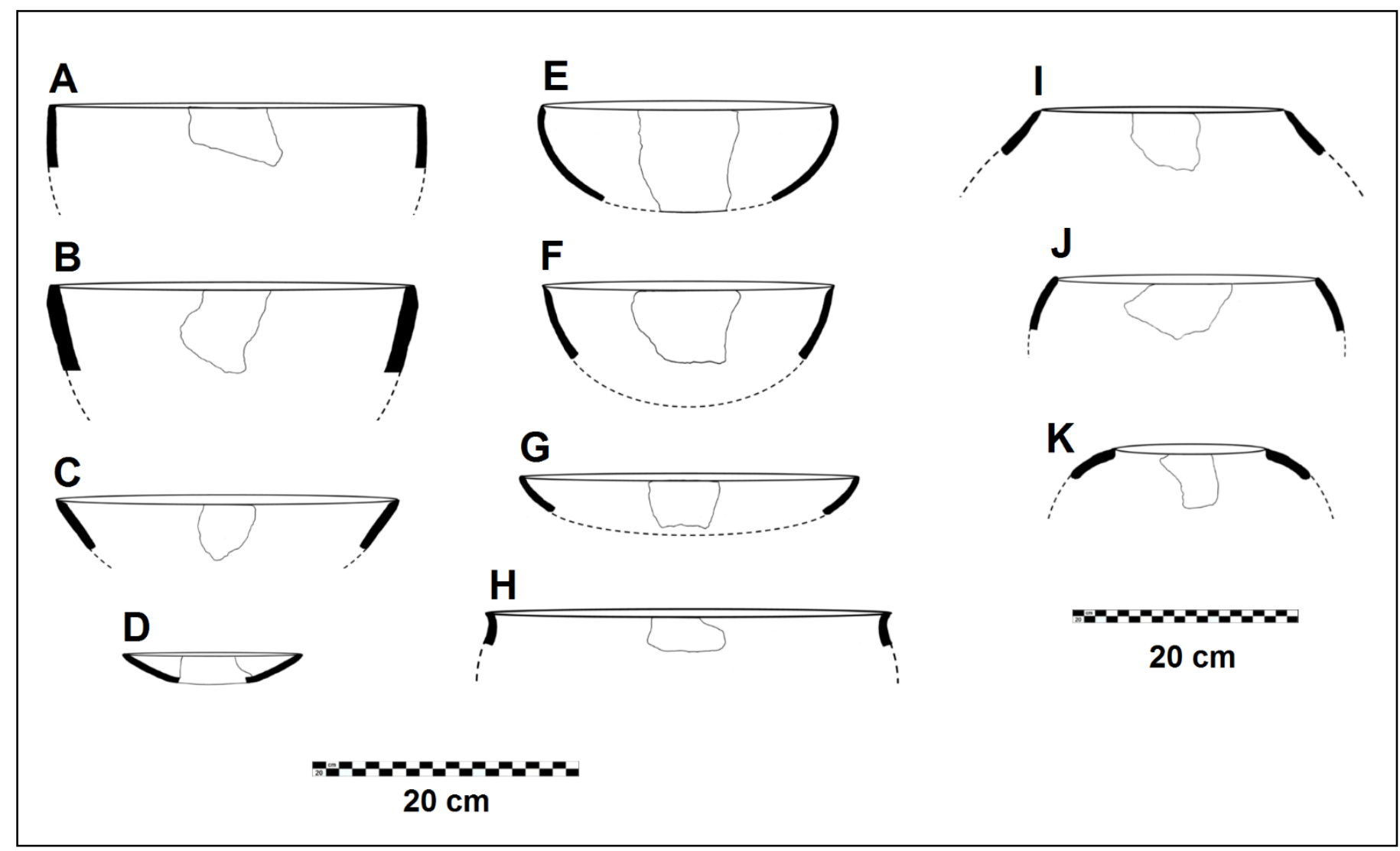

Figura 8.13. Vasijas reconstruidas del sitio arqueológico Cerro de Boari 3.

Formas no restringidas con bordes rectos: A (CDB3-2-19-G1), B (CDB3-2-24-3), C (CDB3-1-17-G1) y

D (CDB3-1-28-1). Formas no restringidas con bordes invertidos: E (CDB3-2-10-189), F (CDB3-3-6-82) y

G (CDB3-1-11-1). Forma restringida independiente con borde evertido: $\mathbf{H}$ (CDB3-2-24-5).

Forma restringida simple y dependiente con borde recto: I (CDB3-1-18-G1). Forma restringida

simple y dependiente con borde invertido: J (CDB3-2-20-1) y K (CDB3-3-27-G1).

\subsubsection{3- Estructura del conjunto faunístico de Cerro de Boari 3}

El conjunto faunístico de la cuadrícula 1 se compone de un total de 12599 restos faunísticos, que incluyen especímenes óseos, dentarios, astas y valvas de moluscos. A este valor se suman tres especímenes que fueron transformados en un instrumento óseo y dos adornos, los cuales se estudian por separado más adelante. Del total (NISP=12599), 9376 especímenes se asignaron a alguna categoría taxonómica (Filo, Clase, Orden, Familia, Género y Especie) (Tabla 8.15), siendo el resto materiales indeterminados $(n=3223)$. Dentro de estos últimos el $99,1 \%,(n=3194)$ son fragmentos de tamaños menores a $2 \mathrm{~cm}$ y el $0,9 \%(n=29)$ restante mayores a esta medida. 
Tabla 8.15. Abundancia taxonómica del sitio arqueológico Cerro de Boari 3

\begin{tabular}{lcccc}
\multicolumn{1}{c}{ Taxón } & NISP & NISP\% & MNI & MNE \\
\hline MOLLUSCA & 626 & 6,70 & - & - \\
ACTINOPTERYGII & 8033 & 85,70 & - & - \\
Leporinus obtusidens & 202 & 2,15 & - & - \\
Doradidae & 13 & 0,13 & - & - \\
MAMMALIA & 378 & 4,03 & - & - \\
Blastocerus dichotomus & 2 & 0,02 & 1 & 2 \\
Mazama cf. gouazoubira & 1 & 0,01 & 1 & 1 \\
Cervidae & 19 & 0,20 & 2 & 18 \\
Hydrochoerus hydrochaeris & 5 & 0,05 & 1 & 5 \\
Myocastor coypus & 25 & 0,26 & 1 & 24 \\
Cavia aperea & 41 & 0,44 & 8 & 41 \\
Sigmodontinae & 3 & 0,03 & 1 & 3 \\
Rodentia & 6 & 0,06 & 1 & 6 \\
Canidae & 1 & 0,01 & 1 & 1 \\
Dasypus sp. & 9 & 0,09 & - & 9 \\
Dasypus cf. novemcinctus & 3 & 0,03 & 1 & 3 \\
Dasypus hybridus & 5 & 0,05 & 1 & 5 \\
Euphractus cf. sexcinctus & 1 & 0,01 & 1 & 1 \\
Testudines & 2 & 0,02 & 1 & 1 \\
Squamata & 1 & 0,01 & 1 & 1 \\
Total & 9376 & 100 & 22 & 121 \\
\hline
\end{tabular}

\section{Abundancia taxonómica y anatómica}

La Tabla 8.15 muestra los valores de NISP, NISP \%, MNI y MNE de los distintos taxa recuperados en CDB3. La mayoría de los especímenes identificados corresponden a peces óseos (NISP $=8248$ ), dentro de los cuales se determinaron restos de Leporinus obtusidens (boga) representada por dientes $(\mathrm{NISP}=202)$ y Doradidae representado por espinas (NISP=13). La mayoría de los elementos corresponden al esqueleto axial, sobre todo vértebras (MNE=1997). El resto de los elementos axiales incluye espinas dorsales, placas óseas laterales, hipurales, dientes y fragmentos de cráneo indeterminados. Del esqueleto apendicular se registraron espinas pectorales y fragmentos de cinturas. Asimismo, se contabilizaron 3605 especímenes correspondientes a espinas y radios indeterminados. En orden decreciente, siguen los moluscos (NISP $=626)$ representados mayormente por valvas de bivalvos que según las determinaciones del Dr. Leandro Pérez (CONICET; FCNyMUNLP), la mayoría corresponderían a Diplodon sp.

En la categoría MAMMALIA, que incluye aquellos fragmentos óseos que solo pudieron ser identificados hasta ese nivel taxonómico (Clase), se registraron 378 especímenes. Entre estos se subdividen en pequeños (NISP= 20) (de 100 grs. $3 \mathrm{~kg}$.), medianos (NISP=190) (de 3 a $25 \mathrm{~kg}$.) y grandes mamíferos (NISP= 34) (mayores a $25 \mathrm{~kg}$.); menores a 100 grs. se consideran micromamíferos y en este caso todos fueron agrupados dentro de los mamíferos chicos. Los mamíferos indeterminados suman un total de 134 especímenes. 
En cuanto a los grandes mamíferos identificados a nivel de especie se registró Hydrochoerus hydrochaeris (carpincho) (NISP=5), Blastocerus dichotomus (ciervo de los pantanos) (NISP=2) y Mazama cf. gouazoubira (guazuncho) $(\mathrm{NISP}=1)$. El carpincho está representado sobre todo por elementos del cráneo ( $\mathrm{MNE}=4$; hemimandíbula, molar e incisivos) seguido por las extremidades ( $M N E=1$, falange). El ciervo presenta elementos de los miembros ( $M N E=2$, metapodio y falange). En cuanto al guazuncho el elemento presente corresponde a un metapodio $(\mathrm{MNE}=1)$. Los especímenes agrupados dentro de la categoría Cervidae indeterminados (NISP=19), probablemente correspondan en su mayoría a Ozotoceros bezoarticus (venado de las pampas) o guazuncho, excepto una falange incompleta que por su tamaño podría ser ciervo de los pantanos. Esta categoría taxonómica incluye elementos craneales ( $\mathrm{MNE}=10$, molares y asta) y de los miembros ( $\mathrm{MNE}=8$; fémur, astrágalo, metapodios y falanges).

Dentro de los roedores, además de carpincho, se registró la presencia de Cavia aperea (cuis) (NISP=41), Myocastor coypus (coipo) (NISP=25) y sigmodontinos (NISP=3). El cuis está representado sobre todo por elementos de las miembros (MNE= 21) seguido por el cráneo (MNE= 20, incluyendo incisivos y molares aislados). A esta especie corresponde el mayor $\mathrm{MNI}(\mathrm{MNI}=8)$ que fue determinado a partir de las hemimandíbulas. Específicamente los elementos identificados de cuis en CDB3 son: hemimandíbulas ( $M N E=12)$, tibias $(M N E=6)$, molares aislados (MNE= 5), incisivos aislados $(\mathrm{MNE}=3)$, fémures $(\mathrm{MNE}=3)$, calcáneos $(\mathrm{MNE}=3)$, húmeros $(\mathrm{MNE}=2)$, cúbitos $(\mathrm{MNE}=2), y$ representados por un solo elemento hemipélvis, astrágalo, metatarso, metapodio y falange. En cuanto al coipo, presenta elementos craneales ( $\mathrm{MNE}=18$, incisivos aislados), de los miembros ( $\mathrm{MNE}=$ 4; fémur, metapodio, astrágalo y falange) y poscraneales ( $M N E=2$, vértebra y costilla). Los sigmodontinos están representados por elementos del miembro posterior ( $M N E=2$, tibias) y craneales (MNE= 1, incisivo aislado). También hay especímenes clasificados como Rodentia (NISP=6; húmero, cúbito, fémur, tibias y falange) que probablemente correspondan a pequeños roedores como el cuis o ratones.

Se determinaron dasipódidos como Dasypus hybridus (mulita) (NISP= 5), Dasypus cf. novemcinctus (mulita grande) (NISP=3), Euphractus cf. sexcinctus (tatú peludo) (NISP=1), y otros elementos clasificados como Dasypus sp. (NISP=9). Todos los elementos registrados corresponden a osteodermos, móviles (MNE= 14) y fijos (MNE=4).

Se registraron también especímenes de Canidae $(\mathrm{NISP}=1)$ que pueden corresponder a Lycalopex gimnocercus (zorro gris) o Cerdocyon thous (zorro de monte); Testudines (NISP=2) y Squamata (NISP=1). El zorro está representado por una falange (MNE=1); la tortuga por elementos del espaldar (MNE= 2); y el reptil por una vértebra (MNE= 1). Estos dos últimos taxa probablemente correspondan a Phrynops hilarii (tortuga de laguna) y Salvator merianae (lagarto overo) respectivamente, dado que en el sondeo 3 que está próximo a la cuadricula 1 (véase Figura 8.3, esquema de la excavación), se identificaron previamente estas mismas especies (Castro 2011). 


\section{Tafonomía}

La Tabla 8.16 muestra las alteraciones tafonómicas identificadas en los especímenes óseos determinados taxonómicamente (NISP=8750), exceptuando los moluscos. Para el caso particular de la meteorización (sensu Behrensmeyer 1978), la muestra analizada es igual a 449 especímenes, ya que se excluyeron los peces $(\mathrm{NISP}=8248)$, los reptiles $(\mathrm{NISP}=3)$ y los microroedores (cuis y sigmodontinos) (NISP= 50). El diagnóstico de los microroedores se presenta por separado más abajo siguiendo la propuesta de Andrews (1990) para micromamíferos.

Tabla 8.16. Tafonomía de CDB3

\begin{tabular}{lcc}
\hline \multicolumn{1}{c}{ Variables } & NISP & $\%$ \\
\hline Meteorización 2 & 415 & 92,44 \\
Meteorización 3 & 33 & 7,34 \\
Meteorización 5 & 1 & 0,22 \\
Óxido de Manganeso $\left(\mathrm{MnO}_{2}\right)$ & 6598 & 75,40 \\
Huellas de corte & 3 & 0,03 \\
Negativos de impacto & 2 & 0,02 \\
Alteración térmica & 1036 & 11,84 \\
\hline
\end{tabular}

\section{Meteorización}

Si bien los estadíos de meteorización propuestos por Behrensmeyer (1978) en principio deben ser aplicados para animales con un peso mayor a 5 kg., en este estudio, y con objetivo es evaluar la meteorización de forma global sobre el conjunto óseo, se incluyeron los especímenes de coipo y los dasipódidos, cuyos pesos pueden ser generalmente menores a 5 kg. Para la mayoría de la muestra (92,44\%) el grado de meteorización corresponde al estadío 2; los estadios 3 y 5 presentan una muy baja frecuencia. Por otro lado, los restos de microroedores (NISP=50) se ubicarían dentro del estadío 1 para micromamíferos de Andrews (1990). Todo indicaría que los restos faunísticos no estuvieron expuestos a las condiciones ambientales por un largo período.

\section{Depositación química}

Un gran porcentaje $(75,40 \%)$ de especímenes presenta oxido de Manganeso sobre sus superficies. La abundancia de Manganeso puede asociarse a un contexto depositacional con una marcada presencia de agua en el entorno y/o con la descomposición de materia orgánica (Dorn y Oberlander 1981; Gutiérrez 2004). En CDB3 están presenten ambos aspectos de manera significativa.

Huellas de corte

Las huellas de corte se registraron en tres especímenes adjudicados a mamíferos medianos; los mismos corresponden a lascas óseas procedentes de diáfisis de huesos largos, una de las cuales además presenta alteración térmica (carbonizada). Estas trazas se presentan en forma paralela y su 
frecuencia es igual a dos, tres y ocho huellas respectivamente; además en dos casos se ubican agrupadas en un único sector del hueso y en el caso restante en dos sectores distintos.

\section{Negativos de impacto}

Solamente dos especímenes presentan negativos de impacto externo, una huella cada uno de ellos. Los elementos afectados son lascas óseas procedentes de diáfisis de huesos largos de mamíferos medianos, una de las cuales presenta alteración térmica (carbonizada).

\section{Alteración térmica}

Un total de 1036 (11,84\%) especímenes de distintos taxa evidencian termoalteración en diferentes grados, tanto carbonizados $(n=537)$ y calcinados $(n=499)$. Se registró esta evidencia en especímenes óseos de peces (452 carbonizados y 371 calcinados), Cavia aperea (cuatro carbonizados y cuatro calcinados), Dasypus sp. (dos carbonizados y uno calcinado), Myocastor coypus (dos carbonizados), Rodentia (uno carbonizado y uno calcinado), Cervidae (dos carbonizados), Euphractus cf. sexcinctus (uno calcinado), sigmodontino (uno calcinado), reptil (uno calcinado), y mamíferos grandes (cinco calcinados), medianos (55 carbonizados y 60 calcinados) y chicos (uno carbonizado y 13 calcinados), además de mamíferos indeterminados (18 carbonizados y 41 calcinados).

Los elementos anatómicos de los mamíferos que fueron afectados por el fuego corresponden en su mayoría a huesos largos indeterminados ( $n=147$; cinco mamíferos grandes, 113 medianos, 13 chicos y 16 indeterminados); se cuentan también una costilla y una vértebra de mamífero mediano, una epífisis distal de fémur de mamífero chico, y 43 fragmentos indeterminados de mamíferos indeterminados.

\section{Fracturas}

Para los cérvidos en general se registraron fracturas irregulares y transversales sobre huesos largos $(\mathrm{NISP}=7)$ y transversal en un astrágalo $(n=1)$, se agrega una lasca ósea procedente de un metapodio de ciervo $(n=1)$. En Myocastor coypus se registraron fracturas transversales sobre metapodio $(n=2)$, fémur y costilla; y fractura longitudinal sobre una vértebra caudal. También se registró la presencia de numerosas lascas óseas (NISP= 211) procedentes de huesos largos pertenecientes a mamíferos indeterminados de mediano y gran porte. Dos de estas lascas tienen negativos de impacto y tres tienen huellas de corte. Estas lascas pertenecen a huesos largos que son los que tienen mayor cantidad de médula ósea y serían el resultado del procesamiento antrópico. Las fracturas intencionales sobre huesos largos en estado fresco de distintos taxa regularmente son interpretados como el resultado de un procesamiento intensivo de las especies, asociado al consumo de la médula ósea que presentan estos elementos. No obstante, algunas fracturas serían consecuencia de la producción de tecnofacturas óseas. 


\section{Instrumentos óseos y adornos}

En esta sección se analizan todos los instrumentos y adornos recuperados en la excavación de CDB3. Los mismos se registraron en todas las cuadrículas y en el sondeo 3, entre los 10 y $85 \mathrm{~cm}$ desde la superficie del montículo (entre el nivel 4 y 18 de la excavación). En total se cuentan 15 instrumentos óseos (Tabla 8.17), tres adornos y un probable fragmento de instrumento indeterminado.

Tabla 8.17. Instrumentos óseos del sitio arqueológico Cerro de Boari 3

\begin{tabular}{|c|c|c|c|c|c|c|c|c|c|c|c|}
\hline \multirow{2}{*}{ Pieza } & \multirow{2}{*}{ Instrumento } & \multirow{2}{*}{ Taxón } & \multirow{2}{*}{ Elemento } & \multicolumn{5}{|c|}{ Atributos } & \multicolumn{3}{|c|}{ Dimensiones mm. } \\
\hline & & & & $\mathrm{P}$ & $\mathrm{D}$ & A & $\mathrm{F}$ & AP & L & A & $E$ \\
\hline CDB3-S3-6-7 & Punta acanalada & Cervidae & metatarso & si & si & no & si & no & 76,5 & 15,8 & 6,4 \\
\hline CDB3-C6-16-16 & Punta acanalada & Cervidae & metapodio & si & no & no & si & no & 71,3 & 10,6 & 5,7 \\
\hline CDB3-C4-4-G1 & Ápice acanalado & MAMMALIA & hueso largo & si & no & no & si & no & 22,2 & 7,6 & 4,8 \\
\hline CDB3-C8-13-G1 & Ápice acanalado & MAMMALIA & hueso largo & si & si & no & si & no & 23,9 & 6,7 & 3,9 \\
\hline CDB3-S3-16-13 & Ápice acanalado & MAMMALIA & hueso largo & si & si & no & si & no & 29,2 & 6,8 & 3,8 \\
\hline CDB3-C6-13-9 & Punta con epífisis ${ }^{1}$ & Ozotoceros bezoarticus & metapodio & si & si & no & si & no & 130,1 & 16,7 & 12,6 \\
\hline CDB3-C7-15-33 & Punta con epífisis ${ }^{1}$ & Ozotoceros bezoarticus & metatarso & si & si & no & si & no & 94,3 & 24,1 & 16,2 \\
\hline CDB3-C1-18-1 & Punta con epífisis & cf. Mazama guazuobuira & metacarpo & si & si & no & si & no & 76 & 21,6 & 13,9 \\
\hline CDB3-S3-4-B & Punta ahuecada & Cervidae & metapodio & si & no & si & si & si & 67,2 & 17,2 & 10,8 \\
\hline CDB3-S3-6-H & Punta ahuecada ${ }^{1}$ & Cervidae & metatarso & $\mathrm{si}$ & no & si & no & no & 52,2 & 18,5 & 14,6 \\
\hline CDB3-C2-16-2 & Espina aguzada & cf. Doraridae & espina pectoral & si & si & no & si & no & 36,9 & 8 & 5,4 \\
\hline CDB3-C3-18-1 & Espina aguzada & cf. Doraridae & espina dorsal & si & si & no & si & no & 111,4 & 10 & 6,8 \\
\hline CDB3-C2-5-121 & Espina aguzada & cf. Doraridae & espina & si & si & no & si & no & 47 & 7,1 & 4,7 \\
\hline CDB3-S3-16-G1 & Espina aguzada & cf. Doraridae & espina & si & si & no & si & no & 29,6 & 6,9 & 4,3 \\
\hline CDB3-C3-9-G1 & Espina aguzada & cf. Doraridae & espina & $\mathrm{si}$ & si & no & si & no & 38,9 & 7,8 & 5 \\
\hline
\end{tabular}

Atributos. P: pulido; D: desbaste; A: ahuecado; F: huellas de filos; AP: aserrado perimetral.

Dimensiones. L: largo máximo; A: ancho máximo; E: espesor máximo. (1) piezas enteras.

Los instrumentos consisten en: dos puntas acanaladas elaboradas sobre metatarso y metapodio indeterminado de Cervidae y tres ápices acanalados sobre huesos largos de mamíferos indeterminados (Figura 8.14A); tres puntas con epífisis, elaboradas sobre metacarpo de guazuncho, metatarso y metapodio de venado de las pampas (Figura 8.14B); dos puntas ahuecadas (semiacanaladas), elaboradas sobre metapodio y metatarso de Cervidae (Figura 8.14C); y cinco espinas aguzadas, elaboradas sobre espina pectoral $(n=1)$, dorsal $(n=1)$ e indeterminadas $(n=3)$ de cf. Doradidae (Figura 8.14D).

Todos los instrumentos presentan pulido en alguna sección de su superficie, sobre todo en el extremo distal. A su vez, 14 presentan huellas de filos, algunas podrían de corte y otras generadas 
durante el proceso de confección del instrumento mediante el uso de herramientas líticas con filos agudos. Por otra parte, 11 piezas presentan algún tipo de desbaste y también dos presentan ahuecado. Particularmente las cinco piezas cuyo soporte-base consiste en espinas de cf. Doradidae presentan eliminación por desbaste y/o pulido del dentado característico de algunas especies de esta Familia. Por último, solo una pieza tiene aserrado perimetral en su porción proximal. Asimismo, se registró depósito de óxido de Manganeso sobre la superficie de 13 piezas. No se registraron negativos de impacto, lascados o decoración.

Del total de instrumentos, tres se encuentran enteros y otros 12 presentan algún tipo de fractura, ya sea en su porción proximal y/o en su ápice. En 10 casos estas fracturas afectan las tres dimensiones de las piezas y en dos casos (CDB3-S3-6-7 y CDB3-C1-18-1) solamente se ve afectada la longitud. En relación a las puntas acanaladas $(n=2)$ ambas están fracturadas lo que afecta su longitud. Los ápices acanalados $(n=3)$ corresponden al extremo distal de las piezas que a partir de los atributos de la parte presente podrían corresponder posiblemente a puntas con epífisis o puntas acanaladas. En cuanto a las puntas con epífisis $(n=3)$, su soporte-base son metapodios de cérvidos. Una sola se encuentra fracturada. Todas registran los mismos atributos y solo difieren en sus dimensiones. Las puntas ahuecadas $(n=2)$ presentan como soportes-base metapodios de cérvidos. Una se encuentra entera y no presenta aserrado perimetral ni huellas de filos, y la otra está fracturada y sí presenta dichos atributos. En las espinas aguzadas $(n=5)$ los soportes-base son espinas de peces, todas están fracturadas y registran los mismos atributos, solo difieren en sus dimensiones.

Además de los instrumentos de la Tabla 8.17, se registró un fragmento óseo indeterminado con una perforación claramente antrópica que atraviesa todo el fragmento. El orificio tiene 5,3 mm en su diámetro externo y 4,6 mm en el interno, y una longitud de 5,6 mm. También se registraron dos fragmentos de huesos largos de mamífero indeterminado y dos fragmentos de astas, todos tienen evidencias antrópicas como pulido y huellas de filos; corresponderían a desechos de manufactura o fragmentos de instrumentos.

En referencia a los adornos, se registraron tres cuentas elaboradas sobre valvas de moluscos (Figura 8.14E). Dos fueron confeccionadas a partir de valvas de un pequeño gasterópodo (GASTRÓPODA), una de ellas está entera y presenta un pequeño orificio en el ápice de la valva por donde pasaba el hilo suspensor (CDB3-C1-16-A2) y la otra se encuentra fracturada por lo que dicho orificio no se puede observar (CDB3-C1-16-A3); la tercera cuenta (CDB3-C4-14-A1) fue confeccionada a partir de una valva indeterminada (MOLLUSCA), es plana con un espesor de 1,6 $\mathrm{mm}$ y circular con un diámetro máximo de 6,3 $\mathrm{mm}$ y presenta un orificio de 1,4 mm de diámetro en su centro. Los dos primeros proceden de la cuadricula 1 (nivel 16) y el restante de la cuadrícula 4 (nivel 14). 


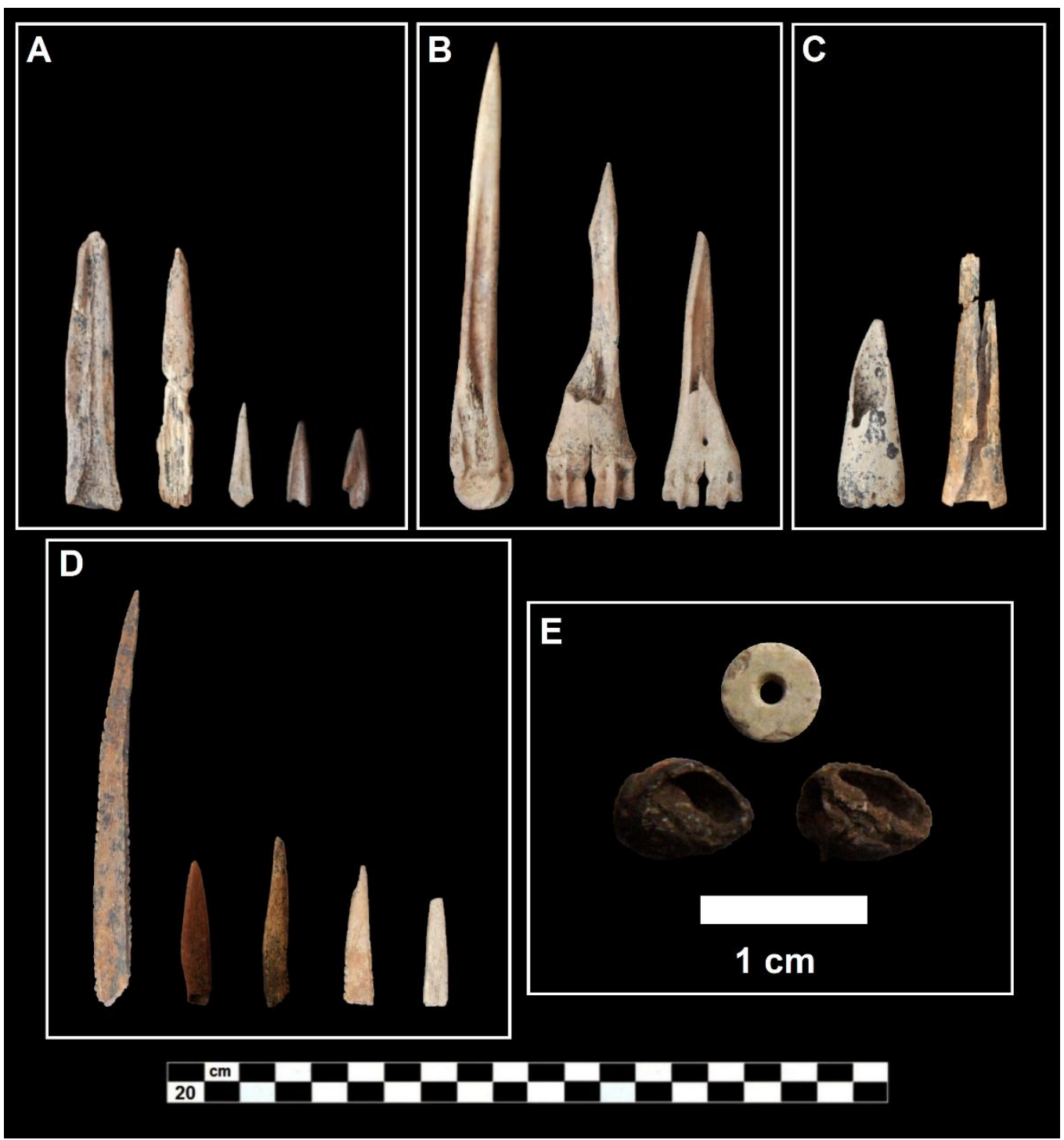

Figura 8.14. Instrumentos óseos y adornos del sitio arqueológico Cerro de Boari 3.

A: puntas y ápices acanalados (de izquierda a derecha: CDB3-S3-6-7, CDB3-C6-16-16, CDB3-S3-16-13, CDB3-C8-13-G1 y CDB3-C4-4-G1). B: puntas con epífisis (de izquierda a derecha: CDB3-C6-13-9, CDB3-C7-15-33 y CDB3-C1-18-1). C: puntas ahuecadas semiacanaladas (de izquierda a derecha: CDB3-S3-6-H y CDB3-S3-4-B). D: espinas aguzadas (de izquierda a derecha: CDB3-C3-18-1, CDB3-C3-9-G1, CDB3-C2-5-121, CDB3-C2-16-2 y CDB3-S3-16-G1). E: adornos de valvas (CDB3-C4-14-A1, CDB3-C1-16-A2 y CDB3-C1-16-A3).

\subsubsection{4- Estructura del conjunto de restos óseos humanos de Cerro de Boari 3}

Se recuperaron restos óseos humanos conformando un paquete funerario. Los mismos proceden de un área que abarca las cuadrículas $1,2,7$ y 8 , y se encontraron a una profundidad entre $0,20 \mathrm{~m}$ y $0,45 \mathrm{~m}$ desde la superficie del montículo. Los elementos anatómicos mayores estaban desarticulados, y los huesos largos estaban dispuestos paralelamente alineados en dirección nortesur, con los cráneos ubicados en el norte. Algunos elementos de un pie se encontraban en posición articulada, lo que indicaría que fue enterrado cuando aún conservaba tejidos blandos que permitieron mantener su forma natural. 
Los restos óseos fueron analizados por la Lic. Agustina Ramos van Raap, la Dra. Clara Scabuzzo y el Sr. Oscar Schwerdt (CONICET; FCNyM-UNLP). Se calculó un NISP= 110 y un MNI= 3 determinado a partir del fémur (dos por lateralidad -derechos- y uno por edad estimada). Es posible que el paquete funerario haya contenido más de tres individuos, probablemente cinco pero falta aún profundizar su estudio que se ve dificultado por el estado de integridad de la muestra. Los individuos corresponden a un infante (0-3 años) y dos subadultos (> de 14 años). Están presentes tanto elementos craneales y poscraneales. Los elementos más representados son los tarsianos, metatarsianos, carpianos, metacarpianos, fémures, falanges y vértebras. También se registraron cráneos, fémures, húmeros, radios, tibias, peronés, cúbito, coxales, escápula, costillas y dientes aislados. Se obtuvieron dos dataciones radiocarbónicas sobre dos cráneos que arrojaron edades de $1080 \pm 60$ años ${ }^{14} \mathrm{C}$ AP (LP-2871) y $1120 \pm 60$ años ${ }^{14}$ C AP (LP-2840) (Tabla 8.1).

\section{2- TENDENCIAS GENERALES E INTERPRETACIONES}

\subsection{1- ESTUDIOS SEDIMENTOLÓGICOS, FITOLÍTICOS Y CRONOLÓGICOS}

En primer lugar, las asociaciones fitolíticas halladas y las presencia de espículas de esporangios indicarían una composición herbácea principalmente de gramíneas meso y megatérmicas. Estas estarían asociadas a cursos de agua o suelos con una alta disponibilidad de humedad, posiblemente mayor a la actualidad, durante el periodo de ocupación del montículo (Colobig et al. 2015). Esto es acorde con el ambiente de llanura de mareas propuesto para la zona luego de la regresión marina holocénica y que estaría caracterizado por abundantes cuerpos de agua entorno a los albardones costeros (Cavallotto et al. 2005; Iriondo y Altamirano 1988).

Por su parte, en base a los resultados sedimentológicos alcanzados se puede proponer que la sucesión sedimentaria estudiada para CDB3 se encuentra integrada por dos sistemas depositacionales (Figura 8.15), según la definición establecida por Castiñeira y colaboradores (2013, 2014) para la región. Un primer sistema depositacional natural (SDN) que se encuentra representado por las muestras del Grupo N (CDB3-16, CDB3-15 y CDB3-14) genéticamente vinculadas a depósitos fluviales de albardón cuyo proceso acrecional es consecuencia de los eventos de crecida del río, interviniendo también depositación eólica. Los depósitos naturales cuspidales Limo arenosos de esta porción de la secuencia (muestra CDB3-14) se encuentran modificados por iluviación y pedogénesis, esta última pudo verse visto favorecida por la adición de componentes orgánicos durante la ocupación y elevación de la estructura monticular.

En contacto transicional se desarrolla el segundo sistema depositacional antrópico (SDA) que caracteriza a la estructura monticular y cuya génesis es atribuida a las estrategias antrópicas de 
elevar estructuras en tierra (véase Bracco et al. 2000a; Castiñeira 2013, 2014; Castiñeira y Piñeiro 2000). El correlato arqueológico de esta estrategia se expresa en las diferencias morfológicas de los depósitos, en su identidad textural, en su composición silico y bioclástica, en sus contenidos arqueológicos, en su evolución cronológica y su afectación bioestratinómica, entre los caracteres más sobresalientes. Este sistema de aproximadamente 1,50 $\mathrm{m}$ de potencia fue datado en su base en 1440 \pm 50 años ${ }^{14} \mathrm{C}$ AP y en su cúspide en $660 \pm 50$ años ${ }^{14} \mathrm{C}$ AP. La correlación entre las edades obtenidas a partir del fechado de la fracción orgánica de los sedimentos monticulares y los eventos constructivos, ya ha sido sustentada en diferentes trabajos referentes a la evolución cronológica de la arquitectura en tierra prehispánica a escala regional y continental (p. ej. Bracco y Ures 2001; y Herrmann et al. 2014). 


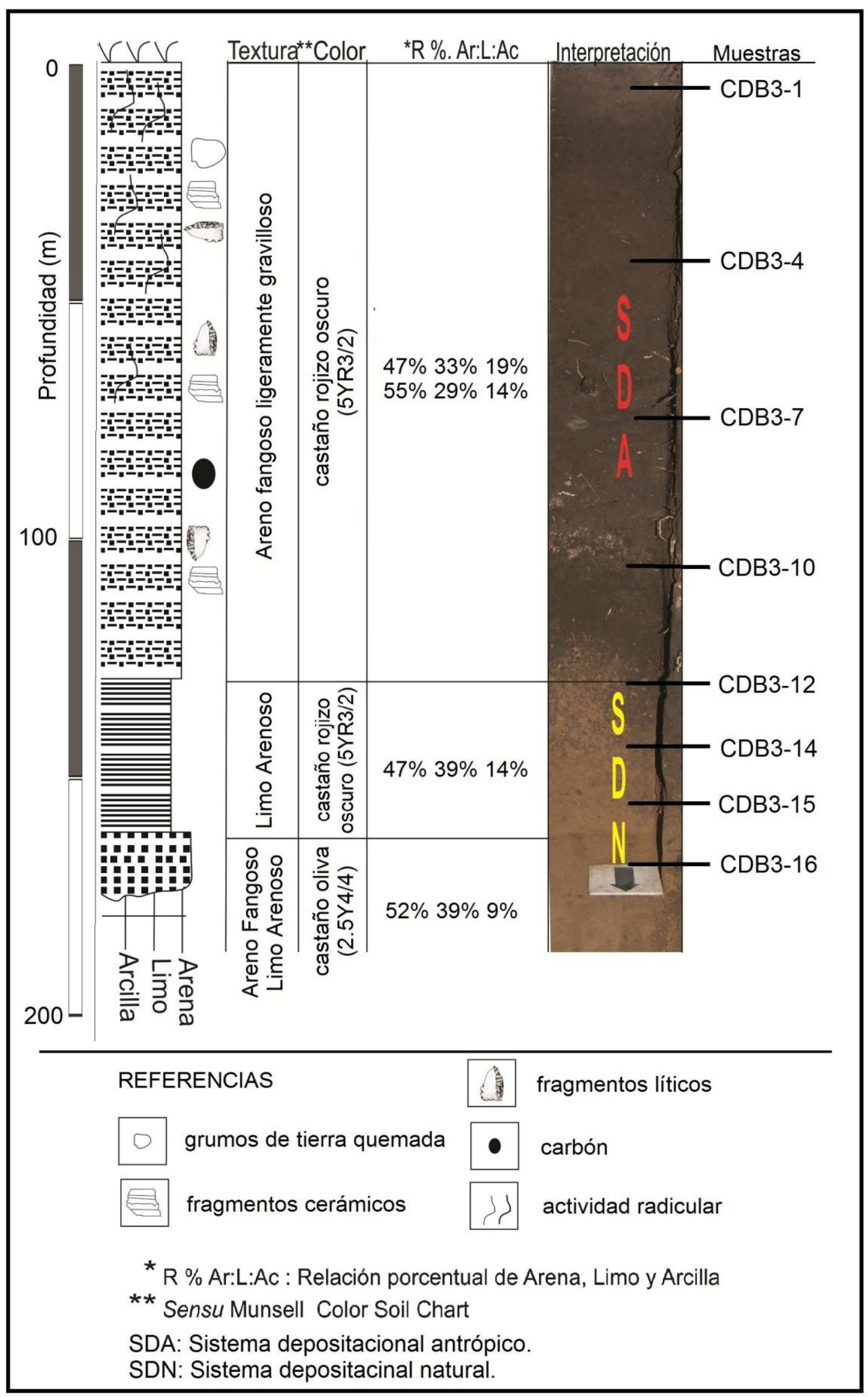

Figura 8.15. Secuencia estratigráfica del sitio arqueológico Cerro de Boari 3.

SDN: sistema depositacional natural (Grupo N). SDA: sistema depositacional antrópico (Grupo A). (Tomado Castro y Castiñeira 2017). 
De acuerdo a los análisis estadísticos ${ }^{1}$ desarrollados sobre las edades calibradas (Tabla 8.1) se puede establecer una secuencia con tres pulsos cronológicos (Figura 8.16). El primero estaría dado por la datación de $1440 \pm 50$ años ${ }^{14} \mathrm{C}$ AP (LP-2746) que corresponde a la interfase entre el SDN y el SDA, y estaría indicando el comienzo del proceso ocupacional del lugar donde se emplaza el montículo CDB3 y también el inicio del proceso crecimiento monticular. Esta edad radiocarbónica

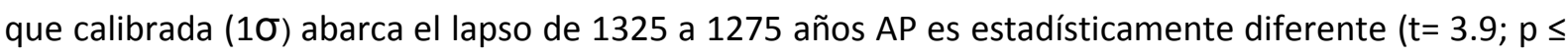
0.05) de la segunda edad más temprana de $1270 \pm 70$ años ${ }^{14} \mathrm{C}$ AP (LP-3069) que calibrada (1б) abarca el lapso de 1186 a 1067 años AP.

El segundo pulso cronológico en torno a los 1000 años ${ }^{14} \mathrm{C}$ AP estaría dado por cinco dataciones (LP-3069, LP-2744, LP-2840, LP-2871 y LP-2590) obtenidas para la porción media del SDA que van desde $1270 \pm 70$ a $1060 \pm 60$ años ${ }^{14} \mathrm{C}$ AP. Estas edades radiocarbónicas calibradas (1б) abarcan el lapso de 1186 a 900 años AP y son estadísticamente indiferenciables ( $t=6.04 ; p \leq 0.05$ ). Es necesario aclarar que dos de estas dataciones corresponden a restos óseos humanos que claramente son intrusivos en la secuencia estratigráfica pero aun así son estadísticamente indiferenciables.

El tercer pulso cronológico estaría dado por la datación más tardía de $660 \pm 50$ años ${ }^{14} \mathrm{C} A P$

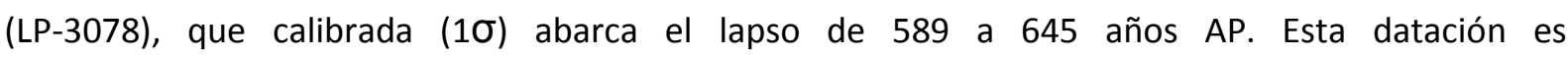
estadísticamente diferente ( $t=26.22 ; \mathrm{p} \leq$ 0.05) a la segunda más tardía (LP 2590) obtenida para la secuencia monticular. En definitiva, como es posible inferir del grafico presentado en la Figura 8.17, el $68 \%$ de la variabilidad cronológica observada es explicada por la profundidad, presentando una sucesión cronológica ordenada donde lo más profundo es más antiguo y lo más reciente es superficial o subsuperficial. Acorde a ello, se puede establecer que la estructura monticular tuvo un crecimiento discontinuo a lo largo de 800 años aproximadamente.

\footnotetext{
${ }^{1}$ Los análisis estadísticos de significancia se realizaron con el programa Calib 7.0.
} 


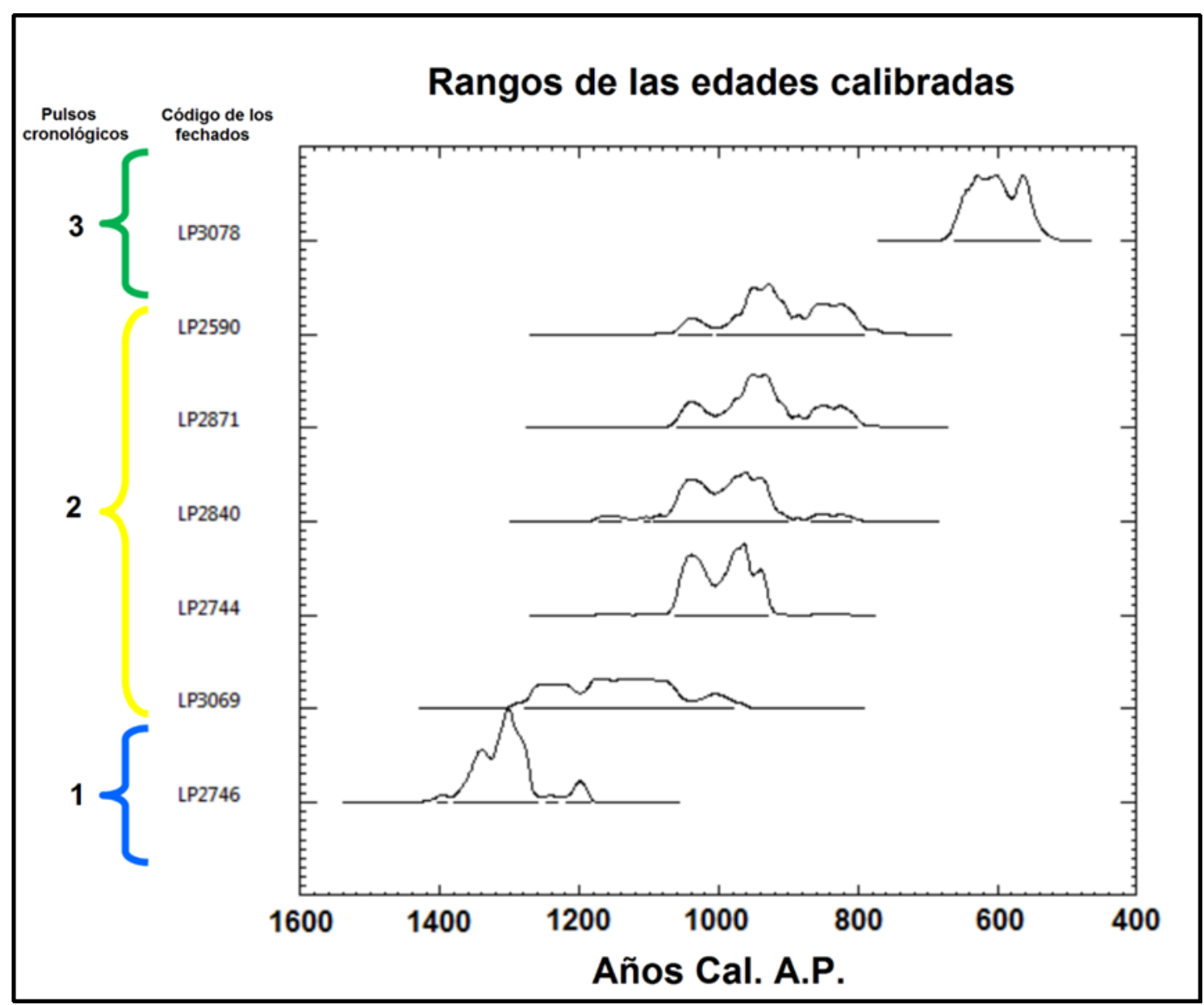

Figura 8.16. Curvas de calibración (1 $\sigma)$ de las edades radiocarbónicas del sitio arqueológico Cerro de Boari 3.

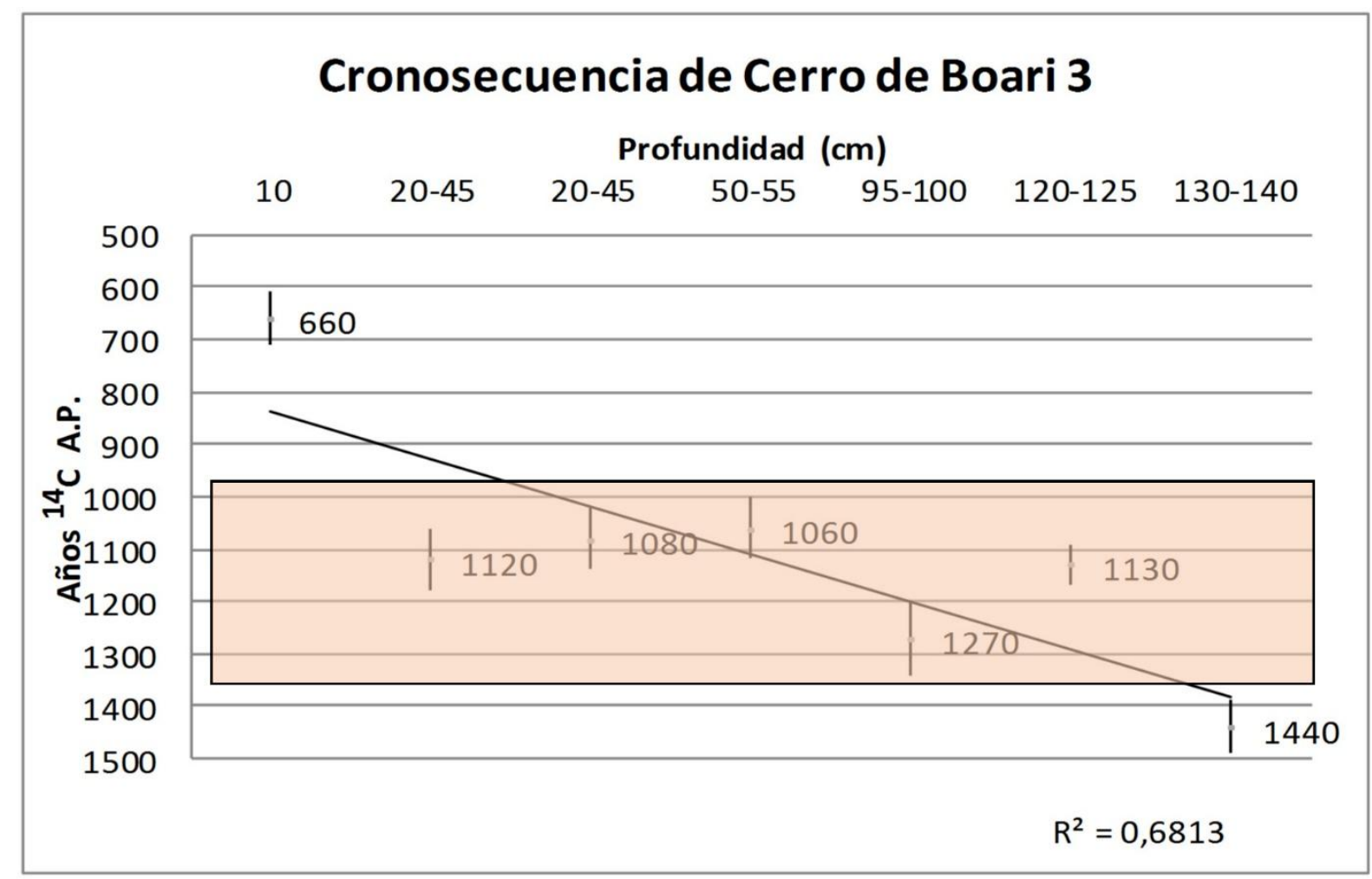

Figura 8.17. Secuencia cronoestratigráfica del sitio arqueológico Cerro de Boari 3. 
Finalmente se puede establecer que el conjunto de dataciones del segundo rango temporal de ca. 1000 años AP corresponden al montículo propiamente dicho. Por su parte, en torno a los 660 \pm 50 años ${ }^{14} \mathrm{C}$ AP se produjo la finalización del crecimiento monticular, pudiendo también haber culminado la ocupación prehispánica y el mantenimiento del montículo; este último momento se presenta separado aproximadamente por 400 años del evento anterior. Por último, si bien de acuerdo a los análisis cronológicos desarrollados se pueden establecer discontinuidades en la secuencia de ocupación de CDB3, no se hallaron aún, en el conjunto de atributos del registro material, cambios tecnológicos que puedan correlacionarse directamente con los tres pulsos cronológicos.

Si se consideran además las dataciones radiocarbónicas de CDB2 se observa que, por un lado, la datación de $1890 \pm 80$ años ${ }^{14} \mathrm{C}$ AP (LP-3080), que corresponde a la interfase entre el albardón y el depósito arqueológico, estaría mostrando que el comienzo de la elevación de este montículo es anterior a CDB3, y por otro lado, la datación de $1160 \pm 80$ años ${ }^{14} \mathrm{C}$ AP (LP-3113) mostraría que al menos en parte la ocupación de ambos sitios arqueológicos fue contemporánea, ya que esta edad es estadísticamente indiferenciable ( $t=1,07 ; p \leq 0.05)$ de la de $1270 \pm 70$ años ${ }^{14} \mathrm{C}$ AP de CDB3.

\subsection{2- CONJUNTO LÍTICO}

En relación a las materias primas identificadas (Tabla 8.3) se observa una tendencia semejante a lo que ocurre con los demás sitios arqueológicos del sector $C$, tanto en relación a los porcentajes de materias primas, donde predominan las silíceas $(n=2547 ; 87,3 \%)$ sobre las areniscas ( $n=364 ; 12,5 \%$ ), como en relación a la abundancia de caliza silicificada (véase Capitulo 7 , Sección 7.2.2). En este sentido, existe una tendencia marcada en favor de la explotación de rocas silíceas de la Formación Guichón provenientes de distancias medias o largas (>60 km), y en segundo lugar se explotaron las areniscas disponibles inmediatamente en los depósitos de la Formación Salto Chico. La gran cantidad de desechos de caliza silicificada en parte probablemente se deba a la eliminación de sus impurezas, inclusiones, vesículas, grietas y fisuras propias de esta materia prima, lo que a su vez apoyaría la llegada de clastos y núcleos con escasa reducción.

Algunos de los instrumentos (p. ej. raspador, bola, piedra lenticular, piedras con hoyuelos y los pulidores/abradidores activos) pueden ser considerados formales, en el sentido de Andrefsky (1994), en contraposición a los conjuntos informales (p. ej. piezas con retoque sumario y piezas con retoque). Los primeros habrían estado asociados a estrategias conservadas y los segundos a expeditivas; resultado de estas últimas también podrían ser las 25 lascas con rastros complementarios que indicarían el uso de filos naturales sin mayor preparación. La primera de estas estrategias respondería a la eficacia funcional de los instrumentos, a la inversión de tiempo en su manufactura u otras causas no económicas e invisibles en el registro (para una discusión más amplia 
véase Colombo 2013; Escola 2004; Hermo 2008), y no a la disponibilidad y maximización de materias primas (Andrefsky 1994; Bamforth 1986; entre otros), dado que en el sector son abundantes sobre todo las areniscas, pero además fue significativo el aprovisionamiento de CDB3 con rocas y minerales silíceos. La segunda respondería simplemente al aprovechamiento de desechos con atributos potencialmente utilizables como filos agudos para tareas inmediatas.

A partir de los instrumentos tallados habría una tendencia hacia la utilización de lascas internas de buena materia prima, a partir de las cuales se elaboraron, mediante retoque y microretoque marginal, filos unifaciales. También se identificó un caso de reciclaje por talla a partir de una lasca desprendida de un artefacto picado/abradido. Asimismo, se han utilizado rocas en estado natural como clastos de arenisca o rodados fluviales, ya sea como instrumentos pasivos (rompecocos) o activos (pulidores/abradidores, bola, piedra lenticular y percutor). En cuanto a las dimensiones de los instrumentos, en los tallados no hay un predominio marcado de algunos de los valores determinados (Tabla 8.4); pero en cuanto a los elaborados por picado, pulido y/o abrasión o modificados por uso, estos tienden a ser mediano normales, grandes y muy gruesos. Particularmente el percutor, si bien es de tamaño grande (sensu Aschero 1983), no es un percutor pesado por lo que sería adecuado para retalla o formatización final, y no tanto para la reducción de grandes bloques (Colombo 2013; Escola 1993; Torrence 1986).

En relación a los desechos de talla y su estado de fragmentación (Tabla 8.5), dejando de lado los desechos indiferenciados, se registra un predominio de los desechos fracturados (lascas fracturadas -con y sin talón- y no clasificables) (79,9\%) sobre las lascas enteras $(20,1 \%)$. Tanto la abundancia de desechos de talla como su estado de fragmentación indican que en CDB3 ocurrió un intensivo proceso de talla. En cuanto a los tipos de lascas (Tabla 8.6), excluyendo aquellos cuyo estado de fragmentación es indiferenciado, existe un predominio de lascas internas $(n=805 ; 75 \%)$ sobre las externas $(n=130 ; 12,1 \%)$, el resto son indiferenciadas ( $n=139 ; 12,9 \%)$. En la muestra analizada las lascas de arista son las más representadas. El predominio de lascas internas estaría evidenciando que las actividades más recurrentes fueron la formatización, la regularización y el mantenimiento de instrumentos. También se debe considerar que la presencia de las lascas externas sugiere que también se realizó descortezamiento y reducción primaria, aunque su baja proporción indicaría que la mayor parte de este proceso probablemente se realizó fuera del área excavada o del montículo.

En relación a la distinción entre desechos externos e internos y sus implicancias, los talones de las lascas contribuyen con información al respecto (Tabla 8.7). En este sentido, se registró un amplio predominio de talones preparados (liso, diedro, facetado, filiforme, puntiforme y fracturado) $(n=478)$ sobre los corticales (natural y liso natural) $(n=35)$. Esto apoyaría la idea sobre la preparación de las plataformas de percusión para optimizar el resultado de los golpes buscando obtener lascas adecuadas para la manufactura instrumentos. La baja frecuencia de talones corticales, sumado a que 
solo el $12,1 \%$ de la muestra corresponde a lascas externas, apoyaría la idea de que las primeras etapas de la reducción lítica habrían ocurrido en otra área del montículo o fuera del mismo. Por su parte, si bien la técnica de talla por presión no fue registrada en instrumentos de CDB3, tanto los talones filiformes y puntiformes podrían estar asociados a esta técnica; su ausencia en el registro estudiado puede ser explicada porque los instrumentos conservados, en los que generalmente la técnica de presión es utilizada, hayan sido descartados fuera del área excavada o del montículo, como lo sugiere la muy baja frecuencia de los mismos (Tabla 8.4).

La asociación más frecuente entre talones lisos con inclinación recta y bulbos difusos $(n=108)$ y pronunciados $(n=67)$ (Tabla 8.7) indicaría la búsqueda de lascas internas para la producción de instrumentos a partir de frentes de extracción y plataformas preparadas; como además lo sugieren las lascas con talones y frentes de extracción abradidos y retocados $(n=3)$, siendo estos atributos evidencia clara de la preparación tanto del frente de extracción como de la plataforma de percusión del núcleo, antes de la extracción. Por otra parte, en cuanto a la relación entre presencia/ausencia de labio y tipo de bulbo (Tabla 8.8) se observa que el $67,2 \%(n=345)$ de las lascas presentan labio. La diferencia más significativa entre presencia/ausencia de labio y bulbos se da dentro del conjunto de lascas con el mismo tipo de bulbo. En este sentido, dentro de las lascas con bulbos pronunciados el $87,2 \%(n=177)$ presenta labio, mientras que el $12,8 \%(n=26)$ carece de este rasgo. A su vez, dentro de las lascas con bulbos difusos la diferencia es mucho menos marcada, ya que el $57,9 \%(n=165)$ presenta labio, mientras que el $42,1 \%(n=120)$ carece de este rasgo. A partir de esto se observa que existe una mayor asociación entre bulbos pronunciados y presencia de labio; mientras que para los bulbos difusos la presencia de labio se da en frecuencias no muy disimiles. La evidencia presentada sugiere un relativo predominio de percutores blandos. Se observa además que la presencia de labio no estaría especialmente vinculada al uso de percutor duro o blando, ya que ambos tipos de bulbos registran labio en proporciones similares.

A partir del origen de extracción de las lascas externas $(n=80)$, internas $(n=18)$, indiferenciadas $(n=6)$ (Tabla 8.6) y desechos indiferenciados $(n=44)$ (Tabla 8.5), además de los tipos de talón (Tabla 8.7); se determinó que una parte de estos desechos de talla proviene de rodados fluviales silíceos $(n=118)$ y otra parte proviene de clastos silíceos o de arenisca $(n=30)$. Estos rodados proceden de depósitos secundarios o de la Formación Salto Chico, y corresponden al 7,4\% de las rocas y minerales explotados. La baja frecuencia total de desechos con reserva de corteza $(n=183$; Tabla 8.7 y 8.9) concuerda con que la mayoría de las materias primas identificadas en CDB3 (Tabla 8.3) corresponden a rocas de la Formación Guichón (calizas silicificadas y probablemente algunas silcretas y sílices), las cuales generalmente no presentan corteza, dado que se obtienen de filones, clastos o bloques, y en menor frecuencia en forma de rodados. En este sentido, esta materia prima habría sido transportada a CDB3 en forma de clastos, núcleos o preformas y allí fueron intensamente talladas. Lo mismo ocurriría con las areniscas de la Formación Salto Chico que se encuentran 
inmediatamente disponibles $(<10 \mathrm{~km})$, considerando además la posibilidad de que una pequeña parte una haya ingresado al asentamiento en forma de instrumentos previamente elaborados en las canteras-taller cercanas (p. ej. El Taller; véase Capítulo 7). En síntesis, los rodados fluviales, inmediatamente y localmente disponibles, ingresarían enteros al asentamiento, y las calizas silicificadas y las areniscas con un previo descortezamiento y reducción primaria, total o parcial.

En relación a la presencia de corteza y número de lascados en la cara dorsal de las lascas internas y externas (Tabla 8.9), los resultados se ajustan a lo esperado. Dentro de las lascas externas $(n=130)$ las más frecuentes son las que no presentan lascados (primarias) $(n=72)$; dentro de las secundarias y con dorso natural predominan las que tienen un lascado. A su vez, dentro de las internas predominan las que tienen dos negativos de lascado $(n=285)$ seguidas por las que tienen tres negativos $(n=228)$. De acuerdo a estos resultados se plantea que el proceso de talla fue relativamente intensivo, dado que predominan las internas por sobre las externas, y dentro de las primeras las lascas con dos y tres negativos de lascado conforman el $47,7 \%$ de la muestra.

En cuanto a las dimensiones de los desechos de talla (Tablas $8.10,8.11$ y 8.12 ) predominan aquellos con tamaño pequeño y espesores muy delgados, y en frecuencia casi similares se registran lascas con longitud-anchura medianas y cortas. Estas dimensiones estarían reflejando actividades de retalla y formatización de instrumentos. Apoyando este punto se destaca que en los análisis sedimentarios se observó la presencia de microlascas (Figura 8.7B). Por otra parte, se registraron alteraciones térmicas en 122 desechos de talla, siendo la materia prima más afectada la caliza silicificada de la Formación Guichón. Como fue planteado para el sector C no se trataría de una alteración intencional.

Se recuperaron 21 núcleos (Tabla 8.13) caracterizados por excelente y buena materia prima. Las formas-base corresponden a rodados silíceos y clastos con tamaños menores a $7 \mathrm{~cm}$, que en general fueron descortezados, ya que la mayoría de los planos de percusión son lisos. Se usaron dos y tres planos para extraer lascas. En general presentan muchos lascados y menos del 50\% de corteza $(n=6)$. En síntesis, se observan núcleos muy reducidos y sin corteza, llegando al punto de su agotamiento $(n=10)$ y descarte en el asentamiento.

A partir del análisis tecnomorfológico en general se puede observar que están presentes todas las etapas del proceso de producción lítica (Ericson 1984), desde el aprovisionamiento hasta el descarte. Está presente una tecnología de manufactura predominantemente unifacial, ya que se registró solo una lasca de adelgazamiento bifacial. La técnica de talla predominante es la percusión directa con percutores blandos y duros, registrándose también talla bipolar; también hay instrumentos elaborados mediante picado, abrasión y/o pulido y modificados por uso. Se confeccionaron tanto instrumentos conservados y expeditivos, y también se usaron filos naturales.

El conjunto lítico de CDB3 se caracteriza por un amplio predominio de desechos de talla ( $\mathrm{n}=$ 2878) sobre instrumentos ( $n=28)$ y núcleos ( $n=21$ ) (Tabla 8.2), y por la explotación predominante de 
caliza silicificada proveniente desde distancias medias o largas que habrían ingresado al asentamiento en forma de núcleos, clastos o preformas. El predominio de desechos fracturados, internos, con alta frecuencia de talones preparados, y de dimensiones pequeñas y delgadas; sumando a la presencia de núcleos pequeños con baja proporción de reserva de corteza, con predominio de planos de percusión lisos, muchos lascados y en algunos casos agotados, permiten plantear que en este sitio arqueológico ocurrió un proceso de talla intensivo, donde una de las actividades más recurrentes fue la producción de instrumentos. En este punto cabe recordar que el $44,9 \%(n=1292)$ de la muestra total de desechos de talla corresponde a desechos menores a $1 \mathrm{~cm}$. Una pequeña fracción de estos microdesechos analizados ( $n=176$ ) apoya esta idea de la talla intensiva, ya que los porcentajes son similares a los registrados en el resto del conjunto estudiado mayor a $1 \mathrm{~cm}$. Asimismo, cabe recordar que todo el conjunto lítico recuperado proviene de apenas poco más de $4 \mathrm{~m}^{2}$ excavados, esta alta densidad de artefactos estaría indicando también una gran producción de instrumentos.

\subsection{3- CONJUNTO CERÁMICO}

El 98,2\% de la muestra total presenta tamaños menores a $5 \mathrm{~cm}$ evidenciando un alto grado de fragmentación. Si bien el conjunto no presenta evidencia de haber sufrido algún tipo de alteración estructural producto de la acción fluvial y/o eólica, tal vez el grado de fragmentación de la muestra se deba en parte a acciones antrópicas como pisoteo o rotura intencional. La presencia de rodetes amasados y masas de arcilla cocida, estas últimas presentes en todas las cuadrículas y niveles y en algunos casos con improntas de dedos humanos, sugiere la fabricación local de cerámica. Paralelamente estos desechos de manufactura habrían funcionado como consolidantes del montículo, junto a los demás restos arqueológicos.

En referencia a la atmósfera de cocción inferida a partir de la observación del color del núcleo y de ambas superficies de los bordes $(n=59)$, se sugiere que la distribución de frecuencias de colores estaría indicando la predominancia de una cocción oxidante incompleta $(n=46 ; 78 \%)$, siendo el resto indeterminada $(n=13 ; 22 \%)$. Dentro de las inclusiones registradas es predominante la presencia de arena en el $81,3 \%(n=48)$ de los bordes, se presenta como única inclusión así como combinada con los demás tipos. Esto sugiere que su incorporación a la pasta es de carácter natural estando presente en las arcillas seleccionadas para alfarería. El tiesto molido presente en el 6,8\% (n= 4) es claramente intencional, lo que sugiere cierto grado consideración especial en la preparación de la materia prima. Asimismo, se determinó la presencia de espículas de esponja en el $11,9 \%(n=7)$ de los bordes, y se trataría de un agregado intencional utilizado frecuentemente en la cuenca del río Uruguay (véase Capdepont et al. 2013; Serrano 1933a; y Capítulo 5, 6, y 7). La presencia de espículas de esponjas como inclusión intencional fue discutida en profundidad en el Capítulo 5 y se hacen 
extensivas algunas de esas consideraciones a CDB3, aclarando que en este caso no se realizaron identificaciones taxonómicas.

En relación a la alfarería decorada se identificaron gran variedad de técnicas, predominando la incisión sobre las demás, registrándose también decoraciones combinadas. La decoración se sitúa mayormente cerca de los bordes o la parte superior de las vasijas. En el conjunto de vasijas reconstruidas se identificaron dos cuencos grandes, tres platos y probablemente el conjunto también incluya varias ollas y escudillas. Es claro el predominio de cerámica utilitaria lisa, que en algunos casos todavía conserva rastros de hollín. Los agujeros de suspensión registrados en algunos recipientes sugieren el uso de cuerdas o tientos para la suspensión de los mismos.

El apéndice zoomorfo y las piezas modeladas (excepto probablemente el asa en arco) son comunes en el registro regional y se identifican con la entidad arqueológica Goya-Malabrigo (Ceruti 2003a; Politis y Bonomo 2012). Asimismo, dentro de las vasijas reconstruidas se identificaron un yapepó y un cambuchí guaraníes (Brochado 1984; Noelli 1993, 2004). El yapepó es utilizado para procesar alimentos en el fuego, análogo a la olla, y el cambuchí es destinado a la producción, almacenaje y servicio líquidos, análogo a la tinaja o jarro. Ambos también pueden funcionar como urna funeraria. Estos hallazgos escasos y relativamente superficiales (desde la superficie hasta los $0,45 \mathrm{~cm}$ ) estarían indicando que la presencia guaraní en CDB3 no sería intensiva como en los demás sitios arqueológicos guaraníes del sector como EDB, LC/IDG1 o Ñ-AC/AU. Estos materiales pueden ser considerados por el momento como intrusivos pero aun así reflejan la presencia guaraní en la LACDB, mostrando algún tipo de interacción entre sus ocupantes y los guaraníes (sobre este punto véase Capítulo 9).

\subsection{4- CONJUNTO ARQUEOFAUNÍSTICO}

Cerro de Boari 3 presenta una variedad de especies propias del tipo de ambiente en el que está inmerso el sitio arqueológico en la actualidad. Por lo tanto, desde el punto de vista paleoambiental, el registro faunístico refleja condiciones semejantes a las actuales para el período de ocupación, y a su vez una relativa estabilidad ambiental para los últimos 1400 años si se consideran solamente las dataciones de CDB3. Ahora bien, considerando la datación de CDB2 de $1890 \pm 80$ años

${ }^{14} \mathrm{C}$ AP y la de otro sitio arqueológico cercano como CL2 de $2050 \pm 60$ años ${ }^{14} \mathrm{C}$ AP que presenta una arqueofauna similar a CDB3 (Capítulo 7), estas condiciones ambientales ya estarían establecidas hace aproximadamente 2000 años AP.

En cuanto a los agentes tafonómicos evaluados en el conjunto arqueofaunístico de CDB3 (Tabla 8.16), se observa que en la muestra donde se relevó la meteorización la mayoría $(92,44 \%)$ presenta estadío 2. Esto indicaría que los restos faunísticos no estuvieron expuestos a las condiciones ambientales por un largo período. Por otra parte, el $75,4 \%$ de la muestra total (excluyendo los 408 
moluscos) presenta depositación de óxido de Manganeso, esto es acorde con lo que cabría esperar para este tipo de ambiente relativamente húmedo que favorece dicho proceso.

Todos los taxa registrados (excepto el zorro) presentan algún tipo de evidencia de procesamiento antrópico (huellas de corte, negativos de impacto, termoalteración y fracturas frescas) en grado variable, siendo la alteración térmica la más representada. La nula representación de modificaciones producto de pisoteo o de la actividad de roedores y carnívoros, muestra que este tipo de factores no afectaron la muestra. Tampoco se registró abrasión producto de la acción fluvial o eólica, lo que permite sostener que los restos no sufrieron transporte por este tipo de agentes. Considerando esto, conjuntamente con el estadio de meteorización predominante, el conjunto habría sufrido un enterramiento relativamente rápido, posiblemente durante los eventos de elevación y/o mantenimiento de la superficie del montículo. Si bien no se han encontrado marcas de raíces, estas sin duda afectaron de alguna manera la distribución espacial de los materiales, ya que se registraron raíces de tamaños medios y chicos hasta una profundidad de 0,60 $\mathrm{m}$ desde la superficie.

Dentro del conjunto analizado predominan los peces, seguidos por los moluscos, mamíferos y por último los reptiles. La mayoría de los peces óseos solo se identificaron a nivel de Clase y no se ha calculado el MNI. Para los peces se registraron elementos axiales y apendiculares, así como algunas escamas (Figura 8.7A), lo que indicaría de manera general que los mismos habrían ingresado completos al asentamiento. Dentro del conjunto se identificaron bogas y armados, las primeras representadas exclusivamente por dientes y los segundos por sus espinas.

Dentro del total de peces $(\mathrm{NISP}=8248)$ se registraron 823 especímenes con alteración térmica, 66 de ellos corresponden a las bogas y dos a los armados. En base al alto NISP $=8248$ registrado en una sola cuadrícula se puede considerar que la explotación de peces ocuparía un lugar destacado en la dieta; y su captura implicaría un tiempo considerable y una tecnología especializada y eficiente. La mayoría de los moluscos corresponderían a Diplodon sp., que al presentarse generalmente muy deteriorados se dificulta su identificación específica. Se destaca su abundancia y se plantea que ingresaban completos al asentamiento; luego del consumo la mayoría de sus valvas fueron descartadas y otras usadas en la elaboración de adornos.

Considerando tanto el volumen y frecuencia relativa de peces y moluscos, no solo en la cuadricula 1 sino en toda la excavación, se plantea que estos taxa resultaron de gran importancia para la subsistencia de los habitantes de CDB3 durante toda su ocupación; ya que ambos se registran a lo largo de toda la columna estratigráfica en proporciones relativamente semejantes entre los niveles 10 y 29, disminuyendo en los niveles de interfase, y registrándose algunos pocos en el albardón (Figura 8.3). Este consumo masivo de peces y moluscos también se registró en otros sitios arqueológicos del río Uruguay inferior (Arrizurieta et al. 2010; Chiri 1972; Cione et al. 1977; Parisi y Liotta 2010). 
Dentro de los mamíferos identificados el mayor $\mathrm{MNI}$ le corresponde al cuis ( $\mathrm{MNI}=8$ ), la categoría Cervidae presenta un $\mathrm{MNI}=2$ y todos los demás mamíferos un $\mathrm{MNI}=1$. El MNI del cuis se obtuvo a partir de las hemimandíbulas, que son el elemento más representado, tal vez esto se deba a una preservación diferencial ya que es uno de los elementos de mayor densidad ósea. A partir del perfil esqueletario del cuis que incluye elementos axiales y apendiculares, junto a las evidencias antrópicas, se determinó que los individuos de esta especie ingresaron completos al asentamiento y allí fueron procesados, consumidos y descartados. No se registraron huellas de corte y se hacen extensivas aquí las consideraciones vertidas en el Capítulo 7 sobre la ausencia de las mismas. Ocho especímenes correspondientes al cráneo y los miembros registran alteración térmica. Esto podría ser indicador de cocción directa sobre el fuego o descarte sobre el mismo. Paucke (1944: 356) describe el asado del cuis entre los mocovíes, un procesamiento similar podría ser el responsable de las alteraciones térmicas observadas. El consumo de este taxón también se registró de manera significativa en otros sitios arqueológicos de la región (Acosta 2005; Pérez Jimeno 2007; Santiago 2004).

Siguiendo con los roedores, el coipo presenta un $\mathrm{MNI}=1$, en cuyo cálculo se excluyeron los incisivos sueltos. Esta es una de las especies faunísticas más representadas en el registro arqueológico regional (Acosta y Sartori 2011; Bonomo et al. 2014a; Tonni et al. 1985; entre otros), en este caso su escasez talvez se deba a que solo se estudió una cuadrícula. Aun así el perfil anatómico del coipo está representado por elementos axiales y apendiculares, lo que junto a las evidencias antrópicas indica que habrían ingresado completos al asentamiento y allí se fueron procesados, consumidos y descartados. El cráneo está representado solo por incisivos fragmentados, esto apoyaría el ingreso de estos animales completos.

En el coipo no se registraron huellas de corte, esto es acorde con los datos regionales, ya que se ha determinado que el coipo en general presenta una relativa baja frecuencia de huellas de corte (Acosta y Sartori 2011; Bonomo et al. 2014a; Santini 2009, 2011). Esto seguramente se debe al bajo grado de trozamiento que requieren animales de este tamaño. Asimismo, se registraron fracturas frescas en metapodios, fémur, costilla y vértebra; y un astrágalo y un metapodio están carbonizados, probablemente productos de su exposición directa al fuego durante el asado.

Para el caso de los sigmodontinos $(\mathrm{MNI}=1)$ y los especímenes clasificados como Rodentia (MNI= 1) se registraron elementos craneales y de los miembros, de los cuales tres evidencian alteración térmica. Esto último apoyaría su origen antrópico. Dado su pequeño tamaño, al igual que el cuis, estos roedores habrían ingresado completos al asentamiento y allí fueron procesados, consumidos y descartados.

El carpincho $(\mathrm{MNI}=1)$ está representado sobre todo por elementos del cráneo, particularmente la hemimandíbula registrada presenta meteorización estadío 4. Si bien también se registró una 2 a falange del miembro posterior, no se puede profundizar sobre el perfil anatómico de 
esta especie. Asimismo, a pesar de que no se registraron huellas de procesamiento antrópico debido al estado de deterioro de la hemimandíbula, se considera que esta especie habría integrado la dieta de los ocupantes de CDB3 como ocurrió en sitios arqueológicos cercanos como CL2 y SPL (Capítulo 7).

Con respecto al total de los cérvidos $(\mathrm{MNI}=4)$, en general se registraron elementos de los miembros. Excepto el fémur, los restantes elementos (cráneo, astrágalo, metapodios y falanges) son de bajo rinde económico. Si bien la escasez de elementos no permite establecer una tendencia clara respecto a la explotación de estas especies, podría ser relevante que partes esqueletarias con medio y alto rinde económico están ausentes; una vez más esto puede deberse a que solo se analizó una cuadrícula, ya que se puede mencionar que en el sondeo 3 se recuperó un axis incompleto de guazuncho o venado (nivel 28), y una epífisis distal de húmero izquierdo de ciervo con una fractura transversal claramente antrópica y huellas de corte (nivel 28). Asimismo, se debe tener en cuenta que la intensidad del procesamiento de estas unidades para la extracción de la médula ósea, puede reducir la frecuencia de elementos determinables. En este sentido, en los cérvidos se registraron fracturas frescas sobre huesos largos $(n=8)$ y fragmentos carbonizados $(n=2)$. Además, las unidades anatómicas mayores pudieron ser desintegradas en fragmentos menores constituyendo parte del conjunto lascas óseas procedentes de huesos largos de mamíferos de mediano y gran porte (NISP= 211). Estas lascas a su vez tienen negativos de impacto $(n=2)$, huellas de corte $(n=3)$ y alteración térmica $(n=193)$. Cabe señalar también que siete de los 15 instrumentos óseos fueron elaborados sobre metapodios de cérvidos, y seguramente el proceso de manufactura de los mismos generó desechos óseos que en este análisis se incluyeron en la categoría MAMMALIA.

La gran mayoría de los especímenes asignados a la categoría Mamífero grande (NISP $=34$ ) o mediano $(\mathrm{NISP}=190)$ indeterminado son fragmentos de diáfisis de huesos largos, lo que estaría indicando la explotación intensiva de estas especies de mediano y gran porte. Esta fragmentación sumada a la presencia de fracturas en estado fresco, se puede vincular a la extracción de la médula ósea y/o a la elaboración de instrumentos.

En relación a los restantes taxa registrados en CDB3, se destaca que entre los dasipódidos $(\mathrm{MNI}=3)$ se registraron tres especies distintas lo que constituye un dato importante en cuanto a la variabilidad taxonómica del sitio arqueológico. El ingreso de estos taxa respondería al consumo. Esto se ve apoyado por el hecho de que tres de los osteodermos presentan alteración térmica. El zorro está representado por una 3 a falange $(\mathrm{MNI}=1)($ nivel 18$)$ sin evidencias de procesamiento; asimismo se debe mencionar que en el sondeo 3 (nivel 16) se recuperó una $3^{a}$ vértebra cervical de zorro (Lycalopex gimnocercus o Cerdocyon thous) también sin evidencias de procesamiento, por lo que no es posible sostener la hipótesis de su consumo. Por último, en relación a los reptiles (MNI= 2 ), la vértebra determinada como Squamata está calcinada y los fragmentos de espaldar de tortuga son el resultado de la fragmentación del caparazón. Ambos atributos, (alteración térmica y fractura) 
pueden considerarse de origen antrópico y reconociendo además que estos taxa han sido registrados en sitios arqueológicos del sector C (Capítulo 7) se considera que en CDB3 fueron consumidas.

A partir de los datos obtenidos en relación al procesamiento de las presas y su representación esqueletaria se plantea que los peces, los moluscos, el coipo, el cuis, la tortuga, el lagarto, los dasipódidos y los microroedores, habrían ingresado completos y allí fueron trozados con distinta intensidad según su tamaño y posteriormente consumidos y descartados. Las espinas de los peces además en algunos casos se usaron para elaborar espinas aguzadas. De los cérvidos habrían ingresado al menos las extremidades, siendo consumidas y descartadas, y también transformadas en instrumentos.

En relación a los instrumentos óseos de CDB3 se identificaron tres tipos (además de espinas aguzadas). En cuanto a los adornos se identificó un solo tipo con dos variantes. Los instrumentos fueron elaborados sobre huesos largos de cérvidos (Ozotocerus bezoarticus y Mazama gouazoubira) y mamíferos indeterminados de mediano a gran porte, y sobre espinas de peces (cf. Doradidae). Los mismos corresponderían a puntas de proyectil (acanaladas y ahuecadas) que reflejan actividades de caza y/o pesca; y a puntas con epífisis y espinas aguzadas que reflejan tareas domésticas como por ejemplo trabajos sobre pieles, textiles, cestería y/o cerámica.

El registro de puntas de proyectil fracturadas, además de los desechos de manufactura (o fragmentos de instrumentos), permite proponer que tanto la confección, la reparación y el recambio de las puntas y los proyectiles se realizada en los asentamientos. Al igual que la confección de la mayoría del instrumental restante y los adornos. Asimismo, los ápices fracturados indicarían su fractura in situ durante su uso o confección; o también podrían responder al retorno a los asentamientos de los instrumentos fracturados durante su uso fuera de los mismos, como fue observado entre los awá de la Amazonía (véase Politis et al. 2013b).

Los adornos corresponden a cuentas hechas con valvas de moluscos, gasterópodos en dos casos e indeterminado en un caso. Cuentas semejantes a esta última fueron halladas en los sitios arqueológicos Cerro Mayor, La Bellaca 2, Punta Canal, Anahí (Acosta et al. 2015a), Cerro Aguará (Pérez Jimeno 2007), Paraná Miní 1 (Schmitz et al. 1972), La Lechuza (Cornero et al. 2007) y Puesto Fantín (Santini 2009). Asimismo, cuentas sobre valvas asociadas a entierros humanos fueron recuperadas en el sitio arqueológico CL2 (Capítulo 7) y Arroyo Sarandí (Lothrop 1932). En CDB3 por el momento estos objetos no se pueden relacionar directamente con los entierros humanos, ya que además se recuperaron en niveles inferiores a los mismos, pero su presencia refleja que el uso de la fauna no simplemente respondió a actividades de subsistencia, sino también a actividades simbólicas y/o rituales. 


\subsection{5- CONJUNTO DE RESTOS ÓSEOS HUMANOS}

El registró bioarqueológico de CDB3 y CDB1 evidencia inhumaciones directas en los montículos. Los restos óseos humanos entremezclados con restos tecnológicos y de subsistencia evidencian una estrecha relación entre las esferas doméstica y ritual de los habitantes de la localidad, al igual que en otros sitios arqueológicos cercanos y de la región en general (Bonomo et al. 2010; Caggiano 1983a; Castro y Del Papa 2015; Greslebin 1931a; Lista 1978; Torres 1911; entre otros). Esto indicaría, la multifuncionalidad de los sitios arqueológicos de la LACDB.

El entierro secundario múltiple de CDB3 correspondería a un mismo evento inhumatorio. Esto se ve apoyado por las dos dataciones que son estadísticamente indiferenciables. Cabe destacar que es poco probable que los individuos que conforman el paquete hayan muerto en un mismo evento y hayan sido preparados simultáneamente para su entierro definitivo en CDB3. En este sentido, el armado de algunos paquetes funerarios incluiría personas muertas en distintos momentos. Asimismo, la manipulación y/o el transporte de los paquetes funerarios hasta su disposición final, posiblemente irían acompañados de la pérdida de elementos óseos, simultáneamente a la incorporación de muertos más recientes. Evidencias sobre la manipulación de los muertos para el armado de los paquetes funerarios ya ha sido registrada en el sector $C$ (véase Capítulo 7). Este tipo de prácticas rituales reflejarían un tratamiento especial de los muertos y una selección de los lugares de su depósito final, generalmente asociados a un contexto doméstico.

\section{3- CONSIDERACIONES FINALES}

La localidad arqueológica Cerros de Boari se caracteriza por presentar tres montículos alineados sobre un gran albardón costero depositado por el río Gualeguaychú. Se menciona que posiblemente haya habido un cuarto montículo, el denominado San Luís Costa-Túmulo 1 de Almeida que cuando fue visitado por este autor ya había sido fuertemente erosionado por el río (Almeida s/fa). El material arqueológico no solo está restringido a los montículos sino que cubre una amplia franja (550x80 m aproximadamente) paralela al río. La morfología de los montículos coincide con el registro general de Entre Ríos (Bonomo et al. 2010; Greslebin 1931a; Krapovickas 1953). Estos montículos permitirían habitar la zona en momentos donde aumenta el nivel de las aguas del río (como también ocurre en la actualidad), favoreciendo el desarrollo de ocupaciones más estables y duraderas en este tipo ambientes fluviales y altamente dinámicos.

A partir de los estudios sedimentológicos desarrollados en base a las perforaciones de barreno y a la excavación sistemática de CDB3, se determinó en esta localidad arqueológica la presencia de dos sistemas depositacionales, uno inferior y natural (albardón) y otro superior y 
antrópico que caracteriza especialmente a los montículos (Figura 8.15). Para la construcción de los montículos los ocupantes indígenas se aprovisionaron de arenas fangosas, que, de acuerdo a los resultados texturales y micro bio-composicionales, podrían provenir de la remoción de los horizontes superficiales y subsuperficiales de los suelos que se desarrollaban en las proximidades. A estas arenas, le fueron adicionados fragmentos cerámicos, líticos, óseos, entre otros, los cuales, además de contribuir al aumento del volumen de los montículos contribuyeron a otorgarles cohesión y solidez estructural. Las modificaciones introducidas a los sedimentos naturalmente disponibles con el objetivo de construir los montículos es lo que caracteriza a los depósitos que definen un sistema depositacional antrópico (SDA).

Las dataciones radiocarbónicas de CDB3 permiten determinar que el comienzo del evento acrecional del montículo se daría alrededor del año 1325 Cal. AP. Asimismo, el momento final estaría ubicado alrededor del año 589 Cal. AP. Dentro de este rango cronológico se obtuvieron una serie de dataciones que revelan una secuencia de ocupación de CDB3 con una duración aproximada de 800 años (Figura 8.9). Por su parte, en CDB2 se obtuvo la datación más antigua de la LACDB con una edad de $1890 \pm 80$ años ${ }^{14} \mathrm{C}$ AP (sobre materia orgánica procedente de la interfase albardón-montículo). Este último fechado indicaría que el comienzo de la elevación de CDB2 es más antiguo que CDB3 por alrededor de 500 años, lo que además extiende el rango temporal de la ocupación de toda la localidad a un periodo de ca. 1300 años. La segunda datación de CDB2 indicaría además la ocupación sincrónica de ambos montículos en torno a los 1000 años ${ }^{14} \mathrm{C}$ AP (Castro y Castiñeira 2017).

En CDB3 fue predominante la explotación de caliza silicificada de la Formación Guichón, proveniente de distancias medias o largas (>60 km), ya sea de la cuenca del río Negro en la ROU o área del Parque Nacional El Palmar (ambas márgenes del río Uruguay). En segundo lugar se explotaron las areniscas inmediatamente disponibles $(<10 \mathrm{~km})$ de la Formación Salto Chico del río Gualeguaychú. También se registró la explotación de rodados silíceos de los conglomerados de la Formación Salto Chico y de los depósitos secundarios de la Terraza I del río Uruguay, que están inmediatamente y localmente disponibles $(<60 \mathrm{~km})$.

La abundante presencia de caliza silicificada está mostrando una talla intensiva y también un importante volumen de roca aprovisionando (sensu Colombo 20013) a CDB3, como también ocurre con otros sitios arqueológicos del sector C (véase Capítulo 7). Esto refleja una importante circulación de personas a través de las vías fluviales y las zonas costeras. La caliza silicificada fue transportada a CDB3 mayormente (no exclusivamente) en forma de clastos, núcleos, o preformas con un previo descortezamiento y/o reducción primaria, total o parcial y allí fueron intensamente talladas. Lo mismo ocurriría con las areniscas de la Formación Salto Chico. La caliza silicificada también llegó a CDB3 en menor medida integrando rodados de silcretas sin tallar (véase percutor de la Figura 8.10H donde se observan las vetas de caliza silicificada). Por su parte, los rodados fluviales, ingresarían enteros y allí serían tallados o usados como percutores en algunos casos. 
El instrumental lítico refleja actividades relacionadas directamente con la subsistencia. La bola y la piedra lenticular se asocian a la caza y/o a la violencia interpersonal. El raspador, las piezas con retoque sumario y las lascas con filos naturales con el procesamiento de subproductos de la caza, pesca y recolección, y/o a la confección de instrumentos y adornos de hueso, asta o valvas. Los pulidores y el percutor con la formatización de otros instrumentos. Los yunques (rompecocos) reflejan el procesamiento de vegetales o minerales, o también de peces (harina) y/o valvas de moluscos (pigmentos). También, los desechos de talla y los núcleos muestran que las actividades más recurrentes fueron la formatización, la regularización y el mantenimiento de instrumentos (Sullivan y Rozen 1985). Además, se realizó el descortezamiento y la reducción primaria de rodados fluviales y clastos de arenisca y caliza silicificada.

La alfarería de formas simples, abiertas y sin decoración evidencia sobre todo un uso doméstico y la alfarería modelada evidencia más claramente la identificación del conjunto con la entidad arqueológica Goya-Malabrigo (Ceruti 2003a; Politis y Bonomo 2012). Esta entidad estaría vinculada a los antecesores del complejo étnico chaná-timbú (Aparicio 1929; Ceruti 2003a; Politis y Bonomo 2012; Serrano 1972; entre otros). Por su parte, el yapepó y el cambuchí guaraníes, con formas compuestas y cerradas, podrían tener tanto un uso doméstico como ritual. A su vez dan cuenta de la presencia de grupos guaraníes en la zona, tal como se registraron en los sitios arqueológicos Ensenada del Bellaco, La Correntina y Ñandubaysal - Arroyo de La Cruz/Arroyo Ubajay (Capítulo 7).

Las especies faunísticas registradas en CDB3 son propias del tipo de ambiente actual y los roedores identificados son claros indicadores de condiciones climáticas húmedas y cálidas, que se habrían establecido al menos hace ca. 2000 años AP. Los taxa explotados fueron consumidos y también utilizados en la confección de instrumentos, adornos y probablemente vestimenta y viviendas. El aporte más importante a la dieta lo constituyen los peces y en segundo término se ubicarían los moluscos y mamíferos. Esto refleja la explotación de una amplia variedad de especies disponibles en el ambiente. El instrumental elaborado a partir de estos mismos taxa refleja actividades de caza ( $y$ tal vez a violencia interpersonal) y posiblemente trabajos sobre pieles, textiles, cestería y/o cerámica.

El registro de un entierro secundario entremezclado con los restantes restos arqueológicos evidencia una estrecha relación entre las esferas doméstica y ritual de los habitantes de la localidad. Los restos óseos humanos recuperados en la parte más elevada del montículo claramente corresponden a mismo entierro secundario. Las dataciones radiocarbónicas muestran que las inhumaciones se realizaron al menos ca. 300 años después del comienzo de la formación del montículo.

A partir de los rasgos generales del registro arqueológico estudiado, la ocupación indígena de la localidad arqueológica Cerros de Boari se puede enmarcar dentro de la entidad arqueológica Goya- 
Malabrigo. Una característica singular para Goya-Malabrigo en el sector C es la presencia de abundantes artefactos líticos tallados, pulidos y modificados por uso. Debido sin duda a la disponibilidad de rocas y minerales en el área, al contrario de lo que ocurre en el río Paraná.

Para finalizar, se concluye que CDB3 es un montículo construido (antropogénico sensu Eidt 1984) donde se desarrollaron de actividades múltiples que incluyen tareas domésticas y rituales mortuorios, durante periodo que va desde ca. 1400 a 600 años AP. Fue ocupado por grupos canoeros ribereños cazadores-recolectores-pescadores y alfareros, con una elevada estabilidad residencial. Las características del registro arqueológico que permiten plantear una ocupación intensiva de CDB3 y de la LACDB, y que apoyarían la existencia de un gran asentamiento ocupado por un largo periodo de tiempo por grupo humano numeroso con un patrón aldeano, en general serían: la amplia dispersión superficial del registro arqueológico; la presencia de tres montículos agrupados y sus grandes dimensiones producto de actividades antrópicas domésticas, funerarias y constructivas; espesor de restos culturales y la densidad artefactual en cada uno de ellos; individuos de diferentes edades enterrados en un mismo lugar; la gran diversidad de recursos biológicos y geológicos disponibles (y efectivamente utilizados); la reutilización de instrumentos (rompecocos); el gran volumen de materias primas líticas que aprovisionaron el asentamiento y la gran distancia de procedencia de la materia prima más utilizada (caliza silicificada), que según el modelo de Kuhn (1994) indicarían baja movilidad residencial y largos eventos de ocupación; y por último, considerando la datación más antigua de CDB2 de $1890 \pm 80$ años ${ }^{14} \mathrm{C}$ AP, el amplio rango temporal de ca. 1300 años que abarca la ocupación de la localidad, independientemente de que la misma se haya dado de manera continua o discontinua. 


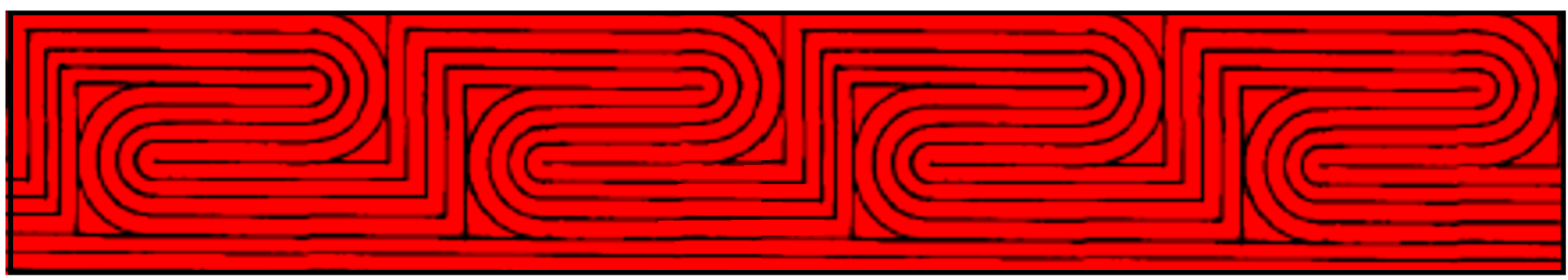

Capítulo 9

\section{DISCUSIÓN Y CONCLUSIONES}

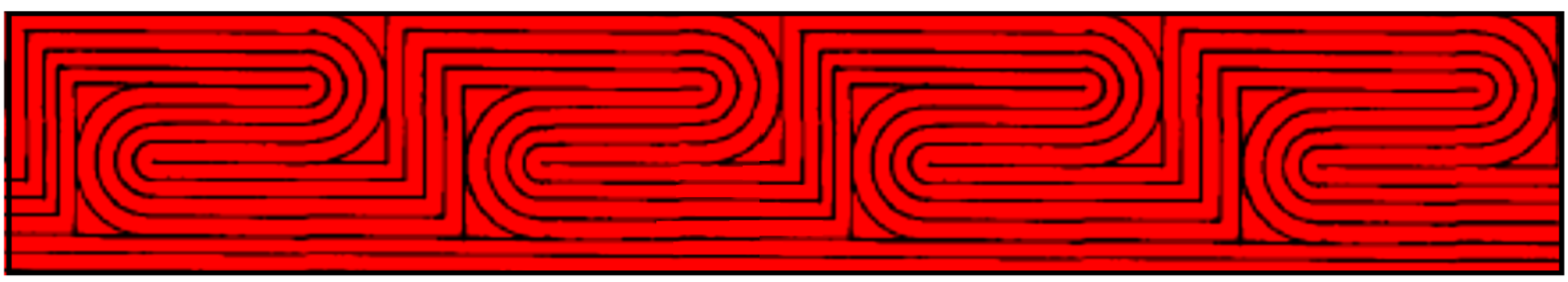




\section{CAPÍTULO 9}

\section{DISCUSIÓN Y CONCLUSIONES}

En este capítulo se discuten los resultados obtenidos en relación a cada uno de los objetivos específicos planteados en el Capítulo 1 y se exponen las conclusiones de esta investigación. Los distintos grados con los que se cumplieron los objetivos permiten discutir aspectos más generales de la arqueología regional. En este sentido, se aborda: la modificación antrópica del ambiente; la circulación de recursos utilitarios y simbólicos dentro de extensas redes de interacción; la cronología de las ocupaciones; la dispersión de las poblaciones vinculadas a la entidad arqueológica GoyaMalabrigo en el río Uruguay; la presencia de los guaraníes y las relaciones de interacción con los grupos "locales"; el grado de complejidad social alcanzado por las sociedades indígenas del área de estudio; la estabilidad de las ocupaciones; la posible influencia de ciertos rasgos ambientales sobre la ocupación de la provincia; y por último, los modelos arqueológicos regionales propuestos con anterioridad a la luz de los aportes realizados de esta tesis.

\section{1- PATRONES DE OCUPACIÓN Y USO DEL ESPACIO}

Para tratar de comprender el uso del espacio por parte de las poblaciones indígenas a nivel regional es necesario primero comprender la variabilidad de las ocupaciones dentro del área de estudio. Para contextualizar cronológicamente estas ocupaciones se han realizado 15 dataciones radiocarbónicas que las ubican en el Holoceno tardío. Si bien se detectaron algunos indicadores más tempranos (paleoindios) en los sectores A y C (Bonomo et al. 2014b; Castro y Terranova 2015), estos no cuentan con fechados absolutos. Aun así se destaca que se han registrado fechados radiocarbónicos correspondientes a la transición Pleistoceno final-Holoceno temprano y Holoceno medio en la zona de Salto Grande, en la ROU y en la provincia de Santa Fe (Austral 1994; Ávila 2011; Baeza 1985; Capdepont 2012; Castiñeira 2008; Hilbert 1991; Suárez 2011), por lo que se considera que la recuperación sistemática de restos arqueológicos más antiguos que los estudiados en esta tesis es cuestión de que continúen las investigaciones en curso en el Nordeste argentino.

Considerando la distribución espacial de los sitios arqueológicos y los hallazgos aislados dentro de los tres sectores de muestreo, se plantea que, si bien las condiciones climáticas son similares registrándose solamente una diferencia marcada en el tipo de vegetación entre el sector $A$, donde predomina el bosque xerófilo, y los sectores $B$ y $C$ donde predominan las selvas ribereñas, en 
los tres sectores las ocupaciones registradas se encuentran estrechamente asociadas a fuentes de agua. El registro arqueológico muestra la ocupación ribereña tanto de tierra firme como de islas. Se presenta en relación a márgenes de ríos, arroyos y lagunas, sobre terrazas, barrancas, playas, médanos, albardones y montículos antrópicos (modificados por actividad humana sin intencionalidad específica) y antropogénicos (intencionalmente modificados con fines productivos o constructivos) (sensu Eidt 1985). La ocupación preferencial de este tipo de geoformas costeras mencionadas también fue observada para la margen izquierda del río Uruguay (Boretto et al. 1975; Capdepont 2012, 2014; Capdepont et al. 2010; Freitas 1953b; entre otros).

Una característica particular del sector $\mathrm{C}$ es que muchos de los sitios arqueológicos son montículos (cerritos) ubicados en zonas completamente inundables. Estos pueden encontrarse aislados o agrupados hasta en número de tres ocupando extensas zonas costeras. Si bien para el río Uruguay medio los antecedentes (Capítulo 2) se refieren a "cerros" o sitios arqueológicos denominados por ejemplo Cerro La Paloma, es necesario aclarar que el término "cerro" en ese caso se refiere a grandes geoformas elevadas presentes en ambas márgenes del río y similares a lomadas o colinas con valles amplios marcados por erosión (véase Austral 1977; Rodríguez 1975) y no a montículos o albardones ocupados, como los registrados en el río Uruguay inferior y en el Delta del río Paraná (latu sensu) y comúnmente denominados "cerros" o "cerritos".

Lo anterior no significa que en el río Uruguay medio no se hayan ocupado albardones para actividades domésticas y funerarias (véase p. ej. Capdepont 2012 y Guidón 1977) sino que su frecuencia es relativamente baja en relación al río Uruguay inferior. Esta diferencia podría explicarse en parte debido a que el territorio entrerriano tiene un declive estructural de norte a sur (Capítulo 3) que provoca que sobre el río Uruguay medio las terrazas estén mejor definidas y sus barrancas altas se encuentren mayormente asociadas de manera directa al cauce del río. Contrariamente a lo que ocurre por ejemplo en el río Paraná a la misma latitud, donde entre las barrancas altas y el cauce del río existen zonas ribereñas más bajas y anegadizas propias de la llanura de inundación de ese río. Esta misma inclinación tectónica del territorio entrerriano a su vez provoca que las márgenes del río Uruguay inferior sean más bajas y que el río presente una amplia llanura de inundación. Considerando esto, y que hasta el momento no se han identificado montículos antropogénicos en el río Uruguay medio, se plantea que la mayoría de las estructuras monticulares del río Uruguay inferior (margen derecha) responden a una estrategia deliberada de ocupación de un tipo de ambiente más bajo e inundable. Donde el asentamiento en lugares protegidos del aumento del nivel de las aguas resulta fundamental para la permanencia por largos períodos.

En el río Uruguay inferior, en su margen izquierda, podría estar ocurriendo una situación similar ya que los sitios arqueológicos que Capdepont (2012, Figura 4.5; 2014, Figura 2) denomina montículos tienen su punto más septentrional en el departamento de Río Negro, más precisamente en la zona del paleodelta. Capdepont (2012, Figura 4.3) también muestra la frecuencia de localidades 
arqueológicas por unidades del paisaje (albardón, médano, costa, barrancas y zona alta) y de allí se desprende que la costa del río Uruguay ha sido ocupada a lo largo de todos los departamentos, desde Salto en el norte hasta Colonia en el sur. En los departamentos de Río Negro y Soriano, que corresponden a la cuenca inferior del río Uruguay, el registro arqueológico se dispone mayormente sobre albardones y la ocupación de barrancas u zonas altas es nula. También en Paysandú se registra ocupación de albardones pero la ocupación más frecuente se da en zonas altas y aumenta la ocupación de barrancas. La ocupación de médanos también es importante en Río Negro, no se registra en Soriano y alcanza su mayor frecuencia en Colonia sobre el Río de la Plata.

Si se consideran las ingresiones marinas que afectaron al río Uruguay en su tramo inferior (Capítulo 3), se puede plantear desde el punto de vista geomorfológico que la ocupación humana registrada en el sector $\mathrm{C}$ se desarrolló sobre las llanuras de mareas, playas de regresión y cheniers (Cavallotto et al. 2005; Iriondo y Altamirano 1988). La zona ocupada habría estado libre de la influencia de la última ingresión marina holocénica y de su estuario hace ca. 3300 años AP y posiblemente antes (Capítulo 3). Las dataciones radiocarbónicas obtenidas no sobrepasan este umbral y permiten plantear que los sitios arqueológicos estudiados en llanura costera entrerriana (Cavallotto et al. 2005) del río Uruguay inferior, estuvieron ocupados con posterioridad al mejoramiento climático, cuando se estabilizaron condiciones ambientales costeras y el territorio ya presentaba una configuración semejante a la actual. En este sentido, la ocupación humana más intensiva en zonas ribereñas se registra desde $c a$. 2000 años AP. Posteriormente, los aumentos de la temperatura y la humedad que caracterizan al Período Cálido Medieval (ca. 1400-800 años AP) (Capítulo 3) probablemente hayan favorecido la abundancia de recursos biológicos y a su vez una mayor presencia humana; como lo sugieren gran parte de las dataciones del Holoceno tardío (Capítulo 2). También por causa de las ingresiones marinas las ocupaciones humanas durante el Holoceno medio o anteriores, talvez puedan registrarse en zonas altas alejadas de los sectores costeros actuales o directamente en la cuenca media como ocurre sobre la margen izquierda del río Uruguay.

En el sector C fue predominante la ocupación de geoformas elevadas, sobre todo albardones y montículos de manera semipermanente, asociados a la cuenca de los ríos Uruguay y Gualeguaychú, y sus arroyos tributarios. Los montículos están elevados por actividad antrópica, comprobándose en algunos casos la incorporación ad hoc de sedimentos, artefactos y restos orgánicos (p. ej. Cerro de Boari 2 y 3). Cabe recordar además que la margen argentina de la cuenca inferior del río Uruguay, al sur de la desembocadura del río Gualeguaychú, está sometida a la erosión fluvial provocada por los vientos del noreste y también por la dinámica de las sudestadas y las mareas del Río de la Plata, lo que hace que esta franja costera, a diferencia de la margen uruguaya, sea más sensible a la dinámica fluvial y eólica. 
El efecto de las sudestadas sobre el registro arqueológico de la margen argentina ha sido altamente destructivo como lo mencionan algunos autores previos (p. ej. Greslebin 1931a, 1931b; y Almeida $\mathrm{s} / \mathrm{fa}$ ) y como se ha observado en nuestras prospecciones, donde generalmente en momentos de bajante de las aguas se encuentran en las playas numerosos restos arqueológicos descontextualizados. El efecto destructivo del agua no solo se registra en el río Uruguay sino también en el río Gualeguaychú donde por ejemplo el sitio arqueológico La Correntina está casi totalmente destruido (Capítulo 7).

Un aspecto por destacar es que los montículos de mayores dimensiones registrados no se ubican en cercanías de la orilla actual del río Uruguay; y posiblemente los que actualmente se encuentran cerca de la orilla en el pasado estaban más alejados debido al retroceso continuo la costa argentina mencionado anteriormente. En este sentido, la localidad arqueológica Cerros de Boari, Cerro Lorenzo 2, Túmulo 1 - Cerro Norte de Machado, Túmulo 2 - Cerro Sur de Machado y Cerro de los Pampas se encuentran bastante alejados del cauce del río Uruguay, lo que podría ser el reflejo de que los asentamientos de mayores dimensiones (p. ej. aldeas principales) se emplazaban en lugares asociados a cursos menores (p. ej. arroyo Lorenzo, Bellaco y Malo), protegidos no solo del avance de las aguas del río Uruguay, sino también de otros grupos humanos y del viento, que en caso del río Uruguay es un factor muy relevante tanto para la habitabilidad ribereña como para la navegación.

La propuesta de que los principales asentamientos no estaban expuestos en las orillas de los ríos más importantes también fue planteada para el Delta del río Paraná a principios del siglo XVI por Politis (2014), en base a su estudio del diario de navegación de Pero Lopes de Sousa (1530-1532). Para el Delta superior del río Paraná esta situación tendría su correlato arqueológico por ejemplo en la localidad arqueológica Los Tres Cerros, Cerro Grande de Los Marinos, El Durazno, El Castaño, y la mayoría de los sitios arqueológicos asignados a la entidad arqueológica Goya-Malabrigo (Apolinaire y Bastourre 2016; Bonomo et al. 2011c; Castiñeira et al. 2013, 2014; Politis 2014). Asimismo, Caggiano (1982a) destaca recurrentemente que los sitios arqueológicos del Delta del Paraná se encuentran en lugares ocultos y estratégicos.

Las ocupaciones del sector $\mathrm{C}$ reflejan una estrecha vinculación con el ambiente fluvial y la explotación sistemática de sus recursos, y entrarían dentro del patrón ecológico de uso del espacio propuesto para Goya-Malabrigo (Ceruti 2003a; Politis y Bonomo 2012). También la dependencia del ambiente fluvial y sus recursos se puede identificar en aquellas ocupaciones guaraníes del sector $C$, pero estas se disponen sobre médanos, playas y albardones arenosos asociados directamente al curso del río Uruguay y a la desembocadura del río Gualeguaychú.

Además de los sectores $\mathrm{B}$ y $\mathrm{C}$, la evidencia regional indica que el registro arqueológico está presente a lo largo de toda la costa entrerriana del río Uruguay. Se encuentra entre estos dos sectores y también al norte y al sur de los mismos (Arrizurieta et al. 2010; Badano 1940a; Caggiano et al. 1971; Cigliano 1967; Cigliano et al. 1971a, 1971b; Gregori 1968; Lafon 1971; Poenitz 1970a; 
Rebord 1998; Rodríguez y Rodríguez 1985; Serrano 1932a; Torres 1911). Esto permite plantear la ocupación intensiva de toda la ribera entrerriana durante el Holoceno tardío, pudiendo haber existido una ocupación más temprana en la zona de Salto Grande como lo indican algunas dataciones (Austral 1994; Baeza 1985; Guidón 1989; Hilbert 1991; Suárez 2011). Este tipo de ocupación también está presente sobre la margen izquierda del río Uruguay (Arredondo 1927; Boretto et al. 1975, 1980; Castillo 2004; Capdepont 2012, 2014; Capdepont et al. 2013; Díaz 1980; Farías 2005; Guidón 1989; Fontana Company 1928, 1930, 1951; Freitas 1953b, 1953c; Iriarte 1995; López Mazz et al. 2014; Teisseire 1927; entre otros).

\section{2- TECNOLOGÍA LÍTICA}

En los tres sectores de muestreo se identificaron instrumentos, desechos de talla, núcleos y geofactos, y la producción in situ de instrumentos. Cada una de estas categorías refleja distintas etapas de la secuencia de producción lítica con algunas diferencias entre los sectores, que en principio serían consecuencia básicamente de las distintas estrategias de aprovisionamiento de materias primas, sobre todo en relación a la distancia a las canteras potenciales y a la calidad de las rocas y minerales.

Dentro del área de estudio se determinó la presencia de diversas técnicas de producción de los artefactos líticos que incluyen: talla por percusión directa, por presión y bipolar; picado, abrasión y/o pulido; y modificación por uso. También se identificaron actividades que van desde el aprovisionamiento hasta el descarte, además del reciclaje de artefactos líticos; destacándose dos situaciones: la primera es que la obtención de todas las materias primas registradas en el sector $A$ ocurrió fuera del sector; la segunda es que toda la caliza silicificada registrada en el sector $C$ fue obtenida fuera del sector. Por lo tanto, en estos casos particulares se puede determinar con precisión que las materias primas provienen de distancias medias o largas (>60 km). Otra situación que marca una diferencia entre el sector $A$ y los otros dos sectores, es que en el primero no se registró una explotación diferencial entre las materias primas silíceas y las areniscas. En cambio en los sectores $B$ y $C$ se determinó una explotación diferencial en favor de las silíceas; además de que en el sector $C$ predomina la caliza silicificada de la Formación Guichón $(>60 \mathrm{~km})$ a pesar de que fueron predominantes los afloramientos de areniscas de acceso inmediato y local (sensu Bayón y Flegenheimer 2004).

Para el caso del sector $A$, que es un área que se caracteriza por la ausencia natural de rocas y minerales adecuados para la elaboración de instrumentos mediante cualquiera de las técnicas identificadas en este trabajo, se puede plantear que al no registrarse materias primas de mala calidad, las mismas fueron seleccionadas en los afloramientos y las canteras antes de iniciarse su 
traslado hacia el interior. Por su parte, en los otros dos sectores al contar con diversos tipos de materias primas se seleccionaron las silíceas para la talla y se usaron areniscas para modificar por uso o por picado, abrasión y/o pulido.

La selección predominante de materias primas silíceas en los sitios arqueológicos del sector $\mathrm{B}$ respondería tanto a la calidad de las rocas como a su disponibilidad inmediata. Por su parte, se destaca que en los sitios arqueológicos del sector C, incluyendo la localidad arqueológica Cerros de Boari, las areniscas tienen una baja proporción relativa a pesar de que los mismos están más cerca de las canteras potenciales. Esto muestra que el volumen de materias primas silíceas utilizado (particularmente caliza silicificada) no estaría relacionado directamente con la distancia a las canteras, sino más bien con la calidad para la talla y la necesidad de instrumentos de corte, raspado y puntas, entre otros.

Las estrategias de aprovisionamiento vinculadas a las materias primas del sector A y a la caliza silicificada del sector C podrían ser semejantes; ya sea por aprovisionamiento directo o indirecto, en canteras "propias", de libre acceso, de propiedad compartida, o bajo el dominio de otros grupos de la misma etnia u otras etnias (véase Capítulo 5). Lo que varía entre estos casos es el traslado, ya que desde la costa del río Uruguay hacia el sector $A$ este tuvo que ser necesariamente terrestre, mientras que desde las canteras potenciales de calizas silicificadas hacia el sector $\mathrm{C}$ pudo ser, terrestre y/o fluvial en el caso de que las mismas procedan desde el río Uruguay medio o necesariamente fluvial si proceden de la ROU. En el caso de que las canteras no fueran de acceso libre se estaría ante sociedades con territorios o puntos del espacio considerados como propios exclusivos o semiexclusivos (Colombo 2013). Esta apropiación de áreas con recursos importantes como las materias primas líticas podría limitar y condicionar el flujo de materiales líticos desde las canteras potenciales hacia las bases residenciales de diversas maneras (Colombo 2013). Por el momento, la evidencia arqueológica así como la disponibilidad de materiales y su amplia distribución en el espacio sugiere que el acceso a las canteras no estaría limitado.

A partir de las propiedades de los conjuntos líticos en el sector A, y una vez considerando los posibles modos de aprovisionamiento, se puede plantear, en base al modelo de Kuhn (1994) (Figura 4.2), que el alto volumen relativo de provisión registrado en los sitios arqueológicos y la distancia a las canteras potenciales sugieren una disminución de la movilidad residencial con eventos ocupacionales de larga duración (Capítulo 5). Esta relativa estabilidad residencial llevó a los ocupantes del sector A a trasladar grandes volúmenes de material lítico. A su vez, el volumen de la provisión disponible no permite proponer eventos de maximización de materias primas. Si bien se detectó mantenimiento y reciclaje, esto solo se identificó en puntas de proyectil líticas, lo que lleva a determinar que estas tareas no responden a la escasez de rocas y minerales, sino al menor costo de renovación de estos instrumentos formales por sobre su reemplazo. Los casos de reciclaje, que alteraron significativamente la morfología de las puntas de proyectil, se darían ante una situación 
similar, donde con una serie de retoques se pueden obtener instrumentos con una nueva función sin tener que recurrir a la provisión local de materia prima o a una obtención en las canteras lejanas.

En cuanto a las técnicas de reducción lítica se observó que son similares en los tres sectores. En todos se registró talla por percusión directa con percutores blandos y duros y talla por presión. Asimismo, en los tres sectores se registraron instrumentos elaborados mediante picado, abrasión y/o pulido y se usaron filos naturales. En los sectores $B$ y $C$ se registró talla bipolar e instrumentos modificados por uso. La talla bipolar registrada en los sectores B y $C$ tiene una baja frecuencias $(n=6)$ y su implementación podría responder a la forma en que se presenta la materia prima (p. ej. rodados), dado que una de las ventajas de la talla bipolar es la posibilidad de reducir nódulos pequeños, duros y redondeados (Flegenheimer et al. 1995). Además, en estos casos no respondería a eventos de maximización y conservación de materias primas ya que no habría escasez.

En los sectores A, B y C la conservación de materia prima no habría sido un factor crítico. En el primero debido al material lítico trasladado y en los otros dos debido a la disponibilidad inmediata de rocas y minerales óptimos para la elaboración de instrumentos. El sector A es aquel donde el aprovisionamiento sería un factor importante, por lo que debe haber tenido una incidencia relevante en la organización tecnológica de los grupos humanos, que debieron implementar estrategias tecnológicas destinadas a solucionar el problema de la ausencia natural de materiales líticos.

En relación a una baja movilidad residencial del sector $A$, según las expectativas propuestas en la Tabla 4.1 (Capítulo 4) relacionadas a las propiedades del conjunto artefactual, se observa que dentro del conjunto de expectativas arqueológicas se registraron la mayoría de ellas, como por ejemplo: bajo grado de inversión de trabajo en la manufactura (excepto en bolas y puntas de proyectil); bajo grado de estandarización, incluyendo las bolas y las puntas de proyectil; dentro del rango de calidades de materia prima que llegó a la cuenca del río Gualeguay los artefactos presentan materias primas de diversa calidad; bajo grado de diversidad en el instrumental; ausencia de instrumentos multifuncionales (ya que si bien algunas puntas fueron recicladas su diseño original no fue pensado para cumplir más funciones que penetración por impacto); instrumentos de corta vida útil (excepto bolas y puntas de proyectil); el mantenimiento registrado en las puntas, como se expresó anteriormente, tendría que ver con bajo grado de inversión de trabajo que implica su mantenimiento en relación a su manufactura total; los desechos de talla reflejan técnicas que implican bajo costo de manufactura; y los núcleos presentan bajo grado de aprovechamiento de la masa útil y no hay un patrón de reducción estandarizado identificado.

A partir de considerar la existencia de ocupaciones más estables en el sector A (Capítulo 5) también es probable que las mismas se dieran sincrónicamente con las de la costa del río Uruguay, tanto en el sector B como en el C. En estos dos últimos sectores los conjuntos líticos también indicarían una baja movilidad residencial, sobre todo en el sector $C$, debido a que se registraron la mayoría de las expectativas arqueológicas de la Tabla 4.1 (Capítulo 6, 7 y 8). Además, en el sector $C$ 
se observa que la principal materia prima con la que se aprovisionaban algunos asentamientos (caliza silicificada) proviene de distancias medias y largas, lo que indicaría, según del modelo de Kuhn (1994), un aumento de la duración de los eventos ocupacionales y la disminución de la movilidad residencial; y a su vez un aumento de la dependencia del aprovisionamiento de lugares y el aumento de la distancia promedio para el traslado de las materias primas hacia los mismos.

En base a la literatura geológica y a las prospecciones se determinaron las localizaciones potenciales de rocas y minerales. Al no realizarse cortes petrográficos no se identificaron fuentes específicas de procedencia pero se realizó una primera aproximación a la base regional de los recursos líticos (Ericson 1984). Dentro del área de estudio el aprovisionamiento de lugares implicó un sistema programado de circulación de materias primas e individuos (y seguramente otros elementos como p. ej. esponjas de agua dulce) desde las canteras hasta los asentamientos. En este sentido, de acuerdo a la presencia de determinadas materias primas en los sectores aquí estudiados, así como en otros sitios arqueológicos del Nordeste y por fuera de la región también, se pueden proponer una serie de vías terrestres y fluviales de circulación de estos recursos (Figura 9.1). En algunos casos como se mencionó arriba el traslado necesariamente tuvo que ser por vía terrestre, pero en los casos donde se pudieron dar ambas formas de traslado posiblemente predominó la vía fluvial por la capacidad de las canoas de transportar un mayor volumen y a mayor velocidad.

Para cada materia prima se grafica el trayecto más simple y directo (terrestre o fluvial) entre las canteras potenciales conocidas de mayor relevancia y los tres sectores $(A, B$ y $C)$ y también los sitios arqueológicos o zonas ubicadas fuera del área de estudio donde cada materia prima fue registrada. No se consideran la distancia social, situaciones de intermediación o una combinación de traslado terrestre y fluvial. No se descarta que esto haya sucedido pero graficar todas estas posibilidades complejizaría innecesariamente la visualización de la Figura 9.1. Asimismo, se considera que la circulación de cada una de las materias primas en general no se habría dado de manera aislada, sino que varias estarían siendo trasladadas simultáneamente. 


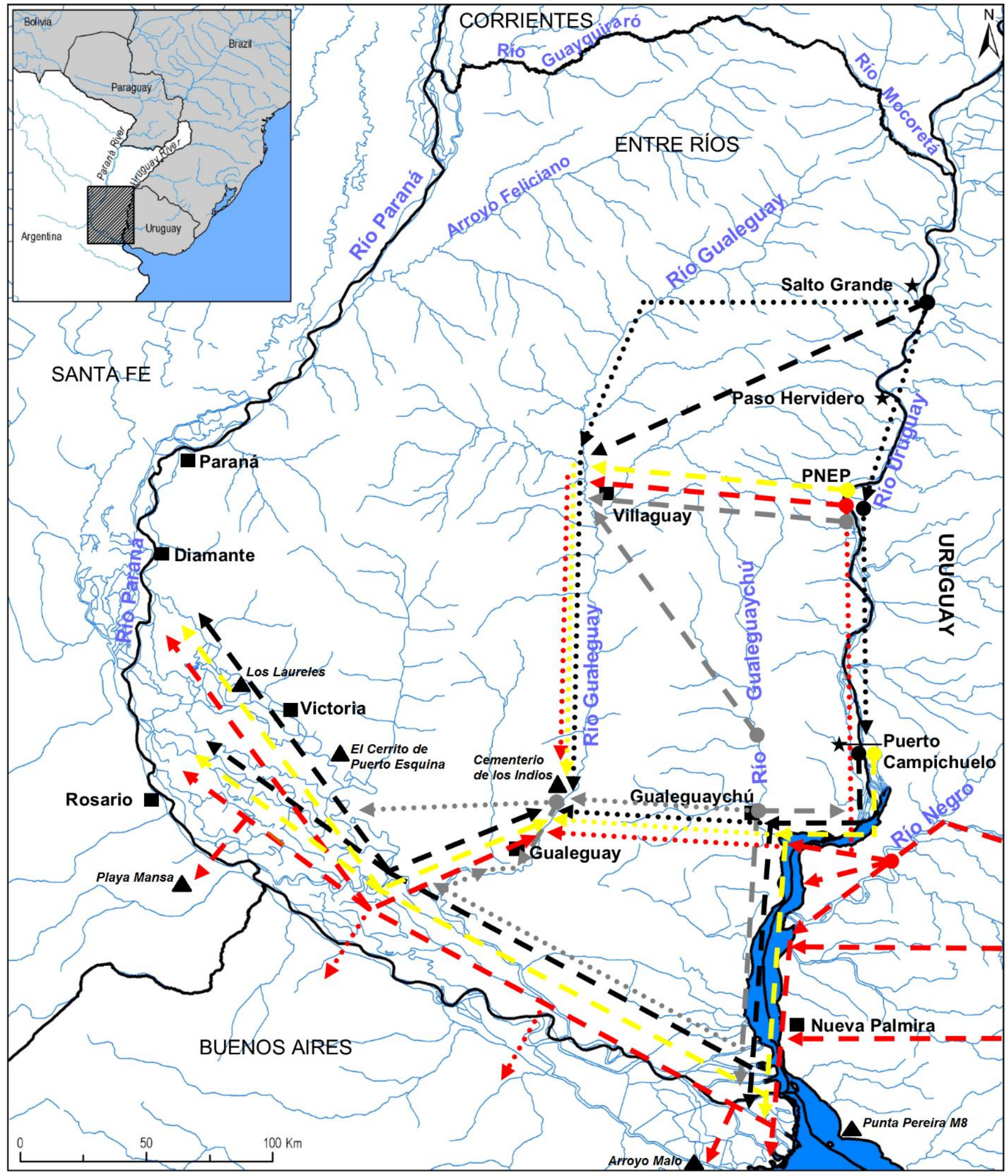

Figura 9.1. Representación esquemática de la circulación de materias primas líticas en la cuenca del río Uruguay y áreas circundantes para el Holoceno tardío. Las flechas de guiones representan las rutas propuestas a partir del registro arqueológico conocido; en su punto de origen marcan las canteras potenciales y en su punto de terminal las zonas más distales donde se han registrado las materias primas, que también en general han sido registradas en zonas intermedias. Las flechas de puntos representan rutas alternativas tentativas. Las bifurcaciones o nodos son puntos de distribución hacia nuevas direcciones. Referencias de los colores. Negro: Basalto y cuarcita intertrap. Amarillo: rodados silíceos (sílice, calcedonia, ágata y cuarzo). Rojo: caliza silicificada y silcreta de la Formación Guichón. Gris: arenisca de la Formación Salto Chico. Se incluyen algunos sitios arqueológicos ( $\boldsymbol{\Delta}$ ) mencionados en esta sección donde se registraron algunas de las materias primas. 
Como se observa en la Figura 9.1 y considerando primero el aprovisionamiento del sector A, el basalto y la cuarcita intertrap tienen su punto de origen en la zona de Salto Grande, pero también se registran afloramientos puntuales menores (los saltos, correderas y restingas) más al sur, a lo largo del cauce del río Uruguay hasta Paso Hervidero. Los afloramientos de Salto Grande debieron estar más expuestos antes de la construcción de la represa hidroeléctrica en 1977.

Los rodados silíceos (sílice, calcedonia, ágata y cuarzo), el xilópalo, la silcreta y la caliza silicificada tendrían su punto de origen en el río Uruguay a la misma latitud; todas estas materias primas fueron registradas en el sector B. La arenisca tendría su punto de origen tanto en la costa del río Uruguay a la misma latitud (pudiendo provenir también de más al norte o más al sur), así como también en el río Gualeguaychú.

En cuanto al aprovisionamiento del sector B, todas las materias primas están disponibles inmediatamente. Particularmente los basaltos y la cuarcita intertrap, dada su baja frecuencia y la presencia de corteza en los desechos de talla, provendrían de depósitos de rodados presentes en el sector $\mathrm{B}$.

En cuanto al aprovisionamiento del sector C, el basalto y la cuarcita intertrap, dado que en aquellos caso donde se identificaron las formas-base (p. ej. choppers de basalto de EDB y el núcleo de cuarcita intertrap de $\mathrm{CL} 2$ ) estas corresponden a rodados fluviales, se considera que por su gran tamaño su punto de origen estaría en Salto Grande o más al norte. Asimismo, Puerto Campichuelo sería el punto de origen de la mayoría las materias primas silíceas como el sílice, la calcedonia, el ágata y el cuarzo (tal vez una pequeña parte de los rodados proviene de los conglomerados de areniscas del río Gualeguaychú o de pequeños depósitos mencionados para este río) (véase también Vega y Andrade 2004). La arenisca proviene de los afloramientos del río Gualeguaychú. El xilópalo puede provenir tanto de los depósitos de rodados del río Uruguay como de los conglomerados de areniscas del río Gualeguaychú (que también contienen rodados fluviales). La caliza silicificada y la silcreta tendrían su punto de origen en afloramientos primarios de la cuenca media (y probablemente en la inferior) del río Negro, o más al sur en los afloramientos de Punta Arroyo San Martín, Estancia Fagalde y Paso de Berget, en la ROU (Baeza et al. 2001; Flegenheimer et al. 2003; Gascue 2009a, 2009b; Gascue et al. 2009, 2016). También parte de las mismas podrían llegar desde la zona del PNEP (ambas márgenes del río). Se debe considerar también que estas materias primas pueden registrarse en forma de rodados fluviales en el río Uruguay, pero la frecuencia de estos rodados es baja comparada con la abundancia de caliza silicificada y silcreta en los sitios arqueológicos. Por lo tanto, a pesar de que una porción podría provenir de depósitos secundarios de rodados (como por ej. el percutor de $\mathrm{CDB} 3$ ) la mayoría provendría de fuentes primarias.

En la margen izquierda del río Uruguay frente al sector $C$, a partir de la excavación sistemática del Túmulo de La Blanqueada (Soriano) (Farías 2005; Farías et al. 2001) se determinó que el $89,4 \%$ de las materias primas $(n=889)$ corresponden a caliza silicificada. Además, en el área 
excavada no se registraron núcleos y tampoco las primeras etapas de la reducción lítica. Asimismo, en el sitio arqueológico El Pingüino (Rio Negro, ROU) (Vega y Andrade 2004) la caliza silicificada indica que las primeras etapas de la reducción se realizaron en fuentes primarias lejanas fuera del sitio arqueológico. También en el sitio arqueológico Cerrito de Colonia Concordia todos los materiales líticos tallados (desechos y núcleos) son de caliza silicificada (Díaz et al. 1980; Hilbert 1991) y sus fuentes no estarían disponibles en la zona (Maruca Sosa 1957). De igual forma, dentro de los conjuntos líticos del Cerrito de Isla del Vizcaíno y Arroyo de los Pocitos (Boretto et al. 1975: 247) se destaca la presencia de caliza silicificada y de basalto, que los autores reconocen como "no locales". En el sitio arqueológico La Yeguada la caliza silicificada provendría de afloramientos primarios distantes al menos a $22 \mathrm{~km}$ de distancia (Loponte et al. 2016). Gascue y colaboradores (2016) también reconocen la presencia mayoritaria de esta materia prima en el sitio arqueológico $\mathrm{El}$ Cerro y su procedencia sería local (Formación Mercedes). Otro dato para la ROU que indica el traslado de recursos líticos desde el interior del país hacia la costa suroeste, pero durante el Holoceno medio (ca. 4200 años AP), surge del registro arqueológico de Punta Pereira M8 (Capdepont 2012); si bien en este sitio arqueológico predomina la explotación de cuarzo, que se encuentra inmediatamente disponible, también se registró la explotación de caliza silicificada procedente desde una distancia de $60 \mathrm{~km}$.

También Fontana Company (1951) identifica al sur de Nueva Palmira un extenso taller lítico, y a partir de este punto geográfico Fontana plantea, considerando a los indígenas del rio Uruguay y del Delta del río Paraná como canoeros, que desde la costa de Nueva Palmira se aprovisionaría a la costa argentina de "...piezas de piedra elaboradas por nuestros indígenas, con rocas del Uruguay, pero exóticas para la zona palmirense." (Fontana Company 1951: 190). En relación a las materias primas más adelante agrega que “..., podemos asegurar que, con excepción de algunas piedras rodadas del río Uruguay, de tamaño chico y algunas ágatas rodadas de igual procedencia, toda la materia prima debe considerarse extraña a la zona que estudiamos;..." (Fontana Company 1951: 213).

De lo anterior se desprenden dos aspectos interesantes relacionados a la circulación de materiales líticos, primero que a la costa uruguaya del río Uruguay inferior llegaban materias primas desde el interior de la ROU; y segundo si se considera el uso de canoas no es difícil suponer que desde la ribera uruguaya las materias primas pasaban a la costa argentina. Además, particularmente la región de Nueva Palmira es el punto donde el río Uruguay inferior es más angosto.

Al sector C, como ya se mencionó (Capítulos 7 y 8), llegarían preformas, núcleos y clastos (y posiblemente algunos instrumentos); entonces si se considera el traslado de materias primas (caliza silicificada, basalto, cuarzo, calcedonia y talvez otras sobre todo silíceas) desde el río Uruguay inferior hacia el oeste a través del Delta del río Paraná, posiblemente a medida que las rocas y minerales (disponibles en la costa argentina del río Uruguay y también aquellas que llegaban desde distancias 
medias y largas) se desplazaban hacia el oeste, sobre todo a través de las vías fluviales, su frecuencia y volumen se irían reduciendo. Según Bonomo y Blasi (2011) al Delta superior del Paraná estarían llegando los instrumentos formatizados, y además los sitios arqueológicos evidencian escasas actividades de talla. Un caso que podría ir en esta línea está dado por el sitio arqueológico Paraná Ibicuy 5 (Caggiano 1982a) en el Delta inferior de Paraná. Caggiano recuperó una punta de proyectil pedunculada y otro instrumento que define como un cuchillo (pudiendo ser también un bifaz o una punta apedunculada; véase Caggiano 1984, Lámina IV, 1 y $2^{1}$ ). Estas son las dos únicas piezas líticas recuperadas, no hay desechos de talla, ni núcleos, ni percutores.

Ahora bien si se considera que gran parte de la región estaba ocupada por el complejo étnico chaná-timbú, al menos en el momento de la llegada de los conquistadores europeos, ¿Por qué entonces no se registra un volumen mayor de materiales líticos en los sitios arqueológicos del Delta superior del río Paraná? ¿Los artefactos líticos tendrían una relevancia menor que otras materias primas como las óseas o la madera? ¿Habría como mencionan las crónicas dos grupos diferentes en el Delta del Paraná como los chaná-timbú y los chaná-mbeguá, y entonces los objetos que circulaban debían atravesar fronteras sociales que incidían en su desplazamiento? Las futuras investigaciones echarán luz sobre estos puntos, pero es claro que al menos desde el Paraná medio hasta el río Santa Lucía (ROU) no se debería esperar un patrón homogéneo en todos los aspectos tecnológicos de las poblaciones indígenas de este complejo étnico. Asimismo, habría que considerar la posibilidad de que a partir del arribo de los guaraníes el acceso a algunas fuentes de aprovisionamiento se haya visto limitado para las poblaciones locales.

En la Figura 9.1 también se observa que algunas de estas materias primas se han registrado fuera de nuestra área de estudio, reflejando una circulación dentro de una extensa red de interacción regional. En este sentido, en el Delta superior e inferior del río Paraná y en el curso inferior del río Gualeguay, en sitios arqueológicos del Holoceno tardío, se registraron distintas materias primas procedentes de medias y largas distancias (Apolinaire 2017; Apolinaire et al. 2016; Bonomo y Blasi 2011; Bonomo et al. 2009), algunas de las cuales podrían estar llegando desde los ríos Uruguay y Gualeguaychú. Por ejemplo la arenisca registrada en el Delta inferior (Bonomo et al. 2009) podría tener su origen en la cuenca del río Gualeguaychú. El cuarzo registrado en Los Laureles en el Delta superior, en el Delta inferior (Bonomo y Blasi 2011; Bonomo et al. 2009) y en el río Gualeguay (Apolinaire et al. 2016) podría tener su origen en sudoeste de la ROU o en el río Uruguay en la zona de la desembocadura del río Gualeguaychú. La calcedonia registrada en el río Gualeguay (Apolinaire et al. 2016) y del Delta inferior (Bonomo et al. 2009) podría tener su origen en el río Uruguay en la zona de la desembocadura del río Gualeguaychú o más al norte. El basalto registrado en el río Gualeguay (Apolinaire et al. 2016) y Los Tres Cerros 1 en el Delta superior (Bonomo et al.

\footnotetext{
${ }^{1}$ Se considera que por un error de escritura en la referencia a esta Lámina estos instrumentos líticos son adjudicados al sitio arqueológico Paraná Ibicuy 4, pero corresponden a Paraná Ibicuy 5 (Caggiano 1984: 106). 
2011c; Gianotti y Bonomo 2013), tiene su origen en el río Uruguay desde Gualeguaychú hacia el norte. La caliza silicificada ha sido identificada en el sitio arqueológico Playa Mansa al sureste de Santa Fe (Coll 2013), en El Cerrito de Puerto Esquina y Los Laureles (Bonomo y Blasi 2011), en la localidad Cementerio de los Indios y otros sitios arqueológicos del río Gualeguay (Apolinaire et al. 2016), en el sitio arqueológico Arroyo Malo (Bonomo 2013) y Arroyo Fredes (Silvestre 2013) en el Delta inferior de Paraná, y más al sur en el sitio arqueológico Techo Colorado en la laguna de Lobos en la Depresión del río Salado en Buenos Aires (Escosteguy et al. 2015).

Para el Holoceno tardío se considera que la ruta más probable de llegada de la caliza silicificada al Delta superior, al curso inferior del río Gualeguay y al sureste de Santa Fe (y tal vez del cuarzo abundante en el sudoeste de la ROU; Capdepont 2012) es por vías fluviales bordeando el sur de la provincia de Entre Ríos a través del Delta del río Paraná, y no por tierra a través del centro de la provincia. Asimismo, la llegada a las costas de Buenos Aires se daría a través de la conexión fluvial entre el río Uruguay con el delta y con el litoral del Río de la Plata (véase Figura 9.1). También esta roca fue registrada en sitios arqueológicos de la transición Pleistoceno-Holoceno en la región pampeana de Argentina (Flegenheimer et al. 2003), indicando una interacción muy antigua que probablemente fue mantenida y ampliada a lo largo del tiempo.

Si se considera que ambas márgenes del río Uruguay inferior estaban ocupadas por las mismas sociedades indígenas, como parece indicarlo en registro arqueológico y la evidencia etnohistórica (Acosta y Lara 1955; Arredondo 1927; Bonino de Langguth 1977; Boretto et al. 1980; Caggiano 1984; Díaz et al. 1980; Farías et al. 2001; Hilbert 1991; Iriarte 2001; López Mazz et al. 2014; Politis 2014; Politis y Bonomo 2012; Rodríguez 2001; entre otros), se puede plantear que el traslado de caliza silicificada desde la ROU hasta la costa argentina durante el Holoceno tardío se daba dentro de redes sociales ampliadas (sensu Gamble 2001) de una misma etnia.

\section{3- TECNOLOGÍA CERAMICA}

El registro arqueológico más antiguo asociado con alfarería dentro del área de estudio y de la provincia de Entre Ríos, corresponde al sitio arqueológico Cerro Lorenzo 2 con una antigüedad de $2050 \pm 60$ años ${ }^{14} \mathrm{C}$ AP. Las dataciones espacialmente más cercanas con fechados semejantes corresponden a Isla del Medio Sitio/Corte 1: $2350 \pm 80$ años ${ }^{14} \mathrm{C}$ AP e Isla de Arriba/Aruera Corte 3: $2370 \pm 80$ años ${ }^{14} \mathrm{C}$ AP (Baeza et al. 1977), ambas islas ubicadas en el río Uruguay medio (Salto Grande) en territorio de la ROU. Si se considera la información extraregional (Politis et al. 2001) es altamente probable que la incorporación de la tecnología cerámica en el área de estudio sea anterior al fechado de Cerro Lorenzo 2. 
La cerámica de los tres sectores comparte algunos atributos como la inclusión intencional de tiesto molido y de espículas de esponja de agua dulce provenientes del río Uruguay, el predominio de la cocción oxidante incompleta, la manufactura mediante rodetes y el uso de contenedores utilitarios. En la cerámica no-guaraní predominan las formas abiertas y la decoración incisa; y en la cerámica guaraní las formas cerradas corrugadas, unguiculadas y pintadas policromas. En el sector $\mathrm{C}$ se registró el uso de la arcilla no solo para elaborar vasijas de uso doméstico sino también para representar la naturaleza mediante el modelado de la fauna. También para la elaboración de objetos como cuentas, una pipa y una pesa de red, entre otros.

En los tres sectores predomina la cerámica sin decoración y los fragmentos del cuerpo de las vasijas sobre los bordes. Asimismo, predominan los tiestos de tamaños menores a $5 \mathrm{~cm}$ evidenciando un alto grado de fragmentación. La presencia de masas de arcilla cocida en los sectores A y C indicaría la manufactura local de cerámica. Si se excluye la fauna, la alfarería es ampliamente dominante en el sector $C$, mientras que en los sectores $A$ y $B$ es relativamente más escasa. En el primero de estos dos últimos sectores se registraron frecuencias semejantes entre lítico y alfarería, y en el segundo predominan los artefactos líticos. En los sectores A y B la posición superficial de los conjuntos arqueológicos y los procesos posdepositacionales sin duda han determinado la frecuencia de los materiales registrados.

Particularmente en el sector $C$ se destaca el gran volumen de producción de cerámica, que mayormente se encuentra incorporada en las estructuras monticulares. Indudablemente las vasijas además de haber cumplido una función doméstica y simbólica cuando estaban enteras, continuaban cumpliendo una función doméstica cuando las mismas se fracturaban. De esta forma se observó el reciclaje y el uso de tiestos molidos como inclusión en la elaboración de nuevas vasijas, pero también el uso tiestos para la consolidación estructural de los montículos de tierra (véase Bracco et al. 2000a, Castiñeira y Piñeiro 2000; Castiñeira et. al. 2013, 2014; López Mazz 1992; López Mazz y Castiñeira 2001; Salles Machado 2005). Por un lado, este gran volumen de producción de cerámica también refleja que el abastecimiento de arcillas, inclusiones y agua, y el desarrollo de todas las etapas del proceso de producción alfarera estuvieron aseguradas. Por otro lado, indica una gran estabilidad residencial, ya para haber generado tanto volumen de vasijas, en determinados puntos del espacio como son los sitios arqueológicos monticulares, necesariamente hubo que permanecer en esos lugares por un periodo prolongado.

En cuanto a la caracterización de los patrones morfológicos, tecnológicos y estilísticos de la alfarería dentro del área de estudio, se identificaron al menos dos conjuntos diferentes y asociados además a dos grupos étnicos distintos. Uno de estos grupos serían los habitantes locales y otro los guaraníes que habrían llegado a la zona con posterioridad. La cerámica del primer grupo presenta una mayor variabilidad morfológica dentro del sector $\mathrm{C}$, y gran parte de la misma puede identificarse 
con la entidad arqueológica Goya-Malabrigo (Politis y Bonomo 2012); la cerámica del segundo grupo es asignable a los guaraníes (Brochado 1984; Noelli 1993, 2004).

El registro de materiales que actualmente pueden identificarse con Goya-Malabrigo (Ceruti 2003a; González 1977; Politis y Bonomo 2012) o con alguna de sus denominaciones homólogas anteriores ( $p$. ej. ribereños plásticos) (véase Capítulo 2) ya había sido propuesto para el río Uruguay desde la zona de Salto Grande hasta su desembocadura (Caggiano 1979, 1984; Ceruti y González 2007; Rodríguez y Ceruti 1999; Politis y Bonomo 2012; entre otros). En la zona de Salto Grande se reportaron apéndices zoomorfos y campanas, casi todos procedentes de la Isla de Arriba y en algunos casos asociados a cerámica guaraní (Díaz 1977, 1980; Femenías 1973). Díaz (1977, 1980) considera a la alfarería modelada (también a la guaraní) de carácter intrusiva y menciona que se presenta en escasa cantidad y esporádicamente. En este sentido, por el momento para Salto Grande no se cuenta concretamente con un sitio arqueológico asignado a Goya-Malabrigo en los términos de Politis y Bonomo (2012); y tampoco hay dataciones vinculadas específicamente a estos artefactos de manera que se pueda establecer con claridad la presencia de Goya-Malabrigo en la zona.

Para el río Uruguay comprendido entre Salto Grande y el paleodelta de este río la presencia de Goya-Malabrigo no cuenta todavía con datos sólidos. En nuestra área de estudio la frecuencia de la alfarería en los sectores $A$ y $B$ es menor que en el sector $C$, y por lo tanto no se puede determinar con certeza si una parte correspondería también a Goya-Malabrigo. Podría darse el caso de que esta alfarería sea una manifestación local de esta entidad arqueológica, o que sea el resultado de sociedades culturalmente diferentes que incorporaron algunos elementos tecnológicos, estilísticos o decorativos de Goya-Malabrigo. En este último caso tal vez la alfarería, y el registro en general, de estos dos sectores podría corresponder los antecesores de los grupos étnicos mencionados por los conquistadores y también en la época colonial como por ejemplo charrúas, yaros y bohanes. Para estos sectores en general algunos autores han propuesto la ocupación por parte de los charrúas y/o minuanos (Poenitz 1970b; Serrano 1950).

La presencia de alfarería Goya-Malabrigo en el río Uruguay inferior (Figura 9.2) es abundante y ya había sitios arqueológicos identificados con esta entidad o sus homólogas como por ejemplo El Aserradero por Lafon (1968), Rodeo Viejo La Nena, Don Santiago, Cerro El Indio y El Ceibal 1 por Caggiano (1982a, 1983b, 1984). A estos sitios arqueológicos se pueden agregar la localidad arqueológica Cerros de Boari, Cerro Lorenzo 2, Túmulo 1 - Cerro Norte de Machado, Túmulo 2 - Cerro Sur de Machado, Túmulo 1 de la Pesquería Nicolini, Cerros de los Pampas y Sambaquí de Puerto Landa (Capítulo 7 y 8). Asimismo, y considerando el registro arqueológico de la margen izquierda del rio Uruguay (ROU) también se pueden agregar los sitios arqueológicos La Yeguada, El Cerro, Cerrito de Isla del Vizcaíno, Túmulo de la Isla del Naranjo, Túmulo de la Isla del Infante, Túmulo de La Blanqueada, Túmulo de Punta Chaparro, Cerrito de Colonia Concordia, y algunos otros ubicados la región de Nueva Palmira (Arredondo 1927; Boretto et al. 1975; Díaz et al. 1980; Farías et al. 1997; 
Farías 2005; Fontana Company 1928, 1930, 1951; Freitas 1953a, 1953b, 1953c; Gascue et al. 2016, Loponte et al. 2016; Montero Zorrilla 1978; Teisseire 1927).

Cabe destacar también que en el río Uruguay inferior, en base a la alfarería, Caggiano (1982a) identifica algunos sitios arqueológicos con la cultura básica del litoral o entrerriana y su facie Ibicueña, como por ejemplo: Túmulo I del Brazo Largo, Túmulo I del Brazo Gutiérrez y Gualeguaychú (Caggiano 1982a). También reconoce cerámica decorada con motivos similares a la facie Salto Grande "...pero con surco rítmico, labios incisos, asas mamelonares y asas verticales, pico vertedero, abundante hueso, fogones, etc." en el sitio arqueológico El Potrero (Caggiano 1982b; y comunicación personal escrita 2016) (Figura 9.2).

También Serrano (1972: 27) incluye en la facie Ibicuy de la cultura entrerriana al sitio arqueológico "paradero-cementerio" de Brazo Largo excavado por Gatto (1939) (Capítulo 2). De igual forma adjudica a la facie Sarandí algunos sitios arqueológicos ubicados al sur de Gualeguaychú (Serrano 1972: 21). Si bien Serrano no especifica cuáles son estos sitios, menciona la presencia de una punta de vidrio en uno de ellos. Ahora bien, considerando que uno de los pocos trabajos de campo realizados en la zona es el de Greslebin (1931a) y que además este es el único autor que publica el hallazgo de una punta de vidrio (véase Greslebin 1931a: 20), se puede plantear que uno de los sitios en cuestión es el Túmulo 1 de Pesquería Nicolini. Cabe señalar que en ambos casos Serrano no especifica en que se basan estas asignaciones culturales. 


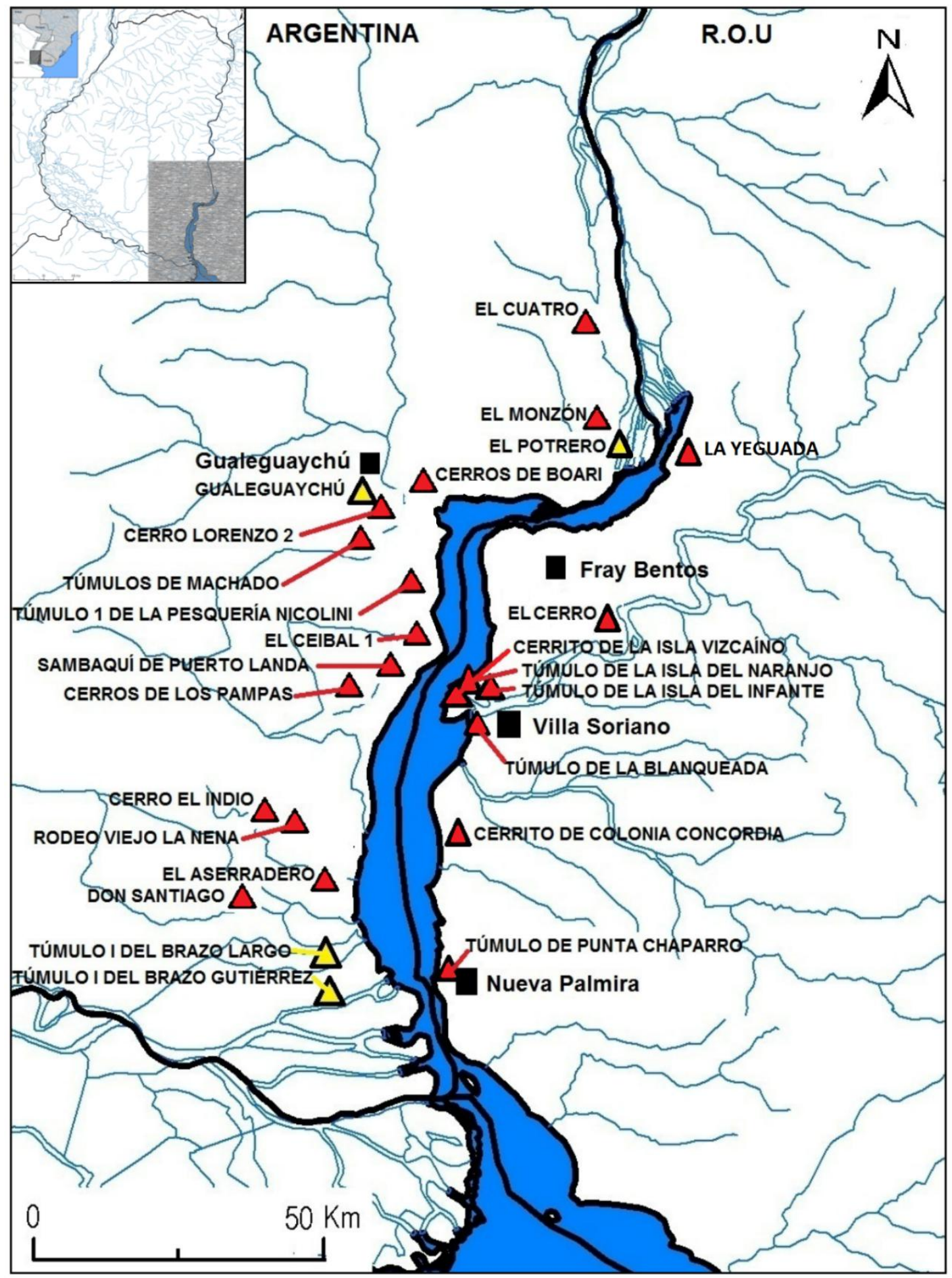

Figura 9.2. Ubicación geográfica en el río Uruguay inferior de los sitios arqueológicos asignables a Goya-Malabrigo (triángulos rojos); y a la cultura básica del litoral según Caggiano (1982a, 1982b) (triángulos amarillos).

En general las formas de las vasijas no-guaraníes son coincidentes con las formas propuestas previamente para el río Uruguay por autores como Serrano (1950), Boretto y colaboradores (1975), Díaz (1980), Cione y colaboradores (1977), Caggiano (1979, 1983b) y Hilbert (1991) (Capítulo 4). En cuanto a la alfarería modelada (en principio no utilitaria) registrada en el sector C (excluyendo 
apéndices aislados), se puede considerar al menos la existencia de cuatro variantes, que pueden ser lisas o decoradas mediante incisión y/o pintura: 1- campanas (stricto sensu Serrano 1970); 2- botellas (?) (Balfet et al. 1992); 3- tubos; 4- formas troncocónicas (botellones cerrados en la parte "superior" con orificios laterales sensu Hilbert 1991), generalmente consisten en un cono truncado con el extremo de diámetro menor ciego sin boca ni borde, con o sin un reborde marcadamente evertido en su extremo de diámetro menor (o superior; protuberancia sensu Hilbert 1991), de paredes gruesas rectas o levemente curvadas (convexas o en " $\mathrm{S}$ ") con las inflexiones apenas marcadas, y orificios laterales (véase Figura 9.3A y B). Estas últimas, sobre todo a la Figura 9.3B, tal vez podrían ser formas transicionales de campanas (sin apéndices biomorfos). También habría que considerar la posibilidad de que los "vasos" publicados por Greslebin (1931b) puedan representar formas semejantes a éstas últimas, pero con agujeros en la parte superior en vez de sus laterales. Si se invierten los dibujos de la Figura 4.3J surgen algunas semejanzas, sobre todo con la Figura 9.3B. En este caso podría ser una variante del cuarto tipo o un tipo diferente pero con baja representación en el registro arqueológico. A las cuatro (o cinco) formas registradas en el sector $C$, y en general en ambas márgenes del río Uruguay inferior, se agregan las estatuillas o figurinas completas de la ROU (véase adelante). 


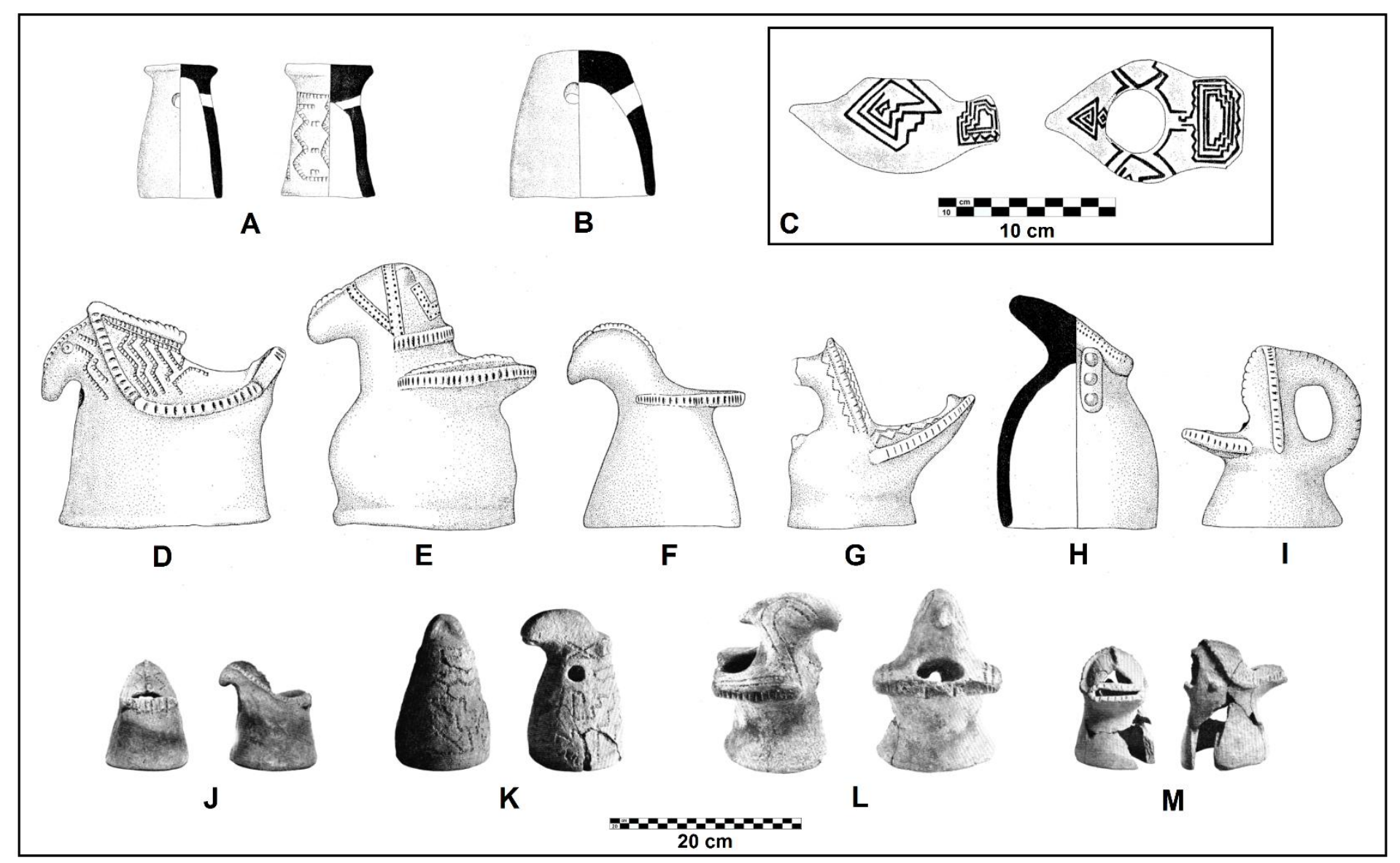

Figura 9.3. Alfarería Goya-Malabrigo de la cuenca del río Uruguay y del Río de la Plata (ROU).

A: formas troncocónicas sin boca ni borde menor y con orificio lateral del Túmulo de La Blanqueada (Soriano) (Capdepont et al. 2010; Hilbert 1991). B: formas troncocónicas sin boca ni borde menor y con orificio lateral de la desembocadura del río Negro (Hilbert 1991). C: vasija ornitomorfa completa (sensu Serrano 1946) del río Negro medio (Freitas y Geranio 1938-41; Hilbert 1991). D e I: campanas de Isla de Arriba/Aruera (Salto Grande) (Cabrera 2011; Díaz 1980; Hilbert 1991). E y G: campanas de la costa del departamento Colonia (Cabrera 2011; Hilbert 1991; Muñoz 1968). F: campana de Colonia Agraciada (Nueva Palmira) (Hilbert 1991). H: campana de Punta Francesa (Colonia) (Bello y Bracco Boksar 2007; Capdepont 2012; Capdepont et al. 2010; Hilbert 1991). J y M: campanas de Arazatí (San José) (Acosta y Lara 1955; Maruca Sosa 1957). K: campana de Campo Morgan (Soriano) (Acosta y Lara 1955; Hilbert 1991; Maruca Sosa 1957). L: campana de Artilleros, costa del Río de la Plata (Colonia) (Acosta y Lara 1955). Imágenes tomadas y modificadas de Acosta y Lara (1955) y Hilbert (1991). En los restantes trabajos citados también se pueden observar más figuras o fotografías.

Para el río Uruguay se han registrado modelados antropomorfos de dos tipos: uno con la forma de campana que sobre su cabeza lleva probablemente un tocado o sombrero (Figura 9.4A); y otros consisten en estatuillas o figurinas completas, esto significa que no son apéndices de vasijas o campanas sino que son modelados que tendrían un fin netamente simbólico (Figura 9.4B, C y D; véase también Hilbert 1991). Serrano (1972) plantea que la facie Sarandí de la cultura entrerriana en el Delta del Paraná “...presenta elementos llegados de la región comechingón como ser estatuitas..." (Serrano 1972: 21). Este autor no especifica cuáles son las estatuitas del delta a las que se refiere, pero probablemente sean las del río Uruguay ya que la facie Sarandí abarcaría también su cuenca inferior. A modo comparativo se incluye la estatuilla de la Figura 9.4E que resulta ser semejante a las 
del río Uruguay, pero que procede de San Roque en la provincia de Córdoba y fue publicada junto a otras semejantes y adjudicada a los comechingones por Serrano (1944).

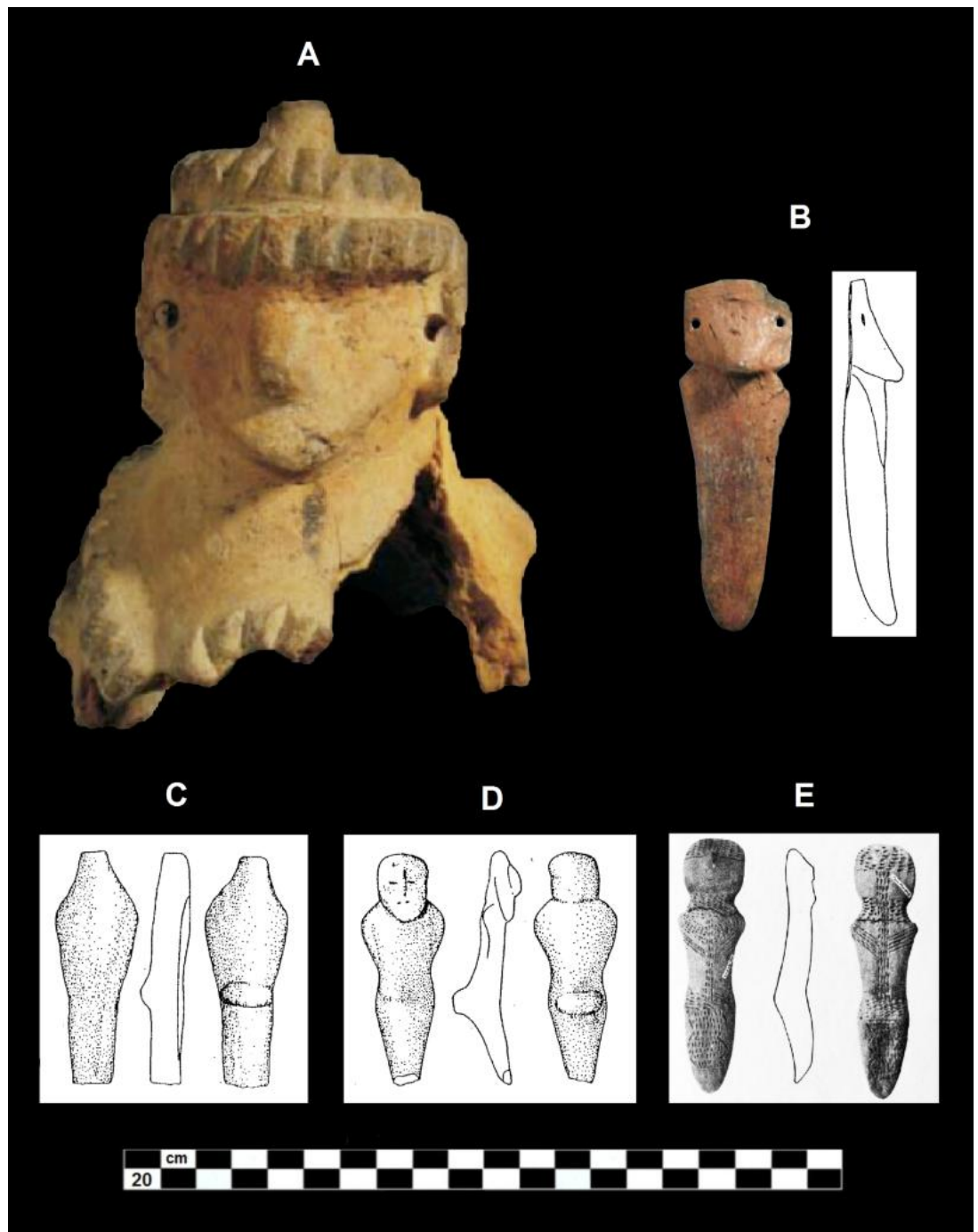

Figura 9.4. Modelados antropomorfos de la cuenca media e inferior río Uruguay. A: campana antropomorfa de Nueva Palmira (Colonia) (Bello y Bracco Boksar 2007; Roselli 1969). B: Arroyo La Yeguada (Río Negro) (Bello y Bracco Boksar 2007; Hilbert 1991; Roselli 1964).

C: Túmulo de La Blanqueada (Soriano) (Hilbert 1991). D: Aruera (Salto) (Hilbert 1991).

E: San Roque (Córdoba) (Serrano 1944). Imágenes tomadas y modificadas de los autores citados. La escala corresponde a todos los modelados excepto a $E$ que tendría un tamaño semejante a B.

El registro de materiales arqueológicos guaraníes tampoco es nuevo para la región, ya que desde el comienzo de la arqueología del NEA, distintos autores han identificado cerámica guaraní (Ambrosetti 1895b; Aparicio 1931; Badano 1940b; Bonomo et al. 2015; Caggiano 1982a, 1984; Cigliano et al. 1971a; Lafon 1972; Lothrop 1932; Maruca Sosa 1957; Outes 1917a; Rodríguez y Ceruti 1999; Serrano 1950; Torres 1911; entre muchos otros) (véase Capítulo 2). Lo que sí cabe destacar es que no se habían identificado al menos en Entre Ríos sitios arqueológicos guaraníes que evidencien una ocupación estable y sobre los cuales además se obtuvieran fechados absolutos. 
Particularmente en el NEA los asentamientos y materiales arqueológicos adjudicados a este grupo están distribuidos en las cuencas de los ríos Paraná y Uruguay. La información disponible muestra que la distribución geográfica de los sitios arqueológicos no es uniforme, indicando la existencia de dos núcleos principales: uno al norte [conformado por los asentamientos detectados en las cuencas superiores de los ríos Paraná y Uruguay (Ambrosetti 1895a, 1895b; Lafon 1971; Rodríguez 1992)] y otro al sur [concentrados en el Delta inferior del Paraná, en la desembocadura del río Uruguay y en menor medida en el Río de la Plata (Caggiano 1982a; Cigliano 1968; Outes 1918a; Lothrop 1932; Loponte et al. 2011b)]. En el área intermedia a estas dos zonas la información disponible indica ocupaciones representadas, por asentamientos puntuales y hallazgos aislados en las islas y ambas márgenes del río Uruguay (Acosta y Lara 1978; Badano 1940a; Boretto et al. 1975; Capdepont 2012; Castro y Costa Angrizani 2014; Díaz 1980; Farías 2005; Rodríguez 1975; entre otros), y por materiales diagnósticos dispersos en el Delta superior del Paraná (Badano 1940a; Bonomo et al. 2011c; Politis et al. 2011).

En cuanto a la cronología del registro arqueológico guaraní en el NEA (33 dataciones correspondientes a 17 sitios arqueológicos) se puede esquematizar una idea general sobre el arribo y la distribución de estas poblaciones en el área. La evidencia más temprana corresponde a un fechado de $1860 \pm 50$ años ${ }^{14} \mathrm{C}$ AP del sitio arqueológico San Miguel II en Corrientes (Mujica 1995a). Según Bonomo y colaboradores (2015) este sitio arqueológico está incluido el primer pulso de expansión de los guaraníes en la cuenca del Plata, caracterizado por ocupaciones muy dispersas entre las cuencas de los ríos Paranapanema (São Paulo, Brasil) e Ibicuí (Rio Grande do Sul, Brasil). Los demás sitios arqueológicos presentan fechados que van desde ca. 1000 hasta 200 años AP, cuando se desarrollaría el segundo pulso de expansión poblacional que arriba a las latitudes más meridionales. En este lapso se registran asentamientos guaraníes en el río Uruguay superior [un sitio arqueológico fechado en $920 \pm 70$ años ${ }^{14} \mathrm{C}$ AP (Sempé y Caggiano 1995)]; en el río Uruguay inferior [un sitio arqueológico fechado en $526 \pm 45$ años ${ }^{14} \mathrm{C}$ AP (Bonomo et al. 2015)]; en el río Paraná medio [ocho sitios arqueológicos con 22 fechados entre $810 \pm 60$ y $240 \pm 50$ años ${ }^{14} \mathrm{C}$ AP (Mujica 1995b; Rodríguez 1997, 2009)]; en el Delta del Paraná [cuatro sitios arqueológicos con seis fechados entre $690 \pm 70$ y $370 \pm 50$ años ${ }^{14} \mathrm{C}$ AP (Bonomo et al. 2011c, 2015; Loponte et al. 2011b)] y en el Río de la Plata [dos sitios arqueológicos fechados en $405 \pm 35$ y $410 \pm 40$ años ${ }^{14}$ C AP (Capparelli 2014; Cigliano 1968)].

Se debe mencionar que los contextos con cerámica guaraní datados en la margen izquierda del río Uruguay refuerzan la idea de un arribo en momentos previos a la conquista y su presencia hasta el siglo XVII [cuatro sitios arqueológicos con ocho fechados entre $1020 \pm 30$ y $310 \pm 30{ }^{14} \mathrm{C}$ años AP (Capdepont 2012; Capdepont et al. 2013; Castillo 2004; Farías 2005; Loponte et al. 2016)]. Las dataciones más tempranas se encuentran en Misiones y Corrientes, sugiriendo una expansión en sentido norte-sur. La llegada de estos grupos a las latitudes más meridionales se habría dado algunas centurias antes de la llegada de los europeos (ca. 400 años). 
Dentro del sector $\mathrm{C}$ las evidencias guaraníes disponibles se concentran en la zona de la desembocadura del río Gualeguaychú y fueron identificadas en primera instancia por Almeida (1971, 1983a, s/fb). El estudio de los materiales recuperados por Almeida en los sitios arqueológicos Ensenada del Bellaco, La Correntina y Ñandubaysal-Arroyo de La Cruz/Arroyo Ubajay, junto a los procedentes de nuestros trabajos de campo, permitió corroborar la existencia de asentamientos guaraníes casi exclusivamente a partir del estudio de la alfarería y apoyada por la datación de Ensenada del Bellaco.

En algunos de estos sitios arqueológicos guaraníes (EDB y Ñ-AC/AU) también se registraron en baja frecuencia evidencias propias de Goya-Malabrigo como campanas; así como también alfarería con rasgos tecnológicos guaraníes combinados con morfologías y técnicas de tratamiento de superficie que no son típicas de la cerámica guaraní (Capítulo 7). Asimismo, en diferentes asentamientos en montículos, que se pueden identificar con Goya-Malabrigo (p. ej. Cerro de Boari 3, Cerros de los Pampas y Sambaquí de Puerto Landa), se han recuperado algunos pocos fragmentos de alfarería típicamente guaraní. Ambos tipos de evidencias señalarían en primer lugar la existencia de interacciones entre los diferentes grupos étnicos que ocuparon el sector $\mathrm{C}$ y el área en general de manera sincrónica; al menos por un lapso de tiempo que comenzó con la llegada de los guaraníes al área (Bonomo et al. 2015) y que se extendería hasta momentos posthispánicos, como lo demuestran por ejemplo las cuentas de collar europeas de Ensenada del Bellaco (Castro 2016; Castro y Costa Angrizani 2014). Paralelamente estas cuentas también están señalando interacciones con los conquistadores europeos.

Particularmente las piezas combinadas, que solo se han registrado en sitios arqueológicos guaraníes, podrían estar reflejando en principio una influencia hispana, pero el problema es que proceden de recolecciones superficiales por lo tanto por el momento no se puede establecer con precisión su cronología. Un caso particular de estas interacciones étnicas materializadas en la cerámica en un contexto colonial, posiblemente este dado por el borde inciso y pintado con una asa en arco vertical de Ensenada del Bellaco (MAMA-EDB-33; Figura 7.11A). Esta pieza es semejante a la porción superior de una vasija de Santa Fe La Vieja (Pieza № 29356; véase Ceruti 2006: 28, Figura 3a y Ceruti 2009b: 390, Figura 6a) que Ceruti identifica por su forma como Goya-Malabrigo, pero plantea que las proporciones, la decoración y la base plana son atípicas, y que el engobe es semejante al que presentan las piezas hispano-indígenas. Esta combinación de rasgos hispanos y Goya-Malabrigo en un sitio arqueológico guaraní, probablemente refleje eventos de copia, replicación e incorporación de técnicas de manufactura y decoración propias de los diferentes grupos locales que ocupaban la región y/o los conquistadores europeos. En caso de que se registren piezas semejantes se podrá profundizar este punto y posiblemente servirían al menos como indicadores cronológicos relativos. 
En el caso de que algunas de estas piezas combinadas sean prehispánicas cabe la posibilidad de que hayan sido manufacturadas por alfareras no-guaraníes residiendo en asentamientos guaraníes. En este sentido, era común que los guaraníes incorporaran a personas de otros grupos, tanto hombres como mujeres, a partir del establecimiento de alianzas o inicialmente como cautivos de guerra, los cuales adultos eran comidos en los rituales antropofágicos o eventualmente asimilados. En este último caso los individuos pasaban a integrar las familias extensas y a participar de la vida cotidiana guaraní casi sin restricciones, pero con las mismas obligaciones como por ejemplo cultivar las rozas y elaborar cerámica en el caso de las mujeres (Noelli 1993). En este contexto, la existencia de estas piezas cerámicas con diseños y técnicas de manufactura combinadas se podría explicar por la asimilación de alfareras de otros grupos, debido a que las alfareras guaraníes no tienden a incorporar generalmente rasgos ajenos a su "modo de hacer" las vasijas, ya que las mismas estaban destinadas a usos muy específicos dentro de la sociedad (Brochado 1984; Brochado y Monticelli 1994; Brochado et al. 1990; La Salvia y Brochado 1989; Noelli 1993); por lo que otros tipos de vasijas probablemente no habrían sido adoptados con facilidad en un contexto prehispánico, ya que no tendrían el mismo significado y función en la vida cotidiana y las ceremonias guaraníes. Esto se plantea en base a que la reproducción de la cultura material guaraní ha sido caracterizada como "radicalmente" prescriptiva desarrollándose continuamente con muy pocos cambios, lo que sin duda se refleja en la "uniformidad" del registro arqueológico guaraní a través de su amplia dispersión espacio-temporal (véase Bonomo et al. 2015; Brochado 1984; Noelli 1993, 1998c, 1999).

La presencia de alfarería guaraní en sitios arqueológicos Goya-Malabrigo del sector C podría considerarse por el momento de carácter intrusiva. Esta misma situación ha sido registrada en algunos montículos de la ROU donde en general también se recuperaron urnas funerarias (p. ej. Cerrito de Isla del Vizcaíno, Túmulo de La Blanqueada, Túmulo de Punta Chaparro y Cerrito de Colonia Concordia). La mayoría del registro arqueológico del Cerrito de Isla del Vizcaíno, considerado una construcción artificial (Arredondo 1927), puede ser identificado con Goya-Malabrigo (Arredondo 1927; Boretto et al. 1975; Figueira 1900) y en el mismo se registraron dos urnas funerarias guaraníes. Esta situación es semejante a lo que ocurre en el Cerro de las Pajas Blancas en el Delta del Paraná (Badano 1940a). Probablemente este tipo de entierros en urnas responderían al uso, apropiación y/o imposición simbólica de la presencia guaraní, en momentos contemporáneos o posteriores a que sus ocupantes se hayan desplazado por distintas causas, entre ellas la guerra de expansión guaraní en primer término y la presencia hispana después.

La interacción entre los guaraníes y los europeos se manifiesta arqueológicamente en el caso de las urnas funerarias guaraníes del Cerrito de la Isla del Vizcaíno, donde se recuperaron restos de un infante y un adulto, asociados a tres discos de cobre y a cuentas venecianas de vidrio azul "veteado" (Figueira 1900). Estos últimos elementos, sumados a las cuentas de vidrio de Ensenada del Bellaco, reflejarían la existencia de redes de circulación de objetos europeos o quizás intercambios 
directos con los conquistadores. En este sentido, también las placas de cobre y bronce, registradas además en otros sitios arqueológicos del río Uruguay medio e inferior y en el Delta inferior del río Paraná (Baeza 2013; Bonomo et al. 2017; Figueira 1900; Guidón 1977; Hilbert 1986, 1991; Torres 1911), indicarían la circulación de objetos exóticos a través de redes de interacción que conectan el río Uruguay con el NOA, y con las áreas intermedias como las Sierras Centrales, y en las que participarían no solo los guaraníes sino otros grupos también. Seguramente por estas redes macroregionales no solo circulaban metales (Figura 9.5), sino también otros objetos de alto contenido simbólico como pueden ser las estatuillas cerámicas y los moluscos marinos Urosalpinx haneti probablemente usados como adornos. Estos últimos recuperados en sitios arqueológicos de la ROU, en la isla Martín García, en el Delta del Paraná y en el centro y noroeste de Argentina (Aparicio 1925; Boman 1920; Bonomo 2013; Doello-Jurado 1940; Outes 1917a; Torres 1911). Estas redes macroregionales seguramente estaban estructuradas desde épocas prehispánicas (Bonomo et al. 2017), y en ellas la circulación de objetos se debe haber intensificado en los primeros momentos de la conquista europea (véase más adelante). 


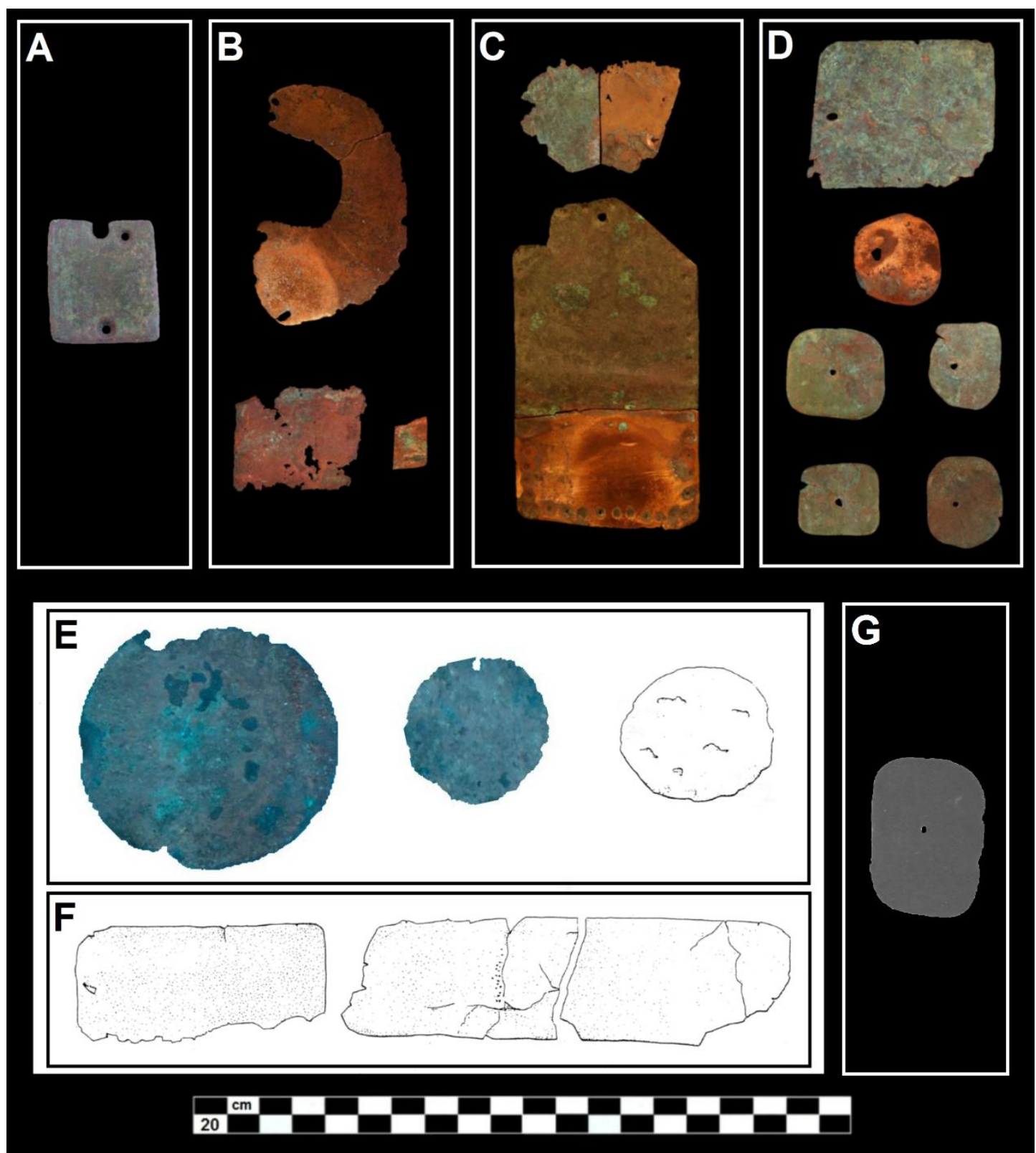

Figura 9.5. Placas de cobre y bronce del Nordeste argentino y la ROU procedentes del área andina. A: La Palmera II (Ceruti 2003a). B: Túmulo I del Paraná Guazú (Bonomo et al. 2017; Torres 1911). C: Túmulo II del Paraná Guazú (Bonomo et al. 2017; Torres 1911). D: Túmulo I del Brazo Gutiérrez (Bonomo et al. 2017; Torres 1911). E: Cerrito de la Isla del Vizcaíno (Figueira 1900; Hilbert 1991). F: Túmulo de Punta Chaparro (Hilbert 1991). G: Los Cardos (Baeza 2013). La pieza superior del conjunto B, en forma de media luna, es de bronce y las restantes de cobre. Las imágenes del conjunto $B, C$ y D son gentileza de Mariano Bonomo y las dos fotografías de las piezas del conjunto E son gentileza de Klaus Hilbert.

\section{4- EXPLOTACIÓN FAUNÍSTICA}

En cuanto a la explotación faunística solo se puede abordar el sector C (Capítulo 7 y 8) debido a la ausencia de restos de fauna en los otros sectores. Se considera que la arqueofauna analizada es taxonómicamente representativa del sector C y zonas circundantes. Asimismo, la incorporación de los materiales arqueológicos del MAMA permitió una aproximación más completa a la representación anatómica de los distintos taxa. A partir del Capítulo 7 y 8 se estableció que la dieta 
de estas poblaciones incluyó el consumo de peces, moluscos, mamíferos, reptiles, aves y posiblemente anfibios.

También es importante destacar que la abundancia de restos faunísticos en las estructuras monticulares está contribuyendo significativamente a su aumento en altura y volumen. El bajo estadío de meteorización general y la consecuente interpretación de su entierro relativamente rápido podría explicarse, al menos en parte, como el resultado de las técnicas constructivas y el mantenimiento de los montículos. Esto a su vez habría favorecido la preservación de los restos, al contrario de los sitios arqueológicos superficiales donde solo se registró una valva de bivalvo (EP2) que no puede considerarse claramente prehispánica.

Tanto peces y moluscos tienen una marcada frecuencia en el registro arqueológico, algunos aspectos que probablemente contribuyeron a su explotación podrían ser su abundancia y su bajo costo de procesamiento en general. Es importante reconocer que aún no es clara la contribución real en términos de nutrientes y la posición que ocupan estos recursos en la paleodieta (sobre todo los moluscos) en relación a los mamíferos y a los vegetales, pero sin duda su consumo fue relativamente significativo.

Si bien el aporte calórico o proteínico de los moluscos puede ser cuestionado dependiendo de las especies y del volumen consumido, lo que los posiciona como un recurso alimenticio relevante son la conjunción de características tales como: ser un recurso predecible, su obtención es segura a bajo riesgo, implican un bajo costo de energía en su obtención y procesamiento, y tienen un rendimiento energético aceptable (Gutiérrez Zugasti 2008; Perlman 1980). Además de que pudieron haber sido recolectados en masa como lo sugieren las grandes concentraciones de valvas. En cuanto a su consumo, la presencia de las valvas en los sitios arqueológicos indica que la mayor parte se realizaba allí. Por lo tanto, el consumo no era inmediato en los lugares de obtención, siendo procesados y consumidos seguramente el mismo día pero en los asentamientos. Su consumo pudo haber sido crudos, hervidos o asados. En este último caso las valvas no necesariamente siempre resultan carbonizadas y tampoco las valvas carbonizadas son indicadores de cocción directa al fuego, pudiendo haber sido descartadas en el fuego o haber sido el sustrato de un fogón (Gutiérrez Zugasti 2008). Asimismo, la cocción de los bivalvos posiblemente habría eliminado la gran cantidad de parásitos que contienen (Dr. Leandro Pérez, CONICET-UNLP; comunicación personal 2016).

La recolección de Diplodon sp. puede realizarse durante todo el año en las playas del río Uruguay y en zonas cercanas a los asentamientos, donde aún en la actualidad se registran amplías concentraciones de este taxón. Por su parte, Megalobulimus sp. es un molusco terrestre y nocturno con una baja densidad poblacional (colonias reducidas) y hábitos subterráneos, que durante el día se oculta de la luz solar enterrándose hasta $15 \mathrm{~cm}$ de profundidad en el suelo u hojarasca. Además, tienen un periodo de letargo bajo el sustrato durante los meses más fríos y secos (estivación), entre marzo y septiembre, y luego sale en los meses más cálidos y húmedos, entre octubre y febrero 
(Beltramino 2016). Esta estacionalidad particular de Megalobulimus sp. permite considerar que durante su período activo su recolección pudo ser mayoritariamente diurna mediante la remoción del sustrato, y tal vez nocturna. De la primera manera también pudo obtenerse durante su periodo de mayor inactividad (Beltramino 2016 y bibliografía allí citada). En los casos de remoción del sustrato posiblemente se usaron instrumentos excavadores como por ejemplo pueden ser palos, cornamentas de cérvidos sin modificar o las puntas ahuecadas curvas. Su consumo pudo haber sido crudos, hervidos, o asados como por ejemplo señala para el río Uruguay Dobrizhoffer (1967: 160 y 444). También las valvas de este género eran usadas por los guaraníes para la formatización final o acabado de los arcos (Noelli 1993: 164) y como silbatos (Noelli 1993: 215).

Los moluscos también fueron recolectados con otros fines más allá de la alimentación como lo evidencian los dos pequeños gasterópodos de CDB3 transformados en cuentas. Además en general los entierros humanos se registran asociados a valvas de moluscos, pero también es difícil determinar si corresponden a un ajuar funerario o formaban parte del sedimento removido para sepultar el cadáver (véase Gianotti y Bonomo 2013). Los guaraníes usaban los moluscos por ejemplo para cortar plantas durante el trabajo de limpieza y preparado de la rozas para la siembra (Noelli 1993: 270); para pelar o descascarar tubérculos o frutos durante la preparación de las bebidas fermentadas (cauim) (Noelli y Brochado 1998: 122); o como una especie de cucharón para servir el cauim (Noelli y Brochado 1998: 124). Otros usos de los moluscos por indígenas históricos en el Nordeste pueden verse en Chiri (1972).

En cuanto a los peces, se plantea que la ubicación de los sitios arqueológicos, siempre en relación a algún curso fluvial, es estratégica. El asentamiento humano en zonas cercanas al río Uruguay, el mayor curso fluvial regional, resulta relevante en cuanto al acceso a los recursos en general, pero sobre todo a los pesqueros. La tecnología de captura de peces, como puntas, arpones, bipuntas (anzuelos?) y la probable pesa de red, indicaría la pesca mediante armas de impacto y redes de inmersión.

La abundancia de peces del río Uruguay en el pasado reciente queda de manifiesto por el establecimiento sobre la costa argentina de varias pesquerías comerciales al sur de la desembocadura del río Gualeguaychú. Algunas de estas ubicadas inclusive sobre los sitios arqueológicos como por ejemplo Ensenada del Bellaco (Castro y Costa Angrizani 2014) o los Túmulos de la Pesquería Nicolini 1 y 2 (Greslebin 1931a). Desde el río Gualeguaychú hacia el sur, y en una extensión aproximada de $20 \mathrm{~km}$, se cuentan además de las mencionadas, tres pesquerías más (Pesquería de Gally, de Duhalde y de Foldesi); incluso esta última dejó de funcionar hace aproximadamente ocho años. La pesquería de Foldesi podría corresponder a lo que Greslebin (1931a) denominó Nicolini dado que se encontraba en la zona de Puerto Basilio. Greslebin (1931a) también resalta la importancia estratégica de los Túmulos de la Pesquería Nicolini en relación a la 
pesca, planteando que la riqueza pesquera sería la causa principal de la ocupación indígena de esa zona.

Una particularidad del cauce del río Uruguay en la zona de la desembocadura del río Gualeguaychú es que tiene sectores muy poco profundos siendo menores a $1 \mathrm{~m}$. Considerando esto se puede plantear que en esta zona se habrían podido implementar varios métodos de pesca, desde la orilla, desde una canoa o incluso pescar de pie sobre lecho del río y en sectores muy alejados de la costa donde incluso a veces sobresalen grandes bancos de arena, usados con este fin aún en la actualidad.

Dentro de los peces identificados el surubí, la boga, la tararira y los armados (p. ej. Pterodoras granulosus) se caracterizan por una gran masa corporal y tienen una apreciable importancia económica. Los hábitos de estos peces permitirían un acercamiento a los métodos de pesca implementados para la captura de cada uno de ellos. Por un lado, Pseudoplatystoma sp. (surubí) es de río abierto, suele nadar cerca de la superficie y frecuentar las riberas para alimentarse por lo que sería adecuado para ser capturado con arpones (Caggiano 1977b; Cione y Tonni 1978), arco y flecha, y anzuelos. Por otro lado, Leporinus obtusidens (boga) y Hoplias malabaricus (tararira) son de río abierto y frecuentan la superficie por lo que pueden ser capturados con arco y flecha, y arpones. Las especies de Doradidae, que son de río abierto y hábitos bentónicos serían más adecuadas para el uso de redes o anzuelos, aunque también suelen acercarse a la superficie para alimentarse por lo que con ellas podrían haberse usado simultáneamente los cuatro métodos de pesca (anzuelos, arco y flecha, arpones y redes). Ramírez [1528] en Maura (2007: 56) menciona la pesca por indígenas del río Paraguay con redes cuando el rio está bajo y con arco y flecha cuando esta crecido. La gran abundancia de peces registrada permite plantear que además del consumo inmediato probablemente se practicara eventualmente su consumo diferido. El secado y ahumado, así como la existencia de harina y grasa de pescado, está documentado en las primeras crónicas para los indígenas del Delta del Paraná (Santa Cruz [1527-1529] 1918: 550; Schmidl [1567] 2009).

La captura de mamíferos, reptiles y aves (y posiblemente anfibios) debió haber involucrado estrategias particulares de obtención en cada caso, lo que parece estar reflejado al menos en parte en la variabilidad de las armas registradas, y sobre todo en la gran diversidad de puntas óseas. Las armas incluyen lanzas y arpones, arco y flecha, propulsor y dardo, y boleadoras. El cuis pudo haber sido capturado con arco y flecha o trampas. Según Paucke (1744: 356-357) los mocovíes cazaban el cuis con fuego y flechas, y según Miraglia (1975, en Pérez Jimeno 2007: 104) los tobas lo hacían con fuego y garrotes.

Los sigmodontinos habrían sido cazados sobre todo con trampas. En este caso la acumulación de desechos antrópicos orgánicos o también la posible presencia de plantas manejadas antrópicamente y/o cultivos domésticos en cercanías de los asentamientos, pueden haber favorecido la concentración de estas especies en busca de alimentos y también de lugares altos y secos como los 
albardones y montículos; una situación semejante a lo que ocurriría con los agutíes (Dasyprocta prymnolopha) entre los awá (Politis et al. 2013c). La presencia de roedores en torno a los asentamientos humanos es una constante, por lo que su aprovechamiento como alimento no debe haber sido dejado de lado, como fue registrado por Paucke (1943: 185; 1944: 357) entre los mocovíes. La presencia de estos taxa ha sido poco documentada en la región (véase Acosta 2005; Pérez Jimeno 2007; Santiago 2004; Sartori y Colasurdo 2010) y muchas veces su incorporación se ha considerado natural.

El ciervo de los pantanos, el venado de las pampas, el guazuncho, el carpincho, el coipo y el lobito de río pudieron ser capturados mediante arco y flecha, lanza, propulsor y boleadoras, en algunos casos usadas como maza de mango flexible. Estas mismas armas también serían eficaces en la captura de los carnívoros como el yaguareté, el aguará guazú y el zorro. Por su parte, los armadillos pudieron capturarse manualmente en sus cuevas o con boleadoras fuera de ellas. También, como mencionan algunas crónicas pudieron usarse redes para la captura de algunos mamíferos como coipos o carpinchos (Fernández de Oviedo y Valdés [1546-1547] 1851-1855: 178) o inclusive cérvidos (Lopes de Sousa 1530-1532, en Castro 1940: 321; Politis 2014).

El lagarto y posiblemente los anuros pudieron ser capturados mediante arco y flecha. La tortuga pudo ser capturada de forma manual; esta especie también pudo haber sufrido algún tipo de gestión antrópica en lagunas o estanques cercanos a los asentamientos (sobre esta práctica en la Amazonía véase Carvajal [1541] 1942; y sobre posibles lagunas antrópicas en la ROU véase Gianotti 2015). Su consumo pudo haber sido diferido como ocurre con los kayapó, los azurini o los awá de la Amazonia, que recolectan numerosos individuos y los conservan colgados vivos hasta el día de su consumo (Francisco Silva Noelli, UEM, Brasil; comunicación personal 2015; Gustavo Politis, CONICETUNLP-INCUAPA; comunicación personal 2017). El ñandú pudo ser capturado mediante boleadoras. Asimismo, las aves voladoras en su mayoría deben haber sido cazadas con arco y flecha, redes o lazos. El lobo marino probablemente habría sido cazado desde canoas mediante arponeo o arco y flecha, o quizás en tierra con lanzas, lazos o mazas. En 1730 Cattaneo (1730; en Freitas 1953b: 159) menciona cerca de la boca del río Uruguay así como en el Rio de la Plata la presencia de abundantes lobos marinos; también refiere abundantes peces y la pesca con arco y flecha por parte de los guaraníes que lo acompañaban.

Además se propone que en la cacería de la mayoría de las presas mencionadas seguramente se utilizó al perro (Canis familiaris). Ya sea para la caza directa, donde el perro captura los animales, o como ayuda ahuyentando a las presas que quedarían expuestas a las armas de los cazadores. La utilización de perros probablemente permitió ampliar el rango de presas capturadas, sobre todo las de tamaños más chicos, y también aumentar la eficacia de los eventos de cacería.

Al proponer que varios tipos de armas se pueden usar en la caza de una misma presa, por un lado, se evidencian las limitaciones para determinar las prácticas de obtención de recursos 
específicos; pero por otro lado, como lo reflejan los datos históricos, no sería adecuado proponer tajantemente el uso de una determinada arma para la captura de una presa específica. Tal vez la relación más univoca que podría plantearse es entre las puntas de arpón y los peces, pero como se expresa en las citas de Paucke (1944) del Capítulo 7 estas puntas también se usaban para animales terrestres y seres humanos. Probablemente las boleadoras estén más vinculadas a la caza de cérvidos y ñandúes, pero seguramente fueron también usadas de modo oportunístico para presas más pequeñas como por ejemplo dasipódidos (véase Paucke 1944: 353).

En relación a la idea extendida sobre que las boleadoras serían menos adecuadas para la caza en ambientes ribereños con densa vegetación como los que bordean a la provincia de Entre Ríos (véase p. ej. Torres 1911), se destacan dos aspectos:

- el primero es que la concepción de que las boleadoras tendrían una baja efectividad en estos ambientes responde, en primer lugar a una comparación relativa con los cazadores de guanaco (Lama guanicoe) y ñandú de la región pampeana y Patagonia, teniendo en mente posiblemente el uso boleadoras arrojadizas de dos o tres bolas y haciendo un paralelismo con la caza de los cérvidos y el ñandú en el NEA.

- el segundo es que las bolas han sido halladas en numerosos sitios arqueológicos ubicados en este ambiente y también en estratigrafía (Aparicio 1928; Greslebin 1931a; Torres 1911; entre otros), y si bien esto en primera instancia no indica que fueran usadas donde se encontraron, tampoco indica lo contrario. Adicionalmente, hay que tener en cuenta que en el sector $A$, caracterizado por un denso y cerrado bosque xerófilo, también se recuperaron numerosas bolas. Estos hallazgos tampoco indican que todas las bolas recuperadas pertenezcan a boleadoras usadas de manera arrojadiza, sean de una o más bolas.

Por lo tanto, se considera que las boleadoras en general pudieron usarse en lugares más alejados y abiertos frecuentados por los cazadores, pero también en el ambiente costero ribereño y boscoso de las llanuras interiores; y no siempre necesariamente como arma arrojadiza pudiendo usarse también como maza de mango flexible. En general, los cazadores experimentados conocen y/o tienen definidas las zonas donde hay más posibilidad de encontrar a las presas deseadas, por lo que en busca de una determinada presa (en este caso factible de ser cazada con boleadoras arrojadizas) es claro que su captura se realizará en un lugar donde el arma elegida pueda ser efectivamente usada y eficaz. Tampoco se puede negar que en determinados puntos del espacio la vegetación cerrada impide hasta el mismo transito humano, y por lo tanto el uso de la mayoría de las armas mencionadas (p. ej. propulsor). También es cierto que en este tipo de ambientes existen lugares, que sin ser espacios abiertos y amplios, están despejados de vegetación donde las boleadoras arrojadizas pudieron haber sido usadas fácilmente por un hábil cazador.

Un ejemplo contradictorio se observa en Torres (1911) cuando refiriéndose al material lítico del Túmulo I del río Carabelas, considera a las piedras lenticulares como piedras de honda y a las 
bolas como piedras de boleadoras. Destacando además que estas últimas se encuentran en un medio poco propicio para su empleo y vinculándolas a la carencia de materias primas líticas en la zona. En este sentido, si se considera que un una zona sin materias primas locales los instrumentos tenderían a conservarse, y en el mismo medio se registran lenticulares y bolas de boleadoras, entonces la estrategia de conservación sería más eficiente en las boleadoras ya que los ramales funcionan a la vez como un sistema de retención y fácil visualización que reduciría su perdida una vez arrojada. Caso contrario pasaría con las lenticulares que si fueran usadas como piedras de honda el riesgo de pérdida sería casi total con el primer lanzamiento que no diera en el blanco. Por estos mismos riesgos, y como ya fue mencionado (Capítulo 7), las piedras lenticulares podrían ser otro tipo de boleadora o al menos no serían piedras de honda. En síntesis, en este ambiente Torres (1911) considera poco factible el uso de boleadoras y factible el uso de lenticulares, o al menos no lo cuestiona y no lo relaciona con la necesidad de conservar los materiales líticos y con el riesgo de pérdida, que con esta última arma sería mucho mayor. Además, el problema de que la vegetación impida o dificulte los giros de las armas previos al lanzamiento se aplica a ambos tipos (boleadora arrojadiza y honda), no así para uso de estas piedras como mazas de mango flexible.

A partir de los requerimientos ecológicos y las características etológicas de los taxa identificados también se pueden determinar los distintos sectores del ambiente por donde circulaban los cazadores-pescadores, estableciendo un continum desde la superficie de los cuerpos de agua hasta lugares altos, secos y más abiertos en tierra firme. Claramente los peces fueron obtenidos en el agua. El ciervo, el carpincho, el coipo, el aguara guazú, el yaguareté, el lobito de río y la tortuga (y posiblemente los anuros) en zonas pantanosas con abundancia de agua como esteros, bañados y pajonales. El guazuncho, los sigmodontinos y el lagarto prefieren áreas secas dentro del ambiente ribereño o del monte xerófilo. El venado, el ñandú, el cuis y el zorro ocupan preferentemente zonas secas y abiertas como praderas y pastizales, y también montes xerófilos. Los armadillos pueden encontrarse tanto en terrenos secos como húmedos, asociados a cuerpo de agua.

Si bien todos los taxa fueron identificados a partir de una muestra arqueofaunística procedente del Uruguay inferior (sector C), es altamente probable que las mismas especies hayan sido explotadas por los indígenas que ocuparon la costa entrerriana entre el sector C y Salto Grande. En este sentido, se destaca que en el Museo de Antropología y Ciencias Naturales de Concordia se registraron seis puntas con epífisis elaboradas sobre metapodios de cf. guazuncho y un radio de cf. venado. Los mismos proceden de los sitios arqueológicos Cerro Chico $(n=5)$ ubicado en Federación y Bajada La Fourcade $(n=1)$ en Concordia. También se registró un dato interesante sobre la fauna del Uruguay medio que pudo ser explotada, en la zona de Barrancas Peladas del Espinillal y en el río Arapey (ROU) se menciona la presencia de yacaré (Caiman sp.) y osito lavador (Procyon cancrivorus) (Laforcada y Ambrosoni 1980). Asimismo, para la zona de Salto Grande se menciona la presencia de 
yacaré overo (Caiman latirostris) y coatí (Nasua nasua) (Melgar et al. 1975) (sobre avisajes más recientes yacaré overo en la ROU véase Borteiro et al. 2006).

Los estudios sistemáticos sobre la arqueofauna del sector $\mathrm{C}$ aún son escasos y necesitan ser ampliados, pero esta primera aproximación permite comenzar a indagar sobre el impacto de los asentamientos estables y su duración sobre la distribución de la fauna terrestre. En este sentido, si bien se registraron mamíferos de mediano y gran porte, cuyo volumen alimenticio es considerablemente mayor al de las presas pequeñas, el registro estudiado muestra la explotación mayoritaria de mamíferos pequeños.

Es probable que la captura de los mamíferos grandes y medianos haya requerido de salidas diarias de forrajeo o logísticas, ya que animales como los cérvidos, los carpinchos y los ñandúes no merodearían los asentamientos estables, primero por la presencia de una importante densidad poblacional en circulación y segundo por la presencia de perros domésticos. En cambio la captura de animales pequeños en un radio más cercano a los asentamientos estaría potenciada por el contacto más frecuente, por el uso intensivo de trampas y por la ayuda del perro. Además, estas presas podrían estar atraídas por las áreas de desechos antrópicos y de actividades de cultivo y manejo agroforestal, como por ejemplo ocurre con los guaraníes quienes ubican sus trampas mayormente en los alrededores y en el interior de sus rozas (Noelli 1993). Si bien estos animales estarían sometidos a una mayor presión predatoria en general corresponden sobre todo a roedores con alta tasa reproductiva.

En síntesis, la caza de animales de tamaños menores con alta tasa reproductiva y que soportan una mayor presión predatoria o tienen gran productividad estacional (roedores, pero también algunos peces, aves y moluscos), aumentaría en cercanías de los asentamientos. Paralelamente, a mayor distancia del asentamiento residencial se obtendrían recursos mayores que implican mayor tiempo y energía (un ejemplo etnoarqueológico véase en Politis et al. 2013c). Estas hipótesis deberán ser profundizadas con datos arqueofaunísticos procedentes de más excavaciones sistemáticas.

\section{5- TECNOLOGÍA ÓSEA Y MALACOLÓGICA}

La elaboración de instrumentos y adornos a partir de los elementos anatómicos duros de los animales explotados solo se registró en el sector C (Capítulo 7 y 8). Los taxa utilizados suman un total de 17; en algunos casos los elementos de cada taxón fueron transformados en instrumentos 0 adornos, y en otros casos con el mismo taxón se elaboraron ambos tipos de artefactos. El conjunto de instrumentos cumplió una amplia gama de funciones utilitarias y los adornos una función 
simbólica y ritual acompañando a los individuos tanto en la vida como en su muerte al ser sepultados junto a los restos humanos.

En relación a los instrumentos, se identificaron 255 piezas de las cuales 215 proceden de 16 sitios arqueológicos y el resto $(n=40)$ no tiene procedencia determinada (Tabla 7.16; Tabla 7.23a, b, c y d; y Tabla 8.17). Se identificaron un total de 13 tipos (agujas, tubos, biseles, bipuntas, puntas acanaladas, puntas ahuecadas, puntas curvas, puntas planas, puntas con epífisis, puntas de arpón, horquetas, espátulas y gancho de propulsor) (además de preformas, Puntas no clasificables y espinas aguzadas) elaborados sobre 10 elementos anatómicos distintos (huesos largos, cúbitos, tibias, tarsometatarso, metacarpos, metatarsos, astrágalo, astas y espinas pectorales y dorsal de peces) de 13 taxa diferentes (ACTINOPTERYGII, Siluriformes, Doradidae, Pseudoplatystoma sp., AVES, Rhea americana, Ciconiidae, MAMMALIA, Blastocerus dichotomus, Ozotoceros bezoarticus, Mazama gouazoubira, Chrysocyon brachyurus y Myocastor coypus).

El relación a los adornos, se identificaron 36 piezas de las cuales 27 proceden de tres sitios arqueológicos (CL2, SPL y CDB3) y el resto $(n=9)$ no tiene procedencia determinada. Se identificaron cinco tipos (pendientes, cuentas de collar, cuentas indeterminadas, tembetás y disco) elaborados sobre dos elementos anatómicos distintos (dientes de carnívoros y valvas de moluscos) de seis taxa diferentes (MOLLUSCA, Diplodon sp., GASTRÓPODA, Megalobulimus sp., Chrysocyon brachyurus y Panthera onca). Por su parte los artefactos decorados incluyen AVES y MAMMALIA.

El único taxón cuya obtención no estaría vinculada a la alimentación es el pequeño gasterópodo de CDB3 que fue transformado en cuentas (Figura 8.14E). El aguará guazú y yaguareté posiblemente no hayan sido cazados primariamente con fines alimenticios. Para ambos se registraron elementos craneales y apendiculares, por lo que además del uso de sus huesos, dientes y cueros (véase Lopes se Sousa 1530-1532, en Castro 1940; Politis 2014), sus tejidos blandos pudieron haber sido aprovechados como refiere Paucke (1944: 343) para los mocovíes de Santa Fe en el siglo XVIII.

La elaboración de pendientes con caninos de carnívoros ya había sido registrada también en la margen izquierda del río Uruguay inferior. Por ejemplo en el Cerrito de Colonia Concordia donde se han recuperado caninos de félidos perforados y decorados (Hilbert 1991; Maruca Sosa 1957). También para el Delta del Paraná Orquera (1973) menciona el hallazgo de dientes de felinos perforados y también un diente humano. El uso de dientes como "talismán" o "porte bonheur" colgados del cuello fue registrado por Torres (1911: 251) en algunos pobladores del Delta del Paraná a principios del siglo XX. Paucke (1944: 294) también registró entre los mocovíes del siglo XVIII la práctica de llevar dientes colgados como protección, pero en este caso corresponden a dientes de yacaré (Caiman sp.). En nuestro caso los pendientes con una clara carga simbólica corresponden a las dos especies de carnívoros de mayor tamaño registradas en la región en momentos prehispánicos (y en cierta forma el yaguareté un predador y competidor con los seres humanos). En este sentido, la 
exhibición corporal por parte de los cazadores de las presas obtenidas, marcaría diferencias interpersonales de acuerdo a las habilidades y valentía de capturar estos animales considerados como presas simbólicamente significativas (Acosta et al. 2015b; Bonomo 2012; Politis 2014; Roe 1998; Saunders 1998), más allá de su posible consumo como alimento.

Como se observó en los capítulos anteriores, la mayoría de las presas (peces, moluscos, cérvidos y coipos) sobre las que se elaboraron instrumentos o adornos estarían ingresando en forma de carcasas completas a los asentamientos. Entonces a partir de esto (excluyendo los sitios arqueológicos guaraníes) se puede plantear que en la mayoría de los casos la obtención de los soportes-base de los instrumentos y adornos se realizaba en los mismos asentamientos, mediante la extracción de los elementos anatómicos adecuados. En esta tarea (además de la formatización de los artefactos) habrían participado intensamente los instrumentos líticos. La interacción física entre instrumentos líticos y restos faunísticos está demostrada por las evidencias de procesamiento presentadas en los Capítulos 7 y 8.

El registro del sector C muestra que la mayoría del conjunto artefactual óseo y malacológico fue confeccionado, mantenido, reparado/reciclado, reemplazado, descartado y sepultado en los asentamientos. Dentro del conjunto óseo se plantea que los desechos de manufactura, las preformas, los ápices y otros instrumentos fracturados (p. ej. arpones y puntas ahuecadas semiacanaladas); la decoración de algunos artefactos (tubos e indeterminados); algunas recurrencias entre taxón, elemento y tipo de instrumento (véase más adelante); la inversión de trabajo que implican algunos diseños específicos (p. ej. agujas, arpones y gancho de propulsor); y la repetición de diseños básicos (p. ej. arpones y puntas ahuecadas); estarían apuntando hacia la implementación de una estrategia conservada. Asimismo, la elaboración de los instrumentos óseos no respondería a la ausencia de otras materias primas, ya que los recursos líticos registrados en los mismos sitios arqueológicos son variados y abundantes. Más bien respondería a la decisión de contar con un amplio instrumental donde cada tipo de instrumento era destinado a una tarea más o menos específica (p. ej. agujas, arpones, espátulas y gancho de propulsor). Entonces se puede plantear que la diversidad morfológica respondería a una especialización funcional. En este contexto, los individuos han determinado que ciertos instrumentos son más eficaces que otros para determinados fines, lo que a su vez muestra la realización de una gran variedad de actividades de subsistencia, domésticas y simbólicas.

La presencia de artefactos decorados (tubos e indeterminados) permite plantear que los usuarios buscaron marcar diferencias a través del tratamiento especial de estos objetos. Al igual que los adornos serían una representación material de una parte del mundo simbólico y de diferencias interpersonales. Las cuentas de valvas asociadas a un cráneo también reflejan su importancia ritual, de forma similar a las cuentas posthispánicas registradas en EDB (Castro y Costa Angrizani 2014). Particularmente los tres tubos decorados sobre huesos aves, con morfologías y decoraciones 
similares procedentes de tres sitios arqueológicos distintos (CL2, EMO y SPL) (Figura 7.14A), y los dos fragmentos de diáfisis decorados también similares y procedentes de CL2 y SPL (Figura 7.6.D y H), pueden interpretarse como objetos con un alto contenido simbólico portadores de mensajes codificados. Los cuales serían compartidos por personas cuya distancia social es reducida, dado que sino esos mensajes pierden eficacia comunicativa y no serían interpretados eficazmente fuera de un contexto común (Di Prado 2015; Wiessner 1983, 1989; Wobst 1977). Esto, además de las similitudes generales del registro arqueológico dentro del sector C (excluyendo el registro guaraní), permite plantear que los ocupantes de estos sitios arqueológicos, y en general del sector $\mathrm{C}$, compartían una afinidad étnica y formaban parte de una población mayor que ocupó ambas márgenes del río Uruguay inferior al menos desde ca. 2000 hasta 600 años AP.

En este estudio se registró la variabilidad instrumental más amplia conocida hasta el momento, tanto en morfologías como en taxa y elementos utilizados. Se observó que dentro de algunos tipos de instrumentos habría cierta tendencia en cuanto al uso de algún taxón y elemento particular. En este sentido, se puede plantear que los metapodios de venado y guazuncho constituyeron los principales soportes-base seleccionados para la elaboración de las puntas con epífisis, las acanaladas y las ahuecadas (semiacanaladas). Esta tendencia en la selección de elementos también estaría vinculada a las propiedades mecánicas de estos huesos, dado que al estar adaptados a la carrera presentan una elasticidad y resistencia adecuadas para elaborar instrumentos que serán sometidos a importantes exigencias mecánicas y/o físicas (Pintos Blanco 2001b; Scheinsohn 1997).

Por último, si bien en este trabajo no se abordó en profundidad el estudio métrico de la tecnología ósea, se considera que, por un lado, ciertas recurrencias entre taxón-elemento y tipo de instrumento (considerando su funcionalidad hipotética) podrían interpretarse como estandarización en la producción de instrumentos. Pero por otro lado, la correspondencia entre el elemento soportebase y la forma de un instrumento no debe ser considerada en primera instancia como estandarización (reducida dispersión de las variables métricas), debido a que los huesos seleccionados presentan una morfología previamente determinada (genética y fenotípicamente). Por lo tanto, es esperable que el tamaño y la forma final de un instrumento esté en gran medida determinada o condicionada por la morfología natural del elemento soporte seleccionado (Pintos Blanco 2001b).

\section{6- EXPLOTACIÓN FLORÍSTICA}

Al igual que con los restos faunísticos y humanos, solo se recuperaron restos vegetales en los sitios arqueológicos en estratigrafía del sector C (Capítulo 7 y 8 ). Se registraron endocarpos 
carbonizados de frutos de palmeras indeterminados, abundantes carbones, y fitolitos en los sedimentos de CDB3 (Capítulo 8). En este mismo sector y como evidencia indirecta de la utilización de plantas se pueden mencionar los "rompecocos", los artefactos de molienda, la utilización de puntas de proyectil óseas y líticas que necesariamente necesitaron de la intervención de astiles o mangos de madera, el uso de canoas, y los negativos de hojas de palmas en la cerámica (esto último posiblemente solo vinculados a los guaraníes). Asimismo, la pipa y posiblemente los tubos óseos decorados (si es que corresponden a inhaladores) reflejarían la presencia y uso de las plantas como medicina o narcóticos.

El uso intensivo de las palmeras por las poblaciones indígenas de la cuenca del Plata está bien documentado, tanto arqueológica como etnográficamente (véase Bonomo y Capeletti 2014; Bonomo et al. 2011a, 2011b; Capdepont 2012; Chiri 1975; Fernández 1979; Paucke 1942; Sánchez et al. 2013; entre otros). De las palmeras se han aprovechado (y todavía continúan siendo usados) sus frutos, hojas, troncos y raíces con múltiples fines como por ejemplo: "Comidas, aceites, harinas, sustitutos de la sal, bebidas, viviendas, herramientas, armas, adornos, contenedores, antiplásticos, combustibles, venenos y medicamentos..." (Bonomo y Capeletti 2014: 227). No solo tienen un uso económico, tecnológico o medicinal sino que en el caso de los guaraníes se vinculan al mundo míticoreligioso (Bonomo y Capeletti 2014 y bibliografía allí citada).

Las especies de palmeras que pudieron ser usadas en nuestra área de estudio son tres: yatay (Butia yatay), pindó (Syagrus romanzoffiana) y caranday (Trithrinax campestris). La primera se distribuye actualmente en diversas concentraciones desde el centro de Entre Ríos hacia el norte, siendo el Parque Nacional El Palmar el núcleo mayor. También está documentada su presencia en islas del río Paraná cerca de Diamante. La segunda se presenta de manera dispersa sin formar concentraciones y se encuentra a lo largo de las riberas del río Uruguay, del Delta del Paraná y del Río de la Plata. La tercera forma concentraciones y se encuentra sobre todo comprendida dentro del Distrito del Ñandubay en el centro-norte y el oriente de Entre Ríos, donde los núcleos se entremezclan con el bosque xerófilo (Báez 1937, 1942a; Lorentz 1878). Los frutos comestibles de las tres especies son estacionales.

Los endocarpos carbonizados recuperados probablemente correspondan a yatay o pindó, sus frutos maduros están disponibles entre la primavera y el otoño a un bajo costo de obtención, por lo que habrían sido un recurso aprovechado por los grupos indígenas del río Uruguay. Fernández (1979) sugiere una posible incidencia de las concentraciones densas de yatay de Corrientes y Entre Ríos sobre el asentamiento de los grupos indígenas. Este punto, junto al papel que posiblemente jugaron los indígenas en la dispersión geográfica de yatay y pindó en el río Uruguay y del Delta del río Paraná merecen ser explorados en mayor profundidad.

En cuanto a los carbones, los resultados preliminares obtenidos por Franco y colaboradores (2016) sobre muestras procedentes de la excavación sistemática de CDB3 permitieron identificar 
Prosopis nigra (algarrobo negro), Parapiptadenia rigida (anchico colorado), Ceiba speciosa (palo borracho), Celtis sp. (tala) y Aspidosperma sp. Todos estos elementos arbóreos tienen usos potenciales que en conjunto incluyen: combustible, alimentos, bebidas, medicinas, colorantes, hilandería, viviendas y artefactos (p. ej. canoas y arcos para flechas) (Brea et al. 2013; Marconetto 2008; Noelli 1998b; Pensiero y Peña 2000; Tortorelli 1956).

Los taxa identificados no solo permiten conocer la oferta paleoambiental de recursos leñosos en torno a la localidad arqueológica Cerros de Boari, sino que también permiten establecer zonas de aprovisionamiento de recursos vegetales. Los materiales identificados sugieren el uso de dos unidades florísticas: bosques xerófilos, con elementos que actualmente crecen en zonas próximas a la localidad arqueológica y que habrían implicado un aprovisionamiento inmediato (Prosopis nigra, Celtis sp. y Aspidosperma sp.); y selvas ribereñas, con algunos elementos vinculados a la Selva Misionera y que posiblemente implicaron un aprovisionamiento a media y larga distancia (Parapiptadenia rigida y Ceiba speciosa). Probablemente Prosopis nigra, Celtis sp. y Aspidosperma sp. fueron utilizadas como leña, debido su valor calórico y duración, destinada por ejemplo a la cocción de la alfarería o de alimentos en los fogones; mientras que Parapiptadenia rigida y Ceiba speciosa pudieron estar destinadas a otros usos más específicos y/o quemadas por distintas razones (p. ej. construcción, elaboración de canoas o medicinas).

El registro actual de Parapiptadenia rigida más cercano al área de estudio está en Corrientes y Misiones, y de Ceiba speciosa está en la cuenca del río Uruguay $35 \mathrm{~km}$ al sur de Santo Tomé (Corrientes) y también se encuentra más al norte, entre Concepción de la Sierra y San Javier (Misiones). Asimismo, se ha registrado en Súnchales (Santa Fe) pero posiblemente allí haya sido cultivada (Gibbs y Semir 2003). Las muestras de Parapiptadenia rigida y Ceiba speciosa proceden de la cuadrícula 3 nivel 19, y esta última especie también se registró en la cuadrícula 2 nivel 22. Por otra parte, Prosopis nigra, Celtis sp. y Aspidosperma sp. proceden en conjunto de las cuadrículas 2 y 3 y entre los niveles 18 y 22. En todos los casos estos taxa estarían estratigráfica y cronológicamente vinculados al conjunto de dataciones que se ubican en torno a los 1000 años AP (Figura 8.9), coincidiendo con el segundo pulso cronológico, y posiblemente indicando que al menos desde ese momento se obtenían recursos vegetales de diversos ambientes y también foráneos.

Considerando que los guaraníes eran agricultores y poseían un amplio conocimiento botánico y que su subsistencia se basaba mayormente en el consumo de productos vegetales obtenidos mediante un sofisticado manejo agroforestal (Noelli 1993, 1994, 1998a, 1998b, entre otros), su llegada al sector ciertamente alteró y enriqueció considerablemente la diversidad vegetal local. Con ellos llegaban algunas de sus plantas alimenticias, medicinales, simbólicas y también aquellas usadas como materia prima (Noelli 1998a). Además, la instalación de una nueva aldea casi siempre se daba dentro de una floresta secundaria, esto es, un territorio donde la vegetación "primaria" ha sido previamente manejada y modificada de manera gradual por sus prácticas 
agroforestales. Aun así cabe la posibilidad de que durante la ocupación inicial algunas aldeas en el frente de expansión se instalaran en áreas sin floresta secundaria de origen guaraní, pero tal vez sí con una vegetación previamente manejada por los ocupantes locales desplazados y aprovechadas posteriormente por los recién llegados guaraníes (Francisco Silva Noelli, UEM, Brasil; comunicación personal 2017). La floresta secundaria favorece la concentración de recursos de subsistencia, no solo de vegetales sino también de animales. Cabe mencionar que la mayoría de las presas de los guaraníes eran obtenidas mediante trampas y caza directa en las rozas o sus alrededores (Noelli 1993).

Por su parte, si bien aún no se han obtenido pruebas de plantas domesticadas en el área de estudio, la identificación de un registro arqueológico asignable a Goya-Malabrigo permitiría plantear la posibilidad de la existencia de prácticas hortícolas a pequeña escala, como fue determinado para esta misma entidad arqueológica inicialmente en el Delta superior e inferior del Paraná, donde se identificó maíz (Zea mays), poroto (Phaseolus vulgaris) y zapallo (Cucurbitaceae) y probablemente mandioca (Manihot esculenta) (Bonomo et al. 2011a, 2011b; Politis et al. 2011; Sánchez et al. 2013); y más recientemente en el Paraná medio donde también se identificó maíz, poroto y zapallo (Cornero y Ragnone 2015). Para el Delta superior del Paraná Politis y Bonomo (2012) plantean la posibilidad de la existencia de "cultivo de huerto doméstico" (house garden horticulture, según Heckenberger y Neves 2009).

Maíz, poroto y zapallo constituyen una tríada que ha tenido amplia dispersión entre los indígenas de América del sur, por lo que sería esperable encontrarla en nuestra área de estudio. En el este de la ROU se registran claras evidencias de horticultura de estas especies a partir de los 2500 años AP (Gianotti 2015); y en el oeste Capdepont (2012) registró la presencia de maíz y zapallo en el sitio arqueológico Guayacas (Capdepont et al. 2013). Asimismo, Castillo (2004) reconoce la presencia de fitolitos de maíz y cucurbitáceas en los sedimentos del sitio arqueológico Puente. También en el río Uruguay podría ser esperable la presencia de mandioca, como lo plantean Politis y Bonomo (2012) para el río Paraná. En este sentido, se ha encontrado una referencia histórica más meridional que la presentada por estos autores para esta planta (entre 30 y 31오 S). Según Pernetty (1770; en Acosta y Lara 1961: 114 y 244) los minuanes de alrededor de Montevideo cultivaban mandioca y producían cazabe. No se discute aquí si los genoa-minuanos (sensu Bracco 2013) cultivaban o no en épocas prehispánicas, ya que el mismo Acosta y Lara (1961) menciona que habían adoptado esta práctica en las misiones jesuitas, lo que sí queda claro es que a la misma latitud de Montevideo (ROU) era posible cultivar alguna de las múltiples variedades de este tubérculo en 1763-64 y posiblemente mucho tiempo antes también. 


\section{7- SITIOS ARQUEOLÓGICOS}

Dentro del área de estudio se registraron sitios arqueológicos en posición superficial y en estratigrafía y numerosos hallazgos aislados. Los depósitos estratificados solo se registraron en el sector C (Capítulo 7 y 8 ).

En el sector A se registraron asentamientos de actividades múltiples que reflejan una estabilidad residencial mayor a la considerada hasta el momento. Se determinaron actividades vinculadas a la subsistencia, como el procesamiento y consumo de alimentos; y a la manufactura, uso, reparación, reciclaje y descarte de instrumentos líticos y vasijas cerámicas. La evidencia muestra que estos asentamientos estaban articulados con la ocupación costera del río Uruguay y había un flujo constante de materiales líticos y espículas de esponjas, y probablemente de otros objetos también. Posiblemente esta interacción este reflejando cierta afinidad étnica que aseguraba el acceso los recursos que estaban ausentes en las llanuras interiores.

En el sector B se registraron canteras-taller de actividades específicas y también asentamientos residenciales de actividades múltiples. En los primeros se determinaron actividades de obtención y talla de materias primas. En los segundos se determinaron actividades vinculadas a la subsistencia, como el procesamiento y consumo de alimentos; al aprovisionamiento, manufactura, uso y descarte de instrumentos líticos; y al uso y descarte de vasijas cerámicas. Para esta franja costera del río Uruguay, asumiendo la sincronicidad de los sitios arqueológicos, se puede plantear un patrón de asentamientos que incluiría campamentos residenciales y sitios específicos de obtención de recursos.

En el sector $C$ se registraron canteras-taller de actividades específicas y también asentamientos residenciales de actividades múltiples. En los primeros se determinaron actividades de obtención y talla de materias primas, y en menor medida la producción de instrumentos. Los segundos están constituidos mayormente por los sitios arqueológicos en estratigrafía que se disponen sobre albardones naturales previos, constituyendo montículos o "cerritos". Algunos de los cuales como por ejemplo Cerro de Boari 3 son construcciones antropogénicas elevadas mediante el agregado ad hoc de diversos materiales orgánicos e inorgánicos (sedimentos, artefactos y restos animales y vegetales) (véase Capítulo 8). En algunos casos dentro del conjunto de materiales agregados predominan las valvas de moluscos como en el sitio arqueológico Las Conchillas (véase Capítulo 7). En la región en general el descarte masivo de las valvas de los moluscos consumidos también ha contribuido con la elevación de los albardones y montículos (Chiri 1972), conformando por ejemplo conchales artificiales en la zona de Salto Grande (sitios arqueológicos Cerro Chico I y II, Los Sauces I y Arroyo Yarará) (Cigliano et al. 1971a, 1971b). Almeida (s/fa) en referencia a Sambaquí de Puerto Landa ha planteado que la capa de valvas, debido a su densidad y compactación, evitaría el ascenso de la humedad del sustrato contribuyendo con la preservación de los numerosos restos 
orgánicos y cerámicos que han quedado "sellados" y protegidos de los agentes naturales. Se puede agregar que posiblemente esto también favorecería una superficie habitable más seca o con menor humedad de la que tendría sin la presencia de las valvas.

Los montículos del área fueron identificados como asentamientos residenciales de actividades múltiples caracterizados por una ocupación semipermanente. En ellos se determinaron actividades rituales y otras vinculadas a la subsistencia, como el procesamiento y consumo de alimentos y el descarte de sus desechos; al aprovisionamiento, manufactura, uso, mantenimiento, reciclaje y descarte de instrumentos líticos; a la manufactura, uso, reciclaje y descarte de vasijas cerámicas; y a la manufactura, uso, reparación y descarte de instrumentos óseos y adornos personales.

La cronología obtenida para estos montículos abarca un rango que va desde $c a .2000$ a 600 años AP. La datación de $2050 \pm 60$ años ${ }^{14} \mathrm{C}$ AP de Cerro Lorenzo 2 (Tabla 7.25) permitió extender el rango temporal conocido para la ocupación de montículos en la cuenca del río Uruguay (margen argentina). Particularmente la datación de Cerro de Boari 2 de $1890 \pm 80$ años ${ }^{14} \mathrm{C}$ AP (Tabla 8.1) marcaría el comienzo la construcción de las estructuras monticulares en la localidad arqueológica Cerros de Boari. Por su parte, dado que la datación de Cerro Lorenzo 2 proviene de la colección del MAMA y que no se han realizado estudios sedimentológicos específicos para determinar cuándo comenzó su elevación, no es posible determinar con certeza si el fechado radiocarbónico refleja el límite más temprano conocido para la construcción de montículos en el área, aunque su semejanza con el fechado de Cerro de Boari 2 sugiere la contemporaneidad de las prácticas constructivas. También cabe mencionar que en la ROU los montículos más antiguos se registran a desde ca. 4500 años AP en el este y desde ca. 3200 años AP en el noreste del país (Bracco 2006; Gianotti 2015; López Mazz 2001).

En relación a la génesis de las estructuras monticulares a lo largo del desarrollo de la arqueología del NEA se han planteado diversas hipótesis (véase Capítulo 2 y Castiñeira et al. 2014). Algunas sostienen un origen natural (Cione et al. 1977; Frenguelli y Aparicio 1923; Orquera 1973), otras la elevación artificial por el aporte antrópico intencional de sedimentos (Greslebin 1931a; Krapovickas 1957; Lista 1878; Zeballos y Pico 1878), y la postura intermedia sostiene que existió una combinación, con distinto grado de intensidad, de procesos naturales y antrópicos (intencionales o no) en la elevación de los montículos (Campos 2003; Ceruti 1993, 2003a; Cornero et al. 2007; González 1947; Lafon 1971; Lothrop 1932; Nóbile 2001). También hay autores que reconocen la existencia de montículos naturales y antrópicos simultáneamente (Gaspary 1950; Serrano 1931; Torres 1911). Los estudios más recientes de alta resolución con planimetrías y estudios geoarqueológicos específicos se han desarrollado en el Delta superior del río Paraná (Bonomo et al. 2011c; Castiñeira et al. 2013, 2014; Gianotti y Bonomo 2013; Politis et al. 2011) y aportan nuevas evidencias a esta larga discusión. Estos trabajos concluyen que los indígenas que ocuparon el área 458 
durante el Holoceno tardío "...seleccionaron, modificaron y adicionaron a los fangos naturalmente disponibles, fragmentos de cerámicas, materiales orgánicos y tierras quemadas para elevar y consolidar estructuras en tierra." (Castiñeira et al. 2014: 33).

En nuestro caso, los estudios de la Dra. Castiñeira Latorre establecieron que los tres montículos de la localidad arqueológica Cerros de Boari son estructuras antropogénicas que fueron elevadas a partir de un albardón natural depositado por el río Gualeguaychú, con algunos aportes eólicos. En CDB3 el incremento de aproximadamente 1,50 m en altitud a partir del albardón se dio mediante la incorporación deliberada de materiales antrópicos (orgánicos e inorgánicos) y sedimentos; y también por acumulación gradual de detritos (orgánicos e inorgánicos) durante la ocupación humana, que también pudieron ser gestionados mediante la limpieza y acondicionamiento de la superficie habitada. Todo el volumen de materiales acumulados caracterizados por una alta densidad de la fracción gruesa $(>2 \mathrm{~mm}$ ) contribuyó a la estabilidad estructural de los montículos; evidentemente construidos para perdurar en el tiempo llegando incluso hasta la actualidad. Esto permite sostener que la ocupación de localidad arqueológica Cerros de Boari fue estable y de larga duración (ca. 1300 años) como lo demuestran las dataciones radiocarbónicas (Tabla 8.1) y los datos presentados en el Capítulo 8. Si bien Cerro de Boari 3 es el único sitio arqueológico excavado sistemáticamente en el marco de esta tesis, los resultados permitieron determinar la construcción humana de los montículos y la modificación antrópica del paisaje fluvial, con fines de habitabilidad y permanencia prolongada, en el río Uruguay inferior durante el Holoceno tardío.

La datación de Cerro Lorenzo 2 fue obtenida sobre restos óseos humanos, por lo tanto la fecha no solo refleja el uso de los montículos como lugares de habitación, sino también simultáneamente como lugares de sepultura, al menos desde hace $2050 \pm 60$ años ${ }^{14} \mathrm{C}$ AP. Considerando la discusión sobre la funcionalidad de las estructuras monticulares se puede plantear que no estaban primariamente destinadas al entierro de los muertos, sino que responden a una estrategia de ocupación de un ambiente fluvial muy dinámico y rico en recursos. Paralelamente los montículos, los únicos puntos del espacio donde se han registrado entierros humanos numerosos y diversos, fueron repositorios de los restos humanos de los ancestros buscando posiblemente de manera intencional que estas estructuras contribuyeran con su preservación. Dado que el paquete funerario de Cerro de Boari 3 y las huellas de corte sobre huesos humanos en Cerro Lorenzo 2 y Sambaquí de Puerto Landa evidencian que algunos individuos estaban sometidos a un cuidado y tratamiento posmortem especial, se puede agregar que el entierro de los muertos en los montículos con fines de preservación también constituye una las instancias de estas manipulaciones y rituales funerarios con alto contenido simbólico. 
Dentro de nuestra área de estudio las prácticas inhumatorias (no-guaraníes) fueron registradas únicamente en los montículos ${ }^{2}$. Por su parte, en la margen izquierda del río Uruguay según el relevamiento de Capdepont (2012), el 93\% de la inhumaciones registradas entre los departamentos de Río Negro y Colonia fueron realizadas en montículos entre $1910 \pm 50$ años ${ }^{14} \mathrm{C}$ AP y el siglo XVII (se incluyen entierros en urnas guaraníes) (véase también Arredondo 1927; Castillo 2000; Gascue 2009c). Asimismo, en Salto Grande las inhumaciones en albardones se registraron entre $2420 \pm 80$ y $1190 \pm 100$ años ${ }^{14} \mathrm{C}$ AP (Guidón 1989). Particularmente en estos albardones los restos óseos humanos se presentan asociados a otros materiales arqueológicos por lo que posiblemente algunos hayan sido montículos antrópicos (sensu Eidt 1985). También en el este de la ROU a partir de ca. 1600 años AP solo se registran inhumaciones en los cerritos (Gianotti 2015); y todos los entierros directamente datados tienen menos de 2000 años AP (Cabrera 2005). Por su parte, en el Delta río Paraná hay entierros humanos en la mayoría de los montículos excavados entre ca. 1800 y 400 años AP (Scabuzzo et al. 2015). A partir lo anterior, se observa que la evidencia bioarqueológica del río Uruguay inferior indica que desde ca. 2000 años AP la mayoría de los entierros humanos, cualquiera fuese su modalidad, se realizaron en los montículos. Probablemente no todos los individuos fueron sepultados en los montículos y tampoco se puede sostener que todos los individuos enterrados en un montículo corresponden a la misma población biológica en sentido estricto. Sobre todo por la falta de dataciones para corroborar contemporaneidad entre los mismos y por que puede haber un defecto de muestreo vinculado a la falta de prospecciones en zonas donde no hay montículos.

Los entierros humanos en geoformas o estructuras positivas del paisaje son también una manera de visibilizar la muerte (véase una discusión más amplia en Gianotti 2015). Esta práctica mantenida en el tiempo, en el seno de una misma comunidad parental, posiblemente habría propiciado que los individuos considerasen relevante la posibilidad de ser sepultados juntos a sus ancestros. Tal vez esto sea uno de los aspectos que permita comenzar a explicar la recurrencia de entierros numerosos en los montículos. Probablemente futuros estudios de ADN antiguo puedan confirmar el grado de parentesco de todas las inhumaciones registradas en un mismo sitio arqueológico y también a una escala espacial mayor (véase un ejemplo en este sentido en Bertoni et al. 2004).

También las prácticas inhumatorias permiten plantear que el ámbito doméstico se vincula íntimamente con el simbólico (la muerte y los antepasados), y ambos integralmente forman parte de la construcción y apropiación social del territorio. De esta forma, el entierro de "los propios" o "los nuestros" en determinados lugares reflejaría la intención de marcar y legitimar una presencia efectiva y una ocupación del espacio que sea perdurable en el tiempo. En este sentido, las

\footnotetext{
${ }^{2}$ Si bien se registraron restos óseos humanos en el sitio arqueológico San Luís Médanos, no está claro si corresponde a un montículo. 
estimaciones etarias sobre los restos óseos humanos (Capítulo 7) reflejaron la presencia de individuos de diversas edades, y esto, junto al gran número de individuos de ambos sexos por sitio arqueológico (véase también Gascue 2009c), permite plantear el uso ritual transgeneracional de los montículos. Esta recurrencia ritual probablemente fue mantenida en el tiempo por las mismas poblaciones conformando espacios mortuorios familiares o comunales.

Según Pardoe (1988) una de las variables para considerar a un lugar como "cementerio" es que se determine su uso exclusivo para la disposición de los muertos, además de que contenga entierros numerosos, contiguos no azarosos y límites definidos. En el caso del NEA no se han registrado sitios arqueológicos que cumplan con el criterio de exclusividad, por lo que difícilmente se pueda sostener la existencia de un cementerio en los términos de este autor. Por el contrario, el registro arqueológico conocido muestra constantemente lugares con una combinación de actividades funerarias y domésticas. En este contexto, el estrechamiento de los vínculos con los ancestros a través del desarrollo de la vida cotidiana en los mismos lugares donde están sepultados los restos materiales de las generaciones anteriores (que en algunos casos han sido objeto de entierros secundarios y por lo tanto de manipulaciones previas), reflejaría estabilidad y la apropiación social del espacio, así como el mantenimiento y la reproducción de la memoria social (Bradley 1993, 2002; Chapman 1995; Criado Boado 1989; Dillehay 2000, 2007; Goldstein 1995; Ingold 1986; Pardoe 1988; entre otros). En este último sentido se han interpretado los montículos del Delta superior del Paraná (Bonomo et al. 2011c; Gianotti y Bonomo 2013) y algunos del río Paraná medio (Pérez Jimeno 2007). Asimismo, en la ROU algunos montículos con entierros humanos han sido interpretados como marcadores territoriales y como un modo de apropiación y construcción simbólico-territorial del espacio (Gianotti 2000, 2015; Iriarte 2006; López Mazz 2001; entre otros).

En el río Uruguay medio el uso de lugares elevados, en este caso un albardón, para entierros múltiples y diversos queda también de manifiesto en el sitio arqueológico Y-57 (Salto Grande), donde según Guidón (1977) se recuperaron 80 "sepulturas", una de ellas asociada a un fragmento de cobre. De estas inhumaciones 68 serían secundarias y una primaria, y la mayoría tiene ocre rojo (véase Farías 2005). Lo mismo puede plantearse para el Cerrito de Colonia Concordia (Soriano) en el río Uruguay inferior donde según Bonino de Langguth (1977) se recuperaron restos óseos de 54 individuos y 50 según Hilbert (1991) (véase también Díaz et al. 1980; Maruca Sosa 1957). Lamentablemente no hay dataciones sobre estos dos sitios arqueológicos o sus materiales óseos. Gascue (2009c) también menciona para la cuenca meridional del Plata que todas las modalidades de enterramiento secundario (en paquete y urna) se registraron en entierros colectivos. En esta línea, Torres (1911) planteaba que el Túmulo I del Paraná Guazú en el Delta inferior del Paraná demostraría un tiempo prolongado de ocupación, ya que presenta más de 40 individuos enterrados que corresponderían a varias generaciones (Torres 1911: 184). 
Para el caso de los sitios arqueológicos guaraníes del área se plantea que al menos Ensenada del Bellaco corresponde a una aldea estable; y que probablemente estaba asociada a La Correntina y Ñandubaysal - Arroyo de La Cruz/Arroyo Ubajay (véase adelante).

\section{8- REFLEXIONES FINALES}

\section{Los datos actuales del área de estudio}

Considerando particularmente los resultados obtenidos dentro del área de estudio, se puede sostener que se identificaron diferencias y semejanzas entre los tres sectores de muestreo. Así, los sectores A y B presentan atributos tecnológicos semejantes entre sí, y a la vez ambos son relativamente bastante diferentes al sector $\mathrm{C}$. Los problemas fundamentales que no permiten una comparación integral entre los tres sectores son la falta de sitios arqueológicos en estratigrafía, la ausencia de restos orgánicos (faunísticos, vegetales y humanos) y la carencia de dataciones absolutas en los sectores A y B. La información obtenida solo permite profundizar sobre la ocupación indígena del río Uruguay inferior (sector C); por lo que a continuación se caracteriza a los dos grupos humanos, identificados a partir del registro arqueológico estudiado, que ocuparon este sector desde hace ca. 2000 años AP hasta momentos posteriores a la conquista europea:

1- El primer grupo corresponde a canoeros ribereños cazadores-recolectores-pescadores (y probablemente horticultores) y alfareros, constructores de montículos y con una alta estabilidad residencial. Se caracterizan por los siguientes rasgos: una estrecha vinculación y dependencia del ambiente fluvial y de sus recursos; una subsistencia basada sobre todo en especies de ambientes fluviales (peces, moluscos, mamíferos, aves, reptiles y posiblemente anfibios); una tecnología orientada a la explotación intensiva del ambiente acuático; la presencia de abundantes instrumentos y artefactos líticos, incluyendo elementos de molienda; una alfarería utilitaria con gran variabilidad morfológica y decorativa, y la presencia de representaciones modeladas de la fauna propia del ecosistema local (p. ej. aves y reptiles); una tecnología ósea diversa y funcionalmente especializada; la presencia de artefactos líticos y óseos decorados con un alto contenido simbólico compartido, y también por el uso de adornos corporales y posibles ajuares funerarios; la elevación de montículos destinados a múltiples actividades que van desde tareas domésticas hasta rituales; la diversidad de las prácticas inhumatorias que incluyen entierros primarios y secundarios; y por su inserción dentro de una red de interacción extensa que incluía la circulación de materiales líticos, leñosos, espículas de esponjas, moluscos marinos, metales y probablemente otros artefactos, además de personas, información e innovaciones. 
A partir de las características generales del registro arqueológico (no-guaraní) (montículos, adaptaciones fluviales, alfarería modelada, cronología, etc.) estas ocupaciones pueden identificarse de manera general con la entidad arqueológica Goya-Malabrigo (sensu Politis y Bonomo 2012). Algunos sitios arqueológicos como CL2, T1-CNM, T2-CSM, CP, SPL, ET y LACDB son los que más claramente evidencian la presencia de Goya-Malabrigo en esta porción del río Uruguay. En este sector, los conjuntos arqueológicos asociados a esta entidad además se caracterizan por la presencia de abundantes artefactos líticos tallados, pulidos y modificados por uso. Debido sin duda a la disponibilidad de recursos líticos en este río, al contrario de lo que ocurre en el río Paraná. Esto no solo permitió abordar el sistema de producción lítica, sino también establecer una primera aproximación a la base regional de los recursos líticos explotados y a las redes de circulación de los mismos a nivel regional. Estas redes conectan el tramo medio con el inferior, y probablemente ambos con el superior también, como lo evidenciarían los recursos leñosos procedentes de Corrientes y/o Misiones.

La vinculación de Goya-Malabrigo con los indígenas (o sus antecesores inmediatos) que encontraron los conquistadores europeos en la cuenca meridional del Plata, denominados genéricamente complejo étnico chaná-timbú y que incluye a los chaná, mbeguá, timbú, chanámbeguá, chaná-timbú, quiloazas, caracaráes, colastines, corondás, mocoretás y mepenes, ha sido planteada por varios investigadores y en general hay un consenso al respecto (Aparicio 1939; Bonomo et al. 2011c; Ceruti 1993; González 1947, 1977; Lothrop 1932; Politis y Bonomo 2012; Serrano 1946, 1972; entre otros). Una de las evidencias destacadas de esta vinculación entre GoyaMalabrigo y el complejo étnico chaná-timbú la presenta Aparicio (1929), cuando menciona el hallazgo de cuentas de vidrio venecianas asociadas a modelados zoomorfos en un sitio arqueológico del arroyo Las Conchas en río Paraná medio. Aparicio plantea que los indígenas descriptos para esa zona por los conquistadores europeos serían los responsables de las representaciones zoomorfas. También la presencia de alfarería Goya Malabrigo en el Fuerte Sancti Spiritus sería otro indicador en esta dirección (Letieri et al. 2015). Esto apoyaría la propuesta de que Goya-Malabrigo correspondería a los indígenas contemporáneos a los conquistadores $y / 0$ a sus antecesores inmediatos. Particularmente en estos dos casos los indígenas que en esa zona describieron los conquistadores son los chaná-timbú, quiloazas y mocoretás (Fernández de Oviedo y Valdés [1546-1547] 1851-1855; García de Moguer [1530] en Fúrlong Cárdiff 1933; Ramírez [1528] en Maura 2007; Schmidl [1567] 2009).

Considerar que la cultura material identificada con Goya-Malabrigo está también presente en el río Uruguay no es equivalente a identificar todo el registro arqueológico con una única identidad étnica; y mucho menos que esto signifique uniformidad y homogeneidad cultural y lingüística dentro del área de dispersión espacio-temporal que abarca esta entidad arqueológica (para profundizar la discusión sobre la cultura material y las fronteras sociales en las Tierras Bajas véase Stampanoni Bassi 
2016). Futuras investigaciones podrán seguir caracterizando el registro arqueológico local y tal vez identificar diferencias y especificidades de estos grupos en relación a los del río Paraná y/o la presencia de otras entidades arqueológicas. Lo que sí está claro es que existe una matriz cultural común, posiblemente como resultado de las adaptaciones fluviales que caracterizan una trayectoria histórica semejante o compartida. Por el momento, y partir del registro arqueológico estudiado, en la comparación entre la cuenca inferior del río Uruguay y el río Paraná medio e inferior, son más evidentes las semejanzas que las diferencias marcadas.

Que algunas ocupaciones del sector C correspondan a Goya-Malabrigo es considerarlas insertas dentro de una red macroregional de poblaciones interconectadas, cuyo sistema vertebral lo constituyen los grandes ríos de la cuenca del Plata y sus tributarios. Indicadores arqueológicos de que los ocupantes del sector $\mathrm{C}$ participaban en redes de interacción extensas, previo a la llegada de los guaraníes, son por ejemplo la presencia de rocas procedentes de distancias medias y largas, la técnica de agregar espículas como inclusión en la alfarería, la semejanza de los modelados y los patrones estilísticos de la cerámica, la semejanza de los instrumentos óseos, la semejanza en la subsistencia basada en recursos acuáticos, la ocupación y construcción de montículos, y todas las demás características del registro arqueológico que muestran similitudes con la cuenca del río Paraná y con la margen izquierda del río Uruguay. Esta red macroregional no se circunscribe a la cuenca del Plata, incluye también el Área Andina Meridional y la región central de Argentina (véase Bonomo et al. 2011c, 2017; Di Prado 2015; Guidón 1977; Hilbert 1986, 1991; Iriarte 2001; Larguía de Crouzeilles 1936; Politis 2014; Serrano 1931; Torres 1911; entre otros).

Por último, si se consideran las tres características principales esperadas para grupos humanos adaptados netamente a un ambiente fluvial (Erlandson 2001; González 2005; Mameli y Estévez Escalera 2004; Orquera y Piana 1999a, 1999b; Waselcov 1987; Yesner 1980): 1- que una parte significativa de los alimentos consumidos sea provista por recursos procedentes del río y su entorno inmediato, por ejemplo, peces, moluscos, anfibios, aves y mamíferos; 2- que el conjunto tecnológico incluya instrumentos elaborados específicamente para la explotación de dichos recursos; y 3- que el registro arqueológico refleje no solo el aprovechamiento intensivo de los recursos mencionados sino también de sus subproductos (p. ej. valvas, huesos, astas, dientes y cueros) como materias primas para la elaboración de su instrumental o parte de él; se observa que las sociedades del sector C cumplen con las tres. En cambio en el Uruguay medio (sectores A y B) la ausencia de materiales orgánicos impide tal aseveración, aunque la fauna registrada en los sitios arqueológicos de la zona de Salto Grande y en el museo de Concordia apuntan hacia esta dirección, al menos para el sector $\mathrm{B}$, que es el más cercano.

2- El segundo grupo está representado por los guaraníes que dentro del sector $\mathrm{C}$ ocuparon la zona ribereña de la desembocadura del río Gualeguaychú (EDB, LC/IDG1 y Ñ-AC/AU). Allí se 464 
establecieron con una alta estabilidad residencial desarrollando su modo de vida como canoeros ribereños cazadores-recolectores-pescadores, agricultores y alfareros. La ocupación de estos espacios seguramente implicó el desplazamiento los ocupantes "locales" mediante el uso de la violencia en primer lugar y/o mediante negociaciones; y una vez asentadas sus aldeas en el frente de expansión desde ellas habrían mantenido interacciones de diversos tipos con los desplazados primero y con los conquistadores europeos después.

EDB es el primer asentamiento guaraní fechado en la cuenca inferior del río Uruguay (Tabla 7.25). La datación de $526 \pm 45$ años ${ }^{14} \mathrm{C}$ AP indica la presencia guaraní en momentos prehispánicos y el registro de cuentas de collar de vidrio asociadas a un entierro humano también evidencia su ocupación en momentos posteriores a la conquista europea. El datación además es coherente con los fechados de los sitios arqueológicos de la Isla Martín García, El Arbolito (405 \pm 35 años ${ }^{14} \mathrm{C}$ AP) (Cigliano 1968) y Arenal Central (410 \pm 40 años ${ }^{14} \mathrm{C}$ AP) (Capparelli 2014); y con el realizado por Termoluminiscencia (TL) sobre cerámica guaraní corrugada (Muestra 1) procedente de Arroyo Negro (Río Negro, ROU) llevado a cabo por Farías (2005) (590 \pm 50 años TL AP). Esta autora realizó otro fechado por TL para la misma localidad arqueológica sobre un tiesto (Muestra 2) que correspondería a cerámica no-guaraní. El tiesto se describe como una base lisa sin decoración, pero también como "modelada" y con arena como antiplástico. A partir de la caracterización y la fotografía presentada no queda claro porque el tiesto no sería guaraní, si además de ser una base se encuentra bastante erosionado. El fechado que arrojó este tiesto es de $610 \pm 40$ años TL AP. Considerando, por un lado, que sería difícil discriminar a partir de una base erosionada lisa y el tipo de inclusión entre cerámica guaraní y no-guaraní, y por otro lado, que como se ha observado en el sector C la alfarería guaraní ha incorporado otros rasgos que no serían morfológicamente típicos, se plantea que no se debe descartar que este fechado también corresponda a una ocupación guaraní en Arroyo Negro.

En cuanto a la ocupación de EDB, si se considera la llegada de Diogo Ribeiro y Estevão Fróis en 1511-1512 DC o de Joao de Lisboa en 1514 DC como fecha inicial de la presencia europea en el Río de la Plata (Laguarda Trías 1973; Maura 2007; Politis 2014), y entonces se traslada a las cuentas de vidrio esta fecha para la ocupación de EDB (aunque probablemente siguió ocupado luego de 1512), existe un lapso temporal que transcurre entre el límite más reciente de la datación y las expediciones de Ribeiro y Fróis de aproximadamente 43 años (1469 a 1512 DC) para la datación sin calibrar y de 64 años (1448 a 1512 DC) para la datación calibrada con 1 sigma (Tabla 7.25).

Lo anterior es viable si se considera que las cuentas provienen del Río de la Plata y siguieron una trayectoria sur-norte, ya que también podrían haber tenido una trayectoria inversa y provenir de los primeros asentamientos portugueses en Santa Catarina (Brasil) a partir de ca. 1510 DC. Considerando la amplia expansión de los guaraníes y sus redes de interacción reconocidas por los primeros conquistadores esto no debería descartarse totalmente. Estas redes por ejemplo permitieron que Gaboto, estando primero en el puerto de Santa Ana (posiblemente ubicado en 
cercanías de la actual ciudad de Itatí en Corrientes) y luego navegando por el río Paraguay, se entera del ingreso al Río de la Plata de las naves de García de Moguer (véase Ramírez [1528] en Maura (2007: 35 y 37). Este último entró posiblemente a fines de marzo de 1528 (Fúrlong Cárdiff 1933: 170) y la información llegó a Santa Ana antes del 28 de marzo, día en que Gaboto dejó ese puerto, lo que indicaría un lapso de una o dos semanas entre ambos eventos separados espacialmente por aproximadamente $1000 \mathrm{~km}$ en línea recta considerando desde la actual ciudad de Itatí al límite marítimo del Río de la Plata, u 800 km desde esta ciudad hasta la confluencia de los ríos Uruguay y Paraná.

Aceptando que la ocupación de EDB fue estable (Castro y Costa Angrizani 2014), como lo indica el registro de abundante alfarería policroma con sus implicaciones sociales (Capítulo 7) y las inhumaciones, se puede plantear primero que al menos este sitio arqueológico estuvo ocupado en dos momentos diferentes. Ahora bien, el intervalo de tiempo entre las dos fechas máximas mencionadas arriba (datación y cuentas de collar) correspondería aproximadamente a dos generaciones, por lo que cabe la posibilidad de que EDB haya estado habitado de manera continua sin periodos de abandono (excepto por grandes inundaciones); funcionando como uno de los enclaves de manutención y apoyo de las redes de expansión guaraní y probablemente como una más de un conjunto de aldeas integradas que existieron a lo largo del río Uruguay. Esta interrelación entre aldeas y la estabilidad a largo plazo de los asentamientos son coherentes con la ocupación espaciotemporalmente continua propuesta para los guaraníes (Noelli 1993). Asimismo, EDB muestra que los guaraníes pudieron desarrollar y reproducir su modo de vida (Tekó), lo que implica que este asentamiento necesariamente debió estar integrado con las rozas para la agricultura, la recolección y la caza, y con campamentos específicos de caza, pesca y obtención de materia primas; y que en conjunto debieron conformar un territorio de dominio (Tekohá) característico de la organización sociopolítica, económica y simbólica de los guaraníes, ya que como plantea Noelli (1993): “Sem Tekohá não há Tekó".

En síntesis, a partir de lo antedicho y de las características generales del registro arqueológico estudiado, se puede sostener que la cuenca inferior del río Uruguay durante el Holoceno tardío fue ocupada por canoeros ribereños con una alta estabilidad residencial; y que por un lado, pueden ser identificados con la entidad arqueológica Goya-Malabrigo, y por otro lado, con los guaraníes.

\section{Estabilidad, interacción y complejidad}

Considerando el sedentarismo o semisedentarismo planteado en relación a las estructuras monticulares del sector C asignables a Goya-Malabrigo, y siguiendo a Dillehay (2013), quien define tres tipos de sedentarismo: funerario, ceremonial y ocupacional o doméstico, se puede plantear que 
en los montículos confluyen el sedentarismo funerario y el doméstico. A partir de esto se estaría ante una situación de sedentarismo excluyente, o sea donde no están presentes los tres tipos de sedentarismo y/o no hay una clara separación espacial funcionalmente específica e independiente entre ellos. Este sedentarismo excluyente e integral, trae implícito un aumento de complejidad social y económica, pero a la vez (y al no registrarse separación funcional o sea sedentarismo inclusivo) probablemente la complejidad se manifieste con relaciones sociales de asimetría poco marcadas. Los asentamientos cada vez más sedentarios requieren el afianzamiento de redes sociales territorialmente extensas que aseguren el flujo y la llegada de bienes lejanos sin la necesidad de la movilidad residencial masiva. A su vez, esto va acompañado del surgimiento de jerarquías que controlen y aseguren la redistribución de bienes. Estas redes amplias también se reflejan en muchos casos en los diseños decorativos de la cerámica. En este sentido, como plantean Frère (2014) y Di Prado (2015) ciertos rasgos estilísticos de la cerámica a nivel regional y suprarregional no parecen atribuibles a coincidencias aleatorias.

En general en las Tierras Bajas de Sudamérica, y particularmente en la cuenca meridional del Río de la Plata, la información etnohistórica y la presencia de montículos y los demás rasgos asociados estarían señalando la presencia de jerarquías políticas y complejidad social y económica (véase Bonomo et al. 2011c; Bracco et al. 2000b; Castiñeira et al. 2013, 2014; Gianotti y Bonomo 2013; Pérez Jimeno 2007; Politis et al. 2011). Bonomo y colaboradores (2011c) y Politis y Bonomo (2012) plantean para el río Paraná la existencia de rank society (Chapman 2003; Fried 1967). Estos últimos autores citan la definición de Chapman (2003) quién plantea que:

"Dentro de este tipo de sociedades, las familias o los individuos de alto rango, tienen una autoridad "regular y repetitiva" (aunque una débil obediencia de sus seguidores), todos los miembros de la sociedad, sean familias o individuos de alto rango o no, tendrían el mismo acceso a los recursos básicos, la división del trabajo sería básicamente por sexo y edad con una especialización muy limitada y con una redistribución de los recursos administrada por estos líderes o jefes permanentes (Chapman 2003: 36-37)" (Politis y Bonomo 2012: 25).

Considerando las ocupaciones Goya-Malabrigo en la cuenca inferior del río Uruguay (si bien las investigaciones sistemáticas aún son escasas) existen indicadores de situaciones que posiblemente habrían requerido de liderazgos, como por ejemplo: la presencia de montículos antropogénicos que requirieron organización constructiva y mantenimiento estructural; la organización y mantenimiento del flujo masivo de rocas y minerales desde distancias medias y largas; la presencia de objetos de metal exóticos procedentes del área andina y de maderas procedentes de Corrientes y/o Misiones; posiblemente también la circulación espículas de esponjas, moluscos marinos y estatuillas cerámicas; y la necesaria interacción organizada y el establecimiento de alianzas 
con otros grupos para asegurar la integración, la reproducción biológica y el flujo de recursos y materiales exóticos a través de redes de interacción e intercambio amplias y estables, y posiblemente también la organización defensiva u ofensiva contra los enemigos (p. ej. los guaraníes).

La escala de interacción, que por ejemplo conecta el NEA con el NOA, muestra que estos contactos (intercambio o circulación de personas) atravesaron fronteras sociopolíticas y barreras étnicas entre algunas de las sociedades involucradas, esto es claro con las placas de metal, los moluscos marinos y posiblemente las estatuillas de cerámica. La organización y el mantenimiento de una red donde están involucradas comunidades étnica y lingüísticamente distintas, necesariamente requieren de diplomacia política y de la reducción de la posibilidad de guerra o conflictos bélicos de envergadura. Así, estas estrategias de negociación eficientes podrían ser canalizadas a través de líderes o interlocutores representativos, que tengan cierto control social que pueda inhibir o evitar comportamientos divergentes y propiciar la interconexión y el establecimiento de alianzas (Stampanoni Bassi 2016). Además, considerando que la alta estabilidad residencial implica cooperación organizada y la existencia de amplias redes macroregionales de intercambio, interacción e integración (cuyo comienzo particularmente Iriarte -2001- sitúa conjuntamente con el inicio de la cultura de los ribereños plásticos o Goya-Malabrigo), se estaría ante la presencia de indicadores de jerarquías y diferenciación social, lo que no implica necesariamente desigualdad social institucionalizada.

\section{La geografía y la distribución del registro arqueológico}

Como fue planteado arriba y en los capítulos previos, el registro arqueológico (no-guaraní) de los tres sectores estudiados presenta semejanzas y diferencias entre sí, y también hay semejanzas y diferencias entre cada sector y otras áreas vecinas. Las diferencias y semejanzas arqueológicas entre los tres sectores ya fueron discutidas y se estableció de manera general que existe una mayor semejanza entre los sectores A y B, y una diferencia más marcada entre estos dos sectores y el sector C. Los sectores A y B corresponden a la cuenca media del río Uruguay y el sector C a la cuenca inferior. También se estableció que el sector $\mathrm{C}$ es semejante al resto de la cuenca inferior del río Uruguay y al río Paraná medio e inferior. Por lo tanto, los sectores A y B no son semejantes al sector del río Paraná ubicado a su misma latitud.

En este punto cabe recordar que dentro de los materiales arqueológicos del sector A la gran mayoría proviene del río Uruguay, como por ejemplo las materias primas líticas y las espículas de esponjas utilizadas en la alfarería. Además, en el río Paraná el registro de materiales líticos procedentes del río Uruguay es muy escaso (Bonomo y Blasi 2011; Serrano 1924). En base a lo anterior entonces es posible preguntarse (si se considera la distancia más corta en línea recta) ¿por qué los materiales líticos trasladados masivamente por tierra hasta las llanuras centrales de Entre Ríos no siguieron desplazándose hacia el río Paraná medio? 
Contrariamente a lo anterior, el registro arqueológico muestra cierta continuidad desde el río Paraná medio hasta el Río de la Plata y estas semejanzas se continúan hacia la cuenca inferior del río Uruguay, pero incluyendo en esta última zona la presencia de abundantes materiales líticos. El modelo planteado por Politis y Bonomo (2012) sobre la dispersión de Goya-Malabrigo indica que ésta ingresa al río Uruguay desde el sur y se desplazaría hacia el norte. Este modelo explica sólidamente el registro arqueológico del sector C aquí estudiado, ¿pero esta dispersión inicial de Goya-Malabrigo mayoritariamente por los grandes ríos se explica únicamente por el modo de vida fluvial de sus portadores, los indígenas del Holoceno tardío?

En este contexto, ¿es posible identificar una única causa para las diferencias entre los sectores A y B y el río Paraná, y las semejanzas entre el sector C y el río Paraná medio e inferior? Claramente en arqueología no se puede identificar una causa única para fenómenos tan complejos ocurridos en un lapso temporal de aproximadamente 1500 años según las dataciones radiocarbónicas de la región. Pero en el estado actual del conocimiento se puede plantear la posibilidad de que durante el Holoceno tardío la movilidad terrestre entre los ríos Uruguay y Paraná haya sido limitada por la existencia de una "barrera ecológica" constituida por la denominada "Selva de Montiel" (Capítulo 3).

La única referencia sobre la posible influencia de esta extensa y densa formación vegetal, que caracteriza las tierras altas de Entre Ríos, sobre las poblaciones indígenas se encuentra en Poenitz (1970b). Este interesante investigador y perspicaz observador del ambiente donde se desenvolvieron las poblaciones indígenas (véase p. ej. Poenitz 1970a y su crítica a los trabajos de Cigliano y colaboradores en el nordeste de Entre Ríos), menciona que la Selva de Montiel "...debió constituir una frontera natural entre los grupos indígenas del Uruguay y del Paraná." (Poenitz 1970b: 23). Asimismo, las características particulares de accesibilidad de esta formación vegetal, no solo dada por la vegetación en sí misma sino también por extensos bañados y numerosos arroyos, permitió que durante la época colonial sirviera de hábitat y refugio a charrúas, genoa-minuanos, yaros, bohanes y chanáes (Bracco 2013; Pérez Colman 1936; Sallaberry 1926; Serrano 1936).

La consideración de la Selva de Montiel como un rasgo natural que dificultaría el desplazamiento terrestre en sentido este-oeste y viceversa, sobre todo en el centro y norte de Entre Ríos donde fue y es más ancha, y donde además coincide con la denominada Lomada de Montiel (la principal divisoria de aguas entre los ríos Paraná y Gualeguay) (Figura 3.5 y 3.9), podría ser un punto de partida para explicar las similitudes mayores del registro arqueológico entre las llanuras interiores centrales y el río Uruguay (sectores A y B), y también la escasa correspondencia entre estas llanuras y el río Paraná en las mismas latitudes. El primer punto por destacar es que no se considera a la Selva de Montiel como una barrera ecológica impermeable, infranqueable o insuperable, sino como una posible limitación real para el desplazamiento terrestre (véase una idea semejante para el NEA en general en Chiri 1975: 83); que habría dificultado la conexión directa por tierra entre los ríos Paraná y 
Uruguay debido a la mayor fricción ambiental que presentaría en relación al desplazamiento acuático por los grandes ríos, sobre todo para las poblaciones con un modo de vida fluvial como las que evidencia el registro arqueológico del río Paraná y del río Uruguay inferior.

Como lo demuestra el registro arqueológico del sector A, el centro de Entre Ríos no estuvo deshabitado, pero probablemente, y como hasta el momento lo indican las evidencias, sus habitantes tenían poca vinculación con los del río Paraná. En caso de que las llanuras interiores hubieran estado ocupadas por poblaciones distintas a las del complejo étnico chaná-timbú del río Paraná, el desplazamiento terrestre en sentido oeste-este no solo estaría afectado por la fricción ecológica de la Selva de Montiel, sino además por la fricción social de otras etnias y/o por la existencia de fronteras étnicas.

Para estos grupos del centro la Selva de Montiel posiblemente no haya implicado la misma dificultad para el desplazamiento y ocupación como para los grupos canoeros fluviales de las riberas de los ríos Paraná y Uruguay. Estos últimos seguramente encontraron simultáneamente una mayor dificultad de desplazamiento en sentido oeste-este (desde el río Paraná hacia las llanuras centrales), y una mayor facilidad de desplazamiento e interconexión entre ambos ríos mediante el uso de las vías fluviales que los conectan a través del Delta del Paraná; lo que a su vez debe haber propiciado el mantenimiento de una red de contactos, informaciones y la presencia de rasgos tecnológicos compartidos, como lo evidencian también las similitudes del registro arqueológico entre el sector $\mathrm{C} y$ el río Paraná.

Es claro que la distribución y disponibilidad de los recursos explotados condiciona al menos en parte la movilidad, las estrategias sociales, las redes de interacción necesarias en el caso de recursos distantes y la intensidad con la que son aprovechados los mismos. En este sentido, el desplazamiento acuático y la ocupación de las riberas, y la consecuente adaptación a ese ecosistema fluvial y su explotación intensiva, pudieron haber sido favorecidos en parte por la presencia de la Selva de Montiel y/o también porque las Tierras altas estaban previamente ocupadas por otros grupos. A medida que avancen las investigaciones esta idea podrá ser explorada en mayor profundidad y discutida con mayor cantidad de datos sistemáticos. No se busca establecer una causalidad, sino considerar algún tipo de correlación. Lo que es importante resaltar es que la Selva de Montiel debe haber tenido alguna relevancia para las sociedades indígenas de Entre Ríos, ya sea como fuente de recursos, como hábitat permanente o sobre todo en sus zonas de mayor extensión este-oeste como limitante a la conexión por tierra entre el río Paraná y el río Uruguay, y a menor escala entre el río Paraná y el río Gualeguay. En este último caso, como limitante pudo consecuentemente haber propiciado, en los márgenes de la provincia, un desarrollo tecnológico integral orientado hacia la explotación sistemática e intensiva del ecosistema fluvial que bordea a Entre Ríos (ríos Paraná y Uruguay). Asimismo, en la Tierras altas posiblemente se hayan desarrollados adaptaciones vinculadas a sus características particulares. 


\section{Los modelos regionales previos}

En 1924 Serrano identifica de manera general al río Uruguay como la zona de la piedra, donde predominan los instrumentos líticos y la alfarería sería escasa; y al río Paraná como la zona del hueso, donde predominan los instrumentos óseos y la alfarería alcanza un gran desarrollo tecnomorfológico y estilístico. Ahora bien, específicamente para las tierras anegadizas del sur de Gualeguaychú, que incluyen al sector $\mathrm{C}$, reconoce una zona donde se combinan una cerámica que es "...rica en formas y ornamentación." como la del río Paraná y un importante desarrollo de la tecnología lítica (Serrano 1924), señalando de esta manera una diferencia entre las cuencas media e inferior del río Uruguay.

Posteriormente Serrano (1932a) será más específico al plantear que el río Uruguay medio es una zona arqueológica distinta al Uruguay inferior y al Delta del Paraná. Para esto se basa en que la cuenca media se caracteriza por la ausencia de "restos de cocina" (restos arqueofaunísticos), por la escasa alfarería y porque los sitios arqueológicos serían mayormente talleres líticos (Serrano 1932a). Entre los dos sectores ubicados sobre el río Uruguay estudiados en esta tesis (B y C) se observan diferencias marcadas que apoyarían la propuesta de Serrano, pero sin duda faltaría profundizar las investigaciones sistemáticas sobre la margen derecha del río. Cabe mencionar además que Serrano (1950), a partir de información documental, plantea que en el siglo XVI el área ubicada desde S31 30' hacia el norte estaba ocupada por los yaros, que podrían corresponder a uno de los "núcleos" o "parcialidades" charrúas (véase también Cabrera 2000; López Mazz y Bracco 2010).

Dentro de los diferentes modelos generales propuestos para la ocupación indígena de la cuenca del río Uruguay en general todos contemplan dos grandes periodos o etapas, donde el más antiguo se caracteriza por ausencia de alfarería (precerámico) y el segundo y más reciente por la presencia de distintas unidades alfareras (véase Capítulo 2). Considerando el área de estudio de esta tesis y en base a las dataciones radiocarbónicas obtenidas se puede plantear que el registro arqueológico estudiado correspondería mayormente al segundo de los periodos.

De acuerdo a los modelos propuestos para el periodo alfarero, específicamente para la cuenca media e inferior del río Uruguay (o también para el NEA en general y que consideran tangencialmente al río Uruguay) por autores como Austral, Baeza, Cabrera, Caggiano, Curbelo, Ceruti, Cigliano, Díaz, González, Guidón, Hilbert, Rodríguez y Serrano (véase Capítulo 2), en general, con algunas variaciones de nomenclatura, cronología y distribución según los autores, éste se caracterizaría por la presencia de tres entidades o manifestaciones arqueológicas o culturales. Estas serían: primero la cultura entrerriana o básica del litoral (facies Salto Grande, Ibicuy y Sarandí); segundo la cultura de los ribereños plásticos, ribereña paranaense o Goya-Malabrigo; y por último la tradición tupiguaraní, tradición guaraní, tradición tupí-guaraní generalizada o guaraní tardío.

La primera de las tres se caracteriza por la adopción de la cerámica, por vasijas de formas simples, lisas o decoradas, pero sin aditamentos biomorfos, y desde el punto de vista cronológico 
abarcaría entre ca. 3000/2500 y 1000/600 años AP. La segunda por la presencia de alfarería modelada con aditamentos biomorfos y una marcada adaptación fluvial, y abarcaría entre $c a$. 1500/1200 años AP y el siglo XVI. La tercera por la cerámica guaraní y tiene su inicio con el arribo de estas poblaciones ca. 1000/700 años AP hasta el siglo XVII.

En cuanto a la cultura básica del litoral o entrerriana es difícil confirmar su presencia en el área de estudio a partir del registro arqueológico abordado en esta tesis, debido a que la misma fue definida por Serrano $(1950,1972)$ en base a materiales que no proceden de excavaciones sistemáticas y a comparaciones cronológicas relativas; y sobre todo basándose casi exclusivamente en los patrones morfológicos y decorativos de la alfarería. Probablemente su definición en parte se deba que este autor necesitaba explicar la existencia de una "cultura" previa a Goya-Malabrigo por varios motivos, pero sobre todo por la corta antigüedad que le asignaba a esta última; también porque su marco teórico no concebía en general los cambios internos o un desarrollo histórico local; y además por considerar la existencia de un período Precerámico, al menos para el río Uruguay medio según los datos de ese momento. Entonces, se habría hecho necesario para su modelo plantear la existencia de un registro arqueológico con una alfarería "simple" y cronológicamente "intermedio" entre el Precerámico y el origen por influencia externa de los ribereños plásticos. Este registro sería el que caracteriza a su período Alfarero Temprano de 1972 , donde se presenta a la cerámica con atributos poco definidos y generales, y con una amplia dispersión geográfica. Actualmente es claro que los atributos cerámicos definidos por Serrano (1972) para la cultura entrerriana como son las formas simples, lisas o decoradas, pero sin apéndices biomorfos y generalmente sin asas, también están presentes dentro de Goya-Malabrigo (sensu Politis y Bonomo 2012). Además, en general los apéndices biomorfos y las campanas procedentes de excavaciones sistemáticas presentan una muy baja frecuencia en relación al conjunto cerámico total, por lo que su ausencia o baja representación en un sitio arqueológico (o en la porción excavada de un sitio arqueológico) no indica en primera instancia que el mismo no corresponda a Goya-Malabrigo y que corresponda a la cultura básica del litoral o a otra cualquiera.

Por su parte, Goya-Malabrigo fue definida sobre todo en base al registro arqueológico del Paraná medio y del Delta del Paraná (Ceruti 2003a; González 1977; Politis y Bonomo 2012). Se caracteriza por una ocupación ribereña, por una tecnología y subsistencia adaptada a la explotación intensiva del ambiente fluvial, por un complejo desarrollo alfarero que no solo elabora recipientes sino que representa un mundo simbólico particular (Ceruti 2003a), por la construcción antropogénica de montículos, por el cultivo de la tríada maíz, poroto y zapallo, por la presencia de jerarquías sociales, por un asentamiento de tipo aldeano con sitios arqueológicos multifuncionales y otros de actividades específicas, y por una novedosa e intensa relación con la arcilla (Politis y Bonomo 2012).

Según el modelo Goya-Malabrigo de Politis y Bonomo (2012) y de Ceruti (2003a) esta entidad arqueológica tiene una distribución geográfica que abarca ambas márgenes del río Paraná desde su 472 
confluencia con el río Paraguay hasta su desembocadura, ambas márgenes el río Uruguay desde la zona de Salto Grande hasta su desembocadura, y también la margen oriental del Río de la Plata hasta el río Santa Lucía (véase Acosta y Lara 1955; Díaz y Fornaro 1977; Politis 2014; Politis y Bonomo 2012). Se desarrolla en un lapso cronológico comprendido entre ca. 2000 y 300 años AP. La presencia de Goya-Malabrigo en el NEA sería el resultado de una interacción a escala macroregional que habría sido generada, mantenida y reforzada mediante el uso intensivo de las grandes cuencas fluviales de las Tierras Bajas sudamericanas, desde hace aproximadamente 2000 años AP (Eriksen 2011; Lathrap 1973; Politis y Bonomo 2012). Esta extensa red dinámica y multidireccional implicaría migraciones, expansiones, desplazamientos, alianzas, intercambio y el aprovechamiento integral del ecosistema fluvial. Dentro de esa dinámica la influencia de grupos arawak pudo haber intervenido en el origen de Goya-Malabrigo en la cuenca del Plata meridional, mediante la influencia sobre las poblaciones locales preexistentes o directamente mediante migraciones de poblaciones de este grupo etnolingüístico (Politis y Bonomo 2012, 2015).

Si bien en el área de dispersión de Goya-Malabrigo siempre se incluyó el trayecto del río Uruguay comprendido entre Salto Grande y su desembocadura, debido a que allí se han recuperado algunos de sus elementos característicos como son las campanas y los apéndices biomorfos, y además se ha verificado la presencia de "cerritos", su estudio no había sido desarrollado en profundidad como sí ocurrió en el río Paraná. En este contexto, son relevantes las dataciones obtenidas para Goya-Malabrigo dentro del área de estudio ya que las mismas sobrepasan ampliamente las fechas propuestas por Serrano (1972) para el surgimiento de los ribereños plásticos (ca. 800 años AP), y además abarcan gran parte del período que correspondería a la cultura básica del litoral (ca. 3000-800 años AP). En este nuevo marco cronológico para la presencia de GoyaMalabrigo en el río Uruguay inferior (ca. 2050-630 años AP) (Tabla 7.25) se encuadrarían perfectamente los fechados de la ROU identificados con los ribereños plásticos, incluyendo el de $1760 \pm 120$ años ${ }^{14} \mathrm{C}$ AP (Beta-1042722) del Túmulo de La Blanqueada, que fuera considerado anómalo en su momento (Farías 2005) (Tabla 2.1b).

En este contexto general, se considera que por el momento los resultados procedentes del estudio sistemático del registro arqueológico son insuficientes para sostener en el río Uruguay la presencia de la cultural básica del litoral o sus homólogas. Por el contrario, hasta el momento las evidencias sistemáticas apuntan a la presencia de Goya-Malabrigo desde la ocupación del área hace ca. 2000 años AP (ya que no se registran dataciones más antiguas), y de los guaraníes desde momentos previos a la llegada de los primeros exploradores portugueses en 1511-1512 DC.

Ahora bien, dejando de lado la cronología propuesta por Serrano $(1950,1972)$ para los ribereños plásticos, este autor luego de definir la dispersión temporal y geográfica acotada aproximadamente al río Paraná medio y el Delta superior, plantea que su presencia fuera de estos límites, o sea en el Delta inferior y la costa uruguaya, se debería a un proceso de expansión que fue 
interrumpido por la llegada de los conquistadores europeos. En esta misma línea, también Díaz y Fornaro (1977) plantean las tres posibilidades para la llegada de Goya-Malabrigo a Salto Grande: 1penetración por el Delta del Paraná y ascenso por el río Uruguay; 2- llegada vía los ríos Guayquiraró y Mocoretá por el norte de Entre Ríos y luego descenso hasta el Río de la Plata; y 3- una combinación de las dos posibilidades anteriores, que pudieron no haber sido sincrónicas. La evidencia actual indica que la más probable es la primera, ya que la segunda y tercera implicarían la presencia de GoyaMalabrigo (no solo su alfarería modelada) al norte de Salto Grande y también en la cuenca del río Mocoretá, en el límite de Entre Ríos con Corrientes (véase Figura 9.1). No se debe descartar esta vía pero faltan investigaciones sistemáticas en esos sectores.

En conjunto se observa que estos autores implícita y explícitamente reconocen una corta antigüedad para Goya-Malabrigo en lo que correspondería al Delta inferior del Paraná, al río Uruguay inferior y al litoral oriental del Río de la Plata. Ahora bien, considerando las dataciones del sector C, se observa que la presencia de Goya-Malabrigo por ejemplo en la localidad arqueológica Cerros de Boari y en el sitio arqueológico Cerro Lorenzo 2 (que presenta una fecha idéntica a Arroyo Aguilar 2 en el norte de Santa Fe -Echegoy 1994-) (Capítulo 7) sería más antigua de lo que se conocía hasta el momento para esta área. Entonces, estas cronologías, por un lado, cuestionan la idea de que la conquista europea interrumpió su expansión hacia el sureste de la cuenca del Plata, y por otro lado, también podrían cuestionar la propuesta de una dispersión progresiva de Goya-Malabrigo desde el río Paraná al Río de la Plata y su ascenso por el río Uruguay. Si bien son necesarias más dataciones rediocarbónicas para este sector, en principio y en base a los nuevos datos aportados por esta tesis sería más adecuado plantear primero que: al momento de la llegada de los conquistadores al Río de la Plata la entidad arqueológica Goya-Malabrigo ya se encontraba sólidamente constituida y ocupando desde el Paraná medio hasta el río Santa Lucía (ROU) y al menos la cuenca inferior del río Uruguay; y segundo que, dado que no hay dataciones más antiguas (ca. 2000 años AP) para GoyaMalabrigo en toda el área que abarca su dispersión conocida (Politis 2014; Politis y Bonomo 2012), la expansión del patrón cultural Goya-Malabrigo debió ser relativamente rápida. Ya sea por ocupación de nuevos espacios disponibles a medida que se conformaba el Delta del Paraná y las riberas bajas del río Uruguay, u operando sobre poblaciones locales previas étnicamente vinculadas o que quedaron vinculadas a partir de la adopción de los rasgos definidos para esta entidad. 


\section{9- CONCLUSIONES}

A partir de los resultados obtenidos y sus interpretaciones, en esta tesis doctoral se arriba a las siguientes conclusiones:

$\checkmark \quad$ En la cuenca media e inferior del río Uruguay en la provincia de Entre Ríos, las poblaciones indígenas prehispánicas ocuparon todos los ambientes disponibles asociados a cuerpos de agua. Habitaron tanto las llanuras altas centrales como los espacios ribereños de tierra firme e islas del río Uruguay; en algunos periodos la ocupación de ambos ambientes se dio de manera sincrónica. La ocupación por largos periodos en las zonas anegables de la cuenca inferior fue posible gracias a una estrategia deliberada de modificación antrópica del paisaje.

$\checkmark \quad$ La cuenca media del río Uruguay y las llanuras interiores fueron ocupadas por cazadores-recolectores y alfareros durante el Holoceno tardío, y probablemente antes también. Por su parte, en la cuenca inferior las ocupaciones humanas se desarrollaron intensamente al menos desde ca. 2000 años AP hasta el siglo XVI, o sea por un periodo aproximado de 1500 años. Durante este lapso temporal este sector fue ocupado al menos por dos grupos humanos claramente diferenciados, las poblaciones locales y los guaraníes que arribaron en tiempos más tardíos. Particularmente los grupos locales están presentes desde ca. 2000 hasta 600 años AP y su cultura material, semejante a la del río Paraná medio e inferior, puede encuadrarse dentro de la entidad arqueológica Goya-Malabrigo.

$\checkmark \quad$ Entre las poblaciones que ocuparon las llanuras centrales y aquellas que ocuparon las costas del río Uruguay, así como entre las que se establecieron a lo largo de ambas márgenes de este río, la circulación de rocas y minerales para la confección de instrumentos líticos fue un fenómeno recurrente. Asimismo, la circulación de estos materiales incluyó zonas alejadas como el Delta superior del río Paraná y el río Salado en Buenos Aires, y seguramente esto involucró la participación de distintas poblaciones intermediarias.

$\checkmark \quad$ Entre los materiales líticos que circulaban la caliza silicificada de la Formación Guichón constituyó una materia prima de excelente calidad para la talla y por ello ocupó un rol destacado en las tecnologías prehispánicas del Nordeste argentino.

$\checkmark \quad$ La arcilla en su estado natural o con agregados intencionales fue utilizada con fines utilitarios, simbólicos y constructivos. Dentro de los agregados se destaca la frecuente inclusión de espículas de esponjas de agua dulce, las cuales eran obtenidas en el río Uruguay y luego circulaban a lo largo de este curso fluvial y sus llanuras adyacentes, y probablemente por fuera de estas zonas también. 
La abundancia de recursos faunísticos explotados muestra, por un lado, que las poblaciones estudiadas usaron variados nichos ecológicos, y por otro lado, que tenían una dieta amplia y genérica, donde el consumo de peces tendría un rol preponderante en la alimentación tradicional. También la diversidad biológica propició el desarrollo de tecnologías específicas para su explotación sistemática y eficiente.

$\checkmark \quad$ La explotación de la fauna no solo implicó su consumo sino también el uso de sus subproductos (valvas, huesos, astas, dientes, etc.) para la elaboración de instrumentos y adornos.

$\checkmark \quad$ El uso de recursos vegetales muestra la utilización de diferentes ambientes, así como también que se usaron plantas procedentes de largas distancias.

$\checkmark \quad$ Particularmente en la cuenca inferior de río Uruguay se desarrolló un complejo sistema instrumental integrado y mutuamente complementario entre el uso de artefactos de hueso, asta, lítico y necesariamente madera, y probablemente valvas de moluscos.

$\checkmark \quad$ En la cuenca inferior del río Uruguay las geoformas elevadas fueron ocupadas y algunas de ellas modificadas intencionalmente mediante el agregado de sedimentos y materiales culturales; con el fin principal de protegerse del aumento del nivel de las aguas y poder establecerse de manera más estable y por largos periodos de tiempo en un ambiente regulado por la dinámica del río Uruguay.

En el río Uruguay inferior los asentamientos residenciales y multifuncionales principales, ubicados en albardones y montículos, estaban integrados en un sistema mayor que incluyó las canteras-taller locales y también las canteras potenciales lejanas de donde proceden algunas de las materias primas líticas. Asimismo, los asentamientos se integrarían con los potenciales lugares de aprovisionamiento de arcillas, los campamentos de pesca y/o caza, y los puntos de recolección de moluscos y productos vegetales.

$\checkmark \quad$ La entidad arqueológica Goya-Malabrigo se manifiesta más claramente en el río Uruguay inferior, siendo a partir del río Uruguay medio su señal arqueológica cada vez más débil; esto podría estar marcando un límite social reflejo de cierta distancia étnica entre ambas zonas.

La organización constructiva y mantenimiento estructural de los montículos antropogénicos, y la organización, coordinación y mantenimiento de las redes macroregionales de interacción e intercambio entre asentamientos estables, requirieron probablemente de la presencia de líderes, tal como se menciona en las 
crónicas del siglo XVI. Esta diferenciación jerárquica no implica necesariamente desigualdad social institucionalizada.

$\checkmark \quad$ Las sociedades indígenas que ocuparon ambas márgenes del río Uruguay inferior desarrollaron adaptaciones fluviales eficientes que posibilitaron la explotación sistemática de sus recursos y el asentamiento estable mediante la modificación del paisaje. Estas ocupaciones, caracterizadas por un conjunto de rasgos de la cultura material compartidos con el río Paraná medio e inferior, reflejan además una persistente estabilidad ocupacional del área que probablemente se extendió desde hace ca. 2000 años atrás hasta el arribo de los guaraníes, aproximadamente 400 años antes de la llegada de los primeros conquistadores europeos.

En síntesis, si bien hay algunos indicadores de que probablemente el área de estudio haya sido ocupada durante el Pleistoceno final-Holoceno temprano, la ocupación humana se registra de manera más intensiva a partir del Holoceno tardío. Durante este período se registró la presencia de grupos cazadores-recolectores y alfareros vinculados a los ambientes fluviales de la cuenca media del río Uruguay. Paralelamente en los ambientes fluviales de la cuenca inferior se reconocieron dos conjuntos arqueológicos que corresponden a dos poblaciones indígenas diferentes, ambas con una marcada adaptación a ambientes acuáticos y con un desarrollo tecnológico orientado a la explotación intensiva y sistemática del ecosistema fluvial determinado por el río Uruguay. La primera representada por grupos canoeros ribereños cazadores-recolectores-pescadores (y probablemente horticultores) y alfareros, constructores de montículos y con una alta estabilidad residencial. Su cultura material puede ser identificada con la entidad arqueológica Goya-Malabrigo. La segunda representada por grupos guaraníes, canoeros ribereños cazadores-recolectores-pescadores, agricultores y alfareros, que arribaron a la región en momentos previos a la conquista europea y ocuparon de manera estable algunas zonas del río Uruguay desplazando a sus ocupantes previos. Cada uno de estos grupos habría estado integrado en un sistema macroregional de interacción e integración que incluía la circulación de bienes, recursos, personas e ideas utilizando preponderantemente como vías de conexión los cursos fluviales de la cuenca meridional del Plata. 


\section{BIBLOGRAFÍA}

\section{A}

Aceñolaza, F. G.

- 2007. Geología y Recursos Geológicos de la Mesopotamia Argentina. INSUGEO Serie de Correlación Geológica 22. 159p. CONICET. UNT. Tucumán.

Aceñolaza, P., Manzano, A.; Rodríguez, E.; Sánchez, L.; Ronche, A. L.; Giménez, E.; Demonte, D. y Z. Marchetti

- 2008. Diversidad de la región superior del Complejo Deltaico del Río Paraná. En F. G. Aceñolaza (ed.), Temas de la Biodiversidad del Litoral III, Miscelánea INSUGEO 17: 1-25. Tucumán.

Acosta, A.

- 2005. Zooarqueología de cazadores-recolectores del extremo nororiental de la provincia de Buenos Aires (humedal del río Paraná inferior, Región Pampeana, Argentina). Tesis doctoral inédita, Facultad de Ciencias Naturales y Museo, Universidad Nacional de La Plata, La Plata.

Acosta, A.; Buc, N. y D. Pau

- 2011a. Huellas de aserrado perimetral sobre restos óseos humanos. El caso del sitio Cerro Lutz, provincia de Entre Ríos. Comechingonia. Revista de Arqueología 15: 155-169.

Acosta, A.; Buc, N. y M. N. Davrieux

- 2015a. Producción y uso de ornamentos en las tierras bajas de Sudamérica: el caso de las poblaciones humanas prehispánicas del extremo meridional de la cuenca del Plata (Argentina). Munibe Antropologia-Arkeologia 66: 309-325.

Acosta, A.; Buc, N.; Ramírez, M.; Prevosti, F. y D. Loponte

- 2015b. Producción y uso de objetos ornamentales elaborados sobre dientes de carnívoros en contextos arqueológicos del Humedal del Paraná Inferior. Revista del Museo de Antropología $8(2): 33-46$.

Acosta, A.; Loponte, D. y C. García Esponda.

- 2011b. Primer registro de perro doméstico prehispánico (Canis familiaris) entre los grupos cazadores recolectores del humedal de Paraná inferior (Argentina). Antípoda Revista de Antropología y Arqueología 13: 175-199.

Acosta, A.; Loponte D. y P. Tchilingurian

- 2010. Análisis comparativo sobre la estructura y los procesos de formación de los depósitos arqueológicos en el humedal del rio Paraná inferior (delta del Paraná). En Cocco, G.; Feuillet Terzaghi M. R. y L. Campagnolo. Arqueología de Cazadores-recolectores en la Cuenca del Plata". pp. 191-208. Santa Fe.

Acosta, A.; Mucciolo, L.; Musali, J. y M. P. Arrizurieta

- 2011c. Avances y problemas relacionados con el estudio del registro arqueofaunístico generado por los grupos cazadores-recolectores del extremo sur de la provincia de Entre Ríos (Humedal del río Paraná inferior). En Feuillet Terzaghi M. R.; Colasurdo M. B.; Sartori J. I. y S. Escudero. Avances y perspectivas en la Arqueología del Nordeste. pp. 43-58. Santo Tomé.

Acosta, A. y J. Musali

- 2002. Ictioarqueología del Sitio La Bellaca 2 (Pdo. de Tigre, Pcia. de Buenos Aires). Informe preliminar. Intersecciones en Antropología 3: 3-16. 
Acosta, A. y J. Sartori

- 2011. Explotación de Myocastor coypus en el extremo meridional de la cuenca del Plata durante el Holoceno tardío. Revista de Arqueologia, São Paulo: Sociedade de Arqueologia Brasileira 24(2): 10-29.

\section{Acosta y Lara E. F.}

- 1955. Los Chaná-timbúes en la antigua Banda Oriental. Museo de Historia Natural de Montevideo 6(5): 1-27 y 12 láminas.

- 1961. La guerra de los charrúas en la Banda Oriental. Período Hispánico - Período Patrio. Ediciones Cruz del Sur.

- $\quad$ 1978. Los guaraníes en el antiguo territorio de la República Oriental del Uruguay. Revista de la Sociedad Amigos de la Arqueología 17: 87-105.

\section{Administración de Parques Nacionales. Parque Nacional El Palmar}

- 1998. Ficha de registro del patrimonio cultural-arqueológico en áreas protegidas. 11 de octubre de 1998, M. Entrocassi y P. Giorgis. APN. MS.

- 2002. Inventario de materiales de Recursos Culturales al 1/08/2002. APN. MS.

- 2008. Informe sobre material de potencial valor arqueológico hallado en el PNEP. 19 de marzo de 2008, R. Daichman. Informe Interno. APN. MS.

\section{Albero, M, y F. Angiolini}

- $\quad$ 1985. Ingeis radiocarbon laboratory dates II. Radiocarbon 27(2): 314-337.

\section{Almeida M. S.}

- $\quad$ 1971. Exploraciones arqueológicas en el sur de Entre Ríos. Ms.

- $\quad$ 1983a. De Soriano y su historia. Revista Histórica de Soriano 25: 85-87.

- 1983b. El arte prehistórico. Bicentenario de Gualeguaychú. Homenaje de diario El Día al cumplir 200 años de su fundación. 1783 - 18 de octubre - 1983.

- $\quad$ 1996a. Cuadernos de Gualeguaychú № 93. Publicación del diario El Argentino, día 4 de agosto de 1996.

- $\quad$ 1996b. Cuadernos de Gualeguaychú № 94. Publicación del diario El Argentino, día 18 de agosto de 1996.

- 1996c. Cuadernos de Gualeguaychú № 101. Publicación del diario El Argentino, día 1 de diciembre de 1996.

- $\quad$ 1997. Cuadernos de Gualeguaychú № 103. Publicación del diario El Argentino, día 5 de enero de 1997.

- $\quad$ 1998. Cuadernos de Gualeguaychú № 131. Publicación del diario El Argentino, día 1 de marzo de 1998.

- $\quad$ Sin fecha a. Catálogo de Sitios arqueológicos. Museo Arqueológico Manuel Almeida. Ms.

- $\quad$ Sin fecha b. Pesquería Vieja-Ensenada del Bellaco. Ms.

- $\quad$ Sin fecha c. Catálogo de Yacimientos. Museo Arqueológico Manuel Almeida. Ms.

\section{Álvarez, M. R. y M. E. Mansur}

- 2004. El problema de ciertas variables morfológicas como criterio clasificatorio en la definición de instrumentos: perspectiva desde el análisis funcional de base microscópica. Taller Morfología Macroscópica en la Clasificación de Artefactos Líticos: Innovaciones y Perspectivas. http:// www.naya.org.ar/eventos/liticosresumenes.htm (Acceso: 1 de marzo de 2010).

Amaya, L. E.

- 1984. Actividades tradicionales de los cazadores correntinos. En Rolandi de Perrot, D. Cultura tradicional del área del Paraná Medio. Buenos Aires: Fundación F. G. Bracht, pp. 49-74. 


\section{Ambrosetti, J. B.}

- 1893. Sobre una colección de alfarerías Minuanes recogidas en la provincia de Entre Ríos. Boletín del Instituto Geográfico Argentino XIV: 242-257.

- $\quad$ 1894a. Segundo viaje a Misiones por el Alto Paraná e Iguazú. Boletín del Instituto Geográfico Argentino XV: 18-115/245-304.

- $\quad$ 1894b. Los paraderos precolombianos de Goya (Provincia de Corrientes). Boletín del Instituto Geográfico Argentino XV: 401-422.

- $\quad$ 1895a. Tercer viaje Misiones. Boletín del Instituto Geográfico Argentino XVI: 391-523.

- 1895b. Los cementerios prehistóricos del Alto Paraná (Misiones). Boletín del Instituto Geográfico Argentino XVI: 227-263.

\section{Ameghino, F.}

- $\quad$ 1880. La Antigüedad del Hombre en el Plata. Vol. 1, 640 p., Buenos Aires.

\section{Andrefsky, $\mathbf{W}$.}

- $\quad$ 1994. Raw-material availability and the organization of technology. American Antiquity 59: 2134.

- $\quad$ 1998. Lithics. Macroscopic Approaches to Analysis. Cambridge University Press, Cambridge.

\section{Andrews, $P$.}

- $\quad$ 1990. Owls Caves and fossils. Natural History Museum Publications, London.

\section{Anschuetz, K. F.; Wilshusen R. H. y C. L. Scheick}

- 2001. An Archaeology of Landscapes: Perspectives and Directions. Journal of Archaeological Research, 9 (2): 157-211.

\section{Aparicio, F. de}

- $\quad$ 1922. Nuevos hallazgos de representaciones plásticas en el norte de la provincia de Santa Fe. Revista de la Universidad de Buenos Aires 49: 5-30.

- $\quad$ 1923. Un nuevo tipo de representaciones plásticas procedentes de los paraderos indígenas del litoral paranaense. Revista de la Universidad de Buenos Aires 51: 94-106.

- $\quad$ 1925. Un nuevo documento relativo a la colocación de las asas zoomorfas en la cerámica del litoral paranense. Physis 8: 244-249.

- 1928. Notas para el estudio de la arqueología del Sur de Entre Ríos. Anales de la Facultad de Ciencias de la Educación 3: 1-63. Universidad Nacional del Litoral, Paraná.

- $\quad$ 1929. Noticias sobre el hallazgo de cuentas de vidrio en un paradero indígena, caracterizado por la presencia de representaciones plásticas. Physis 9: 456-457.

- $\quad$ 1931. Un resto de industria amazónica en el Paraná inferior. Solar I: 65-73.

- $\quad$ 1936. El Paraná y sus tributarios. En Historia de la Nación Argentina I: 473-506.

- $\quad$ 1937. Excavaciones en los paraderos del Arroyo de Leyes. Relaciones de la Sociedad Argentina de Antropología 1: 7-19, Buenos Aires.

- 1939 El Paraná y sus tributarios. En Historia de la Nación Argentina, Vol. I, editado por Ricardo Levene, pp. 419-442. El Ateneo, Buenos Aires.

Apolinaire, E.

- 2017. Arqueología del suroeste de Entre Ríos: tecnología, subsistencia e interacción social en tiempos prehispánicos. Tesis Doctoral inédita. Facultad de Ciencias Naturales y Museo, Universidad Nacional de La Plata, La Plata.

\section{Apolinaire, E. y L. Bastourre}

- 2016. Nets and canoes: A network approach to the pre-Hispanic settlement system in the Upper Delta of the Paraná River (Argentina). Journal of Anthropological Archaeology 44: 5668. 
- 2016. Arqueología de las tierras altas de Entre Ríos: primeros resultados de las prospecciones en el interior del departamento Gualeguay. Intersecciones en Antropología 17 (1), 91-107.

Arnold, J.

- 1996. The Archaeology of Complex Hunter-Ghaterers. Journal of Archaeological Method and Theory 3(2): 77-126.

Arratia G.

- 1997. Brazilian and Austral freswater fish faunas of South America. A contrast: In: Tropical Biodiversity and Sistematics. Proc. Internat. Symp. Biodiversity and Sistematics in Tropical Ecosystem. pp. 179-187. Bonn, Germany.

\section{Arredondo, $\mathrm{H}$.}

- 1927. Informe preliminar sobre la arqueología de la boca del río negro. Revista de la Sociedad Amigos de la Arqueología 1: 7-45.

Arrizurieta, M. P.; L. Mucciolo y J. Musali

- 2010 Análisis Arqueofaunístico Preliminar del sitio Cerro Lutz. En M. Berón, L. Luna, M. Bonomo, C. Montalvo, C. Aranda y M. Carrera Aizpitarte (eds.), Mamül Mapu: pasado y presente desde la arqueología pampeana I, pp. 261-276. Editorial Libros del Espinillo. Ayacucho, Buenos Aires.

\section{Aschero, $\mathrm{C}$.}

- 1975. Ensayo para una clasificación morfológica de artefactos líticos aplicada a estudios tipológicos comparativos. Informe al CONICET. MS.

- 1983. Ensayo para una clasificación morfológica de artefactos líticos aplicada a estudios tipológicos comparativos. Apéndice A y B. Ergología y Tecnología. UBA. MS.

\section{Aschero, C. y S. Hocsman}

- 2004. Revisando cuestiones tipológicas en torno a la clasificación de artefactos bifaciales. En Temas de Arqueología, Análisis Lítico, editado por A. Acosta, D. Loponte y M. Ramos, pp. 7-25. Universidad Nacional de Luján, Luján.

\section{Austral, A.}

- 1977. Arqueología de urgencia en el yacimiento de Bañadero, Departamento de Salto, Uruguay. V Encuentro de Arqueología del Litoral: 11-22. Fray Bentos, Uruguay.

- 1994. Arqueología en el Sudoeste de Buenos Aires. Resúmenes del XI Congreso Nacional de Arqueología Argentina, pp. 201-203. San Rafael, Mendoza.

- 1995. Los cazadores del sitio estratificado Pay Paso hace 10.000 años. En Arqueología en el Uruguay, editado por M. Consens, J.M. López y C. Curbelo, pp. 212-218. AUA, Montevideo.

Ávila, J. D.

- 2011. Resultados de los fechados radiocarbónicos del sitio Laguna El Doce, Departamento General López, Provincia de Santa Fe. Relaciones de la Sociedad Argentina de Antropología 36: 337-343.

Ávila, J. D.; Ayuso M. P. y M. C. Barboza

- 2003. Investigaciones arqueológicas en el sudoeste santafesino. Una aproximación al estudio de los recursos líticos en la Laguna Las Marías (Villa Cañas, Departamento General López, Provincia de Santa Fe). Revista de la Escuela de Antropología 8: 223-230.

Ávila, J. D. y C. N. Ceruti

- 2013. El Holoceno temprano-medio y la ruta del poblamiento: Laguna El Doce, Departamento General López, provincia de Santa Fe, Argentina. Cuadernos del Instituto Nacional de Antropología y Pensamiento Latinoamericano - Series Especiales 4: 21-33. 
Babot, M. P.

- 2004. Tecnología y utilización de artefactos de molienda en el Noroeste Prehispánico. Tesis Doctoral inédita, Universidad Nacional de Tucumán.

Badano, V. M.

- 1940a. Piezas enteras de alfarería del litoral existentes en el Museo de Entre Ríos. Memorias del Museo de Entre Ríos 14. 23 p. Paraná.

- 1940b. Urnas funerarias de los Tupí-Guaraní (opúsculo).

- 1944. Representación plástica de la serpiente en el área de los ribereños paranaenses. Relaciones de la Sociedad Argentina de Antropología IV: 163-168.

- 1946. Sobre algunos ejemplares interesantes de representaciones plásticas. Revista de la Academia de Entre Ríos I: 11-28. Academia Nacional de Historia, Paraná.

- 1955. Caracteres del arte plástico indígena del Paraná inferior. Anais do XXXI Congreso Internacional de Americanistas II:777-800. Sao Paulo.

- 1957. El arte plástico de los ribereños paranaenses. Memorias del Museo de Entre Ríos 34 (Arqueología). 178 p. Paraná.

Báez, J. R.

- 1937. Área de dispersión de las palmáceas en la flora de Entre Ríos. Anales de la Sociedad Argentina de Estudios Geográficos V: 63-78.

- 1942a. Las palmeras en la flora de Entre Ríos. Ministerio de Agricultura de la Nación. Comisión Coordinadora de Servicios - Paraná. 20 p.

- $\quad$ 1942b. Regiones forestales de Entre Ríos. Ministerio de Agricultura de la Nación. Comisión Pro Exposición forestal de Buenos Aires. Paraná.

Baeza, J.

- 1985. Los fechados radiocarbónicos de Salto Grande. Centro de Estudios Arqueológicos (Montevideo, Uruguay). Estado actual de las investigaciones arqueológicas en Uruguay (Parte 1) 3: 20-24.

- 2013. A propósito de algunas posibles relaciones con el NOA. Cuadernos del Instituto Nacional de Antropología y Pensamiento Latinoamericano - Series Especiales № 1 Vol. 4: 75-80.

Baeza, J.; Femenías, J.; Suárez, R. y A. Florines

- 2001. Investigación Arqueológica en el Río Negro Medio. En Arqueología Uruguaya Hacia el Fin del Milenio I: 285-295. Gráficos del Sur. Montevideo.

Baeza, J.; Taddei, A.; Femenías, J.; Rodríguez, O.; Melgar, W.; Díaz, A. y M. Fornaro

- 1977. Investigaciones Arqueológicas en el Área de Salto Grande: Tres Primeros Radiocarbonos. Encuentro de Arqueología del Litoral: 67-88. Fray Bentos, Uruguay.

Balée, W.

- $\quad$ 1989. The culture of Amazonian forests. Advances in Economic Botany 7: 1-21.

- 1994. Footprints of the Forest: Ka'apor Ethnobotany - The Historical Ecology of Plant Utilization by an Amazonian People. New York: Columbia University Press.

- 1995. Historical Ecology of Amazonia. In L. Sponsel (ed.), Indigenous peoples and the future of Amazonia: an ecological anthropology of an endangered world. pp 97-110. The University of Arizona Press, Tucson, Arizona.

- $\quad$ 1998. Advances in Historical Ecology. New York, Columbia University Press. 448 p.

- 2006. The Research Program of Historical Ecology. Annual Review of Anthropology 35: 75-98.

- 2008. Sobre a Indigeneidade das Paisagens. Revista de Arqueologia 21(2): 9-23. 


\section{Balée, W. y C. Erickson}

- 2006. Time and Complexity in Historical Ecology-Studies in the Neotropical Lowlands. New York, Columbia University Press. 432 p.

Balfet, H.; Fauvet-Berthelot, M-F. y S. Monzon

- 1992. Normas para la descripción de vasijas cerámicas. México DF: Centro de Estudios Mexicanos y Centroamericanos.

Bamforth, D. B.

- $\quad$ 1986. Technological Efficiency and Tool Curation. American Antiquity 51 (1): 38-50.

Bamforth, D. B. y P. Bleed

- 1997. Technology Flaked Stone Technology and Risk. En C. Barton y B. Clark (eds.), Rediscovering Darwin: Evolutionary Theory in Archaeological Explanation. pp. 109-139. Archaeological papers of the American Anthropological Association.

Barboza, M. C.

- 2014. Análisis arqueofaunístico del sitio Paso del Tala (Goya, Corrientes, Argentina). Revista del Museo de Antropología 7 (2): 219-226.

Barboza, M. C.; Gallego, M.; Moreira, R.; Martínez, S.; Píccoli, C. V.; Gavilán, M.; Gabrielloni, C.; Cornaglia Fernández, J.; Alonso, A.; Ávila, J. D. y M. P. Ayuso

- 2007. Investigaciones arqueológicas en la llanura aluvial del Paraná medio (Departamento Goya, Provincia de Corrientes, Argentina). Resúmenes del Segundo Encuentro de Discusión Arqueológica del Nordeste Argentino. p.14. Paraná.

Barboza, M. C.; Píccoli, C. V.; Gavilán, M.; Moreira, R.; Freiberg C.; Fabron, G.; Macanuso, A.; Alonso, A.; Ávila, J. D.; De Biassi, M.; Leyria, M.; Gabrielloni, C. y M. Gallego

- 2009. Primeros resultados de las investigaciones arqueológicas realizadas en la llanura aluvial del Paraná medio (Dpto. Goya, Pcia. de Corrientes). II Jornadas de Ciencia y Técnica: 1-6. Universidad Nacional de Rosario, Rosario.

\section{Barone, R.}

- $\quad$ 1990. Anatomía comparada de los mamíferos domésticos. Editorial Hemisferio Sur, Buenos Aires.

Baumel, J. J.; King, A. S.; Breazile J. E.; Evans, H.E. y J.C. Vanden Berge

- 1993. Handbook of Avian Anatomy: Nómina Anatómica Avium. Nuttall Ornithological Club, Cambridge Massachusetts.

Bayón, C. y N. Flegenheimer

- 2004. Cambio de planes a través del tiempo para el traslado de roca en la pampa bonaerense. Estudios Atacameños 28: 59-70.

\section{Behrensmeyer, A. K.}

- $\quad$ 1978. Taphonomic and ecologic information from bone weathering. Paleobiology 4: 150-162.

Beltramino, A. A.

- 2016. Estudios morfo-anatómicos y moleculares de Megalobulimus spp. (Gastropoda Pulmonata) en la Argentina, principalmente de la provincia de Misiones. Tesis doctoral inédita, Facultad de Ciencias Naturales y Museo, Universidad Nacional de La Plata, La Plata.

Bellelli, C.; Guraieb A. y J. Garcia

- 1985-1987. Propuesta para el análisis y procesamiento por computadora de desechos de talla lítica (DELCO - Desechos líticos computarizados). Arqueología Contemporánea 2 (1): 36-53.

Bello, A. M. y R. Bracco Boksar

- 2007. Memorias ancestrales. Arte y arqueología en Uruguay. Museo de Arte Precolombino e Indígena, Montevideo, Uruguay. 
Bernal, V.

- 2008. Procesos de diferenciación biológica entre poblaciones humanas del Holoceno tardío de Patagonia. Una aproximación desde la variación métrica dental. Tesis doctoral inédita, Facultad de Ciencias Naturales y Museo, Universidad Nacional de La Plata, La Plata.

Berón, M. y R. Curtoni.

- 2002. Propuestas metodológicas para la caracterización arqueológica de canteras y talleres en la meseta del Fresco (La Pampa, Argentina). En: Mazzanti, D., M. Berón y F. Oliva (eds.); Del Mar a los Salitrales. Diez mil años de Historia Pampeana en el Umbral del Tercer Milenio: 171184. Mar del Plata, Universidad Mar del Plata.

Bertolini, J. C.

- 2001. Materiales pelíticos para uso cerámico artesanales la provincia de Entre Ríos. VII Congreso Argentino de Geología Económica, Actas 2: 117-122. Salta.

Bertoni, B.; Figueiro, G.; Cabana, G; Mc Donough, J. E.; Bluteau, C.; Merriwether, A. y M. Sans.

- 2004. Primeras secuencias de ADN Mitocondrial de indígenas prehistóricos del Uruguay. En L. Beovide; I. Barreto y C. Curbelo (eds.), La Arqueología Uruguaya ante los desafíos del Nuevo Siglo. CD-ROM, Montevideo, Uruguay.

Bettinger, R.

- 1991. Hunter-gatherers. Archaeological and evolutionary theory. Plenum Press, Nueva York. Traducción Luis A. Orquera. Ms.

Binford, L. R.

- 1962. Archaeology and anthropology. American Antiquity 28 (2): 217-225.

- 1979. Organization and formation processes: looking at curated technologies. Journal of Anthropological Research 35(3): 255-273.

- 1980. Willow smoke and dogs tails: hunter-gatherer settlements sistems and archaeological site formation. American Antiquity 45 (1): 4-20.

- $\quad$ 1981. Bones: Ancient Men and Modern Myths. Academic. Press. New York.

- 1984. Faunal Remains fron Klasies River Mouth. Orlando. Academis Press.

Bird, J.

- 1969. A comparison of south Chilean and Ecuatorial "fishtail" projec-tile points. Kroeber Anthropological Society Papers 40: 52-71.

Bisbal, G. y S. Gómez

- 1986. Morfología comparada de la espina pectoral de algunos Siluriformes Bonaerenses (Argentina). Physis. Secc. B. 44 (107): 81-93. Buenos Aires.

Blasi, A.

- 1988. Argilominerales en depósitos aluviales del Río Colorado. Revista del Museo de La Plata, Sección Geología 10: 113-125.

Boletín del Instituto Geográfico Argentino XV. 1894. Misión O. Durand Savoyat. p. 183.

Boman, E.

- 1920. Cementerio indígena en Viluco (Mendoza), posterior a la Conquista. Anales del Museo Nacional de Historia Natural de Buenos Aires XXX.

\section{Bonetto A. A. e I. D. Ezcurra de Drago}

- $\quad$ 1967. Esponjas del Noreste argentino. Acta zoológica Lilloana 23: 331-348 42.

- $\quad$ 1968. El género Drulia Gray en el río Uruguay (Porifera, Spongillidae). Physis 28(76): 211-216.

- 1969. El Notas sistemáticas sobre el género Uruguaya Carter (Porifera, Spongillidae). Physis 28(77): 351-357. 


\section{Bonino de Langguth, V.}

- 1977. Enderezadores de flechas del litoral del río Uruguay. V Encuentro de Arqueología del Litoral: 112-116. Fray Bentos, Uruguay.

\section{Bonomo, $\mathrm{M}$.}

- 2004. Ocupaciones humanas en el litoral marítimo pampeano: un enfoque arqueológico. Tesis Doctoral inédita. Facultad de Ciencias Naturales y Museo, Universidad Nacional de La Plata, La Plata.

- 2005. Proyecto Investigaciones arqueológicas en el Delta Medio e Inferior del río Paraná". Libro de Resúmenes del Primer Encuentro de discusión arqueológica del Noreste argentino. Arqueología de cazadores recolectores en la Cuenca del Plata: 20-21. Santa Fe.

- 2012. Historia prehispánica de Entre Ríos. Fundación de Historia Natural Félix de Azara. Buenos Aires.

- 2013. Reanálisis de la colección de Samuel Lothrop procedente del delta del Paraná. Relaciones de la Sociedad Argentina de Antropología XXXVIII (1): 169-198.

\section{Bonomo, M.; Aceituno, F.; Politis, G. y M. Pochettino}

- 2011a. Pre-Hispanic horticulture in the Paraná Delta (Argentina): archaeological and historical evidence. World Archaeology 43(4): 557-579.

\section{Bonomo, M.; Bagaloni, V.; Di Prado, V. y E. Apolinaire}

- 2008. Evaluación de impacto arqueológico: proyecto "Cerros Indios" (Gualeguaychú, provincia de Entre Ríos). Museo Antonio Serrano.

\section{Bonomo, M. y A. Blasi}

- 2011. Base regional de recursos líticos del Delta del Paraná. Estudio petrográfico de artefactos y afloramientos en el sur de Entre Ríos. Revista Cazadores Recolectores del Cono Sur 4: 17-41.

\section{Bonomo, M., Cabanillas, E. D. y R. Montero}

- 2017. Archaeometallurgy in the Paraná Delta (Argentina): Composition, manufacture, and indigenous routes. Journal of Anthropological Archaeology 47 (2017) 1-11.

\section{Bonomo, M. e I. Capdepont}

- 2010. Alfarería pintada del Delta del río Paraná: colecciones del Museo de La Plata, En Os ceramistas Tupiguarani, Volume 2. Editado por André Prous e Tania Andrade Lima, 15 pp. CDROM. IPHAN, Universidade Federal de Minas Gerais, Belo Horizonte. ISBN 978-85-7334-147-8.

\section{Bonomo, M.; Capdepont, I. y A. Matarrese}

- 2009. Alcances en el estudio de colecciones. Los materiales arqueológicos del Delta del río Paraná depositados en el Museo de La Plata (Argentina). Revista de Arqueología Sudamericana 5: 68-101.

\section{Bonomo, M. y L. E. Capeletti}

- 2014. Uso prehispánico de las palmeras Syagrus romanzoffiana y Butia yatay en el Nordeste argentino: aportes desde la etnografía y la biometría. Revista del Museo de Antropología 7 (2): 227-234.

Bonomo, M.; Castro J. C. y C. B. Silva

- 2014a. Tecnología y subsistencia en el sitio arqueológico Cerro Tapera Vázquez (Parque Nacional Pre-Delta, República Argentina). Cadernos do LEPAARQ Vol. XI, n²2: 63-92.

\section{Bonomo, M.; Colobig, M.M.; Passeggi, E.; Zucol, A.F. y M. Brea}

- 2011b. Multidisciplinary studies at Cerro Tapera Vázquez site, Pre-Delta National Park, Argentina: the archaeological, sedimentological and paleobotanical evidence. Quaternary International 245(1): 48-61. 
Bonomo, M.; Costa Angrizani, R.; Apolinaire E. y F. Noelli

- 2015. A Model for the Guaraní Expansion in the La Plata Basin and in the Littoral of Southern Brazil. Quaternary International 356: 54-73.

Bonomo, M. y M. Farro

- 2014. El contexto sociohistórico De las investigaciones de Samuel K. Lothrop en el Delta del Paraná, Argentina. Chungara, Revista de Antropología Chilena V. 46, № 1: 131-143.

Bonomo, M.; Politis G. y J. C. Castro

- 2010. Primeros resultados de las investigaciones arqueológicas en el Delta Superior del Paraná y su contribución al atlas arqueológico de la provincia de Entre Ríos. Folia Histórica del Nordeste 18: 33-58.

- $\quad$ 2014b. Los Indígenas de Entre Ríos. En Manual de Historia de Entre Ríos, Paraná, Entre Ríos. pp: $41-75$

Bonomo, M.; Politis, G. y C. Gianotti

- 2011c. Montículos, Jerarquía social y horticultura en las sociedades indígenas del Delta del Río Paraná (Argentina). Latin American Antiquity 22(3): 97-333.

Bonomo, M.; Politis, G.; Silva, C.; Bastourre, L.; Ramos van Raap, M. A.; Castiñeira Latorre, C.; Scabuzzo, C. y E. Apolinaire.

- 2016. Estado actual de las investigaciones en la localidad arqueológica Laguna de los Gansos (Diamante, Entre Ríos). Revista del Museo de Antropología 9 (2): 51-66.

Bonomo, M. y L. Prates

- 2009. La explotación de depósitos secundarios de rodados en el curso medio del río Negro y el litoral marítimo pampeano. En: Artefactos líticos, movilidad y funcionalidad de sitios en Sudamérica. Problemas y perspectivas, editado por P. Escola y S. Hocsman. BAR International Series, Oxford.

Boretto, R.; Bernal, R., Schmitz, P. I. e I. Basile Becker

- 1975. Arqueología en el departamento de Río Negro, Uruguay. Esquema tentativo de una secuencia cronológica para Sitios del Río Uruguay y Río Negro. Resultados parciales a Diciembre de 1973 - Presentación de la Fase Vizcaíno. Il Congreso Nacional de Arqueología y III Encuentro de Arqueología del Litoral, Volumen II: 215-251. Río Negro, Uruguay.

- $\quad$ 1980. Un nuevo sitio Tupiguaraní en el Bajo Uruguay. III Congreso Nacional de Arqueología y IV Encuentro de Arqueología del Litoral. Montevideo, Uruguay.

Borrero, L. A.; J. L. Lanata y B. N. Ventura

- 1992. Distribuciones de hallazgos aislados en Piedra del Águila. En Análisis espacial en la Arqueología Patagónica, editado por L. A. Borrero y J. L. Lanata, pp. 9-20. Ayllu, Buenos Aires.

Borteriro, C.; Prigioni, C.; García, J. E.; Tedros, M. Gutiérrez, F. y F. Kolenc

- 2006. Geographic distribution and conservation status of Caiman latirostris (Crocodylia, Alligatoridae) in Uruguay. Phyllomedusa 5(2): 97-108.

Bossi, J.

- $\quad$ 1966. Geología del Uruguay. Universidad de la República, Departamento de Publicaciones, 1469, 71 figs., 16 mapas. Montevideo.

Bourdieu, P.

- $\quad$ 1987. Legitimation and structured interest in Weber's sociology of religion. En S. Whimster y S. Lash (eds.), Max Weber, Rationality and modernity. pp. 119-136. Londres.

- $\quad$ 1991. El sentido práctico. Madrid, Taurus Humanidades.

\section{Bourlot, T.}

- 2008. Guerreros, máscaras y narices decoradas. Culturas nativas del litoral entrerriano y la colección arqueológica Manuel Almeida. 63 p. Museo Manuel Almeida, Gualeguaychú. 


\section{Bracco, D.}

- 2013. Con las armas en la mano: charrúas, genoa-minuanos y guaraníes. Editorial Planeta.

\section{Bracco, $\mathbf{R}$.}

- 2006. Montículos de la Cuenca de la Laguna Merín: Tiempo, Espacio y Sociedad. Latin American Antiquity 17 (4): 511-540.

- 2009. Diagnóstico Arqueológico de Punta Gorda. Informe CPHCN, Montevideo.

\section{Bracco, R.; Cabrera, L. y J. M. López Mazz}

- 2000b. La Prehistoria de las Tierras Bajas de la Cuenca de la Laguna Merín. Arqueología de las Tierras Bajas, Ministerio de Educación y Cultura: 13-38, Montevideo.

Bracco, R., Montaña, J.; Nadal, O. y F. Gancio.

- 2000a. Técnicas de construcción y estructuras monticulares, termiteros y cerritos: de lo analógico a lo estructural. En Duran, A. y Bracco, R. (eds.) Arqueología de las Tierras Bajas, Ministerio de Educación y Cultura: 285-300, Montevideo.

Bracco, R. y C. Ures P.

- 2001. Ritmos y dinámica constructiva de las estructuras monticulares del sector sur de la cuenca de la laguna Merin-Uruguay. Arqueología Uruguaya hacia el fin del Milenio. Tomo I: 41-53. Montevideo, Uruguay.

\section{Bradley R.}

- 1993. Altering the Earth: Origins of Monuments in Britain and Continental Europe. Society of Antiquaries of Scotland.

- 2002. An Archaeology of Natural Places. Routledge, New York, London.

\section{Bravard, A.}

- 1858. Monografía de los terrenos marinos terciarios de las cercanías del Paraná. Imprenta del Registro Oficial. 107 p. Paraná. (reimpreso por la Imprenta del Congreso de la Nación, 1995). Buenos Aires.

Brea, M., M. J. Franco, M. Bonomo y G. Politis

- 2013. Análisis antracológico preliminar del sitio arqueológico Los Tres Cerros 1 (Delta Superior del río Paraná). Revista del Museo de La Plata 13(87): 345-360.

\section{Brochado, J. P.}

- 1984. An ecological model of the spread of pottery and agriculture into Eastern South America. Tesis Doctoral inédita. University of Illinois at Urbana-Champaign, Urbana. EEUU.

\section{Brochado, J. P. y G. Monticelli}

- 1994. Regras práticas na reconstrução gráfica das vasilhas de cerâmica guarani a partir dos fragmentos. Estudos Ibero-americanos XX(2): 107-118.

\section{Brochado, J. P., G. Monticelli y E. Neumann}

- 1990. Analogia etnográfica na reconstrução gráfica das vasilhas guarani arqueológicas. Véritas 35(140): 727-743.

Buc, $\mathbf{N}$.

- 2010a. Tecnología ósea de cazadores-recolectores del humedal del Paraná inferior. Bajíos Ribereños meridionales. Arqueología de la Cuenca del Plata. Series Monográfica II. Asociación Amigos del Instituto Nacional de Antropología y Pensamiento Latinoamericano, Buenos Aires.

- 2010b. Explorando la variabilidad de la tecnología ósea a lo largo de la cuenca inferior del rio Paraná. Pesquisas, Antropología 68: 133-166.

\section{Buc, N.; Cabanillas, E. D. y M. N. Davrieux}

- 2014. Objetos metálicos entre grupos Guaraníes del Delta del Paraná. Holoceno tardío, Buenos Aires - Argentina. Revista do Museu de Arqueologia e Etnologia 24: 41-52. 
Buc, N. y R. Sacur Silvestre

- 2006. Funcionalidad y complementariedad de los conjuntos líticos y óseos en el humedal del nordeste de la Provincia de Buenos Aires: Anahí, un caso de estudio. Intersecciones en Antropología 7: 129-146.

Buikstra, J. E. y D. H. Ubelaker

- $\quad$ 1994. Standards for data collection from human skeletal remains. Arkansas Archaeological Survey Research Series N44, Fayetteville, Arkansas.

\section{C}

Cabrera, A. L.

- 1976. Regiones fitogeográficas argentinas. En: Enciclopedia argentina de agricultura y jardinería, editado por Parodi M. y M. Dimitri, 2da. edición, Tomo II, fascículo. 1. ACME, Buenos Aires.

Cabrera, A. L. y A. Willink.

- 1980. Biogeografía de América Latina. Secretaría General de la Organización de los Estados Americanos. Programa Regional de Desarrollo Científico y Tecnológico. Washington, D. C.

Cabrera, L. y M. C. Curbelo

- $\quad$ 1990. Análisis de las estrategias adaptativas desarrolladas en el Uruguay Medio. Revista do CEPA, 17, (20): 359-370.

\section{Cabrera P. I.}

- 2000. Los niveles de desarrollo socio-cultural alcanzados por los grupos constructores del este uruguayo. Arqueología de las Tierras Bajas, Ministerio de Educación y Cultura: 169-181, Montevideo.

- 2005. Patrimonio y Arqueología en el sur de Brasil y región este de Uruguay: Los cerritos de indios. Saldvie 5: 221-254.

- 2011. Patrimonio y Arqueología en la región platense. Departamento de Publicaciones, Unidad, Unidad de Comunicación de la Universidad de la República (UCUR). Uruguay.

\section{Caggiano, M. A.}

- $\quad$ 1977a. Breve reseña de una pesquisa efectuada en el Paraná Ibicuy, Argentina. V Encuentro de Arqueología del Litoral: 24-25. Fray Bentos, Uruguay.

- $\quad$ 1977b. La práctica del arponeo en el Delta del Paraná. Relaciones de la Sociedad Argentina de Antropología 11: 101-106.

- $\quad$ 1979. Análisis y desarrollo cultural prehispánico en la cuenca inferior del Plata. Tesis Doctoral Inédita, Facultad de Ciencias Naturales y Museo-UNLP, La Plata.

- 1982a. Análisis y desarrollo cultural prehispánico en la cuenca inferior del Plata. Informe al CONICET. Ms. Archivo de la División Arqueología, FCNyM-UNLP.

- $\quad$ 1982b. El Potrero 1982. Libreta de Campo. Ms. Archivo de la División Arqueología, FCNyMUNLP.

- 1983a. Caracterización y antropodinamia prehispánica en el N. E. argentino a propósito de los primeros fechados radiocarbónicos para el Delta del Paraná. Relaciones de la Sociedad Argentina de Antropología 15 (NS): 61-76.

- 1983b. Análisis y desarrollo cultural prehispánico en la cuenca inferior del Plata. Informe al CONICET. Ms. Archivo de la División Arqueología, FCNyM -UNLP.

- 1984. Prehistoria del Noreste argentino, sus vinculaciones con la República Oriental del Uruguay y sur de Brasil. Pesquisas, Antropología 38: 1-109. 
- 1985. Problemática en torno a una técnica decorativa y su distribución espacio-temporal. El surco rítmico. Sapiens 5:107-124. Chivilcoy: Museo Arqueológico Osvaldo F. A. Menghin.

- $\quad$ 1990. Los Ribereños Plásticos del Delta del Paraná. Revista do CEPA 17: 415-435.

\section{Caggiano, M. A.; Cigliano, E.M. y R.A. Raffino}

- 1971. Consideraciones sobre la arqueología de Salto Grande (provincia de Entre Ríos). Anales de la sociedad de Arqueología y Etnología XXVI: 53-68.

Caggiano, M. A. y O. B. Flores

- 2001. La ocupación humana en el delta del Paraná, a propósito de nuevos fechados radiocarbónicos. Actas del XIV Congreso Nacional de Arqueología Argentina: 1-8. Rosario, UNR.

Caggiano, M. A.; Flores, O. B.; Méndez, M. G. y S. A. Salceda

- 1978. Nuevos aportes para el conocimiento antropológico del Delta del Paraná. Relaciones de la Sociedad Argentina de Antropología 12 (NS): 55-74.

\section{Calvo Trias, M. y J. García Rosselló}

- 2014. Acción técnica, interacción social y práctica cotidiana: propuesta interpretativa de la tecnología. Trabajos de Prehistoria 71 № 1: 7-22.

\section{Campos, G.}

- 2003. Análisis litológico de la matriz sedimentaria de los sitios arqueológicos. Revista de la Escuela de Antropología 8: 211-222

\section{Camps-Fabrer, $\mathbf{H}$.}

- 1977. Deuxième Colloque International sur I'Industrie de l'os dans la Préhistoire, Méthodologie appliquée a L'industrie de l'os préhistorique, Camps-Fabrer, H. (ed.), CNRS.

- 1993. Fiches typologiques de l'industrie osseuse préhistorique. Chier VI: élementns recepteurs. Editions du CEDARC, Treignes.

- $\quad$ 1995. Fiches typologiques de l'industrie osseuse préhistorique. Chier VII: élementns rarbelés et apparentés.

\section{Camps-Fabrer, H.; Bourrelly, L. y N. Nivelle}

- 1974. Lexique des termes descriptifs de l'industrie de l'os, Versión №2, Laboratoire de Anthropologie et Préhistoire du Pays de la Mediterranée Occidental, Aix-en-Provence.

\section{Canevari, M. y O. Vaccaro}

- 2007. Guía de mamíferos del sur de América del Sur. Editorial LOLA, Buenos Aires.

\section{Capdepont, I.}

- 2004. Presencia y ausencia de restos óseos humanos en la cuenca de la Laguna de Castillos, región este del Uruguay. En L. Beovide; I. Barreto y C. Curbelo (eds.), La Arqueología Uruguaya ante los desafíos del Nuevo Siglo. CD-ROM, Montevideo, Uruguay.

- 2012. Arqueología de sociedades indígenas del litoral del río Uruguay. Tesis Doctoral inédita, Facultad de Ciencias Sociales, Universidad del Centro de la Provincia de Buenos Aires, Argentina. Olavarría.

- 2014. Ocupaciones humanas en el paisaje del litoral del río Uruguay. Relaciones de la Sociedad Argentina de Antropología 39(1): 95-117.

\section{Capdepont, I. y M. Bonomo}

- 2010-2011. Análisis petrográfico del material cerámico del Delta del Paraná. Anales de Arqueología y Etnología 65-66: 127-147.

\section{Capdepont, l; del Puerto, L. y A. Ramírez}

- 2013. Potenciales fuentes de aprovisionamiento para la manufactura cerámica: sitio Guayacas, Paysandú, Uruguay. Revista del Museo de La Plata 13(87): 315-331. 


\section{Capdepont, I; Inda, H. y L. del Puerto}

- 2010. Patrones de asentamiento de sociedades alfareras del bajo río Uruguay (República Oriental del Uruguay). Arqueología de cazadores recolectores en la Cuenca del Plata. pp. 8799. Centro de Estudios Hispanoamericanos. Santa Fe.

\section{Capeletti L.}

- 2011. Primer hallazgo de una punta de proyectil "cola de pescado" en la provincia de Entre Ríos. Revista del Museo de La Plata. Arqueología 12: 86.

\section{Capllonch, P.; Ortiz, D. y K. Soria}

- 2008. Importancia del Litoral Fluvial Argentino como Corredor Migratorio de Aves. En F. G. Aceñolaza (ed.), Temas de la Biodiversidad del Litoral III, Miscelánea INSUGEO 17: 107-120. Tucumán.

\section{Capparelli, M. I.}

- 2014. Estudio de las ocupaciones indígenas prehispánicas en la Isla Martín García, Argentina. Tesis doctoral inédita, Facultad de Ciencias Naturales y Museo, Universidad Nacional de La Plata, La Plata.

\section{Carvajal, Gaspar de}

- [1541] 1942. Descubrimiento del Río de las Amazonas. Bogotá: Prensas de la Biblioteca Nacional. Edición a cargo de Juan Bueno Medina.

\section{Carver, $\mathbf{R}$.}

- 1971. Procedures in Sedimentary Petrology. Wiley-Interscience, 653 p., New York.

\section{Carrara, M. T.; Carballo, M. S. y M. P. Valentini}

- $\quad$ 1998. Localización y prospección de sitios arqueológicos en la zona isleña aledaña a la ciudad de Rosario, islas del río Paraná. Argentina. Anuario de la Universidad Internacional Sek 4: 9-23.

Castillo, A

- 2000. Arqueología del Oeste de la República Oriental del Uruguay Departamento de Río Negro. Revista do CEPA 24(31): 71-94.

- 2004. Excavación y Museo: profundizando en el conocimiento de los grupos ceramistas del litoral (Río Negro, Uruguay). En L. Beovide; I. Barreto y C. Curbelo (eds.), La Arqueología Uruguaya ante los desafíos del Nuevo Siglo. CD-ROM, Montevideo, Uruguay.

Castiñeira, C.

- 2008. Aspectos de la colonización humana prehistórica del noreste del Uruguay. Tesis Doctoral inédita, Facultad de Filosofía y Letras, Universidad de Buenos Aires.

Castiñeira, C.; Blasi, A.M.; Bonomo, M., Politis, G. y E. Apolinaire

- 2014. Modificación antrópica del paisaje durante el Holoceno tardío: las construcciones monticulares en el Delta superior del río Paraná. Asociación Geológica Argentina 71(1): 33-47.

Castiñeira, C.; Blasi, A. M.; Politis, G.; Bonomo, M.; Del Puerto, L.; Huarte, R.; Carbonari, J.; Mari, F. y F. García-Rodríguez.

- 2013. The origin and construction of pre-Hispanic mounds in the Upper Delta of the Paraná River (Argentina). Archaeological and Anthropological Sciences 5: 37-57.

Castiñeira, C.; Charlin, J.; Cardillo, M. y J. Baeza

- 2012. Exploring morphometric variations in Fishtail Projectile Points from Uruguay, Pampa and Patagonia. En Southbound: Late Pleistocene Peopling of Latin America, L. Miotti, M. Salemme, N. Flegenheimer y T. Goebel (eds.), pp. 57-61. Center for the Study of the First Americans. Special Edition Current Research in the Pleistocene, Texas. 


\section{Castiñeira, C. y Piñeiro, G.}

- 2000. Análisis estadístico textural para el estudio de las columnas estratigráficas de la excavación I y II del Bañado de los Indios. En Duran, A. y Bracco, R. (eds.) Arqueología de las Tierras Bajas, Ministerio de Educación y Cultura: 467-478, Montevideo.

\section{Castro de, E.}

- 1940. Diário da navegação de Pero Lopes de Sousa 1530-1532. Vol. 1, 2 Edição. Comissão Brasileira dos Centenários Portugueses.

\section{Castro, J. C.}

- 2007. Investigaciones arqueológicas en la cuenca media e inferior del río Uruguay (provincia de Entre Ríos). Plan de Tesis Doctoral. Facultad de Ciencias Naturales y Museo, Universidad Nacional de La Plata, La Plata. Proyecto de investigación desarrollado desde la División Arqueología del Museo de Ciencias Naturales y Antropológicas "Profesor Antonio Serrano". Paraná.

- 2011. Arqueología en la cuenca del río Uruguay (Provincia de Entre Ríos). Cazadores Recolectores del Cono Sur 5: 135-162.

- 2012. Arqueología en el Parque Nacional El Palmar: disponibilidad y explotación de materias primas líticas. Intersecciones en Antropología 13:145-161.

- 2013. Arqueología en el centro de la provincia de Entre Ríos (Argentina). Arqueología 19(2): 287-304.

- 2016. Late-Holocene Indigenous occupation of the Uruguay River. Dig It. Journal of the Flinders Archaeological Society 3: 42-53.

\section{Castro, J. C. y C. Castiñeira L.}

- 2017. Estudio de la secuencia sedimentaria de la localidad arqueológica Cerros de Boari (Gualeguaychú, Entre Ríos). Comechingonia. Revista de Arqueología (en prensa).

\section{Castro, J. C. y R. Costa Angrizani}

- 2014. El sitio arqueológico Ensenada del Bellaco (Gualeguaychú, Entre Ríos) como indicador de la presencia guaraní en el río Uruguay inferior. Revista del Museo de Antropología 7(2): 235242.

\section{Castro, J. C. y M. C. Del Papa}

- 2015. La estructura del registro bioarqueológico del rio Uruguay inferior. Análisis de la colección osteológica humana del Museo Arqueológico Manuel Almeida (Gualeguaychú, Entre Ríos). Intersecciones en Antropología 16: 195-205.

\section{Castro J. C. y E. Terranova}

- 2015. Indicadores paleoindios en la provincia de Entre Ríos (Argentina). Comechingonia. Revista de Arqueología 19(1): 183-190.

\section{Cavallotto, J. L.; Violante, R. A. y F. Colombo}

- 2005. Evolución y cambios ambientales de la llanura costera de la cabecera del río de La Plata. Revista de la Asociación Geológica Argentina 60 (2): 353-367.

\section{Ceruti, C. N.}

- 1982. Entierros aislados de conjuntos de objetos en el Nordeste argentino. Archivo de la División Arqueología, MAS.

- 1984. Investigaciones arqueológicas en el área del complejo hidroeléctrico del Paraná medio. Revista Síntomas 8:20-26.

- 1986. Algo sobre crítica y autocrítica en Arqueología. Revista de Antropología, Año 1, N 1: 1924.

- 1988. Modificación ambiental y adaptación cultural en la cuenca del Paraná medio. Archivo de la División Arqueología, MAS. 
- 1990. Sitio Arroyo Las Mulas 1 (Dpto. La Paz, Provincia de Entre Ríos): Aportes para un estudio del ecosistema. Revista de Antropología, Año V, N 9: 60 - 67.

- 1991. Arroyo Las Mulas 1 (Departamento La Paz, Provincia de Entre Ríos): Relaciones hombremedio ambiente en la actualidad y alteración del sitio por acción antrópica. Revista de Antropología, Año VI, N 10: 34 - 45.

- 1992. Cambios climáticos y poblaciones prehispánicas en el Litoral argentino. El Holoceno en la Argentina I: 39 - 49. Martín Iriondo (ed.) CADINQUA.

- 1993. Arqueología. En A. Renna (ed.), Nueva Enciclopedia de la Provincia de Santa Fe, IV: 557580. Ediciones Sudamérica, Santa Fe.

- 1995a. Reinterpretación de algunos sitios arqueológicos tempranos en la provincia de Santa Fe: Cuenca del Salado-Cululú. Actas y memorias del XI Congreso Nacional de Arqueología Argentina ( $15^{\circ}$ Parte). Revista del Museo de Historia Natural de San Rafael XXVII: 103 - 121.

- 1995b. Hábitat natural y cultural. Historia de Santa Fe, Poblamiento, conquista y colonización. Colección Cuadernillos 1: 1 - 6.

- 1999a. Arqueología urbana en Entre Ríos, barrio del Puerto, ciudad de La Paz. Actas del XII Congreso Nacional de Arqueología Argentina, Tomo III: 369 -377.

- 1999b. Flooding records in archeological stratigrafhy, Río de La Plata basin. Taller Astrobiology, El Niño and South American Ecosystems, organizado por INIDEP, AGENCIA, SECYT, CONAE. Mar del Plata, 7 al 9-4-99.

- 2000. Ríos y praderas: Los pueblos del Litoral. En: Tarragó, M. (dir.), Nueva Historia Argentina. Los pueblos originarios y la conquista: 107-146, Sudamericana, Buenos Aires.

- 2001a. Las formas de techar: un aporte a la historia de la arquitectura regional. Revista de la Junta de Estudios Históricos de Entre Ríos "Prof. Facundo A. Arce" 3: 89-97.

- 2001b. Muros de Santa Fe y Entre Ríos: un aporte a la historia de la tecnología regional. Revista de la Junta de Estudios Históricos de Entre Ríos "Prof. Facundo A. Arce" 4, Paraná.

- 2003a. Entidades culturales presentes en la cuenca del Paraná Medio (margen entrerriana). Mundo de Antes 3: 111-135.

- 2003b. Techos, paredes y pisos: elementos para el estudio de las técnicas constructivas en Santa Fe y Entre Ríos. Actas del Primer Congreso Nacional de Arqueología Histórica: 757-767.

- 2003c. Aportes a la historia de la arquitectura regional: El yeso y la Cal en Santa Fe y norte de Entre Ríos. Junta Provincial de Estudios Históricos de Santa Fe: 69-91.

- 2005. Evidencias del contacto hispano-indígena en la cerámica de Santa Fe la vieja (Cayastá). Revista América 17: 13-38.

- 2006. La cerámica de Santa Fe la Vieja: hacia una revaloración del componente indígena. En: CD "Santa Fe la Vieja: Arqueología de los siglos XVI y XVII" - Programa de Arqueología Histórica de Santa Fe la Vieja, Dir. M.A. Carrara y N. De Grandis. Escuela de Antropología, UNR, Rosario.

- 2007. La Colección Marcelo Lugrin (Villaguay). Informe Final del Programa Identidad Entrerriana CFI "Identidad y patrimonio en el centro de Entre Ríos: aportes arqueológicos y antropológicos para la comprensión de los procesos históricos en el departamento. Villaguay: la etnia Charrua-Minoano", pp 78-87. Paraná. Ms.

- 2009a. Aporte al conocimiento de la "Cultura del Leyes": la colección del Museo de Cs. Nat. y Antropológicas "Prof. Antonio Serrano", Paraná, Entre Ríos, Argentina. En: Austral, A. y M. Tamagnini (Comp.) Problemáticas de la Arqueología Contemporánea, T. III: 335-344, UNRC, Córdoba.

- 2009b. La cerámica de Santa Fe La Vieja: hacia una revalorización del componente indígena. La macroetnia chaná-timbú. En: Chiavazza, H. y C. Ceruti (eds.).Arqueología de ciudades americanas del siglo XVI. pp. 370-400. Mendoza. 
- 2010. Los esclavos africanos en Santa Fe la Vieja. En J. R. Bárcena y H. Chiavazza (eds.), Arqueología Argentina en el Bicentenario de la Revolución de Mayo. Actas del XVII Congreso Nacional de Arqueología Argentina III: 1011-1016, UNC-INCIHUSA, Mendoza.

- 2011. Armando el rompecabezas: piezas enteras del Arroyo Leyes (Santa Fe) vinculadas al agua. En M. Ramos; A. Tapia; F. Bognanni; M. Fernández; V. Helfer; C. Landa; M. Lanza; E. Montanari; E. Néspolo y V. Pineau (eds.) Temas y problemas de la Arqueología Histórica, T. I: 241-254, UNL, Luján.

- 2013a. Indicios de complejidad social en un enterratorio de la entidad cultural arqueológica Goya-Malabrigo. Hernandarias, Departamento Paraná, provincia de Entre Ríos. Libro de Resúmenes de 5o Encuentro de Discusión de Arqueología del Nordeste Argentino, p. 25. Goya.

- 2013b. Homenaje a Jorge A. y Amílcar rodríguez: el poblamiento temprano en la provincia de Entre Ríos, Argentina. Cuadernos del Instituto Nacional de Antropología y Pensamiento Latinoamericano - Series Especiales 1, Vol. 4: 34-47.

- 2014. Artefactos de uso diario representados en la Colección Cerámica del Arroyo Leyes: su empleo en la determinación de cronología. Revista del Museo de Antropología 7 (2): 243-254.

Ceruti, C. N. y G. Cocco

- 1998. Un proyecto de arqueología histórica: Fortín Aguará, Estancia El Lucero, Aguará Grande, Departamento San Cristóbal. Centro de estudios hispanoamericanos, América 14: 111-121.

\section{Ceruti C. N. y R. Crowder}

- 1973. La presencia de cerámica en los cordones conchiles litorales de la Provincia de Buenos Aires (Argentina). Un sitio nuevo. Primer Congreso Nacional de Arqueología y Segundo Encuentro de Arqueología del Interior. Anales de los Congresos Museo de Ciencias Naturales de Río Negro. Fray Bentos (48 p.).

\section{Ceruti, C. N.; Fontana, O.; López, L. y C. Vesco}

- 1980. Arroyo Arenal 4 (Departamento La Paz, Provincia de Entre Ríos). Un hallazgo poco común. Editado por la Comisión Municipal de Cultura de La Paz. Comunicación presentada en el VI Congreso de Arqueología Litoral, Uruguay 1979. CD trabajos de Carlos Ceruti.

\section{Ceruti, C. N. y M. I., González}

- 2007. Modos de vida vinculados con ambientes acuáticos del Nordeste y Pampa Bonaerense de Argentina. Relaciones de la Sociedad Argentina de Antropología 32: 101-140.

\section{Ceruti, C. N. y S. Hocsman.}

- 1999. Investigaciones arqueológicas en la cuenca inferior del arroyo Las Conchas, Departamento Paraná, Provincia de Entre Ríos. Actas del XII Congreso Nacional de Arqueología Argentina, Tomo III: 378-383.

\section{Ceruti C. N. y N. E. Natassi}

- 1974. Un sitio de contacto Hispano-Indígena (Villa Lanús, Misiones). Anales del III Congreso Nacional de Arqueología y IV Encuentro de Arqueología del Litoral, Montevideo, Uruguay.

- 1977. Evidencia de contacto Hispano-Indígena en la cerámica de Santa Fe La Vieja (Cayastá). Actas y Memorias del IV Congreso Nacional de Arqueología Argentina (Segunda parte). Revista del Museo de Historia Natural de San Rafael (Mendoza) IV (1/4):213-236.

\section{Ceruti, C. N.; Nóbile, J. C. y S. Cornero.}

- 1999. Investigaciones arqueológicas en el área de Alejandra, departamento San Javier, Provincia de Santa Fe. Actas del XII Congreso Nacional de Arqueología Argentina, Tomo III: 389393. 


\section{Ceruti C. N. y M. B. Traver Borny}

- 2007. Un aporte a la arqueología experimental: reproducción de material cerámico de la Entidad Goya-Malabrigo. En: Arqueología Argentina en los inicios de un nuevo siglo. Oliva, F. de Grandis, N. Y J. Rodríguez (compiladores).Tomo I: 157-165. Rosario.

\section{Chapman, $\mathbf{R}$.}

- $\quad$ 1995. Ten years after-megaliths, mortuary practices, and the territorial model. En L. A. Beck (ed.), Regional approaches to mortuary analysis. pp. 29-51. Plenum Press, New York.

- 2003. Archaeologies of Complexity. Routledge, London.

Chebez, J. C.

- $\quad$ 1994. Los que se van. Especies argentinas en peligro. Editorial Albatros, Buenos Aires.

Chebez, J. C. y E. Haene

- $\quad$ 1993. La Selva de Montiel. Todo es Historia 334: 26-40.

\section{Cherry, J. F. y S. Shennan}

- 1978. Sampling Cultural Systems: Some Perspectives on the Application of Probabilistic Regional Survey in Britain. En Sampling in Contemporary British Archaeology, J. F. Cherry, C. Gamble y S. Shennan (eds.), pp. 17-48. BAR British Series 50, London.

Chilton, E. S.

- $\quad$ 1999. One Size Fits All. Typology and Alternatives for Ceramic Research. En Material Meanings: Critical Approaches to the Interpretations of Material Culture, editado por E.S. Chilton, pp. 4460. University of Utah Press, Salt Lake City.

Chiri, O. C.

- $\quad$ 1972. Acerca de la utilización de valvas de moluscos y la formación de montículos de valvas en yacimientos arqueológicos del Nordeste argentino. Relaciones de la Sociedad Argentina de Antropología 6: 163-172.

- 1973. La industria de indígena del hueso en el Nordeste argentino según las referencias de algunas fuentes. Relaciones de la Sociedad Argentina de Antropología 7: 47-55.

- 1975. El empleo de la madera y algunos otros productos vegetales por los indígenas del Nordeste argentino según las referencias de algunas fuentes. Relaciones de la Sociedad Argentina de Antropología 9: 83-109.

Cigliano, E. M.

- $\quad$ 1967. Nota preliminar sobre los hallazgos prehistóricos en la zona de salto grande. Notas de la comisión de investigación científica de la provincia de Buenos Aires. Vol. V, Nro. 3. La Plata.

- 1968. Investigaciones arqueológicas en el río Urugiay medio y costa N.E. de la provincia de Buenos Aires. Pesquisas, Antropología 18, estudios leopoldenses 9: 6-9. Brasil.

\section{Cigliano, E. M.; R. A. Raffino y M. A. Caggiano.}

- $\quad$ 1971a. Resultados de las investigaciones arqueológicas efectuadas en la zona de Salto Grande (Provincia. de Entre Ríos). Revista del Museo de La Plata, Antropología 43 (7): 79-107.

\section{Cigliano, E. M.; Schimtz P. I. y M. A. Caggiano}

- $\quad$ 1971b. Sitios cerámicos prehispánicos en la costa septentrional de la provincia de Buenos Aires y de Salto Grande, Entre Ríos. Anales de la Comisión de Investigaciones Científicas de la provincia de Buenos Aires CXCII (III-IV): 129-191.

Cione, A. L., A. Rizzo y E. P. Tonni

- 1977. Relación cultura indígena-medio ambiente en un sitio de Rincón de Landa, Gualeguaychú, Entre Ríos, República Argentina. Nota preliminar. V Encuentro de Arqueología del Litoral: 122-141. Fray Bentos. Uruguay. 
Cione, A. L y E. P. Tonni

- 1978. Paleoethnozoological context of a site of Las Lechiguanas islands, Paraná Delta, Argentina. El Dorado.A Newsletter Bulletin on South American Anthropology III(1): 76-86.

Cocco, G.

- 1996. Procesos de Formación y Transformación de sitios Arqueológicos en el Sector Sur del "Bajo de los Saladillos": Sitio Isla Barranquita. Tesis de licenciatura inédita, Facultad de Humanidades y Artes, Universidad Nacional de Rosario, Rosario.

- 2004. Investigaciones arqueológicas en el sector sur del Bajo de los Saladillos Capón-SetübalLeyes, provincia de Santa Fe. En C. Gradín y F. Oliva (eds.), La Región Pampeana -su pasado arqueológico-. pp. 25-35. Universidad Nacional de Rosario, Rosario.

- 2010. Tendencias actuales en el estudio del registro arqueológico del período Holoceno tardío en el bajo de los saladillos, provincia de Santa Fe. En Cocco, G.; Feuillet Terzaghi M. R. y L. Campagnolo. Arqueología de Cazadores-recolectores en la Cuenca del Plata". Santa Fe, pp. 3348.

Colobig, M. M.; Patterer, N. I.; Zucol, A. F. y J. C. Castro

- 2015. Primeros estudios fitolíticos de muestras sedimentarias del sitio arqueológico Cerro de Boari 3, Gualeguaychú, Entre Ríos. Libro de Resúmenes del XVI Simposio Argentino de Paleobotánica y Palinología. La Plata.

\section{Colombo, M.}

- 2013. Los cazadores recolectores pampeanos y sus rocas La obtención de materias primas líticas vista desde las canteras arqueológicas del centro de Tandilia. Tesis Doctoral inédita, Facultad de Ciencias Naturales y Museo, Universidad Nacional de La Plata, La Plata.

Coll, $\mathrm{M}$.

- 2013. Primeros resultados sobre el análisis de los materiales líticos del sitio "Playa Mansa" (Provincia de Santa Fe). Cuadernos del Instituto Nacional de Antropología y Pensamiento Latinoamericano - Series Especiales 1(2): 216-233.

\section{CCBSJG, Comisión Central para la Celebración del Bicentenario de San José de Gualeguaychú}

- 1986. De Gualeguaychú y su Historia. Desde el Siglo XVI hasta mediados del Siglo XVIII. Comisión Central para la Celebración del Bicentenario de San José de Gualeguaychú (1973 - 18 de octubre - 1983), Gualeguaychú.

Cordini, R.

- $\quad$ 1949. Contribución al conocimiento de la geología económica de Entre Ríos. Anales Dir. Gral. Ind. Minera (Min. Ind. y Com.) II no 87: (1-78), Buenos Aires.

\section{Cornero, $\mathbf{S}$.}

- $\quad$ 1999. Enterratorios humanos en el litoral: sitio La Lechuza, Alejandra Pcia. de Santa Fe. Actas del XII Congreso Nacional de Arqueología Argentina III: 384-388. Facultad de Ciencias Naturales y Museo, Universidad Nacional de La Plata, La Plata.

- 2009 Apuntes de arqueología de islas. Sitio El Castaño, boca de la Milonga, río Paraná. Anuario de Arqueología 1 (1): 153-160.

\section{Cornero, S. y C. N. Ceruti}

- 2012. Registro arqueológico afro-rioplatense en Pájaro Blanco, Alejandra, Santa Fe: análisis e interpretación. Revista del Centro de Estudios de Arqueología Histórica, Año 1. Vol. 1: 67-78.

\section{Cornero, S. y G. Cocco}

- $\quad$ 1995. Arqueología de rescate de Isla Barranquita: informe preliminar. Actas y memorias del XI Congreso Nacional de Arqueología Argentina. San Rafael, Mendoza, 27: 47-54. 


\section{Cornero, S. y L. Ragnone}

- 2015. Análisis arqueobotánicos en sitios de la entidad arqueológica Goya-Malabrigo ubicados en el centro-norte de Santa Fe. Anuario de Arqueología 7: 85-94. Rosario.

\section{Cornero, S.; Salomita, F. y P. Curetti}

- 2007. Componente arqueofaunístico del sitio La Lechuza (Provincia de Santa Fe). En Arqueología Argentina en los Inicios de un Nuevo Siglo. Oliva, F. de Grandis, N. Y J. Rodríguez (compiladores). Tomo I: 167-171. Rosario.

\section{Crabtree, D.E.}

- 1972. An Introduction to Flintworking. Occasional Papers of the Idaho State University Museum 28, Pocatello, Idaho.

\section{Cremonte, M. B. y M. F. Bugliani}

- 2006-2009. Pasta, Forma e Iconografía. Estrategias para el estudio de la cerámica arqueológica. Xama 19-23: 239-262.

\section{Criado Boado, F.}

- $\quad$ 1989. Megalitos, Espacio, Pensamiento. Trabajos de Prehistoria 46: 75-98.

- 1991. Construcción social del espacio y reconstrucción arqueológica del paisaje“. Boletín de Antropología Americana, 24: 5-30. Instituto Panamericano de Geografía e Historia.

\section{Curtoni, R. P.}

- 1996. Experimentando con bipolares: indicadores e implicancias arqueológicas. Relaciones de la Sociedad Argentina de Antropología 21: 187-214.

- 2007. Arqueología y paisaje en el área centro-este de la provincia de La Pampa: la espacialidad humana y la formación de territorios. Tesis doctoral inédita, Facultad de Ciencias Naturales y Museo, Universidad Nacional de La Plata, La Plata.

\section{D}

\section{Dalla Salda, L.}

- 1981. El basamento de la Isla Martín García, Río de La Plata. Revista de la Asociación Geológica Argentina 26: 29- 43.

\section{Daners, $\mathbf{G}$.}

- 2008. Plantas Fósiles. En D. Perea (ed.), Fósiles de Uruguay. Cap. 5: 119-133. Universidad de la República. Facultad de Ciencias. Montevideo Uruguay.

\section{Darwin, C.}

- 1942. Viaje de un naturalista alrededor del mundo. El Ateneo. Buenos Aires.

Day, $\mathbf{P}$.

- 1965. Particle fractionation and particlesize analysis. En C. Black (ed.), Methods of soil analysis, American Society of Agronomy. pp. 545-567, Madison.

De Alba, E.

- 1953. Geología del Alto Paraná, en relación con los trabajos de errocamiento entre Ituzaingó y Posadas. Revista Asociación Geológica Argentina 8(3): 129-161.

De Alba, E. y Serra N.

- 1959. Aprovechamiento del Río Uruguay en la zona de Salto Grande. Informe sobre las condiciones y características geológicas. Dirección Nacional de Geología y Minería Anales 11, Buenos Aires. 


\section{De Nigris, M. E.}

- 1999. Lo crudo y lo cocido: sobre los efectos de la cocción en la modificación ósea. Arqueología 9. pp: 239-364

- 2003. Procesamiento y Consumo de Ungulados en Contextos Arqueológicos de Patagonia Meridional: el Caso de Cerro Casa de Piedra Cueva 7. Tesis Doctoral inédita. Facultad de Filosofía y Letras, Universidad Nacional de Buenos Aires. Buenos Aires.

\section{Del Puerto, L.}

- 2009. Silicofitolitos como Indicadores Paleoambientales: Bases comparativas y reconstrucción paleoclimática desde el Pleistoceno tardío en el SE del Uruguay. Tesis de Maestría en Ciencias Biológicas, Área Ecología, 207 p. Pedeciba-Facultad de Ciencias de la Universidad de la República, Montevideo

Del Puerto. L.; Garda-Rodríguez, F.; Bracco, R.; Blasi, A.; Inda. H.; Mazzeo. M. y A. Rodríguez

- 2011. Evolución Climática Holocénica para el Sudeste del Uruguay: Análisis Multi-Proxy en Testigos de Lagunas Costeras. En: F. García-Rodríguez (Comp.): El Holoceno en la Zona Costera del Uruguay. pp. 117 - 156. UCUR-UdelaR, Montevideo.

\section{Demonte L. D y J. D Arias.}

- 2005. Ictiofauna de afluentes de los Ríos Paraná y Uruguay de la provincia de Entre Ríos, Argentina. Serie Miscelánea. INSUGEO-CONICET 14: 223-234. Tucumán. Argentina.

\section{Di Persia, D. y J. Neiff.}

- 1986. The Uruguay River System. En: B. Davies y K. Walker (eds.): The Ecology of River System, Cap. 12: 599-621. Dr. W. Junk Publishers, Dordrencht.

\section{Di Prado, V.}

- 2013. Estudio de la alfarería del sitio Calera (partido de Olavarría, provincia de Buenos Aires, Argentina) desde la perspectiva del estilo tecnológico. Revista del Museo de La Plata 13 (87): 267-286.

- 2015. Estudio comparativo de las prácticas de elaboración y uso de la alfarería prehispánica del centro-este de Argentina desde una perspectiva macroregional. Tesis Doctoral inédita, Facultad de Ciencias Naturales y Museo, Universidad Nacional de La Plata, La Plata.

\section{Di Prado, V. y C. Castro}

- 2014. Estrategia de remontajes aplicada sobre el registro cerámico del sitio Los Tres Cerros 1 (Delta Superior del río Paraná). Revista del Museo de Antropología 7 (2): 263-270.

Díaz, A. A.

- 1977. Arqueología de Salto Grande: secuencia cultural resultante de las investigaciones realizadas en Isla de Arriba y del Medio (Uruguay). V Encuentro de Arqueología del Litoral: 154164. Fray Bentos, Uruguay.

- 1980. Perspectivas para el estudio de la cerámica del río Uruguay medio. III Congreso Nacional de Arqueología y IV Encuentro de Arqueología del Litoral. Montevideo, Uruguay.

- 1985. Alfarería indígena en Salto Grande. Centro de Estudios Arqueológicos (Montevideo, Uruguay). Estado actual de las investigaciones arqueológicas en Uruguay (Parte 1) 3: 14-19.

Díaz, A. A. y J. Baeza

- 1977. Salvataje arqueológico en el área de embalse de la represa "Salto Grande" (Uruguay). Informe Lítico. Seminario Medio Ambiente y Represas. Facultad de Humanidades y Ciencias. OEA, Montevideo.

Díaz, A. A.; Bosch, A.; Moreno de Bosch, M.; Femenías, J. y O. Becerra

- 1980. Los materiales arqueológicos del sitio Colonia Concordia. III Congreso Nacional de Arqueología y IV Encuentro de Arqueología del Litoral. Montevideo, Uruguay. 
Díaz, A. A. y M. Fornaro.

- 1977. Intento de sistematización de las Modalidades Alfareras del Litoral Uruguayo. $V$ Encuentro de Arqueología del Litoral: 165-174. Fray Bentos, Uruguay.

Dillehay, T. D.

- 2000. Settlement of the Americas: A New Prehistory. Basic Books, Nueva York.

- 2007. Monuments, Empires, and Resistance: The Araucanian Polity and Ritual Narratives. Cambridge University Press, Cambridge.

- 2013. Sedentarismos y complejidad prehispánicos en América del Sur. Intersecciones en Antropología 14: 29-65.

DINASEGE, Dirección Nacional del Servicio Geológico

- 1995. Mapa Geológico de la provincia Entre Ríos. Escala 1:500.000. Dirección Nacional del Servicio Geológico, Buenos Aires.

Dincauze, D. F.

- $\quad$ 1993. The gardeners of Eden. In D.S.Krass, J.B.Thomas and J.W.Cole (eds.). Ela'Qua: essays in honor of Richard B.Woodbury, pp. 43-60. Department of Anthropology Research. Report 43, university of Massachusetts. Amherst.

- 2000. Environmental Archaeology - Principles and Practice. Cambridge University Press, Cambridge. 587 p.

Dobres, A. M. y Ch. R. Hoffman

- 1994. Social Agency and the Dynamics of Prehistoric Technology. Journal of Archaeological Method and Theory 1(3): 211-258.

Doello-Jurado, $\mathbf{M}$.

- $\quad$ 1917. Moluscos hallados en un cementerio indígena de la isla de Martín García. Physis 3(14): 223-225.

- $\quad$ 1940. Síntesis Malacológica. Relaciones de la Sociedad Argentina de Antropología 2: 123-144.

Dorn, R.I. y Oberlander, T.M.

- $\quad$ 1981. Microbial Origin of Desert Varnish. Science, Washington: American Association for the Advancement of Science, v. 213, n. 4513: 1245-1247.

\section{Drobrizhoffer, $M$.}

- $\quad$ 1967. Historia de los Abipones. Facultad de Humanidades, Universidad Nacional del Nordeste. Tomo I. Resistencia, Chaco.

\section{E}

\section{Echegoy, C.}

- 1994. Los fechados C14 de Arroyo Aguilar. Arqueología del Paraná 2. Reconquista, Museo Municipal de Arqueología y Paleontología de Reconquista. 31 p.

Eidt, R. C.

- 1985. Theoretical and practical considerations siderations in the analysis of anthrosols. En: Archaeological Geology, editado por Rapp, G. y J. A. Gifford. Yale University Press: 155-190, New Haven.

\section{El Argentino}

- $\quad$ 1992a. Apuntes de Almeida. Fascículo № 1. Publicación del diario El Argentino miércoles 14 de octubre de 1992.

- $\quad$ 1992b. Apuntes de Almeida. Fascículo № 3. Publicación del diario El Argentino miércoles 28 de octubre de 1992. 
Eliade, $M$.

- 1994. Lo sagrado y lo profano. Novena edición, Grupo Editor Quinto Centenario, Colombia.

Ellen, $\mathbf{R}$.

- 1994. Modes of subsistence: Hunting and ghatering to agriculture and pastoralism. En T. Ingold (ed.), Companion Encyclopedia of Anthropology, Humanity, Culture and Social life. pp. 197225. Routledge.

Erickson, C. L.

- 2006. The Domesticated Landscapes of the Bolivian Amazon. En W. Balée y C. Erickson (eds.) Time and Complexity in Historical Ecology: Studies in the Neotropical Lowlands. Pp. 235-278. New York: Columbia Univ. Press.

- 2010. The Transformation of Environment into Landscape: The Historical Ecology of Monumental Earthwork Construction in the Bolivian Amazon. Diversity 2: 618-652.

Ericson, J.

- 1984. Toward the analysis of lithic production systems. En: Ericson, J. y B. Purdy (eds.), Eriksen, L. Prehistóric Quarries and Lithic Production. pp. 1-10. Cambridge University, Cambridge.

- 2011. Nature and Culture in Prehistoric Amazonia. Using G.I.S. to reconstruct ancient ethnogenetic processes from archaeology, linguistics, geography, and ethnohistory. Tesis Doctoral. Lund, Faculty of Social Sciences, Lund University. 364 p.

Erra, G.; Zucol, A. F.; Kröhling, D. M. y M. Brea

- 2006. Análisis Fitolíticos en el Loess del Pleistoceno tardío-Holoceno temprano en la Provincia de Entre Ríos; Resultados Preliminares. Actas del III Congreso Argentino de Cuaternario y Geomorfología. Tomo II, pág. 691- 699. Córdoba.

Escola, P. S.

- $\quad$ 1993. De Percusión y Percutores. Palimpsesto. № 3: 33-51

- 2004. La expeditividad y el registro arqueológico. Chungará 36: 49-60.

Escosteguy, P. y M. Vigna

- 2010. Experimentación en el procesamiento de Myocastor coypus. En M. Berón, L. Luna, M. Bonomo, C. Montalvo, C. Aranda y M. Carrera Aizpitarte (eds.), Mamül Mapu: pasado y presente desde la arqueología pampeana I, pp. 293-307. Editorial Libros del Espinillo. Ayacucho, Buenos Aires.

Escosteguy, P. D.; Rivas González, M.; Fiel, M. V. y M. S. Vigna

- 2015. A orillas de la Laguna de Lobos: el sitio Techo Colorado (Buenos Aires). Libro de resúmenes del Sexto Encuentro de Discusión Arqueológica del Nordeste Argentino. p. 32. Gualeguaychú.

Ezcurra de Drago, I. D.

- 1995. Porífera. En: Ecosistémas de aguas continentales. Metodología para su estudio. En E. C. Lopretto y G. Tell (eds.). Ediciones Sur. Argentina.

- 2004. Biodiversidad porífera en el litoral argenino. Grado de competencia con el Bivalvo invasor Limnoperna fortunei (Dunker, 1857) (Bivalvia, Mytillidea). Temas de la Biodiversidad del Litoral fluvial argentino, Miscelánea INSUGEO 12: 195-204. Tucumán.

\section{Ezcurra de Drago, I. D. y A. A. Bonetto}

- 1969. Algunas características del bentos en los saltos del río Uruguay, con especiañ referencia a la ecología de los poríferos. Physis 28(77): 359-369. 
Farías G., M. E.

- 2005. El guaraní arqueológico meridional: entre el axioma y la heterodoxia. Tesis Doctoral inédita, Pontificia Universidade Católica do Rio Grande do Sul, Porto Alegre, Brasil.

Farías, M.; Femenias, J.; Iriarte, J. y A. Florines

- 1997. Aproximaciones arqueológicas al área deltaica del río Negro (Uruguay). En Jornadas de Antropología de la Cuaca del Plata. Arqueología y Bioantropología. Tomo III: 22-27. Universidad Nacional de Rosario.

- 2001. Aproximaciones arqueológicas al área del delta del río Negro. Arqueología Uruguaya hacia el fin del Milenio. Tomo I: 125-134. Montevideo, Uruguay.

Feely, A.

- 2013. Los modos de hacer las vasijas: elecciones técnicas y estilo tecnológico del oeste tinogasteño (Catamarca). En: Delineando prácticas de la gente del pasado: los procesos sociohistóricos del oeste catamarqueño. Ratto, N. (Comp.), Sociedad Argentina de Antropología, pp. 69-130. Buenos Aires.

Femenías, J.

- 1973. Informe preliminar sobre un yacimiento epiprotolítico en la zona de Salto Grande (Uruguay). Primer Congreso Nacional de Arqueología y Segundo Encuentro de Arqueología del Litoral. Fray Bentos, Uruguay.

\section{Fernández, J.}

- 1979. Etnobotánica de las palmáceas austroamericanas, en especial Syagrus yatay. Informe al Servicio Nacional de Parques Nacionales. Ms.

- 1982. Historia de la Arqueología Argentina. Anales de Arqueología y Etnología. 320 p. Asociación Cuyana de Antropología. Mendoza.

Fernández de Oviedo y Valdés, G.

- [1546-1547] 1851-1855. Historia general y natural de las Indias, Islas y Tierra-Firme del Mar Océano, 2 (1). Madrid, Imprenta de la Real Academia de la Historia.

Feyerabend, P. K.

- $\quad$ 1975. Tratado contra el método. Esquema de una teoría anarquista del conocimiento. Editorial Tecnos, Madrid.

Figueira, J. $\mathbf{H}$.

- 1900. Chanás. En: Diccionario geográfico del Uruguay por Orestes Araujo. Montevideo.

Flegenheimer, N.; Bayón, C. y M. I. González

- 1995. Técnica simple, comportamientos complejos: la talla bipolar en la arqueología bonaerense. Relaciones de la Sociedad Argentina de Antropología 20: 81-109.

Flegenheimer, N.; Bayón, C.; Valente, M.; Baeza, J. y J. Femenías

- 2003. Long distance tool stone transport in the Argentine Pampas. Quaternary International, The Journal of the INQUA, L. Miotti y M. Salemme (eds.), vol. 109-110: 49-64.

Flegenheimer, N.; Martínez J. y M. Colombo

- 2010. Un experimento de lanzamiento de puntas cola de pescado. En M. Berón, L. Luna, M. Bonomo, C. Montalvo, C. Aranda y M. Carrera Aizpitarte (eds.), Mamül Mapu: pasado y presente desde la arqueología pampeana I. pp. 215-232. Editorial Libros del Espinillo. Ayacucho, Buenos Aires. 
Foley, R.

- 1978. Incorporating Sampling into Initial Research Design: Some aspects of Spatial Archaeology. En Sampling in Contemporary British Archaeology, J. F. Cherry, C. Gamble y S. Shennan (eds.), pp. 49-65. BAR British Series 50, London.

Folk, R.

- 1954. The distinction between grain size and mineral composition in sedimentary rock nomenclature. Journal of Geology 62: 344-359.

\section{Fontana Company, M. A.}

- 1928. Etnografía Uruguaya. Informe sobre la exploración de un túmulo indígena en Punta Chaparro (Colonia - Río Uruguay). Revista de la Sociedad Amigos de la Arqueología 2: 331-349.

- 1930. Memoria de la excursión científica a Nueva Palmira. Revista de la Sociedad Amigos de la Arqueología 4: 119-178.

- 1933. El arqueólogo argentino Arquitecto Héctor Greslebin y su obra. Revista de la Sociedad Amigos de la Arqueología 7: 251-271.

- 1951. Arqueología del Uruguay. Alfarería prehispánica de los paraderos de Nueva Palmira (Depto. de Colonia). - Arqueología descriptiva. Revista de la Sociedad Amigos de la Arqueología 11: 153-222.

France, D. L.

- 2009. Human and Nonhuman Bone Identification. A COLOR ATLAS. CRC Press, Boca Ratón.

Franco, M. J.; Ramos R. S. y J. C. Castro

- 2016. Estudio preliminar de restos antracológicos del sitio arqueológico Cerro de Boari 3 (Gualeguaychú, Entre Ríos). Libro de resúmenes del II Taller de Micropaleoetnobotánica, Relevancia de una Red Interdisciplinaria de Investigaciones en Fitolítos y Almidones. Diamante, Entre Ríos. p. 119.

\section{Freitas, C. A. de}

- 1953a. Alfarería del delta del Río Negro (Paradero "La Blanqueada"). Revista de la Sociedad Amigos de la Arqueología 12: 65-121.

- 1953b. Algunos aspectos de la arqueología del río Uruguay. Revista de la Sociedad Amigos de la Arqueología 12: 148-183.

- 1953c. Alfarería indígena. Hallazgos de trozos de vasijas construidas por los primitivos habitantes del Litoral Uruguayo. Revista de la Sociedad Amigos de la Arqueología 12: 40-49.

\section{Freitas, C. A. de y S. S. Geranio}

- 1938-41. Informe sobre una vasija ornitomorfa del río Negro. Revista de la Sociedad Amigos de la Arqueología 9: 259-270.

\section{Frenguelli, J.}

- 1927a. Nuevo tipo de alfarería indígena ornitomorfa. Boletín de Educación 24, 11 p.

- 1927b. Sobre la posición estratigráfica y la edad de los basaltos del Río Uruguay. Anales de la Sociedad Argentina de Estudios Geográficos. Tomo II (3): 403-424.

- 1939. El Río Uruguay entre "Salto Grande" y "Paso Hervidero" (Apuntes Geológicos y Morfológicos). Anales de la Sociedad Científica Argentina. Tomo 128 (6): 342-368. Buenos Aires.

- 1950. Rasgos generales de la morfología de la Provincia de Buenos Aires. LEMIT. La Plata, Serie II, 33, $72 \mathrm{p}$.

\section{Frenguelli, J. y F. de Aparicio}

- 1923. Los paraderos de la margen derecha del Río Malabrigo (Departamento Reconquista, provincia de Santa Fe). Anales de la Facultad de Ciencias de la Educación, Tomo I, 7-35. Paraná. 
Frère, M. M.

- 2014. Tecnología cerámica de los cazadores-recolectores-pescadores de la microrregión del río Salado, provincia de Buenos Aires. Tesis Doctoral inédita, Facultad de Filosofía y Letras, Universidad de Buenos Aires, Buenos Aires.

Frère, M. M., M. I. González y A. Francese

- 2004. Experimentación y diseño decorativo: primeros ensayos. En La Región Pampeana -su pasado arqueológico-, editado por C. J. Gradín y F. Oliva, pp. 115-121. Laborde Editor, Rosario.

Fried, M. H.

- $\quad$ 1967. The Evolution of Political Society. Random House, New York.

Fúrlong Cárdiff, G.

- 1933. La "Memoria de Diego García (1526-1527). Revista de la Sociedad Amigos de la Arqueología 7: 156-228.

\section{G}

Galván, S. M.; Andreotti, C.; Sbodio, O.; Pastor, R.; y H. Gamero

- 2001. Osteología del Ozotocerus bezoarticus (en soporte digital). Trabajo presentado en el III Congreso de Anatomía Del Cono Sur, XXXVIII Congreso Argentino de Anatomía y XXII Congreso Chileno de Anatomía. Buenos Aires.

Gamble, C.

- 2001. Las sociedades paleolíticas de Europa. Barcelona, Ariel Prehistoria.

Gascue, A.

- 2009a. Tecnología Lítica y Patrones de Asentamiento en la Cuenca de Arroyo Grande (Soriano). En: Arqueología Prehistórica Uruguaya en el Siglo XXI, compilado por JM. López Mazz y A. Gascue, pp 133-150. Biblioteca Nacional - Facultad de Humanidades y Ciencias de la Educación, Montevideo.

- 2009b. Análisis y clasificación de los enterramientos humanos prehistóricos del litoral uruguayo y noreste argentino. En Arqueología Prehistórica Uruguaya en el Siglo XXI, pp 197215, José López Mazz y Andrés Gascue (compiladores), Biblioteca Nacional-Facultad de Humanidades y Ciencias de la Educación, Montevideo.

- 2009c. Análisis y clasificación de los enterramientos humanos prehistóricos del litoral uruguayo y noreste argentino. En Arqueología Prehistórica Uruguaya en el Siglo XXI, pp 197215, José López Mazz y Andrés Gascue (compiladores), Biblioteca Nacional-Facultad de Humanidades y Ciencias de la Educación, Montevideo, 2009.

Gascue, A.; López-Mazz, J. M.; Villarmarzo, E.; d. León, V.; Sotelo, M. y S. Alzugaray

- 2009. La organización de la tecnología lítica de los pobladores tempranos del este de Uruguay. Intersecciones en Antropología 10:63-73.

Gascue, A.; Loponte, D.; Moreno, F.; Bortolotto, N.; Rodríguez, X.; Figueiro, G.; Teixeira de Mello, F. y A. Acosta.

- 2016. Tecnología, subsistencia y cronología del sitio El Cerro, Departamento de Río Negro, Uruguay. Anuario de Arqueología: 8: 113-139.

\section{Gaspary, F.}

- 1945. Las campanas chaná-timbues. Revista Geografía Americana XXIII: 279-282.

- 1947. Una nueva variedad de campana chaná-timbu. Boletín del Departamento de estudios Etnográficos y Coloniales, año 2, II: 59-65. 
- $\quad$ 1950. Investigaciones Arqueológicas y Antropológicas en un Cerrito de la Isla Los Marinos (Pcia. de Entre Ríos). Publicación del Instituto de Arqueología, Lingüística y Folklore 23: 3-66.

Gatto, S.

- $\quad$ 1939. El paradero-cementerio de Brazo Largo (Delta del Paraná). Physis 16: 365-376.

Gentili, C. y H. Rimoldi

- 1979. Mesopotamia. II Simposio de Geología Regional Argentina. Academia Nacional de Ciencias de Córdoba. Tomo I, pág. 185-223. Córdoba.

Ghiani Echenique, N.; Uvietta, A. R. y R. Gambaro

- 2013. Alfarerías tubulares en el noreste de la provincia de Buenos Aires: caracterización y distribución. Revista del Museo de La Plata 13 (87): 287-302.

\section{Gianotti G., C.}

- 2000. Monumentalidad, ceremonialismo y continuidad ritual. En C. Gianotti (ed.), Paisajes Culturales Sudamericanos: de las prácticas a las representaciones. TAPA 19: 81-102. Santiago de Compostela: Laboratorio de Arqueología y Formas Culturales.

- 2015. Paisajes sociales, monumentalidad y territorio en las tierras bajas de Uruguay. Tesis doctoral inédita. Facultade de Xeografía e Historia. Universidade de Santiago de Compostela.

Gianotti, C. y M. Bonomo

- 2013. De montículos a paisajes: procesos de transformación y construcción de paisajes en el sur de la Cuenca del Plata. Comechingonia. Revista de Arqueología 17:59-94.

\section{Gianotti, C. y J. M. López Mazz}

- 2004. Intensificación ceremonial y prácticas mortuorias en la localidad arqueológica Rincón de los Indios. En L. Beovide; I. Barreto y C. Curbelo (eds.), La Arqueología Uruguaya ante los desafíos del Nuevo Siglo. CD-ROM, Montevideo, Uruguay.

Gibbs, P. y J. Semir

- 2003. A taxomnomic revisión of the genus Ceiba Mill. (Bombacacae). Anales jardín botánico de Madrid 60(2): 259-300.

\section{Goldstein, L.}

- $\quad$ 1995. Landscapes and mortuary practices: a case for regional perspectives. En L. A. Beck (ed.), Regional approaches to mortuary analysis. pp. 101-121. Plenum Press, New York.

\section{Gonzaga de Campos, L. F.}

- 1889. Relatorio da Comissao Geográfica da Provincia de Sao Paulo. Sección Geológica 21-34. Sao Paulo.

\section{González, A. R.}

- $\quad$ 1947. Investigaciones arqueológicas en las nacientes del Paraná Pavón. Universidad Nacional de Córdoba.

- 1953. La boleadora. Sus áreas de dispersión y tipos. Revista del Museo de la Universidad Eva Perón 4 (ns), Sección Antropología: 133-292.

- 1977. Arte precolombino de la Argentina. Introducción a su historia cultural. Imprenta Coni, Buenos Aires.

- 1991-1992. A cuatro décadas del comienzo de una etapa. Apuntes marginales para la historia de la antropología argentina. Runa 20: 91-110.

\section{González, A. R. y A. M. Lorandi}

- 1959. Restos arqueológicos hallados en las orillas del Río Carcaraña, Provincia de Santa Fe. Revista del Instituto de Antropología 1. Rosario 


\section{González, M. I.}

- 2002. Los cazadores-recolectores-pescadores de la cuenca inferior del Río Salado (Región Pampeana). Tesis Doctoral Inédita, Facultad de Filosofía y Letras. Universidad Nacional de Buenos Aires.

- 2005. Arqueología de alfareros, cazadores y pescadores pampeanos. Sociedad Argentina de Arqueología. 336 p.

González Ruibal, A.; Hernando, A. y G. Politis

- 2013. Ontologia da pessoa e cultura material: manufatura de flechas entre os caçadorescoletores Awá. En A. Hernando y E. M. Beserra Coelho (Orgs.), Estudos sobre os Awá: caçadores - coletores em transição. pp. 91-130. Editorial EDUFMA/IWGIA. São Luís.

\section{Goody, J.}

- $\quad$ 1995. Cocina, cuisine y clase. Estudio de sociología comparada. Buenos Aires. Gedisa.

\section{Goso, C. y D. Perea.}

- 2004. El Cretácico post-basáltico y el Terciario Inferior de la Cuanca litoral del río Uruguay: geología y paleontología. En: Veroslavsky G., Ubilla M. y S. Martinez (eds.): Cuencas sedimentarias de Uruguay. Geología, paleontología y recursos naturales. Mesozoico. pp. 143171. 2a edición, DIRAC, Facultad de Ciencias, Montevideo.

Gosselain, O. P.

- 1998. Social and Technical Identity in a Clay Crystal Ball. En The Archaeology of Social Boundaries, editado por M. T. Stark, pp. 78-106. Smithsonian Institution Press, Washington D.C.

- 1999. In Pots We Trust. The Processing of Clay and Symbols In Sub-Saharan Africa. Journal of Material Culture 4 (2): 205-230.

- 2000 Materializing Identities: An African Perspective. Journal of Archaeological Method and Theory 7 (3): 187-217.

\section{Grayson, D.}

- 1984. Quantitative Zooarchaelogy. Academic Press. New York.

\section{Gregori, M. A.}

- 1968. Observaciones arqueológicas en la cuenca entrerriana del río Uruguay. Revista Ser 7: 85117.

Greslebin, H. R.

- 1931a. La estructura de los túmulos indígenas prehispánicos del departamento de Gualeguaychú provincia de Entre Ríos, República Argentina. Revista de la Sociedad de Amigos de la Arqueología 5: 5-51.

- 1931b. Dos vasos indígenas hallados en Puerto Basilio (provincia de Entre Ríos). Solar I: 161179.

Guichón, R. A.; A. S. Muñoz y L. A. Borrero

- 2000. Datos para una tafonomía de restos óseos humanos en Bahía San Sebastián, Tierra del Fuego. Relaciones de la Sociedad Argentina de Antropología 25: 297-312.

\section{Guida, N. y M. González}

- 1984. Evidencias paleoestuáricas en el sudeste de Entre Ríos, su evolución con niveles marinos relativamente elevados del Pleistoceno Superior y Holoceno. IX Congreso Geológico Argentino. Acta III., pp. 577-594. San Carlos de Bariloche.

\section{Guidens, A.}

- 1979. Central Problems in Social Theory: Action, Strucure and Contradiction in Social Analysis. University of California Press. Los Angeles- Berkeley.

- $\quad$ 1984. La construccion de la sociedad. Amorrotu, Buenos Aires. 
- $\quad$ 1995. Politics, Sociology and Social Theory: Encounters with Classical and Contemporary Social Thought. Cambridge.

\section{Guidón, N.}

- 1977. Resultados preliminares de la Misión de Rescate Arqueológico de Salto Grande Campaña 1977. V Encuentro de Arqueología del Litoral: 188-200. Fray Bentos. Uruguay.

- 1989. Misión de Rescate Arqueológico de Salto Grande, República Oriental del Uruguay, Tomo 1, 2 y 3, En archivo de la Comisión del Patrimonio, Ministerio de Educación y Cultura, Montevideo.

\section{Gutiérrez, M. A.}

- 2004. Análisis tafonómicos en el área interserrana [provincia de Buenos Aires. Tesis doctoral inédita. Facultad de Ciencias Naturales y Museo. Universidad Nacional de La Plata.

- 2006. Efectos, agentes y procesos tafonómicos en el área interserrana bonaerense. Relaciones de la Sociedad Argentina de Antropología 31: 201-228.

\section{Gutiérrez Zugasti, F. I.}

- 2008. La explotación de moluscos y otros recursos litorales en la región cantábrica durante el Pleistoceno final y el Holoceno inicial. Tesis doctoral inédita. Departamento de Ciencias Históricas Universidad de Cantabria.

\section{H}

\section{Heckenberger, M. J. y E. G. Neves}

- 2009. Amazonian Archaeology. Annual Review of Anthropology 38: 251-266.

\section{Heckenberger, M.J.; Russell, J.C.; Toney, J.R. y M.J. Schmidt}

- $\quad$ 2007. The legacy of cultural landscapes in the Brazilian Amazon: implications for biodiversity. Philosophical Transactions of the Royal Society B - Biological Sciences 362: 197-208.

\section{Herbst, R.}

- $\quad$ 1971. Esquema estratigráfico de la provincia de Corrientes, República Argentina. Revista de la Asociación Geológica Argentina 26(2): 221-243.

\section{Herbst, R.; Santa Cruz, J. N. y L. L. Zabert}

- 1976. Avances en el conocimiento de la estratigrafía de la Mesopotamia Argentina, con especial referencia a la provincia de Corrientes. Revista de la Asociación de Ciencias Naturales del Litoral 7: 101-121.

\section{Hermo, D. 0.}

- 2008. Los cambios en la circulación de las materias primas líticas en ambientes mesetarios de Patagonia. Una aproximación para la construcción de los paisajes arqueológicos de las sociedades cazadoras-recolectoras. Tesis Doctoral inédita. Facultad de Ciencias Naturales y Museo, Universidad Nacional de La Plata, La Plata.

Herrmann, E. W.; Monaghan, G W.; Romain, W. F.; Schilling, T. M.; Burks, J.; K. L. Leone; Purtill, M. P. and A. C. Tonetti.

- 2014. A new multistage construction chronology for the Great Serpent Mound, USA. Journal of Archaeological Science 50: 117-125.

Hilbert, $\mathbf{K}$.

- $\quad$ 1985. Sitios arqueológicos de los ríos Uruguay, Tigre y Mandiyú. Beitfrage Zur Allegemeinen and Verrgleichenden Archaeologie 7: 447-561.

- $\quad$ 1986. Kupferschmuck vom Río de la Plata. Marburger studien zur vor-und fruhgeschichte. Band 7: 82-90. 
- 1990. Die keramik der fundplátze am Tigre, Río Uruguay, Rep. Uruguay. Beitfrage Zur Allegemeinen and Verrgleichenden Archaeologie 9-19: 381-392

- 1991. Aspectos de la Arqueología en el Uruguay. Mainz am Rhein: von Zabern, Materialien zur allgemeinen und vergleichenden Archäologie, $44 \mathrm{p}$.

Hilbert, P. P.

- 1955. A cerámica arqueológica de Oriximiná. Publicacao do Intituto de Antropología e Etnología do Pará. Museu Goeldi, Belém.

\section{Hocsman, $\mathbf{S}$.}

- 1999a. Tecnología lítica prehispánica en la cuenca inferior del arroyo Las Conchas (Depto. de Paraná, Pcia. de Entre Ríos): El sitio VU 4 como caso de estudio. Trabajo final de la Carrera de Arqueología, Facultad de Ciencias Naturales e Instituto Miguel Lillo, Universidad Nacional de Tucumán, Tucumán.

- 1999b. Aprovisionamiento de materias primas líticas en el Paraná Medio Prehispánico. En C. Aschero; A. Korstanje y P. Vuoto (eds.), Los Tres Reinos: Prácticas de recolección en el Cono Sur de América. pp. 39-49. Universidad Nacional de Tucumán.

- 2006. Producción lítica, variabilidad y cambio en Antofagasta de la Sierra - ca. 5500-1500 ap-. Tesis Doctoral inédita. Facultad de Ciencias Naturales y Museo, Universidad Nacional de La Plata.

- 2007. Características tecnológicas y tipológicas de puntas de proyectil de la cuenca del río Gualeguay (departamento Villaguay, provincia de Entre Ríos). Anexo II del Informe Final del Programa Identidad Entrerriana CFI "Identidad y patrimonio en el centro de Entre Ríos: aportes arqueológicos y antropológicos para la comprensión de los procesos históricos en eldepartamento. Villaguay: la etnia Charrua- Minoano.". pp 87-121. Paraná. Ms.

- 2015. Caracterización petrográfica y calidades de areniscas (margen entrerriana del Paraná medio). Revista de Antropología del Museo de Entre Ríos 1 (1): 1-11.

\section{Hodder, I.}

- 1982. Toward a Contextual Approach to Prehistoric Exchange. En Contexts for Prehistoric Exchange, J. Ericson y T. Earle (eds.), pp.199-211. Academic Press, New York.

\section{I}

lbáñez, F. M.

- $\quad$ 1962. Vegetación de la provincia de Entre Ríos. Nordeste 4: 93-127.

- 1963. Evolución de la cartografía de Entre Ríos. Revista Presencia 1: 1-15. Paraná.

Ibarra Grasso, D. E.

- 1967. Argentina indígena y prehistoria Americana. Tipográfica Editora Argentina. Ingold, T.

- 1986 The Appropriation of Nature. Essays of Human Ecology and Social Relations. Manchester University Press. Manchester.

- 1990. Society, Nature and the concept of Technology. Technologie in the Humanities. Archaelogica review from Cambridge 9 (1): 5-17.

- 1993. The temporality of the landscape. World archaeology 25 (2): 152-174.

INTA

- 2002. Carta de Suelos de la República Argentina. Departamento Colón. Plan Mapa de Suelos (Acuerdo complementario del Convenio INTA-Gobierno de Entre Ríos). Estación Experimental Agropecuaria Paraná. Serie de Relevamientos de Recursos Naturales № 21. Ediciones INTA. 
Iriarte, J.

- 1995. Análisis de los desechos de talla del Sitio S 5-42. En Arqueología en el Uruguay: 120 años después. Actas del VIII Congreso Nacional de Arqueología Uruguaya: 162-171. Maldonado, Uruguay.

- 2001. Arqueología de las culturas cerámicas del Río Uruguay Medio: retrospectiva y futuras direcciones. Arqueología Uruguaya hacia el fin del Milenio. Tomo I: 355-363. Montevideo, Uruguay.

- 2006 Landscape Transformation, Mounded Villages and Adopted Cultigens: The Rise of Early Formative Communities in South-Eastern Uruguay. World Archaeology 38: 644-663.

Iribarne, E. A.

- 1937. Algunos vasos indígenas de las márgenes del Paraná inferior. Relaciones de la Sociedad Argentina de Antropología 1: 181-190.

Iriondo, M. $\mathbf{H}$.

- 1980a. El Cuaternario de Entre Ríos. Revista Asociación Ciencias Naturales Litoral 11: 125-141. Santa Fe.

- 1980b. Esquema evolutivo del Delta del Paraná durante el Holoceno. Resúmenes del Simposio sobre problemas geológicos del litoral bonaerense: 73-88. Mar del Plata.

- 1991. El Holoceno en el litoral. Comunicaciones del Museo Provincial de Ciencias Naturales Florentino Ameghino. (Nueva Serie) 3 (1): 1- 40. Santa Fe.

- 2004. The littoral complex at the Paraná mouth. Quaternary International 114: 143-154.

Iriondo, M. H. y L. Altamirano

- 1988. Delta del Paraná. Guía de campo № 1. Simposio Internacional sobre el Holoceno de América del Sur, INQUA- CADINQUA; 13 pp. Paraná. Entre Ríos.

Iriondo, M. H. y C. N. Ceruti

- 1981. Las unidades geomorfológicas fluviales del extremo noroeste de Entre Ríos y su relación con los asentamientos humanos prehispánicos. Revista Asociación Ciencias Naturales Litoral 12: 72-84. Santa Fe.

Iriondo, M. H., Ceruti, C. N. y R. Tardivo

- 1985. Geomorfología y Cuaternario en el tramo inferior del arroyo Feliciano. Revista Asociación Ciencias Naturales Litoral 16: 149-156. Santa Fe.

Iriondo, M. H. y D. M. Kröhling

- 1995. El Sistema Eólico Pampeano. Comunicaciones del Museo Provincial de Ciencias Naturales "Florentino Ameghino". (Nueva Serie), 5 (1): 1 - 68. Santa Fe.

- 2007. La Formación El Palmar (informalmente Salto Chico) y el acuífero San Salvador, Entre Ríos. V Congreso Argentino de Hidrología: 433-441. Paraná.

- 2009. Cambios Ambientales en la cuenca del Río Uruguay. Desde dos millones de años hasta el Presente. Universidad Nacional del Litoral. 360 p. Santa Fe.

Iriondo, M. H., Tardivo R. y C. N. Ceruti

- 1985. Geomorfología y Cuaternario en el tramo inferior del arroyo Feliciano. Revista Asociación Ciencias Naturales Litoral 16 (2): 149-156. Santa Fe.

\section{J}

Judge, W. J.; J. I. Ebert y R. K. Hitchcock

- 1979. Sampling in Regional Archaeological Survey. En J. W. Mueller (ed.), Sampling in Archaeology. pp. 82-123. Segunda edición. The University of Arizona Press, Tucson, Arizona. 
Kelly, R.

- 1992. Mobility/sedentism: Concepts, archaeological measures and effects. Annual Review of Anthropology, 21: 43- 66.

- 1995. The foraging spectrum. Diversity in hunter-gatherer lifeways. Smithsonian Institution Press, Washington-Londres.

Kozameh, L.

- 2009. Un ejemplo de dentistería prehistórica en un resto humano del Delta del Paraná. En: Arqueología Argentina en los inicios de un nuevo siglo II, editado por Fernando Oliva, Nélida de Grandis y Jorge Rodríguez, pp. 59-65. Universidad Nacional de Rosario, Rosario.

Krapovickas, P.

- 1957. Excursión arqueológica a Rincón de Landa. Revista Geográfica Americana Vol. 41, n²45: 149-156.

Kuhn, S.

- 1994. A formal approach to the design and assembly of mobile toolkits, American Antiquity 59: 426-442.

\section{$\mathbf{L}$}

\section{La Salvia, F. y J. P. Brochado}

- 1989. Cerâmica guaraní. Posenato Arte e Cultura, Porto Alegre.

Lafon, C. R.

- 1968. Investigaciones arqueológicas en el Nordeste argentino. La Prensa, 8 de diciembre de 1968.

- 1971. Introducción a la arqueología del nordeste argentino. Relaciones de la Sociedad Argentina de Antropología V (2): 119-152.

- $\quad$ 1972. El replanteo para la arqueología del nordeste argentino. Antiquitas 14: 1-16.

Laforcada, G. y J. Ambrosoni

- 1980. Informe preliminar sobre las investigaciones arqueológicas realizadas en los yacimientos del río Uruguay. III Congreso Nacional de Arqueología y IV Encuentro de Arqueología del Litoral. Montevideo, Uruguay.

Laguardia Trías, $\mathbf{R}$.

- 1973. El Predescubrimiento del Río de La Plata por la expedición portuguesa de 1511-1512. Lisboa.

\section{Lambert, $\mathbf{R}$.}

- 1939. Memoria explicativa del mapa geológico de los terrenos sedimentarios y rocas efusivas del departamento de Durazno. Boletín del Instituto geológico del Uruguay 25: 1-37. Montevideo.

Lanzelotti, S.; Politis G. G.; Carbonari, J. E.; Huarte, R. y J. F. Bonaparte

- 2011. Aportes a la cronología del Sitio 1 de Cañada Honda (partido de Baradero, provincia de Buenos Aires). Intersecciones en Antropología 12: 355-361.

Laporte, L.

- 2014. Estudio del ajuar funerario de los entierros humanos. En: Estado actual de las investigaciones en el sitio arqueológico Arroyo Seco 2 (Partido de Tres Arroyos, Provincia de 
Buenos Aires, Argentina). Politis G. G.; Gutiérrez M. A. y C. Scabuzzo (eds.). Serie Monográfica Número 5, INCUAPA-CONICET, UNICEN. pp. 393-415. Buenos Aires.

\section{Larguía de Crouzeilles, A.}

- 1936. Datos arqueológicos sobre paraderos indígenas de Santa Fe (Isla del Periquillo, Helvecia y Sauce Viejo). Anales de la Sociedad Científica Argentina 122(E4): 22-30.

\section{Lathrap, D, W.}

- 1973. The antiquity and importance of long-distance trade ralationships in the moist tropics of Pre-Columbian South America. World Archaelogy 5(2): 170-186.

\section{Leguizamón, $M$.}

- 1903. La Selva de Montiel. Estudio histórico-geográfico presentado a la Junta de Historia y Numismática Americana.

- 1919. Etnografía del Plata. El origen de las boleadoras y el lazo. R. U. LI. 53 p.

- 1935. La cuna del gaucho. Buenos Aires

\section{Lehmann-Nitsche, $\mathbf{R}$.}

- 1909. Hachas y placas para ceremonias procedentes de Patagonia. Revista del Museo de La Plata XVI (SS III): 204-240.

Lemes, $\mathbf{P}$.

- 2013. Contame, Don Manuel, una vez más... Una mirada personal sobre los textos publicados por Manuel Almeida. 360 p. Editorial Birkat Elohym.

Lemonnier, $P$.

- 1976. La description des chaînes opératoires: contribution a l'analyse des systemes techniques. Techniques et Cultures 1: 101-150.

- 1992. Elements for an Anthropology of Technology. Anthropological Papers N88, Museum of Anthropology, University of Michigan. Ann Arbor, Michigan.

\section{Leroi Gourham, A.}

- 1964. Le geste et la parole. Albin Michel. Paris.

\section{Letieri, F. C. y A. Alonso}

- 2004. Aspectos tecnológicos presentes en el proceso de producción cerámica: sitio Bajada Guereño, ciudad de Villa Gobernador Gálvez, provincia de Santa Fe. En: La Región Pampeana -su pasado arqueológico-, editado por Carlos Gradín y Fernando Oliva, pp. 321-335. Universidad Nacional de Rosario, Rosario, Argentina.

\section{Letieri, F. C.; Cocco, G.; Frittegotto, G. e I. Sánchez Pinto}

- 2015. El fuerte Sancti Spiritus. El primer asentamiento europeo en el actual territorio argentino. Revista Ciencia Hoy 24, n 142: 13-18.

\section{Linné, $\mathbf{S}$.}

- 1932. Contribution á I Estude de la Céramique Sudaméricaine. Revista del Instituto de Ethnología 2: 199-232. Tucumán.

- 1965. The ethnologist and the American indian potter. En F. R. Matson (ed.), Ceramics and man. pp. 20-42.

Lista, R.

- 1878. Los cementerios y paraderos Minuanes de la provincia de Entre Ríos. Revista de Antropología, Tomo I. En Obras de Ramón Lista, Tomo I (1877-1886). 1998: 35-38. Buenos Aires.

- $\quad$ 1885. El hombre primitivo. Revista de la Sociedad Geográfica Argentina 3: 193-199.

\section{Lluch, J. J. y L. Spalletti}

- 1976. Minerales de arcillas en los sedimentos actuales de la región del cerro San Lorenzo, provincia de Santa Cruz. Revista de la Asociación Geológica Argentina 31: 23-32. 
López, H. L.

- 2001. Estudio y uso sustentable de la Biota Austral: Ictiofauna Continental Argentina. Revista Cubana Investigación. Pesq. (supl. Especial versión electrónica). SIN CUB 0138-8452.

López, H. L; Miquelarena, A. M. y J. Ponte Gómez

- 2005. Biodiversidad y distribución de la Ictiofauna Mesopotámica. Serie Miscelánea. INSUGEOCONICET 14: 311- 353. Tucumán. Argentina.

López Mazz, J. M.

- 1992. Aproximación a la génesis y desarrollo de los cerritos de la zona de San Miguel (Departamento de Rocha). En Ediciones Quinto Centenario, Universidad de la Republica, editado por Renzo Pi: 75-96. Montevideo.

- 2001. Las estructuras tumulares (cerritos) del litoral atlántico uruguayo. Latin American Antiquity 12(3): 231-255.

López Mazz, J. M. y D. Bracco

- 2010. Minuanos. Apuntes para la arqueología e historia del territorio guenoa-minuan. Montevideo, Linardi y Risso. $350 \mathrm{p}$.

López Mazz, J. M.; Buffa, V.; De León, V. y C. Cancela

- 2014. La localidad histórico arqueológica del Río San Salvador (Soriano, Uruguay). Revista del Museo de Antropología 7 (2): 285-292.

López Mazz, J.M. y C. Castiñeira

- 2001. Estructura de sitio y patrón de asentamiento en la Laguna Negra (Depto. De Rocha). Arqueología Uruguaya hacia el fin del Milenio. Tomo I: 147-161. Montevideo, Uruguay.

Loponte, D.

- 2004. Atlas Osteológico de Blastocerus dichotumus (Ciervo de los pantanos). Ed Los Argonautas. Buenos Aires.

- 2008. Arqueología del Humedal del Paraná Inferior (Bajíos Ribereños Meridionales). Asociación Amigos del Instituto Nacional de Antropología y Pensamiento Latinoamericano, Buenos Aires.

Loponte, D. y A. Acosta

- 2007. Horticultores amazónicos en el Humedal del Paraná Inferior: los primeros datos isotópicos de la dieta. En Arqueología en las pampas, Tomo I, pp. 75-93. Editado por Cristina Bayón, Alejandra Pupio, María I. González, Nora Flegenheimer y Magdalena Frère, Sociedad Argentina de Antropología, Buenos Aires.

Loponte, D., A. Acosta, I. Capparelli y M. Pérez.

- 2011b. La arqueología guaraní en el extremo meridional de la cuenca del Plata. En D. Loponte y A. Acosta (eds.) Arqueología Tupiguaraní. Buenos Aires: Instituto Nacional de Antropología y Pensamiento Latinoamericano.

Loponte, D.; Acosta, A. y L. Mucciolo.

- 2012. Contribución a la arqueología del delta del Paraná: el nivel acerámico del sitio Isla Lechiguanas I. Comechingonia. Revista de Arqueología 16: 229-268.

\section{Loponte D. y M. J. Corriale}

- 2013. Isotopic values of diet of Blastocerus dichotomus (marsh deer) in Paraná Basin, South America. Journal of Archaeological Science 40: 1382-1388.

Loponte, D.; Ottalagano, F. Acosta, A.; Bertolotto, N. Gascue, A. Viglioco, D. y R. Boretto

- 2016. Avances en la arqueología del Bajo Río Uruguay: El sitio La Yeguada, Departamento de Río Negro (Uruguay). Tessituras, v. 4, n. 1: 8-52. Pelotas

Loponte, D., R. Sacur Silvestre y P. Tchilinguirián

- 2011a. Caracterización de afloramientos de calizas silicificadas de la provincia de Entre Ríos (Argentina) y su vinculación con los circuitos de abastecimiento prehispánico. En: Ma. R. 
Feuillet Terzaghi, M. R.; Colasurdo, M. B.; Sartori. J. I. y S. Escudero (eds.), Avances y perspectivas en la Arqueología del Nordeste. pp. 125-140. Santo Tomé.

\section{Lorentz, P. G.}

- $\quad$ 1878. La vegetación del Nordeste de la provincia de Entre Ríos. Comisión Municipal de Cultura y Museo de Entre Ríos, 1947. 187 p.

\section{Lothrop, $\mathrm{S}$.}

- 1928. The Indians of Tierra del Fuego. New York, Museum of the American Indian Heye Foundation.

- $\quad$ 1932. Indians of the Paraná Delta, Argentina. Annals of the New York Academy of Science 2: 77-232.

Lutz, A.

- 1984. Palmoxylon concordiensis n. sp. del Plioceno de la provincia de Entre Ríos, República Argentina. Actas del 3o Congreso Argentino de Paleontología y Bioestratigrafía 3: 129-140. Buenos Aires.

Lyman, R. L.

- 1994. Vertebrate Taphonomy. Cambridge Manuals in Archaeology. Cambridge Universisty Press. Cambridge.

- 2008. Quantitative Paleozoology. Cambridge Manuals in Archaeology Series. New York: Cambridge University Press. Cambridge.

\section{M}

\section{Machado, 0.}

- 1947. Contribución á I esude de la faune du brésil. Nuuvelle espece de spongiaire fluvial: Turbella melloleitaoi. Bulletin de la Socienté Zoologique de France 72(1): 133-135.

\section{Marconetto, M. B.}

- 2008. Recursos forestales y el proceso de diferenciación social en tiempos prehispánicos. Valle de Ambato, Catamarca. Oxford: BAR South American Archaeology Series $\mathrm{n}^{\circ} 3$.

\section{Márquez Miranda, $\mathbf{F}$.}

- 1932. La navegación primitiva y las canoas monóxilas. Revista del Museo de La Plata 9: 57-87.

Martínez, B. T.

- 1900-1901. Historia de la provincia de Entre Ríos, Tomo I. Bueno Aires.

\section{Martínez, S. y C. Del Río}

- 2005. Las Ingresiones marinas del Neógeno en el sur de Entre Ríos (Argentina) y Litoral Oeste de Uruguay y su contenido malacológico. En: F. G. Aceñolaza (Coordinador), Temas de la Biodiversdiad del litoral fluvial argentino II, Miscelánea INSUGEO 14: 13-26. Tucumán.

\section{Martínez, G.; C. Landini y M. Bonomo}

- 1997-1998. Análisis de los artefactos líticos del sitio Paso Otero 3: una aproximación al entendimiento de la organización de la tecnología lítica en el curso medio del río Quequén Grande. Publicaciones de Arqueología 49: 3-22.

\section{Maruca Sosa, R.}

- 1957. La Nación Charrúa. Editorial Letras. Montevideo.

\section{Matarrese, A. B.}

- 2015a. Tecnología lítica entre los cazadores-recolectores pampeanos; los artefactos formatizados por picado y abrasión y modificados por uso en el Área Interserrana Bonaerense. 
Tesis Doctoral inédita. Facultad de Ciencias Naturales y Museo, Universidad Nacional de La Plata, La Plata.

- 2015b. Tecnología lítica prehispánica en el Delta del Paraná: Los artefactos picados y/o abradidos. Trabajo presentado en el VI Encuentro de Discusión Arqueológica del Nordeste Argentino. Gualeguaychú, Entre Ríos.

- 2016. Informe: Artefactos picados y/o abradidos de la localidad arqueológica Cerro de Boari (Dto. Gualeguaychú, provincia de Entre Ríos). Ms.

Maura, J. F.

- 2007. Carta de Luis Ramírez a su padre desde el Brasil (1528): orígenes de lo "real maravilloso" en el Cono Sur. Edicición, Introd. y notas de Juan Francisco Maura. Col. Textos de la revista Lemir. 2007. Edición electrónica: http://parnaseo.uv.es/Lemir/Textos/Ramirez.pdf.

\section{Mayntzhusen, $\mathrm{F}$.}

- 2009. Los Aché Guayakí. Junta de Estudios Históricos de Misiones. Posadas, Misiones, Argentina.

\section{Mazza, B.}

- 2010a Cerro Lutz: Aproximaciones al estudio de las prácticas mortuorias de las sociedades cazadoras recolectoras del humedal del Paraná inferior. La Zaranda de Ideas, Revista de Jóvenes Investigadores en Arqueología 6: 91-116.

- 2010b Avances en el conocimiento de los entierros secundarios del humedal del Paraná inferior. En J. R. Bárcena y H. Chiavazza (eds.), Arqueología Argentina en el Bicentenario de la Revolución de Mayo. Actas del XVII Congreso Nacional de Arqueología Argentina II: 665-669, UNC-INCIHUSA, Mendoza.

Mazza, B. y D. Loponte

- 2012. Las prácticas mortuorias en el humedal del Paraná inferior. Arqueología Iberoamericana 13: 3-21.

Melgar, W.; Rodríguez, O. y J. Femenías

- 1975. Comunicación preliminar sobre el material lítico descubierto en las Isla de Arriba (Salto Grande, Uruguay). Segundo Congreso Nacional de Arqueología y Tercer Encuentro de Arqueología del Litoral Volumen II: 289-318. Río Negro, Uruguay.

\section{Meneghin, $U$.}

- 2005. Yacimientos arqueológicos tempranos del Uruguay. Orígenes 3: 1-24.

\section{Menghin, O. F. A.}

- 1955-1956. El Altoparanaense. Ampurias XVII-XVIII: 171-200.

- 1956. El poblamiento prehistórico de Misiones. Anales de Arqueología y Etnología XII: 19-40.

- 1957. Das Protolitikum in Amerika. Acta Praehistorica, 1: 5-40.

\section{Mengoni Goñalons, G.}

- 1986. El estudio de huellas en arqueofaunas. Una vía para reconstruir situaciones interactivas en contextos arqueológicos: Aspectos teórico-metodológicos y técnicas de análisis. De procesos, contextos y otros huesos: 17-28. A. Haber y N. Ratto (eds.). Facultad de Filosofía y Letras, UBA.

- 1988. Análisis de los Materiales Faunísticos de los Sitios Arqueológicos. XAMA 1: 71-120. Mendoza

- 1999. Cazadores de guanacos de la estepa patagónica. Sociedad Argentina de Antropología, Buenos Aires. 


\section{Métraux, A.}

- 1934. El estado actual de nuestros conocimientos sobre la extensión primitiva de la influencia guaraní y arawak en el continente sudamericano. Actas y Trabajos Científicos del XXV Congreso Internacional de Americanistas I: 181- 190. La Plata, Universidad Nacional de La Plata.

\section{Migale, L. A. y J. F. Bonaparte}

- 2008. Arqueología de Cañada Honda y Río Areco. Baradero. Buenos Aires. Museo Municipal de Ciencias Naturales "Carlos Ameghino". Fondo Editorial Mercedes, Buenos Aires. 42 p.

Miller, E.

- 1976. Resultados preliminares das pesquisas arqueológicas paleoindígenas no Rio Grande do Sul, Brasil. Actas del XLI Congreso Internacional de Americanistas. Chiaramonte, J. C. (ed.), Instituto Nacional de Antropología y Historia de México, Vol.3: 484-491.

- 1987. Pesquisas arqueológicas paleoindígenas no Brasil ocidental. Estudios Atacameños 8: $37-$ 61.

Miotti, L.

- 1995. Piedra Museo locality: a special place in the New World. Current Research in the Pleistocene 12: 36-38.

Miotti L. y M. Salemme

- 1989. De fracturas óseas modernas y arqueológicas: una hipótesis alternativa. CEIDER 2: 4148.

Miotti, L. y E. Terranova

- 2015. A hill full of points in Terra Incognita from Patagonia: notes and reflections for discussing the way and tempo of initial peopling. PaleoAmerica 1(2): 181-196.

\section{Molinari, R. y P. Cansanello}

- 1992. Recursos Culturales en el Parque Nacional El Palmar. Informe Interno. APN. MS.

\section{Mollerach, M. I. y I. L. Ferro.}

- 2008. Comentarios sobre algunas especies de mamíferos del Litoral Argentino. Temas de la Biodiversidad del Litoral III INSUGEO, Miscelánea, 17(2): 467-488. F.G. Aceñolaza (Coordinador-Editor) Tucumán.

\section{Mondini, M.}

- 2003. Formación del registro arqueofaunístico en abrigos rocosos de la Puna argentina. Tafonomía de carnívoros. Tesis Doctoral inédita. Facultad de Filosofía y Letras, Universidad de Buenos Aires, Buenos Aires.

\section{Montero Zorrilla, P.}

- 1978. Noticia sobre dos piezas de alfarería zoomorfa. Revista de la Sociedad Amigos de la Arqueología 17: 111-114.

\section{Montón Subías, $\mathbf{S}$.}

- 2005. Las prácticas de alimentación: cocina y arqueología, En M. Sánchez-Romero (ed) Arqueología y Género. Granada. Universidad de Granada.

Moran, E. F.

- 1982. Human Adaptability: An Introduction to Ecological Anthropology. Westview Press, Boulder. Westview.

\section{Mujica, J. I.}

- 1994. Prospecciones arqueológicas en el área de inundación de la represa Yaciretá en el territorio de la provincia de Corrientes. XIV Encuentro de Geohistoria Regional: 299-314. Resistencia.

- 1995a. De Corrientes Argentina. Informe de dos sitios arqueológicos guaraní en la provincia. XV Encuentro de Geohistoria Regional. Gdor. Virasoro. 8-9 de septiembre. 119-128. 
- 1995b. Un sitio guaraní en el centro de la provincia de Corrientes.- Llamarada- Sta. Rosa. Depto. de Concepción. XV Encuentro de Geohistoria Regional. Gdor. Virasoro. 8 y 9 de septiembre. 135-148.

- 1996. Aproximación a la caracterización de los sitios arqueológicos en los Esteros Batel en la provincia de Corrientes. XVI Encuentro de Geohistoria Regional: 393-400. Resistencia.

- 2000. Informe de sitios arqueológicos en el centro de la provincia de Misiones - Municipio de San Vicente. XX Encuentro de Geohistoria Regional II: 653-660. Resistencia.

Muñiz, F. J.

- 1925. Noticia sobre las islas del Paraná. Publicaciones del Instituto de Investigaciones Geográficas 9: 3-25.

Muñoz P., E.

- 1968. Los primitivos habitantes del Uruguay. El mundo indígena, Enciclopedia Uruguaya. Uruguay. $20 \mathrm{p}$

Muñoz, J. D.; Milera, S.; Romero, C. y A. B. Brizuela

- 2005. Bosques Nativos y Selvas Ribereñas en la Provincia de Entre Ríos. Serie Miscelánea. INSUGEO-CONICET 14: 169-182. Tucumán. Argentina.

\section{$\mathbf{N}$}

Nami, H. G.

- 1991. Desechos de talla y teoría de alcance medio: un caso de Península Mitre, Tierra del Fuego. Shincal 3 (2): 94-112.

- 1992. El subsistema tecnológico de la confección de instrumentos líticos y la explotación de los recursos del ambiente. Shincal 2: 33-53.

- 2007. Research in the Middle Negro River Basin (Uruguay) and the Paleoindian occupation of the Southern Cone. Current Anthropology 48(1): 164-174.

- 2011. Tecnología paleoindia de Sudamérica: nuevos experimentos y observaciones para investigar la secuencia de reducción Fell. Orígenes 9. Fundación Arqueología Uruguaya, Montevideo.

\section{Nami, H. G. y J. Rabassa}

- 1988. Experimentos, petrografía y confección de instrumentos de piedra con ignimbritas Pilcaniyeu. Observaciones para el conocimiento de las sociedades del pasado. Revista de Estudios Regionales, 2: 131-149.

\section{Neves G., E.}

- 2006. Arqueologia da Amazônia. Rio de Janeiro: Jorge Zahar. 86 p.

- 2007. El Formativo que nunca terminó: la larga historia de la estabilidad en las ocupaciones humanas de la Amazonía Central. Boletín de Arqueología PUCP 11: 117-142.

- 2008. Ecology, Ceramic Chronology and Distribution, Long-Term History and Political Change in the Amazonian Floodplain. In Silverman, H. I. and W. H. Isbell (eds.), Handbook of South American Archaeology. pp 359-379; Nueva York.

- 2011. El nacimiento del "Presente Etnográfico": la emergencia del patrón de distribución de sociedades indígenas y familias lingüísticas en las tierras bajas sudamericanas, durante el primer milenio D. C. En J. P. Chaumeil (ed.), Por donde hay soplo: Estudios amazónicos en los países andinos. pp 39-65. Editorial Lima: Instituto Francés de Estudios Andinos. 


\section{Neves G., E. y P. Petersen}

- 2006. Political Economy and Pre-Columbian Landscape Transformations in Central Amazonia. In Balée W. and C. Erickson (eds.), Time and Complexity in Historical Ecology: Studies in the Neotropical Lowlands. pp 279-309; Columbia University Press, Nueva York.

Neves, E.; Petersen, J. B.; Bartone, R. N. y C. A. Da Silva

- 2003. Historical and Socio-Cultural Origins of Amazonian Dark Earths. In Lehmann, J., Kern D. C., Glaser B. and W. I. Woods (eds.) In: Amazonian Dark Earths: Origins, Properties, Management. pp 29-50. Dordrecht: Kluwer Academic.

\section{Neves, E.; Petersen, J. B.; Bartone, R. N. y M. J. Heckenberger}

- 2004. The Timing of Terra Preta Formation in the Central Amazon: Archaeological Data from Three Sites. In Glaser B. and W. I. Woods (eds.), Amazonian Dark Earths: Explorations in Space and Time. pp 125-134. Heidelberg: Springer.

Nóbile, J.

- 1993. Análisis arqueofaunistico del sitio Arroyo Arenal I, Paraná Medio (Provincia de Entre Ríos). Tesis de Licenciatura inédita. Facultad de Humanidades y Artes, Universidad Nacional de Rosario. Rosario.

- 2001. Asentamiento y Subsistencia en la llanura aluvial del río Paraná (Sector Bajo Paraná): Aproximaciones a un modelo regional. Arqueología Uruguaya hacia el fin del milenio 1: 187193. Montevideo.

Nóbile, J.C.; Ceruti C. N. y S. Cornero

- 1999. Investigaciones arqueológicas en el área de Alejandra, departamento San Javier, Provincia de Santa Fe. Actas del XII Congreso Nacional de Arqueología Argentina, Tomo III: 389393. La Plata.

Noelli, $\mathbf{F}$

- 1993. Sem Tekohá não há Tekhó. Disertación de magíster inédita. Pontifícia Universidade Católica do Rio Grande do Sul, Porto Alegre.

- 1994. El Guaraní agricultor. Acción 144: 17-20. Asunción.

- 1998a. Aportes históricos y etnológicos para o reconhecimento da classificação Guaraní de comunidades vegetais no século XVII. Fronteiras, Revista de História, Vol 2, n 4: 275-296.

- 1998b. Múltiplos usos de espécies vegetais pela farmacologia Guaraní através de informações históricas. Diálogos, Revista do Departamento de História, Universidade Estadual do Maringá, 02: 177-199.

- 1998c. The Tupi: explaining origin and expansions in terms of archaeology and of historical linguistics. Antiquity 72 (277): 648-663.

- 1999. Curt Nimuendajú e Alfred Métraux: a invenção da busca da "terra sem mal". Suplemento Antropológico Vol. XXXIV. N²: 123-166.

- 2004. La distribución geográfica de las evidencias arqueológicas guaraní. Revista Indias 64(230): 17-34.

Noelli, F. y J. P. Brochado

- 1998. O cauim e as beberagens dos Guarani e Tupinambá: equipamentos, técnicas de preparação e consumo. Revista do Museu de Arqueologia e Etnologia, São Paulo 8:117-128.

Noelli, F. y A. S. Dias

- 1995. Complementos históricos ao estudo funcional da indústria lítica Guaraní. Revista do CEPA 19(22): 7-23.

\section{Nordenskiöld, E.}

- 1912. La vie des indiens dans le chaco (Amérique du Sud). Revue de Gégraphie, Tomo VI, Fascicule III. 
- [1916] 2009. Indian Adaptations in Flooded Regions of South America (Introduction Denevan, W.). Journal of Latin American Geography 8(2): 209-224.

\section{0}

\section{Orquera, L. A}

- 1973. El Delta prehispánico. Tiempo de Sosiego, Año VI, n²2. Productos Roche S.A.Q. e I. (ed.). Orquera, L. A. y E. Piana.

- 1986-1987. Composición tipológica y datos tecnomorfológicos y tecnofuncionales de los distintos conjuntos arqueológicos del sitio Túnel I (Tierra del Fuego). Relaciones de la Sociedad Argentina de Antropología 17 (1): 201- 239.

\section{Orton, $\mathrm{C}$.}

- 2000. Sampling in Archaeology. Cambridge Manuals in Archaeology, Cambridge.

\section{Orton, C.; P. Tyers y A. Vince}

- 1997. La cerámica en arqueología. Crítica, Barcelona.

\section{Ottalagano, F. V.}

- 2004. Consideraciones sobre la aplicabilidad de la arqueología conductual al estudio cerámico en la llanura aluvial actual y antigua del río Paraná (sector santafesino). En: Martínez, G., M. Gutiérrez, R. Curtoni, M. Berón y P. Madrid (eds.) Aproximaciones contemporáneas a la arqueología pampeana argentina. pp. 169-189. Facultad de Ciencias Sociales (UNCPBA), Olavarría.

- 2005. La evidencia documental en el litoral fluvial del Paraná: algunas implicancias para el registro arqueológico. Revista de la Escuela de Antropología 10: 29-39.

- 2007a. Propuesta e implementación de medidas metodológicas para el estudio de los motivos abstractos y representativos cerámicos de Arroyo Arenal 1 (Dpto. La Paz, Pcia de Entre Ríos). Revista de la Escuela de Antropología 13: 197-207.

- 2007b. Algunas referencias en torno al simbolismo de las aves en los registros etnohistóricos y etnográficos de guaycurúes y mataco-mataguayos. Arqueología Suramericana 3(2): 213-228.

- 2008. Hacia la identificación taxonómica de las representaciones de psitácidos en la cerámica de la cuenca del río Paraná. Comechingonia. Revista de Arqueología 11: 79-98.

- 2009. Aproximaciones al simbolismo de los grupos cazadores-recolectores del Paraná medio: un abordaje del arte mobiliar cerámico. Tesis Doctoral inédita, Facultad de Humanidades y Artes. Universidad Nacional de Rosario. Rosario.

- 2010a. Decoración experimental de cerámica aplicada al estudio de las técnicas incisas del área del Paraná. Intersecciones en Antropología 11: 237-247.

- 2010b. Simbolismo e identidad en las Tierras Bajas del Paraná. Un abordaje contextual del arte moviliar cerámico. Relaciones de la Sociedad Argentina de Antropología 35: 195-218.

- 2012. Estado actual y nuevas perspectivas de estudio para la arqueología del Paraná medio entrerriano. Anuario de Arqueología 4: 233-248.

- 2014. El estudio de la variabilidad cerámica: conceptos teóricos y praxis arqueológica en las tierras bajas del río Paraná. Arqueología 20 (2): 225-242.

\section{Ottalagano, F. V. y J. C. Castro.}

- 2011. La elaboración de lo decorativo: un acercamiento comparativo hacia los gestos técnicos implicados en la alfarería incisa de los ríos Paraná y Uruguay. Comechingonia. Revista de Arqueología 15:172-180. 
Ottalagano, F. V.; Darigo, M.; Pereyra, B.; Brancatelli, C. y L. Lannelli

- 2015. Investigaciones arqueológicas en el sitio La Palmera 2 (cuenca del Paraná medio, provincia de Entre Ríos, Nordeste de Argentina). Revista de Antropología del Museo de Entre Ríos 1 (1): 55-65.

Ottalagano, F. V.; Darigo, M.; Sulich, K. y L. Arelovich

- 2010. Investigaciones arqueológicas en el Delta superior entrerriano: sitio Cerro Puesto Acosta (Dpto. Victoria, Entre Ríos). En J. R. Bárcena y H. Chiavazza (eds.), Arqueología Argentina en el Bicentenario de la Revolución de Mayo. Actas del XVII Congreso Nacional de Arqueología Argentina IV: 1475-1480, UNC-INCIHUSA, Mendoza.

Ottalagano, F. V. y D. Loponte

- 2016. Stable isotopes and diet in complex hunter-gatherers of Paraná River Basin, South América. Archaeological and Anthropological Sciences. DOI 10.1007/s12520-015-0308-6.

Outes, F.

- 1912. Cráneos indígenas del departamento de Gualeguaychú (Provincia de Entre Ríos). Anales de la Sociedad Científica Argentina 73: 5-37.

- 1917a. El primer hallazgo arqueológico en la isla de Martín García. Anales de la Sociedad Científica Argentina 82: 265-277.

- 1917b. Valor del hallazgo de una pipa de piedra tallada en la provincia de Entre Ríos. Anales de la Sociedad Científica Argentina 82: 278-282.

- 1918a. Nuevos rastros de la cultura Guaraní en la cuenca del Paraná inferior. Anales de la Sociedad Científica Argentina 85: 153-182.

- $\quad$ 1918b. Nuevo jalón septentrional en la dispersión de representaciones plásticas de la cuenca paranaense y su valor indicador. Anales de la Sociedad Científica Argentina 85: 53-66.

\section{$\mathbf{P}$}

\section{Pardoe, C.}

- 1988. The cemetery as symbol. The distribution of prehistoric aboriginal burial grounds in Southeastern Australia. Archaeology in Oceania 23: 1-16.

\section{Parisi, F. S. y J. Liotta}

- 2010. Primera aproximación al consumo de moluscos bivalvos [Diplodon variabilis (maton 1809)] en el sitio Cerro Lutz, planicies inundables del Paraná inferior. En M. Berón, L. Luna, M. Bonomo, C. Montalvo, C. Aranda y M. Carrera Aizpitarte (eds.), Mamül Mapu: pasado y presente desde la arqueología pampeana I. pp. 349-358. Editorial Libros del Espinillo. Ayacucho, Buenos Aires.

\section{Pasquali, C.; Sánchez-Pinto, I.; Meletta, H. y C. Giobergia}

- 2014. Debate entre niveles artificiales y unidades estratigráficas: el entierro humano posterior al Fuerte Sancti Spiritus (1527-1529), Puerto Gaboto (Santa Fe). Revista del Museo de Antropología 7 (2): 293-300.

\section{Patterer, N. I.}

- 2012. Análisis Fitolíticos de la Formación El Palmar (Pleistoceno superior) en la cuenca del río Uruguay (este de Argentina). Tesis Doctoral inédita. FEFN-UNC. 307 p.

Patterer, N. I.; E. Passeggi y A. F. Zucol.

- 2011. Análisis Fitolíticos de Suelos del Sudoeste de la Provincia de Entre Ríos (Argentina) como una Herramienta para Comprender sus Procesos Pedológicos. Revista Mexicana de Ciencias Geológicas 28(1): 132-146. 
Paucke, F.

- 1942. Hacia allá y para acá (una estada entre los indios Mocovíes 1749-1767). Tomo 1. Tucumán: Instituto Cultural Argentino-Germano, Universidad Nacional de Tucumán.

- 1943. Hacia allá y para acá (una estada entre los indios Mocovíes 1749-1767). Tomo 2. Tucumán: Instituto Cultural Argentino-Germano, Universidad Nacional de Tucumán.

- 1944. Hacia allá y para acá (una estada entre los indios Mocovíes 1749-1767). Tomo 3. Tucumán: Instituto Cultural Argentino-Germano, Universidad Nacional de Tucumán.

\section{Pensiero, J. y M. de la Peña}

- 2000. Flora y avifauna de la provincia de Santa Fe. El Litoral, Santa Fe. 384 p.

Pérez Colman, C. B.

- 1936. Historia de Entre Ríos. Época colonial (1520-1810). Tomo I, 511 p.

\section{Pérez Jimeno, L.}

- 2005. Análisis ictioarqueológico de un sitio del humedal paranaense del holoceno tardío (Florencia, Santa Fe. Argentina). Resúmenes del XI Congreso Nacional de Arqueología Uruguaya. Asociación Uruguaya de Arqueología, Salto, p. 13.

- 2007. Investigaciones arqueológicas en el sector septentrional de la llanura aluvial del Paraná, margen santafesina. La variabilidad del registro arqueológico. Tesis doctoral inédita, Facultad de Ciencias Naturales y Museo, Universidad Nacional de La Plata, La Plata.

\section{Pérez Jimeno, L. y N. Buc}

- 2010. Tecnología ósea en la cuenca del Paraná. Integrando los conjuntos arqueológicos del tramo medio e inferior. En M. Berón, L. Luna, M. Bonomo, C. Montalvo, C. Aranda y M. Carrera Aizpitarte (eds.), Mamül Mapu: pasado y presente desde la arqueología pampeana II. pp. 115127. Editorial Libros del Espinillo. Ayacucho, Buenos Aires.

\section{Perlman, A. M.}

- $\quad$ 1980. An optimum diet model, coastal variability and hunter-gatherer behavior. En B. Schiffer (ed.), Advances in arqueological method and theory 3: 257-310. Academic Press, New York.

Piccoli, C. V.

- 2014. Estudios de los paisajes arqueológicos en el sector de islas y borde frontal de la terraza baja de la Ilanura aluvial del Paraná Medio. Departamento de Goya. Tesis Doctoral inédita, Facultad de Humanidades y Artes, Universidad Nacional de Rosario, Rosario.

Píccoli, C. V.; Ávila, J. D. y M. E. Gavilán

- 2014. Tecnología lítica en la margen izquierda del Paraná medio: los materiales recuperados en jurisdicción Goya (Corrientes, Argentina). Revista del Museo de Antropología 7 (2): 301-308

Píccoli, C. V.; Barboza, M. C.; Gavilán, M.; Macanuso, A. y A. Alonso

- 2011. Estudio preliminar del material cerámico procedente de la llanura aluvial del Paraná Medio (Departamento Goya, Provincia de Corrientes). En: Ma. R. Feuillet Terzaghi, Ma. B. Colasurdo, J. I. Sartori y S. Escudero (eds.), Avances y perspectivas en la Arqueología del Nordeste. pp. 87-100. Santo Tomé.

Pierce, J. y F. Siegel

- 1969. Quantification in clay mineral studies of sediments and sedimentary rocks. Journal of Sedimentary Petrology 39, 187e193.

\section{Pintos Blanco, $\mathbf{S}$.}

- 2001a. Arqueología en el sitio Cráneo Marcado, Laguna de Castillos, Rocha (ROU). Arqueología Uruguaya hacia el fin del Milenio. Tomo I: 207-221. Montevideo, Uruguay.

- 2001b. Arqueología en el sitio Cráneo Marcado, Laguna de Castillos, Rocha (ROU). Arqueología Uruguaya hacia el fin del Milenio. Tomo I: 223-239. Montevideo, Uruguay. 


\section{Plog, S.; F. Plog y W. Wait}

- 1978. Decision Making in Modern Surveys. Advances in archaeological Method and Theory 1: 383-421.

\section{Poenitz, E. L. W.}

- 1970a. Características de los yacimientos arqueológicos del Río Uruguay medio y problemas que presentan. Boletín de Arqueología 1: 5-20. Concordia.

- $\quad 1970 b$. Un yacimiento en el centro de Entre Ríos. Su relación con el problema del patrimonio arqueológico charrúa. Boletín de Arqueología 1: 21-38. Concordia.

- 1971. Morfología, relaciones y funcionalidad de las placas grabadas de Salto Grande. Boletín de arqueología 2: 27-47. Concordia.

\section{Politis, G. G.}

- 1988. Paradigmas, modelos y métodos en la arqueología de la Pampa bonaerense. En Yacobaccio, H. (compilador), Arqueología contemporánea argentina. Actualidad y perspectivas, pp. 59-107. Ediciones Búsqueda. Buenos Aires.

- 1991 Fishtail projectile points in the Southern Cone of South America: an overview. En Clovis. Origins and Adaptations, R. Bonnichsen y K. Turnmire (eds.), pp. 287-303. Center of the Study of the First Americans. Oregon State University, Corvallis.

- 1995. The socio-politics of the development of archaeology in Hispanic South America. En Theory in Archaeology, a world perspective, edited by P. Ucko, pp. 197-235. Routledge, Londres.

- 1996. Moving to produce: Nukak mobility and settlement patterns in Amazonia. World Archaeology 27 (3): 492-511.

- 2003. The theoretical landscape and the methodological developments of archaeology in Latin American. American Antiquity. 68(2): 247-272.

- 2014. Las implicancias arqueológicas del Diario de Pero Lopes de Sousa (1531) durante su viaje al Río de la Plata y al Delta Inferior del río Paraná. Revista del Museo de Antropología 7 (2):317326.

\section{Politis, G. y P. Barros}

- 2006. La región pampeana como unidad espacial de análisis en la arqueología contemporánea. Folia Histórica del Nordeste 16: 51-73.

\section{Politis, G. y M. Bonomo}

- 2012. La entidad arqueológica Goya-Malabrigo (ríos Paraná y Uruguay) y su filiación Arawak. Sociedade de Arqueologia Brasileira 25(1): 10-46.

- 2015. Una revisión del Túmulo de Campana. Relaciones de la Sociedad Argentina de Antropología XL (1): 149-181.

- 2016. Más sobre el Túmulo de Campana. Relaciones de la Sociedad Argentina de Antropología XLI (1): 151-167.

Politis, G.; Bonomo, M.; Castiñeira, C. y A. Blasi

- 2011. Archaeology of the Upper Delta of the Paraná River (Argentina): mound construction and anthropic landscapes in the Los Tres Cerros locality. Quaternary International 245(1): 7488.

Politis, G.; Bonomo, M. y V. Di Prado.

- 2013a. Ceramistas de la ribera. Los antiguos pobladores del delta del Paraná. Revista Ciencia Hoy 23, n 133: 31-37.

\section{Politis, G.; Bonomo, M. y G. Moreira}

- (en prensa). Análisis de la colección del Túmulo II de Brazo Largo (Islas del Ibicuy, provincia de Entre Ríos). 
Politis, G.; Costa Angrizani, R.; Hernando, A.; González Ruibal, A. y E. Beserra Coelho

- 2013c. Quarenta e oito saídas: Etno-arqueologia das saídas diárias de forrageio dos Awá. En A. Hernando y E. M. Beserra Coelho (Orgs.), Estudos sobre os Awá: caçadores - coletores em transição. pp. 155-185. Editorial EDUFMA/IWGIA. São Luís.

Politis, G. y R. P. Curtoni

- 2011. Archaeology and Politics in Argentina During the Last 50 Years. En L. R. Lozny (ed.), Comparative Archaeologies: A Sociological View of the Science of the Past. pp. 495-525.

Politis, G.; González Ruibal, A.; Hernando, A. y E. Beserra Coelho

- 2013b. Etno-arqueologia do descarte de flechas entre os Awá-Guajá da Floresta Amazônica brasileira. En A. Hernando y E. M. Beserra Coelho (Orgs.), Estudos sobre os Awá: caçadores coletores em transição. pp. 131-154. Editorial EDUFMA/IWGIA. São Luís.

Politis, G. y P. Madrid

- $\quad$ 1988. Un Hueso Duro de Roer: Análisis Preliminar de la Tafonomía del Sitio Laguna Tres Reyes 1 (Pdo. De Adolfo González Cháves, Pcia. de Buenos Aires). En De Procesos, Contextos y Otros Huesos, editado por N. Ratto y A. Haber, pp. 29-44. ICA Sección Prehistoria. FFyL. UBA, Buenos Aires.

Politis, G., Martínez, G. y M. Bonomo

- 2001. Alfarería temprana en sitios de cazadores-recolectores de la Región Pampeana (Argentina). Latin American Antiquity 12 (2): 167-181.

Politis, G.; Messineo, P. y C. Kaufmann

- 2004. El poblamiento temprano de las llanuras pampeanas de Argentina y Uruguay. Complutum, 15: 207-224.

Poujade, R. A.

- $\quad$ 1995. Mapa Arqueológico de la Provincia de Misiones. Secretaria de Estado de Cultura de la Provincia y Entidad Binacional Yacyretá. 35 p. Misiones. Argentina.

- 2007. Recuperación de Santos Mártires del Japón (Sistema Jesuítico-Guaraní). Misiones, Argentina (RE.SA.MA.JA.). En XIV Congreso Nacional de Arqueología Argentina. Universidad de Rosario T I: 413-425. Mar del Plata.

Poujade, R. A. y M. V. Roca

- 2011. Reducciones de Santa Ana y San Ignacio Miní -apoyatura arqueológica a la puesta en valor-Anuario de Arqueología 3: 245-268.

Prates, L.; Politis, G. y J. Steele

- 2013. Radiocarbon chronology of the early human occupation of Argentina. Quaternary International 301: 104-122.

Primera Convención Nacional de Antropología

- $\quad$ 1966. Facultad de Filosofía y Humanidades. Instituto de Antropología. Universidad Nacional de Córdoba.

Programa Nacional de Arqueologia Brasileira (PRONAPA)

- 1970. Brazilian archaeology in 1968: an interim report on the National Program of Archaeological Research. American Antiquity 35(1): 1-23.

Prous, A. y M. Alonso

- 2010. As indústrias líticas dos ceramistas Tupiguarani. En A. Prous y T. A. Lima (eds.) Os Ceramistas Tupiguarani. Eixos Temáticos. vol. III, pp: 27-76. IPHAN, Belo Horizonte. 
Quintana, C.

- 2001. Composición y Cambios en la Secuencia Faunística. En Cazadores y recolectores de las Sierras de Tandilia Oriental, I Geología, Paleontología y Zooarqueología, editado por D. Mazzanti y C. Quintana, pp. 37-64. Publicación Especial 1. Laboratorio de Arqueología, Universidad Nacional de Mar del Plata. Mar del Plata.

\section{Quintana, C., F. Valverde, D. y Mazzanti}

- 2002. Roedores y Lagartos como Emergentes de la Diversificación de la Subsistencia durante el Holoceno Tardío de la Región Pampeana, Argentina. Latin American Antiquity 13 (4): 455473.

Quirós, R. y S. Cuch

- 1981. Características limnológicas del embalse de Salto Grande, 1. Cambios estacionales de ciertos parámetros físico-químicos. Ecología 7. Buenos Aires.

\section{$\mathbf{R}$}

Raffo, F. C.; De la Peña, M. R.; Silva, R. L.; Capuccio, G. y L. M. Bonin.

- 2008. Aves del Río Uruguay. Guía ilustrada de las especies del bajo río Uruguay y el embalse de Salto Grande. Publicaciones de la Comisión Administradora del Río Uruguay.

Ratto, $\mathbf{N}$.

- 2003. Estrategias de caza y propiedades de registro Arqueológico en la Puna de Chaschuil (Dpto. de Tinogasta, Catamarca, Argentina). Tesis Doctoral, Universidad de Buenos Aires. http://cambiocultural.homestead.com/ratto.html

Read, D. W.

- 1979. Regional Sampling. En J. W. Mueller (ed.), Sampling in Archaeology. pp. 45-60. Segunda edición. The University of Arizona Press, Tucson, Arizona.

Rebord, E. J.

- 1998. Arqueología del Río Uruguay: los sitios Paso de Vera I y II. Ms. Archivo de la División Arqueología, Museo Antonio Serrano.

Reig, 0.

- 1956. Sobre la posición sistemática de Zygolestes paranensis Ameghino y de Zygolestes entrerrianus Ameghino. Con una consideración de la edad y correlación "Mesopotamiense". Holmbergia. Revista del Centro de Estudiantes de Ciencias Naturales, 5: 209-226. Buenos Aires.

\section{Revista El Tren Zonal}

- 1994. Ayuda Memoria. Investigador Manuel Almeida, detrás de la otra historia. Paraná, Entre Ríos. (Abril de 1994).

Ribeiro, P. A. M.

- 2008. A tradição ceramista Tupiguarani no sul do Brasil. En Os ceramistas tupiguarani, v. 1, pp: 179-196, editado por A. Prous y T. A. Lima. Sigma, Belo Horizonte.

Rice, P. M.

- 1987. Pottery Analysis: A Sourcebook. Chicago, University of Chicago Press.

Richard, A.

- 2015. Cotidianeidad y etnogénesis en la cuenca media del arroyo Las Conchas, (Dpto. Paraná, Pcia. de Entre Ríos) hacia el Siglo XVII. Trabajo final de la Carrera de Arqueología, Facultad de Ciencias Naturales e Instituto Miguel Lillo, Universidad Nacional de Tucumán, Tucumán. 
Rick T. C., J. M. Erlandson y R. L. Vellanoveth

- 2001. Paleocastal Marine Fishing on the Pacific Coast of the Americas: Perspectives from Daisy Cave, California. American Antiquity 66 (4): 595-613.

Rimoldi, H. V.

- 1962. Aprovechamiento del río Uruguay en la zona de salto Grande. Estudio geotectónicogeológico para la presa de compensación proyectada en paso hervidero (prov. Entre Ríos). Anales de la Primera Jornada Geológica Argentina, 2: 287-310.

Ringuelet, R. A.

- 1961. Rasgos fundamentales de la zoogeografía de la Argentina. Physis, 22(63): 151-170.

- 1975. Zoogeografía y ecología de los peces de aguas continentales de la Argentina y Consideraciones sobre las áreas ictiológicas de América del Sur. Ecosur 2: 1-151.

Ringuelet, R. A., Arámburu R. y Alonso de Aramburu, L.

- 1967. Los peces argentinos de agua dulce. Comisión de Investigaciones Científicas. Provincia de Buenos Aires, $602 \mathrm{p}$.

Rivas, G.

- 2014. El Puerto de Gualeguaychú: su pasado, el barrio y su gente. Conferencia dictada en el nstituto Magnasco. 23 de mayo de 2014. Gualeguaychú.

https://sites.google.com/site/gualepedia/el-puerto-de-gualeguaychu

Rizzo, A.

- 1968. Hallazgos arqueológicos efectuados en un yacimiento en gruta, Tres de Mayo, Misiones, Argentina. Pesquisas, Antropología 18: 11-19.

- 1969. Noticias sobre algunos talleres líticos ubicados en las costas del Río Alto Paraná (Pcia. Misiones) República Argentina. Pesquisas, Antropología 20: 25-29.

Roca, M. V.

- 2013. Puesta en valor de la Reducción Jesuítica de Santa Ana. Proceso de apoyatura arqueológica. Boletín de la Junta de Estudios Históricos de Misiones: 17-21. (Mayo 2013). Misiones.

Rocchietti, A.M., De Grandis, N. y M. Valentini

- 2005. Arqueología de la costa e islas del Paraná santafesino: área Monje-Gaboto. Revista de la Escuela de Antropología 10: 41-55.

Rocha, T.

- 1978. Población etnohistórica del territorio entrerriano. Enciclopedia de Entre Ríos. Historia. Tomo 1: 65-101. Paraná.

Rodríguez, A. A.

- 1969. Arqueología del Nordeste de Entre Ríos (Río Uruguay Medio). Nota preliminar. Revista del Departamento de Antropología y Folklore. 32 p. Comisión Municipal de Cultura, Concordia, Entre Ríos.

- 1975. Consideraciones para el estudio arqueológico del río Uruguay medio. II Congreso Nacional de Arqueología. III Encuentro de Arqueología del Litoral, Volumen 1: 55-75. Río Negro, Uruguay.

Rodríguez, J. A.

- 1985. Diseño de Investigación para la arqueología del río Uruguay medio. Tesis Doctoral inédita. Facultad de Ciencias Naturales y Museo, Universidad Nacional de La Plata, La Plata.

- 1992. Arqueología del sudeste de Sudamérica. En Prehistoria sudamericana. Nuevas perspectivas, editado por B. Meggers, pp. 177-209. Taraxacum, Washington.

- 1997. Avances en la arqueología de Yacyretá (Corrientes, Argentina). Actas del XII Congreso Nacional de Arqueología Argentina. La Plata, Argentina. 
- 1998. Esquemas de integración cultural y síntesis en la arqueología del Nordeste argentino. En: Homenaje a Alberto Rex González. 50 años de aportes a desarrollo y consolidación de la Antropología argentina, editado por FFyL-UBA: 121-153. Buenos Aires,

- 2001. Nordeste prehispánico. En: Historia Argentina Prehispánica, dirigido por E. E. Berbeberían y A. E. Nielsen, tomo II: 693-736.

- 2001-2002 Poblamiento prehistórico de la Mesopotamia Argentina. Folia Histórica del Nordeste 15: 129-146.

- 2006. El poblamiento y el proceso de la secuencia cultural prehistórica de la Cuenca del Plata. Folia Histórica del Nordeste 16: 139-159.

- 2009. La ocupación (poblamiento) del norte de Corrientes (Argentina) por fase de la Tradición Tupiguaraní. Em B. Meggers (ed.), Arqueologia interpretativa. O método quantitativo para o establecimento de sequências cerâmicas: estudos de casos. pp 49-62. UNITINS, Porto Nacional.

\section{Rodríguez, J. A. y C. N. Ceruti}

- 1999. Las tierras bajas del nordeste y el litoral mesopotámico. Nueva Historia de la Nación Argentina. Tomo I: 109-133. Academia Nacional de la Historia. Editorial Planeta. Buenos Aires.

\section{Rodríguez, J. A. y A. A. Rodríguez}

- 1983-1985. Investigaciones arqueológicas en el sitio Los Sauces II (Salto Grande, Argentina). Cuadernos del Instituto Nacional de Antropología 10: 459-491.

- 1984. Nota preliminar sobre investigaciones arqueológicas en el NE de Entre Ríos y SE de Corrientes: el sitio Rancho Colorado (ENT. FED. 20). Revista del Museo de La Plata (NS), Antropología 64, tomo VIII: 385-403.

- 1985. Proyecto antropológico-ecológico Salto Grande. Universidad Nacional de Entre Ríos, Concordia.

Roe P. G.

- 1998. Paragon or peril? The jaguar in Amazonian Indian society. In N. J. Saunders (ed.), Icons of power. Feline Symbolism in the Americas. pp. 171-202. Routledge.

Roselli, L.

- 1964. Una cerámica prehispánica, ornitomorfa y ceremonial del Uruguay. Amerindia 2: 39-55.

- 1969. Una cerámica prehispánica campanuliforme antropomorfa. En R. Pi Hugarte (ed.), "El Uruguay Indígena", Revista Colección "Nuestra Tierra" № 1: 64-66. Uruguay.

\section{Rusconi, C.}

- 1933. Instrumentos óseos trabajados por indígenas prehispánicos de Santiago del Estero. Revista de la Sociedad Amigos de la Arqueología 7: 229-250.

Rye, O. S.

- 1994. Pottery technology. Principles and reconstruction. Manuals on archaeology 4. Washington DC, Taraxacum.

Salemme, M.; Miotti, L.; Tonni, E. P.

- 1988. La determinación sistemática de los mamíferos en el análisis faunístico. En Haber, A.; Ratto, N. (eds.) De procesos, contextos y otros huesos. Buenos Aires. pp. 65- 73. Instituto de Ciencias Antropológicas Facultad de Filosofía y Letras de la Universidad de Buenos Aires. 
Salemme, M., Tonni, E. y C. N. Ceruti

- 1985. Los materiales faunísticos del sitio arqueológico La Maza 1 (partido de Berisso, provincia de Buenos Aires): revisión crítica. Revista de la Asociación de Ciencias Naturales del Litoral 16 (2) p: 169-178.

Salemme, M., Tonni, E., Ceruti C. N., Iriondo M. H. y A. L. Cione

- 1987. Los vertebrados del sitio arqueológico La Palmera V, Departamento Paraná, provincia de Entre Ríos (Argentina). CD trabajos de Carlos Ceruti.

Sallaberry, J. F.

- $\quad$ 1926. Los charrúas y Santa Fe. Montevideo. 292 p.

Salles Machado, J.

- 2005. Montículos artificiais na Amazônia central: um estudo de caso do sitio Hatahara. Tesis de Maestría. Museo de Arqueología y Etnología de la Universidad de San Pablo, San Pablo.

Sánchez, J. O.; Colobig M. M.; Zucol, A.; Politis, G.G.; Bonomo, M. y C. Castiñeira

- 2013. Primeros resultados sobre el uso prehispánico de los vegetales en el Sitio arqueológico los tres cerros 1 (victoria, entre ríos, argentina): Análisis del registro biosilíceo. Darwiniana (ns) 1(2): 201-219.

Sánchez, L.; Zucchino, R.B. y A. Manzano

- 2008. Mapa de distribución de los anuros de la provincia de Entre Ríos en base a colecciones herpetológicas. Temas de la Biodiversidad del Litoral III, Miscelánea INSUGEO 17: 239-258. Tucumán.

Sanhueza Riquelme, L.

- 1998. Antecedentes y proposición metodológica para el estudio de huellas de alteración en cerámica. Conserva. Santiago: Centro Nacional de Conservación y Restauración, DIBAM, v. 2: 69-79.

Santa Cruz de, A.

- [1527-1529] 1918. Islario general de todas las islas del mundo. Madrid. Imprenta del Patronato de Huérfanos de Intendencia e Intervención Militares.

\section{Santiago, $\mathbf{F}$.}

- 2004. Los roedores en el "menú" de los habitantes de Cerro Aguará (provincia de Santa Fe): su análisis arqueofaunístico. Intersecciones en Antropología 5: 3-18.

\section{Santini, $M$.}

- 2009. Prehistoria de la región meridional del Gran Chaco. Aportes del análisis de restos faunísticos en la reconstrucción de las estrategias adaptativas de los grupos aborígenes. Tesis Doctoral Inédita. Facultad de Ciencias Naturales y Museo, Universidad Nacional de La Plata. La Plata.

- 2011. Aprovechamiento de Myocastor coypus (Rodentia, Caviomorpha) en sitios del Chaco Húmedo argentino durante el Holoceno tardío. Intersecciones en Antropología 12: 195-205.

\section{Sartori, J.}

- 2013. Variabilidad del registro arqueofaunístico de la cuenca media e inferior del río Coronda (Margen derecha, Provincia de Santa Fe). Análisis desde una perspectiva integral. Tesis doctoral inédita. Facultad de Humanidades y Artes. Universidad Nacional de Rosario. Rosario. Ms.

- 2014. La información etnográfica y etnológica como marco interpretativo para contextos zooarqueológicos en la Llanura Aluvial del Paraná (Santa Fe, Argentina). Revista del Museo de Antropología 8 (2): 77-90. 
Sartori, J. y M. B. Colasurdo

- 2010. El análisis arqueofaunístico del sitio Playa Mansa: Nuevas perspectivas. En M. R. Feuillet Terzaghi; M. B. Colasurdo; J. I. Sartori y S. Escudero (eds.), Avances y perspectivas en la Arqueología del Nordeste. pp. 25-41. Santo Tomé.

Sartori, J. y P. Galligani

2014. Zooarqueología en el humedal de la cuenca fluvial del centro este santafesino. Relaciones de la Sociedad Argentina de Antropología 39(2): 387-409.

\section{Sartori, J. y L. Pérez Jimeno}

- 2012. Zooarqueología en la llanura aluvial del Paraná: el Sitio Campo Binaghi desde una perspectiva regional. Comechingonia. Revista de Arqueología 16 (2): 93-113.

Sastre, D. M.

- $\quad$ 1891. El Tempe Argentino. Buenos Aires.

Saunders, N.

- 1998. Architecture of symbolism. The feline image. En N. J. Saunders (ed.), Icons of power. Feline Symbolism in the Americas. pp. 12- 52. Routledge.

\section{Scabuzzo, C. y A. Ramos van Raap}

- 2011. Primeros estudios bioarqueológicos en el sitio Los Tres Cerros (departamento de Victoria, Entre Ríos). Comechingonia. Revista de Arqueología 15: 167-172.

\section{Scabuzzo, C.; A. Ramos van Raap; Bonomo, M. y G. Politis}

- 2015. Estudios bioarqueológicos en el sitio Los Tres Cerros 1 (Delta Superior del río Paraná, Entre Ríos, Argentina). Boletim do Museo do Para. Emílio Goeldi. Ciências Humanas. Belém 10, n. 2: 509-535.

\section{Scheinsohn, V.}

- 1997. La explotación de materias primas óseas en la Isla Grande de Tierra del Fuego. Tesis doctoral, Universidad Nacional de Buenos Aires, Buenos Aires.

Schiffer, $M$.

- 1971. Archaeological Context and Systemic Context. American Antiquity 37: 156-165.

- 1987. Formation Processes of the Archaeological Record. University of New Mexico Press, Albuquerque.

Schmidl, U.

- [1567] 2009. Viaje al Río de La Plata. Traducido por Samuel Lafone Quevedo. Claridad, Buenos Aires.

Schmitz, P.I.

- 1987. Prehistoric hunters and gatherers of Brasil. Journal of World Prehistory 1(1): 53-126.

Schmitz, P.I.; C. N. Ceruti; A. R. González y A. Rizzo.

- 1972. Investigaciones arqueológicas en la zona de Goya (Corrientes), Argentina. Dédalo, Revista de Arqueología y Etnología 8(15): 11-121.

Seijo, C.

- 1931. Instrumentos de hueso indígenas. Revista de la Sociedad Amigos de la Arqueología 5: 227-230.

\section{Sempé, M. C. y M. A. Caggiano}

- 1995. Las culturas agroalfareras del Alto Uruguay (Misiones, Argentina). Revista do Museu de Arqueología e Etnología 5: 27-28. Sao Paulo.

\section{Sempé, M. C. y A. Rizzo}

- 2000. El uso del espacio entre cazadores y agricultores prehispánicos en Misiones, República Argentina. Actas del XX Encuentro de Geohistoria Regional: 927-937. Resistencia, Chaco. 


\section{Serrano, A.}

- $\quad$ 1922a. Sobre un recipiente indígena de Hernandarias. Provincia de Entre Ríos. Prometeo 14: 2-3.

- $\quad$ 1922b. Arqueología de las Tejas. Revista Universitaria del Litoral, 12: 66-110.

- 1923. Notas para el capítulo Introducción de Apuntes de Etnografía y Arqueología de la provincia de Entre Ríos. Prometeo 26-27: 32-35.

- 1924. Contribución al conocimiento de la industria de la piedra entre los primitivos habitantes de la Mesopotamia. Suplemento de la Revista Argentina de Ciencias Naturales 4. Tomo I, 8 p. Paraná.

- 1930. Un nuevo tipo de instrumento de piedra del litoral argentino. Revista de la Sociedad "Amigos de la Arqueología" IV: 205-209.

- 1931. Arqueología del Litoral. Memorias del Museo de Paraná 4 (Arqueología). 24 p. Paraná.

- 1932a. Exploraciones arqueológicas en el río Uruguay Medio. Memorias del Museo de Paraná 2 (Arqueología). 89 p. Paraná.

- 1932b. Noticias sobre un paradero indígena de la margen izquierda del arroyo Las Conchas (Departamento Paraná, Entre Ríos) contemporáneo a la conquista. En: Actas y Trabajos Científicos del XXV Congreso Internacional de Americanistas, La Plata.

- 1933a. Observaciones sobre la alfarería de los médanos de Colón. Memorias del Museo de Paraná 6 (Arqueología). 11 p. Paraná.

- 1933b. Las culturas protohistóricas del este argentino y Uruguay. Memorias del museo de Paraná 7 (Arqueología). 58 p. Paraná.

- $\quad$ 1933c. Nota sobre una punta de arpón del río Uruguay. Revista de la Sociedad Amigos de la Arqueología 7: 141-143.

- 1934. Arqueología del arroyo Leyes (Provincia de Santa Fe). Noticia preliminar a propósito de la Colección Bousquet. Memorias del museo de Paraná 8 (Arqueología). Paraná.

- 1936. Etnografía de la antigua provincia del Uruguay. 209 p. Paraná.

- 1944. Las estatuitas de arcilla e Córdoba y su significado arqueológico. Universidad de Córdoba, 99 p. Córdoba.

- 1946. Arqueología del Arroyo Las Mulas en el Noroeste de Entre Ríos. Universidad de Córdoba, 119 p. Córdoba.

- 1950. Los primitivos habitantes de Entre Ríos. Biblioteca Entrerriana "General Perón". 177 p. Paraná.

- 1954. Contenido e interpretación de la arqueología Argentina. El área Litoral. Revista Universidad 29:5-38. Universidad Nacional del Litoral, Santa Fe.

- 1970. Las enigmáticas campanas de la arqueología del Litoral. La Prensa, 9 de agosto de 1970.

- 1972. Líneas fundamentales de la arqueología del litoral (una tentativa de periodización). Instituto de Antropología. Universidad Nacional de Córdoba, Córdoba.

\section{Shepard, A. 0.}

- 1956. Ceramics for the archaeologist. Publication 609. Carnegie Institution of Washington, Washington.

\section{Shott, M.}

- 1996. An exegesis of the curation concept. Journal of Anthropological Research 52(3): 259-280. Silva, C. B.

- 2013. Hallazgo de un "entierro aislado" en Las Cuevas (Dpto. Diamante, Entre Ríos). Libro de Resúmenes de 5o Encuentro de Discusión de Arqueología del Nordeste Argentino, p. 122. Goya. 
- 2015. Primeros resultados de las excavaciones arqueológicas en el sitio Cerro Farall (departamento Diamante, Entre Ríos). Libro de resúmenes del Sexto Encuentro de Discusión Arqueológica del Nordeste Argentino. p. 80. Gualeguaychú.

\section{Silvestre, $\mathbf{R}$.}

- 2013. Estrategias tecnológicas de grupos guaraníes prehispánicos: el sitio A Fredes como caso de estudio. Humedal del Paraná inferior, Argentina. Cuadernos del Instituto Nacional de Antropología y Pensamiento Latinoamericano - Series Especiales 1(2): 279-301.

Soares, A. L. R.

- 2004. Contribuição à arqueologia guarani: estudo do sítio Röpke. Tesis Doctoral inédita. Universidade de São Paulo, São Paulo.

Soriano, A.; León, R. J. C.; Sala, O. E.; Deregibus, V. A.; Cauhépé, M.A.; Scaglia, O.A.; Velázquez, C. A. y J. H. Lemcoff.

- $\quad$ 1992. Río de la Plata Grasslands. En R. Coupland (ed.), Natural Garsslands. Introduction and Western Hemisphere. pp. 367-407. Elsevier.

\section{Stampanoni Bassi, F.}

- 2016. A maloca saracá. Uma frontera cultural no médio Amazonas pré-colonial, vista da perspectiva de uma casa. Tesis doctoral inédita. Museo de Arqueología y Etnología de la Universidad de San Pablo, San Pablo.

\section{Stark, M. T.}

- $\quad$ 1998. Technical Choices and Social Boundaries in Material Culture Patterning: an introduction. En M. Stark (ed), The Archaeology of Social Bounndaries: 1-11. Washington, Smithonian Institution Press.

- 1999. Social Dimensions of Technical Choice in Kalinga Ceramic Traditions. En Material Meanings: Critical Approaches to the Interpretations of Material Culture, editado por E. S. Chilton, pp. 24-43. University of Utah Press, Salt Lake City.

Suárez, R.

- 2011. Arqueología durante la Transición Pleistoceno Holoceno: Componentes Paleoindios, Organización de la Tecnología y Movilidad de los Primeros Americanos en Uruguay. BAR International Series 2220, Oxford.

- 2015a The paleoamerican occupation on plains of Uruguay: technology, adaptations, and mobility. PaleoAmerica 1(1): 88-104.

- $\quad$ 2015b Tecnología lítica y conjunto de artefactos utilizados durante el poblamiento temprano de Uruguay. Chungara 47(1): 43-54.

Sullivan, A. P. y K. C. Rozen

- 1985. Debitage Analysis and Archaeological Interpretation. American Antiquity, 50 (4): 755779.

Sverlij, S. B; Delfino Schenke, R. L; López, H. L y A. Espinach Ros

- 1998. Peces del Río Uruguay. Guía ilustrada de las especies más comunes del río Uruguay inferior y el embalse de Salto Grande. Publicaciones de la Comisión Administradora del Río Uruguay.

\section{Taçon P.S.C.}

- 1991. The power of stone: symbolic aspects of stone use and tool development in Western Arnhem Land, Australia. Antiquity 65: 192-207. 


\section{Teisseire, A.}

- 1927. Expedición a los Departamentos de Colonia y Soriano. Revista de la Sociedad Amigos de la Arqueología 1: 47-61.

\section{Teruggi, M. E.}

- 1982. Diccionario Sedimentológico. Vol. I, Rocas Clásticas y Piroclástica. Librart, Buenos Aires.

Tobella, M. y G. Figueiro

- 2002. El sitio CG14E01: Aproximación a la tecnología lítica de los "constructores de cerritos". En Del mar a los salitrales. Diez mil años de historia pampeana en el umbral del tercer milenio, editado por D. L. Mazzanti, M. A. Berón y F. Oliva, pp. 219-229. Universidad Nacional de Mar del Plata (UNMdP), Mar del Plata.

Tófalo, R. 0.

- 1986. Caracterización sedimentológica y estratigrafía de los Formaciones Puerto Yeruá y Arroto Ávalos. Provincias de Entre Ríos y Corrientes. Tesis Doctoral inédita. Facultad de Ciencias Exactas y Naturales. Universidad Nacional de Buenos Aires. Buenos Aires.

Tófalo, R. O. y P. J. Pazos.

- 2002. Caracterización de calcretes de la Formación Puerto Yeruá (Cretácico), en base a su micromorfología (Entre Ríos, Argentina). Revista de la Asociación Argentina de Sedimentología, Vol. 9, no 2: 127-134.

Tonni, E. P., Ceruti, C. N. y M. H. Iriondo

- 1985. Los vertebrados del sitio Arroyo Arenal 1, Departamento La Paz, provincia de Entre Ríos (Argentina). Revista de la Asociación de Ciencias Naturales del Litoral. 16 (2) p: 157-167.

Tortorelli, L. A.

- $\quad$ 1956. Maderas y Bosques argentinos. Editorial ACME, Buenos Aires. 910 p.

\section{Torrence, $\mathbf{R}$.}

- 1986. Production and exchange of stone tools: Prehistoric obsidian in the Aegean. Cambridge University Press.

\section{Torres, L. M.}

- 1903a. Los cementerios indígenas del sur de Entre Ríos y su relación con los del Uruguay, túmulos de Campana (Buenos Aires) y Santos (Brasil). Anales del Museo Nacional de Buenos Aires IX: 57-75.

- 1903b. El cementerio indígena de Mazaruca (Entre Ríos). Historia I: 447-451.

- 1907. Arqueología de la cuenca del río Paraná. Revista del Museo de La Plata XIV: 53-122.

- 1911. Los primitivos habitantes delta del Paraná. Biblioteca Centenaria Universidad de La Plata, Tomo IV. Buenos Aires.

Trigger, B. G.

- 1992. Historia del pensamiento arqueológico. Traducido por I. G. Trócoli. Editorial Crítica. Barcelona.

\section{U}

\section{Ubelaker, D. H.}

- 1989. Human Skeletal Remains: Excavation, Analysis, Interpretation. Manuals on Archaeology 2. Taraxacum, Washington. 
Vassallo de Cettour, C.

- 1995. Aborígenes del norte entrerriano. Dirección de Cultura. Municipalidad de Concordia. 70 p.

Vecchi, R.

- 2010. Bolas de boleadora en los grupos cazadores recolectores de la pampa bonaerense. Tesis Doctoral inédita, Facultad de Filosofía y Letras, Universidad de Buenos Aires.

Vega F., J. J. y R. E. Andrade

- 2002. Análisis del material lítico recuperado en el "Infierno". Departamento de Río NegroRepública Oriental del Uruguay. En Del mar a los salitrales. Diez mil años de historia pampeana en el umbral del tercer milenio, editado por D. L. Mazzanti, M. A. Berón y F. Oliva, pp. 289-297. Universidad Nacional de Mar del Plata (UNMdP), Mar del Plata.

- 2004. Infierno: resultados del análisis realizado sobre el material lítico recuperado en el sitio "Pingüino", Departamento de Río Negro, República Oriental del Uruguay. En L. Beovide; I. Barreto y C. Curbelo (eds.), La Arqueología Uruguaya ante los desafíos del Nuevo Siglo. CDROM, Montevideo, Uruguay.

Verde, M. y D. Perea.

- 2008. Icnofósiles. En D. Perea (ed.), Fósiles de Uruguay. Cap. 6: 135-163. Universidad de la República. Facultad de Ciencias. Montevideo Uruguay.

Vignati, M. A.

- 1925. Noticia sobre las islas del Delta del Paraná por Francisco Muñiz. Publicaciones del Instituto de Investigaciones Geográficas 9: 24.

- 1941. Censo óseo de paquetes funerarios de origen guaraní. Revista del Museo de La Plata (NS). Antropología. Tomo II: 1-11.

Vitelli, K. D.

- 1997. Inferring firing procederes from sherds: early Greek kilns. En P. Rice (ed.), Ceramic and civilization VII. The prehistory and history of ceramic kilns. pp. 21-44. Ohio: The American Ceramic Society.

\section{W}

Webb, C.

- $\quad$ 1993. The lithification of a sandy environment. Archaeology in Oceania 28:105-111.

\section{White, I.}

1908. Relatório sobre as "Coalmeasures" e rochas associadas do Sul do Brasil. Relatório final da Comissão de Estudos das Minas de Carvão de Pedra do Brasil, 1: 2-300. Imprenta Nacional, Rio de Janeiro.

Wiessner, P.

- 1983 Style and Social Information in Kalahari San Projectile Points. American Antiquity 48 (2): 253-276.

- 1989. Is there a unity to style? En Conkey. M. y Hastorf, C (eds.), The uses of style in archaeology. pp. 105-112. Cambridge University Press, Cambridge.

\section{Winterhalder, B. y A. Smith}

- 1992. Hunters and gatherers today and reconstruction of the past. Soviet and Western Anthropology. E. Gellner (ed). New York. 


\section{Wobst, H. M.}

- 1977 Stylistic Behavior and Information Exchange. En For the Director: Research Essays in Honor of James B. Griffin, editado por C. E. Cleland, pp. 317-342. University of Michigan Museum of Anthropology Anthropological Papers N61, Ann Arbor.

Wood, W. y D. Johnson

- 1978. A survey of disturbance processes in archaeological site formation. En Advances in Archaeology Method and Theory, Vol. 1, editado por M. Schiffer, pp. 539-601. Academic Press, Nueva York.

\section{Z}

Zeballos, E.

- $\quad$ 1878. Note sur un tumulus préhistorique de Buenos-Ayres. Revue d'Anthropologie 4(1): 577583.

Zeballos, E. y P. Pico

- 1878. Informe sobre el túmulo prehistórico de Campana. Anales de la Sociedad Científica Argentina 6: 244-260.

Zucol, A.; Brea, M.; Lutz, A. y L. Anzotegui

- 2004. Aportes al conocimiento de la paleobiodiversidad del Cenozoico superior del litoral argentino: Estudios paleoeflorísticos. En: F. G. Aceñolaza (Coordinador), Miscelánea INSUGEO 12: 91-102. Tucumán.

Zucol, A.; Brea M. y A. Scopel

- 2005. First record of fossil wood and phytolith assemblages of the Late Pleistocene in El Palmar National Park (Argentina). Journal of South American Earth Sciences 20: 33-43.

Zucol, A. F.; Passeggi, E.; Brea, M.; Patterer, N. I.; Fernández Pepi, M. G. y M. M. Colobig

- 2010. Phytolith analysis for the Potrok Aike Lake Drilling Project: Sample treatment protocols for the PASADO Microfossil Manual. En H. Corbella y N. Maidana (eds.), 1ㅁ Reunión Internodos del Proyecto Interdisciplinario Patagonia Austral y 1er Workshop Argentino del Proyecto Potrok Aike Maar Lake Sediment Archive Drilling Project. pp. 81-84. Proyecto Editorial PIPA. Buenos Aires. 


\section{ANEXO I}

Instituciones, números de catálogo y procedencia de las bolas presentadas y reanalizadas en la Tabla 5.17 (Capítulo 5). Además, cuando sea pertinente se agrega la publicación donde están mencionadas las bolas.

MCQ: Museo Regional Camila Quiroga (Chajarí), Colección Brignardello.

MACN: Museo de Antropología y Ciencias Naturales (Concordia).

MCB: Museo Municipal de Conscripto Bernardi (Federal).

MTM: Museo Arqueológico y Antropológico Indígena Tierra de Minuanes (Villaguay). MAS: Museo de Ciencias Naturales y Antropológicas "Profesor Antonio Serrano" (Paraná), Colección Serrano.

ML: Museo Histórico Martiniano Leguizamón (Paraná).

MAMA: Museo Arqueológico Manuel Almeida (Gualeguaychú).

CPG: Colección Particular Gómez (Feliciano).

\section{Tipo Ab:}

[MAS-430 (1688)] Arroyo Gualeguaycito, Federación; Serrano 1932.

\section{Tipo Bc5:}

[MAS-2067 (1320)] Distrito Chiqueros, Nogoyá.

[MAS-88 (4488)] Villaguay.

\section{Tipo Bg:}

(MAMA-1039) Costa del arroyo Gualeyán, Gualeguaychú.

\section{Tipo Bh:}

(MACN-16733) Salto Grande, Federación.

(MACN-16732) Salto Grande, Federación.

(MACN-402) Salto Grande, Federación.

(MACN-16731) Salto Grande, Federación.

(MACN-16732) Salto Grande, Federación.

(ML-2368) Costa del río Uruguay, Federación.

[MAS-83 (1311)] Federación.

(MCB-s/n) Federal $(n=2)$.

[MAS-53(1304)] Distrito Tala, Paraná.

(ML-3227) Localidad Antonio Tomás, Paraná.

(MCQ-A-B-0153) Río Uruguay medio.

(MAS-489) Entre Ríos. 
(MAMA-494) Estancia “La Selmira”, Concepción del Uruguay; CCBSJG 1986.

(MAMA-295) Estancia “El Potrero” Gualeguaychú; CCBSJG 1986.

\section{Tipo C:}

(CPG-sin número de pieza) Feliciano. (Forma oval)

(MCQ-A-B-0154) Río Uruguay medio. (Forma esférica)

[MAS-80 (1312)] Quinta "El Peloponeso", Distrito Salto, Diamante; Leguizamón 1935. (Piriforme)

\section{Tipo D:}

(CPG-sin número de pieza) Feliciano.

(MACN-16725) Paraje Los Sauces, Salto Grande, Federación; Vassallo de Cettour 1995.

(MACN-16726) Paraje Los Sauces, Salto Grande, Federación; Vassallo de Cettour 1995. 